


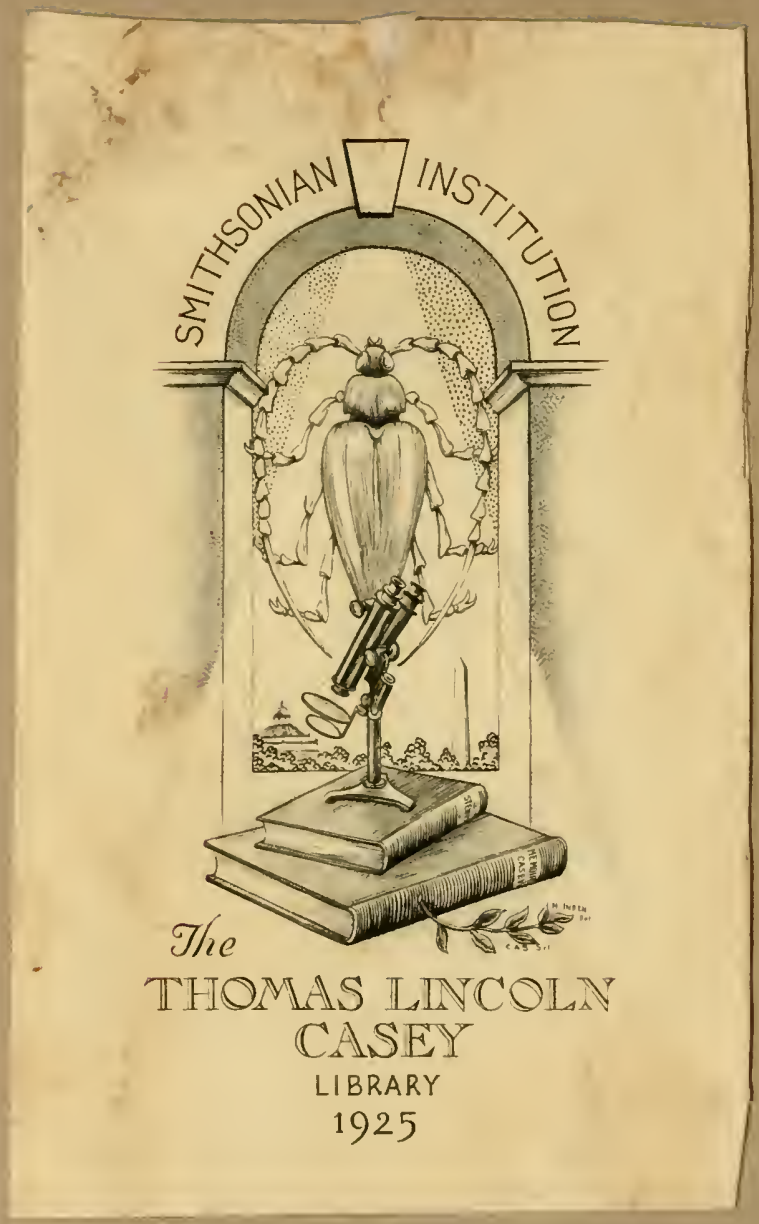






\section{I N N A E A}

\section{E N T 0 M 0 L L 0 G G I G A.}

\section{Z E I T S C H R I F T}

HERA USG E GEB EN

VON DEM

\section{ENTOMOLOGISCHEN VEREINE}

I N S T E T T I N.

FUNFZEHNTER BAND.

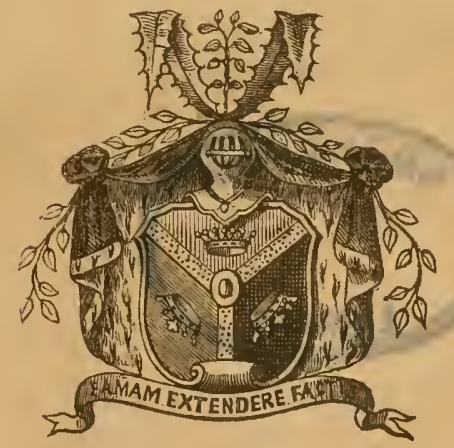

LEIPZIG 1863.

VERLAG VON FRIEURICH FLEISCHER. 


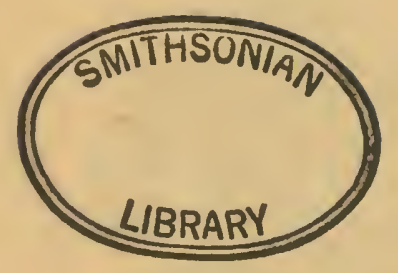




\section{Vorwort.}

Dem im vierzehnten Bande vor drei Jahren verheissenen Abschlusse der Monographie der Cryptocephalen haben sich hauptsächlich zweierlei Hindernisse bisher als hemmend entgegengestellt: znerst das von mehreren Seiten zuströmende, Nachträge, Einschiebsel und Umarbeitungen nöthig machende Material, zweitens aber die gesteigerten, mit vielen Reisen verbundenen Berufsgeschäfte des Monographen, meines verehrten Frenndes. Beide Umstände und die Rücksicht auf den räumlichen Umfang machten es unthunlich, den verheissenen Abschluss der Arbeil schon jetzt zu geben, und es wird dazu noch eines neuen Bandes bedürfen.

Leider hat inzwischen der Tod unsern ehrenwerthen Verleger, Herrn Stadtrath Friedrich Fleischer abgerufen. Der entomologische Verein hat diesen Verlust um so tiefer zu bedanem, als Herr Fleischer schon seit Bcgrïndung der entomologischen Zcitung sich mm deren Vertrieb sehr ancrkennenswerthe Verdienste erworben hat. 
In dem vorliegenden Bande ist ausser der Fortsetzung der Suffrian'schen Monographie der Schluss der EmesidenArbeit von Anton Dohrn und eine Bearbeitung der Gattung Ornix aus der kmudigen Feder des Herrn Prof. Frey enthalten. Der nächste Band soll dem gegenwärtigen möglichst bald folgen.

Stettin, Ende: October 1863.

\section{A. Dohrn,}

Vereins-Präsideut. 


\section{Inhalt.}

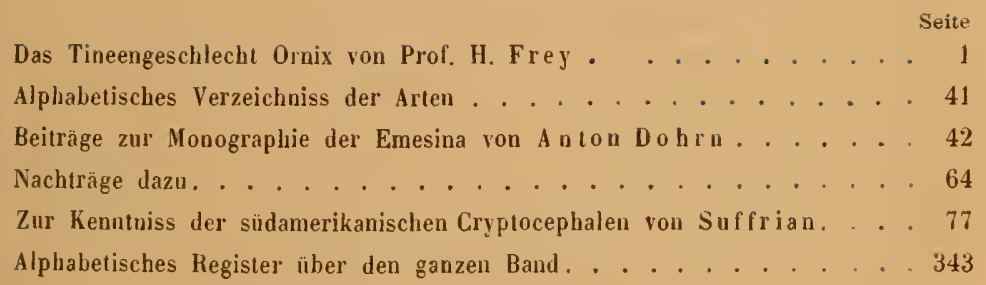





\title{
Zur Kenntniss der südamerikanischen Cryptocephalen.
}

\author{
Schulrath (Dr. Suffrian in Münster.
}

Ungeachtet des Artenreichthums, mit welchem die Cryptocephalen-Fauna von Südamerika über die jedes andern gleich ausgedehnten Theiles der Erdoberfläche hinausreicht, sind doch von diesen ihr angehörenden Arten bis jetzt verhältnissmässig nur wenige durch Beschreibungen zur Kienntniss des entomologischen Publicums gelangt. Fabricius, mit dem auch hier unsere Artenkenntniss beginnt, zählt in der Entomologia Systematica (1792) nur sechs hierler gehörige Arten auf, von denen er eine (den $\mathrm{Cr}$. lar) bei der späteren Trennung der Gattungen Cryplocephalus und Clythra in der letzteren stehen liess; in dem Syst. Eleutheratorum (1801) ist der'en Anzahl auf 11, oder einschliesslich jenes $\mathrm{Cr}$. lar und dreier gleichfalls zur Gattung Clythra gebrachten Monachen auf 15 angewachsen, von deren einer, seinem von den Neueren richtiger zu den Eumolpiden gebrachten $C r$. dubius, er aber selbst bezweifelt, "dass derselbe dort seine rechte Stelle gefunden habe. Olivier in der Ent. (1808) kennt im Ganzen 8 Arten, von denen 5 aus Guyana stanmend sich nicht bei Fabricius finden, falls, was mir noch zweifelhaft, sein $\mathrm{Cr}$. perlatus wirklich von $\mathrm{Cr}$. guttatus Fabr. verschieden ist. Zu diesen (im Ganzen 20) Arten fügte Germar (1824) noch einen Cr. bisignatus aus Brasilien, Perty (1830) einen Cr. carneolus und fiollari, gleichfalls aus Brasilien, Erichson (in Wiegm. Archiv. 1847) einen Pachybrachys cariosus aus Peru, und (im 3. Theile von Schomb. Reisen 1848) einen P. hyacinthicus und argentatus aus dem britischen Guyana, und Blanclıard (Bd. 5. von Gay hist. fis. y polit. de 
Chile. Zool. 1851) neun neue Arten aus Chile, zu denen dann neuerdings durch Stål (in den Verh. der K. Schwed. Akad. der Wiss. 1857) noch 21, theils aus Chile, theils aus Brasilien, eine auch aus Nel-Granada, und durch Boheman (Freg. Eug. resa Ins.; 1859) noch weitere 9 Arten aus verschiedenen Gegenden Südamarika's hinzugekommen sind. Hliernach beläuft sich die Zahl der bereits beschriebenen Arten im Ganzen auf 65; ich glaube aber niclit zu irren in der Annahme, dass dieselben höchstens den zehnten Theil der in Südamerika wirklich vorhandenen Arten ausmachen werden, wenn gleich die Zahl der in unsern Sammlungen bereits enthaltenen beschriebenen und nicht beschriebenen Arten zusammen noch nicht über 400 hinausreichen mag.

Hinsichts der in Südamerika vertretenen Cryptocephalen - F ormen bietet sich manches beim ersten Anblicke Auffallende dar. Jedoch erklären sich diese Eigenthümlichkeiten wenigstens theilweise aus dem Umstande, dass es sich hier um eine sehr ausgedehnte Ländermasse handelt, welche das Charakteristische der südlichen Halbkugel mit specifisch Amerikanischem verbindet, und dabei so ausgedehnter wüster Flächen entbehrt, wie sie in Afrika und Australien der Entwickelung und Gestaltung einer formenreichen Insectenwelt hemmend entgegentreten. Es darf desshalb nicht befremden, dlass die dem Süden überhaupt angehörenden, in der alten Welt auf ihn ausschliesslich (Vorgeb. der g. Hoffnung, Australien) beschränkten Monachiden in Südamerika in einer sehr bedeutenden Artenzahl auftreten, sich auch bis in die Tropenzonen der nördlichen Halbkugel vorschiehen und mit einigen wenigen Arten sogar die südlichen Landschaften der V. Staaten erreichen; und dass eben so der den Tropengegenden eigenthümliche, habituell den Monachiden nah verwandte, kurz eiförmige CryptocephalenTypus, wie er in Ostindien und Westafrika zahlreiche Vertreter findet und eben so auf den Antillen die analoge Gruppe mit der merkwürdigen Querrunzel auf den Flügeldecken herrorgebracht hat, auch auf dem südamerikanischen Festlande in einer wieder in anderer Bezichung abweichenden, sich auch in Ban der Vorderbrust den Monachen überaus ähnlich gestaltenden Form erscheint. Selbst die kleine, aber merkwürdige südafrikanische Gruppe echter Cryptocephalen mit lappenförmig erweitertem Ilinterraude des Halsschildes findet eine ihr analoge Artemreihe, und zwar seltsamer Weise nicht am östlichen, sondern am westlichen Rande unseres 
Faunengebietes. An der sclıon anderswo von mir hervorgebohenen Zunalıme der Pachybrachen auf der westlichen Halbkugel ist auch Südamerika, wie zu vermuthen, sehr stark betheiligt; specifisch amerikanisch und zwar südamerikanisch aber ist es, dass bierbei die eigentlichen Pachybrachen verhältnissmässig sehr zurücktreten, und die Hauptmasse der Arteı der eben südamerikanischen, gleichfalls nur mit einer geringen Artenzahl nach Mittelanıerika und dem südlichen Theile der V. Staaten vorrückenden Scolochren-Form angehört. Das Vordrängen dieser scolochren hat die Formenbildung innerhalb der Pachybrachen-Familie allmäblich in solchem Grade überwältigt, dass eine ganze Reihe echter Pachybrachen ( $P$. 15 guttatus und seine Verwandten) habituell von jenen kaum noch zu trennen ist; anderseits schiebt sich bei einzelnen ScolochrenFormen rler Körper in der Länge bei gleiclızeitiger Ausrlehnung nach Breite und Höhe so zusammen, dass solche Arten in den $\mathrm{Ha}_{-}$ bitus der Monachen und der eiförmigen Cryptocephalen hinüberspielen, und durch diese üheraus grosse Mannichfaltigkeit der Form die systematische Anordnung und Gruppirung des reichen Artenmaterials im höchsten Grade erschwert wird. Die Natur scheint sich hier nun einmal nicht in unsern Gattungszwang fügen $\mathrm{zu}$ wollen; mir wenigstens hat es nicht gelingen wollen, die Principien eines solchen auch lier in so folgerechter Weise durchzuführen, dass die unten versuchte Anordnung meinen eigenen Anforderungen nach jeder Riclıtung hin entspräche, und für melır als einen Versuch gelten könnte, das bis jetzt aufgefundene ArtenMaterial für künftige Benutzung nach Möglichkeit kenntlich zu machen.

Gegen diese vorwaltenden Mo $\mathrm{nachiden}$ und Pachybrachiden treten nun die eigentlichen Cryptocephalen gar sehr in den Hintergrund zurück. Selbst die Anzahl der Gruppen ist eine nur besclıränkte; nicht wenige derselben enthalten nur winzige und unscheiubare Arten, und ausser der bereits oben angefülıten chilenischen Gruppe mit hinterwärts gelapptem Halsschilde sind deren nur noch zwei besonders hervorzuheben, die eine (Cr. lar und seine Verwandten) wegen der eigenthümlich gegitterten Sculptur ihres flachen, Hispa-ähnlichen Körpers, die andere (den $\mathrm{Cr}$. lalicornis und die verwandten Arten enthaltend) als Vertreterin einer auf den Antillen ziemlich zahlreichen Form mit gestrecktem Körper und oberwärts zusammengeneigten Augen, von welcher Antillen- 
gruppe sie sich eigentlich nur durch das hinten jederseits tief schräg eingedrückte Halsschild unterscheidet.

Zu einer Abgrenzung bestimmter Gebiete innerhalb des weiten Raumes, den man mit dem Namen Südamerika zu bezeichnen pflegt, ist noch keineswegs ein hinreichendes Material vorhanden, indem nicht allein die ganze Südspitze, sondern auch nicht wenige Striche im Imnern von Brasilien und der La-Plata-Staten bis jetzt noch so gut wie unbekannt geblieben sind. Nur Chile westlich von den Anden scheint sich, wie für so manche andere ColeropterenFamilie, so auch für die vorliegende als ein hestimmt geschiedenes Gebiet abzusondern, das ganze Land östlich von jenem Gebirge aber, wenigstens nordwärts soweit das Flussgebiet des Amazonenstroms reicht, nur ein einziges ausgedehntes Faunenğebiet zu bilden, und das Gebirgsland von Neu-Granada, Venezuela und Gu y an a dem mexicanisch-mittelamerikanischen Gebiete anzugehören, aus welchem sogar einzelne Arten sich bier wiederfinden, während anderseits auch manche Arten und Formen des ausgedelnten Ostgebiets bis hierher herüberreichen. Die Staaten von Bolivia, Ecuador und Peru sind bis jetzt zu wenig durchforscht, als dass sich über den Charakter ihrer Fauna schon jetzt etwas Bestimmtes äussern liesse, wenn gleich die wenigen aus Peru und Bolivia mir zu Gesichte gekommenen Arten sich am meisten den mittelamerikanischen Formen anschliessen; und von den Inseln unter dem Winde ist bis dahin keine einzige Art bekannt geworden, so dass es für jetzt noch unentschieden bleiben muss, ob dieselben rücksichtlich der vorliegenden Familie wirklich dem Antillent, oder, was die Lage eher vermuthen lässt, dem mittelamerikanischen Gebiete zuzurechnen sein werden.

Eine Ausscheidung neuer Gattungen ist bis jetzt nur von St å I a. a. 0 . vorgenommen worden. Yon den beiden, ron ihm auf überwiegend habituelle Nerkmale begründeten Gattungen Mylas s a und II ecostethus bildet die letztere, einen kleinen brasilianischen Käfer enthaltend, eine allerdings im llabitus etwas eigenthümlich erscheinende Form; die erstere unfasst die mehrfach genannte chilenische Gruppe mit hinten gelapptem Ilalsschilde mit zwei Arten, deren erstere ron Blanchard sogar den Pachybrachen zugezählt worden ist. Ich hale mich keiner dieser Ansichten anschliessen können.

Eine Uelersicht der Gattungen habe ich diesmal nicht beige- 
fïgt, da neue von mir nicht vorgeschlagen worden sind, und ich überdem beahsichtige, demnäclıst eine Synopsis der ganzen Familie unter Einschaltung der inzwvischen auch wieder für die übrigen Erdtheile mir zugegangenen überaus reichhaltigen Nachträge zusammen zu stellen. Es heibt mir daher nur noch übrig, den Ursprung des von mir für die folgende Arbeit benutzten Materials nachzuweisen. Schon früber waren mir mit dem. Gesammtbestande der Arten aus dem Kaiserl. Museum zu Pelersburg (von Hrn. M énétriés) und des Hamburger Museums (durch Herrn Thorey), sowie der Sannmlungen der Herren IV. IV. Saunders und Senator v. Heyden auch die zahlreichen darin enthaltenen südamerikanischen Arten zum Vergleiche zugrgangen; hiuzugekommen sind zu denselben in den letzten Jahıen noch die exotischen Gesammtluestände aus den Sammlungen der III. Baly, Clark, Deyrolle, Dohrn und Lacordaire, sowie die südamerikanischen Arten aus der Universitätssammlung zı Ilalle (durch Hrn. Dr. Taschenberg) und aus den Sammlungen (ler Herren vom Bruck, Felix, Hag, Riehl, Schaum und Sturm; sowie ich auch die bezüglichen Arten der K. zoolog. Sammlung in Berlin durch die Gefält ligkeit ihrer Vorsteher wiederholt sowohl an Ort und Stelle, als nach erfolgter Mittheilung habe vergleichen können. Ihnen Allen, sowie denjenigen unter ihnen, welche mich noch ausserdem mit litterarischen Nachweisungen und Hülfsmitteln unterstützt haben, dafür den aufrichtigsten Dank!

\section{Monachus Chr.}

(Linn. VI. 210).

Bei dem Artenreichthum, durch welchen diese Gattung in Südamerika vertreten ist, darf es nicht auffallen, dass in derselben auch eine verhältnissmässig bedeutende Reihe von habituellen Formenverschiedenheiten hervortritt. Es ist desshalb nöthig geworden, ihre Arten in eine grössere Anzalıl von Gruppen zu vertheilen, auf deren letzte erst die in der Linn. VII. 229 angeführte zweite nordamerikanische Rotte folgen würde; die vier ersten derselben vertreten den normalen Monachen-Typus, wie er sich in M. saponatus und seinen Verwandten bis nach den Vereinigten Staaten von Norrlamerika ausbreitet; in der fünften erscheint bei wesentlich gleichem Umrisse schon eine tiefe Querfurche vor dem Hinterrande des Halsschildes, und bei den folgenden streckt sich dann noch $\mathrm{xV}$. 
der Körper in Annäherung an die echte Cryptocephalen-Form immer mehr in die Länge, während er zugleich durch die eckig hervortretenden Schultern einigermaassen auf die Körperbildung der Metachroma-Arten hindeutet. Einzelne hierher gehı̈rende Artenı zeigen dabei eine solche Achnlichlieit mit manchen Cryptocephalen, dass es nicht leicht wird, hier überall die scharfe Grenze zwisclıen beiden Gattungen festzuhalterl.

Erste Rotte. Körper klein, eiförmig, dunkelmetallisch, zum Theil mit röthlichen Beinen oder Halsschilds-Seiten; das Halsschild hinten ohne deutliche Querfurche.

1. M. sulfuripes m. Tief erzlarbig, Fühlerwurzeln und Beine hellgelb; die Punktstreifen nur rorm bemerkbar, der neunte etwas tiefer eingedıückt, mit flachen, glänzenden Zwischenräumen. L. $3 / 4{ }^{\prime \prime \prime}$; Br. 1/2 ${ }^{\prime \prime \prime}$.

Im Bau am meisten dem unten folgenden, in den Sammlungen weit verbreiteten M. nigritulus älınlich, aber an den hellen Beinen und dem Mangel des blauen Schimmers auf der Oberseite von ihm leicht zu unterscheiden. Der liopf flach, kaum punktirt, das Kopfschild wenig eingezogen, oben nur undeutlich abgegrenzt, die Farbe schwärzlich mit scliwachem Clanze, der untere Saum der Oberlippe und die Mundtheile gelblich; die Augen mässig ausgerandet. Die Fühler etwas schlanker als bei den verwandten Arten, die fünf unteren Glieder liellgelb, die oberen sclıwarz und nur dünn behaart. Ias Halsschild fast ron der Wurzel ab nach vorn sanft übergekrümmt, vorn über den rechtwinkligen Vorderecken tief eingedrückt und dadurch verschmälert; die Seiten fein gerandet, mit der vorderen Hälfte fast geradlinig zusammen geneigt, die Hinterecken breit und spitz dreieckig vorgezogen, der Hinterrand jederseits nur leicht ausgebuchtet, mit fast gerade abgestutztem Mittelzipfel, und vor letzterem ein kurzer und schwacher Quereindruck. Die Olerfläche äusserst fein punktirt, mit mässigem Glanze. Die Farbe tief metallisch schwarzbraun, an den Seiten heim Sonnenlichte etwas mehr ins Bräunliche fallend. Das Schildchen aus tief quer niedergedrückter Wurzel hinterwärts mit starker Krümmung ansteigend, spitz dreieckig, um 1/4 länger als breit, gleichfalls glänzend metallisch schwarzbraun. Die Dechschilde etwas länger als breit, linter ten Schultern noch pin wenig erweitert und dann in breitem Bogen hinterwärts wieller verschmälert, so dass der Umriss sich dadurch zum Verkehrteiförmigen ergänzt; der Rücken um die Schildchenspitze 
buckelig erhöht und von da seitlich mit stärlierer, hinterwärts mit sanfterer Krümmung abfallend. Die Wurzel hinter ilırer Vorderkante flach quer niedergedrückt, auch die breiten Schulterbeulen nur flach erhöht, und die Seitenlappen wenig bemerkbar. Die Punktstreifen sehr regelmässig, schwach, auch die olseren kaum bis zur Mltte zu verfolgen, der 9te seiner ganzen länge nach in eine seichte Furche eingedrückt, und dadurch der 9te Zivischenraum in sanfter Wölbung emporgehoben. Die übrigen Zwischenräume nur flach; die Farbe ein ziemlich glänzendes metallisches Schwarzbraun, bei hellerer Beleuchtung deutlicher ins Erzfarbige fallend. Auch Pygidium und Unterseite schwarzloraun, die Beine hellgelb mit dunkler angelaufener Aussenkante der Vorder- und Mittelschenkel. Das letzte Segment des $\delta$ leicht eingedrückt, das $q$ mit einem eiförmigen, glänzenden Grübcheı.

Aus Brasilien (von Tejuca: Mus. Clark, und von Rio de Janeiro: Mus. Deyrolle). Im Mus. Deyrolle war die Art mit dem ganz passenden Namen Mr. pallipes Chevr. bezeichnet, welcher aber wegen des von Stål a. a. 0 . beschriebenen Mr. pallipes Stål nicht beibehalten werden konnte.

2. M. phalacroides m. Pechschwarz, Fühler und Beine röthlich; das Halsschild deutlich punktirt, auch die Punktstreifen deutlich mit flachen, glänzenden Zwischenräumen. L. 2/5 "'; Br. 1/4"'.

Von der Grösse und der Gestalt eines kleinen Phalacrus, und nebst dem M. sordidulus die kleinste bis jetzt bekannt gewordene Art dieser Gattung; ausserdem aber durch die verhältnissmässig deutliche Punktirung des Halsschildes sehr ausgezeichnet. Der Kopf flach, längs der Stirn seicht eingedrückt, quer runzlig punktirt; das zerstreut punktirte Kopfschild oben nur durch einen schwachen Querwulst abgesetzt. Die Farbe pechschwarz, ins Bräunliche fallend, die wenig ausgebuchteten, oben ziemlich weit getrennten Augen greis. Die Fühler nur wenig über den Hinterrand des Halsschildes hinausreichend, das Wurzelgliert gestreckt keulig, das 2te kurz eiförmig mit stark eingeschnürter Wurzel, die drei folgenden schmal verkehrt kegelfürmig, kaum länger aber merklich dünner als das zweite, die sechs oberen zu einer deutlichen Keule verdickt, deren Glieder fast breiter wie lang, innerseits stark erweitert, aber nur schwach zusammengedrückt, mit liaum bemerkbarem Fortsatze des Endgliedes. Die Farbe der fünf unteren hell röthlich-gelb, der Keule schwach gebräunt. Das Halsschild so lang als breit, vom Schildclıen 
ab nach vorn sanft übergekrümmt, und hier über den scharf spitzwinkligen, tief eingezogenen Vorderecken zusanmengedrückt und verschmälert; die Seiten fein gerandet, nach vorn fast in gerarlen Linien zusanmengeneigt, vor den kurzen scharf rechtwinkligen Hinterecken leicht ausgeschweift; der Hinterrand fast gerade, nur jederseits des ku'zen, undeutlich ausgerandeten Mittelzipfels schwach gebuchtet. Der Rücken.innerseits dieser Einbuchtungen ein wenig quer niedergedrückt, anch nach den Hinterecken zu sich sehr schräg abflachend, die Nittelfirste unscheinbar kiclig erhöht. Die Punktirung dentlich und ziemlich dicht, mit mässig glänzendem Zwischengrunde. Das Schildchen fast gleichseitig dreieckig, fach niederliegend, gleichfalls glänzend pechschwarz. Die Deckschilde vor'm breiter als das Ilalsschild, hinterwärts noch etwas in Bogen erweitert, und dann durch Zurundung den Umriss des Kïrpers zum Schnaleiförmigen abschliessend; der Rücken an Ende des ersten Fünftels der Deckschilde am höchsten und von da nach vorn und hinten gleichmässig ahfallend; die Schulterbeulen hreit höckerig, imnerseits nur durch einen undentlichen Eindruck abgesetzt, die Seitenlappen wenig bemorklbar. Die I'unktstreifen sehr regelmässig, vorn doppelt stärker als die Punktirung des Ialsschildes, schon vor der Mitte sich abschwächend, aher bis zur Spitze sichtbar, die flachen Zwischemräume glänzend. Das grösstentheils berleckte Pygidium äusserst lein runzlig punktirt. Auch die Unterseite dicht und fein punktirt, ziemlich glänzend; die Beine röthlich mit gebräunten Hinterschenkelir. Das Prosternum so lang wie breit, deullich punktirt, hinter den Vorderhüften erweitert, nit flach ausgeschnittenem Hinterrande; das letzte Segment des einzigen vorliegenden $q$ mit einer nicht sehr tiefen eiförmigen glänzenden Grube.

Gleichfalls aus Brasilien (Mus. Schaum).

3. M. a nach o reta m. Ticf stahlblau mit rothen Mundtheilen und Fühlerwurzelı; das Halsschiłł dichıt gerunzelt, die Punktstreifen fein, ron der Mitte al fast weggeschliffen, der 9te vertieft, mit flachen glïnzenden Zwischenrïumen. L. $11 / 3{ }^{\prime \prime \prime} ; \mathrm{Br} .3 / 4$.

Die grüsste Art dieser Gruppe, ron der Grösse und dem Habitus des nordamerikanischen M. saponatus Fab., und von diesem eigentlich nur dureh die tiefere, ins Veilchenblane fallendr Färbung, die glänzcudern Deckschilde, und das fein aber dicht gerunzelte IIalsschilı rerschieden. Der kopf flach gewölbt, das Kopfschild 
etwas eingezogen, oben durch einen schwachen Querwulst und eine darüber liegende feine Querlinie alggegränzt, zerstreut punktirt und matt metallischblau, die von einer feinen Längslinie durchzogene Stirn glatter und glänzender. Der Unterrand des Kopfschildes mit der Oherlippe pechbraun, die Mundtheile heller röthlichgelb, die langgestreckten, breit aber nicht tief ausgebuchteten Augen greis, (bei dem $f$ ) weit getrenut. Die Fühler hei dem einzigen vorliegenden Stücke nur theilweise vorhanden, anscheinend selır kurz; das 2te Glied gestreckt elliptisch mit stark eingeschnürter Wurzel, doppelt länger 'wie hreit, das 3te um die Hälfte länger, das 4te dem 2ten, und das 5te mit den oberen, soweit sie noch vorhanden sind, wieder je dem 3ten gleich, diese schon vom 5ten und stärker noch vom 6ten ab zusammengedrückt und verbreitert. Die 4 unteren hell rothgelb, das 5te tief gebräunt, die Glieder der Keule schwarz. Das Halsschild um die Hälfte breiter wie lang, mit der kleineren Vorderhälfte nur sanft übergekrümmt, über den rechtwinkligen tief eingezogenen Vorderecken stark zusammengedrückt und dadurch verschmälert, die Seiten fein gerandet, hinter der Mitte leicht ausgeschweift, vor ihr nach dem Vorderrande zu stark zusammengebogen, die Hinterecken spitz ausgezogen, durch einen leichten Eindruck etwas aufwärts gedrüclit, der Hinterrand jederseits tief ausgebuchtet und eingesenkt, mit breit doppelt ausgerandetem Mittelzipfel. Vor letzterem jederseits eine schwach eingedrückte, stärker punktirte Querlinie, und über dieser das Mittelfeld des Halsschildes breit algeflacht, über der Mitte des Seitenrandes aber stärker flachgedrückt und dadurch ziemlich steil abfallend. Die Oberlläche nicht tief aher dicht wellig gerunzelt, was besonders an den Seiten und auf der hinteren Hälfte hervortritt, die Farbe ein dunkles ins Veilchenblaue ziehendes Stahlıbau, der Vorderrand unter gewisser Beleuchtung bräunlich durchschimmernd. Das Schildchen mässig ansteigend, gestreckt dreieckig, doppelt länger wie breit, mit undeutlichem Vordergrrübchen, gleichfalls glänzend stahlblau. Die Deckschilde wenig länger wie breit, hinter len Schultern nur schwach erweitert und daun hinterwärts breit zugerundet; die Wurzel nach dem Halsschilde lin leicht abwärts gekiümnt, die grossen Schulterbeulen eckig heraustretend, innerseits durch cinen breit dreieckigen, zugleich das Vorderende des 5ten Punktstreifen mit aufnehmenden Längseindruck ahgesetzt, die Seitenlappen von mässiger Aushildung, aber mit selır loreit ungeschlagenem Rande. 
Die Punktstreifen regelmässig und fein, vom 2ten Drittel ab merklich schwächer und die mittleren auf der Wölbung fast erloschen; der 9te seiner ganzen Länge nach in eine deutliche, besonders unter den Schulterbeulen krüttig ausgeprägte Furche eingedrückt, die Zwischenräume fast spiegelglïnzend, flach, nur der 9te etwas aufgewölbt; die Farbe anch hier ein schönes, dunkles Stahlhlau. Das Pygidium fein punktirt, längs dem Rande von einer ziemlich tiefen Furche umzogen, mit etwas schwächer punktirtem Mittelfelde; duukelblau. Unterseite und Beine metallisch schwarzblau, die Hüften und Schienenenden ins Trühpechbraune fallend, die Fussglieder schwarzlich. Das Prosternum kurz und breit, hinter der Nitte Jeicht quer eingedrückt, hinten nur scicht ausgerandet. Das letzte Segment des $q$ mit einer halbkugeligen, glänzenten Grube, das $\delta$ unbekannt.

Aus Brasilien (llus. Berol., ron Sello)

4. M. nigritulus Boh. Natt stahlblau, die Fühlerwurzeln, Schienenenden und Fussglieder röthlich gelb oder braun; die Punktstreifen fein, hinten verschwindend, der 9te vertieft, mit flachen Zwischenräumen. L. $2 / 3-1{ }^{\prime \prime \prime} ; \mathrm{Br}$. 1/2-4/5"'.

M. nigritulus Boh. Freg. Eug. Resa Ins. S. 158. n. 331!

Eine anscheinend in Brasilien sebr verhreitete und mir desshalb in zahlreichen Stïcken vorliegende, ihrer Färbung nach wie die vorhergehende den nordamerikanischen Arten aus der Nähe des M. sayonalus am meisten verwandte Art. Im Hahitus ist dieselbe merklich schmäler als die meisten süılamerikanischen Arten, und ausserdem an der überaus einfachen Färbung und Sculptur sehr leicht zu erkennen. Der Kiopf Mach, auf dem Scheitel znweilen mit einer schwach angedeuteten Lïngslinie, das Kopfschild zwischen deı Fühlerwurzeln durch eine elwas gekrümmte, äusserst feine und oft ganz erloschene Querleiste alogesetzt; die ganze Oberfliche glanzlos dunkel stahlblau, die kurz dreieckig ausgelochteten Augen schwarz. Die Mundtheile rothbraun oder pechbraun, die Mitle der etwas vorspringenden Oberlippe gewölnlich verwaschen gesclıwärzt. Die Fühler ron nicht halber Körperlinge, das Wurzelglied über dreimal länger wie breit, oberwärts wenig verdickt und bis zum äusseren Augenrande schwach B̈hergekrümmt, das 2te Glied lürz eifürmig, dreimal kürzer und un die IJ̈̈lfte schmäler als das erstr, die drei folgenden cinander und denı zweiten an Länge glıich, aber merklich dünner als letzleres, die sechs oberen je doppelt läıger, innerseits hreit dreickig erweitert, mit kurzem Fortsatze des Endgliedes. 
Die fünf unteren hell rothgells mit einer schwarzen Längslinie auf der Oberseite des Wurzelgliedes, seltener dunkler gebräunt, die Keule schwarz, mit angedrückter greiser Behaarung und einzelnen längeren abstehenden Wimpern. Das Halsschild hinter der Mitte ein wenig quer aufgewölbt und dann mit ${ }_{/ 3}$ seiner Länge nach vorn flach übergekrümmt, über den scharf rechtwinkligen Vorderecken stark zusammengedrückt und dadurch verschmälert, die Seiten fein gerandet, erst von der Nitte'ab nach vorn zusammengeneigt, vor den breit und scharf spitzwinkligen IIinterecken sanft ausgeschweift, der Hinterrand jederseits weit ausgebuchtet, von einer eingedrückten Reihe vereinzelter gröberer Punkte begleitet, mit kurzem doppelt ausgerandetem Mittelzipfel. Vor jener Punktreihe jederseits des Mittelziptels noch ein kurzer, mehr oder weniger deutlicher Quereindruck. Die Oberfläche einfarbig matt stahlblau, ohne sichthare Punktirung. Das Schildchen länglich-dreieckig, um die Hälfte länger als breit, hinterwärts mässig ansteigend, mit deutlichem Vordergrübchen, gleichfalls matt stahlhlau. Die Deckschilde vorn etwas breiter als das Halsschild, hinterwärts noch ein wenig. verbreitert und dann schmal zugerundet, etwa um $1 / 4$ länger als breit, hinter der aufgeworfenen und an die breit eiförmigen höckerigen Schulterbeulen anschliessenden Vorderkante tief quer eingedrückt, und dann wieder stark wulstig ansteigend, um die Schildchenspitze buckelig erhöht und von hier aus seitlich stärker-, die Naht entlang mit sanfterer Krümmung abfallend, die Seitenlappen von mässiger Stärke. Die Punktstreifen sehr regelmässig und äusserst fein, aus vereinzelten und vorn deutlichern, etwas in die Länge gezogenen Punkten gebildet, hinterwärts immer mehr verschwindend, und gegen die Wölbung hin nur noch hier und da, namentlich zunächst der Naht, in schwachen Spuren wahrnehmbar, bei dem $\delta$ die Vorderenden, hesonders hinter den Schulterbeulen, etwas kräftiger ausgeprägt. Der 9te Streifen seiner ganzen Länge nach furchig eingedrückt, so dass, wenn hinterwärts auch die Punkte velschwinden, doch die Furche kenntlich bleibt. Die Zwischenräume flach, nur der 9te leicht aufgewölbt. Die Farbe auch hier matt stahlblan, etwas melır seidig schimmernd als das Halsschild. Das Pygidium äusserst fein aber nicht sehr dicht querrunzlig punktirt, auch die Unterseite feiı quer gerunzelt und mit den Beinen glänzend schwarzblau; die Hüften, Unterenden der Schienen und die Fussglieder fuchsig gebräunt oder geröthet, seltener, zumal bei 
den $\&$, heller rostroth, in welchem Falle dann auch wohl die ganzen Vorderschieneı diese Färbung annehmen. Das Prosternum kurz und breit, runzlig punktirt, hinten seicht ausgebuchtet, mit stark aufgeworfenen Seitenleisten. Das letzte Segment des of mit einer leicht quer niedergedrückten Stelle, das o mit einer länglichen stark glänzenden Grube.

Aus Brasilien, und fast in allen von mir verglichenen Sammlungen in Mehrzahl vorhanden (von Santos: Mus. Dohrn; von Petropolis: Mus. Clark; von Caasapava: Mus. Berol., von Sello gesammelt; von Rio de J.: Mus. Holm., von F. Sahlberg gesammelt; ohne nälsere Angabe des Fundorts im Mus. Halens., Schaum, Haag, Baly, Deyrolle). Ein kleines $\delta$ mit fast ganz schmutzig gelb gefärbten Schienen und Füssen aus Montevideo im Mus. Holm. scheint mir nicht wesentlich verschieden.

5. M. umbrosus m. Matt purpurblau, Fühlerwurzeln, Schienenenden und Fussglierler rothgelb oder rothbraun; die Punktstreifen äusserst fein, bald hinter der Wurzel verschwindend, der 9 te schwach vertieft, mit flachen Zwischenräumen. L. $1 / 2-3 / 4{ }^{\prime \prime \prime}$; Br. $1 / 3-3 / 5 "$.

Dem vorhergehenden überaus ähnlich, so dass ich desshalb auf die Beschreibung des letzteren Bezug nehmen, und mich auf die Angabe der nur feirren, aber nach meiner Ansicht die Selbstständigkeit der Art genugsam nachweisenden Abweichungen beschränken kanı. Der Käfer ist bei im Ganzen gleichem Umrisse etwas kleiner, besonders breiter, mit stärker heraustretenden Schultern, die Farbe ein stark ins Purjurbräunliche fallendes dunkles, kaum seidenschimmerndes Blau, die rölhliche Färhung an Fühlerwurzelı, Schienen und Fussgrliedern intensiver, lieller, weiter ausgedelnnt, auch die Schenkelwurzelı und zuweilen die ganzen Schienen umfassend, und bei den $\delta$ noch das ganze Kopfschild trüb rothgelb. Die Punktreihe am Hinterrande des Halsschildes ist merklich feiner, auch die Punktstreifen auf den Deckschilden sind schwächer, so dass von den oberen nur die kurzen Vorderenden kenntlich werden und auch die seitlichen vom Ende des ersten Drittels ah verschwinden. Auch die den 9ten Streifen bergende Längsfurche ist merklich schwächer als bei der genannten Art, mit welcher der Käfer im Uebrigen übereinkommt.

Von Paramaribo (Mus. Dohrn).

6. M. picipes Buh. Oben kupferbraun, unten schwarz, 
Fühler, Mundtheile und Beine pechbraun; das Halssclild sehr fein punktirt, die Punktstreifeı deutlich mit flach gewölbten, glänzenden Zwischenräumen. L. $2 / 3-3 / 4{ }^{\prime \prime}$; Br. $1 / 2-2 / 3{ }^{\prime \prime \prime}$.

M. picipes Boh. a. a. 0. S. 158. n. 330 !

Von dein Bau des M. sulfuripes, aber noch etwas kleiner, und an den derben, kräftigen Punktstreifeu leicht von den verwandten Arten zu unterscheiden. Der Kopf flach mit etwas eingezogenem, mattem Kopfschilde, kupferbräunlich, die ziemlich tief dreieckig ausgebuchteten Augen schwarz, die stark vorspringende Oberlippe mit den Mundtheilen schımutzig gelb)raun. Die Fühler (des ठ) kräftig, nicht ganz bis zum Hinterrande des Halsschildes reichend, das zweite Glied eiförmig, das dritte verkehrt kegelförmig, an Länge dem zweiten glëich, das vierte und fünfte je um ein Drittel kürzer und letzteres schon etwas zusammengedirückt; die Keule derb, die Glieder derselhen etwas länger als breit, das erste davon nicht ganz so breit wie die folgenden, und das Endglied mit kurzem, kurz kegelförmigem Fortsatze. Die Farhe der vier unteren Glieder hellrothgelb, die folgenden schmutzig gebräunt mit etwas mehr verdunkelter Spitze. Das Halsschild kurz und breii, fast von der Wurzel ab sanft nach vor'ı übergekrümmt, hinterwärts wieder ein wenig eingesenkt, über den rechtwinkligen Vorderecken stark eingedrückt und dadurch verschmälert; die Seiten fein gerandet, schräg nach vorn und unten mit starker Krümmung zusammengeneigt; die Hinterecken breit und scharf spitzwinklig ausgezogen, der Hinterrand jederscits leicht ausgebuchtet, gegen die Mitte hin tief eingesenkt, mit kurzem, breitem, durch einen leichten Quereindruck abgesetztem Mittelzipfel. Die Oberfläche fein aber ziemlich dicht punktirt, mit metallisch glänzendem Zwisclrengrınde. Das Schildchen stark schräg ansteigend, um die Hälfte länger als vorn breit, glänzend, mit deutlichem Vordergrübchen. Die Deckschilde llach gewölbt, hiıter den Schultern noch etwas rrweitert und daun in breiten Bogen sich hinterwärts wieder verschmälernd, um die Schildchenspitze buckelig erhöht und von da ab hinterwärts selır sanft-, seitlich steiler abfallend, die Seitenlappen schwach, aber die Schulterbeulen höckerig lervortretend, und hinter ihnen die Deckschilde breit zusammengedrückt. Die Punktstreifen selır regelmässig, derb und kräftig, in ihrer ganzen Länge erkennbar, die Vorderenden der Rüclienstreifen aus grubigen Eindrücken entspringend, durch welche hinter der Wurzel eine schmale und unterbrochene Querfurche gebil- 
det wird; die Zwischenräume flach gewölbt, fein gerunzelt mit måssigem Kupferglanze. Das Pygidium deutlich aber zerstreut punktirt, mit der Unterseite schwarz, die Beine schmutzig gelbbraun mit helleren Vorderbeinen, an denen aber die Aussenkante der Schenkel geschwärzt ist. Das Prosternum flach, dicht narbig punktirt, hinten nur in einem Jeichten Bogen ausgeschnitten; das letzte Segment des $\delta$ leicht quer eingedrückt, das + mit dem gewöhnlichen Grübchen.

Aus Brasilien. (Von Constancia: Mus. Clark; von St. João del Rey: Hus. Berol., von Sello gesammelt; von Rio de J.: Mus. Holm.

7. M. scrobiculatus m. Schwarzblau, Kopf, Fühlerwurzeln, Beine und die sclmmalen Seiten des matten Halssehildes rothgelb; die Deckschilde purpurbläılich, die Punktstreifen dèrb mit flachgewölbten, glänzenden Zwischenräumen. L. 3/4"'; Br. 1/2 "'.

Von kurzem, gedrungenem, verhältnissmässig breitem Körperbaı, bei einer gewissen Aehnlichlieit in der Färbung, doch von dem vorhergehenden leicht an dem schmal und trübgelben Seitenrande des Halsschildes und den groben Punkitstreifen zu unterscheiden. Der Kopf flach mit unten kaum eingezogenem Kopfschilde, hellrothgelb; die grossen, nur schmal ausgebuchteten oberwärts etwas zusammengeneigten Augen sclıwarz; von einer Punktirung kaum etwas zu bemerken. Von den Fülılern sind an dem einzigen vorliegenden Stücke nur die unteren 2-3 Glieder erhalten und diese gleichfalls rothgell. Das Halssehild mit $2 / 3$ seiner Länge vorn breit übergewölbt und anch hinterwärts merklich abwärts gesenkt, über den scharf rechtwinliligen Vordereeken zusammengedrückt und dadurch verschmälert, die fein gerandeten Seiten nach rorn fast in geraden Linien zusammenlaufend, die Hinterecken scharf spitzwinklig, etwas ausgezogen, der Hinterıand fein gesägt, jederseits leicht ausgebuchtet und nach der Vitte zu tief eingesenkt, mit kurzem, gerale abgestutztem Mittelzipfel. Die Farbe ein tiefes mattes nur leicht seidenschimmerndes Schwarzblau, die Seiten rothgell, trüber als der Koppf, und nach Innen zu rerwaschen begräuzt. Das Sehildchen schräg ansteigend, schmal dreieckig und fast doppelt länger als breit, gleichfalls schwarzblau. Die Deckschilde um die Spitze des Schildchens deutlich aufgebuckelt und ron da ab nach hinten ziemlich sanft-, seitlich und nach roru hin steiler abfallend, hinter der Wurzel durch dif grübchenartigen Vorderenden der Punktstreifen quer niedergedrückt, und diese Grübchen je wei- 
ter seitlich desto stärker, daher die breiten Schulterbeulen innerseits deutlich abgesetzt, auch die Seitenlappen kräftig ausgebildet. Die Punktstreifen derb, überall aus groben, vorn besonders starken Punkten gebildet, das neunte und das Hinterende des achten in deutliche Furchen eingedrückt, die Zwischenräume flach gewölbt, der neunte fast doppelt breiter als die vorhergehenden. Die Farbe ein schönes, metallisch glänzendes Purpurblau, welches sehr auffällig gegen die trübe Färbung des fast glanzlosen Halsschildes absticht. Vorderbrust und die ihr an Länge und Breite fast gleich kommende Mittelbrust mit den Beinen hellrothgell, die Aussenseiten der Schenkel und die Schienenwurzeln, bei den Hinterbeinen fast die ganzen Schenkel verwaschen gebräunt; Hinterbrust und Hinterleib tief schwarzblau. Die Vorderbrust fein runzlig punktirt, quer eingedrückt, hinten nur flach ausgehuchtet. Das letzte Segment des $\delta$ mit einer leicht niedergedrückten glänzenden Stelle, das $q$ unbekannt.

Aus Surinam. (Mus. Felix, gesammelt von Deutschbein.)

8. II. rotundatus Moritz. Pechbraun, die Fühler und der Vorderrand des äusserst fein punktirten Halsschildes mit Vorder-, Mittelbrust und Beinen hellgelb; die Punktstreifen derb, der achte und neunte verlieft, mit flachgewölbten, glänzenden Zwischenräumen. L. $3 / 4 "$; Br. $5 / 12$ "'.

Dem vorhergehenden überaus ähnlich, aber etwas breiter, flacher, ausserdem aber von ihm noch durch die abweichende Färbung und Farbenvertheilung, den Quereindruck auf dem hinteren Theile des Halsschildes und die stärker hervortretenden Schulterbeulen leicht zu unterscheiden. Der Kopf flach, sehr fein und zerstreut punktirt, mit mattem Zwischengrunde; das tief eingezogene Kopfschild oben durch eine deutliche Querfurche abgesetzt, mit den Mundtheilen schmutzig gelbbraun, die Stim etwas dıukler gebräunt, die tief ausgebuchteten, oben einander ziemlich nahe gerückten $\mathrm{Au}$ gen greis. Taster und Fühler hellgelb; letztere verhältnissmässig lang, über den Hinterrand des Halsschildes hinausreichend, ihre Glieder rom dritten ah einander ziemlich gleich und etwa um die Hälfte länger als das zweite; die Keule locker, nur mässig zusammengedrückt und verbreitert, dicht weisslich behaart. Das Halsschild kurz und breit, vorn mit $3 / 4$ seiner Länge stark übergekrüınmt, auch hinterwärts etwas im Bogen abfallend, üher den scharf rechtwinkligen Vorderecken zusammengedrïckt und dadurclı 
verschmälert, die Seiten fein gerandet, mit der grösseren Hinterhälfte nach vorn geradlinig zusammengeneigt und dann erst stärker einwärts gekrümmt; über ihnen hinter der Mitte je ein breiter und flacher, das Halsschild zusammendrückender Schrägeindruck. Die Hinterecken kurz und breit, scharf spitzwinklig, der Hinterrand jederseits schwach ausgebuchtet, mit kurzem, breitem, deutlich doppelt ausgerandetem Mittelzipfel; vor diesem ein kurzer, ziemlich scharfer Quereindruck. Die Oberfläche äusserst fein und zerstreut punktirt nit glänzendem Zwischengrunde; die Farbe dunkel pechbraun, wie bei unserem Aspidiphorus orbicularis; ein schmaler sich in deı Vorderwinkeln hinterwärts ausbreitender, aber auch abschwächender Vordersaum verwaschen hellgelb. Das Schildchen stark schıäg ansteigend, um 2/3 länger als breit, dreieckig mit kräftigem Vordergrübchen, gleichfalls glänzend pechbraun. Die Deckschilde kaum länger als breit, hinter den Schultern noch etwas bauchig erweitert und dann von ler Mitte ab hinterwärts kurz und breit zugerundet; die Wurzel durch die tief eingegrabenen Vorderenden der imneren Punktstreifen stark quer niedergedrückt. Die Schulterbeulen breit eckig heraustretend, inner'seits durch einen dreieckigen Längseindruck abgesetzl, die Seitenlappen schwach, und über ihnen der neunte Punktstreifen der Länge nach breit eingedrückt. Der Rücken von der Schildchenspitze ab hinterwärts mit sehr flacher Wölbung abfallend. Die Punktstreifen sehr' regelmässig, kräftig und bis zur Spitze deutlich, der achte und neunte nebst den Vorderenden der inneren leicht furchenartig eingedrückt und die entsprechenden Zwischenräume stärker-, die übrigen schwächer aufgewölbt; die Farbe auch hier glänzend pechlbraun. Das Pygidium selır lein gerumzelt, mit der Unterseite gleichfalls pechbraun, nur die Vorder- und Mittelbrust mit den Hüften und Beinen hellgelb; die umgeschlagenen Seiteu des Halsschildes dunkler bräunliclı gelb. Das Prosteruum fast quadratisch, gleichbreit und flach anfgewölbt, hinten nur schwach ausgeschnitten. Das letzte Segment des $q$ mit dem gewöhnlichen, lier ziemlich flachen Grühchen; das o unbekanut.

Von Puerto Cabello. (Mus. Berol., von Morilz gesammelt.)

9. M. obscurellus m. Natt schwarzblau oder schwarzbraun, Kopf, Fühlerwurzelı, Beine und das kaum punktirte Halsschild trül) röthlich mit einen runden schı̈̈rzlichen Scheibenfleck auf tler Mitte des letzleren; die Punktstreifen sehr fein, hinten erloschen, 
der neunie vertieft, mit flachen, scilig glänzendeu Zwischenräumen. L. $1 / 2-3 / 4^{\prime \prime \prime} ; \mathrm{Br}$. $1 / 3-1 / 2{ }^{\prime \prime \prime}$.

Eine kleine und zierliche, an dem hinterwärts stark verschmälerten Körper und dem runden Scheibenflecke des Halsschildes leicht kenntliche Art. Der Kopf flach trübroth, das Kopfschild nur seitlich scharf abgesetzt, etwas eingezogen, oben mit der Stirn zusanmenfliessend, äussérst fein und dieht punlitirt und dadurch matt; die Mundtheile pechbram, die ziemlich tief ausgebuchteten, bei dem ð oben etwas genäherten Augen greis. An den Fühlern die 5 unteren Glieder roth, die Keule schwarz. Das Halsschild fast doppelt breiter wie lang, linterwärts etwas abgeflacht, vor'u mit $3 / 4$ seiner Länge sanft übergekrümmt, über den selır tief eingezogenen scharf rechtwinkligen Vorderecken zusammengedrüekt und dadurch verengt, die Seiten fein gerandet, nach vorn in breiten flachen Bogen zusammengekrümmt; die kurzen scharfen Hinterecken etwas niedergedrückt, der Hinterrand jederseits seicht ausgebuchtet, mit kurzem, undeutlich doppelt ausgerandetem Mittelzipfel; vor ihm eine schmale eingedrückte, mit der gewöhnlichen gröberen Punktreihe besetzte Querlinie. Die übrige Oberfläche kaum sichtbar punktirt, mit matt seidig schimmerndem Zwischengrunde. Die Farbe trüb roth, auf der Mitte, ein breiter rundlicher, Yorder- und Hinterrand berührender schwärzlicher Scheibenfleck, welcher sich bei nicht vollständig ausgefärlıten Stücken zu einem trüb bräunlichen Wische verwässert, während er anderseits zuweilen einen ins Dunkelgrünliche fallenden Schimmer zeigt. Das Schildehen dreieckig, etwas länger als breit, hinterwärts nur sehwach ansteigend, äusserst fein punktirt und wenig glänzend, schwarz. Die Deckschilde vorn etwas breiter als das Halsschild, hinterwärts noch etwas erweitert und dann fast geradlinig verschmälert, mit kurz zugerundeter Spitze; die Wurzel breit und flach aufgewulstet, dahinter durch die tief eingegrabenen Vorderenden der Punktstreilen quer eingedrïckt, um die Schildchenspitze buckelig erhöht und von da ab allseitig in stark gekrümmten Bogen abfallend, linter den kräftigen Schulterbeulen etwas zusammengedrückt, mit breit lierabgezogenen Seitenlappen. Die Punktstreifen aus tiefen Vorderenden bald sich abschwächend, die mittleren oft schon vor der Vlitte erlosclıen, auf der Wölhung alle wie abgeschliffen, und nur die den 9ten aufnehmende, seichte Furche bis zur Spitze bemerkbar. Die Zwischenräume flach mit schwachem Seidenschimmer, nur der 9te etwas aufgewölbt. Die Farbe schwar', 
manchnal besonders hinterwärts ins Bräunliche, Bläuliche oder Grünliche überspielend; das Pygidium zerstreut- aber ziemlich grob und nicht tief punktirt, mit matt narhigem Zwischengrunde; die Farbe, wie die der runzlig pumktirten Unterseite, schwarz. Die Vorderbrust trïb roth, runzlig punktirt, fast um die Hälfte breiter wie lang, hinten in einem sehr flachen Bogen ausgeschnitten. Die Beine trüb roth, nur bei nichıt völlig ausgefärbten Stücken hell rothgelb, die verdickten Schenkelenden und die Hinterschienen manchmal, besonder's bei den $\delta$ schwärzlich angelaufen. Das letzte Segment des ơ mit einem seichten rundlichen Eindruck, das $f$ mit einer stärkeren, gleichfalls rundlichen Grube.

Von Pernambuco (Mus. Deyrolle).

10. M. orbicularis m. Schwarzgrün, die Fühlerwurzehn und das deutlich punktirte Halsschild ziegelroth mit einem länglichen schwarzen Scheibenflecke des letzteren; die Punktstreifen mässig, hinten etwas feiner, der 8te und 9te vertieft, mit flachen, glänzenden Zwischenräumen. L. $4 / 5{ }^{\prime \prime}$; Br. $7 / 12{ }^{\prime \prime}$.

Von dem kurzen, gedrungenen Bau des M. scrobiculatus, in der Färbung mehr dem vorhergehenden ähnlich, und von letzlerem hauptsächlich durch die viel deutlichere Punktirung von Halsschild und Deckschilden, sowie durch die abweichende Färbung von Kopf und Beinen verschieden. Der Kopf flach, schwarzllau, mit wenig eingezogenem Kopfschilde, die Augen gestreckt, mässig ausgebuchtet, die Fühler bis zum hinteren Rande des Halsschilıles reichend, die unteren Glieder dunkel ziegelroth, ins Bräunliche fallend, mit schwarzer Keule. Das Halsschild ron der Wurzel al, sanft nach vorn übergekrümmt, über den rechtwinkligen Vorderecken leicht zusammengedrückt und dadurch verschmilert; die fein gerandeten Seiten nach voru in flachın Bogen convergirend, linterwärts ein wenig ausgeschweift; die Ilinterecken spitz dreicckig vorgezogen, der Hinterrant jederseits nur schwach ausgebnchtet, mit kurzen, breiten, fast geradem Vittelzipfel. Die Oberfläche fein aber deutlich und dicht punktirt, mit mässig glänzendem Zwischengrunde, vor dem Hiuterrande die gewöhnliche Reihe grölırer Punlite. Die Farbe roth, auf der Mitte ein halbeiförmiger schwarzer Längsfleck, welcher mit seinem Vorderrande den mittlerm Theil rom Vorderrande des Ilalsschildes eimimmt, mit schmalem Querwische bis zu den Vorderecken überfliesst, und sich anch hinterwärts, jedoch so dass hier der röthliche Grund noch durchscheint, bis zum Mittel- 
zipfel fortsetzt. Das Schildchen um die Hälfte länger als breil, mässig ansteigend, glänzend schwarzgrün. Die Deckschilde fast so breit als lang, linter den Schultern noch etwas verbreitert und dann in breiten Bogen sich verschmälernd, so dass der Körper einen kurz und breit verkehrt eiförmigen Umriss erhält; die Wurzel seicht quer niedergedrückt, der Rücken um die Schiluchenspitze breit und flach anfgebuckelt und von da nach der etwas stärker gekrümmten Wölbung zu allmählich abfallend, die Schulterbenlen gross, aber nicht sehr hervortretend, anch die Seitenlappen fast nur an dem selır breit umgeschlagenen Rande bemerkbar. Die Punktstreifen regelmissig, vorı deutlich, von der Mitte ab schwächer, aber doch bis zur Spitze hin kenntlich; der 8te und noch mehr der 9 te in eine leichte Furche eingedrückt. Dic Zwischenräume flach, nur die Vorderenden der oberen und der 9te leicht emporgewölbt. Pygidium, Unterseite und Beine schwarz; die Vorderbrust quadratisch mit kräftig aufgetriebenen Seitenleisten, hinten in breitem Bogen ausgeschnitten. Das letzte Segment des $q$ mit einem rundlichen, nicht sehr tiefen Grülschen, das $\delta$ unbekannt.

Von Caraccas (Mus. Berol., von Mlloritz gesammelt).

$\mathrm{Z}$ weite Rotte. Körper meist klein, eiförmig, schwärzlich mit metallisch blauen oder grünlichen Deckschilden; das Halsschild hinten olne deutliche Querfurche, hell rothgelb, zuweilen schwarz gezeichnet oder auch ganz geschwärzt, auch die Deckschilde zuweilen röthlich gefleckt.

11. M. melanospilus m. Schwarzgrün, Fühlerwurzeln, Pygidium und letzter Bauchring, sowie das Halsschild roth mit einem schwarzen schildförmigen Vorderflecke des letzteren; die Punktstreifen fein, bald hinter der Wurzel verschwindend, der 9te etwas vertieft, mit flachen wenig glänzenden Zwischenräumen. L. $11 \%{ }^{\prime \prime \prime} ; \mathrm{Br} .3 / 4 "$.

Ein grosser, schöner Käfer von etwas mehr gestrecktem Umrisse als die vorhergehenden Arten, durch seine Färbung dieselben mit den nächstfolgenden verbindend, besonders durch die gegen den ganzen übrigen Hinterkörper sehr abstechende Färbung des Pygidiuns ausgezeichnet. Her Kopf flach, das Kopfschild kurz und breit, oberwärts kaumn verschmälert, und daselbst durch einen schwachen Querwulst, seitlich durch deutlich eingeşchnittene Längslinien abgesetzt; der untere Theil der Stirn zwischen den Augenbuchten seicht quer eingedrückt. Die Oberfläche matt schwarz- 
grüulich, die ziemlich gestreckten, tief dreieckig ausgebuchteten Augen schwarz. Oberlippe und Hundtheile schmutzig gelb. Die Fühler des einzigen vorliegenden Stückes unvollständig, das 2te Glied birnförmig, dreimal kürzer ahıer kaum schnı̈ler als das erste, die drei folgendeı je so lang als das zweite, gestreckt-verkehrtkegelförnig, das 5te oberwärts schon etwas verbreitert, die noch rorhandenen Glieder der Keule nach innen breit dreieckig ausgezogen und deutliclı zusammengedrückt. Die Farbe der unteren Glieder durchscheinend rothgelb mit gebräunter Spitze des 5ten, die der Keule leicht geschwärzt. Das Hajsschild fasi von der Wurzel ab in flachem Bogen mach vorn übergekrümmi, über den scharfen fast rechtwinkligen Vorderecken dicht hinter dem etwas erhöhten Vorderıande sclmmal quer zusammengedrückt und dadurch verschmälert; die Seiten fein gerandet, von der Mitte ab uach vorn in sauften Bogen zusammengekrümms; die Hintereckeı kurz und scharf spitzwinklig vorgezogen, der llinterrand jederseits breit ausgebuchtel, der Mittelzipfel breit, undeutlich ausgerandet, vor ihm jederseits eiı kurzes Läıgsgrübcheı, und zwischen beiden vor der Mitte des Hinterrandes der gewölnnliche etwas gelirümmte mii gröberen Punkten besetzte seichte Quereindruck. Die Oberfläche matı und ohne sichthare Punktirung, hellroth mit fein schwarzem Samme des Hinterrandes; diese letztere Färbung, aber mit einem Stich ins Grünliche, zeigt auch ein halb eiförmiger Vurlerfleck, welcher vom Vorderrande ab hinterwärts bis über die Mitte des Halsschildes hinausreicht, vorn bis zu den Vorderecken überlliesst, und in seiner grössten Breite nicht die ganze mittlere IIälfte des IIalsschildes einnimmt. Das Schildchen dreieckig, etwa um $1 / 4$ länger als breit, schwach ansteigenu, gleichfalls schwarzgrüı. Die Deckschilde nicht breiter als der Ilinterrand des llalsschildes, mit leichter hirümmung hinterwärts verschmälert und danı Jn'eit zugrrundet, an der schildchenspitze buckelig erhüht und von da ab seitlich ziemlich steil-, naclı der Spitze hin samfter abfallend, die Naht auf der Wöllung eingedrückt und breit lilaflend. Hinter der Wurzel jederseits ein breiter, flacher, his' zu den breit hückerigen Schulterbenlen reichender und sich lier dreieckig nach hinten erweiternder Quereindruck; die Seitenlapjen lirältig mit sehr breit ungeschlagenem Rande. Die Punlitstreilen schr regehnassig, äusserst fein und rom Eude des ersteı Drittels al, nur noch bei sehr starker Vergrösserung erkemulrar, der ate in eine schwache Furche eingedrückt, welche 
auch nach dem Verschwinden der Punkte noch kenntlich bleibt; die durch den Randstreifen selbst gebildete Furche um die Spitze herum noch bis zur Wölbung hinauf zu verfolgen. Die Zwischenräume flach, nur der neunte leicht erhöht; die Oberfläche schwach seidenschimmernd, dunkel schwarzgrüı. Das Pygidiım dicht und fein punktirt, mit dem letzten Bauchringe und den umgeschlagenen Halsschildsseiten hochroth; der übrige Theil der Unterseite nebst den Beinen schwarz mit metallisch grünlichem Glanze der letzteren, die Schenkelwurzeh und die quer aufgetriebene slitte der grob zerstreut punktirten, hinten nur flach ausgebuchteten Vorderlrust tief gebräunt. Das letzte Segment des $q$ mit einer elliptischen, stark glänzenden, und im Innerı geschwärzten Längsgrube; das of unbekannt.

Von Caraccas (Mus. Ber., von Moritz gesammelt).

12. M. peltasta m. Blau oder grünlich, Füllerwurzeln und Vorderbeine sowie das Halsschild hellrothgelb, ein schildförmiger Vorderfleck des letzleru und der Kopf schwärzlich; die Punlitstreifen fein, hinten verschwindend, der neunte vorn vertieft, mit flachen, glänzenden Zwischenräumen. L. 3/4"'; Br. 1/2"'.

Dem vorhergehenden sehr ähnlich, und von ihm hauptsächlich durch die viel geringere Grösse, die deutlicher metallischblaue oder ins Grünliche fallende Färbung und die etwas deutlicheren Punktstreifen bei einfarbigem Unterleibe verschieden, so dass es hier nur einer genaueren Angabe der Alwweichungen von der genannten Art bedürfen wird. Er ist nicht allein merklich kürzer, sondern auch verhältnissmässig breiter und gedrungener, mit stärker heraustretenden Schultern; das Rothgelb der Fühlerwurzeln und des Halsschildes bleicher, mehr ins Gelbe fallend, der ganze liopf tief schwarzbraun, und dieselbe Färbung zeigt der auf der Hitte der vordern Halsșchildshälfte liegende schild- oder halbeiförmige Fleck, welcher olne seitlich sich bis zu den Vorderecken auszudehnen, nur die Mitte des Vorderrandes eimnimmt, während sein hinterer Bogen über die Mitte der Halsschildslänge hinausreicht, und danı noch eine bräunliche verwaschene Längslinie bis zum Mittelzipfel sich forterstreckt. Die Vorderenden der Punktstreifen entspringen aus kurzen, tiefen Längsgrübchen, und die Streifen selbst sind deutlicher als bei M. melanospilus, auch bis über die Mitte hinaus zu verfolgen; die Furche des neunten ist merklich breiter, wenn auch linterwärts sehr verflacht. Pygidimm XV. 
und Unterseite schwarz; der letzte Bauchring bei einem der vorliegenden Stücke tief verwaschen gebräunt, die Vorderbeine bei deuselben Stücke fast gelblich, während sie bei normaler Färbung nur ins Pechbraune fallen. Das Prosternum sehr kurz, in der Mitte quer eingedrückt, das letzte Segment des $q$ mit einer tielen, elliptischen Grube. Ilas ơ unbekannt.

Aus Brasilien (Mus. Haag; Deyrolle; nach Letzterem bei Rio de Jan. gelunden).

13. II. furcifer m. Schwar'z, Kopf und Fühlerwurzeln, Vorder- und Mittelhrust, sowie das Halsschild rothgelb mit einem schwarzen, hinterwärts zweitheiligen Längsflecke des letzteren; die Punktstreifen fein, von der Mitte ab verloschen, der neunte vertieft, mit flachen glänzenden Zwischenrämmen. L. $3 / 4 " \prime$; Br. $1 / 2{ }^{\prime \prime \prime}$.

Eine kleine, zierliche, bei alter Aehnlichkeit mil der vorhergehenden doch durch die eigenthümliche Zeichnung des Halsschildes, sowie durch die bellrothe Färbung von Vorder- und Mittelbrust. wohl mnterschiedene Art. Der Kopf flach gewöllıt, mit unten leicht eingezogenem, aber undeutlich abgesetztem liopfschilde, matt rothgelh, die ziemlich langgestreckten, nur schmal ausgebuchteten Augen greis. Die Fühler nach den bei dem einzigen mir rorliegenden Stïcke vorlandenen Resten nicht ron denen der vorhergehenden Arten abweichend, die unteren Glieder rothgell, die der Ḱeule schwarz. Das Halsschild von der Wurzel aus abwärts gekrümmt, über den scharf rechtwinkligen Vorderecken stark zusammengedrückt und dadurch verschmälert, die Seiten fein gerandet, in breiten Bogen nach rorn zusammengeneigt, hinter der Mitte leicht. ausgeschweilt, mit breit und scharf vorgezogenen Hinterecken; der Ilinterrand jederseits breit ausgebuchtet, scharf gesägt, mit undentlich ausgerandetem, fast grade algestutztem Mittelzipfel. Die Oberfläche matt und ohne sichtbare Punktirung, nur der flinterrand von der gewölnnlichen Rrihe gröberer Punkte begleitet. Die Farbe rothgelb, ein feiner Saum der Bänder, und ein vorn die Mitte des Vorderrandes einnehmender, linterwärts bis über die Mlitte hinausreichender, und ron hinten her nit etwas auseinander stehenden Zipfeln fast bis zur Hällte gespaltener Lïngsfleck schwarz. Das Schildchen gleichseitig-dreieckig, glänzend schwarz. Die Deckschilde kaum länger als vorn breit, ron der Schildchenspitze an hinterwärts allnählich abwärıs gekrümmt, linter dem zientich treiten Wurzelrande durch die etwas tiefer eingegra- 
benen Vorderenden der Punktstreilen leicht quer niedergedrückt, die Schultejbeulen breit und schr flach, die Seitenlappen dagegen stark herabgezogen. Die Punktstreifen sehr regelnı̈ssig, vorn deutlich, und die zwischen Schildchen und Schulterbenlen liegenden aus den erwähnten längsgrubigen Vertiefungen entspringend, von der Mitte ab allmählich erlöschend, der neunte besonders auf der vordern Hälfte elwas vertieft. Die Zwischenräıme flaclı, der änsserste leicht gewölht, die Farbe schwarz mit mässigem Glanze. Pygidium, Unterseite und Beine gleichfalls schwarz, nur die Vorder- und Mittelbrust glänzend rothgelb, die erstere hinten in breitem Bogen ausgerandet.

Von Para (Mus. Baly, und hier mit dem Namen M. flavicollis Dej. bezeichnet, welchen ich seiner Widersinnigkeit wegen nicht beibehalten habe).

14. M. variabilis Blanch. Metallisch schwarzgrün onler schwarzblau, die Fühlerwurzeln und eiı breiter Rand des äusser'st fein punktirten Halsschildes roth; die Punktstreifen fein, hinten fast erloschen, der achte und nemute vertieft, mit flachen mässig glänzenden Zwischenräumen. J. 11/12 -1 1/4"'; Br. 1/2-5/6"'.

Monachus variabilis Blanchord in Goy historia fisica y polit. de Chile. V. S. 541., und im Atlas Zool. Ent. Coleopt. lam. 31. fig. 10. wo aber die Begránzung des Halsschildsflecks virl zu scharf dargestellt ist. - M. rubrosignalus Stăl Till Kännedomen elc. in der ofversichl elc. P. 61. no. 9 !

Etwas grösser als die nächsı vorhergehenden Arten, hesonders flacher, hinterwärts noch weniger verschmälert, auch die Oberlläche von geringerem Glanze. Der Kopf flach, das Kopfschild olen durch ein paar flache Querlöcker abgesetzt, unten wenig eingezogen, die Oberfläche matt schwarzgrün, ohne deutliche Punktirung; Oberlippe und Mundheile pechbräunlich, die tief ausgeluchteten Ángen schwarz. Die Fühler kurz und deu Hinterrand des Halsschildes nicht erreichınd, das zweite Glied doppe]t breiter aber niclıt kürzer als die drei folgenden. Die Farbe der unteren trüb rothgell, die oheren schwarz mit dünner greiser Behaarung. Das Halsschild doppelt breiter als lang, mil 3/4 seiner Länge vorn sanft abwärts gekrümmt, über den scharf rechtwinkligen Vorderecken zusammengedrückl und darlurch verschmälert; die Seiten lein gerandet, von der Yitte ab in flachen Bogen zusammengeneigt, hinter ihr leicht ausgeschweift, mit kurzen, scharf spitz- 
winkligen Hinterecken; der Ilinterrand jederseits breit ausgebuchtet und etwas eingesenkt, mit fast grade alogestutztem Mittelzipfel. Die Oberfläche äusserst fein und zerstrent punktirt, mit glänzendem Zwischengrunde; die Farbe bei den vorliegenden Stücken eigentlich ziegelroth, auf der Nitte mit einem breiten, verwaschen hegränzten schwarzen, zuweilen in zwei vereinzelte Punkte zerrissenen Querflecke; Blanchard a. a. 0. gedenlit jedoch auch einer Abänderung mit ganz schwarzem Halsschille, die mir his jetzt nicht zu Gesichte gekummen ist. Das Schildchen fast doppelt lïnger wie breit, spitzdreieckig und wenig ansteigend, schwarzgrün. Die Deckschilde etwa so lang als vorn breit, hinter der Wurzel noch etwas erweitert und dam in breiten Bogen siclı verschmälernd; der Rücken hinten am Schildchen leicht buckelig aufgetrieben, sonst aber nur flach gewölbt, und hinterwärts sehr sanft abfallend; die Wurzel etwas nach vorn niedergedrückt, die llachen Schulterbeulen innerseits kaum abgesetzt, und auch die Seitenlappen nu' schwach angedeutet. Die Punktstreifen sehr regeImässig, fein und aus ziemlich vereinzelten Punkten gebildet, von der Mlitte ab allmählich erlöschend, der achte und noch mehr der neunte als seichte Furchıen eingedrückt. Die Zwischenrăıme flach, nach den Seiten hiı selı schwach aufgewölht, mit rorı mässigem, linterwärts sich immer mehr abschwächenden Glanze. Die Farhe, wie die des ülnrigen Körper's, schwarzgrün oder schwarzblau; bei einer Abänderung

$\beta$. zeigt sich ein rerwaschen begränzter, innerseits dreieckigverschmälerter ziegelrother Querfleck hinter der Schulterbenle, welcher nach aussen den ganzen Seitenlappen einschliesst, ınd auf dessen umgeschlagenem Rande bis zur Schulterbeule, mit seinem Innenende bis zum dritten Punktstreifen reicht. Bl. a. a. O. var. b. und, weun zugleich der IIalsschildsfleck in zwei Punkte aufgelöst ist, die von Stă a. a. O. heschriebene Form. Pygidium und Unterseite fein punktirt, mit den beinen schwarzgrün, die Schienenenden und Fussglieder bei den nir rorliegemlen Stücken der var. $\beta$. liuchsigbraun. Die Vorderbrust deutlich pmuktirt, lackglänzend, in der Hitte quer eingedrückt, hinten hreit ausgerandet; das letzte Segment des $\delta$ in der Mitte leicht abgellacht, bei dem $q$ mit einer mässig tielen, spiegelglatten Grube.

Aus Chile (von Deyrolle mitgetheilt). Ebendaher auch im Mlus. ilolm., vou suhlberg stanmend, vorlanden. 
Blanchard a. a. 0. nenul die Deckschilde in der Diagnose , haud

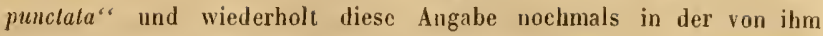
beigefiigten Beschreibung: jedenfalls aber liegt ibr ejne Ungenauigkeil zum Grunde, da Nonachen ohne Punktstreifen bis dahin uicht bekannt geworden sind, und die Abhildung solehe auch ausdrücklich angibt. Als Fundort nenıt $\mathrm{Bl}$. Santa Rosa und die niederen Cordilleras bei Coquimbo, als Futterpflanze dic ,Alfalfa", eine Pflanze, deren Namen in den Wörterbüchern durch ,,spanischer Klec ${ }^{66}$ wiedergegeben wird, deren systematisehe Bencunung ich jedoch nicht bahe ermilteln können.

15. M. gemellus m. Schwarzgrün, Kopf, Füllerwurzeln, Vorderbeine und Halsschild roth mit zwei schwarzen Flecken des letztern; die Punktstreifen dentlich, hinterwärts etwas schwächer, der neunte vertieft, mit flaclıgewölbten, glänzenden Zwischenräumen. L. $3 / 4-1 \frac{1}{4}{ }^{\prime \prime \prime} ;$ Br. $1 / 2-3 / 4{ }^{\prime \prime \prime}$.

Eine anscheinend weit verbreitete Art, deren Stücke aus Surinam und Brasilien jedoch lieine Merkmale zu weiterer Unterscheidung darbieten. Der Kopf flach, mit etwas niedergedrücktem, oben durch eine feine Bogenlinie abgegränztem Kopfschilde, glatt, aber nicht glänzend, eiıfarhig ziegelrotlı mit gebräunten Mundtheilen, die schmal aber tief dreieckig ausgebuchteten, oberwärts ziemlich genäherten Augen greis. Die Fühler liurz und kräftig, das Wurzelglied schlank keulenförmig, fast dreimal länger als breit, wenig nach aussen gekrümmt, das zweite bei fast gleicher Breite doch dreimal kürzer, fast kugelig, die drei folgenden verkehrt kegelfürmig mit etwas verbreiterter Spitze des fünften, das dritte und fünfte je an Länge dem zweiten gleich aber schınäler, das vierte un die Hälfte kürzer; die sechs oberen stark zusammengedrückt und innerseits erweitert, mit kurzem Fortsatze des Endgliedes. Die fünf unteren Glieder gelb mit gebräunter Spitze des fünften und einem schmalen schıärzlichen Läugswische auf dem ersten Gliede, die Keule schwarz, in gewölnnlicher Weise angedrückt behaart und abstehend gewimpert. Das Halsschild um die Hälfte breiter als lang, hinten leicht quer niedergedrückt, vorn mit $2 / 3$ seiner Länge stark abwärts gekrümmt, über den scharf rechtwinkligen Vorderecken etwas zusammengedrückt und dadurch verschmälert; die fein gerandeten Seiten von der Mitte ab nach vorn zusammengekrümmt, hinter ilır leicht ausgesclıweift, mit spitzvorgezogenen, durch einen seichten Schrägeindruck etwas aufgetriebenen IInterechen; der Ilinterrand jederseits nur schwach 
ausgebuchtet, mit kurzem undeutlich doppelt ausgerandetem Mittelzipfel. Die Oherfläche durch eine überaus feine runzlige Pınktirung matt, mit schwachseidigem Schimmer; läıgs dem Hinterrande die gewöhnliche Querreihe etwas grösserer in die Länge gezogener Punkte. Die Farbe ziegehroth, der Hinterrand schmal schwärzlich gesäumt, und vor der Mitte neben einander ein paar grössere schwärzliche, zuweilen verwaschene oder zu dunkeln Schatten verschwindende Längsflecke. Das Schildchen gestreckt-dreieckig, doppelt länger als breit, mit etwas ausgeschweiften Seiten hinterwärts verschmälert; wenig ansteigend, schwarzgrün mit mässigem Glanze. Die Deckschilde vorn etwas breiter als das Halsschild, hinterwärts noch etwas erweitert, und damn in weiten, die Spitze kurz zurundendeıl Bogen verschmälert; die Wurzel hinter dem breiten, flachen Wurzelrande dureh die tief eingegrabenen Vorderenden der Punktstreifen quer eingedrückt und dann wierler etwas wulstig ansteigend; der Rücken un die Schildchenspitze bucklig erhöht und von da seitlich steiler, hinterwärts flacher abfallend, mit kurz abwärts gekrümmter Wölbung. Die Schulterbeulen breit und flach, und auch die Seitenlappen wenig entwickelt. Die Punktstreifen deutlich, vorn kräftig, hinterwärts besonders die ınittlerẹn abgeschwächt, aber auch diese bis zur Wölbung erkennbar, der neunte in eine stärkere, unter der Wölbung verlaufende Furche eingedrückt. Die Zwischenräume sehr llach gewölbt, der äusserste etwas stårker erhöht, die Farbe schwarzgrün mit manchmal ins Bläuliche oder Purpurfarbige himüberspielendem Sehimmer und mässigem Glanze. Pygidiun und Unterseite runzlig punktirt, schwarz; die Beine roth mit gebräunten Hinterschenkeln. Die Vorderbrust breiter als lang, die Mitte quer aufgewulstet und dahinter eingedrückt, der Hinterrand stark hogig ausgeschnitten. Das letzte Segment des $\delta$ einfach, des $q$ mit der gewölnulichen, hier ziemlich grossen aber nicht sehr tiefen Grube.

Aus Surinam (Mus. Schaum. Felix; die Stücke des letztern von Deulschbein gesammelt) und Brasilien (Mus. Ilaag. Deyrolle, in letzterem näher Bahia als Heimath angegeben; anch von Tejuca: Mus. Clark. Bei dem letztern Stück ist der Kopf mit der Mittelbrust schivirzlich; den Uehergang bildet das Stück im Vus. Haag, bei welchem nur der Unterkopf rothgelb ist und die Farbe sich je weiter nach oben, desto melır zum Bräunlichen verdunkelt. 16. M. semicyaneus m. Stahllblau, Kopf, Fühlerwur- 
zeln, Halsschild und Beine rothgelb, Hintẹrbrust und Itinterleib schwarz, die Punktstreifen fein, der neunte vertieft, mit flachen, glänzenden Zwischenräumen. L. $3 / 4-1^{\prime \prime \prime} ;$ Br. $1 / 2-2 / 3{ }^{\prime \prime \prime}$.

Dem in den Sammlungen häufigern MI. bicolor Fab. nahe verwandt, aber, wenn man ausgefärbte Stücke volı beiden vor sich hat, an der hellen Färbung am Kopfschild und an den Beinen, den rein stahlblauen Deckschilden und den gleichmässigeren Punktstreifen leicht kenntlich. Der Kopf flach, mit unten wenig eingezogenem Kopfschilde, ohne deutliche Punktirung; die Tasterenden leicht gebräunt, die schımal aber tief dreieckig ausgebuchteten, langgestreckten und oben bei dem $\delta$ stärker, dem of nur mässig zusammengeneigten Augen schwarz. Die Fühler über den Hinterrand des Halsschildes hinausreichend, unten hellgelb mit kräftiger schwarzer Keule. Das Halssehild hinten etwas eingesenkt, hinter der Mitte quer aufgewölbt und von da mit $3 / 4$ seiner Länge nach vorn abwärts gekrümmt, über den scharf rechtwị̣kligen Vorderecken zusammengedrückt und dadurch verschmälert; die fein gerandeten Seiten nach vorn in flachen Bogen zusammengeneigt, die Hinterecken scharf, mässig vorgezogen, der Hinterrand jederseits leicht ausgebuchtet, mit kurzem, grade abgestutztem Mittelzipfel. Die Oberfläche hell rothgelb, matt und ohne sichtbare Punktirung, die eingedrückte Querlinie vor dem zart schwarz gesäumten Hinterrande mit der darin stehenden Punktreihe bei dem (grösseren) $q$ deutlicher als bei dem $\delta$. Das Schildchen um die Hälfte länger als hreit, sehr schräg ansteigend, glänzend stahlblau. Die Deckschilde hiuter den Schultern noch etwas verbreitert, dann hinterwärts mit weiter hrümmung verschmälert und kurz zugerundet, hinter der scharf erhöhten Wurzelkante tief quer eingedrückt, dann deutlich aufgebuchtet, und dieser Wulst an die buckelige Erhöhung des Rückens um die Schildchenspitze sich anschliessend, von wo aus derselbe nach der Spitze zu sehr sanft abfällt. Die Schulterbeulen eckig hervortretend, die Seitenlappen schwach mit ziemlich breitem, umgeschlagenem Rande. Die Punktstreifen fein aber doch deutlich, bei dem $q$ schwächer als bei dem $\delta$, hinterwärts noch mehr abgeschwächt, aber wenigstens hei dem $\delta$ niemals ganz ver'schwindend, der neunte in eine leichte Furche eingedrückt, die Zwischenräume flach und ziemlich glänzend; die Farbe ein schönes, reines Stahlblau, heller und glänzender als bei der folgenden Art. Pygidium, Hinterbrust und Hinterleib schwarz; Vorder- und Mittelbrust 
nebst den Beinen rothgelb mit geschwärzten Hintertarsen, erstere dabei grob gerunzelt, leicht quer niedergedrückt, hinten tief ausgerandet. Das letzte Segment des $\delta$ leicht niedergedrückt, des $q$ mit dem gewöhnlichen Grübchen.

Aus Brasilien (von Conslancia: Mus. Clark; von Rio de Jan.: Mus. Berol., von v. Olfers gesammelt; ohne nähere Angabe des Fundorts im Mus. Holm. Deyrolle).

17. M. bicolor Fab. Dunkelstahlblau oder schivarzblau, Fühlerwurzeln und Halsschild rothgelb mit schmutzigbräunlichen Beinen; die Punktstreifen fein, hinterwärts schwächer, der nemnte vertieft, mit flachen wenig glänzenden Zwischenräumen. L. $5 / 6$ bis $1^{\prime \prime \prime} ;$ Br. $2 / 3-3 / 4 "$.

Clythra bicolor Fab. Syst. Eleuth. II. 40 n. 55! vergl. Ent. Zeit. 1852.

\section{S. 217.}

Ein anscheinend in Brasilien keineswegs seltener, in den meisten mir vorliegenden Sammlungen vertretener Käfer. Der Kopf flach mit abgekürzter, äusserst fein eingeschnittener Stirnlinie und wenigg eingezogenem Kopfschilde, die Oberfläche matt, sehr fein und zerstreut punktirt, trüb schwarzblau, die Fühlerhöcker und der untere Theil des Kopfschildes eben so trüb und verwaschen bräunlich durchscheinend, welche Färbung sich bei schlecht ausgefärbten Stücken melır oder weniger auch über den oleren Theil des Kopfes ausdehnt. Die Mundtheile nebst den Rändern der Oberlippe braungelb; die langgestreckten, liurz und tief ausgerandeten, oben etwas zusammengeneigten Augen schwarz. Die Fühler kaum über den Hinterrand des Halsschildes hinausreicliend, von dem Bau der verwandten Arten; das Wurzelglied schlank und gestreckt, wenig verdickt und gebogen, das zweite kurz und breit eiförmig, fast dreimal kürzer aber kaum schmäler als das erste, das dritte un die Hälfte länger als das zweite, aber merklich dünner, stielrund, die beiden folgenden an Länge dem zweiten gleich, das fünfte oberwärts schon etwas rerbreitert, die Glierler der Keule von gleicher Länge und Breite, innerseits stark dreieckig erweitert mit abgerundeten oberen Ecken, mit wenig bemerkbarem Fortsatze des Endgliedes. Die Farbe der fünt unteren Glieder ein trübes aber glänzendes Rotlıgelb, die Keule schwarz mit angedrückter dünner greiser Behaarung. Das Ilalsschild kurz und breit, hinten leicht abgeflacht und mit $2 / 3$ seiner Länge nach vorn abwïrts gekrümmt, durch die tief eingezogenen 
scharf rechtwinkligen Vorderecken merklich verschmälert, die fein gerandeten Seiten nach vorn fast in geraden Linien zusammengeneigt, die gleichfalls scharfen und fast rechtwinkligen Hinterecken wenig vorgezogen, der Hinterrand jederseits breit und sehr seicht ausgebuchtet, mit kurzem undeutlich ausgerandetem Mittelzipfel. Vor demselben längs dem Hinterraude ein abgekürzter, zuweilen unterbrochener schmaler Quereindruck. Die Oberfläche wenig glänzend, hellrothgelb mit verwaschen schrwarz gesäumtem Hinterrande. Das Schildchen gestreckt-dreieckig, mit deutlichem Vordergrühchen, wenig ansteigend, schwarzblau. Die Deckschilde vorn etwas breiter als das Halsschild und mit abgerundeten Seiten hinterwärts verschmälert, fast so breit als lang, hinter dem etwas aufgeworfenen Wurzelrande quer eingedrückt und dann wieder wulstig ansteigend, um die Spitze des Schildchens buckelig erhöht und von da ab seitlich und hinterwärts sehr schräg abfallend, hinter den breit eckig hervortretenden Schulterbeulen stark zusammengedrückt und dadurch die Seitenlappen tief hinabgeschohen. Die Punktstreifen sehr regelmässig, fein, mit deutlichen Vorderenden aus dem vordern Quereindruck entsplringend oder vielmehr den letztern dadurch erzeugend, von der Nitte ab merklich feiner, und zuletzt, zumal bei dem $q$, fast erloschen, nur der neunte leicht vertieft bis zur Spitze kenntlich. Die Zwischenrïume flach, der äusserste sehr schwach gewölbt, die Farbe ein ziemlich mattes nur an den Seiten gewöhnlich etwas stärker glänzendes dunkles Stahlblau odèr Schwarzblau, welches bei schlecht ausgefärbten Stücken besonders gegen die:Spitze hin röthlich durchscheint. Pygidium und Unterseite fein runzlig punktirt, schwarz, Vorder- und Mittelbrust nebst den umgeschlagenen Rändern des Halsschilds hellrothgelb, die Beine schmutzig braungelb mit dunkel angelaufenen Schenkeln, die je weiter hinterwärts desto mehr ins Schwarzbläuliche überschimmern; auch die hinteren Schienen nehmen oft mehr oder weniger an dieser Verdunkelung Theil. Die Vorderbrust flach, runzlig punktirt, längs den scharf erhabenen Seitenkanten der Länge nach etwas eingedrückt und hinten in breitem Bogen ausgeschnitten. Das letzte Segment des $\delta$ flach eingedrückt, des $q$ mit einer eiförmigen glänzenden Grube.

Aus Brasilien (von Constancia: Mus. Clark; olne nähere Angabe der Heimath im Mus. Fab. Hal. Berol. Schaum. Haag. Baly. Ein einzelnes Stück im Mus. Holm. (gleichfalls aus Brasilien 
und von Ferd. Sahlberg gesammelt) scheint durch sehr fein gerunzeltes Halsschild und etwas stärkere Punktstreifen abzuweichen; ich halte jedoch dies, bevor nicht mehrere gleiche Stücke gefunden werden, nicht ausreichend, darạuf eine neue Art zu begründen.

Ansser der Beschaffenheit der Punktstrifen, deren Vorder- und Hinterenden bei der vorliegenden Art an Stärke mehr von einander verschieden sind als bei der vorhergehenden, zeigt sich die Verschiedenheit beider hauptsächlich in der bei $M$. bicolor dunklern Färbung der Deckschilde, sowie der schwarzbläulichen Farbe von Stirn und Beinen. Fabricius sagi nun zwar a. a. 0. von seiner Clythra bicolor: "atra capite thoraceque flavis", und dies würde streng genommen mehr zu der vorhergehenden Art passen; ich habe jedoch schon in der Ent. Zeit. a. a. O. bemerkt, dass das von mir verglichene Exenplar des Mus. Fabric. unvollständig ausgefarbt ist, und seine Angabe über die bei jenen Stïck mangelhaft gebliebene Farbe des Kopfes kann daher fiu die Dentung seiner Art nicht entscheidend sein, znmal die weiteren Worte der Beschreibung: „Corpus nigrnm, femoribus imprimis anticis fulvis" entschieden auf einen Käfer mit duukeln, an den Vorderschenkeln hellbraunen Beinen hinweisen, wie sie nur bei der zuletzt beschriebenen Art zı finden sind. Dazu hatle Fabricius seinen Käfer aus dem Mus. Sehestedt erbalten, und eiu aus derselben Quelle, nämlich von Lund, herstammendes Exemplar im Mus. Berol., welches ich durch die Gefalligkeil des Hrn. Dr. Gersticker vergleichen konnte, gehört gleichfalls entschieden der vorliegenden Art an, welche sonach als die echte A. bicolor Fabr. festzuhalten ist. Uebrigens kann ich die Vermuthung nicht zurückhalten, dass der von mir in der Linn. Ent. IX aus Gr. Mannerheims Sammlung als ostsibirischer Käfer beschriebene und seitden meines Wissens nirgends wieder zum Vorschein gekommene $M$. peregrinus von der vorliegenden Art nicht verschiedeı und nur durch ein Versehen Gr. Mannerheims oder seiner Quelle irrthïmlich unter sibirische Arten gerathen ist. Ohne eine nochmalige, mir jelzt, da ich den Kafer längst zurückgegeben, nicht mehr mögliche Vergleichnng jenes von mir beschriebenen Stiickes wird sich hierüher allerdiugs keine unhedingte Gewissheit erhalten lassen.

18. MI. ha emat opygus m. Stahlblau, Kopf, Halsschild, Mittel- und Hitte der Hinterbrust mit Pygidium und Hinterleibsgrube des \& ziegelroth; die Punktstreifen fein, hinten verloschen und nur der neunte daselbst vertieft, mit flachen glänzenden Zwischenräumen. L. $1 \frac{1}{4}{ }^{\prime \prime \prime} ;$ Br. $11 / 12^{\prime \prime \prime}$.

Eine vollständige Mittelart zwischen den Monachen und der 
unten aufgeführten dritten Cryptocephalengruppe, im Habitus mehr der letztern ähnlich, aber doch nach dem Bau der Vorderbrust von Monaclsus nicht zu trennen, und in der Färbung und Farbenvertheilung zunächst dem M. semicyaneus und bicolor verwandt, wenn gleich die Besclıaffenheit des Halsschildes, abgeselsen von der fehlenden Hinterfurche desselben, den Käfer mehr in die Nähe des M. melanippus und seiner Verwandten stellen würde. Kopf und Fühler wie bei M. semicyaneus, nur die Seiten des Kopfschildes fast parallel und der ganze Kopf sammt dem Kopfsclilde von einer äusserst feinen Kiellinie durchzogen. An den Fühlern nur die beiden unteren Glieder rotligelb, die drei folgenden braun, die keule schwarz, die letztere etwas mehr gestreckt und weniger verhreitert als bei den verwandten Arten. Das Halsschild ist nur mit der vorderı Hälfte vorn stark übergewölbt, hinten breit abgeflacht, jederseits des undeutlich doppelt ausgerandeten Mittelzipfels linten leicht schräg eingedrückt, die fein gerandeten, in der Mitte leicht erweilerten Seiten von da ab nach vorn sehr stark convergirend, wodurch das über den tief eingezogenen Vorderecken sehr breit zusammengedrückte Halsschild vorn merklich verschmälert wird. Die Farbe ein dunkles spiegelglänzendes Ziegelroth. Das Schildchen mässig ansieigend, um die Hälfte länger als breit, mit deutlichem Vordergrübchen, glänzend schwarzblau, hiuter der Mitte bei gewisser Beleuchtung schwach ins Trübröthliche spielend. Die Deckschilde hinter der stark aufgetriebenen Wurzelkante durch die etwas tiefer eingegrabenen Vorderenden der Punktstreifen in einer ziemlich deutlichen Querfurche eingedrückt, mit grossen halbeiförmigen Schulterbeulen und lang herabgezogenen Seitenlappen, über welchen die Deckschilde nochmals breit zusammengedrückt sind; die Punktstreifen sehr fein, schon vor der Mitte noch mehr abgeschwächt und die mittleren auf der Wölbung verschwindend, der neunte nur erst von der Wölbung ab furchenartig vertieft. Die Zwischenräume flach, spiegelglänzend stahlblau. Auf der Unterseite sind der grössere Theil der Hinterbrust und des Hinterleibes mit den Beinen schwarzblau; roth dagegen sind ausser dem greishaarigen Pygidium die Vorder - und Mittelbrust mit den Schulterblättern; die Mitte der Hinterbrust mit allen Hüften, den Wurzelı der Vorderschenkel, den verwaschenen Vorder- und Hinterenden der Parapleuren und der zugleich das Grübchen des $q$ einschliessenden Mitte des letzten Bauchringes. 
Dahei ist die Vorderbrust um die Hälfte breiter wie lang, äusserst dicht und ziemlich fein punktirt, der Hinterrand nur flach ausgehuchtet, die Hinterleibsgrube des o ziemlich tiel, eiförmig und im Innern glänzend. Das ठ mubekannt.

Vom Amazonenstrom. Mus. Baly.

19. II. cribricollis m. Schwarz, die Fühlerwurzeln und das siebartig punktirte Halsschild roth; die Punktstreifen fein, hinten erloschen, der neunte vertieft, mit flachen, gläızenden Zwischenräumen. L. $3 / 4{ }^{\prime \prime \prime} ; \mathrm{Br}$. $2 / 3{ }^{\prime \prime \prime}$.

Von dem echten kurz eiförmigen Monachentypus, und an der Sculptur des Halsschildes sogleich von allen Arten mit einfarbig hellem Halsschilde und dunkeln Deckschilden zu unterscheiden. Der Kopf flach, das Kopfschild leicht eingezogen, die Farbe schwarz mit schwachem Seidenschimmer, der Rand der Oberlippe, die Wangen und die Nundtheile röthlich; die tief ausgebuchteten Augen oben zientich weit getrennt, gleichfalls schwarz. An den Fühlern die vier unteren Glieder ziegelroth, das fünfte röthlich oder auch etwas gebräunt, die Keule schwarz. Das IIalsschild mit der grösseren Vorderhälfte abwärts gekrümmt, auch hinterwärts etwas herabgesenlit, vorn über den stumpf rechtwinkligen Vorderecken mässig zusammengedrückt; die scharfen Hinterecken kurz und breit, fast rechtwinklig; der Hinterrand fast grade, nn jederseits des kurzen hreiten kaum ausgerandeten Mittelzi\}fels schwach ausgebuchtet und ror letzterem ein schmaler, sich jederseits linienförmig bis zu deı Hinterecken linzielıender, nit gröberen Punkten besetzter Quereindruck. Die Oberfläche matt, mit deutlicher, hinten ziemlich dicht gedrängter, nach dem Vorderrande zu allmählich sich abschwächender Punktirung; die Farbe ziegelroth. Das Schildchen selır schräg ansteigend, fast doppelt länger wie breit, mit ausgeschweiften Seiten hinten in eine schmale Spitze ausgezogen, glänzend schwarz. Die Deckschilde fast so breit wie lang, von den Schultern aus allnählich im Bogen rerschmälert und durch ilıre hintere Abrundung deı breit eiförmigen Umriss des Körpers abschliessend, von der Schildschenspitze aus nach den Seiten ziemlich steil, hinterwärts sanfter abfallend, linter dem breiten, vorn nochmals kantig erhöhten Wurzelende durch die grubigen Vorderenden der Punktstreifen in einer tiefen Querfurclie eingedrückt; die Scbulterbeulen lreit und flach, und auch die Seitenlappen nur schwach ausgebildet. Die Punktstreifen sehr 
regelmässig, hinter ihreı kräftigen Vorderenden sich bald abschwächend, die mittleren schon vor der Mitte erloschen, der neunte seiner ganzen Länge nach in eine seichte Längsfurche eingedrückt. Die mittleren Zwischenräume flach, die Vorderenden bei allen, der neunte und in schwächerer Andeutung auch die der Nahıt zunächst liegenden sehr flach gewälbt. Die Farbe schwarz mit leicht metallischem Anfluge und ziemlich starkem Glanze. Pygidium, Unterseite und Beine schwarz mil tief gebräunten Fussgliedern; Vorder- und Mittelbrust roth mit dunklerem Saume, die erstere hinten in breitem Bogen ansgeschnitten. Das letzte Segment des $q$ mit einer grossen kreisrunden Grube.

Von Ega am obern Amazonenstrome (Mlus. Baly), und aus Columbien (Mus. Berol., von Moritz gesammelt). Bei dem letzteru Exemplare fällt der Ranıl der Deckschilde hinter den Schultern und die Mitte des Schildchens verwaschen ins Röthliche, auch sind der ganze Kopf und die Vorderschenkel mit dem obern Theile der Mittelschenkel roth. Weitere Untersehiede finde ich nicht, und halte das Exemplar desshalb auch nicht für specifisch verschieden.

20. M. rebelli s m. Stahllblau, die Fühlerwurzehı, eine innerseits abgekürzte Querbinde der Flügeldecken und deren Spitze roth; die Punktstreifen fein, hinter der Mitte verschwindend, der achte und neunte seicht vertieft, mit flachen, glänzenden Zwischenräumen. L. ${ }^{5} / 6{ }^{\prime \prime} ; \mathrm{Br} .2 / 3{ }^{\prime \prime}$.

Eine höchst zierliche, bei ihrer ausgezeichneten Färbung mit keiner andern zu verwechselnde Art. Der Kopf flach gewölht mit sanft eingezogenem Koplschilde und einer äusserst fein angedeuteten Stirnlinie, matt stahlblau und ohme deutliche Punktirung; Oberlippe und Mundtheile schmutzig geröthet. Die (bei den $q$ ) weit getrennten, schmal aber tief ausgebuchteten Augen schwarz. Die Fühler von gewöhnlichem Baı, das zweite Glied sehr stark eiförmig aufgetrieben, auch die beiden letzten Glieder der Keule stärker als die vorhergehenden. Die Farbe der vier unteren hellrothgelb, dlas füıfte bräınlich, die Keule schwarz mit ziemlich dichter Behaarung. Das Halsschild fast mit seiner ganzen Länge vorn sanft herabgekrümmt, ïber den rechtwinkligen Vorderecken breit zusammengedrückt wnd dadurch stark verschmälert, die fein gerandeten Seiten fast gradlinig nach vorn convergirend, die Hinterecken kurz und breit zugespitzt, wenig ausgezogen; der Hinterrand jederseits nur leicht ausgebuchtet, mit kurzem fast grade 
abgestutztem Mittelzipfel. Vor letzterm ein deutlicher, mit beiden Enden nach vorn gekrümmter Quereindruck. Die Oberfläche matt stahlblau, ohne merkliche Punktirung. Das Schildchen schräg ansteigend, gleichseitigdreieckig mit schwachem Vordergrübchen, glänzend blau. Die Deckschilde etwas länger als breit, hinter den Schulteru noch etwas im Bogen erweitert und dann hinterwärts kurz und breit zugerundet; der Räcken ron der Spitze des Schildchens ab mit leichter Krünmung ablallend, seitlich stärker abwärts gekrümınt, und hinter der Wurzel rin breiter, durch die tiefer eingegrabenen Vorderenden der l'unktstreifen hervorgebrachter, von den Zwischenräumen schwach unterbrochener Quereindruck. Die Schulterbeuten breit und ziemlich flach. Die Seitenlappen kräftig entwichelt. Die Punktstıeilen regehnässig, ans kräftigen, grubig vertieften Vorderenden laald alogeschwächt, die mittleren schon von der Vlitte ab kaum noch bemerkbar, auch der achte und neunte nur in schwache Furchen eingedrückt. Die Zwischenräume flach und glänzend. bie Färbung stahlblau, etwas heller als das Halsschild, die Schulterbeulen ins tief Veilchenblaue fallend, die Spitze unter der Wölbun!g und eine innerseits abgekürzte Querbinde hinter der Schulterbeule hellroth. Diese Binde zieht sich rom Seitenlappen aus aufwärts, erweitert sich auf der Innenseite der Schulterbeule nach vorn und hinten, und verschmälert sich daun wieder, bis sie auf dem zweiten Zwischenraume ganz abreisst. I'ygidlium, Unterseite und Beine tiefer blau; Hüften, Schienenpndeu und Finssglieder tiel' geröthet; das Prosternum vor dem Hinterrande tief' quer eingedrückt, letzterer breit ausgeschnitten mit kıältig und scharf vortretenden Hinterenden. Das letzte Segment des? mit der gewöhnlichen hier starli gläızenden Grube, das ơ unbekannt.

Aus Brasilien (von P'etropolis: Mus. Clark).

21. M. fa sciolatus m. Stahlblau mit weissem Kopfschilde, Fühlerwurzeln, Beine und Declischilde roth, eine schmale Querbinde der letzteren mit den Schenkeln blau; die Punlitstreifen fast verschwindend, der neunte schwach rertieft, mit llachen, glänzenden Zwischenräumeı. L. $3 / 1, "$; Br. 1/2"'.

Eine durch die weisse Farbe ihres Kopfschildes ganz anomale Art. Der liopf flach, das liopfschild breit dreieckig, seitlich durch scharfe Leisten, ohen durch zwei neben einander liegende Qnergrübchen begränzt. Die Stirn äusserst lein narhig punktirt und dadurch matt; die Farbe dunlielstahlblau, Kopfschild und Wangen 
weiss, die Mundtheile mit dem unteren, in seiner Mitte bogig erweiterten Kopfschildsrande brammroth, die breit aber nicht tief ausgebuchteten, bei dem vorliegenten $\delta$ olsen weit getrenuten Augen schwarz. Die Fülıler fast von halber Körperläıge, das Wurzolglied schlank keulig, mnten stark eingeschnïrt, etwas mehr als doppelt so lang wie breit, das zweite eiförnnig, um die Hälfte länger als breit, die drei folgendeu dünn verkehrtkegelförmig, das dritte etwas länger als las zweite, das vierte und fünfte einander gleich,jenoch etwas länger als das zweite, und das fünfte oben etwas erweitert; die folgenden wiederun gleich, je noch etwas länger als das fünfte, innerseits dreieckig verbreitert und zusammengedrïcht, mit dreieckigem Fortsatze des gegen das vorhergehende noch um 1/4 verlängerten Endglieds. Die Farhe der fünf unteren Glieder hellrothgelb, die ober'en schwärzlich, durch eine dicht angedrückte Behaarung greis erscheinend. Das Halsschild nur um die Halfte breiter wie lang, hinter der Mitte cuer aufgewölbt und von da ab hinterwärts etwas eingesenkt, vor'n mit $2 / 3$ seiner Länge stark abıärts gekrünmt, über den scharf rechtwinkligen etwas pingezogenen Vorderecken zusammengedrückt und dadirch verschınälert, die Seiten fein gerandet, nach vorn in breiten Bogen zusanmengeneigt, die Hinterecken kurz und breit spitzwinklig ausgezogen, der Hinterrand jederseits breit und seicht ausgebuchtet, tief eingesenkt und vor den Schultern noch tiefer eingekniffen, mit kurzem, doppelt ansgerandetem Mittelzipfel. Die Oberfäche kaum sichtbar genarht, stalılblau mit mattem Seidenschimmer. Das Schildchen fast gleichseitigdreieckig, wenig ansteigend, mit ıleutlichem Vordergrühclıen," die Oberfläche gleichfalls stahıblau, etwas ins Grünliche fallend. Die Deckschilde schınal eiförmig, vorn nur wenig breiter als das Halsschild, hinterwärts erst dicht vor der Spitze kurz zugerundet, die Wurzel vorn leicht eingesenkt und dam ohne Quereindruck eben so Jeicht aufgewulstet, init flachen, innerseits nur durch einen schwachen, dreiseitigen Eintluck abgesetzten Schulterbeulen. Der Rücken von der Spitze des Schildchens seitwärts mit stärkerer, nach hinten mit flacher Krümmung abfallend und erst auf der Wölbung stärker abwärts gebogen; die Seitenlappen tief herabgezogen, und über ihnen die Deckschilde leicht quer zusammengedrückt.' Die Punktstreifen äusserst fein und eigentlich nur deren Vorderecken kenntlich, hinterwärts nur in vereinzelten Spuren und zun Theil nur an der dunkleren Färbung ihrer Punkte wahrnehmbar, der neunte in eiue 
leichte Furche eingedrückt; und mit dieser bis zur Spitze zu verfolgen. Die Zwischenräume flach, glatt und ziemlich glänzend, nur der neunte leicht gewölbt. Die Farbe hell rothgelb, ein feiner Saum längs Wurzel und Naht, und eine breitere auf der Wölbung liegende, in der Nitte jeder Flügellecke rorn und hinten buchtig verschmälerte Querhinde stahlblau. Das Pygidium rereinzelt grub aber nicht tief narbig punktirt, nelsst der runzligpunktirten Unterseite gleichfalls stahlblau mit rothgellsen Vor(lerzipfeln des ersten Bauchringes; auch die Beine rollı, die unteren verdickten Schenkelhälften blau überflogen. Die Vorderbrust dicht runzlig punktirt, hinterwärts erweitert und hinter der Vorderseite lejcht quer eingedrückt, mit sehr flach ausgeschnittenem Hinterrande; las letzte Segment des $\delta$ einfach, das $q$ unbekannt.

Von Caraccas (von Herm Wagner mitgetheilt).

22. M. biplagiatus Boh. Schwarzblau, die Fühlerwurzeln und eine breite Bogenbinde der Flügeldecken roth; dlas Halsschild äusserst fein narbig punktirt, die Punktstreifen fein, hinterwärts noch mehr abgeschwächt, der neunte vertieft, mit flachen selır fein rumzlig punktirten Zwischenräumen. L. $1-1 \frac{1}{1} 4^{\prime \prime \prime}$; Br. $3 / 4-5 / 6 "$.

M. biplagiatus Boh. Eugenies resa, Col. p. 156. n. 326.

In der Farbenvertheilung eine Mittelform zwischen der vorhergehendeı Art und dem $M$. coenobita, juvenilis $u$. a. Arten, im Habitus mehr den letzteren ähnlich, daher im Umriss bei etwas grösserer Länge merlilich breiter, gedrungener eiförmig, und dabei an seiner überaus einfachen Farbenvertheilung leicht zu erkennen. Der ganze Körper ist, bis aul die dunkelrothen Wurzelı der im Baı von den übrigen Arten nicht abweichenden Fühler, die Bogenbinde der Deckschilde und die röthlichen Seitenzipfel des ersten Bauchringes matıstahlblau mit äusserst feiner und zerstreuter Punktirung des Halsschildes, vor dessen Hinterrande sich eine tiefer eingedrückte Querlinie gröberer Punlite benerklich macht; das Schildchen um die IIälfte länger als breit, mit ausgeschweiften Seiten hinterwärts verschmälert und etwas stärker glänzend. Auf den Flügreldecken ist der Quereindruck hinter der Wurzel fast nur auf der Innenseite des Schildchens bemerklich, dagegen treten die geschwärzten Schulterbenlen als längliche Höcker hervor, und die Seitenlappen sind eben so tief herabgezogen als bei der vorhergehenden Art. Die Punktstreifen sind fein und werden hinterwärts noch schwächer, ohıne jıdoch auch bei dem o völlig zu 
verschwinden; der neunte ist in eine hinterwäts etwas liefere Furche eingedrüclit, und eine solche tritt, ob auch schwächer, am Hinterrande des achten hervor. Die Zwischenräume flach, feiı runzlig punktirt und dadurch besonders anf der rothen Binde matt, der nennte sehr leicht aufgewölbt. Die gemeinsame rothe Bogenbinde beginnt, die hintere Hälfte der gestreehten Schulterbeule umschliessend, auf den Schultern, reicht am Aussenrande bis über den Seitenlappen hinaus, und erstreckt sich dann, sich nach immen verschmälernd, derartig gegen die Naht hin, diss sie, von der Wurzel des Schildchens an gerechnet, das mittlere Drittel der Naht durchsetzt und hier mit der entgegengesetzten zusammentrifft. Die Vorderseite der Binde ist dadurch tiel halbkreisförmig ausgeschnitten, während ihr die Wölbung nicht ganz erreichender Hinterrand den flacheren Bogen eines grösseren Kireises zu bilden scheint. Die Vorderbrust um die llälfte länger als breit, hinten etwas verbreiter't und niedergedıückt, vereinzelt dero punktirt und in breitem Bogen ausgeschnitten; die Mittelbrust bei gleicher Breite kürzer, eng an die Vorderbrust anschliessend. Das letzte Segment des ठ’ leicht quer niedergedrückt, les of mit einer länglich elliptisclıen glänzenden Grube.

Aus Brasilien (von Allegrelto: Mus. Ber., von Sello gesanmelt; von San Leopoldo: Mus. Dohrn; ohne Angabe der Heimath im Mus. Deyrolle); von Montevideo (Mus. Holm.).

Dritte Rotte. Körper Klein, breit eiförmig, flach gewölbt, schwärzlich mit gelber Zeichnung von Halsschild und Deckschilden; das erstere hinten ohne deutliche Querfurche.

23. M. antlureniformis m. Oben gelb, der Kopf, ein Vorderfleck des Halsschildes, das Schildchen und drei Flecke der Flügeldecken $(2,1)$ mit der Unterseite trül schwarzblau; die Punktstreifen deutlich, linterwärts schwächer, der nemnte stark vertieft, mit flachen glänzenden Zwischeuräumen. L. $3 / 5-1^{\prime \prime \prime} ; \mathrm{Br}$. 1/3-1/2"'.

Die gegenwärtige und die folgende Art bilden eine ganz eigenthümlich durch ihre hellgelben Zeichnungen auf der Oherfläche ausgezeichnete Gruppe, die zwar später noch in einer andern Gruppe eine analoge Art findet, aber weder mit dieser Art, noch mit einer der ülırigen Rotten verlunden werdeu kann. Jer Kopof flach mit etwas niedergedrückten, seitlich durch eine Bogenlinie hegräuztem, oben zwischen den Fühlerwurzeln durch einen undentlichen Querwulst alıgesetztem Kopfsehilde und stark vorspringender Oberlippe. XV. 
Die Oberfläche sehr fein und zerstreut punktirt, matt stahlblau, die Mundtheile gelb, die breit dreieckig und ziemlich tief ausgehuchteten Augen greis. Die Fühler von etwa $2 / 3$ der Körperlänge, derb und kräftig, das Wurzelglied schlank keulig, schwach gekrümmt, das zweite eiförmig, die drei folgenden schmal verkehrt kegelförmig, je kaum länger als das zweite, das fünfte oben schon leicht verbreitert, die oberen die gewöhnliche innerseits stark erweiterte Keule bildend, deren Glieder fast so breit wie lang, stark zusammengedrückt, mit haum Jemerklbarem Fortsatze des Endgliedes. Die lünf unteren gelb mit gebrïunter Spitze des lïnften, die Keule schwarz mit angedrückter greiser Behaarung. Das IIalsschild halb so lang wie lreit, rorn mit hallser Länge abwärts gekrümnt, über den scharf stumpfwinkeligen Vorderecken zusammengedrückt und dadurch verschmälert, die Seiten fein gerandet, nach vorn und unten in flachen Bogen zusammengeneigt, die Hinterecken in breiten spitzen Winkeln vorgezogen, der Hinterrand jederseits leicht ausgebuchtet, mit kurzem, fast gerade abgestutztem Nittelzipfel. Die Oberllïclıe hinter der Mitte wieder sclıwach niedergesenkt, längs dem Hinterrande nach den Hinterecken zu mässig, abfallend, so dass das Halsschild von hinten und oben aus gesehen hinten doppelt breiter als vor'n erscheint. Dabei der Hinterrand fein gesägt, von einer dichten Reilıe grober, etwas in dip Länge gezogener Punkte begleitet, und vor dieser längs der Mitte des Hinterrandes ein flacher hufeisenförmiger Quereindruck. Die Punktirung äusserst fein und zerstreut mit mattem Zwischengrunde; die Farbe hell strolggelb, auf der vordern Hälfte ein die mittlere Häfte des Vorderrandes eimnehmender, hinten eckig hegränzter schildförmiger tief schwarzblauer Fleck, dessen hintere Spitze durch eine kräftige dunkle Längslinie mit der Mitte des Hinterrandes verbunden ist. Das Schildchen gestreckt-dreieckig, doppelt so lang wie breit, hinterwärts mit in der Mitte leicht ausgeschweiften Seiten zugespitzt, wenig ansteigend, kaum sichthar punktirt, schwach glänzend, schwarzblau. Die Declischilde breit und flach gewöllst, wenig länger wie breit, vorı Jreiter als das Halsschild, hinterwärts fast gradlinig verschmälert, mit kurz und breit zugerundeter Spitze, der Rïclicı hinter der Schildchenspitze an hüchsten, und von da ab längs der Naht selır schwach abwärts gekrümmt, seitlich stärker abfallend, vorn hinter der Wurzelkanie leicht quer eingedrückt und dann wieder aufgewulstet; die Schulterbeulen breit und ziemlich 
flach, die Seitenlappen kurz, aber tief abwärts gezogen. Jie Punktstreifen vorn deutlich mit tief eingegrabenen Vorderenden, rom zweiten Drittel ab schwächer, aber doch nur die mittleren auf der Wölbung fast erloschen, der neunte in eine kräftige Furche eingedrückt. Die Zwischenräume flach, nur der äusserste etwas aufgewölbt, mässig glänzend. Die Farbe strohgelb, ein schmaler Saum längs der Wurzel, und an diesen gelehnt ein kleiner Fleck auf der Schulterbeule und ein grösserer im Nahtwinkel verwaschen schwarzblau mit schwach bräunlichem Schimmer; ausserdem auf der Wöllung ein grosser gleichgefärbter mit dem Innenende nach hinten geneigter Schrägfleck zwischen dem dritten und neunten Punktstreifen, welcher bei intensiver gefärbten Stücken überfliessend die ganze Spitze der Flügeldecke einnimmt. Unterseite und Beine tief schwarzhlau, Hüften und Schenkelwurzeln zuweilen gebräunt. Die Vorderbrust vereinzelt punktirt, quer viereckig nit etwas geschweiften, stark aufyeworfenen Seitenkanten, hinten nur leicht ausgebuchtet, eng an die eben so gestaltete nur etwas kürzere Mittelbrust angeschlossen. Das letzte Segment des $\delta$ leicht quer eingedrückt, des $q$ mit dem gewöhnlichen Grübchen.

Aus Brasilien (Mus. Schaum. Deyrolle).

24. M. plagiellus m. Schwarz, Kopfschild, Fühlerwurzelı, schenkel, die hinterwärts verbreiterten Seiten des Halsschildes und die Flügeldecken gelb, auf letzteren die hinterwärts verbreiterte Naht und zwei Flecke $(1,1)$ schwarz; die Punktstreifen fein, hinten verschwindend, der neunte schwach vertieft, mit flachen glänzenden Zwischenräumen. L. $3 / 4-1^{\prime \prime \prime} ; \mathrm{Br}$. $1 / 2-2 / 3{ }^{\prime \prime \prime}$.

Von der vorhergehenden nahe verwandten Art sogleich an der hellgelben Farbe des Kopfschildes und der Schenkel zu unterscheiden. Der Kopf flach gewölht, mit mattschwarzer braun punktirter Stirn, das etwas eingezogene Kopfschild lehmgell mit schnuızig pechbräunlichen Mundtheilen, die schmal aber tief ausgebuchteten Augen (bei dem ठ) oben etwas genähert, die Augenbuchten selbst und eine leichte das liopfschild ohen absetzende Querschwiele glänzend. Die Füller ziemlich gestreckt, das zweite Glied lang eiförmig, fast dopjelt länger als breit, die beiden folgenden einander gleiclı und je etwas kürzer, das fünfte dagegen etwas länger als das zweite, und ihm auch die oberen gleich, letztere breit zusammengedrückı und erweitert, so aber, dass die Breite nirgends die Länge erreicht, mit kurz dreieckigem Fortsatze 
des Endgliedes. Uie Farbe der fünf unteren Glieder hellgelb, die Spitze des fünften und die Wurzel des sechsten leicht gebräunt, die oberen schwarz mit dünner greiser Behaarung. Das Halsschild kurz und breit, hinter der Mitte hoch quer aufgewölbt und ron da ab nach vorn und hinten mit starker Krummung abfallend, über den stumpf-rechtwinkligen Vorderecken zusammengedrückt und dadurch verschmälert, die Seiten fein gerandet, hinter der Hitte leicht ausgeschweift, mit den Vorderhüften bogig zusammengenejgi, die Hinterecken lurz und breit zugespitzt, etwas aufgetrieben; der Hinterrand jeder'seits leicht ausgebuclıtel, vor den Schultern etwas tiefer ausgeschnitten, mit kurzem, doppelt ausgerandetem Mittelzipfel. Vor lem llinterrande die gewöhnliche dicht eingestoclıene Reihe grober, etwas in die Länge gezogener Punkte, durch welche eine schmale von einer Schulter bis zur andern reichende, das breite Hinterende des Mittelzipfols etwas aufwärts schiebende Querlinie gebildet wird. Die Oberfläche mattschwarz, ein hreiter Seitenrand hellgelb, welcher sich hinter der Hitte winkelig soweit nach innen erweitert, dass der schwarz verbleibende Theil nur etwa die doppelte Breite des Mittelzipfels erreicht. Von dem eigentlichen gelben Seitenrande ist diese Erweiterung durch einen verwaschenen bräunlichın Längsschatten geschieden, sodass möglicherweise auch Stücke vorkommen könnten, bei denen sich jene Erweiterung von dem Seitenrande jederseits als ein selbstständiger runder gelber Fleck ablöst. Das Schildchen schräg ansteigend, Mreieckig und fast doppelt länger wie breit, mit deutlichem Vordergrübchen, glänzend schwarz. Die Deckschilde etwa 1/4 länger wie breit, hinter den Schultern noch etwas im Bogen erweitert und dimn in breiter Krümunng hinterwärts zugerundet, der Rïcken hinter der Schildchenspitze bucklig erhöht, und von da ıach vorı und seitlich stärker, läugs der Naht nur sanft alıtallend; luinter dem elwas erhöhten Wurzelrande eine durch vier Längsgrübchen - die tief eingedrücliten Vorderenden des 2. bis 5. Punktstreifens - gebildete unterbrochene Querfurche, die Schulterbenlen gross, aber nur llach, die Seitenlappen mässig, und über ihmen die Deckschilde schwach que! zusammengedrüclit. Die Punktstreifen sehr regelmiissig, die Punkte gross, aber schon vom Hinterende der erwälınten Längsgrübchen ab so schwach eingedrückt, dass sie ıur durch ihre dunkle Färhung auf dem lıellen Grunde bemerlibas werden, der neunte in einc schwache Längs- 
furche eingedrïckt, die glänzenden Zwischenräume flach und nur der neunte ein wenig aufgewölbt. Die Farbe lehmgell, etwas dunkler wie die Seiten des Halsschildes, ein schmaler Saum längs Wurzel und Naht schwarz, die letztere aul der Wölhung zu einem jederseits bis zum zweiten Punktstreifen reichenden Nahtfleck erweitert, und ausserdem auf jedss Flügeldecke noch zwei schwarze Flecke hinter einander, der vordere die ganze Schulterbeule einnehmend und vorı an den Wurzelsaum gelelnnt, der hintere längliche von der Mitte bis zur Wölbumg reichend, zwischen dem siebenten und neunten Punktstreifen, hinterwärts beide übersehreitend, und aussen den Rand berührend. Aendert $a b$

$\beta$. Der Saum der Wurzel zu einer breiten hinteu zugerundeten, beide Schulterflecke verbiudenden Querbinde verbreitert, und auch der Hinterfleck nach innen soweit ausgedehnt, dass er von der erweiterten Naht nur noch durch einen verwaschen gelblichen Zwischeuraum getrennt wird. Bei anderen Stücken verschwindet auch noch dieser, bis sich zuletzl die ganze Spitze der Deckschilde schwarz färbt. Das Pygidium vereinzelt grob punktirt, mit Unterseite und Beinen schwarz; nur die obere grössere Hälfte der Schenkel gelb, und an den Vorderbeinen die untere Innenseite der Schienen, an den hinteren nur die Schienenspitzen gebräunt; bei der var. $\beta$. die tlunklere Färbung der Schenkel etwas weiter ausgedehnt. Die Vorderbrust runzlig punktirt und greishaarig, linter dem Vorderrande quer eingedrückt und hinterwärts in der Mitte muldenförmig vertieft, der Hinterrand breit ausgeschnitteu mit scharf rorspringendeı Hinterecken. Das letzte Segment des $\delta$ mit einer quer eingedrückten, glänzenden Stelle; las $q$ unjekkannt.

Gleichfalls aus Brasilien (von Conslancia: Mus. Clark; ohue Heimathsangabe im Hus. Haag und Berol.)

Vierte Rotte. Körper von versehiedener Grösse, his zu $2^{\prime \prime \prime}$ Länge ausgedehnt: mehr oder weniger breit eiförmig; rothuıd schwarzbunt, oder auch ganz roth. Das Halsschild ohne deutliche Querfurche.

25. I. rubidulus m. Matt ziegelroth mit gebräunten Kinnbacken und Fühlerenden; das IIalsschild glatt, die Punktstreifen fein, schon vor der Mitte erloschen, der neunte vertieft, mit flachen Zwischenräumen. L. $15 / 1{ }^{\prime \prime \prime}$; Br. $3 / 4{ }^{\prime \prime \prime}$.

Eine durch ihre nüchterne Eintörmigkeit in Sculptur und Färhuug nicht weniger, wie durch ihre Grösse auffallende A't, 
durch letztere, sowie durch ihren länglich elliptischen Umriss zunächst dem folgenden, allerdings noch nierklich grösseren II. giganteus verwandt. Der Kopf mit breit und rundlich flach eingedrückter Stirn, und über diesem Eindruck noch eine kurze Längslinie; das deutlich eingezogene Kopfschild oben durch eine Querlinie abgesetzt und unten gleichfalls breit dreieckig eingedrückt. Die Oberfläche matt ziegrelroth, olne Spur einer Punktirung, die Kinnbacken und ungleich schwächer noch die Tasterenden pechbräunlich; die lang gestreckten, mässig ausgebuchteten Augen schwarz. Die Fühler verhältnissmässig länger und lockerer als bei den meisten Arten dieser Gattung, etwa von balber Körperlänge; das Wurzelglied in der Mlitte am breitesten und ron hier aus nach beiden Enden zu zientich gleiclınässig verschmälert, etwa dopjelt länger wie breit und oberseits Jeicht abgeflacht, das zweite breit elliptiscl, die drei folgenden dünn verkelırt liegelfürmig, das dritte und vierte je zweimal, das fünfte $2 \frac{1}{2}$ mal länger als das zweite, die oberen je dem fünften gleicl, breit dreieckig zusanmengedrückit und erweitert, aber doch ülserall länger wie hreit und dadurch nur eine lockere lieule bildénd, mit sehr kurz dreieckigem Fortsatze des Endgliedes. Die Farbe der fünf unteren hell rothgelb, die sechs oberen gebräunt mit heller geringelter Wurzel und dabei dünn greis bchaart. Das Halsschild von der Mitte aus nach rorn unrl hinten gleichförmig sanlt übergekrümmt, fast doppelt so breit wie lang, vorn durch die tiefe Einbiegung der rechtwinkligen Vorderecken verschmälert; die Seiten fein gerandet, nach vorn in selır flachen Bogen zusammengekrüinmt; die Hinterecken kurz und breit zugeschürft, der Hinterrand nur vor den Schulterbeulen tiefer ansgeluchtet, gegen die Mitte zu leicht wellig gebogen und deutlich eingesenkt; mit kurzem, breitem, doppelt ausgerandetem Mittelzipfel. Die Oberläche gleichfalls matt ziegelroth. Das Schildchen wenig ansteigend, fast gleichscitig dreieckig, an clen Rändern etwas niedergedrückt, mit schwachem Vordergrübchen, ziegelroth mit schwachem Seidenschimmer. Die Deckschilde flach walzenförmig, $1 \frac{1}{3}$ mal so lang wie breit, hinter den Schultern noch etwas erweitert, danı hinterwäts in Jreiten Bogen zugerundet und dadurch den elliptischen Umriss des Körper's alsschliessend, nach der Wurzel zı leicht niedergesenkt; die mässig aufgetriebenen länglichen Schulterbeulen immerseits durch einen breiten, flach dreieckigen Eindruck abyesetzt, die Seitenlappen schwach, aber mit 
sehr breitem ungeschlagenem Rande, der Quereindruck über ilnnen kaum bemerkbar: Die Punktstreifen regelmässig und selı fein, auch vorn nur schwach angedeutet, die mittleren schon von der Mitte ah nur noch mit Mühe an der dunkleren Färbung der Punkte keuntlich, der neunte in eine sehr schwache Furche eingesenkt, die Zwischenräume flach, durch sehr feine Querwurzeln matt, mit leichtem Seidenschimmer. Die Farbe auch hier ziegelroth, mit verwaschen hellerem Hinterleibe, die Vorderbrust quer viereckig, hinterwärts mit etwas geschwungenen Seiten el'weitert, dicht ahęr nur fein runzlig punktirt; das Mittelfeld vorn kurz beulig aufgetrieben, vor dem etwas aufgeworfenen, nur seicht ausgeschnittenen Hinterrande quer niedergedrückt. Das letzte Segment des . $\mathrm{mit}$ dem gewöhnlichen Grübchen, das ơ unbekannt.

Aus Columbien (Nus. Berol., von Moritz).

26. M. giganteus in. Schwarz, der vordere Theil der Deckschilde mit Brust, Schildchen und Fühlerwurzelı roth; das Halsschild spiegelglatt, die Punktstreifen fein, die Hinterenden des achten und neunten leicht vertieft, mit flachen glänzenden Zwischenräumen. L. $2^{\prime \prime \prime}$; Br. $11 / 6^{\prime \prime \prime}$.

Eine grosse, stattliche, durch den Lackglanz der ganzen Oberseite und den breiten rothen dèn ganzen Körper umziehenden Quergürtel ausgezeichnete Art, die zwar durch ihren Umriss und den Mangel der eingedrückten groben Punlitlinie vor dem Hinterrande des Halsschildes habituell etwas von der Hehrzahl der übrigen Arten dieser Gattung abweicht, aber doch nach dem Bau von Fühlern und Ilalsschild hier ilure richtige Stellung findet. Der Kopf flach, unten etwas schräg eingezogen, das Kopfschild durch einen deutlichen Quereindruck zwischen den Fühlern von der Stirn getremmt und zugleich fein gekielt, dabei äusserst fein und dicht punktirt; gläızend schwarz, die dreieckigen Augenbuchten nebst den Ilumdtheilen pechbraun; die lang gestreckten Augen (des \&) ohen stark zusammengeneigt. Die Fülıler kurz und kräftig, das Wurzelglied gestreckt, ziemlich dümn, etwas gebogen, das zweite liurz eiförmig, das dritte doppelt länger, das vierte etwas kürzer als das dritte, das fünfte noch etwas länger, oben schon leicht verbreitert, die folgenden je dem dritten gleich, breit zusammengedrückt und erweitert, mit abgerundeten Aussenecken und kaum merkliehem Fortsatze des Euldgliedes. Die Firbe der beiden unteren Gilieder rothlraun, die drei folgenden pechbraun, die oberen 
schwarz mit dicht angedrückter feiner Behaarung. Das Halsschild kurz und breit, vorn mit der grösseren Hälfte sanft abwärts gekrümmt, über den stumpf rechtwinkligen Vorderecken sehr stark znsammengedrückt und dadurch verschmälert, die Seiten fein gerandet, hinter der Mitte leicht ausgeschweift, nach vorn gradlinig zusammengeneigt, die kurzen Ilinterecken scharf, fast rechtwinklig. Der Hinterrānd jederseits breit- und vor den Schultern noch tiefer ausgebuchtet, der Mittelzipfel breit, deutlich doppelt ausgerandet, und vor ihm jederseits ein kurzer Schrägeindruck. Die Farbe spiegelglïnzenl schwarz. Das Schillchen sehr schräg ansteigend, um die Hälfte kürzer wie breit, linterwärts mit leicht ausgeschweiften Seiten verschmälert, daselhst kurz abgestutzt, mit deutlichem Vordergrübchen. Die Farbe glinzend roth, die Seiten tief braun, die Wurzel schwärzlich gesäumt. Die Deckschilde walzlich, um fast $1 / 3$ länger wie breit, hinterwärts mit abgerundeten Seiten verschmälert, seitlich zusammengedrückt und dadurch der Umriss zum Elliptischen verengt, die Wurzel etwas nierlergedrüclit und die länglichen Schulterbeulen innerseits durch einen breiten dreieckigen Eindruck abgesetzt; der Rücken von der Schildchenspitze ab längs der Naht allmählich, seitwärts etwas stärker abfallend, die Scitenlappen kräftig, mit sehr breitem umgeschlagenem Raude, über ihnen aul' dem neunten Punktstreifen ein stärkerer Längseindruck als Vorderende der nur hinten dentlichen Längsfurche. Die Punktstreifen sehr regelmässig, fein, die mittleren fast verloschen, theilweise auf dem rothen Grunde nur an der dunkleren Färbung ihres Inneren erkennbar, die Hinterenden des achten und neunten in sehr schwache Längsfurchen eingedrüclit, die Zwischenräume flach, glänzend, die leichte Erhöhung der seitlichen nur bei sehr schräger Beleuchtung wahrzunehmen. Die Farbe ein schönes, dunkles Ziegelroth, ein feiner Vordersaum und das hintere Viertel mit scharfer aher etwas welliger Begränzung schwarz. Das Pygidium fein punktirt, mit den Beinen und dem grössteı Theile des Hinterleibes schwarz; Hüften, Brust und ein schmaler Vorderrand des ersten Bauchringes - gewissermaassen den oheren Quergürtel fortsetzend und in der Yitte nach vorn his zum Munde äberfliessend - mit dessen Vorderzipfeln roth, bei einem Stïcke auch der letzte Bauchring trüb geröthet. Die Vorderbrust liurz, grob rumzlig punlitirt, hinter dem Vorderrande leicht quer aufgewulstel, ror dem in breiter Rundung ausgeschnittenen Hinterrande etwas eingedrückt. Das 
letzte Segment des $\subsetneq$ mit einer grossen länglichrunden glänzenden Grube; das $\delta$ unbekannt.

Von Ega am oheren Amazonenstrom (Mus. Baly. Holm.), und eine von den vielen ganz eigenthümlishen Formen, welche diese Gegend in rler vorliegenden Familie darbietet.

27. II. tumidulus m. Schwarz, Mundtheile, Fühler, Beine und die mit einem sclıwarzen Längsflecken gezeiclıneten Flügeldecken ziegelroth; die Punktstreifen fein, hinten fast verloschen, der 9te daselbst leicht vertieft, mit flachen mässig glänzenden Zwischenräumen. L. $1 \frac{1 / 2}{\prime \prime \prime} ; \mathrm{Br}, 1 \frac{1}{12}{ }^{\prime \prime \prime}$.

In Habitus, Färbung und Farbenvertheilung dem vorhergehenden sehr ähnlich, aber merklich kileiner, an beiden Enden stumpfer abgerundet, und durch deı regelınässigen, breit elliptischen Umriss sehr ausgezeichnet. Der Kopf flach mit etwas eingezogenem, uben durch eine feine Querfurche begränztem Kopfschilde, mit den langgestreckten, mässig ausgebuchteten Augen schwarz, ohne merklichen Glanz; die Mundtheile bis auf die schwarzen Kinubacken ziegelroth. Die Fühler etwas über den Hinterrand des Halsscluildes hinausreichend, das dritte Glied etwas länger als das länglichelliptische zweite, das vierte wieder dem 2 ten gleich, die rauclıgrau angeflogene keule innerseits nur schwaclı erweitert. Das Halsschild mit der grösseren Vorderhälfte übergekrümmt, über den scharf rechtwinkligen Vordejecken zusammengekiümmt und dadurch verschınälert, die Seiten gesandet und nach vorn in breiten Bogren zusammengeneigt; die breit dreieckigen Hinterecken kurz und scharf vorgezogen, der Hinterrand jederseits nur leicht ausgebuchtet, nach seiner ganzen Ausklehnung eingesenlit, mit liurzem dopjelt ansgerandetem Mittelzipfel; jederseits des letzteren ein liurzer schmaler sehr schrägliegender Längseindruck, und ein zweiter sclıwächerer vor den Hintervinkeln. Die Oberfläehse spiegelglänzend schwarz ohue deutliche Punktirung. Das Schildchen dreieckig, um 1/4 länger wie breit, schräg anstcigend, mit deutlicheın Vorder'grübchen, gleichfalls glänzend schwarz. Die Deckschilde vorn breiter als das Halsschild, dann mit sehr stumpf abgerundeten Schultern hinterwärts noch etwas im Bogen verhreitert und nach der Spitze zu wieder mit breiter Krrümmung versehmälert, so dass die grösste Breite wenig hinter die Mitte der Körperlänge fällt und der ganze Umriss eine nach vorn wenig verschmälerte Ellipse bildet. Der Rücken hinter del Wurzel nur leicht schräg niedergedrückt, hinter dem Schildchen 
schwach aufgewölbt, die grossen flachen Schulterbeulen innerseits durch einen dreieckigen Eiudruck abgesełzt, die Seitenlappen mässig mit sehr breitem Unterrande, über ihnen der gewöhnliche, hier sehr breite und scharfe Queseindruck. Die Punktstreifen fein, schon voı der Mitte ab sich abschwächend, die mittleren auf der Wölbung fast erloschen, der 9te nur hinten in eine seiclite Furche eingedrückt. Die Zwischenräıme mässig glänzend, flach, nur der äısscrste leicht gerrölht. bie Farbe ziegelroth, wie bei unserem Cr. lipunctatus L., Wurzel und Naht schwarz gesäunt, und ausserdem auf jeder Flügeldecke ein scharf begränzter schwarzer Längsfleck zwischen den 3ten und Sten Punktstreifen, aber beide nicht erreichend, etwa doppelt so lang wie breit, in der Länge etwa das mittlere, grösseste Drittel der Flügeldecken einnehmend. Pygidiun und Unterseite schwarz mit verwaschen geröthetem Saume des ersteren und Mittelflecke des letzten Bauchringes; die Beine ziegelroth. Die Vorderhrust fast doppelt breiter wie lang, grob runzlig punktirt, flach, mit einer feinen Querfurche linter dens scharfen Vorderrande, hinten nur schwach ausgerandet, mit stumpfwinklig zıgeschärften Hintereclien. Das letzte Segnent des \& mit einer grossen rundlichen im Innern glänzenden Grube, deren Ungebung hesonders auf der hinteren Seite stark ins Röthliche fällt; das $\delta$ unbekannt.

Aus Brasilien (Mus. Deyrolle).

28. M. pallipes Stål. Schwarz mit rollıgelben Fühlerwurzehn und Beinen, Pygidium und letzter Bauchring braun, die Deckschilde ziegelroth mit eiıer hufeisenförmigen schwarzen Bogenlinde; das Halsschild spiegelglatt, die Punktstreifen fein, der 9te leicht vertieft, mit flachen gläızenden Zwischemrämmen. L. I" ; Br. 5/6"“.

I. pallipes Sı̊̊l Till Kannedomen elc. in der Öfrersichı elc. p. 61, n. 7!

Von dem fast kreisrunden Umriss einer kleinen Coccinelle, und einer solchen anch durch den flach halbkugeligen Körper äusserlich sełı ähnlich; übrigens an der ganz eigenthümlichen Zeichmung der Deckschilde sehr leicht zu erkennen. Der Kopf flach gewölht mit glänzentler Stirı und matterem, etwas eingezogenem, oben durch eine deutliche Querlinie algegränzten liopfschilde, schwarz; die lingestreckten, ziemlich stark ausgebuchteten, ohen (hei dem of) durch eimen schmalen Zwischenraum getremten Augen greis. Oberlippe und Mundtheile röthlich gelb, die vorhandenen Fühlerreste etwas heller gelb. Das 2te Glied der letzteren 
eiförmig, die drei folgenden gleich lang und je etwas länger als das 2te, dünn und sclimal, das noch vorhandene 6te stark dreieckig erweitert und schwarz. Das Halsschild kurz und sehr breit, hinten flach niedergedrückt, vorn mit $3 / 4$ seiner länge stark übergewölht, über den scharf rechtwinkligen Vorderecken zusammengedrückit und dadurch verschmälert; die feingerandeten Seiten nach vorn in breiten Bogen zusammengekrümmt, die kurzen und breiten Hinterecken auch fast rechtwinklig, durch einen breiten Schrägeindruck etwas aufgetrieben; der Hinterrand jederseits nur leicht we]lig gebogen, mit kurzem, breitem, doppelt ausgeraudetem Mittelzipfel; " zu jeder Seite des letzteren ein kurzer und schwacher Quereiudruck. Die Farbe spiegelglänzend schwarz. Das Schildchen ziemlich stark ansteigend, dreieckig, um die Hälfte Jänger wie breit mit deutlichem, von zwei feinen Beulen eingeschlossenem Vordergrüluchen, gleichfalls glïnzend schwarz. Die Deckschilde nicht länger wie breit, vorn jederseits des Schildchens stark zum Halsschilde abwärts gedrückt, von der Spitze des Schildchens ab mit sehr flacher Wölbung herabgekrümmt; die Sciten von den Schultern bis zur Spitze hin breit zugerundet, die grossen ziemlich flachen Schulterbeulen immerseits durch einen schmalen und seichten Längseindruck abgesetzt; auch die Seitenlappen nur schwach entwickelt, mit breit umgeschlagenem Rande, über ihnen der gewöhnliche breite und flache Quereindruck. Die Punktstreifen fein, hinterwärts fast erloschen, mit flachen glänzenden Zwischenräumen, der 9te Punktstreifen leicht vertieft und der ausserhalb desselben liegende Zwischenraum entsprechend flach aufgewölht. Die Farbe ziegelroth, ein breiter Wurzelrand und ein schmaler, sich hinterwärts verwaschen verlierender Nahtsaum schwarz, und dieselbe Färbung zeigt auf jeder Flïgeldecke eine an dem Eindrucke hinter der Schultepbeule beginnende, nach hinten und innen ziehende Schrägbinde, deren Ilinterende sich auf der Wülhung nach der Naht zu krümmt und hier mit dem entsprechenden Hinterende der entgegengesetzten zu einem nach vorn geöfheten Ilufeisenflecke vereinigt. Das fein punktirte Pygidium mit dem letzten Bauchringe, den Hüften und den Schulterblättern pechbraun, der übrige Theil der Unterseite schwarz, und nur die Beine einfarbig rothgelb. Die Vorderbrust hinten nur schwach ausgeschnitten; das letzte Segment des $q$ init einer tiefen, glänzenden Grube, das $\delta$ mbekaunt.

Von der vorhergehenden, nahe verwandten Art unterscheidet 
sich die rorliegende ausser der geringeren Grösse leicht durch den viel weniger gestreckten, mehr kreisförmigen Umriss und die ganz abweichende Lage der schwarzen Binde auf den Flügeldecken; da aber bis dahiı von jeder nur ein einzelnes $q$ vorliegt, so lualte ich es nicht für unmöglich, dass sie später durch die Entdeckung von Uebergangsfurmen als zu einer Art gelı̈rig nachgewiesen werden köınteı.

Gleiclıfalls aus Brasilien (Nus. Holm., von F. Sahlberg bei Rio de J. gefunden).

29. M. juvenilis m. Tief schwarzblau, die Füllerwurzeln, das vorn schwarzblau gefleckte Halsschild, eine Querbinde und die Spitze der Flügeldecken roth; die Punktstreifen deutlich, hinten erloschen, der 9te vertieft, mit flachen glänzenden Zwischenrämmen. L. $1 \frac{1}{4}-1^{2} / 3^{\prime \prime \prime}$; Br. $1-1 \frac{1}{1}{ }^{\prime \prime \prime}$.

Zwar etwas kleiner als $\mathbf{M}$. giganteus und durch die breit eirunde Gestalt mehy, dem echten Honachen-Typus entsprechend, aber doch noch immer eine grosse schöne, zugleich durch ihre saubere Färbung und die scharf begränzte Zeichnung ausgezeichnete Art. Der Kopf flach mit seitlich scharf hegr'ünzten, oben kaum abgesetztem Kopfschilde, malt schwarzblau, ohne sichthare Punktirung, die ziemliclı tiel' dreieckig ausgeschnittenen Augen schwarz, bei dem $\delta$ fast zusammenstossemu, bei lem otwas weiter getrennt. Die Musdtheile braunruth mit dunkler Mitte der Oberlippe. Die Fühles nicht von halber Körperlänge, derb und kräftig; das Wurzelglied sclımal lieulig, etwa $2 \frac{1}{2}$ mal länger wie breit, wenig nach aussen gekrümmt, das 2te bei fast gleicher Breite nicht halb so lang, eiförmig, das 3te und 5te an Länge dem 2ten gleich, das the un die Hälfte kïrzer, alle drei verkehrtkegelförmig mit etwas verbreiterten oberen Ende des 5ten, die sechs oheren die gewöhnliche lienle bildend, deren Glieder je noch etwas länger als das 5te, innerseits stark erweitert, etwas zusammengedrüclit, mit sehr kurz abgesetztem Fortsatze des Endgliedes. Die Farbe der vier unteren rothgell, das fünlte grobräunt, die Keule schwarz, dünı angedrückt behart und weisslich gewimpert. Das Halsschild gross, himten flach quer niedergedrückt und mit sehr schräg abfallenden Hinterwinkeln seitlich stark verlureitert, rorn nut fast $3 / 4$ seincr Länge abwärts gewölht, über den scharf rechtwinliligen tief eingezogenen Vorderecken stark zusammengedrückt und dadurch verschmälent, die Seiten fein gerandet, nach rom in sehr flachen 
Bogen convergirend, vor den scharf spitzwinklig ausgezogenen Hinterecken etwas ausgeschweift, der Hinterrand jederseits sehr seicht und breit ausgebuchtet, fein gesägt, mit kurzem deutlich doppelt ausgerandetem Mittelzijfel; vor dem letzteren ein schmaler, zicmlich scharfer' Quereindruck; ausserdem längs dem Hinterrande eine dichte Reibe grober in die Länge gezogener Punkte. Die Oberfläche aussertlem ohme sichtbare Punktirung, aher doch nur matt seidenschimmerud; die Farbe dunkelziegehroth, ein halb elliptischer, vorn die Mitte des Vorderrandes eimnehmender, hinterwärts bis über die Mitte der Längsfirste hinausreichender Längsfleck ımıl an diesen sich anschliessend der Samm des Vordorrandes tief schwarzblau, zuweilen mit einem leichten grüulichen Anfluge. Das Schildchen gestreckt dreieckig, doppelt breiter als lang, hinterwärts mit leicht ausgebuchteten Seiten zngespitzt, sehr schwach ansteigend, mit deutlichem Vordergrübcheı, ziemlich glänzend schwarzblau. Die Deckschilde vorn etwas breiter als das Halsschild, hinterwärts noch etwas erweitert und dann bis zu der kurz ahgerundeten Spitze fast gradlinig verschmälert, vorn hinter dem breiten flachen Wurzelrande leicht quer eingedrückt und danı wieder aufgewulstei, der Rücken um die Schildchenspitze buckelig erböht, und von da seitlich ziemlich steil-, hinterwärts mit sanfter bis zur Spitze fortziehender Krümmung abfallend. Die Schulterbeulen stark hervortretend, innerseits durch einen kräftigen dreiechigen Längse indruck abgesetzt, auch die Seitenlappen stark entwickelt. Die Punktstreifen vorn deutlich, von der Mitte ab allmählich abgeschwächt und die mittleren auf der Wölloung fast erloschen, der 9te in eine stärkere Furche eingedrückt. Die Zwischenräume flach, ihre Vorderenden und der äusserste seiner ganzen Länge nach schwach aufgewölbt, glatt, mit mässigem Glanze. Die Farbe tief schwarzhlan, manchnal ins Schwarzgrünliche spielend, die Spitze und eine vom Seitenlapspen aus hinter der Schulterbeule hinaufziehende, etwas nach hinten gerichtete und bis zum ersten Punktstreifen reichende Schräghinde roth; der Zwischenramu zwischen ihr und der gleichfalls rothen Spitze beinahe der Breite der Binde sellst gleich. Das Pygiditm groh narbig aher nicht tief punktirt, mit der äusserst fein punktirten und gerumzelten Unterseite und den Beinen selbst gleichfalls -schwarzhlau oder schwarzgrün; die gröber punlitirten Parapleuren greisharig; die Schienenspitzen zuweilen gebräunt. Das Prosternum um die Hälfte breiter als lang, runzlig punktirt 
und behaart, hinten quer niedergedrückt und flach ausgerandet, mit scharf erhöhten Scitenleisten. Das letzte Segment des ơ einfach, des $q$ init einer tiefen eiförmigen, glänzenden Grube.

Aus Caraccas (Mus. Schaum. Felix. Deyrolle. Baly. Dohrn; die meisten dieser Exemplare, sowie die meiner eigenen Sammlung von Wagner gesammelt). Ilie Stücke des Mus. Deyrolle sind mit dem Namen II. X. littera Chv. bezeichnet.

30. M. c oenobita m. Schwarzblau, die Fühlerwurzeln und das doppelt gefleckte fein punktirte Halsschild nebst einer gezackten Bogenbinde der Deckschilde roth, die Punktstreifen vorn derb, hinterwärts erloschen, der 9te sehr schwach vertieft, mit flachen, äusser'st fein runzlig punktirten Zwischenräumen. L. 11/4-I $1 / 3{ }^{\prime \prime \prime}$; Br. $11 / 12-1 "$.".

Dem vorhergehenden sehr ähnlich, etwas kleiner, mehr gläızend uncl auch ausser der abweichenden Zeichnung durch den Mangel des Quereindrucks an der Wurzel der Deckschilde von jenem verschieden. I)er Kopf flach mit etwas eingezogenem, oben durch eine undentliche Querlinie abgesetztem Kopfschilde, die Oberfläche äusserst fein und zerstreut punktirt, matt schwarzblau, die Oberlippe unten rüthliclı gesäumt, die tief ausgebuchteten, (bei dem \$) durch einen mässigen Zwischenraum getrennten Augen greis. Die Fühler etwas über den Hinterrand des Halsschildes hinausreichend, das Wurzelglied schmal keulenförmig, fast dreimal länger als breit, das 2te eiförmig, fast tmal kürzer und kaum halb so lreit als das erste, die drei folgenden yerkehrtkegelförmig, das 3te und 4te an Länge je dem 2ten gleich, das 5te etwas kürzer, und die sechs oberen zı einer mässig rerdickten Kenle verbreitert, deren Glieder an Läıge etwa dem 5ten gleich, ım die Hälfte länger a!s breit, mit liaum hemerkharem Fortsitze des Endgliedes. Die Farbe der 5 unteren rothgelb mit leicht gebräunter Spitze des 5ten, die oberen schwarz mit dicht angedrückter greiser Behaarung und einzelnen Wimpern. Das Ilalsschild gross, um die Hälfte breiter als lang, hinten etwas eingesenlit und vorn mit $3 / 4$ seiner Länge übergekrünmt, üh^r den tief eingezogenen scharf rechtwinkligen Vorderecken etwas zusanmengedrüekt und dadurch, jedoch weit schwächer als bei dè vorhergehenden Art, versehmälert, die Seiten fein gerandet, nach rom in seln breiten Bogen convergirend, vor den lang und scharf spitzwinklig ausgezogenen Hinterecken etwas ausgeschweift: der Hinterrand jederseits schwach wellig ausgebuch- 
tet, vor den Schultern tiefer ausgeschnitten, mit undeutlich doppelt ausgerandetem Mitteizipfel. Die Oberfläche mit einer sehr feinen alıer an Stärke etwas ungleiclien Punktirung dicht bestreut, der Zwischengrund glänz'nd, und vor dem Hinterrande die gewöhnliche Reihe grösserer, besonders vor dem Mittelzipfel derber Punkte. Ilie Farbe roth, der Hinterrand fein schwärzlich gesäumt, und vor der Mitte nebrn einmonder ein paar ähnliche rundliche, etwas verwaschen begränzte Flecke. J)as Schildchen gestreckt dreieckig, etwa doppelt so lang als breit, die Seiten vor der Mitte leicht ausgebuchtet, mit undentlichem Vordergrühchen, gläızend schwarzblau. Die Deckschilde vorn etwas breiter als das Halsschild, hinter den Schultern noch ein wenig im Bogen erweitert und daun bis zu der breiten, kurz ungebogeneı Spitze fast mit geradeu Seiten verengt, daher der Umriss breit verkehrteiförmig; der Rücken von der Schildchenspitze ab seillich stärker-, hinterwärts in sehr flach gekrümmtem Bogen abfallend, auch die grossen aher flachen Schulterbeulen innerseits uur durch einen seichten Eindruck abgesetzt; die Seitenlappen sehr lang herabgezogen und ihr umgeschlagener Rand hinterwärts noch mehr verbreitert. Die Punktstreifen vorn kräftig und mit ihren Vorderenden tiefer eingegraben, olıne dass jedoch dadurch ein wirklicher Quereindruck, wie bei den meisten anderen Arten gebildet würde; hinterwärts die Streifen schon vom er'sten Drittel ab feiner und die mittleren schon ror der Wölbung ganz verloschen, der 9te zwar ein wenig vertieft, aber nicht in eine eigentliche Furche eingedrückt, nur s'in Vorderende unterhalb der Schulterbeule etwas schärfer eingesenkt, und raher auch nnr der 9te Zwischenraum schwach erhöht, die übrigen ganz flach, alle aber äusserst fein runzlig punktirt, mit mässigem Glanze. Die Färbung lässt sich am hesten als Roth bezeichnen; ein schmaler Nahtsaum, die am Vorderrande zwischen dem 2ten und 5ten Streifen buchtig ausgerandete Spitze, und die Wurzel zwischen den beiden Schulterecken, letztere als Lreiter hinten abgerundeter und das ganze Schildchen einschliessender Wurzelfleck zwischen den Schulterbeulen mit jederseits sich daran schliessendem Schulterbeulenflecke schwarzlolau. Die rothe Färbung bildet darlurch eine breite zackig begrănzte hinterwärts gekrïmmte Querbinde, welche etwa $2 / 3$ der Flügeldecken einnimmt, und vorn jederseits die Schulterecke erreichend auch den breiten umgeschlagenen Rand des Seitenlappens mit einschliesst. Das Pygidium grob, aber nicht 
tief punktirt mit narbigem Zwischengrunde, und wie die fein runzlig junktirte Unterseite und die Beine schwarzgrün, die Unterenden der Vorderschieuen schwach gerüthet. Das Prosternum flach, fein punktirt, mit gleichfalls feinen Seitenleisten, hinten breit ausgeschnitten; das letzte Segment des of mit einer mässig tiefen, sehr glänzenden eiförmigen Grube. Das ơ unbekannt.

Aus Paraguay (Mus. $\because$ Heyden, von Vogt gesammelt) und Brasilien (Mus. Beyrolle, hier als H. concinmus Dej. bezeichnet).

31. M. seriepunctatus m. Dunkelkirschroth, die Fühlerenden, die Ränder von Halsschild und Flügeldecken, ein hinterer Wisch der letztern und die Schulterbeulen nebst der Unterseite trüb geschwärzt; das Halsschild deutlich punlitirt, die Punktstreifen derb, der Ste und 9te vertieft, mit flachen glänzenden, reilsenweise punktirten Zwischenräumen. L. $1 \frac{11}{3}{ }^{\prime \prime \prime} ; \mathrm{Br}$. 1"”.

Abermals eine von den grüsseren Arten der Gattung, dabei durch den Glanz der Oberseite unł deren eigenthümliche Punkti- rung sehr ausgezeichnet. Der Kopf flach, mit mattem unten kaum eingezogenem Kopfschilde, die Stirn äusser'st fein und dicht punktirt, uben durch die gestreckten, tief dreieckig atisgebuchteten greisen, (bei dem vorliegenden ठ) stark zusammengeneigten Augen selı verengt; die Mundtheile noch heller gerüthet als die Oberfläche des Kopfes selbst. Die Fühler his zum Hinterrande des Halsschildes reichend, die 4 unteren Glieder gleichfalls hellroth, von ihmen das dritte und vierte elwas lin̈rzer und last um die Hälfte lümner als das zweite, das fünfte gebräunt, dic 6 Glieder der lienle liurz und ziemlich ljreit zusammenged'ücht, schwarz. Das Ilalsschild fast von der Wurzel ab nach rorn abwärts gelirümmi, über den abgerundetrechtwinkligen Vorderecken zusammengedrückt und dadurch verschmälert, die Seiten fein gerandet, in der Mitte flach bogig erweitert, vor und hintes ihı leicht ausgesclıweift, die Hintereclien kurz und breit scharf spitzwinklig ausgezogen, der Hinterrand jederseits tlach ausgebuchlet, fein gesägt, der Nittelzipfel gerade algestutzt. Vor der litte des Hinterrandes ein schmaler mit einer gröberen Punktreihe besctzter Quereindruck; die üln'ige Oberfläche zerstreut aber deullich und nach den Rändern hin stärker punktirt mit spiegelglänzendem Zwischengrunde, die Fạl’e cin schönes dunkles Kirirschroth, der vordere Theil der Mittelscheibe, da wo die: Punlite sparsames' und leiner' werten, "twas mehr rerdunkelt und leicht metallisch schimmernd; ausserdeu die Ränder verwaschen gebrännt. Das 
Schildchen sehı schräg ansteigend, fast um die Hälfte länger als breit, glänzend dunkelroth. Die Deckschilde hinter den Schultern wenig erweitert und damn hinterwärts in flachen Bogen verschmälert, hinter dem wulstig aufgetriebenen Wurzelrande durch die längsgrubig eingedrïckten Vorderenden der Punktstreifen quer gefurcht, um die Schildchenspitze flach anfgebuckelt und ron da ab hinterwärts sehr sanft abfallend; die Schuilterbeulen breit höckerig heraustretend, und die Seitenlappen stark abwärts gezogen. Die Punktstreifen regelmässig und hräftig, hinterwärts etwas schwächer aber überall kenntlich, der netinte und in geringerem Maasse der achte furchenartig eingedı̈nckt, daher die beiden äusseren Zwischenräune leicht gewölbt, die übrigen flach, jeder aher mit einer deutlichen - Längsreihe feiner Punkte besetzt, mit äusserst feiı gerunzeltem, glänzendem Zwischengrunde. Die Farbe gleichfalls dunkel kirschroth, die Wurzel nebst einen rerwaschenen Fleck auf der Schulterbeule tiefer gebräunt; ein feiner, Naht, Spitze und die hintere grössere Hälfte des Aussenrandes bis zum Seitenlappen umziehender Saum schwarz, und dieselbe nur ganz verwaschene Färbung zeigt ein leichter, wolkiger Längswisch auf dem hinteren Theile der Flügeldecken vor der Wölbung, der aber nirgends den Rand erreicht, auch auf der Mitte der Zwischenräume viel schwächer als in den Punktstreifen erscheint. Das grob punktirte Pygidium kirschroth. Unterseite und Beine etwas dunkler roth, die Seiten und Nähte der Hinterbrust nelsst den Rändern der Bauchringe tief geschwärzt. Das Prosternum greishaarig; vorn quer eingerl'ückt, hinten mässig ausgerandet; das letzte Segment des ठั mit einer leicht eingedrückten glänzenden Stelle, das o unbekannt.

Aus Surinam (Hus. Felix, von Deutschbein gesammelt).

32. M. brunneus Fab. Biaunroth, Kopf, Füblerkeulen und Unterseite tiefer geschwärzt; Halsschild und Flügeldecken tief narbigrunzlig punktirt, die Punktstreifen ziemlich fein, der aclıte und neunte schwach vertieft, mit flachen Zwischenräumen. L. 11/3"'; Br. I"'.

Clythra brunnea Fab. Syst. Eleuth. II. 38. n. 47!

Dem vorhergehenden an Grösse und Färbung nah verwandt, aber in letzlerer etwas dunkles, weniger glänzend, und ausserdem von ihm zugleich an der zwar nicht tiefen, aber dichten und zu Runzehn verfliessenden Punktirung des Halsschildes und der Zwischenräume zu unterscheiden. Der Kiopf flach, matt, zer'streut punktirt, $\mathrm{XV}$. 
das Kopfschild oben durch eine feine aber deutliche Querfurche von der Stirn getremt. Die Farhe schwarz, die Oberlippe mit den Nundtheilen gebräunt, die ziemlich tief ausgebuchteten, oben etwas zusammengeneigten Augen greis. Die Fühler kurz und kräftig, mit lang gestrecktem, schmal keulenförnigem, etwas gekrümmtem Wurzelgliede, die vier folgenden von gleicher Länge, das zweite hlasenförmig aufgetrieben, das dritte lis fünfte verkehrt kegelförmig, letzteres schon etwas zusammengedrückt und oberwärts erweitert; die Glieder der Keule je um die Hälfte längrer und breiter als das fünfte, mit breit kegelförmigem Fortsatze des Endgliedes. Die Farbe der vier unteren hell durchscheinend braungelb, das fünfte pechbraun, die Keule schwärzlich, durch ilnre dicht angedrückte greise Behaarung grau er'scheinend. Das Halsschild kurz und breit, vor dem Schildchen leicht abgeflacht und dann mit $2 / 3$ seiner länge nach vorn stark abwïrts gekiümmt, über den scharf rechtwinkligen Vorderecken etwas zusammengedrüclit und dadurch verschmälert; die Seiten fein gerandet, nach vorn in sehr flachen Bogen zusammengeneigt, hinter der Nitte leicht ausgeschweift, mit scharf und spitz ausgezogenen Hinterecken. Der Hinterrand jederseits schwach ausgebuchtet, dicht und fein gesägt, mit breit ausgerandetem Mittelzipfel. Die Obertläche nicht tief aber ziemlich dicht punktirt mit genarbtem, durch die sternförmig ansgerissenen Punkte zugleich fein gerunzeltem und desshalb nur schwach glänzendem Zwischengrunde; vor der Mitte des Ininterrandes cine Querreihe dicht an einauder gerückter gröberer Punkte. Die Farbe ein dunkles Braunroth, mit zart schwarzem Saume des Hinterrandes und der Hinterecken. Das Schildchen dreieckig, un die Iälfte länger als breit, mit leicht ausgeschweiften Seiten hinterwärts stark verschmälert, sehr fein punktirt, schwarz. Die Deckschilde etwas länger als breit, hinter den stumpfen Schulterecken nur wenig im Bogen erweitert und dann hinterwärts breit zugerundet, hinter der Wurzel nur schwach quer niedergerlrückt; die Schulterbeulen länglich und wenig bemerkbar, die Seitenlappen mässig entwickelt, aber mit stark abwärts erweiterten umgeschlagenem Rande. Die Punktstreifen sehr regelmässig, durch vereinzelte, vorn ziemlich krältige, von der Mitte ab sich immer mehr abschwächende, und auf der Wölbung für die daselbst auslaufenden mittleren Streifen fast verschwindende Punkte gebildet, der neunte und in geringerem Grade auch der achte in eine leichte Furche eingedrïckt. Die Zwischenränme matt, dicht und fein narbig gerunzelt, 
daher nur schwach spidig schinmmernd, flach, der äusserste und das hintere Ente des näclıstvorhergehenden ein wenig erhöht. Die Farbe gleichfalls braunroth, eiı linienförmiger Längswisch auf der Sclıulterbenle und ein feiner, die ganze Flügeldecke umziehender, nur den Seitenlappen frei lassender Saum schwarz. Das Pygidium grob narbig punktirt, braunroth, mit schwarz gesäumter unterer Rundung. Unterseite und Schenkel schwärzlich, der letzte Bauchring mil den Seiten des vorletzten, dem vorderen Theile des ersten Ringes, der Mitte der Hinterbrust und den Schenkelwurzeln gebräunt, Schienen und Fussglieder, sowie Mittel- und Vorderbrust heller braunroth, die letztere leicht in die Quere eingedrückt, mit etwas aufgebogenem, seicht ausgesclınittenem Hinterrande. Das letzte Segment des $\delta$ mit einem breiten, flachen Quereindruck, das $q$ unbekannt.

Südamerika olme nïhere Angabe der Heimath. (Mus. Berol., von Lund mitgetheilt, und dadurch das Citat ans Fabricius verbürgl, da auch dieser seinen Käfer von Lund erhalten halte.)

33. M. mode stus Boh. Oben ziegelroth, Kopf, Fühlerenden, zwei Punkte des matten Halsschildes, der Wurzelsaum der Deckschilde und das Schildchen schwarz, unten sclıwarz, Vorder-und Mittelbrust nebst den Beinen roth; die Punktstreifen fein, der neunte tief eingedrückt, mit flachen matten Zwischenräumen. L. $1^{\prime \prime \prime}$; Br. $2 /{ }^{\prime \prime \prime}$.

Monachus modeslus Bol, Eng. resa elc. Col. p. 157. n. 327 !

Merklich kleiner als die vorhergehente Art, aber sich ihr zunächst durch die Färbung das Kopfes anschliessend, sonst nach Habitus und Farbenvertheilung, mehr den stärker gerötheten Formen des unten folgenden M. contractus, decolorans und rubropustulatus ähnlich, von welchẹn allen sich der vorliegende Käfer aher durch den schwarzen Kopf und die matte, glanzlose Oberseite, wie durch die kaum anders als an der Färbung der Punkte kenntlichen Punktstreifen leicht unterscheidet. Der Kopf flach gewölbt, mit etwas eingezogenem, oben durch eine deutliche Querlinie abgegränztem liopfschilde, matt schwarz, nur zerstreut punktirt; die langgestreckten, mässig ausgebuchteten, oben (bei dem \&) ziemlich weit getrennten Augen greis. Die Mundtheile pechbraun; die Fühler kurz und kräftig, das gestreckte Wurzelglied etwas flach gedrückt, etwa $2 \frac{1}{2}$ mal länger als breil, das zweite länglich eiförmig, und diesem die folgenden an Länge fast gleich; das dritte bis fünfte schmal verkelırtkegelförmig, letzteres olıen schon etwas verbreitert, die oberen deutlich dreieckig erweitert und zusammengedrückt. 
Die unteren rothgelb mit einem bräunlichen Schattenflecke auf der Oberseite des fünften, die Keule schwarz mit dünner, greiser Behaarung. Das Halsschild fast mit ganzer Länge vorn sauft abwärts gekrümmnt, über den scharf rechtwinkligen Vorderecken tief eingezogen und dadurch verschmälert, die Seiten fein gerandet, nach vorn in weiten Bogen zusammengekrümmt; die Hinterecken gleichfalls kurz und breit, scharf und fast rechtwinklig; der Hinterrand jederseits breit und flach ausgełuchtet, mit kurzem mässig ausgerandetem Mittelzipfel; ror diesen letzteren ein schmaler und seichter, mit den etwas nach. vorn gebogenen Enden noch eine Strecke über ihn hinansreichender Quereindruck, durch welchen der lintere Theil des Halsschildes etwas niedergedrückt wird. Die Oberfläche sehr fein und zerstrent pumktirt, mit matt seidig schimmerndem Zwischengrunde, die Farbe ziegelroth mit zwei verwaschen schwärzlichen Punkten auf der Mitte neben einander. Das Schildchen stark ansteigend, aus breit dreieckiger Wurzel mit ausgebuchteten Seiten hinten in einen langen Zipfel ausgezogen, um mehr wie die Uälfte länger als vorn breit, schwarz mit mässigem Glanze. Die Deckschilde um 1/4 länger wie vorn breit, hinter den Schultern am breitesten, und von da ab hinterwärts stark in flachen Bogen verschmälert, mit kurz zugerundeter Spitze, wodurch der Umriss sich verkehrteifürmig in die Läıge zieht; die Wurzel nur flach niedlergedrückt, auch die mïssig hervortretenden Schulterbeulen innerseits nur durch einen schmalen und schwachen Lüngseindruck abgesetzt; dic Seitenlappen fast nus durch iluren breiten umgeschlagenen Rand bemerkbar. Die Punktstreifen fein, nur vorn deutlich, von der Mitte ab nu' an der dunkleren Färbung der Punkte kenntlich, der neunte in eine deutliche Furche eingedrückt. Dic matten und glanzlosen Zwischenräume flach, nur der neunte leichıt gewölbt. Die Farbe cin fahles Ziegelroth, ein schmaler, scharf begränzter Nahtsaum schwarz. Pygidium, Hinterbrust und Hinterleil schwarz, Vorder- und Mittelbrust roth mit schwarzen Säumen, die umgeschlagenen Seiten des Halsschildes, sowie die Beine zicgelroth mit schwärzlichen Knien und Schenkelenden der letzteren. Das Prosternum brciter wie lang, querrechteckig mit mässig ausgeschnittenem Hinterrande; das letzte Segment des $\subsetneq$-mit dem gewölınlichen Grübchen: das ơ unbekannt.

Von Montevideo (Mus. Holm.)

34. M. consimilis Dej. Dunliflziegelroth mit schwärzlichen 
Vordersaum der Deckschilde; das Halsschili kaum sichtbar punktirt, die Punkistreifen fein, hinterwärts verschwindend, der neunte vertieft, mit flachen, spiegelglänzenden Zivischenräumen. L. $1 \frac{1}{3}{ }^{\prime \prime \prime}$; Br. $5 / 6 "$.

Bei gleicher Länge mit M. brunneus etwas schmäler, besonders hinterwärts verschmälert, mehr noch der einfarbigen Varietät des M. contractus ähnlich, und von diesem ausser dem melır gestreckten, grösseren Körper hauptsächlich durch dlie glänzenden Zwischenräume der Deckschilde verschieden. Der Kopf flach, matt, das unten eingezogene Kopfschild nur seitlich scharf abgesetzt; die grossen kurz aber tief dreieckig ausgebuchteten Augen oberwärts zusammengeneigt, greis. Die Fühler bei dem einzigen vorliegenden Stücke nur bis zum siebenten Gliede vorhanden; die unteren Glieder etwas mehr gestreckt wie bei den verwandten Arten, die beiden der Keule angehörenden etwas dunkler gebräunt wie die unteren. Das Halsschild vorn mit 3/4 seiner Länge stark kugelig übergekrümmt, über den eingezogenen scharf reclıtwinkligen Vorderecken zusammengedrückt und dadurch verschmälert, die fein alggesetzten hiıten etwas verbreiterten Seitenränder nach vorn in weiten Bogen zusammengeneigt, vor den scharf dreieckig ausgezogenen Hinterecken ausgeschweift, der Hinterrand leicht wellig gebuchtet, von einer Querreilhe eingestochener gröberer Punkte begleitet, mit fast grade abgestutztem Mittelzipfel. Die Oberfläche matt seidig schimmernd, mit äusserst feiner zerstreuter Punktirung. Das Schildchen fast gleichseitigdreieckig, wenig ansteigend, spiegelglatt, braunroth, mit verwaschener hellerer Mitte. Die Deckschilde aus breiter Wurzel hinterwärts stark imi Bogen verengt und mit kurz and ziemlich schmal abgerundeter Spitze den eiförmigen Umriss des Kïrpers abschliessend, hinter der Wurzel nur durch die tiefer eingegrabenen Vorderenden der. Punktstreifen leicht quer niedergedrückt, um die Schildchenspitze bucklig erhöht und von lier aus seitlich mit steiler, hinterwärts mit flacherer Krümmung abfallend; die Schulterbeulen kaum bemerkbar, und eben so wenig über den breiten Seitenlappen eine Spur des gewölınlichen Quereindrucks vorhanden. Die Punkistreifen sehr regelmässig, aus tief eingedrückten Vorderenden bald abgeschwächt, die mittleren kaum von der Mitte ab noch wahrnehmbar, der neunte in eine leichte auch noch die Wölhung umziehende und den äussersten Zwischenraum etwas empordrückende Furche eingesenkt, die übrigen Zwischenräume flach, und dic ganze 
Oherflïche der Deckschidde spiegelglïnzend. Die Farhe dunkelziegelroth mit einem feinen, die Wurzelkante einnehmenden schwirrzlichen Samne. Pygidium, Unterseite und Beine gleichfalls einfarbig ziegelroth mit tiefer gethäunten Nöhten, die Vorderbrust hinter der \$litte leicht quer niedergedrückt, hinten wenig ausgerandet. Das letzte Segment des $q$ init einem ziemlich breiten und tiefen Grübchen, dis of unbekannt.

Aus Columbien (Nus. Deyrolle, und aus diesem unter obigem Namen zum Vergleich erlualten;.

35. M. contractus Boh. Ziegehroth, zwei Punkte des matten Halsschildes, die Wurzel und eine abgelin̈rzte Querhinde vor der Spitze der Deckschilde mit Pygidium und Beinen schmutzig schwarzgrün; die Punkistreifen hinten verschwindend, der nemberertieft, mit flachen mössig gilänzenden Zwischennäumen. L. ${ }^{3 / 4}-\mathrm{I}^{\prime \prime \prime} ;$ Br. ${ }^{2 / 3}-3 /{ }^{\prime \prime \prime}$.

Monachus contractus Boh. Eug. resa elc. Col, p. 157, n. 32S! (die var. $\beta$.)

Kurz und breit eiförmig, ron den zahlreichen verwandten Arten hauptsächlich durch die rothe Unterseite bei dunkler Färhung der Beine abweichend. Der Kopf flach, nur zwischen den Fühlerwurzeln etwas rortretend, das wenig eingezogene Kiopfschild fast quadratisch, oben durch eine undeutliche Querrunzel, seitlich durch schärfere Leisten begränzt. Die Oherllïche sehr vereinzelt und fein punktirt mit genarbtem und dadurch melır oder weniger mattem Zwischengrunde, die Farbe ziegelroth mit etwas melr verduukelter Stirn; die langgestreckten, lurz halhlireisförmig ausgebuchteten, oben ein wenig zusammengeneigten Augen schwarz oder zum Greisen verblichen. Die Mitte der etwas vorspringenden Oberlippe schmutzig grehräunt. Die Fühler nur his zum Ifinterrande des Halsschildes reichend, das 2-5. Glied ziemlich gleich lang, aber ersteres doppelt breiter als jedes der folgenden, kurz eiförmig, das fünfte schon etwas breit gedrückit, die sechs oberen innerseits dreieckig erweitert, mit kurzem Fortsatze des Endgliedes. Die fünf unteren Glieder hell rothgelh, die lienle schwarz, fein angedrüclit behaart und an der Spitze alstehend gewimpert. Das Halsschild kurz und lreit, vorn mit 4/5 seiner Länge n̈bergekrümmt, über den scharf rechtwinkligen Vorderecken zusammengedrückt und dadurch verschmälert, die Seiten fein gerandet und nach rorn in breiten Bogen zusanmengeneigt, vor den kurzen, scharf spitzwinklig ausgezogenen llinterecken etwas ausgeschweilt; der llinterrand jederseits breit amsgebuchtet, durch eine vor ihnn liegende dichte Punlit- 
reihe als feine Kante emprorgeholıen, mit kurzem, breitern, undeutlich doppelt ausgerandetem Mlittelzipfel. Die Olıerläche glatt, aber nichıt elsen glänzend, ziegelroth, Seiten- und Ilinterraul leicht gebräunt; aul' der Mitle neben einander zwei dreieckige schwarzgrünliche selur verwaschene, und zuweilen ganz verloscliene Flecke. Das Schildchen dreicckig, um ılie Hälfte länger wie lıreit, hinterwärts wenig ansteigend und mit undeutlichem Vordergrübchen, ziegelroth nit breit schwarzgrünlichem Saume. Die Jeckschilde vorn etwas breitel wie das Halsschild, so lang wie breit, linterwärts noch etwas in Bogen erweitert und dann kurz zugerundet, vorn hinter dem breiten flach aufgewulsteten Wurzelranle quer eingedrincki; die Schulterbeulen schmal höckerig, die Seitenlappen tief' herabgezogen, die über ilnen liegenden Qıereindrücke wenig bemerkbar. Der Rücken vom Hinterende des Schildchens ab seitlich stärker-, hinterwärts selır flach abfillend, die Naht auf der hinteren Jälfte leicht eingedrückt, zwischen den alggerundeten Spitzen der Flügeldecken klaffend. Die Punktstreifen sehır regelmässigr, fein und auf der Wöllsung verschwindend oder nur noch durch das dunklere Inıere der P'unkte bemerkbar, die Vorderenden etwas tiefer eingegraben und der neunte seiner ganzen Länge mach in eine deulliche Furche eingedrückt; die Zivischenräume breit und flach, die Vorderenden und der äusserste flaclı gewölbt, der letztere ülıer den Seitenlappen breil erweitert. Die Farhe ziegelroth, der aufgeworfene Saun von Naht und Seitenrand bis zum Seitenlappen hin gebräunt, ausserdenr die Wurzel zu beiden Seiten des Schildchens über dessen Spitze hinaus mit verwaschener Begränzung sclıwärzlichgrün, welche Färbung nach aussen hin sich immer melır ab)sclıwächt, imnerseits der Schulterbeulen erlischt und nur auf letzteren selbst wieder mit stärkerer Intensität hervortritt. Ausserdem vor der Spitze ein gemeinsamer, jederscits von der Naht ab bis etwa zum fünften Punktstreilen reichender rerwaschen grünlich brauner Querwisch. IJas I'ygidium vereinzelt grols punktirt, mit fein genarbtem und dadurch mattem Zwischengrunde, schwarzgrün, die Unterseite fein und dicht runzlig punktirt, ziegehroth, das letzte Segment und die I'arapleuren mil den Nähten der Bruststücke schwärzlich angelauf:ı. Auch die Beine schwarzgrün mit breit gerötheten Schenkelwurzeln. Acndert jedoch ab dur'ch alogeschıächte Ausfürlung

$\beta$. Dic Punkte des Ilalsschildes erloschen, die Färbung der 
Flïgeldeckenrurzel zu einem verwaschenen, nur auf den Schulterbeulen etwas deutlicheren Saume geschwunden, und von der Hinterlbinde nur bei gewisser Beleuchtung manchmal eine Andeutung zu sehen. Auch das Pygidium bei solchen Stücken gewöhnlich roth, und an den Beinen nur die unteren Schenkel- und oberen Schienenenden mehr oder weniger geschwärzt.

Das Prosternum sehr kurz und breit, leicht quer anfgewulstet, hinten in einem flachen Bogen ausgeschnitten. Das letzte Segment des $\delta$ einfach, des $q$ init einer eirunden, hinten an den Seitenrändern etwas niedergedrückten, glänzenden Grube.

In Südamerika anscheinend weit verlreitet. Die mir vorliegenden Stürke stammen aus Brasilien (von Rio de Jan.: Mus. Hal. Holm. Deyr.; von Bahia: Mus. Deyrolle; - ohne nïhere. Angabe des Fundorts: Mus. Baly; von Paramaribo Mus. Dohrn) und Columbien (Mus. Ber, von Moritz gesammelt). Die letzteren Stücke gehören zur var. $\beta$, von welcher mir aber anch brasilianische Exemplare aus dem Mus. Baly und Holm. und eben daher stammende. Uebergänge zwischen beiden Formen aus dem Mus. Deyr. vorliegen. Wesentliche Unterschiede zwischen beiden finde ich nicht.

36. M. pygidialis m. Oben ziegelroth, die Naht und ein grosser dreieckiger Wurzelfleck der Deckschilde schwarz, unten schwarz, Vorderbrust, Schenkelwurzeh und letzter Banchring roth; die Punktstreifen mässig, hinterwïts ahgeschwïcht, der neunte vertieft, mit flachen glänzenden Zwischenräumen. L. $3 / 4-1{ }^{\prime \prime \prime}$; Br. $2 / 3-3 / 4 "$.

Dem vorhergehenden überaus nahe verwand, aber doch, wie es scheint, ausser den glänzendern Deckschilden durch die rothe Färbung des letzten Bauchringes bei übrigens schwarzem Hinterleibe von ihm zureichend rerschieden. Der Kopf breit und flach, mit fast parallelen Rïndern des oben nicht abgesetzten Kopfschildes; die ziemlich gestreckten, schmal aber tief dreieckig ausgebuchteten Angen greis und oben ziemlich weil getrennt. Die Fühler roth mit gebräunter Spitze. Das IIalsschild mit $3 / 4$ seiner Länge vorn sanft ülsergekrümmt und daselbst stark verschmälert, mit rechtwinkligen Vorder- und scharf dreieckig ausgezogenen Hinterecken, die nach rorı bogig zusammengeneigten Seiten fein gerandet, hiuter der Mitte ausgeschweif, der Hinterrand jerlerseits hach ausgeschnitten mit kurzem fast grade abgestutztem Mittelzipfel. Die Oberfläche matt seidig schimmernd, sehr fein und zerstreut punktirt, 
vor dem Hinterrande die gewöhnliche Reihe gröberer Punkte. Das Schildchen gleichseitig dreieckig, sehı schräg ansteigend, dunkler gehrämt, mit sclıwärzlicher Wurzel. Die Deckschilde hinter den Schultern noch etwas erweitert, dann hinterwärts in Bogen verschmälert, daher der Umriss eiförmig; der Rücken hinter der flach aufgrewulsteten Wurzel durch die tiefer eiugegrabenen Vorderenden der Punktstreifen leicht quer eingedrückt, um das Schildchen hoch buckelig aufgewölbt und von da seitlich ziemlich steil-, hinterwärts schwächer abfallend; die Punlitstreifen regelmïssig, schon vor der Mitte allmählich feiner, aber nirgends ganz verschwiudend, die ziemlich glänzenden Zwischenräume flach, nur der äusserste durch den tiefer eingedrückten neunten Streifen etwas aufgetrichen; die Schulterbeulen breit und flach, innerseits durch das gröbere Vorderende des fünften Streifens abgesetzt, mit einem schwarzen Längsflecke besetzt, auch die Wurzel zwischen ihnen mit einem grossen dreieckigen Fleck, wie bei der vorhergehenden Art bezeichnet, an welchen sich hinterwärts ein die Naht begleitender, je zuweilen auch vor der Spitze zu einem abgekürzten Querwisch erweiterter: Saum anschliesst. Aendert jedoch ab

$\beta$. Der Schulterfleck nur verwaschen geschwärzt, die schwarze Fürbung an Wurzel und Naht zu einem unscheinbaren Randsaume geschwunden, der var. $\beta$. der vorhergehenden Art täuschend ähnlich und von ihr kaum anders als an der scharf begränzten rothen Färbung des letzten Bauchringes zu unterscheiden.

Unterseite und Beine schwarz, die Schenkelwurzeln roth, an den Vorderbeinen auch der untere anfgetriebene Theil der Schenkel und die Schienen rothbraun durchscheinend, die hinten breit ausgeschnittene Vorderbrust und der letzte Bauchring gleichfalls roth und der letztere hei dem $q$ mit dem gewöhnlichen Grübchen.

Aus Brasilien (die IIauptform von Tejuca im Mus. Clark, und vom Amazonenstrom im Mus. Deyrolle; die var. $\beta$. von Pernambuco im Mus. Deyrolle).

37. M. contrusus m. Ziegelroth, ein dreieckiger Wurzelfleck der Deckschilde mit dem Schildchen, der Hinterbrust und dem Ilinterleibe schwarz; die Punktstreifen fein, hinten verschwindend, der neunte leicht vertieft, mit flachen auf dem dunklen Vorderflecke glïnzenden Zwischenräumen. L. 3/4"'; Br. 5/12"'.

Wiederum dem vorhergehenden üheraus ähnlich, aber anclı abgesehen von der verschiedenen Färbung der Beine namentlich 
noch durch den Bau des Schildchens von ihm abweichend, wesshalb ich in ihm keine blosse Form des M. pygiclialis zu erkennen vermag. Der Kopf flach gewölbt mit eingezogenen, runzlig punktirtem Kopfschilde, ziegelroth, die gestreckten, tief dreieckig ausgeschnittenen, oben zusammengeneigten Augen nebst der Fühlełlieule schwarz. Das Halsschild mit $2 / 3$ seiner Länge vorn sanft übergekrümmt und hinterwärts eben so schwach abwärts geneigt, vorn über den scharf rechtwinkligen Vorderecken zusammengedrüclit und dadurch verschmälert; die Seiten fein gerandel, hinter der Vitte sanft ausgeschweift, nach vorn in flachen Bogen zusammengeneigt; die Hinterecken scharf spitzwinklig aus- und abwärts gezogen, der Hinterrand leicht wellig gebuchtet, mit kurzem, grade algestutztem Mittelzipfel. Die Oberfläche matt ziegelroth, ron der gewöhnlichen Querlinie vor dem Hinterrande keine Spur vorhanden. Das Schildchen sehr schräg ansteigend, schmal und spitz dreieckig, doppelt länger wie breit, glänzend schwarz. Die Deckschilde hinter den Schultern noch etwas erweitert, damn in breiten Bogen hinterwärts verschmälert und zugerundet, hinter der etwas aufgewulsteten Wurzel breit und flach quer eingedrüclit, die Schulterbeulen als kräftige Höcker herausgehoben, die Seitenlappen wenig bemerkbar, auch der Rï̈cken um die Schildchenspitze nur mässig aher breit aufgewölbt. Die Punktstreifen sehr regelmässig, aus tiefer eingegrabenen Vorderenden bald abgeschwiteht, hinten rerschwindend und nur noch an ilırer dunkleren Färbung erkennbar, mur der neunte in eine seichte Furche eingesenhte bis zur Spitze walırzunclımen. Die Zwischenräume flach, nur ter neunte ein wenig aufgetriehen. Die Farbe ziegelroth, ein grosser dreieckiger, gläızender Wurzelfleck zwischen den Schulterbeulen schwarz; derselbe erreicht mit seinem abgerundeten Ilnterrande fast die Mitte der Naht und verläuft sich von da ab in einen zarten auch noch die Spitze umziehenten Nahtsamm; die Schulterbeulen sellst sind schmmtzig gebsäunt. Das grob punktirte, in der Mitte gebräunte Pygidium, die seicht ausgerandete Vorderbrust, die Beine und der letzte Banchıring ziegelrotı; der übrige Theil der Unterseite schwarz. Das letzle Segment des $q$ mit dem gewöhnlichen Grübchen; das o inloekannt.

Aus Brasilien (Mus. Mcyrolle).

38. M. decolorans m. Ziegelroth, das Schildchen und ein dreieckiger Wurzelfteck der Deckschilde mit dem Pygidium und 
dem Hinterleibe schwarzgrün; die Punktstıeifen måssig, hinterwärts schwächer, der neunte vertieft, mit flachen fein gerunzelten Zwischenräumen. L. $11 / 12{ }^{\prime \prime \prime}$; Br. $2 / 3{ }^{\prime \prime \prime}$.

Eine Mittelart zwischen den drei vorhergehenden und der unten als M. rubromstulatus Stål beschriebenen Art, der letzteren ähnlich durch die schwarze Färbung von Pygidium und Hinterleib, wie auch bei einer Varietät durch die Farbenvertheilung der Deckschilde; mit den drei vorhergehenden dagegen übereinstimmend in dem ungefleckten Halsschilde, der normalen Zeichnung der Deckschilde, mit M. contrusus auch in den einfarbig rothen Beinen und dem Bau des Schildchens, aber auch von diesem letzteren an dem ganz schwarzen Hinterleibe leicht zu unterscheiden, übrigens habituell am nächsten dem M. contractus verwandt, auf dessen Beschreibung desshalb im Allgemeinen Bezug genommen werden kann. Die Färbung der Oberseite steht gewissermaassen zivischen der der beiden Formen des M. contracius in der Mitte; die Punkte des Halsschildes und der Querwisch vor der Flügeldeckenspitze fehlen ganz und die Schulterbeulen sind nur bräunlich angeflogen; das Schildchen dagegen ist eiufarbig schwarzgrün, und dessen Umgehung zeigt den breit dreieckigen scharf begränzten schwarzgrünen Wurzelffeck der Normalform der nächst vorhergehenden Arten, lessen Spitze fast die Nitte der Naht erreicht. Auf der Unterseite ist der ganze untere Theil des Halsschildes mit der Mittelhrust, den Schulterblättern und den Beinen roth, die Mitte ler Hinterbrust und des letzten Ringes bei einem der vorliegenden Stücke verwaschen gebräunt, sonst, wie das Pygidium, schiłarz. Das Schildchen ist, wie bei M. contrusus, schmal und gestreckt, reichlich doppelt länger wie breit, die Fläche nicht eigentlich schräg ansteigend, sondern mit leichter Krümmung der Krümmung der Deckschilde folgend; die Zwischenräume sind deutlich querrunzlig und dadurch matter als bei den vorhergehenden Arten. Alles Uebrige wie bei diesen, das letzte Segment des $\delta$ mit einem leichten Längseintluck, des \& mit einer grossen glänzenden Grube.

Aus Brasilien (Mus. Schaum) und Cayenne (Mus. Deyrolle). Bei einem $\delta$ Stïck aus Columbien im Mus. Deyrolle ist die Sculptur etwas feiner und vor der Spitze fast verloschen, daher die Oberfläche etwas mehr glänzend, auch die dunkle Färbung der Deckschilde soweit ausgedehut, dass diesell,en einfarbig schwarzgrün mit einem grossen trübrothen verwaschenen Mittelflecken erscheinen. 
Weitere Unterschiede finde ich jedoch nicht, und halte daher dies Stück einstweilen nur für eine merkwürdige Farbenvarietät, welche, wenn sie sich öfters fände, wohl nach der Analogie des $\boldsymbol{M}$. contractus und pygidialis als die normale Form angesehen werden müsste. Die oben als die normale beschriebene war im Mus. Deyrolle als M. rubicundus Dej. bezeichnet.

39. M. rubropustulatus Stå. Ziegelroth, zwei Punkte des Halsschildes, das Schildchen und eine $x$-förmige Zeichnung der Deckschilde mit Pygidium, Hinterleib und Beinen schwarzurün; die Punktstreifen mässig, hinten ver'schwindend, der neunte vertieft, mit flachen, fein zerstreut punktirten Zwischenräumen. L. $3 / 4-1^{\prime \prime \prime}$; Br. $1 / 2-2 / 3{ }^{\prime \prime}$.

Mon. rubropuslulatus Slål Till Kännedomen elc. in der öfversicht etc. p. 61 . ก. 8 !

Eine überaus veränderliche, in ihrer Heimath anscheinend keinesweges seltene, den nächstvorhergehenden Arten ungemein nahestehende Art, die den Bau des Schildchens und die Färbung der Oherseite von dem $M$. contractus mit der Hinterleibsfärbung des $M$. decolorans verbindet, nach der Sculptur der Deckschilde und der Färbung der Beine aber mit keiner von beiden vereinigt werden kanu, sofern man nicht, was auch manchen Bedenken unterliegt, alle vorstehend von M. contractus ab lieschriebenen Arten zu einer einzigen Collectivart zusammenziehen will. Bei der grossen Uebereinstimmung mit M. contractus kann ich jedoch auf die Beschreibung dieses letzteren rerweisen und mich auf dic Angabe der wesentlichen Abweichungen beschränken. Der Käfer ist bei etwa gleicher Länge mit der genannten Art ein wenig schmäler, melır walzenförmig und hinter ılen Schultern weniger deutlich erweitert; auf dem Halsschilde sind die beiden grünen P'unkte deutlich, wohlbegränzl, zu etwas eiförmigen Längsfleckichen erweitert; der Hinterrand des Halsschildes ist schwarzgrün gesäunt, und das wie bei der genannten Art gestaltete Schildchen einfirbig spiegelglänzend schwarzgrün. Längs der Wrurzel der Deckschilte bildet die grüne Färbung eine breite, die Schulterbeulen mit umfassende Querbinde, deren Mitte sich längs der Naht breit, aber mit verwaschener Begränzıng bis zur Wölbung erstreckt md hier mit. einer zweiten breiten vor der Spitze liegenden, jederseits bis zum neunten Zwischenraume reichenlen Querbinde zısammenhängt. Dadurch entsteht die oben angegebene $\mathrm{x}$-förmige Zeichnung, bei deren normaler Aus- 
bildung die schmale Spitze frei bleibt; durch ein Mehr oder Weniger in der Entwickelung dieser Zeichnung ergeben sich jedoch ein paar Formen, nämlich

$\beta$. Die hintere Binde soweit ausgedehnt, dass auf jeder Flügeldecke nur eine rothe Schrägbinde, oder gar nur vor der Spitze ein bräunlicher Querwisch und seilich auf dem neunten Zwischenraume eine ähnliche noch schwächere und verwaschene Stelle übrig bleibt, und die Flügeldecken auch als schwarzgrün mit einem innerseits abgekürzten röthlichen Schrägwische bezeichnet werden können, wobei sich gleichzeilig meist auch die Punkte auf dem Halsschilde zu kräftigen Längsflecken ausdehnen (die von Stå a. a. 0 . beschriebene Form); und

$\gamma$. die Nahtfärbung zu einem zarten Saume zusammengeschwunden, und dadurch die Vorderbinde anscheinend von der hinteren abgelöst. Bei dieser Form, welche Germar von Buquet als $\mathbf{M}$. bipunctatus Buq. erhielt, fült manchmal auch der untere Rand des Pygidiums ins düster Bräunliche; in der Zeichnung der Deckschilde ist dieselbe dem M. contractus sehr ähnlich, aber doch von ihm an der Färbung iles Schildchens und der Sculptur der Deckschilde leicht zu unterscheiden.

Auf der Unterseite ist der Hinterleily mit der Hinterbrust schwarzgrün, letztere vorn und ebenso der Mittelzipfel des ersten Bauchringes manchmal schınutzig geröthet. Vorderbrust und Schulterblätter roth, auch die Vorderbeine bis auf die Unterenden der Schenkel und die oberen und unteren Schienenenden röthlich, an den Mittelbeinen und noch beschränkter an den hinteren nur die Schenkehwurzeln geröthet und die unteren Schienenenden gebräunt, die Fussglieder überall schwärzlich. Bei recht dunkeln Stücken der var. $\beta$. sind die Beine fast, einfarbig schwarz; bei überhandnelımendem Roth auf Halsschild und Deckschilden werden auch die Beine heller rötlllich und die dunklere Färbung beschränkter.

Ausser diesen Farbenverschiedenheiten zeigt auch noch die Sculptur eine bemerkenswerthe Abweichung von den vorhergehenden Arten, indem die flachen, bei den ơ ziemlich glänzenden, bei den $q$ fein gerunzelten Zwischenräume der Punktstreifen mit zerstrenten, aber deutlichen und stellenweise unordentliche Längsreihen hildenden Punkten besetzt sind. Alles Uebrige, auch die grobe Punktirung des Pygiliums, wie bei den verwandten Arten. 
In Brasilien, und dort anscheinend nicht selten, daher in den meisten von mir verglichenen Sammlungen vorhanden. Von Rio de J. - Mus. Baly, Holm., Clark, Deyrolle, Dohrn; von Bahia Mus. Berol. (von Böck gesammelt). Ohne nähere Angabe des Fundorts im Mus. Baly, Mosqu. (von Eschscholtz gesammelt), Schaum (von Buquet mitgetheilt).

40. M. dia e reticus m. Schwarzgrün, die Wurzeln der Fühler, Schenkel und Schienen mit dem Kopfe und dem zweifleckigen Halsschilde, auch einer breiten Läıgsbinde der Flügeldecken ziegelroth; die Punktstreifen deutlich, linten feiner, der neunte vertieft, mit flachen fein zerstreut punktirten Zwischenräumen. L. 11/12"'; Br. $2 / 3{ }^{\prime \prime \prime}$.

Den dunkleren Formen des vorhergehenden überaus älnlich, aber von demselben auch ausser der etwas grösseren Breite noch durch die verschiedene Gestalt und Richtung ler Flügeldeckenbinde und die scharfe Begränzung dieser sowohl als der Färbung an den Beinen abweichend, laher nach meinem Bedünken eine gute und selbstständige Art. Kopf und Halsschild wie bei dem vorhergehende'n, nur das letztere etwas melır glänzend, dabei äusserst fein punktirt; die schwarzgrünen Punktflecke desselben rund, nicht wie bei Jenen in die Jänge gestreckt, auch der hintere Theil nach den Deckschilden zu tiefer eiugesenkt. Die Deckschilde um das Schildchen stärker buckelig gewölbt, die Punktstreifen gröber, hinterwärts zwar auch schı̈icher, aber selbst auf der Wölbung nicht versclıwindend; die Schulterbeulen viel stärker echig hervortsetend. Die Flügeldecken wie bei jenen Stücken des vorigen schwarz mit grüılichem Anfluge, aber selı abweichend gezeichnet. Bei der genamnten Art läuft die rothe Färbung als Schrägbinde vom Seitenlappen nach tlem hinteren Drittel der Naht hin, olme letztere zu erreichen; sie ist nur in der Mitte intensir roth gefïrbt, am Rande verwaschen, selbst in der Mitte zuweilen unterbrochen; bei der vorliegenden beginnt sie hinter der Schulterbeule, letztere innen und aussen umfassend, und zieht sich damm in ziemlich scharfer Begränzung. als breite Längsbinde fast bis zur Spize hin, deren Saum damn noch als tief gebräunt erscheint. An den Beinen sind die Schenkel und Schienen roth, die Spitzen derselben, bei den Hinterschenkelı deren ganze mutere Iälfte nebst den oberen Schienenenden scharf hegrănzt schwarz. Alles Uebrige wie bei der vori- 
gen Art; das letate Segment des $q$ mit dem gewöhnlichen Grübchen, das ơ unbekannt.

Aus Brasilien (von Pernambuco - Mus. Deyrolle).

41. M. a rgutulus Dej. Ziegelroth, Schildclien, Hinterlorust und Hinterleib, Schenkelspitzen und Deckschilde schwarz mit rothem Hinterflecke der letzteren; die Punktstreifen mässig, hinterwärts feiner, der neunte stark vertieft, mit flachen, ziemlich glänzenden Zwischenräumen. L. $2 / 3{ }^{\prime \prime \prime} ; \mathrm{Br}, 1 / 3{ }^{\prime \prime \prime}$.

Ob dieser mir nur in einem einzigen Stücke vorliegente Käler wirklich eine eigene Art older nur eine Form des M. contrusus ist, wage ich nicht mit Siçherheit zu entscheilen, möchte michı aber doch nach der Verschielenheit der Heimath, der Grösse und der Zeichnung für ersteres aussprechen, wenngleich ein endgültiges Urtheil darüber dem Vergleiche einer grösseren Anzahl von Exemplaren vorbebalten bleiben muss. Ilabitus und Farhenvertheilungr sind im Ganzen wie bei der genannten Art, und die Abweichungen bestehen im Wesentlichın in Folgendem. Der Körper ist noch merklich kleiner, besonler's schmäler, das Schildchen nur etwa um die IJälfte länger wie breit; die Deckschilde sind ganz trïb schwarzgrüı mit einem ihre ganze Hinterhälfte einnehmenden, verwaschen ziegelröthlichen Längstvische, welcher sich an Spitze und Aussenrand soweit ausdehnt, dass hier nur ein schmutzig bräunlicher verwaschen begränzter Rand übrig bleibt. An den Beinen sind die Enden der Mlittel- und Hinterschenkel verwaschen geschwärzt; eben so sind Pygidium und Hinterleib einfarhig schwarz. Endlich sind die Punktstreifen etwas deutlicher, hinterwärts zwar auch abgesclıwächt, aber nicht verschwindend, der neunte in eine sehr kräftige Längsfurche eingedrückt, die Zwischenräume nicht ganz so gläızend, und die Schulterbeulen sehr flach. Auch das Prosternum ist flach, hinten breit ausgerandet, das letzte Segment des einzigen vorliegenden ơ einfach. Das $q$ unbekannt.

Aus Neu-Granada (von Carthagena - Mus. Deyrolle).

42. II. rejectus m. Oben ziegelroth, zwei Flecke des matten fein punktirten Halsschildes, das Schildchen, die Wurzel und eine hintere Querbinde der Deckschilde schwarzgrün, Unterseite und Beine schwärzlich; die Punktstreifen`mässig, hinten verschwindend, der neunte vertieft, mit flachen, glänzenden Zwischenräumen. L. $11 / 6{ }^{\prime \prime \prime} ; \mathrm{Br} .3 / 4{ }^{\prime \prime \prime}$.

Eine Mitlelart zwischen M. coenobita und contractus, von 
jenem hauptsiichlich durch den geringeren Glanz, die feine Punktirung des matten IIalsschildes und die dicken Längsflecke des Halsschildes abweichend; näher aber dem MI. contractus stehend, wesshallb ich auf die Beschreibung dieses letzleren Bezug nehmen und mich auf die Angabe der Alwveichungen beschrïnken kann. Die letzteren zeigen sich vorzugsweise in der Färbung und Farbenvertheilung. Die Unterseite ist nicht roth, sondern, wie die Beine, schwarz, die schwarzgrünen Flecke des Halsschildes sind grösser, intensiver gefärbt und schärfer begränzt, eilörmig in die Länge gezogen. Auf den Flügeldecken ist auch die hintere Binde deutlich, vorn und hinten scharf begränzt, seitlich bis zum Rande ausgedehnt, und die rothe Spitze dadurch vollstindig ron dem gleichgefärlten Mittelledde geschieden, so dass man die Deckschilde als abwechselnd mit zwei schwarzgrünen und rothen Querbinden, die vordere dieser lezzteren an der Naht unterbrochen, bezeichnen kann. Anch die schwarzgrüne Wurzelbinde ist hinter'wïr's schärfer hegrïnzt, in der Mitle dreieckig ausgezogen, fast die hintere Binde erreichend. Ilas Halsschild ist sehr fein und zerstreut-, aber doch kenntliclı punktirt, die Vorderenden der Punktstreilen sind tief eingegraben, wodurch hinter der flachen Wurzel eine deutliche bis zu der sehr flachen Sclulterbeule reichende Querfurche eingedrückt wird; hinterwärts werden die Streifen schon vor der Mitte schwïcher und sind vor der Spitze kium noch kenntlich. Unterseite und Beine sind schwarz mit röthlichen Vorderhüften, die Nitte der Vorderbrust, sowie ein mit gelben Härchen besetzter Querlleck auf der Mitte des ersten Bauchringes und der letzte Ring trübroth; der letztere bei dem rorliegenden ot einfach.

- An den letztgenamnten Mlerkmalen ist der Käfer auch, abgesehen von ter Grösse und ron der Sculptur des Ilalsschildes, leicht von der sonst gleichfalls nicht unäludichen var. $\beta$. des $\boldsymbol{M}$. rubropustulatus zu unterscheiden.

Aus Brasilien (Ilus. Baly).

43. ‥ punctum Chr. Schwarz, das mit einem grossen schwarzen Querflecke grezeichnete Ilalsschild und eine Schr:ioglonde der Flügeldecken mil Vorderbrust, Pygidium und dem letzten Bauchringe ziegelrotl; die Punktstreifen fein, hinter der Mitte verschwindend, der neunte schwach vertieft, mit llachen glänzenden Zwischenräunen. L. 1"'; Br. $2 / 3{ }^{\prime \prime \prime}$.

Der vorliegende Käller rerbindet die rothe Ilinterleibsspitze des 
M. pygidialis und contrusus mit der Flügeldeckenzeichnung der dunkleren Stücke des M. rubropustulatus, unterscheidet sich aber von beiden slurch den sclıwarzen Kopf und den grossen nierenförmigen, gleichfalls sclıwarzen Querfleck des Halsschildes, und ist daher ohne Zweifel eine gute Art. Der Kopf flach, matt und nur undeutlich punktirt, schwarz; die tief ausgebuchteten Augen greis, der Unterrand der Oberlipje nebst den Fühler'n ziegelroth nit gebräunter Spitze der letzteren. Das Halsschild vorn mit $3 / 4$ seiner Länge sanft abwärts gekrümmit, hinterwärts nur alggeflacht, über den scharf rechtwinkligen Vorderecken zusammengedrückt und dadurch verschmälert, die fein und hinten breiter gerandeten Seiten nach vorn in flachen Bogen zusammengekrünmt, vor den scharf und spitz ausgezogenen Hinterecken leicht ausgeschweift, auch der Hinterrand nur leicht wellenförmig gebuchtet, mit grade abgestutzten Mittelzipfel. Die Oberfläche matt und glanzlos; vor dem Hinterrande eine feiue, tief eingedrückte, mit groben Pmkten besetzte Querlinie. Die Farbe ziegelroth, hinter der Mitte des Vorderrandes, aber diesen nicht berülırend, eiı grosser schwarzer unregelmässig gerundeter Querfleck, welcher ein Drittel der Breite und reichlich die halbe Länge des Halsschildes einnimmt. Das Schildchen etwas länger wie breit, wenig ansteigend, glänzend schwarz. Die Deck- schilde hinter der Wurzel noch etwas verbreitert, dann bogig verschmälert und kurz zugerundet, vorn breit und flach quer niedergedrückt, um die Schildchenspitze sehr schwach aufgebuckelt und von da nach vorn und hinten sehr sanft-, seitlich etwas steiler abfallend, die Schulterbeulen gleichfalls sehr breit und flach, die Seitenlappen sehr stark ausgebildet, so dass sich hier der äusserste Zwischenraum auf das Doppelte erweitert. Die Punktstreifeı aus grübchenartigen Vorderenden entspringend, aber bald so sehr abgeschwäclıt, dlass sie schon von der Mitte ab unscheinbar werden; die Zwischenrämme flach, glänzend, auf dem hinteren Drittel wie abgeschliffen, mur der äusserste durch den flach eingesenkten neunten Streifen etwas aufgetrieben. Die Farbe eigentlich ziegelroth, ein grosser dreieckiger, zugleich die Sclıulterbeulen unfasscnder, innerseits der letzteren etwas ausgebuchteter Wurzelfleck schwarz. Das bis über das Irittel der Naht hinausreichende Hinterende des letzteren verlängert sich dann zu einem breiten Nahtsamme, welcher sich unter der Wölbung wieder zu einem breiten Spitzenfleck erweitert und dadurch die rothe Grundfärbmig zu einer ziemlich XV. 
ausgerlehnten Schräglinde einschränkt. Unterseite und Beine sind schwarz, ıur das Pygidium mit dem letzten Bauchringe, der Vorder- und Nittellırust roth, auch die Schenkelwurzeln und bei den Vorderheinen die ganzen Schenkel verwaschen röthlich durchscheineml; dahıi die Schẹılel selbst ungewöhṇlich breit und kräftig. Die Vorderhrust ror der Mitte leicht quer eingedrüclit, limten missig ausgerandet; das letzte Segment des $q$ mit der gewölnlichen, glänzenten Grube. Das ơ unbekannt.

Aus Brasilien (Nus. Deyrolle).

44. I. peccato I m. Lehmgelh, zwei Längsllecke des Halsschiddes, das Schildchen und dor Vorderrand der Deckschilde gebräunt; die Punktstreifen bis auf ihre schwachen Vorderenden erloschen, der ncunte leicht verticft, mit flachen wenig glänzenden Zwischenräumen. L. $5 / 6$ "'; Br. $2 / 3$ "'.

Eine sehr breit eiförmige, dabei zierliche und durch ihre rigenthïmbiche, aber doch nicht ten Ausdruck unvollkommener Aushildung tragende Firloung ausgezeichnete Art. Der Kopf Aach, mit seitlich scharf begränztem, oben nur durch einen schwachen Wulst abgesstztem Kopfschilde und stark vorspringender Oberlippe; die Oberflïche nicht pmiktirt, aher olne Glanz, einfarbig lehmgelb, die breit ausgabuchteten Augen greis. Die Fühler sehr kurz, das Wurzelglięl schmal keulenförmig, etwa dreimal lünger wie breit, das zweite linl'z eilörmig, kaum dem tritten Theile dles ersten gleich, die beillen folgenden je so laug alser nerklichı dünnes als llas zwcite, verkehrt kegelförmig; das fünfte bei gleicher Länge oherwirts schon etwas erweitert; die sechs oberen innerseits stark verbreitert unıl zusammengrilrückt, so lıreit wie lang, mit kurz dreieckigen Fortsitze des Endgliedes. Die Farbe der vier unteren durchschınuend gelb, das fünlte gebräunt, die Kenle schwarz mit dünı angedrückter grriser Bchaarung. Das Halssehild gleich rom Ilinterrande al, nach rorn logrig ähorgekrümmt, vorn äher den selı lief eingezogmurn, scharf rechtwinkligen Vordereclien zusammengedrïcht mal daulureh verschuälert, die Seiten fein- mol hiiitrrwärts stïlier aufgebogen-gerandet, nich rorn in breiten Bogen zusanmengeneigt, vor den gleichfalls scharfen llinterechen etwas ansgeschweilt, der Ilintermand jedrerseits breit ansgebuchtet, fein geserigt, mit fast grade alogestutzlem Mittelzipfel. Die (Hberfliche kamm sichthar genartot und dirdurch matt, ror dem Ifinterrante mit

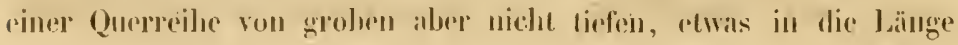


gezogenen Punkten liesetz. Die Farbe lehmgelb, auf der Mille zwei ziemlich scharl lrogränzte braune Längsflecke neben eininder. Ias Schildchen drececkig, etwa 1/3 länger wie breit, nur wenigg ansteigend und mit undeutlichem Vordergrülıchen, glinzend bram mit etwas dunklerem Saume. Die Deckschilde wenig länger als breit, vorn elwas lireiter als das IIalsschild mol hinten mit lumer Rundumg den breit eiförmigen Umriss des Körpuers abschliessem, vorn durch die tiefer eingegralienen Forderenden der Punkistreifen leicht quer niedergedrückt, über den stark herabgezogenen Seitenlappen! schwach zusammengedrückt, linten mil sanfter Wülbung alılallend; die Schulterbeulen als breite Höcker hervortretend. lie Punkistreifen vorn deullich, aber schon von Anlang des zweiten Viertels an so sehr abgeschwächt, dass hinterwarts nur geringe mehr an der dunkeln Färlumg als der Sculptur merkbare sjuren ron ihnen gefunden werden; der neunte in rine leichte Längsfurche eingedrürkt. Die Zwischonräume, bis anf den leichı gew ölıcn neunten, flach, wenig glänzend; die Farbe ein helles, reines Lehmgralb mit braun gesiumter Wurzol. Pygidimm und Unterseite äusserst frin rmalig punktirt, gleichfalls lohmgelh, die Hinterhust, die Wurzel ves linterleibes und dic ausseren Schenlielenden otwas dumkler; die Vorderbrust um die Hälfte hreiter als lang, fach, hinten lureit ausgerandet. Das letzte Segment des of mit einer mässig vertiefteı, eilörmigen, slark glänzenden Grube; das $\delta$ unhekimut.

\section{Von Caraccas (Mus. Schanm).}

45 M. quietus n. Rohlygell, der Vordersaum der Drckschilde, die Schulterheulen und der Saum des Pygidiums gebräunt, die Fühlerenden und Beine schwarz mit röthlichen Schenkelwurzehn; die: l'unkistreifen mässig, linten erloschen, der nembe vertioft, mit flachen lén punktirtrı gläızenden Zwischenräımen. L. 11/1;"; Br. $5 / 6 "$ ".

Eine Mittelfor'm zwischen dem rorhergelsenten ums dem $M$. consimilis, an Grösse und Hahitus dem letzteren nicht unähulich, aher von heiden sogleirh an den schwarzen Beinen zu unterscheiden. Her Kopf llach, mit kurem, breitem, nur seitlich scharf abgesetztem Kopfschilde, die langgestreckten Augen oberwirts etwas zusammengeneigt, lurz alser tief dreieckig ausgeschnitlen, der obere Raud der Oberlippe und die Tasterenden gebriunt. Hie breit erwriterten Glieder der Fühlerkenle schwar\%. Das Halsschild mil 5/6 
seiner Länge nach vorn sanft übergewölbt, hinten leicht niedergesenkt, über den scharf rechtwinkligen Vorderecken zusammengedrückt und dadurch verschmälert, die Seiten fein-, hinterwärts breiter gerandet, nach vorn in sehr flachen Bogen zusammengeneigt, die Hinterecken scharf dreieckig aus- und etwas abwärts gezogen, vor ihnen die Seiten etwas ausgeschweift. Der Hinterrand kaum merklich ausgebuchtet, mit grade abgestutztem Mittelzipfel. Der ganze Hinterrand mit einer Reihe grober P'unkte besetzt, welche nach der Mitte zu stärker werdend hier eine scharfe Querlinie niederdrücken und dadurch den Hinterrand selbst als eine feine Kante hervortreten lassen. Die Oberfläche kaum sichtbar zerstreut punktirt, einfarbig rothgelb. Das Schildchen wenig ansteigend, länglichdreieckig, spiegelglatt und gleichfalls rothgelb. Die Declischilde hinter den Schultern noch etwas erweitert, dam hinterwärts in hreiten Bogen verschmälert und kurz zugerundet, etwas länger als breit, vorn durch eine breite flache Querfurche niedergedrückt, un die Schildchenspitze mässig aufgebuckelt und von da ab hinterwärts sehr flach abfallend, die Schulterbenlen breit und flach, die Seitenlappen kräftig mit eben so stark entwickeltem umgeschlagenem Raude. Die Punktstreifen mit grübchenartigen, die vorgenannte Querfurche eindrückenden Vorderenden, dann plötzlich abgeschwächt und auf der Wülhung fast verschwindend, lasellst nur noch an der dunklern Färbung der Punkte kenntich. Die Zwischenräume fein punktirt, dahei ziemlich glänzend, flach, nur ler äusserste durch den leicht eingedrückten neunten Punktstreifen etwas emporgetrieben. Die Farbe rothgelb, das Innere der Punkte, ein verwaschener Saum der Wurzel und des Pygidiums, und ein eben so verwaschener eiförmiger Fleck auf der Schulterheule schmutzig gebräınt. Die Unterseite gleichfalls rothgelb, dic Ränder der Bauchringe und die Seiten der Hinterbrust verwaschen bräunlich. Die Beine schwarz, die Sclienkelwurzeln und an den Vorderbeinen fast die ganze obere Hälfte der Schenkel trül, geröthet. Das Prosternum kurz und breit, vor der Mlite quer eingedrüclit, hinten flach ausgerandet. Das letzte Segment des $q$ mit dem gewöhnlichen Grübchen; das $\delta$ unbekannt.

Aus Brasilien (Mus. Deyrolle).

46. If. metallescens m. Prchlhan, die Füllerwureln, das Halsschild und die bram gesïmmten Deckschilde lehmgelb mit hellem Messingglanze der letzteren; die Punktstreifen verloschen, 
der achte und neunte sehr schwach vertieft mit flachen Zwischenräumen. L. $5 / 6{ }^{\prime \prime \prime} ; \mathrm{Br}$. 1/2"'.

Im Vergleich zu seiner Länge merklich schmäler als die verwandten Arten, und dabei durch die metallischspiegelnden gegen das matte IIalsschild eigenthümlich abstechenden Flügeldecken sehr ausgezeichnet. Der Kopf flach, äusserst fein narbig punktirt, mit etwas eingezogenem, oben durch ein paar schwache Querbeulcn abgesetztem Kopfschilde, nur der Unterrand des letzteren etwas glänzend. Die Farbe dunkel pechbrauı, Mundtheile ınd Kopfschild etwas heller schmutzig gelbbraun, die oben etwas genälıerten, breit und tief ausgebuchteten Augen schwarz. Die Fühler kurz, das zweite Glied länglich eiförmig, die drei folgenden dünn verkehrt kegelförmig, das dritte dem zweiten an Länge gleich, das vierte und das oben stärlier verbreiterte, schon ctwas zusammengedrückte fünfte etwas kürzer; die Glieder der Keule innerseits breit rundlich erweitert, nicht völlig so breit wie lang, je um die Irälfte länger als das fünfte, mit kurzem breit dreieckigem Fortsatze des Endgliedes. Die Farbe der vier unteren lehmgelb, das fünfte pechbraun, die Keule schwarz. Das Halsschild hinten leicht quer niedergedrückt, fast von der Wurzel ab nach vor'n sanft abwärts gehrümmt, daselbst über den stumpf rechtwinkligen, tief eingezogenen Vorderecken zusammengedrückt und dadurch sehr verschmälert; die Seiten fein gerandet, mit der vorderen Hälfte stark zusammengekrümmt, die Hinterecken sehr kurz und breit zugespitzt, der Hinterraud jederseits breit ausgebuchtet mit kurzem undeutlich ausgerandetem Mittelzipfe?. Die Oberfläche matt lehmgelb mit leicht gebräuntem Hintersaume, vor dem letzteren eine schmale eingedrückte mit einer gröberen Punktreihe besetzte Querlinie. Das Schildchen mässig ansteigend, dreieckig und um die Hälfte länger als breit, hell pechbräunlich mit metallischem Glanze. Die Deckschilde vorn nur wenig breiter als der Hinterrand des Ilalsschildes, hinterwärts kaum merklich erweitert und dann in sehr flachem Bogen verschmälert, mit kur'z und breit zugerundeter Spitze; der Rücken hinter dem Schildchen flach buckelig gewölbt und dann die Naht entlang bis zur Spitze mit sanfter Krümmung abfallend, auch längs der Wurzel nach vor'n schwach abwärts gekrümmt; die läuglich-eckigen Schulterbeulen innerseits durch einen deutlichen Längseindruck abgesetzt, auch die Seitenlappen kräftig entwickelt. Die Punktstreifen fein, an dem zweiten bis vierten die ersten Punkte 
grübchenartig vergrössert, auch die folgenden noch erkennbar; bald aber die Punkte nur noch bei starker Vergrössermug und fast nur an ihres dunklen Färbung walızunehmen, der neunte unl in norh geringerem Cirate anch ler achte Streifen in selı schwache Längsfurchen riugerlrüclit. Ihe Zwischenräume flach; die Farbe hell lehmgell) mit spirgelulem Messinggọlanze; ein feiner Saum längs Wurzel, Naht und dem hinteren Theile des Aussenramles leicht gebräunt. Das Pygidium grob aber nicht tief punktirt, mit schwachem Lackglanze, nelst Unterseite und Beinen schmutzig pechloraun; die Vorderbeine, besonders an den Schienen und Schenkehwurehn, etwas melır ins Gelbliche falleud. Das Prosterum breit, matt gerunzelt, etwas liefer geschwärzt, hinter der Mitte leicht quer aufgetrieben und an Hinterrande lneit ausgeschnitten. Das letzte Segment des $\delta$ mit einem leichten Eindrucke; das of unbekannt.

Von Caraccas (Mus. Berol.).

47. M. psammites m. Rosthraum mit hellerer Scheibe des Ilalsschildes, der Vorler- und Seitentand des letzteren mit Kopf, Beinen und Vorderbrust gellı; die Punktstreifeu derh, der nemte stäher vertielt, mit flach gewölbten glïnzenden Zwischenräumen. L. $1 / 2{ }^{\prime \prime \prime} ; \mathrm{Br} .2 / 5{ }^{\prime \prime}$.

Eine lileine und zierliche, durch die Färbung und die sehı gleichmässig ausgeprägten, verhältnissmässig kriftigen P'unktstreifen sehr ausgezeichnete Art. Der Kiopf llach, das kiopfschild zwischen den Fühlerwurzehn durch eine muleutliche Querrunzel begränzt, anch die sich bei den meisten Arten fundende fein eingeschnitlene Stirnlinie kaum wahrnehmbar. Die Olerflïche spiegelglatl, hellgell, die tief ausgebuchteten, olıen etwas gemäherten Augen schwarz; die Mundtheile brännlich. Die Fühler bei dem einzigen rorliegenden Stücke nur unvollstïndig erhallen, thas zweite Glied liurz eiförmig, die drei folgenden gestreckt, aber dïnn, jedes mehr als doppelt linger wie das zweite; die vorlandenen lieste der lieule ron idem Ban der übrigen Arten. Die Farbe hell gelb. Jas Ilalsschild mehr als doppelt breiter wie lang, hinten etwas eingesenkt, hinter der Mitte leicht quer aufgewölht und mit der grösseren llälfte vorn albwärts gekrünmt, hier über den tief eingezogenen schanf' rechlwinkligen Vorderecken zusammengenlrückt und dadurch etwas verschmälert, die Seiten fein gerandet, in ler frin eingedrïcliten Randlinie von einer Reihe tief eingestochener I'unkte begleiter, nach vorn in leichten Bogen zusammengekrïumt und vor den breit aus- 
gezogenen, scharf spitzwinkligen Hinterecken sanft ansgeschweift; der Ilinterrand eingesenkt, fein gesigh, nur vor den Schulterbenlen und wieder jederseits des deutlich doppelt ansgerandeten Mittelzipfels etwas ausgebuchtet. Vor dem letzteren die Oberfläche in einem leichten Bogen quer eingedrückt. Die Farbe gelbbraun, spiegelglatt, ein breiter Vorder- und Seitenrand rerwischen hellgell,. Das Schildchen langgestreckt-dreieckig, etwa doppelt so lang als hreil, sehr schräg ansteigend, mit deutlichem, vor'n jederseits von einem Querbenlchen begränzten Vordergrühchen, glïnzend braun. Die Deckschilde kugelig, eben so breit wie lang. und hinten mit kurzer breiter Krümmung zugerundet, 1 m die Spitze des Schilalchens buckelig erlıöht, und von lier aus linterwärts flacher-, seitlich steiler abfallend; der Vorderrand leicht wulstig erhöht und sich nach aussen an die grossen hạlbkugelig hervortretenden Schulterheulen anschliessend, hinter ilım eine leichte Querfurche; die Seitenlappen ziemlich stark ausgebildet, und über ihnen die Deckschilde breit aber nicht tief quer zusimmengedrüclit. Die P'unktstreifen sehr regelmässig, aus leutlichen, tief eingestochenen und bis zur Spítze hin kenntlichen l'unkten gebildei, der neunte stärker vertieft, auch die Vorderenden der Rückenstreifen etwas tiefer eingedrückt, daher die überall flach gewölbten Zwischenräume dlort als flache Rippen liervortreten, der neunte als sulche fast in seiner ganzen Länge zu verfolgen. Die Oberfläche gläuzend rostroth mit etwas hellerer Spitze. Das Pygidium äusserst fein runzlig punktirt, glänzend hellbraum. Der Hinterleib dunkel pechbraun mit breitem verwaschen heller gebrïuntem Rande; Vorder- und Mittelbrust nebst den Beinen hellgelb, erstere flach, ziemlich so lang wie breit, hinten flach ausgerandet. Das letzte Segment des einzigen vorliegenden $\delta$ einfach; das $q$ unbekannt.

Aus Brasilien (Mus. IIalens.).

45. M. sordidulus m. Lehmgell, die Fühlerkeulen und der IIinterrand des deullich punktirten IIalsschildes schwarz; die Punktstreifen mässig, hinterwärts schwächer, der achıte und neunte vertieft, mit thachen gläızenden Zwischenräımen. L. 1/3-1/2"'; Br. $1 / 6-1 / 4 "$.

Die kleinste Art dieser Gattung, überhanjt dler kleinste aus Südanerilia mir bekannt gewordene liäfer dieser Familie, ausserdem aber an seiner überaus einfachen Färbung leicht kenntlich. Der Kopf flach gewölbt mit breiter, zerstreut punlitirter glänzenter 
Stirn; die weit getrennten, schwach ausgebuchteten Augen greis, das Kopfschild nur mit dem unteren Rande ein wenig eingezogen. Die Fühler etwas über den Hinterrand des Halsschildes hinausragend, das zweite Glied stark kugelig aufgetrieben, noch länger und breiter als die Glieder der Keule, von welcher letzteren es durch das sehr dümne dritte, vierte und fünfte Glied sehr augenfällig getrennt wird. Die Farbe der fünf unteren bleichgelb, der breit zusammengedrückten Keule schwarz. Das Halsschild fast mit ganzer Länge vorn sanft übergekrümmnt, über den scharf rechtwinkligen Vorderecken etwas zusammengedrückt und dadurch verschmälert, die fein gerandeten Seiten vor der Mitte sehır schwach verbreitert und dann nach vorn kurz zusammengekrümmt; die Hinterecken scharf, fast rechtıvinklig, der äusser'st fein gesägte Hinterrand jederseits nur leicht ausgebuchtet und ohne deutliche Ecken in den grade abgestutzten Mittelzipfel übergehend; vor dem letzteren eine feine eingedrüclite Querlinie. Die Oberfläche zerstreut und ziemlich deutlich punktirt, mit lackglänzendem Zwischengrunde, lehmgelb mit schwarz gesäumtem Ilinterrande. Das Schildchen wenig ansteigend, dreieckig mit schwach gerundeten Seiten, etwas länger wie breit, gleichfalls lehmgelb mit sehr feiner Punktirung. Die Deckschilde hinter der Wurzel nur schwach erweitert, hinterwärts in flachen Bogen verschmälert, etwas hinter der Schildchenspitze leicht aufgewölbt, und nach hiıten mit sanfterer, seitlich mit mehır steiler Lirümmung abfallend, die Schulterbeulen als längliche Höcker heraustretend, die Seitenlappen wenig bemerkbar. Die Punktstreifen aus groben, grübchenartigen Vorderenden entspringend, aber bald abgeschwächt, die Ilinterenden der mittleren auf der Wölbung verschwindend, der neunte und in geringerem Grade auch der achte furchenartig eingedrückt; die Zwischenräume glänzend, flach, der äusserste und der hintere Theil des vorhergehenden schwach aufgewölht. Die Farbe lehmgelb, ein zarter Saum längs Wurzel und Naht leicht gebräunt. Pygidium, Unterseite und Beine gleichfalls hell lehmgelb; die Vorderbrust llach und hinten wenig ausgebuchtet. Das letzte Segment des $\delta$ einfach, des $q$ mit einer länglichen gläızenden Grube.

Von Surinam (Mus. Felix, von Deutschbein gesammelt) und Aragua (Mus. Berol., voll Moritz gesammelt). Aus Brasilien (Bahia: Mus. Deyrolle, und Rio de J.: Mus. Holm., von F. Sahlberg gesammelt). 
F ïnfte Rottc. Körper länglich eiförmig, dunkel metallisch blau oder bräunlich, das Halsschild hinten mit einer deutlichen Querfurche.

49. M. lucidulus m. Glänzend stahlblau mit rothgelben Fühlerwurzeln; das Halsschild fein punktirt, die Punktstreifen sehr fein und schon vor der Mitte verschwindend, der neunte etwas vertieft, mit flachen Zwischenräumen. L. 1"'; Br. $3 / 4{ }^{\prime \prime \prime}$.

Im Habitus manchen Arten der ersten Rotte, und besonders dem dor' beschriebenen M. nigritulus sehr ähnlich, so dass ich im Allgemeinen auf dessen Beschreibung Bezug nehmen und mich auf die Angabe der Abweichungen beschränken kann. $\mathrm{Er}$ ist etwas grösser und von abweichendem Umriss, indem er sich gleich von den Schulterecken ab schräg hinterwärts fast gradlinig verschmälert und dann kurz zurundet; die grösste Breite füllt deshalb nahe vor die Mitte der Körperlänge, inclem der Umriss sich von da ab nach vorn in kürzerem Bogen, hinterwärts in längerer, aber erst dicht vor der Spitze sich lirümmender Strecke verengt. Die Körperfärbung ist der des M. nigricans gleich, aber nicht matt, sondern auf der Ober- und Unterseite glänzend, auch die Färbung der Beine dunkler, daher nur die Hüften und Fussglieder schmutzig gebräunt. Eudlich ist auch die Sculptur sehr abweichend. Das Halsschild ist mit einer ziemlich feinen aber dichten, besonders jederseits vor dem Hinterrande deutlichen Punktirung bestreut, und zeigt ausserdem längs dem ganzen Ilinterrande eine tiefe mit gröberen und feineren Punkten dicht besetzte Querfurche, welche vor der Mitte jeder Flügeldecke sich nach Breite und Tiefe etwas abschwächend dann nach aussen sich wieder kräftigt, und jederseits dicht vor dem Ilinterwinkel mit ihrem Ende sich nach vorn biegt. Auf den Flügeldecken werden die ans tiefer eingegrabenen Vorderenden entspringenden Punktreihen weit früher und plötzlicher schwächer, so dass die mittleren schon von der Mitte ab kaum noch kenntlich sind, und eben so ist die durch den neunten Streifen gebildete Längsfu'che weit schwächer wie bei der genannten Art. Alles Uebrige, auch die eiförmige glänzendle Grube auf dem letzten Segmente des + , wie bei $\boldsymbol{M}$. nigritulus.

Aus Brasilien (von S. Catharina - Mus. Deyrolle; und ohne nähere Angabe der Heimath im Mus. Hal.).

50. M. granarius m. Glänzend pechbraun mil helleren Fühlern und Beinen; die Punktstreifen deutlich, hinterwärts abge- 
schwächt, der neunte stark rertieft, mit flachen Zwischenräumen. L. $2 / 3-3 / 4 "$; Br. $1 / 2-2 / 3{ }^{\prime \prime \prime}$.

Bei obertlächlicher Betrachtung unserem europiisischen Aspidiphorus orbiculuris nicht unähnlich, aber etwas grösser, mehr in die Länge gestreckt, der Färbung nach unter den amerikanischen Arten dieser Familie an nichsten dem gleichfalls etwas kleineren Cryptoc. alomus Er. verwandt. Der Kopf flach, tief und matt braun, olıne deutliche Punktirung; das Kopfschilıl durch feine aber scharfe Leisten alggesetzt, die grossen Augen deutlich ausgebuchtet, die Fühlırwurzehn durch einen schmaleı etwas gebogenen Querwulst verhunden. Die Fühler nur wenig über den Ilinterrand des Halsschildıs hinausreichenl, mit gestreckten, ctwas gebogenem Wurzelgliede; das zweite Glied eiför'mig aufgetrieben, etwas länger als breit, die drei folgenden je den zweiten an Länge gleich, das dritte und vierte aher kaum lıalb so breit als das zweite, das fünfte schon schwach zusammengedrückt und dadurch verbreitert, die sechs oberen zu einer derben lieule erweitert, mit schr kurzem wenig hemerkbarem Fortsatze des Emlgliedes. Ilie Farbe der unteren Glietler hellgelb, die lienle mehr oder weniger dunkel angeflogen. Das Halsschilı doppelt breiter als lang, !nach rorı verschmälert umı ılasplbst, wie seitlich, stark alıwärts gekrümmt, auch hinten durch einen breiten bogenlörmigen Qnereindruck tief eingesenkt; die Seiten fein gerandet; der Hinterrand vor den Schultern stark ausgebuchtet, fein gesïgt, mit breiten, spitzen Ilinterecken und fast grade abgestutatem Mittelzipfel. Von einer feinen und selır zerstreuten P'unktirung zeigt sich nur bei starker Vergrösserung eine schwache Spur; der Zwischengrund glïnzend, und vor dem Schilılehen eine Querreilıe gröberer, jellerseits lis zur Mitte Jey Flügrdecke reichender P'unkte. Die Farbe pechbraun. Das Schildehen linglich dreieckig, gleichfills gläızend pechlnrauı, ohıe merlibares Vordergrübchen. lie Deckschilde von der Wurzel ab etwas ansteigend, hier schwach erweitert und danı linterwärts eiförmigg sich verschmälermd, mit hreit grewölhtem längs der Naht alluälılich albfallentem Rücken, die Scitenlapplen tief herabgezogen, die rmulen Schulterbenlen und, wonn gleich in geringerem Haasse, dir Ungehnug der Schildchenspitze buckelig aufgeworfen; hinter Jer Wurzel ein deutlicher, imnerseits der Schulterbeulen sich hakenförmig linterwirts biegenter Quereindruck. Die in dem letateren mit tief eingedrückten P'unkten lnginnenden P'unktstreilen sind bei 
dem đ kräftig und bis zur Spitze deutlich, obwohl hinterwärts etwas schwächer, bei dem grösseren o merklich feincr, hinter der Mitte fast verloschen, der nemte furchenartig eingedrückt und dadurch den äussersteı Zwischenraum breit und gewölls emporhebend, dic übrigen flach; dic Farbe ein bei dem ơ glänzendes, bei dem 9 etwas matteres Pechbraun. Auch das mit einzehnen gröberen Punkten bestreute Pygidium glänzend pechbraun. Die Unterseite kamn gerunzelt, schwarzbraun, mit grob punktirten Parapleuren; die Beine mit den Hüften heller gelbbrann, die hinteren Schenkel- und Schienenenden etwas dunkler. Das Prosternum kurz und breit, deutlich gerumzelt, linten quer niedergedrïckt und in flaclsem Bogen ausgeschnitten. Das letzte Segment des o einfach, des $f$ mit einer breit eiförmigen, glänzenden Grube.

Aus Paraguay (Mus. n. Heyden, vỏn Vogt gesammelt).

51. M. binarius m. Stiblblau, Mundtheile, Fühlerwurzeln, Ilüften und Flügeldecken rothgelb, die Wurzel und ein gelappter Ilinterfleck der letzteren blau; die Punktstreifen fein, der neunte schwach vertieft, mit flachen Zwischenrïumen. L. $11 / 12{ }^{\prime \prime \prime}$; Br. $3 / 4{ }^{\prime \prime \prime}$.

Von dieser Art habe ich nur ein einziges und sehr schlecht erhaltenes Stück vergleichen können; doch wird dasselhe immerlin zu deren Wiedererkemnen ausreichen, bis das Auffinden mehrerer Exemplare eine Vervollständigung der hier nachfolgenden Beschreibung ermöglichicı wird. IDer Kopf flach, anf der Stirn mit einem seichten Längseindruck, die Oherfläche nicht punktirt, matt stahlblau, die Mundtheile mit der hurzen wieder etwas vorspringenden Oberlippe röthlich gell, mit geschwärzter Mitte der letzteren. Die langgestreckten, ziemlich tief ausgeluchteten Augen greis; von den Fülılern nur das gleichfalls sehr gestreckte und dünne, schwach nlaclı aussen gekrümmte gelle Wurzelglied vorhanden. Das Halsschild kurz, vorn mit $2 / 3$ seiner Länge stark übergekrïmmnt, längs dem Vorderrande leicht eingeschünt unl dureh diese Einschnürung verengl, üher den scharf rechtwinkligen Vorderecken noclı etwas zusammengedrückt, die fein gerandeten Seiten nach vorn in loreiten Bogen zusammengeneigt, die gleiclufalls scharfen Hinterecken spitzwinklig vorgezogen, über ilınen die Seiten nochmals leicht zusammengedrüclit; der Hinterrand jederseits wellig ausgebuchtet, etwas eingesenkt, mit ausserst sclwwach hervortretendem, undentlich doppelt ausgerandetem Mittelzjpfel. Vor der Mlitte des Hinterrandes eine tief eingedrückte schmale bogenförnige Querfurche, durch 
welche der Hinterrand selbst als ein schmaler Querwulst aufgetrieben wird, während nach rorn hin die Mittelfirste in sanftem Bogen ansteigt. Die Oberfläche, wie die des Kopfes, matt blau, ohne sichtbare Punktirung, aber auch ohne Glanz, fast wie bereift erscheinend. Das Schildchen länglich dreieckig, etwa nur 1/3 länger wie breit, hinten kurz abgestutzt und wenig ansteigend, rlas Vordergrübchen breit und seicht, die Seiten hinterwärts leicht ausgeschweift, gleichfalls matt blau. Die Deckschilde nur flach gewölbt, so breit wie lang, vorn etwas breiter als das Ilalsschild und hinterwärts kurz zugerundet, längs der Wurzel schwach quer niedergedrïckt und dann eben so schwach wieder ansteigend, nur die Schildchenspitze leicht buckelig erhöht; die Schulterbeulen länglich höckerig, durch die tiefer eingedrückten Vorderenden des fünften und neunten Punktstreifens emporgehoben, die kurzen Seitenlappen stark abwärts gezogen. Die Punktstreifen nur vorn deutlich, schon vor der Mitte algeschwächt, und hinterwärts ıur noch der in eine leichte Längsfurche eingedrückte neunte beınerkbar, die übrigen stellenweise an der dunkeln Färbung auf hellem Grunde zu erkennen. Die Zwischenräume glatt und ziemlich glänzend, flach, пแr der äusserste leicht gewölbt. Die Farbe ziegelroth, die Wurzel in unregelmässiger, innerseits der Schulterbenlen tief ausgebuchteter Begränzung stahlblau, und diesc Färbung auf der Mitte zu einem grossen dreiechigen, das Schildchen mit einschliessenden Nahtfleck ausgezogen, an den sich ein gleichfalls unregehmässiger bänlicher Nahtsaum auschliesst; ausserdem auf der hinteren IÏ̈lfte jeder Flügeldecke ein. vereinzelter grosser mit seinem Innenrande an den vierten Punktstreifen gelehnter blauer Fleck, der sich an achten Streifen mit einer hinteren Ausbuchtung verschmälert, und diesen verschmälerten Querarm bis zum Seitenraude ausstreckt. Pygidium und Ilinterleib fehlen dem vorliegenden Stïcke; nach den spärlich vorhandenen Resten des letzteren ist derselbe blan mit verwaschen greöthetem hanle. Die Brust gleichfalls blau, der lintere etwas aufgetriebene Thıil des Prosternums röthlich, die Mitte desselben leicht quer niedlergedrückt, der Ilinterrand breit und seicht ausgeschnitten. Die Beine blau mit röthlichen Hüften und trüb gebräunten Fussgliedlem.

Aus Brasilien (Mus. Hal.).

Sechste Rotte. Lïrper länglich eiförmig, zum Theil his nahe an $2^{\prime \prime \prime}$ ausgedehnt, nach vor'ı stark verschmälert, mit eckig 
hervortretenden Schultern. Das ILalsschild hinten mit einer deutlichen Querfurche. Die Farbe schwarz oder doch dunkel metallisch, mit hellgelben oder röthlichgelhen, zum Theil schwarz gezeichneten Flïgeldecken.

52. M. melanippus m. Glänzend schwarz, Fühlerwurzeln, Schienen und Fussglieder pechbraun, die Deckschilde strolıgelb mit schwarzer Spitze; die Punktstreifen fein, der neunte vertieft, mit flachen, dicht und fein runzlig punktirten inatten Zwischenräumen. L. $13 / 4 " ' ;$ Br. $1 \frac{1}{4}{ }^{\prime \prime \prime}$.

Der Kopf flach mit grossem, zwischen den Fühlerhöckern durch eine deutliche Querfurche begränztem Kopfschilde, lurch eine dichte und feine Punktirung unatt, die Mundtheile bis auf die schwärzliche Oberlippe braungelb. Die Augen breit und ziemlich tief ausgebuchtet, oben zusammengeneigt, so dass (bei dem $q$ ) der Zwischenraum der oberen Innenränder nur etwa der Dicke des ersten Fühlerglietes gleich kommt. Die Fühłer bei dem einzigen vorliegenden Stücke nur unvollständig erhalten, anscheinend kurz; das Wurzelglied gestreckt, etwa dreimal länger als breit, die drei folgenden etwa gleich lang und zusammen dem ersten gleich, von diesen das zweite breit eiförmig, das dritte und vierte verkehrt kegelförmig und letzteres schon etwas verbreitert und zusammengedrückt, was noch melır bei dem fünften hervortritt, so dass letzteres einen vollständigen Uebergang zu der eigentlichen Keule bildet; von letzterer nur die drei unteren innerseits stark verbreiterten Glieder noch vorhanden. Die unteren bis zur Wurzel des vierten durchscheinend pechlıraun, die übrigen schwarz mit angedrückter dünner Behaarmug. Das Halsschild hinterwärts niedergesenkt und vorn mit $2 / 3$ seiner Lünge stark kugelig abwärts gekrümmt, über den tief eingezogenen scharf rechtwinkligen Vorderecken stark zusammengedrückit unt dadurch sebr verschmälert; über der Nitte der fein gerandeten, nach vorn in flachem Bogen zusammengeneigten Seiten nochmals ein rundlicher, das Halsschild zusammendrückender und die Nitte des Seitenrandes leicht herausdrängender Eindruck. Die Hinterecken scharf spitzwinklig ausgezogen, vor ihnen die Seiten leicht geschweift, auch der Ilinterrand jederseits nur sanft ausgebuchtet, fein gesägt und zunäclsst an den Schultern etwas eingekniffen, mit kurzem, breitem, undentlich doppelt ausgerandetem Mittelzijfel. Vor letzterem die Hinterfläche des Halsschildes durch cine seitlich bis zur Mitte der Flügeldecken 
reichende Bogenfurche eingedrükt, und der hinter dieser schmal wulstig ansteigende Ilinterrand mit einer Querreihe grölıerer Punlite bezeichnet; die älnige Oberfläche äusserst fein und dicht punktirt, glänzend sclıwarz. Das Schildchen dänglich dreieckigg, fast noch cinmal so lang als breit, hinterwärts missig ansteigend, mit deutlichem Vordergrübchen, gleichfalls glänzend schwarz. Die Deckschilde breit und sehr flach gewöllst, kaum längrer als breit, vorn noch ein wenig breiter als ter hintere Theil des IIalsschildes, hinterwärts mil fast geraden Seiten nur wenig versclmälert und dam mit stark klaffender Nalıt plötzlich und breit zugerundet. Der Pücken hinter ten breit aufgetriebenen Wurzehrandi durch die tief eingegrahenen Vorderenden der P'unkistreifen breit quer eingedrüclit, um das Schildcheu schwach erhülıt, hinter ilm wicder quer niedergedrïckt, und dam his zur Spitze selur sanft-, seitlich etwas stärker abfallend; lie grussen hörkerigen Schulterbeulen innerseits nur durch das Anssenende des vorderei Quereindrucks ahgesetzo; die Seitenlalpen mïssig mit sehr stark entwickelten, aber doch nur mit einer einfachen Punktreilse beselzten umgeschlagenen Rande. Die Punktstreifen aus grolen Vorderenden hinterwärts immer mehr abgeschwächt, die mittleren auf der Wöllong fast erloschen, der ueunte missig vertieft, die Zwischenräume durch eine feine aber dichte quer-r'unzlige P'unktirung matl, flach, nur ihre Vorderenden und der änsserste his gegen den hinteren Aussenwinkel hin leicht gewëly und etwas glänzend. Die Farbe ein helles reines Strohgell, pin feiner Samm längs der Wurzel, cin ähnlicher aber weniger denlich hrggänzter längs der Naht und die breite spitze muter der Wölbung schwarz; die Färlong der letzleren rorn mit cinem breiton Ziplel in den Nahtsamm übergrheus, wodurch der spitzenfleck jurlerseils in der Hitte hrojt ansgehuchtet erscheint. Das I'ygidium dentlich punditirt, mil der ling punktirten Unterseite dünn greishaarig, schwarz; auch die mïssig starken Schenkel schwarz, Schicnent umd Fussgliesler schmulzig pechloraun, mit schwarzen, hinlerwäls undentlich verburiteren krallenhälichen. Irie Vorderbrust loreit, grob runzlig funlitirt, rtwa so lreit als ling, hinterwärts in

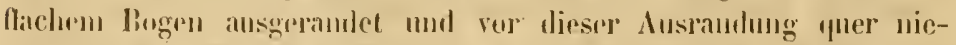
dergedrückt. Jas letzte Sergment des of mit viner tiefent glänzenden hallkugreligen Grube, das ơ mubekannt.

Aus Brasilien (Mus. Holens.).

53. M. hemichlorus m. Netallisch schwarzgrün mit ge- 
bräunten Fühlerwurzeln, die Deckschilde strohgelb mit schwarzgesäumnter Wurzel und Naht; die P'unktstreifen nässig, hinten schwächer, der neunte etwas vertieft, mit flachen glänzenden Zwischenräumen. L. $11 / 4-1 \%{ }^{\prime \prime \prime}$; Br. $3 / 4-1^{\prime \prime \prime}$.

Abermals eine verhialtuissmässig grosse, dahei schöne und wie die vorhergehenden durch den mehr eiförmigen Unriss von den folgenden in Habitus etwas abweichende, aher doch von denselben nicht wohl zu tremende Art. Der Kopf flach, mit einer kurzen Längslinie auf der oberen Stirn; das Koptseliild oben durch eine die Fühlerhöcker verbindende feine Querkante abgeselzt, aber nur wenig eingezogen. Die Oberllïche glatt mit mässigem Glanze, die ziemlich lang gestreckten, wenig ansgehuchteten, ohen ctwas zusammengencigten Augen greis. An den Fühlern das zweite Glied stark eiförmig aufgetrieben, die vier uıteren rötılich brau, auch die Wurzel des füıften träunlich durchscheinend, die oberen schwarz mit dichter greiser Belıaarung. Das Halsschild mit der vorderen IIalfte stark kugelig ühergewölbt, hinten leicht qner niedergedrückt, längs den fein gerandeten Seiten nach den schart rechtwinkligen Vorderecken hiı stark zusanmengedrückt nud dadurch verschmälert, die spitzwinkligen Hinterecken kurz aber scluarf vorgezogen, der Hinterrand jederseits breit ausgebuchtet, feiı aber deutlich gesägrt, mit breitem, molentlich doppelt ausgerandetem Mittelzipfer. llie Oberfläche spiegelglatt, иur an den Seiten mit spuren schwacher und sehr zerstrenter Punktirung. Vor dem Hinterrande jederseits ein tiefer Schrägeindruck, und heide durch pine leicht niedergedrückte Stolle ror dem Mittelzipfel zu einer gekrünmten lufeisenfürmigen Furche verbunden; anch scillich nach den flinterecken zu der Hinterrand noclumals tief eingesenkt. Itas Schildchen gestrecht dreieckig, um die Ilällte länger als hreit, mit leichter Krümmung ansteigend, gleichılalls spiegelghatt mit deutlichem Vordergrühchen. Die Deckschilde hinter der. Wurzel in sinfter, die Seitenrundung des Halsschildes fortselzender Krïmnnung verhreitert. und dam hinterwärts beu so almälılich verengt, wodurch der liörper einen sehr regelmässig eiförmigen, nach vorn nur wenig stärker zlugerundeten Unuriss erlält. Der Rücken ron der Wurzel ab) noch etwas ansleigend und dann linterwïrts mit sanfter Krünmung abfallend, hinter der Wuzel mit einem schwachen, durh alie vertieften Vorderenden der oheren Punktstreifen erzengten (Unereindruck. Ihe Schnlterbenlen breit mod flach, imerseits nur durch 
einen seichten Eindruck abgesetzt, die Seitenlappen ziemlich lang herabgezogen; üher ihnen die Deckschilde flach zusammengedrückt. Die Punktstreifen von mässiger Stärke, hinterwärts schwächer, aher doch auch bei dem feiner gestreiften $q$ bis zur Spitze kenntlich, der neunte etwas stärker eingedrüclit und dadurch der äusserste Zwischenraum in flacher Wölbung emporgehoben, die übrigen flach; die Oherflïche glänzend und nur mit sehr vereinzelten überaus feinen Pünktchen bestreut. Die Farbe hell strohgelb mit dunklerem Grumle der Punkte, ein schmaler Saum der Wurzel, und ein noch feinerer, vom Schildchen ab Naht, Spitze und den hinteren Theil der Seiten umziehender Rand schwärzlichgrüı. Pygidium und Unterseite deutlich punktirt, sehr kurz und dümn greishaarig, mit den Beinen gleichfalls metallisch schwarzgrün. Die Vorderbrust kurz und breit, vereinzelt grob punlitirt, hinten quer niedergedrückt und in breitem Bogen ausgeschnitten. Das letzte Segment des ठ mit einer quer niedergedrückten, stärker glänzenden Stelle, des mit einer grossen eiförmigen, im Innern spiegelglatten Grube.

Aus Venezuela (Mus. Dohrn, von Hm. Schiefferdecker mitgetheilt).

54. M. a car oides m. Glänzend schwarz, Fülıler und Beine gelb, die Flügeldeclien ziegelroth; die Punktstreifen derb, der neunte vertieft, mit flachen glänzenden Zwischenräumen. L. $3 / 4{ }^{\prime \prime \prime}$; Br. $1 / 2{ }^{\prime \prime \prime}$.

Der nachfolgenden grösseren Art in der Fürbung und Farbenvertheilung selır ähnlich, aber bei geringerer Grösse durch die flachere scitliche Halsschildsschramme und die hellgelbe Färbung von Fühlern unt Beinen leicht ron ihm zu unterscheiden. Der Kopf flach gewölbt mit teiner Stirnlinie und etwas eingezogenem, oben deutlich begrïnztem Kopfschilde; die Farbe schmutzig braungelb, unterwïts etwas lichter, die langgestreckten, oben etwas zusammengeneigten, breit ausgebuchteten Augen schwar'z. Die Fühler hellgell, das zweite Gilied etwas kïrzer als das dritte, die folgenden fast ganz einanter gleich, die oberen leicht rauchgrau angeflogen. Das Ilalsschild kurz, rorn mit der kleineren Hällte mässig übergeliümmt, mit stumpfwinkligen Vorderecken, die Seiten fein gerandet, ıach vorn zusammengeneigt, über ilırer Mitte das Halsschild durch einen breiten Schrägeindruck abgeflacht und nach vorn hin verschmälert; die Hinterecken kurz aber breit und scharf vorgezogen, der Hinterrand jederseits leicht ausgebuchtet, fein 
gesägt, mit deutlich ausgerandetem Mittelzipfel; vor dem letzteren eine schwache, mit den nach vorn gebogenen Enden in den mittleren Theil jenes Schrägeindrucks verlaufende Querfurche. Die Farbe glänzend schwarz, ein schmaler Vordersaum verwaschen pechbraun. Das Schildchen schmal dreieckig, fast doppelt so lang als breit, schı̈äg ansteigend, gleichfalls glänzend schwarz. Die kurzen Deckschilde nur etwa 1/4 länger wie breit, rorn breiter als das Halsschild und in der Mitte noch etwas bauchig erweitert; der Rïcken seitlich stärker-, hinterwärts nur allmählich abfallend; die Schulterbeulen als starke Höcker heraustretend, innerseits durch einen tiefen Längseindruck alggesetzt, auch der Rücken um die Schildchenspitze etwas buckelig erhöht. Die Seitenlappen mässig herabgezogen, umı über ihnen die Deckschilde deutlich zusammengedrückt. Die Punktstreifen deutlich, die Vorlesentlen der seillichen etwas gröber unıl tiefer eingedrückt, was namentlich bei dem neunten nach seiner ganzen Lünge vertieften Streifen hervortritt. Die Zwischenräume flach, nur der äusserste etwas aufgewölht, die Farbe ein glänzendes, schwach ins Bräunliche fallendes Ziegelroth, ein feiner Wurzelsaum und das Innere der Punkte schmutzig gebräunt. Pygidium mit Ilinterleib und Hinterbrnst schwarz, Vorderbrust und Beine liellgelb; die erstere vorn leicht quer aufgewulstet, hinten nur schwach ausgerandet. Das letzte Segment des $q$ mit dem gewöhulichen Grübchen; das ठ̊ unbekaunt.

Aus Columbien (Mus. Haag).

55. M. stricticollis Klug. Glänzend schwarz mit pechbraunen Fühlerwurzehı und ziegelrothen Flügeldecken; die Punktstreifen derb, der neunte stark vertieft, mit flachen glänzenden Zwischenräumen.

\section{o Deckschilde einfarhig;}

\& dieselben hinter ter Mitte mit einem grossen verwaschen begränzten schwarzen Querwische bezeichnet.

L. $1-1 \frac{1}{3}{ }^{\prime \prime \prime} ;$ Br. $2 / 3-3 / 4 " \prime$.

Aus der nächsten Verwandtschaft des rachfolgenden M. deplanalus, und gewissermaassen eine Nittelform zwischen ihm und dem vorhergehenden; von M. acaroides durch die Grösse, die dnulilere Färbung, die eckiger liervortretenden Schultern und die tielere IIalsschildsfurche, von II. deplanatus durch den gestreckteren Körper und die braunrothen, nichi gellon Deckschilde leicht zu unterscheiden. I)er Kiopf flach gewölbl, schwarz; das stark eingezogene 
Kopfschild oben durch eine deutliche Querlinie abgesetzt, und die wieder etwas vorspringende Oberlippe mit den Mundtheilen rostbraun. Die Fühler von mässiger Länge, das zweite Glied ziemlich stark aufgetrieben, an Dicke dem vorhergehenden gleich, fast so lang wie jedes der folgenden, die Glieder der Keule stark erweitert und zusammengedrückı; die Farbe schwarz, nur die beiden unteren Glieder pechbraun. Das Halsschild um die Hälfte länger wie breit, vorn mit halber Länge stark übergekrümmt, und über den tief eingezogenen, scharf rechtwinkligen Vorderecken durch eine Einschnürung verschmälert, seitlich fein gerandet und vor den breit aber scharf dreieckig ausgezogenen Hinterecken etwas ausgeschweift, hinten jederseits leicht ausgelsuclıtet, mit wenig vortretendem Mittelzipfel. Vor dem letzteren die Oherfläche tief quer eingedrückt, und dieser Eindruck seitlich sich in schrägem Bogen gegen die vordere Hälfte des Seitenrandes hinziehend, wo er allmählich verbreitert und verflacht sich verliert, so dass das Mittelfeld dadurch in Gestalt eines rundlichen Querwulstes emporgehohen wird. Die Oberfläche spiegelglänzend schwarz. Das Schildchen schıräg ansteigend, um die Hälfte länger als breit, dreieckig, vorn leicht quer niellergedrückt und gleichfalls glänzend schwarz. Die Deckschilde flach gewölbt, vorn breiter als das Halsschild, und seitlich noch etwas in Bogen erweitert, hinten kurz und stumpf zugerundet; der flach gewölbte Rücken linterwärts sehı schräg abfallend, die Wurzel als deutlicher Querwulst emporgehoben, und hinter ilı ein durch die tiefer eingegrabenen Vorderenden der Punktstreifen gebildeter Quereindruck. Die Schulterbeulen lang und schmal höckerig, auch die Seitenlappen stark entwickelt. Die Punktstreifen vorn kräftig, aber auch hinterwärts lis zur Spitze dentlich; der neunte bei dem $\delta$ nacl seiner ganzen Länge, besonders aber vorn, stilrker eingegrahen, was bei dem $q$ nur vor'n merklich hervortritt. Die Zwischenräume ziemlich glätzend, breit und flach, der äusserste vorn etwas gewölbt; die Farbe ziegelroth, etwas ins Bräınliche fallend, der Wurzelsaum rerwaschen gesclıärzt, auch dle Schulterbeulen mit einer sehwäıliehen Längslinie gezeichnet mul die Naht schmal verwaschen grebräunt, welche Fürbung sich bei den vorliegenden $q$ hinter der Mitte zu einem grossen trïben, im Inneren tiefer schwarzen, zuweilen jedoch sehr rerwasehenen Querwische erweitert. Pygidiun, Unterseite und Beine schwarz; dis erstere mit den Vorderschienkeln unt Knien, auch dem letzten Bauchringe 
ins trüb Bräunliche fallend; auch die narbig punktirte, leicht quer eingedrückte, hinten breit ausgeschnittene Vorderbrust leicht gebräunt. Das letzte Bauchsegment des $\delta$ einfach, des $q$ mit der gewöhnlichen stark glänzenden Grube.

In den Nordküstenländern von Südamerika längs dem CaraibenMeere: In Columbien (Mus. Haag., Berol, die Stücke des letzteren von Morit gesammelt), Surinam (Mus. Felix) und Cayenne (Mus. Deyrolle).

56. M. deplanatus m. Glänzend schwarzblau mit gelbbunten Beinen; Fühlerwurzeln und Flügeldecken gelb, vier manchmal zusammenhängende Flecke der letzteren und die Nahı schwarz; die Punktstreifen mässig, hinterwärts feiner, der neunte etwas vertieft, mil flachen glänzenden Zwischenräumen.

$\delta$ Die Naht und ein hinterer zuweilen getheilter Randfleck schwarz, letzterer hinten mit einer Erweiterung der Naht verbunden und dadurclı auf jeder Flügeldecke einen gelben Spitzenfleck absondernd;

q ein sclimaler Nahtsaum und zwei kleine getrennte Fleckchen hinter einander auf jeder Flügeldecke mit einem breiten verwaschenen Saume des Hinterleibes gelb.

L. $3 / 4-11 / 4 " \prime$; Br. $1 / 2-3 / 4{ }^{\prime \prime \prime}$.

Bei gleicher Breite mit dem vorhergehenden merklich kürzer, was besonderw in der weit geringeren Länge des Halsschildes begründet ist, sonst ilm aher sehr ähnlich, besonders in den breit heraustretenden Schultern nahe stehend, und dabei durch Glanz, Färbung und Zeichnung eine der zierlichsten Arten dieser Gattung üherhaupt. Der Kopf flach gewölbt, mit stark eingezogenem, oben zwischen deı Fühlerwurzeln durch eine Querleiste begränztem Kopfschilde, matt stahılblau, die grossen mässig ausgelıuchteten Augen sclıwarz und hei den $\delta$ etwas zusammengeneigt, bei den $q$ weiter getrenut; Oherlippe und Mundheile knochengelb. Die Fühler nicht voı halber Körperlänge, das Wurzelglied schmal keulig, dreimal länger als breit, his zum äusseren Augeurande reichend; das zweite bęi fast gleicher Breite viermal kürzer, daher fast kugelig, die folgeuden merklich schmäler, von ilıen das vierte etwa dem zweiten gleich, das dritte und fünfte um die Hälfte lănger und oherwärts schon etwas zusammengedrückt, die sechs oberen innerseits stark dreieckig erweitert, gleich lang, und etwa doppelt so lang und breit als das fünfte, mit kurz dreieckigem Fortsatze des Endgliedes. Das 
Wurzelglied gelb mit einer sclmaten schwarzen Längslinie auf der Oberseite, das zweite dunkel gellbraun, die folgenden schwarz; vom sechsten ah angedrückt behaart und an den Spitzen abstehend gewimpert. Das Halsschild halh so lang als hinten hreit, sehr flach gewölbt und vorn nur mit dem ersten Drittel seiner Länge sanft abwärts gekrümmut, über den tief eingezogenen stumpfivinlligen Vorderecken zusammengedrückt und dadurch verschmälert; die fein gerandeten Seiten erst von der Mitte al) nach vorn in stärkeren Bogen zusammengeneigt, hinter ihr leicht ausgeschweift, die Ilinterecken scharf rechtwinklig, dureh einen Schrägeindruck etwas aufgetrieben; der Ilinterrand jederseits nur flach ausgebucltet, mit kurzem, doppelt ausgerandetem Mittelzi]fel. Jederseits desselben die Oberfläche schräg eingedrücht, und diese Eindrücke durch einen leichten Quereindruck verl)unden, wodurch der mittlere Theil des Ilinterrandes als sclwwacher Querwulst aufwärts geschoben wird; übrigens ist die Oberfläche spiegelglïnzend schwarzblau, fast schwarz. Das Schildchen gestreckt dreieckig, fast doppelt so lang als breit, vorn fast flach und nur mit dem hinteren Theile mässig ansteigend, mit dentlichem Vordergrübchen, gleichfills spiegelud schwarzblan. Die Deckschilde wenig linnger wie breit, vorn breiter wie das Halsschild, dann noch etwas im Bogen erweitert und zuletzt mit kurzer Rundung den breit eiförmigen Umriss des Körpers alssehliessend; der Rücken hinter der scharf aufgeworfenen Vordewkante tief quer eingellrückt, die Schutterhenlen als breit eiförmige Ilöcker hervorgequollen, auch die Seitenlappen stark herabgezogen, und die über ihnen liegenden Quereindrüclie nur hei den ot etwas stirker, bei den of flach und wenig hemerklarr. Der Rücken sehr flach gewöllb, von der Mitte al his zur Spitze mit sanfter Krüummung ahfallend; dic Punktstreifen aus tiefer eingegrabenen Vorderenden sich schon baid hinter der Querfurche abschwächend, ather doch bis zur Spitze kemntlich, bei dem of etwas krifftiger wie hei dem $f$, der neunte bei jenem nach seiner ganzen Länge, bei tem of nur das kurze Hinterende desselben, zuweilen auch des davor liegenden achten Streifens tiefer eingedrïekt; die Zwischenrä̈ume glänzend, flach, der äusserste nur bei dem ơ flach gewölht, der ungeschlagene Ranl des Seitenlappens mit einer feinen Punktreilie besetzt. Die Farbe ein reines helles Strohgelb mil schwarzem Saume der Flügellecken, welcher nur den Seitenlappen frei lässt, und sich dagegen vorn jederseits des Schildchens, meist auch auf der Wöl- 
bung zu einem dreieckigen an die Naht gelehnten Zipfel erweitert. Das einfacher gezeichnete ? trägt danı auf jeder Flügeldecke noch zwei schwarze schlecht begrånzte Flecke hìtereinander, einen grösseren und meist deutlicheren dicht vor der Mitte, etwa zwischen dem sechsten und nemten Streifen, ınd einen kleineren melı verwaschenen auf den eingedrückten Stellen des achten und neunten Streifens, der Erweiterung der Naht gegenüber und zuweilen bis zum Aussenrande überfliessend. Bei den $\delta$ ist die ganze Färlung des Randes und 'der Flecken klarer, kräftiger und intensiver, auch der Nalıtsaum breiter; die beiden Flecke fliessen sowohl auf der Rand-als der imneren Seite durch feine schwarze Längslinien zusammen, zwischen denen nur ein schmales helles Längsfleckchen übrig bleibt, bis sich zuletzt auch dieses durch Bildung eines dicken schwarzen Längsfleckes verlierı; eben so vereinigt sich das hintere Innenende dieses Fleckes mit der Erweiterung der Naht zu einem Querbalken, durch welchen vor der Spitze der Flügeldecke noch ein rundlicher gelber Querfleck al,geschnitten wird. Uebrigens ist diese Färbung beider Geschlechter nur die normale; es finden sich zuweilen recht dunkel gefärlıte $q$ mit fast vollständiger Zeichnung des $\delta$, bei denen aber doch stets der breite gelbe Rand des Hinterleilss vorhanden ist; und eben so kommen einzelne $\delta$ vor, bei denen in Annäherıng an die Zeichnung des o der seitliche Vorderfleck vereinzelt geblieben und auf der Unterseite wenigstens der letzte Bauchring gelb gefärlıt ist; aber auch bei solchen ơ bleibt immer der schwarzlıegränzte gelbe Spitzenfleck der Flügeldecken vorhandeı. Ausserdem ändert die Art ab

$\beta$. Der schwarze Vorderrand rler Flügeldecken auf dem zweiten Zwischenraume zu einem über die Schildclrenspitze hinausreichenden Zipfel, als Anfang einer zweiten inneren Längsbinde, erweitert. Ich habe auch diese Form in beiden Geschlechtern vor mir.

Pygidium und Unterseite fein punktirt und-dünn behaart, schwarzblau, bei dem $q$ ersteres und der Hinterleib breit verwaschen schmutzig gelb oder gelbbräunliclı gerantet. Vorder - und Mittellorust gelb, auch Ilüften und Schenlielwurzeln, bei heller gefïrbten Stücken, besonders $q$ manchmal die ganzen Schenkel mit den Schienen, oder doch deren Innenseite, oder nur ihre Spitzen gell. Die Vorderbrust liurz und schr breit, fein runzlig punktirt, hiuten breit ausyeschnitten; das letzte Segment des o einfach, des $q$ mit 
der gewöhnlichen, hier sehr grossen und seitlich etwas erweiterten, glänzenden Grube.

Aus Brasilien und dort anscheinend nicht selten, daher mir in ziemlicher Anzahl vorliegend. (Von Rio de J. im Mus. Clark; ohne nähere Angabe der Heimath in dem Mus. Hal., Baly, Schaum., auclı mir von $\mathrm{Dr}$. Walll mitgetheilt.)

Siebente Rotte. Körper gestreckt, mit eckig vortretenden Schultern, im Habitus den kleineren Eumolpiden ähnlich; die Farbe schwarz oder blau ohne alle Zeichnung. Das Halsschild hinten mit einer einschnürenden, tief eingesenkten Querfurche.

57. M. un ctus m. Glänzend stahlblau, Yundtheile und Fühlerwurzeln röthlich; die Punlitstreifen derb, der neunte vorn vertieft, mit flachgewölbteı Zwischenräumen. L. $1-11 / 12 "$; Br. $1 / 2-2 / 3$ "'.

Eine selı zierliche, in Glanz, Färbung und Grösse dem $\boldsymbol{M}$. lucidulus nicht unähnliche, aber von ihm sugleich an dem abweichenden Habitus, den kräftigen Punktstreifen unt der spiegelglatten Oberfläche zu unterscheidende Art. Der Kopf flach, mit fein punktirter Stirn, das Kopfschilıl trüb geschwärzt, ınten liaum eingezogen, obẹn durch eine deutliche Querfurche begräızt, die Mundtheile bei dem ơ röthlich, bei dem $q$ dunkler pechbraun, mit einem trüberen Querwisch auf der Oberlippe. Die Fühler fast von halber Körperlänge, das Wurzelglied gestreckt, etwa viermal länger als breit, oherwärts schwach verdickt, das zweite elliptisch und bei gleicher Breite dreimal kürzer als das erste, die drei folgenden je dem zweiten gleich aber dünner, oberwärts wenig verdickt, das fünfte jedoch etwas verbreitert; die Glieder der Keule je noch etwas länger, fast unter cinander gleich, sehr stark zıtsammengedrückt und mit abgerundeter Aussenseite erweitert, das Endglied wieder etwas kürzer und schmäler mit sehr kurzem Fortsatze. Das erste Glied roth mit einer schwärzlichen Längslinie auf der Oberseite, die drei lolgenden schwarzblau mit hellerer Wurzel und Spitze, die übrigen schwarz mit dümner angedrückter greiser Behaarung der Kenle. Auch die grob gekörnten, tief ausgebuchteten, oben liaum zusammengeneigten Augen schwarz. Das Halsschild etwa um die Hälfte breiter wie lang, vorn mit der grösseren Hälfte stark kugelig übergewölbt, über den tief eingezogenen stumpfwinklig abgerundeten Vorderecken etwas eingedrückt und dadurch verschmälert; die fein gerandeten, von einer gröheren Punktreihe begleiteten Seiten nach vorn in flachen Bogen zusammengeneigt, die kurzen 
Hinterecken spitz ausgezogen, der Hinterrand jederseits breit ausgebuchtet, mit selır kurzem, aber dentlich doppelt ausgerandetem Mittelzipfel. Das ganze Mittelfeld längs dem Hinterrande durch eine tiefe Einsenkung abgeschnürt und dann noch jederseits vor dem Mittelzipfel ein ziemlich breiter Schrägeindruck. Die Oberfläche spiegelglatt und rein stahılblau. Das Schildchen schräg ansteigend, gestreckt dreieckig mit leicht ausgebuchteten Seiten, reichlich doppelt länger wie vorn breit, mit deutlichem, jederseits von einer Beule begränztem Vordergrübchen, gleichfalls glänzend stahlblau. Die Deckschilde nur etwa $1 / 4$ länger wie breit, um die Schildchenspitze leicht buckelig erhöht und von da ab nach vorn und den Seiten stärker-, hinterwärts allmällich abfallend, vorn bei fast rechtwinklig-abgerundet vortretenden Schultern merklich breiter wie das Halsschild; der Rücken vorn hinter der flach erhöhten Wurzel durch die tief eingegrabenen Vorderenden der Punktstreifen breit querfurchig eingedrückt, die Schulterbeulen fast halbkugelig heraustretend, auch die Seitenlappen kräftig und über ihnen der neunte Streifen zu einem etwas stärkeren Längseindrucke erweitert, auch weiter aufwärts hinter den Schulterbeulen der ganze Körjper breit quer zusammengedrückt. Die Punktstreifen derb und kräftig, bis zur Spitze deutlich, die Zwischenräume besonders vorn flach - und bei dem ठ̊ etivas stärker gewöllıt, spiegelglänzend stahlblau, der Wurzelsaum etwas tiefer geschwärzt. Das Pygidium vereinzelt punktirt, mit der Unterseite und den Beinen gleichfalls stahlblau, die Hüften und die Wurzeln der Vorderschenkel urüb gerötlıet, an den Mittel- und Hinterbeinen nur schwach gebräunt. Das Prosternum kurz und breit, fein punktirt, hinten in flachem Bogen ausgerandet; das letzte Bauchsegment des $\delta$ leicht quer niedergedrückt, des + mit einer rundlichen, stark glänzenden Grube.

Aus Brasilien (Mus. Baly, Deyrolle).

55. II. tenebricosus m. Glänzend schwarz, Mundtheile und Fülılerwurzeln pechbraun, die Punktstreifen fein, hinten fast erloschen, der neunte vertieft, mit flachen an den Enden flach gewölbten Zwischenräumen. L. $1 \frac{2 / 3}{{ }^{\prime \prime \prime}}$; Br. $1 \frac{1}{4}{ }^{\prime \prime \prime}$.

Dem vorhergehenden überaus ähnlich, aber um melır als die Iälfte grösser, und an seiner reinen wichse-schwarzen Färbung selı leicht kenntlich. Der Kopf flach mit leicht eingezogenem Kopfschilde, das letztere oben durch eine schwach wellige Querlinie abgegränzt. Die Oberfläche sehr feiı runzlig punktirt, daher nur 
schwach glänzend, die tief ausgebuchteten oben wenig genäherten Augen greis, die Mundtheile pechbraun. Die Fühler kaum von $1 / 3$ der Körperlänge, das Wurzelglied gestreckt, reichlich viermal länger als breit, das zweite schmal elliptisch, um die Hälfte lünger als breit, die beiden folgenden schmal verkehrtkegelförmig, das dritte kaum und das vierte nur um ein wenig länger als das zweite, das fünfte schon merlilich verbreitert und einen vollständigen Uebergang zur Keule bildend; die Gilieder der letzteren selır breit zusammengedrückt und erweitert, mit sehr kurz zugerundetem Fortsatze des Endgliedes. Die vier untern Glieder glänzend pechbraun mit geschwärzter Oberseite, die übrigen schwarz mit angedrückter greiser Behaarung der Keule. Das Halsschild um die Hälfte breiter als lang, ınit der grösseren Vorderhälfte sanft übergekrümmt und hinterwärts noch schwächer abwärts geneigt, über den scharf rechtwinkligen Vorderecken stark zusammengedrüclit und dadurch verschmälert, die Seiten fein gerandet, fast in geraden Linien zusammengeneigt, die Hinterecken kurz und breit, fast rechtwinklig. Der Hinterrand jederseits schwach wellig ausgebuchtet, der Mittelzipfel kurz und breit, undeutlich doppelt ausgerandet, durch einen vor ihm liegenden schmalen aber tiefen Quereindruck etwas aufgetrieben; dieser letztere rerbindet die breiteren Schrägeindrücke, deren einer weiter seitlich jederseits vor dem Ilinterrande gefunden wird. Die .Oberfläche spiegelglatt, schwarz. Das Schildchen selır schwach ansteigend, gleichseitig dreieckig, mit mndeutlichem Vordergrïlıchen, gleichfalls spiegelglatt, das Mittelfeld herzförmig niedergedrückt. Die Deckschilde kurz eiförmig, etwa $1 / 5$ lünger als breil, rorn merklich breiter als das IIalsschild, von den hervortretenden Schultern aus hinterwärts in flachen Bogen verschmälert und dann plötzlich breit zugerundet; der Rücken an Hinterende des Schildchens etwas buckelig erhöht und von da ab nach der Spitze sanft abwärts gekrünmt, hinter der aufgetricbenen Wurzel durch die grubig vertieften Vorderenden der Punktstreifen quer eingedrückt; die Schulterbeulen breit und flach, die Seitenlappen ziemlich stark lerahgezogen, und über ihnen der gewöhnliche, lier sehr schwache Quereindruck. Die Punktstreifen ziemlich fein, lıinterwärts noch melı abgeschwächt und die mittleren auf der Wölbung kaum noch erkennbar, der neunte etwas tiefer eingegraben. Die Zwischenräume wachsglänzend, flach, die hurzen Vorderenden, die Hinterendeu der zunächst an Naht und Rand liegenden unter der Wölbung, und 
der äusserste seiner ganzen Läıge nach sehr schwach gewölbt. Das Pygidium ziemlich vereinzelt grob punktirt, mit Unterseite und Beinen gleichfalls schwarz; die Vorderbrust kurz und breit, fein runzlig punktirt, hinter der Mitte quer eingedrückt, mit flach bogig ausgeschnittenem Hinterrande. Das letzte Segment des $q$ mit einer ziemlich grossen rundlichen Grube; das $\delta$ unbekannt.

Von Ega au oberen Amazonenstrome (Mus. Baly):

A chte Rotte. Körper gestreckt mit mehr oder weniger eckig hervortretenden Schultern und oben stark genäherten Augen, schwarz oder bläulich ınit rothgefleckten Deckschilden; das Halsschild hinten mit einschnürenden, tief eingesenkten Querfurchen. Die Arten äusserlich manchen echten Cryptocephalen aus der Gruppe des nordamerikanischen $\mathrm{Cr}$. notatus Fab, nicht unähnlich.

59. M. basilar is m. Schwarz, die Fühlerwurzeln, eiı grosser Schulterfleck der Flügeldecken und der Hinterleib kirschroth; die Punktstreifen selı fein und hinter der Mitte verschwindend, der neunte schwach vertieft, mit flachen glänzenden Zwischenrämmen. L. $11 / 4 " \prime$, Br. $5 / 6 "$.

Der folgenden Art überaus ähnlich, aber etıas kleiner, feiner punktirt, ausserdem aber an dem grossen Schulterfleck und dem rothen Hinterleibe leicht kemntlich. Der Kopf kaum punktirt, glïlzend, die grossen auch bei dem o selır genäherten, breit alıer nicht selır tief ausgebuchteten Augen braun. Das Kopfschild dreieckig mit etwas gekrümmten Seiten, oben kur'z abgestutzt mol allseitig durch eine feine aber deutliche Linie abgesetzt, unten stark eingezogen. Die Fühler kaum bis zum Hinterrande des Halsschildes reichend, schwarz, die beilen unteren Glieder, wie die Mundtheile, trüb rotlı, die folgenden dunkler gebräunt, die Glieder der Keule nur mässig erweitert. Das Halsschild hinter der Hitte schıvach quer aufgewölbt und von da nach vorn breit abwärts gekrünmt, vor dem Schildchen schmal aber ziemlich tief quer gefurcht und seitlich dann noch von einem bogenförmigen, sich über der Mitte des Seitemrandes verlierenden Schrägeindrucke umzogen, dessen hinteres Innenende jedoch nicht deutlich mit jener Querfurche zusammenhängt. Der vordere Theil über den fast rechtwinkligen Vorderecken breit zusammengedrückt, die Seiten fein gerandet, vor' den scharf dreieckig ausgezogenen Hinterecken breit ausgeschweift; der Hinterrand jederseits flach ausgehuchtet und der Mittelzipfel fast gerarle abgestutzt. Die Farbe glänzend schwarz ohne deutliche 
Punktirung. Das Schildchen gleichseitig dreieckig, wenig ansteigend, gleichfalls schwarz. Die Deckschilde dopuelt lïnger als das Halsschild, um die Hälfte länger als breit, linter den stumpf abgerundeten Sclıulterecken bogig erweitert, mit kurz zugerundeter Spitze. Der Rïcken linter der schmal aufgetriehenen Wurzel jelerseits des Schildchens querfurchig eingedrückt, hinter dem letzteren buckelig aufgewölbt, und von da ab seitlich ziemlich steil-, längs der Naht nur schwach abfallend, mit hinten lurz abwärts gekrümmter Wölbung. Die Schulterbeulen breit, die Seitenlappen tief heralggezogen und ihr umgeschlagener Rand stark erweitert. Die Punktstreifen schon vorn ziemlich fein, von der Mitte ab wie abgeschliffen und kaum noch erkennbar, der neunte in eine sclıwache Längsfurche eingedrückt. Die Zwischenräume flach, nur der äusserste schwach gewölbt; die Farbe glänzend schwarz, ein grosser schıäg viereckiger, vorn die Schulterbenle frei lassender, aber den Seitenlappen einschliessender und mit dem linteren Innenende bis zum dritten P'unktstreifen reichender Schulterfleck kirschroth. Brust und Beine schwarz, mit bräunlich durchscheinenden Vorderschenkeln, Pygidium und Hinterleib roth. Das Prosternum flach, linten nur schwach ausgeschnitten; das letzte Bauclısegment des $q$ nit dem gewöhnlichen Grübchen; das of unbekannt.

Aus Neu-Granada (von Carthagena - Mus. Deyrolle).

60. M. pustulipennis Stå. Schwarz, die Fühlerwurzehı und eine abgekürzte Querlinde der Flügeldecken kirschroth, die Punktstreifen deutlich, der neunte leicht vertieft, mit flachen vorn und seitlich sehr flach gewölbten glänzenden Zvischenräumeı. L. $11 / 6-1 \frac{1}{3}{ }^{\prime \prime \prime}$; lir. $3 / 4-11 / 12 "$.

M. pustulipennis Slăl Till Kännedomen elc. in der öfrersicht etc. p. $61 . \mathrm{n}, 5$ !

Ltwas grösser als der vorhergehende, und von ihm an den derberen I'unktstreifen, sowie der schwarzen Firhung von PJgidium und Ilinterleib leicht zu unterscheiden. Der liopf fein punktirt, sclıwach ins Stahlblate fallend, die Augen (des $q$ ) nur durch einen schmalen Zwischenraum getrennt, das Wurzelglied der Fühler und die Oberlippe hellroth. Das IIalsschild in der Mitte schwach quer anfgewölht, hinten dlurch eine breite Querfirche niedergedrüclit, aus deren Enclen sich seitlich je ein ziemlich liräftiger Schrägeindruck entwickelt; ein zweiter, hinterer Schrägeindruck vor den Ilinterecken weniger dentlich ausgeprïgt. Das grosse, an Länge die Breite 
etwas übertreffende dreieckig zugespitzte Schildchen hinten nur mässig ansteigend und wie das IIalsschild glänzent schwarz. Die Deckschilde um die Schildchenspitze leicht buckelig aufgetrieben, hinter der Wurzel innerseits der Schulterbeulen tief quer eingedrückt, wodurch die Vorderkante scharf erhöht wird; auch Schulterbeulen und Seitenlappen kräftig ausgebildet. Die Punktstreifen aus sehr tiefen, die vordere Querfurche eindrückenden Vorderenden bald etwas abgeschwächt, dann aber bis zur Spitze gleichmässig und deutlich; die Zwischenräume kaum sichtbar zerstreut punktirt, glänzend, die Vorderenden und der durch den tiefer eingedrückten neunten Punktstreifen etwas aufgetriebene äusserste flach gewölbt, und der letztere zugleich über dem Seitenlappen doppelt breiter als die vorhergehenden. Die Farhe ein reines und glänzendes Schwarz, vorn mit einer den Seitenlappen mit umfassenden, hinter der Schulterbeule emporsteigenden, his zum vierten Punktstreifen reichenden rothen Querbinde, welche sich von dem Schulterflecke der vorhergehenden Art hauptsächlich durch ihre geringere Breite und ilıren merklichen Abstand von der Wurzel der Flügeldecken unterscheidet. Das Pygidium vereinzeIt grob punktirt, schwarz, Unterseite und Beine leicht ins Stahlblaue fallend, die Vorderschenkel auf der oberen Hälfte gelıräunt. Die Vorderbrust wie bei dem vorhergehenden; das letzte Segment des $q$ mit einem eiförmigen, glïnzenden Grübchen. Das ơ unbekannt. Bei dem von Stål a. a. 0. beschriebenen, etwas kleineren Stücke ist der Fleck der Flügeldecken etwas mehr gelblich; elsen so fallen auch die Schenkelwurzeln und der letzte Bauchring etwas ins schmutzig Röthliche. Weitere Unterschiede finde ich nicht; überdem ist dies Exemplar augenscheinlich nicht gehörig ansgefïrbt.

Von Paramaribo (Mus. Dohrn) und aus Brasilien (von Rio de J.: Mus. Holm., von F. Sahlberg gesammelt).

61. M. ulcerosus m. Schwarz, die Fühlerwurzehn, eine ahgekürzte Querbinde und die Spitze der Flüggeldecken rothgelb; die Punktstreifen derb, der achte und neunte etwas vertieft, mit flach gewülbten, glänzenden Zwischenräınıen. L. $1 \% / 3{ }^{\prime \prime \prime}$; Br. 1"“.

Wiederum dem vorhergehenten sehr ähnlich, noch etwas grösser, die Punktstreifen noch kräftiger, die rothe Zeichnung heller und auch noch auf die Spitze der Flügeldecken ausgedehnt. An Kopfe ist der Zwischenraum der Augen (bei dem $q$ ) etwas hreiter, die Oberfläche matt und doch olme sichtbare Punktirung, etwas 
ins Schwarzbläuliche fallend; das Kopfschild leicht eingedrückt, das erste Fühlerglied röthlich gelb mit schwarz angelaufener Oberseite. Das Halsschild in der Mitte nur schwach aufgewölbt, seitlich eben so schwach zusammengedrückt, die Querfurche jederseits vor dem Hinterrande ticf eingegraben, aher nur liurz, und das äussere schräg nach vorn gerichtete Ende derselben als besonderer Schrägeindruck über der Mitte des Seiteurandes abgerissen; der Hinterrand selbst mit seiner äusseren Hälfte tief eingesenkt. Das Schildchen etwas länger als breit, wenig austeigend, wie das Halsschild glänzend schwarz. Auf den Flügeldecken sind die P'unktstreifen noch etwas kräftiger als bei der vorhergehenden Art, und aus sehr dicht gedrängten Punkten gebildet, daher fast überall leichte Furchen eindrüchend, von denen die durch den neunten und in geringerem Maasse durch den achten gebildeten besonders hervortreten, daher alle Zwvischenräume flach gewölbt, und der äusserste über dem Seitenlappen auch hier noch eimmal so breit als der vorhergehende. Endlich bietet auch noch die Zeichnung wesentliche Verschiedenheiten dar, Der Ton derselhen ist viel heller, ein reines Rothgelb; die Vorderbinde ist merklich breiter, schräg nach hinten gerichtet, vor'n und hinten unregelmässig wellig begränzt, und ausser ihr auch noch die Spitze jeder Flügellecke rothgelb. Pygidium, Unterseite und Beine sind schwarz, die Hüften, und an den Vorder- und Mlittelbeinen anch die oberen Schenkelhïlften trüb geröthet, die Schulterblätter gebrämnt. Die Vorderbrust fein runzlig punktirt, um die Hälfte breiter als lang, mit geschwungenen Seiten, hinten nur schwach ansgerandet, das letzte Segment des einzigen vorliegenden $\&$ mit dem gewölmlichen Grübchen; das ठ̊ unbekannt.

Aus Brasilien (von Santos: Mus. Dohrn).

62. M. babioiles m. Schwarz, die Fühlerwurzcln, eine breite Vorderbinde und die Spitze der Flügellecken roth; die Punktstreifen mässig, hinterwärts etwas schwächer, ıler neunte leicht einged'ïckt, mit flachen, fein gerunzelten, mässig glänzenden Zwischenräumen. L. 1“"; Br. $2 / 3 "$.

Bei aller Aehnlichkeit mit dem vorhergehenden um mehr als die Hälfe kleiner, die l'unktirung merklich feiner, und die Vorderlignde ausgedehnter, diher sicher eine von jenem wohl unterschiedene Art. Der kopf flach mit deutlich eingezogenem, oben durch eine liele Querlinie lregränztem lioplschilde, „lie Stim oben durch die einander fast berührenden imneren Augenränder beinalıe auf den 
Raum der fein eingeschnittenen Stirnlinie beschränkt. Die Oberfläehe matt schwarz, die Augenbuchten schımal aber tief, die Mundtheile röthlich. Die Fühler an dem einzigen vorliegenden Stücke nicht melır vollständig, das erste Glied oberwärts nur schwach keulig verdiekt, dreimal länger als breit, das zwcite kurz kugelig, bei fast gleicher Breite mit jenem etwa viernal kürzer, die drei folgenden wenig länger aber merklich dünner, und die vier noch übrigen innerseits breit dreieckig erweitert; die beiden ersten Glieder hell rothgelb, die nächstfolgenden tief gebräunt, die oberen schwarz. Das Halsschild fast so lang als breit, hinten etwas eingesenkt, vorn mit $2 / 3$ seiner Länge stark kugelig ühergekrümmt, über den stumpf rechtwinkligen Vorderecken zusammengedrückt und dadurch verschmälert, die Seiten fein gerandet, hinter der Nitte leicht ausgeschweift, und dann nach vorn in flachen Bogen zusammenlaufend, die breiten Hinterecken kurz aber scharf spitzwinklig vorgezogen, der Hinterrand jederseits breit ausgebuchtet, an den Schulterbeulen etwas cingekniffen, mit kurzem, undeutlich doppelt ausgerandetem, und dureh einen davor liegenden bogenförmigen Quereindruek etwas aufwärts gedrücktem Mittelzipfel. Ausserdem über der Mitte des Seitenrandes jederseits noch ein breiter, sehır flacher Schrägeindruck. Die Oberfläche glänzend schwarz. Das Schildchen länglich dreieckig, um die Hälfte länger als breit, selıäg ansteigend mit deutlichem Vordergrübchen, gleichfalls glänzend schwarz. Die Deckschilde kaum länger wie breit, aber ım etwa 1/3 länger und auch etwas hreiter als das Halsschild, hinter. der aufgeworfenen Vorderkante tief quer eingedrückt, $\mathrm{mm}$ die Schildchenspitze buckelig erhölıt und von da al) seitlich stärker-, hinterwärts mehr allmälılich abfallend, über den selır stark entwiekelten Seitenlappen wenig zusammengedrückt; die Schulterbeulen schmal aber stark heraustretend. Die Punktstreifen deutlich, hinterwäıts etwas feciner, die Vorderenden der inneren bis zur Schulterbeule etwas tiefer eingegrahen, und zwisehen ihuen die übrigens flachen Zwischenrïume leicht aufgewölbt; auch der äısserste durch den ihn begränzenden tieler eingedrïckten neunten Streifen etwas aufgetrieben; dabei alle fein gerunzelt mit mässigem Glanze. Die Farbe schwarz, eine lïngs der Wurzel hinziehende, aber deren aufgeworfene Kante mit dem Schildchın freilassende, hinterwärts, besonders längs der Naht nur verwasehen begränzte Querbinde und die Spitze unter der Wülbung roth; die Schulterbeulen und der vordere Kiel des Sei- 
tenlappens im Anschlusse an die Vorderkante etwas geschwärzt. Das Pygidium deutlich aber zerstreut punktirt, mit der Unterseite und den Beinen schwarz. Die Vorderbrust flach, hinten logig ausgeschnitten, das letzte Segment des $\delta$ seicht quer eingedrückt; das i unbekanut.

Aus Brasilien (Mus. Hal.).

\section{Cryptocephalus Geoffr.}

(Linn. II. 13. VI. 220.)

Die schon oben hervorgehobene Armuth der südamerikanischen Käferfanna an echten Cryptocephalen lässt diese Gattung hier als ein Conglomerat von sehr verschiedenartigen Bruchstücken erscheinen,-deren Abweichungen von einander besonders desshalb so augenfällig hervortreten, weil es an den Vertretern der in Nordamerika oder gar in noch entfernteren Erdtheilen zu suchenden Uebergangs- und Zwischengruppen gebriclıt. Es wïrde sich daher auch für die Ansicht, welche in jeder habituellen Verschiedenheit zugleich deı Typus einer eigenen Gattung erkennt, ein reiches Feld derartiger Thätigkeit darbieten; ich hahe mich jedoch zu einer solchen Zersplitterung nicht entschliessen mögen, weil ich jenen anders woher zu ergänzenden Uebergängen gegenüber die vorhandenen Verschiedenheiten nicht für wesentlich genug erachte, um auf Grund derselben die Systematik sofort mit einer lieihe nener Gattungen und Gatungsnamen zu helasten. Es mag dies Geschäft viehmehr, nachılen die tïglich anschwellende Masse der ans den rerschiedensten Gegenden zmm Vorschein kommenden Arten gehörig gesichtet und lienntlich gemacht scin wird, einem späteren glücklicheren Revisor dieser Familie rorbehalten bleihen; bis dahin fasse ich alle jene echten Cryptocephaten-formen hier noch in der einzigen Gatung Cryptoceplialus zusammen, und beschränke mich darauf, bei jeder darin vou mir angenommenen Gruppe zugleich die stelle zu brzeichnen, an welcher sie in einer, alle bekannten Cryptocephalen umfassenden Gruppirung m. E. eingeschaltet werden müsste.

Erste Rutte. Körper liurz, lureit und gedhngen, etwas jlump, mit grossem, voru kugelig zugerundetem Halsschilde; der Hinlerrand des letzteren in der Mille in cinen schrïg anfwirts gerichteten Zipfel rorgrzogen, dessen abger'undeter, leicht ausgehühlter Rand den vorderen Theil des Schildehens in einem flachen Bogen 
niederdrückt, und dadurch das feste Schliessen der Rückentheile bewirkt. Die Augen nur leicht ausgebuchtet, die Fühler lang und derb. Die Farbe sehwarz mit rother oder gelber, bei einer Art zur Hauptfarhe gewordener Zeichnung der Deckschilde. Die Punktirung fein, mit wenig bemerkbaren Punktstreifen; die Oherseite des Körpers, besonders das Halsschild, mit einer kurzen und feinen Behaarung bedeckt. Der Hinterrand des Prosternuns fast grade alggeschnitten. Arten von der Westküste von Südamerika. Mylassa Stål a. a. O. (Nit der folgenden Rotte einzuschalten vor der ersten afrikanischen Rotte Lin. XI. S. 71.)

1. Cr. obliquatus m. Schwarz, ein Schrägfleck vor der Mitte der Flügeldecken und deren Spitze kirschroth; das Halsschild feil punktirt, die Punktstreifen mässig mit flachen quer gerunzelten Zwischenräumen. L. $2 \frac{1}{2}-3^{\prime \prime \prime}$; Br. $1 \frac{1 / 2}{2}-1 \frac{2}{3}{ }^{\prime \prime \prime}$.

Eine grosse kräftige, in Färbung und Habitus den nordamerikanischen Pachybrachen aus der Rotte des P. pubescens Oliv. nicht unähnliche Art. Der Kopf breit. und flach, die Stirn der Länge nach tief eingedrückt und dieser Eindruck unten grubig erweitert, das Kopfschild seitlich durch schärfere Kanten, oben durch einen leichten Querwulst abgesetzt, etwas eingezogen, die Tasterspitzen des $\delta$ vorn schwach verbreitert. Die Fühler des $\delta$ dünı und schlank fadenförmig, reichlich von Körperlänge, das Wurzelglied aus stark eingeschnürter Basis plötzlich blasig aufgetrieben, etwas gekrümmt, doppelt länger als breit, das zweite kugelig, die folgenden verkelırt kegelförmig, am Oberende mit bogig geschweiften Seiten verbreiter't, das dritte dreimal und die übrigen efwa je viermal lïnger ats das zweite; das Endglied unter dem kurz dreieckigen Fortsatze am stärksten verbreitert und zusammengedrückt; die Farbe schwarz, dünn greishaarig. Die Fühler des q etwas kürzer, die Spitze des ersten Gliedes und das zweite, bei einem Stücke auch noch die Unterseite des dritten trüh geröthet. Vie Augen kurz und breit, innerseits nur schwach aber doch etwas deutlicher als bei den folgenden Arten ausgerandet, schwärzlich oder greis. Das Halsschild kurz und breit, vor'n mit $3 / 4$ seiner Länge stark kugelig übergewölht und dann noch längs dem Vorderrande breit ınd seicht cingeschunirt; die rechtwinkligen Vorderecken wenig eingezogen, die Seiten fein gerandet, fast gerade, die Hinterecken lurz und sehr breit, wenig vorgezogen, gleichfalls fast rechtwinklig. Ber Hinterrand nur zunächst am Schildchen etwas ausgebuchtet, 
danı mit leichter Krümmung in den breit lappig hervortretenden Mittelzipfel ühergehend, in dessen grade abgestutztem Hinterrande sich noch eine schwache Querfurche bemerklich macht. Der Mittelzipfe] sellsst flach gewölbt, vorn durch einen breiten Sattel von dem Mlittelfelde getrennt, welcher sich seitlich zu einer den Hinterrand fast his zum Ilinterwinkel begleitenden Querfurche verlängert. Von dem Innenende der letzteren zieht sich ein schwächerer Schrägeindruck jederseits auf dem Mittelzipfel hin und heht dadurch auf diesem ein melır oder weniger deutliches Schrägfältchen empor. Ein ähnliches aber etwas gekrümm!es Schrägfälıchen zeigt sich jederseits vor der Aussenhïlfte des Hinterrandes, und ist namentlich bei dem $q$ gewöhnlich noch eine Strecke läıgs dem Seitenrande zu verfolgen. Das Mittelfetd der Länge nach durch einen breiten seichten Eindruck getheilt, in welchem zuwcilen eine Spur von einer erhöhten glatten Längslinie hervortritt. Die Oberfläche dicht und fein punlitirt, matt schwarz, mit kurzer und etwas krauser angedrückter greiser Behaarung bedeckt. Das Schildchen gleichseitig dreieckig, dicht punktirt und quer wellig nneben, gleichfalls schwarz. Lie Declischilde breit und flach walzenförmig, doppelt lïnger als das IIalsschild und etwa 1/4 länger als breit, linterwïrts etwas verschmïlert, die Wurzel durch die tiefer eingegrabenen Vorderenden der P'unkistreifen etwas niedergedrückt, die ziemlich schmalen flachen Schulterhenlen innerseits durch einen breiten seichten Eindruck abgesetzt, die Scitenlappen stark entwickelı, durch eincn tiefen längseindruck ahwärts geschoben, und über ihnen vorn je noch eime besomlers bei dem of breite, von der Schulterbeule durclı den achten Punktstreifen gesonderte Beule. Der Rücken breit und flacl, hinten mit sehr schrïger Wülbung abfallent, ror und wiederum linter dem ersten Drittel seiner Länge schwach quer niedergedrüclit. Dic Punktstreifen regelnässig, lie inneren fein, die äusseren etwas liräftiger, jene bei dem $q$ vor der Wülbung fast unscheinbar. Die Zwischenrïune Anch, die Vorderenden der mitteren stellenweise sehr leicht gewöllst; der Zwischengrund dicht querrunzlig, auf ter rothen Zeichnung dicht und fein punktirt, und dadurch, wie durch die dicht angedrüclite kurze greise Behaarung ziemlich matt; die alggerielienen Stellen besonders bei dem ơ mit schwach metallischem Aufluge. I) Farbe schwarz, ein nach aussen sich mondförmig rer'schmälender Spitzenfleck und ein eiförmiger Schräglleck vor der Mitte hinter der Sclutterbenle aul jeder Flügel- 
decke kirschroth; von dem letzteren zieht sich bei zweien von den vorliegenden of ein schmaler Längsarm innerseits der Schulterbeule nach der Wurzel hin, die er, zu beìden Seiten des fünften Punktstreifens sich ansbreitend, bei dem einen auf beiden Flügeldecken, hei dem andern nur auf der linken wirklich erreicht. Pygitlium mit Unterseite und Beinen schwarz, gleichfalls fein punlitirt und dünn greishaarig, an den abgeriebenen Stellen schwach metallisch schimmernd. Auch die Beine schwarz, die Vorder- und Hinterbeine bei dem $\delta$ stark verlängert, das erste Fussglied reichlich von der Längé der beiden folgenden zusammengenommen; die selır langen Ifinterschenkel und Schienen von gewöhnlichem Bau, die gleichfalls langen Vorderschınkel, wie die kürzeren Mittelschenkel stärlier verdickt, die langen Vorderschienen mit dem unteren Viertel stark einwïts gekrümmt, vor den Enden rhombisch verbreitert und ılanm noch seitlich in eine spornartige Spitze ausgezogen; auch bei den $q$ ist die grössere Länge der Vorder- und Hinterschenkel, wenn gleich nicht in demselben Grade wie bei den $\delta$, wahrnelımbar. Die Vorderlorust grobrunzlig punktirt und dicht greishaarig, schwach eingedrïcki, mit leicht ausgesehweiftem Hinterrande; bei dem $\delta$ erweitert sich die den Pfanmenrand der Vorderhüfte bildende Seite der Vorderbrust je innerseits der Vorderhüfte zu einem langen dreieckigen, mit der Spitze wieder einwärts gekıümmıten Zalme. Das letzle Segment des o mit einen flachen glïnzenden Quereindrucke, des o mit dem gewöhnlichen auch nur seichten Grübchen.

Aus Chile; das $\delta$ (von Valdivia) von Hrn. Sturm, das $q$ (ohne Bezeichnung der Ileimath) von IIrn. Riehl mitgetheilt; das letztere liegt mir auch aus dem Mus. Deyrolle und Haag zum Vergleiche vor.

2. Cr. rubro-notatus Blanch. Schwarz, die Fühlerwurzeln und eine breite buclıtige Längsbinde der Flügeldecken roth; das Halsschild fein punktirt, die Punktstreifen fein, mit flachen dicht narbig punktirten Zwischenräumen. L. $1 \frac{2 / 3}{3}{ }^{\prime \prime \prime}$; Br. $1^{\prime \prime \prime}$.

Pachybrachys rubro-notalus Blanchard in Gay hist. fisica etc. de Chile. V. 540. n. 2 .

Dem vorhergehenden ähnlich, aber kleiner, gestreckter und an der gänzlich abweichınden Gestalt der rothen Zeichnung leicht kenntlich. Der Kopf flach mit sehr l,reiter, wenig niedergedrückter Stirn, das Kopfschild leicht eingezogen, oben nur durch einen XV. 
schwachen Querwulst zwischen den Fühlerwurzeln abgesetzt, mit schmal vorspringender Oberlippe. Die Oberfläche schwarz, durch eine dichte aber ausserst feine Punktirung matt, mit sehr kurzen greisen Härchen bedeckt, die weit getrennten Augen kurz und breit eirund, am Innenrande kaum merkbar ausgeschweift, gleichfalls schwärzlich. Die Fühler (des $f$ ) nicht ron halber Körperlänge, das Wurzelglied kurz und breit eiförmig, etwa doppelt länger wie breit, das zweite birnförmig, halh so lang und breit wie das erste, die nächstfolgenden dünn rerkchrt kegelförmig, das dritte um die Hälfte länger als das zweite, das vierte und fünfte je den beiden vorhergehenden zusammen gleich, die oberen wieder allmählich kürzer und anfangs schwach-, die drei letzten stärker verbreitert und verkürzt, so dass das zehnte kaum die Länge des dritten erreicht, mit kurz kegelförmigem Fortsatze des Endgliedes. Die vier unteren Glieder ziegelroth mit gebräunter Oberseite des Wurzelgliedes, das fünfte stärker gelır̈unt, die oberen schwarz mit angelrückter greiser Belıarung. Das Ilalsschild breit, vorn mit halber Länge stark übergekrümmt, über den stumpf abgerundeten, etwas anfgebogenen Vorderecken wenig zusammengedrückt, die Seiten fein gerandet und in der Vitte in flachen Bogen erweitert; die Hinterccken stumpfwinklig, der Hinterrand jederseits auf der Aussenhälfte fast gerade, in der Hitte plötzlich in einen breiten, gleichzeitig erhöhten lappig heraustretenden Zipfel erweitert, welcher die Mittelfirste des Halsschildes fast um die Hälfte verläıgert, und lurch einen sich jederseits vor dem Ifinterrande zu einem stärkeren Quereindrucke verticfenden Sattel von dem aufgewölbten Mittelfelde des Ilalsschildes getrennt wird. Vor dem Ilinterrande dieses Zipfels jederseits nochmals ein schwïcherer Schrägeindruck. Die Oherfläche durch eine dicht gedrängte feine I'ınktirung matt, einfarbig schwarz, mit kurz geschorner greiser, etwas ins Gelbliche fallender Behaarung. Das Schildchen verhăltnissmässig gross, durch den in gleicher Flïche sich anschliessenden Hinterzipfel dreieckig, der Vorderrand des letzteren fein, aber doch kenntlich; die Oberfläche gleichfatls schwarz, dicht und fein punktirt, aber etwas glänzender als das Ilalsschild. Dic Deckschilde kurz und breit walzenförmig, un etwa $1 / 4$ länger als breit, vorn hinter der Wurzel nur leicht quer niedergedrückt, die Schulterbeulen länglich höckerig, und üher den schwachen Seitenlappen ein länglicher Eindruck. Der Rücken llach gewölbt, mit hiıten kurz und sclırïg abfallender Krümmung 
und breit abgerundeter Spitze. Die Punktstreifen regelmässig, aus vorn gröberen, hinterwärts feineren, ülerall vereinzelten Punkten gebildet, die Zwischenräume dicht narhig gerunzelt und dadurch matt, der neunte über den Seitenlappen mit einigen zerstreuten Punkten von der Stärke der die Streifen bildenden besetzt. Die Färbung lässt sich am besten als ziegelroth bezcichnen, mit breit schwarzgesäumten Flügeldecken, welcher Saum sich längs der Wurzel zu einer schmalen Vorderbinde erweitert, und hinter der Mitte von Naht und Seitenrand aus mit hallorunder Erweiterung in den rothen Grund eingreift, den letzteren dadurch auf die Hälfte seiner Breite einschränkend. Aendert ab

$\beta$. die schwarze Vorderhinde sehr verbreitert, und die rothe Färbung durch das Zusammenstossen der beiden schwarzen Ausbuchtungen in cinen grossen rundlichen Vorderfleck und einen kleineren Spitzenfleck zerrissen, welche anscheinend seltenere Form von Blanchard a. a. 0. als die Grundform vorangestellt worden ist, während er der oben als die Hauptform betrachteten nur in der Diagnose, nicht aber in der von ihm gegebenen Beschreibung gedenkt.

Das Pygidium etwas eingedrückt, matt schwarz, dicht und fein punktirt, mit kurzer, dünner, gelblich greiser Behaarung. Auch die Unterseite mit den Beinen schwarz, dünn angedrückt greishaarig, die Vorderschenkel schwach verdickt, die Schienen wenig gekrümmt, aber breit zusammengedrückt. Die Vorderbrust kurz und breit, flach, hinten unmerklich ausgeschweift. Das letzte Segment des $q$ mit einer rundlichen, nicht eben tiefen Grube; das $\delta$ mir unbekannt.

Aus Chile (von Ierr'n Deyrolle mitgetheilt, und eben daher auch im Mus. Baly in leiden Formen). Bei einem mir von Herrn Dr. Kraatz mitgetheilten Stücke der Hauptform ist Lima als Heimath angegeben. Nach der Augabe von Gay a. a. 0. ist der Käfer iu Chile bei Santiago, Sta. Rosa und anderwärts gefunden worden. Auch im Ius. Holm. (die var. $\beta$., wohei Valparaiso als Fundort angegeben ist), und Mus. Berol. (var. $\beta$.).

3. Cr. socius Stål. Schwarz, die Fühlerwurzeln und Flügeldecken gelb mit schwarzem Saum der letzteren; das Halsschild fein punktirt, dünn greishaarig, die Punktstreifen fein, mit flachen, fein narbig punktirten Zwischenräumen. L. $1 \frac{1}{3}{ }^{\prime \prime \prime}$; Br. $3 / 4{ }^{\prime \prime \prime}$.

Mylassa socia Stål Till Kännedomen of Phytophaga in der öfversicht af Kongl. bel. Akad. Förhandlinger XIV. S. 60. n. 2! 
Noch kleiner und zierlicher als der vorhergehende, und ausserdem von ihm durch die kahlen gelben Flügeldecken abweichend, übrigens eine anscheinend seltene, mir nur in wenigen Stücken zu Gesicht gekommene Art. Der Kopf breit, der Länge nach seicht niedergedrückt, mit stark eingezogenem, gleichfalls etwas quer eingedrücktem Kopfschilde und wieder vorspringender Oberlippe; die Farlbe sehwarz, durch dichte aber sehr' feine Punktirung matt, nur die an den Rändern etwas gebrăınte Oberlippe glänzend. Die eiförmigen Augen klein, imnerseits sclıwach ausgerandet. Die Fülıler (des ठ) von melır als $3 / 4$ der Körperlänge, derb und kräftig; die unteren Glieder von dem Bau der vorhergehenden Art, die oberen vom fünften ab gleich lang, mässig zusammengedrüclit, das sechste und siebente am breitesten, das Endglied mit kurz und breit dreieckigem Fortsatze. Die Farbe der fünf unteren hochgelb mit einen verwaschen schwarzen Längsfleck auf der Oberseite des Wurzelglietles, die folgenden allmählich dunkler gebräunt, die oberen scliwarz. Das Halsschild breit, vorı mit $3 / 4$ seiner Länge übergekrümmit, über den scharf rechtwinkligen Vorderecken kaum zusammengeIrrïckt, die Seiten sehr fein gerandet und hinter der Mitte schwach erweitert, die Ilinterecken gleichfalls scharf und fast rechtwinklig; der Itinterrand seitlich fast gerade, der Mittelzipfel als kappenförmig erlıölıter Lappen vorgezogen, hinten quer abgeschnitten und ausgefurcht, vorn durch einen Sattel von dem flach erhöhten Mittelfelde getrennt, von welchem aus ein allmählich an Stärke abnehmender Quereindruck den Ilinterrand lis in die Nähe der Hinterwinkel begleitet. Die Olerfläche dicht und fein punktirt, matt, mit schwaclier Spur einer kieligen Linngslinie auf der Mitte des Mittelfeldes, schwarz, mit einer feinen angedrückten gelblichgreisen Behaarung besetzt. Das Schildchen gleichseitig-dreicckig, flach niederliegend, gleichfills schwarz. Die Deckschilde breit und flach walzenförmig, etwa doppelt länger als das Halsschild und um 1/4 länger als breit, hinterwärts etwas verschmälert, hintter der leicht niedergedrückten Wurzel sauft ansteigend, die Schulterbeulen breit und sehr llach, imnerseits durch einen seichten dreieckigen Eindruck abgesetzt, die Seitenlappen lirältig, durch einen darüber liegenden grübchenartigen Längseindruck noch tiefer alswärts gedrängt. Der flache Rücken hinten mit mässiger Wölbung alfallend. Die Punktstreifen fein, auf der hinteren Hïllte noch melır abgeschwächt, die Zwischenräume flach, fein. narbig gerunzelt und daher nur matt schimmernd, an der 
Vurzel mit Spuren angedrückter greiser Behaarung. Die Farbe hochgelb, ins Röthliche fallend, ein breiter Rand längs Wurzel und Naht, und als Fortsetzung desselben von der Wölbung ab ein, Spitze und Anssenrand umziebeuder, an letzterem beim Beginn der Wülbung bei dem von Slål a. a. 0 . beschriebenen Stïcke zu einem verwaschenen Randwische erweiterter Saum schwarz. Pygidium, Unterseite und Beine einfarbig schwarz, mit dünner, auf den Parapleuren stärkerel greiser Behaarung. Das letzte Segınent des $\delta$ mit einer leicht eingedrückten Vertiefung, das $\&$ unbekannt.

Aus Chile (Mus. Holm., von Fairmaire mitgetheilt; auch im Mus. Berol., wo Coquimbo als Fundort genannt ist). Ob etwa das б der vorhergehenden Art??

4. Cr. crassicoll is Blanch. Schwarz, Vorder- und Hintersaum mit einer manchmal unterbrochenen Mittelquerbinde der Flügeldecken bleichröthlich; das Halsschild fein punktirt, die Punktstreifen fein, hinter der Mitte verschwindend, mit flachen dicht und fein punktirten Zwischenräumen. L. $1 \frac{2 / 3}{3}-2 \frac{1}{2}{ }^{\prime \prime} ;$ Br. $1-$ $1 \frac{1}{1} 3^{\prime \prime \prime}$.

Pachybrachys crassicollis Blanchard 1. c. S. 539. n. 1. lab. 31. fig. 9. - Nylassa fascialipennis Slål 1. c. S. 60. n. 1!

Gewölnnlich noch etwas grösser als $C r$. rubro-nolatus, im Habitus aber mehr dem $C r$. obliquatus ähulich, der Zeichnung nach eine üheraus veränderliche Art. Der liopf flach, zwischen den Augen seicht niedergedrückt und hier bei abgeriebener Behaarung metallisch glänzend, sehr dicht und fein punktirt, fein greishaarig, nebst den Mundtheilen schwarz. Die Augen kurz und breit eiförmig, innerseits etwas deutlicher ausgeschweift als bei den nächst vorhergehenden Arten. Die Fühler dles $\delta$ von $3 / 4$ der Körperlänge, derb und kräftig, das Wurzelglied stark aufgetrieben, doppelt länger als breit, das zweite eiförmigg, halh, so lang und breit wie das erste, das dritte um die Hïlfte länger aber dünner als das zweite, das vierte und fünfte je den zweiten und dritten zusammen gleich, die oberen wieder einander gleich und nur wenig kürzer als das fünfte. Dabei alle vom vierten ab deutlich zusanmengedrückt, das vierte oberwärts schwach erweitert, die oberen stärker verbreitert, der Fortsatz des Endgliedes kurz und breit dreieckig. Die Fühler des $q$ etwas kürzer und dünner als die les $\delta$. Die Farbe schwarz mit dünner Belraarung. Das Wurzelglied an ter 
Spitze und Unterseite trüb röthlichbraun, auch die folgenden auf letzterer schwach gebräunt. Das Halsschild sehr breit, vorn mit halber Länge kugelig übergebogen, über den stumpf rechtwinkligen tief eingezogenen Vorderecken etwas zusammengedrückt, die Seiten fein gerandet, fast gerade, der Länge nach von einem breiten seichten Eindruck begleitet. Die scharfen Hinterecken etwas ausgezogen; auch der Hinterrand nach aussen hin fast gerade, die Mitte in den breiten seitlich leicht zusammengedrïckten Zipfel ausgezogen. Der auf dem Schildchen aufliegende Hinterrand des letztern leicht quer ausgefurcht, der Zipfel selbst von dem polsterförmig aufgetriebenen Mittelfele durch einen vertieften Sattel getrennt, an welchen sich jederseits ein fast bis zum Hinterwinkel hinziehender deutlicher Qurereindruck anschliesst. Die Oberfliche dicht und fein punktirt, ziemlich stark greishiarig und bei abgeriebener Behaarung metallisch schwarz. Das flache Schildchen gleichseitig-dreieckig mit abgerundeter Spitze, fein aber deutlich punktirt, auf der hinteren Hälfle schwach niedergedıïckt. Die Deckschilde kurz und breit walzenförmig, um die Hälfte länger als das Halsschild, etwa 1/4 länger als breit, hinterwärts etwas verschmälert; der breite Rücken nach der Spitze zu mil sehr flacher Wölbung abfallend, die Spitze selbst abgerundet mit weit klaffender Naht. Die länglichen flachen Schulterbeulen innerseits durch einen schwachen Eindruck abgesetzt; eben so umzieht die Deckschilde ein breiter und flacher Quereindruck im ersten Drittel der Länge, und senkt sich hinter den Schulterbeulen mit einen tiefen Grübchen zu dem mässig entwickelten Seitenlappen hinab. Die Punktstreifen vorn sehr regelmässig und deullich, hinterwïrts abgesclıwächt, aber doch bis zur Mitte kenntlich und von da ab sich allmählich unter der feinen aber dicht gedrängten P’unktirung der flachen Zwischenräume verlierend; letztere dabei nit einer dicht angedrückten greisen Behaarung bedeckı, ınd durch die schwarze Crundfarbe hindureh etwas ins Bleigraue ziehend, an den algeriehenen Stellen mit leicht metallischem Anfluge. Die Zeichmung sehr veränderlich; bei deı typischen Stücken (s. unten var. $\gamma$ und $\delta$ ) sind Wurzel mol Spitze mit einer nach der Mitte hin unregelmässig buclitigen rothgelben Randbinde gezcichnet, und n̈ber die Mitte selbst zieht sich eine aus zwei Flecken zusanmengesetzte, dicht hiuter dem Quereindruck liegende Querbinde von gleicher Farbe, aus welcher Zeichnung sich theils durch Schwinden, theils durch Ueberhandnehmen der zuweilen bis ins Weissliche 
verbleichenden rothen Binden die übrigen Formen entwickeln. Als solche liegen mir vor

$\alpha$. die Vorderbinde fehlend, und sonach ausser dem breiten Ilintersaume nur eine zusammenhängende Mittel-Querbinde vorhandell. $\delta$

$\beta$. wie $\alpha$, aber die Mittelbinde in zwei Flecke, deren innerer der kleinere, zerrissen; der Kiel des Seitenlappens bräunlich gesäunt. 오

$\gamma$. Die Mittelbinde wie bei $\beta$., die Wurzel der Flügeldecken zwischen Schildchen und Schulterbeulen breit und hinten buchtig roth gesäumt, der Kiel des Seitenlappens roth und du'ch einen zarten Randsaum mit dem verbreiterten Spitzensaume verbunden. $\delta$. $q$

$\delta$. wie $\gamma$, aber der Seitenlappen ganz roth, der an ihn anschliessende Seitensaum merklich verbreitert, das Aussenende der unterbrochenen Mittelbinde berührend, der Spitzensaum an der Naht fleckartig erreitert. $\delta$

$\varepsilon$. Alle Binden so weit verbreitert und zusammenfliessend, dass die Flügeldecken roth erscheinen und nur vier unförmliche schwarze dreieckige Wische ührig bleiben $(2,2)$, dercn vorderer äusserer einen Längsarmu üher die Schulterbeule hiustreckt. $\delta$

Pygidium, Unterseite und Beine schwarz mil manchmal trüb röthlichen Hüften, fein und dicht punktirt, dümn greishaarig, die Vorderschienen des đo etwas verlängert und mit dem unteren Drittel ein wenì einwärts gebogen. Die Vorderbrust breit und flach, in der Mitte (bei den vorliegenden of schwächer) eingedrückt; der Hinterrand in der Mitte leicht aher deutlich ansgebuchtet und dabei fein röthlich gesäunnt. Das letzte Segment des o mit einem flachen rundlichen glïnzenden Eindrucke, des $q$ mil einem etwas stärkeren Grübchen.

Gleichfalls aus Chile (von IIerm Deyrolle erhalten; eben daher auch im Mus. Holm., Dohrn und Haag.). Nach Gay a. a. 0. auf Moosen in der Gegend von Santiago, Sta. Maria, Concepcion und anderwärts gefunden.

Die Abbildung bei Blanchard a. a. 0. soll dic obige var. $\delta$ darstellen, ist aber fast in allen Bezichungen verfehlt, da sic weder den HabiIns noch den Bau des Halsschildes richtig wiedergibs und dagegeu die Punktstreilen viel zı kräftig zeichnet. Eben so unzureichend ist die Beschreibung, welcher nur selır abgeriebene Stücke zum Grunde gelegen habeu können. 
Z weile Rotte. Der Körper kurz und gedrungen, breit gewölbt, mit grossem stark abwärts gekrümmtem Halssehilde; der Hinterrand des letztern in der Mitte in einen schräg aufwärts'gerichteten Zipfel vorgezogen, welcher mit deutlich doppelt ausgeschnittenem Hinterrande in drei Spitzen auf das Schildehen niedergreift. Die Flügeldecken jederseits der Nahıt mit z wei algeliürzten Streifen, die Obertläche kahl und glatt, ohne deutlich ausgehildete Zeichnung. Der Hinterrand der Vorderbrust hinter einem gegabelten Längswulste gerade ahgeschnitten.

5. Cr. praeustus m. Schwarz, Fühler und Beine gelb, die Flügchlecken rothlıraun, mit schwarzem Rande und breit sclıwarzer Spitze; die Punktstreifen zicmlich feiı, die Zwischenräume flach, glänzend, undeutlich punklirt, mit Ansülzen überzälıliger Streifen längs Nalıt und Aussenrand. L. $2 \frac{3}{4} "$; Br. $1 \frac{5}{6}{ }^{\prime \prime}$.

Von der breiten, gedrungenen Form der Stereomia-Arten unter den Clythriden, und zugleich durch die starke Wölbung einzehnen Monachen-formen nicht ganz unälınlich, aber wegen des vor dem Schilıchen lappenförmig ausgezogenen Halsschililes der vorhergehenden Grupje am nächsten verwandt. Der Kopf breit und llach, üher den Fühlerwurzeln leicht eingedrückt, mit kaum merlibares Stirnlinie; das Kopfschild oben in einen pfriemlich zugespitzten Zipfel ausgezogen, unten tief ausgerandet. Die Punktirung deutlich aber zerstrent, auf dem Kopfschilde feineî", die Farbe glänzend schwarz, Oberlippe und Taster lıellgell. Die Augen lang unil schmal, mit gestreckten aber nicht tiefen Augenbuchten. Die Fülıler von ctwas über halber Körperläuge, das zweite Glied kurz und knotig, die beiden folgenten gleich lang und je etwas läuger als das zweite, das fünfte noch etwas vrrlängert, die folgenden wieder dem vierten gleich, vom sechsten ab deutlich zusammengedrückt mnd erweitert, das Endgylied mit lang dreieckigem, fast die Hälfte des Gliedes bildendem Fortsatze. Das anscheinend kurze Ilalsschild mit $2 / 3$ der Länge vorn übergewölbt und bei tief eingezogenen Vorderecken stark verschmälert, der Ilinterrand jederseits dopject ausgeschweift, vor dem Schilschen in einen längeren Ziplfel ausgezogen, welcher dlurch eine nach vorn convexe gebogene Querfurche vou dem Mittelfelde gesondert ist und schräg gegen das Schildchen ansteigt, aucl bei deutlich doppelter Ausrandung mit seiner mittleren Stachelspitze in das Vordergrübchen des Schildchens eingreift. Die Hinterecken dreieckig rorgezogen, die Schultern seharf um- 
schliessend, die Seiten gerandet, mit der grösseren Vorderhälfte nach vorn fast in geraden Linien zusammengeneigt. Die Punktirung äusserst fein und zerstreut, seitlich und besonders in den Hinterwinkeln deutlicher und dichter; die Farhe glänzend kohlschwarz. Das Schildchen lang und schmal, mit fast parallelen Seiten, hinten kurz zugerundet, mit undeutlichem Hinterzipfel, vorn quer niedergedrückt mit deutlichem Grübchen, ebenfalls glänzend schwarz. Die Deckschilde kurz und breit, vorn etwas schmäler als der IInterrand des Halsschildes und hinterwärts mit schräg zusammenlaufenden Seiten noch mehr verschmälert, die Spitze mit abgerundeten Ecken fast abgestutzt, die Seiten hinter den Schultern wenig zusammengedrückt; die Wurzel jederseits an Schildchen quer niedergedrüclit, und innerseits der hreit höckerig emporgehobenen Sclsulterbeulen nochmals ein liefer dreieckiger Eindruck, die Seitenlappen lang herabgezogen. Der Rücken um die Spitze des Schildchens beulig erhöht und dann bis zur Spitze hin schräg abfallend. Die Punktstreifen sehr regelmässig, aus etwas getrennten, von der Mitte ab sclıwächeren Punkten gebildet; zwischen der Naht und dem ersten Streifen sind deren zwei abgekürzte vorhanden, von denen der erste vorn, der zweite in der Mitte des Rückiens ausläuft, und die Punktstreifen erhalten dadurch eine sehr schräge Richtung gegen die Naht hin; eben so zeigen sich auf dem, über den Seitenlappen verbreiterten neunten Zwischenraume noch die deutlichen Ansätze von zwei je aus $6-8$ Punkten bestehenden Streifen. Die Zwischenräume breit und flach, glänzend, vorn sehr fein und vereinzelt punktirt; die Farbe ein schnntziges dunkles Rothloraun, ein schmaler Saum der Wurzel, ein breiter anch die Schulterbeule umfassender schlecht begränzter Seitenrand und das hintere Drittel der Flügeldecken schwarz, gleiclıfalls mit verwaschener, allmählich in die Grundfarhe übergehender Begränzung. Das Pygidium fein narbig punktirt, kaum behaart, unten grade abgestutzt, schivarz. Auch die Unterseite schwarz, dünn greishaarig, die Brust durch dichtere Punktirung matt, der Ilinterleib fein gerunzelt. Schulterblätter und Seiten des letzten Bauchringes trüb bräunlich, Vorderund Mittelbrust mit Beinen und Hüften wachsgelh. Die Vorderbrust breit mit einem flachen linterwärts gegabelten Längswulste, der Hinterrand selbst grade in die Quere abgeschnitten. Das letzte Segment des $\&$ mit einer tiefen, im Innern glänzenden, am Rande lang greis gewimperten Grube; das ơ unbekannt. 
Aus Südamerika ohne uähere Angabe der Heimath. (Mus. Petrop.)

Dritte Rotte. Körper gedrungen eiförmig mit kurzem, vorn stark übergekrümmtem Halsschilde und buckelig gewölbten Deckschilden. Die Fühler von mässiger Länge mit stark vergrössertem dritten und vierten Gliede, oben deutlich zusammengedrückt und verbreitert. Die Punktstreifen regelnässig, bei einigen Arten in tiefe Längsfurchen eingedrückt, so dass sich hier die ver'schiedene Sculptur der Antillengruppe des Cr. grossulus wiederlıolt. Die Grundfärbung überwiegend gelb oder roth, mit zuweilen mehr oder weniger geschwärzter Unterseite, die Deckschilde manchmal metallisch blau, grün oder schwarz, auch wohl das Halsschild mit einer dunkeln Querzeichnung, nur bei einer einzigen Art einfarbig blau. Der Vorderrand des Halsschildes zur Aufnahme der Mundtheile mehr oder weniger stark vorgezogen, die Krallen hinter jedem Häkchen mit einem blattartigen Zahne besetzl.

Diese Gruppe ist in dem nordöstlichen Theile von Südamerika, von Rio de J. bis Guyana einheimisch, und nebst der folgenden vor der nordamerikanischen Gruppe des Cr. grossulus (Linn. V. S. 248 und XII. S. 350) einzuschalten.

6. Cr. costulatis in. Stahllblau, Unterkopf, Beine und Hinterleib helh'oth; das Halsschild zerstreut rumzlig punktirt, die Deckschilde gefurcht punktstreifig mit rippenförmigen Zwischenräunen. L. $2-21 / 3^{\prime \prime \prime} ; \mathrm{Br} .11 / 2-12 / 3{ }^{\prime \prime}$.

Von allen Arten dieser Gruppe leicht an dem einfarbig blauen Halsschilde zu unterscheiden, überden eine der am stärlisteı auf den Deckschilden gefurchten Arten. Der Kojf flach mit etwas zurücktretender Stirn, das Kopfschild seitlich durch deutliche Kanteı abgegränzt und gegen die schräg abfallenden Wangen erhöht, unten leicht eingedrückl. Die Oberflïche kaum punktirt, doch wenig glänzend, die Stirn schmutzig gebräunt, der Unterkopf gelbrotl, die gestreckten nicht breit aber tief ausgebuchteten Augen ohen etwas zusanmengeneigt. Die Fühler (des f) nicht von hallıer Körperlänge; das Wurzelglied gestreckt, oberwärts wenig verdiclit und sclıwach nach aussen gekiümmt; das zweite kugelig, lalb so breit wie das erste, das dritte sehr dünn, mehr als doppelt länger wie das zweite, das vierte gleichfalls dünn, den beiden vorhergehenden zusammen gleich; die folgenden je so lang wie das vierte, aber deutlich zusammengedrückt und rom sechsten ab innerseits merkbar 
erweitert. Die vier unteren hell gelbroth, das fünfte gebräunt, und die oberen schwarz, dünn greis behaart und abstehend gewimpert. Das Halsschild mehr als doppelt breiter wie lang, in der Mitte leicht quer aufgewölht und svon ihr ab mit der grösseren Vorderbälfte abwärts gekrümmt, über den tief eingezogenen scharf rechtwinkligen Vorderecken stark zusammengedrückt und dadurch verschmälert, die ziemlich breit gerandeten Seiten mit selır flachen, hinter der Mitte sanft ausgeschweiften Bogen nach vorn zusammengeneigt, die spitzwinkligen Hinterecken breit und flach ausgezogen, durch einen leichten Schrägeindruck etwas aufgetrieben; der Hinterrand jederseits weit ausgebuchtet, mit kurzem, breitem, undeutlich ausgerandetem Mittelzipfel. Vor diesem jederseits ein kräftiger Schrägeindruck, und beile Eindrücke durch eine schwächere, vor dem Mittelzipfel hiuziehende Querfurche verbunden. Die Oberfläche deutlich, aber nicht tief zerstreut punktirt, in den Hintervinkeln die Punlite etwas dichter gedrängt, theilweise zu flachen Quer- und Schrägrumzeln verfliessend, die Farhe dunkel stahılblau mit ziemlich starkem Glanze. Das Schildchen dreieckig, um die Hälfte länger als breit, hinterwärts sanft ansteigend und kurz abgestutzt, Hinterzipfel und Vordergrülochen undeutlich, die Farbe gleichfalls glänzend stahlblau. Die Deckschilde so breit wie lang, vorn etwas breiter als das Halsschild, hinter den Schultern noch etwas im Bogen erweitert und dann mit breiter Krümmung hinterwärts abgerundet; die Wurzel breit quer niedergedrūckt und clann wieder stark aufgewulstet, so dass ein hinter dem Schildchen liegender, dessen Eude mit einschliessender Querwulst den höchsten Theil des Rückens bildet, welcher von hier ab seitlich stärker, längs der Naht bis zur Spitze hin in sanfterem Bogen abfällt. Die grossen halbkugeligen Schulterbeulen innerseits durch das dreieckig erweiterte Vorderende iles fünften Punktstreifens abgesetzt, die Seitenlappen breit, mit tief heralıängendem ungeschlagenen Rande, üher ihnen eiı flacher, den Rücken hinaufzichender Quereindruck. Die Punktstreifen sehr regelmässig, aus tief eingestochenen dicht gedrängten Punkten gebildet und in deutliche Längsfurchen eingedrückt, hinterwärts etwas schwächer, und nur die ersten Punkte der drei hinter den Schulterbeulen entspringenden Streifen vereinzelt. Ausser dem imern abgekürzten Streifen läuft auch der erste unter der Wölbung für sich aus, während die Hinterenden des zweiten und neunten, dritten und vierten, fünften und sechsten, siebenten und achten zusammen- 
treffen. Die Zwischemräume heben sich als breite, flach gewölbte Längsrippen empor, voll denen die neunte die vorhergehenden an Breite übertrifft; die Oberfläche ist glänzend stahllblau, nur der breite umgeschlagene Rand des Seitenlappens matt sclıwarzblau, und mit dichter narJiger Punktirung bedeckt. Pygidium und Hinterleib fein runzlig punktirt, dümn behaart, nebst den Beinen hell gelbrotl, die Unterseite des Halsschildes mit Vorder- und Mittelbrust tief schwarzbraun; die Hinterbrust dicht punktirt, schwarzblau, nur die von den Seitenlappen bedeckten Seitenränder der matten Paraplenren spiegelglänzend gelbbraun. Der Vorderrand des Prosternums in der Mitte abgerundet und napförmig vorgezogen, das Nittelfeld vereinzelt grob punktirt, nach vorn wulstig aufgetrieben, hinten halbkreisförmig eingedrückt, mit lang und spitz vortretenden Hinterecken. Die Mittelbrust juer rechteckig, gewissermaassen das Prosternım fortsetzend, die Krallenhäkchen schwarz. Das letzte Segment des $q$ mit einer tiefen, halbliugeligen Grube, das $\delta$ unbekannt.

Aus Brasilien (Mus. Schaum. Clark, in letzterem Rio de J. als Fundort bezeichnet).

7. Cr. Bombarda m. Rostroth, die Fühlerenden und ein Querfleck auf dem spiegelglatten Halsschilde schwarz; die Deckschilde stahlblan, gefurcht punktstreifig, mit stark gewölbten, an den Seiten rippenförmigen Zwischenräumen. L. $2^{\prime \prime \prime}$; Br. $1 \frac{112}{\prime \prime \prime}$.

Dem vorhergehenden nihe verwandt, aher an der Zeichnung des Halsschildes und den sclıwächeren Furchen auf dem Rücken der Deckschilde von ihın leicht zu unterseheiden. Der Kopf flach gewölbt, nur zwischen den Fühlerwurzeh etıvas stärker in die Quere heraustretend, Stim und Kopfschild seicht niedergedrüclit, letzteres seitlich durch sclıwache, fast gleichlaufende Kanten begräızt, so dass sich von den Fühlerwurzeln jederseits längs dem unteren inneren Augenrande eine schwache Rinne bis zu den Augen hinabzieht; oben auf der Stirn macht sich ausserdem noch eine äısserst fein eingeschnittene Längslinie bemerklich. Die Farbe, wie die des ganzen lï̈rpers glänzend rostroth, mit äusserst feiner und zerstreuter Punktirung; nur die langgestreckten, Jreit und seicht ausgehuchteten, olıen etwas genäherten Augen und die Kimmbackenspitzen schwarz. Die Fülıler kurz, kaum n̈ber den IInterrand des Halsschildes himansreichend, das gestreckte Wurzelglied fast gleichbreit, etwa $3 \frac{1}{2}$ mal länger als breit, das zweite kurz und kugelig, 
kaum schıäler als das erste, die beiden folgenden schlank und dünu, von der Länge aber nur der halben Breite des ersten, die drei folgenden je nur halb so lang aber merklich breiter als das vierte, innerseits breit dreieckig erweitert, die obcren vom achten ab wieder etwas länger, aber allmählich sich versclımälernd, mit deutlichem, durch eine Ausıandung abgesetztem Fortsatze des Endgliedes. Die vier unteren Glieder rostroth, die oberen schwarz, mit gebräunter Wurzel des fünften. Das Halsschild kurz und breit, mit der vorderen Hälfte kugelig abwärts gebogen, über den scharf rechtwinkligen Vorderecken zusammengedrückt und dadurch verschmälert, die Seiten deutlich gerandet, durch einen starken Quereindruck über ihrer Mitte fast gradlinig nach vorn zusammenlaufend, hinter der Vitte leicht geschweift und dadurch die etwas aufgetriebenen Hinterecken scharf ausgezogen, der Hinterrand jederseits breit und seicht ausgebuchtet, tief eingekniffen und scharf gesägt, mit kurzem, breitem, deutlich doppelt ausgerandetem -Mittelzijffel; jederseits des letzteren noclımals ein tiefer Schrägeindruck. Die Oberfläche spiegelglänzend rostroth, ein feiner Saum des Hinterrandes und ein grosser, breit nierenförmiger, fast eine jederseits abgeküızte Querlinde darstellender Querfleck vor der Mitte schwarz. Das Schildchen länglich dreieckig, hinten kurz abgestutzt und kaum ansteigend, mit deutlichem Vordergrülschen, glänzend schwar'z. Die Deckschilde kurz und kugelig, vorn breiter als das Halsschild, mit gekrümmten Seiten hinterwärts verschmälert und dann breit zugerundet, hinter der-quer niedergedrückten Wurzel stark ansteigend und um das Schildchen buckelig erlıöht, von da al seitlich und hinterwärts mit sanfter Krümnıng abfallend; die Schulterbeulen kräftig heraustretend, innerseits durch einen Längseindruck abgesetzt, die Seitenlappen lang lierabgezogen, über ihnen ein sich hinter der Sclıulterbeule hinaufzielıender Quereindıuck, welcher durclı eine grübchenartige Verbreiterung des neunten Punktstreifens nock mehr verstärkt wird. Die I'unktstreifen sehr regelmässig, vorn tief eingedrückt, durch deutliche P'unkte gebildet, hinterwärts etwas abgeschwächt aber nicht erlöschınd; die lıreiten Zwvischenräume gewölbt, die seitlichen rippenförmig erlıölıt, die Farbe ein glänzendes Stalılblau oder (bei einem sich ausserdem durch heller gelbliche Körperfärbung auszeichmenden, sonst aber keine Abweiclıngen zeigenden Stücke in Mus. Berol.) purpurviolett, der Farbe des $\mathrm{Cr}$. perplexus ähnlich. Pygidium und Unterseite hell rostroth, fein 
runzlig punktirt und dünn greishaarig; auch die ziemlich schlanken Beine heliglänzend rostroth, die dünnen Vorderschienen an der Wurzel deutlich einwàrts gekrümmt, die kurz umgebogenen Kúrallenläkchen schwarz. Die Vorderbrust mit stark vorgezogenem, die Mundtheile aufichmendem Vorderrande, hinten eingedrückt, fast grade abgeschnitten, mit kurz vorspringenden Hinterecken; die Mittelhrust kurz und breit, hinten leicht doppelt ausgerandet, mit deutlichem Mittelzipfel. Das letzte Segment des allein vorliegenden $q$ mit einem tiefen, glänzenden Grübchen, das $\delta$ unbekannt.

Aus Brasilien (Mus. Halens. und Berol.).

8. Cr. lute icoll is S I ål. Lehmgelb, Fühlerenden und Hinterbrust mit Schenkelspitzen, Schienen und Fussgliedern schwar', das Halsschild zerstreut punktirt; die Deckschilde dunkel stahlblau, gefurcht punktstrèifig, mit rippenförmigen, ziemlich glänzenden Zwischenräumen. L. 2"'; Br. 12/5"'.

Monachus luteicollis Stål Till Kännedomen etc. in der öfversicht etc. p. 61. n. 2 !

Von der Grösse und im Ganzen auch den Bau der vorhergehenden Art, und von ilır hauptsächlich nur durch den Mangel des schwarzen Querflecks auf dem IJalsschilde bei Ausdehmung dieser Färbung auf der Unterseite, durch das hellere Gelb der Grundfarbe, und die deutliche Punktirung des llalsschildes abweichend, daher ich mich auf die Beschreibung des Cr. Bombarda beziehen und auf den näheren Nachweis dieser Abweichungen beschränken kamı. Die Grumlfarbe ist, wie bemerkt, nicht rostroth, sondern ein schönes, lichtes Lehmgelb, die Nebenfärbung zwar auch schwarz, aber abweichend vertheilt, inden der Halsschildsfleck ganz fehlt; dagegen sind dir Beine his auf die obere grössere Hälfte der Schenkel schwarz, und dieselbe Färbung zeigt die ganze Hinterbrust mit Parapleuren und Sclutterblättern; die Färbung der Deckschilde fïllt bei einem übrigens schlecht ausgefärbten Stücke des Mus. Berol. stark ins liupferfarbene, dem Cr. perplexus ähnlich, wie dies alıer auch zuweilen bei der folgenten Art ter Fall ist. Auch Bau und Sculpfur bieten einige Verschiedenheiten dar; das Halsschild ist, ob anch nicht tief, doch deutlich punktirt, dabei vorn nur missig abwirts gekrünmt, und hinter dem Vorderrande ron einem ziemlich starken, die mittlere Hälfte desselben umspannenden Quereindrucke umzogen. Die durch die P'unktstreifen auf den Flügeldecken geloildeten Furchen sind etwas tiefer und hinterwärts 
kaum abgeschwächt, die erste über der Wölbung plötzlich abgebrochen und in eine einfache Punktreihe auslaufend, die neunte und zehnte vorn ausserhalb der Schulterbeule durch Abflachung des neunten Zwischenraumes 211 einem dreieckigen deutlich punktirten Längsfelde zusammengeflossen. Die besonders nacli aussen stark rippenförmigen Zwischenräume sehr fein punktirt und zugleich querrunzlig, daher weniger glänzend als bei den vorhergehenden. An den Fühlern ist das vierte Glied um die Hälfte länger als das dritte, und an den vier unteren Gliedern die Oberseite der Länge nach geschwärzt, auch die Verhreiterung des fünften bis siebenten Gliedes viel geringer als bei der vorigen Art, und die oberen inneren Augenränder einander vollständig berührend. Die unteren Enden der Vorderschienen auffallend breit. Das letzte Segment des einzigen vorliegenden $\delta$ einfach, des $q$ mit dem gewöhnlichen Grübchen.

Aus Brasilien (von Petropolis; Mus. Clark, von Rio de J.: Mus. Holm., olne nähere Angabe des Fundorts im Mus. Berol.).

9. Cr. cyanopterus Stål. Rostroth, Fülulerenden und Schildchen schwarz, Flügeldecken stahlblau; das Halsschild spiegelglatt, die Punktstreifen derb mit flaclı gewöllsten, glänzenden Zwischenräumen. L. $2 \frac{1 / 4}{4}-3^{\prime \prime \prime} ; \mathrm{Br} .12 / 3-2^{\prime \prime \prime}$.

Monachus cyanopterus Stål Till Kännedomen etc. in der Öfversicht etc. p. 61 . n. 1 !

Anscheinend die am wenigsten seltene Art dieser Gruppe, und daher auch in fast allen von mir verglielsenen Sammlungen vorhanden, in denen sie meist unter der Benennung Monachus chalybeipennis Dej. vorkommt. Auch von Stål ist sie zu dieser Gattung gebracht worden, sie gehört jedoch ıach dem Bau des Prosternums unzweifelluaft der vorliegenden Gruppe an, in welcher sie zwischen den Arten mit rippenförnigen und mit flach gewölbten Zwischenräımen der Deckschilde einen deutlichen Uebergaıg bildet. Der Kopf flach, zwischen den Augen seicht quer eingedrückt, das Kopfschild fast viereckig, auch seitlich gegen die zurücktretenden Wangen durch scharfe Kanten abgesetzt. Die Oberfläche spiegelglänzend, rostroth, nur die in der Mitte schmal aber tief ausgerandeten, bei dem ठ̋ oben stark zusanımengeneigten Augen schwarz. Die Fühler kurz, das zweite Glied eiförmig, die folgenden ziemlich gleichlang und je etwa doppelt länger als das zweitc, die oberen 
vom fünften ab deutlich zusammengedrückt, oben nur schwach erweitert. Die Farbe der vier unteren rostroth, der übrigen schwarz. Das Halsschild kurz und breit, nach vorn stark verschmälert, mit der grösseren Hälfte übergewölbt und nach der Stirn zu ziemlich steil abfallend; die Seiten breit gerandet und nach vorn in breiten Bogen zusammenlaufend, die Hinterecken kurz und breit zugespitzt, und durch einen Schrägeindruck etwas aufgetrieben; der Hinterrand diclıt gesägt, jederseits flach ausgeschweift, mit kurzem, schwach doppelt ausgerandetem Mittelzipfel. Vor dem Schildchen jederseits ein kurzer tiefer Quereindruck; die Oberfläche spiegelnd rostroth. Das Schildchen länglich dreieckig, schiräg ansteigend, hinten kurz abgestutzl und vorn mit dem gewöhnlichen Grülschen, glänzend sclıwarz. Die Deckschilde etwa doppelt länger als das Halsschild, von der Wurzel aus etwas ansteigend, um die Schildchenspitze llach buckelig erlıöht, innerseits der schmal aber höckerig hervortretenden Sclıulterbeulen sclımal aber tief der Länge nach eingedrüclit, hinter ihnen quer zusammengedrückt und dann wieder etwas bauchig erweitert, hinten breit zugerundet; die Seitenlappen lang herabgezogen, und über ilınen nochmals ein deutlicher runder Eindruck. Die Punktstreifen sehr regelmässig, aus dicht gedrängteı, in sanft eingegrabene Längslinien gestellten Punkten gebildet, hinterwärts kaum feiner; die Vorderenden der drei an den Sclulterhenlen entspringenden (des sechsten bis achten) etwas geschwungen. „Die Zwischenräume llach gewölbt, die äusseren etwas stärker und hinterwärts rippenförmig aufgetricben, die Farbe ein schöıes, reines Stahlblau, zuweilen ins liuplirige oder Grünliche überspielend. Der umgeschlagene Rand des Seitenlapjens etwas ausgelı̈hlt, längsrunzlig, schwarz. Das Pygiclium dicht und fein punklirt, dünn behaart, mit Unterseite und Beinen einfarbig rostroth; Hinterleib und Parapleuren scliwach runzlig punktirt. Der Vorderrand des Prosternums mit naplförmig ausgehı̈̋lter Rundung zur Aufnahıme der Numdtheile vorgezogen, die Mitle yuer aufgewulstet und dahinter niedergedrückt, der Ilinterrand fast grade alogeschnitten mit scharf vorspringenden Seitenecken. Auch die Mittellınst quer viereckig, vorn eingedrïckt und mit ihren scharfen Seitenleisten sich eng an die Vorderhrust anfügend. Das letzte Segment des o quer eingedrückt, des in den Sanmlungen ungleich selteneren $q$ mit einer grossen elliptischen, im lnnern glänzenden Grube.

Gleichfalls aus Brasilien. Mus. Saunders, IIalens. (von Areas), 
Holm. (von Rio de J.), Dohrn, Haag, Baly, Deyrolle (von Sta. Catharina), Felix.

10. Cr. mollachodes m. Schwarzblau, Kopf, Fühlerwurzelı und Halsschild mit Schenkeh, Pygidium und Spitze des Hinterleibes rothgelb; das Halsschild feiı und zerstreut punlitirt, die Punktstreifen deutlich, mit tlach gewölbten glänzenden Zwischenräumen. L. $1 \frac{1 / 3}{\prime \prime \prime} ; \mathrm{Br}$. $5 / 6 "$.

Dem vorhergelıenden ähnlich, aber merklich kleiner und von ihm ausserdem an der Färbung der Unterseite und der Beine leicht zu unterscheiden. Der Kopf flach, das etwas eingezogene Kopfschild oben durch zwei Quergrübchen begränzt; die Oberfläche fein punktirt, mässig gläızend, schmutzig rothgelb mit gebräunten Kinnbacken; die (bei dem ð) oben stark genäherten, lang gestreckten, Ireieckig ausgebuchteten Augen schwärzlich. Die Fühler von elwas über halber Körperlänge, dünı und schlank; das Wurzelglied schmal keulenförmig, schwach nach aussen gekrüumt, etwa viermal länger als breit, das zweite elliptisch, etwas schmäler und dabei dreimal kürzer als das erste, die drei folgenden allmählich verlängert, so dass das fünfte (längste) etwa $3 / 4$ des ersten erreicht, die übrigen etwa je dem vierten gleich, dabei schwach erweitert, mit kurz dreieckigem Fortsatze des Endgliedes. Das Wurzelglied schmutzig rothgelb, die drei folgenden etwas dunkler, das fünlte gebräunt und die oheren schwarz. Das Halsschild un die Hälfte breiter wie lang, nit der grösseren Vorderhälfte stark kugelig übergewölbt, über den tief eingezogenen rechtwinkligen Vorderecken zusammengedrückt und dalurch merklich verschmälert, die Seiten fein gerandet, nach vorn in flachen Bògen zusammengeneigt; die Hinterecken kurz, scharf rechtwinklig, der Hinterrand jederseits flach ausgebuchtet, mit kurzem, seicht ausgerandetem Mittelzipfel; auf jeder Seite des letzteren ein kurzer, schräger Eindruck. Die Oberfläche sehr feiı zerstreut punktirt, ziemlich glänzend rothgelb. Das Schildchen schräg ansteigend, länglich dreieckig, Hinterzipfel und Vordergrühchen undeutlich; die Oberfläche glänzend schwarzblau. Die Deckschilde wenig länger als breit, voru breiter als das Halsschild, linterwärts kaum verschmälert, aber dann kurz und breit zugerundet, wodurch der ganze Körper einen breit eiförmigen Umriss erhält; der Rücken um die Schildchenspitze etwas aufgebuckelt, vorn hinter der aufgewulsteten Wurzelkante quer gefurchi, die Schulterbeulen als kräftige Läıgshöcker emporgehoben, die $\mathrm{XV}$. 
Seitenlappen mässig herabgezogen und über ihnen die Deckschilde quer zusammengedrückt, auch hier der neunte Punktstreifen noch zu einem stärkeren Längseindrucke erweitert. Die Punkistreifen regelmässig, vorn kiraftig und auch hinterwärts nur wenig abgeschwächı; die flach gewölbten Zwischenräume glänzend stahlblaı, der achte von der Schulterbeule ab eine Strecke lang stärker aufgetriehen. Das Pygidium fein punktirt, dünn behaart, hell rothgelb; Unterseite und Beine dunkel-stahlhlau, mit gleichfalls hell rothgelbem, in der Mitte breit verwaschen geschwärztem Hinterleibe; Hiiften und Sichenkelwuzeln, an den Vorderschenkeln bis über deren Hälfte hinaus, nebst der Vorder- und Mittelbrust dunkler rothgell. Die Vorderbrust gerunzelt, hinten mit vorspringenden Ecken abgestutzt, in der Mitte höckerig aufgetrieben, der Vorderrand zur Aufnalıme der Hundtheile in einen langen, vorn abgerundeten Zipfel vorgezogen. Das letzte Segment rles ठ leicht quer niedergerlrückt.

Ebenfalls aus Brosilien. Mus. Baly, Clark; in dem letzteren ist Petropolis als Fundort genannt.

11. Cr. perplexus m. Hell rothgell, mit schwarzen Fühlerenden, Schildchen und Deckschilde kupferdıaun; das Halsschild äusser'st fein punktirt, die Punktstreifen leicht furchenartig mit oben llach gewölbten, seitlich rippenförmigen glänzenden Zwischenräumeı. L. $1 \frac{1 / 3}{3}-2 \frac{1}{2}{ }^{\prime \prime \prime}$; Br. $3 / 4-1 \frac{1}{4}{ }^{\prime \prime}$.

Inem unten folgenden $\mathrm{Cr}$. cuprascens ähnlich, aber um dic Hälfte lileiner, heller gell, Unterseite und Beine einfarbig, und ausser den Augen nur die Fühlerenden geschwärzt. Der liopf flach, das Kopfschild leicht eingedrückt, aber nicht eingezogen, ron der Stirı durch einen schwachen Quereindruck zwischen den Angen getrennt; die Oberfläche glänzend hell rothgelb, olne deutliche Punktirung, die lang gestreckten, schwach ausgebuchteten, oben besonders bei dem klemeren ô stark zusammengeneigten Augen schwarz; die Mundtheile leicht gebräınt. Die Fühler auch des $\delta$ kaun ron halber liörperlänge, dünn; das schımale Wurzelglied last gleichbreit und etwa dreinał länger ałs hreit, wenig gekrümmt, das zweite kurz elliptisch, die beiden folgenden fast linealisch, je doppelt länger als das zweite, die folgenden zusammengedlückt und oberwäts drejeckig erweitert, rom sechsten ab je elwas länger als das vierte, die vier Ielzten wieder allmählich ver'schmälert, das Endglied linealisch mit wenig merklarem Fortsatze. Die: Farhe 
hellgelb, die oberen von der Milte des fünften ab schmutzig geschwärzt. Die Fühler des $q$ kürzer, in allen Theilen schlanker, fast fadenförmig, sonst aber nicht verschieden. Ilas Halsschild breit und ziemlich flach, mit seiner vorteren Häfte leicht übergewölbt, daselbst über den scharf rechtwinliligen Vorderecken etwas zusammengedrückt und dadurch rerschmälert, die Seiten fein gerandet, nach vorn last gradlinig zusammengeneigt, die Hinterecken breit mol scharf spitzwinklig, der Hinterrand jeder'seits weit ausgebuchtet mit kurzem, deutlich doppelt ausgerandetem Nittelzipfel, vor letzterem jederseits ein kurzer Schrägeindrnck, und ein zweiter, schwächerer weiter nach vorn über der hinteren Hälfte des Seitenrandes. Die Oherfläche äısserst fein und zerstreut punktirt mit spiegelglatten Zwischengrunde, hell lehıngelb. Das Schildehen mässig ansteigend, länglich dreieckig, hinten lurz abgerundet, mit deutlichem Vorlergrübchen, glänzend kupferbraun, hei einem ungewöhnlich grossen $q$ im Mus. Deyrolle mit ganz hellgelbem Mittelfekle, bei den übrigen mir vorliegenden Stücken in der Mitte nur verwaschen gelbbräunlich durehscheinend. Die Deckschilde kaum 1/6 länger als breit, von den Schultern ab hinterwärts mit geliümmten Seiten verschmälert und dadureh den verkehrt eiförmigen Uṇriss des Körpers ergänzend; der Rücken von der Schildchenspıtze ab hinterwärts nur allmählich, seitlich stärker abfallend, die Wurzel hinter ihrem breiten, flachen Vorderrande durch die tiefer eingegrahenen Vorderenden der Punkistreifen niedergedrïckt, und dadurch eine von den erhölıten Zwischenräumen unterbrochene flache Querfurche zwischen Schildchen und Schulterheulen gebildet, letztere als kıäftige Längshöcker emporgehoben; die Seitenlappen mässig, mit sehr lang herabhängendem, mattschwarzem Unterrande. Die Punktstreifen sehr regelmässig und kräftig, hinterwärts wenig schwächer, in oben flachere, sejtlich immer stärliere Längsfurchen eingedrückt, daher die oben nur flach gewölbten Zwischenenäume sich je weiter seitwärts desto deutlieher zu abgerundeten Rippen ausbilden; der neunte Streifen über dem Seitenlappen zu einem breiten Längseindrucke prweitert. Die Farbe ein sclıönes glänzendes, unserer Chrysomela enprea ähnliehes Kinfferbrann, die Zwischenräume mit Spuren einer äusserst feinen und zerstreuten Punktirung. Pygidium und Unterseite fein und dicht punktirt, mit den Beinen Lellgell. Der Vorderrand des Prosternums Ireit napfförmig vorgezogen, die Mittelläche runzlig punktirt, hinten eingedrïclst 
und ausgebuchtet, mit stärker vortretenden Hinterecken. Das letzte Segment des $\delta$ leicht quer niedergedrückt, des grösseren und merklich schwächer gestreiften $\&$ mit einer eiförmigen, in Innern stark glänzenden Grube.

Aus Brasilien. Mus. Deyrolle, Baly, in letzterem Ega am oberen Amazonenstrom als Fundort angegeben. Auch von Cayenne (Mus. Holm., von Dupuizet gesammelt) und Surinam (Mus. Berol.).

12. Cr. cuprasceus m. Hell rothgelb, Fühlerenden, Brust und Beine schwärzlich, die Deckschilde kupfrig blau; das Halsschild spiegelglatt, die Punktstreifen furchenartig mit rippenförmigen, punktirten Zwischenräumen. L. $1 \frac{1 / 3}{3}-2 \frac{1}{4}{ }^{\prime \prime \prime} ;$ Br. $1-1 \frac{1}{2}{ }^{\prime \prime \prime}$.

Dem Vorhergehenden nahe verwandt, aber die Farbe der Deckschilde mehr ins Bläuliche fallend, die Furchen auf den Rückien derselben tiefer, überdem Brust und Beine ganz abweichend gefärbt. Der Kopf flach, mit etwas zurüclitretendem Nacken und Kopfschilde, letzteres der Länge nach seiclıt niedergedrückt, seitlich durch eine deutliche Kante gegen die unteren immeren Augenränder und die an diese sich anschliessenden Wangen abgesetzt. Die Olserfläche nur zwischen den Fühlerwurzeh fein punktirt, sonst spiegelglatt, glänzend hell rothgelb, nur dic langgestreckten, in der Mitte tief ausgebuchteten, und bei dem ơ mit den oberen inneren Rändern auf der Stirn zusammenstossenden Augen schwarz. Die. Fühler kaum von halber Körperlänge, schlank; das Wurzelglied sehr düın, oben nur schwach verdickt und wenig nach aussen gebogen, das zweite $t^{1} / 2$ mal hürzer aber wenig dünner, fast so breit wie lang, die folgenden merklich schmäler, das dritte doppelt-, das vierte und fünfte je dreimal länger als das zweite, die folgenden noch ein wenig länger, gleich lang, schwach zusammengedrückt und erweitert, mit dreieckig zugespitztem Fortsatze des Endgliedes. Die beiden unteren Glieder lehmgelb, die beiden tołgenden mit der Wurzel des fünften pechbräunlich, die oberen sclıwarz mit angedrückter dümner greiser Behaarung. Ilas Halsschild kurz und breit, mit $2 / 3$ seiner Länge vorn kugelig übergekrümmt, durch die tief eingezogenen scharf rechtwinkligen Vorderecken dasellsst stark verengt; die vor den breit spitzwinklig ausgezogenen Hinterecken sanft geschweiften Seiten fein gerandet, nach vorn fast in graden Linien zusammenlanfend; der Ilinterrand jederseits breit aber nicht tief ausgebuchtet, daher in den sehr kurzen Mittelzipfel olme merkliche Ecke ühergehend; vor dem letzteren auf jeder Seite ein kurzer, 
aber breiter und ziemlich tiefer Schrägeindruck. Die Oberfläche kaum bemerkbar punktirt, spjiegelglänzend lehmgelb. Das Schildchen gestreckt dreieckig, um die Hälfte länger als breit, hinterwärts schwach ansteigend und kaum abgestutzt, mit undeutlichem Vordergrübchen, glänzend schwarzblau. Die Deckschilde wenig länger als breit, vorn breiter als das Halsschild, hinter den breit höckerig heraustretenden Schulterbeulen stark zusammengedrückt, dann in breiten Bogen verschmälert und an der Spitze kurz zugerundet, vorn hinter der aufgeworfenen Wurzelkante quer eingedrückt, ım die Schildchenspitze buckelig erhöht, mit stark herabgezogenen Seitenlappen. Die Punlitstreifen sehr regelmässig, aus tiefen furchig eingegrabenen Punkten gebildet, durch deren stärkere Einjrägung vorn der Quereindruck an der Wurzel entsteht; der fünfte Streifen vorn innerseits der Schulterbeule zu einem dreieckigen Eindruck erweitert. Die Zwischenräume gewölht, breit rippenförmig, zerstreut punktirt. Die Farbe ein glänzendes ins Kupferbräunliche spielendes Stahlblau, welches letztere bei einem Stücke im Mus. Clark entschieden vorwaltet. Pygidium und Unterseite zerstreut-, aber deutlich punktirt, dünn greishaarig, ersteres mit dem Hinterleibe bleich gelb, die Mitte des letzteren mit verwaschener Begränzung geschwär'zt, was bei dem aıgefülırten Stücke aus lem Mlus. Clark in intensiverer Weise der Fall ist. Die Hinterbrust pechschwarz, Mittel- und Vorderbrust wieder hellgelb; letztere quer viereckig, flach, deutlich runzlig punktirt, linten mit scharf vorspringenden Hinterecken fast grade abgestutzt, das Mittelfeld linten der Länge nach tief eingefurcht, der Vordertand breit napffürnigg vorgezogen. Die Beine von mässiger Stärke, Schienen und Fussglieder schwarz; die Vorderschenkel gelb mit schwarzen Spitzen, an den Mittelschenkeln die obere Hälfte, an den hinteren das obere Drittel nit den Hüften gelb. Das letzte Segment des $\delta$ in der Mitte breit quer niedergedrückt, des $q$ mit einer ziemlich grossen, glämzenden Grube.

Gleichfalls in Brasilien. Mus. Hal., Baly, Clark, - in dem letzteren ist Rio de $J$. als Heimath angegeben.

13. Cr. x anthopygus m. Schwarzblau, der Kopf mit den Fühlerwurzeln, das spiegelglatte Halsschild und das Pygidium mit den beiden letzten Bauchringen hellgelb, die Deckschilde kupferbläulich; die Punktstreifen mässig mit flachen, glänzenden Zivischenräunten. L. $2 \frac{1}{4}{ }^{\prime \prime \prime} ; \mathrm{Br}$. $1 \frac{116}{\prime \prime \prime}$. 
Von der Grösse und dem Habitus des vorhergehenden, aber Unterseite und Beine reiner und mit schärferer Begränzung geschwärzt, ausserdem die Punktstreifen viel feiner und auch nicht furchenartig eingedrückt. Der Kopf flach mit äusserst feiner Stirnlinie und etwas eingezogenem Kopfschilde, die Oberfläche lackglänzend gell, unterwärts etwas heller; die lang gestreckten, laug und zienulich lief ausgebuchteten, oben genäherten Augen mit der Mitte der Oberlippe und den Mundtheilen schwarz. Die Fühler von halber Köıperlänge, zienlich schlank; das Wurzelglied dünn, über dreimal länger als breit, das zweite dünn elliptisch, fast halb so lang und breit wie das vorhergehende, die beiden folgenden schmal verkehrt kegelförmig, je um die Hälfte läıger als das zweite, das fïnfte noch etwas länger, und die folgenden allmählich aber langsam wieder abıehmend, so dass das zehnte wieder dem zweiten ghleichkommt, und das Endglied mit seinem liurz kegelförmigen Fortsatze etwa die Länge des siebenten erreicht. Dabei alle vom oberen Ende des fünften ab nach innen schwach erweitert und zusammengeurückt. Die Farbe der fünf unteren gelb mit wischartig geschwärzter Oberseite, welcher Wisch sich bei dem Wurzelgliede zı einer ziemlich deutlich lıegränzten Läıgslinie ausbildet, während er bei dem fünften fast die ganze obere Hälfte desselben eimuimmt; die sechs oberen schwarz, mit angedrückter dünner greiser Behaarung. Das Halsschild vorn mit der kleineren Hälfte stark übergewölbt, hinten etwas abgeflacht, über den rechtwinkligen tief eingezogenen Vorderecken breit zusammengedrückt und dadurch rerschmälert, die fein gerandeten Seiten hinter der Mitte leicht ausgeschweift, vor ihr ehen so leicht erweitert und nur mit dem vorderen Drittel fast gradlinig convergirend; auch ilie Hinterecken fast rechtwinklig, mit einer kurzen, scharf vortretenden Schwiele besetzt und vor dieser durch einen Schrägendruck etwas aufgetrieben; der Hinterrand sehr leicht ausgeschweift, mit kurzem, breitem, undeutlich doppelt-ausgerandetem Nittelzipfel. Vor letzterem jederseits ein kurzer tiefer Schrägeindruck, dessen Ende nach langer Unterbrechung vorn üher der erweiterten Stelle des Seitenraudes wieder zum Vorschein kommt. Die Oberflïche spiegelglatt, hellgelh, mit. verwaschen ins Lehmgelbe fillendem Mittelfelde. Das Schilkluen schrigg ansteigend, gleichseitig dreieckig mit alggestutztem Hinterende, gläızeud schwarz. Dir Deckschilde vorn etwas breiter als das Halsschild, kimu 1/4 länger als hreit, linterwärts in 
flachen Bogen verschmälert und dann kurz zugerundet, die Wurzel sanft niedergedrückt, der Rüclien um die Schildelienspilze mässig aufgewöllı, die Schulterbeulen zu kurzen aber krältigen llöckern aufgetrieben und innerseits durch eineu tiefen Längseindruck abgesetzt; auch die Seitenlappen kräftig, und über ilınen die Deckschilde. breit zusammengedrückt. Die Punktstreifen sehr regelmässig, vou mässiger Stärke, aber in ihrer ganzen Austehnung kenntlich, der neunte durch den Eindruck über den Seitenlappen etwas verbogen, die Zwischenräume flach, glänzend, sehr fein querrunzlig Die Farbe ein schönes, reines purpurschimmerndes Kuplerblau, den unserer Chr. cuprea entsprechend, ein schmaler Wurzelsaum und im Anschluss an diesen der selı breit umgeschlagene Rand des Seitenlappens glänzend schwarz. Das Pygidium mit den beiden letzten Hinterleibssegmenten liellgelb; der übrige Theil des Hinterleibes nebst der Hinterbrust, den Schulterblättern und den Beinen in reiner, scharfer Beyränzung schwarz, die Vorder- und Mittellüften mit der Mittelbrust gebräunt, die Vorderbrust mit den umgeschlagenen Seiten des Halsschildes wieder hellgelb. Der Vorderrand der ersteren nicht eigentlich vorgezogen, aber doch zur Aufnahme der Mundtheile muldenförmig gekrïmmt. Alles Uebrige wie bei der vorhergehenden Art.

Eluenfalls in Brasilien (Mus. C'lark, in welchem Petropolis als Fundort genannt ist).

14. Cr. chloropterus m. Lehmgelh, die Fühlerenden und der Saum des verwaschen gebräunten Schildchens schwarz, die Deckschilde freudig metallischgrün; das Halsschild spiegelglatt, die Punklstreifen derb mit flach gewölbten, fein querrunzligen Zwischenräumen. L. $3^{\prime \prime \prime}$; Br. 1 ${ }^{2} / 3$ "'.

Von dem nah rerwandten Ćr. cyanopterus stål durch den gestreckteren Körper und die etwas gröberen Punktstreifen, von dem gleiclıfalls nahe stehenden Cr. perplexus durch die viel feineren, nicht in Furchen eingedrückten Streifen und die nur flach gewöllsten, daJsei deutlich quer gerunzelten Zwischenräume, und von beiden ausserdem noch durch die schöne metallisch hellgrüne Färbung der Veckschilde verschieden. Uer Kopf flach gewölbt mit eingedrückter, noch von einer kuzen, tiefen Längsrinne durchzogener Stirn; das liopfschild fast quadıatisch, oben nur durch die über ilm begimende Wölbung der Stirnfläclıe abgesetzt. Die Oherfläche glänzend lehmgelb ohne deutliche Punktirung, die lang gestreckten, 
breit und tief ausgebuchteten, oberseits genäherten Augen schwarz. Die Fühler von niclıt halber Körperlänge, das zweite Glied länglich elliptisch, dreimal kürzer und halb so breit als das sehr gestreckte Wurzelglied, das dritte und vierte dünn verkelırt kegelfürmig, jenes doppelt- und dieses $21 / 4$ mal länger als das zweite, das fïnfte dem vierten, und das sechste wieder dem dritten gleich, die folgenden wenig kürzer, bis auf das zehnte noch etwas verkürzte einander gleich; das Endglied mit seinem kegelförmigen Fortsatze wieder so lang als das dritte. Dabei alle von der Spitze des füıften ab schwach zusammengedrückt und verbreitert. Die Farbe der vier unteren durchscheinend hellgelb, die übrigen sclswarz, dünn angedrückt greishaarig, mit gebräunter Wurzel des fünften. Das Halsschild vorn mit seiuer grösseren Hälfte breit kugelig übergewölbt, über den stumpf rechtwinkligen Vorderecken breit und flach zusammengedrückt und dadurch verschmälert, die Seiten breit gerandet und nach vorn in flachen Bogen zusammengeneigt, die Hinterecken kurz und scharf spitzwinklig ausgezogen, durch einen Schrägeindruck etwas aufgetrieben, der Hinterrand jederseits breit aber nicht tief ausgebuchtet, mit kurzem, undeutlich doppelt ausgerandetem Mittelzipfel; vor dem letzteren auf jeder Seite der gewöhnliche, hier kurz eiförmige aber ziemlich tiefe Schrägeindruck, in dessen Verlängerung sich über der Mitte des Seitenrandes eine breite flachgedrückte, von zwei kurzen gleichlaufenden schwächeren Schrägeindrücken durchzogene Stelle bemerklich macht. Die Oberfläche spiegelglänzend lehmgelb. Das Schildchen schräg ansteigend, ein wenig länger als breit, mit kurz abgestutztem Hinterende und ziemlich deutlichem Vordergrübchen, spiegelglatt und anscheinend schwärzlich, bei genauerer Betrachtung aber, besonders unter schräger von vorn einfallender Beleuchtung trül gelbbraun mit verwaschen geschwärztem Rande. Dir Deckschilde vorn etwas breiter als das Halsschild, etwa um 1/3 länger als loreit, hinterwärts allmälılich verschmälert und danı liurz zugerundet, die Wurzel schräg niedergedrückt, die grossen länglichıen Schulterbeulen innerseits durch einen tiefen dreieckigen Eindruck alogesetzt, die Seitenlippen lang herabgezogen und über ilsneu die Deckschilde hreit zusammengedrückt, der Rücheı um die Schildchenspitze nur flach buckelig aufgewölht und von da ab längs der Nalıt mit sphr sanfter lírnmmung abfallend. Die Punktstreifen regelnässig und dentlich, die vorderen l'unkte bei alleı, ausserdem der neunte Streifen und die 
Hinterenden der übrigen etwas stärker eingedrückt; die Zwischenräume flach gewölbt und diese Bildung hinterwärts deutlicher, dabei fein querrunzlig; die Farbe ein schönes helles, aber der Runzeln wegen nur mässig glänzendes metallisches Grün, ein feiner Saun der Wurzel und der breite dicht punktirte umgeschlagene Rand des Seitenlappens schwärzlich. Das dicht und fein punktirte Pygidium mit der Unterseite und den Beinen hell lehmgelb, die Nälıte der Unterseite und die Fussglieder etwas dunkler, die Krallenhäkchen schwarz. Der Vorderrand der Vorderbrust halbkreisförnig gelirümmt und etwas vorgezogen, das letzte Segment des $q$ mit einer grossen rundlichen Grube.

Gleichfalls aus Brasilien, und mit dem vorigen an gleichem Fundorte. Hus. Clark.

15. Cr. chalcites m. Blau, der Kopf mit den Fühlerwurzeln, das kaum punktirte Halsschild mit den Schulterblättern und Hüften roth; die Punktstreifen mässig mit flachen, fein gerunzelten Zwischenräumen. L. $1 \frac{1}{3}{ }^{\prime \prime \prime} ;$ Br. 1"'.

Die vorliegende Art ist eine von denen, welche sich nur schwer in den Rahmen unserer Systernatik fïgen wollen, da sie fast mit gleichem Rechte der vorliegenden Gattung und Gruppe, wie den Monachen zugezählt, oder auch als eine zwischen beiden stehınde Mittelform aufgeführt werden könute. Den Monachen, unter denen sie namentlich mit dem IJ. bicolor Fab. und seinen Verwandten eine grosse habituelle Aelnnlichkeit zeigt, gleicht sie durch die verhältnissmässig kurzen, oben breiter erweiterten Fühler und den kurzen, kaum vorgezogenen Vorderrand des Prosternums, während der nicht bogenförmig ausgeschnittene, sontern grade und in der Vitte spitz ansgeschweifte Hinterrand des Halsschildes sie von jenen Formen entfernt, unıl der breite blattartige Zahn hinter den Krallenhäkchen sie unverkennbar in die Nähe der vorliegeuden Gruppe. bringt. Indem ich nun von der Aufstellung einer auf eine einzelne Art begründeten Uebergangsgattung auch keinen erheblichen Nutzen vor Augen sehe, liabe ich es vorgezogen, den Käfer einstweilen als eine aberrante Form an dieser Stelle unterzubringen, bis sich nach dem Auffinden einer grösseren Anzahl von Stücken in beiden Geschlechtern und vielleicht auch anderer ihm nahe stehender Arten über seine systematische Stellung bestimmte Entscheidung treffen lässt.

Unter den Arten dieser Gruppe steht der Käfer den kleineren 
Stücken des $\mathrm{Cr}$. perplexus am uächsten, weicht aber auch ausser der Färbung vou ihm durch den mehr länglichen Umriss merklich ab. Der Kopf ist flach, zwischen den Augeubuchten leicht hervortretend, das Kopfschild sanft niedergedrüclit, so dass sowohl der untere Rand als auch die Seiten als leichte Kanten heraustreten; die langgestreckten, mässig ausgebuchteten und oberwärts etwas zusammengeneigten Augen sclıarz; der ührige Theil des Kopfes spiegelglänzend roth mit etwas dunlileren liundtheilen. Bei einem der vorliegenden Stïcke ist auch die Stirn leicht der Länge nach niedergedrïckt. Die Fühler kaum von halber Körperlänge, llas Wurzelglied dünn, wenig gekrümmt, etwa dreimal länger als breit, das zweite elliptisch, etwa dreimal kürzer und halb so breit wie das erste, die beiden folgenden dünn und fast gleichbreit, das fünfte oberseits schwach verbreitert, die oberen nach innen breit dreieckig mit abgeruudeten Ecken erweitert und zusammengedrückt, mit kurz dreieckigem Fortsatze des Endgliedes; alle vom dritten ab einander gleich Ind etwa $1 \mathrm{~m}$ die Hälte länger als das zweite. Die Farbe der fünf unteren Glieler lıell durchscheinend rothgelb mit gebräunter Spize des füuften, die oberen schwarz mit fein angedrückter greiser Behaarung. Das Halsschild kaum halb so lang als hinten breit, hinter der Mitte leicht aufgewölht und vorn mit fast $2 / 3$ seiner Länge abwärts gekrümmt, in den tief eingezogenen, fast rechtwinkligen Vorderecken eingedrückt unı dadurch verengı, die Seiten fein gerandet und nach rorn in. Wreiten Bogen zusammengeneigh, die kurzen Hinterecken breit spitzwinklig ansgezogen, der Hinterrand jederseits nur leicht ansgebuchtet, fein gesiigt, mit kurzem, breitem, doppelt ausgerandetem Mittelzipfel. Die Oberfliche vor der Mitte des Hinterrandes schmal puer eiıgedrückt, kaum merklich punktirt mit mässig glänzend’m Zwischengrunde, eiufarbig roth, hinten fein schwarz gesäunt. Das Schildchen dreieckig, fast doppelt länger als breit, hinten kurz abgestutzt unt wenig ansteigend, mit deutlichem Vordergrühchen, dunkelblau. Die Deckschilde vorn merklich breiter als das Halsschild, etwa $11 \mathrm{~m} 1 / 4$ läıger als breit, und hinter den Sclultern noch etwas im Bogen erweitert, linten kurz eiförmig zugerundet, hinter der scharfen Wurzelkante durch lie tiel' eingegrabenen Vorderenden der Punktstreifen yner nirslergedrückt, ım die Schildchenspitze leichı buckelig erdıöht, und von dieser aus mit abgeflachter Naht allmïlich zur Spitze ablallend. Die Schulterbeulen als kräftige Läugrshöcker heraustretenıl, inner- 
seits durch einen mit dem Vorderende des fünften Streilens zusammenfallenden Eindruck abgesetzt, die Seitenlappen breit, aber nicht tief herabgezogen. Die Punktstreifen regelmässig und his zun Ende deutlich, ausser den Vorderenden der fünf oberen auch der neunte tiefer eingedrückt. Die Zwischenräume breit, flach, äusserst dicht ınd fein r'unzlig punktirt, daher nır mässig gläızend, der neunte schwach rippenförmig erhölıt. Die Farbe schön stahlbau, die Mitte des Rückens bei einem der vorliegenden Stücke mit einem, auch das Schildchen mit einschliessenden trüb metallisch schwärzlichen Anfluge. Das Pygidium grob runzlig punktirt, unten fast grade abgestutzt, schwäızlich; die Unterseite feiner runzlig punktirt, die Hinterleibsseiteı und die Parapleuren dicht angedrückt greishaarig, Hinterleih und Hinterbrust schwarzblau, Schulterblätter, Nittel- und Vorderbrust roth, letzlere breiter als lang, in der Mitte quer aufgewulstet, nit kurz abwärts gebogenem Vurderrande, hinten quer eingedrückt; der Hinterrand selbst gramle, in der Mitte mit einer Spitze ausgeschweift, mit kurz dreieckig vor'springenden Hinterecken. Die Beine schwarzblau mit gebräunten Fussgliedern, die Hüften und an den Vorderbeinen auch die oberen Schenkelhälften roth. Das letzte Segment des o mit einer tiefen rundlichen spiege]gläızenden Grube, das $\delta$ unbekannt.

Aus Brasilien. Mus. Hal., Schaum.

16. Cr. hemixanthus m. Gelb mit schwarzen Fühlerenden, das fein und zerstreut punktirte Halsschild und die Deckschilde stahlblaı; die Punktstreifen fein mit flachgewölbten, glänzenden Zwischenräımen.

$\delta$ ein breiter Vorder- und Seitenrand des Halsschildes gelb;

\& nur die Vorderecken desselben gelb.

L. $1 \frac{2 / 3}{3}-2 / 3{ }^{\prime \prime \prime} ;$ Br. $1 \frac{1}{6}-1 / 2{ }^{\prime \prime \prime}$.

Von der breiten gedrungenen Gestalt des Cr. cyanopterus, und dieser Art auch in der Färbung nicht unähnlich, aher an dem blauen, nur an den Rändern oder Ecken gelb gefärbten Halsschilde leicht zu erkenmen. Der Kopf flach mit sehr feimer Stimlinie, das sehr lange Kopfschild oben nur durch eine unscheinbare Quererlöhung über den Fülılerhöckern begränzt, die Oberlippe selır schmal und stark schräg vorspringend. Die Obertlïche sehr fein und zerstreut punktirt, lackglänzend lıelgelb, nur die Kinnbachen gebräunt, und die lang gestreckten, tief dreieckig ausgebuchteten. oben genälıerten Augen schwarz. Die Fühler des $\delta$ von hadber 
Körperlänge, das Wurzelglied dünn keulenförmig, deutlich nach aussen gekrümmt, reichlich dreimal länger als breit, das zweite kurz knotig, etwas dünner und viermal liürzer als das erste, das dritte und vierte verkehrt kegelförmig, gleichlang und beinahe dem ersten gleich, die sieben folgenden zusammengedrückt und bis zum zehnten breit dreieckig erweitert, und zwar so, dass das sechste, siebente und achte die grössie Breite zeigen, die beiden folgenden sich allmälılich verschmälern und verkürzen; das Endglied fast wieder gleichbreit und mit seinem stumpfen Fortsatze wenig länger als das zehnte. Die fünf unteren hellgelb mit gebräunter Oberhälfte des fünften, die sechs oberen schwarz. Die Fühler des $q$ in allen Theilen etwas kürzer und schmäler, übrigens nicht abweichend. Das Halsschild kurz und sehr breit, vorn mit der grösseren Hälfte stark kugelig abwärts gehrümmt, auch seitlich ziemlich steil abfallend, über den rechtwinkligen Vorderecken stark zusammengedrückt und dadurch verschmälert; die Seiten fein gerandet, nach vorn in flachen Bogen convergirend, die Hinterecken ku'z aber scharf, der Hinterrand jederseits breit und seicht ausgebuchtet, mit kurzem, breitem, deutlich doppelt ausgerandetem und durch einen sattelförmigen Quereindruck etwas aufwärts gedrängtem Mittelzipfel, jederseits des letzteren vor dem Hinterrande ein tiefer Schrägeindruck. Die Oberfläche äusserst fein und zerstreut-, seitlich etwas dichter punktirt, spiegelglänzend hell stahlblau, bei dem ð ein breiter Vorder- und Seitenran!, bei dem $f$ nur die verwaschenen Vorderecken hellgelb. Das Schildchen stark schräg ansteigend, dreieckig, um die Hälfte länger als breit, vorn đuer niedergedrückt mit deutlichem Vordergrübclıen, hinten kurz abgestutzt mit eben so deutlichem Hiuterzipfel, gleichfálls glänzend stahlblau. Die Deckschilde aus breiter Wurzel hinterwärts verschmälert, hinten kurz und hreit zugerundet, so lang wie breit, längs der Wurzel stark schräg nielergedrückt, um die Schildchenspitze luckelig gewöllıt und von da ah seitlich und hinterwärts mit schı̈̈ger Krünnung abfallend, die stark aufgetriebenen Schulterbeulen imnerseits durch das tief eingegrabene Vorderende des fünften Punktstreifens abgesetzt, die Seitenlappen kurz und breit, mit tief herabgezogenen Unterrande, üher ihnen die Deckschilıte kräftig zusimmmengedrückt. Die Punktstreifen sehır regrelmässig, ans tief' grulig eingedrückten Vorlerenden plötzlich abgeschwächt und damm lein, aher deutlich bis zmr Spitze verlaufend, die Zwischenräume breit uml flach, mit einer feinen Punk- 
tirung sparsam bestreut, der äusserste flach gewölbt. Die Farbe lıell und glänzend stahlblau, bei einem der vorliegenden $q$ die Schulterbeuleu, der Vordersaum der Dechschilde mit Unterbrechungeu, der Hinterzipfel des Halsschildes und einige zufällige Eindrücke des letzlerı messinggrünliclı angeflogen; der umgeschlagene liand ıler Seitenlappen uarbig punktirt, matt und tief schwarzblau. Aendert jedocil ab

$\beta$. Halsschild und Deckschilde kupferbläulich, wie Cr.perplexus und cuprascens; nur in einem $q$ vorliegend.

Das Pygidium fein runzlig punktirt, dünn behaart, hellgelb; Unterseite und Beine etwas dunkler gelb, bei dem $\delta$ mit lichten Hüften und Bauchrändern. Der Vorderrand des Prosternums brei८ viereckig vorgezogen, mit abgerundeten Ecken, das Mittelfeld grob punktirt, hinten etwas eingedrückt; der Hinterrand fast quer abgestutzt, mit scharf heraustretenden Hinterecken. Das letzte Segment des $\delta$ leicht quer niedergedrückt, des $q$ mit der gewöhnlichen rundlichen Grube.

Vom Amazonenstrom; Mus. Baly (bei der var. $\beta$. ist in demselben speciell Ega als Heimath genannt).

17. Cr. absconditus m. Rostroth, die Fülılerenden, ein verwaschener Vorderfleck des spiegelglatten Halsschildes und die Deckschilde sclıwarz; die Punktstreifen ziemlich fein, mit flachen glänzenden Zwischenräumen. L. 2"“; Br. $11 \frac{1}{2}{ }^{\prime \prime}$.

Von dem breiten gedrungenen Ban des Cr. perplexus und seiner Verwandten, durch die Farbenvertheilung einigermaassen dem Cr. Bumbarda und der folgenden Art, durch die feine Sculptur mehr den letztvorhergehenden Arten verwandt. Der Kopf flach, das Kopfschild last quadratisch, unten wenig eingezogen und oben nur undentlich aljgegräuzt, die Stirn mit einem kurzen und schwachen Längsgrübchen; die Farbe lackglänzeusl dunkel rostroth, die Kinnbacken gebräuıt, clie langgestreckten, breit ausgebuchteten, oben etwas zusanmengeneigten Augen schwar'z. Die Fülıler bei dem einzigen vorliegenden Stücke unvollständig, aber nach den vorhandenen Resten nicht wesentlich von denen der verwandten Arten abweichend; das Wurzelglied gestreckt, mässig verdickt, fast dreimal länger als breit, das zweite elliptisch, um die Häfte länger als breit, die folgenden einander gleicl, je fast doppelt länger als das zweite, das fünfte oberwärts sclıon eiı wenig zusammengedrüclit 
und verbreitert, was bei den folgenden in höherm Maasse der Fall ist; die drei letzten nicht mehr rorhanden. Die Farbe der rier unteren glänzend dunkel rostroth, das fünfte gebräunt, die oberen schwarz. Das Halsschild doppelt breiter als lang, rorn mit der kileineren Irälfte stark kugelig übergewölbt, über den alogerundetrechtwinkligen Vorderecken breit zusammengedrückit und dadurch verschmälert, die Seiten gerandet und mit flachen, hinter der Mitte etwas ausgeschweilten Bogen nach vorn zusammengeneigt, die liurzen breit spitzwinkligen Hinterechen scharf voryezogen und durch einen leichten Schrägeindruck elwas aufyetrieben. Der Ilinterrand wellig gekrümmt, vor den Schultern etwas stärker ausgeschnitten und innerseits derselben eingeknifien, der Vittelzipfel seln breit, schwach doppelt ausgerandet; vor ilım jederseits ein deutlicher eiförmiger Schrägeindruck, und dazwischen der hintere Theil des Mittelfeldes sanft dler Länge nach aufwärts gedrückt. Die Obertläclıe spiegelglatt, dunkel rostroth; vor der Mitte ein bis hart an den Vorderrand herantretender, verwaschen begränzter lıreit niereıförmiger schwarzer Quertleck oder Querwisch. Das Schildchen wenig ansteigend, dreieckig und um die Hälfte lïnger als breit, hinten kurz abgestutzl, mit undeutlichem Vordergrübchen; die Farbe glänzend schwarzbrann mit heller braunröthlich durchscheinender Spitze. Die Deckschilde kurz und gedrungen, wenig länger als breit, von den stark heraustretenden Sclultern ab hinterwirts noch etwas im Bogen erweitert und dann kurz zugerundel, um die Schildchenspitze etwas aulgrebuckelt und ron da ab nach allen Seiten ziemlich steil alffallent, rorn hinter dem breiten Wurzelrande mit einer llachen Querlurehe eingedrückt, anch die eckigen Schulterbeulen immerseits durch eimen schmalen Eimdruck algesetzt; die Seitenlappen tief heralugezogen, ülser ilmen die Deckschilde hreit quer zusammengedrückl, wodurch sich gleiclızeilig in dem achten und noch mehr dem nemulen Streifen ein flacher muldenförmiger Längseimlruck bildet. Die P’unkistrejfen selır regelmässig, ziemlich fein, die mittleren auf der Wülbung fast erloschen, die Naht- und Kandstreilen leicht eingedrüclit und dadurch deren Zwischenräume mit. sehr schwachr. Wölhung emporgehohen. Die Farbe g]änzend kohlschwarz. I'ygidlum, Unterseite und Beine chen so einfarlig rostroth, die oberre Ilälfte des ersteren dicht silherharig. Der Vorderrand des Prosternums wenig rorgezogen, alser tief halblireisförmig gekrümut, der hintere wenig ausgeluchtet, mit kurz und scharf 
vortretenden Hintereclien; das letzte Segment des $q$ mit der gewöhnlichen Gruhe, das $\delta$ unhekannt.

Aus Brasilien (Mus. Baly).

IS. Cr. ochropus Stîl. Gelb mit gescluwärzter Stirn und Brust, ein vorderer Querfleck des spiegelglatten Halsschildes nebst Schildchen und Deckschilden metallisch purpublan; die Punktstreifen äusserst fein, hinten elloschen, mit llachen, glänzenden Zwischenräumen. I. $13 / 4$ "'; Br. $11 / 6 "$.

Monachus ochropus Slăl Till Kannedomen etc. in der öfiersichı etc. p. $61 . \mathrm{n} .3$ !

Acusserlich dem Cr. Bombarda nicht unähnlich, aber kleiner, voiı viel schwächerer Sculptur, und auch ausserdem durch die ganz abweichende Lage der hier an den Vorderrand des Halsschildes gelehnten Querbinde verschieden. Der kojf flach gewölbt, mit etwas vorgezogenem, in der Hitte noch flach eingedrücktem Kopfschilde, fein und zerstreut punlitirt, lackglänzend dunkelgelb mit einem verkehrt dreieckigen, verwaschen geschwärzten, auch wohl die ganze Stirn einnehmenden Stirnflecke zwischen den oberen Augenräıdern; Oberlippe und Mundtheile dunkel braungelb, die langgestreckten ziemlich stark ausgebuchteten Angen schwarz. Au den Fülılem sind die vier unteren Glieder bellgell, das zweite elliptisch, kaum um die Hälfte schmäler als der breiteste Theil des Wurzelgliedes, die beiden folgenden dlüm rerkehrt-kegelförmig, gleichlang und je etwa dreimal lïnger als das zweite; die folgenden ziemlich stark verbreitert und zusammengedrückt, schwarz, mit gebräunter Wrurzel des fünften. Letzteres dem dritten gleich, die oberen dagegen merklich rerkürzt. Das Halsschild mit der vorderen Hälfte mässig übergelirümmt, hinter der Mitte breit und sehr flach gerrölbt, vorn über den abgerundet rechtwinkjigen, sebr tief eingezogenen Vorderecken zusammengedrückt und darlurch verschmälert; die Seiten fein gerandet, linter der Mitte weit aber nur llach ausgeschweift, vor ilı leicht erweitert und dann nach vorn fast in graden Linien zusanmengeneigt; die Hinterecken kurz aber breit dreieckig zugeschärft, der Itinterrand jederseits auch nur flacl ausgebuchtet, mit kurzem, dentlich doppelt-ausgerandetem Nittelzipfel; zu jeder Seite des letzteren ein flacher Schrägeindruck. Die, Oberfläche kaum sichtbar zerstreut punktirt, spiegelglatt, hellgellb, mit einem an den Vorderrand gelehnten ziemlich scharf hegränzten nierpufürmigen schwarzblauen Querflecke, dessen vorderer Zipfel 
gleichsam durch den dreieckigen Stirnfleck gebildet wird. Das Schildehen stark ansteigend, gleichseitig-dreieckig mit kurz abgestutzter Spitze und deutliehcm Vordergrühchen, glejchfalls glänzend schwarzblau. Die Deckschilde sehr breit und flach gewölbt, vorn etwas breiter als das Halsschild, etwa $1 / 4$ länger als breit, die Wurzel nur sehr schwach aufgewulstet, der Rücken un die Spitze des Schildchens mässig erhöht, die länglichen Schulterheulen innerseits durch einen schmalen Längseindruck abgesetzt, und auch auf ihrer Aussenseite ein deutliches, durch das abgerissene Vurderende des neunten Streifens gehildetes Längsgrülıchen; die Seitenlappluen von mässiger Entwickelung. Die Punktstreifen seh" regelmässig und fein, ıแ die Vorderenden der äussesen etwas kräftiger, die Hinterenden der mittleren schon vor der Wölhung undeutlich und aul ihr wie abgeschliffen, die des ersten, achten und neunten etwas tiefer eingedrückt, so dass durch das Zusammentreffen des ersteren und letzteren unter der Wölbung eine schwache Bogenfurche gebildet wird. Die Zwischenräume flach, glänzend, nit kaum sichtbaren Querrunzeln bedeckt; die Farbe ein schönes, ins Purpurfarbige fallendes Stahlhlau. Pygidium, Unterseite und Beine gelb, die Brust schwärzlich, nur die Scitemränder der Parapleuren in ziemlich scharfer Begränzung und die Mitte der Hinterbrust nebst der Mittelbrust verwaschen gelblich. Der Vorderrand des Prosternums mit algerundeter Spitze breit vorgezogen, die Mitte quer niedergedrückt, der Hinterrand wenig ausgeschweift. Das letzte Segment des $f$ mit einer sehr tiefen, rmudichen Grube, das $\delta$ unbekannt.

Gleichfalls aus Brasilien (Mus. Deyrolle, und in demselhen als Monachus pulchellus Dej. hezeichnet; auch im Mus. Berol., von v. Olfers, und im Mus. Holm., ron F. Sahlberg mitgebracht. In letzterem ist speciell Rio de J. als Heimath genannt).

19. Cr. semicircularis m. Gelb mit schwarzen Fühlerenden, ein habbreisförmiger Hinterfleck des spiegelglatten Halsschildes nehst dem Schildchen und den Deckschilden tief stahlblau; die Punktstreifen fein, hinten verschwindend, mit llachen glänzenlen Zwischenü̈umen. I. $23 / .1$ "'; Br. $2^{\prime \prime \prime}$.

Ein grosser, schöner, im llabilus dem Cr. cuprascens und chloropterus ähnlicher Käfer, in Sculptur und Färbung an nächsten den vorderbrschriebenen C'r. ochropus stål verwandt, von dem er siclı jedoch, auch abgesehen von der bedeutenderen Grösse, 
leicht an der ganz abweichenden Lage des Halsschildsfleckes unterscheidet. Der Kopf flach, mit sehr kurzer Stirnlinie, das Kopfschild oben nicht vour der Stirn gesehieden, unten leicht eingeIrückt, die Fläche hellgell, mässig glänzend, ohne Spur einer Punktirung; die lang gestreckten, ziemlich tief ausgebuchteten, oben weit getrennten Augen schwarz, die Enden der Kinnbacken pechbrauı. Die Fülıler (des + ) nicht von halber Körperlänge, aber breit und kräftig, das zweite Glied kurz eiförmig, die beiden folgenden gestrecki, oben kaun verbreitert, je $21 / 4$ mal länger als das zweite, die folgenden bei etwa gleicher Länge mit dem vierten stark zusammengedrückt und erweitert, das fünfte verkehrt dreieckig, die folgenden mit abgerundeter Innenseite sich nach rem oberen Ende allmählich verschmälernd und dadurch immer melır ins Gleichbreite übergehend, mit kurzem aber breitem Fortsatze des fast linealischen Endgliedes. Die Farbe der vier unteren hellgelb, der oberen schwarz mit angedrückter greiser Behaarung. Das Halsschild fast doppelt so breit als in der Mitte lang, mit der Vorderhälfte selır sanft übergebogen, auch hinterwärts eben so sanft abwärts geneigt, über den etwas eingezogenen, rechtwinkligen Vorderecken breit zusammengedrückt und dadurch nach vorn hin fast kegelförmig ver'sclımälert; die Seiten fein gerandet, von der Mitte a) in sehr flachen Bogen zusammenlaufend, die Hinterecken kurz und breit zugeschärft, etwas niedergedrückt; der Hinterrand jederseits nur vor den Schultribeulen tiefer ausgebuchtet, dann in schräger Richtung fast gradlinig zum Mittelzipfel verlaufend, letzterer breit, deutlich doppelt ausgerandet, durch einen flachen vor ihm liegenden Eiıdıuck etwas aufwärts gedrückt, und dann jederseits noch ein stärkerer Schrïgeindruck; von einem zweiten flacheren Schrägeindrucke zeigt sicl über der Mitte des Seitenrandes eine schwache Spur. Die Oberlläche mit sehr vereinzelten Pünktchen bestreut, dazwischen spiegelglatt, hellgelb; ein auf der grösseren mittleren Ilälfte des Hinterrandes rulıender, nach vorn hin über $2 / 3$ der Nittelfirste einnehmender lıalbkreislörmiger Fleck metallisch veilehınblau. Das Schildelıen stark ansteigend, breit- und fast gleichseitig-dreieckig, hinten kurz abgestutzt, mit deutlichem Vordergrübchen, gleichfalls glänzend dumkelhlau. Die Decksehilde so lang wie vorn breit, hinterwärts etwas verschmälert und dann breit zugerundet; die Wurzel nur sclıwach niedergedrüclit, die grossen halbkugeligen Schulterbeulen innerseits durch einen tiefen Längsxv. 
eindruck abgesetzt, auch die Seitenlappen kräftig, mit sehr lang herabgezogenem umgeschlagenem Rande; über ihnen je ein breiter und tiefer Quereindruck. Die Punktstreifen sehr regelmässig, äusser'st fein und die mittleren schon gltich hinter der Mitte verschıvindend, die hintere Hälfte des neunten als seichte, die Spitze umzielıende Furche eingedrückt. Die flachen Zwischemräume spiegelglatt, die Farbe auch hier ein schönes dunkel metallisches Veilchenblau, der grolı runzlig punktirte umgeschlagene Rand der Seitenlappen schwärzlich. Pygidium, Unterseite und Beine hellgelb; der Vorderrand des Prosternumis als breiter, runder, ansgehölster Lappen vorgezogen, das Mittelfeld vorn leicht gewölbt, hinten eingedrückt; der Hinterrand in der Mitte sanft ausgebuchtet, mit wenig vortretenden Hinterecken. Das letzte Segment des $f$ mit einem tiefen, halbkugeligen Grübchen, das ỡ unbekannt.

Aus Surinam (Mus. Berol.).

20. Cr. i ndecoratus $\mathrm{S} t a ̊ l$. Hell rostgelb mit schıärzlichen Fühlerenden, das Halsschild spiegelglatt, die Punlitstreifen leicht furchenartig mit gewölbten, seitlich rippenförmigen Zwischenräumen. L. $13 / 4-2^{\prime \prime \prime} ;$ Br. $1 \frac{1}{4}-1 \frac{1}{3}{ }^{\prime \prime \prime}$.

Monachus indecoratus Stål Till Kännedomen elc. in der üfversicht etc. p. $61, \mathrm{n} .4$ !

In der jetzt beginnenden Artenreihe wiederholen sich fast alle Sculpturverschiedenheiten der vorhergehenden, während sie von jenen wesentlich durch die lichte von der liörperfärbung gar nicht oder doch nicht wesentlich verschiedene Färbung der Deckschilde abweicht; mit der letzteren stimmt denn auch stets die Farhe des Halsschildes überein. Von diesen hell gefürbten Arten steht die vorliegende dem Cr. costulatus an nächsten, ist aher doch noch etwas kürzer und besonders schmäler; der Kopf flach, mit unten etwas eingedrücktem, seillich durch stumpfe Leisten hegränztem Kopfschilde und lang gezogenen, schrïg abfallenden Wangen, spiegelglatı und wie der ganze übrige Körper rostgelb; nur die langgestreckten, in der Mitte tief ausgebuchteten, ohen nur durch einen schmalen Zwischenraum getrennten Augen greis, zwischen ihnen eine Spur einer fein eingeschnittenen Längslinie. -IDie Kinnbacken schwarz, die Taster wieder hellgelb. Die Fühler des o von etwas über halber Körperlänge, dünu und schlank, das Wurzelglied oherwärts schwach rerdickt, etwa $2 \frac{1}{2}$ mal linger als hreit, das zweite eiförmig, um die IIillte lïnger als breit, die drei folgenden etwa 
gleichlang. fast doppelt länger als las zweite, aber dünner, erst das fünfte oberwärts etwas zusanmengedrückt und verbreitert, was noch mehr bei den folgenden, dieselbe Länge zeigenden Gliedern der Fall ist. Die Verbreiterung ist bei dem siebenten und acliten Gliede an stärksten und nimmt weiter oben lin, besonders an der Wurzel der einzelnen Glieder, wieder ab; der Fortsatz des Endgliedes ist kurz und breit, durch eine deutliche Ausrandung alggesetzt. Die Farbe der fünf unteren Glieder hellgelb mit verdunkelter Spitze des fünften, die sechs oberen schwärzlich mit angedrückter weisslicher Behaarung. Die Fühler des $q$ in allen Theilen schlanker, sonst nicht abweichend. Das IIalsschild vorn mit halber Länge stark übergewölbt, hinten wieder etwas herahgesenkt, über den stumpf rechtwinkligen Vordereclien ljis gegen die Mitte hin schıräg zusammengedrücki und dadurch stark verschmälert, die Seiten fein geraudet und nach rorn fast in graden Linien convergirend, die spitzwinkligen Hinterecken scharf dreieckig ausgezogen und durch eimen leichten Schrägeindruck etwas aufwärts geschoben, der Hinterrand jederseits zunächst innerseits der Schulterbeulen tief ausgebuchtet, mit kurzem, breitem, undeutlich doppelt ausgerandetem Mittelzipfel; vor clem letzteren auf jeder Seite ein liräftiger, schı̈äg eiförmiger Eindruck. Die Oberfläche mit äusserst feinen Pünktchen sparsam bestreut, spiegelglatt, rostgelb mit bräunlichem Hintersaume. Das Schildchen dreieckig, etwa um $1 / 4$ länger als breit, sehr schwach ansteigend, mit schwachem Vordergrübchen und undeutlichem, schmalem Hinterzipfel, gleichfalls glänzend rostgelb mit dunkleren Säumen. Die Declisschilde vorn kaum breiter als das Halsschild, elıen so breit als lang, linterwärts mit flacher Rundung verschmälert, daher der Umriss etwas länglicher als bei den nächst vorhergehenden Arten. Die Wurzel durch die tiefer eingegrabenen Vorderenden der Punktstreifen etwas niedergedrückt, die Schulterbeulen kurz und breit höckerig, die Seitenlappen gross, mit tief herabgezogenem Unterrande, über ihnen hinter den Schulterbenlen je ein lıreiter, durch den stark erlıöhten achten Zwischenraum unterbrochener Quereindruck. Der Rücken um die Schildchenspitze buckelig erlı̈̈ht, und von hicr aus seitlich stärker-, hinterwärts flacher abfallend. Die Punktstreifen höchst regelmässig, rorn und an den Seiten in tiefere, nach der Naht zu in seichtere Furchen eingedrückt; die Punkte derselhen vorn dicht zusammengedrängt und grob, hinterwärts feiner und melır vereinzelt. Die Zwischen- 
räume gegen die Naht hin gewölbt, seitlich rippenförmig aufgetrieben, glänzend rostgelb; der Wurzelsaum etwas dunkler gebräunt, der breite umgesclilagene Rand des Seitenlappens auf seiner unteren Häfte ziemlich dicht punktirt und matt. Das Pygidium zerstreut punktirt mit glänzendem Zwischengrunde, hellgelb; die Unterseite gleichfalls fein runzlig punktirt und mit den Beinen bis auf die sclıwarzeı Kirallenhäkchen rostgelb; das Zähnchen hinter den letzteren stumpf und wenig hemerklar. Die Vorderlorust flach gewölbt, vereinzelt punktirt, hellgelb; der breit schüsselförmig vorgezogene Vorderrand und ein paar leichte Querbenlen vor dem Hinterrande dunkler braun; zwischen den letzteren ein leichter Eindruck. Der Hinterrand selbst in der Mitte kaun ausgebuchtet, mit scharf vortretenden Hinterecken. Die Mittelbrust quer viereckig mit dreizipfligem Hinterrande. Das letzte Segment des $\delta$ leicht quer niedergedrückt, des $\&$ mit einem tiefen, rundlichen Grübchen.

Von Cayenne (Mus. Deyrolle) und Brasilien (Mus. Holm., von Freyreiss gesammelt und aus dem Mus. Schh. stammend).

21. Cr. xanthocephalus m. Lehmgelb, das spiegelglatte Halsschild und die Deckschilde hochroth; die Punktstreifen furchenartig mit breiten, flachgewölhten, seitlich rippenförmigen Zwischenräunen. L. $1 \frac{3}{4}-2^{\prime \prime \prime}$; Br. $1 \frac{1 / 3}{3}-1 \frac{1 / 2}{\prime \prime \prime}$.

Dem vorhergehenden überaus älnnlich, daher es nur einer Angahe der allerdings die Selbstständigkeit der Art vollständig sichernden Abweichungen bedürfen wird. Der Umriss ist im Ganzen melı rundlich, hinterwärts auffälliger verschmälert; dem entsprechend sind auch die Zwischenräume auf den Deckschilden breiter und etwas flacher, die mittlercn Punktstreifen besonders hinterwärts weniger eingegraben, wodurch die äusseren von jenen als kräftigere Rippen hervortreten. Die Fühler (sie sind nur bei den rorliegenden $f$ vorhanden) sehr liurz und dünn, das Wurzelglied dentlich nach aussen gebogen, mehr als dreimal länger wie breit, das zweite schmal eiförmig, dic beiden folgenden gestreckt verkehrtkegelfürmig, gleichlang und etwa doppelt länger als das zweite, die folgenden wieder etwas lïrzer, ziemlich gleichlang, zusammengedrückt und dreieckig erweitert, so aber dass diese Erweiterung vom achteı al, allmählich wieder abnimmt, und das Endglied mit seinem schnalen Fortsatze kanm die Breite des dritten erreichı. An abweichendsten ist die Färbung. Ialsschild und Deckschilde 
sind glänzend hochroth mit schmal gelblichem verwaschenem Vordersaume des ersteren und tief gebräuntem Wurzelsaume der letzteren; dagegen ist der Kopf mit den Fühlern und der ganzen Unterseite des Körpers hell lehmgelb, an dem ersteren nur die oben durch einen schmalen Zwischienraum getremnten, langgestreckten, tief dreieckig ausgebuchteten Augen mit den Spitzen der gebräunten Kinnbacken, an den Füssen nur die Krallenhäkchen schwarz, zuweilen auch die äusserste Spitze des letzten Fühlergliedes leicht geschwärzt. Alles Uebrige, auch die Geschlechtsverschiedenheiten wie bei der vorhergehenden Art.

Von Cayenne (Mus. Deyrolle, Holm., von Dupuizet gesammelt) und aus Brasilien (Mus. Schaum, Baly, Berol.), und hier anscheinend weit verbreitet, denn bei den Stücken im Mus. Baly ist theils Ega am oberen Amazonenstrome, theils S. Paolo, bei dem von Sieber mitgebrachten Stücke des Mus. Berol. Parà als Heimath angegeben. Bei dem (ठ) Stücke im Mus. Schaum sind die Zwischenräume auf dem Rücken etwas stärker gewölht, fast rippenförmig, und die Schenkel fallen stark ins Röthliche. Weitere Unterschiede finde ich jedoch nicht.

22. Cr. hebetatus m. Rostgelb, Fühlerenden und Beine schwarz; das Halsschilıl spiegelglatt, die Punktstreifen selır fein, mit flachen spiegelnden Zivischenräumen. L. $2-2 \frac{1}{3} 3^{\prime \prime \prime} ; \mathrm{Br}$. $1 \frac{1}{2}-1 \frac{2}{3}{ }^{\prime \prime \prime}$.

In der Färbung schliesst sich diese Art eben so an $\mathrm{Cr}$. indecoratus, wie in der Feinheit der Punktstreifen und in der dadurch bedingten Beschaflenheit der Zwischenräume auf den Deckschilden an Cr.absconditus und ochropus an, während sie sich durch die schwarze Farbe der Beine von allen übrigen Arten mit hellen Deckschilden unterscheidet. Der Kopf flach mit unten mondförmig eingedrücktem Kopfschilde, das letztere oben nur durch eine schwache Unebenheit abgesetzt, die Stirn durch die langgestreckten, schmal dreieckig ausgebuchteten, oben stark zusammengeneigten schwarzen Augen verengt, übrigens kaum punlitirt, glatt und glänzend rostroth, der untere Theil des Kopfschildes mit den Mundtheilen pechbram. Die Fühler des $\delta$ liurz, aber derb und kräftig, das Wurzelglied gestreckt, dreinal linger als breit, das zweite elliptisch, die folgenden von ziemlich gleicher Länge, je reichlich doppelt länger als das zweite, von der Spitze des fünften ab sehr stark verbreitert und zusammengedrückt, so dass die obere Breite kaum um 
die Hälfte gegen die Länge zurückbleibt, mit kurzem kaum wahrnehmbarem Fortsatze des nur wenig kürzeren Endgliedes. Die Fühler des $q$ in allen Theilen schlanker und zarter, sonst nicht abweichend. Die Farbe schwarz, nur die bejden unteren Glieder roth mit einem schwärzlichen Längswisch auf der Oberseite. Das Halsschild breit kugelig gewölbt, vor’ı mit halber Länge übergekrümnt, über den tief eingezogenen scharf rechtwinkligen Vorderecken zusammengedrückt und dadurch verschmälert, die Seiten gerandet, in sehr flachen Bogen nach vorn zusammengeneigt, die scharf spitzwinkligen Hinterecken ausgezogen, ler Hinterrand jederseits eingesenkt, breit und ziemlich tief ausgebuchtet, mit kurzem, doppelt ausgerandetem Mittelzipfel, vor letzlerem auf jeder Seite ein kurzer aber breiter und tiefer Schrägeindruck. Die Oberfläche spiegelglänzend rostgelb. Das Schildchen mässig ansteigend, länglich dreieckig, hinten kurz ahgestutzt mit kräftigen Vordergrübchen, gleichfalls glänzend rostgelb mil schwärzlichem Vordersaume. Die Deckschilde breit gewölbt, kaum länger als breit, von den Schulteru ab hinterwärts etwas verschmälert, der Rücken von der Schildchenspitze al) hinterwärts allnı̈lılich-, seitlich etwas stärker abfallend, die grossen aber ziemlich flachen Schulterbeulen immerseits durch einen breiten, seichten Eindruck abgesetzt, anch die Seitenlappen nur wenig entwickelt, jedoch mit lreitem, mattem Unterrande. Die Punktstreifen regelmässig, sehr fein, die mittleren schou vor der Mitte fast erloschen, die längs Nalıt und Spitenrand liegenden etwas deutlicher und his zur Spitze kenntlich; in dem neunten über dem Seitenlappen ein schwacher Längseindruck. Die Zwischenräıme flach, der neunte ein wenig aufgewölht; die Farbe gläızend rostgelb, ein schmaler Wurzelsaum tiefer gebräunt. Pygidiun und Unterseite deutlich punktirt, elenfalls rostgelb, die Beine schwarz, die IIn̈ften, Vorlerkniee und die obere Hälfte der Vorderschenkel rostgelb. Der Vorderrand der Vorderbrust stark schüsselförmig vorgezogen, die Mittelfläche runzlig punktirt, der Ilinterrand leicht ausgebuchtet mit schärfer vorspringenden Iinterecken. Das letzte Segment des o quer flach niedergedrückt, des $q$ mit einer tiefen rundlichen Grube.

Aus Nordbrasilien (von Pernambuco: Mus. Deyrolle; - und vom Amazonenstrom: Mlus. Baly).

23. Cr. pasticus m. Bleich strohgelb, spiegelglatt, mit schwarzen Angen und Kimubcken, dic Punktstreilen fein, hinter- 
wärts fast erloschen, mit flachen Zwischenräumen. L. 23/4-3"'; Br. $12 / 3-13 / 4 "$.

In der bleiclı weissgelhen Färbung dem ostindischen $\mathrm{Cr}$. heclicus und faluus, in der überaus feinen Streifenbildung dem vorhergehınden ähnlich, von dem letztern aber auch ausserdem an den gleichlialls bleichgelben, nicht schwarzen Beinen leicht zu unterscheiden, übrigens eine der grössten Arten dieser ganzen Rotte. Der Kopf flach mit efwas cingedrückter, von einer sehr fein eingeschnittenen Längslinie durchzogener Stirn, das Kopfschild oberwärts wenig verschmälert, nicht deutlich abgesetzt. Die Oberfläche glänzend, ohne deulliche Punktirung, die langgestreckten, breit und ziemlich tief ausgebuchteten Augen nebst den Kinnbacken schwarz. Die Fühler (des \&) nicht von halber Körperläuge, das dünn keulenförmige Wurzelglied dreimal länger als breit, das zweite elliptisch, Imm die Hälfte länger als breit, dem dritten Theile des ersten gleich, das dritte und vielte gleichlang, schmal verkehrt kegelförmig und etwas mehr wie doppelt länger als das zweite, die folgenden oberseits verbreitert und zusammengedrückt, bis zum zehnten an Länge allmählich abmehmend, das Endglied mil seinem kurz dreieckigen Fortsatze wieder dem neunten gleich. Die oberen Glieder dünn greishaarig, an den Spitzen abstehend weiss gewimpert. Das Halsschild vorn mit dem er'sten Drittel seiner Länge mässig übergekrümmt, über den stumpf abgerundeten Vorderecken zusammengedrückt und dadurch ver'schmälert, die Seiten bı'eit gerandet, hinter der Mitte lang und tief ausgeschweift, die scharf spitzwinkligen Hinterecken kurz ausgezogen, auch der Hinterrand breit- und vor den Schultern tief ausgebuchtet, feiı gesägt, mit breitem, deutlich doppelt ausgerandetem Mittelzipfel. Vor letzterem jederseits ein tiefer Schrägeindruck, welcher sich mit kurzer Unterbrechung nach den Seiten des Halsschildes hinabzielıt, und sich kurz vor deren Mitte, das Halsschild breit und stark zusammendrückend, verliert. Die Oberfläche spiegelgläızend. Das Schildchen wenig ansteigend, gleichseitig dreieckig mit kurz abgestutzter Spitze und deutlichem Vordergrübchen. Die Deckschilde 1 m $1 / 4$ länger als breit, vorn etwas breiter als das Halsschild und dann hinterwärts in flachem Bogen verschmälert, der Rücken hinter der Schildchenspitze leicht buckelig erhölıt und von da ab nach vorn sehr flach- und auch hinterwärts nur in sanfter Krünmung abfallend, die länglichıer Schulterbeulen innerseits durch einen breit dreieckigen Eindruck 
abgesetzt, die Seitenlappen gross mit lang herabgezogenem Unterrande, über ihnen die Deckschilde sehr breit aber nur flach zusammengedrückt. Die Punktstreifen vorn von mässiger Stärke, aber schon von der Mitte ab schwächer und die mittleren auf der Wölbung fast nur noch an ihrer dunkleren Färbung kenntlich; das Vorderende des neunten nicht über das des vorhergehenden hinausreichend. Die flachen Zwischenräume gleichfalls spiegelglatt. Das Pygidium dicht und fein punktirt, düun weiss behaart, der Hinterleib noch feiner querrunzlig, schwach glänzend, die Hinterbrusı spiegelglänzend, an den Beinen nur die unteren Schienenränder und der untere Theil der Fussglieder bräunlich durclsscheinent. Das fein punktirte Prosternum gross, die Mitle breit längswulstig zusammengedrückt, und vorn mit hreit abgestutztem Rande zur Aufnahme der Mundtheile vorgezogen; hinterwärts ist dieser Wulst durch einen tiefen rundlichen Eindruck gabelig getheilt, und der Rand selbst in der Mitte sanft ausgebuchtet. Das letzte Segment des $q$ mit einer tielen eiförmigen Grube; das $\delta$ unbekimnt.

Von Cayenne. Mus. Deyrolle (als Monachus pallidus nitgetheilt), Dohrn, Holm. (von Dupuizet gesammelt).

Vierte Rotte. Körper von mässiger Grösse und fast regelmässig elliptischem Umrisse, mit flach gewöllbten Deckschilden. Die Fühler ziemlich kurz, uben nur schwach verbreitert; die Punktstreifen regelmuissig, ziemlich fein, mit flaclıen theilweise punktirten Zwischenräumen. Die Vorderhrust vorn etwas vorgezogen, hinten breit zweispitzig. Die Färbung braun oder rothbraun, meist mit grünlich-weissen Zeichnungen, welche bei einer Art überwiegend werden. Zierliche Arten, in Brasilien einheimisch.

24. Cr. moribundus m. Bleichyrün, der Kopf mit Brust und Beinen, zwei Flecke des punktirten Halsschildes und zwei Querbinden der Flügeldecken gellbbraun; die Punktstreifen derb mit flachen, punktirten Zwischenräumen. L. 12/3"'; Br. I"'.

Nach Habitus und Sculptur manchen europäischen Arten aus der Gruppe des $\mathrm{Cr}$. nitens nicht unälnlich, andererseits durch die auf der Stirn zusammenstossenden Augen und das schmale gestreckte Schiddchen den Antillenarten aus der Rotte des $\mathrm{Cr}$. Ihalassinus wahe stchend; durch den Unriss und durch die Stellung der Augen sich aber doch am nïchsten der vorhergchenden Rotte anschliessend, wälırend die meist sehır aluorme Zeichnung diese und dic folgenden drten sofort als Tropenkilfer erkenuen lässt. 
Der Kopf flach, das Kopfschild seitlich gegen die zurücktretenden Wangen durch dentliche Längsleisten begränzt, und zwischen den Fühlerı durch eine eben so dentliche Querleiste von der Stirn gesondert, die Oberllïche fein aber dicht runzlig punktirt, matt, schmutzig gelb, unten mehr ins Bleichgrünliche fallend, die langgestreckten, tief ausgebuchteten und mit den oberen Innenrändern eimander hejührenden Augen schwar'z. Die Fühler (des ठ) etwa von halber Körperlänge, das Wurzelglied gestreckt kenlenförmig, reichılich dreimal länger als breit und wenig nach aussen gekrümmt, das zweite eiförmig und treimal kïrzer als jenes, die beiden folgenden schmal verkehrtkegelförmig, das dritte $1 \frac{1}{2}$ mal und das vierte doppelt länger als das zweite, die folgenden einander gleich, je ein wenig länger, von der oberen Hälfte des fünften ab zusammengedrïckt und erweitert, die beiden letzten wierler etwas verschmälert. Die Farbe der unteren Glieder bis zur Wurzel des fünften schmutzig gelb mit gebräunter Oberseile des dritten und vierten, die oberen schwarz, dünn angedrückt weisslich behaart und vereinzelt abstehend gewimpert. Das Halsschild ziemlich breit, vorn mit mehr als halber Länge kugelig übergekrümmt, über den tief eingezogenen scharf rechtwiukligen Vorderecken stark zusammengedrückt und dadurch sehr merklich verschmälert, die fein gerandeten Seiten nach vorn in breiten Bogen zusammengekrüınmt, die Hinterecken kurz, aber breit und scharf drejeckig ausgezogen, durch einen seichten Schrägeindruck etwas aufgetrieben, der Hinterrand jederseits schwach wellig ausgebuchtet, aber nach den Schultern zu ziemlich tief eingesenkt, mit kurzem, schmalem, deutlich doppelt ausgerandeten Mittelzipfel; vor diesem letzteren die Oberfläclıe schwach quer niedergedrückt. Die Punktirung deutlich und ziemlich dicht mit lackglänzendem Zwischengrunde, die Farbe ein bleiches schwach ins Bläuliche fállendes Weissgrün, ein verwaschenes Hinterrand und zwei unregelmässig begränzte Fleckchen auf der Mitte nebeneinander schmutzig gelbbraun. Das Schiluchen schmal dreieckig, fast doppelt länger als breit und hinterwärts wenig verschmälert, daselbst grade abgestutzt und wenig ansteigend, mit schwachem Hinterzipfel; der Vorderrand in Gestalt einer durch das Vurdergrübchen getheilten Querbeule anfgetrieben, und hinter dieser noch ein seichter Quereindruck. Die Färbung glänzend gellıbrauı. Die Deckschilde sehr regelmässig walzenförmign, um 1/4 läıger, als breit, hinter den stark aufgetriebenen, innerseits durch 
einen dreieckigen Eindruck abgesetzten Schulterbeulen etwas erweitert und damı kurz zugerundet, hinter der Wurzel nur schwach quer niedergedrückt und dann sanft gegen die Spitze des Schildchens ansteigend, der Rücken gegen die måssig gekrünmte Wölbung-hin schwach abfallend. Die Punktstreifen sehr regelmässig, aus vereinzelten, vorn zwar etwas stärkeren, aber doch bis zur Spitze hin überall dentlichen Punkten gebildet; die breiten Zwischenräume flach, deutlich punktirt, über den stark herabgezogenen Seitenlappen auf dem erweiterten neunten Zwischenraume noch einige gröbere Punkte. Die Farbe, wie die des Halsschildes, ein lackglänzendes bleiches Weissgrüı mit schwach bläulichem Aufluge; ein schmaler auch noch den umgeschlagenen Rand des Seitenlappens eimnehmender Vordersaum und zwei abgekürzte Querbinden auf jeder Flügeldecke gelbbraun; die vordere, aus zwei Flecken zusammengeflossene von der Schulterbenle bis zum zweiten Punktstreifen reichend, die hintere gleichfalls durch zwei Flecke, deren äusserer etwas mehr nach hinten gern̈ckt ist, gebildet und von der Naht bis zum neunten Streifen sich erstreckend; beide Binden übrigens schlecht und verwaschen begränzt, und eigentlich nur das äussere auf der Schulterbeule liegende Ende der Vorderbinde etwas intensiver gefärbt. Pygidium und Unterseite fein runzlig punktirt mit mässigem Glanze. Ersteres mit dem Hinterleibe gleichfalls weissgrün, die Hinterbrust braungelb, die Beine etwas heller gelh mit einem schwachen dunkleren Wische vor den Schenkelspitzen. Vorder- und Mittelhrust wieder weisslich grün, erstere flach gewölbt, hinten deutlich eingedrückt und in zwei breite stumpl dreieckige Lappen vorgezogen. Die Beine kurz und kräftig, dlie Schienen unterwärts breit dreieckig erweitert, die vorderen von der Wurzel ab innerseits ausgeschweift; die drei oberen Fussglieder kurz und breit, das zweite fast so breit und wenig kürzer als das erste, der Stiel des Krallengliedes fast ganz zwischen len Lappen des dritten verborgen. Das letzte Segment des of mit einem schwachen Quereindruck, das of unbekannt.

Aus brasilien. Mus. Malens.

25. Cr. li ippocraticus m. Bleich gellgrün, Kopf, Schildchen, ein Hinterfleck des glatten Halsschildes und ein Fleck auf der Schulterbeule mit Brust und Beinen braun; die I'unktstreifen mässig, hinten schwächer, mit llachen, fein punktirten und glänzen-

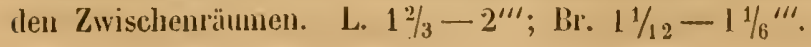


Dem vorhergehenden sehr ähnlich, aber breiter, hinterwärts stumpfer zugerundet, und auch ausser der fehlenden Punktirung des Halsschildes an der ganz abweichenden Farbenvertheilung leicht von ihm zu unterscheiden. Der líopf flach, das Kopfschild oberwärts verschmälert und hier zwischen den Fühlerwurzeln durch eine feine Querleiste, seitlich durch schärfere Leisten begränzt, die Oherfläche runzlig punktirt, heller oder dunkier braun mit mässigem Glanze, die tief ausgebuchteten, bei den vorliegenden $q$ oben nur durch einen schmalen Zwischenraum getremnten und bei dem $\delta$ vermuthlich zusammenstossenden Augen schwarz. Die Fühler von lıalber Körperlänge, ziemlich schmal; das Wurzelglied keulig, $2 \frac{1}{2}$ mal länger als breit, das zweite ganz kurz eiförmig, die folgenden ziemlich gleichlang, etwa doppelı länger als das zweite, das fünfte oben schon ein wenig verbreitert, die übrigen innerseits stärker erweitert und zusammengedrückt, mit kurz und breit dreieckigem Fortsatze des Endgliedes. Die fünf unteren Glieder gläızend braun, die oberen schwarz mit dünner angedrückter greiser Behaarung. Das Halsschild reichlich doppelt breiter als lang, über den scharf stumpfwinkligen Vorderecken zusammengedrückt und dadurch verschmälert, seitlich fein gerandet, und nach vorn mit breiten, in der Mitte etwas abwärts gekrümmten Bogen convergireurl, die Hinterecken in kurze scharfe grade hinterwärts gericlıtete Spitzen ausgezogen, der Hiuterrand jederseits doppelt wellig ausgebuchtet, fein gesägı, mit sehr kurzem und schmalem, doppelt ausgerandetem Mittelzipfel. Vor letzterem die Oberfläche zu beiden Seiten sehr breit und flach niedergedrückt, auch die Seiten vor den Hinterecken flach zusammengedrückt. Die Oberfläche spiegelglatt, hell gelbgrün, hinten schwärzlich gesäumt, und vor dem Nittelzipfel ein verwaschen dreieckiger, anscheinend aus drei wischartigen Punkten zusammengellossener brauner Fleck. Das Schildchen schmal dreieckig, um die Hälfte länger als breit, hinterwärts stark ansteigend und scharf abgestutzt, Hinterzijfel und Vordergrübchen deutlich, die Farbe gläızend braun. Die Deckschilde etwa $2 \frac{1}{4}$ mal länger und vorn etwas breiter als das Halsschild, linterwärts noch etwas erweitert und dann nach der stumpfen Spitze hin in breiten flachen Bogen sich abrundend, daher der Unriss sich etwas dem schlauk eiförmigen näherud; die Wurzel schräg niedergedrüclit, die Schulterbeulen schmal und flach, innerseits durch einen gleichfalls schmalen dreieckigen Eindruck abgesetzt, die Seitenlappen lang herabgezogen, 
über ilınen die Seiten etwa vom Iritten bis zum achten Streifen hin breit-, aber nur leicht zusammengedrückt. Der Rücken von der Spitze des Schildchens ab erst sehr flach-, dann auf der Hinterhälfte mit stärkerer Krümmung bis zur Spitze hin abfallend. Die Punktstreifen sehr regelmässig, aus vereinzelten rundlichen, rorn stärkeren, hinten schwächeren und in die Länge gezogenen Punkten bestehend, die Hinterenden der mittleren auf der Wölbung fast ganz erloschen. Der umgeschlagene Rand des Seitenlappens nur am äusseren Saume mit einer schwachen Punlitreihe besetzt. Die Zwischenräume breit und flach, fein punhtirt und gerunzelt, lackglänzend, bleich gelbgrün, ein zarter Wurzelsaum und das Innere der Punkte geschwärzt, ausserdem auf ter Schulterbeule ein bei einem Stücke auch den Eindruck auf deren Innenseite mit einschliessender bräunlicher Fleck, zu welchem bei einer Abänderung

$\beta$. auch noch auf der Wölbung jeder Flügeldecke eine aus zwei verwaschenen braunen Fleckchen gebildete Querhinde hinzukommt. Bei dem einzigen vorliegenden Stïcke dieser Form ist zugleich der Fleck auf dem Halsschilde etwas dunkler, wälırend Kopf und Beine weniger intensiv ausgefärbt sind.

Das Pygidium äusserst fein querrunzlig punktirt, dünn behaart, noch etwas heller weisslichgrün, eben so der an der Wurzel gebräunte Hinterleib und die umgeschlagenen Seiten des Halsschildes; der ganze übrige Theil der Unterseite nebst den Beinen braun mit etwas helleren Fussgliederı. Das Prosternum flach gewölbt mit etwas vorgezogenem Vorderrande, einzeln grol, pmuktirt, hinter der Mitte ringedrückt mit stumpfen Hinterenden. Das letzte Segment des of mit der gewöhnlichen rundlichen Grube, las o unbekannt.

Aus Brasilien. Mus. Schaum, Baly. In dem letzteren auch die var. $\beta$.

26. Cr. apocryplius m. Braun, vier Flecke des glatten Halsschildes, eine Querbinde und ein Hinterfleck der Flügeldecken und der Ilinterleib weiss; die Punktstreilen vorn mässig, hinten erloschen, mit flachen glänzenden Zwischenrïumen. L. 13/4-21/4"'; Br. $11 / 6-1 \frac{1}{4} "$.'

Alrermals dem Cr. moribundus nahe verwandt, aber grösser und in der Sculptur dem vorhergehenden näher stehend, von welchèm er besonders durch die Farhenvertheilung sich unterscheidet. Der Kopf llach, das Kopfschild seitlich und oben durch deutliche 
Leisten begränzt, spiegelglatt; die Stirn bei feiner aber deutlicher Punktirung schwächer gläuzend, oben mit einer feinen eingeschnittenen, in die Leiste zwischen den oberen Augenrändern auslaufenden längslinie. Die l'arbe schmutzig gelbbraun mit etwas lichterem Kopfschilde, die langgestreckten, ziemlich tief ausgeluchteten und mil den oberen Inuenrändern fast zusammenstossenden Augen schwarz. Die Fühler des $\delta$ von melır als hallıer Körperlänge, ziemlich schlank, im Wesentlichen gebaut wie bei den vorhergehenden Arten; das zweite Glied liugelig, kaum schmäler als das erste, die beiden folgenden dünn verkehrt kegelförmig, das dritte unı die Hälfte, und das vierte doppelt länger als das zweite, die oberen etwa dem vierten gleich und von der Spitze des füuften ab schwach zusammengedrückt und erweitert, mit lang dreieckig zugespitztem For'satze des Endgliedes. Das Wurzelglied schmutzig röthlichgelb, die drei folgenden tiefer gebräunt, die übrigen schwarz mit dïnner angedrückter greiser Behaarung. Das Halsschild gebaut wie bei $C r$. moribundus, nur der Seitenrand noch etwas breiter aufgeschlagen, und über dessen Mitte ein deutlicher von hinten und oben herabziehender Schrägeindruck, welcher gewissermaassen eine Fortsetzung des hier etwas stärkeren Eindrucks vor dem Mittelzipfel bildet. Die Oberfläche spiegelglatı, die Farbe braun, ein breiter inmerseits verwaschener Seitenrand, zwei eiförmige Schı̈̈gflecke vor dem Hinterzipfel, und ein trülser schmutzig verwaschener, mit zwei Buchten in das dunkle Mittelfeld eingreifender Vorderrand weisslich; diese Zeichnung aber überall um so unklarer, je mehr sie sich dem braun verbleibenden Mittelfelde nähert. Auch das Schildchen wie bei der letztgenannten Art, nur die braune Fïrbung noch etwas dunkler. Die Deckschilde kurz und breit walzenförnigg, um $1 / 4$ länger als breit, linter den Schultern noch etwas im Bogen erweitert, und dann kurz zugerundet, hinter der Wurzel schwach quer niedergedrückt, von der Spitze des Schildchens ab längs der Naht und seitlich sanft abfallend, erst von der Wülbung an stärker abwärts gekrünımt; lie länglichen Schulterbeuleı innerseits durch einen breiten Eindruck abgesetzt, äusserlich durch das tief eingegrabene Vorderende des neunten Streifens begränzt; auch die Seitenlappen gross und breit. Die Punktstreifen sehr regelmässig, aus vereinzelten, vorn tief eingerlrückten Punkten gebildel, schon vom ersten Drittel al, schwächer und hinterwärts allmälılich erlüschenl, so dass vor der Spitze nur noch von den der Nahıt und dem laude 
zunächst liegenden eine schwache Spur vorhanden ist. Die glänzenden Zwischenräıme flach; die Farbe braun, auf der Mitte eine breite wellige nit dem Innenende stark nach vorn gekrümmte, bei einem ơ im Mus. Baly in zwei getrennte rundliche Flecke, der innere etwas nach vorn gerückt, aufgelöste weisse Querbinde, und unter der Wölbung ein gleichfalls weisser, die ganze Spitze einnehmender, nur schmal braun umsäumter Querfleck; zwischeı ihm und der vorderen Binde ist die brame Grundfïrbung lichter als an der Wurzel, gewissermaassen durch den Einfluss der hellen Zeichnung abgeschwïcht. Das einzige vorliegende o zejchnet sich (ob zufïllig?) ausser der Grösse noch durch die ausgedehnte helle Zeichnung des Halsschildes aus, auf dem jeder Hinterfleck durch einen bräunlichen Wisch mit dem entsprechenden Vorderflecke zusammenfliesst; eben so durch einen schwärzeren Ton des Braun an der Wurzel der Deckschilde, womit zugleich eine schwärzere Färbung der Beine bei brïunlichen-Schenkelwurzeln verbunden ist. Dahei sind die Punktstreifen merklich feiner als bei den ठ. - Das Pygidium liaum punktirt, weiss. Auch der Hinterleib weiss, der Hinterrand des ersten und die beiden folgenden Ringe in der Mitte leicht in die Queve gebräunt, und eben so die Fläche des ersten Ringes jederseits des Mittelzipfels brämlich angelaıfen. Die Hinterbrust hraun, Hüften, Mittel- und Vorderbrust lieller, ins Gelblichweisse fallend, die ungeschlagenen Seiten des Halsschildes bis zu den Vorderfüssen weiss, der Vorderrand des Prosternums breit napfförmig vorgezogen, die Nittelflïche hinterwärts niedergedrückt und in zwei breite dreieckige Spilzen ausgezogen. Die Beine kurz und liräftig, die Schienen unten mässig erweitert, die Farbe braun mit fast schwarzen Füssen, die Wurzeln der Schenkel und Schienen heller gell, mit verwaschener Begrïnzung. Das letate Segment des $\delta$ in der Vitte breit und flach niedergedrückt, des $q$ mit riner breiten aber nicht tiefen, spiegelglänzenden Grube.

Aus Brasilien. Mus. Ilal. Schaum, Baly, Clark; in denı letzteren ist Rio de $\mathrm{J}$. als Heimath genannt.

27. Cr. la esus m. Braun, Vorder- und Seitenrand mit zwei Hinterflecken des deullich punktirten Ilalsschildes, und die Unterseite gelb, zwei unterbrochene Querbinden der Flügeldeclien mit deren Spitzenrande und Pygilium weiss; die Punktstreifen derl mit schmalen, gewölbten Zwischenräumen. L. 1"'; Br. 1/2"'.

Eine lileine und zierliche, mir un in einem einzigen sehr be- 
schädigten, aber doch zum Wiedererkeunen des Käfers völlig ausreichenden Stïcke vorliegende Art. Der Kopf fehlt demselben, ist jedoch olme Zweifel glänzend braun, muthmaasslich mit lichterer Färbung des Kopfschildes. Das Halsschild fast doppelt breiter als lang, ziemlich walzenförmig, vorn über den scharf stumpfivinkligen Vorderecken zusammengedrückt und dadurch verengt, die fein gerandeten Seiten nach vorn in flachen Bogen convergirend, dip gleichfalls scharfen Hinterecken ganz kurz pfriemlich ausgezogen, der Hinterrand fein gesägt, jederseits leicht ausgeschweift, mit ganz kurzem, fast gerade abgestutztem Mittelzipfel. Die Mittelfirste fast gerade, nach vorn und hinten gleichmässig schwach abwärts gekrümmt, vor den Hinterecken jederseits ein breiter gegen die Mitte des Seitenrandes abfallender Schrägeindruck. Die Punktirung zerstreut aber deutlich; die Farbe ein helles, etwas ins Röthliche fallendes Braun, ein breiter nach innen verwaschen begränzter Vortlerund Seitenrand, der letztere in der Mitte tief und schmal ausgebuchtet, lıeller gelb; ein noch lichterer, fast weisslicher Querfleck jederseits vor dem Schildchen. Dieses letztere dreieckig, etwas länger als breit, wenig ansteigend und vorn ohne merkbares Grïbchen, glänzend braun. Die Deckschilde etwas breiter und mehr als doppelt länger wie das Halsschild, gestreckt walzenförmig, hinter der scharfen Wurzelkante leicht quer eingedrückt und über den breiten Seitenlappen deutlich zusanmengedrückt, die länglichen Schulterbeulen innerseits durch einen schmalen Längseindruck abgesetzt. Die Punktstreifen kräftig, aus rundlichen, tief eingestochenen Punkten gebildet, sehr regelmässig und hinterwärts kaum abgeschwächt, die seitlichen in deutliche schmale Furchen eingedrückı und dadurch deren Zwischenräume, besonders der neunte, als leichte Rippen emporgehoben, aber auch die oberen flach gewölbt; der breite umgeschlagene Rand der Seitenlappen mil einer Reihe grolıer, etwas quer gezogener Punkte besetzt. Die Oberfläche kaum gerunzelt, die Farbe ein lackglänzendes, ziemlich helles P'echbraun, mit lackartig aufgetragener, die Punktstreifen vollständig deckender weisser Zeichnung. Die letztere bildet zuerst vor der Mitte eine jederseits alogekürzte, vom ersten bis zum neunten Streifen reichende, in ihrer Nitte vorn und hinten buchtig verschmälerte Querbinde, ron deren Aussemrande schräg nach vorn und aussen auf der Erweiterung des nemten Zwischenraumes über dem Seitenlappen sich noch ein schnales weisses Längsfleckchen bemerkbar macht; eine 
zweite aher weniger ausgedehnte, unterhrochene Querbinde liegt auf der Wölhımg, reicht nur vom zweiten bis zum neunten Streifen, und wird durch den bram verbliebenen siebenten Zwischenraum in zwei getrennte Flecke, eineu grösseren inneren und einen äusserpn Lïngsfleck auf dem achten Zwischenraume, getheilt. Ausserılen ist noch der durch das Zusammenfliessen des ersten und nemten Zwischen'aumes gebildete breite Spitzenrand verwaschen weisslich - doch weniger rerin, als jene beiden - gefärbt. Das Pygidimn fein pmoktirt, dünn behaart, schmutzig gelblich weiss mit verwaschen hellerer Spitze. Die Lnterseite röthlich gell, die Ränder des Ilinterleiles, Iler Mittrlzijfel des ersten Ringes und die Beine heller gelb. Die Vorderbrust grob runzlig punlitirt mit Jeicht ausgebuchtelem Hinterrande mul schwach vortretenden Hinterzipfehn, der Vorlerrand in eine kurze, stumpfe Spitze vorgezogen. Das letzte Segment des $\delta$ mit einem leichten Quereindruck, das $q$ unbekannt.

Aus Brasilien. Mlus. Hal.

28. Cr. leucospilus m. Braun mit schwarzbunten Beinen, vier Flecke des spiegelglatten Halsschildes schwarz, eine algekürzte Vorderbinde und ein Hinterfleck der Flügeldecken weiss mit schwärzlichem Hofe; die Punktstreifen derb mit schmalen, flachgewölbten Zwischenrïumen. L. $1 \frac{1 / 3}{3}-2^{\prime \prime \prime} ; \mathrm{Br}$. 3/4 $-11 / 12 "$.

Dem vorhergehenden ähnlich, aber grösser, das IIalsschild spiegelglatt, mit ziemlich flach ausgebreiteten Hinterecken, mul die Zeichnnng auf den Deckschilden mit einem eigenthümlichen schwarzen Hofe umgehen. Dex Kopf flach, zwischen den lang gestrecliten winliclig ansgeluclıteten, bei dem $\delta$ oben fast zusanmmenstossenden mnd auch bei dem of um wenig getremten Augen mit einer feinen Stirnlinie, der untere Theil rler Stim mit feiner zerstreuter Punlitirumg besetzl; das Kopfschild seitlich gegen die stark zurïcliIreteuden Wangon dentlich alngesetzt, ziomlich schmal, olsen durch eine Querrunzed zwischen den Fühlerhöckern begränzt. Die Farbe bei dem ơ hellhram gell, hei dem of dunkelloraum, mit Lackglauz. lle Fühler des ersteren von $2 / 3$ der Körperlinge, derb und liräftig, das Wurzelglied lienlig aufgetrieben, etwa doppelt länger als lreit, dis zweite elliptiseh, hallh so lang und breit als das vorhergehende, die drei folgenden dün verlichntliegeltömnig, aber gleich lang und je um die Hälfte länger als das zweite; auch die olıeren von derselben Länge, immerseits ein wenig rweitert mol zusanmengedrückt, 
mit kurzem Fortsatze des Endgliedes. Die fünf unteren durchscheinend honiggelb mit gebrïunter Spitze des fünften Gliedes, die oberen schwarz, fein anyedrückl behart und abstehend weiss gewimpert. Die Fülıler des $q$ etwas kürzer und gedrungener, sonst nicht alweichend. Das Halsschild un die Hälfte breiter als lang; hinten etwas niedergesenkt, die Mitte leicht quer aufgewölbt, und danı das vordere Drittel sanft nach dem Kopfe zu abwärts gekrümmt, vor'n durch die tiefe Einbiegung der scharf rechtwinkeligen Vordereckeı merklich vereıgt, und linterwärts wieder durch die ziemlich flach ausgebreiteten, kurz aber scharf zugespitzten Hinterecken rerbreitert; die Seiten fein gerandet, nach vorn in breiten Bogen convergirend, und über ihrer Mitte ein kurzer, tiefer Schrägeindruck. Der Hinterrand jederseits breit ausgebuchtet, vor den Schulterbeuleı tiefer ausgeschnitten und zngleich eingesenkt, scharf gesägt, mit kurzem, deutlich doppelt ausgerandetem Mittelzipfel. Vor dem letzteren auf jeder Seite ein leichter, sich schräg nach dem tieferen Grübchen über dem Seitenrande hinabsenkender Eindruck. Die Oberfläche spiegelglatt, nur in den Vorderwinkeln mit einigen P'ünktchen hestreut, hell zimmtbraun, mit vier in eine Querreihe gestellten schwarzen Fleckchen, zwei grösseren fast rundlicheı iı der Vitte neben einander, ınd dann jederseits noch einem kleineren, zuweilen bis zum Seitenrande überfliessenden in dem Eindrucke n̈ber dessen Vitte. Das Schildchen dreieckig, um die Hälfte länger als breit, vorn quer niedergedrückt mit deutlichem Grübcheı, mit der hintereı Hälfte mässig ansteigend, kurz abgestutzt mit undeutlichem Hinterzipfel, gleichfalls glänzend zimmtbraun. Die Deckschilde $2 \frac{1}{2}$ mal länger und vorn etwas breiter als das Halsschild, hinterwärts noch etwas bauchig erweitert und an der Spitze eiförmig zugerundet, vorn leicht quer abgeflacht, die Schulterbeulen kräftig in die Länge gestreckt und innerseits durch eisen länglichen schmalen Eindruck abgesetzt, auch die Seitenlappen kräftig, und die bej den verwandten Arten über ihnen liegenden Eindrücke hier durch die lackartig aufliegende weisse Zeichnung verdeckı; der Rücken hinterwärts allmälılich abgeflachı und in die selır schı̈̈y sich hinabsenkende Wölljung übergehend. Die Punktstreifen regelnässig und lirältig, aus tiefen rundliclıen Punkien bestehend, in oben schwach angedeutete, seitlich etwas stärkere Furchen eiugedrückt, daher die oben flach gewölbten Zwischenräıme hier stärker, weem auch ticht eigentlich riplenförınig hervortreten. 
Auch der umgeschlagene Rand des Seitenlapjens mit einer derben Punktreilı besetzt. Die Zwischenräume selbst fein gerunzelt, lackglänzend; die Farbe braun, eine innerseits abgekürzte, von dem zweiten Zwischenraume bis zum Seitemande reichende, in der Mitte buchtig verengte Querhinde und ein grosser rundlicher Fleck auf der Wölbung zwischen dem zweiten und fünften Streifen weiss aufgetragen, und mit einem breiten verwaschen hegränzten schrvarzen Hole ungeben, welcher vorn gewölnnlich den ganzen Raum bis zur Wurzelkante einnimmt, bei dem Hinterflecke aber manchmal auf dessen Aussen- und Hinterseite beschränkt ist. Das Pygidium fein punktirt, hellbraun, auf der Mitte mit einem schwärzlichen Querschatten. Auch die Unterseite hellbraun, meist mit etwas dunkleren Nähten der Bruststücke; eben so die Beine braun, das untere Drittel der Schenkel und die untere Häfte der Schienen mit den Füssen geschwärzt, die Hinterschienen zuweilen ganz schwarz mit einem bräunlichen, verwaschenen Ringe über der Mlitte. Dis Prosternum flach, runzlig punktirt, jederseits der Länge nach schmal eingedrückt, der Hinterrand fast grade mit zwei ganz liurzen dornartig vorspringenden Spitzen, deren Zwischenraum ungefähı der Entfernung jeder von der stumpfen Hinterecke gleich liommt; die Mittelbrust mit einem rundlichen, glänzenden Eindruck. Das letzte Segment des o leicht quer niedergedrïckt, des $f$ mit einer grossen runden, stark glänzenden Grube.

Bei schlecht ausgefärhten Stücken ist die Grundfarlıe hell lederhraun; auf dem Halsschilde sind die Mittelflecke kleiner, verwaschener, weniger intensiv gefärlıt, und die seitlichen zu bräunlichen Schatten geschwunden. Auch die Höfe der Flïgeldeckenzeichnungen verbleichen ins Braune, werden am Hinterrande der Vorderbinden unscheinbar, und heschränlifn sich bei den Hinterflecken auf deren Unterrand unter der Wölbung.

Aus Brasilien. Mus. Hal., Schaum, v. Bruck, Clart; in den beiden letzteren Sammlungen ist Rio de J. als Fundort angegebelı.

29. Cr. turgidus ı. Rothlırau, Fühlerenden, Schildchen, Wurzelı und Nahtsaum der Flügeldecken, Schenkel, Hinterbrust und IInterleih schwarz; das Halsschild fein punktirt, die P'unktstreifen mässig mit flachen, runzlig pnnktirt’n Zwischenräum»n. L. $1 \frac{1 / 3}{{ }^{\prime \prime \prime}}$; Br. 1"'.

Diese Art ist hier eigentlich nicht an ihrer rechten Stelle, und 
gehôrt überhaupt wieder zu denen, die sich als eine augenscheinliche Mittelform zwischen Monachen und echten Cryplocephalen nur schwer in unsere gegenwärtige Systematik schicken wollen. Ich bringe sie jedoch einstweilen hierher, weil sie habituell noch am besten zu den vorherbeschriebenen Arten passt, und sich überhaupt nach einem einzigen und nicht besonders erhaltenen Stücke nicht leicht über ihre definitive Stellung entscheiden lässt. Der Kopf flach gewölbt, mit kurzer und wenig deutlicher Stirnlinie, dicht und fein runzlig punktirt, das Kopfschild stark eingezogen, oben durch eine eingedrückte Querlinie abgesetzl, der untere Rand desselben mit der kurzen stark vorspringenden Oberlippe schwärzlich; die Wangen ins Bleiclıgelbliche fallend, die langgestreckten tief' ausgebuchteten Augen greis. Die Fühler nicht von halber Körperlänge, ziemlich kräftig, das zweite Glied gestreckt elliptisch, das dritte und vierte je demselben an Länge gleich, verkehrtkegelförmig, das fünfte etwas länger und oben breiter, diesem letzteren die oberen gleich, etwas stärker erweitert und zusammengedrückt, mit stumpfliegelförmigem Fortsatze des Endgliedes. Die vier unteren Glieder durchscheinend rothbraun, das fünfte tiefer gebräunt, die oberen schwarz mit angedrückter dünner greiser Behaarung. Das Halsschild mit $3 / 4$ der Länge vorn stark übergekrümmt und daselbst zugleich stark verschmälert, die Vorderecken tief eingezogen und scharf rechtwinklig, die Seiten gerandet, üher dem Rande mit einer eingedrückten Bogenlinie umzogen, nach vorn in breiter Krümmung zusammengeneigt, die Hinterecken kurz und scharf, fast rechtwinklig, der Hinterrand jederseits breit ausgebuchtet, etwas eiugesenkt, mit doppelt ausgerandetem Mittelzipfel; vor letzterem auf jeder Seite eine grosse flach niedergedrückte, linten mit einem kurzen auf dem Rande selbst liegenden Eindruck endende Stelle. Die Oberfläche sehr fein und zerstreut punlitirt, glänzend rothbraun mit schwarzem Hintersaume. Das Schildchen selırägr ansteigend, dreieckig, um $1 / 3$ Jänger als breit. mit undeutlichem fordergrübchen, gleichfalls schwarz mit mässigem Glanze. Die Deckschilde um 1/4 länger als breit, vorn kaum breiter als der Hinterrand des Halsschildes, hinter den stumpfwinklig zugeschärften Schulterecken noch elwas verbreitert, und dam wieder hintel'wärts iı weiten Bogen verschmälert; die Wurzel vorn sanft abwärts gekrüımt, der Rücken flach gewölbt, Schulterbeulen nnd Seitenlappen wenig bemerkbar. Die Punktstreifen von mässiger Stärke, auf dem letzten 
Drittel der Flügeldecken merklich schwächer, und die mittleren sich auf der Wölbung unter der runzligen Punktirung der Zwischenräume verlierend, die letzteren flach, mit dichter fein runzlig verflicssender Punktirung bedeckt, daher nur schwach glänzend, mehr seidig schimmernd. Die Farbe dunkelrothbraun, die Wurzel mit schıälerem, die Naht mit breitem ziemlich scharf beyränztem schwäızlichem Saume. Pygidium, Hinterleib und Hinterlorust schwarz mit verwaschen gebrüuntem Sanme des ersten und letzten Hinterleibsringes; Vorder- und Vittelbrust rothbraun, erstere vorn längswulstig mil kurz halblireisförmig vorgezogenem Vorderrande, hinten ausgeschnitten mit scharf vortretenden Hintereckerı. Hüfteı und Beine rothbraun mit geschwärzten Schenkehn, das letzte Segment des of einfach; das $q$ unbeliannt.

Aus Südamerika ohne nälıre Angabe der Heimath. Nus. Deyrolle.

Fïnfte Rotle. Körper kırz und breit, meist hochgewölht und hinterwirts rerschmälert, bram mit gehen Flecken und Querbinden. Fühler sehr dïnn und lang, Auren bei den $\delta$ einander oben genähert. Deckschilde kerhstreifig mit gewölbten Zwischenräumen, die Strcifen hinter deı Schulterbeulen dırch eine seitliche Querrunzel nuterbrochen, hinter welcher der sechste und siebente zum Theil oder ganz fehlen. Eine auf den Antillen einheimische Gruppe, bis jetzt in Südamerika nur durch eine einzige Art aul der Nordliüste vertreten. Vergl. Limn. Ent. VI. 248. Vierte Rotte.

30. Cr. multigullatus Mus. Fab.? Ohen braun, unten hraun- und gelbbunt, das fein punktirte Halsschild mit sieben, die Flügeldecken mit neun gelben Flecken; die Punktstreifen derb mit gewölbten, fein querrunzligen Zwischenräumen. L. $2 \frac{1}{3}{ }^{\prime \prime \prime}$; Br. $1 \frac{1}{1}{ }^{\prime \prime \prime}$.

(r. mulligullalus Suffr. Linn. Ent. V1. S. 250. n. 11?

Den vorliegenden Küfer vereinige ich nichı ohne einiges Bedenken mit den von mir a. a. U. beschrielsenen $\mathrm{Cr}$. multiguttatus Mus. Fab. Dej. von St. Domingo, zu wolchem er im Mus. Berol. gebracht worden ist. Dals vorliegende Stück (ein f) stimmt zwal im Algemeinen mit der genannten drt überein, arscheint aber gestrecliter, mehr gleichbreit, und dadurch auch melır walzenförmig; das Halsschild spiegrelgl:̈nzend, die Zwischentiume anf den Dechschilden schmälor, stirlier gewölht mol dadurch mehr rippenartig. Die gelbe Zrichnumg des liopfes ist trïber, und ron den gelbun 
Flecken des Rautenvierecks an der Spitze der Flügeldecken, welches bei den zahlreichen von mir verglichenen Stücken des $\mathrm{Cr}$. multigullalus stets rorhanden ist, fellt hier der äussere Fleck ganz; nicht weniger fehlt auch der Raum, auf dem er seine Stelle finden müsste, da der achte und neunte Streifen, in deren Vereinigungswinkel er bei $C r$. multigullatus gestellt, ist, hier gar nicht zusammentreffen, sondern jeder für sich in den Vorler- bezüglich Ifinterrand des hier sehr stark nach aussen in clie Quere gezogenen Hinterflecks der Raute auslaufen.

Die genauere Feststellung des Verhältnisses zwischen diesem Käfer uni der bekannteren Antillen-Art muss indess der Auffindung einer grösseren Zahl von Exemplaren vorbehalten bleiben, zumal das einzige mir zugegangene Stück so schadhaft ist, dass es keine genauere Untersuchung mehr gestattet.

\section{Aus Venezuela (Mus. Berol., von Moritz).}

Sechste Rotte. Körper klein, kurz und gedrungen, aus vorn elliptischem Umrisse hinterwärts fast gleichbreit, und dann plötzlich quer abgestumpft. Die Fühler ziemlich kurz, oben schwach rerbreitert, die Augen oben genähert. Die Punktstreifen deutlich mit glänzenden Zwischenräumen. Die Farbe dunkelroth oder braun, bei einer Art mit schwarzer Zeichnung. Das Halsschild vorn wenig vorgezogen, hinten deutlich ausgebuchtet.

Eine im nordöstlichen Theile von Südamerika vorkommende Rotte, einzuschalten vor der Asiatischen des Cr.depressus (Linn. XIV.S.34.).

31. Cr. aduncus m. Schwarz, die Fühler- und Schenkelwurzeln, der Hinterleib, die Seiten des Halsschildes, ein Fleck am Schildchen und ein grosser Bogenfleck auf jeder Flügeldecke ziegelroth; das Halsschilıl spiegelglatt, die Punktstreifen kräftig mit flachgewölbten, glänzenden Zwischenräumen. L. $1 \frac{1}{2}{ }^{\prime \prime \prime}$; Br. 3/4 ${ }^{\prime \prime \prime}$.

Von fast vollständig elliptischem Umrisse, nur hinten etwas hreiter unı stumpfer zugerundet wie vorn, auch im Habitus schmäler als die Arten der vorhergehenden Gruppe, anscheinend auch eine eben so seltene, als durch ilıre Zeichnung auffallende Art. Der Kopf flach, das Kopfschild seitlich scharf alggesetzt, oben zwischen den Fühlern durch cin Paar feine Grülıchen begränzt, die Stirn (des f) oben durch die stark zusammengeneigten, lang gestreckten und breit dreieckig ausgerandeten Augen sehr verengt. Die Farbe mattschwarz mit gehräunten Mundtheilen. Das Ualsschild kurz, mit der grösseren Vorderhälfte stark kugelig überge- 
wölbt, über den tief eingezogenen scharf rechtwinkligen Vorderecken stark zusammengedrückt und dadurch verschmälert; die Seiten fein gerandet, nach vorn in sehr flachen Bogen zusammengeneigt, die kurzen Hinterecken breit spitzwinklig zugeschärft und über ihnen die abfallenden Seitenflächen des Halsschildes hreil schräg abgeflacht, mit cin paar weiteren auch nur leicht angedeuteteu Schrägeindrücken. Der Hinterrand jederseits seicht ausgebuchtet, innerseits der Schulterbeulen tief eingesenkt, mit kurzem stark doppelt ausgerandetem, durch eiuen leichten Quereindruck etwas aufgetriebenem Mittelzipfel; zu jeder Seite desselben ein etwas stärkerer elliptisclıer Schrägeindruck. Die Oberfläche spiegelglatt, schwarz; der sich hinterwärts erweiternde, durch eine schräge Linie vom Vorderwinkel bis zu dem Schrägeindrucke am Hinterrande abgegränzte, jedoch nur verwaschen begränzte Seitenrand ziegelroth mit schwärzlichem Saume des Hinterrandes. Das Schildchen mässig ansteigend, gestreckt dreieckig, mehr als doppelt länger wie breit, hinten kurz abgestutzt, mit undeutlichem Hinterzipfel aber kräftigem Vordergrübchen, spiegelglänzend schwarz. Die Deckschilde etwa 1/4 länger als breit, hinterwärts mit gerundeten Seiten wenig verschmälert, dann aber kurz zugerundet, hinter der breit und flach aufgewulsteteı Wurzel durch die tiefer eingegrabenen Vorderenden der Punktstreiten quer eingedrückt, um die Schildchenspitze flach bucklig erhöht, und von da aus bis zur Spitze mit ziemlich gleichmässiger lírümmung abfallend; die Schulterbeulen halbkugelig aufgetrieben, die Seitenlappen stark herabgezogen und über ilnen die Deckschilde quer zusammengedruckt. Die Punktstreifen selır regelmässig, aus kráftigen Vorderenden hinterwärts etwas abgeschwächt, aber doch bis zur Spitze deutlich, nur unmittelbar über derselhen eine durch das Ausbleiben der Naht- und Randstreifen gehildete spiegelglatte Stelle. Die Zwischenrïume flach gewölbt, spiegelgläızend, der neunte über dem Seitenlappen erweitert und dabei leicht schwielig aufgetrieben. Die Farbe schwarz, ein gemeinsamer, das Schildchen umziehender und jederseits bis zum ersten Punktstreifen reichender Vorderlleck, und ausserdem noch auf jeder Flügeldecke ein schııf begräızter, hakenförmig gekrümmter Biılenflıck zirgelroth. Der letztere umfasst den mittleren Theil der Spitze, zieht sich dann, nach vorn etwas verschmälert, zwischen den zweiten und fünften Streifen aufwärts, und krümmt sich am ersten Drittel der Nalıtlänge fast rechtwinklig nach aussen, wo er sich hiuter 
der Schulterbeule zum Seitenlappen hinabsenkı und sich hier so weit verbreitert, dass er die oben genannte üher denselben liegende Schwiele mit einschliesst. I'ygidimm und Unterseite fein aber dicht punktirt, dünn greishaarig, jenes mit Brust und Beinen schwarz, der Hinterleib mit den Schenkelwurzehn dunkel ziegelroth, Vorderund Nittelbrust nebst den Hüften heller röthlich. Das breite Prosternum punktirt, vereinzelt aber lang greishaarig, hinten quer niedergedrückt und vor der Mitte des tief ausgebuchteten Hinterrandes stärker eingedrückit. Das letzte Segment des $q$ mit einer grossen spiegelglatten, vorn etwas in die Länge gezogenen Grube, das $\delta$ unbekannt.

Aus Brasilien. Mus. Baly.

32. Cr. profugus m. Ziegelroth, Fühlerenden, Hintersaum des spiegelglatten Halsschildes und dic Beine bis auf die oberen Schenkelhälften schwarz; die Punktstreifen fein, hinterwärts noch schwächer, mit flachen glänzenden Zwischenräumen. L. 11/4"'; Br. $2 / 3 " \prime$.

Ein zierlicher, spiegelglatter, dem vorhergehenden nahe verwandter Käfer, der gleichzeitig durch seine Färbung und seine feine Sculptur einigermaassen an ostiudische Formen, namentlich an den Cr. laevissimus ron den Philippinen erinnert. Der Kopl klein, flach, mit kaum eingezogenem Kopfschilde, das letztere oben zwischen den Fühlerhöckiern durch ein paar deutliche Quergrübchen begränzt. Die Oberflïche wenig glänzend, aber ohne deutliche Punktirung, hell ziegelroth, der untere Theil der Stirn mil einer fein eingeschnittenen Längslinie, der obere durch die langgestreckten, oben zusimmenstosseuden schwarzen Augen eingenommen. Die Kimbacken bräunlich, die Mundtheile gleichfalls roth. Die Fühler kurz, mit gestrecktem wenig verdicktem Wurzelgliede, das zweite Glied liurz und kugelig, die drei folgenden je demselben gleich, aher schmäler und das fünfte schon schwach zusammengedrückt und verbreitert, die sechs oberen wieder fast von gleicher Länge, je doppelt länger als das fünfte, stark zusammengedrückt und dadurch erweitert, vom achten al, wieder cin wenig an Breite abnehmend, mit kurzem breit dreieckigem Fortsatze des Endgliedes. Die drei unteren Glieder hell gelbroth, die beiden folgenden gebräınt, die oberen schwarz mil feiner angedrückter greiser Behaarung. Das Halsschild mit der grösseren Vorderhälfte sanft kugelig übergekrümmt, anch hinterwärts wieder etwas hinabgesenkt, ülıer 
den tief eingezogenen, scharf rechtwinkligen Vorderecken etwas zusammengedrückt und dadurch verschmälert, die Seiten gerandet, nach vorn fast in graden Linien zusammengeneigt, die kurzen Hinterecken breit alser scharf, und vor ihnen ein leichter Schrägeindruck; der Hinterrand jederseits nur sanft ausgeluclıtet, mit kurzem, breitem, doppelt ausgerandetem Mittelzipfel. Die Farbe spiegelglänzend ziegelroth, mit schwarzem Hintersaume. Das Schildchen schräg ansteigend, dreieckig, mit kurz abgestutzter Spitze und kurzem Vordergrübchen, um die Hälfte länger als breit und hinterwärts mit leicht ausgebuchteten Seiten sich verschmälemd, gleichfalls glänzend ziegelroth. Die Deckschilde walzlich, um ein Drittel länger als breit, hinterwärts mit gekiümmten Seiten verschmälert und dann kurz zugerundet; die Wurzel vorn nur leicht niedergedrückt, und auclı die flachen Schulterbenlen nur durch einen sehr seichten Eindruck innerseits abgesetzt, dagegen die Seitenlappen und besonders deren ungeschlagener Raud sehr stark entwickelt, der Quereindruck üher ilmen gleichfalls breit, alser nur flach. Die selır regelmässigen Punktstreifen fein, und von der Mitte ab noch schwächer, die mittleren aus der Wölhung fast abgeschliffen. Die Zwischenräume gläızend, flach, der neunte über dem Seitenlappen leicht aufgewöllst, die Farbe gleichfalls ziegelroth mit leicht geschwärztem Vordersaume. Pygidium und Unterseite mit dem oberen grösseren Theile der Schenkel ziegelroth, das untere Eude der letzteren mit den Schieneı und Füssen schwarz. Die Vorderbrust breit und flach, um die Hälfte breiter als lang, hinten seicht ausgebuchtet und vor der Mitte des Hinterrandes seicht quer nieclergedrïckt. Auch das letzte Segment des ơ leicht quer niedergedrückt, das $\&$ unbekannt.

Vom Amazonenstrom. Mus. Baly.

33. Cr. brunneus m. Braun mit hellerer Unterseite und schwarzem Vordersaume der Deckschilde; das Halsschilu grob zerstreut punktirt, hinten tief quer eingedrückt, die P'unktstreifen leicht furchenartig mit rippenförmigen Zwischenräuneı. L. 11/4"'; Br. $3 / 4 "$.'

Bei gleicher Länge mit dem rorhergehenden doch breiter; und ausserdem durch die gefurchien, fast kerbstreifigen Dechschilde sehr ausgezeichnet. Der Kiopf flach, glänzend und unr mit einzelnen feinen Punkten bestreut, das liopfschild tief eingezogen, lie Farbe hellbraun, nur die tief ausgebuchteten, anch bei dem $f$ mit den 
oberen Innenrändern zusammenstossenden Augen schwarz. Die Fühler von mehr als halber Körperläıge, dünı fadenförmig, das sehr schmale Wurzelglied leicht nach anssen gekrümınt, etwa viermal länger als oben breit, das zweite kurz und knotig, fast so breil als das erste, aber kaum länger als breit, die folgenden fast ron gleiclıer Länge, oben wenig verbreitert, mit lurz liegelförnig zugespitzlem Fortsatze des Endgliedes. Dic Farbe der unteren bis zur Mitte des vierten hellbran, die oberen schwarz mit dümner greiser Behaarung. Das kurze Halsschild vorn mit $\%$ seiner Länge breit kugelig übergewölbt, vor dem flinterrande hufeisenförmig quer nicdergedrüclit, die gerundeten Seiten nach vorn im Logen zusammengeneigt, Vorder- und Hiuterecken scharf, jene fast rechtwinklig, diese kurz und breit ausgezogen. Der Hinterrand nur breit und seicht ausgebuclıtet, mit kurzem doppelt ausgerandetem Mittelzipfel. Die Punlitirung olen mässig stark und zerstreut, seitlich gröher und dichter, in der Vertiefung vor dem Ifinterrande sehr dicht zusammengedrängt und fist grubig; der Zwischengrund glänzend, und die Farbe auch hier braun. Das Schildchen mässig ansteigend, schmal herzförmig, linten kurz abgestutzt, mit deutlichem jederseits von einer Beule begränztem Vordergrülchen, glänzend lıraun mit schwärzlicheın Vorderrande. Die Deckschilde kurz und breit walzenförmig, etwa $11 \ldots 1 / 4$ länger als breit, vorn durch die etwas tiefer eingegrabenen Vorderenden der Punktstreifen leicht quer niedergedriclit, daun schwach aufgewulstet, und von der Spitze des Schildchens ab seitlich stärker-, hinterwärts die eingedrückte Naht entlang flacher ahfallend, Schulterheulen und Seitenlappen krältig ausgebildet. Die Punktstreifen aus vorn runden grübchenartigen dicht gedrängten, hinterwärts in schmale Längsfurchen eingedrückten Punkten gebildet, die Zwischenrämme als breite flache, hinter den Schulterbeulen schunäler leistenlörmige Rippen enporgelıoben, dabei zicmlich gläuzent. Die Farbe bıau mit schmalem schwarzem Vordersamme. Das Pygidium deutlich punktirt, dünn greishaarig, hran; Unterseite und Beine etwas lıeller gellhbrau, die Vorderbrust viereckig, in der Vitte querwulstig und dahinter cingedrückt, mit schwach vortretenden Hinterecken. Das letzte Segment des $q$ mit einer grossen hallbkugeligen, am Rande gellogreis gewimperten frube, das ठ unbelamnt.

Von Paramaribo. Nus. Dohrn, von Hern Endrulat mitgetheilt. 
Siebente Rotte. Körper aus dem Walzenförmigen etwas verbreitert, von mässiger Grösse, mit dünnen, ziemlich langen Fühlern, rostroth mit weissgetropften Deckschilden. Die Punktstreifen regelmässig mit seitlicher Querrunzel. Eine artenarme, sich auch über die Antillen und Nordamerika ausdehnende Gruppe. (Liın. VI. 310. Zehnte Rotte; vergl. XII. 365.)

34. Cr. bis-septemguttatus m. Rostroth, die Ecken und zwei Hinterflecke des spiegelglatten Halsschildes nebst sieben Flecken der Flügeldecken $(2,2,2,1)$ weiss; die Punktstreifen selır derb mit rippenartig erhöhten glatten Zwischenräımen. L. $21 / 4{ }^{\prime \prime \prime}$; Br. $1 \frac{113}{3} "$.

Der rostrothen Varietät des nordamerikanischen $\mathrm{Cr}$. gullulatus Oliv. sehr nahe verwandt, und dessen Rotte in Südamerika vertreteıd, ausserdem auch an Färbung und Farbeıvertheilung dem unten folgenden $\mathrm{Cr}$. anceps Dej. nicht unähnlich, von welchem sich der Käfer aber sogleich durch die ganz abweichende Sculptur und die deutlich ausgepłägte Querrunzel auf den Flügeldecken uıterseheidet; bis jetzt die einzige, diese merkwürdige ursprünglich den Antillenarten eigenthümliche Bildung zeigende rein südamerikanisclse Art, zu welcher die Zukunft möglicherweise ılort noch eiue und die andere verwandte Art auffinden lassen wird. Der Kiopf flach, unterwärts etwas hervortretend, gläızend weissgell, eine lurze tief eingedrückte Stirnlinie und ein mit ihr zusanmenstossender Schı̈̈gfleck jederseits über den Fühlerwu'zeln rostgell, die breit aber nur seicht ausgebuchteten Angen schwarz. Die Fühler (des q) dünn und schlank, von $2 / 3$ der Körperlänge, das zweite Glied pilörmig, das dritte und vierte fast dreimal, das fïnfte fast viermal länger als das zweite, und die oberen dem fünften gleirh, dabei wenig zusammengedrückt und rerbreitert, mit kurz dreieckigem Fortsatze des Endgliedes. Die Farbe roströlhlich, die unteren filipder honiggelb durchscheinend, die oberen rauchgrau. Das Hakschild kurz, vorn mit der Hilfte äbergebogen und zugleich verschmälert, seitlich ülser den Vordereckeı deutlich zusammengedrüclit, die fein gerandeten Seiten dahin last in graden Linien zusammenlanfend; die Hintereclien kurz und breit zugespitzt, etwals aufgetrieben, der Ilinterrand jederseits hreit und seicht ausgehuchtet, mit kurzem doppelt ausgerandetem Mittelzipfel, vor dem letzteren ein kurzer tiefer Quereindruck. Die kamm punktirte Oberfläche spiegelglatt, rostroth; ein grösserer Flech in den Vorder- 
und ein kleinerer in den Hinterwinkeln, zwei unscheinbare Querfleckchen in der Mitte des Vorderrandes als Reste eines geschwundenen Vordersaums, und zwei nach vorı divergirende Schrägflecke vor dem Hinterrande weiss, schwach ins Gelbliche fallend. Das Schildchen läıglichdreieckig, stark ansteigend und hinten ku'z abgestutzt, vorn mit dem gewöhnlichen Grübchen, glinzend rostgelh. Die Deckschilde fast dreimal länger als das Halsschild, vor'n breiter als dieses und hinter einer schwachen Verengung über den schmal aber tief heralgezogenen Seitenlappen wieder stärker verbreitert, um das Schildchen etwas aufgeworfeı und hinter demselben läığ der Naht seicht eingedrückt, mit länglich höckerigen Schulterbeulen. Die Punktstreifen vorn sehr grob, zunächst der Wurzel in furchenartige Längslinien eingedrückt und dadurch die schmalen Zwischenräume rippenförmig emportreibend; von der Querrunzel ab die Zwischenräume breiter und flacher, die P'unktstreifen schwächer, die Querrunzel selbst sehr regelmässig, deutlich aufgetrieben, vor ihr die Vorderenden des sechsten und siehenten Streifens stark ausge rüagt und theilweise mit dem des achten zusammenfliessend; hinter der Runzel der fünfte Streifen etwas wellig, der achte deutlich, der sechste und siebente nur durch wenige und ungeordnete Punkte angedeutet. Die Farbe glänzend hell rostroth mil drei Paaren weisser Flecken und weisser Spitze; an der Wurzel ein schmaler Fleck hart am Schildchen, und ein grösserer linten durch die Vorderenden des dritten, vierten und fünften Streifens in vier ungleiche Lappen zerrissener Querfleck; dann vor der Mitte zwei grössere Flecke, der innere unregehnässig viereckige zunächst der Naht, der äussere grössere mit seinem rorderen Theile zugleich die Ruuzel einschliessende rom fünften bis zum Randstreifen ausgedehnt; das dritte Paar dem vorhergehenden ähnlich, alıer aus kileineren Flecken bestehend, grade auf der Wölhung; endlich noch die Spitze von einem rundlichen Quertlecke eingenommen. Das Pygidium deutlich punktirt und längskielig, hell rostroth, jederseits mit einem weissen Querflecke am Unterrande. Unterseite und Beine rostgelb, ler letzte Bauchring, die Vorderhüften und die Vorderbrust trüb weisslich, die Hinterenden der letzteren kurz und breit. Das letzte Segment des $q$ mil einer tiefen lalbliugeligen Grube, das $\delta$ unbekannt.

Aus Columbien. Nus. Saunders.

Ach te Rotte. Körper walzlich oder hinterwärts etwas ver- 
schmälert, die Fülıler ziemlich düın, von mässiger Länge; die Farbe braungelb oder rothgelb mit weisslicher Zeichnung der Flügeldecken und hinten zweiflechigem Halsschilde. Die Punktstreifen derb, hinten eingefurcht, der sechste und siebente gestört, zum Theil durch ein nicht erhöhtes Qnerfeld unterbrochen. Eine vorzugsweise mittel-amerikanische, mit einzelnen Arten sich nach dem südlichen Theile von Nordamerika und den Südküstenländern des CarailsenHeeres ausdehnende, so wie auffallender Weise auch in Chile rertretene Gruppe. Limn. VII. 1. und XII. 366. Eilfte Rotte.

35. Cr. anceps Dej. Oben braun, der Kopf, ein unterbrochener Vorder- und Seitenrand nelst zwei Hinterflecken des spiegelglatten Halsschildes, und drei unregehnässige Querbinden der Deckschilde gelb, unten braun- und gelbJjunt; die Punktstreifen derb, die Zwischenräume gewölht, gläızend, hinter der Schulterbeule durch eine Krümmung des achten Streifens gestört. L. $11 / 3-2$ "'; Br. $1-1 \frac{1}{1}{ }^{\prime \prime \prime}$.

Cr. anceps Dej. ap. Suffr. Lino. Ent. VII. S. 6. I. 51!

Von Caraccas, mir von Hru. Wagner mitgetheilt; ehen daher auch in Nus. Berol., Felix, Deyr., Lacord. Die Vaterlandsangabe: Brasitien, in dem letzteren beruht ohne Zweifel auf einer Verwechselung.

Die vorliegenden Stïcke sind von den von mir a. a. Orte beschriebenen cubanischen, bis auf das bei einigen etwas dunklere Gelb der Flecken, durchaus nicht alıweichend; das mir früher nicht heliannt gewordene ơ zeigt auf dem letzten Segmente einen schwachen, glänzenden Längseindruck.

36. Cr. $\{$ urbatus m. Oben gelb, ein gekrenzter Fleck des spiegelglalten Halsschildes und zwei unregrelmässige, unierhrochene Querhinden der Dechischilde rothbraun, unten gelb- und rothbraunbunt; die Punktstreifen mässig, der sechste und sieliente hinter den Schulterheulen abgerissen, der arlite winklig snterbrochen, die Zwischemräume flach, matt iner gerunzelt. L. I 1/3"'; Hr. 3/4"”.

Eine kleine und zierliche, nach Ilabitus und Zeichumg dem vorhergehenden nahe verwandte $\mathbf{A} t$, an den matten, dicht quer

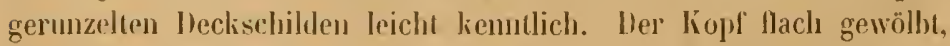
mit fein eingeschnittener, mnten in rinen hreiten llachen Eindrnck verlanfender Stirnlinie; das hopfschild quer rierechig, unten etwas eingezogen, oben durch eine deutliche Querkante ahgesetzt, ron einer äusserst feinen Kiellinie durchzogen. Dic Oberfläche lack- 
glänzend hellgelb, Kopfschildsränder, Mundtheile, Fühlcrhöcker und der Nacken verwaschen geröthet, der letztere zugleich ziemlich dicht und fein punktirt, welche Punkte sich unterwärts immer mehr rereinzelı. Die langgestreckten, sehr hreit ausgebuchteten Augen schwarz. Die Fühler nur unvollstäntig vorluanden; das Wurzelglied dreimal länger als breit, etwas gelirümmt; das zweite eiförmig, halb so breit und dreimal kürzer als das erste, die drei folgenden dünn verkehrt kegelförmig, von ilmen das dritte und vierte je doppelt länger als das zweite, das fünfte noch etwas verlängert, und diesem die noch vorhandenen beiden folgenden gleich, dabei schwach zusammengedrückt und verbreitert. Die Farbe bellgelb, die oberen von der Mitte des fünften ab mit ıauchgrauem Aufluge. Das Ifalsschild kurz, mit $3 / 4$ der Länge vorn stark übergekrümmt, über den stumpf rechtwinkligen Vorderecken breit zusammengedrückt und dadurch stark verschmälert, die Seiten feiı gerandet, nach vorı schräg abwïrts in fast graden Linien zusimmenlaufend, die scharfen Hinterecken kurz und breit rorgezogen, durch einen leichten Schrägeindruck etwas, aufgetrieben, der Hinterrand jederseits sehr flach ausgebuchtet, deutlich gesägt, mit sehr kurzem, schwach doppelt ausgerandetem Mittelzipfel. Vor diesem letzteren die Oberfliche zu beiden Seiten breit, und flach niedergedrückt, ausserdem daselbst längs dem Hinterrande ein kurzer, stärlierer Querendruck. Die Seitenflïchen selbst sehr steil abfallend, breit zusammengedrückt und tief herabgezogen. Die Oberfläche spiegelglänzend lıellgelb mit einer hell rothbraunen Zeichunng, welche sich aus der des Cr. anceps leicht erklärt, wemu man sich tlessen acht gelbe Halsschildsflecke (zwei am Vorder-, je zwei am Seitemrande und zwei Schrägflecke ror dem Hinterrande) so weit vergrüssert denkt, dass der dizwischen liegende dumklere Grund zu einer zierlicheı maschenförmigen Zeichnung, eigentlich zu drei durch eine verwaschene Querlinie durchlkreuzten Längsflecken zusammenschwindet, deren lieiner den Vorderrand erreicht, und deren mittlerer die seitlichen an Breite um das Doppelte übertrifit; dabei der ganze Hinterrand zart schwarz gesäunt. Das Schildchen so breit wie lang, hinterwärts etwas verschmälert und stumpf abgerundet, stark ansteigrnd, Hinterzipfel und Vordergrübchen dentlich; die Oberfläclse fein runzlig punktirt, braun. Die Deckschilde kurz und gedrungen walzenförmig, um die Hälfte lïnger als breit, hinter den Schultern noch ein wenig erweitert mod 
dann fast gleichbreit bis zur Spitze fortziehend, der Rücken nur flach gewölbt und hinterwärts sehr sanft abfallend; die Schulterbeulen kaum bemerkbar, auch die Seitenlappen nur von mässiger Ausbildung. Von den Punktstreifen der abgekürzte nur aus vier bis fünf Punkten hestehend, alie fünf folgenden mit ihrer grösseren Vorderhälfte regelmässig; hinter der Mlitte fliessen der zweite und dritte mittelst eines tief eingedrïckten, auch den ersten Streifen hart an die Naht Irängenden Grübchens zusammen und ziehen dann in einer tiefen Längsfurche bis zur Wölbung hin, wo lieselbe in einem hinteren, auch den vierten Streifen aufnehmenden Grübchen albricht. In einem dritten Grïbchen, dem ersthezeichneten gegenüber, endet dann auclı der fünfte Streifen; der sechste bis achte Jrechen balı hinter der Schulterbeule ab, und zwar zuerst der achte, dann der siebente und zuletzt der sechste, der letztere reicht fast bis zur Mitte, und zeigt neben seinem Hinterende noch einen vereinzelten, augenscheinlich das abgerissene Ende des siebenten lijkenden Punkt, welcher hier ein aus dem Zusammen\|liessen des sechsten und siehenten Zwischenraumes entstandenes, seitlich sich an den neunten Streilen anschliessendes Feld abschliesst. Ilinterwärts setzt sich der sechste Streifen wieder vom hinteren Ende des lünften ab fort und ist in einer Längsfurche bis zur Wölbung kemntlich, das Eude des siehenten fehlt von dem bezeichneten Einzelpunkte ab ganz, und dadurch bildet sich hier ein zweites länglich viereckiges Felı, welches nach aussen durch den sich rou jenem Punkle ab wieder regelmässig fortsetzenden achten Streifen geschlossen wird. Auch das Ilinternde dieses, wie des ganz regelrecht verlaufenden neunten Streifens sinl furchenartig eingedrüclit, und den Endgrübrhen des fünften Streifens gegenüher der nemte durch ein äluliches Grühchen unterbrochen. Dahei ist die ganze Olrerfläche durch dichte und feine Quermanzeh malt: die Zwischenüame vorn llach, hinterwïrts lach gewölbl, gegen das Encle etwas glänzender unl ripjuenförmig. Die Farle hellgell, das Innere der Punkte, Grühchen und Hinterfurchen rothbraun, unıl dadurch bihlen sich nehen den durch die P'unkte entstandenen rothen Längslinion noch zwei unregelmïssig wellige Querhinden, deren hintere anf deın letzlen Invittel die Grübchen am Zısimmentreflen des zweitrn und driltan, am knte des fünften Streifens und anf denu ueuntru Zwischenraune verbiodet, während die rordere selır schräg nach hinten zichende ron der Schulterbeule 
aus zuerst als Schrägwisch die Vorderenden des seclısten bis achten Streifens bedeckt, und dann den fünften und vierten Streileı durchsetzend in dem Grübchen am Auslaufen des zweiten und dritten endet. Das Pygirlimm runzlig punktirt, gelh mit bräunlichem Rande, die Unterseite braunroth, der letzte Bauchring, die verwaschenen Seiten des vorhergehenden, und der Mittelzipfel des ersten mit den Schulterblättern, der Mittel- und Vorderbrust gell. Letztere vorn der Länge nach sclıwach aufgewulstet mil kauni vorgezogenem Rande, hinten niedergedrückt, breit ansgesclnitten mit scharf dreieckigen Hinterenden. Hüften und Beine gleichfalls gall, die Schenkel in der Mitte verwaschen bräunlich geringelt, auch die Schienenkauten bräınlich angelaufen, die Krallenhälichen brauı. Das letzte Segment des 오 mil einer grossen giliuzenden, im Inuerı gleichfalls gebräunten Grube; das ठ unbekannt.

Aus Chile. Mus. Deyrolle.

37. Cr. silaceus m. Knochengelb mit schwarzen Fühlerenden, der Saum der Flügeldecken gebräunt; das Halsschild spiegelglat, die Punlitstreifen derl, auf dem Rücken praarweise geuähert, der sechste abgekïrzt und der sielıente fehlend, mit llachgewölbten glänzenden Zwischen'äumen. L. $13 / 4{ }^{\prime \prime \prime}$; Br. $1 \frac{1}{3}{ }^{\prime \prime \prime}$.

Dem Mexicanischen Cr. saginatus (Limn. VII. S. 19. n. 58) sehr älınlich, aber etwas länger, bis auf die gebräunten Punktstreifen einfarbig gelh, und durch die Sculptur sehr leicht von jener Art zu unterscheiden. Der Kopt' flach und etwas uneben, die Stirn ınit kurzer aber tiefer Längslinie, das liopfschld etwas eingezogen, ohen durch eine unterbruchene Querlinie nur undeutlich algesetzt. Die Oberlläche lackglänzend gell, auf der Stirn mit einigen zerstreuten aher deutlichen Punkten besetzt, die Kimbackenspitzen gebräunt, die langgestreckten, breit und tief ausgebuchteten Angen schwarz. Die Fülıler (đles ठ) von $2 / 3$ der Körperlänge, selır düıı, das Wurzelglied stark nach aussen gekrüumt, etwa dreimal so lang: als oben breit, das zweite kuz elliptisch, das dritte doppelt-, das vierte $2^{1}$ mal so lang als das zweite, das fünfte dreimal länger, das sechste dem vierten, und die oberen wieder dem fünften gleich, dabei vom sechsten ab zusammengedrückt und mässig erweitert, mit schmal dreieckigem Fortsatze des fast linealischen Endglieles. Die Farbe der unteren hell knochengelb, die ohere Hälfte ıles fünften verwaschen gebıäunt, die übrigen schwarz mit dünner greiser 
Behaarung. Das Halsschild um die Hälfte länger als breit, von der Mitte ab nach vorn und hinten gleichmässig sanft abwärts gekrümmt, über den rechtwinliligen, ziemlich tief eingezogenen Vorderecken zusammengedrückit und dadı'ch verschmälert; die Seiten fein gerandel, nach vorn in flachen Bogen zusammengeneigt; die Hinterecken scharf, kurz und breit vorgezogen, durch einen leichten Eindruck etwas aufgetrieben, der Hinterrand jederseits breit ausgeluchtet, mit kurzem, ziemlich schmalem, doppelt ausgerandetem Mittelzijfel; ror diesem jederseits ein gleiclffalls kurzer, aber deutlicher Schrägeindruck. Die Oherflïche spiegelgläızend knochengelb, mit zart schwarzem Hintersaume. Das Schildcheı stark schräg ansteigend, gestreckt dreieckig mit stumpfem Hinterende, fast $2 / 3$ länger als breit, das Vordergrübchen deutlich, die Farbe ein glänzendes Gelb, mit dunkelm, vorn etwas stärker geschwärztem Saume. Die Declischilde etwa $1 / 3$ länger als breit, flach walzenförmig und hinterwärts etwas verschmälert, um die Schildchenspitze und jederseits derselben sehr schwach querwulstig erhölıt, von da ab nach vorn und noch schwächer hinterwär's allmählich herabgesenlit; die länglichen Schulterheulen innerseits nur durch das tiefer eingedrückte Vorderende des lünften Streilens abgesetzı, die Seitenlappen mässig, und ülıer ilıen ein breiter, flacher Quereindruck. Die Punktstreifen sehı regelmässig, ihrer ganzen Länge nach in seitlich und hintrrwärts tiefere Längsfurchen eingedrüclit, der erste und zweile, und dann wieder der dritte und rierte einander mehr genïhert, rom sechsten nur pin kurzes Vorderende vorhanden, der siebente ganz fehlent und nur durch eine entsprechende VerbreiIerung der Furche des achten angedleutet; anch der neunte über dem Seitenlappen etwas erweitert. Die Zwischenräune vorn flacher-, hinten stärker gewölh, die spitlichen fast rippentörmig, alle lackglänzend linochengell, mit einer äusserst feinen und vereinzelten Punktirung bestrent. [as Innere der Prunlis, ein leichter Wisch auf dre Schulterbeule, und des Saum ron dem imgeschlagenen, mit einer Reihe grölwerer Punkte beseizten Rande des Seitenlappens leicht geduäunt. Pygidium und Unterseite hell linochengell, die Beine, besunders die Nitle der Schenliel und Schienen, ptwas dunliler. Das Prostermum in der Mitte flach längswubtig, Welcher Wulst sich hinterwärts gahelt und hier eine dreieckige niederyedrüclite Strlle einschliesst, die Hinterenden dreieckig rorgezogen und scharl zugespitzt. Das letzle Segment 
des $\delta$ mit einem flachen elliptischen Quereindruck; das $\&$ unbekannt.

Von Bogotà. (Mus. Berol., von Goudot mitgetheilt.)

Neunte Rot te. Körper gedrungen walzlich, braun- und gelbbunt, mit ziemlich dünnen, mässig langen Fühlern. Die Punkte der Streifen auf den Deckschilden vorn vereinzelt, gr'oss und gr'übchenartig, auf der hintereı Hälfte in seichte Furchen eingedrückt, der sechste und siebente Streifen gestört, doch ohne liervortretendes Querfeld. Gleichfalls eine mittelamerikanische, aber, wie die vorhergehende, auch am Südrande des Caraibischen Meeres und in Chile vertretene Form. Limn. VII. 30. und XII. 369. Zwölfte Rotte.

38. Cr. cordatus m. Oben gelb mil schwarzen Fühlerenden, ein herzförmiger Mittelfleck und zwei seitliche Kreuzflecke des spiegelglatten Halsschildes mit dem Schildchen und zwei welligen Querbinden der Deckschilde braun oth, unten braun- und gelb) bunt; die Punktstreifen derb, hinten furchig eingedrückt, der sechste und siebente abgeliürzt, mit flach gewölbten, ziemlich glänzenden Zwischenräumen. L. $23 / 4 " \prime$; Br. $1 \frac{1}{2}{ }^{\prime \prime \prime}$.

Von durchaus mittelamerikanischem Habitus, von den verwandten aber an der sehr eigenthümlichen Zeichnung des Halsschildes leicht zu unterscheiden, wesshalb dem Käfer auch von seinem Entdecker Moritz der an sich ganz jassende, aber dem älteren $\mathrm{Cr}$. cordiger Lin. gegenüber nicht zulässige Name $\mathrm{Cr}$. cordiger ertheilt worden war. Der Kopf sehr flach gewölbt mit etwas eingezogenem Kopfschilde; letzteres oben durch eine feine Querlinie, seitlich durch schärfere Kanten abgesetzı, die Stirn mit einer unterwärts abgeküızten Längslinie. Die Oberfläche deutlich aber zer'streut punktirt, mässig glänzend; die Farbe hochgelb, die Ränder des Kiopfschildes mit der Stirnlinie, den Fühlerhı̈ckerı und den Nundtheilen braunroth, die langgestrechten, breit alser nicht tief ausgebuchteten Angen schwarz. Die Fühler (les ㅇ) sehr düın und zart, kaum von laalber Körperlänge; das Wurzelglied schlank, etwas abgeflaclıt, etwa $2 \frac{1}{2}$ mal länger als breit, das zweite kurz und breit, fast kugelig, rlie drei folgenden verkelırtkegelförmig, von ilmen das dritte und vierte gleichlang und je un die Hälfte länger als das zweite, das fünfte oben schon ein wenig rerbreitert, doppelt länger als das zweite, die oberen wieler etwa dem vierten gleich, auch nur schivach zusammengedrückt und erweitert, mit kurz dreieckiXV. 
gem Fortsatze des Endgliedes. Die Farbe der fünf unteren gelb mit gehrämnter Spitze des fïnften, die oberen schwarz mit feiner angedrückter greiser Behaarung und längeren abstehenden weissen Wimpern. Das Halsschild etwa dopjelt breiter als lang, vorn mit der grösseren Hälfte mässig übergewölht, auch hinten sanft abwärts gekrümmt, die rechtwinkligen Vorderecken stark eingezogen und dadurch das Halsschild verschmälert; die Seiten fein gerandet, hinten fast grade, mit dem vorderen Drittel in starker Krümmung zusammenlaufend; die kurz und breit zugeschärften Hinterecken durch einen deutlichen Schrägeindruck aufgetrieben, der Hinterrand jederseits zienılichı tief ausgebuchtet, seiner ganzen Länge nach eingesenkt, mit kurzem breitem doppelt ausgerandetem Mittelzipfel. Die Oherfläche spiegelglatt, die Färbung und Zeichnung den verwandten Arten analog, aber durch das Umsichgreifen der bei jenen vorhandenen gelben Rand- und Hinterflecken soweit aufgelöst, dass von der ursprünglichen braunrothen Färbung nur noch eine gewissermaassen netzartige Zeichnuing ülırig geblieben ist. Diese bildet zumächst auf der llitte einen ziemlich grossen herzförmigen Fleck, welcher hinten mit einem zarten Zipfel den Rand berührt und von seinen Seitenzipfeln eine gleichfalls nu' zarte dunkle Querlinie bis zur Mitte des Seitenrandes aussendet. Jede dieser Querlinien wird dann noch in ihrer Mitte von einer etwas kräftigeren, auf dem. Hinterrande aufstehenden Längslinie durchschuitten, und dadurch entsteht jederseits des Mittelfleclis ein braumrother Kreuzfleck, so dass die inneren Hinterwinkel dieser Kreuzflecke augenscheinlich durch die beiden, bei den verwandten Arten vor lem Hinterrande liegenden hellen Schrägflecke gelildet werden. Dazu ist noch der ganze Ilinterrand zart schwarz gesäumt. Das Schildchen breit dreieckig, hinterwärts mit auswï'ts gekrümmten Seiten verschmälert und kur'z abgestutzt, wenig linger als breit, mässig ansteigend mit kräftigem Vordergrübchın, glänzend braunroth mit verwaschen hellerer Mitte. Die Deckschilde breit und flach walzenförmig, um die Hälfte länger als breit, hinter den Schultern noch etwas erweitert und ،lann hinterwärts in flachem Bogen zugerundet, längs der Wurzel nur schwach niedergesenkt, auch die flachen und länglicheı Sclıulterbeulen innerseits nur durch einen kurzen, seichten Eindruck abgesetzt ; die Scitenlapısen ziemlich breit mit gleichfalls breitem umgeschlagenen Rande, üher ihnen die Dechschilde leicht quer zusammengedrückt. Die Punktstreifen vorn ats vereinzelten groben 
Punkten gebildet, auf der hinteren Hälfte und der neunte schon vom Seitenlappen an in schmale, aber tiefe Längsfurchıen eingedrückt, der sechste und siebente an dem Eindrucke hinter der Schulterbeule alggerissen, so dass dadurch hier zwischen dem fünften und achten Streifen ein hinten nur durch einen vereinzelten Punkit geschlossenes Längsfeld gebildet wird; auch der achte Streifen an jener Stelle durch Verwerfung gestört, jerloch ohıe dass dadurch ein deutliches Querfeld zu Stande käme, wiewohl der Ansatz zu einem solchen zuweilen vorhanden ist. Die Zwischenräume auf der vorderen Hälfte flach und glänzend, auf der hinteren und nach aussen flach gewölbt, und mehr oder weniger deutlich querrunzlig. Die Farbe hellgelb, ein die ganze Flügreldecke einschliesslich des umgeschlagenen Raudes vom Seitenlappen umziehender Saum braunroth, und dieselbe Färbung zeigt ausserdem nicht allein das Innere aller Punkte, wodurch bei deren $\mathrm{Zu}$ sammenrücken auf der hinteren Hälfte die Längsfurchen zugleich zu dunkeln Längslinien werden, sondern auch eine zweifache wellig begränzte, etwas schräg von vorn und aussen uach hinten und innen ziehende Querbinde; die vordere von der Schulterbeule aus nach dem ersten Sechstel der Naht gerichtet, wo letztere von einem schwachen Reste des vom Seitenlappen heraufielıenden Eindrucks durchschnitten wird; die hintere in der Mitte, auf dem dritten Zivischeuraume sich nach vorn hin unregelmaissig erweiternd, und hier bei einem Stũcke auf der linken Flügeldecke mit einem schmalen Zipfel die vordere berülırend, übrigens beide an den Rändern zerrissen und stellenweise selbst unterbrochen. Das Pygidium fein runzlig punktirt, kurz aber dicht weisslich behaart, gelb; die Unterseite bräunlich gelb, ein seitlicher Querfleck auf jedem Bauchringe, der breite Mittelzipfel des ersten Ringes und die Mitte der Hinterbrust verwaschen heller gelbliclı; Schulterblätter, Mittel- und Vorderbrust reiner gelb mit gebräunten Säumen. Die Beine braunroth mit gelben Schenkelspitzen; die Wurzeln von Schenkeln und Schienen mit den Innenseiten der letzteren verwaschen bräunlich gells. Das Prosternum flach gewölbt mit stark dornig vortretenden Hinterzipfeln; das letzte Segment des $q$ mit einer lalbkugeligen, im Inneren glänzenden und braunrothen Grube; das $\delta$ unbekannt.

Von Aragua. (Mus. Berol., von Moritz mitgebraclit.)

39. Cr. consentaneus Dej. Braun, der Kopf, der unter- 
brochene Seitenrand des spiegelglatten Halsschildes und vier Flecke der Flügeldecken $(1,2,1)$ mit den Schenkelspitzen gelb; der sechste und siebente Punktstreifen hinter der Schulterbeule ahgerissen, der achte winklig gebogen, mit flachgewölbten, glänzenden Zwischenräumen. L. $2 \frac{2}{3} " \prime ; 1 \frac{1}{4}{ }^{\prime \prime \prime}$.

Eine habituell und in der Zeichnung des Halsschildes dem Cr. anceps uicht unähnliche, an der Sculptur und Fleckenvertheilung der Deckschilde aber von demselben leicht zu unterscheidende Art. Der Kopf flach gewölbt mil tief eingeschnittener Stirnlinie, das Kopfschild etwas eingezogen, kurz und breit, äusserst fein längskielig, oben durch eine flach convexe Kante begränzt. Die Oberfläche zerstreut punktirt, mässig glänzend, hellgelb, das Kopfschild und die Fühlerhöcker gehräunt, die Kimbacken und die langgestreckten breit dreieckig ausgebuchteten Augen schwarz. Die Fühler bei den mir vorliegenden $q$ Stücken nicht mehr vollstäıdig vorhanden, aher anscheinend etwa von halber Körperlänge, das Wurzelglied nach ohen mässig verdickt, etwa $2 \frac{1}{2} \mathrm{mal}$ so lang als breit, das zweite eiförmig, dreimal kürzer und dümmer als das erste, die Arei folgenden dünn verkehrthegelförmig, das dritte doppelt-, das vierte $2 \frac{1}{4} \mathrm{mal}$, das fünfte $2 \frac{1}{2}$ mal lïnger als das zweite, das sechste etwa den vierten, das siebente und achte wieder den fünflen gleich. Die fünf unteren hıll durchscheinend honiggelb, das sechste und siebente oben rauchigrau angeflogen, welcher Anflug sich bei dem achten zum Schwärzlichen verdichtet; die fehlenden obejen walırscheinlich ganz schwarz. I)as Halsschild mit sanft gelirümmter Mittelfirste nach vorn und hinten gleichmässig abwärts geneigt, vorı über den scharf rechtwinkligen Vorderecken breit zusammengedrückt und dadurch verschmälert, die Seiten tief herabgezogen, fein gerandel, in der Mitte leicht im Bogen erweitert und dann uach rom stark zusammengekrümmt; die Hinterecken kurz mul breit zugeschäıft, fast rechıtwinklig, der Hinterrand jederseits flach ausgebuchtet, tief eingesenlit, mit undentlich toppelt ausgerandetem Mittelzipfel; vor letzterem auf beiden Sciten ein leichter an den Hinterrand gelehnter Schrägeindruck, ein zweiter breiterer aber schwächerer ïher der Vitte des Seitenrandes, und von cinem dritten ror den Hinterwinkeln noch eine sclıwache Spur. Die Oherfläche äusserst fein und zerstrent punktirt, mit spieyelglänzendem Zwischengrumde, dunkellorimu, Vorder- und Sritenrand hreit gell, aher diese Firloung an den Sciten durch eine feine von dem Mit- 
telfelde ausgehende Querlinie, vorn durch einen grössereu Zwischenraum in je zwei grosse Flecke getheilt, und dann vor den Hiıterrande jederseits noch ein breit eiförmiger zugespitzter Schrägfleck von gleicher Färbung; dazu ein feiner Hintersarmm schwar'z. Das Schildchen schmal dreieckig, um die Hälfte läıger als breit, schräg ansteigend und hinten kurz abgestutzt, das deutliche Vordergrülschen von zwei feinen Querbeulen eingeschlossen, die Farbe glänzend braun. Die Deckschilde walzenförmig, um die IIälfte länger als breit, hinter den Schultern wenig verbreitert und dann linterwärts in gleicher Breite bis zu der kurz abgerundeten Spitze fortlaufend; der Rücken hinter der Wurzel leicht quer eingedrückt, vom Schildchen ab die Naht entlang schr sanft abwärts gekrïnmt, die Schulterbeulen und Seitenlappen wenig bemerkbar. Die Punktstreifen auf der grösseren Vorderhälfte aus sehr vereinzelten grossen grübchenartigen Punkten gebildet, deren Zwischenräume nur sehr flach gewölht sind; die letzten zwei Fünftel der Streifen feiner, aber in deutliche, die schnäleren Zwischenrïume rippenförnigg auftreibende Furchen eingedrïckt, der sechste hinter der Schulterbeule durch zwei his drei, der siebente meist nur durch einen einzigen Punkt angedeutet, der aclıte aus gradem Vorderrande schräg un die Hinterenden der beiden abgerissenen Streifen nach dem fünften zulaufend uıd danı vieder in einer gekrümmten Schräglinie in seine ursprüngliche Richtnng zurüchlaufend, wodurch sich der achte Zwischenraum nach innen zu dreieckig erweitcrt; auch der fünfte Streifen bei einem Stüclie auf der Wölbung derartig unterhrochen, dass sein hinteres Ende nach der Analogie anderer Arten eigentlich als las liier wieder zum Vorschein kommende Ende des sechsten Streifens angesehen werden müsste. Die Farbe dunkelbraun nuit schmal schıvarz gesäumter Wurzel, und vier grossen getben Flecken auf jeder Flügeldecke; vorn ein mit dem äusseren Ende sich hakenförmig lïngs der Wurzel hinziehender Längsfleck am Schildchen, damı auf der Mitte zwei Flecke noben einander, der innere kleinere eiförmig, ron der Naht lis zum dritten I'ınktstreifen oder etwas über ihı hinausreichend, ıler äussere grössere rom fünften Streifeu bis zum Seitenrande, und hier mit schmalem den Seitenlappen mit begreifendem Vorderarme bis zur Schulter ausgedehnt, endlich cin ankerförmiger Bogenfleck vor der Spitze auf dem zusammenfliessenden hinteren Theile des zweiten und achten Zwischenraumes, in dessen Bogen sich auf den drei 
darin auslaufenden Zwischenräumen, dem dritten, vierten und dem zusammenfallenden fünften bis siebenten, je eine abgekürzte gelbe Längslinie zeigt. Eine ähnliche grössere liegt auf dem neunten Zwischenraune neben dem äusseren Arme des Ankerfleckes; zuweilen ist auch noch das Aussenende des Schildchenfleckes als ein vereinzelter gelber Punkt abgerissen (hei einem der vorliegenden Stücke auf der rechten, bei einem anderen auf der linken Flügeldecke), oder es kommt auch wohl sonst noch irgendwo ein verwaschenes gelbes Pünktchen zum Vorschein. Das Pygidiun runzlig punktirt, gelb; der Rand und eine, die Mitte durchziehende Kiellinie braun. Die Unterseite braun, die Seiten der Bauchringe jede mit einem verwaschenen gelben Querflecke gezeichnet, der aber eigentlich nur auf dem letzten Ringe deutlich ins Auge fällt. Auch der breite Mittelzipfel des ersten Bauchringes und die Schulterblätter, besonders deren Ende, fallen ins verwaschen Gelbliche; Mittel- und Vorderbrust sind hellgelb mit braunen Rändern, die letzteren dabei vorn in einen kurzen schwieligen Zipfel ausgezogen, hiuten breit zweilappig. Die Beine braun mit gelben Hüften und Schenkelspitzen, auch die Schenkelwurzeln trüb gelblich durchscheinend. Das letzte Segment des $q$ mit einer grossen, runden Grube; das ơ unbekannt.

Von Carthagena (Mus. Deyrolle) und aus Bolivia (Mus. Berol.).

40. Cr. topiarius m. Oben gelb, eine gelappte Zeichnung des narbig punktirten Halsschildes und zwei unterbrochene wellige Querbinden der Deckschilde rostbraun, unten braun, die Vorderund Mittelbrust mit den Beinen gelb; die Zwischenräume flach gewöllt, gläuzend, die beiden äusseren in ihrer ganzen Länge rippenförmig. L. $3-3 \frac{1}{2}{ }^{\prime \prime \prime} ; \mathrm{Br}$. $1 \frac{1 / 3}{3}-13 / 4$."

Cr. picturatus Boh. Fregal. Eugenies resa. Col. p. 156. n. 325 !

In der Färbuıg und Farbenvertheilung dem Mexicanischen Cr. irroratus nicht unähnlich aber viel gestreckter, auf der Oberseite mehr gelb, und ausserdem von jenem leicht an den viel schwächeren Querbrüchen auf der Vorderhälfte der Deckschilde und den ganz durchlaufenden beiden ãusseren Zwischenräumen zu unterscheiden. Der Kopf flach gewölbt mit deutlicher Stirnlinie, das querviereclige Kopfschild tief eingezogen und zugleich sanft eingedrückt, oben durch eine scharfe liante hegräızt. Die Pıuktirung deutlich, nach denı Nacken zu dichter gedlängt und stellenweise zu Jängsrunzelı 
verfliessend, in den breit zugerundeten Buchten der langgestreckten Augen schwächer. Die Farbe lackglänzend gelb, Kopfschild, FühJerhöcker und die Mitte der Stirn verwaschen gebräunt, die letztere bei dem $\delta$ in stärkerer Ausdehnung. Die gestreckten Fühler bei dem $\delta$ von $3 / 4$ der Körperlänge, bei dem $q$ etwas küızer, das IVurzelglied nach aussen bauchig aufgetrieben, stark gekrümmn, etwa doppelt länger als breit, das zweite kantig, nicht so lang wie breit, die drei folgenden verkehrtkegelförmig, allmählich an Länge zunehmend, so dass das dritte reichlich doppelt-, das vierte dreimal so lang ist wie das zweite, und das fünfte dem Wurzelgliede gleich kommt; diesem letzteren auch im Ganzeu die folgenden Glieder gleich, die oberen kaum merklich verkürzt, so dass das zehute (kürzeste) doch noch etwas länger ist als das vierte, und von dem Endgliede mit seinem kurzen, kegelförmigen Fortsatze noch etwas übertroffen wird. Die oberen Glieder vom sechsten ab schwach zusammengedrückt, kaum erweitert; die Farbe schmutzig gelbgreis mit schwärzlichem Anfluge der oberen. Das Halsschild breit und flach walzenförmig mit schwach aufwärts gebogener Mittelfirste, voru über den scharf stumpfwinkligen Vorderecken zusammengedrückt und dadurch verschmälert, die fein gerandeten Seiten lang herabgezogen, nach vorn mit breiter Krümmung convergirend, die scharfen Hinterecken kurz und Jreit vorgezogen, durch einen kurzen Schrägeindruck etwas aufgetrieben; der Hinterrand jederseits wellig gebuchtet, vor den Schultern tiefer ausgeschnitten und eingesenkt; der kuze Mittelzipfel deutlich doppelt ausgerandet, vor ihm zu beiden Seiten ein kurzer tiefer Schrägeindruck, und noch ein breiterer Quereindruck über der Mitte des Seitenrandes. Die Oberfläche deutlich aber nicht tief narbig punktirt mit lackglänzendem Zwischengrunde; die Farbe dunkelrothbraun, ein verwaschener Vorderrand, ein breiterer in der Mitte durch einen von dem Mittelfelde ausgehenden Querzipfel getheilter Seitenrand, und zwei grosse längliche, etwas gekrümmte Schrägflecke vor dem Hinterrande hellgelb. Das Schildchen stark ansteigend, wenig länger als breit, hinten mit abgerundeten Ecken abgestutzt, mit deutlichem Vordergrübchen und Hinterzipfel, die Farbe gleichfalls dunkelrothbraun. Die Deckschilde gestreckt walzenförmig, un die Hälfte länger als breit, etwas breiter als das Halsschild, die Wurzel sanft niedergesenkt, der Rücken nur llach gewölbt, hinter den flachen Schulterbeulen auch nur schwaçı zusammengedrückt, die Seiten- 
lappen eben so schwach ausgebildet. Die Punktstreifen im Ganzen regelmässig, hinter den Schulterbeulen etwas gestört, vorn aus grohen rundlichen durch deutliche Querbrücken getrennten Grübchen bestehend, auf dem letzten Drittel in tiefe, durch kräftige aber flach gedrückte Längsrippen getrennte Furchen eirgedrückt; die beiden äussersten dieser Rippen reichen vorn bis zur Wurzel hinauf, während die mittleren durch das Zusammenfliessen mehrerer Zwischenräume gebildet werden. Durch eine Unterbrechung des siebenten und achten Streifens über dem Seitenlappen bildet sich hier eine grössere punktfreie Stelle, ohne dass jedoch dadurch eigentlich ein erhöhtes Feld entstände. Die Farbe glänzend lehmgelb, der Saum von Wurzel und Naht, ein Längswisch auf der Schulterbeule, und das Innere der Grübchen, so wie der hinteren Längsfurchen rothbraun, wodurch hinten dunklere den Furchen folgende Längslinien entstehen. Eben so bilden sich weiter nach vorn durch das Ueberfliessen der Grübchenfärbung zwei unterbrochene, aus grossen unregelmässigen Flechen zusammengesetzte Querbinden, deren Intensität sich jedoch bei den einzelnen Stücken in selır verschiedener Weise, bis zum fast gänzlichen Verschwinden dieser Binden, gestaltet; und bei dunkleren Stücken ist dann auch noch wohl der ganze umgeschlagene Rand des Seitenlappens braun. Das Pygidinm grob runzlig punktirt, längskielig, dünn greishaarig, rothbraun mit einem grossen verwaschenen gelben Längsflecke jederseils neben dem abgeschwächten Encle des Längskiels. Auch die Unterseite mit den Beinen rothbraun, der breite Mittelzipfel des ersten Bauchringes, das Prosterımm mit den Vorderhüften, die Schulterblätter und die Innenkanten der Schenkel heller gelb. Das Prosteruum hinten tief eingedrïckt und in zwei breit aber scharl dreieckige Zipfel auslaufend, das letzte Segment des $\delta$ mit einem leichten rundlichen Eindruck, des $\$$ mit einer tiefen halblingeligen glänzenden Grube.

Aus Chile, von Herrn Deyrolle unter dem Namen Cr. Duboisii Chv. mitgetheilt. Auch im Mus. Holm. (von Puna) als $\mathrm{Cr}$. picturatus Boh. zum Vergleich erhalten, welcher Name wegen des älteren $\mathrm{Cr}$. picturatus Germ. ans Nordamerilia nicht beibehalten werden konnte.

Zehnte Rotte. Körper ziemlich walzenförmig, hinter den Schultern durch einen melır oder weniger starken Quereindruck eingeschnürt und dann wieder etwas erweitert. Die Fühler lang und 
dnnn, die Punktstreifen fein, seitlich ohne Querrunzel oder Querfeld, dafür durch den Qnereindruck gestört. Farbe heller oder dunkler braun, mit hell gefleckten, bei den verschiedenen Arten sehr übereinstimmend gezeichneten Deckschilden. Eine Mittelamerikanische und von da aus nach der Nordküste von Südamerika sich ausdehnende Form, von der die in Brasilien vorkommende Art nur habituelle Abweichungen zeigt. Vergl. Linn. Ent. VII. S. 40. Vierzelonte Rotte.

41. Cr. praeposterus m. Oben braun, Kopf, Vorder- und Seitenrand mit zwei Hinterflecken des spiegelglatten Halsschildes und vier Flecken der Flügeldecken $(1,2,1)$ nebst dem Pygidium hellgelb, unten rothgelb; die Punktstreifen fein, mit flachen glänzenden Zwischenräumen. L. $1 \frac{113}{{ }^{\prime \prime}}$; Br. $5 / 6{ }^{\prime \prime}$.

Im Habitus gleicht diese Art ungleich mehr den Arten der vorhergehenden vierten Rotte, und zeigt namentlich eine grosse Uebereinstimmung mit dem dort beschriehenen ('r. apocryphus und laesus; die Sculptur der Deckschilde aber und die allgemeine Farbenvertheilnng bringt sie unverkennbar in die Nähe der folgenden Art und ihrer mittelamerikanischen Verwandten, mit denen sie daher vorläufig als eine etwas abweichende Form verbunden bleiben mag. Der Kopf flach mit deutlicher Stirnrimı, spiegelglatt, hellgelb; das etwas mattere Kopfscliild ein wenig eingezogen und oben durch eine feine aber deutliche Querkante abgesetzt; die Mundtheile röthlich gelb, die langgestreckten, breit und ziemlich tief ausgebucliteten, obeı (bei dem ठ) zusammenstossenden Augen schwarz. Die Fühler fast von Körperlänge, dünn und fadenförmig, das erste Glied über der Mitte wenig verbreitert, kaum $2 \frac{1}{2}$ mal länger als breit, das zweite kurz eiförmig, die drei folgenden fast stielrund, kaum verkehrtkegelförmig, davon das dritte fast doppelt länger als das zweite, das vierte noch etwas grösser, und das fünfte noch um die Hälfte länger als das vierte, das sechste und siebente je den fünften gleich, die folgenden wieder etwas kürzer, aher auch dlas zehnte noch länger als dlas vierte; die oberen vom sechsten ab wenig erweitert und zusammengedrückt, das linealisclıe Endglied mit seinem kurz dreieckigen Fortsatze wieder dem fünften gleich. Die Farhe hellgelb, mit langer greiser Behaarung der oberen Glieder. Das kurze und breite Halsschild vorı mit seiner grösseren Hälfte hoch buckelig übergewölbt, ülıer den eingezogenen scharf rechtwinkeligen Vorderecken stark zusammengedrückt und dadurclı 
verschmälert; die Seiten fein gerandet, nach vorn fast in graden Linien zusammengeneigt; die kurzen und breiten Hinterecken scharf vorgezogen, der Hinterrand jederseits tief ausgebuchtet und zunächst an den Schulterbeulen eingesenkt, mit kurzem, breitem fast grade abgeschnittenem Mittelzipfel; vor diesem auf jeder Seite ein leichter Quereindruck. Die Oberfläche spiegelglatt, mit sehr vereinzelten und unregelmässig vertheilten Pünktchen bestreut; die Farbe dunkelbraun, Vorder- und Seitenrand loreit hellgelb, letzterer in der Mitte durch einen schmalen, und im Vorderwinkel durch einen breiteren Einschnitt je in zwei halbrunde Lappen getheilt, wodurch die gesammte Randzeichnung als aus fünf theilweise verbundenen Flecken zusammengeflossen erscheint; ausserdem noch hinten jederseits des Mittelzipfels ein grosser, eiförmiger Schrägfleck. Das Schildchen stark ansteigend, dreieckig, etwas länger als breit und hinten kurz abgestutzt, mit deutlichem Vordergrübchen, glänzend braun. Die Deckschilde um $1 / 4$ länger als lreit, hinter den Schultern nur wenig erweitert, dann hinterwärts mit sanfter Rundung verschmälert und dadurch den breit elliptischen Umriss des Körpers abschliessend, längs der Wurzel schwach niedergedrückt und von der Schildchenspitze ab allmählich zur Wölbung abwärts gekrümmt; die grossen aber ziemlich flachen Schulterbeulen innerseits durch einen breiten und tiefen Eindruck abgesetzt, die Seitenlappen schwach, mit lireit umgeschlagenem Rande. Die Punktstreifen fein und hinterwärts noch schwächer, die oberen regelmässig, der sechste und siebente durch den vom Seitenlappen lieraufziehenden Quereindruck unterbrochen, der achte an dieser Stelle einwärts gekrümmı unı ıladurch den achten Zwischenraum buchtig, doch ohne Bildung eincs erhöhten Querfelıles, erweiternd. Die flachen Zwischenräume glatt und mässig gläızend, bei starkel Vergrösserung mit sehr vereinzelten Pünkichen bestreut. Die Farhe gleichfalls braun mit vier gelben Flecken, der erste an der Wurzel und nur klein, zwischen dem vierteı und fünften Punktstreifen; danı zwei auf der Mitte neben einander, der innere rundlich, zwischen dem ersten und dritten Streifen nnd jeden derselben ein wenig überschreitend, der ̈̈ussere etwas längliche nach vorn und anss'n gerichtet, vom fünften Streifen bis zum Hinterende des Seitenlappens reichend; entlich noch ein grosser runder Fleck ror der Spitze, ron dieser aher, wie von Naht und Seitenrand noch durch einen breiten Zwischenraun getremnt. Der umgeschlagene, 
mit einer gröberen Punktreihe besetzte Rand des Seitenlappens hell braungelb; das Pygidium gelb, auf der Mlitte mit einer breiten braunen Längslinie, auch an den Rändern schmal bräunlich gesäumt. Unterseite und Beine heller röthlichgelb mit geschwärzten Parapleuren. Die Hinterzipfel der Vorderbrust lang und scharf dreieckig vorspringend, der Vorderrand in einen lang und schmal dreieckigen Zipfel vorgezogen. Das letzte Segment des $\delta$ einfach, das $?$ unbekannt.

Aus Brasilien (von Rio de Janeiro, Mus. Holm., von F. Sahtberg mitgebracht).

42. Cr. incredulus m. Oben braungelb, der Kopf, ein breiter Vorder- und Seitenrand mit zwei Hinterflecken des spiegelglatten Halsschildes und acht Flecken der Flügeldecken $(3,2,2,1)$ weiss, Unterseite und Beime greisgelb; die Punktstreifen äusserst fein, der neunte vorne gelockert, mit flachell spiegelglänzenden Zwischenräumen. L. $21 / 4^{\prime \prime \prime}$; Br. $1 \frac{1}{3}{ }^{\prime \prime \prime}$.

Von der vorliegenden, in der Färbung und Farbenvertheilung dem Mexicanischen $\mathrm{Cr}$. pathelicus m. (Linn. Ent. VII. S. 10. n. 53) nicht unähnlichen Art kann ich zwar nur ein einziges und augenscheinlich nicht vollständig ausgefärbtes Stück vergleichen; dasselbe reicht jedoch vollständig hin, die Art zum Wiedererkennen zu charakterisiren, und ich glaube nicht, dass sich der vollkommene Käfer von ihın wesentlich anders als durch eine tiefure Färbunng der Ober- und Unterseite unterscheiden werde. Der Kopf flach, die Stirn breit eingedrückt, und dieser Eindruck noch von einer kurzen Längslinie durchzogen; das Kopfschild schräg eingezogen, oben durch eine feine aber deutliche Querkante abgesetzt, die Oberfläche lackglänzend ohne Spur einer Punktirung, mit den langgestreckten, breit aber nicht tief ausgebuchteten Augen weisslich. Der Nackeı über der Stirn braungelb. Die Fühler (des q) dünn und fadenförmig, das zweite Glied kurz elliptisch, die folgenden schon vom dritten an oberwärts etwas erweitert, vom fünften ab stärker verbreitert und zusammengedrückt, das dritte um die Hälfte, das vierte doppelt- und das fünfte etwa $2 \frac{1}{2} \mathrm{mal}$ länger als das zweite, die oberen nur wenig kürzer als das fünfte. Die Farbe bleichgelh, die olıeren leicht gebräunt, bei dem vollkommenen Thiere wahrscheinlich schwärzlich. Das Halsschild doppelt breiter als lang, vor'u mit seiner grösseren Hälfte stark kugelig übergewöllts, die scharf rechtwinkligen Vorderecken tief eingezogen und dadurch das 
Halsschild verschmälernd, die Seiten fein gerandet, nach vorn in sehr flachen Bogen zusammengeneigt, vom letzten Drittel ab hinterwärts wieder etwas nach innen gekrümmt; die Hinterecken sehr kurz und breit zugeschärft, der Hinterrand scharf gesägt, leicht wellig gehuchtet, mit breitem, tief doppelt ausgerandetem Mittelzipfel, gegen welchen sich das Mittelfeld mit sanfter Krümmung hinabsenkt; vor ihm jederseits am Hinterrande ein leichter eiförmiger Schrägeindruck. Die Oherfläche spiegelglatt, hell braungelh, wie bei den Coccinellen ans der Gruppe der C. 10guttata Linn., mit feinem aber scharf alıgesetztem schwarzem Saume des Hinterrandes; ein breiter Vorder- und Seitenrand, letzterer linter der Mitte der Innenseite leicht ausgebuchtet, und die beiden gewöhnlichen linteren Schrägflecke weiss mit verwaschener Begränzung. Das Schildchen mässig ansteigend, dreieckigherzförmig und wenig länger als breit, mit deutlichem Vordergrübchen, glänzend hraungell, vorn zart schwarz gesäumt. Die Deckschilde breit und flach walzenförmig, etwa um $1 / 3$ länger als breit, die Wurzel nach vorn hin nur leicht niedergesenkt, Schulterbeulen und Seitenlappen kaum hemerkbar. Auch die Punktstreifen nur schwach, wellig nach imnen gekrümmt und fast nur auf dem zweiten Viertel ihrer Länge deutlich, die Vorderenden wie weggeschliffen und auch die Hinterenden nur als äusserst fein eingegrabene Linien erkembar; der sechste bis achte hinter der Schulterbeule auf eine längere Streclie unterlorochen, auch der neunte hier abgeschwächt und nur durch einige vereinzelte Punkte angedentet. Die flachen Zwischenräume spiegelglatt. Die Färbung hell braungell, mit schwarzem Vordersaume und acht weissen Flecken auf' jeder Flügeldecke; die erste Reihe an der Wurzel aus drei Flecken bestehend, der innere rundlich, rom Schildchen bis ülıer den er'sten Streifen linausreichend, der zweite länglich, zwischen dem dritten und fünften Streifen, der dritte gleichfalls längliche ausserlıalb der Schulterbeule bis zum Aussenrande hin. Dann folgt ein Paar auf der Nitte, der innere kleinere ist nur ein unscheinbarer, verwaschener Wisch zwischen der Naht und dem zweiten Streifen, der äussere dagegen ein grosser unregelmässig viereckiger Fleck zwischen dem vierten Streifen und dem Seitemrande, lïıgs welchiem er sich, den ımgeschlagenen hand des Seitenlappens frei lassend, nach vorn zieht und mit dem Schulterflecke der ersten Reilie zu einem grossen Randflecke verbindet. Die dritte Reihe liegt vor und auf der Wölbung, beide 
Flecke rundlich viereckig, der innere zwischen dem ersten und dritten Streifen, der äussere etwas mehr nach hinten gerückt, zwischen dem Hinterende des achten Streifens und dem Aussenrande; endlich noch ein Querfleck hart vor der Spitze. Das fein runzlig punktirte Pygidium mit der glänzenden Unterseite und den Beinen greisgelb; die Vorderbrust länger als breit, mit scharf vortretenden, innerseits je durch eine feine Längslinie abgesetzten Seitenkanten; der Vorderrand zur Aufnahme der Mundtheile in der Mitte kurz bogig vorgezogen und abwärts gekrümmt, die Mitte schwach gewölbt, die Hinterecken als schwielig aufgetriebene Spitzeı vortretend. Das letzte Segment des $q$ nuit der gewölnnlichen halbkreisförmigen glänzenden Grube, das $ठ$ unbekannt.

Aus Bolivia (Mus. Berol., von Warscewicz mitgetheilt).

Eilfte Rotte. Körper gestreckt walzenförmig, hinterwärts etwas verhreitert, unterseits kaum behaart, schwar'z, mit mässig langen und dünnen Fühlern, und rothgezeichneten, sehr regelmässig punktstreifigen Deckschilden. Linn. VI. 59. Siebenzehnte, und XII. 376. Sechszehnte Rotte. Die bis dahin einzige südamerikanische Art ist den nordamerikanischen in Färbung und Habitus überaus ähnlich, während die hierher gehörigen zahlreichen Arten der alten IVelt in jenen Beziehungen eine grosse Mannigfaltigkeit darbieten.

43. Cr. quadrivulnerus m. Schwarz mit gelblichen Füllerwurzeln, ein Schulter- und Spitzenfleck der Flügeldecken kirschroth; das Halsschild hinten quer eingedrückt, die Punktstreifen grob mit flachen, seitlich flach gewölbten Zwvischenräumen. L. $11 / 4-11 / 2{ }^{\prime \prime \prime} ;$ Br. $2 / 3-5 / 6{ }^{\prime \prime \prime}$.

Wie bemerkt, den nordamerikanischen Arten dieser Rolte, namentlich dem Cr. quadrigutiulus $m$. und quadruplex Newm. überaus ähnlich, aber durch den für viele südamerikanische. Arten typischen hinteren Eindruck des Halsschildes von ihnen abweichend. Der Kopf flach, das Kopfschild wieder etwas eingezogen, dalei in der Mitte leicht eingerlrückt, die dadurch anfgetriebenen Ränder als stumpfe Kanten erböht; üher ilınen zwischen den Fühlerhöckerı ein paar tiefe eingestochene Grülochen. Die Oberfläche durch eine feine Punktirung matt, schwarz; die grossen Augen schunal aher tief ausgebuchtet und in dieser Bucht quer niedergedrückt, die oberen Innenränder nur durch einen schmalen, von einer haarfürmig eingeschnittenen Längslinie durchzogenen Zwischenranm ge- 


\section{4}

trennt. Die Fühler (des ठ) von $2 / 3$ der Körperlänge, fadenförmig; das gestreckte Wurzelglied etwa viermal länger als breit, wenig gekrümm!; das zweite um die Hälfte länger als breit und kaum halb so breit als das vorhergehende, die drei folgenden dünn verkelırtkegelförmig, his zum fünften an Grösse allmählich zunehmend, und dieses dem Wurzelgliede, das sechste und die folgenden wieder dem vierten gleich; dabei alle nur sehr wenig zusammengedrückt und kaum erweitert. Die Fühler des $q$ in allen Theilen etwas kürzer, olnne weitere Abweichungen. Die Farbe der unteren Glieder durchscheinend gelblich braun, der oberen dunkler gebräunt, zuletzt schwarz mit angedrücliter greiser Behaarung. Das Halsschild sehr kurz, vor dem Schildehen durch einen tiefen, hall,mondförmigen Eindruck niedergedrückt, durch welchen das Mittelfeld hoch buckelig aufwärts geschoben wird, während es nach dem Kopfe zu wieder eben so stark alıf̈llt; der vordere Theil über den tief eingezogenen, scharf rechtwinkligen Vorderecken zusammengedrückt und dadurch verselımälert, die Seiten besonders hinten breit aufgeschlagen, vor den kurzen scharfen Hinterecken bogig heraustretend und von da nach vorn mit breiter Krünmung convergirend; der Hinterrand jederseits schwach wellig geschweift, durch den ılavor liegenden bogenförmigen Eindruck wulstig aufwärts gedrängt, mit kurzem, aber deutlich doppelt ausgerandetem Mittelzipfel. Das Mittelfeld jederseits mit einem breiten Schrägeindrucke, welcher sich hinterwärts an den bogenförmigen Eindruck vor dem Schildchen anschliesst; ein schwächerer und schmälerer Schrägeindruck danı noch vor jeder Hinterecke. Die Farbe ein spiegelglattes Kolılschwarz; der Vorlerrand bei einem Theile der vorliegenden Stüclie roth durchscheineut. Das Schildchen lang gestreckt dreieckig, doppelt länger als vorn breit, hinten bogig aufsteigend und kurz abgestutzt, vorn quer niedergedrückt mit deutlichen, jederseits roı einer Beule begränzten Grübchen. Die Farbe gleichfalls glinzend schwař. Die Deckschilde kurz und gedrungen walzenförmig, kaum um $1 / 4$ lïnger als breit, vorn breiter als das Halsschild, und danı fast gleichlıreit bis zu der liurz zugerundeten Spitze fortziehend; die Wurzel nur zunäclıst lem Schildchen niedergedrückt und damı zu dessen Hinterende selırïg ansteigend, der Rücken breit und tlach gewölbt, hinterwärts allnählich ablallend, und auch die Wölbung uur sanft abwïrts gekrümmt, die länglich-höckerigen Schulterbeulen beiderseits durch schmale, mit den Vorderenden des fünften und 
neunten Punktstreifens zusammenfallende Längseindrücke abgesetzt, die Seitenlappen măssig, mit stark abwärts gezogenem, mit einer groben Punktreihe besetztem umgeschlagenem Rande; üher ihnen je ein tiefer, hinter der Schulterbeule hinaufziehender Quereindruck. Die Punktstreifen grob, aus vereinzelten, tief eingestochenen Punkten gebildet, linterwärts abgeschwächt aber nirgends erloschen, in dem Quereindrucke hinter der Schulterbeule merklich verstärkt und stellenweise etwas gestört. Die glänzenden Zwischenräume breit und flach, der äussere und bei dem $\delta$ auch die Hinterenden der übrigen flach gewölht. Die Farbe ein reines Schwarz, ein etwas schräg gezogener, meist mit dem inneren Hinterzipfel etwas verlängerter und bis zum ersten Punktstreifen reichender Schulterfleck und die Spitze duukel kirschroth; bei den vorliegenden ㅇ sind die Flecke grösser, und bei einem derselben durch einen trüb-röthlichen Längswisch auf dem vierten Zwischenraume verbunden; endlich färbt sich auch dieser aus, und dadurch entsteht eine Form

$\beta$. mit einer rothen, hinter der Mitte jerlerseits efwas buchtig verengten Längsbinde auf jeder Flügeldecke.

Pygidium und Unterseite fein punktirt und dünn greishaarig, nebst den Beinen schwarz, die Hüften und an den Vorderbeinen anch die Schenkelspitzen und die Innenseiten tler Schienen trüb geröthet, bei den $\delta$ fast die ganze obere Schenkelhälfte verwaschen rötlılich. Der Vorderrand des Prosternums lang grade vorgezngen und quer abgestutzt, das Mittelfeld sehr grob punktirt, hinten etwas niedergedrückt, der Hinterrand in der Mitte breit ausgebuchtet und die Seiten dadurch als scharf dreieckige Zipfel ausgezogen. Das letzte Segment des $\delta$ quer niedergedrückt, des $q$ mit einer tiefen rundlichen Grube.

Aus Brasilien. Mus. Hal., Berol., Dohrn, Deyrolle. Als Heimath wird S. João del Rey, auch Ouro preto, eine Goldwäsche unter dem $20^{\circ} \mathrm{s}$. Br., genannt. Ausserdem in Montevideo (Mus. Holm.). In den Sammlungen findet sich die Art unter dem Namen Cr. crux Klug, del aber wegen des viel älteren und längst beschriebenen $\mathrm{Cr}$. crux Gebl. aus Sibirien nicht beibehalten werden konnte.

Zwölfte Rotle. Körper kurz und gedrungen, mit dünnen und schlanken, ziemlich langen Fühlern und (bei den ठ) auf der Stirn zusanmenstossenden Augen. Das Halsschild hinten mit einem gekrümmten Quereindrucke; die Punktstreifen kräftig, die oberen 
und wieder die seitlichen tief eingedrückt, der sechste und siebente hinter der Schulterbeule mehr oder weniger deutlich gelockert. Kleine, glänzend rostrothe oder bräunliche Arten mit theilweise geschwärztem Rande der Flügeldecken, von eigenthümlichem Habitus und am Südrande des Caraibischen Heeres einheimisch.

44. Cr. cinctellus Mus. Berol. Rostroth, Fühlerenden und Hintersaum des Halsschildes schwarz, Wurzel, Naht und Spitze der Deckschilde gebräunt; las Ilalsschild spiegelglatt, hinten mit liurzem Quereindrucke, die Punktstreifen derb, leicht furchig eingedrückt, der sechste und siebente hinten etwas gelockert, mit flach gewölbten, undeutlich punktirten, glänzenden Zwischenräumen. L. $3 / 4-1^{\prime \prime \prime} ;$ Br. $2 / 3-3 / 4{ }^{\prime \prime \prime}$.

Bei geringer Länge verhältnissmässig breit, und im Habitus weit mehr einem kleinen Eumolpiden als einem Cryptocephalus ähnlich, von allen anderen Arten dieser Gattung nur noch dem folgenden aber merlilich kleineren $C r$. fulvescens $\mathrm{zu}$ vergleichen. Der Kopf llach gewölbt; das Kopfschild tief eingezogen, fein punktirt, oben durch eine deutliche Querlinie abgegränzt, zuweilen feiı längskielig; die Stirn glatı, die grossen, scliwarzen Augen breit und tief ausgelsuchtet, und ihre oberen Enden (bei dem ठ) in solcher Ausdehnung zusammenstossend, dass der obere Zipfel der Stirn weder an Läıge noch an Breite den Augenbuchten gleirhkommt. Die Farbe des Kopfes glänzend rostroth, bei gut ausgefärbten Stücken die Euden der Kinubacken und der Vordertaster gleichfalls schwarz. Die Fühler (des ठో) ron reichlich $3 / 4$ der Körperlänge, dünı und schlank, das Wurzelglied mässig nach aussen gebogen, etwa dreimal lïnger als breit; das zweite kurz birnförnig, die drei folgenden dünn verkehrtkegelförmig mit schwach dreieckig erweitertem Ende des fünften, ron ihnen das dritte doppelt-, das vierte $2 \frac{1}{3}$ mal so lang als das zweite, das fünfte (längste) fast den beiden vorhergehenden zusammen gleich, die oberen schwach zusammengedrückt und verbreitert, immer mehr ins Linealische übergehend und an länge allmählich wieder abnchmend, so dass dis zehnte etwa dem vierten gleichliommt; das Endglien nit seinem lang dreieckigen Fortsatze fast wieder dem fünften gleich. Die vier unteren hell rothgelb, das fünfte gelnäunt mit schwärzlicher spitze, die sechs oberen ohne Rücksicht auf die Ausfärbung der Deckschille schwarz. Das Halsschild mehr als doppelt länger wie breit, mit der grösseren Vorderbälfte stark kugelig übergrekrümmt und 
auch hinterwärts wieder niedergesenkt, über den tief eingezogenen rechtwinkligen Vorderecken stark verengt; die Seiten fein gerandet, nach vorn in breiten Bogen convergirend, vor den spitz ausgezogenen Hinterecken leicht ausgeschweift; der Hinterrand eingesenkt, stark gesägt, sanft doppelt ausgebuchtet, mit kurzem, deutlich doppelt ausgerandetem Mittelzipfel. Vor dem letzteren ein hreiter, mit den Enden etwas nach vorn gekrümmter Quereindruck, in welchem jederseits des Mittelzipfels sich noch eine tiefere mit einigen groben Punkten besetzle Stelle bemerkbar macht. Die Farbe spiegelglänzend rostroth mit zart geschwärztem Hintersaume. Das Sehildchen schräg ansteigend, um die Hälfte länger als vorn breit, dreieckig mit kurz abgestutzter Spitze und deutlichem Vordergrübchen, gleichfalls glänzend rostroth, vorn schwarz gesäumt. Die Deckschilde fast so breit als lang, ziemlich gleichbreit und etwas breiter als das Halsschild, vorn an den Schultern und hinten nächst der Spitze beinahe gleichmässig zugerundet, hinter dem etwas aufgewulsteten Vorderrande durch die tiefer eingegrabenen Vorderenden der Punktstreifen leicht quer eingedrückt, der toreit abgeflachte Rücken von der Schildchenspitze ab hinter'värts sanft abfallend; die länglichen Schulterbeulen innerseits nur durch das Vorderende des fünften Streifens abgesetzt, die Seitenlappen kräftig, und über ihnen die Deckschilde leicht quer zusammengedrückt. Die Punktstreifen derb, die Vorderenden der fünf ersten und wieder des achten dlurch grosse grülschenartige Punlite gebildet, welche bei jenen so dicht zusammengerïckt sind, dass dadurch deutliche tiele Längsfurchen entstehen; hinterwårts werden diese Furchen zwar schwächer, sind aber doch für den ersten bis vierten Streifen bis zur Wölbung zu verfolgen, und eben so sind der achte und neunte Streifen vom Seitenlapjen ab in solche Furchen eingedrüclit. Bei dem fünften sind die Punkte etwas weiter auseinandergerückt und hinterwärts mehr abgeschwächt, wesshalbs sich die Furche bald verliert, noch mehr aber lockern sich der sechste und siebente Streifen gegen die Mitte hin, und ihre Punkte werden zuletzt so schwach, dass sie sich mit denen des fünften auf der Wölhong vertieren, so dass hier der fünfte bis siebente Zwischenraum in einem glatten Längsfelde zusammenlaufen, neben welchem sich der vierte nicht unmerklich verbreitert. Die Zwischenrämme besonders vorn und auf deı Seiten flach gewölbt, mit vereinzelten, stelleıweise eine unordentliche Längsreihe bildenden feineren Punkten $\mathrm{xv}$. 
besetzt, ziemlich glänzend rostroth mit schwarzen Samme der Wurzel; ausserden ist bei dem von den vorliegenden Exemplaren am besten ausgefärbten Stücke ein breiter, Schulterbeulen und Seitenlappen einschliesscnder Vorderrand, ein durch Zusammenschliessen desselben hinter dem Schildchen gelsildeter und sich hinterwär's Ireieckig verschmäleruder Nahtsaum und die Spitze rerwaschen geschwärzl. Bei schwächerer Ausfirbung ist nur ein Wisch auf der Schulterbeule und ein zweiter vor der Spitze nebst einem schmalen Nahtsaume rerwaschen gehräunt, his zuletzt auch diese Zeichnung fehlt, unil dip Jeckschilde, mit Ausuahme des schwarzen Wurzelsaumes, wic der ülırige Körper einfarlhig hell rostgell ersclıeinen. Pygilium, Unterseite und Beine gleichfalls einfarbig liell rostgelb, der Vorderrand des Prostermuns nicht rorgezogen, aber zur Aufuahme der Mundtheile tief ausgehölılt, der Hinterrand mit zwei scharfen Spitzen rorspuningend. Das letzte Segment des ot leicht quer niedergedrüclit, das $q$ unbekamnt.

Aus Tenezuela. (Mus. Berol., von Moritz gesammelt.)

45. Cr. fulvescens m. Rothhraun mit geschwärzten Fühlerenden, die Ründer der Flügcldecken breit verwaschen schwarzbraun; das Ilalsschild glatt, linten leicht schräg eingedrückt, die Punktstreifen derd, hinter den Schulterheulen stark gelockert, mit gewölhten, ğläuzenden Zwischenräumen. L. $5 / 12{ }^{\prime \prime \prime}$; Br. 1/4"'.

Eine gleichfalls liurze und gedrungene, im Ilabitus gegen den eben beschriehenen C $r$. cinctellus etwas mehr gestreckte, zugleich dunkler gelärbte Art. Der Kopf flach, rumzlig punktirt, mässig glänzend, lıell rothlıraun, die breit ausgebuchteten bei dem vorliegenden ठे einander obeu berülırenden Augen greis. Die Fühler von halber lï̈rperläıge, das Wurzelglied stark keulig aufgetrieben, das zweite länglich eifürmig, doppelt so lang als breit, die drei folgenden schmal verkchrtliegelförmig, oben fast gar nicht verl,reitert, an Länge einander mol dem zweiten ziemlich gheich, alle diese Glieder lıell rothgelb mit gelıriunter Spitze der fünlten, die olieren zusammengedlückt und olwas stirlier erweitert. schwarz mit feiner angedrückter greiser Behaarung. Das IJalsschild liurz umıl breit, in der Mitte stark aufwärts gewölht und ror'n mit dem ersten Drittel seiner länge slark lingelig abwälts gewölbt. auch hinterwärts tief herabgesenlit, und hier von einem lufeisenförmigen mit den Enden seitlich schräg nach voru gekrümmten, fast bis zur Jitte des Scitenrandes hin wahrnehmbaren Eindrucke durchzogen. 
Die Seiten fein gerandet, nach rorn fast in graden Linien schräg abwärts zusammengeneigt, Vorder- und Hinterecken scharf, er'stere rechtwiuklig, diese etwas vorgezogen: der Ilinterrand fast grade, mit sehr liurzen liaum ausgerandeten Mittelzipfel. Die Oberfliche hell rothbraun, spiegelglänzend, des Hinterranıl selıwach gelıräunt, vor ihms in dem Eindrucke und in den Hinterwinkeln selhst ein paar vereinzelte gröbere Punkite. Das Schildchen schräg ansteigend, etwas länger als breit, herzfürmig mit lleinem Vordergrübchen, gleichfalls glänzeud rolhbraun. Die Deckschilde gedrungen walzenförmig, etwa $1 /$ s lïnger als breit, hinterwärts nur wenig verschmälert, hinter der stumpf erlühten Wurzelkante leicht quer eingedrückt, über den tief herahgr'zogenen Seitenlappen breit zusammengedrückt; die Schultcrbeulen gleichfalls breit und flach, die Naht den Rücken entlang seicht niedergedrückt und die Spitze kurz abgermndet. Dic Punktstreifen selır regelmässig, vorn aus tiefen Ausätzen entspringend, auch hinterwärts kuäftig und bis zun Ende gleichmässig verlliessend, der mittlere Theil des fünften, sowie der sechste und sielsente linler den Schulterbeulen in rereinzelte Punkte aufgelöst, die beiden iusseren, sowie die der Naht zunächst lirgenden furchcnartig eingerlü̈elit, mit rippenförnig erhöhten, lackglänzenılen Zwischeurämen. Die Farbe rothbraun, ein breiter verwaschener Rand um die Flïgeldecken schwarzbraun, so dass deren Färbung auch als sclıwarbluaun mit eiuem breiten rothbraunen Längswisch in der llitte bezeichnet werden kömnte. Pygidiun und Unterseite rothhraun mit etwas helleren Beinen; das Prosternum breil, rercinzelt grob gerunzelt, flach, mit kurz vortretenden Hinterecken. Das letzte Segment des $\delta$ quer flach niedergedrückt, das $q$ unbeliannt.

\section{Von Varinas.}

Dreizehnte Rotte. Körper sehr klein, von dünn walzlicher Gestalt, mit kurzen oben schwach verdickten Fülılern. Das Halsschild zuweilen matt odes punktirt, die Punktstreifen vorn stets deutlich und manchmal tief eingegralsen, hinterwärts gewöhnlich abgeschrächt, hinter der Schulterbeule durch einen Quereindruck mehr oder weniger deutlich gestört oder selbst unterbrochen, hinter ilım zuweilen eine deutliche Längssunzel vorhanden. Die Farbe meist gelb, roth orler braun, zuweilen mit verwaschener metallischer Zeichnung, seltener metallisch grün mit rothgelben Flecken. Eine Rotte von unscheinharen und winzigen Arten, mit der ror- 
hergehenten einzuschalten vor der Nordamerikanischen Rotte des Cr. exilis. (Linn. VI. 69. XII. 377.)

46. Cr. miserabilis m. Rostroth, Brust, Schildchen und ein grosser dreieckiger Fleck um letzteres schmutzig braun; das Halsschild fein narhig punktirt, die Punktstreifen hinten etwas schwächer, der sechste und siebente abgekürzt, mit flach gewölbten Zwischenrä̈unen. L. ${ }^{3}{ }_{4}{ }^{\prime \prime} ; \mathrm{Br} .1 / 3{ }^{\prime \prime \prime}$.

Eine habituell melır einem kleinen Cis als einem Cryptocephalus gleichende, übrigens an dem grossen dreieckigen Schildchenfleck sehr leicht kenutliche Art. Ter Kopf flach gewölht, mit feiner aher deutlicher Stirnlinie, das Kopfschild wieder etwas eingezogen, oben zwischen den Fühlerwurzeln durch eine deutliche Querlinie begrönzt. Wie Farbe rostroth mit leicht gebräunten Fühlerhöckern, die langgestreckten breit ausgebuchteten Augen schwarz. Die Fühler fehlen dem einzigen mir vorliegenden Stücke, sind jedoch nach den vorhandenen Resten gleichfalls roströthlich; die Oberlippe ist etwas mehr gelh als die übrigen Theile des Kopfes. Das Halsschild um die Hälfte länger als breit, vorn mit halber Länge sanft übergewölbt, die rechtwinkligen Vorderecken tief eingezogen, die Seiten fein gerandet, hinter der Nitte leicht ausgeschweift und dadurch die scharfen Hinterecken breit dreieckig ausgezogen, vor ihnen ein leichter, dieselhen etwas auftreihender Schrägeindruck. Der Hinterrand jederseits schwach ausgebuchtet, fein gesägt, mit kurzem doppelt ausgerandetem Vittelzipfel. Die Oberfläche deutlich aber nicht sehr tief narbig punktirt, die Farbe rothgelb, die Ränder, eiı verwaschener Querfleck vor dem Hinterrande, und eine gleichfalls verwaschene Mittellinie heller gelb, der Saum des Hinterrandes schwarz. Das Schildchen fast gleichseitigdreieckig, etwas ansteigend, mit geschweiften Seiten und deutlichem Vordergrübchen, hraunroth mit dunklerem Vorderrande. Die Deckschilde walzenförınig, etwa doppelt länger als das Halsschild und un die Hälfte länger als breil, um das Schildchen kaum erhüht, vorn durch die tiefer eingegrabenen Vorderenden der Punktstreifen etwas niedercredrückt, längs der Naht abgellachı und hinten mit leichter Wölbung alballend, die länglichen Schulterlenen imuerseits durch einen schwachen Eindruck abgesetzt, und über dem ın̈ssig starkeı Seitenlappen cin breiter, scichter Quereindruck. Die Punkistreifen sehr regehmüssig, aus starken Vorderenden allmăhlich immer feiner, auf der Wölbung fast verloschen, die oberen aus vereinzelten 
Punkten gebildet, und daher die Zwischenräume hier breit und flach, der sechste und siebente Streifen bald hinter der Schulterbeule abgerissen, der achte hinter jenen etwas aufwärts geschwungen, der neunte in eine tiefe Längsfurche eingedrückt, und dadurch der achte und noch mehr der neunte Zwischenraum gewölbt emporgehoben; der umgeschlagene Rand des Seitenlappens ohne Punkte. Die Oberfläche nur mässig glänzend, die Farbe hell rostroth, die Wurzel fein schwarz gesäumt, die Schulterbeulen und ein sehr verwaschener Randwisch hinter der Mitte etwas dunkler geröthet, ausserdem das Schildchen von einem herzförmigen oder dreieckigen tiefer braunen Flecke umgeben, welcher seitlich bis zum vierten Streifen, hinterwïrts bis zur Mitte reicht, und gegen den hellen Grund mit ziemlich scharfer Begränzung abstichıt. Das Pygidium vereinzelt aber deutlich punktirt, hell rothgelb, auch die Beine und der letzte Hinterleibsring rothgelh, die vorderen Ringe dunkler geröthet, die Brust, bis auf einen verwaschenen Querfleck jederseits am Hinterrande schmutzig schwarzbraun. Die Vorderbrust hinten ausgebuchtet mit deutlich vorspringenden Hinterenden; der letzte Ring des \& mit einem eiförmigen, stark glänzenden, in der Mitte etwas tiefer eingedrückten Lüngsgrübchen, das đ unbekannt.

\section{Aus Caraccas.}

47. Cr. formosellus Moritz. Rothgelb, Fühlerenden, Schildchen und ein breiter hinten verschmälerter Saum der Flügeldecken mit den Seiten von Hinterhrust und Hinterleib schwarz; das Halsschild spiegelglatt, die Punktstreifen hinterwärts etwas schwächer, der seclıste und siebente abgekïrzt, mit flachen, seitlich flach gewölbten g]änzenden Zwischenräuneı. L. 3/4" ${ }^{\prime \prime} ; \mathrm{Br}$. 1/2"'.

Den vorhergehenden üheraus nahe stehend, aber bei gleicher Läuge breiter, das Halsschild glänzend, mehr lingelig gewölbt, hinten tiefer eingesenkt, der schwarze Rand der Flïgeldecken breiter, sehr scharf hegränzt, und nur um die Spitze unter der Wölbung zu eineın zarten Saume geschwunden. Der Kiopf flach gewölbt, mit deutlicher Stirnlinie und tief eingezogenem, oben durch eine deutliche Querlinie begränztem Kopfschilde; die Oberfläche kaum punktirt, schwach glänzend, hell rothgelb, die langgestreckten, breit aber nicht tief ausgebuchteten und (bei dem $q$ ) weit getrennten Augen sclıwarz. Die Fühler von kaum halber Körperlänge, ziemlich düıı; das zweite Glied breit eiförmig, aber um die Hälfte 
länger als breit, die folgenden einander gleich, je un die Hälfte länger als das zweite, von der Spitze des fünften al mässig zusammengedrückt und erweitert; die unteren hellgelb, die Spitze des fünften gebräunt, die olseren schwarz mit dümner angedrückter greiser Beharung. Das Halsschild um die Hälfte breiter als lang, nit der grösseren Hälle nach vorn hin, der kleineren hinterwärts stark lingelig abwärts gekrümmt, so lass sich die Mitte quer lıoch emporwölst; die scharf rechtwinkligen Vorderecken tief eingezogen und dadurch das Ialsschild cinengend, die fein geraudeten Seiten nach vorn fast gradlinig zusammengeneigt, die Hinterecken kurz und breit zugespitzt, durch cinen kurzen Eindruck auf ihrer Inmenseite etwas aufgetrieben, der Hinterrand jederseits schwach ausgebuchtet, aber tief eingesenkt, mit kurzem, breitem, tief doplelt ausgerandetem Vittelzipfel. Vor diesem eine feine, aber ziemlich scharl' eingedrüclite Querlinie, an welche sich jederseits eine ähıliche ein wenig schräg nach vorn und aussen gerichtete anschliesst. Die Oberfläche spiegelglänzend rotlıgelb mit zart schwarz gesäumtem Hinterrande. Das Schildchen schräg ansteigend, dreieckigherzförmigs, etwa $1 / 3$ lönger als breit, mit tiefem Vordergrübchen, glänzend sclıwarz. Die Deckschilde flach walzenförmig, gleichfalls etwa $1 / 3$ länger als breit, rorn etwas breiter als das Halsschild, hinter den Schultern noch pin wenig erweitert, und dann mit flacher lirümmung sich hinterwärts wieder allmählich verschmälernd; die Wurzel hinter dem wulstig aufgetriebenen Vorderrande durch die tief eingegrahenen Vorderenden der immeren Punktstreifen querfurchig eingedrückt, die kräftigen länglich eiförmigen Schulterbeulen innerseits durch das Aussinende jener Querfurclıe abgesetzt; auch die Seitenlappen tief heralggezogen, und über ihnen ein breiter und flacher, hinter den Schulterbenten hinaufzichender Quereindruck. Die Punktstreifen sehr regelmässig, aus derloen Vorderenden laal sich abschwächend, und die Rückenstreifen auf dem letzlen Drittel fast erloschen, der sechste und siehente an dem Quereindrucke abgebrochen; die glänzenden Zwischenräune flach, die spitlichen und die Vorderenden der imneren leicht gewölbt. Die Farbe hell rotlırelb, Wurzel, Nalıt und Aussenrand his zur Wölbung hin breit schwarz cingefisst, welche Einfussung sich auf der Schulterleule zı eimem grossen Längsfleck, an Niht und Aussenrand auf der Wölhumy zu eiupn in das rotligelbe Vittelfeld hineintretenden Querfleckichen, zu jeder Seite des Schildchens und 
dieses mit einschliessend zu einer breiten, sich hinterwärts dreieckig verjüngenden Nahtbinde erweitert, dann aber auf der Wölloung sich plützlich zı einem zarten, die Spitze umziehenden Saume verschmälert. Pygidium, Unterseite und Beine gelb, die Seiten ron Hinterleib und Hinterbrust verwaschen geschwärzt. Das Prostermum quer viereckig, mit einer feinen scharf eingedrücliten Querlinie hinter dem Vordersaume, das Mittelteld leicht aufgewulstet, der Hinterrand nur flach ausgerandet. Das letzte Segment des $f$ mit der gewöhnlichen glïnzenden Grube; das $\delta$ unbekannt.

\section{Von Puerto Cabello (Mus. Berol., von Moritz gesammelt).}

48. Cr. a to marioides m. Rostbraun mit sehwarzem Vordersaume der Decksehilde, das Halsseliild glatt, die Punlitstreifen hinterwärts feiner, der siebente und achte alogeliürzt, die Zwischenräume glänzend, die äusseren gewölbt. L. $2 / 3{ }^{\prime \prime \prime}$; Br. $1 / 3{ }^{\prime \prime \prime}$.

Den vorhergehenden nahe verwandt, auch dem unten folgenden Cr. abbreviatellus in dem gedrungenen Körper und dem hinten stark eingesenkten Ilalssehilde älınlich, von beiden aber durch die Abkürzung nicht des seclısten und siebenten, sondern des siebenten und acliten Streifens selır augenfällig abweiclıend. Der Kopf flach mit kaum benerkbarer Stirnlinie, das seitlich und oberwärts durch deutliche Linien abgegränzte Kojfschild etwas eingezogen. Die Färbung glänzend rostroth, Kimbacken und Unterrand der Oberlippe noch etwas heller, die langgestreckten breit ausgeluuchteten Augen greis, die gleichfalls rothgelıen Fühler nicht von denen des $\mathrm{Cr}$. abbreviatellus verschieden. Auch das IIalsschild gebant wie bei dieser Art, ıur die Seiten fast grade und die Hinterecken durch einen kräftigeren Schrägeindruck stürker anfgetrieben, der Mittelzipfel deutlicher doppelt ausgerandet. Die Farbe spiegelglänzend rostbrauu, hinten schwarz gesäumt, hier und da mit Spuren äusserst feiner und zerstrenter Punktirung. Das Schildehen wenig ansteigend, gleichseitigdreieckig, rorn ınit deutlichem Grübchen, glänzend dunkelbraun. Die lleckschilde kurz und breit walzenförmig, etwa ${ }_{15}$ länger als breit, breiter als das Halsschild, hinter den Schultern noch etwas verbreitert und dann linterwärts wieder leicht zugerundet; der Rüelien alggeflacht und zuletzt mit sanfter WöJbung nach der Spitze hin abfallend, die Schulterbeulen länglich, und wie die Seitenlappen nur mässig entwickelt; über den letzteren die Deckschilde leicht quer zusammengedrückt. Die Punkt- 
streifen sehr regelmässign, aus tief eingegrabenen Vorderenden bald in Reihen sehr vereinzelter Punkte übergehend und gleichzeitig sich abschwächend, so dlass die oberen schon vor der Wölbung fasł unkenntlich werden, der siebente und achte bald hinter der Schulterbeule abgekürzt und mit ihren Hinterenden zusammenlaufend, der gleichfalls von der Schulterbeule ausgehende sechste und der neunte linter jenen in geschwungenen Linien einander dergestalt genähert, dass ihr Zwischønraum den daneben liegenden an Breite gleichkommt; beide Streifen zugleich in tiefe Furchen eingedrückt und dadurch ihren Zwischenraum, so wie die beiden anstossenden mit deutlicher Wöllıng emportreibend, die oberen Zwischenräume mehr flach, alle aber mässig glänzend, einfarbig hell rostbraun mit schwärzlichem Wurzelsaume. Pygidium, Unterseite und Beine heller rostroth, das letzte Segment des einzigen vorliegenden $f$ mit einer grossen, nicht sehr tiefen, spiegelglatten Grube; das $\delta$ unbekannt.

\section{Von Caraccas.}

49. Cr. fusculus m. Braun, vier Längswische des matten Halsschildes, die Wurzel und einige Längslinien der Flügeldecken heller gelb; die Punktstreifen derb, der sechste und siebente abgeküızt, mit rippenförmigen Zivischenräumen, der vierte linter der Mitte stark erweitert. L. 5/6"'; Br. 1/2"'.

Eine sehr eigenthümliche, in ihrer Sculptur in dieser Rotte ehell so wie die vorhergehende vereinzelte Art. Der Kopf in der Vitte flach gewölbt, mit tief eingegrabener Stirnlinie, das unten wieder starh eingezogene Kopfschild zwischen den Fülılerwurzelı durch eine scharfe Querleiste begränzt. Die Farbe schmutzig gelb mit Iuässigem Glanze, die Stirnlinie, die Fühlerhöcker und der untere Theil des Kopfschildes schnntzig gebräunt, die lang gestreckten, ziemlich tief ausgebuchteten Augen schwarz. Die Fühler von halber Kórperlänge, das zweite und dritte Glied fast gleichlang, auch die oberen von jenen in der Länge nicht merklich verschieden, die füıf letzten deutlich zusanmengedrückt und erweitert, die Farbe schmutzig gell, die oberen erweiterten greschwärzt. I)as Halsschild um die Hälfte breiter als lang, vorn mit halber Länge mässig übergekrümmt, hinten wieder etwas eingesenkt, über den stumpfwinkligen Vorderecken schwach zusanmengedrückt und dadurch verschmälert, die Seiten fast grade, die Hinterecken spitz ausgezogen 
und äber ibnen ein leichter Schrägeindruck. Der Hinterrand jederseits etwas eingekniffen, schwach ausgebuchtet, mit deutlich ausgerandetem Mittelzipfel. Die matte Oberfläche schmutzig braun, Vorder- und Seitenrand verwaschen gelb, welche Färbung sich in den Vorderecken und ler Mitte des Vorderrandes winklig erweitert; eben so auf dem braunen Mittelfelde jederseits noch ein sich nach vorn verlierender gelblicher Wisch, so dass die braune Grundfärbung zuletzt die Gestalt eines plumpen verwaschenen $(D$ erhält. Das Schildchen etwas länger als breit, dreieckig mit kurzem Hinterzipfel und deutlichem Vordergrübchen, stark ansteigend und gleichfalls schmutzig gellb. Die Deckschilde walzenförmig, erst vor der Spitze etwas verschmälert, doppelt so lang als das Halsschild und un die Hälfte länger als breit, hinten kurz schräg abfallend, die Wurzelkanten wulstig aufgetrieben, die Schulterbeulen länglich, innerseits durch einen deutlichen Eindruck abgesetzt, die Seitenlappen mässig und über ilınen noch ein flacher breiter Quereindruck. Die Punktstreifen kräftig, aus tief eingegrabenen, in leichte schmale Furchen eingedrückten Punkten hestehend, der abgekürzte und die fünf folgenden regelmässig, der sechste und siebente gleich hinter der Schulterbeule abgerissen, und weiter hinterwärts grade ülser dem Seitenlappen noch durch einen einzelnen quer gezogenen, den fünften und achten Streifen verbindenden Punkt vertreten, die drei äusseren wieder regelmässig und bis zur Spitze deutlich. Die schmalen Zwischenräume rippenförmig, der vierte durch Ausbiegung des fünften von jenem Punkte ab verbreitert und dadurch den vorn breiteren Zwischenraum zwischen dem fïnften und achten Streifen wieder verengernd; übrigens alle ziemlich matt, und nur seidenartig schimmernd. Die Farbe schmutzig braun, mit einigen verwaschenen helleren Längslinien auf den Zwvischenräumen; die Wurzelkante, der Seitenrand, der lreite vierte Zwischenraum, und ein durch dessen Zusammentreffen mit dem Seitenrande gebildeter, nach vorn sich stralılenförmig auf die Hinterenden der Zwischenräume fortsetzender Fleck an der Spitze hellgelh und zugleich ein wenig stärker glänzend. Das Pygidium deutlich narbig punktirt, matt braun mit verwaschen gelblicher Mitte. Unten sind Vorderbrust, Schulterblätter und Beine schmntzig gelb, Hinterbrust und Hinterleib braun mit verwaschen lichteren Seitenrändern des leıztern, auch die Mitte der Schenkel etwas dunkler angelaufen, die l'ussglieder tief gebräunt. Die Hinterenden der Vorderbrust stark 
zugespitzt; das letzte Segment des $\delta$ flach quer niedergedrückt, das $q$ unbehamnt.

Von Buenos Ayres (Mus. Haag).

50. Cr. fumigatus m. Schwarz, der Nacken mit Fühlern und Mundtheilen, Vorder- und Seitenrand mit drei Hinterflecken des deutlich punktirten Halsschildes und einige Längsıvische auf den Deckschilden mit dem Pygidium, den letzten Bauchringe und den Beinen rothbraun; die P'unktstreifen fein, der sechste und siebente abgerissen, mit matten flachen Zwischenräumen. L. $2 / 3-5 / 6{ }^{\prime \prime \prime}$; Br. $1 / 3-1 / 2{ }^{\prime \prime}$.

Von der Grösse und dem Habitus der rorhergehenden Art, und ihr auch in der Farbenvertheilung nicht unähnlich, aber an den flachen Zwischenräumen der fein punktstreifigen Deckschilde von ihr sogleich zu unterscheiden. Der Kopf flach gewölbt, mit kurzer abes deutlicher Stirnlinie, zerstreut punktirt; das deutlicher punktirte liopfschild oben durch zwei kleine Quergrühchen, seitlich durch scharfe Kanten begränzt, etwas eingezogen. Die Oberflïche matt, die Farbe schwarz, Wangen und Mundtheile rothbraun, der Nacken und noch trüber die Innenränder der Augenbuchten und der obere Theil des Kopfschildes verwaschen rothbräunlich; die lang gestreckten aher nur seicht ausgehuchteten Augen greis. Die Fühler (des f) nicht ron halber Körperlänge, das Wurzelglied stark keulig verdickt nit etwas flach gedrïckter Oberseite, etwa $2 \frac{1}{2} \mathrm{mal}$ länger als breit, das zweite breit eiförmig, wenig schmäler aber nicht völlig halb so lang als das erste, die folgenden einander zienlich gleich, wenig länger als das zweite, das dritte bis fünfte dünn verkehrt-kegelförmig, die sechs oheren deutlich zusanmengedrückt und besonders nach dem Ende zu stank rerbreitert, so dass die Fülıler fast keulenförmig genannt werden künnten, die Farbe ziemlich hell rostroth. Das Halsschild etwa halh so Jang wie breit, mit der kürzeren Vorderhälfte sauft übergelirümmt, über den stumpf rechtwinkligen Vorderecken nur wenig zusammengedrückt und verschmälert, die Seilen fein gerandet, nach rorn fast in graden, erst nalıe an den Vorderecken stärker einwärts gekrümmten Linien zusammenlaufend, die Hinterecken kurz und breit zugeschärft, der Hinterrand, nach welchem sich das ganze Mittelfeld sanft herabwölht, jederseits nur leicht ausgebuchtet, mit fast grade abgestutztem Nlittelziplel. Die Oberfläche fein aber ziemlich dicht punktirt, mit mattem Zwischengrunde; die Farbe lässt sich am 
besten als ein ziemlich helles aber verwaschenes Rostbraun bezeichneı, der aufgeschlagene Saum der Seiten, der verwaschene IInterrand und vier auf dem letzleren stehende, gleichfalls schlecht begränzte und vorn kaum üher die Mitte hinausreichende Längsflecke schwärzlich. Letztere fliessen auch mit ihren Vorderenden zusanmen, und schliessen dadurch drei ziemlich eifürmige Lïngsflecke ein, ron denen die beilen seitlichen etwas schrïg nach aussen gerichtet siml. Das Schildchen mässig ansteirend, fist gleichseitig dreieckig und hinten kurz algestutzt, das schwache Vordergrübchen jederseits von einer schmalen Querbeule begränzt, die Oberfläche trüb und matt rothbraun mit breit und verwaschen geschwärztem Rande. Die Deckschilde gebaut wie bei dem vorhergehenden, nur die Wurzelkante nicht so stark aufgetrieben, und die Schulterbeulen dagegen etwas kräftiger heraustretend. Die Punlitstreifen sehr regelmässig, mit ilıren derben Vorlerenden hinter der Wurzel eine leichte Querfurche niederdrückend, bald abgeschwächt, aher doch bis zur Spitze kenntlich; die Punkte des fünften selır vereinzelt, der sechste und siebente an dem schwachen Quereindruclie hinter der Schulterbeule alogerissen, und der achte hier nur wenig aufwarts gebogen, so dass zwischen ihm und dem fünften ein sehr hreiter Zwischenraun rorhanden bleiht; der neunte seiner ganzen Länge nach in eine feine Längsfurche eingedrïckt. Die Zwischenräume matt, flach, nur die heiden jener Längsfurche anliegenten leicht gewöllt. Die Farbe lässt sich auch hier an besten als rostbraun bezeichnen, der mittlere Theil der Naht, ein breiter Längswisch an der Wurzel zwischen dem ersten und vierten Streifen, und ein zweiter von der Schulterbeule ausgehender und dem achten Zwischenraume folgender, hinten nach aussen überfliessender verwaschen geschwärzt, beide nuit ihren Yorderenden an die entsprechenden beiden schwärzlichen Hinterflecke des Halsschildes angeschlossen; ausserdem noch der schmale Seitenrand schwarz. Das Pygidium grob punktirt, rostbraun, unten eingedrückt und in diesem Eindrucke geschwärzt. Die Unterseite schwarz, nur die Beine, der letzle Bauchring und der verwascliene Ilinterrand des ersten Ringes rothbraun. Die Vorderbrust glänzend, dis schwach aufgewulstete Mitelfeld hinterwärts verhreitert, der Hinterrand breit ausgebuchtet mit dreieckig vorspringenden Hinterecken. Das letzte Segment des $q$ mit einel grossen aber nicht sehı tiefen hallıeiförnnigen, glänzenden Gruhe, des ठ̊ einfach. Bei weniger deullich ansgefürbten Stücken erschei- 
nen die dunkleren Theile der Oberseite nur heller oder dunkler rostbraun, die lichteren ziemlich hellgelb.

Aus Brasilien (von Bahia, Mus. Deyrolle) und Columbien (Mus. Berol., von Morilz).

51. Cr. abbreviatellus m. Rostbraun, Naht, Schildchen und drei verwaschene Flecke der Flügeldecken $(2,1)$ schwarz; das Halsschild spiegelglatt, die Punktstreifen oben vereinzelt und hinterwärts schwäclıer, der sechste und siebente abgerissen, mit flachgewölbten, glänzenden Zwischenräumen. L. 3/4"'; Br. $2 / 5 "$.

Bei gleicher Länge mit dem $\mathrm{Cr}$. miserabilis und atomarioides doch etwas breiter und gedrungener als der erstere, von beiden aber an der Sculptur, wie an den schwarzgefleckten Deckschilden leicht zu unterscheiden. Der Kopf flach mit kurzer breiter Stirnrinne, das Kopfschild etwas eingezogen und oben durch eine äusserst feine Querlinie abgesetzt; die Oberfläche fein und zerstreut punktirt, mit glänzendem Zwischengrunde, rostroth, die Kinnhacken schwärzlich, die ziemlich langgestreckten, stark ausgebuchteten Augen greis. Die Fühler von halber Kōrperlänge, das kurz eiförmige Wurzelglied doppelt länger als breit, auch das zweite kurz eiförmig, halb so lang und lreit als das vorhergehende, die folgenden von ziemlich gleicher Länge, um die Hälfte länger aber kaum breiter als das zweite, die oberen nur schwach zusammengedrückt und erweitert, mit kurz kegelförmigem Fortsatze des Endgliedes. Die füıf unteren Glieder rostroth, die oberen schwar'z. Das Halsschild kur'z und breit, mit dem ersten Drittel der Länge vorn kngelig übergewölbt, auch hinterwärts wieder niedergesenkt und dadurch das Mittelfeld sanft emporgehoben; der vordere Theil über den scharf rechtwinkligen Vorderecken stark znsammengedrückt, die Seiten fein gerandet, leicht zugerundet, mit kurzen breiten aber scharf spitzwiuliligen Hinterecken, vor diesen ein Ilacher Schrägeindruck. Der IIıterrand jederseits breit ausgebuchtet, innerseits der Sclıulterbeulen tiefer eingesenkt, fein gesägt, mit tief ausgebuchtetem Mittelzipfel. Die Oberfläche glänzend rostroth mit zart schwarzem Hintersamme. Das Schildchen dreieckig, fast gleichseitig, wenig ansteigend, mit deutlichem Vordergrübchen, glänzend schwarz. Die Deckschilde kurz und breit walzenförmig, hinter den Schulterecken etwas gerundet heraustretend und hinterwärts wieder im Bogen verschmâlert, uur das Schildchen flaclı aufgewölbt und daun im ersten Drittel durch einen starkeı Qureindruck etwas zusammengeschnürt, 
mit hinten ziemlich steil abfallender Wölbung; die schmalen Schulterbeulen sammt den Seitenlappen von mässiger Stärke. Die Punktstreifen sehr regelmässig, aus vereinzelten stellenweise verloschenen, an anderen Stellen wieder grühchenartig vergrösserten Punkten gebildet, die vordere Hälfte des fünften und acliten, besonders in dem Quereindrucke, am grölssten, der sechste und sicbente nur durch wenige unordentlich vermengte Punkte angedeutet, durch welche hinter der Schulterbeule ein zweites rundliches Beulchen alggegränzt wird, die mittleren schon auf der Mitte verloschen, der neunte sciner ganzen Länge nach in eine deutliche Längsfurche eingedrückt. Die Zwischenräume flach, in der Nähe des Eindrucks und längs den Seiten leicht gewölbt, der Zwischengrund spiegelglatt; die Farbe dunkel rostroth, ein Längsfleck auf der Schulterbeule, ein zweiter vorn zwischen dem ersten und vierten Streifen, beide an den schwarzen Wurzelsaum gelehnt, schwarz; und dieselhe Färbung zeigt hinten die Nalıt und vor der Wölbung ein vorn ausgebuchteter grösserer Querfleck zwischen dem dritten und neunten Streifen mit innerseits etwas verwaschener Begränzung. Pygidium, Unterseite und Beine rostroth, die Vorderbrust schmal, längs der Mitte flach längswulstig. Dás letzte Segment des $q$ mit einer tiefen glänzenden Grube, das $\delta$ unbekamnt.

\section{Von Caraccas.}

52. Cr. flagitiosus m. Rostroth mit zwei metallisch braunen Wischen der Flügeldecken; das Halsschild spiegelglatt, die Punktstreifen oben fein, seitlich tief eingegraben, der sechste und siebente abgerissen, mit gewölbten glänzenden Zwischenräumen. L. $3 / 4{ }^{\prime \prime \prime} ;$ Br. $1 / 3{ }^{\prime \prime \prime}$.

Den vorhergehenden Arten älınlich, von ihnen allen aber durch den metallischen Glanz der Wische auf den Deckschilden verschiedeı. Der Kiopf flach gewölbt, mit scharf eingeschnittener Stirnlinie, das liopfschild eingezogen, oben durch eine deutliche Querlinie abgegränzt. Die Oberfläche spiegelglatt, lackglänzend rostroth, die Stirnlinie und die Fühlerhöcker mit einem Fleckchen üher jedem der'selben etwas dunkler, die langgestreckten, sehr breit und seicht ausgebuchteten Augen schwarz; die Nundtlıeile gebräunt. Die Fühler nicht ron lıalber Körperlänge, das Wurzelglied etwa doppelt länger als breit, uberseits etwas flach gedrückt, das zweite kurz und knotig, das dritte doppelt länger, und diesen alle folgenden bis zum zehnten gleich, das dritte bis fünfte fast gleichbreit, 
dümn und olserwärts wenig erweitert, die folgenden zusammengedrückt und verbreitert, das Endglied etwas länger, ron der Vitte aus nach beiden Enden hiı zienlich gleichnässig verschmälert. Die fünf unteren Glieder mit der grösseren unteren Hälfle des sechsten und siebenten gelb, die übrigen geschwärzt, mit angedrückter greiser Behaarung. Das IIalsschild um die Hälfte lireiter als lang, mit der vorkleren Hälfte kugelig ühergewölbt und hinterwärts wieder herabgesenkt, über den scharf rechtwinkligen Vorderecken zusammengedrückt und dadurch rerschmälert, die Seiten in fachen Bogen zusanmengeneigt, die Hinterechen kurz und breit spitzwinklig, durch einen leichten Schrägeindruck etwas aufgetrieben, der Hinterrand jederseits sanft ausgehuchtet mit deutlich doppelt ausgerandetem Hittelzipfel. Die Oberfläche spiegelglänzend, trüh rostrolls, mit einem dunkleren Querschatten über lie Mitte, und schwarz gesiumtem Hinterrande. Mas Schildehen schrïg ansteigend, etwas lïnger als breit, hinten kurz alggestutzt, mit dentlichem Vordergy'tilıchen, glänzend schwarz. Die Deckschilde walzenförmig, um die Halfte lïnger als breit, längs der Wurzel sanft nach vorn abwïls gekrümmt, die schmalen Schulterbeulen innerseits durch einen gleichfalls schmalen Längseindruck abgesetzt, auch die Seitenlappen nur ron schwacher Entwickrlung. Die Punktstreifen zwischen Nalıt umi Schultribeulen fein und bis zur Wölbung gleichmässig fortziehend, der viorte hinter Jer Mitte, der aus dem Längseindruck inncrseits der Schulcerleule entspringende aus etwas grüsseren I'unkten gebildete fünfte schon ror ihr etwas tiefer eingedrücht, und letzterer gegen die Mitte selbst mehr oder wentger deutlich muldentömng erweitert; ron dem sechsten und siehenten nur dicht hinter der Sclublorbeule litrze und tief eingedrüclite Ansïtze rorhanden, der achte lis üler die Mitte hinaus vertieft und an Ilinterende der ahgerissemen Streifen tiefer eingedrückt, der neunte bis zur Spitze hin in eine stärkere Furche eingesenkt. Die spingelglänzenden Zwischenriume der Streifenbiltung entsprechend, die oluen flach, der vierte hinter der Mitte, der breite zwischen ılem fünften nud achten Streifen liegende schon vor ilır längswulstig aufgetrieben mal nach der Schulterbenle zu in gleicher Weise gegabelt, der achte und neunte in ilner ganzen Länge flach rippenförmig aufgeröllht. Die Farbe holl rostroth orler bei weniger gut atsogefärbten Stïclien hellgelb, die Säume und das Innere der Punlite gebräunt, der Vordersam schwarz, ein Längs- 
fleck auf der Schulterbeule, ein breiler Längswisch rorn zwischen dem abgekürzten und dem vierten Streifen, sowie ein nach hinten und innen zielıender Schrägwisch auf der Wölbung zwischen dem ersten und achien Streilen tiefer gebrüunt, verwaschen begränzt und an der intensir dunkelsten Stelle ins Metallischgrünliche schimnernd, Das Prgidium äusserst fein punktirt, mil Unterseite und Beinen einlarlig rostgell, die Hinterbrust und zuweilen auch des vordere Theil des Hinterleibes schwarz oder doch trïb gebräunt; die Vorderhrust schmal, der Länge nach elwas aufgewulstet, hinten last grade abgeschnitten, mil kurz rorspringenden Hinterecken. Das letzte Segment des $\delta$ einfach, des of mul einer länglichen glänzenden Grube.

Aus Peru. Mus. Baly: auch von Herrn Deyrolle milgetheilt.

53. C.r. cousputus m. Lederbraun, der Kopf, der Vorderrand und zwei Hinterflccken des Halsschildes, Wurzel, Spitze und ein schräger Seitenlleck der Flïgellecken hellgelb; die Punktstreifen mässig, ller sechste und siebente alıgerissen, mit oben flachen, seitlicl, llachgewölbten Zwischenräumen. L. $3 / 4{ }^{\prime \prime \prime}$; Br. $2 / 5{ }^{\prime \prime \prime}$.

Gewissermaassen eine Mittelform zwisclsen dem vorhergehenden und den Cr. fusculus; dem ersteren in dem Habitus, letzterem in der Zcichnung nicht unähulich. Der Kopf flach gewölbt mit kurzer aber tiefer Stirufurche, das Kopfschild eingezogen und oben durch eine deutliche Querlinic abgegränzt. Die Farbe hellgelb, die Stirnfurche mit den Fühlerhöckern, dem Ober- und Unterrande des Kopfschildes und den Mundtheilen dunkler lederbraun, die Flächı glänzend und ohne Punlite. Die langgestreckten, dreieckig ausgehuchtetcn, oberwärts etwas genäherten Angen schwarz. Die Fübler ron elwa lralber Kürperläıge, das oberseits etwas abgeplattete Wurzelglied $2 \frac{1}{2}$ mal länger als breit, das zweite kirz eifürmig, das dritte doppelt länger und diesem die oberen gleich, letztere vom sechisten al ziemlich stark zusammengedrüclit und rerbreitert, mit kurz dreieckigem Furtsatze des Endgliedes. Die Farbe der unteren Glierler gell, dis oberen rom sechsten ah schmutzig geschwärzt. Das kurze und loreite HaJsschild hinter der Mitte fist buckelig quer aufgewöllbt, mul damn nach vorn mit der grösseren Ilälfte sanfter, hinten mit der lileineren stärker abwärts gekrümmt, vorn über den sehr lief eingezogenen scharf rechtwinkligen Vorterecken zusammengedrückt und dadurch verschmälert, die feinen Seitenränder durch eine dichte Reihe grober Qucrpunkte abgeseizl, 
nach vorn fast in graden Linien zusammengeneigt, die Hinterecken kurz und breit zugespitzt, etwas aufgetrieben, der Hinterrand jederseits breit ausgebuchtet, tief eingesenkt, mit kurzem aber deutlich doppelt ausgerandetem Mittelzipfel. Die Oberfläche lederbraun, bei einem vorliegenden $\delta$, sowie bei dem $\&$ ziemlich matt unl glanzlos, bei einem anderen spiegelglatt, ein breiter sich hinterwärts zu einer abgekürzten Längslinie, in den Vorderecken zu viereckigen Flecken erweiternder Vorderrand, ein kleiner Fleck in jedem Hinterwinkel, und ein eiförmiger, bei dunkleren Stücken zu einem verwaschenen Schrägwische geschwundener Schrïgfleck jederseits vor dem Hinterrande heller gelb. Das Schildchen mässig ansteigend, etwas länger als breit, dreieckig mit kurz alggestutzter Spitze und deutlichem Vordergrübchen, glänzend schwar'z. Die Deckschilde walzenfürnig, etwa $1 / 4$ läıger als breit, vorn hinter der eingesenkteu Wurzel schwach ansteigend, die breiten Schulterbeulen durch einen tiefen von dem Vorderrande des fünften Streifens gebildeten Längseindruck abgesetzt, die Seitenlappen schwach herabgezogen und über ihnen die Deckschilde auch nur schwach zusammengedrückt. Die Punktstreifen regelnässig, von mässiger Stärke, hinterwärts schwächer aher nirgends ganz verschwindend, der fünfte leicht wellig gekrümmu, vor'ı und wieder hinter der Mitte tiefer eingegiaben, der sechste und siebente bald hinter der Sclunlterbeule abgerissen, die drei letzten wieder vollständig, der achte über dem Seitenlappen, und der neunte seiner ganzen Länge nach etwas tiefer eingedrüclit. Die Zwischen'äume oben flach, seitlich flach gewölbt; der vierte vorn, der breite zwischen dem fünften und achten Streifen liegende hinter dem Ende der abgerissenen Streifen längsbeulig aufgetrieben, und letzterer an dieser Stelle auch noch durch einen ziemlich scharf^u, den fünften und achten Streifen verbindenden Quereindruck durchsetzt; eine eben so lingsbeulige Auftreibung zeigen die beiden äusseren Zwischenräume über den Seitenlappen, und alle diese aufgetriebenen Stellen sind zugleich hellgelb gefärbt. Eben so gelb sind auch die hreite nicht punktirte Spitze und ein ziemlich hreiter Wirzelsium, von welchem aus sich ein etwas melar verwaschener heller Wisch längys der Naht über den Rücken hinzieht. Die Grundfarbe selhst lederbraun, iuf dem Rücken meist noch mit schwïcheren und sehr verwaschenen helleren Wischen, der Glanz nur mı̈ssig, an den hellgelben Stellen stärker, lackartig. Aendert $a b$ 
$\beta$. schwarz, die Mundtheile und Beine bis auf die unteren Schenkelhälften pechlıraun, Fühlerwurzeln, Kopfschild und zwei Stirnflecke, Vorder- und Hinterecken des Halsschildes mit zivei Hinterflecken desselhen und dem Vorderrante gelb; auf den Flügeldecken nur die schwielige Auftreibung hinter dem seitlichen Quereintrucke und ein Fleck vor der Spitze in verwaschener Begränzung gelblich. Ein einzelnes $\delta$ mit glänzendem Ilalsschilde im Mus. Berol., von Sello bei S. João del Rey gefunden.

Das Pygidium dicht punktirt, kurz und dünn greishaarig, und wie die Unterseite etwas dunkler hraun, die Beine gelb. Die Vorderbrust viereckig mit leicht anfgewulsteter Mitte, hinten fast grade abgestutzt mit vorspringenden Ecken. Das létzte Segment des ¿ leicht ques eingedrückt, des $q$ mit dem gewühnlichen Grübchen.

Aus Brasilien. Mus. Deyrolle, Baly, Berol.; in letzterem in sehr verschiedenen Formen.

54. Cr. plicatus m. Lederbraun; Kopf, Fühler und Beine mit den Rändern und zwei Hinterflecken des matten Halsschildes, so wie verwaschene Längslinien der Deckschilde sclımutzig gelb; die Punktstreifen derb, in vertiefte Läugslinien eingedrückt, der sechste und siebente fehlend, mit flachgewölbten matten Zwischenräumen. L. $5 / 6{ }^{\prime \prime \prime}$; Br. $1 / 2{ }^{\prime \prime \prime}$.

Etwas grösser als $C r$. consputus, übrigens demselben sehr nahe verwandt, und von den helleren Stücken desselhen hauptsächlich durch die tieferen, ihrer ganzen Länge nach in feine aber dentliche Iängsturchen eingedrückten Punktstreifen, so wie durch den gänzlichen Mangel des sechsten und siebenten Streifens abweichend. Der Kopf flach gewölbt, mit tief eingezogenem, oben durch eine deutliche Querlinie abgegränztem liopfschilde, die Stirn mit krältiger Längslinie; die Farhe ein mattes schmutziges Gelbbraun, jedoch ohne deutliche Punktirung, die Kimbacken und die lang gestreckten, hreit aber nicht tief ausgebuchteten, oben weit getremnten Augen schwarz. Die Fühler gebaut wie bei Cr. consputus, die fünf unteren Glieder durchscheinent hellgelb, die oberen sclımutzig gebräunt mit starker greiser Behıarung. Das Halsschild mit $3 / 4$ seiner Länge vorn stark ühergewölbt, durch die tief eingezogenen scharf rechtwinkligen Vorderecken verschmälert; die feiı gerandeten Seiten nach rom in breiten Bogen zusammengeneigt, die Hinterecken kurz und lreit zugespitzt, durch einen Schrägeindruck schwielig aufgetrieben; der eingesenkte Hinterrand jederXV. 
seits breit und seicht ausgebuchtet, mit kurzen, doppelt ausgerandetem Mittelzipfel. Die Farbe matt lederbraun, Vorder- und Scitenrand nelsst zwei Flecken vor dem Hinterrande verwaschen gellylich, nur die Schwielen in den Hinterwinkeln etwas lıeller gell. Das stumpf dreieckige Schillchen schräg ansteigend, etwas lïnger als breit, mit deutlichem, von zwei kurzen Beulen eingeschlossenem Vordergrübchıı, schı̈ärzlich. Die Deckschilde walzeıförmig, etwa $1 / 4$ länger als breit, rorn etwas breiter als das Halsschild und damm ziemlich gleichbreit bis zu der kurz ahgerındeten Spitze verlaufend, hinter dem aufgetriehenen Vorderrande durch die tiefer eingegrabenen Vorderendeı der oberen Punktstreifen quer niedergedrückt; die grossen halb eiförmigen Schulterbeulen innerseits nur durch das Vorderende des fünften Streifens abgesetzt, die Seitenlappen scliwach, und über ihnen die Deckschiłle nur wenig zusammengedrückt. Die Punktstreifen sehr regehnässig und kräftig, aus dicht gedrängten, in feine aber besonders vorn und an den Seiten tief eingrgrabene Längslinien eingestochenen Punkten gebildet; der sechste. und siebente ganz fehlend, und statt ihrer die vorn etwas erweiterte Furche des achten hier noch mit einigen überzähligen Punkten besetzt. Der breite zwischen dem fünften und achten Streifen liegende Zwischenraum hinter der Schulterbeule ist tlann dem Seitenlappen gegenüber von einem mit cinigen Punkten besetzten oder durch solche entstandenen Quereindruck durchschnitten, und vor und hinter demselhen schwielig aufgetrieben; älntiche, aber schwächere und nach beiden Enden allnählich verlaufende Autreibungen zeicen der vierte Zwischenraum innerscits der Schulterbeule, so wie der achte und neunte über dem Seitenlappen; aher auch des übrige Theil der Zwisclıenrämne ist flach gewölht, und labei die ganze Oberflähe der Deckschitgle matt und glanzlos. ,Dic Farbe lederbrauı, an den bezeichmeten aufgetriehenen Stellen heller gelb mit verwaschener Begränzung, und eine ähnliche nur noch mehr verwasclıene Färbung zeigen anch der Wurzelıand, die Spitze, die drei ersten Zwischenräume längs der Naht und die hintere Hälfte des vierten, so dass dadurch die ganze Oberfläche ein schmutzig braun und gelh gewässertes Ansehen erhält. Das Pygidiun gelb mit gebrüuntem Saume, die Hinterbrust und der Hinterleils dunkelbraun, jene mit den Jarapleuren fast schwärzlich; der letzte Banchring mit dem Vittelzipfel des ersten vorwaschen gellolichluam. Vorderund Mittelbrust mit den lieinen hellgelb, arstere in der Mitte auf- 
gewulstet, mit kurz vortretenden ilinterecken. Das letzte Segment des 9 mit einer grossen rundlichen stark glänzenden Grube, das $\delta$ unbekannt.

Aus Brasilien (IIus. Berol.: bei Causapava, von Sello gefunden).

55. Cr. impressus m. Dunliel metallischgrün, Mundtheile, Fühlerwurzehn, der Vorderrand des ghatten flalsschildes, ein Fleck hinter der Schulterbeule und die Spitze der Flïgeldecken rothgelb; die Punktstreifen fein, der sechste und sichente abgerissen, mit sehr flach gewölbten Zwischenräumen. L. 1"'; Br. 2/3"'.

Diese und die nächstfolgenden Arten bilden durch ihre metallische Färbung einen unverkembaren Uebergang zu der nächsıfolgenden Rotte, kömmen aber nach Habitus und Sculptur nicht wohl vou den vorhergehenden Arten getrennt werden, und stehen insbesondere durch die letzte mit dem Cr. conspmums und plicalus in der genamesten Verwandtschaft. Bei der vorliegenden Art ist der Kupf flach gewölht, auf der Stirn leicht ringedrückt und über diesem Eindrucke von einer feinen Längslinie durchschnitten; das grosse liopfschild nach oben verschmälert und daselbst zwischen den Fühlern durch eine scharf eingedrückte Querlinie, seitlich durch ehen so deutliche líanten begränzt. Die Uberfläche glatt, die Stirn metallisch schwarzgrrüı, das Kopfschild rothbraum, die tief ausgebuchteten Augen greis, die Wangen und Mundtheile röthlich gell. Die Fühler liurz aber kräftig, kaum über den Hinterrand des Halsschildes himausreichend, das keulige Wurzelglied doppelt länger als breit, das zweite gestreckt elliptisch, etwa halb so lang und breit wie das erste, das dritte fast doppelt länger als das zweite, und ihın auch die folgenten gleich, das dritte his fünfte schmal linienförmig, die folgenden schwach zusammengedrückt und verhreitert, mit wenig bemerlibarem Fortsatze des Endglirdes. Die Farbe der fünf unteren hell rothgelb, die oberen schivarz, dünn anliegend greis behaart und einzelı abstehend länger gewimpert. Das Halsschild etwa halb so lany wie breil, in der Mitte quer aufgewöllt und damn nach vor'n mässig heralıgekrüımu, üher den scharf rechtwinkligen Vorderecken etwas zusammengedrückt und dadurch verengt; die Seiten lein gerandet, nach vorn in leichten Bogen zusammengeneigt, vor den lurz und lıreit aher scharf spitzwinkligen Hinterecken etwas ausgeschweift, anch der Hinturand jederseits nur schwach ausgebuchtet, aher tief eingesenkt, mit kurzem, sehr deutlich toppelt 
ausgerandetem Mittelzijfel. Die Oberfläche ohne deutliche Punktirung, aber doch nur matt und seidig schimmernd, die Farbe dunkel metallischgrün, der' Vorderrand roth gesäumt, so dass dieser Saum sich in der Nitte bogenförmig nach hinten erweitert und auch in den Vorderecken grössere Flecken bildet, ausserdem auch bei einem der vorliegenden Stücke die durch einen Schrägeindruck etwas anfyetriebenen Hinterwinkel schwach geröthet. Das Schildchen selı sanft ansteigend, länglich dreieckig, hinten kurz abgestutzt umbl vorn mit deutlichem Grübchen, glänzend schwarzgrün. Die Dechschilde liurz und breit walzenförmig, vorn etwas breiter als das Halsschild und hinterwärts noch elwas verbreitert, etwa um $1 / 3$ länger als breil, mil mässig abfallender Wöllıung, die Schulterbeulen als grosse hallıugelige spiegelglatte Höcker aulgetrieben, innerseits durch eine tiefe Längsfurche abgesetzt, die Seitenlappen und der ïber ihnen liegende gewölnuliche Quereindruck wenig bemerkbar. Die Punktstreifen sehr regelmässig, die Punkte der Rïclienstreifen fein, elwas auseinander gerückt und in die Länge gezugen, die Vorderenden des fünften und achten, so wie der neunte und der Randstreifen aus gröberen, dichter gestellten und tiefer eingedrückten Punkten gehildet, auch von dem sechsten und siebenten hinter der Schulterbeule nur die aus groben und tiefen Puntiten bestehenden Ansätze vorhanden, und durch diese allerseits grobe Punhtirung der breite Zwischenraum zwischen lem fünften und achten Punktstreifen wulstig aufgetrieben, zugleich alıer dem Seitenlappen gegenüber durch zwei nebeneinander stehende grobe Punkte - unzweifellıfte Reste des sechsten und siebenten Streifens - lurchsetzt, und dadurch nach rorn ein viereckiges, nach hinten ein langgestrecktes erhöhtes Feld abgeschnitten, welches letzlere sich nach der Spitze zu allmählich in den flacheren Theil jenes breiten Zwischenraumes verliert. Dabei die oberen Zwischenräume uur flach-, die seitlichen stürker gewölht, jene mit matterem, diese mit stärkerem Glanze; die Farbe metallisch schwarzgrün, ein grosser schräg rautenförmiger Fleck hinter der Schulterbeule, dessen längere Mitle auf den fünften und dem auf diesen folgenden breiten Zwischenranme liegt und auf letzlerem die beiden erhölsten Felder mit einschliesst, wälırend seine kürzeren Seitenenden auf den vierten und achın Zwischenraum ühergreifen, rothgelb; ejsen so die Spitze der Flügeldecken unter der Wöllnmy rothgelb. Aendert jedoch ab 
$\beta$. Die Flügeldecken vorı ungeffeckt, und auch deren Spitze ıur leicht bräunlich durchschimmernd. Bei dem einzigen vorliegenden Stücke dieser For'm ist auch der Vorderrand des Ilalsschildes einfarbig, die Hinterecken aher sind sclımal geröthet.

Das I'ygidium vereinzelt aber deutlich punktirt, schıvach gläızend, schwarzgrün, Vorder- und Mittelbrust rothbrann, erstere breit und flach, jederseits der Länge nach, und hinten in die Quere leicht eingedrückt, mit kurz vorspringenden Hinterecken. Die Beine roth, mit gesclıwärzter Unterhälfte der Schenkel. Das letzte Segment des o mit einer grossen, aber nicht tiefen spiegelglänzenden Grube; das $\delta$ unbeliannt.

\section{Aus Brasilien. Mus. Hal., Schaum.}

56. Cr. c oerule olus Moritz. Hell stahlblau, Fühlerwurzeln, Mund, zwei Stirnflecke, und die Beine mit Vorder- und Mittelbrust hellgelb; das Halsschild grob gerunzelt, die vorn deutlichen Punktstreifen hinterwärts schwächer, der sechste und siebente abgekürzt, mit flachen fein querrunzligen Zıvischenräumen. L. $2 / 3{ }^{\prime \prime \prime}$; Br. $1 / 3{ }^{\prime \prime \prime}$.

Eine kleine äusserst zierliche und vor allen Verwandten durch ihre fast himmelblaue Farbe, die gelben Stirnflecke und das grobgerunzelte Halsschild sehr ausgezeichnele Art. Der Kopf flach gewölbt nit breiter, seichter Stirnrime, das stark eingezogene Kopfschild oben durch eine deutliche Querlinie alggesetzt, mit den Mundtheilen lehmgelb, die Mitte der Stirn deutlich zerstreut punktirt, hellbłau, die langgestreckten, tief ausgebuchteten, (bei dem ठ) noch durch einen schmalen Zwischenraum getremten Augen schwarz; in jeder Augrenbucht ein breiter, viereckiger gelber Querfleck, welcher sich oben mit einem Ziplel an den oberen inneren Augenrand anlehnt, während seine breite Unterseite ïber den Fühlerhöckern in die verwaschen loräunlichgelbe Färlıng der Wangen übergeht. Die Fühler von halbẹ Körperlänge, das zweite Glied eifürmig, die drei folgenden düun verkelırtkegelförmig, das dritte und vierte einander gleich und je um 1/4, das füıfte um die lälfte länger als das zweite, die oberen dem fünften gleich, aber deutlich zusammengedrückt und rerbreitert. Die fünl' unteren hellgelb, die oberen sclıwar\%, dümm gr'eis behaart. Das Halsschild um die Hälfte breiles als lang, von der Mitte ab nach vorn und hinten gleichmässig sanft abwärts gekrümmt, über den scharf rechtwinkligen Vorderecken tief einge- 
zogen und dadurch verschmälert; die fein gerandeten Seiten nach vorn in breiten, flachen Bogen zusanmengekrümmt, die Hinterecken kurz und hreit zugeschärft, wenig vortretend, durch einen leichten Schrägeindrucli etwas aufgetrieben, der Hinterrand jederseits nur leicht wellig gebuchtet, mil kurzem, breitem, dopjelt ausgerandetem Mittelzipfel; vor dem letzteren eine feine, aber tief eingegrabene Querlinie, zu welcher sich die hintere Mitte les Halsschildes stärker hinabsenkt. Die Oberfläche nit welligen, nicht tiefen aber dichten Quer- und Schrägrunzeln bedeckt, hell stahlblau mit mattem Schimmer. Das Schildchen stark ansteigend, etwas länger als breit, stumpf herzförmig mit deutlichem Vordergrühchen, glänzend und gleichfalls hell stahlblau. Die Deckschilde gestreckt walzenförmig, umı die Hälfte länger als hreit, fast gleichbreit und erst nahe vor der Spitze kurz zugerundet, die Wurzel nur jerlerseits des Schildchens etwas niedergedrückt; die breiten flachen Schulterbeulen innerseits kaum abgesetzt, die Seitenlappen dagegen kräftig ausgebildet, mit scharf hervortretendem Kiele, über welchem tler neunte und zehnte P'unktstreifen der Läıge nach tiefer eingedrüickt und etwas verbreitert sint. Die Punktstreifen aus vereinzelten, auf dem ersten Drittel ziemlich kriftigen Punliten gebildet, von da ab schwächer und auf der Wölbung kaum noch bemerkbar, der sechste und siebente durch eine den fünften und siebenten Zivischenraum verbindende Querbeule abgeschnitten; hinter dieser ein schwacher Quereindruck, und hinter letzlerem wieder der Anfang des breiten Zwischenraunes zwischen den fünften und achten Streifen llach beulig aulgetrieben. Die Zwischenräume tlach, ziemlich dicht iber sehr fein querrunzlig, daher stärker glänzend als ılas Halsschild, und gleichwie dieses hell stahlblau. Pygidium, llinterleib und Hinterbrust schwarzblau, der übrige Theil der Unterseite mit den Beinen hellgell, die Mittellırust mit den umgeschlagenen Seiten des Halsschildes etwas dunkler gelb. Das Prosternum etwas länger als breit, die scharfen Seitenkanten durch eine feine eingegrabene Längslinie alygesetzt, das Mittelfeld der Länge nachı sauft aufgewölbt, die Hinterecken wulstig aufgetrieben. Das letzte Bauchsegnent des $\delta$ einfach; das $q$ mbekamut.

Aus Venezuela (Mus. Berol, voll Morit).

57. Cr climactericus m. Schwarzgrüı, Fühlerwırzeln, Vorderbeine, ein Fleck hinter der Schulterbenle und die Spitze der Flügeldeclien golb, ras Halsschild spiegrelglatt, die P'unkistreifen derJ, 
der sechste und sieheıte alggerissen, mit flachgewölhten, gläızenden Zwischenräunıen. L. 1"“; Br. $2 / 3$ ".

llen vorhergehenden ähılich, aber durch den helleren Glanz und die reinere Zeichnung viel zierlicher, in der Mitte etwas mehr verbreitert, auch durch den Nangel jerler Querverbindung zwischen dem füıften unıl achıten l'unkistreifen von ihnen abweichend. Der Kopf flach mil etwas eingezogenem Kopfschilde, letzteres oben durch eine leichte Querleiste abgeselzt, auch die Stirn von einer tiefer eingegrabenen Längslinie durchzogen. Eine sehr feine Punktirung nur an den Seiten des Kopfschildes bemerkbar, die Obernäche aber fast matt, äusserst fein genarbt, die Farbe schwärzlich, Kopfschild und Ilundtheile pechbraun mit hellerem Unterrande der Oberlippe; die breit und seiclıt ausgehuclıteten, oben etwas genäherten Augen greis. Die Fühler ziemlich kurz, das langgestreckte Wurzelglied fast gleichbreit, etwa $2 \frac{1}{2}$ mal länger als breit, das zweite schmal eiförmig, kaum hall so lang als (las erste, die drei folgenden verkehrtkegelförmig mit etwas stärker verbreitertem oberem Ende des fünften, das dritte ctwas läuger als das zweite, das vierte dem letzteren gleich und das fünfte noch ein wenig kürzer; die oberen etwas stärker zusanımengedrückt und verbreitert, an Länge je etwa dem dritten gleich, mit kurzem Fortsatze des Endgliedes. Die Farbe der unteren gelb mit gebräunter Spitze des fünften, die obercn schwarz mit angedrückter dünner greiser Behaarung. Das Halsschild um die Hälfte breiter als lang, hinterwärts etwas niedergesenkt, hinter der Mitte quer aufgewölbt und daun mit $2 / 3$ der Länge nach vorı stark kugelig übergekrümmt, hier über den sehr tief eingezogenen rechtwinkligen Vorderecken stark zusanmengedrückt und dadurch verschmälert; die fein gerandeten Seiten nach vorn in breiten Bogen convergirend, hinten sehr sclıwach ausgeschweift, mit breit und scharf ausgezogenen, durch einen Schrägeindruck etwas aufgetriebenen Hinterecken, der Hinterrand jederseits ausgehuchtet, vor den Scluulterbeulen tief eingekniffen, mit kurzem, deutlich doppelt gerandetem, und durch einen davor liegenden scharfen etwas gekiünmten Quereindruck aufwärts geschobenem Ilinterzipfel. Die Punktirung sehr fein und zerstreut mit spiegelglatten Zwischengrunde, die Farbe dunkelgrün; die Vorderwinkel trüb röthlich durchscheinend. Das Schildchen schräg ansteigend, dreieckig, um die Hälfte länger als breit, mit grossem Vordergrübchen, hinten kurz alggestutzt, gleichfalls glänzend dunkel- 
grün. Die Deckschilde vorn etwas breiter als das Halsschild, flach walzenförmig, hinterwärts bogig verschmälert und etwa $11 \mathrm{~m}$ die Hälfte länger als breit; die Wurzel in die Quere wulstig erhöht, und hinter ihr durch die tief eingegrabenen Vorderenden der Punktstreifen eine zusammenlıängende Querreihe von Eindrücken gebildet, durch welche eime in der Mitte etwas hinterwärts gekrümmte Querfurche entsteht; die Schulterbeulen breit und kräftig emporgehohen, auch die Seitenlappen ziemlich stark herabgezogen. Der Rücken von der Schildchenspitze hinterwärts in sanft gekrümmtem Bogen abfallend, seitlich erst flacher, dann hinter den Schulterbenlen steiler abwärts gerichtet. Die Punktstreifen derb und besonders vorn liräftig eingedrückt, hinterwärts etwas schwächer aber doch in ilırer ganzen Ausdehnung kenntlich, der sechste und siebente hinter der Schulterbeule hald abgerissen, die Zwischenräume glänzend, flachgewölht, der vierte durclı eine nach aussen gehende Ausweichung des fünften Streifens so weit verbreitert, dass er die Breite des zwischen dem fünften und achten Streifen liegenden Zwischenraumes erreicht. Auch der umgeschlagene Rand des Seitenlappens mit einer deutlichen Punktreihe besetzt. Die Farbe g]cichfalls ein schönes dunkles Grün, die Spitze und ein grosser Querfleck hinter der Schulterbeule, welcher innerseits bis nahe an den dritten Streifen, aussen fast bis zum Seitenrande reicht und vorn die Hinterenden des sechsten und siebenten Streifens berührt, hellgelb. Das Pygidiun vereinzelt grob aber nicht tief punktirt, mit der feiner runzlig punlitirten Unterseite schwarz, schwach ins Grünliche oder Bläuliche fallend; die Beine gelb, von den Vittelund Hinterbeinen die unteren grösseren Schenkelluälften, an den letzteren auch die Schienen schwärzlichgrün. Die Vorderbrust flach, runzlig punktirt, linten fast quer abgeschnitten mit stark vortretenden Hinterecken, und, wie die Mittelbrust, gelb. Das letzte Segment des $q$ mit einer flachen, gläuzenden Grube; das $\delta$ unbekannt.

Aus Brasilien (von Santos: Mus. Dohrn).

Vierzelınte Rotte. Körper breit und flach walzlich, mit kurzen, oben etwas verdickten Fublern und lileinen, weit getrennten, nur seicht ausgebuchteten Augen. Das Sclildchen mit seinem Hinterende nicht erhöht, und um letzteres die Deckschilde nicht aufyeworfen. Die Puuktstreifen sehır fein, hinterwärts zu zarten Punktlinien alogeschwïht, theilweise erloschen. Kleine, IJaltiken 
ähnliche Küfer, vorzugsweise in den Küstenländern des Caraibischen Meeres einheimisch, daher auch noch nordwärts auf den Antillen und um dell Mexicanischen Neerbusell vertreten. Linn. VII. 70. Zwanzigste, und XII. 377. Nemnzehnte Rotte.

58. Cr. viridi-aeneus Bolı. Dunkel goldgrün, Unterkopf und Beine gelb, das Ilalsschild spiegelglatt, die Punktstreifen hinterwärts last erloschen, der sechste und siebente abgekürzt nit flachen glänzenden Zwischenräumen. L. $5 / 6{ }^{\prime \prime \prime}$; Br. 1/2 "'.

Monachus viridi-aeneus Boh. Fregatten Eugenies resa Col, p. 158. n. 329 !

Den kleineren Stïcken des bekannteren Cr. auratus Fab. an Grösse gleich, und diesem Käfer überhaupt in Habitus und Färbung sehr nahe verwandt. Der Kopf breit und flach, mit mässig ausgerandeten Augen, matt schmutzig gelbbraun, obwohl ohne deutliche Punktirung; die Stirn und das oberwärts fein und deutlich punktirte Kopfschild bei dem $q$ mehr ins Grünliche fallend, bei dem überhaupt reiner ausgefärbten ơ heller gelb. Die Fühler fehlen beiden von mir verglichenen Exemplaren, sind aber nach den spärlich vorhandenen Resten anch wenigstens in ihrem unteren Theile gelb. Das Halsschild kurz, hinten eingesenkt und vorn mit halber Länge übergewölbt, seitlich fein gerandet, die Ränder in schwach gekrümmten Bogen nach vor'n convergirend, die Hinterecken breit dreieckig vorgezogen, der Hinterrand nur vor den Schultern merklich ausgebuchtet, mit kurzem, breitem, schwach doppelt ausgerandetem Mittelzipfel. Die Oberfläche spiegelglatt, dunkel goldgrün. Das Schildchen lang dreiechig, vorn mit dem gewöhnlichen Grübchen, gleichfalls gläızend grün. Die Deckschilde breit walzenförmig, längs der Wurzel schwach aufgeworfen und dahinter durch die längsgrübchenartigen Vorderenden der Punktstreifen quer eingedıückı, die Srhulterbeulen als grosse länglichrunde Höcker aufgetrieben, der Rücken sehr allmählich bis zur Wölbung, und etwas stärker von dieser bis zur Spitze abfallend, letztere selbst breil zugerundet. Die Seitenlappen von mässiger Stärke, unterseits mit einer Reihe gröberer Punkte besetzt. Die Punktstreifen vorn aus tiefen Längsgrülchen entspringend, dann bis zum Encle des Seitenlappens durch runde grübchenartige Punkte fortgesetzt und hier der sechste und siebente algehrochen, die ührigen ziehen danm überaus fein aber uirgends völlig erlöschend bis zur Spitze hin, die Zwvischenrïume flach, hinterwärts durch die Ab- 
schwächung der Punkte verbreitert, nur der breite drittletzte durch eine Ausweichung des achten Streifens merklich verengt. Die Zwischenräume einfarbig dunkel goldgrūn, glänzend, die Schulterbeulen etwas ins Messingrgelbliche spielend. Pygidlum und Unterseite vereinzelt punktirt, dunkel schıvarzgrün, hinterwärts etwas ins Bräunliche fallend, die Beine mit den Hüften, Vorder- und Mittelbrust gelb, auch die Seiten des Halsschildes unten gelblich durchscheinend. Die Vorderbrust flach, runzlig punktir't, hinten ques alggeschnitten, mit scharf vorspringenden Hinterecken; das letzte Segment des $\delta$ einfach, des $f$ mit eines glänzenden runden, an den Seiten breit niedergedrïckten Grube.

Aus Brasilien (Ius. Saunders, Holm., in dem letzteren ist Rio de J. als Fundor't angegeben).

59. Cr. globulosus m. Dunkel goldgrüı, Unterkopf, Hüften und Beine nit den Schulterblättern und der Vorlerbrust gelb; das Halsschild spiegelglatt, die Punktstreifen deutlich, des siebente und achte abgekürzt, mit flachen, glänzenden Zwischenrïumen. L. $1 / 3{ }^{\prime \prime \prime} ; \mathrm{Br} .1 / 4{ }^{\prime \prime \prime}$.

In der Färbung dem vorhergehenden Cr. viridi-aeneus Boh., im Hahitus mehr einzelıen kleinen Monachen ähnlich, aher doch vou der gegenwärtigen Gruppe nicht wohl zı trennen, und der Grösse ıach am nächsten dem norlamerikanischen Cr. atomus Er. verwandt. Der Unterkopf mit Fülılern und Mundtheilen hellgelb, ohne deutliche Punktirung. Das etwas eingezogene Kopfschild von der Stirn durch eine deutliche Querlinie getrennt, die Stiru gुlänzend dunkel goldgrün, die langgestreckten, stark ausgebuchteten, wcit getremnten Augen schwarz. I)as Halsschild kurz und breit, vorn mit 2/3 rler Läıge stark ühergewölbt, die scharf' rechtwiuliligen Vorderecken tief eingezogen und dadurch das Halsschild verschmälerm, die Seiten fein gerandet, mit der vorderen Ifilfte stark zusanmengekrünnt, die Hinterecken kurz und breit, der Hinterrand jederseits tief eingesenkt, loreit ausgebuchtet, fein gesägt, mit liurzem, tief doppelt ausgerandetem Mittelzipfel. Das Mittelfeld linterwärts merklich abwärts gekrümunt. Die Oberlläche spiegelglänzend dunkel goldgrüı. Das Schildchen gleichseitig-herzförmig mit starkem Vorlergrühchen, hinterwärts merklich ansteigend, gleichfalls glänzencl goldgrün. Die Deckschilde kaum 1/4 lïnger als breit, nach der breiten Wurzel zu stark heralggesenkt, von đa ah hinterwärts fast geradlinig verschmälert, zuletzt kuř zugerundet; die länglichen, 
flachen Schulterbeulen nur hinterwärts durch einen breiten flachen, sich zu dem auch nicht grade kriftigen Seitenlappen herabziehenden Quereindruck etwas abgesetzt. Die Punktstreifen aus vereinzelten, aber deutlichen und hinterwärts nicht abgeschwächten Punkten gebildet, der siebente und achte an dem Quereindrucke ahgerissen und der sechste vou da ab etwis nach aussen gekrünmm, der neunte und das Hinterende des ersten in eine deutliche Längsfurche eingedrückt und dadurch der neunte Zwischenraum etwas aufwïrts geschoben, die übrigen flach, und die ganze Oherfläche glänzend goldgrïn. Auf der Unterseite sind Vorder- und Vlittelbrust mit den Schulterblättern, Hüfteı und Beiıen hellgelb, die ungeschlagenen Seiten des Halsschildes mit dem Pygidium jechbraum, und eben so fällt der schmale Spitzenrand der Deckschilde leicht ins verwaschen Pechbranne; Hinterbrust und Hinterleib aber sind tief schwärzlich grüı. Das letzte Segment des einzigen vorliegeuden $\delta$ ist einfach.

Aus Columbien (von Hrn. Dr. lirats mitgetheilt).

60. Cr. auratus Fab. Erzfarbig, Unterkopf, Fühler und Beine gelb; das Halsschild fein genarbu und ınatt, die Punktstreifen fein, hinten und seitlich erloschen, mit flachen feiı genarbten Zwischenräumen. L. $1 / 2-1 \frac{1 / 12}{\prime \prime \prime}$; Br. $1 / 3-2 / 3{ }^{\prime \prime}$.

Cr. auratus Fab. ap. Suffr. Linn. Ent. VI. 71. n. 87. cf. ib. 418. und XII. 377. n. 96.

Bei allen mir vorliegenden südamerikanischen Stücken sind die Seiten des Halsschildes einfarbig, auch scheinen dieselben etwas flacher, verhältnissmässig breiter, und daher vorn kürzer zugerundet zu sein. Auch fällt das Messinggelh der Oberseite mehr ins Feuergelbe; weitere Unterschiede finde ich nicht, und auch Erichson erachtete den südamerikanischen Käfer nicht von dem nordamerikanischen specifisch verschieden.

In Columbien. (Mus. Haag, und eben dahter mir auch von Erichson mitgetheilt. Bei den Stücken des Mus. Berol. ist Aragua und Caraccas als Fundort genannt.)

61. Cr. a enescens in. 'Trül erzfarhig, Unterkopf, Fühler und Beine gelb, das Halsschild fein genarbt und matt, die Punktstreifen aus krätigen Vorderenden hald erloschen, mit thachen fein genarbten Zwischenrïumen. L. $1 / 2{ }^{\prime \prime \prime}$; Br. 1/4"'.

Denı vorhergehenden ungrmein ähnlich und mil ihn auch in delı Sammlungen verwechselt, aber doch von ihm anscheinend 
hinlänglich ver'schieden. Er gleicht an Grösse den kleinsten Stüchen des $\mathrm{Cr}$. auralus, oline merkliche Grössenver'schiedenheit beider Geschlechter, ist dahei schmäler und melır walzenförmig, die Farbe. ein trübes Broncegrün, doch merklicher gtänzend als bei der genannten Art, und am líopfe nur das untere Viertel gelblich. Auf den Flügeldecken bildet bei den zwischen Schildchen und Schulterbeule liegenden Punktstreifen jeder erste Punkt ein kräftiges Grübchen, und dadurch entsteht hinter der Wurzel ein leichter Quereindruck; hinterwärts aber schwinden die Streifen schneller, so dass hinter der Mitte nur noch von dem neunten eine schwache Spur vorhauden ist, die sich auch noch unter starker Vergrösserung unter der Wölbung bemerklich macht, und endlich erscheint bei dem vorliegenden das Kopfschild unten tiefer eingezogen, oben stärker verschmälert, und die Grübchen über den Fühlerhöckern sind kleiıer, aber tiefer eingegraben und schärfer begränzt, so dass die Stirn über dem líopfschilde mit einem deutlichen Läıgslapjen abwärts tritt. Das Prosternum hinterwärts stärker verbreitert und vorn durch das tiefere Eingreifen der Vorderhüften deutlicher verengt. Alles Uebrige, wie auch die Geschlechtsmerkmale, wie bei der vorhergehenden Art, von welcher die vorliegende freilich am leichtesten an dem Habitus unterschieden wird.

Gleichfalls aus Columbien (von Caraccas, Mus. Deyrolle, Schaum).

62. Cr. misellus m. Trüb erzgrün mit gelben Mundtheilen, Fühlern und Beinen, die Spitze der Deckschilde gebräunt; das hinten tief quer eingesenkte Halsschild deutlich zerstreut punktirt, die Punktstreifen linterwärts feiner, der siebente und achte abgerissen, mit flachen schıach gläızenden Zwischenräumen. L. $3 / 4{ }^{\prime \prime}$; Br. $1 / 4 "$.'.

Ein kleiner unansehnlicher Käfer, in Ilabitus dem rorhergehenden noch näher als dem $\mathrm{Cr}$. auratus verwandt, in dieser Rotie aber durch das stark punktirte, hinten tief quer eingedrückte Halsschild ausgezeichnet. Der Kiopf flach gewölht, mit äusserst fein eingeschnittener Stimlinie und wieder eingezogenem, oben nicht alogegräıztem kiopfschilde, kanı merklich punktirt, trül metallisclı grüulich, die weit getrennten ziemlich tief ausgerandeten Augen greis. llie Oberlippe gelblich bran, unten heller gerandet, Mundtheile und Fühler hellgell. Dip letzteren reichen nur wenig über den Hinterrand des Ilalsschildes linaus, und das zweite Glied ist 


\section{5}

nicht kürzer als die folgenden, die oberen sind nur schwach zusammengedrückt und erweitert, mit leicht greisem Anfluge. Das Ilalsschild un die Hälfte länger als breit, mit der grösseren Vorderhälfte in sanfter lírümnung nach vorı abfallend, und hier über den tief eingezogenen scharf rechtwinkligen Vorderecken etwas zusammengedrückt, die Seiten fein gerandet, nach vorn in breiten flachen Bogen zusammengeneigt, mit kurzen, breit und scharf spitzwinkligen Hinterecken; der Hinterrand jederseits in einem flachen Bogen ausgeschnitten, tiel eingesenlit, mit kurzem, schwach ausgerandetem Mittelzipfel; nehen dem letzteren das Mittelfeld gegen deı Hinterrand hin in breiter Schrägfläche abfallend. Die Oberfläche zerstreut- aber deutlich punktirt mit matt schinmerndem Zwischengrunde, die Farbe gleichfalls trüb erzgrün. Das Schildchen fast gleichseitig dreieckig, gleichfalls fein punktirt und trüb grün. Die Ileckschilde lang gestreckt, doppelt länger als breit, und auch doppelt länger als clas Halsschild, walzlich, mit flachem, hinter dem Schildchen breit quer niedergedrücktem Rücken, hinter der gleichfalls niedlergedrückten Wurzel etwas ansteigend, die Schulterbeulen rundlich, imuerseits durch einen schwachen Eindruck alggesetzt, die Seitenlappen deutlich und über ibnen der Randstreifen der Länge nach stärker eingedrückt. Die Punktstreifen regelmässig, von der Mitte ab feiner, aher doch bis zur Wölbung deutlich, von dem siebenten und achten un ein schwacher Ansatz vorhanden, und von deren Ende ab die Punkte der übrigen zu feineu Längslinien ausgezogen, der neunte etwas stärker eingedrückt. Die nur matt schimmernden Zwischenräume flach, der neunte sehr flach gewölbt, ülser dem Seitenlappen etwas stärker aufgetrieben. Die Farbe auch hier trüb erzgrüı, die Spitze ron der Wölbung ab verwaschen schmutzig ziegelrötlılich. Bei dem etwas kleineren $\delta$ sind die Punktstreifen ein wenig deutlicher. Das deutlich punktirte Pygidium mit der Unterseite schwärzlich, die Beine hellgelh, die Vorderbrust ziemlich lang gestreckt, punktirt mit scharf ausgezogeneı Hinterenden. Das letzte Segment des ơ einfach, des $q$ mit einer länglichen glänzenden Grube.

Von den vier mir aus dem Mus. Haag vorliegenden Stücken sind zwei als aus Columbien, zwei als ron Buenos Ayres stanmend bezeiclınet. Deı letzteren Fundort halte ich für den richtigen, zumal der Käfer mit Angabe dieser letzteren Heimath aıch im Mus. Berol. vorhanden ist. 
63. Cr. striola m: Oben goldgrün, unten schwarz, Fühler, Beine und der Seitenrand der Deckschilde gelb; das Halsschild spiegelslatı, die Punktstreifen schon vor der Mitte feiner, der siebentr und achte abgerissen, mit fein querrunzligen Zwischenräumen. L. $1^{\prime \prime \prime} ; \mathrm{Br}, 2 / 3{ }^{\prime \prime \prime}$.

Die zierliclıste Art dieser Gruppe, dabei den grössten Stïcken des $\mathrm{Cr}$. auratus an Grösse gleich, und an dem breiten gelben Seitenrande der Deckschilıle sogleich zu erkemuen. Iler Kopf flach, das Kopfschild lalbkreisförmig, ringsum durch eine feine aber sclarfe Leiste abgesetzt, die Stirn der Länge nach tief eingedrückt. Die Oberfläche matt, mit oben schwächerem, auf dem Kopfschilde stärkerem Glanze, schwäızlich grün, die grossen breit und tief ausgebuchteten, nach oben ein wenig genäherten Augen greis. Die Fühler denen des Cr . auratus ähnlich, das Wurzelglied mässig verdickt, etwa $21 / 2$ mal länger als breit, das zweite kurz und linotig, die folgenden je etwa doppelt länger, und von ihnen das dritte bis fünlte sehr dünn verkehrtkegelförmig, auch die oberen nur schwach zusammengedrüclit und erweitert; die Farbe hellgelb, bei alten Stücken wie die ler Beine schmutzig röthlich. Das Halsschild halb so lang wie hinten breit, vorn mit lalber Länge stark liugelig ühergekrümmt, ïlser den scharf rechtwinkligen tief eingezogenen Vorderecken znsammengedrïckt und verschmiilert, die Sciten fein gerandet, nach vorn in breiten Bogen zusammengeneigt, mit kurzen breit zugespitzten Hinterecken, der Hinterrand jederseits leicht dojpelt ausgebuchtet, stark gesägt, mit ebenfalls stark vortretendem, ziemlich schmalem, doppelt ausgerandetem und durch einen vor dem mittleren Theile des Hinterrandes liegenden Quereindruck etwas anfyetriebenem Mittelzipfel. Dic Oberfläche spiegelglatt, die Farlue schön goldgrinn, bei einem der vorliegremlen Stücke mit bunt. kupferfirbigem Anfluge, die Vorlerwinkel verwaschen röthlich durchscheinent. Das Schildchen länglich dreieckig, un die Ilïlite länger als breit, mit deutlichem Vortergrübchen, gleichfalls glänzend grïn. Die Deckschilde walzlich, $21 / 2 \mathrm{mal}$ länger und ror’n etwas breiter als das Ilalsschild, hinter der Wirzel durch die tief vingegrabenen Vorderenden der Punktstreifen quer eingedrückt, dann wieder allmihlich ansteigend und inı ersten Fünftel ihrer Länge an höclısten, von da linterwärts mit nach und nach stälierer lírümmung bis zır Spitze alffallend, letztere mit klaflender Nalıt breit al)gerundet. llie Schulterbrulen hreit und llach, imnerseits 
durch einen stärkeren dreieckigen Längseindruck abgesetzt; die Seitenlappen unbedeutend, dagegen der Seitenrand ausserlalb des tief eingedrückten Randstreifens kielartig aufgeworfen. Die Punktstreifen sehr regelmässig, die Vorderenden ants kriftigen, etwas vereinzelten Punkten gebildet, di̊ von der Höhe des Rückens ab plötzlich zu feinen linienförnigen Pünktchen zusammenschwninden, su dass die Hinterenden nur mit scharfer Linse erkennbar werden, der siebente und achte schon vorher abgerissen, und der neunte hesonders in seiner hinteren Hälfte tief furchenartig eingedrückt, daher auch der ihm anstossende neunte Zwischenraum als flache Rippe aufgetrieben, sein Vorderende jedoch unter der Schulterbeule der Länge nach niedergedrückt: die übrigen Zıvischenräume flacl, und auf dem breit umgeschlagenen Rande eime Reihe von gröberen Punkten. Die Farbe goldgrün, auch wohl dunkler messinggrün, bei dem oben bezeichneten Stücke die Wurzel vor und längs dem vorderen Quereindrucke mit bunt kupferfarbigem Anfluge; dabei die Oberfläche äusserst fein querrunzlig und ziemlich stark glïnzend; der äusserste Zwischenraum von der Mitte des Seitenlappens ab bis zu dem hinteren Aussenwinkel lsellgelb, wie mit einem aufgetragenen Lack bedecht. Pygidium und Unterseite fein punktirt und gerunzelt, schwarzgrün, mil einfarbig gelben Beinen; die Vorderbrust stärker runzlig punktirt, jeder'seits der Länge nach etwas eingedrüclit mit kurz vorspringenden Hinterenden. Das letzte Segment des $\&$ mit einer grossen, rundlichen Grube; das $\delta$ unbekannt.

Aus Brasilien. Mus. Schaum, Clark; in dem letzteren Petropolis als Fundort angegeben.

Fünfzehnte Rotte. Körper breit und plump oder schmäler und zirlicher, von mittleier oder geringerer Grösse, die Fühler lang uud dünn, seltener in der Mitte verbreitert, die Augen uben genähert, bei dem ơ meist zusammenstossend, das Halsschild hinten jederseits tiel schräg eingedrïckit, die Krallenhäkchen mit einem blattartigen Zahme besetzt. Die Punktstreifen regelmässig und derh. Die Färbung überwiegend gelb oder röthlich, manchmal mil theilweise schwarzen Fühlern und Beinen, seltener die Deckschilde liran mit gelben, oder roth mit schwarzen Flecken; cluen so selten die Unterseite und mit ihr dis Halsschild oder die Deckschilde schwarz. Eine durch Gestalt und Farbe wenig ausgezeichnete, über den nördlicheı und üstlichen Theil ron Süılamerika 
verbreitete Rotte, mit welcher vielleicht auch die einzige, oben als eilfte Rotte aufgeführte Art ( $C r$. 4vulnerus $m$.) zu vereinigen ist, und welche mit den beiden folgenden zunächst hinter der nordamerikanischen (Antillen-) Rotte des $\mathrm{Cr}$. thalassinus eingeschaltet werden muss.

64. Cr. bisignatus Grm. Schwefelgelb mit dunklerem Vorderfelde des glatten Halsschildes und schwarzen Fühlerenden, die Flügeldecken braunroth mit gelbem Nittelflecke; die Punktstreifen grob mit vorn rippenförmigen, hinten flach gewölbten glānzenden Zwischenräumen. L. $2 \frac{1}{12}-3^{\prime \prime \prime}$; Br. 11/3-13/4"'.

Cr. bisignalus Germ. Ins. Sp. S. 559. n. 763. das $q$ !

Ein grosser, schöner, dirch seine eigenthümliche Zeichnung sehr auffallender, und in dieser Beziehung nur noch den folgenden einigermaassen verwandter Käfer. Der Kopf flach, die Stirn oben und dann wieder zwischen den Fühlerwurzeln seicht eingedrückt, so dass das Kopfschild auch ohne scharfe Begränzung seiner Seiten nach oben hin deutlich begränzt erscheint, die Oberfläche nur auf der Stirn und in den Augenbuchten mit vereinzelten Punkten besetzt, übrigens glatt und glänzend. Die Farbe hell schwefelgell, nur die langgestreckten breit und tief ansgebuchteten Augen schwarz. Die Fühler des $\delta$ fast von Körperlänge, des $q$ um ein Drittel kürzer, bei beiden äusserst dümn und fadenförmig; das zweite Glied ohen stark birnförmig aufgetrieben, das dritte dreimal länger, die drei folgenden allmählich noch mehr vergrössert, und die obereu dem sechsten gleich, diese auch nur sclıwach zusammengedrückt und erweitert, mit lang pfriemlichem Fortsatze des Endgliedes. Die Farbe der fünf unteren Glieder durchscheinend schwefelgelb, der oberen schwarz mit dlümer greiser Behaarung. Das Halsschild selır kurz, vor'n mit seiner grösseren Hälfte stark liugelig übergewôlbt, seitlich breit gerandet und durch die mit starker lirümmung nach vorn zusammengeneigten Ränder eben so stark verengt, mit lang und spitz vorgezogenen, durch die lirümmung der Seitenfurche aufgetriebenen Hinterecken; der Hinterrand nur vor den Schulterbeulen tief ausgeschnitten, der Mittelziptel breit, deutlich doppelt ausgerandet. Vor demselben jederseits ein tiefer Quereindrucl, zwischen denen sich der schmale Zwischenraum als ein rundlicher Wulst emporhebt; ausserdem jederseits noch eine starke, nach rorn und aussen ziehende, über der Mitte des Seitemandes abbrechende 
Schrägfurche. Die Oberfläche spiegelglatt, die Farbe schwefelgelb mit schmal gebräuntem Itintersaume, ein halbrunler verwaschener, bis zu den Seiteneindrücken reichender Vorderfleck schmutzig gelbJraun. Das Schildchen sehr lang und schmal dreieckig, fast viermal länger als breit, hinterwärts stark ansteigend und vorn mit dem gewölınlichen Grübchen, dessen Ecken bei rler geringen Breite der Wurzel als zwei in die Ausschnitte des Halsschildszjpfels eingreifende IIöcker hervorspringen; der Hinterzipfel deutlich abgesetzt und wieder niedergebogen. Die Farłse glänzend zimmtbraun, Wurzel und Spitze zart schwarz gesäunt. Die Deckschilde loreit und flach walzenförmig, längs der Wurzel schwach ansteigend, jederseits des Schildchens weit niedergedrückt und um dessen Hinterende beulig aufgetricben; auch die Schulterheulen als längliche kräftige Höcker heraustretend und innerseits durch einen tiefen Längseindruck abgesetzt. Die Seitenlappen lang herabgezogen, auf dem unigeschlagenen Rande mit einer groben Punktreihe besetzt; die Naht vom Schildchen al, bis zu der sehr flach ahfallenden Wöllsung seiclıt niedergedrückt, auch hinter den Schulterbeulen ein breiter flacher, von den Seitenlappen aus emporsteigender Eindruck. Die Punktstreifeı sehr regelmässig, aus vorn dicht gedrängten, hinterwäıts melır vereinzelten groben und grülschenartigen Punkten gebildet, die der Naht und dem Seitenrande zunächstliegenden in leichte Furchen eingedrückt, die Vorderenden des siebenten und achten hinter den Schulterbeulen, eben so des neunten und zehnten von den Schultern al, bis über die Mitte der Seitenlappen hinaus runzlig in einander geflossen. Die glänzenden Zwischenräume vol'ı schmäler, und rippenförmig erlıöht, hinterwärts etwas breiter und flacher, aber nur die mittleren auf der Wölbung ganz aligeflacht. Die Farbe braunroth, ins Zimmthraune fallend, mit zart schwarzem Vordersaume, hinter der Mitte auf jeder Flügeldecke ein grosser querrundlicher, vom zweiten bis zum neunten Punktstreifen reichender schwefelgelher Fleck. Das Pygidimm deutlich- und am unteren Rande grob punktirt, dünn greishaarig, mit der Unterseite gleichfalls schwefelgelb; die Beine etwas dlunkler, mit bräunlich überlaufenen Fussgliedern. Des Vorderrand der Vorderbrust zur Aufuahme der Mundtheile breit vorgezogen und grade alıgestutzt, das Mittelfeld etwas erhöht, und die Hinterenden breit lappenförmig zugerundet. Das letzte Segnent des anscheinend seltenen $\delta$ - unter allen mir vorliegenden Stücken befinden sich deren nur dV. 
zwei - mit einem seichten rundlichen Eindrucke, des $q$ mit einer tiefen, halbeifürnuigen Grube.

Aus Brasilien. Mus. Saunders, Schaum, Haag, Baly, Deyrolle, Berol.

65. Cr. flavoplagiatus m. Schwefelgelb mit dunhlerem Vorderflecke des glatteı Halsschildes, Fühleremlen und Samm der Deckschilde schwarz, die Wurzel und eine lintere Querlinde der letzteren braunroth; die Punktstreifen grob, der sechste und siebente abgerissen, mit glänzenden, rippenförmigen Zwischenräumeı. L. $13 / 4 " \prime$ Br. $1^{\prime \prime \prime}$.

Dem vorhergehenden ähnlich, aber kleiner, und auch ausserdenn aı der gelben Spitze der Flügeldecken leicht kenntlich, auch dem ostindischen $\mathrm{Cr}$. fenestratus $m$. von Ceylon in der Färbung und Zeichung nicht mähnlich. Der liopf flach mit sehr feimer Stirnlinie, das wenig eingezogene Kopfschild etwas eingedrückt und oben durch die sich in die Quere ausdehnenden Fühlerböcker abgeselzt; die Oberfläclse lackglänzend schwefelgelb, die Muudtheile honigbraun, die langgestreckten tief ausgebuchteten Augen schwarz. Die Fühler (des ठ) von Körperlänge, diinı und fadenförmig, das Wurzelglied etwa $2 \frac{1}{2}$ mal länger als oben breit, oberseits etwas abgeflacht, dlas zweite kurz birnförmig, die folgenden selır dünı verkelırtkegelförmig, nach oben nur selır schwach verbreitert, das dritte doppelt- und das vierte dreimal länger, aber wie die folgenden dïnner als das zweite, das fünfte noch etwas verlängert und diesem die oberen gleich, das Lndglied mil schmal kegelförmigen Fortsatze. Die vier unteren Glieder hellgelb, las lïnfte und seclıste tiefer gebräunt, die oheren schwarz, dünn greisbehaart und an der Spitze abstehend gewimpert. Das kurze Halsschild vor'n mit dem ersten Drittel seiner Länge schwach übergekrümmnt, hinter der Mitte sanft quer niedergedrückt und dann wieder sanft ansteigend; die stark eingezogenen Vorderecken sclsarfrechtwinklig, die Seiten tief herabgezogen und über ilırer Mitte jederseits ein das Italsschild stark zusammenschıüreuder, naclı oben sich alluäłslich in die niedergedrückte Hinterfläche verlierender Schrägeiudruck, vor welchen sich das Halsschild auch nach vorn lin sehr merklich versehınälert. Die Ilinterecken scharf dreieckig ausgezogen, der Hinterrand wellig gebogen, mit wenig bemerkharem Mittelzipfel. Die Oberthiche spiegelglatt, die Farhe wird bei dem Ueberwiegen der dunkleren Vorderhälfte an besten als dunkel honiggell, bezeichnet, mit 
einem grossen gleiclısam aus zwei Rautenllecken zusammengesetzten hellgelben Querfleck vor der Mitte des Hinterrandes. Das Schildchen sehr lang und schmal dreieckig, etwa dreimal länger als breit, mässig ansteigend, hinten kurz abgestutzt mit deutlichem Vordergrübchen, glïnzend rothbraun mit geschwärzter Wurzel. Die Deckschilde llach walzenförmig, breiter und etwa $2 \frac{1}{2}$ nıal länger als das Halsschild, um die Hälfte lïnger als breit, hinter der niederge-drückten Wurzel sanft ansteigend und vom letzten Drittel ab mit allmählich gekrümmter Wölbung wieder abfallend, über den lang herabgezogenen Seitenlappen durch einen kräftigen Quereindruck zusammengedrückt, auch die Schulterbeulen als grosse eiförmige Längshöcker aufgetrieben, innerseits durch einen länglichen Eiıdruck abgesetzt. Die Punktstreifen regelmässigg und selır derb, aus dicht an einander gerückten groben Punkten bestehend, besonders der fünfte und neunte unnittelbar hinter dem Quereindrucke, wo ihre Punkte zngleich deutlich in die Qnere ausgezogen sind, der sechste und siebente an diesen Eindrucke abgerissen; auf der Wölbung zeigt sich daun wieder ein deutliches Ende des siebenten Streifens, neben welchem auf rler rechten Flügeldecke des eimzigen vorliegenden Stückes auch noch der sechste durch ein Paar vereinzelte Punkte angedeutet ist. Die Vorderenden der inneren Streifen zivischen Naht und Schulterbeule, sowie der neunte in seiner ganzen Länge in feine aber deutliche Furchen eingedrückt, daher lıier die glänzenden llach gewölbten Zwischenräume rippenförmig erhöht; der umgeschlagene Rand des Seitenlappens gleichfalls mit einer kräftigeı Punhtreilıe besetzt. Die Grundfarbe lässt siclı auch hier am besten als rothhraun annehmen, mit einem die ganzen Deckschilde umziehenden schwarzen Saume, welcher zugleich den umgeschlagenen Rand des Seitenlappens einschliesst und um die Spitze längs der Naht linaufzieht, soweit die Wülbung reicht; daneben trägt jede Flügeldecke vor der Hitte einen grossen querrundlichen gelben Fensterfleck, welcher rom ersten bis auf den neunten Zwischenraum reichend etwa das zweite Drittel der Flügeldeckenlänge eimnimnt und anf seiner Aussenseite von dem hier ühertretenden schwarzen Seitenrande umzogen wird. Endlich ist auch noch die breite Spitze unter der Wölbung bis zu dem schwarzen Randsaume in gleicher Weise hell schwefelgelb. Das fein punktirte Pygidium mit der glänzenden Unterseite und den lackgläızenden Beinen gleichfalls hellgelb, die Vorderbrust hinten tief ein- 
gedrïckt und leicht ausgerandet, mit fast senkrecht abwärts gericltetem, in einen langen abgerundeten Zipfel vorgezogenem Vorderrande. Dis: Krallenlıäkchen schwarz, an der Wurzel mit einem breiten blattartigen Zahne. Das letzte Segment des $\delta$ schwach quer niedergedrïckt, das $q$ unbekannt.

\section{Aus Brasilien (von Rio de J., Hus. v. Bruck).}

66. Cr. cons obrinns m. Schwefelgelb mit schwarzen Fühlerenden, die Flügeldecken dunkel hlutroth mit gellıem Hittelflecke und gelber Spitze; das Ilalsschild spiegelglatt, die Punkistreifen mässig, der sechste fehlend und der siebente abgerissen, mit flachgewölbten glänzenden Zwischenräumen. L. $13 / t^{\prime \prime \prime}$; Br. $11 / 12$ "'.

Dem vorhergehenden täuschend ähnlich, so dass, wenn ich nicht von beiden dasselbe Geschlecht (ठ) vor mir hätte, ich kein Bedenken tragen würde, beide mit einander zu verbinden, und die allerdings vorhandenen Abweichungen für Geschlechtsmerkmale zu nehmen, während mir jetzt ihre specifische Verschiedenheit nichi zu bezweifeln scheint. Uebrigens gleichen beide Käfer einander so sehr, dlass ich mich auf die oben gegebene Beschreibung der vorhergehenten Art bezichen, und für lie vorliegende auf die Angabe jener Abweichungen beschränken kann. Diese letzteren zeigen sich zunäclıst im Bau, indem dieser letztere Käfer etwas grösser ist, anch die olseren inneren Augenränder einander nicht, wie bei $C$ 'r. flavoplagiatus, berühren, vielmehr durch einen schmalen, von einer deutlichen Längslinie durchizogenen Zwischenraum geschieden sind. Weiter treten solche in der Färbung hervor; das Halsschild ist einfarbig hellgell, olne die dunklere Färbung, wie die beiden vorhergehenden Arten sie auf der vorderen IIälfte zeigen; auf den Deckschilden beschrïult sich der schwarze Rand anf einen feinen Vordersaum, und ihre Grundfarbe ist nicht rothbraun, sondern ein schönes dunkles Blutroth, dabei ist der Vorderfleck jeder Flïgeldecke grösser, mehr rund und weiter nach hinten gerückt, während der lintere die ganze Spitze einninmt, ohne rom Raude noch durch einen dunkleren Saum getrennt zu sein. Hinsichtlich der Sculptur endlich sind die Punktstreifen, von denen nur der neunte in eine leicht rertiefte Lüngslinie eingedrückt ist, nicht allein viel feiner und linterwärts stärker abgeschwächt, sondern auch nu' aus rereinzelten, hesunder's auf der grösseren Vorderhälfte weit auseinanler gerücliten l'unkten gebildet; der sechste fehlt ganz, vom siebenten ist nur der vordere Theil bis zu dem Quereindrucke und 
das Hinterende vorhanden, und zivar so, dass der breite anf der Mitte zwischen den fünften und achten P'unktstreifen entstandene Zwischenraum durch eine leichte Krïmmung dieses letzteren Streifens etwas verengt wird. Die Zwischenräume nur selır flach gewölbt. Alles Uebrige wie bei der vorhergehenden Art.

Gleichfalls aus Brasilien. Mus. Lacordaire, Berol., das Exemplar des letzteren von Sello bei S. João del Rey gefunden.

67. Cr. miniatus m. Roth, Kopf und Unterseite lichter, die Fühler bis auf das Wurzelglied, die Schienenenden und Füsse schwarz; das Halsschild hochbuckelig, hinterwärts zer'streutpunktirt, die Punktstreifen sehr fein, mit flachen, fein querrunzligen, glänzenden Zwischenräumen. L. 23/4"'; Br. 11/4"'.

Ein schöner durch die einfarbig hochrothe Oberseite änsserlich dem 'ostindischen $\mathrm{Cr}$. cinnabarinus $m$. gleichender Käfer, an Bau und Grösse aber am nächsten dem unten beschriebenen $\mathrm{Cr}$. ventricosus $m$. verwandt. Der flache Kopf dicht rumzlig punktirt und matt, röthlichgelb, das Kopfschild oben durch ein paar schwache Quergrübchen algesetzt, unten tief halbmonlförmig eingedrückt, mit wieder vorspringender, hell knochengelber Oberlippe; die Kinnbacken schwärzlich und auch die Tasterspitzen gebräunt, die lang gestreckten, tief ausgebuchteten und auch bei dem $\delta$ nicht ganz zusammentreffenden Augen greis. Die Fühler (des ö) von $3 / 4$ der Körperlänge, sehr derb und kräftig, das Wurzelglied mit stark eingeschıürter Basis fast gleichbreit ausgestreckt, etwa dreimal lïnger als breit, mit etwas abgeflachter Oberseite, die drei folgenden verkehrtkegelförmig und nach oben schwach verdickt, das zweite an Länge der Breite des ersten gleich, das dritte etwa $2 \frac{1}{4}$, das vierte dreimal länger als das zweite; die folgenden zusammengedrückt, dabei - und zwar das fünfte aus sehr schmaler Wurzel - stark verbreitert, rom neunten ab wieder schmiler, das Endglied fast linealisch mit kurz und spitzdreieckigem Fortsatze: das fünfte (längste) noch un $1 / 3$ länger als das vierte, und die folgenden nach und nach so weit verkürzt, dass das zehnte noch ein wenig üher das vierte hinausreicht, das Endglied aber wieder dem achten gleich kommt. Die Farbe des Wurzelgliedes rothgell mit einem schwarzen Längswische auf ller oberen Kante, die folgenden schwarz, das zweite bis vierte lackglänzend mit bräunlich durchscheinender Wurzel des zweiten und dritten; die oheren matt mit dicht angedrückter greiser Behaarung, an delı oberen Ecken ling weiss gewimpert. 
Das Halsschild halb so lang wie breit, hinter der Mitte in die Quere hochbuckelig aufgetrieben und von da ab, wie bei dem nordamerikanischen Cr. gibbicollis Dej., mit der grösseren Vorderhälfte steil zum Kopfe abwärts gekrümmt, ïber den tief eingezogenen, rechtwinkligen Vorderecken stark verschmälert, die breitgerandeten Seiten in der Mitte rundlich erweitert und von ihr aus nach vorn in starken Bogen zusammengekrümmt, vor den kurzen, schwieligen, etwas abwärts gedrückten Hinterecken leicht ausgeschweift, der Hinterrand jederseits tief ausgeschnitten, mit kurzem fast grade abgestutztem Mittelzipfel. Auf jeder Seite des letzteren ein ihn etwas emporschiebender Schrägeindruck, welcher sich nach kurzer Abschwächung plötzlich wieder vertieft und erweitert, und dann als breite und kräftige Schrägfurche in etwas welliger Krümmung dem Seitenraude zuzieht, kurz vor dessen Mitte aber, ohne ihn selbst zu berührelı, abhricht. Anscheinend wird dlurch diesen Eindruck die Masse des Halsschildes so nach vorn und anfwärts gedrängt, dass in ihm die eigentliche Ursache der buckeligen Quererhebung desselben gesucht werden muss. Die Oberfläche äusserst fein und zerstreut-, vor den Hinterenden besonder's in den Hinterwinkeln etwas dichter punktirt, glänzend lochroth, vorn verwaschen etwas heller, und der abgesetzte Vorderrand gelblich durchscheinend, ein eben so feiner Ilintersaum gebräunt. Das Schildchen stark schräg ansteigend, ans etwas breiterer Wurzel mit geschweiften Seiten ver'schmäler't und danı gleichbreit bis zu der kurz alogestutzten Spitze fortziehend, doppelt so lang wie breit, Ilinterzipfel und Vordergrübchen deutlich, die Farbe gleichfalls gläızend roth mit hreit schwarzen Vordersaume. Die Deckschilde breit und flach walzenförmig, etwa $1 / 4$ lünger als breit, von der Schildchenspitze längs der Naht bis zur Wölbung abgeflacht und danı etwas stärker abwärts gekrümmt, auch vorn jederseits des Schildchens nach dem Halsschilde zu sanft abwïl'ts gedrückt, dic längshöckerig aufgequollenen Schulterheulen inuerseits durch einen tiefen dreieckigen Eindruck abgesetzt, dessen schwächeres Hinterende sich nachher in dem flachen, von den sehr breiten Seitenlappen hinaufziehenden Quereintrucke verliert. Die Punktstreifen fein, bis auf die gröberen Vorderenden des vierten und fünften, sowie der drei hinter der Schulterbeule entspringenden fast nur an der dunkeln Färbung der P'unkte kemutlich, die miltleren schon vor der Wölbung erloschen. Die Zwischenriume äusserst fein quer gerun- 
zelt, glänzend und flack, nu' der neunte von dem Seitenlappen ah sehr flach gewölbt. Die Farbe auch hier hochıoth, die Spitze unter der Wölbung ius Gellliche verblichen, und ein feiner Wurzelsaum gebräunt. Das Pygidlium grob runzligpunktirt und undeutlich längskielig, dünn gelblich behaart, rothgelb; Unterseite und Beine. lıeller gelb, die unteren Schienenhälften und die Füsse rein schwarz; die Krallenhäkclıen unter ilırer gelblichen Wurzel mit einem ziemlich breiten stumpfen blattartigen Zahne besetzt. Die Vorderbrust runzligpunktirt, hinten seicht ausgebuchtet und breit zweilappis, mit mässig eingezogenem abgerundetem Vorderrande. Das letzte Segment des $\delta$ flach quer niedergedrückt, das $\&$ mit einer tiefen glänzenden, an den Rändern breit niedergedrückten Grube.

Gleichfalls aus Brasilien. Mus. Berol. (v. Olfers), Deyrolle, v. Heyden (von Clausen in Südbrasilien gesammelt).

6S. Cr. ventricosus m. Schwarz, Halsschild und Deckschilde ziegrelroth mit verwaschenen schwarzen Flecken; das Halsschild hochbuckelig, glatı, die vorn kräftigen Punktstreifen hinten erloschen, mit flachen feinpunktirten Zivischenräumen. L. 2-2 $3 l_{4}{ }^{\prime \prime \prime}$; Br. $1-1 / 4{ }^{\prime \prime \prime}$.

Von der Grösse und dem Bau des vorhergehenden, aber an der abweichenden Sculptur und der schwarzen Unterseite von ihm leicht zu unterscheiden, in Beziebung auf Färbung und Farbenvertheilung gewissermaassen eine Mittelform zwischen der vorhergehenden und der folgenden Art. Der Kiopf flach, zwischen den Fühlerwurzeln etwas eingedrückt, dicht runzlig punktirt, mattschwarz, seltener mit verwaschen gerötheter Stirn, die Ränler der Oberlippe und die Mundtheile gelblich braun. Die langgestreckten tief ausgebuchteten Augen auch bei den ơ oben noch durch einen schmaleı, manchmal gebräunten Zwischemraum getrennt. Die Fülıler fast von Körperlänge, das zweite Glied liurz verkehrtkegelförmig, das dritte doppelt länger, die beiden folgenden allnällich soweit vergrüssert, dass das fünfte doppelt länger ist als das dritte; die oberen wieder dem vierten gleich, vom sechsten ab deutlich verbreitert und zusammengedrückt, mit kurzem, stumpf dreickigem For'satze des Endgliedes, Die vier unteren gelblich mit meist geschwärzter Oberseite, das fünfte schwïrzlich mit braun durchscheinender Wurzel, die oberen schwarz. Das Halsschild anscheinend sehr kurz, weil, wie bei dem vorhergehenden, mit der grösseren Hälfte vorı übergebogeı und stcil nach der Kopffläche zu herab- 
gekrümmt, oben quer buckelig aufgetrieben, hinterwärts wieder niedergesenkt und jederseits vor dem Schildchen durch einen Quereindruck noch ınehı niedergedrïckt, dessen flicheres schräg nach vorn gekrümmtes Vorderende his fast über die Mitte des Seitenrandes hin verfolgt werden kann. Der Hinterraud jederseits leicht ausgebuchtet, mit kurzem breitem, doppelt ausgerandetem Mittelzipfel, auch die Hinterecken breit zugespitzt, die Seiten gerandet und über ihnen das Halsschilı durch die flach auslaufenden Enden der linteren Eindrïcke flach zusammengedrückt, die tief eingezogenen Vorderecken fast rechtwinklig. Die Oberflïche spiegelglatt, mit kaum sichtharer, sehr zerstreuter Punktirung, mehr oder weniger dunkelziegelroth, auf dem höchsten Theile ıles Rïckens eine jederseits abgekinzte, manchmal nur schattenartige oder auch ganz fehlende, manchmal aber auch den grössten Thei] des Halsschildes einnehmende verwaschen-schwärzliche Querbinde. Das Schildchen lang und schmal, schräg ansteigend, mit undeutlichem Ifinterzipfel aber deutlichem Vordergrübchen, glänzend schwarz. Die Deckschilde kurz und gedrungeu walzenförmig mit alogeflachtem, hinten stärker abfallendem Rücken und breit abgerundeter Spitze; jederseits vom Schildchen ein breiter und flacher, innerseits der langen höckerigen Sclıulterbeulen ein zweiter, stärkerer Eindruck; die Seitenlappen lang herabgezogen, mit einer sehr groben Punktreihe auf dem umgeschlagenen Rande. Die P'unktstreifen sehr regelmässig, vorn kräftig, schon von der Mitte ab allmählich feiner, und die mittleren auf der Wölbung erloschen. Die flachen Zwischenräume fein und zerstreut punktirt, lackgłänzend, der achte über dem Seitenlappen kurz aufgewölbt, und unter diesem Wulste der neunte Streifen vertieft und erweilert, welcher Eindruck zuweilen noch auf den, seiner ganzen Länge nach flach gewöllten neunten Zwischenraum übergreift. Die Farbe ziegelroth mit einem feinen die ganzen Flügeldecken umziehenden schwarzen Samme, die Schulterbeulen und ein verwaschener Längswisch auf dem dritten Zwischenraume vor der Wölbung schwarz, oder bei einer Abart

$\beta$. zwischen dem Schildchen und der Schulterbenle noch eine verwaschene, schattenartige Längsbinde, und der hintere Wisch zu einem manchmal unförunlich grossen, gleichfalls verwaschen begräızten, selbst wohl die halbe Breite der Flïgeldecke und mehr noch eimnehnenden, mit scinen Vorderenten bis zu den beiden vorderen Flecken ïberfliessenten oder auch längs der Naht mit 
dem Gegenflecke zu einem gemeinsamen grossen Mittelschilde vereinigten schwarzen Flecke erweitert, zwischen welchen Extremen und der Grundform der Uebergang durch eine ganze Reihe vou Zwischenstufen vermiltelt wird. Mit der Färbung des Halsschildes steht diese Zeichnung der Deckschilde in keinem Zusammenhange.

Seltener aber ist eine dritte Form

$\gamma$. Kopf, Halsschild und Deckschilde einfarhig roth, auch die Unterseite roth, mit verwaschen geschwärzten Seiten von Hinterbrust und Hinterleib. Diese Form, von der ich ein einzelnes if aus Ien Mus. Berol. vor mir habe, sieht auf den ersten Blick etivas fremdartig aus, wird aber mit der Hauptform durch Uebergänge verbunden.

Pygidium und Unterseite fein runzlig punktirt, dicht silberhaarig, schwarz, zuweilen mit geröthetem Mittelzipfel des ersten Bauchringes, anch die Beine schwarz, Hüften und Knie, nebst deı Schenkel- und Schienenwurzehn rothbraun; bei sehr hellen Stücken die Beine roth mit geschwärzten Füssen. Der Vorderrand der grob runzligen Vorderbrust nur wenig vorgezogen, der Hinterrand seicht ausgebuchtet; das letzte. Segment des $\delta$ seicht eingedrückt, des o nit einer halbkugeligen tiefen, am Rande lang greis gewimperten Grube.

Aus Brasilien. Mus. Pelrop., Berol., Deyrolle.

69. Cr. la queatus m. Schwarz, Fühlerwurzehı, das spiegelglatte Halsschild und die Beine rothgelh, die schwarz gesäumten Flügeldecken heller gelh mit einer hinteren schwarzen Längsliniץ; die vorn kräftigen Punktstreifen linten fast erloschen mit flachgewölbten glänzenden Zwischenräumen. L. 11/2-2"'; $\mathrm{Br}$. 5/6$11 / 6 "$.

Dem vorhergehenden in der Färbung und Farbenvertheilung nicht unähnlich, aber schmäler und gestreckter, daher zierlicher, auch ohne das buckelig aufgetriehene Halsschild, welches die beiden vorherbeschrichenen Arten auszeiclnet. Der flache Kopf runzlig punktirt, mattschwarz mit bräunlichgelben Hundtheilen, die grossen tief ausgebuchteten Augen oben auch bei dem đo nicht völlig zusammenstossend. Die Fühler von $3 / 4$ der Körperlänge, zienlich dünn; das zweite Glied birnlürmig, das dritte etwas mehr als doppelt länger, und die beideu folgenden noch etwas verlängert, die obrren dem fünften gleich, schwach zusammengedrückt und erweitert mit kurzem Fortsatze des Endgliedes; die unteren röth- 
lichgelb mit meist verdunkelter Oberseite, die oberen von der Mitte des vierten ab schwarz. Das Halsschild kurz und breit kugelig, vorn mil der grösseren Hälfte stark übergekrümmt, hinter der Mitte jedoch in geringerem Grade als bei den vorhergehenden Arten buckelig aufgewölbt, hinten jederseits vor dem Schildchen tief quer eingedrückt umd daselbst zwischen diesen beiden nur selten zusammenhängenden Eindrücken faltig erhölıt; die Aussenenden derselben schräg nach vorn und aussen gerichtet und in mehr oder weniger abgeschwächter Weise bis üher die Mitte der deutlich gerandeten und nach vorn in breiten Bogen zusammengeneigten Seiten zu verfolgen. Die Hinterecken kurz und breit zugespitzt, der Hinterrand jeclerseits seicht ausgebuchtet, der Mittelzipfel schmal, deutlich doppelt ausgerandet. Die Oberfläche äusserst fein und zerstreut punktirt, spiegelglatı, in den Eindrücken am Hinterrande ein paar vereinzelte grössere Punkte. ,Die Farbe rothgelb. Das Schildchen stark ansteigend, lang und schmal viereckig, vorn quer niedergedrüickt, mit deutlichem Hinterzipfel und Vordergrübchen, głänzend schwarz. Die Deckschilde walzenförmig, hinterwärts sehr schräg abfallend und um das Hinterende des Schildchens leicht erhölıt, auch die Schulterbeulen als längliche Höcker aufgetrieben und immerseits durch einen schmalen Eindruck abgesetzt; die Seitenlappen lang herabgezogen, auf dem breiten Unterrande nit einter groben Punktreihe beselzt, und auch über ihnen ein deutlicher Eindruck. Die Punktstreifen vor'n derb und in leichıe Längslinien eingedrückt, von der Mitte ab schwächer, und die mittleren aul der Wölbung kaum nochı kenntlich; die glänzenden Zwischenräume vorn flach gewölbt, hinterwärts zwischen den feineren Punktstreifen breiter und flacher. Die Farbe ein sehr helles Rothgelb, ein schmaler, sich hinter dem Schildchen und an den Schultern verbreiternder, hier die Schulterbenlen mit einschliessender Saum der Flïgeldecken schwarz, der umgeschlagene Raud des Seitenlappens gewöhnlich nur trüh gebräunt. Ausserdem nach hinten vor der Wölhung auf dem dritten Zwischenraume ein schlecht hegränzter, nach imnen auf deı zweiten übergreifender schwarzer Lïngsfleck. Pygidlimm und Unterseite fein runzlig punktirt, dicht silberhaarig schwarz, mit manchnal bräunlich angeflogenem Hinterrande des letzton Banchringes; die Schulterblätter und die Beine mit den Hüften rothgelb, die Schienen an den Aussenkanten und Unterenden geschwäızl, die Füsse meist ganz schwarz, und zuweilen, be- 
sonders bei Stücken mit sehr breitem Saume der Flügeldecken, auch die Schenkel schmutzig gebräunt. Die Vorderbrust breit, mit vorgezogenem stumpf abgerundetem Vorderrande, hinter der Mitte quer eingedrückt, mit kurz vorspringenden Hinterzipfeln. Das letzte Segment des $\delta$ mit einem seichten elliptischen Längseindrucke, des $\&$ mit einer grossen halbkugeligen Grube.

Aus Brasilien, und dort anscheinend nicht selten, daher in fast allen von mir verglichenen Sammlungen vorhanden. (Nus. Hamb., Hal., Saunders, Dohrn, Berol., v. Bruck, Baly, Deyrolle. In mehreren dieser Sammlungen ist Minas als Heimath angegeben.)

70. Cr. pentagrammus m. Lehmgelb mit schwärzlichen Fühlerenden, das spiegelglatte Halsschild vorn leiclıt gebräunt, das Schildchen und fünf abgekürzte Längsbinden der Deckschilde schwarz; die Punktstreifen derb mit flachgewölbten glänzenden Zwischenrâumen. L. $13 / 4-2^{\prime \prime \prime} ;$ Br. $2 / 3-3 / 4{ }^{\prime \prime \prime}$.

Eine feine und zierliche, bei gleicher Länge vou den vorhergehenden doch durch den schmalen Körper wesentlich abweichende und dadurch zu den folgenden mehr gestreckten Formen überleitende Art. Der Kopf flach, das Kopfschild oben durch eimen leichten Quprwulst abgesetzt, die Oberfläche lackglänzend gełb mit schmutzig gebräunten Fühlerhöckern, die ziemlich gestreckten, nicht lang aber tief ausgebuchteten, auch bei dem $?$ fast oben zusammenstossenden Augeı schivarz. Die Fühler des ơ von $3 / 4$ der Körperlänge, des + etwas kürzer; dünn farlenförmig, das WVurzelglied nur mässig verdickt, etwa dreimal länger als breit, das zweite kurz eiförmig, wenig länger als hreit, das dritte und vierte gleich lang, je etwa doppelt länger als clas zweite, das fünfte (längste) dem zweiten und dritten zusammen gleich, die folgenden bis zum zehnten allmählich, aber wenig verkürzt, letzteres wieder dem dritten, dagegen das Endglied mit seinem liegelförmigen Fortsatze beinahe wieder dem fünften gleich; dabei die oberen ron der Spitze des fünfien ab sehr schwach zusammengedrüclit und erweitert. Die Farbe der unteren bis zur Mitte des fünften durchscheinend hellgelb, die obere Hälfte des fünften gebräunt, unı die übrigen sclıwarz. Das Halsschild fast doppelt breiter als lang, nit der kleineren Hälfte vorn sanft übergewölbt; und hier über den scharf rechtwinkligen, tief eingezogenen Vorderecken zusammengedrïckt und dadurch ver-. engt, die Seiten fein gerandel, nach vorn in leichten Bogen zusam- 
mengeneigt, die kurzen und breiten Hinterecken scharf zugespitzt, der Hinterrand nur leicht wellig gebuchtet, mit sehr liurzem und schmalem aber deutlich doppełt ausgerandetem Mittelzipfel. Vor dem letzteren ilie Oberfläche jederseits teicht und zuweilen kaum merklich eingedrückt, ausserdem ron jenem losgerissen an den Seiten etwas hinter deren Mitle je ein tiefer einschneidender, etwas gekrümmter Sclırägeindruck. Die Oberfläche spiegelglänzend gelb, die Mitte der Vorderhälfte mit verwaschener Begränzung schwach ins Bräunliche fallend, Das Schildchen stark ansteigend, schmal und fast linienförmig, etwa dreimal länger als breit, mit deutlichem Hinterzipfel und Vordergrübchen, glänzend braun. Die Deckschilde walzenförmig, hei dem $q$ hinterwärts etwas verbreitert, um die Hälfte länger als breit, längs der Wurzeł flach niedergedrückt, die gleichfalls flachen Schulterbenlen innerseits durch einen kurzen dreierkigen Eindruck abgesetzt, die Seitenlappen breit herabgezogen, und üher ihnen schräg hinter der Schulterbeule je ein grosser muldenförmiger Längseindruck. Die Punktstreifen sehır regełmässig, aus grossen tiefen, etwas getrenuten und hinterwärts zwar schwächeren, aber doch bis zur Spitze deutlichen Punkten gehiłlet, der sechste und siebente erst eine kurze Streche hinter der Schulterbeule beginmend, dafür das Vorderende des achıen durch lileinere Punkte verdoppelt, und auch der erweiterte neunte Zwischenraum von der Schulter bis zu dem Eindrucke über dem Seitenlappen durch solche dichtgedrängle überzählige Junkte niedergedrückt. Die Zwisclıenräume vorn schnäler und mehr linienförnig, hinterwärts breiter und in gleicher Weise sich immermehr verflachend, stark glänzend, lehmgelh und bei weniger ausgefärbten Stückeu heller strohgelb, mit schwarz gesäumter Wurzel und fünf bis zur Wölbung reichenden schmalen schwarzen oder bri schwächerer Ausfirbung braunen Längsbintlen, deren mittlere in Anschluss an das Schildchen die Naht eimnimmt, und hier auf der Wölbung sich zu einem einfachen Spitzensaume verschmälernd, jederseits am Aussenrande mit der Seitenbinde zusammenhaangt. Dic letztere schliesst die Schulterbenle ein, und zieht sich dann in deren Breite schı̈̈g mach linten und aussen, indem sie die Punktstreifen bis zum neunten durchschneidet, am Hinterende des Seitenlappens auf den neunten Zwischenraum übertritt und danı diesem letzteren folgt, his sie auf der Wöllung mit dem erwähnten Spitzensaume zusammentriflt. Zwischen dieser ınd der Nahtbinde 
liegt nun jederseits noch eine Mittelbinde; dieselbe stösst vurn nicht an den Wurzelsaum, sondern beginnt erst zwischen den Vorderenden des zweiten und vierten Streifens, und zieht sich danı etwas schräg nach hinten und aussen, wo sie auf der Wöllsung beim Zusammentreffen des fünften und siebenten Streifens abreisst. Pygidium und Unterseite sehr fein punktirt, dünn greishaarig, die Beine mit den Nälıten mehr ins Bräunlichgelbe fallend, und die Kirallenhäkchen dunkler gebräunt, seltener auch die Schienenenden stärker gebräunt und die Füsse schwäızlich. Die Vorderbrust uneben mit wenig vorgezogenem Vorderrande, hinten tiefer eingedrückt und leicht ausgebuchtet. Das letzte Segment des $\delta$ mit einem flachen rundlichen Eindruck, des $f$ mit dem gewöhnlichen halbliugeligen Grübchen.

\section{Ebenfalls aus Brasilien. (Nus. Baly, Deyrolle.)}

71. Cr. incommodus m. Rothgell mit helleren Seiten des spiegelglatten Halsschildes, Fühlerenden, Fussglieder, ein Schultertleck und eine mit ihm manchmal zusammenhängende, hinten abgekürzte Längsbinde der Flügeldecken schwarz; die Punktstreifen derb, mit flachen glänzenden Zivischenräumen. L. 11/2-22/3"“; Br. $3 / 4-11 / 6 "$.

Bei mancher Aehmlichlieit mit dem vorlıergehenden doch von ihm leicht an der nur einfachen, linten auswärts gekrümmten Längsbinde der Flügeldecken zu unterscheiden. Der Kopf flach mit feiner Stimlinie, die Stim bei dem ठ durch die fast zusammenstossenden oberen Augenenden sehr eingeengt, bei dem $q$ etwas breiter; das Kopfschild ein wenig eingezogen, oben durch eine deutliche Querlinie alggesetzt. Die Farbe glänzend rothgelb, die langgestreckten, ziemlich tief ausgebuchteten Augen schwarz. Die Fühler des $\delta$ von mehr als $3 / 4$, des $\&$ von reichlich halber Körperlänge, das dümn keulenförmige Wurzelglied etwa d’eimal länger als breit, und stark nach aussen gelirümmı, das zweite kurz und linotig, die beiden folgenden dünn verkehrtliegelförmig, gleichlang, und je um die Hälfte länger als das zweite; das fünfte - längste fast so lang als die beiden vorhergehenden zusammen, oberwärts schon leicht zusanmengedrïckt und verbreitert, die oberen wieder einander gleich, je etwas kürzer aber breiter als das fünfte, welchem das verschmälerte Endglied mit seinem breit dreieckigen Fortsatze wiederum gleichkommt. Die Farbe der vier unteren Glieder hell rothgelb, bei dunkleren Stücken mit einem schwärzlichen 
Längswisch auf der Oberseite des zweiten bis vierten Gliedes, an fünften nur noch die Wurzel gelblichlıraun, die Spitze mil den olseren Gliedern schwarz. Das sehr kurze Halsschild vorn buckelig aufgewölbt, nicht ganz mit halber Länge stark abwärts gekrümmt, über den stark eingezogenen rechtwinkligen Vorderecken zusammengedrückt und dadurch versclımälert; die Seiten gerandet, hinter der Mitte leicht ansgeschweift und vor ihr in flachen Bogen zusammengeneigt; die Hinterecken breit und spitz ausgezogen; der Hinterrand etwas eingesenkt, jederseits lreit ausgeluchtet, mit selır kuzem, sclımal aber tief doppelt ausgerandetem Mittelzipfe]. Vor letzterem jederseits ein leichter, länglicher Schrägeindruck, und an diesen schliesst sich nach vorı und aussen ein zweiter, viel stärkerer, fast furchenartiger Schrägeindruck an, welcher das Halsschild seitlich stark zusammenpresst und sich zuletzt über der Mitte des Seitenrandes abwärts biegt, diesen Rand selbst aber nicht erreicht. Die Farbe spiegelglänzend rothgelh mit rerwaschen lehmgelblichen Seiten, der Hinterrand fein schwärzlich gesäumt. Das Schildchen stark schräg ansteigend, gestrecktdreieckig, doppelt länger als vorn breit, glänzend rothgelb, mit dentlichem Vordergrübchen und kurz abgestutzter Spitze. Die Deckschilde ziemlich walzenförmig, fast $13 \frac{3}{4}$ mal so lang wie hreit, bei dem grösseren $q$ hinterwärts etwas verloreitert, längs der Wurzel quer niedergesenlit; die grossen halbeiförmigen Schulterbeulen immerseits durch einen kräftigen Läıgseindruck abgesetzt, auch die Seitenlappen breit und ïher ilnen je ein starker, den nenuten Zwischenraum abflachender Längseindruck. Der Rücken um die Schildchenspitze etwas aufgetrieben und linterwïrts längs der Naht flach niedergedrückt. Die Punktstreifen regelmässig und liräftig, bei dem $q$ nicht viel schıächer; die hinter den Schulterbeulen liegenden besonders bei dem ठ tiefer eingegraben, aus dichter an einander gerückten etwas in die Quere ausgezogenen Punkten gebildet, daher besonders vorn die Querrücken als Querrunzeln aul' die Zwischen'ïume übergreifent. Die Zwischenräume stark glïmzend, flach, die seitlichen flach gewölbt, das Vorderendt: des achten und der neunte ron dem Längseindrucke al, etwas stirker emporgehoben. Jie Farbe heller oder dunkler rostgell,; ein f'einer Vordersaum, ein Längsfleck auf jeder Schulterbeule, unt eine Lïngsbinte atl' jerler Flügeldeclie sclıwarz. Bei normaler Zeichnung ist diest: Binde schmal, liegt mit der grüsseren vorderen IIälfte zwischen dem zweiten und fünften Strei- 
fen, wendet sich an letzten Drittel schı̈g nach aussen, und bricht hier anf der Wölhung am achteı oder neunten Streifen ab. Bei dunkleren Stücken, deren ich von beiden Geschlechtern vor mir habe, fliesst die ohmehin nicht scharf begränzte Binde allseitig mit rerwaschener Begränzung über, fültt den ganzen Raum der Krümmung auf der Aussenseite und erreicht zuletzt vorı auch die Sclıulterbeule, in welchem Falle die Flügeldecke geschwärzt mit breiterem lıellerem Rande längs Naht, Spitze und Aussenseite erscheint, während an der Wurzel nur noch ein schmaler gelber Quersaum bis zur Schulterbeule hin vorhanden ist. Das Pygidium deutlich punktirt, dünn behaart, mit Unterseite und Beinen hell rothgelb, die Schienenenden und Fussglieder, bei lichteren Stücken nur die letzteren schwarz. Die Vorderbrust runzlig punktirt, hinter der Nitte yuer eingedrüclit, mit stumpfzweilappigem Hinterranile. Das letzte Segment des $\delta$ yuer niedergedrückt, des $q$ mit einer tiefeı halbkugeligen Grube.

Aus Buenos Ayres (Mus. Berol., von Müller) und Brasilien (eben tla, von Virmond). Exemplare im Mus. Baly und Haag stammen ohne Zweifel eben dorther, obwohl bei den ersteren gar keine Heimath angegeben, bei den letzteren - offenbar irrthümlich Michigan als solche genannt ist.

72. Cr. ellipticus m. Rothyelb mit helleren Declischildeu; Fühlerenden, Schildchen und ein breiter, sich vor der Spitze ringförmig schliessender Rand der Flügeldecken schwarz; das Halsschild spiegelglatt, die Punktstreifen derb nit flachen, glänzenden Zwischenräumen. L. $1 \frac{1 / 3}{3}-2^{\prime \prime \prime}$; Br. $2 / 3-1^{\prime \prime \prime}$.

Bei fast gleicher Breite mit dem vorhergehenden merklich kürzer, ülrigens demselben so ähnlich, dass ich auf dessen Beschreibung Bezug nelmen und mich auf die Angabe der Abweichungen beschränken kann. Die Grundfarhe ist ein gleichmässigeres und dunkleres Ziegelrotlıgelb, ohne lichtere Stellen des Halsschildes, an Unterseite und Beinen eben so dunkel, wie an Kopf und Halsschild, während die helleren Deckschilde deutlich gegen jene Grundfarbe abstechen; hei dem einzigen vorliegenden $f$ ist der hintere Theil des Unterleilses leicht schwärzlich angelaufen. lie Oberfläche des Halsschildes ist weniges glänzend, namentlich ubne den Lackglanz der vorigen Art; die seitlichen Eindrücke sind liürzer, aber tiefer, daher das Miltelfeld etwas stärker gewöllht und vor der Mitte des Itinterrandes viel weniger quer niedrrgesenkt. 
Die Punktstreifen sind eben so krättig, aber bei der geringeren Breite der Flügeldecken näher aneinander gerückt, daher die Zwischenräume schmäler, melır linealisch, was besonders bei den hinter den Schulterbeulen liegenilen hervortritt; der neunte und noch melır der etwas schmälere achte sind ilırer ganzen Länge nach schwach aufgewölbt. Ueher den Seitenlappen je ein rundlicher, unordentlich aber diclıt punktirter Eindruck. Die bedeutendste Verschiedenheit aber bietet die Zeichnung der Deckschilde dar. Wurzel, Naht und Seitenrand jeder Flügeldecke (Schildchen und Schulterbeule-eingeschlossen) sind von einem breiten, innerseits schlecht begränzten schwärzlichen Rande umzogen, dessen Hinterenden sich auf der Wölbung von Naht und Seitenrand ablösen und in einem ziemlich spitzen Bogen zum Abschlusse eines etwas unregelmässig gestreckten elliptischen Ringes vereingen. Der innere Raum desselben ist dicht vor seiner Mitte an breitesten, liegt hier zwischen dem zweiten und achten P'unktstreifen, und erreicht vorn zwischen dem vierten und fünften mit einem schmalen Zipfel fast die Wurzel der Flügeldecken; die Farbe spielt hesonders hinterwärts nehr oder weniger ins Metallisch-Sclıwarzbläuliche, während der breile uingeschlagene Rand des Seitenlappens leicht ins Pechbräunliche fällt. Der Vorderrand des Prosternums ist lang stumpfdreieckig vorgezogen und zur Aufnahme der Mundtheile löffelförmig ausgehöhlt, der Hinterrand kurz und stumpf zweilappig. Alles Uebrige, auch die Geschlechtsmerlimale, wie bei der vorigen Art.

Aus Brasilien (Mus. Berol., von v. Olfers mitgebracht).

73. Cr. nigriventris m. Oben lehmgell mit scluvarzen Fühlerenden, unten schwarz, die Schenkelwurzeln und Vorderschienen mit den Ifinterä̈nderı der Bauchringe schmutzig gelb; das Halsschild spiegelglatt, die Punlitstreifen hinterwärts al)geschwächt, mit flachen, seitlich flachyewülbten Zwischenräumen. L. $2 \frac{1}{3}{ }^{\prime \prime \prime}$; Br. 1"',

Von dem gestreckten Ban des nïchstfolgenden, anscheinent minder seltenen $\mathrm{Cr}$. bisulcalus m., aber von ihm und allen anderen Arten dieser Grupje durch die sehr schwachen Seiteneindrüche des IIalsschildes und die geschwärzte Unterseite leicht zu unterscheiden. Ure kopf flach mit kaum ringezogenem, oben undentlich ahgegrïnzlem liopfschilde, glänzend lehmgelh, Oberlippe und lïmbacken bei einem der vorlipgenden Stücke schmutzig gelıräunt; die sehr langen, in der Mitte ziemlich tief ansgebuchteten, (bei 
dem f) nicht sehr weit getrennten Augen schwarz. Die Fühler von melır als halber Körperlängre, sehr dünn; das Wurzelglied sclımal keulenförmig, unten stark gekrümmt, etwa dreimal länger als breit, das zweite liurz und fast kugelig, das dritte doppelt- und das vierte dreinal länger, beide dünn verkehrtkegelförmign, das fünfte fast den dritten und vierten zusammen gleich, oberwärts schon schwach dreieckig erweitert, die oberen bis zum zehnten je etwa doppelt so lang als das dritte, auch nur mässig zusammengedrückt und verbreitert, mit kurz kegelförmigem Fortsalze des fast linealischen, wiederum beiıahe dem fünften gleichen Endgliedes. Die Farbe der beiden unteren gell, des drilten und vierten tief' pechbraun, die oberen schwvarz mit dünner greiser Behaarung. Das Halsschild etwa doppelt läıger als breit, mit der kürzeren Vorderhälfte sanft übergekrümmt, ̈̈ber den scharf rechtwinkligen Vorderecken zusammengedrückt und dadurch verschmälert, die Seiten fein gerandet, nach voru fast in graden Linien zusammengeneigt, anch die scharfen Hinterecken kurz und fast rechtwinklig mit schwielig aufgetriehener Spitze; der Hinterrand jederseits nur flach ausgebuchtet, scharl gesïgt, mit schmalem, tief doppelt ausgerandetem Mittelzipfel. Vor diesem der hintere. Theil des sich sanft herabsenkenden Mittelfeldes breit und flach quer niedergedrückt, und danı jederseits über der Mitte des Seitemrandes noch ein kurzer, schwacher, sich hinterwärts ałlmählich verlierender Schrägeindruck. Die Farle ein helles, spiegelglänzendes Lelımgell. Das Schilıchen stark ansteigend, fast linealisch, doppelt länger als breit, hinten abgestutzl mit deullichem Hinterzipfel; das kurze aber kräftige Vordergrübchen jerlerseits von einer Querbeule hegränzt, die Farbe gleichfalls glänzend lehmgell. Die Deckschilde flach walzenförmig, ım mehr als die Hälfte läıger wie hreit, von den Sclıultern ab hinterwärts noclı l,is äher die Mitte hinaus erweitert und dann allnählich wieder bis zu der breit alogerundeten Spitze rerengt, vor'n in schwacher Krümmung zun Wurzelrande abfallend, der Rücken längs der Naht leicht abgeflachı; die halbeiförnigen Schulterbeulen liraflig, imnerseits durch einen mässigen Längseindruck ahgesetzt, die Seitenlappen laug herabgezogen, und über ilınen je ein breiter, den gewölbten neunten Zwischenraum stïlier niederdrückender Quereindruck. Die l'unktstreifen regehnässig, die vier wheren auf jeder Flügeldecke nur schwach, die äusseren kriftiger und besonders hiuter den Schulterbeulen tiefer ausgeprägt, von der $\mathrm{XV}$, 
Mitte ab alle bis auf den in eine leichte Längsfurche eingedrïckten neunten feiser, und die mittleren auf der Wölbung ganz abgeschliffen, die glänzenden $Z$ wischenrämme flach, der neunte und in geringerem Maasse der achte flach gewölbt, der ungeschlagene Rand des Seitenlajpens mit einer schwachen Punktreihe besetzt. Die Farbe auch hier lehmgelb. Ilas Pygidimm sehr fein runzlig punktirt, dümı greishaarig, etwas lueller gelb. Auf der Unterseite ist der ganze untere Theil des Halsschildes mit der Vorderbrust, so wie die Nittelbrust mit den Schulterblättern, IIüften und oberen Schenkellıälften hellgelb; die Vorderschienen schmutzig braungelb mit dunkleren Ober- und Unterenden; Hinterbrust, Hinterleil, und der übrige Theil der Beine schwarz, die Hinterränder der Bauchringe, und in breiteres Ausdelnumg der letzte Ring mit dem Mittelzipfel des ersten verwaschen gelblich, mehr oder weniger ins Bräunlichgelbe fallend. Das I'rosternum sehr kurz, der Vorderrand breit lölfelförmig vorgezogen und abwärts gekrümmt, das Hittelfeld hinten tief quer eingedrïclit, und der Hinterrand in zwei halhkreisförmigen Lappen vortrelend. Das letzte Segment des $q$ mit dem gewöhnlichen rundlichen Grübchen, das đ๋̊ unbekannt.

Aus Brasilien (Hus. Berol., von Virmond).

74. Cr. bisulcatus m. Oben ziegelroth, unten heller gelb, mit schwarzeı Fühlerenden, Schienen und Füssen; das Halsschild spiegelglatt, die Punktstreifen grob mit flach gewölbten glänzenden Zwischenräumen. L. 2"'; Br. 1"'.

Von dem gestreckten Bau des rorlıergehenden, aber ein wenig breiter, ausserdem ohne alle Zeichnung der Unterseite. Der Kopf flach und etwas unchen, der untere Theil des Kopfschildes eingezogen und dafür die Oherlippe wieder sclıräg vorspringend; die Punktirung grob, aher ungleich vertheilt, nur die Stirn über deu Fülılerwurzeln bis zu der schwach angedenteten Stirurinne ptwas glatter. Die Farbe hell ziegelroth, die Oberlippe noch etwas lichter, die Spitzen der Kinnbacken geschwäızt, die langgyrstreckten, tief ausgehuchteten und oben stark genäherten, bei dem ठ vollständig zusammenstossenden Augen schwarz. Die Fühle» des $\delta$ ron Körperlinge, des etwas liürzer, schlank und dümı; das zweite Glienl kurz und knotig, das dritte fast dreimal länger, das vierte noch etwas verlängert, und das lïufte doppelt länger als das dritte, dic oberen wenig hürzer, von sechsten ah schwach zusammengedrückt und prweitert, mit lang dreieckigem Fortsatze des 
Endgliedes. Das Wurzelglied hell l'othgelh, die folgenden bei dem ठ gell, bei dem \& bräunlich, die oberen von der Mitte des fünften ab schwarz. Das liurze Halsschild mit der vorderen Hälfte stark übergekrümmt, vor den Schildchen quer pingedrüclit und dieser Eindruck mit seinen Enden schı̈̈g nach vorn gebogen, liier fast unterhrochen, und dann tiefer einschneidend fast bis zur Mitte des Sejtenrandes hinabgesenkt; der Hinterrand deutlich gesägt, jederseits breit ausgeschweift, mit schmalem, deutlich doppelt ausgerandetem Mittelzipfel und liurzen breil zugespitzten Ifinterecken; die Seiten gerandet, nach den stark eingezogenen Vorderecken zu in breiten Bogen zusammengeneigt. Die Oberflïche spiegelglatt, hell ziegelroth mit schivärzlichem Hintersaume. Das Schildchen lang und schmal, fast gleichbreit, linten kurz ahgestutzt mit undeutlichem llinterzipfel, aber ziemlich grossem Vordergrübchen; die Farbe ziegel'oth mit dunkleren Säumen. Die Deckschilde schlank walzenförmnig, mehr als doppelt länger wie das Halsschild und hinterwärts kaunı verschmälert; die breit eirunden Schulterheulen innerseits durch einen tiefen Längseindruck abgesetzt, die Seitenlappen selır breit, durch einen gieichfalls tiefen Lïngseindruck auf dem neunten Zwischenraume noch mehr abwärts gedrängt, auch die Schildchenspitze mit dem anstossenden Theile der Naht als deulliche Benle aufgeworlen. Die Punlitstreifen selır r'egelmässig, hesonders die mittleren aus grübchenartigen, etwas in die Quere gezogenen Punkteı gebildet, zwischen denen die Brücken stellenweise als Qnerrunzeln auf die Zwisclıenräume übergreifen; die Hinterenden der mittleren Streifeı auf der Wölbung merklich abgeschwächt. Die Zwvischenräume vorn sclımal und flachgewölıt, durch das Eingreifen der Punkte theilweise gekerbt, hinten breiter und flacher; der ausserhalb der Schulterbeule beginnende achıte vorn kielartig erhı̈ht, der neunte verbreitert, über dem gleichfalls dicht punktirten Seitenlappen durch eine unordentliche, dicht gedrängle hasse eingestochener Punlite niedergedrückt. Die Farbe hell ziegelroth, nach der Spitze zu ins Gelbliche verbleichend, mit schwarzom Vordersaume, das Innere der Punkte gebräunt. Das Pygidium fein punktirt, dïmn hehaart, mit den Schulterbälteru, den Kändern der l'arapleuren und den foin gerunzelten Hinterleilse heller gell); die grob punktirte Brust wieder ziegelroth. Die Schısıliel rothgell mit helleren WVurzelı; Kinie (mitumter bis zur Mitte der Scheukel hin), Schienen unf Fussglieder schwarz. Der Vorderrand des Proster- 
nums breit vorgezogen, die Mitte schwach beulig erhöht und die Hinterzipfel einzeln breit abgestutzt. Das letzte Segment des $q$ mit einer rundlichen tiefen Grube, des $\delta$ leicht quer niedergedrückt.

Gleichfalls aus Brasilien (Mus. Petrop., Berol., Deyrolle, iı dem letzteren Sla. Catharina als Heimath genamnt).

75. Cr. melampus m. Rothgelb, Fühler, Knie, Schienen und Füsse schwarz; das Halsschild äusserst fein querrunzlig, die Punkıstreifen grob mit flach gewölbten, glänzenden Zwischenräumen. L. $2 \frac{1}{4}{ }^{\prime \prime \prime} ;$ Br. $11 / 12{ }^{\prime \prime \prime}$.

Dem vorhergehenden überaus ähnlich, aber von ihm doch auch wieder so weit verschieden, dass ich, da mir von beiden gleiche Geschlechter vorliegen, sie nicht füglich mit einander vereinigen kann. Ich kann mich desshalb jedoch, unter Bezugnahme auf die oben gegebene Beschreibung, auf die Angabe der Verschiedenheiten beschıänken. Dieselben zeigen sich zuerst in der Färbung; lie ganze Oberseite ist, wie die untere, hell rothgelb, mit wenig dunklerem Halsschilde, und dabei tritt die schwarze Nebenfarbe in entschieden grösserer Ausdehnung hervor. Am Kopfe sind nämlich die ganzen Fühler schwarz, mit licht pechlı̈anlichem Anfluge der Spitzen von dem zweiten bis vierten Gliede, eben so ist die Oberlippe geschwärzt, und an den Beinen ninmt jene Färbung ausser den Schienen und Fussgliedern auch noch die ganze untere Hälfte der Schenkel ein. Dagegen ist der Hinterrand des Halsschildes, wie dessen ganze übrige Färbung, gelb. Ilie Oberfläche des letzteren ist nicht ganz spiegelglatt, sonderı durch wellige Querrunzeln uneben, und auf den Deckschilden siud die Punlite der Streifen rund, nur zunächst lrinter den Schulterbeulen schwach in die Quere gezogen, daher auch die Zwischenräume nur einfach gewölbt, ohne hervortretende Querbrücken. Endlich ist das Schildchen mehr dreieckig, hinterwärts deutlicher verschmälert, und die Fühler sind kräftiger, schon vom oberen Eude des fünften Gliedes al zusammenged'ückt. Die Vorderbrust ist grob gerunzelt, vorn kurz napförmig vorgezogen, hinten in der Mitte nur leicht ausgebuchtet, die Mlittelbust hinterwäts in Gestalt eines Trapezes versclmmälert. Alles Uebrige, auch das grosse runde glänzende Grübchen auf dem letzten Segmente des of wie hei der vorhergehenden Art; das ơ unbeliannt.

Ebenfalls aus Brasilien. Mus. Hal. 
76. Cr. laticornis m. Strohgelb, die in der Mitte breit erweiterten Fühler bis auf die Wurzel mit Schienen und Füssen schwarz; das IIalsschild spiegelglatt, llic Punktstreifen grob mit flachgewölbten und gekerbteı glänzenden Zwvischenräumen. L. 2\%3"'; Br. $1 \frac{1}{4} "$.

Abermals den beiden vorhergehenden sehr ähnlich, aber doch bestimmt von ihnen verschieden. Er ist merklich grösser als beide, in der hellgelben Färbung der Deckschilde mit dem Cr.melampus, in dem spiegelglatten hinten fein schwärzlich gesäumten Halsschilde, den quer ausgerissenen Punkten der Punktstreifen, dem fast gleichbreiten Schildchen und den hellen Fühlerwurzeln mit dem $C r$. bisulcatus übereinstimmenı, von beiden aber abweichend durch die rein gelben Schenkel, so dass die schwarze Färbung der Beine erst mit den oheren Schienenenden beginnt, und durch den sehr eigenthümlichen Fühlerbau, welcher allein schon hinreichen würde, die Selbstständigkieit der Art sicher zu stellen. Dieselhen erreichen bei dem vorliegenden $q$ reichlich $3 / 4$ der Körperlänge; das erste Glied ist aus sehr dünner Basis schmal keulenförmig, etwas nach ausseı gekinummt, fast dreimal länger als breit, das zweitc kugelig und wenig schmäler als das erste, das dritte doppelt länger als das zweite und verkehrtkegelförmig, das vierte dem zweiten und dritten zusammen gleich, oberwärts schon etwas verbreitert, das fünfte (längste) so lang wie das dritte und vierte zusammen, nach oben sehr stark dreieckig erweitert und zusammengedrückt, die beiden folgenden gleich lang, etwas hürzer als das fünfte und ziemlich gleichbreit, so breit wie das obere Ende des fünften, die drei nächsten an Länge und Breite allnählich abnehmend, so dass das zehnte an Länge wieder dem vierten gleichkommt, an Breite es aber doch noch etwas übertrifft; das Endglied mit seinem schmal kegelförmigen, durch eine deutliche Ausrandung abgesetzten Fortsatze wiederum dem achten gleich. Die Farhe der vier unteren gelb mit gebräunter Spitze des vicrten, die sieben oberen, die man am besten mit der durch Abnutzung schartig gewordenen und oberwärts sich zuspitzenden flachen Kklinge eines alten Messers vergleichen könıte, tief schwarz mit dicht angedrückter glcichfalls schwarzer Belıarung und abstehend weiss gewimperten Spitzen. Die Vorderbrust grob runzlig punktirt, mit stark napfförmig ausgezogenem Vorderrande, der Hinterrand in zwei stumpf dreieckige Spitzen verlänger't und zwischen denselhen breit niedergedrückt. 
Die Nittellrust gleichlreit, auf ilırer Mitte den Hintereindruck der Vorderbrust fortsetzend, der Hinterrand ausgebuchtet. Alles Uebrige, auch die grosse rundliche Hinterleibsgrube des $q$, wie bei den vorhergehenden Arten; das ơ unhekannt.

Von den beiden vorhergehenden unterscheilet sich die vorliegende Art sonach durch den grösseren Kiörper, den Bau der Fühler, und die Färbung der Beine; ausserdenı von dem Cr. bisulcalus durch die hellgelbe Färbung, von $\mathrm{Cr}$. melampus dagegen durch den Bau des Schildchens, und die Sculptur von Halsschild und Deckschilden.

\section{Von Paramaribo (Nlus. Dohrn).}

77. Cr. siceus m. Strohgelb mit dunklerem Halsschilde und Saume der Flügeldechen, die Fühlerenden schwärzlich; das Halsschild spiegelglatt, die Punktstreifen grob, der siebente und achte unterbrochen, mit vorn stärker gewölbten, glänzenten Zwischenräumen. L. $2 \frac{1 / 3}{\prime \prime \prime} ; \mathrm{Br}$. $1^{\prime \prime \prime}$.

Wenig kleiner als der vorhergehende Cr. laticornis, und demselhen auch habituell nicht unähnlich, aher von ihm und allen anderen Arten der Gruppe mit eiufarhig gelben Deckschilden leicht an der Unterbrechung des sielsenten und achten Punktstreifens zu unterscheiden. Der Kopf flach, mit tief eingedrückter noch von einer feinen Längslinie durchzogener Stirnrinne; das liopfschild wenig eingezogen, oben nur undeutlich alyregränzt; die Oberfläche spiegelglänzenıl strohgelh, die Kinnbacken srhwärzlich, die grossen breit und ziemlich tief ausgebuchteten Augen oben (bei dem $\delta$ ) fast zusammenstossend, und greis. Die Fühler bei dem einzigen vorliegenden Stücke nur unvollständig vorllanden; das Wurzelglied aus selır dünner Basis stark keulig aufgetrieben, kaum doppelt länger als hreit, das zweite kurz eiförnigg, fast so breit wie lang, die beideu folgenden verkehrtkegelförmig, das dritte doppelt- und las vierte $2 \frac{1}{2}$ mal so lang als das zweite, das fünfte nach oben hin schon etwas zusammengedrüclit und erweitert, um die Hälfte länger als das vierte, das sechste wieder ein wenig kürzer aber stärker verbreitert als das fünfte, die oberen bis auf ein kurzes Stirck des siebenten fehlent. Die Farbe der unteren durchscheinend honiggelb, die Spitze des rierten und die Wurzel des lïuften gelnäunt, die vorhandenen Reste des oberen Theils schwarz. Ilas Ilalsschild halb so lang wie hinten lireit, mit dem ersten Viertel ler Länge vorn sanft übergelin̈mm und auch linterwärts wieder 
leicht niedergesenkt, über der vorderen Hälfte des Seitemrandes starki zusammengedrückt und dadurch nach vorn sehr merklich ver'schmälert, die Vorderecken scharf rechtwinklig, die Seiten fein gerandet, in der Mitte sehr schwach gerundet, die kurzen Hinterecken breit und scharf, der Hinterrand jederseits nur flach ausgebuchtet, innerseits der Schulterbeulen etwas eingesenlit, gesiggt, mit kurzem, ziemlich breitem, undeutlich doppelt ansgerandeten Mittelzipfel. Vor diesem jeder'seits eiu breiter, llacher Schrägeindruck, welcher in der verläıgerten Richtung des dritten und vierten Punktstreifens last ver'schwindet, dann wieder dentlicher wird, und sich zuletzt etwas verstärkt bis zur Mitte des Seitenrandes hinabsenkt. Die Oberfläche spiegelglänzend, dunkel lehmgelb, vor dem Mittelzipfel jederseits ein sebr verwaschener, hellerer rhombischer Querfleck, und der Hinterrand selhst noch etwas stärker gebräunt. Das Schildchen schräg ansteigend, etwa $2 \frac{1}{2}$ mal länger als breit und fast linealisch, hinten kurz verschmälert, mit deutlichem Vordergrübchen, glänzend dunkel lehmgelb mit gebräınter Wurzel. Die Deckschilde walzenförmig, um die Hälfte läıger als breit, vorn ein wenig breiter als der Hinterrand des Hialsschildes und dann fast gleichbreit bis zu der kurz abgerundeten Spitze verlaufend; die Wurzel starli nach vor'ı abwärts gedrückt, und der Rücken von der Schildchenspitze ab hinterwärts sanft und flach abfallend; die Schulterbenlen lang und ziemlich schmal, innerseits uur durch das stärker eingedrückte Vorderende des fünften Streifens abgesetzl, auch die Seitenlappen nur schwach, aher ihr umgeschlagener, mit einer dichten Punktreibe besetzter Rand sehr breit und über diesem je ein kräftiger, die Deckschilde verengender Quereindruck. Die Punktstreifen derb, aus vorı ziemlich dicht gedrängten, linterwärts besonders in den äusseren Streifeı mehr vereinzelten Punkten gebildet; die Rückenstreifen in besonder's vorn und hinten deutliche Längsfurchen eingedrückt, wodurch die spiegelglänzenden Zwischenräume in mehr oder weniger deutliclıer Wölhung hervortreten, der siebente und achte vor dem Quereindrucke abgebrochen, und hinten auf dem letzten Drittel nur das Hinterende des achten dentlich zı erkenneı, während von dem siebenten nur wenige und rereinzelte Punkte zu sehen sind. Die Farbe leell strohgelh, der ganze Saum der Flügeldecken einschliesslich der Naht und des umgeschlagenen Randes vom Seitenlappen dunkler braun. Jas grob punktirte Pygidium mit Unterseite und Beinen bräunlich gelh, rlas 
Prosternum hinten tief rundlich eingedrückt und stumpf zweilappig, der Vorderrand starli vorgezogen und mit abgerundeter Spitze abwärts gekrünmt. Das letzte Segment des einzigen vorliegenden $\delta$ einfach, das $q$ unbekannt.

Aus Brasilien (Nus. Holm., von Sahlberg bei Rio de Janeiro gefunden).

78. Cr. esuriens m. Bleich knochengelb mit schwärzlichen Fühlerenden; das Halsschild spiegelglatt, die Punktstreifen sehr grob, der fünfte und sechste schon auf der Mitte zusammentreffend, mit flach gewölbten, vorn längsschwielig aufgetriebenen, glänzenden Zıvischenräumeıl. L. $1-1 \frac{1}{3}{ }^{\prime \prime \prime}$; Br. $1 / 2-2 / 3{ }^{\prime \prime}$.

Eine langgestreckte schmale, besonders durch die eigenthümliche Scujptur der Deckschilde ausgezeichnete Art. Der Kopf sehr flach, obeı nit sehı kurzer aber deutlicher Stirnlinie, das Kiopfschild quer viereckig, um die Hälfte breiter als hoch, oben durch eine feine in der Mitte leicht nach unten gekrümmte Linie, seitlich durch deutlichere Kanten abgesetzt. Die Fläche glänzend knochengelb ohne alle Punktirung, die Kinmbacken und die sehr lang gestreckten, breit dreieckig ausgebuchteten, oben (auch bei dem $q$ ) fast zusammenstossenden Augen schwarz; die ülrigen Mundtheile lejcht gebräunt. Die Fühler bei dem einzigen vorliegenden $q$ nur unvollständig erdalten, anscheinend von nicht mehr als halber Körperlänge; das Wurzejglied schmal keulig, reichlich dreimal länger als breit, das zweite schmal eiförmig, fast dreimal küızer als das erste, das dritte $2 \frac{1}{2} \mathrm{mal}$, das vierte dreinal länger als das zweite, beide sehr dünn verkelırtkegelfö̀mig, das fünfte noch etwas läuger und oberwärts dreieckig erwnitert, die drei folgenden je dem vierten gleich, stark zusammengedrückt und verbreitert; die drei letzten nicht mehr vorhanden. Die Farbe der beiden unteren durchscheinend honiggelb, der beiden folgenden gelbbram; die oberen schwarz nit gehräunter Wu'zel des fünften, dicht anged'ückt greishaarig. Das IJalsschild schmal walzenförmig, um die Hälfte breiter als lang, vorn mit dem ersten Drittel mässign n̈bergewölbt. ïber den fein gerandeten in der Mitte leicht bogig erweiterten, und mit der grösseren Vorderhälfte nach den scharf rechtwinkligen Vordereclien zu fast gradlinig convergirenden Seiten breit tlach gedrïckt und dadurch nach vorn leicht kegelfürmig verschmälert, die Hinterecken kurz und scharf: gleichfills fast rechtwinklig, der Hinterrand jeder- 
seits nur leicht ausgebuchtet, mit sehr kurzem, kaum merklich ausgerandetem Mittrlziplel. Neben demselben zu jeder Seite ein er'st schmaler sich quer lïngs dem Hinterrande hinziehender, dann in grösserer Breite und Tiefe sich nach vor'n und aussen wendender Eindruck, welcher aber plötzlich abbricht, noch ehe er die breite Fläche über der Mitte des Seitenrandes erreicht. Die Farbe spiegelglänzend knochengelb, das Mittelfeld verwaschen ins Lehmgelbliche fallend. Das Schildchen stark ansteigend, aus breiterer Basis bald linealisch verschmillert, doppelt länger als vorn breit; Hinterzipfel und Vordergrübchen klein aber deutlich, letzteres den querbeulig aufgeworfenen Vorderrand durchsetzend, die Farbe gleichfalls knochengelb. Die walzenförmigen Deckschilde vorn breiter als das Halsschild, gleichbreit und erst mit dem letzten Drittel sich im Bogen verschmälernd, un die Hällte länger als breit; die Wurzel etwas thach gedrückt und hinter ilı eine leichte durch die tieler eingegrabenen Vorderenden der Punktstreifen gebildete Querfurche; die grossen Schulterbeulen länglich ansgezogen, die Seitcnlappen mässig, mit sehr breitem mit einer regelmässigen Punktreihe besetztem Unterrande. Auch die P'unlistreifen selbst regelmässig, grob, und erst auf dem letzten Drittel allmählich feiner, der erste auf der Wölbung erlöschend, der fünlte und sechste schon auf der Mitte zusammenlanfend, in diesem und den siebenten die Punkte hinter der Schulterbeule elwas vereinzelt; das erste Füuftel der fünf oberen bis über den schwachen himter den Sclıulterbeulen heraufziehenden Quereindruck hinaıs, ınd eben so clie trei äusseren in schmale Längsfurchen eingedrückt; die Zwischenräune flach-, die beiden äusseren elwas stärker gewölbt, die Vorderenden der inneren zwisclıen Schildchen und Schulterbeule liegenden, besonder's aber des dritten und vierten, längsschıvielig aufgetrieben, und dadurch der vierte und fünfte Punktstreifen mit einer lirümmung nach aussen gedrängt. Die Farbe auch hier glänzend knochengelh, etwas heller als das Halsschild. Pygidiun und Unterseite fein punktirt, mit den Beinen gleichfalls einlarbig knochengelb, Schienenenden und Fussglieder etwas dunliler mit geschwärzten Spitzen der auch hier mit einem Zähuschen besetzten krallenhälichın; die Vorderbrust einzeln punktiri, vorı schwach aulgewölbt, mit stark vorgezugenem, schräg wach unten gelogenem, breit alggerundetem Vorderrande, hinten ausgerandet mit breit dreieckigen Hinterenden, die scharl aufgeworfenen Seitenkanten von 
einer feinen Längsfurche begleitet. Das letzte Segment des ơ einfach, des of mit einer grossen, rundlichen Grube.

Von Cayenne: Mus. Deyrolle; und aus dem nördlichen Brasilien (von Parà : Nus. Berol., von Sieber mitgebracht).

79. Cr. mancus m. Bleichgelb mit geschwärzten Fühlerenden; das Halsschild spiegelglatt, die Punktstreifen kräftig, mit abgeschwächten Vorderenden und flach gewöłbten, äusserst fein punktirten und ziemlich glänzenden Zwischenräumen. L. $1 \frac{112}{2}$; Br. $3 / 4$ "

Obgleich von dieser Art nur ein cinziges sehr unvollständig erhaltenes Stück vorhanden ist, so wird derselben doch durch ihren einfarbig bleichgelben, sehr gestreckten und flach gewölbten Körper, in Gegensatz zu den folgenden melır gedrungenen, dabei kleineren und melır oder weniger ins Röthlichgelbe überspielenden Arten, hier ihre richtige Stelle angewiesen, und es muss dem Auffinden einer grösseren Zahl von Exemplaren vorhehalten bleiben, die fiir jetzt nur mangelhaft zu gebende Beschreibung weiter zu ergäızen. Der Kopf flach gewölbs, zwischen den Fühlerwurzeln etwas aufgetrieben, das Kopfschild wenig eingezogen und oben durch eine Querlinie abgegränzt; die Stirn spiegelglatt, wie der ganze Kopf bleich gell, nur die Mundtheile schmutzig gebräunt, und die lang gestreckten, breit aber nicht tief ausgebuchteten, oben durch einen kleinen Zwischenraum getrennten Augen schwarz. Die Fühler (Jes $\&$ ) beinahe von Körperlänge, schlank; das zweite Glied kugelig, die drei folgenden dünn verkehrtkegelförmig, das dritte doppelt-, das vierte $2 \frac{1}{4}$ mal länger als das zweite, das füufte, so wie das ihm gleiche sechste dem zweiten und dritten zusammen gleich, die obcrem allmähtich sich wieder verkinrzend, alle vom sechsten ab schwach erweitert und zusammengedrückt, das zehnte wenig länger als das vierte, das Entglied nuit seinem liurzen und breiten Fortsatze kaum wieder dem fünften gleich. Die Farbe der vier unteren durchscheinend honiggelb, mit dunkler angeflogener Oberseite des zweiten his vierten, das fïnfte tiefer braun, die oberen schwarz mit dünner greiser Behaarung. Das Hatsschild doppelt breiter als lang, mit der vorderen Hälfte stark übergelirümınt, die rechtwinligigen Vorderecken tief' eingezogen, die Seiten gerandet und in stark gekrümmten Bogen nach vorn zusammengeneigt, vor den liurz und hreit zugespitzten, etwas aufwärts gedrückten Hinterecken sanft ausgeschweift, der Ilinterrand eingesenlit, jeder- 
seits leicht ausgehuchtet, mit kurzem, deutlich doppelt ausgerandetem Nittelzipfel. Die Oherflïche spiegelglatt, bleiclıgelb mit schwach gebräuntem Hinterrante; jederseits ein tiefer, über der Mitte des Seitenrandes noch etwas mehr nach vorn gehrochener Schrägeindruck. Das Schildchen schräg ansteigend, schmal dreieckig, um mehr als die Hälfte länger wie vorn breit, mit kurzem, jederseits von einer lileinen Beule begränztem Vordergrübchen, gleichfalls glïnzend hleichgell. Die leckschilde gleichlıreit und fast walzenförmig mit flach gewölbtem Rücken, um die Hälfte länger als breit, vorn schwach niedergekrümmt und hinter dem Schildchen leicht quer niedergedrückt; die kräftigen, halbkugeligen Schulterbeulen innerseits durch einen dreieckigen Eindruck abgesetzt, die Seitenlappen måssig, mit stark heraustretendem Kiele, über letzterem die Deckschilde quer zusammengedrückt. Die Punkistreifen selır regelmässig, aus sehr schwachen, sich fast verlierenden Vorderenden bald sehr gekräftigt und dam in gleicher Stärlie his zur Wölbumg fortziehend, die Punkte des fünften gegen dessen Ende lin und die des fünften bis achten hinter der Schulterbenle etwas weniger dicht gestellt; die Zwischemrüume breit, flach, kaum sichtbar zerstreut punktirt, glänzend bleichgelb. Dieselhe Färbung zeigen Pygidlium und Unterseite; die Beine fellen dem einzigen vorliegenden Stücke. Der Vorderrand des Prosternums breit und kurz dreieckig ausgezogen unt abwärts cekrümmt, die Nittelfläche dicht und grob runzlig punlitirt, mit einem unregehıässigen glatten Längskiele, der Hinterrand nur leicht ausgebuchtet. Das letzte Segment des of mit einem rundlichen glänzenden Grübchen, das $\delta$ Imbekaunt.

Aus Brasilien (Mus. Berol., von Virmond).

80. Cr. figulinus m. Gelb mit schwarzen Fühlerenden, das hinten punktirte Halsschild mit den Deckschilden roth; die Punktstreifen kräftig mit llaclı gewölbten fein punktirten Zwischenräunıelı. L. 1“"; Br. 1/2"“.

Mit dicser Art leginnt wiederum eine Gruppe von nahe verwandten, dem Körper nach kleinen, schlank gebauten Arten, die von einanter nu durch feine Merkmale abweichen, sämıntlich aber in des ganz oder floch überwiegeud gellen oder rötlılichen Färbung übereinkommen, während das bei mehreren als Nebenlarbe auftretende Schwarz in der mannigfachsten Weise bald an dem pinen, bald an dem anderen Körperdseile zum Vorschein kommt. Die 
vorliegende Art ist von diesen Thieren eine der kleinsten; der Kopf flach gewölbt, das Kopfschild unten etwas eingezogen und oben durch eine deutliche Querfurche abgegränzt, die Stirn fast ganz durch die oberen Enden der grossen hallıkreisförmig ausgebuchteten und bei dem $\delta$ daselbst zusammenstossenden schwarzen Augen eingenommen. Der Unterkopf hell lackglänzend rothgelb mit schwärzlichen Kinnbacken. Die Fühler etwa von halber Kiörperlänge, ziemlich dünn; das schmale Wurzelglied reichlich dreimal länger als breit, etwas nach aussen gebogen, das zweite elliptisch, die drei folgenden dünn verkehrtkegelformig, das dritte um die Hälfte und das vierte doppelt länger als das zweite, das fïnfte dem zweiten und dritten zusammengenommen gleich, auch die folgenden von der Länge des fünften, dabei nur schwach zusammengedrückt und erweitert, mit schmal dreieckigem Fortsatze des Endgliedes. Die Farbe der beiden unteren hell rothgell, die drei folgenden immer stärlier gebräunt, die oberen schwarz mit angedrückter dünner greiser Behaarung. Das Halsschild um die Hälfte breiter als lang, mit der vorderen Hälfte ülsergewölbt, über den stumpf rechtwinkligen Vorderecken tief eingedrückt und dadurch verschmälert, seitlich ziemlich breit gerandet und laselbst in der Mitte in schwachem Bogen erweitert, die liurzen Hinterecken scharf dreieckig ausgezogen, der Hinterrand nur sehr leicht ausgebuchtet, mit kurzem, aber deutlich doppelt ausgerandetem Mittelzipfel. Vor diesem jerlerseits ein breiter und tiefer, sich mit leichter Krümmung bis über die Mitte des Seitenrandes hinziehender und das Halsschild stark zusammenschmürender Schrägeindruck. Die Oberfläche spiegelglatt, mit vereinzelten nach rorn immer schwächeren, hinten besonders an und in den Schrägeindrücken deutlichen Punkten bestreut; die Farbe hochroth, längs dem Vorderrande schwach ins Gelbliche verblichen. Das Schildchen $11 \mathrm{~m}$ die llälfte läuger als breit, hinterwärts mit etwas grermuleten Seiten verschmälert, vor der Mitte quer niedergedrückt, glänzend roth, mit deutlichem Vordergrülchen. Die lleckschilde um die Hälfte länger als breit, aus dem Walzenförmigen linterwärts leicht verschmälert, hinter dem breiten Wurzelrande durch den ersten, tief und breit grübchenartig eingestochenen Punki der inneren Punktstreifen breit quer nierlergedrüclit; die längliehen Schulterbeulen rorn echig heranstretend und sich hinterwärts verbreiternd und verflachend: die Seitenlappen schwach, und äber ihnen der gewöhnliche, hier gleichlalls nur 
schwache Quereindruck. Die P'unlitstreifen selı regelmässig, verhailtnissmässig grob und tief, auch hinterwärts nur wenig abgeschwächt; die Zwischenräume llach gewölbt, glänzend, je mit einer ziemlich regelmässigen selı feinen l'unktreihe und einzelıen überzähligen gleichfalls feinen Pünlitchen besetzt. Die Farbe hochroth mit ins Gelbliche verblichener spitze, die Wurzel fein bräunlich gesäumt. Pygidium, Unterseite und Beine hellgelb; der Vorderrand der Vorderbrust mit hreiter Rundung vorgezogen; das letzte Segment des ơ leicht quer niedergedrückt. Das ? unbekannt.

Von Ega am oberen Amazoneustrome (Mus. Baly).

81. Cr. phil o th ermus m. Hellgelb mit schwarzen Fühlerenden; das Halsschild spiegelglatt, die Punktstreifen aus derben Vorderenten bald abgeschwächt, nit flachgewölbten gläızenden Zwischenräumen. L. $1-1 \frac{1}{3}{ }^{\prime \prime \prime} ; \mathrm{Br}$. $1 / 2-3 / 4{ }^{\prime \prime \prime}$.

Von der Grösse des vorhergehenden, aber wicht roth sondern gelb unit nur schwach röthlichem Anfluge, und auch ausserdem von ihn dureh die Sculptur der Dechschilde leicht zu unterscheiden. Der Kopf flach, das Kopfschild durch eine deutliche Querlinie zwischeı den Fühlerwurzeln begräuzt; die Oberfläche durch eine feine Punklirung matt, licht gelb; nur die langgestreckten, sclınal aber tief ausgebuchteten, olsen nur durch eine feine eingeschnittene Längslinie getrennten Augen schwarz. Die Fühler von mehr als Lalber Körperlänge, dünn und schılank, das zweite Glied kurz birnförmig; das dritte um die Hilfte und das vierte fast ıloppelt länger als das zweite, das fünfte so lang wie die beiden vorhergehenden zusammen, und diesem die oberen gleich, letztere dabei sehr wenig zusammengedrückt und verbreitert, mit kurz pfriemlichem Fortsatze des Endgliedes. Die Farbe der unteren bis zur Mitte des lünften gelb, die uberen schwarz. Das Halsschild kurz, linten ahgeflachı und vorı mit der Hälfte stark kugelig über'gewölbt, auch seitlich tief herabgezogen, durch die lein gerandeten nach vorn fast in graden Linien convergirenden Seiten daselbst merklich verengt, vor dem Schildchen der Länge nach sanft aufgetrieben und von hier aus jederseits breit und tief quer eingedrückt, welcher Eindruck sich dann in schräger Richtung bis fast zum vorderen Hrittel des Seitenrandes hinabzieht, hei seiner Biegung nach unten jedoch durch einen leichten Wulst schwach unterbrochen erscheint. llie Hinterecken scharf dreieckig vorgezogen, der Hinterrand wenig ausgeschweift, der Mittelzipfel kurz und schmal, mil liräftigen 
Sritenzïhnchen deutlich dopjelt ausgerandet. Die spiegelglatte Oberfläche hellgelb. Das Schildchen stark ansteigend, länglich dreieckig mit schwachem Vordergrübchen, gleichfalls glänzend gelb. Die Deckschilde etwas mehr wie doppelt länger als das Halsschild, hreeit und flach gewölbt, längs der Basis erst flach aufgewulstet, dam durch die Vorderenden der Punktstreifen deutlich quer niedergedrückı, um die Schildchenspitze huckelig erhöht, die Schulterbeulen stark in die Länge aufgetrieben und innerseits durch einen tiefen Lïngseindruck alıgesetzt, die Seitenlappen sehr lang herabgezogen, mit einer deutlichen Punktreihe auf ilı'em umgeschlagenen Rande. Die Punktstreifen sehr regelmässig, aus vereinzelten vorn grübchenartigen, von der litte ah besonders in den Rückenstreifen feineren Punkten gebildet, der neunte hinten in eine leichte die Spitze umziehende Furche übergehend; die glänzenden Zwischenräıme vorn schmäler und flach gewölbt, linterwärts breiter und sich allmählich verflachend. Die Farbe gleichfalls hellgelb. Pygidium und Unterseite fein punlitirt, dünn weiss behaart, mit den Brinen gelb, nur die Krallenhäkchen schwïzlich und die Vorderfüsse zuweilen schmutzig gehräunt. Die Vorderbrust flach, der Länge nach wenig aufgewulstet, dentlich punktirt, mit stark vorgezogenem, grade abgestutztem Vorderrande, der Hinterrand ausgebuchtet mit spitz dreiechig vortretenden Hinterecken. Das letzte Segment des $\delta$ llaclı niedergedrückt, des $q$ mit einel tiefen rundlichen Grube.

Aus Brasilien (Hus. IIal., Saunders, Dohrn, Deyrolle, Holm., in letzterem Rio de J. als Fundort genannt; - auch im Nus. Berul:: von S. Joũo del Rey).

82. Cr. varipes m. Hellgell, Fïhlerenden, Schiene'n und Füsse mit den unteren Schenkelhälften schwarz; das Halsschilı spiegelglatt, die P'unlitstreilen ans zirmlich derloen Vorderenden balu abgeschwächt, mit flach gewölhteı, stark glänzenden Zwischenräımelı. L. $1 \frac{1 / 12}{12} 1_{12}{ }^{\prime \prime \prime}$; Br. $2 / 3-5 / 6 "$.

Jem vorhergehenden so älnnlich, dass ich ihn lange Zeit nur für eine Form desselben gehalten habe, während ich in ilım jetzt nach Verghleich cines grösseren Anzah! von Stïcken brider Arten eine eigene Art erkenme. Bei aller l'elsereinstinmmng mit jenem in Bau und Färbuugr ist er, wemn man ron beiden gleiclur Geschledter zusammenhlült, rtwas grösser, besomler's lureiter, aul dem Kücken, die Nahı. intlang, mehr ahgeflacht, s" dlass daher der 
Rumpf verluälntissmässig kürzer und das Halsschild nach vorn stärker verschmälert erscheint. Eben so sind die Punktstreifen der Deckschilde vorn etwas weniger liräftig, hinterwärts mehr verschwindend, daher die 'Zwischenräume stärker glänzend. Meist fällt auch die Färhung der Oberspile mehr ins Ziegelrothe, bei einem der vorliegeuden Stücke sind die unteren Fühlerglieder auf der Oherseite verwaschen gebräunt; charakteristisch aber ist die Färbung der Beine, welche lis auf die oberen gell, verbleihenden Schenkelhälften ganz schwarz sind, so dass ter Küfer in diesel Beziehung die Farlsenvertheilung des Cr. melampus in Kleinen wiederholt. Alles Uelırige, auch die Geschlechtsmerkmale, wie bei der vorhergehenden Art.

Gleichfalls aus Brasilien (Mus. Hal., Saund., Schaum, Deyrolle). Im Mus. Deyr. war der Käfer als Car. unicolor Chv. bezeichnet.

83. Cr. succulentus m. Lelmigelb, Fühler- und Schenkelenden schwarz; (las Halsschild spiegelglatt, die Punlitstreifen mässig, hinterwärts feiıer, mit flachen glänzenden Zwischenränmen. L. $1 \frac{1 / 2}{\prime \prime \prime} ; \mathrm{Br}, 2 / 3 " \prime$.

Vou der Grösse und dem Habitus des Cr. varipes, aler besonder's vorn etwas breiter, die Eindrücke des Halsschildes linten schıächer, die Punktstreifen etwas liräftiger, die schwarze Färbung an den Beineı auf den unteren Theil der Schenkel beschräıkt, so dass die Schienen gar nicht davon berührt werden, daher nach meinem Dafürhalten eine gute Art. I) Kopf ist zwischen deu Fühlern mehr unelıen, das Koplschild tiefer eingezogen, die Punktirung der Stirn schwächer, und fast allein auf die etwas tiefere Stirnrinne beschränkt. Auf dem Halsschilde sind die heiden hinteren Schrägeindrüclie nur schwach angedeıtet, dagegen die vorderen, eigentlich die Fortsetzungen von jenen bildenden, über dem Seitenrande fast noch stärker als bei der vorhergenannten Art. Die Punktstreifeı sind, wenn man gleiche Geschlechter zusammenhält, lıräftiger, aus dichter stehenden Punkten gebildet, anf der Wölhung weniger abgeschwächt, die seitlichen tiefer cingedrückt; der neunte Zuvischentaum ist über dem Seitenlappen der Länge naclı tief niedergedrückt, und über ihın der aclıte fast rippenförmig anfgetriebrn. An den Bejuen ist die grössere Unterhälfte der Hinterschenliel, das untere Drillel der Mittelschenkel rein schwarz; an den Fordersehenkeln sind die Spitzen verwaschen geschwärz, so aber, 
dass diese Färbung nirgends auf die Schienen übergreift. Der Vorderrand der Vorderbrust ist rundlich vorgezogen und ausgehöhlt, das Mittelfeld der Länge nach flach aufgewulstet, und der Hinterrand breit zweilappig. Alles Uebrige wie bei $\mathrm{Cr}$. varipes. Das letzte Segment des $q$ mit einer tiefen halhkugeligen glänzenden Grube, das $\delta$ unbekannt.

Aus Brasilien (Mus. Berol., ron Sello bei S. João del Rey gefunden).

84. Cr. geniculatus Sti̊l. Ziegelrolh, Fühlerenden, Knie und Fussglieder geschwärzt; rlas Halsschild spiegelglatt, die Punktstreifen aus ziemlich derben Vorderenden bald abgeschwächt, mit flachen star'k glänzenden Zwischenräumen. I. 1 1/4"'; Br. 5/6"'.

Monachus geniculatus Stål Till Kännedomen elc. in der öfversicht elc. p. 61 . n. 6 !

Wiederum den vorhergehenden Arten ähnlich, aber bei fast gleicher Länge verhältnissmässig breiter, mehr gleichbreit, noch stärker glänzend, und auch durch die Sculptur und Farbenvertheilung ron jenen abweichend. Der liopt flach mit leicht eingezogenem, ubeu durch eine deutliche Querfurche abgegränztem liopfschilde, ziemlich glänzend und schmutzig braunroth, der ganze obere Theil der Stiru durch die lang gestreckten und tief ausgebuchteten, oben zusammenstossenden sclıwarzen Augen eingenommen. Die Fühler nach den rorhandenen Resten ziemlich schlank, das Wurzelglied keulenförmig mit etwas alggellatteter Oberseite, etwa $2 \frac{1}{2}$ mal länger als breit, das zweite elliptisch, um die Ilälfte länger als breit, die dıei folgenden dünı rerkehrtkegelförmig, je doppelt lïnger als das zweite, das fïufte dem zweiten und dritten zusammen gleich, und dipsem auch die oberen gleichend, letztere dabei zusammengedrückt und schwach erweitert. Vie Farbe der unteren bis zur Wurzel des fünften rothgell, del oberen, soweit sie noch vorhanden sind, schwarz, mit dïnner angedrückter greiser Behaarung. Das Halsschilı um die Ilälfte länger als breit, in der Mitte leicht quer buckelig aufgewölbs, rom ziemlich steil-, nach denı Hinterranıle zu sanfter alwär'ts gekrümmt, ülıer den stumpfwinkligen Vorderecken lricht zusimmengenlrückl um dalurch relschmälert, die Seiten friı gerantet, naelı vorn fast in graden Linien convergirend, die Hintereclien hreit und scharf rorgezogen; der Hinterrand jederseits breit- und nur vor deu Schulteru tiefer ausgebuchtet, hier auch etwas eingesenkt; Jel Mittelzipfel undentlich 
doppelt ausgerandet, und zu jeder Seite desselben ein erst querliegender, dann nach vorn und aussen gelirümmter und hier in schrïger Richtung über der vorderen Hälfte des Seitenrandes verlaufender, furchenartiger Eindruck. Die Oberfläche selbst spiegelglatı, und wie der ganze übrige Körper dunkel ziegelroth. Das Schildchen mässig ansteigend, dreieckig, fast doppelt länger als vorn breit, hinterwärts mit ausgebuchteten Seiten ver'schmälert und kurz abgestutzt, Hinterzipfel und Tordergrübchen undentlich, die Oberfläche gleichfalls spiegelglatt. Die Deckschilde ziemlich breit walzenförnig, etwa $1 / 4$ länger als breit, vorn linter dem breiten Wurzelrande durch die tiefer eingegrabenen Vorderenden der Punktstreifen leicht quer eingedrückt, die lang eifürmigen kräftigen Schulterbeulen innerseits durch einen längliclıen Eindruck abgesetzt, die Seitenlappen sclıwach und über ihnen die Deckschilde nur sanft quer zusammengedrückt. Die Punktstreifen sehr regelnässig, aus ziemlich lıäftigen Vorderenden hinterwärts allmählich schwächer und die mittleren anf der Wölbung fast erloschen; die Zwischenräume spiegelglänzend, flach, nur der neunte und über dem Seitenlappen auch noch der vorhergehende flach gewölbt. Pygidium, Unterseite und Beine gleichfalls roth, an den Hinterbeinen Knie und Schienenspitzen leicht gelıäunt, an den Mittelbeinen tiefer geschwärzt, an den Vor'derbeinen ausser den beiden Kinieen bei dem $\delta$ auch die in der Nitte breit röthlich geringelten Schienen, bei dem of die Spitzen aller Schienen schıvarz; die Füsse ülerall schwarz. Die Vorderbrust vorn breit vorgezogen, hinten fast grade abgestutzt mit ku'z vorspringenden Hinterecken. Das letzte Segment des $\delta$ flach quer niedergedrückt, des $q$ mit dern gewöhnlichen Grübchen.

Vom Amazonenflusse (Mus. Baly) und von Rio de J. (Sahlberg im Mus. Holm.).

85. Cr. lutarius m. Ziegelroth, Fühlerwurzeln, die unteren Schenkelhälften und Knie nebst der Hinterbrust und dem Hinterleibe bis auf den letzten (gelben) Bauchring sclıwarz; das Halsschild in der Hinterfurche grol, punktirt, die Punktstreifen aus ziemlich derben Vorderenden bald abyeschwächt, mit flachen stark glänzenden Zwischenräımen. L. 11/3"'; Br. 5/6"'.

Bei gleichır Färbung, auch gleicher Breite mit dem vorhergethenden etwas länger, und an der abweichenden Vertheilung der schwarzen Farbe leicht kenntlich. Der Kopf flach, mit einer fei$\mathrm{XV}$. 
nen, sich auch über die bei dem đo oben zusammenstossenden Augen hinaus fortselzenden Stimlinie, glänzend hell ziegelroth, nur die langgestreckten, breit und tief ausgebuchieten Augen mit den Kinnbacken schwarz. Die Fühler von etwa $3 / 4$ der Körperlänge, das Wurzelglierl dünn, reichlich drejmal länger als Jıreit, das zweite elliptisch, dreimal kïrzer mud etwas sclımäler als das erste, die drei folgenden dünn rerkehrtkegrförmig, das dritte mnd vierte einander gleich und je ım die Hälfte, das fünfte doppelt länger als das zweite; das seclıste dem fünften gleich, die folgenden an Grösse kaum merklich wieder abnehmend, bis das zolınte wieder dem vierteu gleich kommt, das etwas Jüıgere Endglied mit schunal kegelförmigem Fortsalze: dabei die oberen vom sechsten al unmerklich zusammengedrückt und kaum erweitert. Die Farbe der vier unteren rothgell mit wischarlig gebräunter Oberseite, die oberen schwarz mil angedrücliter dïmmer greiser Behaarung. Das Halsschild ım die Hälfte länger als Jreit, in der Mitte stark buckelig anfgewölbt und dann vorn breit ühergekrümmnt, hinten durch eine tiefe Querfurche eingeschnürt, deren Enden sich schräg nach vorn und anssen krümmen und hier zı den fein gerandeten, in der Ilitte stark bogig erweiterlen Seiten sich heralssenkenıl das Halsschild breit znsammendrücken; die tief eingezogenen Vorderecken scharf rechtwinklig, auch die Hintereclien fast rechtwinklig zngeschärft, der Hinterrand jederseits kamm ausgebuchtet, mit kurzem sclıwach ausgerandetem Mittelzipfel. Ije Oberfliche dumlielziegelroth mit Glasglanz, überall mit einer feinen, sehr vereinzelten Punklirung hestrent, die Qurrlurche hinten mit eingen undentlichen Reilıen dicht gedrüngter und theilweise runzlig verfliessender gröherer Punlite beselzı. Das Schilılchen schräg ansteigend, $2{ }_{4}$ mal länger als breit, aus etwas hreiterer Wurzel hald verschmälert und fist linealisch, mit kurzem aber deutlichem Vordergrübchen, gleichlalls glïnzend ziegelroth. Die Decksclildle breit und flach walzenlörmig, vorı elwas breiter als das Halsschild, hinter den ahgermudeten Schultem noch pin wonig verhreitert und damn mit fast gleicher Breite bis zu der kurz algermuleten Spitze fortziehend, hinter der Wurzel durch die gruhigen Vorderenden der oberen P'unlistreifen quer eingedrückl, die Schulterbenlen lıreit laallokugelig aufgetrieben, die Seilenlappen von mässiger Aushildung. Die Punktstreilen aus ziemlich getremiten, rorn lirilligen l'mkten bestehend, schon vor der Nitte schwacher; rom letzten Drittel ab sehr abge- 
schwächt, und die nittleren auf der Wölbung kaum noch keuntlich; die glänzenden Zwischenräume stellenweise kaum sichtbar zer'streut punktirt, flach, die inneren zunäclsst an der Wurzel, und der achte und neunte ihrer ganzen Lïnge nach sanft aufgewölbt. Die Farbe auch lijer dunkelziegelroth, der umgesclılagene Rand des Seitenlappens und dessen Kiel wie brandig schwarz, und diese Färbung auch sehr verwaschen auf den anstossenden Theil des neunten Zsvischenraumes übertretend. Das Pygidium fein punktirt und mit dem letzten Bauclringe hell rothgelb; Hinterleib und Hinterbrust mit dem unteren grösseren Theile der Schenke], den Knieen und den oberen Schienenenden schwarz, Hüften und Schenkelwurzelı mit dem äbrigen Theile der Schienen und den Füssen rothrelb. Alles Uebrige wie bei der vorhergehenden Art.

Aus Brasilien (von Petropolis; Mus. Clark, und olne Angabe des Fundorts: Mus. Berol.).

Das offenbar nur murollständig ausgehärtete und ausgefärbte Stück im Mus. Berol. ist einfarbig hellgelb, bat nur die Augen und Krallenhäkchen schwarz, die Kuie schmutzig gebräunt, zeigt aber sonst keine Abweichungen.

S6. Cr. velatus m. Schwarz nit braunbunten Beinen; Fühlerwurzeln und Deckschilde rothbraun; das Halsschild spiegelglatt, die Punktstreifen zicmlich derb mit flachgewölbten, glänzenden Zwischenräumen. L. 1-1 $1 / 3{ }^{\prime \prime \prime} ; \mathrm{Br}$. $1 / 2-5 / 6 "$.

Von der Grösse und dem Habitus des Cr. philothermus, aber von ihm und allen vorhergehenden leicht an dem schwarzen Halsschilde zu unterscheiden. Der Kopf flach, das Kopfschild oberwärts rerschmälert und zwischen den Fühlern durch eine feine eingegralsene Querlinie, seitlich' durch schärfere Leisten begränzt, und von diesen ans gegen die langgestreckten, unter den Augen breit hervortl'etenden Wangen sehr sehräg abfallend. Die kaum punktirte Oherlläche glänzend schwar', Oherlippe und Taster fuchsroth, die oberwärts genäherten und bei dem $\delta$ fast zusammenstossenden, tief winlilig ausgeljuchteten Augen greis. Die Fühler des of vou $3 / 4$ der Kïrperlïnge, des $q$ etwas kïrzer, dünn und sclımal; das Wurzelglied etwa $2 \frac{1}{2}$ mal länger als breit, das zweite kurz eifürmig, die beiden folgenden gleich lang, doppelt länger aber etwas schmäler als das zweite, dünn verkehrtliegelförmig; das fïnfte bei gleichem Bau dem zweiten und dritten zusamnen gleich, die folgenden wieder ron gleiclıer Länge, etwas kürzer als das 
fïnfte, nur sehr schwach zusammengedrückt und erweitert, mit schmal kegelförmigem Fortsatze des Endgliedes. Die Farhe der vier unteren gelblich braun, das fünfte an der Spilze slärker gebräunt, die oberen schwarz, dünı angedrückt lehaart und abstehend gewimpert. Das Halsschild kurz und breit, hinter der Mitte sattelförmig yuer niedergesenkt, ror ihr kugelig aufgewölbt und mit dem trsten Drittel der Länge abwärts gelirümmt, hart über den kurzen scharf rechtwinkligen Vorlerecken zusammengedrückt und dadurch rerschmälert. Die ziemlich breit gerandeten Seiten nach vorn im Bogen zusammengeneigt, anch die scharf stumpfwinkligen, noch mit einem Zähnchen besetzten Hinterecken nur lurz vortretend; der lein gesigte Hinterrand fast grade, mit sehr kurzem und schmalem, doppelt ausgerandetem Mittelziplel. Die Oherfläche spiege]glatl; auf ihı schliesst sich an deı linteren Quereindruck jederseits eine aus zwei Absätzen bestehende Verlängerung desselben, welche breit und tief einschmeidend sich schräg nach rorn bis zur Mitte des Seitenrandes hinabzieht, und dadurch das fast halbkreisförmig al)gegränzle Mittelfeld in die Höhe schiebt. Die Farbe rein schwarz. Das Schildchen schräg ansteigend, üher $1 \frac{1}{2}$ mal läuger als breit und fist gleichbreit, mit deutlichem Vordergrïbchen, gleichfalls gläuzend schwarz. Die Deckschilde schmal und flach walzenförmig, etwa $2 \frac{1}{2} \mathrm{mal}$ länges als das Halsschild, roru wenig breiter als letzteres, hinterwärts noch etwas verbreitert, hinter dem breiten Wurzelsaume leicht quer niedergedrückt; die Schulterheulen als breitr eckige Höcker emporgehoben, imnerseits durch einen dreieckigen Eindruck abgesetzt, die Seitenlappen mit weiter Rundung abwïts gezogen; und üler ihnen hinter den Schulterbeulen hinauf ein dis Deckschilde hreit einengenter, oberwärts bis zur Naht zu verfolgender Eimdruck. Der Räcken breit abgeflacht, mit hiuten kurz alffallender Wöllung. Die Punktstreiten selır regelmässig, hei dem ơ derh unı kräftig, hei dem $q$ schwächer und bei diesem die mittleren schon ror der Wülbung fast erloschen; die wheren Zwischenrïume nur flach-, die seitlichen etwas stärker gowölb, spliegelglatı. l)ie Farbe ein reines, lilares Rollulıaun, ein feiner Wurzelsanm und der untere von einer Punktreilie hegleitele Saum des umgesclılagenen Randes vom Scitenlap'jen dunkler gelıäunt. Pygidlium und Unterseite deutlich aber rereinzelt und nicht tief (querrunzlig punktirt, cinzeln frin behaart mit glinzendem Zwischengrunde, gleichlalls rein schwarz; die Beine hellbram mit 
breit geschwärzter unterer Hälfte der Schenkel und etwas verdunkelten Fussgliedern. Die Vorderbrust vereinzelt grob punktirt mit etwas alwärts gebogenem nicht eigentlich vorgezogenem Vorder-. und nur leicht ausgebuchtetem Hinterrande. Das letzte Seginent des of mit einem seichten rundlichen Quereindrucke, des $f$ mit einer breiten und tiefen rundlichen Grube.

Ebenfalls aus Brasilien. Mus. Schaum, Berol. (die Stücke des letzteren ron Sello bei S. João del Rey gesammelt).

S7. Cr. ruficeps m. Metallisch schivarz oder blau, der Kopf mit den Fühlerwurzeln, das spiegelglatte Halsschild und die Vorderschienen ziegelroth; die Punktstreifen mässig, hinterwärts feiner; mit flachen glänzenden Zwischenräumen. L. $1 \frac{1 / 3}{3}$ "'; Br. 3/4"'.

Den grössten Stücken des $\mathrm{Cr}$. philothermus an Grösse gleich, durch die Färbung der Deckscliilde vor allen Arten der Gruppe ausgezeichmet. Her Kopf flach und etwas uneben, mit deutlich punlitirten, oben scharf algegr:inztem Kopfschilde, lie Farbe ziegelroth mit mässigem Glanze, die schmal aber tief ausgebuchteten, mit den oberen Innenrändern einander stark genäherteu Augen schwarz: auf der Stirn nur einzehe zer'streute Punkte. Die Fühler derb, das zweite Glied kurz birnförmig, das dritte doppelt länger und diesen auch das vierte gleich, das fünfte noch etwas verlängert, die oberen deutlich zusammengedrückt und erweitert; die Farbe schwarz, nur die drei unteren ziegelroth und das vierte gebräunt. Das kurze und breite Halsschild vorn mit der grösseren IJälfte stark kugelig übergewölbt, hinterwärts abgeflacht und etwas eingesenkt, die Seiten fein gerandet, nach vorn in flachen Bogen zusammengeneigt, die Hinterecken kurz mnd breit zugespitzt, fast rechtwinklig; auch der Hinterrand wenig ausgeschweift, der Mittelzipfel fast grade abgestutzt. Jerlerseits desselben ein vor der Mitte der Flügeldecken liegender, schräg nach vorn und aussen ziehender, durch eine seichtere Stelle unterbrochener Eindruck. Die Oberfläche lianm punktirt, spiegelglänzend ziegelroth. Das Schildchen schräg austeigend, länglich dreieckig, glänzend schwarz. Die Deckschilde walzenförmig mit etwas abgeflachtem Rückeı und sanft abfallender Wölbung, längs der Wurzel nur sclırach aufgeworfen, um das Ilinterende des Schildchens etwas erhöht, inıerseits der länglich lı̈ckerig emporgehobenen Schulterbeulen breit eingedrückt, die Seitenlappen eben so breit herabgezogen und auf ihrem umgeschlagenen Rande mit einer deutliclıen Punhtreihe besetzt. 
Die Punktstreifen sehr regelmässig und ziemlich kräftig, die inneren vorn je mit einem Grübcheı begimnend, auch das Vorderende des achten linter der Schulterbeule etwas vertieft, und der neunte in eine leichte Längsfurche eingedrückt, alle von der Mitte ab allmällich feiner. Die Zwischenräume flach, der achte vorn schwach rippenförmig erhöht, und der neunte flach gewölbt. Die Farbe ein glänzendes Kohlsclıwarz, fast blau oder auch (bei einem Stücke im Mus. Berol.) dunkel metalliscligrün. Das Pygidium sehr fein punktirt, kaum bchaart, mit der Unterseite und den Beinen schwarz, nur die Unterseite des Halsschildes nelst der Wurzel der Vorderschenkel und der Vorderschienen ziegelroth, die übrigen Schienen an den Spitzen gebräunt. Das letzte Segment des $q$ mit einer grossen rundlichen Grube, das $\delta$ unbekannt.

Bei einem Theile der vorliegenden Stücke sind die Punktstreifen etwas stärker, die Vorder- und Mittelschınkel fast ganz roth; weitere Unterschiede finde ich nicht, und wage desshalb auch nicht, auf solche Stücke ohne Weiteres eine neue Art zu gründen.

Gleichfalls aus Brasilien. Mus. Saunders, Haag., Berol. (die Expl. des letzteren bei Caasapava ron Sello gesammelt).

85. C r. a mb b ti o sus m. Rothgelb, Fühlerenden, Schildchen und Beine bis auf die oberen Schenkellıälften sclıwarz, die Deckschilde metallisch schwarzblau; das Halsschild spiegejglatt, die Punktstreifen derb nit flachen glänzenden Zwischenräumen. L. 11/3"'; Br. 3/4".

Von der Länge der vorhergehenden Art, aber merklich flacher, und von ilı besonders durch die einfurbig rothgelbe Unterseite abweichend. Der Kopf flach, das etwas eingezogene Kopfschild oben durch eine tiefe Querfurche abgesetzt. Die Farbe glänzend rothgell, die langgestreckten und tief ausgebuchteten, oben auch bei dem ठ̊ nicht völlig zusammenstossenden Augen schwarz. Die Fülıler (des ठ) von Körperlänge, dünn und fadenförmig, das stark keulige Wurzelglied etwa $2 \frac{1}{2} \mathrm{mal}$ länger als breit, las zweite kurz und knotig, fast so breit wie lang, die drei folgenden sehr schwach verkehrtkegelförmig, das dritte und vierte einander gleich, je $2 \frac{1}{2}$ mal länger als das zweite, das fünfte so lang wie das dritte und vierte zusammen, das sechste nur wenig kiürzer als das fünfte und ihn die oberen bis zum zehnten gleich, das fast linealische Endglied mit seinem schmal dreieckigen Fortsatze so lang wie das zweite bis vierte zusammengenommen; dabei alle vom sechsten ab selır schwach zusammengedrüclit uni nur am oberen Ende schwach erweitert, 
Die Farbe der unteren bis zum obcren Drittel des fünften hin röthlich gelb mit einer schwarzen Längslinie auf dem ersten Gliede, die oberen schwarz mit dümer greiser Belıaarung. Das Halsschild liurz und breit, mit dem vorderen Drittel ziemlich stark übergewölbt, über den schar' rechıwinkligen, tief eingezogenen Vorderecken zusammengedrückt und dadurch verschnälert; die fein gerandeten, hinter der Mitte schwach bogig erweiterten Seiten von da ab nach vorn fast gradlinig zusammengeneigt, auch die scharfen Hinterecken nur kurz und fast rechtwinklig. Der Hinterrand kaum merklich ausgeluchtet, mit knrzem, schmalem, tief ausgerandetem Mittelzipfel. Vor letzterem am hinteren Drittel des Halsschildes ein breiter, flacher Qucreindruck, an den sich jederseits eine tiefere, aus zwei Absätzen bestehende und nach der Mitte des Seitenraudes hin sich lıinabziehende Schrägfurche anschliesst. Die Oberfläche spiegelglatt, ziemlich dunkel ziegelroth. Das Schildchen stark ansteigend, schmal linienförmig, $2 \frac{1}{2}$ mal länger als breit, mit kräftigem Vordergrübchen, glänzend schwarz, bei gewisser Beleuchtung hellbräunlich durchscheinend. Die Deckschilde um die Hälfte länger als breit, vom breiter als das IJalsschild, und dann in ziemlich gleicher Breite bis zu der liurz abgerundeten Spitze fortziehend; der Rücken sehr flach gewöllı, hinten sanft abfallend, hinter dem ersten Viertel breil quer niedergedrückt und auch läng's der Wurzel gegen das Ilalsschild zu abgeschrägt; die halbeiförmig aufgetriebenen Schulterheulen immerseits durch einen tiefen, schmalen Eindruck abgesetzt, die Seitenlapıjen von mässiger Länge, und über ilınen gleichfalls ein muldenförmiger Längseindruck. Die Punktstreifen derb und in ihrer ganzen Länge mil ziemlich gleicher Stärke verlaufend, aus groben ziemlich dicht gedlängten, erst auf der Wöłbung bei den mittleren Streifen etwas mehr vereinzelten Punkten gebildet; die Zwischenräume flach, nur der nemte und der vordere Theil des achten leicht aufgewölbt, die zunächst an der Naht und hinter der Schulterbeule liegenden durch die quer ausgezogenen, nur durch schmale Querbrücken getrennten Punkte der Streifen etwas gekerbt. Die Farbe ein glïnzendes, ins Purpuroder Kinjferfarbige üherspielendes metallisches Schwarzblau. Das feinpunktirte Pygidium mit der Unterseite und der grösseren oberen Schenkelhä]fte hell rothgelb, der äbrige Theil der Beine schwarz, die Nitte der Schienen bräunlich durchscheinend. Die Vorderbrust länger als breit, vorn runzlig aufgetrieben, hinten eingedrückit mit 
kaum merklich vortretenden Lappen des nur rvenig ausgebuchteten Hinterrandes; der Vorderrand vorgezogen und fast senkrecht abwärts gerichtet, in der Mitte tief ausgeschnitten, mit schmal zugerundeten Vorderdappen. Das letzte Segment des o mit einem flachen, rundlichen Eindruck; das $f$ unbekannt.

Gleichfalls aus Brasilien (Mus. Deyrolle).

Sechszehnte Rotte. Körper schmal und gestrcckt walzenförmig mit oben zusammenstossenden oder doch genäherten Augen. fadenförnigen Fühlern, und stark abgeflachtem Rücken der Deckschilde, das Halsschild jederseits tief schräg eingedrückt. Die Punktstreifen selır regelmässig, die Färbung braun, bei einer Art schwarz mit weisser Zeichnung der Unterseite; die Krallenhäkchen mit einem breiten und stumpfen Zähnchen besetzt. Wenige, sehr zerstreut vorkommende Arten, von denen der vorhergehenden Rolte hauptsächlich durch den schmaleı, flachen, einer Hispa oder Leptomorpha ähnlichen Körper abweichend. Mecosthetus Stål.

89. Cr. Sahlbergii Stål. Rothbram, das spiegelglatte Halsschild und die Deckschilde pechbraun, Schienen und Füsse schwarz; die Punktstreifen grob und grubig, mit g]änzenten schmalen gekerbten Zwischenräumen. L. $2^{3} 4_{4}^{\prime \prime \prime} ; \mathrm{Br} .1^{\prime \prime \prime}$.

Mecostelhus Sahlbergii Stål Till Kännedomen etc. in der öfversichı elc. p. 66. n. 1 !

Schmal und flach walzenförmig, mehr durch die Grösse und den eigenthümlichen Habitus als durch die Fär)ung ausgezeichnet, und im Körperbaı an einzelne australische Arten erinnernd. Der Kopf flach aher uncben, das schmale halbmondförmig aufgetriebene Kopfschild durch eine tiefe, etwas wellige Querfurche von der Stirn getrennt; letztere mit unscheinbarer Lïngslinie, die Oberlippe gegen den tief eingezogenen Unterrand des Kopfschildes wieder stark vorspringend. Die Oberfläche mit einzelnen sehr zerstrenten Punkten besetzt, lackglänzend rothbram, die breit und bis über die Mitte ausgebuchteten, auch bei den vorliegenden $q$ oben zusammenstossenden Augen sclıwarz. Die Fühler fadenförmig, von $2 / 3$ der Körperlänge, das zweite Glied eiförmig, die drei folgenden gleichhreit und auch die oheren kaum merklich rerbreitert und zusammengedrückt. Die Färbung der unteren leell grelbbraun, die oberen ron der Mitte des fünften ab selıwarz. Das Halsschild fast doppelt hreiter als lang, vorı mit der kleineren Hälfte ühergekrümmt, mit stark eingesclnürtem, alogesetztem Vorderrande, welcher sich unter- 
wärts noch über die scharf rechtıwinkligen Vorderecken hinaus fortsetzt, und nahe vor dem breit schüsselförmig vorgezogenen Vorderrande des Prosternmms in Gestalt eines scharf dreieckigen nach unten gerichteten Zahnes abbricht; die Seiten fein gerandet, iu der Mitte bogig erweitert, vor und hinter ilır leicht ausgeschweift, und dann nach vorn in fast graden Linien convergirend; über ihnen das Halsschild schräg nach vor'u zusammengediñckt und dadurclı verschmälert. Die Hinterecken kurz und breit dreieckig, wenig vorgezogen, der Hinterrand jederseits breit ausgebuchtet, mit kurzem doppelt ausgerandetem Mittelzipfel, und vor letzterem ein etwas buchtiger tiefer Quereindruck, welcher sich mit etwas wellig gebogenen ungleichmässig verbreiterten Vorderenden schräg bis über die Mitte des Seitenrandes hinabzielıt und dadurch das Mittelfeld als einen rundlichen Wulst nach vorn drängt. Auch über der Mitte des Vorderrandes noch ein kurzer, elliptisch muldenförmiger Quereindruck, den ich seiner Lage Imd Gestalt nach nicht wohl für einen bloss zufälligen halten kann. Die Farbe glänzend pechbram, mit schwach röthlich durchscheinendem Vorderrande. Das Schildchen stark ansteigend, aus breiterer Wurzel linealisch, doppelt länger als breit, mit kurzem Ilinterzipfel und grossem halbelliptischem hinterwärts auf der Mitte allmählich verlaufendem Vordergrübchen, die Farbe glänzend pechbraun mit schwarzer Wurzel. Die gestreckt walzenförmigen Deckschilde $1 \% / 3$ mal so lang wie breit, gleichbreit und hinten kiturz abgerundet, hinter der Wurzel leicht quer eingedrüekt, der Rü̈cken breit abgeflacht, die läıglichen, sclımalen Schulterbeulen stark aufgetrichen, die Seitenlappen mässig, mit einer undeutlichen Punktreihe auf dem ungeschlagenen Rande, und üher ihnen die Deckschilde breit aber nicht tief zusanmengedrückt. Die Punktstreifen sehr regelmässig, aus groben, grübchenartigen Punkten gebildet, vorn und hinten etwas abgeschwächt, in leichte, seitlich stärliere Längslinien eingedrückt, die seitlichen hinter den Schulterbeulen dichter zusammengeschohen und die Punkte in ihnen durch erhöhte Querbeulen geschieden; die oberen Zwischenräume flach gewölbt, die seillichen schmal und leistenförmig, durch das Eingreifen der groben Punlite gekerht, dabei mit äusserst feinen Pünktchen bestreut, pechbraun. Pygidium und Unterseite fein alser dicht runzlig punktirt und gell) behaart, mit den Schenkeln rothbraun, die Schienen und Füsse mit den Spitzen der Vorderschenkel schwarz. Die Vorderbrust hinter dem breit nach vorn und 
unten ausgezogenen Vorderrande tief quer gefurcht und dahinter zwischen den Vorderhüften zu einer eben so kräftigen, aber stumpfen Querleiste aufgetrieben; die Hinterenden kurz aber scharf dreieckig vorgezogen. Das letzte Segment des o mit einer grossen glänzenden halbkugeligen Grube; das đ̋ unbekannt.

Aus Brasilien (bei Rio de J. von F. Sahlberg gesammelt; Mus. Holm.). Bei einem Stücke im Mus. Deyrolle ist, rielleicht irrthümlich, Chile als Heimath genannt.

90. Cr. chr o m a t ic us in. Schwarz, Kopf, Fühlerenden, Schenkelwurzeln, Schulterbätter, Vorderbrust und ein breiter Samm ron Hinterbrust und Hinterleib weisslich gelb, die Deckschilde stahlblan; das Halsschild spiegelglatt, die Punktstreifen kräftig, mit flachen, rorn leicht gewölbten, glänzenden Zwischenräumen. L. $2 \frac{1}{4}{ }^{\prime \prime \prime}$; Br. 5/6"“.

Auch diese Art zeigt anscheinend etwas Fremdartiges, an australische Arten Erimnerndes, schliesst sich aher bei näherer Betrachtung nithe an die vorliergehende, nicht weniger aber an die langbeinigen Arten der folgenden Rotte an, ron denen sie sich kaum ander's als durch die nicht gegitterten Deckschilde unterscheidet; daneben ist der Kiffer durch seine Farbenvertheilung eben so eigenthünlich, als er bis dahin in den Sammlungen selten zu sein scheint. Der Kopf klein, flach, oben ganz durch die grob gekörnten schwarzen nur durch eine feine Längslinie getrennten Augen eingenommen; letztere tief dreieclig ausgebuchtet, das Kopfschild etwas eingezogen; die Farbe des Kopfes luell stroligelb, lackglänzend spiegelglatt, mit schmutzig pechbramer Oberlippe. Dic Fühler (des ठ) von melı als Kö̀pperlänge, dünn und fadenförmig, das keulenförmige Wurzelglied fast dreimal so lang wie breit, das zweite hurz und knotig, die folgenden sehr dünn, erst von der Spitze des sechsten ab schwach zusammengedrüclit und an oberen Ende erweitert; von ihnen das dritte $2 \frac{1}{2}$ mal länger als das zweite, das vierte so lang wie das zweite und dritte, das fünfte fast wic das dritte und vierte zusammengenommen, letzteres dabei etwas gebogen, die folgenden allmählich aber sehr schwach sich verliürzend, so dass das zehnte noch dem vierten gleichkonmut, das Endglied mit scinem sclınal kegelförnigen Fortsatze etwa wieder dem neunten gleich, Die Farlse schwarz, die unteren bis gegen die Mitte des vierten schmutzig gelblich mil gebräunter Oberseite, die drei letateren hell weisslichgelh, alle von der Mitte des fünften al, mit dicht angedrücliten IIärchen besetzt und an den oberen Innen- 
ecken deutlich gewimpert. Das Halsschild fast doppeit breiter als lang, mit stark aufgewölbtem, uach vor'n und hinten kugelig abwärts gekrümıntem Mittelfelde, ülser den rechtwinkligen Vorderecken zusammengedrückt und dadurch verschnnilert, die Seiten fein gerandet, vor den kurzen scharfen llinterecken schwach er'veitert und dann nach vorn in graden Linien zusammengeneigt, der Hinterrand jederseits schwach wellig gebuchtet, mit kurzem breitem stark doppelt ausgerandetem Mittelzipfel; neben letzterem an Hinterrande zu beiden Seiten ein liurzer liefer Sclırigeindruck, und in dessen Verlängerung nach kurzem Zwischenraume eine tief eingedrŭckte und etwas gekrümmte, über der Mitte des Seitenrandes sich verlierende Schrägfurche, durch welche jederseits vor der Schulterhenle eine dieser entsprechende hohe rundliche Beule emporgetriehen wird. Dabei ist das ganze Halsschild spiegelglatt und rein schwarz, nur der Vordersaum und die Vordereclien fallen rerwascheu ins Gelblichbraune. Das Schildchen starli ansteigend, gestreckt dreieckig und doppelt länger als breit, mit länglichem Vordergrübchın und sehı kurz abgestutzter Spitze, glänzend stahlhlau. Die flaclı walzenförmigen Deckschilde um die Hälfte länger als breil, hinterwärts ein wenig erweitert und zur Spitze nur leicht abfallend, vorn jederseits der Schildchenwurzel schrăg niedergedrï̈ckt, und un dessen Spitze schwach erhölıt; die halbeiförmigen Schulterbentlen innerseits durch einen deutlichen Eindruck abgesetzt, auch die Seitenlappen selır stark herahgezogen, und über ihnen die Deckschilde stark zusammengedrückt. Die Punktstreifen regelmässig und von ziemlich gleichmässiger Stärke, nur die Vorderenden der äusseren, namentlich dẹs neunten, über den Seitenlappen aus gröber'en, tiefer eingegrabenen Punkten gebildet; die kurze Spitze unter der Wölbung spiegelglatt. Auch die flachen Zwischenräume spiegelglänzend, der neunte seiner ganzen Länge nach ein wenig aufgewölbt, die Farbe hell stahlblau. Das Pygidium fein punktirt und düm behaart, weisslich gell, der Ifinterleih sclıwarz mit breitem weissgelbem Saume; anch die Hinterbrust schwarz, Parapleuren, Schulterblätter, Mittel- und Vorderbrust wcissgelb. Die Beine laug und ziemlich dümn, IHüften und Schenkelwurzeln nebst den Innensciten der Schenliel gleichfalls weissgelb, Knie und Fussglieder weisslich durchscheinend, der übrige Theil der Schenkel mil den Schienen schwarz. Der Vorderrand mit der Vorderbrust rundlichnapfförmig vorgezogen, las Mittelfeld der Länge nach sehr flach 
aufgewulstet, der hintere Theil in zwei kurze rundliche durch einen Eindruck getremte Lappen auslaufend, welcher Eindruck sich als seichte Längsfurche auf die Mittelbrust fortsetzt. Das letzte Segment des of einfach; das $q$ unbekannt.

Aus Brasilien (von Santarem: Mus. Baly).

91. Cr. hispaeformis m. Oben lederbraun, Unterseite und Beine lehmgelb; das Halsschild glatt, die Punktstreifen grob, hinten furchenartig, mit rippenförmigen, auf der Mitte querrunzlig verfliessenden Zwischenräumen. L. 1 1/2-13/4"; Br. 1-11/12"'.

Verhältıissmässig kïrzer und breiter als die vorhergehenden, auch in der Sculptur von ilınen abweichend, aber nach dem Bau von Kopf, Halsschild und Beinen doch nicht wohl von ihnen zu trennen, wenn man die Anzahl der kleineren Gruppen nicht über Gebühr vervielfältigen will. Der Kopf flach, mit unten etwas eingezogenem, oberwärts stark verschmälertem, seitlich durch scharfe Leisten begränztem Kopfsehilde; die oben zusammenstossenden, schmal aber tief ausgebuchteten Augen die Stirn selır rerengend; die Oberfläche runzlig punktirt, nur die innersten Winkel der Augenbuchten und das längs den Kanten sanft eingedrückte Kopfschild fast punktlos und lackglänzend. Die Farbe heller oder dunkler lederhraun, die Augen schwarz. Die Fühler (des q) dümn und fadenförmig, von melı als $3 / 4$ der Körperlänge; das gestreckt keılenförmige Wurzelglied mehr als dreimal länger wie breit und leicht nach aussen gekrümmt, das zweite sehr kurz eiförmig, dreimal kürzer aber wenig schmäler als das erste, die folgenden überaus schlank und zart, das dritte reichlich doppelt-, das vierte fast dreimal länger als das zweite, aber nur hall, so breit, die drei folgenden einander und dem Wurzelgliede gleich, nach der Spitze hin allüihlich aber nur schwach erweitert, die vier oberen wiederum cinander gleich, mit schmal dreieckigem Fortsatze des Endgliedes. Die unteren lis zur Mitte des fünften durchscheinend braungelb, die oberen sclıwarz mit feiner greiser Behaarung, dabei einzeln ab)stehend gewimpert. Das Ilalsschild kaum halb so lang wie breit, ror'n in ten tief eingezogenen, scharf reehtwinligen Vorderecken eingedrückt, und daclureh stark verschmälert, in der llitte lutgelig aufwärts gewölbt und von da ab hinterwärts schwächer, nach dem Vorderrande zu etwas stärker abwärts gekrümmt; die Seiten fein gerandet, naclı vor'n bugig zusammengeneigt, die Ilinterecken lany mnd scharf spitzwinklig ausgezogen, der Hinterrand jederseits breit 
ausgebuchtet, mit kurzem, doppelt ausgerandetem Mittelzipfel. Letzterer durch einen zu jeder Seite liegenden kurzen aber tiefen Schrägeindruck etwas emporgehoben; in der Verlängerung dieses Eindruckes, aber mit ilm nicht stets zusammenhängend, liegt diunn noch ein zweiter längerer und tieferer, welcher mit welliger Kíümmung sich bis zum Seitenrande fortzieht und über dessen Nitte sich allmählich verflach,, aber durch seine Windung den mittleren Theil der Scheibe als ein erhöhtes zierlich gewölıtes Mittelfeld, mul eben so die Fläche ror der Schulterbeule als rine dieser entsprechende rundliche Beule in die Höhe treibt. Dabei das ganze Halsschild spiegelglänzend heller oder dunkler lederbraun. Das Schildchen sehr gestreckt dreieckig, etwa $2 \frac{1}{2}$ mal länger als breit, hinten liurz ahgestutzt und etwa halb so breit wie vorn, mit stark eingegrabenem Vordergrübchen, gleichfalls glänzend lederbrauı mit schwärzlichem Vordersaume, bei dunkleren Stücken etwas heller als die übrige Oberseite. Die Deckschilde flach gewölht, Jänglich viereckig, vorn breiter als das Halsschild und hinterwärts noch etwas verbreitert, mit sehr breit und kurz abgerundeter Spitze, fast dreimal länger als das Halsschild, nicht ganz um die Hälfte länger als breit. Die Wurzel nur jederseits des Schildchens sanft quer niedergedrückt, innerseits der länglich elliptischen, stark aufgetriebenen Schulterbeulen nochınals eingedrückt, die Seitenlappen schwach, und über ihnen hinter deı Schulterbeulen je ein undentlicher, oberwärts in den Runzeln des Mittclfeldes sich verlierender Schrägeindruck. Die Punktstreifen grob und tief, vorn aus mehr vereinzelten und grübchenartigen Punkten gebildet, auf der hinteren Ilälfte dicht aneinander geschoben, dadurch deutliche Furchen eingrabend und die vorı nur gewölbten Zwischenräume zu deutlichen Längsrippen erhebend. Auf dem mittleren Drittel zwischen dem ersten und siebenten oder achten Streifen, so wie längs den letzteren bis über den Seitenlappen hin ist die Streifenhildmng durch Verwerfung der Punkte gestürt, und dic Zwischenräume fliessen zu groben Querrunzeln zusammen, deren Gestaltung nicht einmal auf beiden Flügeldecken dessellıen Stïckes, vielweniger bei verschiedenen Stücken sich gleichmässig entwickelt. Die Zwischenräume selbst überall spiegelglïnzend, die Farbe lieller oder dunkler lederbraun, wie die des Halsschildes; der breit umgeschlagene Rand des Seitenlappens gleiclıfalls mit einer Reihe quer ausgezogener grobu' Punkte besetzt. Pygidiun und Unterseite fein rumzlig punktirt, 
jenes dicht greishaarig und seidig glänzend, diese dünner behaart, und nebst den Beinen hell lehmgelb, nur die Fussglieder dunkler und die vorderen fast schwarz. Die Vorderbrust grob runzlig punktirt, mit breit napfförmig vorgezogenem Vorderrande; der Hinterrand breit ausgebuchtet, vor der Mitte eingedrückt, mit grossen lappig zugerunloten Hinterenden. Das letzte Segment des $q$ mit einer grossen rundlichen glänzenden Grube, das đ̛ unbekannt.

Gleichfalls aus Brasilien (Mus. Hal., Schaum).

Siebenzchnte Rotte. Körper breit mol flach gedrückt mil langen fadenförmigen Fühlern, bei dem ơ völlig zusammenstossenden Augen, und dünnen, besonder's vorı stark verlängerten Beinen. Das Halsschild siebartig punktirt, das Hittelfeld durch einen gekrïmmten Schrägeindruck zu jeder Seite kugelig emporgetrieben; auch der Kopf sehr uneben. Die Deckschilde gegittert punktstreifig mit regelmässigen Doppelstreifen. Die Kirallen mit einem kurzen dreieckigen Zähnchen besetzt. Eine durch ihre Sculptur höchst ausgezeichnete, auch in der gelben Körperfärbung mit meist rother Oberseite sehr übereinstimmende Gruppe aus dem östlichen Theile von Südamerika.

92. Cr. clathratus m. Blutroth, ein Mittelfleck des Halsschildes und die Deckschilde schwarz nit zwei unterbrochenen rothen Querbinden der letzteren; das Halsschild groh rmuzlig punktirt mit glattem Kiele, die Punktstreifen grol doppelreihig mit abwechselnd leistenförmigen erhöhten, glatten Zwischenräumen. L. 4"'; Br. $11 / 2 "$.

Ein auf den ersten Anblick etwas seltsamer, einem Cryptocephulus wenig ähınlicher Käfer, der sich aber bei näherer Prüfung doch eng an die vorhergehenden Arten anschliesst und dadurch den Uebergang zu den nächstlolgenden Arten mit ungleich deutlicher entwickelter Sculptur der Flügeldecken vermittelt. Der Kopf verhältnissmässig klein, llach und unehen, das grosse liopfschild uben durch eine deutliche Querloiste abgesetzt, gegen welche der darüberliegende untere Theil der Stirı vertieft zurücktritt; der ubere 'Theil der letzteren durch die oberen Enden der grossen, stark ausgebuchteten und zusammenstossenden greisen Augen eingenommen. Die Fühler (des $f$ ) dünn und zart, von üher $2 / 3$ der liürperlänge, das Wurzelglied schwach lieulig rerdickt, mässig nach aussen gekrïmmt, etwa dreimal länger als breil, das zweite wenig schmäler, kugelig, die folgenden gestreckt, das dritte dreimal, das 
fünfte fast fünfmal, das vierte, sechste und siebente je viermal läıger als das zweite, die drei folgenlen allmählich wieller kürzer, so dass das zehnte nur noch dem dritten gleichkommt; das Endglied mit seinem schnnal kegelförmigen Fortsatze wiederum dem neunten gleich; dabei die oberen nur nach der Spitze zu ein wenig zusammengedrückt und erweitert. Die Farbe der vier unter'en hellroth, das fünfte gebräunt, die oberen schwarz mit dentlicher greisel Behaarung. Das breite und flache Halsschild vorn mit dem ersten Drittel der Länge leicht übergewölbt, über den scharf rechtwinkligen Vorderecken stark zusammengedrückt und dadur'ch verschmälert, die Seiten gerandet, hinter (ler Mitte stmmpfwinklig erweitert und vor ihr leicht ansgebuchtet, auch die kurzen Hinterecken scharf spitzwinklig, der Hinterrand wellig gebuchtet, mit sclmalem, tief doppelt ausgerandetem Mittelzipfel. Vor diesem ein broit eiförmiger, flacher Quereindruck, dessen Mitte von einer über das ganze Halsschild hinziehınden, auf dessen gewölbtem Mittelfelde słark verbreiterten glänzenden Kiiellinic durchsetzt wird. Ausserdem jederseits noch ein kräftiger, mit einer Krümmung gegen das vordere Drittel des Seitenrandes gerichteter, dann schwächer längs den letzteren nach den Vorderecken hinziehender Schrägeindruck, durch welchen ein dreieckiges Feld im Ilinterwinkel von dem gleichfalls wułstig aufgetriebenen Mittelfelde ahgesondert wird. Die ganze Olserfläche mit dicht gedrängten groben und grübchenartig in lie Länge gezogenen Punkten besetzt, deren meist nur linienförmige Zwischenräume hei schräger Beleuchtung einigen Glanz zeigen. Die Farbe dunkel blutrolh, ein schmaler verwaschener Hinterrandssaum und ein gleichfalls verwaschener grosser rhombischer Querfleck auf der Mitte schwarz; von dem letzteren aus zieht sich hinterwär's längs der Kiellinie bis zum Mittelzipfel ein schwärzlicher Schatten, und ein ähnlicher schwächerer zeigt sich jederseits an der tiefsten Stelle des Schrägeindruckes. Das Schildchen $2 \frac{1}{2}$ mal lïnger als breit, hinterwärts wenig verschmäler't, grade abgestutzt, mit deutlichenı Hinterzipfel und Vordergrïbchen, glänzend schwar'z mit bräunlich durclıscheinender Spitze. Die Deckschilde vorn etwas breiter als das Ilalsschild, gestreclit viereckig und fast gleichbreil, doppelt länger als breit, crst vom letzten Achtel al, kurz zugerundet, um die Schildchenspitze nur durch den sich an diese anlegenlen Nahtrand etwas aufgetrieben, ausserdem ter Rïcken flach, und die Nalıt rom Schildchen ab der Läıge nach eingedıückı; die 


\section{6}

Schulterbeulen lang und schmal, innerseits nur durch den etwas stärker vertieften fünften und sechsten Punktstreifen abgesetzt; die Seitenlappen von mässiger Stärke, äber ihnen der neunte Zwischenraum etwas gelirünmt, und der zehnte Punktstreifen längsgrubig vertieft. Die Punlitstreifen regelmässig, aus groben, rundlich viereckigen, nahe an einander gerücklen Grübchen gebildet, deren Sonderung nur durch linienförmige Querwände bewirkt wird; die Streifen selbst derartig paarweise geordnet, dass die ungraden Zwischenräume gleichfalls nur als schmale und niedrige, nicht einmal überall grade fortzichende, nur an den Hinterenden etwas deutlichere Längsleisten sichthar werden, wïhrend die graden, d.h. der zweite, vierte, sechste und achte, als stark erhöhte und verbreiterte Rippen hervortreten, die beiden ersteren mit ihren Vorderenden sich unmittelhar an den gleichfalls wulstig erhöhten Vorderrand anschliessen, und hinten besonders durch die Vereinigung des zweiten und achten unter der Wölbung die Spitze so weit erhöht wird, lass ein eigentliches Abfallen des Rückens, wie bei den gewöhnlichen Fornen, nicht zu bemerken ist. Die Punkte des inneren abgekürzten Streifens kleiner, noch dichter an einander geschoben, bis zum Ende des ersten Drittels leichend, und hierselbst da endend, wo ein leichter Quereindruck sich über den Jücken hinwegzieht. Die Farbe glänzend schwarz mit bräunlichen Schulterbeulen und zwei aus getremnten Flecken bestehenden blutrothen Querbinden; in der vorderen auf jeder Flügeldecke zwei Flecke, der äussere grösser'e lald hinter der Schulterbeule innerseits des achten Zwischenranmes bis zum fünften ausgedehnt, der innere kleinere nahe an der Naht auf dem ersten und zweiten Zwischenraume; die zweite Binde vor der Wölbung, rom zweiten bis zum achten Zwischenranme reichend, eigentlich aus vier Längsflecken auf den breiten Zwischenräumeı gebildet, nur theilweise auch das Imnere der Doppelstreifen und deren schmale (ungrade) Zwischenleisten mit umfassend; innerhalb dieser rothen Zeichnung sind die Querbrücken zugleich etwas breiter und lleutlicher; dabei sind die breiten Zwischenräune stark glänzend, und ihre Vorderenden, ähnlich wie die Schulterbeulen, nur etwas schwächer, bräunlich durchscheinend. P'ygidium und Unterscite fein punktirt, düm greishaarig, nebst den Beinen blutroth, mil geschwärzten Enden der Vorderschenkel, die Fussglieder hesonders an den verlängerten Forderbeinen stark verbreitert und licht greis gẹolstert, mil kurzen, schwarzen Krallenhälichen. Die 
Vorderbrust grob runzlig punktirt, vorn etwas aufgetrieben mit napfförmig vorgezngenem Vorderrande, hinten tief grubig eingedrückt mit kurzen, hreit zugerundeten Hinterenden; anch die Mittelbrust breit quer aufgewulstet. Das letzte Segment des $f$ mit einer mässig grossen, aber tiefen lallkugeligen, glïnzenden Grube; das ơ unbekannt.

Aus Südamerilia olne nähere Angabe der Heinath, aber wohl ohne Zweifel Brasilianischen Ursprunges. (Mus. Baly.)

93. Cr. Lar Fab. Gelb, das dicht siebartig punktirte Halsschild mit den Deckschilden purpurbraun, die Punktstreifen gegittert-doppelreilig mit leistenlürmigen, abwechsclnd schwächeren Zwischenräumen. L. $2^{1 / 2}-3^{\prime \prime \prime}$; Br. 1 1/4 - 1 1/2"'.

Cryptocephalus Lar Fab. Ent. Syst. II. 58. n. 26. - Clythra Lar Fab. "Syst. Eleutl. II. 37. n. 41.

Nach Habitus und den langen Fühlem könnte man diesen Käfer und seine beiden folgenden Verwandten am ersten mit den australischen Arten aus der Gruppe des Cr. scabrosus Oliv. vergleichen; in der Sculptur der Deckschilde aber stehen sie ganz und gar für sich, und zcigen nur etwa mit dem oben beschriebenen Cr. clathratus einige, wenn auch nicht vüllige Uehereinstimmung. Der Kopf bei dem vorliegenden Käfer llach, die kurze Stirn über den Fühlerwurzelı leicht niedergedrückt, eben so der untere Theil des oben durch einen wulstigen Querlıöcker hegränzten Kopfschildes; ausserdem noch zwischen den Fühlerwurzehn ein paar neben einander stehende Quergrübchıı. Oberfläche und Mundtheile hellgelb, fast ohne Glanz, die langgestreckten, in der Mitte tief ausgebuchteten, oben zusammenstossenden Augen schwarz. Die Fühler des $\delta$ von Körperläıge, düın und fadenförmig, das Vurzelylied oben mässig verdickt und schwach nach aussen gekrümmt, etwa dreimal länger als breit, das zweite kurz und knotig, un die Ilälfte schmäler als dlas crste, dic folgenden verkehrtkegelförmig, aber erst die oberen etwas zusammengedrückt und innerseits kaum erweitert, das dritte fast drei-, das vierte viemal länger als das erste, das fünfte dem dritten und vierten zusammen gleich, das sechste venig kürzer, und die folgenden damí allmählich so weit abnehmend, dass das neunte und zelınte doch noch je dem vierten gleichkommen; das Endglied mit seinem lang dreieckigen, durch eine dentliche Ausrandung abgesetzten Fortsatze wieder dem achten gleich. Die Farbe der beiden ersten Glieder gelb, die Spitze des ersten und $\mathrm{XV}$. 
die Oberseite des zweiten leicht gebräunt; das dritte und der untere Theil des vierten verwaschen pechbraun, die oberen schwarz, dünn angedrückt behaart und abstehend gewimpert. Die Fühler des $\&$ nur etwa von $4 / 5$ der Körperlänge, aber nicht weiter abweichend, als dass zuweilen die unteren Glieder fast ganz schwärzlich sind. Das breite und flache Halsschild vor ler Mitte leicht quer aufgewölbt und dann mit dem ersten Drittel der Länge sanft übergekrümmt, hinterwärts eben so sanft abwärts geneigt, vorn über den stark abwärts gerichteten, durch einen Ausschnitt am Vorlerende des Seitenrandes abgesetzten Vorderecken tief eingedrückt und dadurch verschmälert; die Seiten breit und flach gerandet, nich vorn in stumpfen Bogen zusammengeneigt, die scharfen auch etwas eingedrückten Hinterecken fast rechtwinklig und nur kurz vorgrzogen; der IInterrand fein gesägt, jederseits nu leicht ausgeschweift, mit kurzem, doppelt ausgerandetem Mittelzipfel. Vor letzterem zu beiden Seiten ein flacher, bis zur Mitte des Seitenrandes himabziehender Schrägeindruck, welcher sich hier in einer noch flacheren, den abgesetzten Seitenrand begleitenden Längsvertiefung verliert, gleichzeitig aber in Verbindung mit dem entsprechenden Eindrucke auf der andern Seite das wulstig erhölıte Mitlelfeld des Halsschildes abschliesst. Die Oberfliche dicht und grolı siebartig punktirt mit seidig schimmerndem Zwischengrunde, purpurbraun, der durch eine zarte Einschnürung algesetzte, etwas durchscheinende Vorderrand hellgell). Das Schildchen lang und schmal dreieckig, über zweinal länger als breit, hinter der breiteren Wurzel leicht ausgeschweift, und dann fast in gleicher Breite bis zu der scharf algestutzten Spitze fortziehend, hinten stark schräg ansteigend; Hinterzipfel und Vordergrülschen deutlich, letzteres jederseits von einem scharfen Höcker begränzl, und hinterwärts in eine fasi bis zur Mitte reichende, schmal dreieclige Lingsfurche auslaufend. Wie Farbe gleichfalls purpurbraum, glïnzend, mit schwärzlichem Vorderrande. Die Deckschilde sehr breit und flach gewölbt, länglichriereckig, um melır als die Ifïlfte linger wie breit, hinten kurz und breit zugerundet, vor'n längs der Wurzel und dann wieder nach dem ersten Drittel der Länge leicht quer niedergedrüclit, so dass dadurch dieses erste Drittel als ein schwach erhöhıtes Querfeld hervortritt; auch die Schulterbeulen stark halbeiförmig emporgehoben, und die kurzen Seitenlappen ziemlich tief herabgezogen. Die Punktstreifen sehr regelmässig, aus grossen und tiefen, quer viereckigen 
dicht an einander gerückten Grülchen gebildet, die statt der Querlrücken nur durch feine, die Zwischenräume verbindende Querleisten getrennt werden; anch die Zwischenräume selbst nur schmal und leistenförmig, die graden (der ziveite, vierte, sechste und achte) etwas breiter und lıöher, unter diesen wieder der zweite und achte stïrker hervortretend; von den ungraden nur der neunte kräftig und fast dem achten gleich, die übrigen feiner und niedriger, olıne jedoch irgendwo völlig zu verschwinden. Die ganze Oberseite erhält dadurch ein netzartig gegittertes Ansehen, bei dem der Glanz der Längs- und Querleisten gegen das mattere Innere der Grübchen etwas absticht; die Schulterbeulen dabei glatt, und der umgeschlagene, zugleich hell gelluhrame Rand des Seitenlappens mit einer groben Punktreilse besetzt. Die Farbe schön purpurbraun mit violettem Schimmer, bei weniger ausgefärbten Stücken etwas lichter gelbbraun. Das stumpf gekielte Pygidium mit der Unterseite fein runzlig punktirt, hellgell mit anliegender weisslicher, bei dem đotwas schwächerer Belıarung; auch die dünnen Beine gelb mit gebräunten, bei dem ठ schwärzlichen Füssen; bei dem letzteren alle Beine, besonders aber die vorderen länger als bei dem grösseren $q$, und das erste Fussglied stark verlängert. Der Vorderrand der Vorderbrust breit vorgezogen und abwärts gelogen, der Hinterrand mit zwei breiten rundlichen Lappen vortretend und zwischen denselben tief eingedrückt, auch die Mittelbrust stumpf zweilappig. Das letzte Segment des $\delta$ mit einer leicht quer eingedrückten, glänzenden Stelle, des + mit einer verhältnissmässig kleinen, rundlichen Grube.

\section{Aus Brasilien (Mus. Schaum, Lacordaire).}

Die vorstehend beschriebene, in den Sammlungen sehr seltene Art findel sich im Mus. Schaum von Germars Hand als $\mathrm{Cr}$. Lar Fab. bezettelı, und auf diese Autorität habe auch ich sie dafür angenommen, da Dasjenige, was Fabricius von seinem schon seit Langem zu den entomologischen Räihscln gehörenden Käfer angibt, jener Deutung wenigstens nicht zu widersprechen scheint. Es heisst nämlich in der Ent. Syst. a. a. 0.: „Rufns, elytris fuscis, cyaneo-nitidis, pedibus anticis elongatis. - Ilabilat in America moridionali. Mus. Ihtnter. - Antennae obscure pallidae. Elytra punctato-striata. Corpus cum pedibus rufum." In dem Syst. Elenth. a. a. O., wo der Käfer zur Gattung Clythra versetzl worlen ist, wird die obige Diagnose (mit einziger, vielleicht nur auf Fluchtigkeit beruhender Aenderung des "nitidis" in ,nilidulis") nebst der Heimathsangabe olne irgend einen weiteren Zusatz wiederholt. Diagnose und Beschreibung der 
Ent. Syst. passen in aller Beziebung gut zul dem vorliegenden Käfer, und die unter andereu Verhältnissen unbegreifliche, übrigens schon im Suppl. zur Eu1. Syst. vorgenommene Versetzung der Art in die dort zuerst neu aufgenommene Gattung Clythra erklärt sich leicht und einfach daraus, dass Fabricius die, auch jetzt noch, wie die meisteu übrigen von ibm aus der Hunter'schen Sammlung beschriebenen Käfcr in seiner Sammlung feblende Art niemals selbst besessen hat, und ihm daher, als er die Arten seiner früheren Gatıng Cryptocephalus später unter die Gatungen Crypl. und Clythra vertheilte, für die ihm nicht mehr vorliegenden Arten Nichts übrig blieb, als uach seinen früheren Notizen deren muthmaassliche Stellung zı errathen, wo denı für die vorliegende Art die Pedes antici elongati ilun ganz natürlich verleiten mussten, anch in ihr eine Clyllura zu erkeunen. Will man diese Deutung des Fabr. Käfers nicht gelten lassen, so bleibt derselbe einstweilen eine verschollene Art; Illiger in Mag. IlI. übergeht sie ganz mit Stillschweigen, und auch Lacordaire in den Phytoph. II. begnügt sich damit, sie unter den ihm unbekanıt gebliebenen Clythra-Arten aufzuführen, ohne darïber irgend eine Vermuthung anszusprechen. Was die von Lacordaire noch weiter angeführteı Aıtoren darüber meinen, kann ich augenblicklich nicht vergleichen, ist auch für die Deutung les Fabr. Käfers selbst schwerlich von Bedeutung. Eine echte brasilianische Clythride, auf welche Fabr. Worte auch nur erträglich angewandt werden könnten, ist mir bis jelzt eben so wenig, wie Hrn. Lacordaire, bekanu geworden. Im Mus. Berol. findet sich als $\mathrm{Cr}$. Lar Fab. die folgende Alt, und auch das spricht für eine Tradition, welche den Fabr. Käfer wenigstens auf eine Art der vorliegenden Gruppe bezielıt.

94. Cr. carneolus Perty. Lehmgelb, das dicht siebartig punktirte Halsschild und die Flügeldecken blutroth mit einer abgekürzten stahlblauen Längsbinde des letzteren; die Punktstreifen gegittert-iloppelreihig mit leistentörmigen abwechselnd sch wächeren Zwischenräumen; der fünfte schon vor der Mitte erloschen. L.

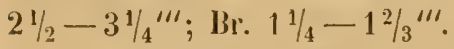

Cryptocephalus carneolus Perty delect. animal. articnlat. in Brasilia etc. p. 104. tab, 21. fig. 1.

Dem vorhergehınten überaus ähnlich und von ihm nur durch féne Merkmale absreichend, aber doch nach meinem Bedünken pine von demselben gut unterschiedene Art. Crösse, Bau, Sculptur und Färbung wie bei jenem, mit folgenden Abweichungen. Der ganze Körper erscheint etwas plumper, besonder's breiter, durch die etwas kräftigere Seulptur der Deckschilde gewissermaassen roher und ungeschickter; die graden Rijpen der Deckselilde treten hölıer hervor, wälırend die ungraden, die einzige nemute atsgenommen, 
in ihrer Ausbildung sehr stark zurückbleiben, so dass das Vorderende der ersten, neben dem abgekiürzten Streifen liegenden, zu einem dünnen Faden zusammenschivindet, während von dem fünften ïberhanpt nur das sehr schwache vordere Drittel als wirklich erhöht wahrzunehmen ist, und auch von dem siebenten nur das eben so schwache Vorder- und Hinterende deutlich in die Augen fällt. Dagegen ist das Hinterende des zweiten und dritten auf der Wölbung weit stärker schwielig aufgetrieben. Die Farbe von Halsschild und Deckschilden ist dunkler blutroth, und auf den letzteren zeigt sich eine breite matt stahllblaue Längsbinde, welche mit verwaschener Begränzung und intensiverem Kerne voll der Wurzel al den Raum zwischen der ersten und fünften Rippe eimnimmt, und linterwärts verschmälert sich kurz vor der Wölbung am Ende der vierten Rippe verliert, bei schwächer ausgefärbten Stücken aber zu einem kaum bemerkbaren Schatten schwindet. Die Unterseite ist küızer und dümmer gelblich greis behaart, dagegen sind die beiden letzten Bauchringe, und weniger deutlich auch die Seiten der vorderen matt und verwaschen bleich röthlich angelaufen. Alles Uebrige, auch die Geschlechtsunterschiede, wie bei der vorhergehenden Art.

Aus Brasilien (Mus. Baly, Deyrolle; in dem letzteren Pernambuco als Heimath angegeben; auch im Mus. Berol. als C'r. Lar F. rorhanden, von Virmond, und - bei Parà - von Sieber gesammelt).

Die von Perly a. a. 0. gegebene Besehreibung seines Cr. carneolus, fiur deren Beziehung anf den vorliegenden Käfer ich allerdings keineu Grund habe als die Aulorität des Mus. Deyrolle nnd meine U11kenntuiss einer andern erträglicher zu Perty's Worten passendeı brasilianischen Art, lässt, weun diese Beziehung richlig isl, fast ebeu so viel zn winschen ülırig, als die, welche Fabricius von scinem $\mathrm{Cr}$. Lar gegeben hat. Von Perty's Angaben passen eigentlich nur die Farbe der Oberseite (purpuruscens, wenn dabej an Stücke mit geschwundener Längsbinde gedacht wird) und ron Kopf und Unterseite (rufo-leslaceus), das Sculellum elongalum, und die Antennae corporis longiludine, lenuissimae, fuscac, ad basin flavicantes; auch kann der dem Käfer heigelegle Habilus fere alienus hicrher gezogen werdeı. Unzulanglich dagegen sind die Angahen über die hier so wiehtige Scmlptur (,Thorace punctulalo, elytrisque crenalo-strialis"); und die Angabe, dass die Elylra purpurascentia zugleich "albido-micantia" seien, weiss ich mir kaum anders als durch die Aumahme zu erklären, dass dieselbe durch einen unter gewisser Beleuchtung allerdings 
bei allen diesen Arten hervortretenden Licht-Reflex veranlasst worden sei. Perly's Kafer stammte vou "Serra do Caraça. Prov. Minarum", und der Deyrolle'sche war im Mus. Deyr. mil dem Synonym Strigophorus exaratus Dej. bezeichnet.

95. Cr. dictyopterus m. Lehmgelb, das dicht siebartig punktirte, seitlich tiefer eingedrückte Halsschild mit den Deckschilden röthlich gelb; die Punktstreifen gegittert-doppelreilig mit leistenförmigen, abwechselnd schwïcheren Zwischemräumen, der fünfte schon vor der Mitte fast erloschen. L. $2-21 / 4{ }^{\prime \prime \prime}$; Br. $11 / 12-1{ }^{\prime \prime \prime}$.

Den beiden vorhergehenden sehr ähnlich, in der Färbung mehr dem $C r$. Lar, in der Sculptur dem Cr. carneolus verwandt, aber doch von beiden wohl hinreichend specifisch verschieden. $\mathrm{Er}$ ist zunächst merklich kleiner, indem das vorliegende 옹 noch hinter den kleinsten mir vorliegenden ठ̋ der vorhergehenden Arten zurückbleibt; dazu ist die Farbe von Halsschild und Deckschilden einfach rostgelb mit heller gelblichem Seiten- und Vorderrande des ersteren, ohne den Purjurschimmer des Cr. Lar; Unterseite und Beine hell lehmgelb. An den Fühlern sind die fünf unteren Glieder gleichfalls gelb mit kaum gebräunter Spitze des fünften Gliedes, die obereı leicht geschwärzt. Die Seiteneindrücke des Halsschildes sind tiefer, fast furchenartig eingedrückt, die Seiten selbst in der Mitte breit gerundet und hinter derselben leicht ausgebuchtet; auf deı Flügeldecken ist die Bildung der fünften und siebenten Rippe mit der des $C r$. carneolus übereinstimmend; die Hinterenden sind viel weniger aufgetrieben, mnd anch clie Vorderenden der Streifen zwischen Schildchen und Schulterbeule merklich schwächer als bei der genanuten Art. Alles Uebrige, auch die Geschlechtsuntersehiede, wie hei den vorhergehenden.

Von diesen letzteren unterscheidet sich die vorliegende sonach durch die geringere Grösse, die einfarl)ig roströthliche Oberseite und die merklich tieferen Eindrücke des Halsschildes; von Cr. Lar ausserdem durch die Alsschwäclumg der fünften und siebenten Liingsrippe, und von Cr. carneolus durch den Hangel des rötllichen Anflngs auf der Unterseite, sowie durch die geringere Stärlie der Vorder- und Hinterenden der Lïngsrippen.

Vom Amazonenstrom (Mus. Baly), und aus Brasilien ohne nähere Angalse des Fundorts (Mus. Ilolm., ans dem Mus. Schonh. stammend und rou Freyreiss gesammelt).

(Der Schluss folgı im nächsten Bande.) 


\section{Alphabetisches Register.}

Crypto cephal us abbreviatellus absconditus

aduncus

aenescens

ambitiosus

anceps

apocryphus

atomarioides

anratus

hisignatus

bisseptemguttatus

bisulcatıs

bombarda

brunneus

carneolus

chalcites

chloropterus

chromaticus

cinctellus

clathratus

climactericus

coeruleolus

consentaneus

consobrinus

consputus

cordatus

costulatus

crassicollis

cuprascens

cyanopterus

dictyopterus

ellipticus

esuriens

figuliuus

flagitiosus

flaroplagiatus

formosellns

fulvescens

funigatus

fusculus

geniculatus

globulosus

hchetalus

hemixanthus

lijppocraticus

hispaeformis

impressus

incommodus
268 Cryptocephalus incredulus 251

205 indecoratus 210

229 laesus 222

2S3 laqueatus 297

326 Lar 337

236 laticornis 309

220 lencospilus 224

263 lutarius 321

283 Inteicollis $\quad 190$

2S8 mancus 314

234 melampus 308

306 miniatus 293

188 misellus 284

232 miserabilis 260

340 monachodes 193

201 moribundus 216

199 multigutlatus 228

330 nigriventris 304

256 obliquatus 175

334 ochropus 207

278 pasticus 214

277 pentagrammus 299

243 perplexiss 194

292 philothermus 317

271 plicatus 273

241 praeposterus 249

186 praeustus 184

181 profugus 231

196 quadrivulnerus $\quad \mathbf{2 5 3}$

191 rubronotatus 177

342 ruficeps 325

303 Sahlbergii 328

312 semicircularis 208

315 siccus 310

269 silaceus 239

290 socius 179

261 striola 286

258 succulentus 319

266 topiarius 246

264 turbatus 236

320 turgidus 226

$2 \varsigma 2$ varipes 318

213 velatus 323

203 ventricosus 295

218 viridiaenens 281

332 xanthocephalus 212

275 xanthopygus 197

301 D eliastes reticulatus $\quad 76$ 
Emesa annulata caspica

Emesella robusta

Emesidae

Emesina

Gardena Semperi

Gerris

Ghilianella Bethei tenera

Luteva longiventris

$\mathrm{Mal}$ a c opus cellnlaris

Necostethus

Monachus acaroides anachoreta anthreniformis argutulus

babioides

basilaris

bicolor

binarius

biplagiatus

brunneus

coenobita

consimilis

contractus

contrusus

cribricollis

decolorans

deplanatus

diaereticus

fasciolatus

furcifer

gemellus

giganteus

granarius

haematopygus

hemichlorus

juvenilis

lucidulus

melanippus

melanospilus

metallesceus

modestus

nigritulus

obscurellus

orbicularis

pallipes

peccator
$65 \mathrm{Mon}$ achus peltasta $\quad 97$

66 phalacroides 83

72 picipes 88

43 plagiellus 115

42 psammites 150

64 - punctum 144

55 pustulipennis 170

68 pygidialis 136

70 quietus 147

73 rebellis 109

53 rejectus 143

54 rotundatus 91

328 rubidulus 117

160 rubropustulatus $\quad 140$

84 scrobiculatus 90

113 semicyaneus 102

143 seriepunclatus 128

172 sordidulus 151

169 stricticollis 161

104 sulfuripes 82

155 tenebricosus 167

112 tumidulus 121

129 ulcerosus 171

126 umbrosus 88

132 unctus 166

134 variabilis $\quad 99$

137 Mylassa $\quad \mathbf{1 7 5}$

108 ornix 1

138 alphabetisches Register 41

163 analytisches Register 4

$1420 \mathrm{rthung}$ a

110 Wahlbergii 45

$98 \mathrm{Palacus}$ cubensis $\quad 75$

101 Ploiaria 55

119 ambigua 62

153 Baerensfrungi 60

106 culiciformis $\quad 59$

158 errabunda 62

124 pallida 63

153 pilosa 58

157 unianmulata 61

95 vagabunda 56

$148 \mathrm{Ploi}$ aridae 43

131 Stenolemus $\quad 50$

86 fasciculatus, spiniventris 51

92 Westermannia annulata 49

94 difficilis 47

122 tenerrima 48

8

Druck von C. P. Melzer in Leipzig. 


\section{I N N A E A}

\section{E N T O M O L L 0 O G I G A.}

\section{ZEITSCHRIF'T}

HERAUSGEGEBEN

VON DEM

\section{ENTOMOLOGISCHEN VEREINE}

I N S T E T T I N.

SE G H Z E H N E R B A N D.

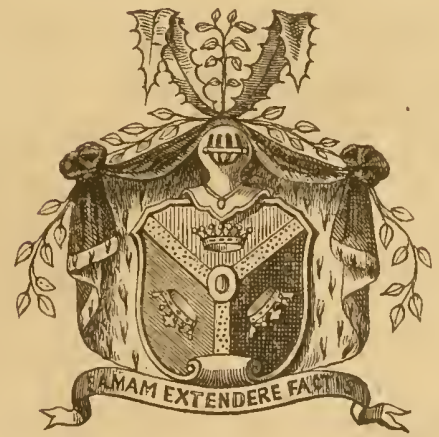

L E IP Z I G 1866.

VERLAG VON FRIEDRICII FLEISCIIER. 



\section{Vorwort.}

Dass mit diesem Bande versprochnermaassen der Abschluss der südamerikanischen Cryptocephalen erfolgt, dafür sind die Entomologen meinem Freunde, dem Verfasser, zu um so aufrichtigerem Danke verpflichtet, als nur Wenige wissen können, wie umfangreich seine $\mathrm{Be}-$ rufsgeschäfte sind und wie fleissig er die wenige Musse, die ihm gegönnt ist, auskaufen musste, um das viele, ihm von achtbaren Seiten zuströmende Material mit gewohnter Gewissenhaftigkeit zu sichten und zu bearbeiten.

Die mir in neuerer Zeit aus Frankreich, namentlich aber aus England zugegangnen competenten Zeugnisse über die ausgezeichnete Brauchbarkeit dieser Monographie dürfen mich wohl zu der Hoffnung berechtigen, dass ein lebhafter Absatz dieses Bandes und seiner zugehörigen Vorgänger den Verleger für die saubre und correcte Ausstattung angemessen entschädige. Unter den Mitgliedern des Stettiner Entom. Vereins sind manche, deren finanzielle Verhältnisse ihnen den Ankauf der Lin- 
naea entomologica aus richtiger Würdigung der Obliegenheiten eines Socius auch dann zur Pflicht machen sollten, wenn der Band nicht gerade die Ordnung behandelt, mit welcher sie sich ausschliesslich beschäftigen.

Stettin, im Februar 1865.

\section{Dr. C. A. Dohrn,}

Vereins-Präsident. 


\section{In li a t.}

Seite

Zur Kenntniss der südamerikanischen Cryptocephalen von Suffriau (Schluss). 1

Systematisches Artenverzeichniss . . . . . . . . . . . . 484 



\title{
Zur Kenntniss der siidamerikanischen Cryptocephalen.
}

\author{
Vom \\ Schulrath Dr. Suffrian iı Münster.
}

(Schluss.)

Seit im 15. Bande unserer Zeitschrift die erste Abtheilung meiner Bearbeitung der südamerikanischen Crypt oce pl alen erschienen ist, hat sich das Material für deren Ergänzung und Abschluss in einer kaum zu erwartenden Weise gemelırt. Schon wälırend des Druckes jener ersten Abtheilung wurde mir durch die Gefälligkeit der Herren Prof. Bohe ma n und Dr. S tål der ganze hierher gelıörende Bestand des Entomolog. Museums zu Stockholnı (darunter die Typen sämmtlicher von beiden Herren beschriebener Arten) zum Vergleiche mitgetheilt, und konnten desshalb auch noch für jene erste Abtheilung benutzt werden. In gleicher Weise verpflichtet fühle ich miclı dem Vorstande der K. Zoologischen Sammlung in Berlin, wie den Herren H. Clark und E. vo m Bruck für die reichlichıeı Nachıträge zu den früher schın nir mitgetheilten Arten, den Herren Kirsch und Schaufuss in Dresden für die Uebersendung der betreffenden Arten ihrer Sammlungen, und nicht mincler dem Vorstan de des K. K. Entomolog. Museums in Wien, welcher auf einen von mir nur indirect geäusserten Wunsch alles aus den Beständen des Museums mir Brauclıbare in der entgegenkommendsten Weise mir zur Benutzung anvertraut hat. Durch die mir in solcher Art gewordenen Unterstützungen, für welche ich meinen Dank hier nochmals öfentlich wiederhole, hat die Zahl der von mir heschriebenen Arten die von mir früher (Limn. Ent. XV. S. 78.) über'schläglich angenommene Höhe von 400 vollständig erreicht: es hat sich mir aber auch diesnual wieder die bemerkens- 
werthe Thatsache hestätigł, dass ınter allen von mir verglichenen grösseren oder kleineren Sammlungen sich kaun eine einzige befindet, welche nicht eine oder die andere in ihr ausschliesslich vorhandene Art aufzuweisen hätte.

Der Fortsetzung jener Arheit sende ich num zunächst einige Nachträge und Berichtignngen voraus, zu denen das mir vorliegende netre Material den Anlass gegeben liat. Den Aufang derselben macht eine inzwischen unter den reichen Beständen des Mus. Berol. aufgefundene neue Gattung

\section{1n. Meptarthrius in.}

A ug e n ausgerandet.

Vorderbrust der Länge nach rimenförmig vertieft, läıger als breit, hinten breit dreieckig ausgeschnitten, vorn mit abgesetztenı Halskrageı.

Fïlller mil sielengliedriger, locherer Keule.

Schild chen rorhandeu,

welche Bd. XV.S.S1. vor ler Gattung II o naclıus eingeschaltet werden muss.

Diese bis dahin nur in einer einzigen Art bekannte Galtung bildet eine der grössten bis dahin bekannten Monachiden-Fornen; sie lässt sich aber nicht füglich mit einer der bereits untersehiedenen Gattungen dieser Gruppe rereinigen, von deren versehiedeneı Formen sie vielmelı ein ganz eigenthümliches Gemisch darstellt. Habitus und Sculytur sind die eines echten Monachus, und damit kommt namentlich anch der Bau von Hinterrand und Mittelzipfel des Ialsschilds überein; dabei erimern die langen Vorderbeine des $\delta$ an einzelne Australische Ditropidus-Arten (D. Davisii Saund. u. A.), die lockere Fühlerkeule an Elaphodes und Prasonotus, der dreieckige Ausschnitt am Ilinterrande des Prosternums an die Beschaffenheit dieses Theits bei einer nenen Australischen Montachiden-Gattung, die ich einstweilen mit dem vacant gewordenen Namen Pleomorphus bezeichnet habe: aber von allen diesen Gattungen weicht die vorliegende ab durch die Pachybrachenartige Vertiefung des Prostermums und die lockere siebengliedrige Fühlerkeule, welche, wie die Grösse des Käfers, ilı mit Recht die erste Stelle iu der Reilie der Monachiden-Gattungen zuweiset.

Der Körper länglich-verkehrteifürmig, hochgewöllıt, an der 
Wurzel der Deckschilde am breitesten, und ron da ab nach vorn kurz zugerundet, hinterwärts langsam verschmälert.

Der Kopf thach, das Kopfschild nicht eingezogen, seitlich nnd oben deutlich abgegränzt, sehr gross; die Augen gross, breit und lief ansgeluchtet, mit den olvern Enden stark genähert. Das Endgliel der Vordertaster sehr lang gestreckt, kegelförmig zugespitzt. Die Fühler liurz, aber duch etwas länger als bei den eigentlichen Monachen; das Wurzelglied sehr dünn und lang, die drei folgenden wie jenes, kahl und glänzend, und von ilınen das vierte das längste; die sieben Glieder der Keule belnaart, einander gleich und je etwas kürzer als das vierte, die drei unteren dichter zusammengedringt, wenig länger als oben breit, die vier oberen etwas schmaler und mehr gelockert als die vorhergehenden.

Das Halsschild nach vorn stark übergewölls, die Vorderecken tiof einwärts gekrümmt, der Mittelzipfel des fein gesïgten Hinterrandes breit, kaum ausgebuchtet, gleichmiissig gesägt, sodass nur die Eckzähıe, nicht aber auch der mittlere deutlich hervortretert.

Llas Schildchen gleichseitig-dreieckig und hinten kurz abgestutzt, ohne Vordergrübchen, aber mil deutlichen Hinterzipfel.

Die Deckschilde hinter dem Schildchen hochbuckelig, und von da ah nach hinten allmählich abwärts gekrümmt, seitlich sehı steil abfalleml und hreit zusamnengedrïcht; die Punktstreifen aus längsgrübigen Vorderenden bald erloschen, und nur der 9te durch eine seichte Längsfurche seiner ganzen länge nach kenntlich gemacht.

Die Unterseite mit deutlich und dicht punktirter Hinterbrust; die Mittelhrust quer viereckig, mit anfgeworfenen, elwas ansgeschweiften Seitemrändern hinterwärts verschmälert und daselbst bogig ansgerandet; die Vorderbrust mit kurz abwärts gebogenem Halsliragen, un mehr wie die Hälfte länger als hreit, zwischen den Vorderheinen durch ihre breil aufgerichteten, die imeren Pfannemänder der Ilüftgelenkköpfe bildenden Seiten der Läıge nach muldenförmig vertieft, am Hinterrande in der Mitte scharf dreieckig ausgeschnitlen, sodass die Hinterecken als breitlrececkige Ziplel hervortrelen.

Die Brine verhältuissmässig lang und dalıei ziemlich dünn; die Vorderschenkel (ob nu bei dem ơ ?) nur mehı als die Hälfte länger wie die der Mlttelbeine, umel dahei stark gekriümmt; die Vor- 
derschienen gleichfalls verlängert, nachı unten und innen gekrümmt, und auf der Aussenseite bis hart an die Spitze in flachem Bogen verbreitert; über der letzteren ein schräger, etwas ausgehöhlter und anscheinend zum Einlegen des ersten Fussgliedes bestimmter Ausschnitt. Die Krallenhäkchen je an der Wurzel mit einem stumpfen Zahne.

Die einzige bis jetzt bekannte Art dieser Gattung stammt aus Venezuela.

1. H. I o n gimanus Mo ritz. Schwarz, die Fühlerwurzehn, der umgeschlagene Rand der Seitenlappen und das Pygidium mit dem letzten Bauchringe rothlraun; das Halsschild kaum punktirt, gläızend, die Punktstreifen ans grüligen Vorderenden bald erloschen, des 9te tiefer eingedrückt, mit flachen glänzenden Zwischenräumen. L. $2 \frac{1}{3}{ }^{\prime \prime \prime} ;$ Br. $1 \frac{1}{3}{ }^{\prime \prime \prime}$.

Aeusserlich dem Monachus tenebricosus nicht unähnlich, aber doppelt grösser, besonders hreiter, in Habitus an einzelıe ScolochrusFormen, namentlich der ersten Rotten, erimernd. Der Kopf flach mit kurzer; aber tief eingedrückter Stirnlinie; das an Länge fast der Stirne gleiche Kopfschild seitlich scharf begränzt, oben durch zwei unter einem sehr stumpfen Winkel zusammenlaufeude Schräglinien von der Stirn getrennt, der Länge nach seicht niedergedrückt. Die Farbe ein wenig glänzendes Schwarz, die Stirn mit sehr vereinzelten Punkten besetzt, oben durch die grossen, (bei dem ठ̋) sehr genäherten Augen verengt; die Oberlippe mit den Tasterı braun, die Augen selbst greis. Die Fühler kaum bis zu dem Hinterrande les Halsschilds reichend; das langgestreckte Wurzelglied schmal keulenförmig, etwa viermal läıger als oben breit, das 2te wenig dünner, aus kugelfürmiger Wurzel nach oben hin etwas verschmälert, das 3te kaum länger aher düuner, rerkelırtkegelförmig, das 4te um die Hälfte länger unıl anch etwas breiter als das dritte, und diese vier zugleich glänzend hellrothbrauı, das Wurzelglied mit einer schwärzlichen Längslinie auf seiner Oberseite, das 2te und 3te in der Mitle und das 4te überhaupt etwas tiefer gebräunt. Die aus den sieben übrigen bestehende keule leicht zusammengedrückl, mit kurz kegelförmigem Fortsatze des Endglieds, schwarz, mit dicht angedrückter greiser Behaarung. Das grosse Halsschild kaun doppelt breiter als lang, mit seiner Vorderhälfte kugelig über'yewölbt, mit den scharf rechtwinkeligen Vorterecken tief eingezogen und dadurch verschmälert; die Seiten gerandet, nach unten einwärts 
gebogen und nach vorn in breiten Bogen convergirend, dic kurzen hreiten Hinterecken wenig ausgezogen. Der Hinterrand jederseits leicht ausgeluchtet, innerseits der Schulterbeulen etwas eingesenlit, mit kurzem wenig ausgerandetem, ziemlich gleichmässig und mi kaum stäıkerem Mittelzälınchıen gesägtem Mittelzipfel. Die Oberfläche äusserst fein und zerstreut punktirt, mässig glänzenı, rein wachsschwarz, mit dunkelrothbräunlich durchscheinenden Vorderecken. Das Schildchen nierlerliegend, gleichseitig-dreieckig mit seicht ausgerandeter Wuzel, hinten kurz ahgestutzt mit deutlichen Hinterzipfel, gleichfalls schwar'z. Die Deckschilde wenig länger als breit und von der Spitze des Schildcheis ab) hinterwärts allmählich abfallend, hinter dem Wurzelrande durch die tief eingegrabenen, grühchenartigen Vorderenden der Punktstreifen sehr stark quer eingedrückt; die Seitenlappen mässig mit sehr breitem umgeschlagenem Rande, und über diesem die Deckschilde breit zusammengedrückt. Die Schulterbeulen gross, aber nur flach, mil sehr scharf stumpfwinkligen Schulterecken. Die Punktstreifen linter ilıren längsgrübigen Vorderenden plötzlich abgeschwächt, und von da ab aus sehr feinen, etwas in die Länge gezogenen Pünktchen gebildet, von der Mitte al kaum noch kenntlich; von dem Sten hinter der Schulterbeule nur noch einige gröhere Punkte zu selıen, der 9te seiner ganzen Länge nach in eine seichte, über dem Seitenlappen etwas stärker vertiefte Furche eingedrückt. Die Zwischenıäume flach mit mässigem Glanze, der 9te leicht aufgewölbt. Die Farbe auch hier rein schwarz, der ungeschlagene Rand des Seitenlappens rothbraun. Das Pygidium mit dem letzten Bauchringe gleichfalls rothbraun, die seitlichen Vorderzipfel des ersten Ringes, die Schulterblätter und die umgeschlagenen Seiten des Halsschilds tiefer gebräunt; der übrige Theil der Unterseite mit den Beinen schwarz. Das letzte Hinterleibssegment des $\delta$ leiclıt quer eingedrückt; das $f$ unbekannt.

\section{Aus Venezuela. (Moritz im Mus. Berol.)}

S. 83. hinter n. 1. M. sulfuripes $m$. ist als neue Art einzuschalten :

1b. (63.) M. flavicaudis m. Schwarzbraun, Mund, Fühler, Spitze der Deckschilde und Beine gelblich; das Halsschild sehr fein punktirt, die P'unktstreifen fein, hinten erloschen, der 9te etwas vertieft, mit flachen, feingenarbten Zivischenräumen. L. 2/3"'; Br. $5 / 12 "$. 
Dem Mr. sulfuripes uahe verwandt, aber doch ctwas kleiner, und vou ilım auch ausser der Sculptur noch an der gelblichen Spitze der Deckschilde leicht zu unterscheiden. Der Kopf flach mit dentlich eingezogenem, oben durch ein paar Quereindrücke abgegränztem Kopfschilde; die Oberfläche dicht und fein punktirt, ziemlich matt. Der obere Theil schwärzlich, der mittlere gelb, leicht in's Brüunliclie fallend, Halsschild und Mundıheile heller lelımgelb, die weitgetrenıten, mässig ausgélbuchteten Augen greis. Auch die kurzen, von den gewöhnlichen Bau nicht abweichenden Fühler gelblich. Das Halsschill mit seiner grösseren Hälfte vorn sanft übergekrünımt, auch hinterwärts wieder ein wenig abwärts geneigt, über den tief eingezogenen scharf rechtwiukligen Vorderecken zusammengedrückt und dadurch verschmälert, die gerandeten Seiten mit der schräg abwärts gerichteten Vorderhälfte stark zusammengekrümmt; die Hiuterecken sehr kurz und breit zugeschärft, der Histerrand jederseits ıur leicht ausgeluchtet, mit fast grade abgestutztem Mittelzipfel, und vor letzterem ein lurzer, schmaler, mit einer gröberen Punktreihe besetzter Quereindruck. Die Oberfläche sehr fein-, lïngs dem Hinterınde etwas deutlicher punktirt, mässig gläuzend, einfarbig schwarzhraun. Das Schildchen sclıräg niederliegrend, gestrecktdreieckig und um die Iläffte läıger als rorı breit, gleichfalls gläuzend schwarzbraun. Die Deckschilde etwa so lang wie vorn breit, hinter der Schildchenspitze noch etwas aufgebuckelt uud von dort ab seitlich steiler, hinterwärts mit sanfterer Krïmmung abfallend, hinter der Wurzelkante nur leicht quer niedergedrückt; die Schulterbenlen eckig heraustretend, die Seitenlappen vou nässiger Stärke. Die Punktstreifen sehr regehuässig, hei den oberen die ersten P'unlite gröber, die folgenden bis zur Mitte schwächer aber doch noch dentlich, die hinteren sehı unscheinbar und schon von der Mitte ab fast erloschen, der 9 te in eine seichte Längsfurche eingedrückt. Dic Zwischenräume durch rine feinnarbige Punktirung ziemlich matt und nur vorn etwas stärlin grï̈zend, flach, der 9te schwach aufgewölht. Die Farbe schwarzbraum mit leicht metallischem Anfluge, die breite Spitze mit rorn verwaschener lipgräuzung schnutzig gelb. Aendert jedoch alb:

$\hat{\imath}$. Die gelle Färbung der Flügeldeckenspitze soweit alygeschwächt, dlass nur bei seitlicher schıägrer Beleuchıtııg cin Rest davon wahrgenommen werden lianu. Bei den licelıergehörenden Stïcke sind auch die Beine etwas dunkler, I'ygidium und 
Hinterleibsspitze geschwärzt; sonst finde ich jedoch keinen Unterschied.

Das Pygidium fein runzlig punktirt, bei der Stammform mit dem letzten Hinterleibsringe gelblich; auch die Beine mit den Hüften, wie auclı Vorder- und Nittelbrust schmutzig lehmgelb, der n̈brige grössere Theil der Unterseite schwarz. Das letzte Hinterleibssegment des $\delta$ einfach, des $q$ unbekannt.

Aus Venezuela (Mus. Clark. v. Bruck, in dem Letzteren die var. $\beta$ ).

S. 101. M. gemellus m. Bei einem Stücke im Mus. Clark, bei welchım im Allgemeinen Sülamerika als Heimath genannt ist, zeigt das Halsschild eine sehr hellrothgelhe Färbung, und die Punktstreifen der Declischilde sind etwas feiner. Weitere Abweichungen habe ich jedoch nicht auffinden können.

S. 106. hinter n. 17. M. bicolor Fab. ist als neue Art einzusclsalten :

17h. (64.) M. globator m. Roth, Fülılerenden und Ränder der Unterseite geschwärzt, die Deckschilde metallischschwarzgrün mit verwaschen gebräunten Seiten; das Halsschild mässig glänzend, hinten fein punktirt, die Punktstreifen deutlich, der 9te leicht verlieft, mit flachen, gläızenden Zwischenräumen. L. $2 / 3-5 / 6{ }^{\prime \prime}$; Br. $1 / 3-1 / 2 "$.

Ein wenig kleiner als M. bicolor, sonst aber demselben nicht unälınlich, die P'unktstreifen deutlicher, und die Deckschilde nicht blau, sondern schwärzlich grün. Der Kopf flach, matt, aber ohne deutliche Punlitirung, ziegelroth; die breit ausgebuchteten, einander oben ziemlich geuäherten Augen greis. Die Füller kaum bis zum Hinterrande des Halsschilds reichend, die oberen Glieder vom 6ten ab breit zusammengedrückt und dreieckig erweitert. Das Wurzelglied hellrothgelh, die 4 folgenden etwas dunkler und je weiter der Keule zu, desto mehr in's Brämnliche fallend, das 2te nur ein wenig liürzer, aber un die Hälfte breiter als die folgenden; die oberen schwarz. Das Ilalsschild fast von der Wurzel ab nach vorn sanft übergekrümmt, über den scharf rechtwinkligen Vorderecken zusammengedrïckt und dadurch verschmälert; die Seiten fein gerandet, hinter der Mitte kaum merklich ausgeschweift, von ihr ah nach vorn iı sehı flachen Bogen zusammenlanfend, die Hinterecken ku'z aher scharf spitzwinklig ausgezogen, der Ilinterrand jellerseits sehr leicht ausgebuchtet, mit sehr kurzem, fast grade alggestutztem 
Mittelzipfel. Die Oberfläche überaus fein narbig punktirt, die Punkte hinten ein wenig kenntlicher; die Farbe ein schwach glünzendes Ziegelroth, der Hinterrand sehr zart schwärzlich gesäumt. Ias Schildchen sehr schıäg niederliegend, gestreckı dreitekig und fast doppelt länger als vorn breit, glänzend schwarzgrün. Die Deckschilde wenig länger als vorn breit, hinter den Schulteru roch etwas verbreitert und dann hinterwärts breit und stumpf zugeruıdet, hinter der breiten Wurzelkante quer eingedrückt, un die Schildchenspitze bucklig erhöht und von da ab seitlich stärlier, hinterwärts in flacherem Bogen abfallend, die Schulterbeulen gross und kräftig, die Seitenlappen schwach mit sehr breitem umgesehlagenenı Rande. Die Punktstreifen sehr regelmässig, aus vertieften Vorderenden entspringend, von der Mitte ab zwar feiner, aber doch bis zur Spitze kenntlich; der 9te in eine schwache Furche eingedrückt. Die Zwvischenräume flach, vorn stärker, hiıterwärts schwächer glänzend, der 9te schıvach erhöht. Die Farhe eiı dunkles metallisches Grün, nach den Seiten und der Spitze zu verwaschen in's Trüb-Bräunliche fallend, der umgeschligene Rand der Seitenlappen stärker gebräunt. Pygidiun und Unterseite schwärzlich, nur die Vorder- und Mittelbrust mit den Beinen (deren Mittel- und Hinterschenkel zuweilen geschwärzt) hellroth, auch die Vlitte der Hinterbrust und des Hinterleibes mehr oder weniger lreit verwaschın geröthet, was auf dem Hinterleibe bei dem $f$ deutlicher als bei dem $\delta$ hervortritt. Das letzle Segment des $\delta$ einfach, das $f$ mit einer länglichen, stark glänzenden Grube.

$\mathrm{Zu}$ dieser Art, die ich jetzt nach Vergleich einer grüsseren Anzahl von Exemplaren als selbstständig anerkeme, gehört das am a. 0. S. 109 bei I. cribricollis angeführte zweifelhafte Stïck aus Columbien im Mus. Berol., und aus lerselben Heimath habe ich den Käfer auch aus dem Mus. Clark und vom Bruck (die Stücke des Letzteren vom Magdalenensirom stammend) in beiden Geschlechtern vor mir.

S. 132. n. 34. H. cousimilis Dej. Bei einem anderen \& dieser Art, gleichfalls aus Columbien (im Mus. Clark), sind nur die beiden unteren Fühlerglieder ziegelroth, das dritte pechbraun, und die übrigen rom vierten ab schwarz. Im Zusammenhange damit sind auch die Fussgliedler gebräunt; sonst aber sehe ich keinen weiteren Unterschied.

S. 136. ․ 36. M. pygidialis m. Ein $q$ voll $11 / 12$ " Länge 
im Mis. Clark, angeblich aus Venezuela stammend, zeigt auch noch eine hintere, joderspits alıgeliürzle und verwaschen begränzte schwärzlichgrüne Querbinde der Flügeldechen, aber keine weiteren Abweiclıungen. Durch eine Missbildung ist bei diesen Stücke zugleich die Mitte des Schildchens grubig eingesenkt.

S. 138. n. 3S. M. decolorans m. Auch von dieser Art fiutet sich noch cin sehr gut erhaltenes $q$ aus Brasilien in demselhen Mus. Clark vor Es ist etwas grösser als die beselıriehenen Stüclie (L. 1", bei fast $3 / 4$ " Breite), und aul der Oberseite chen so scharf gezeichmet. Vorder- und Mittelbrust mit der Mitte des ersten Bauchringes fallen stark in's Rotligelbe, auch der Vorderrand des letzten Ringes ist stark gerötlıet, mit hinterwärts verwaschener Begränzung.

S. 144. hinter 11. 42. M. rejectus m. ist als neue Art einzuschalten:

42 b. (65.) M. curtulus m. Schwarz, der Kopf mit den Fühlerwurzeln,' das zweifleckige dicht und fein punktirte Halsschild mit einer verwaschenen Querbinde der Flügeldeclien, der Vorderbrust und den Schienen röthlich; die Punktstreifen fein und hinterwärts noch sclıwächer, der neunte tiefer eingedrückt, mit flachen, fein quer gerunzelten Zwischeuräunen. L. $5 / 6$ "', Br. $2 / 3{ }^{\prime \prime}$.

Iı der Zeichnung dem M. rejectus am nächsten verwandt, aber kleiner, verlıälnıissmässig breiter und dadurch mehr eiförmig, auch an der Lage der zu einer verwaschenen Querhinde zusammengeschwundenen rothen Zeichnung der Deckschilde leicht kenntlich. Der Kopf flach gewölht, durch eine feine aber dichte Punktirung matt, das Kopfschild etwas niedergedrückl, oben undeutlich abgegräızt. Die Farlje ziegelroth, die nichıt breit aber ziemlich tief ausgebuchteten Augen greis, die Mundtheile röthlichbıaun, die stärker vorspringende Oberlippe unten heller gelblich gerandet. Die Fühler his über die Mitte hinaus röth]ich mit geschwärzter Keule. Das liurze Halsschild mit der grösseren IIälfte vorn übergekrüınıt, hinten kaum abwärts geneigl, über den tief eingezogenen, scharf rechtwinkligen Vorderecken zusammenged'ückt und dadurch verschmälert, die Seiten vorı fein, hinten breiter gerandet, nach vorn fast in graden Linien zusammengeneigt, hinterwärts etwas ausgeschıveift; die Hinterenden kurz und breit zugeschärft, der Hinterrand jederseits leicht ausgebuchtet, und von einer eingestochenen etwas gelogenen Querreihe gröberer Punkte begleitet, mit kurzem, 
undeutlich doppelt ausgerandetem Mitielzipfel. Die Oberfläche sehr dicht und fein punktirt mit seidig schimmerndem Zwischengrunde, ziegelroth, der hintere Theil des abgesetzten Seitenrandes schmutzig gebräunt, das Mittelfeld vorn mit zwei convergirendeı, den Vorderrand nicht ganz erreichenden dicken aber schlecht begränzten schwäızlichen Längsflecken gezeichıet. Das Schildchen mässig ansteigend, um die Hälfte länger als vorn breit, dreieckig mit lang ausgezogener Spitze und undeutlichem Vordergrübchen, glänzend schwarz. Die Deckschilde so lang wie rorn breit, unter den Schulterbeulen am breitesten und nach hinten sanft zugerundet, wodurch der Käfer einen sehr kurz und breit eiförmigen Unriss erhält, um die Schildchenspitze an höchsten und von da nach vor"l und hinten sanfter, seitwärts steiler abwärts gekrümmıt, hinter der breit aufgewulsteten Wurzel durch die tief eingegrabenen Vorderenden der oberen Punktstreifen ziemlich Jreit und stark quer eingedrückt, mit grossen eckig heraustretenden Schulterbeulen; auch die Seitenlappen kräftig mit sehr breitem ungeschlagenen Rande. Die Punktstreifen sehr regelmässig, vorn aus grubigen Vorderenden entspringend und kräftig, bald aber sich allmählich abschwächend, und die oberen auf der Wölbung liaum noch benterklich, der neunte und das Vorderende des achten tiefer eingedrückt. Die Zwischenräume breit und flach, die Vorderenden der oberen und der nemte sehr leicht aufgewölbt, dabei alle sehr dicht und fein querrunzlig mit ziemlich schwachen Glanze. Die Farbe schwarz, eine lreite, etwas verwaschen begränzte und an der Naht sich verdunkelnde geneinsame Querbinde ror der Mitte roth, und von deren Aussenenden ansgehend anch noch ein trüler bis gegen die Spitze sich hinziehenter Seitenrand geröthet. Das deutlich punktirte Pygidiun mit Hinterleib und llinterbrust schwarz, der umgeschlagene Theil des Halsschildes mit der Vorderhrust trüb röthlich. An den Beinen die Schenkel schwarz mit röthlichen Hüften, Schienen und Fussglieder nehst der Wurzel der Vorderschenkel röthlich. Das bräunlich gerandete letzte Hinterleibssegment des $\delta$ einfach, das $q$ unbekanıt.

Aus V'enezuéla (Moritz im Mus. Vindob.).

S. 146. 11. 44. M. peccator m. Noch ein \& Stück dieser Art, etwas kleiner als das beschriebene, auch ein wenig dunkler Jelımgell, mit leicht und verwaschen gebräuntem Hinterrande des 
Halsschildes, sonst aber nicht abweichend, von Moritz aus Venezuela mitgebracht, besitzt das Mus. Vindob.

S. 152. hinter n. 48. H. sordidulus m. sind als neue Arten einzuselıatten:

49 b (66). M. pusillimus m. Lehmgelb, die Fühlerkeule und der Hinterrand des an den Seiten dentlich punktirten Halsschildes schwärzlich; die P'unktstreifen mässig, hinterwärts schwächer, der achte und neunte vertieft, letzterer gekerbt, mit flachen, glänzenden Zwischenräumen. L. 1/4"“, B!r. 1/6"“.

Dem M. sordidulus zwar sehr ähnlich, aber noch merklichı kleiner, llachıer, vieI mehı gestreckt, und bei übrigens völliger Uebereinstimmung von ihm hauptsächlich an der Seulptur zu unterscheiden. Auf dem Mittelfelde des llalssehildes ist die Punlitirung zwar auch noch sichtbar, aber viel feiner und mehr zerstreut als bei dem vorhergehenden; seitlich werden die Punkte allmählich kräftiger, rücken näher an einander, und sind zuletzt noch etwas derher und dichter als bei der genannten Art. Auf den Deckschilden sinıl die Punktstreifen vorı verhältnissmässigr etwas stärker, die des vertieften 9ten Streilens gleiehfalls grob und dabei zienlich weit auseinander gerüekt, so dass sie leicht kenntlich sind und die anstossenden Ränder des Sten und 9ten Zwiseheurauns gekerbt erscheinen. Alles Uebrige wie hei M. sordidulus. Das letzte Segment des $\delta$ einfach, das $q$ umbekannt.

Aus Venezuela (von Herrn Pfarrer Scriba mitgelheilt).

49 c (67). M. microscopicus m. Oben heller, unten dunkler gelbbraun mit geschwärztem Hinterrande des derb und seitiich noch gröber punktırten Halssehildes; die P'unktstreifen mässig, hinterwärts schwächer, der Ste und gte vertieft, mit flachen, glänzenden Zwischenräumen. L. 1/4 "“, Br. 1/6 "“.

Von der Grösse und der gestreckten, länglichen Gestalt des vorhergehenden, aheı dıukler gefärbt, höher gewölbs, und in der Seulptur mehr dem it. sordidulus ähnlieh, alser doeh nach nıeinem Bedünken von beiden Arten zureichend verschieden. Die Farbe ist ein oben helleres, unten trüberes Gelbbrauı mit geschwärztem Hinderrande des Halssehildes, die Punktirung auf dem Vittelfelde des letzteren so grob und dicht wie bei II. sordidulus, seitlich aher noch merklich gröber und dichter bei übrigens glänzendem Zvisehengrunde; auf den Flügeldecken der Ste Streifen mur leicht. der 9 te tiefer eingedrückt, die Punkte des letzten aloer lein und so 
dicht an einander gerückt, dass man sie auch bei scharfer Vergrösserung nur mit Mühe unterscheiden kann. Alles Uebrige wie bei den vorhergehenden Arten. Das letzte Segment des $\delta$ einfach, das $\&$ unbekannt.

Eben daher, und von Demselben mitgetheilt.

S. 153. hinter n. 49. M. lucidulus $m$. sind als neue Arten einzuschalten:

49 b (68). M. splendidulus m. Metallisch schivarz oder braun mit pechbraunen Fühlerwurzeln; das Ialsschild glatt, die Punktstreifen mässig, hinterwärts schwächer, das Hinterende des 8ten und der 9te liefer eingedrückt, mit flachen, fein zerstreut punktirten Zwischenräumen. L. $5 / 6-1$ "', $\mathrm{Br}, 2 / 3-3 / 1$ "'.

Dem M. nigritulus Boh. und noch vielmehr dem nächst vorhergehenden M. lucidulus älınlich, aber von Beiden durch die nicht in's Bläuliclıe, sondern in's Kupferbräunliche Färbıng und die zerstreut punktirten Zwischenräume der gröber punktstreifigen Deckschilde, von M. nigritulus ausserdem durch die Querfurche des Halsschildes und die glänzende Oberseite, von M. lucidulus durch die nicht punktirte Oberfläche des Halsschildes unterschieden. Der Kopf flach gewölbt mit in der Mitte flach niedergedrïckter Stirn und grossem unten eingezogenem, in der Mitte tiefer eingedrücktem, oben durch eine deutliche Querlinie abgesetztem Kopfschilde; auch ausserhalb der Fühlervurzeln nach dem unteren, innêren Augenrande zu jederseits ein tiefer Längseindruck. Die Farbe schwarz mit mässigem Glanze, auf der niedergedrückten Stelle noch matter; die Oberlippe mit den Mundtheilen tief pechbraun, die grossen, in der Mitte tief dreieckig ausgebuchtelen Augen greis. Die Fühler bis zum Hinterrande des Halsschildes reichend, das gestreckte Wurzelglied mit dem 2ten, länglich eiförmigeı gleichfalls tief pechbraun, die folgenden schwarz, das 5te schon an der Spitze ein wenig breiter; die sechs oberen breit zusanmengedrïclit und erweitert, mit dünner angedrücliter Behaarung. Das Halsschild mit $3 / 4$ seiner Länge vorn stark kugelig übergekrümmt, über den scharf rechtwinkligen Vorderecken zusammengedrückt und dadurch verschmälert, die Seiten fein gerandet, nach vorı in einem breiten Bogen zusammenlaufend; die Hinterecken' kurz und breit spitzwinklig, der Hinterrand jederseits tief ausgebuchtet, mit deutlich doppelt ausgerandetem Mittelzipfel: vor dem letzteren eine tiefe, mit den Enden etwas nach vorn gekrümmte Querfurche. Die Ober- 
fläche spiegelglatt, nur bei sehr scharfer Vergrösserung Spuren einer äusserst freien Punktirung zeigend, die Farlve ein besonders an den Rändern in geringerer oder grösserer Ausdehnung verwaschen kupferbräunlich durchscheinendes Schwarz. Das Schildchen wenig ansteigend, länglich dreieckig und hinten kurz abgestutzt, glänzend sclıvarz. Die Deckschilde kaın 1/6 länger als breit, hinter den Schultern noch etwas verbreitert und daun durch sanfte Abrundung den eifürmigen Umriss des Körpers abschliessend, hiuter der Wurzel durch die grühchenartigen Vorderenden der Punktstreifen tief quer eingedrückt, die Schulterheulen flach, die Seitenlappen mässig stark, un」 über letzteren die Deckschilde etwas zusammengedrückt. Die Punktstreifen sehr regehnässig, aus grübchenartigen Vorderenden hinterwärts bald ahgesclıwïcht, aber doch bis ziI Spitze deutlich, der 9te und auch die hintere Hälfte des 8ten in leichte Längsfurchen eingedrückt. Die beiden äusseren Zwisch९nräune deshalb leicht aufgewölbt, die älsrigen flach, alle aber glinzend und mit einer feinen aher deutlichen Punktirung bestreut. Die Farbe schwar'z mit einem stark braunröthlichen, bei stärkerer Vergrösserung deutlicheren, zuweilen die schwache Grundfärbung ganz verdunkeluden Schimmer. Pygidium und Unterseite fein punktirt, mit den Beinen schwarz; Vorder- und Mittelbrust, Hüften und Vorderzipfel des ersten Bauchringes pechbräunlich. Die Vorderbrust dicht runzlig punktirt, fast doppelt breiter als lang, hinten in breilem Bogen ausgeschnitten. "Das letzte Segment des $\delta$ einfach, das $q$ mit einer grossen und tiefen halbkugeligen, glänzenden Grube.

Aus Venezuela (Moritz im Mus. Vindob.) und angeblich auch aus Brasilien (Mus. Clark).

49 c (69). M. oblongulus m. Dunkel stahlblau mit röthlichen Fühlerwurzeln; das Halsschild glatt, die Punktstreifen derlu, der 9 te tiefer eingedrückt, mit besonders vorn und seitlich gewölbten, ziemlich glänzenden Zwischenräumen. L. $5 / 6$ "', Br. 1/2 "“.

Eine durch ilıren gestreckten Körper und die derben, bis zur Spitze vollkommen deutlichen Punktstreifen sehr ausgezeichnete Art. Der liopf flach, mit etwas eingezogenem, oben deutlich abgegränztem Kopfschilde und kurzer Stirnlinie, die Augen tief dreieckig ausgebuchtet. Die Farbe dunkel stahlblau mit geringem Glanze, die Oberlippe röthlich gerandet, auch die unteren Fühlerglieder roth, auf der oberen Seite ınit einer schıväızlichen Längs- 
wische bezeichnel. Das Halsschild etwa doppelt breiter als lang, über die Hitte quer aufgewulstet und von da nach vor'n und hintpı gleichmässig abwärts gekrümnt, über den tief eingezogenen, stumpf rechtwinkligen Vorderecken zusammengedrüclit und dadurch verschmäler, die gerandeten Seiten nach vorn mit mässiger Krümmung zusammengeneigt, hinier der Mitte ausgeschweift, mit kurz und scharf dreieckig ausgezogenen Hinterecken; der Ilinterrand jederseits leicht ausgebuchtet, der Mittelzipfel sehr undeutlich ausgerandet, fast quer abgestutzt; vor ihm eine ziemlich tiefe, aber schmale, mit beiden Enden nach vorn und aussen gehogene Querfurchı. Die Oberthäche spiegelglänzend stahlblau. Das Schildchen leicht ansteigend, dreieckig und um die Hälfte lïnger als vorn Isceit, mit undeutlichem Vordergrübchen und etwas aufgebogener Spitze, gleichfalls glänzend stahlblau. Die walzenförmigen Deckschilde $1 m$ etwa $1 / 3$ länger als lreit, um die Schildchenspitze am Jüchsten, und von da al, nach hinten mit allmälılicher, seitlich mit steilerer lírümmung abfallend, hinter der etwas aufgetriebenen Wurzel tief quer gelurcht, mit halbkugelig vortretenden, spiegelglatten Schulterbeulen umd krältigen Seitenlappen, über letzteren breit zusamnengedrückt. Die Punktstreifen aus gruhig eingedrückten Vorderemlen entspringend, in ilırem ganzen Verlaufe regehnässig und lerb, bis zur Spitze vollstindig erkemnbar, der 9te in eine tielere Lïngsfurche eingesenkt. Die Zwischenräume vorn und seitlich stärlier, auf der Milte ıles Rücliens flacher gewölbt, fein runzlig punktirt, aber doch ziemlich glänzend, die Farbe auch hier stahlhluı. Pygidium, Unterseite und Beine liefer einfarbig schwarzblau. las letzte Segment les o einfach, das o unbekannt.

Aus Brasilien (bei Rio de J. von Fry gefunden: Mus. Holm). $49 d(70)$. M. couvexicoll is m. Mattschwar, Fülıler, Schieneı und Füsse fuchsroth; das Ifalsschild kaum punktirt, die Punktstreile» mässig, hinterwärts feiner, der gte tieler eingedrückt, mit flachın, vorn unıl secillich flachyewölsten Zwischıräumen. L. 3/4"“, Br. $1 / 2 "$.

Nach Färluug und Bau zeigt dieser Kiffer Nanches von dem Typus der Gattung Abweichende mol nähert sich in mancher Beziehnng der eigenthümlichen Monachenform, welche in dem Mexicanischen M. bicruciatus ilnen eigentlichen Vertreter findet. Es liegt mir hier aber von Sülamerikaner'n nur diese einzige Art, und anch diese nur in eincm rinzelnen nicht gut rolıaltenen Stïcke 
vor, und ich habe es deshall, für angemessen gehalten, sie vorläufig in dieser Rotte unterzubringen, bis sich später wach dem Autfinden von mehreren und besser erhaltenen Stücken über ihre definitive Stellung Entsclıeidung treffen lassen wird. Wer Kopf flacl, mil grossem, oben durch eine feine Bogenlinie abgegränztem Kop fschilde, sehr fein und dicht punktirt, matt schwarz; die weit getrennten, breit und tief ausgebuchteten Augen greis, der Rand der in der Mitte breit gebräm gelb. Die Fühler kurz und kaum lıis zum Hinterende des Halsschilds reichend, hell rothgell, die aus liurz dreieckigen, stark behaarten Gliedern gebildete und etwas zusammengedrüclite lieule rauchgrau; das erste Glied der letzteren nicht ganz so breit als die folgenden. Uas Halsschild etwa um die Hälfte breiter als lang, von der quer aufgewölbten Mitte nach hinten und vor'n zienlich gleichmässig alı̈irts gekrümmt, über den scharf rechtwinkligen Vorderecken zusammengedrückt und dadurch verschmälert, die Seiten fein gerandet, in der Mitte in flachem Bogen erweitert, vor den spitz dreieckig ausgezogenen Hinterecken leicht ausgeschweift; ler IIinterrand kaum ausgebuchtet, mit kurzem fast gerade abgestutztem Mittelzijfel. Das Mittelfeld jederseits mit einem kräftigen Quereindruck. Ilie Obertläche kaum sichthar punktirt, mit mattem Zwischengrumde, rein und tief schwarz. Das Schildchen fast llach niederliegend, dreieckig und linger als vorn breit, nit ausgezogener Spitze, gleichfalls schwarz. Die Dechschilde walzenförmig, etwa $1 / 4$ länger als breit, hinter der stark erhöhten Wurzelkante quer gefurch, hinten sehr flach abfallend, die Schulterheulen eckig vortretend, die Seitenlappen schwach mit breitem umgeschlagenem Raude. Die Punktstreifen regelmässig, vorn kräflig, die oberen von der Mitte an merklich alogeschwächt, der 9te und in viel geringerem Grade anch der 8te tiefer eingesenkt. Die Zwischenräume flach, die Vorderenden der oberen, auch der 9te und schwïcher noch der 8te leicht aufgewölbt; die Farbe schwarz mit matt seidigem Schimmer. Pygidium, Unterseite und Schmahel gleichfalls schwarz, Schienen und Füsse hell rothgelb. Das Prosternum breiter als lang, punktirt und querrunzlig, hinten in flachem Bogen ausgeschnitten, mit scharl vor'springenden Hinterecken, die Mittellorust laalb so lang aber noclı breiter als jenes, das letzle Segment des $\&$ mit einer tiefien hallbkugeligen Grube, dias ơ unbekannt.

Aus Brasilien (Mus. I'indob.). 
S. 177. hinter n. 1. Cr. obliquatus m. ist als neue Art einzuschalten :

1 b (96). Cr. pectinicornis m. Schwarz, cin breiter verwaschener Rand der Deckschilde kirschroth; das Halsschild fein punklirt, anch die Punktstreifen fein mit flachen quergerunzelten Zwischenräumen. L. $21 \frac{1}{3}$ “", Br. $1 \frac{1}{6}{ }^{\prime \prime \prime}$.

Dem Cr. obliqualus ungemein ähnlich, aber, wenn man $\delta$ mit đ vergleicht, in den Schulterı verhältnissmässig breiter, hinterwärts stärker verschmälert, die Vorderschienen etwas abweichend gebaut, der Zahn an den Vorderlüften schwïcher ausgebildet, endlich auch die Fühlerenden - ohne Zweifel nur als sexuelles Merkmal des $\delta$ - in einer an australische Formen erimernde Weise entwickelt. Der Kopf lireit und flach, der Nacken mit einem tiefen Längseindrucke, das kurze liopfsehild eingezogen, oben durch eine leichte Querrunzel alıgesetzi, der darüber liegende Theil der Stirn leicht quer niedergedrïckt und nach oben durch ein paar schmale über den Fühlerhı̈ckern liegende Querbeulchen begränzt. Die Oberlläche durch eine dichte und feine runzlige Punktirung matt, dahei sehr kurz unt düm greishaarig, schwarz mit leicht gebräunten Ründern eler Oberlippe; die seicht und kurz ausgebuchteten, auch bei dem of weit getrennten Angen schwarz. Die Fühler des allein vorliegenden o von Körperlänge, das Wurzelglied keulig, etwa $1 \frac{1}{2} \mathrm{mal}$ so lang als breit, das 2 te kurz und knotig, die drej folgenten gestreckt, Jeicht zusammengedrückt, an der Spitze nach Innen rtwas anfgetrieben, das 3te reichlich dreimal, das 4te fast viermal, das 5te (längste) etwa fümfmal länger als clas 2te, das 6te und Tte je wieder dens 4ten gleich, nebst den folgenden zusammengedrückt, das fite an der Spitze nach Innen vorgezogen, das The von der Nitte ab im Bogen dreieckig erweitert, das Ste dem 3ten gleich, von der Wurzel ans auf der Innenseite in breiten Bugen so stark verbreitert, dass die obere Breite fast der Länge gleichliommt. Aelnliche lappenartige, nach Innen dreieckig ausgezogene Fortsitze zeigen auch die beiden lolgenden, successir länger'n und je von der Wurzel ah dreieckig crweiterten Glieder, so dass bei heiden dir Länge von der oberen Brpile fast mm die Hälfte äbertroflen wirl, mul sonach jene Breite bei dem 9ten, weil etwas längerem Gliede anch die grössere Ausdehmung erhält; das Endglied wieder elwas linger, breit elliptisch, mnd bei seinem nur kurzen Fortsatze an der Spitze wie ausgerandet. Diese oberen 
Glieder bilden dadurch eine 4 blättrige, kammartig zerschlitzte, auf der Unterseite der Länge nach muldenförmig ausgehöhlte Keule, die sich aber in gleicher Weise schwerlich bei dem noch nicht bekannt gewordenen $q$ rorfinden wird. Die Farbe schwarz mit. dünner greiser Belaarung, die beiden unteren Glieder auf der Unterseite tief pechbraun. Das grosse Halsschild vorn mit $3 / 4$ seiner Länge breit kugelig übergewölbt, über den stumpfwinkligen Vorderecken zusammengedrückt und dadurch verschmälert, die Seiten tief herabgezogen, fein gerandet, und dieser fast geradlinig nach vorn verlaufende Rand unter der weil vortretenden Masse des Mittelfeldes nach unien einwärts gekrünımt; die Hinterecken stumpfwinklig, mit deu anstossenden Theile des Hinterrandes etwas eingesenkt; letzterer jederseits leiclıt ausgebuclıtet, mit breit ausgezogenem, hinten abgestutztem, durch einen auf jeder Seite liegenden Schrägeindruck etwas zusammengedrüclitem Mittelzipfel. Die Oberfläche sehr dicht und fein runzlig punktirt, kurz angedrückt greislıaarig, nıatt schwarz mit Seidenschimmer. Das Schildchen flach niederliegend, dreieckig, etwas länger als breit, längs der Mitte niedergedrückt, dicht und fein punlitirt, gleiclıfalls sclıwarz. Die Deckschille kaum 1/6 länger als vorn breit, aus dem IValzenförmigen hinterwärts verschmälert und daselbst mit flacher Wölbung abfallend, die grossen flachgewölsten Schulterbeulen innerseits durch einen breiten Eindruck abgesetzt, die Seitenlappen ziemlich breit, und über ilmen die Deckschilde scharf schräg zusammengedrückt; die Punktstreifen auf den Rücken kaum bemerkbar, die äusseren vom 5ten ab etwas deutlicher, was namentlich bei dem 9ten und der vorderen Hälfte des 8ten hervortritt; die Zwischenräume flach, durch dichte und feine Querrunzelı matt, dazu mit einer sehr feinen und dünnen greisen Behaarung bedeckt. Die Farbe schwarz, ein ziemlich breiter, die Wurzel, Spitze und Aussenseite umziehender Rand dunkel kirschroth mit nach Innen verwaschener Begränzung, in welcher derselbe sich hinter dem Quereindrucke über dem Seitenlappen mit einem Ansatze zu einer abgerissenen Querbinde innenwärts erweitert. Pygidium und Unterseite sehr fein runzlig punktirt, dünn greishaarig, mit den stark verlängerten Beinen schwarz. Die Vorderschienen oben dünn, auf der grösseren Unterhälfte nach Innen breit messerförnig erweitert, diese Erweiterung unten sanft ausgehöhlt, und bei ihrem Beginne in einem geschweiften Bogen in den oberen dünnen, stielartigen Threil der Schienen XVI. 
übergehend. Die Mittelschienen in ähnlicher Weise, aber minder stark und nur mit dem unteren Drittel verbreitert, beim Beginn dieser Verbreiterung etwas einwärts gekrümmt; beide Schienenpaare zugleich am unteren Ende auf der Unterseite etwas beulig aufgetrieben. Die Hinterschienen g]eichfalls länger als die Schenkel, dünn, über der Mitte leicht geschweift. Das Prosternum breit, in der Mitte von einem bogenförmigen, ziemlich scharfen Querwulst durchzogen, dessen Aussenenden sich als kurze, etwas einwärts gekrümnite Zähnchen von rothgelber Farbe sichtbar machen; hinter jenem Querwulst ist die Fläche des Prosternums tief quer niedergedrückt, mit leicht ausgebuchtetem Hinterrande. Die Mittelhrust fast so lang als breit, gleichfalls gerunzelt; die Mitte der Hinterbrust ohne Punkte und Haare, spiegelglatt. Das letzte Segment des $\delta$ hinten quer niedergedrückt. Das $q$ unbekannt.

Aus Chile (Mus. Clark).

S. 184. Die hier aufgeführte zweite Rotte sammt der darin beschriebenen Art ( $\mathrm{Cr}$. praeustus $\mathrm{m}$.) ist zu streichen. Der Käfer ist, wie ich durch ein Exemplar im Mus. Clark belehrt worden bin, auf Madagaskar zu Hause, und muss mit meiner ersten afrikanischen (gleichfalls auf Madagaskar eiuheimischen) Rotte (Linn. Ent. XI. S. $70 \mathrm{ff}$.) vereinigt werden, wo er S. 72 hinter $\mathrm{Cr} \cdot m u$ tilatus aufzuführen ist. Die allerdings eigenthümliche Sculptur kann hier nur als Artmerkmal gelten. Uebrigens ist auch dies zweite Exemplar ein o. Dafür ist einzuschalten eine neue

Zweite Rotte. Der Körper gross und plump, breit und flach walzenförmig, hinteı gleichbreit; das Halsschild vorı stark übergelirümmt, anscheinend sehr liurz, hinten tief quer eingedrückt, mit eingesenktem Hinterrande. Die Punktstreifen sehr regelmässig, die Färbung ziegelroth mit schwarzer Fleckenzeichnung. Als Art gehört zu ihr:

5. Cr. abhorrens m. Ziegelroth, ein grosser Schulter- und ein kleiner Hinterfleck der Flügeldecken sclıwarz; das Halsschild äusserst feiu punktirt, hinten lief eingedrückt, die Punktstreifen regelmässig und kräftig, mit flachen, glänzenden Zwischenräumen. L. $3^{\prime \prime \prime} ; \mathrm{Br} .12 / 3{ }^{\prime \prime \prime}$.

Der südamerikanische Ursprung dieses mir nur in einem vereinzelten Stücke vorliegenden Käfers erscheint mir zwar in sofern etwas zweifelhaft, als mir lis dahin keine ähnliche Form von dorther bekannt geworden ist: eben so wenig habe ich aber auch po- 
sitive Gründe für die Annahme einer anderen Heimath desselben, und ich führe ihı deshalb auf die Autorität der Clark'schen Sammlung einstweilen als eine südamerikanische Art auf, wiewohl ich nicht verhehlen darf, dass eben dieselbe Sendung, welcher diese Art angehörte, auch ein ganz unverkemnbares $q$ unseres bekannten europäischen $C r$. nilens als einen angeblich südamerikanischen Käfer enthielt. Der Kopf der vorliegenden, auch durch ihre Grösse ausgezeichneten Art ist flach, die Stirn niedergedrückt und dann noch von einer ziemlich breiten, aber kurzen und seichten Längslinie durchzogen, das Kopfschild oben durch eine etwas gebogene Querlinie und einen über dieser liegenden schmalen Querwulst abgesetzt, über dem Unterrande mondförmig eingedrückt, auch am oberen und unteren Rande mit einer feinen und ziemlich.dichten Punktirung besetzt. Die Farbe hell ziegelroth, die langgestreckten, ziemlich breit und tief ausgebuchteten, oben weit getrennten Augen schwärzlichgreis, die Kimnbacken gesclıwärzt. Von den Fühlern sind nur die beiden unteren Glieder vorhanden und gleichfalls ziegelroth; das erste gestreckt, über $2 \frac{1}{2}$ mal länger als breit, auf der Oberseite etwas abgeflacht, das 2te korallenförmig, wenig länger als breit, und etwa halb so breit als das vorhergehende. Das Halsschild etwa $2 \frac{1}{2}$ mal breiter als lang, mit der grösseren Vorderhälfte stark kugelig übergekrümmt, über den sehr tief eingezogenen, scharf rechtwinkligen Vorderecken breit zusammengedrückt und dadurch verschmälert, die Seiten gerandet, hinter der Mitte leicht ausgeschweift, nach vor'n in flachen Bogen zusammengekrümmt; die Hinterecken kurz und breit spitzwinklig ausgezogen, der Hinterrand jederseits tief ausgeschnitten, vor und innerseits der Schulterbeulen sehr tief quer eingekniffen; der Mittelzipfel kurz und breit, doppelt ausgerandet, durch einen zu jeder Seite liegenden kräftigen Schrägeindruck der Länge nach emporgedrückt. Die Oberfläche fein und zerstreut, aber deutlich punktirt mit spiegelglänzendem Zwischengrunde, gleichfalls ziegelroth, hinten zart bräunlich gesäumt. Das Schildchen stark schräg ansteigend, dreieckig und etwas länger als vorn breit, hinten mit abgerundeten Ecken breit abgestutzt, mit deutlichen, zwischen zwei Längsbeulchen liegendem Vordergrübchen, ebenfalls glänzend roth mit gebräunten Säumen. Die Deckschilde breit und flach walzenförmig, etwa $1 / 3$ länger als breit, um die Schildchenspitze etwas buchlig erhöht, und von da die Nabt entlang bis zur Spitze mit sehr schwacher Wöl- 
bung abfallend; hinten liurz und breit zugerundet, vorn zwischen dem 2ten und dem 5ten Punktstreifen etwas wulstig ansteigend; die Schulterbeulen balbeiförmig, innerseits durch einen tiefen Längseindruck abgesetzt; die Seitenlappen schwach, und üher ihnen die Deckschilde kaum zusammengedrückt. Die Punktstreifen sehr regelmässig, von mässiger Stärlie, aber bis zum Ende deutlich; die Zwischenräume flach und glänzend, kaum sichtbar gerunzelt. Die Farbe auch hier ziegelroth, das Innere der Punkte und ein zarter Saum dunkler gebräunt; ausserdem zeigt jede Flügeldecke noch zwei grosse sclıwarze Flecke, einen grösseren, quer nierenförmigen Schulterfleck zwischen dem 2ten und 9ten Punktstreifen, welcher anch die Schulterbeule mit einschliesst, und einen kleineren, mehr rundlichen auf der Wölbung zwischen dem 3ten und Sten Streifen, ersteren noch etwas in den 2ten Zwischenraum hinein überschreitend. Pygidium und Unterseite fein runzlig punktirt, dünn greislıarig, mit den Beinen ziegelroth; das Prosternum kurz und breit, hinter der Mitte quer aufgewulstet, mit kiurzen lappigen Hinterenden. Das letzte Segment des $q$ mit einer grossen und tiefen, glänzenden Grube, das đँ unbekannt.

Mit der Vaterlandsangibe: Cayenne? aus dem Mus. Clark zum Beschreiben mitgetheilt, und dasellıst mit dem Namen $\mathrm{Cr}$. Tilliersii bezeichnet.

S. 216. hinter n. 23. Cr. pasticus m. sind als neue Arten einzuschalteu:

23 b (97). Cr. compressicoll is m. Rostroth mit schwarzen Fühlerenden, die breiten Seiten des überaus fein punktirten, glänzenden Halsschildes und ein grosser Längsfleck der Flügeldecken hoclıgelb; die Punktstreifen dentlich, mit llachen, gläızenden Zwischenräumen. L. $1 \frac{2 / 3}{\prime \prime \prime}$; Br. $1 \frac{1}{12}{ }^{\prime \prime \prime}$.

Verhältnissmässig etwas schmaler als die vorhergehenden, das Halsschild nach vorn deutlicher kegelförmig verjüngt und die Rïckenstreifen nicht gauz so abgeschwächt wie bei $\mathrm{Cr}$. pasticus. Der Kopf flach, runzlig punktirt, mit kurzer Andeatung einer Stimlinie und lackglänzendem Zwischengrunde, das eingezogene Kopfschild oben durch eine deutliche Bogenlinie abgeselzt. Die Farbe hochgelh, Kopfschild und Mundtheile etwas dunkler, die langgestreckten, breit und in der Mitte ziemlich tief ausgebuchteten, auf der Stirn zusammenstossenden Augen greis. Die Fübler (des f) nicht von halber Körperlänge, das Wurzelglied ziemlich dünn, gestreckt keulen- 
förmig, etwa $2 \frac{1}{4} \mathrm{mal}$ länger als breit, das 2te kurz eiförmig, das 3te und 4 te dünn verkehrtkegelförmig und je nur wenig, auch das 5te kaum um $1 / 4$ länger als das 2te, das 6te und 7 te je dem 5ten gleich, die oberen je etwa wieder so lang als das 4te, mit kurzem und breitem Fortsatze des Endgliedes; die 5 unteren durchscheinend honiggelb mit etwas stärker gebräunter Oberseite, die 6 oberelı etwas erweiterten und zusammengedrücliten Glieder schwarz mit bräunlicher Wurzel des 6ten und 7 ten. Das IIalsschild etwa $21 / 4$ mal breiter als lang, vor der Mitte kugelig aufgewölbt und dann nach vorn mit dem ersten Viertel der Länge stïrker, hinterwärts sanfter abwärts gekrümmt, über den scharf rechtwinkligen Vorderecken selır breit zusammengedrückt und dadurch fast kegelförmig verschmälert; die Seiten gerandet, nach vorn in sehr flachen Bogen zusammengeneigt, die Hinterecken kurz und breit dreieckig ausgezogen, der Hinterrand jederseits breit ausgesclıweift, vor den Schulterbeulen tiefer ausgebuchtet, stark eingesenkt und mit grösseren Zähnchen besetzt, mit nicht eben breitem, durch die stark heraustretende Mitte des Hinterrandes fast unkemntlich gemachtem, auch nur undeutlich doppelt ausgerandetem Millelzipfel; vor letzterem jederseits ein kurzer, aber tiefer eiförmiger Sclıägeindruck. Die Oherfläche spiegelglatt, hochgelb, mit einer breiten, das kleineré mittlere Drittel einnelımenden, Vorder- und Hinterrand erreichenden, seitlich schlecht begiänzten rostrothen Mittelbinde; der Hintersaum schwärzlich, die abgesetzten Seitenränder leicht gebräunt. Das Schildchen schräg ansteigend, lang und schmal dreieckig, um die Hälfte länger als breit, hinten kurz abgestutzt mit deutlichem Vordergrübchen, gleichfalls rostroth. Die Deckschilde eng an das Halsschild angeschlossen, um etwa 1/4 länger als breit, aus dem kurz Walzenförmigen hinterwärts etwas im Bogen verschmälert und dann kurz und breit zugerundet; der Rücken linter der Wurzel durch die vertieften Vorderenden der Punktstreifen quer niedergedrückt, dicht hinter dem Schildchen leicht buckelig erhöht und von da ab hinteriärts mit sanfter Krümmung abfalleind: die breiten flachen Schulterbeulen innerseits durch einen tiefen Längseindruck abgesetzt, die Seitenlappen breit und fast dreieckig, und über ihnen der 8te und 9te Punktstreifen etwas tiefer eingedrückt. Die Punktstreifen deutlich und regelmässig, aus kräftigen Vorderenden hinterwärts zwar etwas feiner, aber nur die mittleren erst vor der Wölbung merklich abgeschwächt, der 7 te vorn aus etwas gröbereu 
Punliten gebildet, die Hinterhälfte des 9ten furchenartig vertieft und in dieser Weise die Spitze bis zum Hinterrande des 2ten umziehend. Die Zwischenräume äusserst fein runzlig punktirt, mit ziemlichem Glanze, breit und flach, nur der 9te und in geringerem Grade das Vorder- und Hinterende des Sten leicht aufgewölbt. Die Farbe rostroth mit zart schwarzem Vordersaume, das Mittelfeld jeder Flügeldecke von einem grossen hochgelben Längsflecke eingenommen, welcher sich vorn von dem abgekürzten Streifen bis zur Schulterbeule ausdehnt und, hinterwärts sich abrundend, mehr als $2 / 3$ der Flügeldeckenlänge einnimmt, dahei mit verwaschener Begränzung innerseits die Färbung der Halsschildsseiten fortsetzt, aussen aber durch die roth verbliebenen Schulterbeulen merklich gegen jene Seitenfärbung des Halssclildes beschränkt wird, wenn er gleich hinter den Schulterbeulen sich verwaschen wieder bis gegen den 9ten Streifen hin erweitert. Das Pygidium runzlig punktirt und dünn greishaarig, rostbraun; Unterseite und Beine bis auf die tiefer geröthete Hinterbrust nebst Parapleuren heller rostgelh. Die Vorderbrust breit und flach, der Vorderrand nicht eigentlich vorgezogen, aber zur Aufnahme der Mundtheile muldenförmig ausgehöhlt und abwärts gekrümmt, der Hinterrand ausgebuchtet und in der Mitte nochmals tiefer ausgerandet: vor der letzteren das Mittelfeld deutlich eingedrückt. Die seitlichen Hinterzipfel breit und scharf dreieckig, wodurch, wie auch sonst im Körperbau, eine gewisse Annäherung an einzelne Monachenformen auch hier unverkennbar hervortritt. Das letzte Segment des $f$ mit einem grossen, rundlichen Grübchen, das o unbekannt.

Aus Brasilien (Minas Geraes: Mus. Clark).

23c (98). Cr. limitatus m. Kirschroth mit gebräunten Schenkeln, die Fülılerenden, die Mitte der Hinterbrust und ein breiter Saum der Deckschilde schwarz; das Halsschild spiegelglatt, die Punktstreifen fein, mit flachen, gleichfalls spiegelglatten Zwischenräumen. L. $1{ }^{2} / 3^{\prime \prime \prime} ;$ Br. $1 \frac{1 / 12}{}{ }^{\prime \prime}$.

Von der Grōsse des vorhergehenden, und demselben auch in der Farbenvertheilung nicht unähulich, nur das Braun desselben durch Schwarz, das Gelb durch Roth ersetzt, und das Halsschild sammt der Naht ohme den dunkeln Mittelstreifen der genannten Art. Der Kopf flach gewölbt, mit stark eingezogenem, oben nur durch einen leichten Querwulst abgegränztem Kopfschilde, mässig glänzend, dunkelroth; die lang gestreckten, breit ausgebuchteten, 
oben auch bei dem $q$ stark genäherten Augen schwarz. Die Fühler nur etwa von $1 / 3$ der Körperlänge, das Wurzelglied gestreckt reichlich länger als breit, das 2te lang und schmal elliptisch, die beiden folgenden dünn, in der Mitte etwas breiter als an den Enden, je um die Hälfte länger als das 2te, die übrigen schwach erweitert und zusammengedrückt, ziemlich gleich lang, je etwas kürzer als das vierte, mit kurzem und stumpfem Fortsatze des Endgliedes. Die vier unteren roth, die oberen schwarz mit dünner angedrückter greiser Behaarung. Das Halsschild $2 \frac{1}{2}$ mal breiter als lang, nach vor'ı zu über den abgerundet-rechtwiıkligen Vorderecken breit zusammengedrückt und dadurch stark verschmälert, mit der grösseren Hälfte kugelig übergekrümmt; die Seiten gerandet, nach vorn fast gradlinig zusammengeneigt, die kurzen Hinterecken breit und scharf spitzwinklig ausgezogen, durch einen tiefen Schrägeindruck ein wenig aufgetrieben, der Hinterrand jederseits tief ausgebuchtet, scharf gesägt, mit deutlich doppelt ausgerandetem Mittelzipfel, und vor letzterem jederseits ein kräftiger Schrägeindruck. Die Oberfläche überaus fein punktirt, dazwischen spiegelglänzend, dunkel ziegelroth mit zart schwarzem Hintersaum. Das Schildchen schräg ansteigend, dreieckig und etwas länger als vorn breit, mit undeutlichem Vordergrübchen, glänzend schwarzbraun. Die Deckschilde aus breiter Wurzel hinterwärts im Bogen verschmälert und dadurch den eiförmigen Unriss des Körpers schliessend, kaum $1 / 6$ länger als vorn breit, die Wurzel nur jederseits an Schildchen schmal quer eingedrückt, die eckigen Schulterbeulen innerseits durch einen dreieckigen Eindruck abgesetzt. Die Seitenlappen mässig mit sehr breitem umgeschlagenem Rande, und über ihnen die Deckschilde stark zusammengedrückt. Der Rücken vom Schildchen ab binter'wärts mit ziemlich steiler Krümmung abfallend. Die Punktstreifen fein, aber nirgends verschwindend, dabei sehr regelmässig, die Vorderenden der oberen und der neunte etwas tiefer eingedrückt; die Zwischenräume breit und flach, mit sehr feiner Punktirung bestreut und dabei noch eben so fein querrunzlig, lackglänzend, der neunte und ṡchwächer der achte ein wenig aufgewölbt. Die Farbe roth mit etwas dunklerem Grunde der Punkte, ein breiter, die ganzen Deckschilde umziehender und auch die Schulterbeulen einschliessender, nach innen verwaschen begränzter Rand und ein feiner Nahtsaum schwarz. Pygidium und Unterseite fein runzlig punktirt, dünn behaart, bleicher rothgelb. Die Beine ge- 
bräunt, die Wurzeln und Spitzen der Schenkel nebst den Schienenwurzeln heller rötllich, das Vordertheil der Hinterhrust nebst der Mittelbrust geschwärzt. Das Prosternum runzlig punktirt, kurz, vorn kaum vorgezogen, hinten leicht ausgebuchtet und daselbst schwach quer eingedrückt, die Hinterecken dann nochmals vorspringend. Das letzte Segment des $q$ mit dem gewöhnlichen Grübchen, das ơ unbekannt.

Aus Venezuela (Mus. Clark).

S. 226. hinter II. 28. Cr. leucospilus m. ist als neue Art einzuschalten :

- 28b (99). Cr. cachecta m. Lehmgelb mit weisslichen Deckschilden, die Fühlerenden, vier Flecke des zerstreut punktirten Halsschildes und drei der Flügeldecken (1, 2; das hintere I'aar schräg) schwarı, die in der Mitte erweiterte Naht gelıräunt; die Punktstreifen fein, mit flachen, fein punktirten glänzenden Zwischenrämmen. L. 11/3"'; Br. $3 / 4 "$ ".

Dem Cr. leucospilus sehr ähnlich und auch von gleicher Grösse, aber doch durch Sculptur und Zeichnung von demselben genugsam verschieden. Der Kopf flach mit kurzer Stirnlinie und stark eingezogenem Halsschilde, schmutzig lehmgelb mit mässigem Glanze, die langgestreckten, breit ausgebuchteten, (auch bei dem q) oben stark zusammengeneigten Augen schwarz. Die Fühler von mässiger Stärke, oben nur schwach zusammengedrückt und erweitert, die vier unteren Glieder hell durchscheinend gelb, die oberen schwarz mit dünner greiser Behaarung und gebräunter Wurzel des fünften Gliedes. Das Halsschild mehr wie doppelt länger als breit, in der Mitte quer buckelig aufgewölbt und von da ab nach vorn und hinten ziemlich gleichmässig abwärts gekrümmt, über den stumpf rechtwinkligen Vorderecken breit zusammengedrückt und dadurch stark verschmälert, die gerandeten Seiten nach vorn in flachen Bogen zusimmengeneigt, die Hinterecken kurz und breit zugeschärft, der Hinterrand eingesenkt, jederseits etwas wellig leicht doppelt ausgebuchtet, mit kurzem undeutlich doppelt ausgerandetem Mittelzipfel. Vor letzterem jederseits ein kurzer, aber kräftiger Schrägeindruck, und ein zweiter breiterer aber schwächerer weiter nach rorn und aussen über der Mitte des Seitenrandes. Die Oberfläche deutlich aber zerstreut punktirt, mit lackglänzendem Zwischengrunde; die Farbe eil besonders auf dem Mittelfelde in's schmutzig braungelbliche fallendes Weissgelb, ein feiner Saum un 
das ganze Halsschild und vier brandig begränzte, durch ihr verwaschenes, auf den Zwischengrund überfliessendes Randpigment gewissermaassen auch die Grundfarbe trühende Längsflecke schwarz; die äusseren grösseren eiförmig, je vor der Mitte der Flügeldecken ain Hinterrande liegend, die kleineren mittleren mehr gestreckt, nach der Mitte des Halsschildes vorgerückt, und dadurch mit jenen einen auf dem Hinterrande ruhenden Bogen bildend. Das Schildchen schräg ansteigend, schmal und gestreckt, doppelt länger als breit, mit länglichem Vordergrübchen, glänzend schıvarzbraun. Die Deckschilde gestreckt walzenförmig, um die Hälfte länger als breit, hinter der Wurzel noch ein wenig verbreitert und dann hinterwärts in sanftem Bogen verschmälert, und dadurch deı elliptischen Unriss des Körpers schliessend; der Rücken vom Schildchen ab hinterwärts sehr flach abwärts gekrümmt, die breiten und flachen Schulterbeulen innerseits durch einen dreieckigen Eindruck abgesetzt, die Seitenlappen kräftig mit breit umgeschlagenem Rande. Die Punktstreifen sehr regelmässig, die oberen bis zur Spitze deutlich, die seitlichen hinter den Schulterbeulen merklich abgeschwächt, und erst der neunte über dem Seitenlappen wieder etwas stärker eingedrückt. Die Zwischenräume lreit und flach, fein und zerstreut punktirt, lackglänzend; die Farbe weisslich gelb, ein vorn, aussen und hinten scharf begränzter, auf der Schulterheule zu einem grossen rundlichen Schulterflecke erweiterter Saum jeder Flügeldecke rein schwarz. Derselbe umfassit auch das erste und letzte Drittel der Naht, und erweitert sich vor tnd in deren Mitte zu einem breiten, bis zum er'sten Punktstreifen reichentlen Nahtwische, dessen Färbung sich dadurch aber gleichzeitig bis zum hell Zimmtbräunlichen abschwächt. Ausserdem aber trägt jede Flügeldecke noch zwei schwarze Flecke, der äussere etwas quer gezogene liegt hinter der Mitte ausserhalb des sechsten Streifens und erreicht zuweilen den Seitenrand, der innere auf der Milte, zwischen dem zweiten und füıften Streifen, zuweilen nach der Naht zu derartig überfliessend, dass er durch einen ganz schwachen bräunlichen Schatten mit dem Nahtwisch zusammenhängt. Alle vier Flecke bilden solcherweise gleichfalls einen in der Mitte nach voru gekrümmten Bogen, dessen Zusamnenhang auf der Naht durch deren wischartige Erweiterung bewirkt wird. Das Pygidium fein runzlig punktirt, weisslich gelb; Unterseite und Beine einfarbig lehmgelb. Das letzte Segment des 
\& mit einer breiten und tiefen, länglichen, glänzenden Grube, das ơ unbekannt.

Aus Venezuela (Moritz im Mus. Vindob., auch im Mus. Clark vorhanden).

S. 234. n. 34. Cr. bis - septemguttatus m. Das $\delta$ dieser Art, gleichfalls aus Columbien stammend, findet sich im Mus. Clark, und weicht von dem $q$ kaum anders $a b$, als durch die dunklere Färbung. Die Grundfarbe ist dunkel rostroth, die Zeichnung nicht weiss sondern gelb, und derartig tiefer gefärbte Stücke möchte ich für die Grundform halten. Das letzte Hinterleibssegment ist leicht quer niedergedrückt.

S. 239. hinter n. 36. Gr. turbatus m. ist als neue Art einzuschalten :

$36 \mathrm{~b}$ (100). Cr. bambalio m. Oben gelb, ein dreifach gekreuzter Fleck des spiegelglatten Halsschilds, das Schildchen, der Saum und zwei Fleckenbinden der Flïgeldecken mit einem Hinterfleck derselhen schwarz, Unterseite und Beine schwarz- und gelbbunt; die Punktstreifen derb, hinter den Schulterbeulen gestört und der achte bald abgerissen, mit flachen, mässig glänzenden Zwvischenräumen. L. 1 1/2-21/3 "'; Br. 1-1 $1 / 6$ "'.

Eine schöne und zierliche, mir bis dahin anderweit nicht zu Gesicht gekommene Art. Der Kopf flach, mit kurzer, aber deutlicher Stirnlinie, das oben deutlich abgesetzte Kopfschild wenig eingezogen, die Stirn durch die langgestreckten, breit aber nicht tief ausgebuchteten Augen besonders bei dem $\delta$ oben sehr verengt. Die Oberfläche glatt, die Farbe hellgelb, Nacken, Stirnlinie, Fühlerhöcker und der untere Rand des Kopfschildes dunkler gebräunt. Die Fühler dünı und schlank, die unteren Glieder gleiclifalls gelb, die oberen je nach der stärkeren Zeichnung vom Halsschild und Deckschildeı mehr oder weniger geschwärzt. Das Halsschild doppelt breiter als lang, mit der grösseren Vorderhälfte stark quer übergewölbt, auch hinterwärts wieder etwas abwärts gekrümmt, über den scharf rechtwinkligen Vorderecken breit zusammengedrückt und dadurch verschmälert, die Seiten gerandet, nach vorn in flachen Bogen zusammengeneigt; die Hinterecken kurz und breit zugeschärft, durch einen Schrägeindruck etwas aufgetrieben, der tief eingesenkte Hinterrand jederseits doppelt ausgebuchtet, mit kurzem aber deutlich doppelt ausgerandetem Mittelzipfel; vor letzterem jederseits ein kurzer, tiefer Quereindruck. Die Oberfläche spiegel- 
glatt. Die ursprüngliche braune Färbung durch Ausdehnung der gelben Rand- und Fleckenzeichnung soweit zusammengescliwunden, dass von ihr nur ein breiter, rautenförmiger Mittelfleck, dessen vier Zipfel sich bis zu den Ränderı des Halsschildes verlängern, und jederseits eine den langen Querarm durchkreuzende schmale Längsbinde übrig geblieben ist; rler Hinterrand ausserdem schmal schwarz gesäumt. Das Schildchen schräg ansteigend, dreieckig und etwas länger als breit, mit kurz zugerundeter Spitze und kräftigem Vordergrübchen, glänzend sclıwarzbraun. Die Deckschilde walzenförmig, um $1 / 3$ länger als breit, hinter der nach vorn abfallenden Wurzel etwas ansteigend, die eckigen Schulterbeulen innerseits durch einen schmalen Längseindruck abgesetzt, die Seitenlappen von mässiger Stärke. Auch die Punktstreifen mässig, die Hinterhälfte des sechsten sehr gelockert, der siebente in der Mitte unterbrochen, und der achte bald hinter der Schulterbeule abgerissen, sodass hier ein breites, hinter der Mitte in einem ziemlich breiten Zwischenraum auslaufendes Feld gebildet. Die Zwischenräume kaum flach gewölbt, glatt, nur der vierte bis sechste auf dem vorderen Drittel durch grobe, die hier etwas gröberen Punkte in den Streifen trennende Querbrücken und Querrunzeln zerrissen. Die Farbe hellgelb init schwarzem Saume der Flügeldecken, und drei mehr oder weniger ausgebildeten Fleckenlinden; die erste vor der Mitte, aber den Seitenrand nicht erreichend, zickzackförmig, mit zwei nach vorn vorspringenden Ecken, deren äussere die Schulterbeule mit einschliesst; die zweite hinter der Mitte, aus einem gemeinsamen Nahtfleck und jederseits zwei Flecken bestehend, deren innerer auf dem dritten und vierten, der äussere auf dem breiten vorletzten Zwischenraume liegt; die dritte endlich ein grösserer Querfleck auf der Wölbung, da wo der dritte, vierte, fünfte und siebente Streifen zusammentreffen; alle diese Zeichnungen aber tiefer geschwärzt als die des Halsschildes. Das Pygidium fein punktirt, gelb mit schwarzer Mittellinie und fein geschwärztem Rande. Die Unterseite schwarz, die Seiten des Hinterleibes, der Mittelzipfel des ersten Ringes, die Mittelbrust und die scharfen dornigen Hinterenden der Vorderbrust gelb. Auch die Beine gelb, die Mitte der Schenkel breit schwärzlich geringelt, auch die Aussenseite der Vorderschienen mit den Vorderfüssen gesclıwärzt. Das letzte Segment des $\delta$ einfach, das $\&$ mit einer grossen halbkugeligen Grube.

Vom Magdalenenflusse in Columbien (Mus. vom Bruck). 
S. 246. hinter n. 39. Cr. consentaneus Dej. ist als neue Art einzuschalten :

39 b (101). Cr. bullatus m. Gelbbraun mit gelbbuntem Kopfe, der Vorderrand, vier Seiten- und zwei schräge Hinterflecken des dicht runzlig punktirten Halsschildes mit dem Schildchen und drei unterbrochenen Querbinden der Deckschilde hellgelb; die Punktstreifen derb, hinten furchig eingedrückt, mit schmalen flachen, seitlich flach gewölbten Zwischenıäumen. L. 2"'; Br. 11/6"'.

Der Kopf flach gewölbt mit stark eingezogenem, oben deutlich abgegränztem Kopfschilde und undeutlicher Stirnlinie, auf dem dunkeln Theile leicht runzlig punktirt, lackglänzend. Die Farbe honiggelb, ein unterwärts verbreiterter, die Augenbuchten mit ausfüllender, verwaschen begränzter Raum längs den inneren Augenrändern und ein leicht schwielig erhöhter Längsfleck über dem Kopfschilde heller weisslichgelb und punktfrei; die langgestreckten, auch sehr breit aber nicht tief ausgebuchteten, (bei dem ơ) oben sebr stark genäherten Augen schwarz. Die Fühler von mehr als halber Köl'perlänge, oben schwach zusammengedrückt und kaum erweitert, schlank; das Endglied mit seinem kurzen Fortsatze noch etwas länger als das fünfte, die Farbe hellgelh, die unteren Glieder durchscheinend, die oberen angedrückt weisslich behaart und abstehend gewimpert. Das Halsschild etwa $2 \frac{1}{2}$ mal breiter als lang, mit der grösseren Vorderhälfte stark kugelig übergewölbt, nach den tief eingezogenen, rechtwinkligen Vorderecken zu stark verschmälert, die gerandeten Seiten nach vorn stark zusammengekrümmt, und über ilrrer Mitte je ein kräftiger Quereindruck. Die Hinterecken breit zugespitzt und kurz ausgezogen, durch einen schwächeren Schrägeindruck leicht aufgetrieben, der Hinterrand fein gesägt, jederseits breit ausgebuchtet, mit deutlich doppelt ausgerandetem Mittelzipfel; vor letzterem noch zu jeder Seite ein schmaler, kurzer Quereindruck. Die Oherfläche dicht runzlig punktirt mit mässigem Lackglanze, honiggell); ein schmaler, in den Vorderwinkeln zu einem grösseren Flecken erweiterter Vorderrand, ein grosser Fleck jederseits im Hinterwinkel und zwei Schrägflecke vor der Mitte des Hinterrandes in zienrlich scharfer Begränzung weisslichgelb. . Das Schildchen schı̈̈g ansteigend, fast gleichseitig dreieckig, hinten kaum abgestutzt, mit dentlichem Vordergrübchen, honiggelb mit verwaschen hellerem Mittelfelde. Die Deckschilde aus breiter Wurzel hinterwärts leicht verschmälert, flach walzenförmig mit breit 
abgeflachtem Rückeu und hinten sehr sanft abfallender Wölbung; auch die Schulterbeulen ziemlich flach, die Seitenlappen nur schwach entwickelt, und über ihnen die Deckschilde leicht zusammengedrückt. Die Punktstreifen deutlich, vorn bis über die Mitte hin aus vereinzelten groben und grübchenartigen Punkten bestehend, welche auf dem letzten Drittel schwächer und melır in die Länge gezogen, aber in deutliche Längsfurchen eingegraben sind: bei dem neunten Streifen tritt diese Furchenbildung schon von rer Mitte ab hervor. Bei dem Beginne jener Furchen laufen der erste und zweite Streifen in die erste derselben aus, und eben daselbst verbindet sich der fünfte mit dem sechsten, wälırend der siebente schon bald hinter der Sclıulterbeule abbricht. Die Zwischenräume gewülbt, hinten zwischen den Furchen und die beiden seitlichen schon fast von dem Seitenlappen ab rippenförmig erhöht, gleichfalls lackglänzend. Die Farbe honiggelb, Wurzel und Spitze weissgelb; ausserdem zeigt jede Flügeldecke drei unterbrochene, eigentlich aus theilweise zusammenfliessenden Flecken gebildete weissgelbliche Querbinden, die erste zwischen Schulterbeule und Naht, durch das dunkle Innere der Grübchen unterbrochen, und stellenweise mit der Färbung der Wurzel, auch mit der zweiten Binde zusammenhängenıl; die zweite, breitere, schliesst sich nach Aussen an das hintere Ende des an seinem Kiele und umgeschlagenenı Seitenraurle gleichfalls weisslichen Seitenlappens an, und zieht sich, gleich der ersten durch die Grübchen zerrissen, über die Mitte der Deckschilde hin; die dritte endlich liegt auf der Wölbung und besteht aus einer etwas gekrümmten Reihe von sieben weissen, auf den Rippen liegenden und durch die dunkel verbliebenen Furchen getrennten Längsfleckchen, von denen der zweite und mehr noch der vierte etwas stärker nach vorn gerückt sind. Das Pygidium grob runzlig punktirt, dünn behaart, gelb, jederseits mit einem weisslichen Schrägflecke; auch Unter'seite und Beine gelb, mit sehr kurzer und dünner, weissliclıer Behaar'ung, Schulterblätter, Vorderhüfteı und Vorderbrust gelb, die Hinterenden der letzteren sehr kurz und breit dreieckig zugespitzt. Das leizte Segment des $\delta$ in ter Mitte mit einem sehr leichten rundlichen Eindruck, das $q$ unbekannt.

Aus Neu-Granada (Mus. Clark).

S. 248. hinter n. 40. Cr. topiarius m. ist als neue Art einzuschalten:

$40 \mathrm{~b}$ (102). Cr. simplicipennis m. Schwarz mit stroh- 
gelben Fühlerwurzeln und Deckschilden; das Halsschild deutlich aber zerstreut punktirt, die Punktstreifen derb, hinten leicht furchig eingedrückt, mit oben flach, seitlich stärker gewölbten Zwischenräumen. L. $2^{\prime \prime \prime} ;$ Br. 11/12"“.

Ungeachtet des etwas fremdartigen, bei genauerer Betrachtung jetoch nur in der einfachen Färbung von Halsschild und Deckschilden sich aussprechenden Habitus ist diese Art doch den vorhergehenden nalie verwandt und von denselben nicht zu trennen. Der Kopf flach mit leicht eingedrückter Stirn, ziemlich grob und dicht punktirt mit mässig glänzendem Zwischengrunde, unten mit kurzen, abwärts gerichteten greisen Härchen besetzt; das etwas eingezogene Kopfschild durch eine deutliche Querlinie abgesetzt. Die Farbe schwarz, Oberlippe und Taster strohgell, die langgestreckten, breit aber nicht tief ausgebuchteten, (bei dem ठ) oben ziemlich weit getrennten Augen greis. Die Fühler von mehr als halber Körperlänge, schlank aber kräftig, oben wenig zusammengedrückt und verbreitert, unten strohgelb, ohen rauchgrau mit dünner angedrückter greiser Behaarung. Das IIalsschild doppelt breiter als lang, in der Mitte hoch quer aufgewölbt und von da mit nach voru stärkerer, hinterwärts flächerer Krümımung abfallend, vorn durch die stark eingezogenen scharf rechtwinkligen Vorderecken merklich verschmälert, die gerandeten Seiten nach vorn in breiten Bogen convergirend, über der Mitte leicht quer zusammengedrückt; die Hinterecken kurz und breit; der Hinterrand jederseits sehr tief ausgeschnitten, mit breitem, stark vorgezogenem, doppelt ausgerandetem Mittelzijfel. Die Oherfliche deutlich aber nicht sehr tief narbig punktirt, mässig glänzend, rein schwarz. Das Schildchen mässig ansteigend, eben so lang wie vorn breit, hinten abgestutzt und etwas verschmälest, mit deutlichem Vordergrübchen, rein schwarz. Die Deckschilde etwa um $1 / 3$ länger als breit, aus dem Walzenförmigen hinterwärts sehr wenig verschmälert, längs der Wurzel quer niedergedrückt, der Rücken abgeflacht mit hinten sehr sanft abfallender Wölhung. Die Schulterbeulen gross aber nur flach, auch die Seitenlappen schwach, aber mit sehr breitem umgeschlagenem Rande. Die Punktstreifen schrr regelmässig, fast bis zur Wölbung groh, und aus rereinzelten grübchenartigen, durch deutliche Querbrücken getrennten Punkten gebildet, rom Beginne des letzten Viertels ab plötzlich feiner, mehr gestreckt, dichter zusammengerückt und in schwache Lälngsfurchen eingedrückt, die des neun- 
ten und zelnten Streifens üherhaupt schon von vorn ab schwächer und auch dichter gestellt. Der erste und zweite laufen beim Beginne der Furchen in der ersten derselben zusammen, während der fünfte und sechste daselbst abbrechen. Der Zwischengrund vorn stellenweise durch die übergreifenden Querbrücken zwischen den Punkten uneben, hinten sich zu deutlichen, flach gewölbten Zwischenräumen gestaltend, von denen der achte und neunte sich als leichte Längsrippen etwas stärker emporheben. Die Farbe hell strohgelb mit mässigem Glanze. Pygidium und Unterseite grob runzlig punktirt, diese schwarz, jenes nebst dem letzten Bauchringe und dem Hintersaume der vorhergehenden Ringe schmutzig gelbbraun. Das Prosternum grob gerunzelt und uneben, mit breit dreieckigen, scharf zugespitzten Hinterenden. Das letzte Segment des $\delta$ tief quer eingedrückt, das $q$ unbekannt.

Aus Brasilien (Mus. Clark, und hier mit dem Namen $\mathrm{Cr}$. binotalus Dej. bezeichnet, dessen Bedeutung mir vollständig unklar ist).

S. 269. n. 52. Cr. flagitiosus m. Einen im Mus. Clark unter dem Namen Cr. nigroplagialus Guér, vorhandenen und mit der Vaterlandsangabe: Taiti versehenen Käfer kann ich nicht von dem von mir beschriebenen Cr.flagiliosus aus Peru unterscheiden. Guérin's Beschreibung seiner Art lässt sich auch sehr wohl auf den letztgenannten Käfer deuten, und ehen so wenig hat das Vorkommen eines Peruanischen Käfers auf den Gesellschaftsinseln etwas an sich Unwahrscheinliches; dasselbe würde vielmehr nur die von mir schon anderswo (Linn. Ent. XIII. S. 9) hervorgehobene Thatsache bestătigen, dass auch für die Cryptocephalen-Familie die Fauna der kleinen ostoceanischen Inseln und Iuselgruppen viel mehr von der westamerikanischen, als von der continentalaustralischen ablıängig ist.. Das in neuester Zeit bekannt gewordene Vorkommen einer kleinen Form echter Cryptocephalen mit hinten gelapptem Halsschilde auf deı Firdschi-Inseln bietet dafur einen neuen Beweis.

Die Benennung. der bezeichneten Art ist deshalb in Cr. nigroplagialus Guérin umzuändern, und ihr das Citat Revue zoolog. 1850. p. 121. n. 155 beizufügen. Der bei einem andern, gleichfalls im Mus. Clark vorhandenen Stücke angegebene Fundort Columbien heruht olne Zweifel auf einem Irrthum, da die Heimath des Käfers in Peru durch die übereinstimmende Angabe des Mus. Baly und Deyr. ausreichend verbürgt scheint. 
S. 273 ; hinter 11. 53. Lir. cousputus m. sind als neue Arten einzuschalten:

53 b (103). Cr. bigatus m. Metallisch-schwarzblau, zwei Stirnflecken, der Vorder- und Seitenrand mit zwei schrägen Hinterflecken des. äusserst fein gerunzelten Halsschildes und einer seitlichen Längsbinde der Flägeldecken gelb; die Punktstreifen deutlich, der sechste abgekürzt und der siebente fehlend, mit seitlich slark gewölbten, glänzenden Zwischenräumen. L. 1"'; Br. 2/3"'.

Eine kleine und zierliche Art, die mir zwar nur in einem einzigen und nicht gut erlaltenen Stücke vorliegt, aber auch nach diesem mit keiner anderen verwechselt werden kann. Der Kopf flach gewölbt mit undeutlicher Stirnlinie und stark eingezogenem, oben durch eine Querlinie, seidlich durch scharfe Kanten abgesetztem Kopfschilde, matt schwarzblau; das Kopfschild mit den Wangen, unı jederseits ein dreieckiger, bis in die ziemlich tiefen Augenluchten hineinreichender Stirnfleck gelb. Auch die Oberlippe schmutzig gells mil gebräunter Mitte, und die Tasterenden hell bräunlichıelb. Die Fühler von mehr als halber Körperlänge, derb und kräftig, die fünf unteren Glieder röthlichgelb mit gebräunter Oberseite des dritten bis fünften, die oberen schwarz, angedrückt greisbehaart und an den Spitzen einzeln abstehend gewimpert. Das Halsschild mit mehr als halber Länge vorn kugelig übergewölbt, auch hinten wieder etwas gekrümmt; die Seiten fein gerandet, in breiten Bogen nach den scharf rechtwinkligen, mässig eingezogenen Vorderecken hin zusammengeneigt, die kurzen Hintereclien breit spitzwinklig zugeschärft, etwas abwärts gedrückt, der Hinterrand jederseits nur mässig ausgebuchtet, deutlich eingesenkt, mit doppélt ausgerandetem Nittelzịpfel. Die Oberfläche äusserst fein gerunzelt und daher ziemlich glänzend, schön metallischschwarzblau, der in den Vorderecken zu einem breiten Flecke.erweiterte Vorder- und ein schmaler, weniger gut begränzter Seitenrand mit zwei hintereu, vor dem Schildchen zusammenstossenden Schı̈äglecken hell röthlichgelb. Das Scliildchen sclı̈äg ansteigend, dreieckig und um die Hälfte länger als breit, hinterwärts mil gebogenen Seiten versclımälert und kurz abgestutzt, mit deutlichem Vordergrübchen, glänzend schwarzgrün. Die Deckschilde walzlich, um etwa $1 / 4$ länger als breit, ziemlich gleichbreit and hinten liurz zugerundet, hinter der ausgewulsteten Wurzel durch die tief eingegrabenen Vorderecken der Punktstreifen quer eingedrückt; die 
Schulterbeulen hilbeiförmig, innerseits durch einen tiefen dreieckigen Eindruck abgesetzt, die Seitenlappen kurz nit sehr breitem, unngeschlagenem Rande; über ihnen die Deckschilde breit quer zusammengedrückt, und dieser Eindruck lis zur Naht hinauf bemerkbar. Die Punktstreilen regelnüssig, die seitlichen und die vordere Hälfte der Rückenstreifen tief furchenartig eingedrückt, der sechste an dem Quereiudrucke ahgelsrochen und der siebente fehlend, oder eigentlich durch eine Verbreiterung des achten mit angedeutet. Die seitlichen Zwischenräume und die vortere Hälfte der oberen flach gewölbt, die hintere Hälfte dieser letzteren bei abgeschwächten Streifen abgeflacht. Die Farbe ein mässig glänzendes, auf dem Rücken mehr ins Broncefarbene spielendes metallisches Schwarzblau, die Schulterbeulen spiegelnd schwärzlichgrün; eine den neunten Zwischenraum vom Seiteulappen, den achten schon von der Schulterbeule ab cimnehmende, die Spitze mit umfassende und vor ihrer Mitle durch einen kurzen Längsfleck auf dem breiten Zwischenraume zwischen dem fünften und achten Streifen nach Innen erweiterte Längsbinde hell lehmgelb. Pygidium, Unterseite und Beine matt schwarzblau, die Unterseite der Schenkel, die oberen und unteren Schienenenden und die Füsse schmutzig pechbraun durchscheinend. Das letzte Segment des $\delta$ mit einem flachen, rundlichen Eindrucke, das $q$ unbekannt.

Aus Columbien (Mus. Clark).

53 c (104). Cr. circumfusus m. Schwarz, das in der Mitte trüb gewölkte, glänzende Halsschild und eine Längsbinde der Flügeldecken mit Vorderlırust und Beinen gelb; die Punktstreifen derb, der sechste und siebente abgekürzt, mit oben flachen, seitlich rippenförmigen Zwischenräumen. L. $7 / 12-2 / 3{ }^{\prime \prime \prime} ; \mathrm{Br}$. $1 / 6-1 / 4{ }^{\prime \prime \prime}$.

Dem vorhergehenden nahe verwandt, aber nur halb so gross, an der Wurzel der Deckschilde stärker eingeschnürt, der Rïcken stark buckelig und auch die Bildung der abgekïrzten Punktstreifen etwas abweichend. Der Kopf flach gewölbt, das Kopfschild stark eingezogen, oben durch eine leutliche Querlinie abgesetzt, die Stirn durch die stark genäherten, breit aber nicht tief ausgebuchteten, schwärzlichen Augen sehr verengt, mit kurzer Stirnlinie. Die Oberfläche hell gelblich, mässig glänzend; Stirnlinie, Fühlerhöcher und Unterrand des Kopfschildes mit der Oherlippe etwas dunkter gebräunt, die Nundtheile schwarzlich. Die kurzeı Fühler bis zum fünften Gliede bell durchscheinend gelb, die oberen Glieder schwarz 
mit dünner angedrückter greiser Behraarung, wenig zusammengedrückt und erweitert. Das Halsschild fast cloppelt breiter als lang, in der Mitte quer aufgerwölbt, nach vorn und hinten gleichmässig abwärts gelrümmt, über den scharf rechtwinkligen, ziemlich tief eingezogenen Vorderecken verschmälert; die Seiten gerandet, nach vorn in flachen Bogen zusammenlaufend, die breiten Hinterecken spitzwinklig zugeschärft, durch einen kurzen Schrägeindruck aufgetrieben, der Hinterrand jederseits eingesenkt und ausgebuchtet, mit kurzem, deutlich doppelt ausgerandetem Mittelzipfel; vor letzterem jederseits ein kurzer Quereindruck. Die Oberfläche spiegelgłänzend gelb, in der Mitte dunkler gelb oder bräunlich in die Quere gewölkt, welcher Wolkenfleck hellere Vorder- und Seitenränder, sowie zwei lichtere Schrägwische vor dem Hinterrande als Analogon einer ähnlichen Färbung bei den verwandten Arten melnr oder weniger deutlich erkennen lässt. Das Schildchen stark schrïg ansteigend, dreieckig und etwas länger als vorn lreit, hinten kurz zugerundet, mit deutlichem Vordergrübchen, glänzend schwasz. Die Deckschilde ziemlich schmal walzenförmig, nur $1 / 3$ länger als hreit, hinter den Schultern noch etwas erweitert und damn hinterwärts in flachen Bogen zugerundet, von der Spitze des Schildchens ab nach hinten erst in flacherer, dann in stïrkerer lirümmung abfallend, hinter der Wurzelkante durch die tief eingegrabenen Vorderenden der oberen Punktstreifen quer eingedrüclit; die Schulterbeulen eifürmig, die Seitenlapłen mässig mit breitem umgeschlagenem Rande. Die Punktstreifen regelmässig und der ganzen Länge nach kenntlich, der sechste und siebente bald hinter der Schulterbeule abgerissen, der fünfte und achte lier etwas tiefer eingedrückt, der neunte in eine vertiefte Längslinie eingesenkt. Die oberen Zivischenräıme flach, der vierte schon von der Wurzel al) verbreitert und hies etwas schwielig aufgetriehen, die drei nach aussen folgenden leiclit gewölbt, und dabei alle glänzend. Die Farbe schwarz mit leicht bläulichem oder grünlichem Schimmer, ein Querfleck auf der Wurzelkante innerhalb der Schulterheule, und im Anschlusse an diesen der vierte Zwischenranm, hinter der Schulterbenle auch der breite zwischen dem füuften und neunten Streifen liegente Raum und im Anschlusse an diesen auch die breite Spitze, in trüberer Färbung auch der neunte Zwischenraum gellb, so dass dadurch eine breite, innerseits ziemlich scharf legränzte, nach aussen mehr verwaschene Längshinde gebildet wird. Seltener sind die Hinterenden des ach- 
ten und neunten Zwischenraumes trüb geschwärzt, während die Binde verwaschen bräunlich vor der Mitte auf den dritten Zwischenraum übergreift; bei Stücken mit dunklerem Halsschilde schwinclet sie grösstentheils, und es bildet sich eine etwas eigenthümlich elscheinende Form,

$\beta$. bei welcher nur auf dem Vorderende des vierten Zwischenraumes ein schmaler gelber Längsivisch, und vor der Spitze auf jeder Flügeldecke ein eben so kleiner gelber Querfleck ülırig bleibt, wăhırend die Mitte des vierten und fünften Zwischenraumes nur noch trüb bräunlich durchscheint.

Das Pygidium dicht und fein runzlig punktirt, schwarz, bei dem vorliegenden $q$ mit zwei gelben Schrägflecken an unteren Rande; die Beine hellgelb. Das letzte Segment des ठ einfach, des \& mit einer grossen, napffürmigen, glänzenden Grube.

Aus Columbien, und zwar vom Magdalenenflusse (Mus. vom Bruck).

S. 275. hinter 11. 54. Cr. plicatus m. sind als neue Arten einzuschalten:

54 b (105). Cr. patulus m. Schmutzig gelb mit schwarzen Fühlerenden, ein Querfleck des dicht und feiı punktirten Halsschildes, das Schildchen, der Vordersaum und eine Schattenbinde vor der Spitze der Deckschilde trüb metallisch grün; die Punktstreifen mässig, der sechste und siebente abgekürzt, mit flachen, seitlich flach gewölbten Zwischenräumen. L. $1-1 \frac{1}{12}{ }^{\prime \prime \prime} ; \mathrm{Br}$. $2 / 3-3 / 4 "$.

Diese Art bildet nebst den nächstfolgenden eine eigene kleine Gruppe in der vorliegenden Rotte, deren Arten sich durch einen seitlich etwas rundlich erweiterten Körper charakterisiren, während ich sie doch nach ihren übrigen Merkmalen nicht wohl als eine eigene Rotte auszusondern vermag. Bei der vorliegenden, die sich an dem grünlichen Querwische auf dem Halsschilde sehr leicht kenntlich machı, ist der Kopf flach, die Stirn der Länge nach eingedrückt, mit schärfer eingeschnittener Mittellinie; das Kopfschild eingezogen, ohen durch einen leichten Querwulst abgegränzt. Die Farbe schmutzig lehmgelb, zwischen den oberen Augenrändern gebräunt; die lang gestreckten, breit aber nicht tief ausgebuchteten und oben genäherten Augen greis, die P'unktirung kaum walırnehmbar. Die Fühler nur etwa bis zum Ilinterrande des Halsschildes reichend; das Wurzelghied lang, mit flach gewölbter Oberseite, das 
zweite länglich eiförmig, die beiden folgenden gleichlang und je nur um die Hälfte länger als das zweite, sehr düın verkehrtkegelfôrmig, das fünfte etwas länger und nach oben schon ein wenig verbreitert, die folgenden stärlier zusammengedrückt und erweitert, je noch etwas länger als das fünfte, mit fein zugespitztem Fortsatze des Endgliedes. Die Farbe der fünf urteren hellgelb mit schwach gebräunter Spitze des fünften, die sechs oberen schwarz, dünn behaart und lang abstehend gewimpert. Das Halsschild etwa $2 \frac{1}{4}$ mal breiter als lang, hinten abgeflacht, mit der grösseren Vorderhälfte stark kugelig abwärts gekrümmt, über den tief eingezogenen, scharf rechtwinkligen Vorderecken breit zusammengedrückt und dadurch stark verschmälert; die Seiten fein gerandet, von der Nitte ab in flacheı Bogen zusammengekrümmt, die scharfen Hinterecken kurz und breit spitzwiıklig ausgezogen; der Hinterrand sanft gebuchtet, mit kurzem, deutlich doppelt ausgerandetem Mittelzipfel; jederseits von diesem an Hinterrande ein kurzer, flacher Quereindruck. Die Oberfläche äusserst fein und dicht punktirt, seidenschimmernd, lehmgelb; auf der Mitte ein grosser, dunkler Querwisch, dessen Kern ins Metallischgrünliche überspielt, während die breiten verwaschenen Rïnder sich durch ein trüles Braun allmählich in die gelbliche Grundfarbe verlieren; die Mitte des Wisches ist vorn gespalten, als ob derselhe aus zwei Flecken zusammengeflossen wäre. Der Hinterrand zart schwärzlich gesäumt. Das Schildchen mässig ansteigend, dreieckig, etwas länger als vorn breit; mit deutlichem Vordergrübchen, gleichfalls trüb metallischgrün. Die Deckschilde flach walzenförmig, unı 1/4 länger als breit, seitlich etwas im Bogen erweitert, hinter der Wurzel durch die stärker vertieften Vorderenden der l'unktstreifen leicht eingedrückt; die Schulterheulen breit und flach, hinterwärts durch den Anfang des sechsten und siebenten Streifens gabelig getheilt, innerseits durch einen dreieckigen Eindruck abgesetzt; die Seitenlappen schwach, mit breitem umgeschlagenem Rande. Die Punktstreifen regelmïssig, die oberen aus tiefer eingedrückten Vorderenden bald abgeschwächt, alıer doch bis zur Spitze kenntlich, die Mitte des füuften mit dem achten und neunten stärker vertieft, lelzterer vor'n in die Schulterecke auslaufend; der sechste und siebente bald abgerissen. Die Zwischenräume oben flach, der achte und neunte nebst dem hinteren Theile des zwischen den füıften und achten Streifen liegenden flach gewölht. Die Farbe gleichfalls lehıgelb mit einem feinen dunkleren 
IVurzelsaume, auch die Naht schwach gebräunt, und auf dem letzten Drittel vine dem Halsschildswische gleichende, mauchmal jedoch weniger intensive und jederseits abgekürzte schwärzlichgrüne Querbinde, die sich aber auch wolıl bei hellerer Ausfärbung seitlich erweitert und dann wischartig längs der Naht bis zum Schildchen ausdehnt. Das Pygidiun fein gekielt und punktirt, lehmgelb mit verwaschen grüulichem oberen Rande; auch die Unterseite mit den Beinen lehmgelb, die Wurzel des ersten Bauchringes und die Mitte der Hinterbrust leicht gebräunt. Das letzte Segment des $q$ mit dem gewöhnlichen Grübchen.

Das $\delta$ ist auf der Oberseite etwas heller und glänzender, mit luellgelbem Oberkopfe, auf der Unterseite dunkler, mit einem breiten verwaschenen Querwische auf dem Pygidium, und einfachem letztem Bauchringe.

Aus Caraccas (von Herrn Wagner mitgetheilt) und Cayenne (Mus. Clark).

54 c (106). Cr. un if ormis m. Matt lehmgelh mit schwarzem Wurzelsaume der Deckschilde; das Halsscliild kaum punktirt, die Punktstreifen sehr fein, hiniterwärts erloschen, der fünfte bis siebente bald zusammenlaufend, mit flachen, glanzlosen Zwvischenräumen. L. $1 \frac{1 / 4}{t \prime \prime} ; \mathrm{Br} .{ }^{5} / 6^{\prime \prime \prime}$.

Im Habitus dem vorhergehenden nahe verwandt, aber noch etwas breiter eiförmig, und an der matten Oberfläche des einfarbig gelben Körper's und den sehr feinen Punktstreifen leicht kenntlich. Der Kopf flach, mit deutlich eingezogenem, oben durch eine feine Querlinie abgesetztem Kopfschilde; die Stirn der Länge nach breit eingedrückt, und dieser Eindruck, sowie die Fühlerhöcker und ein Hof un dieselben, der ober'e und untere Rand des Kopfschildes mit dem oberen Theile der Oberlippe schmutzig gebräunt. Der ïbrige Theil der Oberfläche matt hellgelb, etwas ins verwaschen Weissliche fallend, die grossen, breit und ziemlich tief ausgebuchteten, (bei dem $q$ ) weil getrennten Augen greis. Die Fühler von halber Körperlänge, oben nur wenig zusammengedrückt und erweitert, gleiclıfalls hellgelb. Das Halsschild doppelt breiter als lang, in der Mitte breit quer aufgewölbt, und von da uach vorn und hinten sanft abwärts gekrümmt, über den rechtwinkligen Vorderecken zusanımengedrückt und dadurch verschmälert, die Seiten fein gerandet, von der Mitte ab nach vorn in flacher Krümmung zusammengeneigt, hinter ihr leicht ausgeschweift; die Hinterecken breit 
und scharf spitzwinklig ausgezogen, der Hinterrand jederseits tief ausgebuchtet, deutlich eingesenkt, mit kurzem, undeutlich doppelt ausgerandetem Mittelzipfel. Die Oberfläche auch hier kaum sichtbar punktirt, matt lehmgelb mit zart geschwärztem Hintersaume. Das Schildchen wenig ansteigend, gleichseitig dreieckig, und durch die abgerundeten Vorderecken ins Herzförmige fallend, gleichfalls gelb. Die Deckschilde kurz und breit walzenförmig, seitlich in flachen Bogen erweitert und dadurch den elliptischen Umriss des Körpers abschliessend, im ersten Viertel der Naht am höchsten, und von da ab mit nach vorn und hinten mässiger, seitliclı steilerer Krümmung abfallend, Jängs der Wurzel nach vorn etwas eingesenkt, die halbkugeligen Schulterbeulen sowie die Seitenlappen wenig bemerkbar, mit sehr breit umgeschlagenem Rande des letzteren. Die Punktstreifen sehr regelmässig aber fein, die oberèn von der Mitte ab kaum noch bemerkbar, der neunte etwas vertieft, der fünfte bis siebente bald hinter der Schulterbeule in einen einzigen Streifen zusammenfliessend, der achte überhaupt unscheinbar. Die Zwischenrïume matt und flach, der neunte ein wenig crhölıt. Die Farbe auch hier hell lehmgelb mit zartem schwarzem Vordersaume. Pygidium, Unterseite und Beine noch etwas bleicher gelb, die Vorderbrust quadratisch mil hinterwärts etwas geschweiften Seiten, daselbst kaum ausgerandet, runzlig punktirt. Das letzte Segment des $q$ mit einer halbkugeligen Grube, das $\delta$ unbekannt.

Aus Venezuela (Moritz im Mus. Vindob.).

54 d (107). Cr. piceolus m. Schmutzig braungelb, hinterwärts etwas heller, mit schwarzem Vordersaume der Deckschilde; das Ialsschild kaum punktirt, die Punktstreifen fein, hinterwärts erlosehen, ler sechste und siebente abgerissen, mit flachen, ziemlich matten Zwischenräumen. L. $11 / 4 "$ "; Br. $5 / 6 "$ ".

Dem vorhergehenden so ähnlich, dass man leicht versucht werden kömnte, in ihm lediglich eine durch klimatische Einflüsse (z. B. anhaltende Nässe) verfärbte Form desselben zu erkennen, wozu ich nich aber doch bei dem Vorliegen von zwei ganz gleichen Exemplaren und dem Vorlandensein auch noch weiterer Abweichungen vorläufig noch nicht entschliessen mag. Bei völliger Uebereinstimnung in Grösse, Gestalt und Umriss ist ler vorliegende Kïfer zunïchst dunkler, seine Farbe ein schmutziges Bramgelb, welches auf dem Ilalsschilde am dunkelsten ist, nach hinten aber allmählich heller wird, doeh auch bei dem hellsten der beiden mir 
vorliegenden Stücke nicht die rein lehmgelbe Färbung der vorhergehenden Art erreicht. Die Schulterbeulen sind kräftiger, innerseits durch einen schmalen aber tiefen Längseindruck (bei $\mathrm{Cr}$. uniformis nur durch eine breitere, aber kürzere und flachere Vertiefung) abgesetzt, und in diesen Längseindrucke entspringt der 5te Punktstreifen, welcher, wenn auch hinterwärts abgesclıwächt, doch bis zur Wülbung verfolgt werden kann, während der sechste und siebente, bald abgerissen, jeder für sich und ohne zusammenzutreffen auslaufen. Dabei sind die Punktstreifen vorn etwas stärker als bei jenem, und wenn auch nur an der dunkleren Färbung der Punkte doch bis zur Spitze kenntlich. Alles Uebrige, auch die Grube auf

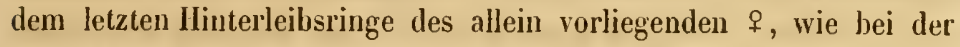
vorhergehenden Art.

Ein drittes $q$ ist etwas schmaler, zeigt gröbere Punktstreifen und einen rerwaschen lichteren Vorder- und Seitensaum, auch vor dessen Hinterrande einige hellere Wolkenflecke. Das Exemplar ist jedoch etwas verkrüppelt, olıne kiopf und auch an den Beinen beschädigt, entzieht sich deshalb einer genaueren Bestimmung, wenn es nir gleich von dem beschriebenen Käfer nicht wesentlich abzuweichen scheint.

Gleiclıfalls aus Venezuela (Moritz im Mus. Vindob.)

54e (108). Cr. li quidus m. Lelımgelb mil schwärzlichem Vordersaume der Deckschilde, Vorder- und Seiteurand nebst zwei Hinterwischen des kaum punktirten Halsschilds, und 5 Wische der Flügeldecken $(1,3,1)$ verwaschen lieller gelb; die Punktstreifen sehr fein, hinten erloschen, der sechste und siebente ahgerissen, mit flachen, wenig gläuzenden Zwischeuräumen. L. $5 / 6$ "'; Br. ${ }^{2} / 3{ }^{\prime \prime \prime}$.

Abermals den vorhergehenden im Habitus ähnlich, aber bei geringerer Grösse merklich schmaler, etwas glänzender, und in der Färbung an die gelben weisslich getropften Coccinellen erinnernd. Der Kopf flach mit wenig eingezogenem Kopfschilde und sehr feiner Stirnlinie, ohne sichtbare Punlitirung, hell weisslich getb mit geringem Glanze; ein verwaschener Längswisch auf der Mitte der Stirn, die Fühlerhöcker und deren sehr grosser Hof, und der untere Raum des Kopfschildes mit den Mundtheilen dunkler lehmgelb. Die grossen, weitgetrennten, breit aber nicht tief ausgebuchtetelı Augen greis. Die Fühler von halber Körperlänge, kräftig, oben ziemfich stark erweitert und zusammengedrückt, gleichfalls gelb, die oberen Glieder dunkler rauchgrau angeflogen. Das Hals- 
schild etwa doppelt so breit als lang, hinter der Mitte sanft quer aufgewöllıt und von da mit $2 / 3$ der Länge vorn abwärts gekrümmt, linterwärts schwächer niedergesenkt, über den rechtwinkligen Vorderecken zusammengedrückt und dadurch verschmälert; die Seiten fein gerandet, nach vorn in flachen Bogen zusammengeneigı, an den spitz ausgezogenen Hinterecken sehr leicht ausgeschweift; der Hinterrand jederseits leicht ausgehuchtet, mit kurzem, undeutlich doppelt ausgerandeten Mittelzipfel. Die Oberfläche kaum sichthar punktirt, seidenschimnernd, dunkellehmgelb, ein verwaschener Vorder- und Seitenrand und zwei kurze, auf dem Hinterrande senkrecht stehende, scharf begränzte Längsfleckchen hell weissgelb. Das Schildchen wenig ansteigent, gleichseitig dreieckig mit etwas abgerundeten Vorderecken, gleichfalls mässig glänzend lehmgelb. Die Declischilde kurz und breit walzenförnig, hinten stumpf zugerundet, hinter dem Scbildchen noch etwas aufsteigend und dann mit sanfter Krümmung hinterwärts abfallend; die selır flach eiförmigen Schulterbeulen innerseits du'ch einen ziemlich breiten aber seichten Längseindruck abgesetzt: die Seitenlappen schwach mit sehr breitem umgeschlagenem Rande, und über ilhnen die Deckschilde nur leicht zusammengedrückt. Die Punktstreifen selı fein, aber regelmässig, die oberen ron der Mitte ab kaum noch kemntlich, der neunte etwas deutlicher, der sechste und siebente sehr bald abgerissen. Die Zwischenräume flach mit mässigenı Glanze. Die Farbe auch hier dunkellehmgelb mit zart geschwärztem Vordersaume und fünf ziemlich scliarf begränzten weissen Tropfen; der vordere davon liegt an der Wurzel, etwas ausserhalb des entsprechenden Halsschildsfleclichens, und nimmt dort das Vorderende lus vierten Zwischenraums ein, dann folgen drei in einer Querreihe an Ende des er'sten Drittels der Flügeldeckenlänge, der innere auf dem zweiten, der äussere auf dem neunten Zwischenraume, der mittlere etwas kleinere, zuweilen undeutliche etwas hinterwärts gerückt am abgerissenen Ende des siebenten Streifens; endlich noch ein dreizipfliger Wisch vor der Spitze, dessen der Naht zunächstliegender Arm als vereinzeltes Längsfleckchen algerissene rscheint. Pygilium, Unterseite und Beine schmutzig lehmgelb, die Schenkelwurzeln etwas heller, die Kanten der Schienen leicht gebräunt. Das letzte Segment des $\delta$ einfach, das o unbekannt.

Ebenfalls aus Venezuela und von Moritz mitgelıracht. (Mus. Vindob.) 
54f. (109). Cr. obfuscatus m. Schmutzig lehngelb) mit schwärzlichen Fühlerenden, das kamm sichtbar punktirte, vorn und seitlich gellogerandete, zweifleckige Halsschild, das Sehildchen und ein herzförmiger Fleck um dasselbe mit der Spitze der Deckschilde und den Schenkeln trüb pechbraun; die Punkistreifen sehı fein, hinten erloschen, der sechste und siebente abgerissen, mit flachen, wenig gläızenden Zwischenräunen. I. $11 / 12{ }^{\prime \prime \prime} ; \mathrm{Br}$. 3/4"'.

Wenig länger, aber merklich breiter als der vorhergehende, und daher habituell mehr mit dem Cr. uniformis und piceolus übereinstimmend. Der Kopf flach mit wenig eingezogenem Kopfschilde und kanm sichtbarer Stirnlinie, die Stirn der Länge naclı seicht nierlergedrückt. Die Oherfläche ohne Punkte, bleichgelb, die Nitte der Stirı und die Fühlerhöcker verwaschen gebräunt, auch der Unterrand des Kopfschildes mit den Muntheilen bis auf die knochengelbe Oberlippe brämmlich: die selır breit aber nicht tief ansgebuchteten Augen greis. Die Fülıler von halber Körpperlängre, derb und kräftig, oben ziemlich breit znsammengedrückt und erweitert, die unteren Glieder gelhlich, das fünfte ınd sechste mehr oder weniger gebräunt, die oberen schwarz mil angedrückter greiser Behaarung. Das Halsschild doppelt breiter als lang, hinter der Mitte quer aufgewölht und von da ab mit nach vorn sanfterer, hinterwärts stärkerer Krümmung abfallend, ülıer den scharf rechtwinkligen, tief eingezogenen Vorderecken zusammengedlrückt und dadureh merklich verschmälert; die Seiten schwach gerandet, nach vorı in fachen Bogen zusaınmengelirünmt, mit spitz ausgezogenen Hinterecken, der eingesenkte Hinterrand ausgeschweift, mit kurzem, deutlich doppelt ausgerandetem Mittelzipfel. Die Oberfläche kaum sichtbar punktirt, seidenschimmernd, pechbraun, ein verwaschener, über der Stirn uni in den Vorderecken erweiterter Vorder- uud Seitenrand nelsst zwei hinteren Schrägflecken gelb. Das Schildchen weuig ansteigend, gleichseitig-rlıpieckig mit abgerundeten Vorderecken und deutlichem Vordergrübchen, gleichfalls pechbraun. Die Declischilde wenig länger als bıeit, von den Schultern ab hinterwärts in flachen Bogen erweitert und danu wieder zugerundet, daher der Umriss des Körpers zienılich breit elliptisch; die Wurzel etwas eingesenkt, die kurzen aber eckigen Schulterbenlen innerseits durch einen breitdreieckigen Eindruck abgesetzt, dic Seitenlappen kurz ihr umgeschlagener Rand aber' breit und' mit einer kräftigen Punktreilhe besetzt. Die Punktstreifeu vorn deutlich, aber anch fein, hin- 
terwärts bald noch mehr abgeschwächt, und die oberen von der Mitte ab nur noch an der dunkleren Färbung der Punkte keuntlich: der sechste und siebente bald abgerissen, und nur von jenem hinterwärts zuweilen noch ein schwacher Rest wahrzunehmen. Die Zwischenräume flach mit sehr geringem Glanze; die Farbe schmutzig lehmgelb, ein breit herzfürmiger, das Schildchen mit umfassender gemeinsamer Wurzelfleck und die durch lichtere Wische zerrissene Spitze der Deckschilde pechbraun. Ausdehnung und Intensität dieser Zeichnung ist jedoch nicht bei allen Stücken gleich, und es findet sich selbst eine Form

$\beta$. Bei welcher der Wurzelfleck bis auf das pechbraun verbliebene Schildchen ganz geschwunden und die Färbung der Spitze zu einem nur schwach angedeuteten Querschatten abgeschwächt ist. Die Färbung des Halsschildes jedoch bietet bei allen mil vorliegenden Stücken keine Abweichungen dar. Pygidium, Unterseite und Beine gelblich; die unteren Schenkel- und (wiewohl etwas schwächer, auch) die oberen Schienenhälften schmutzig und verwaschen pechbraun, auch der hintere Theil der Hinterbrust und die Mitte des Hinterleibes leicht gebräunt. Das letzte Segment des $\delta$ einfach, das $q$ unbekannt.

Ebenfalls aus Venezuela (Moritz im Mus. Vindob.)

54g (110). Cr. melanogastrius m. Oben gelb, Fühlerenden, Schildchen und Vordersaum der Deckschilde schwarz, unten schwarz mit gelber Vorderbrust; das IIalsschild spiegelglatt, die Punktstreifen mässig, der sechste und sielente abgekürzt, mit flachen, fein gerunzelten, etwas glänzenden Zwischenräumen. L. 1"'; Br. $2 / 3$ '"'.

Wiederum etwas schmaler als die nächstvorhergehenden, aber doch von ihnen nicht zu trennen, und durch den Gegensatz der einfachen Färbung auf Ober- und Unterseite leicht kenntlich gemacht. Der Kopl flach gewölbt, mit kurzer aber tiefer Stirnlinie ınd zu deren Seiten mit vereinzelten groben Punkten bestreut, das Kopfschild tief eingezogen und oben durch eine eingedrückte Querlinie deutlich abgegränzt: die Farbe glänzend strohgell, die Mundtheile und die Stimlinie dunkler gelbbraun, die langgestreckten, breit ausgebuchteten, oben etwas zusammengeneigten Augen schwarz. Die Fühler des einzigen rorliegenden Stückes unvollständig, anscheinend von mehr als halber Körperlänge, las zweite Glied kurz birnförmig, das dritte und vierte einander gleich, je doppelt länger 
als das zweite, die folgenden bis zum neunten wiederum einander gleich, jedes um ınehr wie die Hälfte länger als das dritte, rom sechsten ab schwach zusannmengedrückt und verbreitert; die beiden oberen fehlen. Die füıf unteren schmutzig grüulich gell mit etwas hellerer Unterseite, und efwas dunklerer oherer Hälfte les fünften, die folgenden schwarz, anliegend dünn greis behaart. Das Halsschild doppelt länger als lreit, mit der grössern Vorderlälfte stark kugelig übergewölht, über den scharf rechtwinkligen, tief eiıgezogenen Vorderecken etwas zusammengedrückt und dadurch verschmälert, die Seiten fein gerandet, in breiten auf dem vorderen Drittel sich stärker einwärts krümmenden Bogen zusammenlaufend, die Hintereclien kurz umıl breit zugeschärft, etwas abwärts gedrückit, der Hinterrand eingesenkt, breit aber nicht tief ausgelsuchtet, mit deutlich doppelt ansgerandetem Mittelzipfel. Vor letzterem jederseits ein kurzer, aber kräftiger Schrägeindruck; ein zweiter, sclıwächerer auf jeder Seite üher der Mitte des Seitenrandes. Die Oherfläche hell strohgelh mit zart geschwärztem Hinterrande, spiegelglatt. Das Schildclıen schr̈̈g ansteigend, fast doppelt länger als vorn breit, hinten kurz zugerundet, mit destlichem Vordergrübchen, schwarz, vorn verwvaschen brämulich durchscheinend. Die Deckschilde hinter der Wurzel noch etwas verbreitert, dann aus dem Walzlichen in Bogen verschmälert und darlurch den elliptischen Umriss des Körpers abschliessend, längs der Wurzel seicht quer niedergedrückt; Schulterbeulen und Seitenlappen wenig bemerkbar, mit breitem ungesehlagenem Rande des letzteren. Die Punktstreifen vorn gröber, bald aber schwächer, auf der hinteren Ilälfte etwas wellig und stellenweise schwer zu erkennen, der sechste und siebente bald abgerissen und der breite Zwischenraum dahinter mit einigen ungeordneten Punkten besetzt. Die Zivischenräıme breit und flach, fein runzlig punktirt; die Farbe gleichfalls leell strohgell mit zartem schwarzen Vordersaune. Auch Pygidium und Unterseite fein runzlig punktirt, nebst den Beinen schwarz, der Mittelzipfel des ersten Bauchrings mit der Vorder- und Mittelbrust hellgelb, die Sclnulterblätter pechbraun. Die Vorderłnust in der Mitte dreieckig aufgewulstet, mit scharf dreieckigg hervortretenden Hintereclien und zur Aufnahme der Mundtheile etwas vorgezogenem und abwärts gekiümmtem Vorderrande. Das letzte Segment des o einfach, das $q$ unbekanut.

Vou Bogota. (Mus. Clark.). 
54h (111). Cr. urbanus m. Oben ziegelroth mit schwarzen Fühlerenden, Flügeldeckensäumen und Schildchen, unten schwarz mit röthlichen Schenkełwurzeln; das Halsschild fein und ziemlich dicht punktirt, die Punktstreifen furchig eingedrückt, der sechste fehlend, der siebente abgeküızt und mit dem achten zusammenlaufend, mit flachgewöllıten glänzenden Zwischenräumen. L. 11/12 "'; Br. $3 / 4 "$.

Von dem Habitus der vorhergehenden Art, aber grösser und bei etwas melır ins Röthliche fallender Färbung an den gefurchten Deckschilden von ilı leicht zu unterscheiden. Der Kopf klein, flach gewölbt, mit scharf eingedrückter Stirnlinie und eingezogenem seitlich dureh scharfe Kanten, oben durch eine deutliche Querlinie begränztem Kopfschille. Die Oberfläche fein gerunzelt, ziegelroth, die Stirn mit einem rostbräunlichen Längsflecke gezeichnet, die Fühlerhöcker noch dunkler gebräunt und die Murdtheile pechschwarz. Die Fühler fast von halber Körperlänge, das Wurzelglied aus dünner Basis stark keulig aufgetrieben, etwa doppelt so lang wie breit, das zweite breit eiförmig, die beiden folgenten dünn verkehrtkegelförmig, je um die Hälfte länger als das zweite, das fünfte noch etwas länger und oberwärts ein wenig erweitert, die folgenden noch etwas verlängert, nach oben hin verbreitert und zusan̄mengedrückt, mit breit dreieckigem Fortsatze des Endglieds. Die fünf unteren Glierler rothgell oder auch das fünfte bräunlich, die oberen schwarz mit dünner greiser Behaarung. Das Halsschild etwa $2 \frac{1}{4}$ mal breiter als lang, vorn mit $3 / 4$ seiner Länge stark kugelig abwärts gekrümmt, über den scharf rechtwinkeligen, tief eingezogenen Vorderecken stark verschmälert; die fein gerandeten Seiten nach vorn in flachen Bogen zusammengekrümmt, die Hinterecken liurz und breit zugeschärft, der Hinterrand jederseits doppelt ausgebuchtet, innerseits der Schulterbeulen etwas eingesenkt, mit kurzem, breitem, doppelt ausgerandetem, durch eine jederseits noch etwas verlängerte Querfurche aufwärts gedrïcktem Mittelzipfel. Die Oberfläche fein aher ziemlich dicht junktirt, mässig glänzend, einfarbig ziegelroth mit feinem, schwarzem Hintersaume. Das Schildehın länglichlherzförmig, mässig ansteigend, mit deutlichıem Vordergrübchen, schwarz. Die Deckschilde um 1/3 länger als breit, hinter dem Schildchen noch etwas ansteigend und damn hinterwärts mit sanfter, seitlich mit stärkierer Krümmung abfallend, hinter der Wurzel durch die vertieften Vorder'enden der Punkt- 
streifen seicht quer eiugedrückt. Die Schulterbeulen sclımal und flach, die Seitenlappen mässig, mit gradlinig nach den Schulterecken verlaulendem Vorderrande, und über ilmen die Deckschilde nur leicht quer zusammengedrückt. Die Punktstreifen sehr regelmässig, aus dicht zusammengedrängten Punkten gebildet, und in rorn tiefere, hinterwärts allmählich seichtere Lüngsfurcheı eingedrückt, aber nur der neunte bis zur Spitze auslaufend, der secliste ganz fehlend und deshall, der fünfte stark nach aussen geneigt, der siebente auch nur aus wenigen Punkten bestehend und in dem Eindrucke über dem Seitenlappen mit dem achten zusammenstossend. Die Zwischenräume flach gewülbt, die äusseren über den Seitenlappen und die Vorderenden der oberen fast rippenförmig aufgetrieben, alle glänzend und änsserst feiı punktirt. Die Farbe ziegehroth mit feiı schwarzem Saume der Flügeldecken, ein Wisch auf den Schulterbeulen und das Innere der Punkte bräunlich, woraus sich auf dem letzten Drittel der beiden äussersten Streifen je eine zarte bräunliche Längslinie entwickelt; seltener bildet sich von hier aus eine aus vereinzclten und verloschenen Wischen bestehende dunklere Längsbinde. Pygidium, Hinterleib und Hinterbrust schwarz, Mittel- und Vorderbrust roth; die Beine schwarz mit breit gerötheten Schenkelwurzeln, auch die Füsse mehr oder weniger gebräunt. Das letzte Segment des $f$ mit dem gewöhnlichen Grübchen, das ơ unbekannt.

Aus Columbien. (Mus. Clark.)

54i (112). Cr. laetificus m. Schwarz, der Kopf und das glatte Halsschild mit Vorder- und Mittelbrust, eine ununterbrocheme Querbinde und die Spitze der Deckschilde roth; die Punktstreifen deutlich, der sechste abgekürzt, der siebente fehlend, mit tlach gewölbten, glänzenden Zwischenräumen. L. $3 / 4-11 / 12{ }^{\prime \prime \prime} ; \mathrm{Br}$. 1/2-2/3"'.

Von der Länge und dem Habitus des vorhergelıenden, aher etwas schmaler und von ihm an der abweichenden Farbung und Sculptur leicht zu ınterscheiden. Ver Kopf flach gewölbt mit feiner Stirnlinie und tief eingezogenem, olsen durch eine Querlinie begıänztem Kopliscliilde, kaum sichıtbar punktirt, matt röthlichgelb, die tief ausgebuchteten, bei dem of oben etwas mehr zusammengeneigten Augen schwarz, der Unterrand des Kopfschildes und die Mundtheile, bei dem $\delta$ auch noch der obere Nackenrand und die Imenwiukel der Augenbuchten schmutzig pechbraum. Die Fühler etwas mehr gestrecht wie bei dem vorigen, auch bei dem $q$ von 
mehr als halher Körperlänge, bei dem $\delta$ die vier, lem $q$ die fünf unteren Glieder hell rothgelb, das fünfte bei jenem schmutzig gebräunt; die oberen Glieder schwarz mit angedrückter kurzer greiser Behaarung. Das Halsschild mit $2 / 3$ seiner Länge vorn sanft übergewölbt, auch hinterwärts etwas herabgekrümmt, nach vorn verschmälert; die Seiten fein gerandet, in breiten Bogen nach den scharf rechtwinkligen, ziemlich tief eingezogenen Vorderecken hin zusammengekrünmt, die Hinterecken in eine breit zugeschärfte Spitze ausgezogen und durch einen davor liegenden Schrägeindruck etwas aufwärts geschoben. Der Ifinterrand breit ausgebuchtet, nach den Hintereclien zu tief eingekniffen, mit deutlich doppelt ausgerandelem Mittelzipfel, und vor diesem die mittlere Hälfte des Hinterrandes von einer schmalen, aber deutlichen Querfurche begleitet. Die Oberfläche kaum sichtbar runzlig punktirt, glänzend ziegelroth mit zart schwarzem Hintersaume, bei dem vorliegenden $\delta$ (vielleicht nur zufällig) auf dem Nittelfelde noch ein rundlicher und verwaschener schmutzig bräunlicher Schatten. Das Schildchen schräg ansteigend, länglich dreieckig, mit deutlichem Vordergrübchen, glänzend schwarz. Die Deckschilde um $1 / 3$ länger áls breit, hinterwärts im Bogen wenig verschmälert und dann kurz zugerundet, hinter dem flach anfgewulsteten Vorderrande durch die tiefer eingegrabenen Vorderenden der Punktstreifen quer gefurcht; die länglichen Schulterbeulen innerseits durch die lang dreickig ausgezogene Vertiefung des fünften Streifens ahgeselzt, die Seitenlappen mässig, und ülser ihmen die Deckschilde breit zusammengedrückt. Die Punktstreifen dentlich, besonders vorn und an den Seiten tief eingedrüclit, der sechste abgekiurzt, der siebente ganz fehlend und nur durch eine Erweiterung des achten angedentet. Die Zwischenräume vorn und an den Seiten stärker-, auf den übrigen Theile des Rückens schwächer gewölbt, glänzend. Die Farbe schwarz, eine innerseits ahgekürzte, vom Rande bis zum zweiten Streifen reichende Querbinde auf der Mitte der Flügeldecken, unl ein breiter, nur von eimen schmalen schwarzen Saume umzogener Spitzenfleck rothgelb; bei dem $q$ ist diese Zeichnung breiter und lichter, bei dem $\delta$ schmiler und trüber, daher bei diesem auch der die Spitzenflecke trennende verwaschen schwarze Nahtsaum hreiter, und überhaupt die ganze Färbung mehr ins Dunkle fallend. Pygidium, Hinterleib und Hinterbrust schwarz, Mittel- und Vorderbrust roth, auch die Schulterhlätter rüthlichbraun. Die Beine schwarz mit gerötheten 
Schenkelwurzelı, bei dem $q$ auch die Schienenenden und Füsse trüb gebräunt. Ias letzte Segment des $\delta$ einfach, des $q$ mit der gewöhnlichen, gläızenden Grube.

Ebenfalls aus Columbien (Mus. Clark).

54 k (113). Cr. lividipenn is m. Bräunlichgell, die Fühlerenden, Knie, Parapleuren und der Vordersaum der Deckschilde schwarz, der Vorder- und unterbrochene Seitenrand mit zwei Hinterflecken des sehr fein punktirten Halsschildes, die Spitze und eine abgekürzte Querbinde der Flügeldecken heller gelb; die Punktstreifen fein, der sechste und siebente abgekürzt, mit flachen, glänzenden Zwischenräumen. L. 1“"; Br. ${ }^{2 / 3}{ }^{\prime \prime \prime}$.

In der Zeichnung der Deckschilde dem vorhergehenden, in der Sculptur und der helleren Färbung mehr dem Cr. uniformis und den verwandten Arten nahe stehend. Der Kopf flach gewölbt, die Stirn in der Mitte niederged’ückt, mit wenig deutlicher Stirnlinie; das Kopfschild tief eingezogen, quer mondförmig eingedrückt, oben durch eine deutliche Querlinie abgesetzt. Die Oberfläche ohne deutliclse Punktirung und dabei zienlich matt, die Farbe lehmgelh, der Stirneindruck, die Fühlerhöcker und die Räırler des Kopfschildes dunkler gebräunt, die laug gestreckten, breit aber nicht tief ausgebuchteten, (auch bei dem o) einander ziemlich genäherten Augen greis, die Mundtheile pechbraun. Die Fülıler nicht von halber Kölperlänge, aber kräftig; das Wurzelglied gestreckt keulig, $21 / 2$ mal länger als breit, mit abgeflachter Oberseite, das zweite schmal elliptisch, die drei folgenden einander gleich und je etwas länger als das zweite, die sechs oberen wiederum einander gleich und je noch etwas länger als das fünfte, dabei dentlich zusammengedrückt und erweitert, mil kurz dreieckigem Fortsatze des Endgliedes. Die fünl' unteren lıellgelb, die ober'en schwarz mit heller durchscheinender Wurzel des sechsten und siebenten Gliedes. Das Halsschild doppelt breiter als lang, mit der grösseren Hälfte vorn übergekrïmmıt, hiuten mehr ahgeflacht, üher den rechtwinkligen, etwas eingezogenen Vorderecken zusammengedrücki und dadurch verschmälert; die Seiten fein gerandet und in flachen Bogen nach vorn zusammengeneigt; die Hinterecken liurz und breit zugespitzt, des Hinterrand jederseits dopjelt ansgelıuchtet, mit kurzem, undeutlich doppelt ausgerandetem Mittelzipfel. Die Oberfläche fein punktirt, mit lackglänzendem Zwischengrunde, bräunlichgelb, der in der Mitte hinter- 
wärts erweiterte Vorderrand und die in der Mitte unterbrochenen Seitenränder verwaschen hellgelb, und dieselbe Färbung zeigen zwei verwaschene unförmliche Schrägflecke vor dem Hinterrande, die durch eiue hellbräunliche Querlinie vor dem Mittelzipfel verbunden sind. Der äusserste Saum des Hinterrandes zart geschwärzt. Das Schildchen schräg anstejgend, dreieckig und etwas länger als vorm breit, hinten stumpf abgerundet, mit deutichım Vordergrübcheı, glänzend schwarz, mit tief gebräunter Hinterhälfte. Die Deckschilde um $1 / 4$ länger als breit, von den Schultern ab hinterwärts noch etwas erweitert und dann in flachem Bogen wieder bis zu der lreit abgerundeten Spitze verschmälert, daher der ganze Umiriss des Körpers ziemlich schmal elliptisch; der Rücken flach gewôlbt, von der Schildchenspitze ab mit seitlich stärkerer, hinterwärts schwächerer Krürmung abfallend, hinter dem flachen Wurzelrande durch die grülıchenartigen, nach aussen hin immer stärker vertieften Vorderenden der Punlitstreifen quer eingedrïckt; die Schulterbeulen eiförmig, die Seiteulappen mässig mit breitem umgeschlagenem Rande, und über ihıen die Ieckschilde flach zusammengedrückt. Die Punktstreifen deutlich, aber aus jenen grübchenartigen Vorderenden bald sehr abgeschwächt, nur bis zur Wölbung kenntlich, wo hinter den zusammenlaufenden Enden der mittleren sich zivischen dem zweiten und neunten eine breite, punktfreie Stelle bildet; der sechste und siebente bald hinter der Schulterbeule abgerissen, der lintere Theil des achten, sowie der neunte in eine leichte Furche eingedrüclst. Die Zwischenrämme flach und glänzend, der neunte und auch die Vorderenden des oberen zwischen jenen Grübchen leicht erhöht. Die Farbe bräunlichgell mit schwarzen Vordersaume, eine innerseits bis zum dritten Punktstreifen reichende, nach innen immer mehr verwaschene Querbinde über dem Seitenlappen und die breite Spitze hellgelb, dagegen das Innere der überhaupt auf dem dunkleren Grunde grösseren aber anscheinend flacheren Punkte schmutzig geschwärzt, wodurch besonder's vorn auf dem zweiten und dritten Streifen sich ein paar kurze schwärzliche Schattenwische bilden. Das Pygidium fein runzlig punktirt, gelblich mit gebräunter, unterwärts erweiterter Mittellinie; Unterseite und Beine bräunlich gelb, das letzte Segment etwas heller, die Parapleuren schwarz, und die Schenkelenden, an den hinteren Schenkeln fast deren ganze untere Hälfte verwaschen geschwärzt. Das Prosternum grob gerunzelı, der Vorderrand in einen zur Aufuahme der Mund- 
theile ausgchöhlten Zipfel ausgezogen; das letzte Segment des $q$ mit dem gewöhnlichen Grübchın, das ठั unbekannt.

Vom Magdalenenflusse in Columbien (Mus, vom Bruch).

54 1. (114). Cr. haematopterus m. Schwarz mit blutrothem Mittelfelde der Flügeldecken, Brust, Schenkelwurzeln, Schienenspitzen und Füsse mit dem Mittelzipfel des ersten Bauchringes heller roth; das Halsschild matt, die Punktstreifen fein, fast erloschen, der sechste und siebente abgerissen, mit flachen, glänzenden Zwischenräumen. L. $1^{\prime \prime \prime}, \mathrm{Br}$. $2 / 3{ }^{\prime \prime \prime}$.

Eine durch ihre höchst eigenthümliche Färbung von allen anderen gar sehr verschiedene, nicht zu verkennende Art. Der Kopf flach gewölbt, mit breit aher nur seicht niedergedrückter Stirn, und etwas eingezogenem, oben durch eine deutliche Querlinie abgesetztem Kopfschilde. Die Farbe bei dem $q$ ein mattes Schwarz, welches je weiter nach unten, desto mehr ins Bräunliche übergeht; die unteren Ecken des Kopfschildes und die Mundtheile heller bräunlichgelb, die langgestreckten, breit aber nicht tief ausgebuchteten, ziemlich weit getrennten Augen greis; bei dem ơ der ganze Unterkopf mit Oberlippe und Nundtheilen heller rothgelb. Auch die Fühler bei dem ot rothgelb, bei dem einzigen vorliegenden $q$ sind dieselben nicht mehr vorlıanden. Das Halsschild doppelt breiter als lang, vorn mit der grösseren Hälfte kugelig ahwärts gekrümmt, hinterwärts leichter abfallend, über den scharf rechtwinkligen Vorderecken breit zusammengedrückt und dadurch versclımälert; die Seiten fein gerandet, in flachen Bogen znsanmengekrümmt, der Hinterrand jederseits breit ausgebuchtet, fein gesägt, mit deutlich doppelt ausgerandetem Mittelzipfel; vor dem Letzteren jederseits noch ein verloschener kurzer Schrägeindruck. Die Oberfläche matt schwarz, etwas ins Bläuliche fallend, ein schımaler und schlecht begränzter Vorder- und Seitenrand, oder doch die Vorderwinkel bis zur Mitte des Seitenrandes hin dunkel geröthet. Das Schildchen wenig ansteigend, dreieckig und etwas länger als vorn breit, mit deutlichem Vordergrübchen, glänzend schwarz. Die Deckschilcle hinter den schräg abgerundeten Schultern noch etwas verbreitert, dann hinterwärts mit selı llacher Krümmung den elliptischen Umriss des Körpers abschliessend, etwa $1 / 4$ länger als breit, längs der Wurzel kaum quer niedergedrückt, die ziemlich flachen Schulterbeulen innerseits durch einen breiten, seichten Eindruck abgesetzt; auch die Seitenlappen nur wenig ausgebildet, doch mit ziemlich XVI. 
breitem, umgeschlagenem Rande. Die Punktstreifen regelmässig, ans deutlichen Vorderenden bald abgeschwächt, so dass nur die zunäclıst an Naht und Seitenrand liegenden Streifen bis zur Spitze kenntlich bleiben, die mittleren aber schon von der Mitte ab unscheinbar werden und nur noch an ihrem geschwärzten Inneren wahruelımbar bleiben; der sechste und siebente hinter der Schulterbcule bald abgerissen, und von da ab der fünfte Streifen im Bogen nach aussen, der achte nach Innen gekrümmt, wodurch sich hier die Zwischenräume vom fünften ab fast gleichmässig erweitern. Die Zwischenräume selbst breit und flach, nur die Vorderenden des achteı und neunten leicht erhöhıt, die Oberflïche selır fein gerunzelt und daher nur mässig glänzend. Die Farbe blutroth, ein grosser dreieckiger Schildchenfleck und ein feiner, die ganze Flügeldecke oder anssen mur den umgeschlagenen Rand des Seitenlappens umziehender, in ersteren Falle atch wohl sich längs der Wurzel und dem anstossenden Theile von Naht und Seitenrand verwaschen verbreiternder Saum schwarzblaı. Bei einem Stücke erweitert sich derselbe an der Naht vor der Wölbung dreieckig bis zum dritten Punktstreifen, dieser Stelle gegenüber zeigt sich cine ähnliche obwohl schwächere Erweiterung des Seitenrandes, und zwischen beiden auf dem vierten, achten und neunten Streifen je ein linienfürmiger schwarzer Längswisch als Anfang einer hier in Entstehen begriffenen Querbinde; es könnten sich daher auch noch wohl Stücke fintlen, bei tlenen eine solche wirklich vorhanden ist und dadurch vor der Spitze ein grosser, rother Querfleck abgeschnitten wirt. Pygidium, Unterseite und Beine schwarz, Vorder- und Vittelbrust, der breite Mittelzipfel des ersten Bauchringes, die Schenkelwurzeln, Schienenenden und Fussglieder fuchsröthlich; der letzte Bauchring nebst dem unteren Theile des Pygidiums bei den ठ nur gebräunt. Die Vorderbrust in der Mitte quer niedergedrückt, hinten leicht ausgerandet, mit kurz vorspringenden Hinterccken. Das letzte Segment des ơ einlach, des $q$ mit der gewölınlichen, hier tiefen, eiförmigen und glänzenden Grube.

Aus Venezuela (Moritz im Mus. Vindob.; anch in Mus. Clark vorhanden).

S. 277 hinter n. 55. Cr. impressus mo, ist als neue Art einzuschalten:

55 h. (115). Cr. parvicollis m. Schwarzhlau mit gelben Mundıheilen, Fühlerı und Beinen, die Deckschilde hell el'zgrün; 
das Halsschild jederseits schräg eingedrückt, junktirt, die P'unktstreifen kräftig, mit flach gewöllten glänzenden Zwischenräumen. L. $3 / 4 " \prime$; Br. $5 / 12{ }^{\prime \prime \prime}$.

Ein kleiner, überaus zierlicher, besonders durch die derben Punktstreifen, von denen keiner abgekürzt ist, ausgezeichneter Käfer. Der Kopf flach gewölht, das Kopfschild oben durch eine feine Querfurche alggesetzt, und über dieser noch ein zweiter schwächerer Quereindruck, wodurch zwischen den Fühlerwurzeln ein schmales, rechteckiges Querfeld algegränzt wird. Die Oberfläche gleichmässig und ziemlich grob punlitirt, mit mattem Zwischengrunde. schwarz, leicht ins Bläuliche oder Grünliche fallend; die lang gestreckten, hreit aber nicht tief ausgebuchteten, oben weit getrennten Augen greis, Oberlippe, Mundtheile und nach den erhaltenen Resten auch die Fülıler lochgelb. Von letzteren nur die sechs unteren Glieder vorhanden; hiernach sind die Fülıler kurz, aber derh und kräftig, die Glieder vom dritten ab kaum lünger als das derb eiförmige zweite Glied; auch das erste üher der Mitte stark aufgetrieben, kaum um die Hälfte länger als breit. Das Halsschild fast dreimal länger als breit, mil der vorderen Hälfte nur leicht übergekrüımt, über den tief eingezogenen, scharf spitzwinliligen Vurderecken quer eingeschnürt, dahinter noch zusammengedrückt und dadurch verschmälert; die Seiten fein gerandet, mit den Vorderhälften leichı zusammengekrümmt; die Hinterecken kurz und breit, fast rechiwinklig, der Hinterrand jerlerseits ausgebuchtet, mit kurzen, schwach ausgerandetem Mittelzipfel; vor letzterem jederseits ein breiter, aber ziemlich tlacher, bis zu der Mitte des Seitenrandes hinziehender Schrägeindruck. Die OJjerfläche deutlich und ziemlich tief punktirt, schwarzhlau mit mässigem Glanze. I)as Schildchın niederliegend, länglich dreieckig mit kurz ahgerundetem Hinterende, glänzend schwarzgrün. Die Deckschilde gestreckt-walzenförmig mit hinten sehr flach abfallender Wölbung, hinter der Wurzel gucr niedergedrückt, die länglichen Schulterbeulen innerseits durch einen stärkeren Längseindruck abgesetzt, die Seitenlappen sclawach ausgebildet mit breitem, umgeschlagenem Rande. Die Punktstreilen sehr regelmässig, kräftig, aus grosseu, nur beim Auslaufen dler mittleren Streifeı auf der Wölbung etwas abgeschwächten Grübchen gebildet, und dadurch vorn und an den Seiten eingedrückte Längslinien bildend; die Zwischenräume dadurch flach gewölbt, glänzend erzgrüı. Pygidium und Unterseite fein runzlig punktirt, schwärz- 
lich, mit hochgelben Beinen. Das letzte Segment des ồ mit einem leichten Quereindruck, das $f$ unbekannt.

Aus Neu-Granada (Mus. Clark).

S. 280 hinter n. 57. Cr. climactericus m. ist als neue Art einzuschalten:

57 b. (116). Cr. dec orus m. Schwarz (oder braun), der Kopf, Vorder- und Seitenrand mit zwei Hinterflecken des fein und zerstreut punktirten Halsschilds, eine nach Innen abgekürzte Querbinde und die Spitze der Flügeldecken nii den Beinen gelb; die Punktstreifen derl, der sechste und siebente ahgekürzt, mit flachen, seillich flaclı gewölbten, glänzenden Zwischenräunen. L. $2 / 3-3 / 4{ }^{\prime \prime \prime} ; \mathrm{Br}$. $1 / 4-1 / 3{ }^{11}$.

Eme kleine, zierliche Art, dem vorhergehenden nahe verwandl, aber von ihm, algesehen von der Grundfärbung, besonders durch die hellen Ränder des Halsschilds und den zu einer abgekürzten Querbinde erweiterten hellen Fleck der Flïgeldecken abweiclıend. Der Kopf flacl, mit kurzer tiefer Stirnlinie, die Ungebung der Fühlerhı̈cker mit den letzteren sellsst tief gebräunt, auch die Oheriippe pechbraun, die Mundtheile schwarz, auch die langgestreckten, breit aber nicht tief ausgerandeten Augen schwärzlich greis. Die schlanken Fühler etwa von halber Körperlänge, das zweite Glied gestreckt-elliptisch, um die IIalfte länger als breit, das dritte um die Häfte länger als das zweite, und ilmm je die folgenden gleich, die oheren vom sechsten ab mässig zusammengedrückt und erweitert, mit kurz dreieckigem Fortsatze des Endglieds. Die 5 untere॥ Glieder durchscheinend rölllich-gell, die oberen schwarz. Das Halsschild etwa um die Iläfte breiter als lang, in der Mitte quer aufgewölht und von da nach vorn und hinten ziemlich gleichmässig abwärts geliümmt, über den scharf rechtwinkligen Vorderecken breit zusammengedrückt und dadurch verschmälert, die Seiten fein gerandet, nach vorn fast in geraden Linicn zusammengencigl, die llinterecken breit und scharf spitzwinklig ausgezogen, etwas aufgetrieben; der Hinterrand jederseits leicht ausgelnchtet, aber tief eingesenkt, mit liurzem, undeutlich doppelt ansyerandetem Milledzipfel; vor dem letzteren cine feine, auf jeder Seite his zu dem zweiten P'unktstreifen hinziehende Querfurche. Die Oherfläche fein und zerstreut punktirt mit spiegelglänzendem Zwischengrunde, schwarz oder tief braun, der Vorder- und Seitenrand, letzteres in den Vorder- und Hinterecken dreieckig erweitert, nebst 
zwei vor dem Hinterrande liegenden eiförmigen Schrägflecken hellgelb mit etwas brandiger Begränzung. Das Schildcheı schräg ansteigend, dreieckig und etwas länger als breit, hinten kurz zugerundet, mit deutlichem Vordergrübchen, glänzend schwarz oder bei den bräunlichen Stücken gleichfalls braun. Die Deckschilde etwa um 1/3 länger als breit, hinter den Schultern noch etwas verbreitert und dann hinterwärts flach zusammengekrümmt, daher der Umriss des Körpers nur schmal elliptisch, der Rücken von der Mitte ab hinterwärts in mässiger Krümmung abfallend, hinter der breiten, flachen Vorderkante durch die grübchenartigen Vorderenden der oberen P'unktstreifen breit quer eingedrückt, die kräftigen Schulterbeulen hinterwärts etwas erweitert, die Seitenlappen schwach mit sehr breitem ungeschlagenem Rande, und über ihnen die Deckschilde sehr merklich zusammengedrückt. Die Punktstreilen sehr regelmässig, vorn derb, hinterwärts besonders bei dem $q$ feiner, aber auch bei diesem bis zur Spitze erkenmbar, der sechste und siebente bald abgerișsen, der achte und neunte in seichte Längsfurchen eingedrückt. Die glänzenden Zwischenräume flach, die beiden seitlichen und die Vorderenden der oberen leicht aufgewölbt. Die Farbe schwarz oder bei den Stücken mit braunem Ilalsschilde gleichfalls braun, die breite aber noch von einem zarteı dunkeln Saume umzogene Spitze und eine abgekürzte Querbinde vor der Mitte hellgelb; letztere nach innen verbreitert und fast bis zum ersten Punktstreifen reichend, auf dem achten Streifen eingeschnürt, und augenscheinlich aus zwei hier einander berührenden gelben Querflecken zusammengeflossen. Das Pygidium fein runzlig punktirt, mit der Unterseite bei dem $\delta$ schwarz, dem $q$ schmutzig gelb mit geschwärzter Mitte, oder bei letzterem wenigstens der letzte Hinterleibsring hinten schmutzig und verwaschen gelblich gesäumt. Die Beine mit den Hüften und der Vorderbrust hellgelb. Das letzte Segment, des $\delta$ einfach, des $q$ mit einer grossen, gläızenden Grube.

Aus Columbien (vom Magdalenenstrom: Mus. vom Bruck; auch, von Moritz mitgebracht, im Mus. Vindob.)

S. 281. n. 58. Cr. viridi-aeneus B o h. Bei einem d dieser Art im Mus. Clark (von Petropolis in Brasilien stammend) sind die Vorderectien des Halsschilds breit hochgelb, und dieselbe Färbung zeigt auch der Kopí, bei dem nur die Augen, der Nacken und der obere Theil der Stirn bis zu den Augenbuchten mit einem 
Querwisch jederseits über dem Fühlerhöcker dunkel bleiben. Sonst aber finde ich keinen Unterschied von dem Boheman'schen Käfer. Die Fühler sind in Ganzen dünn, aber von mehr als halber Körperlänge, die fünf unteren Glieder hellgell, mit gebräunter Spitze les fünften, die sechs oberen schwarz, dünn angedrückt greishaarig. Ausserdem ist, wohl nur zufällig, bei jenem $\delta$ die Mitte der Ilinterbrust jederseits der Mittellinie goldgrün, und deutlich gegen den metallisch schwarzgrünlichen Theil der Unterseite abstechend.

S. 283 hinter n. 59. Cr. globulosus m. ist einzuschalten: 59b. (117). Cr. pusio m. Rostroth mit stalıblauen Deckschilden, Fühlerenden, Schildchen und Hintersaum des spiegelglatten Halsschilds sclıwarz; die Punktstreifen hinterwärts etwas feiner, „ler siebente und achte abgerissen, mit flachen, glänzenden Zwisclsenräumen. L. $1 / 2-2 / 3{ }^{\prime \prime} ; \mathrm{Br}$. $1 / 4-1 / 3{ }^{\prime \prime \prime}$.

Cr. pusio m. Linn. Ent. XII. 378. n, 107 !

Aus Venezuela (vom Hrn. Scriba mitgetheilt); auch auf Cuba (Gundlach!) und Portorico einheimisch (Moritz im Mus. Berol.)

Ebd. hinter n. 60. Car. auratus Fab. ist als neue Art einzuschalten:

60b. (118) Cr. pauxillus m. Nessinggelb, der Kopf mit den Fülılerı, das matte Halsschild und die Beine rothgelb; die Punktstreifen fein, schon vor der Mitte fast erloschen, der sechste bis achte abgerissen, mit flachen, glänzenden Zwischenräumen. L. $2 / 3{ }^{\prime \prime \prime} ; \mathrm{Br}, 1 / 3{ }^{\prime \prime \prime}$.

Ob dieser Käfer eine wirklich gute Art, oder nur eine Form des vielgestaltigen $\mathrm{Cr}$. auratus ist, wird sich erst nach der Auffindung mehrerer Stücke entscheiden lassen; einstweilen glaube ich ihn als solche festhalten zu müssen, weil er, auch abgesehen von seiner Heimath, sich von Cr. auratus nelen der abweichienden Farbenvertheilung noch durch einige andere Merkmale zu unterscheiden scheint. An Länge gleicht er den kleineren Stücken der geinamiten Al't, ist aber schmaler und schlanker, besonder's nach vorn hin mehr verschmälert, der Kopf (bis auf die weitgetrennten schwarzen Augen), die Beine mit der Vorderbrust, und das yanze Halsschild hellrothgelb, letzteres nur bei sehr schräger Beleuchtung mit matt grünlichem Anfluge; der hintere Saum desselben, sowie der vordere der Deckschilde, zart geschwärzl, und dabei die Oberfläche des Halsschilds kaum sichtbar gerunzelt und dadurch matt. 
Das Schildchen breit dreieckig, nit abgerundeten Seiten hinterwärts verschmälert, dunkel erzgrïn. Dic Deckschilde schmal walzenförmig, messinggell, wie bei dem verwandten Cr. auratus, mit starkem Glanze, nach der Spitze zu röthlich durchscheinend; die Punktstreifen aus kräftigen Vorderenden bald abgeschwächt und auf der biıteren Illälfte kaum noch wahrzunelımen, der sechste und siebente bald hinter der Schulterbeule ahgerissen, und der dann einwärts gerichtete achte auch nur noch eine kurze Strecke lang bemerkbar; die flachen Zwischenräume fein quer gerumzelt. Die Unterseite bis auf die rothgelhe Vorderbrust erzgriin, ziemlich glänzend, das Pygidium mit dem letzten Ilinterleibsringe wieder messinggelb. Alles übrige wie bei Cr. auratus. Das letzte Segment des $q$ mit einer rundlichen, glänzenden Grube, das đo unbekannt.

Aus Brasilien (von Bahia: Mus. Clarl).

Ebd. n. 61. Cr. aenescens m. Von dieser Art fiudet sich in Mus. Kirsch ein von Bogota stammendes $q$, welches vollständig die Länge des gewöhnlichen Cr. auratus erreicht. Sonst aber stimmt es ganz mit den bescliriebenen Stïcken des Cr. aenescens überein, und zeigt namentlich auch den schmaleren Körper, durch den diese Art am leichtesten von $\mathrm{Cr}$. auralus zu unterscheiden ist.

S. 284 hinter 11. 61. Cr. aenescens m, ist als neue Art einzuschalten:

61b. (119). Cr. humilis m. Schwarzgrüı, Fühlerwurzeln, Taster, Vorderbrust, Vorderzipfel des ersten Bauchringes und Beine gelb mit geschwäızten Knien; das Ialsschild fein genarbt, die Punktstreifen deutlich, der sechste und siebente abgekïrzt mit flachen, seitlich flachgewölbten Zwischenräumen. L. $5 / 6^{\prime \prime} ; \mathrm{Br} .1 / 3{ }^{\prime \prime \prime}$.

Wiederum dem Cr. auralus sehr nahe verwand, aber dunkel schwarzgrün, und von jenem an den kräftigen, hinten nicht erlo-. schenen Punktstreifen, wie an der stärkeren Ausbreitung der gelben Färbung auf der Unterseite und den geschwärzten Knien leicht zu unterscheiden. Der Kopf flach gewölbt, mit stark eingezogenem, oben durch eine feine Querlinie abgesetztem Kopfschilde, matt und tief pechbraun mit heller gelblichen Yundtheilen, die Stirnlinie nur schwach angedeutet, die lang gestreckten, breit ausgebuchteten, oben (bei dem + ) ziemlich genäherten Augen greis. I)ie Füller etwa von $1 / 3$ der liörperlänge, oben mässig zusammengedrückt und verbreitert, die fünf unteren Glierler hellgelb, die oheren schwärzlich mit 
gebräunter Wurzel des sechsten. Das Halsschild reichlich doppelt breiter als lang, vorn mit mehr als halber Länge stark kugelig übergekrümmt, auch hinterwãr'ts wieder etwas abwärts geneigt, über den schırf rechtwiukligen Vorderecken zusammengedrückt und dadurch verschmälert, die Seiten fein gerandet, nach vorn in breiten Bogen zusammengeneigt, die kurzen Hinterecken ljreit und scharf dreieckig ausgezogen, der Hinterrand breit ausgesclnnitten, seitlich eingesenkt, mit deutlich doppelt ausgerandetem Mittelzipfel, und vor letzterem jederseits ein kurzer, hinterwärts von einem feinen Fältchen begränzter Schrägeindruck, beide vor dem Schildchen zu einer hogenförmigen Querfurchı zusammenfliessend. Die Oberfläche vorn feiner-, hinterwärts stärker genarbt, mit schwachem Glanze; die Farhe dunkel sclıwarzgrün, die Vorderecken verwaschen pechbräunlich durchschimmernd. Đas Schildchen schräg ansteigend, dreieckig und etwas länger als vorn breit, hinten kurz abgestutzt, mit sehr deutlichem Vordergrübchen, gleichfalls glänzend schwarzgrün. Die Deckschilde walzenförnig, um die Häfte länger als breit, hinter der aufgetriebenen Wurzelkante durch die grübclıenartigen Vorderenden der Punktstreifen tief querfurchig eingedıückt, über den schwachen Seitenlappen nochmals breit quer zusammengedrückt, und dieser Quereindruck bis zum fünften Punktstreifen bemerkbar; die Schulterbeulen nur schwach ausgebildet. Die Punkitstreifen sehr regelmässig, auf dem vordern Viertel derb und kräftig, und der sechste und siebente an dessen Ende abgerissen; von da ab werden die Streilen feiner, ihre Punkte mehr in die Länge gestreckt, und die Zwischenräume breiter und flacher; die Streifen selbst aber bleiben bis zur Spitze deutlich, wobei der achte und neunte Zwischenraum sich vom Seitenlappen ab sanft empor heben. Die Farbe auch hier glänzend schwärzlich grün. Pygidium und Unterseite fein gerınzelt, sehr dünn behaart, nur die Parapleuren stärker punktirt. Die Farbe schwärzlich, der letzte Ring, die Vorderhälfte des ersten und die Ilinterbrust ins trüb pechbräunliche fallend, die Vorderzipfe] des ersten Ringes heller gelb. Die Beine mit den Hüften, sowie die Vorder- und Mittelbrust gleichfalls hellgelb mit schnnutzig geschwärzten Kínien; die Vorderbrust breiter als lang, grerunzelt und in der Mitte quer eingedrückt, linten leicht doppelt ausgebuchtet mit stärker vorspringenden Hinterecken. Das letzte Segment des $q$ mit einer eiförmigen, glänzenden Grube, das $\delta$ unbekannt. 
Aus Brasilien (von Bahia: Mus. Clark).

S. 293 hinter n. 66. Cr. consobrinus m. ist als neue Art einzuschalten :

66 b. (120). Cr. paleaceus m. Ohen strohgelb, Kopf, Fühlerenden und Schildchen schwarz, unten schwarz, die Schenkelwurzeln und der Rand des Hinterleibes gelblich; das Halsschild glatt, die Punktstreifen sehr grob, mit rippenförmigen, ziennlich glänzenden Zwischenräumen. L. $13 / 4{ }^{\prime \prime \prime}$, Br. $1 \frac{1}{2} 2^{\prime \prime \prime}$.

Von dem Habitus des nächstfolgenden $\mathrm{Cr}$. minialus, aber etwas kleiner, mit sehr schwachen Seiteneindrücken des Halsschildes, aber durch den ganzen Körperbau und besonders die Gestalt des Schildchens als hierher gehörig bezeichnel. Der Kopf flach, das Kopfschild oben durch eine sehr schwache Bogenlinie abgesetzt, aber nicht eingezogen, die Stirn nur in den etwas niedergedrückten breiten, aber niclıt tiefen Augenbuchten fein-, doch dicht und deutlich punktirt, schwarz mit mässigem Glanze, Oberlippe und Mundtheile pechbraun, die langgestreckten Augen greis. Die Fühler des einzigen vorliegenden Stückes unvollständig, anscheinend sehr lang, da schon die noch vorhandenen unteren acht Glieder über die Mitte des Körpers hinausreichen, das dritte und vierte selı dünn und langgestreckt, je fast viermal länger als das fast kugelige zweite, das fünfte fünfmal länger, oben schon etwas verbreitert, was bei den folgenden noch in viel stärkerem Grade der Fall ist, diese folgenden sich allmählich wieder verkürzend, aber doch das achte noch $4 \frac{1}{2}$ mal länger als das zweite. I)ie Farbe der vier unteren Glieder schmutzig gelb mit je einem schwärzlichen Wische auf der oberen Seite, das fünfte schmutzig pechbrauı, die folgenden schıvarz. Das Halsschild mit 2/3 seiner Länge vorn breit kugelig übergewölbt, über den tief eingezogenen, scharf rechtwinkligen Vorderecken zusammengedrückt und dadurch verschmäłert, die Seiten besonders hinterwärts breit gerandet, nach vorn fast in graden Linien zusammenlaufend, die Hinterecken kurz und breit ausgezogen, der Hinterrand eingesenkt, jederseits breit ausgebuclitet, fein aber dentlich gesägt, mit etwas zusammengedrücktem, deutlich dopjelt ausgerandetem Mittelzipfel. Auf den Mittelfelde jederseits ein schwacher, gegen die Mitte des Seitenrandes gerichteter Schrägeindruck. Die Farhe ein schmutziges aber stark glänzendes Strohgelb ohne sichtbare P'unktirung, der Seiten- und Hinterrand eben so schmutzig gebräunt. Das Schildchen schräg ansteigend und vorn quer nieder- 
gedrückt, gleichbreit und um mehr als die Hälfte länger wie breit, mit deutlichem Hinterzipfel grade abgestutzt, glänzend schwarz. Die Deckschilde kaum $1 / 4$ länger als breit, aus dem flach walzenförmigen linterwärts etwas verschmälert, vorn am Schildchen seicht niedergedrücki, die grossen, rundlichen Schulterbeulen innerseits durch einen breiten Eindruck abgesetzt; die Seitenlappen kräftig, auf dem breit umgeschlagenen Rande dicht runzlig ,punktirt, auf dem erweiterten neunten Zwischenraume durch eine dicht gedrängte feinere Punktirung niedergedrüclit, und dadurch die Deckschilde selbst deutlich quer zusammenged'ückt; rom auf der Naht hinter dem Schildchen noch ein breiterer, aber schwächerer Eindruck. Die Punktstreifen derb, aus grossen, etwas quer gezogenen, dicht an einander gerückten Punkten gebildet, bis zur Spitze kräftig; die Zwischenräume schmal und rippenförmig, theilweise durch das Eindringen der quergezogenen Punkte gekerbı, ziemlich glänzend. Die Farbe gleichfalls ein schmutziges Strolıgelb init dunkler gebräuntem Vorderrande. Ias Pygidium fein runzlig punklirt, mit einem vorn schmaleren, hinten breiteren, fast den ganzen letzten Ring einnehmenden Hinterleibsrande schmutzig gelb, und ebenso der Mittelzipfel des ersten Ringes vorn schmal gelb gesäumt. Der übrige Theil der Unterseite mit den Beinen schwarz, die Hüften und die oberen grösseren Schenkelhälften ehenfalls schmutzig gelblich. Das Prosternum fein gerunzelt, hinten breit niedergedrückt, mit kurz aber scharf dreieckig vortretenden IIinterenden, das letzte Segment des $\delta$ leicht quer niedergedrückt; das $q$ unbekannt.

Die Art findet sich inı Mus. Clark (e collect. Laferté) nur fraglich als südamerikanisch hezeichnet. Nach dem Habitus und dem Bau des Schildchens kann ich ihre Heimath nur auf den Antillen oder im nördlichen Südamerika suchen, und so mag sie hier bis auf Weiteres ihre Stelle finden.

S. 297 hinter n. 6S. Cr. ventricosus m. ist als neue Art einzuschalten :

68 b (121). Cr. rufocinctus m. Schwarz, Füllerwurzeln, Hüften, Schienen und Füsse, ein breiter, verwaschener Rand des fein punktirten Halsschildes und ein buchtiger Rand der Deckschilde roth; die Punktstreifen derb mit vorn etwas aufgetrieḅenen, hinten fein runzlig punktirten Zwischenräımen. L. 2“", Br. $11 / 4 "$.

Von der kurzen, gedrungenen Gestalt des Cr. ventricosus, und 
demselben auch durch Sculptur und Färbung uahe verwandt. Der Kopf flach, runzlig punlitirt nit mattem Zwischengrunde, das Kopfschild etwis eingezogen, oben durch eine tiefe Querfurche abgesetzt. Die Farbe schwarz, Oberlippe und Mundtheile pechbraun, die Augen langgestreckt, tief dreieckig ausgebuchtet, bei dem allein vorliegenden $\delta$ einander fast berïlırend. Die Fühler beinahe von Körperlänge, gestreckt fadenförmig, oben nur schwach zusammengedrückt und verbreitert, das Wurzelglied oberwärts schwach verdickı, reichlich dreimal lünger als breit, das zweite schmal eiförmig, etwas länger als breit, das dritte $11 / 2$ ntal länger als das zweite, das vierte so lang als das zweite und dritte zusammen, das fünfte doppelt länger als das dritte und demselben alle folgenden gleich, mit langem und schmalem, durch eine tiefe Ausrandung abgesetztem Fortsatze des Endgliedes. Die Farbe der fünf unteren durchscheinend röthlichgelb, die Oberseite des ersten und die obere Hälfte des fïnften pechbräunlich angelaufen, die oberen schwarz mit angedrückter dünner greiser Behaarung. Das Ilalsschild doppelt breiter als lang, in der Mitte hoch quer aufgewölbt und von da nach vorn und linten gleichmässig stark abwärts gekrümmt, durch die stark einwärts gekrümmten, scharf rechtwinkligen Vorderecken sehr verengt; die Seiten fein gerandet, nach vorn in breiten Bogen zusammengeneigt, die liurzen Hinterecken fast rechtwinklig zugeschärft, der Hinterrand jederseits breit und flach ausgebuchtet, scharf gesägt, mit kurzem, deutlich doppelt ausgerandetem Mittelzipfel. Vor letzterem jederseits ein tiefer, hinten ein Querfältchen emporschiebender Schrägeindruck, in dessen verlängerter Richtung sich über der Mitte des Seitenrandes noch ein schwächerer Eindruck kenntlich macht. Die Oberfläche sehr fein und zerstreut punktirt, mit spiegelglattem Zwischengrunde. Die Farbe lässt sich am besten als trübroth bezeichıen, mit einer hreiten, an den Ränder’n verwaschen begränzten schwärzlichen Querbinde. Das Schildchen breit linealisch, fast doppelt länger als breit, hinten kurz abgestutzl, mit deutlichem Vordergrübchen, glänzend schwarz. Die Deckschilde etwa um 1/4 länger als breit, breit und flach gewölbt, hinter der Vorderkante jeder'seits des Schildchens seicht niedergerlrïckt und hinten mit sanfter IVölbung alsfallend; die grossen flachen Schulterbeulen innerseits durch einen tiefen, schmal dreieckigen Längseindruck abgesetzt, die Seitenlappen unässig mit breiten, umgeschłageıem Rande, und über ihnen die Deckschilde kräf- 
tig zusammengedrückt. Die Punktstreifen regelmässig und bis zur Spitze deutlich; die Vorderenden der oberen tiefer eingegraben und dadurch ilıre Zwischenräume schmal rippenförmig aufgetrieben, letztere werden hinterwärts breiter und flacher, fein runzlig punktirt, mit mässigem Glanze. Die Farbe schwarz, ein breiter, die Spitze und die beiden äusseren Zwischenräume umlassender Rand der Deckschilde hell rothgelb und hinter den Schulterbeulen buchtig bis zum sechsten Streifen erweitert; der änsser'ste Saum von Spitze und Seiten nebst dem umgeschlagenen Rande der Seitenlappen wieder schwarz. Pygidium und Unterseite fein runzlig punktirt und dünn weissbehaart, gleichfalls schwar', die Beine mit den Hüften trüb ziegrelroth, nur die Schenkel bis auf die verwaschen gerötheten Enden wieder schwärzlich. Das letzte Segment des $\delta$ mit einer flach niedergedrückten, glänzenden Stelle; das $q$ umbekannt.

Aus Brasilien (Minas Geraes: Mus. Clark).

S. 301 hinter n. 70. Cr. pentagrammus m. ist als neue Art einzuschalten:

70 b. (122). Cr. sphacelatus m. Strohgelb mit gebräunter Stirn, das Schildchen, ein schräger Schulterstreifen und eime hinten unterbrochene Längshinde der Flügeldecken mit der Mitte der Hinterbrust schwarz; das Halsschild spiegelglatt, die Punktstreifen deutlich, mit flachen, glänzenden, etwas querrunzligen Zwischenräumen. L. $3^{\prime \prime \prime}, \mathrm{Br} .1{ }^{1 / 3}{ }^{\prime \prime \prime}$.

Eine der grössten, zugleich durch ihre Zeichnung kenntlichsten Arten dieser Gruppe, von der mir zwar nur ein einziges ziemlich schlecht erhaltenes $q$ vorliegt, die sich aber doch durch ihre eigenthümliche Farbenvertheilung leicht von allen anderen unterscheiden lässt. Der Kopf flach, die Stirn durch die nahe zusammenrückenden Augen oben sehr verengt, unterwärts etwas uneben; das lang dreieckige Kopfschild seitlich durch scharfe lianten gegen die selır zurücktretenden Wangen abgesetzt, die Oberlippe wenig vorspringend. Die Farbe schmutzig braun, die Wangen und die Hitte des Kopfschildes rerwaschen gelblich, auch die Oberlippe mit den Mundtheilen knochengelb, die langgestreckten, breit aber nicht sehr tief ausgeluchteten Augen greis. Die Fühler fehlen dem einzigen vorliegeuden Stïcke, sind aber wahrscheinlich schwarz mit gelber unterer Hälfte. Das Halsschild fast doppelt hreiter als lang mit der Vorderhälfte breit kugelig übergewölbt, über den scharf 
rechtwinkligen Vorderecken flach zusanmmengedrückt und dadurch verschmälert, die Seiten breit gerandet, nach vorn in flachen Bogen zusammengeneigt, die kurzen, scharf spitzwinkligen Hinterecken etwas abwärts gedrückt; der Hinterrand leicht gebuchtel, mit der äusseren Hälfte tief eingekniffen, mit kurzem, lief doppelt ausgerandetem Mittelzipfel, und vor diesem jederseits ein schwacher, sich nach kurzer Unterbrechung gegen die Mitte des Seitenraudes hin for'setzender, aber auch hier nur flacher Schrägeindruck. Die Oberfläche spiegelglatt, strohgelb, nach vor'ı in's verwaschen Lehmgelhe ziehend, der Hinterrand zar't brandig geschwärzt. Das Schildelıen stark ansteigend, gestreckt dreieckig und etwa $2 \frac{1}{2}$ mal länger als vorn hreit, linterwärts kaum verschmälert, das Vordergrühchen fast bis zur Mitte erkembar, und auch der Hinterzipfel dentlich. Dic Farbe glänzend schwarz. Die Deckschilde um die Hälfte länger als brcit, vorn längs der Wurzel ctwas abwärts gedrückt, der Rücken alggeflacht und hinten mit kurzer, schräger Wölbung abfallend, die Schulterbenlen ạs kräftige, halbeiförmige Höcker heraustretend, auch die Seitcnlappen ziemlich lang herabgezogen, und über ihnen je ein nuldenförmiger, die Deckschilde etwas einengender Eindruck. Die Punktstreifen derb, die Punkte der mittleren (des vierten bis siehenten) etwas grösser, dichter an einander gerückt und ein wenig in die Quere gezogen, daher deren Zwischenräume brïckenartig erhöht und quer ausgezogen. Die Zwischenräume der Punktstreifen sellst flach, die mittleren etwas schmaler, die Vorderenden der oberen schwach aufgewöllot, alle stark glänzend und mit schwachen, welligen Querrumzelı bedeckt. Die Farbe strolıgelb mit schwarzem Vordersaumie, der übrige Theil der Flügeldeckeı bis auf die Seitenlappen bräunlich gesäımt, und ausserdem auf jeder Flügeldecke drei grosse schwarze Längsflecke, nämlich ein schmaler, schräger Schulterlleck, welcher an der Wurzel innerseits der Sclunterbeule beginnend letztere sammt der Schulterecke und dem Seitenlappen einnimmt, aber den tiefsten Theil des über diesem liegenden Eindrucks loräunlich durchscheinen lässt; dann eine die Wurzel nicht berülnende, auf der Nlitte nit abnehmender Intensität allmählich erlöschende Längslinie auf dem dritten Zwischenranme, und ein Längsfleck vor der Wölloung zwischen dem dritten und achten Punktstreifeu, zwischen welchem und jener Längslinie die unscheinhare Spur eines erloschenen, eine nach aussen gekrümınte, auf die Zeichnung des Cr. incomnodus hin- 
deutende Läıgsbinde darstellenden Zusammenlanges walırzunehme» ist. Pygidlium und Unterseite fein runzlig punktirt, dümı gelbhaarig, hell strohgelb, die Hinterbrust zwischen den Parapleuren schwarz, ein schmaler Hinter- und ein hreiterèr Vorderrand derselben gelb. Auch die Beine hellgelb mit mehr in's Lehmgelbliche fallenden Fussgliedern. Das Prosternum hinten leicht ausgebucltet, mit stumpf dreieckig vorspringenden Hinterecken, der Vorderrand breit löffelförmig vorgezogen. Das letzte Segment des $q$ mit einer tiefen halbkugeligen Grube; das ot unbekannt.

Aus Brasilien (Mus. Clark).

S. 308 hinter 11. 74. Cr. bisulcatus 11 . ist als nene Art einzuschalten:

74b (123). Cr. o chrosomus m. Rostgelb, das Halsschild spiegelglatt, die Punktstreilen vor'l grob, hinterwärts feiner und die mittleren fast erloschen, mit flachen, glänzenden Zwischenräumen. L. $13 / 4{ }^{\prime \prime \prime}$, Br. ${ }^{3} / 4^{\prime \prime \prime}$.

Dem $\mathrm{Cr}$. hisulcatus an Gestalt und Färbung nahe verwandt, aber ein wenig kleiner, auch das Halsschild schwächer schräg gefurcht, und der Käfer von jenem an den einfarligg bellen Beinen leicht zu unterscheiden. Der Kopf flach gewölht, fein und ziemlich dicht punktirt, ohne deutliche Stirnlinie, das ziemlich stark eingezogene Kopfschild oben durch eine deutliche Qurlinie abgesetzt. Die Farbe hell rostgelh mit mässigem Glanze, die langgestreckten breit und ziemlich tief ausgebuchteten, (auch hei dem \&) oben sehr genäherten Augen schwarz. Die Fühler fehlen dem einzigen vorliegenden Stücke his anf die beiden untern Glieder; dieselben sind rothgelb, und das zweite kugelig, lanm länger als in der Mitte breit. Das Ifalsschild etwa doppelt hreiter als lang, in der Nitte hoch quer aufgewölbt, und von da nach vorn und hinten gleichmässig und steil abwärts gekrümmt. über den tief eingezogenen, fast rechtwinkligen Vorderecken stark rerengit; die Seiten fein gerandet, nach vorn in breiten Bogen znsammengeneigt, die Hinterecken kurz und scharf spitzwinklich ausgezogen, der Hinterrand eingesenkt, kaum ausgebuchtet, mit kurzem, doppelt ausgerandetem Mittelzipfel; an letzterem jederseits ein dentlicher Schrägeindruck. dessen allmählich ahgeschwächtes Vorderende sich his fast üher die Nitte des Seitenrandes verfolgen lässt. Die Oherfliche mit Spuren einer feinen und sehr zerstreuten Punktirung, dazwischen spiegel- 
glatt, hell rostgelb. Das Schildchen schmal und fast linienförmig, mehr wie doppelt länger als vorn breit, hinten kurz alogestutzt mit deutlichem Vordergrübchen, gleichfalls glänzend rostgelb. Die Deckschilde gestreckit walzenfürmig, un die Hälfte länger als brcit, mit leicht quer niedergedrïckter Wurzel und hinten mässig ablallender Wölloung; Schulterbeulen und Seitenlappen kräftıg, jene inuerseits durch einen schmal dreieckigen Eindruck abgesetzt, über diesen die Deckschilde breit zusammengedıückt. Die Punktstreilen regelmässig, die Punkte vorn grob und grübchenartig, was besonders bei dein sechsten und siebenten Streifen über dem Seitenlappen hervortritt, von der Mitte ab feiner und die mittleren auf der Wülbung fast erloschen, so dass unter dieser nur noch der zweite und neunte deutlich zusammenlaufen. Die flachen Zwischenräunı glänzend, mit Spuren selır feiner und zerstreuter Punktirung. Die Farbe hell rothgelh. Unterseite und Beine etwas heller gelb; dis letzte Segment des $q$ nuit einem mässigen, runden Grühchın, das $\delta$ ımbekannt.

\section{Aus Brasilien (Mus. Clark).}

S. 310. n. 77. Cr. siccus m. Bei dem q dieser Art (von Minas Geraes: Mus. Clark) sind die Punktstreifen von der Mitte ab merklich feiner, die mittleren auf der Wölbung fast erloschen, der braune Saum der Flügeldecken umfasst auch die Schulterbeulen und bildet hier dadurch einen schrägen, verwaschenen Schulterwisch; das letzte Hinterleibssegment mit einer ziemslich tiefen, glänzenden Grube.

S. 314. hinter n. 78. Cr. esuriens $m$. ist als neue Art einzuschalten:

7Sb. (124). Cr. bicostatus m. Lehmgelb mit schwarzen Fülılerenden; das Halsschild spiegelglatt, die Punktstreifen vor'n grob, die ober'en von der Mitte ab fast erloschen, der fünfte bis siebente vorlıer abgerissen, die Zwischenräume flach und glänzend, das einwärts gekrümmte Vorderende des vierten und die Vorderhălfte des achten schwielig aufgetrieben. L. $1 \frac{1}{6}{ }^{\prime \prime \prime} ; \mathrm{Br} .5 / 12{ }^{\prime \prime \prime}$.

Ein schlanker, schmaler, in Grösse und Grundfïrhung dem Cr. philothermus und seinen Verwandten, in der Sculptur mehr dem Cr. esuriens ähnlicher Käler, durch die eigenthümliche Beschaffenheit der letzlern aber von allen Arten diescr Grupe genngsam verschieden. Der Kopf flach, mit oben deutlich abgesetztem, kaum 
eingezogenem liopfschilde, letzteres von den kaum zurïcktretenden Wangen nur durch feine Schrägkanten geschieden; von einer Stirnlinie zwischen den langgestreckten, breit und ziemlich tief aurgerandeten, fast zusammenstossenden schwarzen Augen nur eine schwache Spur. Die Farbe lackglänzend weissgelb, der untere Rand des Kopfschildes und die Fühlerhöcker dunkler honiggelh, die Kinnbacken schwärzlich. Die Fühler schlank, von mehr als halber Körperlänge, das Wurzelglied gestreckt, oben $2 \frac{1}{2}$ mal länger als breit, das zweite schmal elliptisch, die drei folgenden düın, verkehrtkegelförmig, das dritte und vierte je doppelt länger als das zweite, das fünfte noch etwas verlängert und diesem die oberen gleich, letztere zugleich weuig zusammengedrückt und erweitert, mit kurz dreieckigem Fortsatze des Endglieds. Die Farhe der fünf unteren durchscheinend hellgelb, die sechste an der Wurzel gebräunt, oben, wie die folgenden, schwärzlich. Das Halsschild verhältnissmässig schmal, nicht ganz doppelt breiter als lang, über den tief eingezogeneı breit spitzwinkligen Vorderecken stark quer eingeschnürt, dahinter noch breit zusammengedrückt und dadurch verschmälert; die Seiten gerandet, hinter der Mitte seicht ausgeschweift, nach vorn schräg ahwärts in fast graden Linien zusammengeneigt; die Hinterecken kurz und breit spitzwinklig zugeschärft, der Hinterrand jederseits leicht ausgebuchtet, mit wenig bemerkbarem, fast grade abgestutztem Mittelzipfel. Vor dem letzteren eine lreite sattelförmige Querfurche, welche sich mit ihren Enden schräg nach vorn und aussen wendet und hier ïlıer der Mitte des Seiteurandes mit einer tiefen Schräggrube endet. Durch letztere wird die Fläche der Hinterwinkel schräg wulstig emporgeholen, und eben so auch die Vorderhälfte des Halsschilds als ein hinten von einem flachen Kreishogen begränztes Mittelfeld nach vorn und oben geschoben, wodurch hier zugleich vor der Mitte ein nach vorn abfallender Querwulst gebildet wird. Ilic Oberlläche spiegelglänzend lehmgelh, die Mitte des bezeichncten Querwulstes verwaschen dunkler gelb. Das Schildchen schräg ansteigend, schmal dreieckig und reichlich doppelt länger als vorn breit, nit moleutlichem Vordergrïbchen, gleichfalls glänzend gell. Die Deckschilde gestreckt walzenförmig, um mehr wie die Hälfte läıger als breit, hinter den Schultern noch etwas erweitert und damn hinten kur\% zugerundet, der Rücken flach gewölbt, hinten mit mässiger Krüınmung abfallend; die Vorderkanten kräftig aufgewulstet, und hinter ihnen ein von Schildchen bis 
zum vierten Punktstreifen reichender, eben so kräftiger Quereindruck. Die Schulterbeulen eckig hervortretend, die Seitenlappen mässig, mit scharf erhühtem Kiele und breit umgesehlagenem, mit einer groben Punktreihe besetztem Rande; üher ihnen die Deckschilde breit zusammengedrüekt, und dieser Eindruck, wenn auch nur schwach, bis zur Naht bemerkbar. Die Punktstreifen regelmässig, die oberen aus groben Vorderenden bald abgeseluwäeht und von der Nitte ab wie weggeschliffen, stellenweise, besonders unter der Wölbung, auch an der dunkehn Färbıng der Punkte benıejklieh; der sechste fehlend, der fünfte und siehente schon vor der Mitte in einander laufend und danu hald verschwindend; nur die drei äussern bis zur Wöllung siehtbar. Die Vorderenden des vierten und fünften vorn einwärts gebogen, und das des ersteren dort in rlie Querfurehe hinter der Wurzel auslaufend. Die Zwischenräume flach, die Vorderhälfte des achten aber als eine kräftige Rippensehwiele erhöht, zu deren Seiten der achte und neunte Streifen tiefer eingedrückt, und letzterer soweit abwärts gerlrängt ist, dass er über dem Seitenlappen nur noch durch einen sehmalen Zwischenraum von dem Randstreifen getrennt wird. In sehwächerer Weise setzt sich diese Längsselıwiele hinterwärts auf dem neunten Zwisehenraume fort; dagegen hebt sich das Vorderende des vierten Zivischenraums zwischen den einwärts gekrümmten Vorderenden des vierten und fünften Punktstreifens als eine gleichfalls kräftige Schwiele empor, und biegt sich, jenen Streifen entsprechend, gleichfalls in einem Kreisabschnitte nach vorn und imnen, wo es in den aufgetriebenen Vorderrand der Flügeldeeke ausläuft. Zwisehen dieser Schwiele und der Sehulterbeule liegt das Vorderende des fünften Streifens furchenartig eingesenkt und so dicht mit Punkten besetzt, dass dieselben einzeln kaum zu erkennen sind. Die Farbe auch hier spiegelglänzend lehmgelb. Pygidium und Unterseite fein runzlig punktirt, mit den Beinen gleichfalls einfarbig lehmgelb. Das letzte Segment des $\delta$ leieht quer eingedrückt, das $f$ unbekannt.

Aus Columbien (vom Magdalenenflusse: Mus. v. Bruck).

S. 317. hinter n. 80. Cr. figulinus 11 . ist als nene Art einzuschalten:

80 b. (125). Cr. strangulatus m. Rothgelh mit hellerer Unterseite, die Fühler, Knie, der lintere Theil des fein punktirten und tief sehräg eingedrüekten Halssehilds mit einem Lingswische XVI. 
der Flïgeldecken geschwirzt, die Punktstreifen derb mit flach gewölbten, fein punktirten Zwischenräumen. L. $3 / 4{ }^{\prime \prime \prime}$; Br. $1 / 3{ }^{\prime \prime \prime}$.

Dem Cr. figulinus nahe verwandt, aber noch etwas kleiner, und vou ihm, auch ahgesehen von der fehlenden Punktreihe auf den Zwischenräumen der Deckschilde, leicht an dem Hervortreten schwarzer Färbung an Fühlern, Kinieen unıl Oberseite zu unterscheiden. Der Kopf llach gewölbt, über den Fühlerwurzeln etwas schwielig aufgetrieben, mit zurücktretendem Nacken und grossem, tief eingezogenem, ohen durch ein par Quergrübchen dentlich abgegränztem Kopfschilde. Die Stirnlinie nur oben deutlich, das Kopfschild mit zerstrenten, ziemlich derhen P'unkten besetzt. Die Farbe lackglänzend rothgell mit etwas lichteren Rändern der schmalen Oberlippe, welche Färbung fast zuweilen die letztere ganz einnimmt; die langgestreckten, breit und tief ausgebuchteten, mässig getrennten Augen schwarz. Die Fühıler (lles $\&$ ) etwa von halher Körperlänge, ziemlich dünı, das Wurzelglied stark keulig aufgetriehen, um die Hälfte länger als loreit, das zweite lungelig und fast so breit als das erste, die drei folgenden dünn verkelırtkegelförmig, das dritte und vierte gleich lang und je etwa dem zweiten gleich, das fünfte etwas länger, die oberen mässig zusammengedrückt und erweitert, mit kurz dreieckigem Fortsatze des Endglieds. Die Farhe schwar?, die beiden untern Glieder auf der Unterseite leicht gebräunt. Das Halsschild fast doppelt breiter als lang, von der Mitte stark kugelig aufgewölbt und dann vorn lireit ahwärts gekrümmt, seitwärts sanfter abfallend, über den rechtwinkligen Vorderecken zusanmengedrückt und darlurch verschmälert; die Seiten gerandet, nach vorı in flachen Bogen convergirend, vor den kurzen, breiten Hinterecken leicht ausgeschweift, der selır fein gesägte Hinterrand bis zu dem schwach heraustretenden, nur mdeutlich ausgerandeten Mittelzipfel fast grade verlaufend. Vor letzterem ein schmaler, etwas gebogener Quereindruck, an welchen sich jederseits ein nach vorn und aussen gerichteter briter und tiefer, dlas Halsschild zusammensclınürender Sclırägeindruck anschliesst. Vor diesem Eindruck ist die Oberfläche glatt, kanm mit einem oder dem andern. äusserst feinen Pünktchen besetzt; hinter ihm finden sich dichter gestellte grölıere l'unkte von verschiedener Grösse untereinander gemengt bei glattem und glänzendem Zwischengrunde. Die Farbe rothgell, die hintere Hälfle verwaschen geschwärzt orler (bei einem der vorliegenden Stücke) nur gebräunt, so aber, lass vor dem Hinterrande 
die hellere Grundfarbe wieder eben so verwaschen zum Vorschein kommt. Das Schildchen schräg ansteigend, schmal linienförmig und etwa dreimal so lang wie breit, mit undeutlichem Vordergrül)chen, glänzend rothgell. Die Deckschilde aus dem Walzlichen hinterwärts etwas erweitert, un melır wie die llälfte länger als breit, hinter der wulstigen Vorderkante durch die tiefer eingegrabenen Vorderenden der Punktstreifen quer eingedrückt, sodass sich dieser Eindruck naclı dem Schildchen zı schräg hinterwärts richtet; die Schulterbenlen schmal eiförmig vortretend, die Seitenlappen nur schwach entwickelt. Die Punktstreifen regelmässig und kräftig, auch hinterwärts nicht eben ahgeschwächt, die seitlichen noch etwas tiefer eingedrückt. Die Zwischenräume glatt und glünzend, katm punktirt, flach gewölbt, die beiden äussern noch etwas stärker emporgehoben. Die Farbe rothgell, an den Seiten melır ins heller Gelbliche verblassend, oben dunkler und hier zu einem breiten, in der intensiveren Mitte besonders hinterwärts ins Schwärzliche übergehende Lăngswische verdichtet, welcher vorn durch einen von dem Seitenlappen heraufziehenden seichten Quereindruck etwas abgeschwächt ist, sich alier hinterwärts nach aussen mit zunchmender Intensität wieder verbreitert: bei einem der mir vorliegenden Slücke ist nur dieser lintere Theil des Wisches vorhanden. Das vereinzelt punktirte, dazwischen feiner gerunzelte Pygidium mit Unterseite und Beinen heller rothgelb, die Schenkelspitzen und Knie schwarz. Das Prosternum flach, hinten nur leicht ausgeschweift; das letzte Segment des $q$ mit einer länglichrunden, glänzenden Gruhe, das $\delta$ unbekannt.

Aus Brasilien (Mus. Vindob. Clark).

S. 328. hinter n. 88. Cr. ambitiosus m. ist als neue Art einzuschalten :

88b. (126). Cr. virgineus m. Braun, Kopfschild, Seiten des spiegelglatten Halsschilds, Hinterleib und Beine heller gelbbraun, die Flügeldecken mit virr weissen Flecken $(1,2,1$, das Mittelpaar schräg); die Punktstreifen vorn krältig, mit flachen, spiegelglänzenden Zwischenräumen. L. $21^{1 / 3}{ }^{\prime \prime \prime} ; \mathrm{Br}$. $1 \frac{1 / 6}{}{ }^{\prime \prime}$.

Die vorliegende Art zeigt durch ihren in der Mitte mit flacher Rundung verbreiterten Körper und die dunkle, weissgelleckte Oberseite eine grosse labituelle Aehnlichkeit mit manchen Arten der vierten Rotte, namentlich dem $\mathrm{Cr}$. apocryphus und laesus, schliesst sich aber durch die fast zusammenstossenden Augen, das seitlich 
tief eingedrüclite Halsschild und das schmal dreieckig gestreckte Schildchen so ganz an die Rotte des Cr. bisignatus und seiner verwandten Arten an, dass sie bis auf Weiteres an deren Ende ihre geeignetste Stelle finden wird. Der Kopf flach mit kurzer, unten etwas verbreiterter Stirnlinie, das Kopfschild seitlich abgesetzt, die Fühlerwurzeln durch zwei sich aneinander anschliessende Quergrübchen verbunden, die tief rechtwinklig ausgebuchteten Augen (auch bei dem q) einander oben fast berührend, und zugleich so sclıräg gestellt, dass bei wagrechter Richtung des oberen, senkrechten des unteren Randes der Ausbuchtung die untere Stirnfläche als ein rechtwinkliges, nacl oben zwischen den Augen in einen schmalen Zipfel ausgezogenes Feld erscheint. Die Farbe lackglänzend braun, olne Punktirung, das Kopfschild mit den Fühlerhöckern verwaschen heller gelbbraun, die Oberlippe sclıwärzlich mit greisem Rande, die Augen greis, das Innere ihrer Ausbuchtungen leicht schräg niedergedrückt. Die Fühler, denen bei dem einzigen vorliegenden Stücke die Endglieder fehlen, schlank und von mehr als halber Körperlänge, das Wurzelglied dünn und keulig, oben etwa dreimal so lang als breit, das zweite elliptisch, das dritte und vierte je doppelt-, das fünfte mit den folgenden fast dreimal länger als das zweite und etwa dem Wurzelgliede gleich, die obern dabei selır wenig zusammengedrückt und erweitert. Die unteren beiden pechbraun, das dritte und vierte noch etwas dunkler, die oberen vom fünften ah schwarz. Das Halsschild sehr kurz, etwa $2 \frac{1}{2}$ mal breiter als lang, mit vor der Mitte selır sanft aufgehogenen Mittelfirsten, über den stumpfen Vorderecken seitlich breit zusammengedrückt und dadurch nach vorı selır stark - fast kegrelförmig - verschmälert; die Seiten fein gerandet, hinter der Mitte sanft zugerundet, die Hintcrecken sehr kurz und breit zugeschärft, der Hinterrand fast grade, auch der Mittelzipfel kaum sichtbar ansgerandet. Vor letzterem das Mittelfeld leicht sattelfür'mig quter niedergesenkt, und dann noch jederseits ziemlich schmal aber sehr tief schrïg eingedrückt; ausserdem vor dem Hinterrande von den Hinterecken ab jederseits eine selır fein eingeschnittene, nach innen alıgekürzte Querlinie. Die Oberfläche spiegelglatt, die Farbe dunkelbraun, der Vorder- und Seitenrand hinter dem abgesetzten dunkel bleibenden Saume heller gelbbraun. Das Schildchen sehr schmal und gestreckt dreieckig, melır wie doppelt länger als rorn breit, mässig ansteigend, mit kurz abgestutztem Hinterrande und grossem, 
rundlichem Vordergrübchen, gleichfalls glïnzend braun mil verwaschen lichterer Hinterhälfte. Die Deckschilde etwa IIm die IIäfte länger als breit, hinter den tief eingezogenen, durch die länglichen, eckig lieraustretenden Schulterbeulen fist verdeckten Schultern in flachem Bogen erweitert und dann binterwärts eben so flachı zugerundet; der Rücken hinter der Wurzel schmal und seicht niedergedrückt, über den kaum bemerkbaren Seitenlappen sehr breit und kräftig zusammengedrückt, hinten mit mässiger Krümmung abfallend. Die sehr regelmässigen Punktstreifen vorn derb, von der Mitte ab feiner, und die oberen hinten fast erloschen, der neunte in eine deutliche Längsfurche eingedrückt. Die Zwischenräume spiegelglatt, flach, der neunte leicht aufgewölbt. Die Farbe braun, hinterwärts etwas lichter, mit vier weissen, lackartig aufgetragenen und die Punktstreifen verdeckenden, rundlichen Fleckell. Von diesen liegen drei in grader Linie längs der Naht, der erste etwas in die Länge gezogene im vorderen Nahtwinkel, der zweite hinter der Mitte, der dritte, grösseste, im hinteren Nahtwinkel, gleichweit von Naht und Aussenrand getrennt; der vierte, ein vereinzelter Querfleck und der grösste von allen, liegt etwas vor dem mittleren Flecke zwischen dem fünften und dem Randstreifen. Das Pygidium grob punktirt, in der Mitte sanft niedergedrückt, greisgell); auf der Unterseite ist die Hinterbrust bräunlich mit etwas hellerer Mitte, Vorder- und Mittelbrust sammı dem bleicher greis gerandeten Hinterleihe sind verwaschen lehmgelb, die Beine heller und reinlicher gelb. Die Vorderbrust hinten in zivei stumpf dreieckige Zipfel ausgezogen; das letzte Segment des $q$ mit einer grossen halbkugeligen Grube, das $\delta$ unbekannt.

Aus Venezuela (Morilz im Mus. Vindob).

\section{Scolochrug m.}

(Linn. VII. 104.)

Schon in dem ersten Theile dieser Abhandlung (Bd. XV. S. 79) habe ich auf die Mannigfaltigkeit der Formen hingedeutet, welche bei dem Artenreichthum der Gattung Scolochrus innerhalb der- südamerikanischen Käferfauna hervortritt; und diese Wahrnehmung hat sich nur immer entschiedener geltend gemacht, jemehr ich das in unseren Sammlungen aufgespeicherte überreiche Material einer ıähern Prüfung unterziehen konıte. Denı wälırend 
die wenigen bis Nordamorikat vorgedrungenen Ausläufer dieser Gattung mit Austahme vou vielleicht drei lis vier Arteu in der Hauptgroppes der (battumg (s. muten liotte 9) ihre Stedle finden, zeigh die sïdlanerikanische: Formenreihe einerseits Arten mil ku\% zusanmengeschohenen, buckelig anlgetriehenen Körjer, welche; lheils an dis: echten Cryptucephalen mit kurzem, hedrungenem Körperbau (Bil. 15. Rotte 3 und 7), theils an manche Clythriden (Stereoma und Brodera) erinnern, und diese gehen dimn durch die unnerklichsten Ucherginge in den itusseren Habitus echerer Pachybachen äher, wie sich dieser an reinsten in dem zon den Scolochen zu zälılenden I'. pallidilabris Stal ausgepriggt hat. Dagregen nähern sich aber anch wieder die echten Pachyluachen den Scolechen in manchen formen so sehr, dass es oft schwer hïlt, hier noch

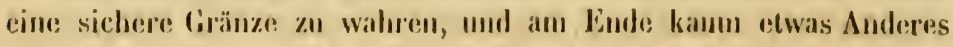

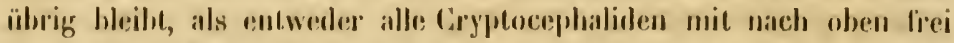
benrglichen Rückentheilen wisder zon rines einzigen bittung Palchyluachys zu versingen, oder sich hei dor weiteren Unterscheidung der dialtungen äherwiegend an den Habitus zon halten,

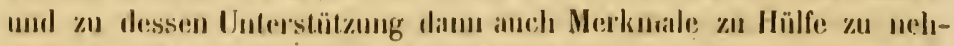
men, anf' die man unter andern Unstinden unr cinen untergeordneten Werth legen wïrde.

In der hiee angenommenen Beglänzung ist die Galtumg Sco-

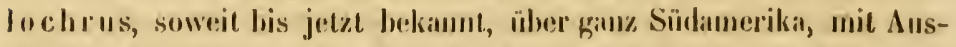
schluss des jeuseits der Auden lodegenen Gebiets von Peru und Chile verbreitet. Sie dehut sich santach äher diss grosse Ost- und Nordland vom La P'lulastrom bis zum Carabischen Meere (lie La Plata-Staaten, Parlagnay, Brasilien in seincer ganzen Ausdehumug,

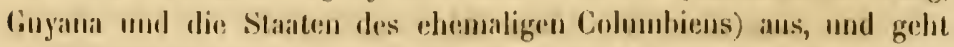

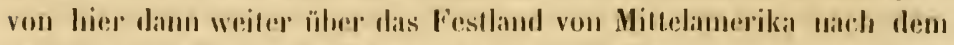
süsllichen' I'hreile von Nordanerika üher. In Chile scheint sie durch eine andere, gleichlalls eigenthïndicher und anf der Ostseite der Auden lidilende Pachyluachidentorm ersetze zu werden, als deren Verdreler voryusweise Cr. chilensis Gay und dessen \& Cr. elegans fiay geltrn kiant.

Listo Rotle. Könper, besonders des 9 , knt\%, breit und

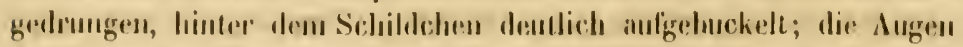

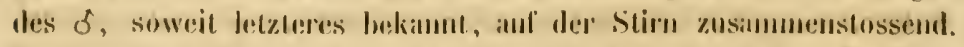

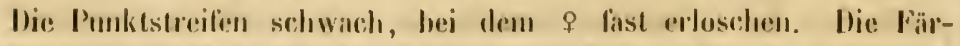
bung culwerler des ganzen liörpers stablblan, oder die Unterseite 


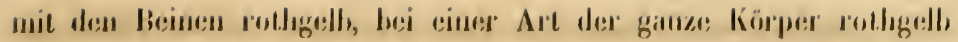
mit metallisch gränlichem Saum der llecksehilds: Arten ans dem

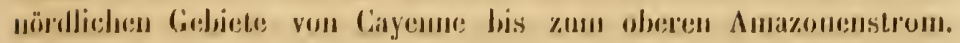
Sericogaster keiche in lill.

1. Scefragrans m. Stalulblan, Pygridiun und Unterseite dicht. goldgeth behatart; das Halsschild selur fein und zerstrent punktirt,

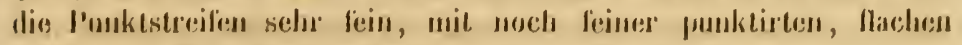

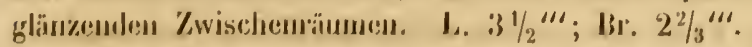

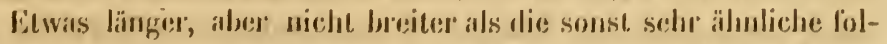

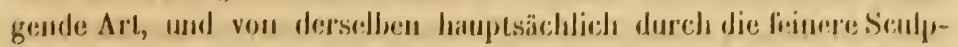

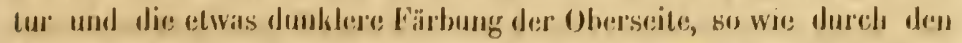

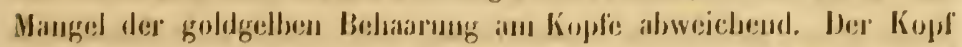

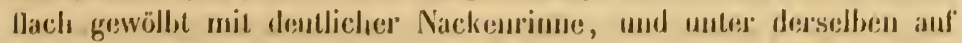

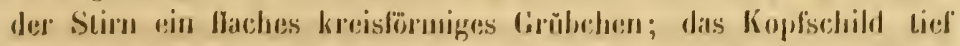

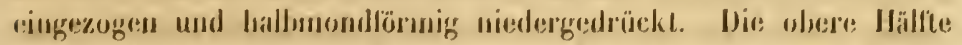

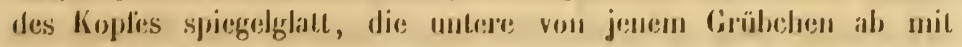

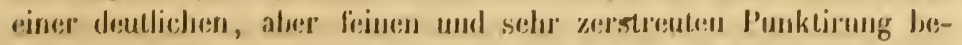

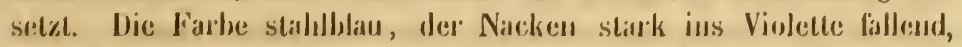

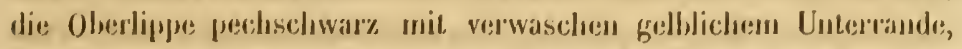

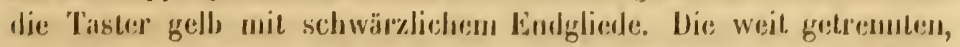

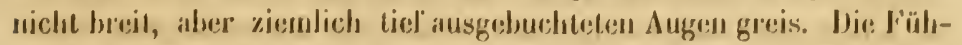
ler bei keinen der drei vordiegenden Stücke vollständig vorhanden; das Wur\%elglied mässig auligetrieben, nicht völlig dopprelt länger als lneit, das zweite kur\% esilörmig, die drei folgenden dünn ver-

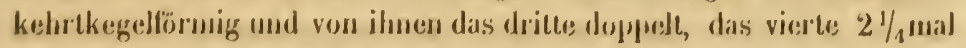
und das läntle: $2 \frac{1}{2}$ mal länger als das zweite, das sechste und siebents je den lï̈nflen gleich, loreit erweitert, dies nächstloblgenden wieder retwass schunaled. Die fünl" unteren fechloräundich mit stärker verdunkelter Oberseite, die olseren schwar\%. Das kur\%, Ilalsschild mohr als zweimal brester wie lang, mit kaum gekrümmter Nittellirste, über den sclarf spitzwinkligen Vorderecken lneit zusanmurengedrückt, hinter den Augen nochmals ringeschnürt und dat-

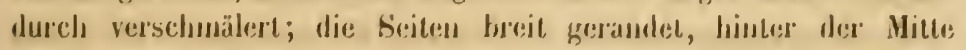
rundlich erweitert und vor iln leicht ausgeschweift, die Jlinterecken scharf stunnfivinklig, der Hinterand jederseits tief ansgrebuchted, mit breiten, atwas aufgedoggenem Mittelzipled. Jederseits dieses let\%-

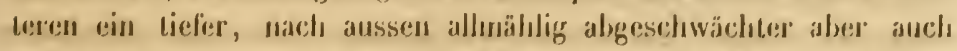
verbsesterter, gegen die seitlicho firweiterung des IIalsschilds hinabzichender Schrägeindruck. Dio Oberdliche sehı fein und riemlich 
dicht punktirt, mit glänzendem Zwischengrunde, auf der Mitle bei einem Stücke eine Querreihe gröberer Punkte, an deren linkes Ende sich einige ähnliche schräg rückwärts nach dem Eindrucke laufende Punkte anschliessen. Die Farbe stahlblau mit lebhaftem Purpurschimmer, der abgesetzte Vordersaum, sowie der mittlere Theil des Hinterrandes manchrnal leicht ins Messinggrünliche fallentl. Das Schildchen nicht so lang wie vorn breit, ziemlich steil ansteigend und hinterwärts verschnälert, daselbst mit abgerundeten Ecken algestutzt, der Hinterzipfel unscheinbar: die Oberfläche sehr fein und dicht punktirt, ein hinterwärts verbreitertes Längsfeld auf der Mitte ohne Punkte. Die Farbe gleichfalls purpurbläulich mit buntkupfrig spielenden Vorderecken. Der unter dem Halsschilde verborgene Theil des Schildchens vorn und seitlich durch eine erhöhte und glänzende Kante geschlossen, dicht runzlig punktirt, hinten durch eine an den offenen Theil des Schildchens sich anschliessende und glänzende Querrinne begränzt, von welcher aus ein in der Mitte vorgezogener dreieckiger Zipfel in das gerunzelte und crhöhte Vordertheil eindringt. Die Deckschilde kaum 1/6 länger als breit, hinter den breit abgerundeten Schultern noch etwas erweitert und dann hinterwärts mit schrägen Seiten wiederun verschmälert, kurz algerundet; der Rücken um das Schildchen buckelig aufgetrieben und, von da ab nach vorn und seitlich stärkerhinterwärts etwas flacher abfallend; an der Wurzel hinter der scharfen aher nicht hohen Vorderkante zwei breite und flache Grübchen, durch deren äusseres Ende die gleichfalls breiten und nur flach gewölbten Schulterbeulen innerseits abgesetzt werden; die rundlichen Seitenlappen ziemlich tief abwärts gezogen, über ihnen die Deckschilde schräg zusammengedrüclit und davor das Vorderende des neunten 'Zwischenraums wieder als leichte Beule aufgetrieben. Auf dem Rücken zeigt sich hinter dem Schildchen und dann wieder vor der Mitte ein schwacher Quereindruck, deren hinterer sich schräg nach deu Seitenlappen hinabwendet und eigentlich nur eine abgeschwächte Erweiterung' der über jene sich schräg aufwär's ziehenden bruckfläche bildet. Die Punktstreifen überaus feil, nur unter gewisser Beleuchtung sichtbar und auf dem letzten Drittel sich unter der gleichfalls feinen und ziemlich dichten l'unktirung der Ilachen, glänzenlen Zwischenräume verlierend. Die Farhe ein schönes dunkles, überall mehr oder weniger ins l'nrpurröthliche spielendes Stahlhlau. Pygidium und Unterseite schwarzblau, 
mit hurzer goldgeller, anch bei alten, theilweise abgeriebenen Stücken wenigstens auf dem Hinterleibe noch ins Goldgelbliche fallender Behaarung; die Beine etwas heller, ins Stahlblaue fallend, mit gebräunten Hüften. Die Vorderbrust in der Mitte flach längswulstig, seitlich eben so Jeicht niedergedrückt. Das letzte Segment des $q$ mit dem gewöhnlichen tiefen Grübchen, das ơ unbekannt.

Von Cayenne (Mus. Holm., von Dupuizet gesammelt; und eben daher auch im Mus. Clark).

2. Sc. auricapillus m. Stahlblau mit gebräunten Fühlerwurzeln, Kopf und Unterseite dicht goldgelb behaart; das IIalsschild dicht punktirt, die Punktstreifen vorn und längs der Naht wellig verdoppelt, hinten verschwindend mit fein gerunzelten hinten flachen Zwischenräumen. L. $3 \frac{1}{6}{ }^{\prime \prime \prime} ; \mathrm{Br}$. $2 \frac{2 / 3}{}{ }^{\prime \prime \prime}$.

Der Kopf flach, unten einschliesslich des Kopfschildes mit dichten, abwärts gedrückten goldgelben Seidenhärchen bedeckt, nur die schwärzliche, unten gelblich gerandete Oberlippe kahıl und spiegelglatt. Der obere Theil des Kopfes (bei dem vorliegenden ठ) durch die breiten oberen Enden der durch eine schmale Ausbuchtung sehr ungleich getheilten Augen eingenommen, welche cinander in langer Ausdehnung berühren, und oberwärts nur einen schmal dreieckigen, glänzend stahllblauen, durch eine deutliche Längslinie getheilten Nackenzipfel übrig lassen. Die Fühler von halber Körperlänge, ziemlich dünn; das Wurzelglied blasig aufgetrieben, kaum doppelt länger als breit, das zweite kurz eiförmig, die drei folgenden dünn verkehrtkegelfürmig, das dritte melır als doppelt-, das vierte dreimal länger als das zweite, das fünfte und sechste je dem zweiten und dritten zusammen gleich, die folgenden wieder allmählig abnehmend, so dass das zehnte kaum noch die Länge des dritten erreicht, das Endglied mit seinem lang zugespitzten Fortsatze so lang als das vierte, dabei alle Glieder vom sechsten ab zusammengedrückt und schwach erweitert. Die Farbe der vier unteren pechbraun, mit besonders bei den beiden ersten stahlblau angelaufener Oberseite, das füufte schwärzlichbraun, die oberen schwarz, dünn angedrückt greishaarig. Das Halsschild mehr als doppelt breiter wie lanģ, vorn mit der grösseren Hälfte sanft abwärts gekrümmt, üher den zahnartig vorspringenden Vorderecken stark zusammengedrückt und dadurch verschnnälert; die Seiten breit gerandet, hinter der Mitte mit fast stumpfwinkliger Rundung erweitert, vor ihr breit ansgesclıweift, die Hinterwinkel stumpl' aloge- 
rundet. Der Hinterrand nur jederseits des breit zugerundeten, schräg aufwärts gebogenen Mittelzipfels etwas ausgebuchitet, und vor dem letzteren jederseits ein tiefer, an Rande selbst liegender Quereindruck; ein zweiter schwächerer liegt weiter nach vor'n, und zieht sich schräg nach des' erweiterten Stelle des Seitenrandes hinab, und hinter diesem zweiten zeigt sich noch ein kürzerer dritter, welcher vor dem Ilinterrande ein besunder's nach aussen zu merkliches scharfes Querfältchen in die Höhe schiebt. Die Oberfläche deutlich und ziemlich dicht punktirt, glänzenıl stahlblau, stellenweise ins Purpurviulette überspielend. Das Schildehen stark ansteigend, breit dreieckig und hinter'wärts mit gerundeten Seiten versclınälert, daselhst kurz abgestutzt, mit undeutlichem Hinterzipfel, f'ein punktirt und gleichfalls stahlblau. Die Deckschilde kaum länger als vorn breit, hinterwärts mit schwacher Rundung verschmäleı't und dann selır breit zugerundet, um das Hinterende des Schildchens huckelig aufgetrieben und hinter ihn auf der Naht, flach r'undlich eingedriickt. Die Wurzel himter der scharfen Vorderkante quer eingedrückt und dieser Eindruck innerseits der flachen Schulterbeulen zu einem breiteren Grübchen erweitert; die Seitenlappen ron mässiger Ausdehnung, und ülser ihnen hinter den Schulterbeulen je ein breiter Quereindruck, welcher sich verflachend schräg linterwärts gegen die Nahıt hinaufsteigt. Die Punktstreifen vorn stärker, dasellsst unregelmässig-wellig verdoppelt und längs. der Naht noch dlurch ïberzählige Punkte getrülıt; die mittleren schon von dem Quereindrucke ab regelmässiger, vereinfacht, oben auch abgeschwächt und auf der Wölbung fast erloschen. Die Zwischenrïume nur vor'u in der Querfurche linter der Wurzel als kurze

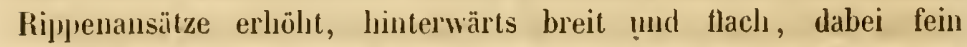
gerunzelt, mit mässigen Glanze; die stablblaue Fürbung auch hier stellenweise mit purpurviolettem Anfluge. Das Pygidium dicht punktirt, grünlichlbliu mit feiner gelblicher Behaarung und einer Spur von einer eingeılrückten flachen Mittellinie. Unterseite und Beine heller stahlblau, erstere mit einer dichteı angredrückten goldgelben, seidig glänzenden Behaarung, nur das letzte Segment des allein vorliegenden đo mit einem kahlen und glänzenden, flach halbmondförmigen Eindrucke; die Hinterlıüften schwach gebräunt. Das Prosternum breit, vorı der Länge nach schwach aufgewulstet und jelerseits niedergedrückt, hinterwärts etwas erweitert und dann in einem breiten Bogen zugerundet. Das $q$ unbekannt. 
Von Ega am oberen Amazonenstrome (Mus. Baly).

3. Sc. hatcyoneus m. Oben stahlblau mit Purpurglanze, Fühlerwurzeln und Unterkopf gelb, unten hochgelb; das IIalsschild zerstreut punktirt, die Punktstreifen von mässiger Stärke, mit flachen glänzenden Zwischenräumen. L. $2 \frac{1 / 6}{6}-2 \frac{5}{6}{ }^{\prime \prime \prime} ; \mathrm{Br}$. $1 \frac{1 / 4}{4}-13 / 4{ }^{\prime \prime \prime}$.

Dem vorhergehenden sehr ähnlich, aber kleiner, und an der hochgelben Unterseite sogleich zu erkemmen. Der kahle Unterkopf deutlich punktirt, das Kopfschild mondförmig eingedrückt, die Stirn des $q$ mit kräftiger Längsriune; bei dem $\delta$ dieselbe der breit zusammenstossenden Augen wegen nur als kurze Nackenlinie vorhanden. Die Farbe des Unterkopfes lochgelb, mit verwaschen bräunlicher Begränzung in die purpurblaue Färbung der Stirn übergehend; die Oberlippe heller knochengelb. Die Fülıler des $\delta$ von halber Körperlänge, des $\subsetneq$ etwas kürzer; das dritte bis fünfte Glied sehr gestreckt, das sechste (längste) in seiner obern Hälfte merklich verbreitert, die folgenden wieder etwas verkïlzt, deutlich zusammengedrückt und erweitert. Die Farbe der unteren gelb, das sechste von der Mitte ab gebräunt, die oberen schwarz, an den innern Spitzen lang abstehend weiss gewimpert, mit kurzem und breitem Fortsatze des Endglieds. Das Halsschild kurz und breit, flach gewölbt mit nur sauft vorn übergebogener Firste, durch die kurz pfrienılich vortretenden, stark eingezogenen Vorderecken vorn verengt, seitlich gerandet, hinter der Mitte daselbst bogig erweitert, vor ihr leicht ausgesch weift; die Hinterecken stumpfwinklig abgerundet, der Hinterrand des jeder'seits breit zugerundeten Mittelzipfels ausgebuchtet und gleichzeitig niedergedrückt, und vor ihm jederseits ein muldenförmiger kräftiger Schırägeindruck, durchı welchen läıgs dem Hinterrande ein denselben begleitender Querwulst emporgeschoben wird. Letzterer tritt hinten auch über dem Seitenrande so merklich hervor, dass der wirkliche Seitenrand hier ganz nach unten gedrängt und theilweise durch jenen Wulst verdeckt wird. Die Punktirung oben zerstreut, seitlich mehr zusammengedrängt, bei dem $\delta$ kräftig, dem $q$ schwächer und auf dem Mittelfelde vorn fast erloschen, mil glänzentem Zwischengrunde. Die Farbe ein schönes lichtes, mit einen Purpurglanze übergossenes Stahlblau, die Ränder bei einem der vorliegenden $q$ ins Messinggrünliche fallend. Das Schildchen kurz und breit dreieckig, nicht länger als vorı breit, stark ansteigend, hinten mit zugerundeten Ecken abgestutzt, mit undeutlichem Hinterzipfel, an der Wurzel leicht quer niederge- 
drückt, fein punktirt, gleichfalls stahlblau, bei dem oben bezeich-1 neten $q$ stark messinggrünlich. Die Deckschilde kurz und breit, mehr gleichbreit als bei den vorhergehenden Arten und auch bei dem $\delta$ etwas gestreckter; der Rïcken um das Hinterende des Schildchens buckelig aufgetrieben und hinter diesem die Naht der Länge nach eingedrückt; auch die Wurzel hinter der scharf erhöhten Vorderkante quer gefurcht und diese Furche innerseits der winklig vortretenden Schulterbeulen grubig erweitert; die Seitenlappen stark abıärts gezogen, über ihnen die Deckschilde quer zusammengedrückt, und diese Eindrücke sich mit allmähliger Verflachung bis zur Naht hin fortsetzend. Die Punktstreifen bei dem $\delta$ deutlich und kräftig, die oberen vorn verdoppelt und wellig gekrümmt, der sechste und siebente bis zur Hälfte bemerklich, und nur die Spitze unter der Wölbung ganz ohne Punkte. Bei dem $q$ werden die Streifen schon vom zweiten Drittel an schwächer, und sind auf der hinteren Hälfte stellenweise kaum noch wahrzunehmen. Die flachen Zwischenräume spiegelglänzend. Die Farbe auch hier ein schönes lichtes Stahlblau mit Purpurschimmer; bei dem mehrgenannten $q$ die Schulterbeulen messinggrün, Naht und Ränder mit gleichem Anlluge gesäumt, jedoch so, dass dieser Saum sich auf der rechten Flügeldecke weiter ausdehnt, und zugleich mit einem an die Schulterbeule sich anschliessenden Längswische auf dem siebenten und achten Zwischenraume bis zu dem Eindrucke über dem Seitenlappen sich nach hinten erstreckt. Pygidium und Unterseite fein punktirt, Hinterbrust und Parapleuren mit angedrückten goldgelben Seidenhärchen bedeckt: die Färbung wie die der Beine hochgelb. Das Prosternum breit und flach, hinten deutlich erweitert, vorn der Länge nach seicht aufgewulstet, und jederseits seicht und schmal niedergedrückt. Das letzte Segment des $\delta$ mit einem seichten Quereindrucke, des $q$ mit einer grossen rundlichen Grube.

Von Ega und Serra Amazons am oberen Amazonenstrome (Mus. Baly).

4. Sc. viridicinctus m. Rostroth, die Seiten das fein und zerstreut punktirten Halsschilds nebst dem Rande der Deckschilde goldgrin; die Punktstreifen fein, hinten verloschen, mit flachen glänzenden Zwischemïumen. L. $3^{\prime \prime \prime}$; Br. $21 / 6{ }^{\prime \prime \prime}$.

Aus der nächsten Verwandıschaft der vorhergehenden Arten, aber an der rostrothen Fürbung des Körpers und den breit und 
schı̈n goldgrün gerandeten Deckschilden sehr leicht von ihnen zu unterscheiden. Der Kopf fiach, die Stirn seicht niedergedrückt mit kurzer wenig deutlicher Längslinie, das Kopfschild schwach halbmondför'mig eingedrückt, oben nicht alygesetzt; die Farbe rostroth, der Nacken glatt, Stirn und Kopfschild zerstreut aber deutlich punktirt mit glänzendem Zwischengrunde. Oberlippe und Taster hell knochengelb, die Kinnbacken und die grossen, durch eine schwache Ausrandung sehr ungleich getheilten, olen (bei dem $q$ ) getreunten Augen schwarz. Die Fülıler von halber Körperlänge, das Wurzelglied breit aufgetrieben, doppelt länger als breit, das zweite eiförmig, die drei folgenden langgestreckt und sehr dünn, fast gleichbreit, einander ziemlich gleich und je so lang wie die beiden unteren zusammengenommen, das sechste bei gleicher Länge nach oben stark dreieckig erweitert und zusammengedrückt, die folgenden noch etwas breiter, aber allmählig so weit verkürzt, dass das zehnte nur noch $2 / 3$ des sechsten erreicht; das Endglied mit seinem kurz dreieckigen Fortsatze etwa wieder dem neunten gleich. Inie Farbe der unteren hellgelb mit einem schmalen dunkleren Längswische auf der Oberseite des dritten bis fünften, das sechste tief bräunlich mit geschwärzter Spitze, die oberen schwarz mit feiner angedrückter greiser Behaarung. Das Halsschild fast dreimal breiter als lang, fast mit ganzer Länge vorn sanft abwärts geneigt, durch die tiefe Einhiegung der scharf spitzwinkligen Vorderecken merklich verschmälert; die Seiten breit gerandet, in der Mitte rundlich erweitert, vor ihr stark ausgeschweift, die abgerundeten Hinterecken mur leicht durch eine aufgebogene Schwiele angedeutet, auch der Hinterrand nur sanft gebuchtet, mit breit lieraustretendem abgerundetem Mittelzipfel. An letzterem jederseits eine eingedrückte, schmale Querlinie, und weiter nach vorn ein breiter seichter Schrägeindruck, durch den die Masse des Halsschilds hinterwärts gedrängt, und lıart vor der den IIinterrand absetzenden Querlinie zu einem feinen Querfältclıen emporgeschoben wird. Die Oberfäche zerstrent punktirt, glänzend rostroth, die Seiten ziemlich breit aber sehr verwaschen metallisch grüı. Das Schildchen stark ansteigend, so lang wie vorn breit, hinterwärts mit ansgebuchteten Seiten verschmälert und mit abgerundeten Hinterecken abgestutzt; der Ilinterzipfel unscheinbar, die Oberfliche gleichfalls zerstreut punktirt und rostroth. Die Deckschilde so lang wie vorn breit, hinterwärts etwas verschmälert und dann breit zugerundet, 
hinter der schmalen Wurzelkante durch die tief eingegrabenen Vorderenden den Punktstreifen unterbrochen quer eingedrückt, mit kurzen breiten Schulterbeulen und stark entwickelten, scharf gekielten Seitenlappen, üher welchen die Deckschilde lreit quer zusammengedrückt sind. Der Rïcken hinter dem Schildchen aufgebuckelt, dahinter und dann noclımals vor der Mitte flach ques niedergedrückt, von letzterer ab mit sanfter Krümmung bis zur Spitze abfallend. Die Punktstreifen etwas wellig, aus tief eingedrückten Vorderenden bald abgeschwächt und auf der Wölbung kaum noch kenntlich, der sechste und siehente schon vor der Mitte ahgebrochen, der neunte üher dem Seitenlappen tief eingekniffen. Die Zwischenräume breit und flach, auf dem neunten ein paar vereinzelte Punkte. Die Farhe ein ziemlich gläızendes dunkles Ziegelroth, ein hreiter, Wurzel, Seiten und Spitze der Deckschilde umzichender Saum dunkel goldgrün mit stärkerem Glanze. Pygidium und Unterseite fein runzlig punktirt, dïnn gelbhaarig, nebst den Beinen heller ziegelroth; das breite Prosternum in der Mitte flach längswulstig, hinten von den ziemlich scharfen Hinterecken aus brcit zugerundet. Das letzte Segment des $q$ mit einem mässigen rundlichen Grübchen, das ơ unbekannt.

Von Cayenne (Mus. Clark).

$\mathrm{Z}$ weite Rotte. lï̈rper gleichfalls kurz und breit, hinterwärts stark verschmälert, hinter dem Schildchen ein wenig aufgetriehen und dann breit abgeflacht. Die Punktstreifen wenig bemerkbar, bei den ठð etwas stärker, die Augen bei den letzteren, soweit dieselhen bereits bekannt sind, zusammenstossend. Die Farbe schıvärzlich-metallisch, mit ganz oder doch zum Theil strohgelben Deckschilden. Diese Gruppe hat mit der vorhergehenden eine gleiche Ileimath, erstreckt sich aber auch nordwärts über Mittelamerika hinaus, indem sich im Mus. Clark eine ihr angehörende mexikanische Art vorfindet.

5. Sc. curtus m. Metallisch-schwarzblau mit strohgelben Deckschilden, Füllerwurzeln und Schulterhlätter rüthlich; das IIalsschild zerstreut - und vorn feiner punktirt, die Punktstreifen fein nit flachen glänzenden Zwischenräumen. L. $3^{\prime \prime \prime} ; \mathrm{Br} .1 \frac{5}{6}{ }^{\prime \prime \prime}$.

Von der Gestalt, Grösse und Färbung der nächstfolgenden Art, und letzterer daher so ähnlich, dass es nur einer Angahe der Abweichungen von letzterer bedürfen wirl. Die metallisch schwarze Grondfarbe fällı nicht sowohl ins Grünliche als ins Bläuliche, zeigt 
auch weder den hräunlichen Scitemrand des Halsschilds noch die. gelblich-braune Färbung der Unterseite, wie beiles sich hei Sc. cernuus findet; es ist leshalb bei dem vorliegenden Nichts röthlich als die Scluulterblätter und die fünf unteren Fühlerglieder, die aber auch auf ihrer Oberseite mit einer breiteı schwarzen Längslinie gezeichnet sind. Das Halsschild ist eben so zérstreut pountirt, die Punktirung aher auf dem Mittelfelde merklich schwächer, und hinterwärts, besonders in den Quereindrücken, in demselben Grade stärker als bei jenem, der Zwischengrund aher kaum bemerkbar genarbt und deshalb noch stärker glänzend. Die Deckschilde sind um das Schildchen stark buckelig aufgetrieben, fallen aber ron dieser Auftreibung nach hinten nicht, wie bei Sc. cernuus, mit sanfter Neigung ah, sondern sind hier tief quer muldenfürnig eingerlrückt, und werlen hinter der Mitte nochmals von einem zweiten schwächeren, sich mit seinen Aussenenden schräg zı leı Seiteulappen hinabstreckenden Eindrucke durchzogen; zwischen diesem Eindrucke und dem ersten, bezüglich den die Wurzel hinter ihrer erhöhten liante niederdrückenden grübchenartigen Vorderenden der Punktstreifen heht sich dann noch ein flacher, die Deckschilde umzieliender Quergürtel empor. Die Punktstreifen sind besonders vorn etwas kräftiger als bei Sc. cernuus, und die Vorderenden der oberen Zwischenräume im Anschlusse an die Wurzelkante flach aufgewölbt. Das breite Prosteruum grob runzlig punktirt, längs der Mitte flach anfgewulstet, hinter ihr winklig erweitert, und hinten breit zugerumdet. Das letzte Segment des einzigen vorliegenden Stückes ist beschärligt, das Stück sellsst aber unzweifelhaft ein $q$.

Von Cayenne (Mus. Holm., ron Dupuizel gesammelt).

Die oben erwähnte mexikanische Art, die ich vorläufig $s c$. indigestus nemmen will, steht der vorstehent beschriehenen am nächsten, unterscheilet sich von ihr jedoch leiclıt durch die rein schwarze Färbung des Körpers, mehr ins Ziegelröthliche fallende Deckschilde, und weisse Färbung des Kopfes, Schildchens und der Vorderecken des Ilalssehilıls. Sie lässt sich dingnosiren als:

Sc. indigestus m. Sclıwarz mit ziegelröthlichen Declischilden, Kopf, Scliildchen und die Vorderecken des zerstrent- und oben fein punktirten Halsschilds woiss; die Pmnktstreifen fein, mit flachen, sehr fein punktirten und glänzenden Zwischenrüumen. L. $234^{\prime \prime \prime} ;$ Br. $13 / 4 "$. (ठ). Mexico, Mus. Clark. 
6. Sc. cernuus. Metalliseh-schwarz mit strohgelben Deckselilden, Fühlerwurzeln, Vorderhrust und Sehulterblätter mit. den Seiten des Halsschildes bräunlichgelb; das Halsschild äusserst fein und zerstreut punktirt mit noch feiner genarbtem Zwischengrunde, die Punktstreifen fein mit flachen glänzenden Zwischenräumen. L. $3^{\prime \prime \prime} ; \mathrm{Br} .1{ }^{5}{ }^{\prime \prime \prime}$.

Von dem Ilabitus und dem Bau der beiden nächstfolgenden

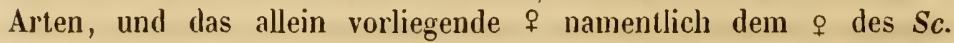
rolundatus überaus älnnlich, nur in den Deckschilden etwas gestreckter, und auch ausserdem in der Sculptur und der Farbenvertheilung abweichend. Die Punktirung des Halsschilds ist vielmehr vereinzelt und auch feiner, so dass sie auf dessen Nitte kaum wahrgenommen werden kamn, während der Glanz des Zwischengrundes durch eine feine narbige Textur der Oberfläche gemildert wirl; auf den Deckschilden sind die Vorderenden der Punktstreifen inerklich feiner, der überzälligen Punkte zwischen dem abgekürzten Streifen und der Naht ungleich weniger, von den äusseren Streifen der sechste und siebente bald hinter der Schulterbeule erloschen, auch der achte und neunte an dieser Stelle fast verwischt und nur noch an der dunkleren Färbung der Punkte bemerkbar. Hinsichts der Färhung sind die Deckschilde einfarbjg lehmgelb, so dass nur das Innere der Punkte etwas ins Röthliche fällt, auf der Unterseite die Schulterblätter sammt dem Mittelzipfel des ersten Bauchringes und der Vorderbrust hell gelbbraun, letzterer ist daleei hinter den Vorderhüften scheibenförmig in die Quere erweitert, daselhst von einer leichten Querfurche durchzogen und hinten fast grade abgestumpft. Auch die Seiten der Hinterbrust, der hintere Theil der Parapleuren und der durchscheinende Seitentand des Halsschilds fallen ins verwaschen Gelbbraune. Das letzte Segment des einzigen vorliegenden $o$ mit der gewölnhlichen Grube, das ơ unbekamut.

Von Ega am oberen Amazonenstrom (Nus. Baly).

7. Sc. platynotus m. Dunkel erzgrün, die grössere Vorderhälfte der Flügeldecken mit den Fühlerwurzeln lehmgelb; das llalsschild zerstrent punktirt, die Punkistreifen ziemlich fein, hinten erlüschend, mit flachen glänzenden Zwischenrüumen. L. 2"“; Br. $1 \frac{1}{3}{ }^{\prime \prime}$.

Der Farbenvertheilung nach eine Mittelart zwischen den vorhergehenden und der folgenden; der Kopf breit und Ilach, die Stirn 
des (allein vorliegenden) ơ fast ganz durch die grossen, grob gekörnten und durch eine dreieckige Ansbuchtung sehr ungleich getheilten Augen eingenommen, so dass über und unter diesen von der Stirn nur ein kurzer, breit oreieckiger Zipfel übrig bleibt. Der obere dieser Zipfel ist kahl, fein punktirt, mit einer kurzen aber deutlichen Längslinie; der untere sanımt dem kurzen stark ausgerandeten Kopfschilde gröber punktirt, mit Spuren einer grösstentheils abgeriehenen gelblichen Behaarung. Die Fühler nicht mehr vollständig vorhanden, das Wurzelglied birnförmig, doppelt länger als breit, das zweite kugelig, das dritte dïnn und oberwärts kaum verhreitert, reichlich doppelt länger als das zweite, das vierte noch etwas verlängert und diesem jedes der drei folgenden gleich, welche von der Spitze des sechsten ab oben schwach verbreitert aber deutlich zusammengedrückt erscheinen. Die fünf unteren hell durchscheinend gelb mit wischartig geschwärzter Oberseite, das sechste an der Wurzel trüb gebräunt, der obes'e Theil nebst dem siebenten (und wahrscheinlich auch den fehlenden folgenden) schwarz. Das Halsschild liurz und hreit, hinten tief quer niedergedrückt und zım Schildchen abfallend, ılas Mittelfeld leicht quer aufgewölbt und mit dler grösseren Hälfte der Nittelfirste sanft nach vorn herabgekrümmt; die Vorderecken tief eingezogen und spitz pfriemlich hervortretend, die Seiten gerandet, hinter der Mitte bogig erweitert, vor ihr breit ausgeschweift, die Hinterecken stumpf abgerundet, der Hinterrand jeder'seits des kurzen breit zugerundeten Mittelzipfels etwas ausgebuchtet, vor letzterem jederseits schrïg niedergedrückt. und hinter diesem Eindruck bis zu den Hinterecken von einem scharfen Querfältchın begleitet, dessen Aussenende sich nach vorn krümmt und in dieser Krümmung einen schmaleı aber kräftigen Schrägeindruck einschliesst. Die Punktirung von mässiger Stärlie, ziemlichı zerstreut, mit glänzendem Zwischengrunde, die Farbe dunkelerzgrün. Das Schildchen selır stark ansteigend, breit dreieclig, nicht lïnger als vorn breit, und hinterwärts $1 \mathrm{~m}$ mehr als die Hälfte verschmälert, mit undeutlichem Hlinterzipfel, trüh schwärzlichgrüu mit feiner Punktirung. Die Deckschilde rorn so breit als das Halsschild, von da ab hinterwärts stark- und fast gradlinigg verschmälert, hinten kurz und breit zngerundet, wenig länger als breit, mit flachem nur um das Schildchen buckelig erhühtem, hinten mit kurzer und leichter Wülhung ahfallendem Rücken, hinter der scharf aufgeworfenen Wurzelkante quer eingedrückt, mul von da gegen die ivi. 
Schildchenspitze hiı sclıäg ansteigend; die Schulterbenlen als gebogene Höcker hervortretend, innerseits durch das mach hinten sich erweiternde Ende der Vorlerfurche abgesetzt, mit stark zugerundeten Seitenlappen; die Naht von dein Höcker hinter dem Schildcheı ab bis zur Wölbung der Länge nach etwas eingedrückt. Die Punktstreifen regelmässig, nur vorn zwischen dem Schildchen und dem zweiten Streifen durch üherzählige P'unkte getrübt, die ersten Punkte der mittleren Streifen tiefer eingegraben, von der Mitte ab alle Streifen feiner, auf der Wölbmng fast abgeschliflen, die drei hinter der Schulterhenle liegenden (sechste bis achte) schon gegen die Mitte stellenweise undeutlich, der neunte über dem Seitenlappen stärker eingedıückt. Die Farbe der grösseren Vorderhälfte ein glänzendes Lehmgelb, die kleinere Hinterlıälfte dunkcl erzgrün, leicht ins Kupfrige spielend, mit stärkerem Metallglanze, der Vorderrand dieses dunkleren Theils an den Seiten etwas nach vorn gekrümmt, und den Raud am hinteren Ende des Seitenlappens erreichend. Pygidiun und Unterseite trïb schwarzgrün, dentlich punktirt und matt, auch die beine sclıwarz mit linzen, stark aufgetriebenen Vorderschenkelo und entsprechend gekrümmten Schienen; Hüften und Schulterhlätter trüh bräumlichgell. Das Prosternum breit, der Länge nach seicht anfgewulstet, hinter den Vorderhïften scheilenförmig erweitert und lann breit zugerundet. Das letzte Segment des $\delta$ einfach, das $q$ unheliannt.

Gleichfalls von Ega (Mus. Baly).

8. Sc. rotundatus m. Lunkelerzgrün, cin kireisfölmiger Vorderfleck der Flügeldecken mit den Fühlerwurzelı lehmgelb; das Hlalsschild zerstrent punktirt, die Punktstreifen ziemlich fein, hintคn erlöschend, mit flachen glänz’uden Zwischeuräumen. L. 2-3“"; Br. $11 / 3-15 / 6 "$.

Dem vorhergehenden üherans ähulich mnd möglicher Weise nur rine For'u desselben, doch aher, wie mich diunlit, anch ansser der bei beiden anscheinend sehr ronstanten Färlung noch durch einige andere Merlinale verschieden, so dass ich ihn bis zu dem Auffuden etwaiger Zwischenformen doch lieber als eine selbstständige Art festlaalten möchte. Las $\delta$ gleicht an Grösse und Gestalt genan dem $\delta$ der vorhergehenden Art, erscheint aber etwas breiter, Jesouders hinterwärts nicht so stark verschmälert; die Punktstreifen sind vorn deullicher. besonders ist daselbst auf dem Ranme neben der Naht die Punktirung gröber und weniger dicht gedrängt, 
der neunte Streifen vor'n hakig un die Schulterhenle gebogen. Die Färbung der Fühlerwurzeln ist dunkler, auf der Oberseite kaum gelıräm, der hintere Theil der Flügeldecken schwärzlichı mit stahlblauem Anfluge, und der vordere lichte Theil durch einen breiten sich an das Schildchen anschliessenden schwarzgrünen Nahtstreifen in zwei grosse rumde gelbe Flecke getheilt: von denselluen liegt einer auf jeder Flügeldecke, berührt vor'u die Wurzel, und reicht seitlich, zugleich die Schulterbeule einschliessend, his an den etwas dunkleren Kiel des Scitenlappens hin. Die Oberlippe ist schwarz, und gleiche Färbung zeigen auch die sechs oberen Fülılerglieder, welche zugleich von der Spitze des sechsten ab deutlich zusammengedrückt und schwach rrweitert erscheinen, und vom achten ab allmählich sich verkürzen, mit schmal kegelförmigem Fortsatze des Endiglieds. Alles Uebrige wie bei dem $\delta$ der vorhergehenden Art.

Das $q$ ist um die Hällte grösser, hesonders hinterwärts breiter, plumper, und gestattet zugleich einen Schluss auf das bis dahin unbekannte $q$ der vorhergehenden Art. Die bedeutendste Abweichung von dem $\delta$ zeigt sich im Bau des Kopfes. Die Augen sind nämlich merklich kleiner, und ihre oberen Theile durch die diesen fast gleichkommende spiegelglatte, nur über den Fühlerwurzeln eine Spur eines Eindrucks zeigende Stirnfläche getrennt. Die Punktirung des Kopfschildes ist etwas deutlicher, die Farbe der Fühlerwurzelı hei geringerer Fühlerlänge lıeller und die Farbe der Oberlippe schwärzlich mit verwaschenen gelben Rändern, daher vermuthlich bei anderen Stücken auch ganz gell). Die Punktstreifen sind etwas feiner als bei dem $\delta$, der secliste und siebente bald hinter der Schulterbeule abgebrochen, die Zwischenräume flacher und stärlier glänzend. Die Farbenvertheilung ist wie bei jenem, nur der gelle Schulterfleck anscheinend ein wenig kleiner. Das letzte Segment mit einer mässigen rundlichen Grube. Das Prosternum bei beiden Geschlechtern flach, hinterwärts scheibenförmig erweitert, und dann fast grade abgestutzt.

Ebenfalls von Ega (Nus. Baly).

Dritte Rotte. Körper kurz und gedrungen, das Halsschild quer buckelig und nach vorn ver'schmälert. Die Deckschilde breiter als lang, mit vorn undeutlichen, hinten verschwindenden Punktstreifen. Die Augen des $\delta$ zusammenstossend. Eine artenarme, in Brasilien einlıeimische Gruppe. 
9. Sc. bicallosus m. Schwarz mit rothem Halsschilde, die Oberlippe und ein Schwielenfleck jederseits des ersten Bauchringes weiss; das Halsschild derb punktirt, die Punktstreifen vorn unre- gelmässig verdoppelt, hinterwärts fast ellöschend, mit flachen Zwischenräumen, der neunte rippenförmig erhöht.

ठ Der untere Theil der Stirn über dem Kopfschilde weiss;

$q$ der ganze kopf bis auf die weisse Oberlippe schwarz.

L. $21 / 2-31 / 2{ }^{\prime \prime \prime} ;$ Br. $13 / 4-21 / 4{ }^{\prime \prime \prime}$.

Ein derber, kräftiger und zugleich durch den Contrast seiner Farben sehr auffallender Käfer, den man äusserlich eher für einen Rhynchites mit abgebrochenem Rüssel, als für einen Cryptocejhaliden halten möchte. Der Kopf gross, flach, die Stirn bei dem ठ grossentheils durch die breiten, schmal dreieckig ausgebuchteten und sehr ungleich getheilten, in langer Strecke zusammenstossenden Augen eingenommen; über ihucn der drejeckige Nackenzipfel fein zerstreut punktirt, von einer feinen Längslinie durchzogen, matt schwarz. Unterwärts nur die Augenbuchten mit den Wangen schwarz, ein dreieckiger, mit der Spitze oben in den Winkel zwischen den Augenrändern eingeschobener Fleck und im Anschlısse an diesen der ohere Theil des Kopfschilds lackglänzend weiss; der untere stärker eingezogene Theil des letzteren schwärzlich, oben lırandig gesäumt, die Oberlippe wicder weiss und die Mundtheile brämlich. Bei dem $q$ ist der ganze Kopf mit Ausschluss der weissen Oberlippe glänzend schwarz, die mässig breite Stirn ilırer ganzen Länge nach von einer derben, unten verbreiterten Längsrimne durchzogen, und in deren Nähe fein und zerstreut-, längs der Augenränder selhst dicht und grüher punktirt. Die Fühler kräftig, das schwach gekrümmte Wurzelglied kirulig, schwach gekrünmt, etwa $2 \frac{1}{2}$ mal länger als loreit, das zweite elliptisch, das dritte dümı verkehrtkegelförmig uml un die Hälftr, das vierte aher doppelt länger als das zwcite, das fünfle fast dem vierten gleich, die folgenden wieder ein wenig liürer, stark erweitert und zusammengedrïckt, das linealische Endglied mit seinem kurz dreieckigem Fortsatze wiedirum dem rierten gleich. Die Farbe der vier muteren durchseheinend robhbrann mit etwas tiefer gebräunter Oberscite, die oheren schwarz. Inas Halsschild sehr kurz und lıreit, hinter Jer Nitte sehr stark quer luckelig aufgewulstet, daher vorn mit $2 / 3$ seiner Länge ziemlich steil abfallend, ïber den tief ringezogeuen scharf spitzwinligen Vorrerecken zusammengedrüclit und da- 
durch verschmälert, die Seiten fein gerandet, hinter der Mitte lang ausgeschweift und vor ihr in flachen Bogen erweitert, auch die Hinterecken durch kurz rorspringende scharfe Spitzen gebildet; der Hinterrand jederseits fast grade, zunïchst an dem kurz aber breit aufgebogenem Hinterzipfel deutlich ausgebuchtet; vor letzterem der hintere Theil des Halsschilds von dem auch hinterwärts stark abfallenden quer buckeligem Mittelfelde ah schräg niedergedrückt, und seillich je ein hreiter, flacher, schräg gegen die Mitte des Seitenrandes himabziehender Eindruck. Die Obertläche ziemlich derb aber nicht dicht punlitirt, mit schwach giänzendem, bei dem $q$ noch matterem Zwischengrunde. Die Farbe roth, der schnale alygesetzte Vordersaum verwaschen schwarzbraun. Das Schildchen fast senkrecht anstejgend, breit dreieckig, hinten kurz abgestutzt mit kaum bemerkbarem Hinterzipfel, glänzend schwar'z. Die Deckschilde fast quadratisch, nicht ganz so lang als voru breit, und vorn auch noch etwas breiter als das Halsschild, hinterwärts ein wenig verschmälert, und dann kurz und loreit zugerundet. Der Rücken flach gewölbt, um die Schildchenspitze buckelig aufgetrieben, hinter ihr die Naht der Länge nach breit niedergedrückt und hinten klaffend, mit kurz und ziemlich steil abfallender Wölbung. Die Wurzelkanten durch eine dahinter liegencle tiefe Querfurche scharf und kräftig emporgehobeu, die Schulterbeulen als breite etwas eckige Höcker heraustretend, die Seitenlappen zu grossen, abgerundet dreieckigen, lang herabhängenden Zipfeh vergrössert, und über ihnen die Deckschilde schräg nach hinten und oben zusammengedrückt. Die Punktstreifen vorn durch überzällig eingemengte Punkte verdoppelt, und besonders nach Naht und Wurzel hin soweit getrübt, dass sie theilwcise nur durch die in der vorderen Querfurche rippenartig vortretenden Zwvischenräume kenntlich iverden; von der Mitte ab sind sie deutlicher entwickelt, aber anch immer melır abgeschıächt, und daher auf und unter der Wölbung kaum noch wahırnehmbar, nur der neunte in seiner ganzen Länge sichtbar, vorn furchenartig eingegraben und dadurch der nemte Zwischenraum bis über die Mitte hinaus als eine stumpfe Längsrippe emporgetrieben, auch hinterwärts noch gewölbt, während die übrigen Zwischenräume flach, voru mit sehr mässigem und durch seine Ruızeln getrübtem, hinten mit stärkerem Glanze erscheinen. Auch der Randstreifen ist über dem Seitenlappen tief eingegraben, und dadurch der Kiel des letzteren stirker anfgetrieben. Die Farbe ein 
reines Kohlschwarz, der Kiel und der umgeschlagene Rand des Seitenlappens bei einem der rorliegenden $\delta$ rothgelb. Pygidium, Unterseite und Beine selır fein und dicht punktirt, vereinzelt kurz angedrückt greishaarig, der erste Bauchring jederseits mit einem grossen rundlichen, scharf begrünzten und lackartig aufgetragenen weissen spiegelnden Schwielenflecke bezeichnet. Die Vorderbrust runzlig punktirt, lang aber nicht dicht greishaarig, hinten etwas erweilirt und breit zugerundet. l)as letzte Segment des $\delta$ seicht rundlich eingedrüclit, das $\subsetneq$ mit dem gewöhnlichen Grübchen.

Aus Brasilien (Nus Baly. Berol. - von Virmond gesammelt. - Deyrolle, in letzterem Bahia als Fundort genannt).

Vierte Rotte. Köpper gross und plump, breit elliptisch oder verkehrteiförmig, flach gewölbt. Die Augen der $\delta$ einander fast berührend. Die Punktstreifen fein, aber im Ganzen regelmässig. Körperfarbe stahlblau mit rothen, oder roth mit schwarzen Zeichnungen. Gleichfalls biasilianische Arten.

10. Sc. corpulentus m. Stahlblau, die Fühlerwurzeln, eine breite an der Naht unterbrochene Wurzelbinde und ein Spitzenfleck der Flügeldecken hell ziegelroth; das Halsschild fein und zerstreut punktirt, die Punktstreifen vorn wellig und stellenweise verdoppelt, hiuten erlöschend mit flachen glänzenden Zwischenrïumen. L. $23 / 4-3 \frac{1}{2}$ "'; Br. 1 $2 / 3-21 / 3$ "'.

Eine an dem kurzen dicken, hinterwärts verbreiterten, stärker als bei den ähnlich gezeichneten Arten anderer Gruppen gewölbten Körper leicht kenutliche Art. Der Kopf hreit und flach, die Augen bei dem $q$ durch einen mässigen, die Oberlippe an Breite etwas ülertreffenden Zwischenraum getrennt, bei dem schlankeren ठ einander näher gerückt; die Stirn oben spiegelglatt mit fein eingeschnittener Stirnlinie, unten mit einzehnen Pünktchen bestreut, die sich auf dem stark eingezogenen, mondförmig quer eingedrückten Kopfschilde etwas dichter zusanmmendrängen. Die Farbe glänzend dunkel stahlblan, die Musdtheile pechbraun mit gelblich gerandeter Oberlippe. Die Fühler des $f$ sehr lang und dünn, das erste Glied keulig mit sehr stark eingeschnürter Wurzel, deutlich nach aussen gekrümmnt, das zweite kurz elliptisch, die drei folgenden schmal mit schwach verdickter Spitze des füıften, das dritte doppelt-, das vierte (lïngste) fast 4 mal länger als das zweite, das fünfte und sechste je etwas külzer als das rierte, die folgenden wieder dem dritten gleich, zugleich schwach zusammengedrückt und erweitert 
mit deutlich abgesetztem Fortsatze des Endglieds. Die Farbe der fünf unteren durchscheinend röthlichgelh mit geschwärzter Oberseite des Wurzelglieds, die obern Glieder schwarz nit gelıäunten Unterrantle des sechsten. Die Fühler des $\delta$ in allen Theilen etwas länger, sonst aber nicht abweichend. Das Halsschild kurz und breit, flach walzlich, hinten etwas niederged'riclit, die Mlittelfirste mit $2 / 3$ ihrer Länge vorn leicht abwäıts geneigt, die Seiten breit gerandet, in der Mitte Jogig erweitert, vor ihr his zu den scharf rechtwinkligen Vorderecken leicht ausgeschweift, die Hinterecken stumpf abgerundet, mit einem kurz aufgelogenen Schwielchen besetzt; der Hinterrand fast grale, nur jederseits des kurzen, breiten Mittelzipfels ausgebuchtet, und daselbst zngleich durch einen kurzen sich nach aussen bald verflachenden Schrägeindruck bezeichnet, der Raud selbst nach jeder Seite hin von cinem feinen, sich im Hinterwinkel krümmenden Fältchen begleitet. Die Puuktirung auf dem Mittelfelde äusserst fein und zerstreut, seitlich besonders nach den Hinterwinkeln zu etwas dichter und deutlicher; der Zwischengrund spiegelglatt, die Farbe dunkel stahlblau, stellenweise ins Purpurröthliche spielend. Das Schildchen schräg ansteigend, hinterwärts mit ausgebogenen Seiten stark verschmälert und mit abgerundeten Ecken abgestutzt; der Hinterzipfel deutlich, die Oberfläche selır fein punktirt, gläızend schwarz. Die Deckschilde kaum um $1 / 6$ länger als breit, sich vorn an das hinterwărts verbreiterte Halsschild in gleicher Breite anschliessend und diese Verbreitung soweit fortsetzend, dass, zumal bei dem $q$, die hintere Breite des Rumpfes die vordere des Halsschilds fast um das Doppelte übertrifft: der Rücken breit und flach gewölbt, auch hinterwärts nur mit flacher Krủmmung abfallend, um die Schildchenspitze merklich aufgetrieben, vorn hinter der scharfen Wurzelkante nur leicht quer eingedrückt. Die Schulterbeulen länglich, die Seitenlappen tief hiıabgezogen, und über ihwen die Deckschilde leicht quer zusammengedrückt. Die Punktstreifen sehr fein und im Ganzen regelmässig, vorn besonders auf der rothen Zeichnung etwas deutlicher, namentliclı bei dem đo kräftiger, an der Naht durclı einige überzählige Punkte gestört; auf der Grundfärbung sind sie undeutlicher, etwas wellig, stellenweise verdoppelt, von der Ylitte ab die äussern oder auch alle fast erloschen; die Rückenstreilen zuweilen leicht eingedrückt. Die Zwischenräume flach, die oberen manchmal an der Wurzel und wieder hinterwärts sehr sauft gewölbt, übrigens 
glatt und glänzend. Die Färbung auch hier ein schönes, dunkles Stahlblau, manchmal mit kupferfarbigem oder pirpurviolettem Anfluge; ein rundlicher, die Spitze einnehmender Querfleck auf jeder Flügeldecke, und eine die Wurzel einnehmende, meist am Schildchen mehr oder weniger breit unterbrochene und dadurch in zwei getrennte grosse Schulterflecke aufgclöste, hinten scharf begränzte und bis zum Hinterende des Seitenlappens reichende Querbinde ziegelroth. Aendert jedoch ab

$\beta$. Der Spitzenfleck der Flügellecken fehlend, in welchem Falle aber ein schınaler Spitzenrand doch noch rerwaschen röthlich durchscheint;

$\gamma$. Der Schulterfleck fehlend, der Spitzenfleck dagegen die breite Spitze der Flügeldeckeı vollständig eimnehmend; endlich

$\delta$. Die Flügreldecken ohne Sclutter - und Spitzenfleck, daher einfarbig stahlblau. Alle diese Abïnderungen sehen auf den ersten Anblick etwas fremdarlig aus, sind aber doch von der Stammform nicht wesentlich verschieden.

Das l'ygidium fein punktirt, stumpf gekielt, mit Unterseite und Beinen stahllblau, dünı greishaarig: das Prosternum grob zerstrent punktir', lie Mitte der Länge nach flach aufgewulstet und glänzend, hinten breit zugerundet, seitlich mit einzelnen greisen Härchen besetzl. Das lelzte Segment des $\delta$ eiufach, das $q$ mit einer grossen rundlichen Grube.

Aus Brasilien olıe nähere Angabe des Fundorts. (Mus. Baly. Deyrolle. Clark. Holm. Berol.) Nach dem Mus. Deyrolle ist diese Art der Pach. crux des Dejean'schen Catalogs, welchen in dieser Familie schon vielfach verwandten Namen beizubehalten ich nicht zweckmässig gefundeu habe. Von den anscheinend seltenen Abänderungen findet sich ein o der var. $\beta$. im Mus. Clark; die var. $\gamma$. und $\delta$. (gleichfalls $f$ ) im Mus. Vindol.

11. Sc. Iuxuriaus m. Stahllılau mit röthlichen Fühlerwurzeln, die Seiten des grob zerstreut punktirten Halsschilds mit Unterseite und Beinen brätmlich durchscheinend, die Wurzel und ein hakenlörmiger Spitzenfleck der Flügeldecken rothgelb; die Punktstreileı derb, in der Mitte gestört und hinten abgeschwächt, mit tlachen ziemlich gläızenden Zwischemräunıen. L. $2 \frac{1}{2}-3 \frac{1}{2}$ "'; Br. $11 / 3-1 \%{ }^{\prime \prime \prime}$.

Dem vorhergehenden tiberaus ähnlich, weshalb ich auf die von 
demselben gegebene Beschreibung Bezug nehmen und mich auf die Angabe der Abweichungen beschräulien kann. $\mathrm{Er}$ ist bei gleicher Länge mit dem $\$ c$. corpulentus doch in beiden Geschlechtern, besonder's aber das ot, schmaler und gestreckter, dahier deutlicher ins Walzenförmige übergelıend; der ganze Vorderkopf, auf dem auch bei dem $\delta$ die oberen iunern Augenräuder vou einander noch um eine måssige Strecke entfernt bleiben, ist von einer breiten und tiefen Längsrinne durchzogen, nur oben fast glatt, auf der unteren Hälfte, die breiten und tiefen Augenbuchten und das mondförmigg niedergedrückte Kopfschild eingeschlossen, fein und dicht punktirt, daher hier von weit schwächerem Glanze. Die Fühler in allen Theilen gestreckter, wenn auch hier nicht die latlbe Kürperlänge erreichend. Das Halsschild zwar nicht diclı-aler grob punktirt und die Punktirung nach den Rändern zu mehr zusammengedrängt; die Punktstreifen auf den Deckschilden sind bei eben só welliger Krümmung und Störung merklich kräftiger, auch auf der Wölbung noch wenigstens an der dunklen Färbung der Punkte kenntlich; der neunte Zwischenraum mit einer sehr vereinzelten Reihe gröberer Punkte besetzt. Die Farbe der Ober'seite ist ein lichteres Stahıblau mit leicht grünlichem, purpurviolettem oder kupferröthlichem Anfluge, besonders am Kiopfe und den Rändern des Halsschilds; die Oberlippe hell kinochengelb mit schnnutzig gebräunter Mitte; auch der untere Rand des Kopfschilds fällt mit den Wangen ins verwaschen Bräunliche, und eine Spur solcher Färbung kommt bei einem der vorliegenden Stücke auch in Inuern der linkeu Augenbucht zun Vorschein. Eben so sind auch die Seiten des Halsschilds verwasehen tief gebräunt, welche Fürbung aber ihres metallischen Glanzes wegen nur hei sorgfiltiger Betrachtung und unter bestimmter Beleuchtung zum Vorschein kommt, und eben so scheint der Saum des Nittelzipfels an Italsschilde und die Wurzel des Schildchens verwaschen bräunlich durch. Auf den Deckschilden verschmälert sich die Vorderbiude vom dritten Punktstreifen wach dem Schiltchen zu sehr merklich, und endet jederseits an dem abgekürzten Streifen, so dass sie hinter dem Schildchen breit unterbrochen ist und nur auf dem Nahtbuckel hinier jenem eine schwache und vereinzelte Spur zurücklässt; nur bei einer sehr seltenen Form

$\beta$. sind die beiden Vorderbinden zu einer die ganze Basis der Deckschilde einnehmenden, fast $1 / 3$ der letzleren bildenden, hinter 
dem Schildchen vollständig verbundenen! Querbinde zusammengeschlossen.

Eine ganz abweichende Gestalt zeigt der Hinterfleck der Flügeldecken. Derselbe erstreckt sich einerseits mit seinem Aussenende soweit nach vorn, dass er fast das ganze letzte Viertel oder Drittel der Flügeldecke einnimmt, wird aber auf seinem vorderen Drittel durch einen dreieckigen Zipfel der Grundfärbung vom Aussenrande geschieden; eben so zieht sich längs der Naht diese Grundfärbung in Gestalt einer breiten, den Raum bis zum zweiten Punktstreifen umfassenden Längslinde bis nahe vor die Spitze hin, so dass dadurch jederseits ein hakenförmiger, mit diesem zienılich spitzen Haken bis zunı Nahtwinkel umgebogener Längsfleck, durch beide aber ein gemeinsamer grosser und in der Mitte tief ausgeschnittener, mit beiden Armen nach vorn zeigender Hufeisenfleck gebildet wird. Das Pygidium leicht gekielt, kaum punktirt, heller oder dunkler gebräunt; auch Unterseite und Beine mehr oder weniger bräunlich. Die Beine zuweilen selbst rötllich, mit metallischem, besonders auf der Mitte der Hinterbrust, der breiten Fläche der Vorderschenkel und der unteren Hälfte der übrigen Schenkel hervortretendem Anfluge. Das breite Prosternum sehr grob punktirt, auf der vorderen Hälfte leicht längswulstig, hinten eben so leicht quer eingedrückt, stahlblau mit fein geröthetem Hinterrande. Das letzte Segment des $\delta$ einfach, das \& mit dem gewöhulichen Grübchen.

Aus Brasilien ohne nähere Angabe des Fundorts. (Mus. Holm. Berol.)

Bei einem zugleich etwas schmaleren $q$ im Mus. Clark zieht sich über die ganze Mitte des Halsschilds eine verloschene rothe Längslinie, die sich in der Mitte zu einem breitern rundlichen Flecke erweitert; ehen so ist der Hintersaum des Halsschilds jederseits des Mittelzipfels und jede Hinterecke fein gerōthet, während der Hinterfleck der Flügeldecken gegen die normale Form merklich verkürzt ist. $0 \mathrm{~b}$ darunter eine eigne Art verborgen ist, wage ich nach diesem einzelnen, ohmehin niclit gut erhaltenen Stücke nicht zu entscheiden. Als Fundort ist S. Paolo (Brasilien) genannt.

12. Sc. octo-maculatus m. Blutroth, die Flügeldecken ziegelroth mit vier schwarzen Flecken (2, 2), die Beine schwarz; das llalsschild kaum punktirt, glanzend, die Punktstreifen fein, mit flachen, spiegelglatten Zwischenräumen. L. $3^{\prime \prime \prime} ;$ Br. 2'“. 
Ein kurz aufgetriehener, im Habitus dem sc. corpulentus am nächsten kommender, durch seine Zeichnung aber von allen verwandten abweichender und an manehe mittelafrikanische echte Cryptocephalen erinnernder Käfer. Der Kopf flach, mit breiter und seichter längsrinne, welche üher dem oben durch eine schivache Bogenlinie begränzten Kopfselilde sich zu einem flachen Eindrucke ausbreitet, glïnzend dunkelblutroth, zwisehen den Augen etwas ins bräunliche fallend, ohne deutliche Punktirung. Die grossen, bei dem vorliegenden $q$ ziemlich weit getrennten Augen greis, die stark vorspringende Oberlippe knochengell, die Mundtheile schwärzlich. Die Fühler kaum von $1 / 3$ der Körperlänge, sehr dünn und schlank, das zweite Glied kurz und knotig, das dritte doppelt länger, mit den beiden folgenden noch etwas an Länge zunehmenden dünn verkehrtkegelförmig, die oberen sehr schwach erweitert und zusammengedrückt, an Länge etwa einander und dem dritten gleich, mit kurz dreieckigem Fortsatze des Endglieds. Ile Farbe der fünf unteren durehscheinend honiggelb mit einem schwärzlichen Längsflecke auf der Oherseite des Wurzelglieds, die oberen schwarz mit düıner greiser Behaarıng. Das Halsschild fast doppelt lıreiter als lang, von der abgeflachten Mitte ab seitlich mässig abwärts gekrüımt, und über den tief eingezogenen scharf spitzwinkligen Vorderecken versehmälert, die Seiten deutlich gerandet, in der Mitte in flachen Bogen erweitert; die Hintereeken scharf stumpfwinklig, der Hinterrand jederseits deutlich ausgeschweift, und in dieser Ausbuchtung entspringt ein kräftiger Quereindruck, welcher längs deın Rande eine Strecke nach Aussen zieht, und durch eine sehwächer niedergedrückte Stelle mit einem vor dem Hinterwinkel liegenden Schrägeindrucke zusammenhängt. Die Farbe glänzend blutroth mit dunkJer gebräunten Säumen; von einer Punktirung zeigt sich nur hier und da, besonders an und in den hinteren Eindrücken, eine schwache Spur. Das Schildchen stark sehräg ansteigend, nicht so lang als vorn breit, unl aus breiter Basis hinterwärts stark verschmälert, mit abgerundeten Ecken abgestutzt, glänzend dunkelroth. Deckschilde so breit wie lang, flach gewölht, hiıter der mässig erhöhten Vorderkante leicht quer gefurcht und dahinter wieder etwas aufgetrieben, hinter dem Schildclien auf der Naht seicht quer eingedrückt; die Sclsulterbeulen breit und flach, die Seitenlappen schmal, aber tief herabgezogen, und über ihnen die Deckschilde etwas zusammengedrückt, die Wölbung ziemliclı steil abfallend. Die Punkt- 
streifen fein und ziemlich regelmässig, die mittleren leicht wellig gebogen, der sechste aufyelöst und der siebente in der Mitte abgerissen, und auf dem dreieckigen Raume zwischen der Naht und dem zweiten Streifen bis zu der Mitte des letzteren hin zerstreute überzählige Punkte. Die Zwischenräume flach und glänzend, die Farbe ein ziemlich helles Ziegelroth, ein feiner Vordersaum und vier Flecke auf jeder Flïgeldecke schwarz. Letzlere stelsen in zwei Paaren, die des äusseren grösser und in die Länge gestreckt, rorn der äusser'e auf der Schulterbeule und ron dieser aus schräg nach linten und innen gerichtet, der innere von Naht und Schildchen nur durch einen schmalen Zwischenraum getrennt; hinten steht der äussere vor und auf der Wölbung zwischen dem fünften und nennten Streifen, der innere merklich kürzere etwas weiter nach vorn zwischen dem zweiten und vierten Streifen, alle an den Rändern etwas unregelmässig begränzt, aber auf beiden Flügeldecken im Wesentlichen gleichgestaltet. 1)as Pygidium längskielig, fein gerunzelt, blutroth mit dünuer, gelblich-greiser Behaarung; auch die Unterseite blutroth, welche Färbung je weiter nach vorn desto mehr ins tief Branurothe übergeht. Die Beine schwarz nit röthlichen Höften unıl eben so durchscheinenden Ḱrallengliede, die Vorderschenkel stark aufgetrieben, die Schienen entsprechend verlängert und gekrümmt. Das Prosternum breit, seitlich der Länge nach flach niedergedrückt, hinten lı’eit zuger'undet, mit vorn heller gerötheter Mitte. Das letzte Segment des $q$ mit einer grossen, vorn zugerundeten und hinten grade aligestutzten Grube. Was $\delta$ unbekanut.

\section{Gleiclıfalls aus Brasilien (Mus. Deyrolle).}

Fünfte Rotte. Körper gross und plunp), aus dem Walzenförmigen hinterwärts etwas verschmïlert, mit schwachen, vorn theilweise undeutlichen I'muktstreifen. Die Oherseite mit mancherJei hellen Farben geziert. Die $\delta$ bis dahin unbekannt. Brasilien.

13. Sc. a bbreviatulus m. Rothgelb mit gelbem Pygidium und schwarzen Fühlerenden, das spiegelglatte Halsschild mit den Flügeldecken gelb, jenes mit zwei, diese mit drei $(2,1)$ grossen rothyelben Flecken; die Punktstreifen fein, rorn wellig und an der Naht etwas gestör't, mit flachen, glïnzenden Zwischenräumen. L. $3-3 \frac{1}{2}{ }^{\prime \prime \prime} ;$ Br. 2-2 $1 / 3$ "'.

Eine grosse, zugleich durch ihre helle Färbung und Zeichmung sehr auflatlende und kemntliche Art. Der Kopf thach mit fein ein- 
geschnittener, am unteren Ende zu einem grösseren Eindrucke erweiterter Stirnrinne und wieder etwas eingezogenem Kopfschilde; die Punktirung ziemliclı dicht, besonders an den Augenrändern und auf dem Kopfschilde dicht zusammengedrängt, mit mässig glänzendem, in den Augenbuchten und am unteren Rande des liopfschilds anliegend gelblich behaartem Zwischengrunde. Die Farbe rostroth, mit melı ins Gelbliche fallender Oberlippe und gebräunten Spitzen der Mundtheile. Die Fühler (des $\varsubsetneqq$ ) kaum von halber liörperlänge, das Wurzelglied eiförnig, oben doppelt länger als breit, auch das zweite eilörmig, halb so lang und breit wie das erste, die drei folgenden sehr dünn, etwas flach gedrüclit, ziemlich gleich lang und je den beideı ersten zusammen gleich, das fünfte nach oben hin schwach verbreitert, die oberen stärker zusammengedrückt und auf der Innenseite erweitert, bis zum zelınten, welches etwa dem ersten gleich kommt, wieder allmählich abnehmend, das Endglied merklich schmaler und mit seinem durch eine dentliche Ausrandung abgesetztem Fortsatze etwa dem sechsten gleich. Die fünf unteren rothgelb mit einer schwärzlichen Längslinie auf der Oberseite, welche letztere davon bei dem fünften sclıon fast ganz bedeckt ist, die sechs oberen schwarz, dümn anliegend greis behaart und an den Spitzen länger abstehend greis gewimpert. Das Halsschild doppelt breiter als lang, mit fast flacher Mittelfirste, über den rechtwinkligen Vorderecken zusammengedrückt und dadurch verschmilert, die Seiten fein gerandet, in der Mitte bogig erweitert und vor ihr leicht ausgeschweift; die Hinterecken stumpfwinklig, mit einer aufgebogenen Schwiele besetzt, der IIinterrand nur jederseits an dem stark heranstretenden Mittelzipfel tiefer ausgebuchtet, und vor dieser Biegung je ein tiefer Schrägeindruck, dessen schmaleres etwas abgesetztes Aussenende ïber der erweiterten Nitte des Seitenrandes abbricht. Vor und hinter diesem Aussenende liegt jederseits noch ein stärkerer, dem Seitenrande näher liommender Quereindruck, und ein vierter, sclıwächerer jederseits hinter dem Vorderrande, reicht aber nicht bis zu den Vorderecken hinab. Die Punktirung äusserst lein und zerstreut, mit spiegelglattem Zwischengrunde; die Farbe lehmgelb, und jederseits der Mitte ein grosser querrundlicher verwaschen begränzter rostrother Fleck, dessen Hinterrand sich an den grössem Schrïgrindruck anthlut; zwischen beiden vor dem Mittelzipfel zuweilen noch eine feine röthliche Längsliuie. Das Schilılchın quer viereckig, 
hinterwärts v'erschmälert und stark anstejgend, mit abgerundeten Hinterecken und undeutlichem Ilinterzipfel, sehr fein zerstreut punktirt und dünn gelbhaarig, rustrotlı mit dunklerem Rande. Die Declischilde sehr breit und flach gewölbt, haum 1/6 länger als breit, vorı etwas breiter als das Halsschild und hinterwärts ein wenig verschmälert, die Spitze kurz zugerundet, fast mit ahgerundeten Ecken abgestutzt; die Vorderkanten schwach aufgewulstet, und hinter ihuen nur immerseits der breiten flach höckerigen Schulterbeulen ein grösserer Längscindruck. Her Rückèl tlach gewölbt, nur binter dem Schildchen etwas eingedrückt, ron da al mit sanfter Krünmmng bis zur Spjtze ablallend; die Seitenlappen ziemlich lang luerabgezogen, und über ihnen die Deckschilde hreit zusammengedrïckt. Die Punktstreifen lein, die oberen anf der Vorderhälfte etwas wellig gekrümunt, anch, hesonder's längs der Naht, durch üherzählig eingemengte Punkte getrübt oder stellenweise verdoppelt. Jie äusseren, sowie die hintere Hälfte aller Streifen deutlicher, aber auch feiner, auf der Wülbung alle melı oder weniger algeschlillen. Die glänzenden Zwischenräume flach, der neunte selır breit, in der Vitte mit einer abgekürzten Reilı, gröberer Punkte besetzt. Die Farbe lelımgelh mit drei ungleichı⿰丿 grossen rothgelben Flecken, ein grösserer vorn im Nahtwinkel zwischen dem ersten und vierten Streifen, von Nahı und Wurzel nur durch einen schmalen Zwischenraun getrennt, mul ein kleinerer Längstleck auf und hinter der Schulterbeule, zwischen welchem und dem Innenfleck der vicrte Zwischenraum frei bleibt; endlich anf der linteren Iälfte noch eiı grosser hall, elliptischer Fleck zwischen dem zweiten und achten Streifen, welcher von der Spitze jedoch noch rtwas weiter als von Niht und Seitenrand entfernt beibt. Das Pygidium stumpf gekielt, feın runzlig punktirt, dicht angedrückt weisshaarig, helgelb, unten leicht ansgerandet; die Unterseite gleichfalls fein punktirt, liurz und dicht weiss hehaart, dunkler roth, mit hreit gelb gesäumtem Hinterleilse. Auch die Beine rostroth, die muteren Enden der Fussglinder mit den Kirallenhäkichen geschwärzt, die Vorderschenkel stark verbreitert mit entsprecbend gekrimmten Schienen. Die Vorlerbrust breit mit zwej kurzen Längseindrücken, zwischen denen das Mittelfeld flach erhöht ist, hinten kurz zugerundet, dicht runzlig punktirt und greishaarig. Das letzte Segment des $q$ mit einer ziemlich Kleiıen, halbkugeligen und im Innern glänzenden Grube; das ơ unbekannt. 
Aus Brasilien (Mus. IIal. Deyr. Berol.). - Das Expl. des letzteren von $v$. Olfers mitgebracht.

14. Sc. incomparabilis m. Bunt, der Kupf, siehen Flecke, des zerstreut punktirten weissen Halsschilds, das Schildchen, die Unterseite und der imnere Saun der Flügeldecken schwarz, letztere ziegelroth und bis auf die Wurzel nochmals weiss gerandet, das Pygidium weiss; die Punktstreifen vorn undeutlich, hinten fast erloschen, mit flachen, fein narbig punktirten Zwischenräumen. L. $3-3{ }^{2} / 3^{\prime \prime \prime} ; \mathrm{Br} .2-2 \frac{1}{3}{ }^{\prime \prime \prime}$.

Eine durch ihre abnorme Färbung und Farbenvertheilung von allen bekaunten gänzlich verschiedene Art. Der Kopf flach gewölbt, nit tief niedergedrückter, von einer feinen aber deutlichen Längslinie durchzogener Stirn, das schmal mondförmige Kopfschild tief eingezogen, und oben zwischen den Fühlerwurzeln durch einen flachen Querwulst begränzt. Die Oberfläche oben ghat und ziemlich glänzend, unten mit den Augenbuchten und dem Kíopfschilde fein und ziemlich dicht punktirt. Die Farbe schwarz, die stark vorspringende Oberlippe hell knochengelb, die kurz halbkreisförmig ausgebuchteten, (bei dem q) weit getremnten Augen greis. Die Fühler nicht wesentlich von denen der vorhergehenden Art verschieden, die fünf unteren Glieder hellgell mit geschwärzter 0lsesseite, die oheren schwarz. Das Halsschild etwa $2 \frac{1}{2}$ mal breiter als lang, oben flach gewöłbt mit fast grader, kaum merklich nach vorn geneigter Längsfirste; über den scharf spitzwinkligen etwas nach aussen gebogenen Vorderecken zusammengedrückt und dadurch verschmälert, die flach abwärts gekrümmten Seiten dentlich gerandet, hinter der Mitte bogig erweitert, vor ilır leicht ausgeschweift; die stumpfwinklig zugeschärften Hinterecken gleichfalls schwach aufgebogen, der Hinterrand doppelt gebuchtet mit flach zugerundetem wenig vortretendem Mlttelzipfel, und vor diesem ein bogenföımiger, seitlich sich verbreiteruder und gleichzeitig verflachender Quereindruck. Die Oherfläche zerstreut und oben feiner-, seitlich etwas k'äftiger punktirt, mit glänzendem Zwischengrunde, der breite weisse Rand ausserhalb der Fleckenzeichnung ganz punhtfrei: die Farhe weiss mit siehen schwarzen in zwei Querreihen vertheilten Flecken, in der Vorderreihe deren vier von ziemlich gleicher Breite, dlie äusseren kleineren ziemlich rund, die mittleren viereckig und hinterwärts noch in einen ülser die Mitte hinausreichenden Zipfel ausgezogen; in der Hinterreihe drei Flecken, seit- 
lich je ein rhombischer Querfleck, schräg nach vorn umd aussen gerichtet, und auf dem beschränkteren Mittelraume noch ein kräftiger in der Mitte leicht gebrochener oder linienförmiger Querfleck, dessen Vitte sich auch sanft nach vorn und hinten in einen kurzen Zipfel erweitert. Das Schildchen schräg ansteigend, fast so lang als vorn breit, hinterwärts verschmälert und zugerundet, mit kurzem Ilinterzipfel, schwarz. Die Deckschilde breit und flach gewölht, mehr walzlich wie bei den Arten der nächstfolgenden Gruppen, von der Wurzel ab hinterwärts leichı verschmälert und dem entsprechend sich hinterwärts mit sehr schräg abfallender Wölbung verflachend, vorn hinter der scharfen aber wenig hervortretenden Wurzelkante schmal und tief quer gefurcht, die Schulterbeulen breit aher ziemlich flach, und die Seitenlappen wenig ahwärts gezogen. Die Punktstreifen aus sehr vereinzelten und nicht tief eingestochenen Punkten gebildet, vorn mehrfach gestürt und durch überzählige Punkte getrüht, überhaupt ziemlich schwach, und auch in ilırer regehmässigeren Hinterhälfte fast nur an der dunkleren Färhung der Punkte kenntlich; die flachen Zwischenräune fein genarbt, hinterwärts etwas stälier glänzend. Jlie Farbenvertheilung ist sehr eigenthümlich; las ganze die Gestalt einer etwas unregelmässigen Ellipse bildende Mlittelfeld jeder Flügeldecke ist fahl ziegehoth mit einem Stich ins Chokoladenbräunliche, und diese Färbung umzieht ein deutlicher und scharf begränzter schwarzer Saum, und letzteren dann noch ein breiterer, nur auf der Mitte des Ruckens zu einer schmalen aber doch immer noch bemerklichen Nahtlinie schwindender weisser Rand, welcher nur lings der Wurzel felılt, und sich dafïr mit dem Schulterende an den breiten weissen Raud des IIalsschilds, mit dem vorderen Imenende neben dem Schildchen an den schrägen weissen Zwischemrann anschliesst, welcher auf dem Ilalsschille die heiden Seitenllecken jederseits von dem Mitteldreiect trennt. Aendert jedoch ab

P. das ganze Mlittelfeld der Flügeldecken bis auf den weissen Raud dersellsen schwarz; sonst aber durchans nicht abweichend.

Ilas Pygidium fein runzlig punktirt, schmutzig weiss; die Unterseite schwarz mit schmutzig weisslichen Rande des Ilinterleibes, die Ringe de's letzleren hinten fuclısröthlich gerandet, der letzte fast yanz roth. Auch die Beine schwarz, die Hüften, Schenkolwurzeln mud Schienenspitzen trïh gebräunt, die Vordershenhel verdickt, mit stark gekrümmten Vorderschienen. Das Prosternum breit und 
flach, grob längsrunzlig, hinten mit abgeschrägten Hinterecken abgerundet. Das"letzte Segment des $q$ mit dem gewöhnlichen Grübchen; das o unhekanut.

Gleichfalls aus Brasilien (Mus. Deyr. Vindob. Berol.; bei den Stïcken des letzteren, welche von Selln gesammelt worden, ist Collo del Sagramento als Fundort angegelien; die var. $\beta$ im Mus. Clark).

Sechste Rotte. Körper ziemlich gross und plump, hinterwärts stark verschınälert. Das Halsschild matt, querrunzlig punktirt; die Punktstreifen vorn groh, hinten verschwindend. Farbe schwarz nit sehr regelmässigen weissen Längs- und Querzeichnungen. Eine einzelne, gleichfalls aus Brasilien stammende Art.

15. Sc. parabolicus m. Schwarz, eine Mittellinie des Kopfes und des matt narbig-querrunzlig punktirten Halsschildes nebst dem Rande des letzteren, Schildchen, Naht und Aussenrand mit einem hinteren Kreuzllecke der Flügeldecken, Pygidium, Beine und Saum des Hinterleibes weisslich; die Punktstreifen hinten feiner, mit flachen, fein runzlig punktirten, ziemlich glänzenden Zwischenräumen. L. $2 \frac{3}{4} ; \mathrm{Br} .1 \frac{1}{2}{ }^{\prime \prime \prime}$.

Anscheinend selten und mir nur in einigen wenigen Stücken vorliegend, an den weissen Linienzeichnungen der Oberseite leicht kenntlich. Der Kiopf flach mit stark zurücktretendem Nacken, über dem gleichfalls eingezogenen und oben durch einen flachen Querwulst begränzten lioplschilde leicht quer niedergedrückt, mit feiner aber dentlicher Stirnlinie: die Oberfläche besonder's auf dem schwarzgefö̈blen Grunde ziemlich dicht punktirt und matt. Die Farbe schwarz, eine breite sich unlerwärts noch etwas erweiternde und auf dem Kopfschilde sich seitlich aushreitende, letzteres bis auf einen breiten schwarzen Untersaum ganz mit einnehmende Längslinie gellulich weiss; auch Oberlippe und Taster gelhlich, letztere etwas ins Röblıliche fallend. Die mässig langen, verhältuissmässigg breiten und tief ausgebuchteten Augen schwärzlich, weit getrennt. Die Fühler (des q) kaım von halber Körperlïnge, das erste Glied aus eingresclnürler Wurzel stark riförmig aufgetriehen, fast doppelt länger als breit, das zweite birnförmig, etwa $1 / 3$ so lang als das erste und um die Hälfte länger als breit, das dritte um die Hälfte, das vierte fast doppelt, und das fünfte reichlich doppelt länger als das zweite, das sechste dem füıften gleich, die folgenden wieder allmälılich absnehmend, so dass das zehnte kanm dem dritten gleich ist, und das XVI. 
Endglied mit seinem kurz dreieckigen Fortsatze etwa wieder die Länge des achten erreichend. Dabei die oberen vom sechsten an leicht zusammengedrückt, rom siebenten ab anch etwas erweitert; die Farbe der fünf unteren gell, etwas ins Röthliche fallend, mit leicht gebräunter Spitze des fünften, die oberen schwarz, fein behaart und länger abstehent greis gewimpert. Das Ualsschild sehr - kurz und breit, mil sanft gekrümmter Nlittelfirste, lüngs den ganzen Ilinterrande leicht yuer eingedrückt und dieser Eindruck vor dem Schildcben von einer vertieften, aber die Nitte nicht erreichenden Längslinie durchsetzt; die fast rechtwinkligen Vorderecken tief eingezogen, auch die Seiten lang herabgezogen, fein gerandet, an den scharf stumpfiwinkligen Hinterecken teicht ausgeschweift, auch der Hinterrand nur unscheinbar gehuchtet, mit kurzem, breitem, leicht anfgebogenem Mittelzipfel: die Oberfläche auch hinter dem Vorderrande leicht niedergedrïclit. Die I'mnktirung ziemlich grob, nässig' dicht, auf dem schwarzen zugleich matt narbig-runzligem Mlittelfeld etwas mehr zusammengedrängt, und dieses Mittelfeld durch einen breiten Rand und eine cben so breite Mittellinie von weisslicher Färluug in zwei grosse nach aussen etwas verschmälerte viereckige Qnerflecke getheilt. Das Schildchen viereckig, mit etwas ausgeschweiften Seiten hinterwärts verschmälert und daselhst leicht abgermndet, mit deutlichem Hinterzi|ffel, glatt, gleichfalls weisslich mit schwarzem Saume. Ilie Dechschilde etwa $2 \frac{1}{4}$ mal linger und in den Schuitern aucin breiter als das Halsschitu, hinterwärts mit leichter Rundung starli rerschmälert, breit und flach walzenfürmig, vorn hinter der seharf erhöhten Wurzelkante tief quer gefurcht und dahinter wieder eben so stark wulstig ansteigend; die Schulterbeulen als kräftige Längshöcker emporgehoben, anch die Scitcnlappen stark herahgezogen, ïber ilnen tlic Deckschilde breit und flach zusammengedrückı, und dieser Eindruck, obwohl allmälılich abgeschwächt, doch bis zur Nahıt hinanf zı verfolgen. Die Punktstreifen regelmässig;, aber nur ilıre Vorderenden bis zu jeıen Qnereindrucke deutlich, die beiden innem vorn durch überzählige Punkte stellenweise rerdoppelt und nit solehen auch dor haum bis zur Naht ansgefüllt. Ilinterwärts werden die Punlite feiner, und nur dic nahe an Naht end Aussenrand liegenden Streifen bleiben liemntlich: die breiten Zwischenrämme sind flach, rorn fein qnerrunzlig und desshalb nur hinterwärts ziemlich glïuzend. Der ungeschlagene (trül) gełbe) Rand des Seitenlappens durch Querrmzeln matt, aher 
ohne Punkte. Die Farbe der Flïgeldecken schwarz, ein breiter Saum längs Naht, Spitze und Aussenrand weissgelb, eben so eine auf dem Quereindrucke liegende, Nalıt und Aussenrand verbindende Querlinie und eine von dieser nach der Wurzel ziehende, den vierten Zwischenraum eimnehmende Längslinie weissgelb, alle diese hellen Zeichnungen von ziemlich gleicher Breite, fast so breit wie die des Halsschilds, und dahei etwas gegen den schwarzen Grund erhöht, wie lackartig aufgetragen. Der schwarze Zwiscnengrund theilt sich dadurch anf jeder Flügeldecke in drei grosse Felder, ein hinteres, der Gestalt nach parabolisches auf der grösseren llinterhälfte, und dann noch in dem, dem Halsschilde an Länge gleichkornmenden vorderen Raume zwei viereckige Längsflecke neben einander, deren innerer den äusseren fast um die Ilälfte an Breite übertrifft: die Unterseite dicht punktirt, schwarz, ein breiter Saum des Ilinterleibs und die Beine, wie das Pygidium, weiss; jenes Saum des Hinterleibs auf dem ersten, und wiederum auf dem letzten Ringe da, wo er sich der Färbung des Pygidliums anschliesst, breit erweitert. Die Fussglieder etwas ins Röthliche fallend, die Mitte der Schenkel mit leichter Andeutung eines schmutzig bräunlichen Wisches. Das Prosternum grob runzlig punktirt, ziemlich breit, in der Mitte stumpf längsriulstig, hinten dreicckig abgerundet; die hintere Hälfte desselben gelblich mit nach rorn verwaschener Begränzung. Das letzte Segment des $q$ breit quer eingedrückt, und damm in der Mitte noch mit einer grossen rundlichen Grube; das $\delta$ unbekannt.

Aus Brasilien ohne nähere Bezeichnung des Fundorts. (Mus. vom Brucli, Clark.)

Siehente Rotte. Kürper von mässiger Grösse, gedrungen, flach walzlich und ziemlich gleichloreit, mit gleichfalls breitem, vorn kurz zugerundetem Ilalsschilde. I)ie Punktstreifen mehr oder weniger deutlich; die Augen des ơ meist getrennt. Die Farbe roth oder gelb, zum Theil mit schwarzen Zeichnungen, zuletzt ganz schwarz, zum Theil nit Auftreten der in der neunten Rotte typischen rothen Schulter- und Spitzenllecke. Eine zicnlich artemreiche Gruppe aus den Länlern an caraibischen und atlantischen Neere.

16. Sc. 17. guttatus m. Gelbbraun, der liopf, zwei seitliche Mondflecke und drei Mittelflecke des fein und zerstreut punktirten Halsschilds, die Vortlerkante und fünf Flecke der Flügelılecken $(2,2,1)$ mit dem Pygidium weissgelh; die Punktstreifen ziemlich fein, linter 
der Mitte fast erloschen, mit flachen, glänzenden Zwischenräumen L. $2-21 / 3^{\prime \prime \prime} ; \mathrm{Br}, 1 \frac{1}{3}-1 \frac{11}{2}{ }^{\prime \prime}$.

An Färbung und Zeichnung bei oberflächlicher Betrachtung dem Cr. 15 guttalus und guttula Fab., besonders dem letzteren, täuschend ähnlieh, und so nochmals in dieser Beziehung ein ähnliches Naturspiel wiederholend, wic es uns in dieser Gattung schon einmal bei dem Sc. 8. maculatus nr. 12 - begegnet ist. Der Kopf flach, mit deutlicher unteı erweiterter Stirnlinie, auf der unteren Häfte, besonders dem etwas eingezogenen liopfschilde deutlich und ziemlich dieht punktirt. Die Farbe ein lackglänzendes Weissgeth, der Rand an Nacken und Augen, die Augenbuchten, die Stirnlinie und der Unterrand des Kopfschildes verwaschen honiggelb; die Kinnbacken und Tasterenden pechloraun, die grossen, durch eine dreieckige Aushuchtung sehr ungleich getheillen, (bei dem of) ziemlich weit getrennten Angen schwärzlich. Die Fühler nicht ron halber Körperlänge, das vierte und sechste Glied einander gleich, je um die Hälfte länger als das dritte, das fünfie (längste) je noch etwas läıger als dias vierte, die oberen wieder allmählich und soweit verkürzt, dass die beiden detzten kaum je dic-Länge des dritten erreichen: dabei die oberen rom sechsten ab schwach erweitert und zusammengedrückt. Die Farbe der fünf unteren hell und durchscheinend honiggelb mit gebräunter Oberseite des zweiten und dritten, die oberen schwarz, dünn angedrückt greishaarig, mil gebräunter Wurzel des sechsten. Das Ilalsschild $2 \frac{1}{2} \mathrm{mal}$ so $\operatorname{lang}$ wie breil, hinter der Nitte sanft quer aufgewulstet uns ron da ab wach vorn und hinten ziemlich gleichmässig abwärts gelirummt, über den scharf spitzwinkligen V'orderecken lreit zusammengedrückt und dadurch verschmilert, die Seiten gerandet, hinter der Hitte im Bogen erweitert und vor iḷ! leicht ausgeschweift; die stumplen llinterechen mil kurz aufgebogenen scharfen Schwielen heselzt, der Hinterrand jederseits leicht doppelt geluuchtet, nit sels kurzem, wenig vortretendem Vittelzi,fel; auf jeder Seite des letateren ein nach aussen verbreiterter und verflachter Schrägeindruck, durch wedchen den Ilinterrand entlang ein flacher treieckiger Querwulst enporgeschoben wird, und ror jenem Eintruche noch ein zwoiter kïrzerer, welcher sich' nach vorn in die schrag zur Vurderecke abliallende Fläche verliert. Die Punktirung selır fein und zerstreut mit lackglänzendem Zwischengrunde, die Farbe gellhbraun, der breite mit den Enden mondförmig nach lunen umgebogrene seitentand weiss- 
gell, und dieselhe Fäbung zeigen dann noch drei Flecke auf dem Mlittelfelde, nämlich ein verkelırt dreieckiger, mit der Basis an die Mitte des Vorterrandes gelehnter Vorderfleck, und zwei mit alogerundeten Spitzen rhombische Schı̈äglecke ror dem Schildchen. Letzteres nur sehr schrrig ansteigend, merlilich liürzer als vorn breit, hinterwäıts mit ausgebuchteten Seiten verschmälert, und mit abgerundeten Ecken aber wenig merkbarem Hinterzipfel sehr breit abgestutzt. Die Oberfliche sehr dicht und fein punktirt, braungelb mit glattem stärker glänzendem Hinterrande. Die Deckschilde um 1/4 länger als breit, linterwärts wenig verschmälert, und dann kurz und breit zugerundet; der Rücken flach gewöllt, längs der Naht und dann nochmals quer über die Nitte leicht niedergedrückt, vorn hinter ler scharfen Wurzelkante schmal aher tief quer eingedrücki, nit ziemlich flachen Ssluulterbeulen, aber stark herahgezogenen Seitenlappen. Die Punktstreifen ziemlich l'ein, in Ganzen regelmässig, die mittleren besonders bei dem of schon von der Mlitte ab fast verschwindend, und auf der Wölbung fast jede Spur von Streifen erloschen. Die Zwischenräume flachı, äusserst fein querrunzlig, aber doch glänzend. Die Farbe loraun, der mittlere Theil der Wurzelkante und fünf Flecke auf jeder Flügeldecke weissgelb, die beiden Paare verkehrt schräg gestellt, sodass jeder Aussenfleck weiter nach hinten als sein Nebenfleck gerïckt ist. Von dem Vorderpaare liegt der Imnenfleck an der Aussenseite des Schildchens, der äussere, stark quer gezogene über dem Seitenlappen hinter der Schulterheule, von dem zweiten in seinen Dimensionen kleineren Paare der Innenfleck gleich linter der Mitte, ohne die Naht zu berïlıren, der quer gezogene Aussenfleck schon auf der Wölbung; endlich nimmt noch ein vereinzelter Querfleck die Spitze ein, so dass nur ein feiner Quer'saum dunkel bleibu. Das Pygidium schwach gekielı, überaus fein runzlig punklirt, nit dem letzten Hinterleibsringe weissgelb, die übrige Unterseite mit den Beinen braungelb, mit einer sehr kurzen und dünnen greisen Behaarung bedeckt. Das Prosternum flach, länger greishaarig, hinten zugerundet. Das letzte Segment des o mit dem gewöhnlichen Grühchen; das o unbekannt.

Aus Venezuela (Mus. Berol. Vindob., von Moritz mitgebracht).

17. Sc. posticatus m. Schwarzblan, die Fühlerwurzeln, das zerstreut punlitirte. Halsschild und die Declischilde roth, jenes mit lü̈n, diese mit zwei oft erloschrnen schwarzen Punkten; die P'unkt- 
streifen ziemlich fein, vorn etwas gestört, mit flachen, fein querrunzligen Zwisclıenräumen. L. $2 \frac{1 / 3}{3}-2^{5} / 6 "$; Br. $1 \frac{1}{3}-1 \frac{2}{3}{ }^{\prime \prime \prime}$.

Etwas mehr gleichbreit als der vorhergehende, und dadurch zu den folgenden fast ganz gleichlbreiten Arten ïberleitend. Der Kopf flach mit etwas zurücktretendem Nacken, ler obere Theil des Kiopfschildes flach wulstig erhöht, und dadurch gegen die untere Stirn abgesetzt; die Stirmrinne bald tiefer, bald schwächer ausgebildet, oder nur mit dem verbreiterten Unterende vorhanden. Die Oberfläche grob zerstreut punktirt, mit Spuren kurzer Behaarung; die Färlung schwarz mit stahlblanem Anfluge, nur die Mundtheile pechbraun und auch die heller gelblicho Oberlippe in der Nitte schmutzig gebräunt. Die breit aber nicht tief ausgelıchteten Augen auch bei dem ठे weit getrennt. Die Fühler des $\delta$ von elwas ïlser laalher Körperlänge, des $q$ kürzer; das zweite Glied lirnförmig, das dritte doppelt länger und die beiden folgenden noch etwas verlïngert, die oberen dem fünften gleich, vom sechsten ab deutlich verbreitert und zusammengedrückt, mit kurz zugespitztem, auf der Innenseite deutlich abgesetztem Fortsatze des Eudglieds. Die fünf unteren Glieder durchscheinend röthlich gelh mit geschwärzter Oherseite des Wurzelgliedes, die oberen schwarz. Das Halsschild hinten fast $2 \frac{1}{2}$ so breit wie lang, mit fast gerader Mittefirste, vol'n ïber den scharf spitzwiukligen Vorderecken zusanmmengedrückt und dadurch verschmälert, an den Suiten fein gerandet, hinter der Mille daselhst bogig erweitert uml vor ihr sohr leicht ausgreschweilt; die stumpfwinkligen Hinterecken scharf, der Ilinterrand jederseits sanft ausgebuchtet, mit kurzem Mittelzipfel. Das Mittelfold hinterwärts leicht abwärts gedrückt, und daran schliesst sich jederseits ein unterhrochener llacher Schrägeindruck, ror welchem zuweilen noch eine Andeutung eines zwoiten noch schwicheren wahruehnbar ist. Die Punktirung rereinzelt und ziemlich fein, nur vor den Hinterecken etwas derber und dichter, anch wohl stellemweise zu Runzehn verlliessent. Die Farbe dunkelziegelroth mit schwachem Glanze, bei normal gezeichneten Stücken nit einer Querreihe von virer schwarzen rundlichen P'nnkten ror der Mlitte, die beiden seitlichen etwas kleiner, mehr nach rorn gerückt, und dann noch ein fïufter, mehr schattenartigner und rerwaschener hinfer dem Zwischenraume der beiden mittleren, und gegen die litte des lliuterrandes in die Länge gestreckt. Solche Stücke sind aber selten, hänfiger dagegen audere mit melr oder weniger verloschenen Aussenpunliten, 
dann auch mit fehlendem Ilinterpunkte, so dass das Halsschild nur die beiden mittleren zeigt; zuletzt theilen sich auch diese je in zwei ail einander stehende unschieinbare Pünktchen, bis auch diese schwinden und das IIalsschild zuletzt einfarbig roth erscheint. Von Stücken mit vergrösserten und in verwaschener Begränzung verschwimmend zusammenfliessenden Flecken ist mir dagegen bis jetzt nur ein einziges (aus dem Mus. Saunders) zu Gesichle gekommen. Das Schildchen kurz und breit viereckig, hinterwärts stark verschnälert und gerade alogestutzt, nit unscheinbarem Hinterzipfe]; die Oberfläche dicht und fein punktirt, mattschivarz. Die Deckschilde länglich viereckig, etwa um $1 / 4$ länger als breit, hinten kurz zugerundet; der Rücken breit und flach gewöllt, hinter dem schildchen und auf der Nitte der Nalıt leicht quer niedergedrückt, hinter der scharfen Wurzelkante von einer deutlichen Querfurche durchzogen, durch deren als stärkerer Längseindruck hinterwärts gebogenes Ende die langhöckerigen Schulterbeulen innerseits begränzt werden: die Seitenlappen kuız, aber tief abwärts gezogen. Die Punlitstreifen fein, vol’n ziemlich unregehmässigg, durch üherzählige Punlite gestört und stellenweise verdoppelt; erst hinter der Mitte eutwickeln sich die Streifen deutlicher, nehmen aber auch immer mehr ah, bis die letzten von iłnen auf der Wölbung, bei dem $q$ schon viel früher, gänzlich verschwinden. Die Zwischenräume flach, fein querrunzlig, bei dem $\delta$ von geringem, dem $q$ etwas stärkerem Glanze. Die Farbe auch hier dunkel ziegelroth, das Innere der Punkte bräunlich; ausserdem zeigt jede Flügeldecke am Ende ihre zweiten Drittels, mehr nach der Naht als dem Seitenıande gerückt, einen bald mehr rundlichen, bald etwas in die Länge gestreckten, auch wohl verwaschenen Fleck zwischen dem zweiten und vierten Streifen, welcher nur in seltenen Fällen ganz vermisst wird. Pygidium und Unterseite fein runzlig punktirt, schwarz, dicht greishaarjo, bei jenem manchmal die Seitenränder, bei dieser die Hintersäume der Ringe, der Mittelzipfel des ersten und die hintere Hälfte des letzten Ringes nicht selten gebräunt. Die Schenkel schwarzblau mit bräunlichen Hüften, die Schienen hraun mit geschwärzter Aussenseite oder auch ganz schwarz, die Fussglieder wieder schwärzlich; bei Stücken mit abnehmenden oder ganz fehlenden Flecken die Beine gewöhnlich heller gebräunt und bei solchen auch wohl die Schulterblätter geröthet. Das dicht silberhaarige Prosternum breit und Mach, längsrunzlig, hinten kurz zugerundet. 
Das letzte Segment des ơ in der Mitte mit einem seichten, glänzenden Eindrucke, das $\stackrel{\wp}{i}$ mit einer runden, ziemlich dileinen Grube.

In Brasilien und südwärts, anscheinend lieine Seltenbrit, da die Art fast in allen von mir verglichenen Sammlungen vorlanden ist. (Mus. Petrop. Hamb. Vindob. Hal. Holm. Berol. Saninders. Baly. Dohrn. Deyrolle. Schaum. v. Heyden. Lacord. Clark.) Sie scheint dort eine weite Verbreitung zu haben, und findet sich nach den mir vorliegenden Special-Angaben noch in Paraguay (Vogt im Mus. v. Heyden), und an Amazonenstrom (Mus. Baly).

18. Sc. distigma m. Ziegelroth, Kopf, Fülıler- und Schenkeleuden nebst den Fussgliedern schwarzblau, vier meist rerloschene Punkte des seitlich dicht punktirten Halsschilds und zwei der Deckschilde schwarz; die Punktstreifen fein, vorn etwas gestört mit flachen ziemlich glänzenden Zwischenräumen. L. 13/4-2“"; Br. $1 \frac{1}{6}-11 / 13$.

Ob dieser Kiffer wirlilich eine gute Art, oder nur eine eigentlun̈mliche Form des vielgestaltigen $S c$. posticatus bildet, ist mir noch einigermassen zweifellaft; iclı finde jedoch keine bestimmten Lebergänge, und stelle ilın einstweilen unter cinem besondern Namen auf, bis das Anffinden mejnrerer Stïcke und namentlich auch des bis jetzı unhekaunten $q$ darülor auf eine oder die andere Weise Gewissheit bringt. Er gleicht in Allgemeinen dem vorhergehenden, ist aber, wemn man $\delta$ mit $\delta$ vergleicht, merklich kleiner und besonder's schuäler, ctwas stärker walzenförmig, die Punlitirung drs liopfes fast ganz anf dessen unterel Häfte zusammengedrängl, hier etwas fciner, aber morklich dichter zusammengeschoben; eben so ist sie auf dem Halsschilde in Allgemeinen feiner, aber ungleich dichter gedrängt. Aul' deiı Declischilden sind die P'unktstreifen merklich schwächer, die Zwischenräune aber kaum gerunzelt und diher glänzender. Die Körperfirhung ist ein lıelles Ziegelroth, die 4 schwarzen Punkte des Halsschilds und der Hinterpunht der Flügeldecken wie bei dem rorhergehenden; Stücke mit rinem fünlten I'unkte des Halsschilds halıe ich noch nicht gesehen, eben so wenig solche mit fehlenden P'unkten der Flügeddecken, wohl ahes Stücke, bei denen nur die beiden mittlern Punkte des Halsschilds rorlandru waren oder auch diese fehlten: älırigens zeigten alle diese Stüclie hiusichts der Körpergrösse lieinen merklichıen Unterschied. Die Spitze der Deckschilde fält zuweilen ins heller Rothgelbe; Unterseite und 
Beine sind ziegelıoth, mit manchınal noch lichterem Ilinterleibsende, dicht und fein silberhaarig, Schenkelspitzen und Fussglieder der vier hinteren Beite rerwaschen geschwärzt, an den Vorderbeinen schwarz mit leicht schwäzblauem Anfluge, welcher sich zuweilen über alle Beine und die ganze Brust ausdehnt und selbst den vordern Theil des Hinterleibes mit ergreift. Das letzte Segment des $\delta$ in rler ylitte sanft niedergedrückt, das $q$ unbekannt.

Aus Brasilien (Hus. Saunders. Vindob. Berol.). Im Mus. Saunders ist Pernambuco als Fundort angegeben, und eben daher stammt auch ein mir von Sturm mitgetheiltes Stück.

19. Sc. Sciurellus m. Hell ziegelroth mit gelben Pygigium, Fühlerenden und Fussglieder schwarz; das Halsschild zerstreut punktirt, die Punktstreifen fein, vorn durch überzählige Punkte gestört, hinten verloschen, mit flachen glänzenden Zwischenräumen. L. $2 \frac{1}{2}{ }^{\prime \prime \prime} ;$ Br. $1 \frac{1}{4}{ }^{\prime \prime \prime}$.

Von den nahe verwandten Arten besonders durch die Färbung des Kopfes abweichend. Der letztere flach, mit tief eingedrückter, unterwärts verhreiterter Stirnrime, die Fühlerwurzeln durch einen leichten Querwulst verbunden, und unter diesem das Kopfschild wieder eingezogen. Die Oberfläche ziemlich dicht siebarlig punklirt, unten dünı greishaarig, mit mässigg glänzendem Zwischengrunde. Die Oberlippe hell knochengelb, die ziemlich tief ausgebuchteten, weit getrennten Augen schwarz. Die Fülıler von mehr als laalber Körperlänge, ziemlich dünn, das Wurzelglied blasig aufgetrieben, das zweite linotig, die drei fulgenden gestreckt rerkelırtkegelformig, das dritte so gross wie die heiden vorhergehenden zusammen, die heiden folgenden noch etwas verlängert, lie oberen jo dem fïnften gleich init breit dreieckigem Fortsalze des Endglieds, dabei mässig zusammengedrückt und rerbreitert. Die fünf unteren röhlich mit geschwärzter Oherseite, die oberen schwarz, auch die Mundlheile geschwärzt. Das Halsschild sehr liurz und breit, llach gewölbt, hinter der Mitte leicht quer anfgewulstet, üher den spitzen Vorderecken stark zusammengedrïrkt und dadurch rerschmälert, die Seiten fein gerandet, hinter der Mitte in stumpfen Bugen erweitert und vor ilır leicht ansgeschweif, die stumpfwinkligen Hinterecken mit einer scharfen aufgenogenen Schwiele besetzl, der Hinterrand jederseits ausgebuchtet, mit kurzen, breit zugerundetem Mittelzipfel. Jederseits des lekterpn die Oherflïche sanft schräg eingedrückt, fein und zerstreut punktir, mit spiegelglïnzen- 
dem Zwischengrunde. Das Schildchen mässig ansteigend, so lang wie vorn breit, hinten mit alggerundeten Ecken breit abgestutat, fein punktirt und dünn angedrückt greishaarig. Die Deckschilde nur etwa um $1 / 4$ länger als breit, sch! flach gewölbt, hinter der schari erhöhten Wurzelkante breit quer eingedrücht, die Schulterbeulen gross aber flach, dic Seitenlappen tief herabgezogen, und über ihnen die Declischilde stark zusammengedrückt. Die Punktstreifen sehr fein, weniger an ilı'er Stärke als an der dunkleren Färbung der Punlite erkennbar, letztere sehr vereinzelt, die Streifen vorn durch überzählige Punkte getrüht, hinter der Mitte deutlicher, auf der Wölbung erloschen, die Zwischenräume breit und flach, die mittleren leicht quer gerunzelt. Die Spitze der Deckschilde fiilt in der Fïrbung etwas stälker ins Gellliche; das Pygidium ist ganz hellgell, und dabei kaum merklich punktirt. Unterseite und Beine rotlıgelb, der letzte Bauchring heller gelb, die Brust und der vordere Theil des Ilinterleibes etwas dunkler, mit dichter greiser, bei schräger Beleuchtung etwas ins Bläuliche fallender Behaarung. Die Fussglieder schwarz, oben mit schwach stahlblauem Schimmer. Das Prosternun breit, mit zwei flachen Längseindrücken, runzlig punk-

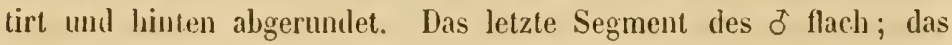
of unbekaunt.

Gleichfalls aus Brasilien (Mus. Lacord. Deyrolle).

20. Sc. parcus m. Lehmgelb mit schwarzen Fülılerenden und Kuien, das Halsschild zerstreut und ziemlich fein punktirt, die Punktstreifen wellig, vorn verdojpelt, hinter der Schulterbeule unterbrochen, hinteı abgeschwäclıt, mit flachen glänzenden Zwisclıenräumen. L. $2^{\prime \prime \prime} ; \mathrm{Br} \cdot 1 \frac{1 / 6}{}{ }^{\prime \prime \prime}$.

Etwas kleiner als der vorliergehende, und durch seine Färbung und Farbenvertheilung an einzelne echte Cryptocephalen derselben Heimath ( $\mathrm{Cr}$. varipes I. a.) erinnernd. Dur Kopl flach gewöllt, mit kurzer Stirnlinie und stark eingezogenem, olven llurch einen leichten Querwulst abgesetztrm líopfschilde, spiegelglïnzend, lehmgelb, nur auf und über dem Kopfschilde bis in die ziemlich tiefen Augrenbuchten hinein mit einer deutlichen, nicht sehr dichten Punktirnng bestreut. Die (hei dem ?) ziemlich weit getremnten Angen sellsst greis. Die Fühler ron etwas über halber Körperlänge, las Wurzelglied mässig aufgetriehen, etwa $21 / 4$ mal längrer als breit, das zweite kurz eiförnig, das dritı doppelt-, das vierte dreinal, das fïnfte etwa $3 \frac{1}{4}$ mal länger als das zweite, letzteres auch 
schon oberwärts ein wenig erweitert, die folgenden etwas stärker zusammengedrückt und schon fast von ihrer IVurzel ab sich verbreiternd, das seclıste noch beinahe so lang als das fünfte, die übrigen allmählich verkïrzt, so dass das zehnte wieder dem dritteu gleichkommt; das Endylied mit seinem kurz dreieckigem Fortsatze etwa dem achten gleich. Die Farbe der fünf unteren Glieder hell durchscheinend gelb, das zweite bis vierte mit einem feineı Längswisch auf der Oberseite und das füufte mit gebrïmnter Spilze, die oberen schwarz, düuı greishaarig, und dabei ahstehend gewimpert. Das Halssehild reichlich doppelt breiter als lang mit fast grader Mittelfirste, über den scharf spitzwinkligen Vorder'eckeu breit zusammengedrückt und dadurch verschmälert, die Seiten fein gerandet, in der Mitte bogig erweitert, vor ihr kaum merklich ausgeschweift, linter ilır in grader Richtung schräg zu den scharf stumpfwinkligen, etwas aufgebogenen Hinterecken ansteigend; der Hinterrand jederseits breit ausgebuchtet, mit kurzem wenig bemerkbarem Mittelzipfel, und vor letzterem jederseits ein tiefer nach Aussen verbreiterter Schrägeindruck, welcher die Hasse des Halsschilds als einen hart an Iinterrande liegenden Querwulst in die Höhe schiebt. Die Punktirung deutlich, aber selır vereinzelt, mit spiegelglattem Zwischengrunde, die Farbe lıell lehmgells. Das Schildchen stark anstejgend, fast so lang als vorn breit, hinterwärts merklich verschmillert und mit abgerundeten Ecken grade abgestutzt, der Hinterzipfel deutlich, die Farbe glänzend lehugelb mit fein gebräunten Säumen. Die Deckscliilte nur um etwa $1 / 6$ länger als breit, hiıterwärts noch ein wenig verbreitert, der Rücken am Schildehen jederseits schräg- und weiterhin nochmals quer niedergedrückt. hinten mil mäsriger Krümınung abfallend, vor'n hinter der scharfen aber wenig erlıöhten Wurzelkante seicht quer eingedrückt, und dieser Quereindruck innerseits der länglichen Schulterbeulen zu einem breiteren Grübchen erweitert; die Sritenlappen auch nur mässigr entwickelt, und ülıer ihnen die Deckschilde schräg hinterwiils stark zusammengedrückt. Die P'unktstreifen nicht tief aber duch deutlich, etwas wellig geschlïngelt und auf ler grösseren Vorderhälfte unregelmässig verdoppelt, der siebente hinter der Schulterbeule mehrfach unterbrochen und dadurch in sehr vereinzelt stehende Punkte anlgelöst. Auf ten letzten Drittel sinı die Streifen stark abgesclıw:̈cht, und sclıon vor der Spitze ganz erlosehen. Die flachen Zwischenrïume glïuzend, die Farlı rein lehungelh. Das 
schwach längskielige fein punktirte Pygidium mit dem letzten Banchringe bleicher gelb, der übrige Theil der Unterseite mit den Beinen lehmgelb, mit schwarzen Knien. Das Prosternum grob punktirt, hinterwärts verschmälert, mit zwei Längseindrücken, zwischen denen sich die Mitte flach wulstig emporhebt. Das letzte Segment des $q$ mit dem gewöhnlichen Grübchen, das $\delta^{\top}$ unhekannt.

Aus Brasilien (Mus. Holm., bei Rio de Jan. von Ferd. Sahlberg gefunden).

21. Sc. expeditus m. Rothgelb mit schwarzen Fühleren den, Schenkeln und Knien, auch Hinterbrust und Hinterleib schwarz, der Rand des letztern mit dem Pygidium weiss; das Halsschild mässig und sehr zerstreut punklirt, die Punktstreifen fein, wellig gekrümmt, mit flachen glänzenden Zwischenräumen. L. $2^{\prime \prime \prime} ; \mathrm{Br} .1^{\prime \prime \prime}$.

Bei gleicher Länge mit dem vorhergehenden doch ctwas schmaler, und ausserdem von ihm durch die ausgedehntere schwarze Färbung, wie durch die einfachere Sculptur verschieden. Der Kopf sehr flach mit wenig merlibarer Stirnlinie und kaum eingezogenem Kopfschilde, spiegelglänzend rothyelb, nur die (bei dem q) weit getrennten, tief dreieckig ausgehuchteten Augen schwarz. Die Fühler fast von Körperläıge, das Wurzelglied aus eingreschnürter Basis innerseits blasig aufgetrieben, etwa $1 \frac{1}{2} \mathrm{mal}$ so lang wie breit, das zweite kurz eiförmign, die drei folgenden gestreckt rerkehrtkegelförmig und von diesen das dritte doppelt-, das vierte $2 \frac{1}{2}$ mal und das fünfte viermal länger als das zweite, die oberen zusammengedrïckt und breit dreieckig erweitert, das sechste den fünften gleich, die folgenden wieder allmälılich so weit verkürzı; dass das zehnte dem dritten gleichkommt, mit schmal dreieckigeni Fortsatze des etwas längeren Endglieds. Die Farbe schwarz, die lieiden unteren Glieder rothgelh mit einem schwärzlichen Wische auf der Oberseite des zweiten, das dritte bis fünfte tief gebrüunt. Das Ilalsschild doppelt breiter als lang, olsen ziemlich flach und hinterwirts lireit niedergedrückt, üher len scharf spitzwinliligen Vorderecken etwas zusammengeschnürt und dadurch rerschmailert, die feiu gerandeten Seiten hinter der Mitte in breitem und flachem Bogen erweitert, ror ihr bis zu den Vorderecken leicht ausgeschweilt, hinten mit einer wenig bemerkharen Schwicle durch die stumpfwinkligen Ifintereclien in tlen Jreit doppelt gebuclıteten Hinterrand übergehend; der kurze Mittelzipfe] schwach anfwäls gebogen, und jederserits dessellsen ein tiefer, die Mitte dles Ilalsschilds etwas emporschiebender Schräg- 
eindruck. Die Oberfläche spiegelglänzend hochgelb, mil sehr vereinzelter, unregelmässig vertheilter, ziemlich kräftiger Punktirung. Das Schildchen stark ansteigend, nicht läıger als vorn breit, hinterwirts stark verschmälert, grade abgestutzt mit deutlichem Hinterzipfel; die Oberfläche fein punktirt, vorn dünn greishaarig, die Ilinterhälfte kahl und in ihrer Mitte der Länge nach stumpf el'löht. Die Farbe gleichfalls rothgelb. Die Deckschilde etwa $1 / 4$ liinger als breit, der flich gewölbte Rücken jederseits des Schildchens nach der Schulterbeule zu etwas in die Quere aufgetrielıen, und ron da ab nach der erhöhten Wurzelkante zu stärker schräg herabgesenkt, hinter dem Schildchen jederseits schräg niedergedrückt, und uach der Spitze zu mit mässiger Kírümınung abfallend. Die Schulterbenlen stark eiförnig, die Seitenlappen lang herabgezogen, und über ilmen die Dechschilde quer zusammengedrückt. Die P'unktstreifen sehr fein, und vom zweiten Drittel ab fast nur noch an den dunkeln Grunde der Punkte bemerklich, wellig gebogen und auf der vordern Hälfte melıfach durch Verdoppelung verbreitert, auf der Wölbung fast ganz weggeschliffen; die Zwischenräume flach und spiegelglatt, die Farbe gleichfalls rotlıgelb. Das Pygidium und ein ziemlich breiter, brandig begränzter Saum des Ilinterleibes weiss, der Hinterleib selbst mit der Hinterbrust schrvarz. Die ungeschlagenen Seiten des Halsschilds mit der Vorder- und Mittelbrust und den Schulterblättern rothgelb. Auch die Beine mil den Hüften rethgelb, an den Vorderbeinen die untere Schenkelhälfte mit den oberen Schienemenden schwarz, und diese Färbung dehnt sich an den hintern Beinen nach den IIüften und Füssen hin immer weiter aus, so dass zuletzt über $3 / 4$ der Schenkellänge und fast die ganzen, an unteren Ende ins verwaschen Bräunliche fallenden Schienen schwarz erscheinen. Das letzle Segment des $q$ mit dem gewöhnlichen Grübchen; das đ̛ unbekannt.

Aus Brasilien (vou Constantia, Mus. Clark).

22. Sc. luxatus m. Rostroth mil schwarzen Fühlerenden und einem briunlichen Wische an des Spitzen der Mittel- und Ilinterschenkel; das Ilalsschild zerstreut punktirt, die Punktstreifen liräftig, wellig, umregehnässig verdoppelt, nit meist flachen wenig glänzenden Zwischenräumen. L. I3/4"'; Br. 11/12 "'.

Abernals den vorhergeheuden ähulich, aber kleiner, mil derberen Punktstreifen, und die schwärzliche Zeichnung an den Beineu noch mehr beschränkt. Der líopf llach, der untere Theil der Stirn 
der Länge nach seicht eingedrückt, !nd dieser Eindruck auf dem eingezogenen Kopfschilde mondförnig in die Quere erweitert, die Augen schmal aber ziemlich tief ausgebuchtet, die grössere Oberhälfte derselben bei dein vorliegenden of zwar anch zusammengemeigt, aber doch noch durch einen die breite Oberlipje erreichenden Zivischenraum getrenut. Die Obertläche fein aber ziemlich dicht punktirt, einfarbig rostroth. Die Fühler nach den vorhaudenen Resten lang gestreckit, das Wurzelglied aus cingeschnürter Basis stark blasig aufgetrieben, nur un die Hälfte lïnger als hreit, das zweite liurz, fast luggelig, das dritte mehr wie doppelt länger als das zweite, das vierte dem zweiten und dritten zusammen gleich, und das fünfte noch etwas verlängert, dem letzteren die oheren, so weit sie noch vorlanden, gleich, dabei vom oberen Ende des füuften al leicht zusammengedrïckt und erweitert. Das Wurzelglied roth, die drei folgenden braunroth mit tiefer gebräunter Wurzel des fünften, die übrigen schwarz. Das IIalsschild kurz und breit, in der Hitte sanft quer aufgewulstet, und ron da nach dem Vorder- und Hinterraude zu gleichmässig leicht abfallend, über den kurz und scharf spitzwinkligen Vorderecken breit zusammengedrückt und dadurch verschmalert; die Seiten fein gerandet, in der Mitte leicht germudet und ror iln kaum merklich ausgeschweift, die stumpren Hinterecken nur durch eine kleine Schwiele angedentet, der Hinterrand jederseits auch nur leicht ansgeluchltet, und dasellist zu jeder Srite vor ilım ein sehr breiter aber nur schwacher Quereindruck. Die Punktirung zer'streut aber deullich, auf der Hiltelfirste etwas schwächer und sparsaner, mil mässig glänzendem Zwischengrumde; die Farhe rostroth. Das Schilıchen schıäg austeigend, nichıt so lang wie vorn breit, nit ausgeschweiften Seiten hinterwärts ver'schmälert, unt mit abgerundeten Hinterecken abgestutzt, ter Ilinterzipfel wenig bemerlibar. Die Oberflache dicht und sehr fein punklirt, gleichfalls rostroth. Die Deckschilde flach gewölht, wenig länger als vorn breil, vorn hinter der scharf erloühten Wur\%elkante schmal quer ringekniffen, mit kräftigen Schulterheuten und stark entwickelten Seitenlappen, üher welchen das Vorlerende des neunten Zwischenraums zu einer zweiten, etwas schwichern Längsbenie aufiretrieben ist. Die Punklstreifen kräftig, etwas wellig gelirünm und fast ilurer ganzen Länge nach mnregehmässig verdoppelt, nur der achte und nemte fast ganz einfach. Auch bei den der Nahit zunäclıst liegenden fliessen die Doppelpunkte vom letzlen Itrittel ab 
zu einfachen Punkten zusammen, womit sich dann gleichfalls die his dahin schmalen, leicht und etwas unregelmässig emporgehobenen Zwischenräume verbreiterı und verflachen; der Glanz derselben bei dicht und fein gerunzelter Oberfliche nur schwach, und nur der stumpfolreieckige Raum unter der Wölbung spiegelglatt. Die Farbe rostroth mit etwas dunklerem Grunde der Punlite. Das Pygidium und die Unterseite fein punktirt, mit den Beinen gleichfalls einfarbig rostroth; die Vorderschenkel stark keulig aufgetrieben, vor der Spitze der Mittel- und Hinterschenkel ein verwaschener schwärzlicher Wisch. Die Vorderschienen leicht gekrümmt; die Vorderbrust grob gerunzelt, vorn etwas eingedrückt, hinterwärts stark verschmälert und damn zugermudet. Das letzte Segment des o leicht quer niedergedrückt, das $q$ mbekannt.

Gleichfalls aus Brasilien (Nus. Baly).

23. Sc. paradoxus in. Schwarz, Stirn und Oberlippe nehst Fühlerwurzehı, Schildchen und Flügeldecken lehmgelh mit schwar zer Spitze der letzteren; das Halsschild grob zerstrent punktirt, die Punktstreifen längs der Naht gestört und hinter der Schulterbeule unterbrochen, mit flachen, glänzenden Zwischenräumen. L. 1 $3 / 4 "$ "' Br. $11 / 12^{\prime \prime \prime}$.

Bei aller Aehnlichkeit mit den vorhergehenden Arten ist doch die vorliegende schon durch ihre Sculptm so ausgezeichnet, dass sie, auch abgesehen von der breiten schwarzem Spitze der Deckschilde, mit keiner andern Art verwechselt werden kann. Der Kopf flach, die Stirn der Länge nach seicht eingedrüclit, und dieser Eindruck da, wo die oberen Innenränder der Augen einander am nächsten kommen, durch einen leichten Querwulst unterhrochen, das liopfschilıl unten noch stärker eingezogen. Die Punktirung groh, oben selı' zerstreut mit spiegelglänzendem Zwischengrunde, je weiter unterwärts desto dichter gedıängt; das Kopfschild dicht damit bedeckt, 'mit schmalen rumzlig verfliessenden Zwischenräumen. IDie Farhe schwarz, die Stirn bis zum unteren Ende der Augenbuchten, mit Einschluss dieser letzleren, und oherwärts fast bis zu den oberen Augenrändern lehmgelb, stark ins Röthliche fallend, nur das Innere des Stirneindrucks verwaschen geschwärzt. Ilie Oberlippe hell knochengell mit gebräunten Mumdheilen, die Augen schmal aber tief ausgebuchtet, hei dem vorliegenden o zwar mit den oberen Enden zusanmengeneigt, aber doch nur etwa bis auf $2 / 3$ des Fühlerabstandes einander genähert. Die Fühler selı dünn und 
schlank, die beiden unteren Glieder stark eiförmig aufgetrieben, je etwa doppelt länger als breit, und das zweite etwa lıalb so lang und breit wie das erste; die drei folgenden dünn, fast stielrund, kaum von der Breite des zweiten, aber das dritte un die Hälfte, las vierte und fünfte je doppelt länger als jenes, das sechste noch etwas verlängert, nach oben lin schmal dreieckig erweitert, die folgenden sich allmällich wieder verkürzend, so dass das zehute kaun dem dritten gleich komnt, und auch das Endglied mit seinem breit dreieckigem Fortsatze nur wenig über das dritte hinausreicht: dabei auch diese oberen nur schwach zusammen gedrückt und verbreitert. Die fünf unteren hell durchscheinend lehmgelh, das sechste unten gebräunt, oben mit deı folgeuden, schwarz, düın angedrücht greishaarig und an den Spitzen einzeln ahstehend gewimpert. Das llalsschild reichlich doppelt hreiter als lang, hinten etwas niedergesenkt und daher die llittelfirste in leichtem Bogen aufwärts gekrümmt, vorn über den tief eingrezogenen scharf spitzwinkligen Vorderecken starli zusammengedrückt und ladırch rerschnı̈̈lert; die Seiten fein gerandet, in der Mitte in breitem Bogen esweitert und vor iln sanft ausgesclsweift, die stumpfwinkligen IInterecken abgerundet, der Hinterrand doppelt gebuchtet, mit limzem, dentlich aufwärts gebogenem Mittelzipfel. Aus der uiedergesenkten Stelle vor den letztereu entwickelt sich jederseits eiı deutlicher schräg gegen die hintere IÏlfte des Seiten'andes hinabzirhender Eindruck, welcher längs dem Hinterrande einen lıreiten Querwulst emporschiebt, und vorn durch einen ähulichen aber schwächeren Querwulst ron dem llach gedrückten seillichın Abhange des Ilalsschilds über der vorderen Hälfte des Seitenrandes geschichen wird. l)ie Punktirung derl, aber selır zerstrent, und nur auf den eingedrückten Stellen etwas dichter gedrängt; die Farhe glänzend schwarz. Das Schildchen guer viereckig, hintrrwärts stark verschmälert und kurz abgestutzl, schräg ànsteigend, unit deutlichem Hinterzipfel, spiegelglänzend lehngelh mit gehrüuntem Ilinterrande. Die lyeckschilde lïnglich-viereckig, etwa un 1/4 lïnger als breit, breiter als das Ilalsschilı, ührigrns gleiehbreit und himlen liurz zugerundet. Der Rüclien flach gewölı, vorı hinles der scharf erhöhten Wurzelkante selumal yues eingedrïckt und dahinter das rordere Viertel der Flïgeddecken flach erlı̈̆ıt; die Schulterbeulen als breite eckige Ilöclier heraustretemd, auch die Lmgebung des Schildchens etwas aufyetrieben und hinter letaterem auf der Naht ein rundlicher Ein- 
druck. Weiter linterwärts die Nalıt der Länge nach flach niedergedrückt, die Wölbung kurz und sanft abfallend, die Seitenlappen stark herabgezogen und äber ilınen die Deckschilde kräftig zusammengedrücki, welche nach oben sich alıschwächende Einschnürung hinter dem erhölıten Vorderfelde der Flïgeldeclien bis zur Naht hin kenntlich ist. Die Srulptur in höchst eigenthümlicher Weise geurduet. Längs der Nahıt hinter dem Schildehen zulürderst der abgekürzte Punktstreifen: demuächst entspringen der erste bis vierte aus dem sich an das Schildchen anschliessenden 'Theile des vorderen Quereindrucks, wenden sich jedoch mil einer Krümmung er'st nach Aussen und dann wieder nach der Naht zu bis an die Stelle, wo der rundliche Eindruck hinter dem Schildchen von der rom Seitenlappen aus heraufziehenden Einschnürung durch eineu flachen, schmalen Querwulst geschieden wird. Wie um jener Eiudruck hinter dem Schildchen mit unregehinassig vertheilten gröberen Punkten ausgefüllt ist, so findet pin Gleiches anch mit dem in Gestalt eines schmalen Längsstreifens die Nalıt hinterwäı's lıegleitenden niedergedrückten Raume statt, und mit diesen l'unkten vermengt sich der erste Punktstreifen derartig, dass er er'st auf der hinteren Uälfte - der Flügeldecken als eine feine, die Naht hegleitende Punktlinie wieder zmm Vorschein kommt, während der zweile bis vierte streifen regehmässig bis zur Wölbung verdaufen. Vor'n billet sich dadurch zwischen dem abgekürzten und dem ersten Streifen ein glänzendes, etwas erhöhtes Lüngsfelı; ein ähnliches aber kleineres und mehr dreieckiges liegt zwischen den Vorderenden des vierten und des fünften Streifens, indem letzterer zwar ziemlich nahe an den vierten in dem vorderen Querendrucke entspringt, sich dam aher zuerst in diesen Eindrucke quer bis zur Schulterbeule, und erst von dieser alı in schräger Richtung nach dem vierten Streifen zu erstreckt, wo er hinter dem ersten Irittel der Flïgeldecke an der Einschnürung plützlich abbricht. Hinter der Schulterbeule zeigen sich die Vorderenden des sechsten bis achten Streifens, jeder aus $3-4$ P'unkten bestehend und gleichfalls an der Einschuñrung abbrechend: ausserhalb der Schulterbenle entspringt damn in gewöhnlicher Weise der neunte Streifen, und zielı sich, olne durch den auf ihm sehr tiefen Quereindruck über dem Seitenlappen gestürt zu werden, regelmässig bis zur Wölbung fort, wo er mit dem sich nach aussen krümmenden Hinterende des vierten Streifens zusammentrillt. Jadurch entsteht hier noch ein XVI. 
drittes und zwar sehr grosses glänzendes Längsfeld, in dessen hinterem Winkel die Ueberreste der vier abgebrochenen Streifen (des fünften bis achten) wieder zum Vorschein kommen, uurl zwar so, dass von dem achten die ganze hintere Hälfte zu erkemen ist, von den übrigen aber nur wenige und feine Punkte kemntlich werden. Die Zwischenüune ülerall flach und glänzend; die Farbe lehmgell, der fast $1 / 4$ der Länge bilkende hintere Theil der Hingeldecken von der Wölbung als spiegelyläızend sclıwarz. Auch das Pygidium mit Unterseite und Beinen schwar\%, fein runzlig punktirt und dünn greishaarig, Schenkelwurzelı, Schienenenden und Fussglieder gebräıut, doch je weiter nach himten, desto dunkler gefärbs; das Prosternum breit, grob pusktirt und zwischen den Vorderhuiften leicht quer niedergedrückt, mit lachem stumpfolreieckig algerundetem llinterziplel. Dis letzte sigment des ot mit einem flichen hallomondförmigen Quereindruck; das o mulsekaunt.

Ébenfalls aus Brasilien (Mlıs. Hal.).

24. Sc. semilutens m. Schwarz, das grol, punktirte Halsschild mit den Fülslerwurzeln und der Wurzel der Deckschilde gelb; die P'unktstreifen vorn gestört und hinter der Mlitte erloschen, mit flachen narbig gerunzeltrı Zwischenräunen. 1. $23 / 4-3 \%$ " Br. $12 / 3-2 "$.

Dem vorhergehenden ähnlich, aber grösser, das Schwarz der Hinterhälfte weiter ausgedehnt, und auch die Streifonbildung der Deckschilde sehr abweichend. Der Kopf flach nit kiäftiger, mnten in ein flaches Längsgrühchen auslaufender Längsrinne, diclıt punktirt, mit glänzendem Zwischengrmole; das Koppssehild oberwärts kaum abgegränzt. Die Farbe, wie die der Munltheile, schwarz, nur die Kimnlackenspitzen mnit den Rändern der Oberlippe lrüb gelblich durchscheinend. Die anch bei dem $\delta$ weit getrennten grossen, dreieckig ausgehuchteten Angen greis. Die Fühler ron mehr als halber Körperlïnge, sehr dünn, das Wurzelglied liurz anfgetrieben, las zweite elliptisch, die drei folgenden dümm rerkehr'kegelförmig, das dritte und vierte gleich lang und doppelt länger als das zweite, das fünfte und sechste wiederum einander gleich und je $2 \frac{1}{2}$ mal länger als jenes, die oheren, wié das sechste, schwach erweitert und zusammengedrückt, allmälılich wiedler abnehmend, so dass das zehnte (kïrzeste) kitum dem dritten gleichliommt, der Fortsatz des Endglieds kurz umb hreit dreieckig. Die Farbe der fïnf unteren durchscheinend honiggelb, die Oberseite bei dem ersten geschwärzt, 
dem zweiten mit einem feinen dunkeln Längsfleckchen gezeichnet, an den irei folgenden ıur die Spitze oben geschwärzt, dlie seclıs oberen schwarz. Das Halsschild kurz und breit mit flacher Mitte und fast grader Mittelfirste, über den scliarf spitzwinkligen Vorderecken zusammengedrückt und dadurch verschmälert; die Seiten deutlich gerandet, in der Nitte bogig erweitert, vor ilı' ausgeluchtet, mit stumpfwinkligen, nur durch eine fein aufgeworfene Randschwiele etwas zugeschärften Hinterecken: der Ilinterrand doppelt gebuchtet, vor dem kurzen Ilinterzipfel etwas eingedrückt, und jederseits desselben etwas mehr nach vorn ein breiter flacher Quereindruck, und auf der Mitte noch ein paar ïlnnliche sclıwächere neben einander, anch der ganze Vorderrand von einer äusserst schwachen Einschnürung umzogen. Die Oberfläche ziemlich grob-, und oben mehr zerstreut-, seitlich dichter punktirt, der Zwischengrund auf der Nitte ziemlich glatt und glänzend, seitwärts fein narbig gerunzelt: dic Farbe gelb, vor der Mitte zuweilen ein palar verwaschene schwärzliche Pünktchen neben einander. Das Schildchen so lang wie vorn breit, hinter'wär'ts etwas verschmälert, und mit abgerundeten Ecken und deutlichem Hinterzipfel ahgestutzt, dicht und fein punktirt, schıvarz. Die Deckschilde kaum 1/6 länger als breit, hinter der mässig aufgeworfenen Vorderkante breit und seicht puer eingedrückt, und hinter dem Schildchen nochmals mit einem flachen Quereindrucke, von dem flachen Rücken aus seitlich, wie auf der Wölbung ziemlich steil alffallend, die länglichen Schulterheulen nur schwach hervortretend, die kurzen Seitenlappen tief herabgezogen, und unmittelbar linter ihnen der nemnte Zwischenraum mit einigen überzähligen gröbern Punkten besetzl. Die Punktstreifen auf der vordern IHälfte ziemlich dentlich, und stellenweise, besonders der dritte und vierte sowie die Mitte des fünften, umregelmässig verdoppelt, wie anch durch äberzällige P'unkte, deren sich auch vorn längs der Nalıt finden, getrülıt, voı der Mitte ab plötzlich abgeschwächt und bald unter der starken narbig runzligen Punktirung der Zwischenräume sich verlierenı; letzlere flach, vorn ziemlich glänzend, auf dem schwarz gefärbten Theile nur matt mit leichtem Schimmer. Die Farbe schwvarz, das vordtere Viertel längs der Wurzel hellgelb wie das IIalsschild, unıl diese Färbung ziehı sich seitlich längs dem Ranıle im Bogen bis zun Ende des Seitenlappens fort, so dass sie hier fast his üler die Mitte der Flügeldecken hinausreichı. Die Spitze schmutzig lyäunlich 
durchscheinend. Pygidium und Unterseite dünn greishaarig, mit den Beinen feinfarbig schwarz, die Vorderschenkel stark verdickt mit entsprechend gekrümmten Schienen. Das Prosternum breit Imd fiach, in der Mitte der Länge nach seicht niedergedrückt; das letzte Segment des $\delta$ einfach, des $q$ mit dem gewöhnlichen Grübchen.

Aus Brasilien (Mus. Deyrolle. Clark. Vindub. Berol., das Exemplar des letzteren von $v$. Ol/ers mitgebracht). Im Mus. Clark ist Minas Geraes als Ileimat genannt.

Bsei dem Stücke im Mus. Vindob, einem o , tritt die dunkle Färlung der Deckschilde mit ilıres vorwärts gekrümmten Mitte bis ummittelbar an den Ilinterrand des Schildchens heran, Ind zeigt dabei einen ins Metallischlkupfrige spielenden Anflug. Weiter Ahweichungen finde ich jedoch nicht.

25. Sc. hyacinthinus Er. Kupferblau mit dunklerem liopfe und Beinen, das zerstreut punktirte IIalsschild, Vorderhrusı, Schulterhlätter, Parapleuren und Ilinterleib roühlichgelb; die Punktstreifen lein, durch eine zienlich dichte Punktirung der flachen gläızenden Zwischenräune getıüht. L. 21/2"'; Br. 11/4"'.

Pachybrachis hyacinthinus Erichs, in Schomburgk Reisen in Brit. Guiana. III. S. 577 !

Von diesel Art habe ich uur das einzige von Erichson a. a. 0. beschriehene aber stark beschärligte und deshall, wahrscheinlich dort auch nur selı dürftig characterisirte Stück aus dem Mus. Berol. vor ınir, kann jerloch dessen Beschreibung hier soweit rervollständigen, dass bei so vielen ähnlich gefärbten Arten ein Wietlererkenıеı des liäfers dadurch ermöglicht wird. Der liopf flach mit etwas zurücktretendem Nacken, die Stirn der Länge nach llach niedergedrückt mit fein cingeschnittener Mittellinie, das Kopfschild eingezogen, oben dureh eiıen breiten Querwulst zwischen den Fülılerwurzelı begränzt. Die Farhe stahlblau, oben melı ins liupferglinzende spletent, die grossen, (bei dem ठ) weit getrenıten, tief und ziemlich weit ausgebuchteten Angen schwarz. Die Mundtheile pechschwarz, die Rinder der Oberlippe und die Taster heller braun mit dunkler Spitze der letzteren. Von den Fühlern mur die beiden unteren Glieder vorhanden, unil deren Farbe röthlich nit geschwärzter Oberseite. Das grosse I Ialsschild etwa $2 \frac{1}{2}$ mal hreiter als lang, vorn durch die tiefe Eimbiegung der spitzen Vorderecken ver'schnälert, die gerandeten Seiten in der Mitte logig erweitert, vor ihr 
deutlich ausgeschweilt, auch die stumpfwiuligen Hinterecken in eine scharfe Schwiele rorgezogen, der Hinterrand fast grade und nur zu jeder Seile des lireit zugerundeten und aufgebogenen Mittelzipfels etwas ausgehuchtet. Jeclerseits des letzteren ein hreiter, ziemlich flacher Schrägeindruck, durch welehen die Masse des Halsschilds einerseits nach hinten, andrerseits nach der Vorderhällte des Seitemrandes hin gedrängt wird und hier so weit hesvortritt, dass dèr eigentliche Seitenrand fast senkreeht unter die hier aufgewulstete Masse des Mittelfeldes zu liegen kommt. Dabei ist die Mitte der Längsfirste nur schwach aufwärts gekrünmmt, und dẹ hiutere Theil des Mittelfeldes zwisclıen jenen Schrägeimlrücken breit ahyeflacht. Die Punktirung ziemlich fein und zerstreut, mil gläızendem Zwischengrunde, die Farbe roth, mit bläuliehem Anfluge des abgesetzten Hintersaums. Das Sehildchen stark ansteigend, nicht ganz so lang wie vor'u hreit, hinterwärts stark verschmälert und mit algerunteten Ecken algestutzt, des Hinterzipfel schmal aher dentlich, und fast wagrecht liegend. Die Oberfliche his auf die der Länge nach etwas anfgetriebene, glattere Mitte dicht und fein punktirt, metallisch purpurblau. Die Decksehilde etwa $1 \frac{1}{4} \mathrm{mal}$ länger als das Halsschild, wenig länger als vorn breit, von den Schultern ab hiuterwärts verschmiled, aber auch vorn schmaler als das Halsschild, so dass der Körper von dem ersten Drittel des Jetzteren al) sich ıach hinteu ziemlich gleichmässig verengt; der Rüelien hinter der nicht hohen aber scliarfen Vorderkante tuer gefurcht, hinter dem Sehildchen und dann wieder auf der Mitte liraftig quer eingedrückt, welcher letzlere Eindruck sich bis zu den kurzen aber breiten Seitenlappen hinalızicht und über diesen die Deckschilde kräftigg zusammendrïckt, ebeı dadurch aber auch den vorderesı Theil des Rüekens wulstig emportreiht. Die Sehulterbeuleu vor'n zusammeugedrückt, hinterwärts verhreitert, und sich hier schräg nach hinten in jene Aultreibung des Vordersüeliens rerlierend. Die Punktstreifen fein, meist nur unter sehr schı̈̈ger Beleuchlung wahrnehmbar, aber durclı eine fast ebeu so deutliche und ziemliclı dichte Punktirung der flachen Zwischenräume verdunkelt. Die Farbe ein schönes metallisch glänzendes Purpurblau, wie bei mserer europäischen Chrysomela cuprea, der Rand mehr ins Stahlbläuliche fallend, welche Färbung auch einige, anscheinend zufïllige Fleekchen auf dem Rücken zeigen. Das selır fein punktirte Pygidium und die letzten Hinterleibsringe, soweit heides noeh vorhanden, hell rothgelb, 
der erste Bauchring schmutzig roh mit verwaschen gebräuntem Vorderrande; die Brust schwarz, nur die Parapleuren und Schulterblätler mit dem Vorderrande des flachen, in der Mitte hinten leicht gekielten und schmal abgerundeten Prosternums und den Ilüften gleichfalls roth; die Beine selbst tief stahlblau mit stark aulgetriebenen Vorderschenkeln und entsprechend gekrümmten Schienen, die Kuie gebrämnt. Das letzte Segment des ơ leicht eingedrïckt, das $q$ imbekannt.

Aus Guyana (Schomburgk im Mus. Berol.).

26. Sc. boops m. Metallisch schwarzblau, Fühlerwurzehn, Fussgliedler und ein Spitzenfleck der Flügeldeckeı röthlich; das Halsschild zerstreut und vor den Hinterecken grob punktirt, die Punktstreifen vor'n deutlich und etwas gestört, hinten last erloscheı, mit flachen glänzenden Zwischenrüumen. L. 11/2-1\%"'”; Bi. $3 / 4-1^{\prime \prime \prime}$.

Eine kleine zierliche mul durch den Spitzenfleck der Flügeldecken sehr ausgezeichuete Art. Der Kopf flach mit eingezogenem Kopfschilde, hei dem ठ die Stirn grösstentheils von den erweiterten Oberhälften der schmal aber lief ausgebuchteten, einander berührenden Augen eingenommen, ihr unterer Theil grob zerstreut punktirt mit glünzendem Zwischengrunde; bei dem $q$ die Ángen kleiner, weit getrennt, die Stimlinie kurz unt wenig bemerkbar, die grobe Punktirung oben sparsaner, unten dichter zusanmengedrängt. Die Farbe metallisch schwarzblau, die Augen greis, die Mumbtheile pechbraun, mit helleren, bei dem $\delta$ fast weisslichen Rändern der Oberlippe. Die Fühler schlank und düm, bei den $\delta$ von etwas über halber Körperlünge, dem o kürzer, das zweite Glied kurz und linotig, das dritte und vierte je etwas verlängert und dem letzteren die oberen ziemlich gleich, dahei letztere nur schwach zusammengedrückt und verbreitert. Die Farbe der füıf unteren hellröthlich gell, mit gehräunter Oberseite, der oberen schwarz. Das Halsschild etwa doppelt länger als breit, oben flach mit kaum gekrümmoter Nittelfirste, üher deı scharf rechtwinliligen Vorderecken vom Vorderrande her eingeschun̈r, zugleich schräg zusammengedrückt und dadureh verschmälert, die breit gerandelen Seiten in der Mitte bogig erweitert mol vor ihr leicht ansgeschweift, die Hinterecken scharf stumpliwinklig, der Hinterrand jederseits des kuzen Nlittelzipfols schwach ausgebuchtrt, und daun weiter seitwärts ron dem letzteren noch ein tiefer Quereindruck, durch wel- 
chen den Rand entlang eine diesem gleichlaufenden Querfalte emporgeschoben wird. Die Punktirung deutlich aber zerstrent, spitlich und nach den Hinterecken zu besonders bei den of dichter und gröber : die Farbe auch hier ein glïnzendes metallisches Schıvarblau. Das Schildchen schräg ansteigend, elwa so lang wie vorn breit, hinterwäts verschmälert und mit deutlichen Ilinterzipfel grade abgestutzt; die Oberfläche läıgs der Mıtte schwach erhöht, von da aus nach den Seiten stetig dichter fein punktirt, gleichfalls glänzend sclıwarzblau. Die Deckschilde etwa um $1 / 3$ lïnger als lıreit, längs der scharfen Wurzelkante tief quer gefurcht, hinter dem Schildchen und wieder aul der Mitte quer eingedrückt und dieser letzte Eindruck als eine breite Einschnürung bis zu den schwachen Seitenlappen herabgesenkt, wodurclı das vordere Drittel der Flügeldecken innerseits der sehr eckigen Schulterheulen als ein besonders bei dem ठ krïftig entwickeltes erhöhtes Querfeld emporgehoben wirl. Die Punlitstreilen lis über die Mitte linans deutlich, bei dem ठ̊ nuch etwas kräfliger, hinter den Schulterbeulen und längs der Naht durch überzälılige Punkte etwas getrübt, auch stellenweise wellig gekrümm, die mittleren in dem Quereindrucke etwas verwirr, theilweise abbrechend, die übrigen von da ah feiner und auch regelmässiger, auf der Wölbung meist elloschen. bie Zwischenräume flach und gläızend, auch hier metallisch schwarzblau mit leichtem P'urpurschimmer, die Spitze mit scharfer Begräızung rothgelb. Bei dem $\delta$ ist dieser Fleck etwas dlunkler, liegt hauptsächlich im Nahtwinkel und erreicht nach aussen den Seitenrand nicht; bei einem der vorliegenden $f$ ist er heller, breiter, und zugleich der ungeschlagene Rand des Seitenlappens besonder's nach der Schulter hin schmmtzig gebräunt, wahrsclıeinhich mehr in Folge unvollkommener Auslärbung, als sexueller Verschiedenheit. Pygidium und Unterseite fein punktirt, kurz und dünn greishaarig, schwarzblau; auch die Bcine schwarzblau, die Hüften, Schenkelwurzeln, in geringerer Stärke und nur durchscheinend auch die Schienen oder doch deren Spitzen röthlichıraun. Die Fussglieder des $\delta$ rothgelb, das $f$ schmutzig gelbhraun: das Prosternum flach, der Länge nach seicht nielergedrüclit. Das letzte Segment fehlt dem vorliegenden $\delta$, bei dem $q$ zeigh dasselbe ein breites rundliches Grübchen.

Aus Brasilien (Mus. r. Heyden, vol Clausen - und Mus. Berol. von l'irmond gesammelt; auch im Mus. Vindob. vorhanden). 
27. Sc. causticus m. Oben bräunlich stahlblau mit röthlicher spitze der Deckschilde, unten bramuroth, dicht sillorharrigg; das Halsschild zerstleut punktirt, die Punktstreifen mässig, vorn durch ̈̈̈berzählige Punkte getrübt, der sechste und siehente abgegerissen, mil llachen, glänzenden Zwischenräunıen. L. 21/4"”; Br. $11 / 6 "$.

Yon dem Ilabitus des nächstvorhergehemlen, aber merlilich grösser, auch von ilın in Sculptur und Färbungr hinlänglich verschieden. Der kiopl' gross, (hei dem d) der obrere Theil durch die grossen, rinander berïhrenden Augen piugenonmen, der untere flach, mit ringezogenent Kopfschilde; die Punlitirung groh und mãssig dıcht, glänzend brauı nit leicht stahılblaupm Anlluge, die Mundlıeile pechlırauı. Die dümsen, badenförmigen Fülıler von reichlich hallser Körjerlinge, das Wurzelglied stark blasig anfgetrirben, nicht ganz doppelt läıger als breit, das sweito kurz elliptisch, die folgenden dünn und oberwänts wenigr erweitert, und die oberen aleo su schwach zusammengedrüclit. Dats drilte etwas länger als das Wurzelylied, das vierte den beiden vordergehenden zusanmen gleich, dis fünfte noch elwas länger, diesem die oheren gleichliommend, mit dünmem liegrelürnigen Fortsatze des Eurlglieds. Die Farbe der unteren röthlich lunun, anf der Oberseite mit einen dunkjeren linientörmigen Jängswische, die oberen schwärzlich. Das Halsschila kurz ums lreit, in der Mitte Jeicht quer ïlsergewölht und die Mittellirste rorn schwach alwirts gelirïmut; die Seiten dentlich gregerander, in der Mitte hogig erweitert, vor dresselben nach den scharfen tiel eingezogenen Vorterecken hin deutlich ansigeschwrilt;

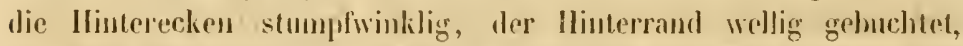
mit hurz'm fast geradem Mittelzipfel. Vor dirsen jederseits eiu breiter mudenförmiger Schrägeindruck, welcher nach aussen und rorn allmällich sich verllacht ums verlieri; ein zwejter schmalerer lregleiter die Seiten des Hinterrandes fast bis zu den Hinterwinkmb, und drückt den Raud entlang rin starkes und zimoliclı scharles Guerialtehen aufwäls, zwischen welchen und den Rande sellost sich noch eine schnale aber zimmlich tief einschueidende Furche lemerlich macht. Die Fande bran mit verwaschen Jeellerem Vordersinme, überall stahlbläulich oder grünlich angoflogen, die P'unlitirung dendich, alıer zerstrent mit mässig glänzendem Zwischrngrumle. Tas Schildelıen lrreit, stark schurig anstrigend, von dem schwarlıen Mittelliple al jederseits leicht heralgewölst, himten mit 
abgerundeten Ecken und undeutlichem Hinterzipfel abgestut:t, glïnzend braun nit leiner und ziemlich dichter Punktirung. Die Deckschilde etwa $1 / 4$ lïnger als breit, mit breiter Wurzel hinterwärts fast geradlinigg verschmälert, oben llach gewölb, hinten unissigg abwärts gelirïmmt, die Sclublterbenlen lyeit ahgerundet, innerseits durch einen deutlichen Eindruck ahgesetzt, welcher sich an eine die scharfe Wurzellante begleitente Qurrfurche anschliesst; die Seitenlappen krältig, über ilınen die Deckschilkle etwas zusammen gredrückt, und dieser Eindruck mit viner leichten lírümmung nach hinten bis zum Rücken hinanf zu verfolgen, wo er die Naht etwas vor ilırer Mitte durchsetzt. Die I'unktstreifen von uässiger Stärke, dir inner'n vorn verdoppelt mul etwas wellig gelirümut, dahır weniger erkembar, die Vorkerenden der "iusseren tiefer eingegrahen, hier und da durch einzelne überzählige I'unkte getrübt. Von der Ilitle ab vereinfachen sich die oberen und werden dadurch deutlicher, der seclsste und siebente aber brechen bald ab, und lassen einen breiten Zwischenranm zwischen dem fünften und achten, ausserluall dessen auch der neunte bis zur Wöllung kenntlich ausläuft. Die Zwischenrïune flach, mit vor'u schwächerem, hinten deutlicherem Glanze. I) Farbe Inaun mit stahlblänlichem Aullıge, das letzte Viertel hellrostruth mil vorn verwaschener Begränznng. Aendert jesloch als

$\beta$. Ler stahlhlaue Anflug der Oherseite fast erloschen, und ıur noch an Kopf unil Schenlieln in schwacher Anteutung vorhanden.

Pygidium und Unterseite trüher roth mit einer dichten und anliegenden greisen, seidig gläuzenden Behaarung bedeckt; die brannen Beine ehenso, aher dünner, behart, die rerdickten Schenkel und melır noch die Schienen ins Bläuliche spielond, die Fussglieder noch melır geschwärzt, Das letzte Segment des of einfach, das $f$ unbeliannt.

Aus Brasilien (Mus. Baly). - Die Ifauptiorn von S. Paolo, die var. $\beta$. von Ega stamment.

28. Sc. gibbipenu is m. Metillisch schwarzllau mil gelhlichen Fühlerwurzehı; das glänzende Ualsschilı deutlich und zienlich dicht punktirt, die vor'n mässigen Punhıstreifen hinterwïrts erloschen, mit flachen glänzenden Zuvischenrïumen. L. 21/2"'; BBr. $11 / 2^{\prime \prime \prime}$.

Der Kopf flach, bei dem allein vorliegenden of fast ganz von den in einer langen Naht zusammenstossenten greisen, weit unten 
nur kurz aber tief dreieckig ausgebuchteten Augen eingenommen, sodass auch über deın oben nicht abgegränzten Kopfschilde nur ein kleiner dreieckiger Stirnzipfel, und eben so oben nur ein ebenfalls kleiner, verkebrt dreieckiger Nackenfleck übrig bleibt. Die Farbe schwarz, das untere Feld samnt dem líppschilde dicht und fein runzlig punktirt. Die Oberlippe breit und verwaschen ziegelröthlich gerandet, auch der unter'e Theil der bei dem einzigen vorliegenden Stücke nur uuvollständig vorhandenen, diesen Resten nach sehır dünnen und schlanken Fülıler bis zur Mitte des sechsten Gliedes rütlılich gelb, das erste und zweite Glied oben je mit einem schivärzlichen Wische bezeichnet, die drei folgenden derartig gestreckit, dass das dritte den beiden ersten zusammen, das vierte wieder den beiden vorhergehenden zusammen, das fünfte kaum länger als das dritte, das sechste kaum so lang als das fünfte ist; und die folgenden werden sich wahrscheinlich noch weiter verkïrzen. Das Halsschild kurz und breit mit sehr flach quer gewölhtem Mittelfelde, daher auch in der Mitte nu' leicht aufgebogener Längstirste, über den scharf spitzwinkligen Vorderecken etwas zusammengedrückt und dadurch verschmälert, die Seiten deutlich gerandet, in der Mitte rundlich erweitert, vor ihr leiclıt ausgeschweift; die stumpfwinkligen Ifinterecken mit leicht aufgehogener scharfer Spitze, der Ilinterrand jederseits welligr gebuchtet, vor dem kurzen und breiten Mitlelzipfel etwas niedergedrückt, und dann noch jederseits ein breiter Hacher Quereindruck, welcher an Hinterrande ein der Vorderkante der Deckschilde entsprechendes, dicht an den Hinterecken durch einen zweiten, schmaleren Quereindruck noch stärker hinterwärts gedrängtes Fältchen aufwärts schiebt. Die Punktirung auf dem Mittelfelde zerstreut und ziemlich feiı, seitlich und in den Eindrïcken etwas dichter und gröber; die Farbe ein glänzendes, ins tief Sclıwarzblaue fallendes metallisches Selıwarz. Das Schildchen ziemlich steil ansteigend, breit dreieckig, hinten mit abgerundeten Ecken und dentlichem Hinterzipfel abgestutzl, lïngs der Mitte sehr schwach aufgetricben, dicht und fein punktirt, schwarz. Die Deckschilde so lang wie rorn breit und hinterwärts etwas verschmälert, längs der ganzen Wurzel hinter den Schulterbeulen tief quer eingedrückt, der Rücken um die Schildchenspitze buckelig aufgeschwollen, hinter ibr durch einen breiten und thachen, auf der Naht etwas hinterwäts gekrümmlen Einduck quer eingeschnürt, dessen Scitenenden fast bis zu den kurzen aber stark ab- 
wärts gezogenen Seitenlappen hinabreichen. Die grossen Schulterbeulen halbeilörmig beraustretenı, und die hintere Wölloung liurz und steil abfallent. Dic P'unktstreifen sehr ungleich, die äusseren auf der vorderen llälfte ziemlich liräftig muıl regelmässig, die oberen zwischen Naht und Schılterheule sclıwächer, mehr wellig gebräunt und stellénweise verdoppelt, von dem Quereindrucke ab alle abgeschwächt, die oberen schon vou der Mitte an fast erloschen, auf dem letzten. Drittel verschwunden und inter der spiegelglatten Wölbung nur noch in einzelnen Pünktchen wahrnehmbar; von den äusseren Streifen nur der nemte bis zur Spitze zu verfolgen. Die Zwischenräume flach und glänzend, nur der neunte besonders üher dem Seitenlajpen stark aufgetrielıen: die Farbe anch lier ein glläızendes, ins tief Schwarzblane fallendes metallisches Schwarz. Pygidiun und Unterseite dicht und fein runzlig punktirt, mit den Beineu sclıwarz, die Köpfe der Mittel- und Hinterhüften gelblich, die Vorderschenkel mässig aufgetrieben, mit entsprechend gekrümmten Schienen. Das Prosternum flach, lang greishaarig, linten jederseits abgeschrägt und mit gerundeten Ecken abgestutzt. I)as letzte Segment des $\delta$ leiclıt quer eingedrückt, das $q$ unliekannt.

Aus Brasilien (Hus. Deyrolle).

29. Sc. bipes in. Metallisch sehwarzblau, unten dicht sillıerhaarig, Fühlerwurzelı, Mittel- und Hinterbrine roth; das Halsschild zerstrent punktirt, die Punktstreifen derb, vorn un'egelmässig verdoppelt, mit vorn llach rippenförmigen, hinten flachen, glänzenden Zwisehenräumen. L. 21/2-3"'; Br, $1 \frac{1 / 4}{4}-1 \% / 1{ }^{\prime \prime}$.

Dem vorhergehenden ähnlich, aber gestreckter, und ansserdem an der verschiedenen Färbung der Vorder- und der hinteren Beine leicht kenntlich. Der Kopt flach, die Stiru bei dem ơ fast ganz von den grossen, in breiter Naht einander berührenden, greisen Augen eingenommen, bei dem $\&$ mit kurzer, ziemlich breiter Stirulinie; das Kopfschild stark eingezugen. Die ziemlich grobe Punktirmug oben sparsamer, unten etwas dichter gedrängt. Die Farbe metalliselı schwarzblau, zuweilen ins Veilchenblaue fallond, die Mundtheile pechbraun mit geschwärzter Mitte der Oberlippe, die tiefen Augenbuclıten uit anliegenden Härchen besetzt. Jie Fühler kaum vou laalber Körperlänge, das Wurzelglied blasig aufgetrieben, nur etwa IIm die Hälfte länger als breit, das zweite sehr kurz eiförunign, das dritte dreimal, das vierte viermal und das fünfte fünfmal länger als jenes, und alle drei verkelırtkegelförmig; das sechste wieder dem 
vierten gleich, und die folgenden so langsam abnehmend, dass das zelnte noch fast dem dritten gleichkommt; dabei die oberen von der Spitze des sechsten alı mässig zusammenged’ückt und erweitert. Die fünf unteren Glieder durchscheinend rüthlich gelb mit gebräunter Oberseite der beiden ersten, die Wurzel des sechsten gleichfalls bräunlich, das Uebrige schwarz mit angedrückter dünner greiser Behaarung. Das Halsschild etwa $2 \frac{1}{4}$ mal Jreiter als lang, oben flach, unı nur hinten ein wenig quer niedergedrückt, über den spitzen Vorderecken etwas zusaumengedrückt und dadurch verschmälert; die Seiten fein gerandel, hinter der Mitte im Bogen erweitert, vor ihr fast in geraden Linien convergirend; die Hinterecken stumpfwinklig, der Hinterrand zu bejden Seiten des kurzen Mittelzijfels leicht ausgeschweift, und ror letzterem jederseits ein ziemlich breiter, hinterwärts eine Querfalte emprorschielender Schrägeindruck. Die Punktirung fein und zerstreut, die Farle metallisch dunkel- oter veilchenblau. I)as Schildchen schräg ansteigend, nicht ganz so lang als vorn breit, hinterwär's verschmälert und mit abgerundeten Ecken abgestutzl; der Hinterzipfel wenig bemerlibar, Die Oberfäche jederseits sauft schı̈̈g niedergedrückt, fein punktirt, sehr kurz und dünn greishaarig, dunkelblau. Die Decksohilde länglich viereckigr und hinten liurz zugerundel, gleichloreit um etwa un 1/4 länger als breit, hinter der schirfen Wurzelkante schmal quer eingedrïckt, und dann zwischen Schildehen und Schulterhenlen flach quer aufgetrieben, hinter dem Schildchen und dam wieder auf der

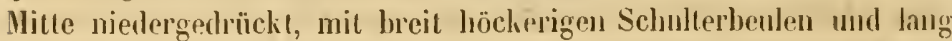
herahgezogenen Seitenlappen, üher letzleren dio Deckschihle hreit zusammengedrückt. Dic Punktstreilen kräftig, l,is zur Mitte theilweise verlopylt und etwas wollig gekrümmt, ziemlich tief eingeeingedrïckt und die schmalen Kwischenräume zu flachen Längsrippen emporhebend, von der Mitte ab regelmässiger und feiner, daher die Zwischemä̈une hreiter und flacher, die Spitze ïlır der Wöllıug spriegelglatt und ohme Punkte. l)ie Farbe ein stark glïmzendes, helleres oder dunkleres metallisches Blau. Las schwach lingskielige Pygidinn mit der Unterseite fein louzlig punklirt, dicht angedrückt silberhaarig, sclıwarzhlan, Mittel- und Iliuterbeine helliollıgell, seltener bei den o schmutzig ins Pechbrame fallend, die Vorderloeine schwarzblau, an letzteren die Wurzelu der stark anfgetriebenen Vorderschentiel and die Inmenseite der entsprechend verlingraten und gekrïmmten Schienen mit den Fussgliedern leicht gebräunt. Das 
Prosternum flach, die Mitte entlang soliwach erhöht. Das letzte Segment des ơ mit einem sehmalen und seichten Quereindrucke, las of mit einer rundlichen, ziemlich grossen Grube.

Aus Brasilien (Mus. Berol. Deyrolle; in letzterem ist $S$. Catharina als Fundor't angegehen.)

30. Sc. luctuosus m. Schrarz, die Fühlerwurzeln, ein Stirnfleck und ein rerwasehenes Querfleckehen vor der Spitze der' Flügeldecken gelb; das Halsseliild grob zerstreut punktirt, die Punktstreifen vorn kräftig, hinten abgeschliffen, mit flachen, glänzenden Zwischenräumen, 21/3"'; Br. 11/6"'.

Von dem Bau des vorhergehenden, aber noch etwas kleiner, rein schwarz, und auch durch die Zeichnung von ihm sehr abweichent. Der Kopf flach, mit einer schmalen aber tiefen, unten elwas erweiterten mul dann plötzlich abbrechenden Stirurinne, das Kopfschild etwas eingezogen. Die Oberfläche glänzend, zerstreut aher deutlich punktirt, die Farbe schwarz, der untere etwas aufgetriebene Theil der Stirn mit einem ziemlich grossen verwaschenen gelblichen Flecke bezeichnet, die oben sehr genäherten, durch eine breite und ziemlich tiefe Bucht sehr ungleich getheilten Augen greis. Die Fühler von reichlich halber Körperlänge, das zweite Glied eiförmig, um die Hälfte lünger als breit, die drei folgenden sehr dümn verhehrtkegelfürmig, und zwar das dritte 1 11/2mal-, das vierte rloppelt länger als das zweite, das fünfte noch etwas verläıgert, die folgenden oberwärts schwach zusammengedrückt und verbreitert, Was sechste wieder dem vierten gleich, und die oberen allmählich sich soweit verkürzend, dass das zehnte kaum noch die Länge des dritten erreicht; das Endglied mit seinem kurz dreieckigen Fortsatze etwa so lang wie das aclite. Die fünf unteren Gliedler hellgelı mit breit gesehwärzter Oberseite der beiden ersten, die oberen schwarz. Das Halsschild etwa doppelt hreiter als lang, auf dem letzten Drittel breit aber flach quer aufgewölht und von da ab nach vorn allmählich abfallend, hinten breit schı̈g niedergedrückt, über den tief eingezogenen scharf spitzwinkligen Vorderecken eingeschnïrt und dadnrch verschmäler't; die Seiten fein gerandet, in der Mitte hogig erweitert und vor ihr leicht ausgeschweift, die Hinterecken stumpfwinklig zugeschärft, der Ilinterrand jederseits leicht gebuchtet, mit kurzem, schmalem, etwas atfgebogenem Mittelzipfel. Die grobe und ziemlich tiefe Punktirung zerstrent, aber doch stellenweise wieder dichter zusammengedıängt und dadurch uuregehnässigg 
vertheilte, flache Vertiefungen niederdrückend. Der Zwischengrund glänzend und einfarbig schwarz. Das Schildchen stark ansteigend, breit quer viereckig, hinterwärts verschmälert, mit abgerundeten Ecken und sehr dentlichem Hinterzipfel abgestutzt; die Farbe anch hier glänzend schwarz. Die Deckschilde etwa 1 m $1 / 4$ länger als breit, oben flach gewölht und hinten mit ziemlich starker Krömmung abfallend, hinter der scharf erhöhten Wurzelkante schumal quer eingedrückt, die lurz und breit eiförmigen Schulterheulen immerseits durch einen schmalen Längseindruck abgesetzt, die Seitenlappen nur schwach, und ehenso schwach die Deckschilde über ihnen zusammengedrückt. Die Punktstreifen aul" der grösseren Vorderłıäfte kräftig und ziemlich regelmässig, nur längs der Nahı unil hinter der Schulterbeule durch überzühlige Punkte etwas gestört, hinter der Mitte almählich schwächer und regelmässiger, auf und unter der Wölbung völlig alıgeschliffen, die Zwischenräume vor’n glänzend und leicht rippenfümig erhäht, hinterwärts allmälılich llacher, und zuletzt auf der spiegelglatten Wölbung vollständlig zusanmengeflossen. Die Farbe ein leines, schönes Schwarz, vor der Spitze unter der Wölbung jederseits ein unscheinbares und verwaschenes gelbes Querfleckchen, dem Cryptoc. marginatus ठ ähılich. Iygidium, Unterseite und Beine einfarbig schwarz.

(Gleichfalls aus Brasilien (von Tejuca: Mlus. Clark).

31. Sc. erythrospilus m. Schwarz, die Fühlerwurzeh rothgelb, die 'Wurzel und Spitze ler Flügeldecken blutroth; das IIalsschild zertreut punktirt, ziemlich glïnzend, die l'unkitstreifen vorn ziemlich fein, gestört und unregelmässig verdoppelt, hinten abgeschwäclı, mit flachen glänzenden sehr tein yuer gerunzelten Zwischenräumen. L. $23 / 4{ }^{\prime \prime}$; [Br. $1 \frac{1}{2}{ }^{\prime \prime}$.

In der Färbung und Zeichnung ist dieser liäfer manchen Arten anderer Gruppen z. B. dem Sc. corpulentus nicht mähnlich; er gelıört aber nach dem Habitus ganz der vorliegenden Gruppe an. Der Kopf ist flach, fein quer germuelt und mit zart eingeschnittener Stirnlinie, unten zwischen den Augrenbuchten loreit und seicht quer eingedrückt, mit den oben (bei dem ठ) weit getrennten, durch die schmalen tiefen Angenhuchten selır ungleich getheilten Augen schwar\%. Die sthr dünnen Fühler etwa von liörperlänge, das zwejte (ilied fast kugelig, die drei folgenden düm rerkehrtkegelförnnig, und von ihmen das dritte reichlich doppelt-, das vierte dreimal- und das fünfte fast viermal länger als das zweite, das 
sechste dem fünften gleich und die oberen wieder allmählich abnehmend, sodass das zehnte kaum die Länge des dritten erreicht. Die fünf unteren durchscheinend rolhgelb, mit gebräunter Oberseite besonders der drei el'sten, die oberen schwarz, und dabei schwach zusammengedrückt und am oberen Ende verbreitert. Das Halsschild hinter der Mitte quer ähergewölbt und dadurch mit der grösseren Vorderbälfte sanft abwärts gekrümml, über den spritzen, tief eingezogenen Vorderecken stark versehmälert; die Seiten deutlich gerandet, vor der Mitte ausgeschweift und dicht hinter ihr in breiten Bogen erweitert, die Hinterecken scharf stumpfwinklig; der Hinterrand jeclerseits sanft gebuchtet, vor dem abgerundeten Mittelzipfel ein mit den etwas verbreiterten und vertieften Enden nach vorn gekrümmter Quereindruck; seitwärts nach den Hinterwinkelı zu noch ein zweiter, durch welchen den Hinterrant entlang ein feines Querfältchen emporgehoben vird. Ueber die Mitte zieht sich der Länge nach eine schwach erhöhte, nur unter gewisser Beleuchtung walımehmbare Kiellinie. Die Punktirung leutlich, aber nicht tief; der Zwisehengrund sehr fein genarbt, die Farbe lackglänzend schwarz. Das Schildchen sehr stark schräg ansteigend, nicht so lang als vorn breit, und hinterwärts stark verschmälert, mit ahgerundeten Ecken und deutlichem Hinterzipfel kurz abgestutzt, fein und zerstreut punktirt, schwarz. Die Veckschilde etwa $1 / 4$ länger als breit, von der Wurzel ab hinterwärts kaum verschnälert und auf dem Rücken nur längs der Naht leicht abgellacht, seitlich und hinterwärts mit ziemlich starker Krümmung abfallend, hinter der aufgeivorfenen Vorderkante zwischen den Schulterbeulen quer gefurcht, letztere nur flach eiförmig, die Sciteulippen tief herabgezogen; und über ihnen die Deckschilde leicht zusammengedrückt. lie Punktstreifen ziemlich fein, auf der vorderen Hälfte umregelmässig verdoppelt, theilweise wellig einander genähert und dadurch gestört, hinter der Mitte sich vereinfachend, regehmässiger, aber auch bis zu der fast glatten Wölbung immer mehr abgeschwächt. Die llachen Zwischenräume überaus fein querrunzlig mil Lackglanz, der neunte (breitere) mit einer mehrfach unterbrochenen Reilıe gröberer Punkte besetzl. Die Farbe schwarz, die Wurzel bis über das erste Viertel der Länge hinaus dunkelroth, und zwar so, dass diese Färbung hiıter dem Schildchen läıgs der Nahıt einen dreieckigen Ausschnitt zeigt, während sie sich seitlich in einem schmalen Bogen bis zum Ende des Seitenlappens himzielıt, und dieselbe Fär- 
bung zeigt dann noch ein grosser rmder Spitzenfleck. Pygidium, Untrrseite und Beine schwarz, mit dümner greiser Behaarung, die Hüften tief gebräunt, die Vorderschenlie] ziemlich stark aufgetrieben. Das feị punktirte Prosternum flach und hinten breit zugerundel. Das letzte Segment des $\delta$ breit quer niedergedrückt, das $q$ unhekamnt.

Aus Brasilien (Mus. Deyrolle).

32. Sc. tetrax m. Stahlblau oder schwarzblau, mit bräunliclıen Fühlerwurzehn, die Deckschilde mit röthlichem Schulter- und Spitzenlleck; das Halsschild kaum punktirt, sjpiegelglatt, die Punktstreifen voru deutliclser, hinten fast erloschen, mit flachen glänzenden Zwischenräumen. L. $2 \frac{1}{4}-3 \frac{1}{4}{ }^{\prime \prime \prime}$; Br. $1 \frac{1 / 3}{3}-1 \frac{3}{\prime \prime \prime}$.

Das breite etwas bauchige of dieser Art zejgt in Habitus einige Aehnlichkeit mit den Arten der vierten Rotte, namentlich dem shen bescloriebenen Sc. corpulentus, dagegen stimm das o ganz und gar mit den hier vorliegenden Arten überein. Der Kopf ist flach, die Stirn bei dem ơ fast gauz durch dis grossen, in lureiter Strecke zusammentreflenden Augen eingrnommen, bei dem $q$ mit einer fein eingeschnittenen, sich zwischen den Augenhuchten zu einem seichten rundlichen Eindrucke erweiternden Längslinie, muterbalb dieses Eiudrucks mit einigen zerstrenten, in den Augenbuchten feine silbergraue Härchen lragenden P'unkton lesetzt, üheraus glänzend stahlblan oder schwarzblau. las liopfschild selhst ringezogen, die Mundtheile sclıwärzlich, lie stark vorspringende Oberlippe rötslich gesïumt. Ilie Fühler von etwas über halber Kürperlänge, zienlich dünn, das kurze Wurzelglied ziemlich stark aufgetrieben, das zweite ejförmig und kaum $1 \mathrm{~m}$ die Hälfte länger als lnveit, das dritte doppelt länger als das zweite, die beiden folgenden noch melr verlingert, die oberen dem lünften gleich mit kurz zugespitztem Fortsatze des Endglieds. Die Farbe schwar\% mit dïmmer greiser Behaarung, die fünf unteren brüunlichgelb mit, lesonders boi den beiden unteren, geschwärzler Oberseite. Has Ilalsschild sehr hur und breit, die Mille der Quere nach schwach aufgewölbt, daher die Mittelfirste nur wenig grobogen, die Seiten loreit gerandet, in der Ilitte bogenförmign erweitert und ror ihr his zu den spitzen Vorderecken ausgeschweift, die Ilinterecken scharf stunıfiwinklig, der Ilinferrand wenig geluchtel, jederseits vou einem scharfen sich innerlalb des Hinterwinkels nach vorn umbiegenden Fältchen begleitet und vor diesem an seichter Schr'igemolruck. Die Punkti- 
rumg sehr fein und zerstreut, nur in jenem Eindrucke ein wenig dentlicher; die Oberfliche spiegelnd stahlblau oder schwarzblau. Das Schildchen stark ansteigeud, breit dreieckig und kurz abgestntzt, ıleutlich punktirt und dünn hehaart, schwarzblau. Die beckschilde fast quadratisch, kurz und breit gewölbt, hinter der scharf aufgeworfenen Wurzelkante quer eingedrückt und dann etwas ansteigeud, un das Hinterende des Schildchens etwas aufgetrieben, hinter ihın eingedrïckt, und wieder längs der eingedrüickten Nalıt allmählich abfallend. Die Schulterbeulen höckerig hervortretend, die Seitenlappen tief herabgezogen, die Schulterecken selbst breit alsgerundet. Die Punktstreifen vorn besonders bei dem đo derb, von der Mitte ab feiner und auf der Wölbung fast abyeschliffen, im Ganzen regelmïssig, nur der Raum zwischen der Nahı uml dem ersten Streifeı mit unordentlich zusanımengedrängten Punkten besetzt. Die Zwischenräume breit und flach, spiegelglänzend; die Farbe heller oder dunkler stalılblau, zuweilen hinten ins Purpurbläuliche spielend, oder auch tief schwarzhlan; ein hreiter nach imen verschmälerter Schulterfleck längs der Wurzel, den Seitenlappen einschliessent und manchunal bis zum ersten Streifen reichend, zuweileı mit abgeschrägten Hinterrande verkürzl, und ausser diesem noch ein die Spitze eimnelnnender Querlleck hell ziegelrotlı. Das Pygiılium gekielt, mit der Unterseite fein punktirt, dünn greishaarig, schwarzblau: auch die Beine schwarzlılaı mit bräunlichen Hüften. Das Prosternum ror'n seicht längswulstig, und seillich der Länge nach flach niedergedrückt, dahinter quer eingedrückt mit breit abgerundetrm Ihinterende. Das letzte Segment des o breit quer niedergedrüickt, das of mit einem kurzen, lreiten, lıalbeiförmigen Grübchen.

Aus Brasilien (Mus. Saunders. Halens. Holm. Berol.). Das Stïck des Mlus. IIolm. (ठ) ist bei Rio de J. voll Ferd. Sahlberg getunden worden.

33. sc. pygidiellus m. Metalliseh schwarzhlau, unteu dicht greishaarig, die FülıJerwurzelı, Seiten des feiı und zer'strent punktirten Halsschilds, Wurzel und Spitzenfleck der Flägeldecken mit Pygidium, Mittel- und Hintrobeinen hell rothgelb; die Punktstreifen an der Wurzel und Naht mregelnässig verdoppelt, mit flachen, glänzenden Zwischenräumen. L. 2"'; Br. $1 \frac{1}{3}{ }^{\prime \prime \prime}$.

Eine kleine und zierliche, durch die ausgedehnte rothe Zeichnung des liörper's leicht lienntlichı Art. Der líopf flach, mit feiXVI. 
ner Stirnlinie und quer mondförmig eingedrücktem Kopfschilde, die Punktirung fein, oberwärts mehr zerstreut, nach mien, besonders in den fein greishaarigen Augenbuchten und auf den Kopfschilde diclıter gedrängt, die Farbe ein stark glänzendes metallisches Schwarzblan mit leicht violetten Anfluge; die ziemlich tief ausgebuchteten sehr ungleich getheilten Augen (bei den o) um die Breite der Oberlippe von einander getrennt, schwarz. Auch der Raum unter den Augen dicht angedrückt greishaarig. Die Fühler von kaum halber Körperlänge, äusserst dünn und schlank. Das Wurzelglied ans stark eingeschnürter Basis blasig aufgetrieben, etwa doppelt länger als breit, das zweite kurz eiförmig, das dritte so lang als die beiden ersten zusammen, eben so das vierte dem zweiten und dritten zusammen und das fünfte wieder den vierten gleich, die folgenden allmählich verkürzt, und das Endglied mit seinem kegelförmigen Fortsatze kaum noch um die Ï̈lfte länger als das zweite; dabei die sechs obern schwach zusammengedrückt und erweitert. Die fünf unteren rothgell, mit geschwärzter Oberseite der heiden ersten und gebräunter Spitze des fünften, die oberen schwarz. Das Halsschilı doppelt breiter als lang, mit fast grader, nur am letzten Drittel leicht aulgebogener Mittelfirste, vorn über den pfriemlich vorgezogenen Vorlerecken mässig zusanmengedrückt und dadurcb verschmälert, die Seiten fein gerandet, in der Mitte bogig erweitert und vor ihr deutlich ausgebuchtet, die Hinterecken stumpp abgerundet. Der Hinterrand jederseits leicht ausgeschweift, mit kurzem schwach aufwärts gelogenem Mittelzipfel. Vor ilım das Mittelfeld leicht quer niedergedrückt, und daraus entwickelt sich seitlich ein erst schmaler uml tiefer, dann nach aussen verbreiterter und verflachter Schrägeinlruck, durch welchen in den Hinterwinkeln ein gekrümmles, den Rand begleitendes Querfältchen emporgehohen wird. Die Punktirung oben fein mit spiegelglïnzendem Zwischengrunde, seitlich lesonder's in den Hinterwinkeln dichter zusammengedrängt und stelłeuweise feine Rumzeln bildend. Die Farbe stahlblau, ein durch eine Schrïglinie von den Vorderecken ans nach jedem Aussenende des Mittelzipfels abgeschnittener, daher hinterwärts dreieckig sich verbreiternder Seitemrand hell rothgell. Das Schildchen stark ansteigend, lreit dreieckig und mit ausgebuchteten Sciten hinterwärts verschmälert, mit kurzen Hinterzipfel, dichı und fein punktirt, schwar\%. Die Deckschide flach gewölbt, länglich-viereckig und $1 \mathrm{~m} 1 / 4$ länger als breit, vorı hinter der 
scharfen Wurzelkaute quer eingerlückt und dahinter etwas aufgetrieben, ïber den stark herabgezogenen Seitenlappen quer zusammengedrïckt, und dieser Eindruck aufwärts bis zur Naht wahruehmbar; die Schulterbeulen breit aber kräftig heraustretend. Die Punktstreifen ziemlich fein, vorn melır oder weniger wellig gekrümmt und unregelmässig verdoppelt, auch besonders längs der Naht durch üherzählige Punkte gestört, die mittleren und äusseren vom Eintritte in den dunkeln Grund ab stärker und aus gröberen Punkteı gebildet, sich inmmer deutlicher entwickehnd, auf dem letzten Drittel ganz regelmässig mit flachen, glänzenden Zwischeuräumen. Die Farbe gleiclıfalls metallisch stahlblau mit purpurfarbenem Anfluge, eine gemeinsame etwa das erste Viertel der Flügeldecken einnehnende Vorderbinde und ein die Spitze einnehmenender, hinten fein schwärzlich gesäumter Querfleck unter der Wölbung hell rothgelb. Das Pygidium fein punktirt und dicht angedrückt greishaarig, gleichfalls rothgelb. Die Unterseite stahlblau mit dicht angedrückter gell)lich greiser Behaarung, die umgeschlagenen Seiten des Halsschilds hell röthlichgelh, uud auch der Hinterrand des letzten Bauchringes trüb geröthet. Die Vorderschenkel stark aufgetrieben mit entsprechend gekrümmten Schienen, auch die Hinterschienen etwas verlängert und deutlich gekrümmt. Die Farhe der Vorderbeine schwarzblau mit röthlichen Hüften und bräunlich durchschimmernden Schienen; Mittel- und Hinterloeine gelb, Schenkel- und Schienenspitzen uehst der Oberseite der Fussglieder schmutzig gelıäunt. Das Prosternum breit ınd flach mit zwei undeutlichen Längslinien und kurz zugerundetem Hinterende. Das letzte Segment rles $q$ mit der gewöhnliclıen rundlichen Grube; das đ unbekaunt.

Aus Brasilien (vom Amazonenstrom: Mus. Baly.)

Achte Rotte. Körper von mässiger Grösse, gestreckt walzenförmig, mit mehr oder weniger ahgrflachtem Rücken. Ilas Halsschild meist nur schwach eingedrïckt, die P'unktstreifen hinten stets verschwindend. Die Farbe eiı helleres oder dunkleres, glänzendes Knochengelb, meist mit punktartigen schwarzen Zeichnungen; die Unterseite zuweilen schwarz. Ilie Gruppe verbreitet sich vom Amazonenstrom his zum La Plata.

34. Sc. lurideolus m. Bleich ziegelroth mit verwaschen gelblicher Spitze der Deckschilde, die Fühler und Vorderschienen, die Enden der hinteren Schienen und ein Fleck der Hinterschenkel schwarz; das Halsschild kaum punktirt, die Punktstreifen hin- 
ten schwächer, die seitlichen bald erloschen mit flachen glänzenden Zwischenräumen. L. $21 / 3-2 \frac{1}{2}{ }^{\prime \prime \prime}$; Br. $1 \frac{1 / 4}{4}-1 / 3^{\prime \prime \prime}$.

Eine eiufach gefarbte, glatte, durch die helle Spitze der Declischilde von andern äusserlich ähnlich gefärbten leicht zu unterscheidende Art. Der Kopf flach, bei dem ठ fast ganz durch die grossen, einander in ziemlich weiter Strecke herühırenden Augen eingenommen, bei dem $\&$ zwischen den mässig entfernten inneren Augenränder'n lackglänzend, mit deutlicher, ob auch feiner Stirnlinie, lıell ziegelroth, nur die kurz und nicht tief ausgebuchteten Angen greis oder schwarz und die Kimbacken gebräunt. Dic Fühler des $q$ nicht von, laalber körperlänge, des $\delta$ letztere fast erreichend, das dritte Glied fast Areimal, dis vierte mehr wie dreimal länger als das zweite, das fünfte bis siebente dem vierten gleich, die oberen wieder ein wenig kürzer mit ziemlich lang ausgezogenem Fortsatze des Endglierles. Die drei unteren Glieder rölhlich gelb mit gebräunter Oberseite, dlas vicrte und fünfte lorüunlich, die sechs oberen schwarz und dabei dentlich zusammengedrückt und prweitert. Uas IJalsschild hreit und flach walzenförmig, über den scharf spitzwiuligen Vorderecken merklich zusammengedrüclit und dadurch verschmälert, seillich fein gerandet und in der litte slumpfwinklig erweitert, vor ilı leicht ausgeschweift, mit stumpfen Hinterecken, der Hinterrand nur jederseits des kurzen runden Mittelzipfels ausgehuchtet und eiugedrückt, seitlich davon je ein breiter, kräftiger Quereindruck, durch welchen hart am Raıde eiı scharfes Querfältchen emporgehohen wird. Die Punktirung anf dem Mittelfelde sehr fein und zerstrent, längs dem llinterrande mul besonders nach den Hinterecken hin grob, aber anch nur vereinzelı, mit spiegelglattem Zwischengrunde, die Farbe ein helles Ziegelroth mit schwach gehräuntem Hintersaume. Has Schildehen schäg ansteigend und vorn breit, hinterwirts mit ansgeluchteten Seiten stark verschmälert, mit deutlichem Hinterzijiel grade alugrstutat, fein punktirt, ziegelroth mit mïsigrm (ilanze. Dio Deckschikle breit und flach walzentörmig, etwa $1 / 4$ lïnger als breit, $1 m$ die Schildchenspitze etwas aufgetrieben, die Wurzel hinter der scharfeu, uässig erhölıten Vorderliante quer cingedrïckt und dieser Eindruck imnerseits der eifürmigen Selulterbeulen hinterwärts erweitert; die Seitenlappen licf heralıgezogen, üler ihnen elie Inechschilde: zusammengenliüclit, und diese Eusschürmug, wemn anch ohen schwicher, doch bis zur Nahı hin bemerkbar; letztere auf' dem lin̈cken 
der Länge nach niedergedrückt. Die P'unktstreiten sehr regelmässig, die oberen schon von der Mitte ab schwächer und anf der Wölbung fast erloschen, der seclıste und siebente hinter der Schulterbente nur in schwachen Ansätzen vorhanden und sich lıald verwischend; die breiten und llachen Zwischenränme spiegetglat, die Farbe gleichfalls hell ziegelroth, schon von der Mitte ab lichter, mil je weiter hinterwärts desto mehr ins Weishchgelbe übergelıend. Pygidium und Unterseite lein punktirt, dünn greishaarig, gleichfalls ziegehoth: auch die Beine ziegrelruth, mit stark aufgetriebenen glänzenden Vorderschenkeln, an den Vorderbejnen Schienen und Fussglieder schwarz, an den mittleren die untere Hälfte der Schienen nebst dem drilten und vierten f'ussgliede, an den hinteren ausser len letzteren nur die Schienenenten geschwirzt, dagegen die Schenkel auf der breiten Anssenllithe von den Kinien mit einem schıärzlichen Längsflecke. Das Prosternun der Länge nach schwach aufgewulstet, fein und zerstrent punktirt, hinten breit abgerunclet. Das letzte Bauchsegment des of einfach, das $f$ mit einer sehr grossen rundlichen Grube.

Aus Brasilien und zwar, vom Amazonenstrome (Vou Ega: Mus. Baly; von S. Paolo: Mus. Clark). Ob ein etwas bleicheres o ebendaher im Mus. Clark mit gröberen etwas welligen Punktstreifen mrehr als blossc individuelle Abweichung ist, muss die spälere Erfalırung lehren.

35. Sc. abstersus m. Schwarz, unten dicht silberhaarig, ein Fleck auf dem Unterkopfe, das vierfach schwarzgefleckte groly und zerstreut punktirte Halsschild und die Deckschilde strohgelb; die Punhtstreilen vor'n durch ïlseræählige Punkte verdunkelt, linten feiner, mit flachen glänzenden Zwischemrumen. L. $234^{\prime \prime \prime}$; Br. $11 \frac{1}{3}{ }^{\prime \prime}$.

Der Kopf flach, oben leicht rundlig eingedrückt mit sehr feiner Stirulinie und eingezogenem Kopfschilde, mässig aber ziemulich dicht punktirt, mit schwachglänzendem lang aber dün greishaarigem Zwisehengrunde. Die Farbe schwarz, die Oberlippe und ein rundlicher mit einer zipfetförmigen Vertüngerung auf das Kopfschild übergreifender Fleck zwischen den Fühlerwurzehı hellgelb, die schmal aber ziemlich tief ausgebuchteten Auren greis. Die Fühler (des q) von $2 / 3$ der Körperłänge, das zweite Glied kurz und knotig, das dritte doppett- uncl dis rierte vicrmal länger, das fünfte noch etwas länger als letzleres, die fünf folgenden ziemlich einander und dem vierten, das schmal linealische Endgfied wirder dem fünlten gleich. 
Die fünf unteren durchscheinend gelblich, die Oberseite des ersten und zweiten breil gebräunt, der drei folgenden mit einem schmalen bräunlichen Wische bezeichnet; die oberen sclıwarz mit dünuer angedrückter greiser Behaarung. Das Halsschild doppelt breiter als lang, hinter der Nitte leicht quer aufgewölbt, längs dem Vorderrande eingeschnürt, über den scharf spitzwinliligen Vorderecken zusammengedrückt und dadurch verschmälert, die Seiten fein gerandet, in der Mitte in flachen Bogen erweitert und vor ihr fast gerade, die Hinterecken scharf stumpfwinklig, der Hinterrand jederseits ausgebuchtet mit kurz aufgebogenem Hittelzipfel; vor dem letzteren das Mittelfeld schräg nach hinten abwärts gedrückı, und danı seitlich je noch ein breiter, flacher Schrägeindıuck. Die Punktirung oben feiner und längs der Mitte fast ganz fehlend, je weiter seitlich destu gröber und dichter gedrängt mit spiegelglattem Zwischengrunde. Die Farbe hell strohgelb, jederseits der Mitte mil zwei schwarzen Flecken, der innere grössere rhombisch und an der linteren Innenseite ausgebuchtet, der äussere kleinere ein neben ter hinteren Aussenseite des inneren stehender Querfleck. Das Schildchen schräg ansteigend, fast quadratisch, hinterwärts kaum verschmäler', mit abgerundeten Ecken und deutlich dreicekigen Hinterzijfel gerade abgestutzt, fein punktirt und kurz anliegend greishaarig, schwarz. Die Deckschilde lïnglich viereckig, fast um die Hälfte länger als breit, auf dem Rücken flach gewölbt und hinten mit starker Krümmıng alfallend, linter der Vorderkante nur leicht quer niedergedrückt, die grossen ziemliclı flachen Schulterbeulen innerseits durch einen dreieckigen Eindruck abgesetzl, auch die Sejtenlappen ziemlich gross mit breitem umgeschlagenem Rande. Die Punktstreifen aus sehr vereinzelten Punkten gebildet, die oberen vorn stellenweise verdoppelt und besonders gegen die Naht hin durch überzällige Punkte verdunkelt, von der Mitte al regelmässiger alser auch feiner, und auf der Wölbung fast erloschen mit flachen glänzenden Zwischenräumen. Die Farbe hell strohgell. Pygidiun und Unterseite fein und dicht runzlig punktirt, mit den Beinen dicht angedrückt silherhaarig, schwarz, nur der breite Mittelzipfel des ersten Bauchrings gelblich. Die flache Vorderbrust in gleicher Weise, aber etwas länger, seitwïls anliegend behart. Das letzte Segment des $q$ mit einer grossen spiegelglatten Grube, das $\delta$ unthekannt.

Gleichlills aus Brasilien (Mus. Berol., von Virmond.) 
36. Sc. bilineolatus m. Kunochengelb, die Fühler, zwei Längslinien und zwei Punkte des grob punktirten Halsschildes mit dem Schildchen, den Füssen und fürıf Punkten der Flïgeldecken $(2,2,1)$ schwarz; die Punktstreifen vorn grol, hinten verschwindend, nit flachen, glänzenden Zvischenräumen. L. $21 / 2{ }^{\prime \prime \prime}$; Br. 1 11/3"”.

Etwas kürzer und zierlicher als der vorhergelıende, ïlsrigens demselben sehr ähnlich, wenn auch sogleich an der abweichenden Zeichnung des Halsschilds und der Flügeldecken kenntlich. Der Kopf flach mit tief eingedrückter, in der Mitte rimnenförmig elweiterter Stirnlinie, das eingezogene Kopfschild oben durch einen leichten Querwulst begrenzt, die Oberlläche grol, punktirt mit lackglänzendem Zwischengrunde. Die Farbe gelh mit einem leichten Stich ins Röthliche, die Oberlippe lıeller gelh, die Tasterenden und die tief dreieckig ausgebuchteten, (bei dem $?$ ) weit getrennten Augen sclıwarz. Die Füller von etwa halber Kürperlïnge, das zweite Glied oberwärts stark aufgetrieben, daselbst so breit wie lang, das dritte doppelt länger als das zweite, und verkehrtkegelförmig, das vierte wieder etwas länger, das fïnlte dem dritten gleich, oberwärts schon etwas zusammengedrückt und verbreitert, was noch mehr bei den sechs oberen der Fall ist, letztere kaum merklich länger als das fünfte, mit breit dreieckigem Fortsatze des Endglieds; die Farbe üherall schwarz. Das llalsschild reichlich doppelt breiter als lang, über die Nlitte leicht quer aufgewölbt, sorlass sich die Mittelfirste vor- Imıl hinterwärts - dort in etwas längerer Ausdehnung - sanft abwirts senkt, über den spitzwinkligen etwas aufgebogenen Vorderecken zusammengedrückt und dadurch versehmälert, die Seiten fein gerandet, von der kaum erweiterten Mitte aus in breiter Rundungr durch die abgestumpften Hinterecken in den jederseits gebuchteten Ilinterrand übergehend; der Mittelzipfel kurz, leicht auligebogen und vor ihm ein schmaler Quereindruck, vor welchem wieder eine etwas gekrümmte, ans derben P'unkten gebildete Querlinie; das Mittelfeld jederseits mit einem breiten, flachen Quereindrucke. Die Oherfläche zerstreut aber grob punktirt, die Farbe ein lackglänzendes, etwas ins Röthliche spielentes Lehngelb, jederseits vor der Mitte ein etwas länglich ausgezogener schwarzer Punkt, und zwischen diesen Punkten noch zwei gleichlaufende, beiderseits alogekürzte schwarze Längslinien, welche nahe den Vorderrand erreichen, hinten aber an letzlen Drittel der IIalsschildslânge abbrechen. Das Schildchen ziemlich stark ansteigend, fast 
so lang wie vorn breit, hinterwärts verschnälert und mit abgerundeten Ecken und deutlichem Hinterzịfel ahgestutzt, fein aber zieınlich dicht runzlig punktirt, schwarz mit brännlicher Spitze. Die Deckschilde etwa $1 / 4$ länger als breit, flach walzenförmig, ziemlich gleichbreit und hioten mit sanfter Wölbung abfallend, hinter der scharfen Vorderkante seicht quer eingedrückt, die Schulterheulen hreit und flach, die Seitenlappen ziemlich tief herahgezogen mo über ilmen die Deckschilde merklich zusammengedrückt. Die Punktstreifen grob und ziemlich regelmässig, mit einigen überzähligen Punkten lïngs der Vorderhälfte dér Naht und zwischen den Streifen linter der Schulterbeule, auf dem letzten Drittel stark abgrschwächt und zulelzt fast weggeschliffen; die Zwischenrämme flach, vorn fein querrunzlig nit mässigem Glanze, hinten spiegelglatt. I)ie Farhe hell knochengell, bleicher als das IIalsschild, mil fünf schwarzen Punkten auf jeder Flügeldecke, lie vier vorderen in einem etwas sclı̈äg mach vorn uud aussen gerückten Rhomhus, dessen äusserer Vorderfleck auf der Schulterbute, der hinter ihm stehende sehr kleine auf dem achten Punktstreifen, die beiden inneren an den vierten Streifun gelehnt, und hier des hintere der grössere; der fünfte vereinzelt anf der Wölhung zwischen dem achten und neunten Streifen, alle zart brandig gesäunt. Pygilium und Unterseite hleichgelb mit trüb rüthlichgelher Brust, anch die Beine röthlichgelh mil geschwärzten Schienenenten und Fussgliedern. Die Vorderhrust leicht eingedrückt und greis behaart. Das letzle Segment des $q$ mil einer kleinen Irundlichen Grube, das $\delta$ leichl quer niedergedrückt.

Aus Südamerika ohne nälıre Angalıe der Heimath (Mns. Deyrolle), und volı Buenos Ayres (Mus. Clark).

37. Sc. conspurcatıs in. Oben bleichknochengell, Nacken, Schildcheı und fünf Punkte der Flügchdicken $(2,2,1)$ nelsst den Fühlern schwarz, unten schwarz mit lreit gellılich gerandetem Ilinterleilse; das Ilalsschild grob punktirt, auch die Punktstreifen vorı derb und etwas gestört, hinten schwächer, mit flachen glïnzenden Zwischenräumen. L. $3{ }^{\prime \prime \prime}$; Br. $1 \%{ }^{\prime \prime \prime}$.

Dem vorhergehenden in Hahitus und Färbung selı ïhnlich, aher etwas plumper, und ron ihm sogleich an dem ungefleckten Halsschilde und den schwarzen Beinen zu unterscheiden. Der Kopf flach mit tiefer anf den Nacken l'muenfümmig erweitrrter Stirulinie und etwas ringezogenem, oben nicht dentlich alıgegränztem liopf- 
schilde, groh und dicht junktirt mit ziemlich glïnzendem Zwischengrunde, beich knochengelb, Nacken, Augenbuchten, Kinnhacken und Fühterhöcker schwarz, die Mitte tler Oherlippe und die ührigen Humbltheile schumbig geschwil'zl, die nicht sehr breit aber (bei tem ?) tief ausgrbuchteten Augen greis. Die Fühler von halber Körperlïnge, las Wurzelglied stark lienlig aufgetrieben, 1 m die Hälfte länger als breit, das zwrite kugelig, die drei folgenden dënn

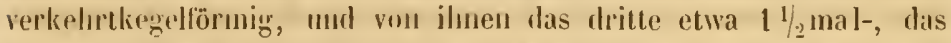
vierte und fünfte je $2 \frac{1}{2}$ mal linger als das zweite, das sechste noch ein wenigy verlängert und diesem alle folgenden gleich, dabei die sechs oberen mässig zusammengedrïckt und erweitert, mit kurz dreieckigem Fortsatze des Enfolieds. Die Farbe sclıvarz mit dümer "rreiser Behaarung der oberen Glieder, die beiden unteren auf der Unterseite ged)äunt, und das zweite an der Wurzel, die drei nïchsten an der Spitze etwas heller durchscheinend. Das Halsschild dopjelt breiter als lang, hinter der Mitte stark quer aufgewölht und ron dis ab nach ror't stärker, hinterwïts etwas schwächer herabgekrümmt; ülıer den tiof eingezogenen spitzwinkligen, etwas nach Aussen gebogenen Vorderecken zusammengedräckt und dadurch verschmalert; die Sciten fein gerandet, linter der Nitte bogig erweitert Ind vou da nach vorn und himten fast gerade verdanfend, die Hinterecken scharf stumpfwinklig, der Hiulerrand jederseits gebuchtet, mit mässig heraustretendem Mittelzipfel, und ror diesem seitwärts je ein flacher Eindruck, sorlass zwischen diesen ein breites Mittelfeld übrig beibt. Die Punktirung nicht selı dicht, aber groh und ziemlich gleichmässig vertheilt, die Farbe knochengelb ohne Zeichnungen. Das Schiddehen schrïg ansteigend, fast so lang wie vorn breit, hinterwärts verschmälert, breil abgestntzt, mit stark vorIretendem Itinterzipfel, feiu punktirt nnd schwarz. Die Deckschilde breit und flaclı walzenförmig, etwa um $1 / 4$ lïnger als breit, ziemlich gleichbreit mit hinten nur sanft abfallender Wölbung, hinter der scharf'on Vorderliante schmal aher zienlich tief quer eingedrückt, die länglichen Schulterbenlen flach: auch die Seitenlappen nur mässig abwärts gezogen, und üher ihnen dir Deckschilde sehr hreit zusammengedrückt. Die l'unktstreifen aus zienlich vereinzelten Punkten grehildet, auf der grösseren Vorderhälfte groh, aber durch ïberzählige Punkte derartig gestört und verdunkelt, lass die oberen nur stellenweise zu erliennen und von jenen theilweise auch zu abgerissenen Iängsieihen geordneten Nebenpunkten nicht olne 
Mïhse zu unterseheiden sind. Von der Mitte ab werden die Streifen regelmässiger, aber auch immer mehr abgeschwächt, und sind auf der Wölbung kaum noch anders als an ihrer dunklern Firbung kemntlich. Die Farbe der Flügeldecken hell knochıngelb mit einem Stich ins Grünliche und füıf schwarzen P'unkten; das Vorderpaar hinter der Wurzel, der äussere auf der Schulterbeule, der imnere grössere etwas hinterwairts gerückt, das zweite Paar hinter der Nitte, der innere etwas weiter nach vorn gestellt, und rin einzelner solsr unscheinbarer aul' den neunten Streifen vor der Spitze, nit den beiden ausseren fast eine gerade Längslinie bilılend. Das P'ygidium runzlig punktirt, gleichfalls gelb. Unterseite und Beine schwarz mit lreit gelbem Rande des Hinterleibs, weleher zugleich die grössere Hinterhälfte des letzten Bauchringes einnimmt; die Hïften und die Rinne auf der Innenseite der starkerdickten Vorderschenliel urüb gebrüunt. Das Prosternum grob I'unzlig punktirt, langr greishaarig, der Länge nach seicht niedergedrückt. Was letzte Segment des o mit eincm mässigen Grübclıen, das ơ unhekannt.

Voll Buenos Ayres. (Mus. Deyrolle).

Neunte Rotle. Körper meist gross und etwas plump, die Deckschilde gleichbreit odler linterwärts etwas verschmälert, das Halsschild nach vor'n deutlich verengt, manchmal an den Seiten und einmal anf der ganzen Fläche behaart, auch die Unterseite häufig dicht silherhaarig. Die Punlitstreifen üherwiegend feill, hinterwärts stets feiner, und vorn meist durch ïberzihlige Punkte gestört. Iie Färbung meist schwarz, oft mit rothen oder gelben ZeichIumgen aut dem IIalssclilde oder an Wurzel, Rand und Spitze der Ueckschilde, seltener die ganze Oher'seite oder doch die Deckschilde: einfarbig roth oder gelb, einmal das Iialsschilil gelb. Die Augen der of zusammenstossend oder doch sehr geniahert. Liese Rotte enthält nebst der vorhergegangenen siebenten den eigentlichen Stann der Galtung, ist deshalb šehr reich an mannigfaltigen Formen, mud dehnt sich ïlıer las ganze Nord- und Ostgehiet von Venezuela his Paragnay aus.

3S. S. metallescens m. Rostroth mit stahlblauen oder kupfirg g̈lïuzenden Deckschilden, Fussglieder und Schienen schwasz, das Iygridiun und der Rand des IInterleibs weisslich; das IIalsschild grob zerstreut punklint, die Punktstreifen vorn theilweise verdopjelt unsd durelı älnerzählige Punkle gestört, mit flachen, glänzenden Zwischenrämmen. 1. $2-3 \frac{1}{2}{ }^{\prime \prime \prime}$; Br. 1-1\%/3"'. 
Eine der grössten Arten dieser Gruppe, und durch den im Allgemeinen auch gleichbreiten liörjer den Uebergang zwischen den vorhergehenden und den folgenden Arten bildend. Der Kopf flach, die Stirn hreit und seicht eingedrückt, das kurze Kopfscliild eingezogen, und nach oben kaum merkbar begräuzt. Die Punktirung grob und zerstreut, die grossen Augen schmal aber tief ausgebuchtet, bei dem $\delta$ nur durch eine feine Längslinie getrennt; die Farbe dunkelrostroth mit schwäızlichen Mundtheilen. Die Fühler dünn und von ınehr als halber Körperlänge, das zweite Glied eiförmig, das dritte fast dreimal und die heiden folgenden je viermal länger als das dritte, und diesen auch die oberen fast gleichkommend, mit spitz dreieckigem Fortsatze des Endglieds. Die Farbe der fünf unteren roth mit schwarz geflectiter Oberseite der beiden unteren und einer dunkleren Längslinie auf den drei folgenden Gliedern; die ülrigen Glieder schwar'z. Das Halsschilıl kurz und breit, mit tief heralggezogenen Vorderecken, vor'ı mı wenig verschmälert, die Mittelfirste hinter des Mitle schwach emporgebogen, vor dem Schildchen flach niedergedrückt und von da ab jederseits ein breiter und tiefer, nach vorn und aussen sich verschmälernder und verflachender, durch eine erlıöhte Querlurücke unterbrochener Schrägeindruck. Die Seiten breit gerandet, von den stumpfwinkligen Hinterecken bis zur Mitte abgeschrïgt und danu unter einem sehr stumpfen Winkel nach den Vorderecken zu gebrochen; der Hinterrand jederseits an Schildchen tief ausgeschweift und dann noch von ciner sclımalen, durch den Schrägreindruck emporgeschobenen Querfalte begleitet: der Mittelzipfel abgerundet, aber deutlich heraustretend. Die Punktirung zerstreut aber grob mit glänzendem Zwischengrunde: die Farbe dunkelrostroth. Das Schildchen viereckig mit etwas gebogenen Seiten und stumpf algerundeten Hinterecken; der Hinterzipfel deutlich, die Oherfliche grob gerunzelt, matt röthlich- oder schwärzlichlıanu. Die Deckschilde breit und flach gewölbt, nicht ganz um $1 / 4$ länger als breit, hinterwärts sehr wenig verschmälest und dann kurz algerundet, hinter der scharfen Vorderkante quer eingedrïckt und dieser Eindruck an Schildchen und innerseits der breit und flach höckrigen Schulterbeulen stärker vertieft; der Rücken hinter dem Schilldchen etwas aufgetrieben und dam üher der Naht quer eingedrückt, die Seitenlappen selır stark entwiclielt, und üher ihnen ein grosser, ziemlich tiefer Eindruck. Die Punktstreifen bis zur Mitte hiı derb und deutlich, mit fast 
überall verdoppelten Vorderenden, und ausserdem auf den Zwischenräumen einzelne zerstrente Punlite, welche sich zwischen der Nalıt umbl dem zweiten Streifen so vernehren, dass hier die Streifen selbst stellenweise unkenullich werden; auf der hintern Hälfte simul dieselben alsdanı regelmässiger und feiner, olnne jedoch ganz zu erlöschıen. Die Zwischenräume brejt und flach, die Farbe ein gläızendes, manchmal ius Pur|urfạbige oder Kupfergläızende öberspielendes Stahlblau. Ilas Pygidlium runzligg punktirt, weisslich; die: Unterseitc rostroth, nit breiterem orler schmileren, weisslichem durch Gelh, in die Farhe der Unterseite übergehendem Rande des Hinterleibes, tind in Auschlusse an diesen bildet sich bei einer Varietät

$\beta$. auf den Flügeldecken eine weisse Schrïglinde, welche an der Naht hinter der Schildchenspitze begimnt und ron da schräg nach hinten und aussen bis zum Anfange des zweiten Irittels der Deckschilde fortzieht. Ilier trift sie mit dem weisslichen Seitenzipfel des ersten Bauchringes zusammen, und delmt sich dann, nach vorı und linten eine kurze Strecke auf dem líele des Seilenlappens aus. Sonst aber zeigt diese form, die mir nur in zwei $f$ vorliegl, keinen weiteren Unterschied vou der Stanmform.

Auch die Schenkel rostroth, zuweilen mit schwarzer Spitze, schienen und Fussglieder schwarz; die stark gekrümmten Vorderschienen bräunlich durchscheinend. Das Prosternum vor'n seicht quer eingedrückt, mit kurzem breit zugerundetem Hinterrande. Das letzle Segment des o einfach, das o mit einer nicht sehr tielin rundlichen Grube.

Bei einem, verhälunissmässig kleinen $\delta$ im Mus. Hal. ist die Unterseite nebst dem Pygilium einfarbig roth, die Seulptur an Halsschild und Flügeldecken merklich feiner, und die Farbe der beckschilde ein selır intensives metallisches Kupferviolett, wie bei unsrer Chrysmala cuprea: sonst aber finde ich keine Abweichung.

In Brasilien, und dor't anscheinend nicht selten, daher in vielen Sammlungen vertren. (Mus. Sunnders. Baly. Deyrolle. Clark: von Tejuca. Ilalens: von Riu de J., Berol. I'indub.) Die Varietä $\beta$. wïrde von $f$. Sahlberg mit der Stammform zusammen hei kio de $J$. gesammelt, und findet sich gleichfalls in $\mathrm{Mus}$. $110 / \mathrm{m}$ wie auch in Mus. Berol.

39. Sc. cerux nigra m. Oben selewar\%, Unterkopf, Ilitsschildsrand, rin grosser Vorderfleck und die Spitze der Flügeldecken 
mit dem Kiele. des Seitenlappens gell, unten röthlichgelb, mit schwarzen Vorder - und Mittelschienen; das Halsschild zerstreut punktirt, die Punkıtstreifen mässig, vorn gestört, mit flachen fein

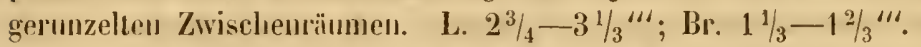

Von dem Iabitus des vorhergehenden, aber aul" der Oberseite gar alsweichenıl gefïrbt. Der liopf llach gewülbt, der ganzen Länge uach von einer seichten Rinne durchzogen, dentlich aber ziemlich zerstrent punklirt mit glänzendem Zwischengrunde, schıvarz; der untere Theil der Stirn mit den Augenbuchten rötlılichgelb, die Oberlippe schwefelgelb, der Aussenrand der Kimnbacken gehıämu. lie grossen, bei dem ơ oben ziemlich zusammengeneigten, durch die liefen Augenbuchten selır ungleich getheilten Augen schwar\%. Die Fülıler fast von $3 / 4$ der Kör|perlänge, das Wurzelglied ziemlich gestreckit eiförnig, das zweite sehr kurz und fast kugelig, das dritte dem ersten gleich, die beiden folgenden noch etwas verlïngert, so dass das fünfte den beiden ersten zusammen gleichkommt, das sechste wieder dem vierten gleich und die übrigen so langsam abnehmend, dass das Endglied noch etwa die Länge des dritten erreicht. Alle oberen vom sechsten ab sehr schwach zusimmenged'ückt und erwoitert; die Farbe der fünf unteren durchscheinend gell mit gebräunter Oherseite des füuften, die oberen schwilrz. Das Halsschild sehr breit und thach gewölls, reichlich doppelt hreiler als lang, lïngs dem ganzen Hinterrande etwas niederyesenkt und dadurch die Mittelfirste dort etwas abwärts gehogen; die Seiten fein gerandet, vou der schwach im Bogen erweiterten Mitte nach den scharfen fast rechtwinkligen Vorderecken hin fast gerade verlaulend, hinter ihs mässig gekrümnnt und an den scharfen Ilutereckrn liurz ausgerandet; der Hinterrant leicht wellig gekrümmt, der Hitlelzipfel kurz und breit, deullich aufwärts gebogen, die OberHiche jederseits dessellıen mit einem leichten Schrïgeindruck, die Punktirung selı zerstreut, von mässigar Stärke, mit ziemlich gläızendem Zwischengrunde; die Farhe schwarz, ein hreiterer Scitenund llintermand, letzterer vorn jederseits leicht geschweift, und ein selı' schmaler Vordersaum lehmuell, ror dem letzteren jedoch der alugesetzte Raudsaum wiedor schwärzlich, and bei einem der vorliegenden Sıücke auch das schwarze Millelfeld nochmals Ilurch eine feine gelbe Längslinie in zwei längliche Feldes gelheilt. Das Schildehen stark anstrigend, etwas länger als breit, drejeckig mit schwach gerundeten Seiten, mil kurzem schı"̈̀ abwärts gerichtetem 
llinterzipfel lneit abgestutzt, sehr fein punktirt, schwarz. Die Deckschilde breit und flach gewölbt, Im fast $1 / 3$ länger als breit, ziemlich rechteckig und hinten sehr kurz zugerundet, hinter len scharfen Wurzelkanten quer eingeiliuckt, die Schulterbeulen stark heraustretend, auch die Seitenlappen lang abwärts gezogen und mit einem tiefen Schrägeindrucke hezeichuet; auf dem Rücken nur dicht hinter dem Schildchen ein schwächerer Quereindruck. Die Punktstreifen hei dem o krältiger, dem $q$ äusserst fein, auf ler vorderen Ilialfte durch überzaililig ringemengte Punkte. etwas getrïbt, erst von der Nitte ah, deutlicher entwickelt, aher sehon aut der Wölbung fast ganz erloschen, die flachen Zwischıenräume fein aber dicht querrunzlig und desshalh nur von mässigem Cianze. llo farlic lisst sich am hesten als gell hezeichuen, eine schmale Qurerbinde lïngs der Wurzel, rine elien solche hinter der Vitte, und ein noch schmalerer Naht- und Scitenrand, welcher sich hinter der Nitle zu einem schmalen Samm aloschwiecht, schwarz, so lass dadurch die gelbe Fïloung in vier grosse Flecke zerrissen wird: anssertem der die Schulter umzichende Kiel des Seitenlappens weisslichgelh. Pygilium und Unterseite fein punktirt, dünn greishaarign, hellgelh, die Mitte les Hinterleilies nelst der Hinterlurust schwach ins lioströthliche fallend. Die Vordersehenkel stark aufgetriehen, mit entsprechend gekrünmten Schienen; die Farhe der Beine gelb, nur die Spitzen der ins Böthliche spielenden Vorder'schenkel mit Schienen und Fussglieder'n, sowie die untere Hälfte der Mithelschienen mit Fussgliedern .schwärzlich, die Mittellinie und manchmal inch das dritte Fussglied der Hinterbeine schmutzig gelnäunt. Was Ietzte Segment des $\delta$ einfach, des $f$ mit einer lileinen halbrmollichen Grube.

Aus Brasilien (Mus. Ilamburg. Ilolm. Berol. Vindob. Clark.).

40. Sc. parmulatus m. Staliblam, der Vorder- und Seitenrand les grob zerstrent punktirten-Halsschilds mit den lieinen bis anf die schwärzlichen Vorderschenkel geröthet, und zwei grosse Flocke aler Fü̈galdecken (I, I) gelb oder roth; die P'unktstreifen grol, vorn unregelmässig verdoppelt, hinten ahgeschwächt, mit tlachen glänzenden Zwischenräumen.

o Vorder- und Seitumrand des Halsschildes und die Brine rothgelh, Flecken der Flïgeldeckrn hellgelb.

$?$ alle ohen genamnten Thrile roth.

L. $3-4^{\prime \prime \prime} ;$ Br. $1 \frac{2 / 3}{3}-15 / 6{ }^{\prime \prime \prime}$. 
Eine grosse schōne, durch die rmulen Schildflecke der Deckschilde sehr ausgezeichnete Art. Der Kopf llach, schwarzblau, lie Augen des o anf der Stirn zusammenstossend, des $q$ getremnt, daher bei den letzteren die kurze Nackenlinie des ersteren zu einer deutlichen Stirnlinie verlïngert; das eingezogene Kopfschild punktirt, Oberlippe und Mundtheile pechschwarz, die sehr dünnen und schlanken Fühler bei dem $\delta$ von etwa $2 / 3$ der lï̈rperlänge, dem $q$ küızer; das zweite Glied kugelig, das dritte um die Iälfte länger als das Wurzelglied, und letzleres anch von den Endgliede mit frinem schunal liegelförmigen Fortsatze ïbertroffen. Dic Farbe der vier unteren hell rothgelb, das fünfte (längste) geloräunt, dlie oberen schwarz. Das Halsschilıl breit und flach, über die Nitte Jeicht quer aufgewölbt und vor dem Hinterrande etwas niedergedsrïckt, die spitlichen Eindrïcke schmal und scharf, Vorrler- und Hinterecken scharf, letztere breit stumplwiuklig, die Seiten nach den spitzen Vorderecken zu fast in geraden Linien verlaufend. Die Oberfläche grob und zerstreut-, in den Vorderwinkeln etwas dichter pusktirt, mit glänzendem Zwvischengrunde, dunkelstahlblau, ein lıreiter Vorderund Seitenrand hei dem o heller, dem $q$ dunkler roth, bei beilen etwas dunkler als die Fühlerwurzeln und Beine. Das Schildchen stark ansteigend, so lang als vorn loreil, hinterwärts merklich verschmälert, mit deutlichem Hinterzipfel, zerstreut punktirt und mit eimzelnen IIärchen besetzt, schıvarz. Die Declischilde loreit und flach gewölbt, ziemlich rechteckig und efwa $1 / 4$ länger als breit, hinter der ziemlich scharfen Vorderhante breit aber nicht tief quer eingedrückt, mil eckigen Schulterbenlen unıl lang heralggezogenen Seitenlappen, und üher diesen ein breiter, bis zum Rücken hinaufziehender Quereiulrück. Die Punktstreilen hei dem ठे vorn groh, dem $q$ etwas leiner, bei beiden durch unordentliche Verdoppelung stellenweise gestört, in tlen seitlichen die P'unkte mehı oder weniger ausgerissen und dadurch Querrunzehn bildend; von der Mitte ab die Streifenbildung regelmässiger, dlie Streifen selbst aber allmählich abgeschwächt und auf der Wölbung fast abgeschliffen, ınit llachen und glämzenden Zwischenrämmen. Die Farbe stahlblau, auf jeder Flïgeldeche vorn in dem Winkel zwischen Wurzer, Schildchen, Naht und Schulterbenle ein grosser zienlich rundrer, hei dem of gelblichweisses, dem of rother Fleck, und ein ähnlicher, aher länglichrmuler in der Spitze, aher den Aussemranul nicht erreichend, so dass der Zwischenraum zwischen ihni und den Vorder- 
flecken kaum das mittlere Drittel der Flügeldeckenlänge einnimm. Pygidiun und Unterseite schwarzblan, jenes schwächer- diese dichter silberlaarig, die Parapleuren und die Schulterblätter, zuweilen auch noch die Seiten der Hinterbrust bräunlich. Die Beine bei dem $\delta$ hellrothgelh, dem of dunkler roth, mit dunklern Fussgliedern; die Vorderschenkel auf der Aussenliante und der hreiten Vorderfläche stark schwarzblau angelanfen. Ilas Prostermum breit und flach, mit zwei seichten Lüngseindrücken, hinten abgerundet. Das letzte Segment des $\delta$ in der Mitte geröthet mit einem kreisförmigen, flachen Eindruck, das $q$ mit der gewöhnlichen Grube.

Gleichfalls aus Brasilien (Mus. Dohrn, Baly, Deyrolle, Berol., Tindob.). Als Ieimath ist in Mus. Deyr. S. Catharina genannt. Das anscheinend sehr seltene $f$ habe ich nur aus dieser letzteren Sammlung vor mir.

41. Sc. flavofasciatus m. Rosthraun mit hellerem Vorderrande des grob zerstreut punktirten Halsschilds, eine breite Wurzel- und Spitzenquerbinde der Deckschilde weissgell); die Punktstreifen derb mit flachgewölbten, ziemlich glänzenden Zwischen-

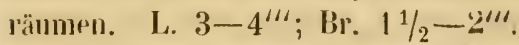

llie vorliegende, zı deı grössten der Gatung gehörende Art macht oberflächlich den Eindruck eines schlerht ausgefärbten und ptwas unreifen Kälers, liegt mir aber in beiden Geschlechtern molurfach und vollständig ausgehärtet vor, zeigt auch keine entsprechenden dunklern Formen, mod ich zweille daher nicht daran, dass jene Beschaffenheit wirklich den normalen Zustand des Thiers ausdrïckt. Der Kopf flach mit stark eingezogenem Koplschilue, fein aber dicht runzlig punktirt, kurz und dümm behaart, rostlıaun, das Kopfschild rerwaschen heller, die Oberlippe knochengell, und die Mumblheile gellbbraum, die kurz dreieckig ausgebuchteten, bei dem ơ selı genäherten Angen greis. Die Stirn des $q$ breiter, grüber punktirt, der Länge nach seicht njedergedrüclit, der mutere, breitere Theil dieses flachen Lüngseindrucks olme Punkte und deshalb stirker glänzend. Die Fülıler des ठ์ von $3 / 4$ der Körperlänge, änsserst dünn, das Wurzelglird blasig aufgetrieben, lianm doppelt länger als breit, das zweite kurz und knolig, die folgenden fast gleichbreit, kaum zusammengedrückt und nur an den olseren Eude ein wenig verbreitert, das dritte fast dreimal-, das vierte viermal länger als das zwcile, das fünfte noch elwas verlängert, das sechste dem fïnflen, das siebente wieder dem rierten gleich, die drei folgenden etwas kür- 
zer, und das Endglied mit seinem schmalen Fortsatze wiederum die Länge des vierten erreichend. Die Farbe durchscheinend honiggelb mit rauchgrau angeflogener Spitze. Die Fühler des $q$ in allen Theilen etwas verkürzt und kaum über die Mitte des Körpers hinausreichend, sonst nicht verschieden. Das Halsschild sehr kurz und breit mit hinten flachem Rücken und gerader Mittelfirste, über den scharf rechtwinkligen pfriemlich zugespitzten Vorderecken merklich zusammengedrückt und dadurch ins Kegelförmige verschımälert, die fein gerandeten Seiten in der Mitte in flachem Bogen erweitert und vor ihr leicht ausgeschweift, die stumpfwinklig abgerundeten Hinterecken mit einer Schwiele bezeichnet, der Hinterrand jederseits leicht ausgebuchtet, mit kurzem, breitem, seitlich durch einen tiefen Quereindruck bezeichnetem Mittelzipfel: zu jeder Seite noch den Rand entlang ein sehr breiter und flacher, nach den Hinterwinkelı zu ein Querfältchen aufwärts schiebender Eindruck, und ein ähnlicher schmalerer aber tieferer auch üluer den Vorderecken, wodurch auch über dem abgesetzten Vorderrande ein denselben begleitender, nach der Mitte hin schwächerer, zugleich punktirter Querwulsi emporgehoben wird. Die Farbe rostbraun mit leicht stahlbläulichem Anfluge, Vorder- und Seitenrand in ziemlicher Breite verwaschen knochengelb. Die Punktirung deutlich, oben mehr zerstreut mit glänzendem Zwischengrunde, seitlich dichter zusammengedrängt, auch etwas gröber und stellenweise zu Runzeln verfliessend. Das Schildchen länger als breit, mit ausgebuchteten Seiten hinterwärts verschmälert viereckig, stark ansteigend und mit abgerundeten Hinterecken abgestutzt, fein und zerstreut punktirt, gleichfalls rostbraun. Die Deckschilde länglich viereckig, etwa um $1 / 4$ länger als breit, bei dem đo gleichbreit, dem 우 hinterwärts etwas rerbreitert, der Rücken sehr flach gewölbt, nur das Schildchen leicht erhöht und binter ilım auf der Naht etwas uiedergedrückt, auch hinter der scharf erhöhten Wurzelkante quer eingedrückt und dann leicht aufgetrieben, und die schwachen Schulterbeulen innerseits durch einen seichten Eindruck abgesetzt. Die Seitenlappen tief herabgezogen, und über ihnen die Deckschilde breit und flach zusammengedrückt. Die Punktstreifen aus vereinzelten groben Punkten gebildet, besonders bei dem $q$ sehr regelmässig, bei dem $\delta$ längs der Naht und in der Richtung der Schulterbeulen stellenweise durch überzählig eingemengte Punkte getrübt; auf dem letzten Drittel die Streifen feiner, und auf der Wölloung selbst wie al-XVI. 
geschliffen; die flachen Zwischenräume vorn schwach gerunzelt, hinterwärts spiegelglatt. Die rostrothe, auch hier leicht ins Stahlbläuliche spielende Grundfarbe beschränkt sich auf den Deckschilden auf einen schmalen, zugleich den breit umgeschlagenen Rand des Seitenlappens mit umfassenden Saum und eine breite von der Naht aus nach dem Rande buchtig verschmälerte Mittel-Querhinde; vor dieser ist die Wurzel breit weisslich gelb, und eben so hinter ihr die kleinere Hinterhälfte der Deckschilde von einer solchen weisslich gelben Querbinde eingenommen. Das Pygidium stumpf gekielt, äusserst fein punktirt, dümn greishaarig, bei dem $\delta$ weissgelb, dem $\&$ roströthlich. Die Unterseite dünn angedrückt silberharig, bei dem $\&$ einfarbig rostbraun mit verwaschen helleren Hinterrändern der Bauchringe; bei dem $\delta$ der ganze Rand des Hinterleibes trüb verwaschen lichter gefärbt. Die Beine heller gelb mit stark aufgetriebenen Vorderschenkeln und entsprechend gekrümmten Schienen; das breite Prosternum grob punktirt, längs der Mitte seicht niedergerlrückt, hinten halbkreisförmig zugerundet. Das letzte Segment des $\delta$ mit einem flachen rundlichen glänzenden Eindrucke, des $f$ mit der gewöhnlichen, hier ziemlich tiefen Grube.

Aus Venezuela (Mus. Baly. Felix. Clark. Berol. Vindob.). Bei dem von Moritz milgebrachten Stücke des Mus. Berol. ist Nova Valencia als Heimath genannt.

42. Sc. pratextatus m. Tief schwarzblau, Kopf und Unterseite dicht silberhaarig, Fühlerwurzeln, Beine und eine sehr veränderliche Fleckenzeichnung des grob zerstreut punktirten Halsschilds und der Deckschilde roth; die Punktstreifen fein, durch die dichte Punktirung der dicht gerunzelten matten Zwischenräume verdunkelt. L. $23 / 4-4^{\prime \prime \prime}$. Br. $11 / 2-2^{\prime \prime \prime}$.

Ein gleichfalls gr'osser und in der Zeichnung sehr verånderlicher Käfer, aber an den matten glanzlosen Deckschilden, wie an dem eigenthümlichen Aısschnitt der Halsschildseiten vor ihrer Mitte sehr leicht bemerklich. Iler Kopf gross, flach und dicht silberhaarig, die Stirnlinie nur bei dem $q$ deutlich, bei dem $\delta$ durch die stark genähırten Augen algeschwächt. Die Fühler dünn und schlank, etwa von halber Körperlïnge, das sechste frlied das lïngste, der Fortsatz des Endgliedes deutlich abgesetzt. Die sechs unteren Glieder hell röthlichgelb mit einer schwarzen Längslinie auf der Oberseite, die übrigen schwarz. Das Halsschild breit und flach, mit leicht quer anfgewölhter Mitte, die Seiten gerandet, in der 


\section{7}

Mitte in einem stark dreieckig heraustretenden Winkel erweitert und vor ihr tief bogig ausgeschnitten, so dass die Vorderecken scharf spitzwinklig heraustreten; auch die stumpfwinkligen Hinterecken scharf; der Hinterrand wellig ausgebuchtet, vor dem mit schwacher Rundung etwas aufgebogenen Mittelzipfel quer eingedrückt; von den gewöhnlichen, damit zusammeuhängenden Seitelleindrückell wenig bemerkbar. Die Punktirung grob, zerstreut, mit wenig glänzendem, seitlich durch eine feine runzlige Punktirung matterem Zwischengrunde. Die Farbe schwarz, schwach ins Purpurbläuliche fallend, bei dem đ’ gewöhnlich nur die breit dreieckigen Vorderwinkel bis zur Mitte des Seitenrandes, manchmal auch noch eine hinten abgekürzte Mittellinie roth; bei dem $q$ ist meist, wenn auch nicht immer, die rothe Zeichnung ausgedehnter, indem die rothen Vorderflecken sich als schmalerer Seitenrand bis zu den Hinterwinkeln ausdehnen, auch woh] hinter dem manchmal zart schwarz bleibenden Vorderrande zusammenhängen, und zuletzt von hier aus mit einem breiten Vorderzipfel in die Grundfärbung eindringen, so dass sich zuweilen das Roth bis zum Ausfüllen des halben Halsschilds ausdehnt. Das Schildchen mässig ansteigend, breit und fast halbkreisförmig, dicht greishaarig, mit kurzen aber deutlichem und glänzendem Hinterzipfel. Die Deckschilde breit und flach gewölbt, um etwa $1 / 4$ länger als vorn breit, und hinterwärts stark versclımälert, hinter der scharfen Vorderkante quer eingedrückt, die Schulterbeulen eckig heraustretend und auch die Seitenlappen kräftig ausgebildet. Die Punktstreifen sehr fein und etwas wellig, nur seitlich und hinter der Mitte deutlich, vorn durch eingemengte Punkte fast vollständig verdunkelt, die flachen Zwischenräume vorn durch narbig verfliessende, hinten durch dicht quergezogene Runzeln matt und glanzlos. Die Farbe schwarzblau, zuweilen selhst schwarz, andrerseits auch wohl trüb stahlblau, selbst mit grünlichem Kupferschimmer; ein breiter nur die glänzenden Schulterbeulen und einen feinen Saum freilassender Rand der Deckschilde roth; derselbe ist manchmal schmäler, überhaupt seitlich hinter der Mitte am schmalsten und hier zuweilen unterbrochen,

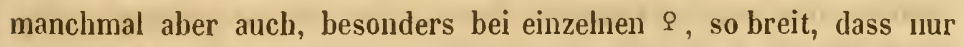
auf der Mitte der Deckschilde ein gemeinsamer herzförmiger Fleck übrig bleibt. Aendert jedoch ab:

$\beta$. Jener Rand an der Wurzel, den Seiten und der Spitze der Deckschilde derartig zerrissen, dass auf jeder Flügeldecke nur ein 
die Schulterbeule umziehender Mondfleck, ein von diesem getrenntes unscheinbares Randfleckchen über den Seitenlappen, und ein kleiner Sclırägfteck im hinteren Nahtwinkel übrig bleibt (sowohl $\delta$ als $q$ ), bei welcher Form die rothen Flecken zugleich merklich dunkler sind, als bei der Stammform; endlich

$\gamma$. bleibt an der Wurzel der Flügeldecken nur ein trübes Fleckchen schräg hinter der Schulterbeule und ein eben so unscheinbares verwaschenes Fleckchen vor der Spitze übrig, beide aber nur bei Anfeuchtung der Oberfläclıe wahrzunehmen, olıne welche die Deckschilde des Thiers ganz schwarz erscheinen (ein grosses $?$ mit rothen Vorderwinkeln des IIalsschilds im Mus. Deyrolle).

Das leicht ausgerandete Pygidium nebst der Unterseite schwarzblau, mit den Beinen dicht silberhaarig, letztere roth mit gebräunten Fussgliedern; bei den $\delta$ die Vorderschenkel schwarz, die übrigen auf der Aussenkante und der breiten Vorderfläche geschwärzt; bei dem $q$ nur die Vorderschenkel in der Mitte schwärzlich, dagegen die Schulterlılätter manchımal gebräunt. Die Vorderhrust breit und flach, hinten zugerundet. Das letztè Segment des $\delta$ leicht quer niedergedrückt, das $q$ mit einer grossen rundlichen Grube.

Gleichfalls aus Brasilien (Mus. Lacordaire. Dohrn. Baly. Deyrolle. Holm. Clark. Vindob. Berol.). Das bei einem Stücke im Mus. Clark angegebene Vorkommen in Columbien ist mir etwas zweifellaft.

43. Sc. ephippiatus m. Schwarzblau, Vorder- und Seitenrand des zerstreut punktirten Halsschilds roth, Fühlerwurzehı, Schulterblätter, Mittel- und Hinterbeine, wie die Deckschilde rothgelb mit schwarzen Schulterrändern und einer seitlich abgekürziten breiten Mittelquerbinde der letzteren; die Punktstreifen vorn ziemlich kräftig, etwas wellig gekrümmt, hinten fast erloschen. L. $2 \frac{2}{3}-3^{\prime \prime \prime}$; Br. $1 \frac{1}{4}-11 / 2 " \prime$.

Bei oberflächlicher Ansicht dem vorhergehenden und noch mehr dem Sc. flavo-fasciatus ähnlich, aber doch nach meinem Bedünken auch von dem letzteren genugsam unterschieden. Der Kiopf flach, der obere Theil der Stirn glatt, spiegelnd, nur an den Aıgenrändern mit einigen Punliten besetzt, der intere deutlich und je. näher dem Kopfschilde desto dichter punktirt; zwischen den Augenbuchten ein leichter Quereindruck, und üler diesem eine kurze, scharf eingeschnittene Mittellinie. Die Farhe schwarzblau, ins Stahlblaue fallend, die grossen oberwärts etwas zusammengeneigten, 
halblkreisförmig ausgebuchteten Augen schivarz. Die Fühler (des $₹$ ) etwa von halber Körperlänge, sehr dünn und schlank, das Wurzelglied eiförmig aufgetrieben, das zweite sehır kurz, knotig, die drei folgenden sehr dïnn, das dritte den beiden vorhergehenden zusaınmen gleich, das vierte und fünfte noch etwas verlängert, das sechste dem fünften gleich, die folgenden wieder allmählich abnehmend, vou der Spitze des seclssten ab schwach erweitert und zusammengedrïckt, mit kurzem, durch eine undeutliche Ausrandung abgesetztem Fortsatze des Endglieds. Die Farbe der untern bis zur Mitte des sechısten gelb, mit einen schwärzlichen Längsflecke auf der Oberseite des Wurzelgliedes, die oberen schwarz. Das Halsschild kurz und breit, mit fast grader, hinten etwas abwärts geneigter Firste, die fein gerandeten Seiten in der Mitte schwach bogig erweitert und ron da nach den scharf rechtwinkligen Vorderecken hin fast in geraden Linien zusanmmengeneigt, daher das Halsschild nach vorn ins Kegelförmige verschmälert; die Hinterecken abgestumpft und nur durch eine leichte Schwiele angedeutet; der Hinterrand leicht wellig geschweift, vor dem nur schwach heraustretenden Mittelzipfel niedergesenkt, die Oberfläche hinter dem Vorderrande und dann wieder jederseits vor dem Hinterrande quer eingedrückt, wodurch an dem letzteren sich ein deutliches Querfältchen emporschieht. Die Punktirung deutlich, oben zerstreut, seitlich besonders nach den Hinterecken zu etwas dichter gedrängt, mit glänzendem Zwischengrunde: die Farbe heller orler dunkler roth, eine auf dem Hinterrande ruhende, nach vorn die halhe Länge des Halsschilds einnehmende, aber Seitenrand und Hinterecken nicht erreichende, an ihrer Gränze allmählich sich in das Rothe verlaufende Querbinde glänzend schwarzblau. Das Schildchen stark ansteigend, fast gleichseitig dreieckig, hinten kurz abgestutzt, deutlich punktirt, tief schwarzblau. Die Deckschilde breit und flach gewölbt, etwa $11 \mathrm{~m} 1 / 4$ länger als breit, fast rechteckig und hinten liurz zugerundet, vorn hinter der scharfen Wurzelkante bis $\mathrm{zu}$ den breit heraustretenden Schulterbenlen tief eingedrückt, mit rundlichen lang herabgezogenen Seitenlappen und hinten steil abfallender Wölbung; die Naht hinter dem Schildchen und dann wieder auf der Mitte des Rückens breit quer eingedrückt. Die Punktstreifen fein, rom letzten Drittel ab fast verschwindend und auf der spiegelglatten Wölhung wie abgeschliffen, besonders vorn etwas wellig gekrümmt und durch überzählige Punkte, hier und da auch 
durch Verdoppelung getrübt, der erweiterte Zwischenraum üher dem Seitenlappen mit gröberen Punkten ziemlich dicht besetzt. Die flachen Zwischenräume mit mässigem, hinterwärts zunehmendem Glauze. Die Farbe ziegelroth, manchmal in ein fahles Gelb, hesonders gegen den Rand hin, ïbergehend, die Schulterbeulen und im Anschlusse an diese der Saum des Seitenlappens schwarz; ausserdem liegt auf der Mitte der Deckschilde eine gemeinsame, hinten fast halbkreisförmig abgerundete stahlblaue Querbinde, die fast die mittlere Hälfte derselben einnimnit, und jederseits bis über den siebenten Streifen hinausreicht. Aendert al)

$\beta$. die Querbinde der Deckschilde so weit ausgedelınt, dass sie Aussenrand und Spitze erreicht, und längs jenem vorn mit dem Schulterflecke zusammenhängt. Die Deckschilde erscheinen danı schwarzhlaı mit einer abgekürzten rothen Wurzelbinde zwischeı den Schulterbeulen. Diese Form, bei der zugleich der rothe Seitenund Vorderrand des Halsschilds sich mit verwaschener Begränzung ver'schınälert, zeigt beim ersten Anblick etwas Fremdartiges, aber keine weiteren irgend wesentlichen Abweichungen (ein $q$ im Mus. Clark).

Das stumpfgekielte Pygidium jederseits am Unterrande etwas eingedrückt, mit der Unterseite fein punktirt, angedrückt greishaarig und schwarzblau; die Schulterblätter heller oder dunkler geröthet, die Mitte der Hinterbrust kahl und glänzend, Die Vorderschenkel stark keulig aufgetrieben schwarzblau, die gekrümmten Schiene॥ gebräunt, Mittel- und Hinterbeine hell röthlichgelb mit bräunlichen Fussgliedern. Das letzte Segment des $q$ mit einer tiefen halbkugeligen Grube; das $\delta$ unbekannt.

Ebenfalls aus Brasilien. (Mus. Hamburg. Haag. Deyrolle. Clark.)

44. Sc. rufomarginatus $m$. Metallisch schwarzgrün oder schwarzblau, unten dicht greishaarig, mit rothen Fühlerwurzeln, Vorder- und Seitenrand des zerstrent punktirten Halsschilds und der Neckschilde rothbunt; die Punktstreifen feil, vorn gestört und hinten verschwindend, mit flachen, fein genarbten, wenig glänzenden Zwischenräumen. L. $2 \frac{1}{3}-3 \frac{1}{3}{ }^{\prime \prime \prime}$; Br. $1 \frac{1}{3}-2^{\prime \prime \prime}$.

Den beiden vorhergehenden selir nahe verwand, aber von Sc. ephippialus ausser dem lïrzeren und gedrungeneren Körper sogleich an den schwarzen Beinen, von denı durch die Wandelbarkeit der Zeichnung noch ähnlicheren Sc. praetextatus durch den 
abweichenden Bau des Halsschilds und die Sculptur der Deckschilde zu unterscheiden. Der liopf flach, die ziemlich tief ausgebuchteten Augen bei heiden Geschlechtern weit getrennt, die Stirnlinie wenig bemerkbar, und zwischen den Augenbuchteı ein breiter und seichter Quereindruck. Auch der untere Theil des liopfschildes mondförmig niedergedrückt, so dass sich zwischen den Fühlerwurzeln ein deutlicher Querwulst emporhebt. Die Punktirung fein aber dicht, die Farhe schwarz mit mässigem Glanze, zuweilen ins Bläıliche oder Grüuliche fallend, die Ränder der Oherlippe pechbraun. Die Fühler kaum von halber Körperlänge, vom sechsten Gliede ab) leicht zusammengedrückt und verbreitert, mit kurz dreieckigem Fortsatze des Endglieds. Die sechs unteren durchscheinend röthlich gelb mit einer schwärzlichen Längslinie auf der Ober'seite, welche bei dem Wurzelgliede den grösseren Theil einuimm, die oberen sclıwarz: bei den Stüeken mit piufarbigem Ilalsschilde sind die unteren Fühlerglieder gewölnlich tiefer gebräunt, und zuveilen ist diese bräunliche Färbung nur auf deren Unterseite sichtbar. Das Halsschild sehr kurz und lireit, mehr als doppelt breiter wie lang, der Rïcken hinten abgeflacht, voru mehr gewölbt unıl dadurch verschmälert, an dem Hinterrande niedergedrückt, und daselbst jederseits mit einem deutlichen, längs dom Rande einen dreieckigen Querwulst emporhebenden Eindrucke, welcher sich schräg nach vorn zieht und vor seinem Ende ron einen zweiten mehr rundlichen und uher der Mitte des Seitenrandes stehenden Eindrucke begleitet wird. Unterhalb dieses letzteren ist der Seitenrand hogig erweitert, von da nach den spitzigen Vorderecken hin leicht ansgeschweift; die Hinterecken stumpf, der Mittelzipfel nur sehwach aufwärts gebogen, die l'unktirung deutlich aber sehr zerstreut, die Farbe glänzend schwarz, meist mit einem stahthlanen, erzgrünen oder kupferfarbigen, auch wohl buntkupferfarhigem Anfluge; cin sich nach rom verbreiternder Seitensaum und ein etwas schmalerer Vordersaum gewöhnlich hochroth; seltener und zwar ohne Zusammenhang mit der Färbung der Deckschilde ist der hintere dunkle Theil des Halsschilds am Vorderrande, hesonder's in dessen Nitte zerrissen, oder gar in zwei vereinzelte Flecke aufgelöst, anderseits aber auch wohl soweit ausgedehnt, dass der rothe Rand sieh in vereinzelte Fleeke auflöset oder zuletzt ganz verschıvindet, wo daun die ganze Oberflïche einfarbig selıwarzblau oder schwarzgrün erscheint. Das Schildchen elwas ansteigend, kurz und breit, hinter- 
wärts mit abgerundeten Hinterecken und undeutlichem Hinterzipfel verschmälert, fein aber dicht punktirt, matt schwarz. Die Deckschilde lănglich viereckig, hinter den Schultern über den kräftigen Seitenlappen etwas zusammengedrückt, kaum $1 / 5$ länger als breit, hinter den schwach erhöhten Vorderkanten nur seicht quer niedergedrückt, die Schulterbeulen höckerig heraustretend; die Naht hinter dem Schildchen stärker und in der Mitte nochmals schwächer quer eingedıückt. Die Punktstreifen fein und bei den $q$ noch schwïcher, auf der Vorderhälfte durch überzählige Punkte getrübt und stellenweise verdoppelt, die Zwischenräume flach, fein genarht und wenig glänzend. Bei einzelnen Stücken aus Brasilien, die auch eine etwas stärkere. Punktirung des Halsscliilds zeigen, sind die Punktstreifen vorn mehr gestōrt und die Zwischenräume durch dichte und feine Runzeln matt: bei aller weitern Uebereinstimmung mit der Normalform kanı ich darin jedoch nur eine individuelle Abweichung erkennen.

Die Farbe auch hier schwarz, melır oder weniger ins Stalılblaue, Erzgrüne oder Kupferviolette fallend, aber die Wurzel und der Rand der Deckschilde nicht weniger wie der Rand des Halsschilds in so verschiedenen Abänderungen rothbunt, dass die Art hiernach als die verănderlichste der ganzen Gattung angesehen werden muss, und man oft kaum denselben Käfer vor sich zu sehen glaubt. Diese verschiedenen Abänderungen lassen sich jedoch im Wesentlichen unter folgende Hauptformen zusammenfassen:

A. Die Deckschilde ohne einen gemeinsamen Fleck hinter dem Schildchen.

. Die Deckschilde einfarbig, wo dann nur der ungeschlagene Rand des Seitenlappens roth bleibt, das Halsschild vorn und an den Seiten gerōthet. \&

$\beta$. Ein länglicher Schulterfleck über dem Seitenlappen, der sich allmälılich zu einem breiten Wurzelfleck ausdehnt, oder auch noch ein rundlicher Querfleck von der Spitze der Flügeldecken roth, gewöhnlich in ziemlich dunkler Tinte; das Halsschild einfarbig oder vorn und seitlich geröthet. ?

$\%$ Ein zusammenhängender Vorderrand der Jeckschilde, durch das Schildchen unterbrochen oder hinter ilım durch einen zarten Farlen zusammenhäugend, roth; das Halsschild einfarbì. 웅.

$\delta$. Die Fleckenzeichnung wie bei $\beta$. aber sich weiter ausdehnend, und der Schulter - und Hinterfleck jeder Flügeldecke durch 
einen feinen rothen Randsaum verbunden; das Halsschild einfarbig. +

$\varepsilon$. Ein zusammenhāngender, hinterwärts meist etwas verhreiterter Aussenrand der Deckschilde roth, gewöhnlich etwas heller als bei Var. $\alpha$. Das Halsschild bald eiufarbig ( $q$ ), bald mit breiten, rothen Seitenrande $(q)$, bald auch noch mit rothem Vorderrande ( $q$, die zierliclıste aller Formen), bei einem Stücke auch noch ein verwaschenes Pünktchen vor dem Schildchen am Hinterrande geröthet. ( $q$ )

B. Die Deckschilde mit einem gemeinsamen, das Schildchen umziehenden, hinterwärts mehr oder weniger gestreckten herzförmigen Wurzelflecke, und zwar

ఢ. die Flügeldecken mit einem länglichen Schulterflecke unterhalh der Schulterbeule über dem Seitenlapyen, das Halsschild einfarbig. (.?.)

$\eta$. Dieser Vorderfleck als Vorderende eines Saums bis über die Mitte des Seitenrandes hinaus gestreckt, und von der Spitze ein rundlicher Querfleck; die Seiten des Halsschilds roth. q

9. Ein nach der Spitze hin stark verbreiterter Aussenrand der Deckschilde roth. Das Halsschild bald einfarbig ( $\delta$ und $q$ ), bald mit rothem Seiteurande ( $\delta$ und $q$ ), einem rothen Querfleck am Vorderrande ( $q$ ), oder auch ganz rothem Vorderrande. ( $q$ )

ı. Ein breiter', den Schildchenfleck einschliessender Vorderrand der Deckschilde und ein Schrägfleck von der Spitze der Flügeldecken roth. ( $\delta$ und $q$.)

\% Die Deckschilde mit einem schmaleren oder breiteren, sie ganz umgebenden rothen Rande, sodass sie roth mit einem grossen gemeinsamen schildförmigeı schwarzblauen oder schwarzgrünen Flecke erschieinen. Das Halsschild eirfarbig $(q)$, oder mit rothem, hinterwärts allmählich verschmälerten Seitenrande $(q)$, oder zugleich der ganze Vorder- und Seitenrand roth (ठ);

und hiermit ist die Reihe der Varietăten wahrscheinlich noch keineswegs erschöpft. Das leicht gekielte Pygidium mit der Unterseite fein runzlig punktirt, dicht silberhaarig schwarz; auch die Beine schwarz mit māssig verdeckten Vorderschenkeln und entsprechend gekrümmten Schienen. Das Prosternum sehr breit, die Mitte entlang sanft niedergedrückt, hinten kurz und stumpf zugerundet. Das letzte Segment des ơ einfach, des $q$ mit einel grossen rundlichen Grube. 
In dem ganzen Raume zwischen dem Amazonenstrome und dem La Plata verbreitet und anscheinend nicht selten, daher fast in allen von mir verglichenen Sammlumgen vorhanden. (Mus. Petrop. Halens. Holm. Berol. v. Heyden. Vindob. v. Bruck. Saunders. Haag. Baly. Clark. Schaum.). Die Stücke des Mus. v. Heyden sind in Paraguay von Vogt, die des Mus. Baly zum Theil in der Serra Amazones gesammelt worden; die des Mus. Berol. (von Virmond, Cornaz, Sello, b. Olfers herrūhrend), stammen wohl meist ans del Ungegend von Rio de J.; bei den Exemplaren im Mus, v. Bruck und Clark ist Minas, bei einem Stïcke des letzteren selbst Bolivia als Heimath angegeben.

45. Sc. commutatus m. Oben mit den Beinen stahlblau, der Rand des fein und zerstreut punktirten Halsschilds, Wurzel und Spitze der Deckschilde nebst den Schenkelwurzeln roth, Pygidium und Unterseite trübroth, dicht greishaarig; die Punktstreifen fein, vor'ı verdoppelt und hinterwärts erloschen, mit hinten flachen, glänzenden Zwischenrämmen. L. $2 \frac{1}{4}{ }^{\prime \prime \prime}$; Br. $1 \frac{1}{6}{ }^{\prime \prime \prime}$.

Dem Sc. praetextatus und rufomarginatus nicht unähnlich, aber lisines und zierlicher, und auch ausserdem von dem ersteren sogleich an den gerundeten Seiten des Halsschilds, von dem letzteren auch alggesehen von dem schlankeren Körper an der abweichenden Färbung der Unterseite leicht zı unterscheiden. Der Kopf flach, metallisch schwarzblau, der ohere Theil der Stirn bei dem allein vorliegenden $\delta$ durch die grossen, einander berührenden Augen eingenonmen, sodass nur ein schmaler, rerkehrtdreieckiger Nackenzipfel übrig bleibt, der untere grob runzlig punktirt mit tief eingezogenem Kopfschilde. Mie Fühler (des ठ) etwa von halber Körperlänge, sehr dümı und zart, das Wurzelglied blasig aufgetrieben, etwa doppelt länger als breit, das zweite kurz eiförmig, die drei folgenden sehr schlank und fast stielrund, das dritte. doppelt-, das vierte dreimat, und das fünfte reichlich viermal länger als das zweite, die oberen je dem fünften gleich, dahri zusamme'ngedrückt und oberseits wrnig erweitert, das Endglied linealisch mit kurz kegelförmigem Fortsatze. Die Farbe der fünf unternn schwarzblau mit röthlicher Unterseite der drei ersten, dir oberen schwarz mit anged'ücliter greiser Behbiarung. Mas Halsschild breit und flach walzenförmig, doppelt breiter als lang, ïlur den scharf spitzwinkligen Vorderecken zusammengedlückt und dadurch verschmälert, die Seiten gerandet, in der Nitte bogig erweitert und ror ibr 
Jeicht ausgeschweift, die Hinterecken stumpf zugerundet, der fast gerade Hinterrand nur jederseits des breit abgerundeten Mittelzipfels schwach ausgebuchtet. Zu jerler Seite längs dem Ifinterrande ein leines, kielartig erhöhtes Querfälchen, und vor diesem ein breiter, ziemlich tiefer, über der Hitte des Seitenrandes abbrechender Schrägeindruck. I) le l'unktirung zerstreut aher deutlich und nur auf dem vorderen Theile des Jittelfeldes fast erloseben, mit spiegelglatten Zwischengrunde; die Farbe ein helles Stahlhlau, ein schmaler Vorder- und ein breiterer, zuntichst an und in den Vorderwinkeln noch mehr verbreiterter Seitenrand verwaschen roth. Das Schiddehen stark ansteigend, nicht so lang wie vorn breit, hinterwärts etwas verschmnälert, mil ahgeruudeten Ecken und deutlichem Hinterzipfel alıgestutzt, die Farbe gleichfalls stahılblau mit dichter feiner Punktirung und Spuren einer abgreriebenen dünnen, greisen Behaarung. bie Deckschilde breit und hach gewölbt, wenig länger als vorn breit und hinterwärts etwas verschmälert, hinter der scharfen Vorderkante tief quer eingedrückt, mit flach gewölhten Schulterbeulen und wenig entwickelten Seitenlappen. Der Rückeu hinter denı Schildchen auf der Nalıt rundlich eingedrückt, und auf der Hitte noch von einem breiten flachen, nach den Seitenlajpen hiuabziplıenden Quereindruch durchsetzt. Die Punktstreifen fein, vorn unregelmässig verdoppelt, von der llitte ah einfach, aber feiner und alhnählich verschwindend; die gläızenden Zwischenräume hinten breit und flach, vorn schmaler und leicht rippenförnig erhöht. Die Farhe stahlblau mit violettem Schimmer, eine jeduch die Schulterbeulen freilassende Querbinde längs der Wurzel, und ein hreiter Querfleck von der Spitze jeder Flügeldecke roth, letzterer durch einen zarten Randsaum Init der vorderen Binde zusammenhäugend. Pygidium und Unterseite trüłroth, mit dichter anliegender silbergrauer Behaarung, und die Beinc silherhaarig, stahlblau, die Schenkelwurzelı trüb gerötıet, auch die Schienen mehr oder weniger bräunlich durchscheinend. Das I'rosternum breit, längs tler Mitte flach wulstig erhöhı, gleichfalls fein greishaarig. Ias letzte Segment des ठ breit quer niedergedrückt; das \& unlekannt.

Brasilien (rou Ega am oberen Amazonenstrom: Mus. Baly).

46. Sc. cupripennis m. Trübroth, die Mitte des fein punktirten Halsschilds und die Vorderschenkel verwaschen gehräunt, Kopf und Flügeldecken kıpferhraun mit rothem Spitzenfleck der 
letzteren; die Punktstreifen vorn grob und theilweise verdoppelt, hinten schwächer, mit flach gewölbten, glänzenden Zwischenräumen. L. $3^{\prime \prime \prime} ; \mathrm{Br} .1 \frac{1}{2}{ }^{\prime \prime \prime}$.

Diese Art verbindet den breiten, gedrungenen Körperbau des $S c$. rufomarginatus mit der gerötheten Unterseite des vorhergehenden, und den kupferfarbigen Deckschilden des Sc. boops, ist aber von allen diesen Arten an der Farbenvertheilung des Halsschilds, und von den beiden vorhergehenden ausserdem an den vorn viel gröberen Punktstreifen leicht zu unterscheiden. Der Kopf flach, die Augen (bei dem $q$ ) durclı einen ınässigen Zwischenraum getrennt, und auf dessen unterem Ende ein schwacher Längseindruck, die Stirn oben zerstreut - unten dichter und stärker punktirt, seitlich und unten mit greisen Härchen besetzt. Die Farbe metallisch schwarzbraun mit starkem Kupferglanze, die Mundtheile schwärzlich mit gebräunter Oherlippe. Die Fühler kurz und dünn, kaum 1/3 der Körperlänge erreichend; das zweite Glied schmal eiförmig, die folgenden ziemlich gleichbreit, und die oberen nur wenig zusanmengedrïckt, das dritte doppelt- und das vierte dreimal länger als das ziveite, die folgenden je dem vierten gleich. Die unteren bis zur Mitte les füıften röthlich, die oberen geschwärzt. Das Halsschild breit und flach grewölbt, doppelt breiter als lang, vorn über den scharf' zugespitzten -Vorderecken zusammengedrückt und dadurch yerengt; die Seiten in der Mitte in breiten Bogen erweitert, ror ihr leicht ausgeschweift, die Hinterecken stumpf abgerundet und nur mit einer kleinen Schwiele bezeichnet, der Hinterrand jederseits des kurzen Mittelzipfels leicht ausgebuchtet. Vor dem Rande zu jeder Seite eine erhöhte Querfalte, und vor dieser wieder eiı kurzer, zienslich tiefer Quereindruck, und ein kürzerer und schwächerer weiter nach vorn über der Erweitermy der Seiten. Die Punktirung oben sehr f'ein und zerstreut, seitwärts ein wenig dichter und deutliclser, die lärbung ein trülses Roth, die Mitte breit und verwachsen dunklel gebrïunt mit schwach kupfrigem Glanze. Das Schildehen mässig ansteigend, merklich länger als vorn breit, binten mit abgerundeten Ecken algestutzt, dicht und ziemlich fein punlitirt, glänzend schwarzbłau. Hie Derlischilde Ireit und flach gewölht, kaum 1/6 läıger als loreit, hinterwärts etwas verschmälert, hinter der scharfen Vorderkante quer eingedrüclit, die Schulterbeulen länglich, die Seitenlappen tief herabıezogen, und über ilınen die Deckschilde stark zusammengedrückt, welche Ein- 
schnürung sich oberwärts etıas verl,reiternd und verflachend über den ganzen Rücken hinwegzieht; vor ihr hinter dem Schildchen auf der Naht nochmals ein schwächerer, mehr rundlicher Eindruck. Die Punktstreifen vorn kräftig, die oberen zwischen Schildchen und Schulterbeule unregelmässig verdoppelt und dadurch die schmalen Zivischenräume leistenförmnig emporgehoben; von der Mitte ab werden auch diese Streifen schwächer, regelmässiger, die sich vertlachenden Zwischenräume breiter, und stärker glänzend. Die Farbe ein schönes metallischies Kupferhraun, wie hei unserer Chrysomela cuprea; im hinteren Nahtwinkel auf jeder Flügeldecke eiı verwaschen begränzter rundlicher hellrother Fleck. Das Pygidium mit Unterseite und Beinen hellziegelroth, mit kurzer dicht angedrückter gelbgreiser Behaarung; Schenkelspitzen und Fussgliedler schmutzig gebräunt, die stark aufgetriebenen Vorderschenkel dunkler geschıärzt, mit röthlicher Wurzel. Das Prosternum dicht behaart, flach, hinten quer niedergedrückt und breit zugerundet; das detzte Segment des + mit dem gewöhnlichen Grübchen, das $\delta$ unbekannt.

Aus Brasilien. (Von St. Arem: Mus. Baly.)

Bei einem um die Hälfte kleineren, gleichfalls \& Stücke im Mus. Clark, bei welchem Cayenne als Heimath genannt ist, ist der dunkle Querschatten des Halsschilds schıvächer und mehr verwaschen, der Spitzenfleck der Flügeldecken grösser und schlechter begränzt; auch die Wurzel.derselben scheint bräunlich durch, und der Hinterleib fällt noch mehr ins hell Rothgelbe. Weitere Abweichungen finde ich jedoch nicht.

47. Sc. supercilio sus m. Schwarzblau, unten dicht silberhaarig, Fühlerwurzeln, Wurzel- und Spitzenfleck der Flügeldecken und die Beine bis auf die Vorder'schenkel, oft auch die Seiten des derb punktirten, seitlich dünn behaarten Halsschildes roth, dic Punktstreifen grob, vorn etwas gestört, mit flach gewölbten, fein gerunzelten Zwischenräumen. L. $23 / 4-3 \frac{1}{2}{ }^{\prime \prime \prime}$; Br. 1 $1 / 2-2^{\prime \prime \prime}$.

Durch die grobe dicht gerlrängte P'unktirung und das seitlich bei den nicht abgeriehencn Stücken dïnn greishaarige Halsschild von allen vorhergehenden Arten verschieden. Der Kopf gross und breit, die Stirn bei dem $\delta$ fast ganz durch die grossen, nur durch einen haarbreiten Zwischenraum getrennten Augen eingenommen, bei dem $\&$ breiter, fein aber dicht punktirt, mit einer jederseits abgekürzten Längslinie. Die Farbe schwarz mit stahlbläulichem 
Schimmer, nur Nacken und Kopfschild mit einigem Glanze, bei dem $\&$ nur dünn greishaarig, bei dem $\delta$ zwischen Augen und Kopfschild mit längeren glänzenden Silberhärchen dicht besetzt, welche zugleich die inneren und unteren Augenränder saumartig umziehen. Die Oberlippe schmutzig gelbbraun mit einem trüben, schwärzlichen Sclıatten in ihrer Mitte, die Mundtheile schwarz. Die liülıler des $q$ von halber Körperlänge, ziemlich dünn, das zweite Glied eiförmig, das dritte doppelt-, das vierte dreimal länger als das zweite und das fünfte noch etwas verlängert, die oberen sich wieder allmählich verkürzend, kaum zusammengedrückt. Die Farbe der fünf unteren röthlichbraun mit geschwärzter Oberseite des ersten, die oberen schwarz. An dem einzigen vorliegenden $\delta$ sind die Fülıler nur unvollständig erlıalten, aber anscheinend von deneı des $f$ nur durclı eine etwas grössere Länge und dic hellere, ins Gelbliche fallende Färbung der unteren Glieder verschieden. Das Halsşchild doppelt länger als breit, flach gewölbt, hinten quer niedergedrückt und das Ende dieses Eindrucks seitlich schräg vorwärts gebogen, die Seiten gerandet, in der Mitte rundlich erweitert, vor ihr zu den pfriemlich vorgezogenen Vorderecken lin kurz aber ziemlich tief ausgeschweift, über letzteren etwas zusammengedrückt und dadurch verschmälert; die Hinterechen stumpfwinklig, der Hinterrand jederseits ausgebuchtet und von einem schmal dreieckigen, nach Aussen verbreiterten Querwulste begleitet, mit breitem aber nur schwach vorgezogenem Mittelzipfel. Die Oberfläche bei dem $\delta$ sehr dicht und grob punktirt, daher stellenweise gerunzelt und nur schwach glänzend, nur dicht vor dem Mittelzipfel der Glanz durch die mehr vereinzelten Punkte etwas stärker: bei den $q$ sind dieselben auf dem ganzen Mittelfelde feiner und melır zerstreut, daher erst an den Seiten sich zu Runzeln zusammendrängend. Die Farbe sclıwarz, mehr oder weniger deutlich ins Stahlblaue spielend, die Seiten und im Anschlusse an diese die breiten Vorderecken trüb geröthet; bei einem der vorliegenden $q$ fliesst diese Färbung soweit über, dass auch der Vorderrand sich röthet und sich dabei hinter der Mitte der Stirn zu einem halbeiförmigen

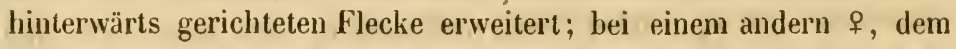
zugleich der' Schulterfleck mangelt, ist der rothe Seitenrand soweit abgeschwächt und unterbrochen, dass nur ein vereinzelter grôsserer Punkt in dem Vorderwinkel und ein kleinerer an der Hintérecke übrig geblieben ist. Endlich bei einem dritten und zwar mit sehr 
ausgedehntem Schulterflecke, ist nur noch von den Hinterecken ein trüber, mit Mühe wahrnehmbarer Querwisch vorhanden. Bei nicht abgeriebenen Stücken sind die äussersten Seiten des Halsschilds kurz und dünn greisbehaart. Das Schildchen etwa so lang wie vorn breit, hinterwärts verschmälert, mit abgerundeten Hinterecken und deutlichem Hinterzipfel abgestutzt, fein punktirt und dicht greishaarig, schwarz. Die Deckschilde länglich viereckig und fast gleichbreit, flach gewölbt und hinten kurz zugerundet, linter der erhöhten, an die breit höckerigen Scliulterbeulen angeschlossenen Vorderkante quer eingedrückt, die Seitenlappen tief herabgegezogen, der Rücken hinter dem Schildchen und dann wieder hinter der Mitte mit den gewöhnlichen Eindrücken. Die Oberfläche auf der Vorderhälfte dicht und grob punktirt, so dass die durch ïberzählige Punkte getrübten Punktstreifen doch stellenweise kenntlich sind, und deren zwei ausserhalb der Schulterbeule von Anfang an kenntlich hervortreten; hinter der Mitte entwickeln sich aus dem Gedränge deutlichere Streifen mit ziemlich regelmässigen bis zur Wülbung fortziehenden, flach gewölbten Zwischenräumen, welche fein gerunzelt sind, und nur bei dem ơ einigen Glanz zeigen, der aber bei dem durch jene narbig verfliessenden Runzeln matteren $q$ weniger hervortritt. Die Farbe schıvarz, mit stärkerem oder sclıwächerem stahlblauem Anfluge, ein die Schulterbeule umziehender, manchmal sich die Naht und den Seitenrand entlang erweiternder, auch wohl den ganzen Seitenlappen einschliessender und sich hier dem Spitzenfleck entgegenstreckender, bei einem $q$ aber auch ganz fehlender Schulterfleck, und ein eirunder, von dem Nahtwinkel aus schräg nach vorn und aussen gerichteter Spitzenfleck blutroth. Das Pygidium mit der Unterseite fein runzlig punktirt, dicht angedrückt silberhaarig, schwarz, auch wohl trüb bläulich angeflogen: der Hintersaum der Vorderbrust, die Mittelbrust und die Mitte der letzten Bauchringe, bei dem $\delta$ auch die Aüssenenden des Prosternums trüb ziegelroth. Hüften und Beine heller ziegelroth, die stark verdickten Vorderschenkel schwarz, die Mittel- und Hinterschenkel mit einem verwaschenen dunkleren Schatten, auch die Fussglieder auf der Oberseite geschwärzt: bei dem erwälınten $\&$ olıne Schulterfleck die Aussenfläche aller Schenkel und die Aussenkante der Schienen schwarz. Das Prosternum seicht muldenförmig eingedrückt, dünn greishaarig, hinten breit abgerundet. Das letzte Segment des $\delta$ mit einem seichten glänzen- 
den rundlichen Quereindruck, das $q$ mit einer nicht grossen aber tiefen halbkugeligen Grube.

Ebenfalls aus Brasilien. (Mus. Petrop. Saunders. Baly, das Exemplar in der letztgenannten Sammlung vom Amazonenstrome stammend.)

48. Sc. argentatus Er. Scliwarzblau, der Kopf, die breiten Seiten des vorn kaum punktirten Halsschilds und die Unterseite dicht silberhaarig, eine breite Vorderbinde und ein Spitzenfleck der Flügeldecken dunkelroh, die Fühlerwurzelı und Beine bis auf die Vorderschenkel rothgelb; die Punktstreifen grob, voru durch grobe und dichte überzählige I'unkte getrübt, mit flachen glänzenden Zwischenräumen. L. $23 / 4 "$; Br. $1 \frac{1}{2}{ }^{\prime \prime \prime}$.

Pachybrachis argentalus Erichs. in Schomburgh Reisen in Brit. Guiana. III. S. 577 !

Dem vorhergehenden sehr ähnlich, aber die Beharung des Halsschilds viel weiter ausgedehnt und zugleich viel dichter, den Zwischengrund vollständig deckend, die Punktirung desselben feiner, selbst nahe an dem Mittelaipfel, wo sich bei dem vorhergehenden stets eine gröbere Punktirung rorfindet; die Punkte der Deckschilde nicht ganz so grob, aber vorn viel dichter zusammengedrängt, daher die Streifenbildung daselbst unklarer und die Zwischenräume nur flach; endlich auch die rothe Vorderbinde der Flügeldeclien abweichend gestellt, iudem dieselbe sich zwar innerseits bis an das Schildchen ausdehnt, nach aussen aber die Schulterbeule frei lïsst, und obwohl die letztere umziehend doch nicht über den zehnten P'unktstreifen hinausreicht, sodass Schulterrand und Seitenlappen ihre schwarze Färbung behalten. Der Kopf tlach mit kaum angedeuteter Stirnlinie, schwarzblau, dicht angedrücht silberhaarig, das breithalbmondförmige liopfschild unten eingezogen, oben durch eine feine aher dentliche Bogenlinie abgegränzt, die grossen (bei dem $q$ ) weitgetremnten, breit und tief ausgehuchteten Augen greis; die glänzente Oberlippe schwař mit fein geröthetem Raride. Die Fühler dünn und schlank, nicht von halber liörperlänge, das dritte bis fünfte Glied allmählich an Länge zunehmend und letzteres das längste von allen, das sechste wieder den vierten gleich, und die oberen bis zum zehnten in sehr allmählichem Alonehmen sich verkürzend, sodass das zehnte fast noch den dritten gleichkommt, mit sehr kurz dreieckigem Fortsatze des wieder etwas längeren Endgliedes; rom sechsten ab alle schwach erweitert und 
zusammengedrückt. Die sechs untereı durchscheinend röthlichgelt, die Oherseite der heiden unteren hreit verwaschen geschwärzt, hei den folgenden mit einem bräunlichen Lüngswische bezeichnet; die fünl' oberen schwarz. Das Halsschild kurz und sehr hreeit, mit alogeflachtem Nittelfelde und kaum aufgelıogener Läıgsfirste, ülser den lang vorgezogenen, spitzwinkligen Vorderecken zusanmengedrückt und dadurch verschmälert, die Seiten gerandet, hinter der Nitte bogig erweitert, vor ihr bis zu den Vorderecken tief ausgebuchtet, die stumpfwinkligen Ilinterecken kurz aufgebogen, der fast gerade Ilinter'rand ıur jederseits des kurzen Nittelzipfels leicht ausgeschweift, und vor ilım seitlich je ein leichter Schı̈ägeindruck. Die Olierflache ülıeraus fein und nur vor dem Mittelzipfel etwas deutlicher punktirt, unit glänzendem, wie abgerieben erscheinenden Mittelfelde, die Seiten mit einer sich besonters an Vorderrande breit nach der Mitte hin ausdehnenden dicht angedrückten und je weiter seitlich, desto vollständiger den Grund deckenden sillsergreisen Behaarung besctat, unter der ein breiter Rand rerwaschen röthlich durchschimmert. Ilas Schildchen ziemlich flach niederliegend, nicht so laug als rorn breit, hinterwärts verschnälert, mit kinum abgerundeten Ecken und schwachem Itinterziplel grade abgestutzt, die längs der Mitte leicht erhölıte Oberfläclıe dichıt und leiu punktirt, angedıückt greislıarig, schwarzblau. Die Deckschilde wenig länger als vorn breit, linterwärts etwas verschmälert und danı lreit zugerundet, der Rücken hinter der scharfen, nicht eben sehı erhöhten Vorderkante kauın quer eingedrückt, auch die Nahı hinter dem Schildchen nur leicht niedergedrückt, die halls eilörmigen Schulterbeulen innerseits durch einen dreieckigen Eindruck abgesetzt, die Seitenlappen lang herabgezogen und über ihnen das Vorderende des neunten Zwischemrauns flach längswulstig aufgetricben. Die Punktstreifen grob, die oberen ant den vorderen Viertel und längs der Naht noch bis über die Mitte linaus durch eben so grobe dicht eingemengte Punkte mehr oder weniger gestört, erst auf der lıinteren Hällte regelmässiger, ıit flachen gläızenden Zwischenräumen. Die Farlse anch hier ein dunkohmetallisches Sclıwarzblau, eine breite, nıelı als das vordere Urittel wegnehmende, vorn nur die Schulterbeule und in Anschlusse àn diese den Schulterrand und den Kiel des Seitenlapprens mit dessen umgeschlagenem Rande freilassende, am Ilinterrande in einen flichen Bogen erweiterte Wurzelbinde, und ein breiter, aber Naht und XVI. 
Aussenrand nicht berührender Spitzenfleck blutroth. Das fein gekielte Pygidium mit Unterseite und Beinen gleichfalls dicht silberlıarig, schwarzblau, ersteres mit den Hinterrändern der Hinterleibsringe trüb röthlich durchschimmernd; die Beine röthlichgelb, nur die stark aufgetriebenen Vorderschenkel schwarzblau, und die beiden unteren Fussglieder mit den unteren Rändern der oberen schwärzlich angelaufen. Das Prostermum hinten breit zugerundet, flach, mit einer feinen, nicht über die Mitte hinausreichenden Längslinie. Das letzte Segment des 우 mit dem gewöhnlichen Grübchen, das $\delta$ unbekannt.

Aus Guyana (Schomburgk im Mus. Berol.)

49. Sc. triangularis in. Metallisch schwarzblau mit dicht silberhaariger Unterseite, die Fühlerwurzeln, die Beine bis auf die Vortlerschenkel und die Deckschilde roth, ler Saum und ein verkehrt dreieckiger Hinterfleck der letzteren schwarzblau; das seitlich weisshehaarte Halsschild mässig punktirt, die Punktstreifen grob, vorn durclı üherzählige Punkte gestört, mit glänzenden hinten flachen Zivischenräumen. L. $21 / 2-3 \frac{1}{4}{ }^{\prime \prime \prime} ; \mathrm{Br}$. $1-1 \frac{1}{3}{ }^{\prime \prime \prime}$.

Schmaler und gestreckter als die verwandten Arten, und dadurch manchen Arten der Clythriden-Gattung Euryscopa nicht unähnlich, einer Form der Mexicanischen E. carnifex Lac. sogar in der Färbung und Farbenvertheilung sehr nahe kommend, übrigens vor den ähnlich gezeichneten Scolochrus-Arten leicht an dem dreieckigen Rückenflecke kenntlich. Der Kopf flach, bei dem kleineren $\delta$ fast ganz durch die grossen, nur durch einen schmalen Zwischenraum getrennten Augen eingenommen, und zwischen den Augenbuchten ein kurzes aber leutliches Läıgsgrülıchen; die Oberfläche dicht und fein punktirt, angedrüclit greishaarig, die Farbe schwarz, an den abgeriebenen Stellen mit einem matten, metallischen Schimmer. Die Fühler des $\delta$ fast von halber Körperlänge, dünn und zart, das Wurzelglied, kurz eiförmig, etwa doppelt länger als breit, das zweite selır kurz und knotig, die folgenden gestreckt, das dritte über zweimal, das vierte fast dreinal länger als das zweite, das fünfte dem zweiten und dritten zusammen gleich, die folgenden etwa einander und dem vierten gleichend, schwach zusammengedrïckt und erweitert, mit kurzem Fortsatze des Endglieles. Die Farbe der sechs unteren durchscheinend rothgelb, dịe Oberseite des ersten und die Spitze des sechsten gebräınt, die oberen schwarz, an den Spitzen abstelıend gewimpert, und dünn angedıückt 
greishaarig. Die Fühler des $q$ in allen Theilen zarter und auch etwas kürzer, sonst nicht abweichend, Das Halsschild kurz und breit, mit sanft gekrümmter Mittelfirste, über den scharf rechtwinkligen, tief eingezogenen Vorderecken etwas zusammengedrückt, die Seiten fein gerandet, bei dem $\delta$ in der Mitte nur leicht bogig erweitert, bei dem $\circ$ in stärkerer Krümmung heraustretend und desshalb auch die Ränder nach vorn stärker convergirend, so dass bei letzterem sichı das Halsschild und mit diesem der ganze Körper nach vorn kegelförmig verschmälert, während derselbe bei dem $\delta$ mehr gleichbreit erscheint. Der Hinterrand fast gerade, nur jederseits des kurzen und breiten Hinterzipfels etwas ausgebuchtet und nach den stumpf zugerundeten Hinterecken hin von einer nur leicht angedeuteten Querleiste begleitet, sonst aber ohne Eindrücke. Die Oberfläche überaus fein und zerstreut-, nach der Mitte zu etwas dichter punktirt, das Mittelfeld glänzend schwarz mit metallischbläulichem Anfluge, die Seiten mit einer kurzen dicht angedrückten greisen Behaarung bedeckt, zwischen welcher der Grund besonders bei dem $q$ trüb brăunlich durchschimmert. Das Schildchen stark ansteigend, fast gleichseitig dreieckig, mit kurz abgerundeter Spitze und deutlichem Hinterzipfel, sehr fein aber dicht punktirt, kurz greishaarig, schwarz. Die Deckschiłde um $1 / 3$ länger als breit, bei dem $\delta$ fast gleichbreit und hinten kurz abgerundet, bei dem $q$ von den eckig heraustretenden Schultern ab hinterwärts ein wenig verschmälert, hinter der kaum erhöhten Vorderkante nur leicht quer niedergedrückt, die eckigen Schulterbeulen innerseits durch einen breiten seichten Eindruck abgesetzt, die kreisförmig abgerundeten Seitenlappen tief herabgezogen, und über ihnen die Deckschilde breit aber nur schwach zusammengedr'ïckt. Die Punktirung grob, die oberen Streifen bis 'zu den Schulterbeulen hin vorn durch eben so grobe überzählige Punkte gestört und theilweise unkenntlich gemacht; erst vom Beginn des zweiten Drittels ab beginnen die Streifen sich aus jenem Gewirre deutlicher zu entwickeln, bis sie auf dem letzten Drittel vollständig ausgebildet erscheinen, aber allmählichı sich abschwächend zuletzt unter der Wölbung völlig verschwinden. Auch die Seitenlappen sind mit einer solchen überzähligen Punktirung dicht bedeckt. Die Zwischenräume glänzend, vorn leicht erhöht und stellenweise zu runzligen Querrücken verfliessend, hinten allmälılich immer mehr abgeflacht. Die Farbe ziegelroth, die feinen Vorderkanten, die Schulterbeulen und ein die 
Flügrldecken ımziehender, längs der hinteren IIälte des Aussenrandes stärker verbreiterter Saum schwarz mit violettem Schimmer, und gleiche Färbung zeigt ein grosser, rerkehrt dreieckiger gemeinsamer Hinterfleck, lessen breite Basis die Naht vor der Mitte rechtwinklig durchscheidet, seitlich aber nur bei einem der vier mir vorliegenden Stücke wischartig überfliessend den schwarzen Randsaum erreicht; dagegen Giesst die Spitze des Dreiecks unter der Wüllung stets mit dem Nahtsaum zusammen, als dessen Erweiterung sich ïberhanıt das ganze Dreieck darstellt. Pygidium und Unterseite tief gebräunt, mit stahlblauem besonders an den Nïlten wahrnelımbarem Anfluge, dicht angedrïckt silberhaarig. Auch die Beine roth, die Vorderschenkel schıvarzblau und an deı ülrrigen die Aussenseite auf der unteren IÏ̈lfte bläuliclı angelaufen, die Fussglieder, besonders das dritte, mehr oder weniger gesclıwärzt. Das breite Prosternum läıgs der Milte seicht niedergedrücht, hinten zugerumlet. Das letzte Segment des o leicht quer niedergedrïckt, des + mit einer grossen runden, im lnuern stahlbläulichen Garule.

Aus Columbien (Mus. Baly. Berol., in letaterem La Guayra von dem Sammler - Münler - als Ileimath genannt.) Bei einem Stïcke im Mus. Clarli ist (wahıscheinlich irrthümlich) Brasilien als Heimath angegeben.

50. Sc. Scrofal m. Rosthram mit schwärzlichem Saune der Flïgeldecken, die Seiten des sehr fein und dicht punklirten Halsschilds mit der Unterseite dicht gelbhaarig; ric Punktstreifen ror'n grol, und durch ïberzählige P'unkte gestör', hinten feiner, nit flachen querrunzligen Zwischenrïumen. L. $23 / 4-3^{\prime \prime \prime} ; \mathrm{Br}$. 1 1/3-1 1/2"'.

In der Vertheilung der Behaarung den nächst vorhergehenden, ans gleichen Gegenden stammenden Arten ähnlich, eben so schr aber in der Eiufachlieit der Färbung ron denselben alsweichend. Der Kopf tlach, mit wenig cingezogenem, oben durch eine leicht gekrïmmte Èlıöhıng alogesetztem liopfschilde, und überaus feiner Stirulinie, auf dem fein punktirten, glänzend rostbraunen Grunde mit einer dicht abwärts angedrückten goldglänzenden Behaarmng berleckt; die wieder elwas vorspringende Oberlippe knochengelb, die Hundtheile tief pechlsaun, die (hei dem + ) weit getrennten, tief ausgeluchleten Angen ln:̈unlich, stellenweise silberglänzend. Die schr dünnen Fühler nicht von halber lí̈rperlänge, das gleichfalls gelblichbeladarte Wurzedglied auf dënner Basis breit birnförmig 
anfgetricben, um die IIällte länger als breit, das zweito lingelig, die drei folgenden schmal verkehrtkegelförmig, das dritte doppelt-, das vierte $2 \%$ mal länger als das zweite, das fünfte noch etwas verlängert, das scchste oben schon etwas erweitert und wieder dem vierten gleich, die oberen zusammengedrückt und noch melır verbreitert, allmählich wieder abnchmend, sodass das zehnte kaum die Länge des dritten erreicht; das Endglied mit seinem liurz dreieckigen Fortsatze etwa so lang wie das achte. Die Farbe schmutzig braun, die oberen mit schwärzlichem Anfluge. Das Hadsschild breit und flach mit fast geraden Mittelfirste, vorn seitlich herabgezogen und dadurch verschmälert, die fein gerandeten Seiten sellost hiuter der Mitte in einem stumplen Winkel stark erweitert und von da nach den scharf rechtwinkligen Vorderecken in graden Linien verlanfend; die Ilinterecken stumpfivinlilig, der Hintermand jederseits des liurzen, dluch eine schmale Querfurche aufwärts gedrücliten Mittelzipfels stark ausgebuchtet. Die Farbe dunkelrostbraun, die Punktirung dicht aber sehr fein, das kahle Mittelfeld glinzend mit leicht metallischem Anfluge, welcher Anflug namentlich auf dem Mittelzipfel ins Stahlbläuliche hinüber spielt; die Seiten breit mit einer dicht angedrückten goldgelblichen Behaarung bedeckt, sodass nur die hinterwärts etwas buchtig erweiterte mittlere Ï̈lfte kahl bleibt. Das Schildchen sehr schräg ansteigend, kaum $2 / 3$ so lang wie voru breit, hinterwärts siark verschmälert, mit abgerundeten Ecken und deutlichem IHinterzipfel gerade abgestutzt. Die Farbe schwärzlich mit dicht gell, behaarter Oberfläche. Die Deckschilde um etwa 1/4 länger als breit, sehr flach gewölbt, hinterwärts etwas verschmälert und mit gleichtalls flacher Krümmung abfallend, hinter der wenigg bemerkbaren Vorderkante kaum niedergedrückt, die länglichen Schulterbeuten innerseits durch einen breiten und seichten Eindruck abgesetzt, die Seitenlappen tief herabgezogen, aber über ihnęı die Deckschilde nur' schwach 'zusammengedrückt. Die Punktirung auf der vorderen Hälfte grob, die Zwischenräume der ziemlich kemntlichen Punktstreifen durch ülevzälılige Punkte und Streifenansätze ron gleicher Stärke derartig ausgefüllt, dass die ganze Flïche bei flüchtigem Anblicke mit einem regellosen P'unktgewirre beleckt erscheint, aus dem sich auf jeder Flügeldecke einige flache, stellenweise verschwindende, den zweiten, vierten und achten Zwischenraum entsprechende Lïngslinien emporheben. Auf der kleineren Hinterhälfte treten durch Zurïckbleiben jener überzälligen Punliti- 
rung die eigentlichen Streifen deutlicher, aber in merklicher Abschwächung lervor, und lassen sich wenigstens in der dunkeln Färbung der Punkte bis zur Spitze verfolgen. Die Zwischenräume fein querrunzlig, vorn durch die ausgerissenen Punkte leicht wellig, hinterwärts breiter und flacher: die Farbe ein mässig glänzendes dunkles Rostbraun, ein feiner Randsaum der Flügeldecken schwarz mil leiclıt stahlblauem Aufluge, und bei einem Stücke hinten auf dem vierten Punktstreifen eine ähnliche, aber sehr verloschene und kurze Längslinie. Pygidium und Unterseite gleichfalls tief gebräunt, wie die heller rothbraunen Beine mit der genannten goldgelben Behaarung dicht bedeckt; die stark aufgetriebenen Vorderschenkel stablblau und auf der breiteı kahlen Innenfläche spiegelglatı. Die kahlen Schulterblätter gleichfalls heller gebräunt. Das breite und flache Prosternum hinter der llitte leicht quer niedergedrückt, hinten kurz abgerundet. Das letzte Segment des $f$ mit einer tiefen halbkugeligen Grube; das ơ unbekaunt.

Ebenfalls aus Venezuela. (Mus. Felix, von Wagner. - Mus. Berol., von Moritz gesammelt.)

51. Sc. pilicollis m. Schmutzig braun, der Kopf, das fein gerunzelte dicht greishaarige Halsschild und die Beine mit stahlblauem Anfluge, die Flügeldecken strohgelb, die Naht und eine abgerissene Längslinie stahlblau; die Punktirung vorn grob, regellos, hinten undeutliche Streifen bıldend mit daselbst flachen glänzenden Zwischenräumen. I. $2 \frac{1}{3}-2 \frac{2 / 3}{}{ }^{\prime \prime \prime} ; \mathrm{Br}$. $1 \frac{1 / 6}{6}-1 \frac{1 / 3}{}{ }^{\prime \prime \prime}$.

Durch Färbung, Sculptur und Behaarung eine sehr eigenthümliche, daher auch leicht kenntliche Art. Der Kopf flach mit oben kaum abgesetztem Kopfschilde, die Stirn bei dem $\delta$ durch die grossen, fast zusanmenstossenden Augen fast gauz eingenommen, auch bei dem $q$ durch deren Annäherung selır verengt, und nur über den Fühlerwurzelı ein wenig eingedrückt, fein aber sehr dicht punktirt, düun greishaarig, braun nit stablblauem Anfluge, die Mundtheile licht pechbraun, die Oberlippe kıochengelb. Die Fühler düın und schlank, von dem Bau der verwandten Arten, die unteren Glieder bis zur Spitze des sechsten durchscheinend honiggelb, die oberen schwarz; das Wurzelglied auf der Oberseite ius Bläuliche fallend. Das Halsschild doppelt breiter als laug, llach gewölbt und nach vorn ziemlich gleichmässig verschnıälert, vor dem Hinterrande zu beiden Seiteı schräg eingedrückt. Die Seiten gerandet, vor der Mitte rundlich erweitert, von da bis zu delı spitzen 
Vorderecken fast gerade verlaufend; die Hinterecken scharf stumpfwinklig, der Ilinterrand jederseits ausgeschweift, mit liurz vortretendem Mittelzipfel. Die Oberfläche durch eine feine runzlig verfliessende Punktirung matt, braun, mit stärkerem oder schwächerem stahlbläulichem Anfluge, mit angedrückten greisen Härchen zienlich dicht besetzt. Das Schildchen mässig ansteigend, quer viereckig und hinterwärts etwas ver'schmïlert, gerade abgestutzt, die Oberfläche dicht punktirt, matt gebräunt, an den Seiten blïulich schillernd. Die Deckschilde um etwa $1 / 4$ länger als breit, fast rechteckig und hinterwärts kaum ver'schmälert, hinter der Vorderkante seicht quer niedergedrückt, und daher nur auf der Innenseite der wenig vortretenden Schulterbeulen ein etwas stärkerer Eindruck; auch die Naht hinter dem Schildchen nur schwach niedergedrückt, die Seitenlappen kurz und breit. Die Oberfläche auf der grösseren Vorderhälfte dicht grol punktirt mit Spuren verdunkelter Punktstreifen, die sich erst hinter der Mitte mit einiger Regelmässigkeit und mit Bildung breiter flacher Zwischenräume zu entwickeln beginnen; der Zwischengrund vorn matt und glanzlos, hinten etwas mehr glänzend. Die Farbe strohgelb mit einem über den Seitenlappen etwas erweiterten stahlbläulichen Saume, ausserdem auf jeder Flügeldecke eine auf der Scluulterbeūle beginnende und bis zur Wölbung reichende stahılblaue Längslinie; bei undeutlicher Ausfärbung erscheinen Rand und Binde schmutzig bräunlich, letztere auch wohl unterbrochen, sodass von ihr nur ein Schulterwisch und das längere oder kürzere Hinterende übrig bleibt. Das Pygidium fein punktirt, schmutzig gelbbraun, dicht greishaarig, am untern Rande jederseits mit einem breiten rundlichen Eindrucke. Auch die Unterseite schmutzig gelbbraun, fein runzlig punktirt und mit anliegenden greisen Härchen dicht bedeckt, die Vorderzipfel des ersten Bauchringes heller gerandet. Die Beine ebenfalls gelblichbraun, die Vordersclıenkel und Schienen ganz, an den Mittel- und Ilinterbeinen jene nur an der Spitze, diese an den Vorderkanten bläulich angelaıfen, die Fussglieder pechbräunlich. Das Prosternum flach, grob gerunzelt, hinten kurz und breit zugerundet. Das letzte Segment des $\delta$ leicht quer niedergedrückt, das $q$ mit einer tiefen halbkugeligen, an den Seitenrändern breit niedergedrückten Grube.

Aus Brasilien (Mus. Pelrop. Baly. Deyrolle. Clark. Berol.)

52. Sc. callens m. Rostroth, Fühler, Füsse, der Saum und eine abgekürzte Längsbinde der lehmgelben Flügeldecken schwarz, 
das Pygidium unt ein breiter Hinterleilosınd gelb; das IIalsschild globl, zerstreut punktirt, auch die Punktstreifen rorn grob und durch überzählige Punkie gestört, hinten feiner, mil flachen, fein querrunzligen, mässig glänzenden Zwischenräunıen. L. $23 / 4^{\prime \prime \prime}$; Br. $11 / 2$ "'.

Noch etwas grösser, besonter's breiter als die grössten Stücke des vorhergehenden, übrigens demselben in dem Habitus und der Farbenvertheihug nicht unalmlich, wenn auch an dem kahlen IIalsschilde von ihm sogleich zı unterscheiden. Der líopf flach mit feiner aber deutlicher Stirnlinie, zwischen den Augenbuchten ein flacher mondförmiger Quereindruck, durch welchen dąs stïrker eingezogene Kopfschild oben abgesetzt wird. Die Punhtirung sehr zerstreut, im Nacken fein, unten gröber, zwischen den oberen Augen」älften kaum wahınehmbar; die Farbe ein ziemlich glänzendes Rostroth; die ziemlich tief ansgebuchteten, (bei dem $₹$ ) oben weit gretrennten Augen greis, die Kinnbacken tiefer gebräunt. Die Fühler von halber Körperlänge, oben nur schwach zusammengedrückt und erweitert, schwarz, die unteren Flirder in der Spitze und auf rler Unterseite bräunlich. Das IIalsschild etwa $2 \frac{1}{2}$ mal breiter als lang, hinter der Nitte kaum merlilar quer aufgewöllst und vou da nach vol'n und hinten abgeflacht, üher den scharf spitzwinkligen, tief eingezogenen Vorderecken stark verschmälert, die Seiten lang herabgezogen, deutlich gerandet, in der Mitte in breiten Bogen erweitert und vor ihr leicht ausgeschweift; die stumpfwinligen Hinterecken mit einer kurzen, scharfen Schwiele, hesetzt, der Hinterrand deutlich doppelt ausgebuchtet, mit krältigem, aber wenig aufgehogenem Hittelzipfer; vor letzterem jederseits ein breiter, flacher Schrägeindruck, welcher längs dem Hinterrande nur cinen flachen Querwulst emporschieht, dagegen die Hauptmasse des Halsschilds derartig zur Seite drängt, dass der hintere Theil des Scitenrandes unter jene üler ihu hinausreichende wulstige Masse zu liegen kommt. Die Punktirmng sehr derb, oben etwas mehr vereinzelt, seitlich dichter gedrängt, mit lackglänzendem Zwischengrunde; die Farbe rostroth, auf der Mitte mit einem verwaschenen, ins verblichen Gelbliche fallenden Längswische; ännliche aher noch undentlichere gelblichı. Stellen zeigen sich vor dem hinteren Mittelzipfel und über ter Mitte der Seiteuränder. Das Schildchen stark ansteigenl, 'fuer viereckig und fast doppelt breiter als lang, hinterwil's wenig verschmälert, mit grossem, flach niederliegendem, fein runzlig punktirtem Hinterzịfel und alggerundeten Eeken breit al,gestutzt, ziemlich 
dicht punktirt, glänzend rosthraun, die Süume und der Hinterzipfel schwarz. Die Deckschilde breit und flach gewölbe, längs der Naht niedergedrückt und linten mit noch flacherer líümmung abfallend, linter der scharfen, mässig erhölıten Vorderkante quer eingedrücki, die grossen, etwas lïnglichen Schulterbeulen immerseits durh eine Areieckige Verlängerung jones Quereindrucks alogesetzt; die Seitenlappen mässig, mud über ilnen die Deckischilde loreit zusannnengedrückt. Die l'unktstreifen von'u grob, etwas wellig und stellenweise gelockert, besonders längs der Naht und dann wieder hinter den Schulterbeulen durch überzälılige, gleichfalls ziemlich zerstreut gostellte Punkte gestört, von der Hitte ah allnählich feiner, regelmässiger, ind die Punkte einander näher gerückt; dic Zwischenräıme flach, zienlich glänzend, mit leinen, aul der schwarzen Lüngshinde deutlicheren Qucrunzeln besetz. Die Farbe hell strohgelb; schwarz ist eine breite gemeinsame Niluthinde, die sich hinterwärts allmällich zı einem die Spitze umfassenten Saume verschmälert, sich daun aussen bis zum linteren Ende des Seitenlappens fortzieht, sich an letzterer Stelle gabelt und sich einestheils auf dem umgeschlagenen schunalen Rande des Seiteulajpens, anderntheils als schmale schwarze Längslinie aul' dem neunten Zwischenraum fortsetzt, sodass zwischen beiden rler lreite Kiel des Seitenlappens geil) bleibt. Ausserilen zeigt jede Flügeldecke noch eine breite, auf der Schulterbeule beginnende, nach aussen dem achten Streifen folgende, inuerseits und hinten brandig hegränzte, auf der Wölbung alıbrechende selıwarze Längsbinde, deren Ende gegenüber die Nalıtbinde sichı merklich zu verschınälern begiunt, und auch der schwarze Randsaum sich ins Braune abschwächt: endlich ist auch noch das Inucre der auf dem hellen Grunde stehenteu Punkte geschwärzt. Durcłı Ausilelıung der schwarzen Färbung bildet sich eine Abänderung

$\beta$. bei welcher die vergrösserte Mittelhinde melır odler weniger mit Naht und Scitenrand zusammenfliesst. Gell, bleibt dann uur das Vorderende vom Kiel des Seitenlappens und ein damit zusanmenhängender Längsflıck auf dem neunten Zwvischenraunıc, die lintere IIälfte des achten und neunten Zwischenraums vom Ilinterende des Seitenlappens aj, bis zum Auslaufen des ncunten Punktstreifens, je eine schmale Lüngslinie auf deur Vorderende des arsten und zweiten Zwischeuraums, eine lingere in der Mitte dles zweiten, und eine ganz kuze auf dem Ilinterende des ersten 
Zwischenraums dicht vor der Wölbung; alle diese oberen Linienzeichnungen mehr oder weniger brandig begränzt, mehr ins Röthliche fallend, nicht einmal auf beiden Flügeldecken gleichmässig ausgebildet, daher möglicherweise bei anderen Stücken abweichend gestaltet oder auch ganz geschwunden. Auch das Schildchen bis auf die verwaschen gebräunte Wurzel schwarz, auf dem Halsschilde die gelbliche Stelle kaum noch kenntlich, dagegen jederseits der Mitte ein verloschener schwärzlicher Punkt.

Das Pygidium dicht and deutlich runzlig punktirt, gelb mit roströthlichem oberen Saume; Unterseite und Beine rostroth, ein breiter auf der Mitte des letzten Ringes unterbrochener Rand des Hinterleibes gelb mit innen verwaschener Begränzung. Die Schienenenden schwärzlich angelaufen und die Füsse ganz schwarz. Die Vor'lerbiust runzlig punktirt, dünn greishaarig; vorn leicht quer niedergēdrückt. Das letzte Segment des $f$ mit einer mässig vertieften Grube, das $\delta$ unbekannt.

Aus Neu-Granada (Mus. Clark.).

53. Sc. rufopallens m. Oben strohgelb mit rostrothem Kopfe, unten rostroth mit breit gelhem Rande des Hinterleibes, Fühlerenden, Füsse und Brust geschwärzt; das Halsschild spiegelglatt, die P'unktstreifen sehr fein, vorn durch überzählige Punkte getrübt, mit flachen, glänzenden Zwischenräumen. L. $3 \%$;"; Br. $11 \frac{1}{\prime \prime \prime}$.

Ein durch seine einfache Färbung nicht weniger als durch seine Grösse ausgezeichneter Käfer. Der Kopf gross, flach, mit feiner, unten in eine tiefe rundliche Stirngrube auslaufender Nackenrinne, und tief eingezogenem, oben wulstig abgesetztem Kopfschilde, oben nur fein und sparsam-, längs der Augenränder und um jene Grube bis in die Augenbuchten hinein dichter und gröber punktirt, in den letzteren kurz und dünn gelb behaart. Die Farbe rostroth mit mässigem Glanze, die (bei dem $q$ ) weit getrennten, halbkreisförmig ausgebuchteten Augen greis. Die Oberlippe heller knochengelb, die Mundtheile pechbraun. Die Fühler von halber Körperlänge, das Wurzelglied ziemlich stark aufgetrieben, das zweite kurz birnförmig, das dritte doppelt länger, mit den beiden folgenden kurz verkehrtkegelförmig, das vierte (längste) dem zweiten und dritten zusammen gleich, das fünfte ein wenig kürzer, die folgenden zusammengedrückt und stark verbreitert, das sechste dem fünften gleich, die oberen allmällich abnehmend, sodass das zehnte nur 
wieder dem dritten gleichkommt; das Endglied mit seinein deutlich abgesetzten Fortsatze so lang als das fünfte. Die Farbe der fünf' unteren rostroth mit einem schwärzlichen Längswische auf der Oberseite, die oberen schwarz. Das Halsschild reichlich $2 \frac{1}{2}$ mal breiter als lang, mit fast gerader Längsfirste und breit abgeflachtem Rücken, über den tief eingezogenen, scharf spitzwinklig vortretenden Vorderecken breit zusammengedrückt und dadurch verschmälert; die Seiten fein gerandet, hinter der Mitte in breiten Bogen erweitert, die Hinterecken stumpfivinklig, mit einer kurzen scharfen Schwiele besetzt; der Hinterrand doppelt gebuchtet, mit zienlich stark vortretendem, aber kaum aufgebogenem Mittelzipfel und von diesem aus seitlich vor dem Hinterrande drei einander gleichlaufende, ziemlich flache Schrägeindrücke, von denen der erste sich nach dem Vorderwinkel, der zweite (längste) gegen die Mitte des Seitenrandes richtet, der dritte (kürzeste) aber schräg im Hinterwinkel liegt. Die Oberfläche kaum merklich punktirt, ziemlich glänzend, hell strohgelb, der abgesetzte Vorder - und Hinterrand leicht geröthet. Das Schildchen mässig ansteigend und vorn etwas niedergedrückt, nicht ganz so lang als vorn breit, hinterwärts im Bogen verschmälert und mit kurzem Hinterzipfel und abgerundeten Ecken breit abgestutzt, fein und ziemlich dicht punktirt, mit Spuren einer sehr kurzen Behaarung, hell rostroth. Die Deckschilde breit und flach gewölbt, kaum 1/5 länger als breit, hinter der Vorderkante nur sehr leicht quer nierlergedrïckt, die breit zugerundeten Schulterbeulen innerseits durch einen breiten, dreieckigen Eindruck abgesetzt, die Seitenlappen schwach, und über ihnen die Deckschilde eben so schwach zusammengedrückt. Die Punktirung fein und sehr zerstreut, auf der Vorderhälfte unordentlich-wellige, durch viele eingestreute Punkte getrübte Punktstreifen bildend, von denen eigentlich nur der aclıte und neunte ihrer ganzen Länge nach deutlich erkennbar sind; die übrigen werden meist erst auf der hinteren Hälfte durch das Zurückbleiben der überzähligen Punkte deutlicher und regelmässiger, aber auch feiner, und sind unter der Wölbung nur noch mit Mühe wahrzunehmen. Die Zwisclıenräıme flach, mit mässigem Glanze, der breite neunte mit einer ungeordneten Reihe überzähliger Punkte besetzt. Die Farbe ein ins schwach Lehmgelbliche fallendes Strohgelb, die Seiten und besonders die Spitze verwaschen heller, das Innere der Punkte leicht gebräunt. Das Pygidiun fein runzlig punktirt, dünn greishaarig, hell stroh- 
gell, auf der Mitte stumpf gekielt und dieser Kiel unten zu einen stärkeren Längshöcker erweitert, anf dessen Seiten die Fläche des Pygidiums am unteren Rande jederseits schräg niedergedrüclit ist. Unterseite und Beine dunkler rostroth, ein breiter Rand des Hinterleibes, nur den mittleren Theil des letzten Ringes röthlich lassend, verwaschen gelblich, die Hinterlsust und der vordere Theil des ersten Bauclıringes mit leicht stahlbläuliclıem, durch die kurze und dünne greisc Behaarung durchschimmerndem Anfluge. Das letzte Segment les $q$ mil einer tiefen, rundliclıen Grube, und jederseits lerselhen cin unterhrochener, an Vorderrande liegender Quereindruck.

Aus Brasilien (Minas Geraes: Mus. Clark).

54. Sc. rubi cundus m. Ziegelroth, Kopf und Vorderschenkel schwarzhlau, die dicht greishaarige Unterseite mit den Beinen bläılich angelaufen; das Halsschild fein und zerstrent punktirt, die Pumktstreifen etwas wellig und vorn stellenweise verdoppelt, mit flachen glänzenden Zwischenräumen. L. $2 \frac{2}{3}-4^{\prime \prime \prime} ; \mathrm{Br}$. 11/3-2"'.

In der Färbung den ungefleckten Stücken des Sc. posticatus nicht unähnlich, aber von sehr abweichendem Baue, flacher, uach vorn mehr allmählich verschmälert, auch in der Sculptur von ihn verschierlen. Der Kopf flach, die Stirn (bei dem o) ziemlich breit, mit fein eingeschnittener jederseits abgekürzte Lüngslinie, das Kopfschild deutlich eingezogen. Die Oberfläche schwarzblau, grob und ziemlich dicht punlitirt mit spiegelglinzendem Zwischengrunde, die grossen ziemlich tief ausgebuchteten Angen greis, etwa um die Breite der Oberlippe von einander getrennt. Die Fülıler kurz und lünn, nicht von halber Körperlänge, das Wurzelglied aus dünner Basis stark birnförmig anfgetrieben, um die Hälfte länger als breit, das zweite knotig, die drei folgenden dünn verkehrtkegelförmig, und von ilmen das dritte $2 \frac{1}{2}$ mal länger als das zweite, das vierte den beiden vorhergehenden zusammen gleich, das fünfte und sechste je noch ein wenig länger als das vierte, das siebente und achte je dem vierten, die beiden folgenden je dem dritten gleich, und das Endglied mit seinem dreieckigen Fortsatze wieder die Läuge des vierten erreichend, labei die sechs oberen wenig zusammengedrüclit und erweitert. Die unteren bis zur Mitte des sechsten durchscheinend honiggell, die oberen schwarz mit dünner greiser Behaarung. Das IIalsschild fast eloppelt breiter als lang, mit flachem nur vor der Mitte sanft aufgewölbtem, linter ihr etwas breitgedrücktem Rücken, 
ïber den scharf spitzwinkligen Vorderecken längs dem Vorterrande zusammengedrückt und dadurch verschmälert, seitlich f'cin gerandet und in der Mitte rundlich erweitert; die IJinterecken stumpfwinkelig, der Ilinterrand jederseits etwas geschweift, mit limzen deullich anfgelogenem Mittelzipfel. Vor dem Ilinterrande zu briden Seiten cin breiter, cin schmales Querfültchen emporschiebender Schrägcindruck; weniger deutlich cingedrückte Stellen liegen seillich melı' nach ror'u, namentlich über der Erweiterung des Seitenrandes. Die Punktirung fein und oben sehr zerstrent, läugs der Seite fast ganz fehlend, seitwäıts etwas dichter und deutlicher, mit gläızendem zuweilen oben fast spiegelndem Zwischengrunde, die Farbe ein meist ziemlich dunkeles Roth. Das Schildchen merklich kürzer als vorn breit, hinterwïr'ts ansteigend und stark verschmälert, mit undeutlichem Iliuterziplel. Die Oberfläche dicht und fein punktirt, „lïmı greishaarig, schwarz. Die Deckschilıle lïnglich viereckig, vor'm kaum breiter als das Ialsschild, ziemlich gleichbreit und etwa 1/3 länger als breit, mit flachen längs der Naht etwas niedergedrücktem und hinten mit mässiger Wöllsung abfallemlem líïcken, seillich über den tief lıerabgezogenen Seitenlap’pen stark zusammengedrückt. Hinter der scharfen aber wenig erhölıten Vorderkante ein leichter, sich imerseits der breiten, flachen Schulterbeulen linterwärts erweiternder Quereindruck. Die Punktstreilen zienulich regelmässig, etwas wellig und nach der Spitze zu abgeschwïcht, auf der Wölbung fast abgeschliffen, die Vorderenden rler fünf oberen stellenweise verdoppelt, der Raun zwiselıen denı ersten und der Naht mit überzähligen etwas dichteren Punkten bestreut. Die Zwischenräume flach, von müssigen Glanze; die Farbe ziegelroth, meisi etwas lichter als das Halsschild, bei helleren Stücken ein verblichenes, fahles Gelbroth, zuweilen mil einem über die Mitte ziehenten, bei einiger Eutfernung vom Ange eine verwaschene an der Naht vorn und linten ausgebuchtete Querbinde darstellenden leichten Schatten, dessen Vor'haudensein aul' die in dieser Rolte typische lichtere Färbung von Wurzel und Spitze der Deckschilde hinweiset; ınanchmal auch noch der hintere Theil des vierten Punktstreifens, vor der Wülbung mit einer zarten schwälzlichen Lüngslinie bezeichnet. Das I'ygidium stumpl gekielt, mit der Unterseite lein runzlich punktirt, melır oder weniger dicht angedrückt greishaarig, bei dunkleren Stückeı schwärzlich nit stahıblanem Anfluge; die Parapleuren, dic Seiten der Hinterbrust und die ımgeschlagenen 
Seiten des Halsschilds röthlichbraun; bei helleren Stücken Pygidium und die ganze Unterseite roth, nur stellenweise bläulich angelaufen. Auch die Beine rothbraun oder ziegelroth, dic stark aufgetriebenen Vorderschenkel schwarzblau, die Fussglieder der Vorder- und Mittelbeine oben leicht geschwärzt. Das Prosternum grob runzlig punktirt, langbehaart, flach, in der Mitte leicht niedergedrückt und hinten halbkreisförmig zugeruudet. Das letzte Segment des $q$ mit einer rundlichen, mässig vertieften Grube; das $\delta$ unbekannt.

Bei einem zugleich ungewöhnlich kleinen $q$ von Ega (kaum $21 / 2$ "' lang) im Mus. Baly sind alle sonst dunkel gefärbten Theile mit Kopf und Schildchen roth, die Schenkel nur an den verdickten Enden stahlblau angeflogen, und die Deckschilde etwas gröber punktirt. Sonst aber finde ich keine Abweichungen, und halte das Stück daher nur für ein schlecht ausgefärbtes, bei dem das Zusammentreffen dieser helleren Farbe mit der geringeren Grösse und der gröberen Punktirung ein zufälliges ist.

Aus Brasilien (Mus. Schaum. Holm. Vindob. Baly. Clark. Dohrn. Deyrolle). Im Mus. Deyr. ist S. Catharina als Heimath genamnt; von den drei Stücken des Mus. Baly stammt das oben erwähnte hellere von Ega am oberen Amazonenstrom.

55. Sc. spectabilis m. Ziegelroth, die Schulterbeulen und ein Längswisch vor der Wölbung der Flügeldecken geschwärzt; das Halsschild grob zerstreut punktirt, die Punktstreifen regelmässig, grob, vorn paarweise genähert, der sechste und siebente abgekürzt, mit flachen glänzenden Zwischenräunıen. L. $23 / 4{ }^{\prime \prime \prime} ;$ Br. $11 / 2{ }^{\prime \prime \prime}$.

Von der Gestalt und Grösse des Sc. rubicundus, aber heller . ziegehroth, und durch die grobe Sculptur und deren eigenthümliche Anordnung auf den Deckschilden leicht keuntlich. Der Kopf nlach mit kaum niedergedrückter Stirn und wenig eingezogenem Kopfschilde, vereinzelt grob punktirt, mit mässig glänzendem Zwischengrunde, ziegelroth mit knochengelber Oberlippe; die grossen, wenig ausgebuchtetelı, oben (bei dem $q$ ) weit getrennten Augen röthlich greis. Die Fühler nach den vorlıandenen Resten gleichfalls ziegelroth. Das Halsschild etwa $2 \frac{1}{2}$ mal breiter als lang, mit der grösseren Vorderhälfte sehr leicht übergekı'ümmt, über den kurz und scharf spitzwinkligen Vorderecken breit zusammengedrückt und dadurch verschnälert, die Seiten gerandet, in der Mitte leicht bogig erweitert und vor ihr sehr schwach ausgeschweift, die Hinterecken kurz und scharf, fast rechtwinklig; der Hinterrand jederseits leicht 
ausgebuchtet, mit kurzem, aufwärts geschlagenem Mittelzipfel, und vor letzterem das Mittelfeld leicht quer niedergedrückt; im Anschlusse an diese Stelle jederseits ein tiefer, nach aussen verbreiterter, gegen die Mitte des Seitenrandes gerichteter Schrägeindruck, hinter welchen sich die Masse des Halsschildes leicht querwulstig emporschiebt. Die Oberlläche in der Mitte feiner und sehr zerstreut-, seitlich gröber und dichter punktirt, gleichfalls ziegelroth mit oben glänzendem Zwischengrunde. Das Schildchen schräg ansteigend, hinterwärts stark verschmälert und mit deutlichem Hiıterzipfel breit abgestutzt, glänzend ziegelroth mit dunklerem Rande. Die Deckschilde sehr flach walzenförmig, fast gleichbreit und etwa $1 / 6$ länger als breit, hinter der scharfen Vorderkante breit aber nicht lief quer eingedrückt und dahinter leicht aufgewulstet, hinter dem Schildchen auf der Naht nochınals breit quer eingedrückt, der Rücken die Naht entlang abgeflacht und hinten mit sehr schräger Wölbung abfallend; die Schulterbeulen schımal und flach, die Seitenlappen selır gross. Ile Punktirung derb und kräftig, die Streifen regelmässig, auf der vordern Ilälfte paarweise. (der erste und zweite, dritte und vierte, sechste und siebente, achte und nemnte) einander genälıert, sodass nur der fünfte für sich ausläuft, sich aber vorı durch ein I'aar überzählige P'unkte verdoppelı, das aus dem sechsten und siebenten Streifen bestehende dritte Paar hald hinter der Schulterbeule abgerissen. Die Zwischenrüume vorn sehr tlach gewölbt, hinten breit und flach, glänzend ziegelroth, das Innere der Punkte geschwärzl; ausserdem ein schwärzlicher Fleck auf der Schulterbeule und ein ähnlicher Längswisch vor der Wölbung auf den vierten Streifen und an dessen innerer Seite, hier sehr verwaschen und schlecht begränzt. Pygidiun und Unterseite fein runzlig punktirt, dünn greishaarig, mit den Beinen heller ziegelroth. Das Prosternum breit und flach nit zwei schmalen Längseindrücken, hinten ziemlich breit abgermulet; das letzte Segment des $\&$ mit einer ziemlich breiten, rundlichen Grube, das $\delta$ unbekannt.

Aus Neu-Granada (Mus. Clark).

56. Sc. arcuatus m. Schwarz mit hochgeller Spitze der Deckschilde, die Parapleuren mit den Mittel- und Hinterbeinen röthlich gelb; das Halsschild zerstreut und ziemlich fein punktirt, die Punktstreifen vorn grob und etwas wellig mit flachgewölbten, hinten flachen Zwischenräumen. L. 3"'; Br. $1 \frac{1 / 2}{\prime \prime \prime}$. 
Bei oberflächlicher Betrachtung manchen Stücken unseres $\mathrm{Cr}$. lipustulatus Fab. nicht unähnlich, in der Färbung dè Oberseite gewissermassen die des Sc. semiluteus umkehrend. Der Kiopf fach mit abgekürzter, aber deutlicher Stirnlinie, über den Fühlerwurzehn seicht quer eingedrückt, das Kopp'schild eingezegen, oben durch einen flachen, voı jenem Eindrucke begränzten Querwulst algesetzı; die Punktirung ziemlich deutlich, aber ungleichmåssig, in der Mitte des Stirn und im Nacken unsclseinbar, längs den imneren Augenrändern und in den Augenbuchten, sovie auf dem Kópfschilde dichter gedrängt. Die Farbe schwar'z mit glänzendem, auf den dichter punktirten Stellen matterem Zwischengrunde, die Oberlippe unten rostroth gesäunıt, die grossen, (auch bei dem \&) weit getrenıten Augen greis. Die Fühler fehlen dem einzigen vorliegenden Stücke bis auf die drei unteren Glieder; hiernach ist das Wurzelglied stark keulig aufgetrieben, etwa ım die Ilälfte länger als breit, das zweite srhr kurz eifürmig, das dritte gestreclit-rerkehrtkegelförmig und etwa viermal länger als das zweite, die Färbung rostroth mit geschwärzter Oberseite der beiden unteren. Das Halsschild etwa 21/4mal breiter als laug, mit flachen Rüclien und grader Mittelfirste, nach vor'n verschmülert, an Vorderrande etwas eingesclınürt, über den scharf spitzwiıkligen tief eingezogenen Vorderecken schı̈̈g zusanmengedrückt und dadurch noch melı verengt; die Seiten ziemlich breit gerandet, in der Mitte bogig erweitert, die stumpfwinkligen Hinterecken abgerundet, und der IInterrand zweiluchlig; vor dem kurzen Mittelzipfel jederseits ein lla- chır, nach aussen erweiterter Schrägeindruck, und hinter diesen längs dem Ilinterrande ein bis zum llinterwinkel reichendes, hier sich nach rorı lirummendes und fast bis zur Nitte des Seitenrandes ziı verfolgendes Fïltchen. Die Punktirung auf dem Mittelfelde und lïngs dem Vorderrande sehr zerstreut, seitlich und hinterwärts deutlicher, weun auch nirgends tief eingestochen; die Farhe ein glänzendes, bei schräger Belenchtung schwach ins trül, Grünlich fillendes Schwarz. Das Schilhlehen stark schräg ansteigend, nicht ganz so lang wie vorn breit, lunterwärts rel'schmïlert, mit dentlichem Hinterzipfel liurz alogestntzt, fem punktirt und gleichlills schwarz. Die Deckschilde etwas plump, lreit und flach walzenfürmig, hinten nit sehr leichter Wölbung alblallend, hinter der scharfen aber wenig erhühten Vorderkante breit quer ringedrückt und dahinter sehr leicht schräg aufgewulstet: die Naht linter dem Schildchen der 
Länge nach eingedrückt, die grossen Schulterbeulen eckig hervortretend, auch die Seitenlappen stark entwickelt, und über diesen die Deckschilde kräftig zusammengedrückt; die Punktstreifen zicınlich regelmïssig, etwas wellig gebogen, auf der vorderen Hälfte grob, von der Nitte ab feiner, und üher der Wölbung röllig erloschen; die fein querrmuzligen und darlurch nur mässig glänzenden Zwisclsenräume vorn flach gewölht, hinten flach; auf der vorderen Hälfte des neunten einige überzählige, sich hinterwärts in eine abgekürzte Punktreihe aullösende Punkte. Die Farbe schwarz, die vor'n durch eiuen, beiden Flïgeldecken gemeiusamen, flach elliptischen Bogen scharf begräızle Spitze hochgelb, so dass die Vorderenten dieses Bogens fast bis zur Mitte des Seitenrandes reichen, während der innerste Punkt desselben auf der Naht etwa deren hinteres Driltel abschneidet. Das schwach längskielige Pygidiun mit des Untersejte fein runzlig punktirt und diclit angedrückt greishaarig, scliwarz; auch die Vorderheine schwarz mit slark aufgetriebenen Schenlieln und bräunlich durchscheinenden Schienen, Mittel- und Hinterbeine rollıgelb, und gieiche Färbung, obnohl trüber, zeigen auch die Parapleuren und Schulterblätter; dieselbe tritt stärker hervor, wenn diese Theile benetzt werden. Das letate Segment des ot mit einer grossen, rundlichen Grube, das $q$ unbeliannt.

Aus Brasilien (Nus. Clark).

57. Sc: melancholicus m. Metallisch-schwarzblau, die Fülılerwurzehn und die verwaschene Spitze der Deckschilde geröthet; das IIalsschild fein und zerstreut punktirt, glänzend, die Punktstreifen etwas wellig, rorn derb, mit vorn flach gewölbten, hinten flachen und daselbst an der Naht längsrunzligen Zwischenräumen. L. $3^{\prime} 4^{\prime \prime \prime} ;$ Brr. $13 / 4$.".

Ein gleichfalls grosser, plumper Käfer, von dem ich zwar nur ein einziges schlecht erhaltenes Stïck vor mir habe, der sich ahes' doch noch zun Wiedererlienıen ausreichend characterisiren lässt. Dasselbe zeigt in der Färbung und Zeichnung eine entfernte Aelınlichkeit mit Sc. cupripennis m., weicht aber, anch abgesehen von dem grösseren, melır gewölbtwalzenförmigen liörper von jenem noch ab Jurch das einfarhige Halsschild, die schwarzen Beine und die Sculptur der Deckschilde, so dass sich an der Selbstständigkeit der Art nicht wohl zweifeln lässt. Der Kopf flach mit deutlicher, oben erweiterter Stirulinie, das etwas eingezogene Kopfschild oben durcl $\mathrm{XVl}$. 
eine deutliche Bogenkante abgesetzt; die Punktirung oben zerstreut, unten dichter gedrängt, der Zwischengrund spiegelglatt, die Farbe tief schwarzblau mit metallischem Glanze; die Oberlippe röthlich gelb gerandet und die Tasterenden pechlbraun, die grossen, (bei dem ?) ziemlich weit getrenuten, breit aber nicht sehr tief ausgerandeten Augen greis. Die Füller bei dem einzigen vorliegenten Stücke nur unvollständig vorhanden; das keulige Wurzelglied fast doppelt so lang wie breit, die drei folgenden dünn verkehrt kegclförnig, das dritte doppelt-, das vierte $2 \frac{1}{2}$ mal länger als das zweite, das fünfte fast dreimal länger, das sechste wieder dem vierten gleich und das siebente noch mehr verkürzt. Die Farle der sechs unteren mit dem Fühılerhöcker rothgelb, mit einem schwärzlichen Längswische auf der Oberseite des Wurzelgliedes, der obere Theil des sechsten leicht gebräunt, das siebente etwas rerloreiterte und zusammengedrückte Glied schwïrzlich, und dieselbe Färbung werden ohne Zweifel auch die fehlenden oberen Glieder zeigen. Das Halsschild etwa $2 \frac{1}{2}$ mal breiter als lang, hinter der Mitte sehr sanft quer aufgewölbt und dahinter wieder quer niedergedrückt, über den breit spitzwinklig vorgezogenen Vorderecken breit zusammengedrückt und dadurch stark versclmälert; die Seiten breit gerandet, hinter der Mitte bogigerweitert und vor ihr merklieh ausgeschweift, die Hinterecken stumpf abgerundet und mit einer liurzen, hinterwärts gerichteten Schwiele besetzl; der Hinterrand jederseits des kurzen Mittelzipfels ausgebuchtet und von cinem his zum Hunterwinkel reichenden und hier sich nach vorn krümmenden Querfältchen begleitet; vor letzterem ein deutlicher, nacha ussen verloreiterter und verflachter Quereindruck. Die Punktirung zerstreut, ohen ziemlich fein, seitlich etwas deutlicher, der Zwischengrund spiegelglatt, die Farbe cin mehr oder weniger ins Stahlblüuliche überspielendes Schwarz. Das Schildchen stark ansteigend, nichı ganz so lang als vorn breit, hinterwäts mit ansgehuchteten Seiteu verschmälert und mit dentlichem Ilinterzipfel grade ahgestutzt; die Oberfläche runzlig punktirt, flach lïngskielig, gleichfalls schwarzblau mit mässigem Glanze. Die Deckschilde loreit gewölbt und hinten etwas verbreitert, daselbst mit flacher Kinunmung abfallend, um das Schildchenende etwas buckelig erlı̈̈ı, hinter der schmalen Vorderkante breit aber nicht tief quer cingedrückt, die Schulterbenlen stark höckerig hervorgehohen, innerseits durch das erwiterte Ende jenes Quereindruclis abgesetzt; die Seitenlappen stark entwickelt, mit 
breitem ungeschlagenem Rande, und über ilmen die Deckschilde gleichfalls lireit zusammengedrüekt. Die Punktstreifen im Ganzen regelmässig, etwas wellig gelirümmt und stellenweise verdoppelt, längs der Naht und hinter den Schulterbeulen auch etwas durch überzählige Punkte gestür, bis zur Nitte grob, von da ab feiner und auf der Wölbung fast ganz erloschen, der sechste bis achte schon früher auslaufench. Die Zwischenräume vorn flach gewölbt und glänzend, hinterwärts breiter und flacher, überaus fein gerunzelt, die der Naht zunächst liegenden auf und unterhalb der Wölbung durch deutliche, ob auch nicht dichte Nadelrisse gröber längsrunzlig. Lie Farhe metallisch schwarzhlau, stellenweise ins Stahloder Kupferblaue ühergehend, die Spitze sehön purpurblau mit schmal und rerwaschen geröthetem Rande. Das unten leicht gekielte Pygidium mit Unterseite und Beinen gleichfalls schwarzblat, Hülteı und Fussglieder trüb geröthet. Das letzte Segment des $q$ mit einer grossen, rundlichen Grube, das ơ unbekannt.

Gleichfalls aus Brasilien (Mus. Clark).

58. Se. caesus m. Rostrotlı mit zwei dunkleren Längslıinden des derl) und ziemlich dicht punktirten Ilalsschilds, die Beine bis auf die Schenkelwurzeln, sowie die Fühles schwarz; die Punktstreifen fein, vorn durch überzälılige Punkte verdunkelt, hinten fast erloschen mit flachen glänzenden Zwischenräumen. L. $31 / 4$ "'; Br. $1 \frac{1}{2}{ }^{\prime \prime \prime}$.

Aeusserlich dem Sc. rubicundus nicht unähnlich, aber von ihm sogleich an dem grob punktirten Halsschilde und dessen breiten verwaschenen dunliJer gerötheten Längsbinden zu unterscheiden. Der Kopf flarh mit feiner Stirnlinie, oben nur lïngs den inneren Augenräulern frin-, unlerwärts dichter und deutlicher punktirt, ziegelroth, die Fülılerhöcker und lis auf die röthliche Oberlippe auch die Mundtheile schwarz, die breit und tief ausgebuchteten, (bei dem f) weit getrenuten Augen greis. Die Fühler ron etwas mehr als halloer Körperlänge, nach oben hin wenig verbreitert, dlas zweite Glied lirnfürmig, das drilte $1{ }_{1}^{1}{ }_{2}$ mal unıl das vierte doppelt länger als das zweite, das fünfte noch ein wenig verlängert, das sechste wieder dem vierten gleich, und die oberen sehr allmählich weiter abnelımend, so dass das zehnte noch nicht die Länge des dritten erreicht, das Endglied mit einem breiten und dicken abgestumpft kegelförmigen Fortsalze. Die Farbe schwarz, das zweite his fünfte Glied auf der Unterseite gebräunt, das dritte und vierte auch an 
der Wurzel und Spitze, das fünfte ivenigstens an tler Wurzel röthlich durchscheinend. Das Ilalsschild selı kurz, etwa $21 / 4$ mal so breit als lang, in der Mitte nur leicht quer aufgewulstet, über den spitzwinklig ausgezogenen Vorderecken quer zusammengedrückt und dadurch verschmälert; die Seiten gerandet, in der Mitte in breiten Bogen erweitert und ror ihr ausgeschweift, die stumpfwinkligen Hintereckrn mil einer kurzen Schwiele aufgehogen, der Hinterrand jederseits leicht doppelt gebuchtet, mit kurzem wenig vortretendem Mittelzipfel. Vor dem letzteren sin den hinteren Theil des Mittelfeldes niederhaltender Querrindruck, llessen Enden jedoch jederseits nur bis zur IJïlfte des Ilinterrandes reichen, und ror dirsem über der Nitte des Seitenrandes ein zweiler, längerer aber tieferer, melır einem Quergrülichen ihnulicher Eindruck. Die Punlitirung grob und ziemlich dicht, seitwärts an Stärlie zunelıment, mit glïnz’ndem Lwischengrumb; die Farbe ziegelsoth, jederseits vom oberen Augenrande his zum Hiuterrande eine dunkler gerüthete selır verwaschen und schlecht begränzte l,ängsbiude, die sich an lienutlichsten zeigt, wrun man den liäer in nicht zu grosser Nähe unı muter etwas schräger Beleuchtung mit dem blossen Ange betıchtet. Das Schildchen sehr schrigg ansteigend, etwa so lang wie voru breit, linterwärts verschmälert und mit breit aliggermndelen Ecken und lurzem Hinterzipfel abgestutzt; die Oherlïche sohr fein punktirt, glänzenel rostroth mit dunkileren Säumen. Die Deckschilde 1 m etwa $1 /$. lä̈nger als breit, ziemlich stark trewölbt, die Nalıt der Längo nach sanft niedergedrüclit, die Wurzel hinter der scharfen Vorderliante nur in einer Querlinic eingedrüclit, welche in. cinen flachen, die gleichfalls nur flach gewöllten Schulterbeulen innerscits absetzenden Eindruck verläuft; auch die Seitenlappen mur schwach entwiclielt. Die Punktirung ziemlich fein, anf dem vorderen Drittel, lings der Naht und hinter den Schulterbenlen his über das zwritr Drilte] hinans regellos und nur stelleuweise spuren ron Streifenbildung zeigend, während der zweite his fünfte, auch der achte und neunte Streifen sich schon frülıer regelunissiger entwickeln. und auf dem letzten Drittel alle Streilin, obwohl fast erloschen und fast nu!r an der dunkleren Färbung der Punkte kenutich, zu bemerken siucl. Die flachen Zwischenrïume missig glinzend, die Farbe hell rostroth, das Innere der Punkte dunkler gethrïunt. P'gidium und Unterseite fein runzlig punktirt, glcichfalls hell rostroth, dünn greishaarig, die Beine bis auf die Hülten und Schenkelwurzeln schwarz. 
Das Prosternum flach mit zwei fein eingedrückten Längslinien, lany greishaarig. Das letzte Segment des o mit einer grossen und tiefen Grube, das ơ mubekannt.

Aus Brasilien (von C'aasapava: Sello im Mus. Berol.).

59. Sc. foe trus m. Trüb lelimgell) orler rötılichgelb, der liopf und rin rerwaschener Mittel-Querfleck des zerstreut punktirten Halsschilds mil Sehildchen und Vorderbeinen schwïzlich, Hißterbeine und Ilinterleib gelb - und schwarzbunt; die Punktstreifen vor'ı grob und durch überzällige Punkte getrülst, hinten feiner mit flachen glïnzenden Zwischenräumen. L. $2^{1 / 2}-2^{3} / 4^{\prime \prime \prime} ;$ Br. $1 \frac{1}{3}$ $-12 / 3 "$.

Der Kopl flach, dicht unl fein punktirt, die Stirn unten mit feiner Längslinie, schwarz; die Mundtheile schmutzig lehmgell mit hellerer Oberlippe und geschwärzten Kimbacken, die durch eine liefe rundliche Bucht sehr ungleich getheilten, (boi dem q) weit getrennten Augen greis. Dic Fühler dïm und nicht ron halber Kürperlänge, das zweite Glied fast kugelig, die drei folgenden dünn verkchrtkegelförmig, und von ihmen diss dritte doppelt-, die drei folgenden je dreimal länger als das zweite, die oberen wieder allmählich kürzer, und das zehnte dem dritten, das Endglied mit seinem kurz dreieckigen Fortsatze fast dem sechsten gleich; die unteren Glieder durchscheinend hellgelb mit leicht gebrännter Oberseite des Wurzelgliedes, die oheren schwach zusammengedrückten und wenig verbreiterten von der Vilte des sechsten ab schwarz. Das Halsschild liurz und sehr breit, mit grader hinten ein wenig schräı herabgeneigter Mittelfirste, über den scharfen fast rechtwinkligen Vorderecken breit zusammengedrückt und dadurch versclımälert, die Seiten gerandet, in der Mitte stark im Bogen erweitert, vor ihr in schräiger Richtung nach den Vorderecken gradlinig rerlaufend, die Ilinterecken breit alggerundet, kaum durch eine feine aufgehogene Schwiele angedentet, der Ilinterrand jederseits Jeicht ausgebuchtet, mit sehr kurzem und flachem Hittelzipfel. Vor dem Ilinterrande zu jeder Seite ein breiter Schrigeindruck, und vor diesem ein zweiter, schwächerer, wchcher das Halsschilı üher der Mitte des Seitrurandes llach zusammenzielıt. Die P'unktirung oben frin und zerstrent, seitlich dichter gedrängt und wenn auch nicht tiefer, doch gröber, die Punkte stellenweisr ausgerissen, wodnrch der Zwischengrmud hier narhig-runzlig erscheint. Die Farbe schmutzig lehmgell, mit mässigem Glanze; auf der vorderen IIälfte ein 
grosser halbkreisförmiger verwaschener schwarzer Querfleck, welcher mit seinem intensiveren Vorderrande die mittlere Hälfte des vorteren Halsschildsıandes eimnimmt, und sich daun hinterwärts immer unklarer werdend mit einem unscheinbaren Wisclie noch bis gegen die Mitte des Hinterrandes hin verfolgen lässt. Das Schildehen stark schräg ansteigend, nicht ganz so lang wie vorn breit, hinterwärts mit ausgelouchteten Seiten verschmälert, nit abgerundeten Ecken und deutlichem Hinterzipfel breit abgestutzt, gleichfalls schwarz. Die Deckschilde wenig länger als breit, fast gleichbreit und längs der Naht abgeflacht, hiıter der ziemlich scharf erhöhten Vorderkante quer gefurcht; die Scluulterbeulen schmal aber kräftig, die Seitenlappen lang herabgezogen, und über ihnen die Deckschilde breit und flach zusammengedrückt. Die Punktstreilen vorn und längs den Seiten grob, aber his üher die Mitte hinaus durch dicht gedıängte äberzählige Punlite vielfach getrübt und deshalb nur stellenweise kenntlich; in dieser Beziehung treten namentlich der zweite und dritte, dann wieder der vierte und füıfte hervor, von denen jedes Paar sich an seineu als schmale und flache Längsrippe erhöhten Zwischenraum anlehnt; und dasselbe ist theilweise auch bei dem achten und neunten Streilen der Fall. Hinter der Mitte werden die Punlite feiner, ohne imless vor der Wülbung ganz zu erlöschen, die vorn etwas unebenen Zwischenräume breiter und flacher, auch ein wenig glänzender. Die Farbe ein trübes Lehıngelb mit schmutzig geschwärztem Saume. Aendert jedoch ab

$\beta$. Die etwas mehr iıs Röthliche fallenden Deckschilde mit einem gemeinschaftlichen grossen verwaschen begränzten viereckigen sehwarzen Flecke an und hinter dem Schildchen, dessen Vorderrand sich zipfelförmig bis zu den Schulterbeulen, und der Hinterrand sich in gleicher Weise bis an die Seiten der Deckschilde verlängert. Auf jeder Flügeldecke wird dadurch ein grosser rother Querfleck vor der Spitze, und ein eben so breiter rother Vorderfleck über und hinter dem Seitenlappen abgesclnitten; auch ist bei dem vorliegenden $q$ dieser Form der Ialsschildsfeck etwas dunkler und ausgedehnter; sonst aber finde ich keine Verschiedenheit.

Pygaidium und Hinterleib heller gelb, jerler Bauchring mit einer schwärzlichen Querbinde, die mit den Enden von dessen flinterrande ausgehend mit ihrer Mitte den Ilinterrand des vorhergehenden berührt, der erste ling nach der Wurzel zu ins Röthlichbraune 


\section{3}

übergelıend. Auch die Brust trüb geröthet, die Hinterbrust in der Nitte schwärzlich. Bei der var. $\beta$. die Ilinterleilssbinden fast ganz geschwunden, gleich als ob das schwarze P'igment sich rorzugsweise auf der Oherseite angehäuft hälte. Die Vorderschenke] stark und fast eiformig aufgetrieben, schwarz, mit schmutzig gelben brä̈unlich angelaufenen Schienen; die vier hinteren Beine lıeller gelb, die Aussenkanten der Schenkel, in ihrer Mitte auf die breiten Vorderflïclıen ühergreifend, geschnä̀zt, und auch die Kinie und die Aussenseiten der Schienen schmuzig gehräunt. Das Prosterıum breit und flich, grob runzlig punktirt und heller röthlich, seitlich der Länge nach leicht niedergedrückt und hinten stumpf alggerundet. Das letzte Segment des of mit einer grossen halbkugeligen, hei der Stammform in der Mitle geschwärzten Grube; das o unbekannt.

Die Stamnform aus Columbien (Hus. Deyrolle), die var: $\beta$. aus Bolivia (Warscewicz im Mlus. Berol.) und Neu-Granada (Nus. Cla: li).

60. Sc. illotus in. IIell röthlich lehmgelb; der zweifleckige Kiopf, ein hreiter Querwisch des kaum punktirten Halsschilds, ein Längswischı der Flügeldecken und die IInterlırust mit Knien und Schienenenden geschwärzt; die P'unktstreifen dentlich, hiuter den Sclıulterbenlen etwas gestört, mit flachıen, glänzenden Zwischenr:̈̈ımeII. L. 13/4"'; Br. 1 1/4".

Dem vorhergehenden in Ilabitus und Grundfärbung nichı unälınlich, aber merklich kleiner, auf den Flügelılecken selı abweichend gezeichnet, und auch in der Sculptur verschieden. Der Kopf flach, mit grossen, oben durch einen leichıen bogenförmigen Einliuck abgesetzten, unten etwas eingezogenem Kopfschilde, die Stirn (des ơ) fast ganz durch die grossen nur durch eiuen linienfürmigen Zwischenraun getrenuten, tief ausgeluchteten, greisen Augen eingenommen. Die Oberfläclıe głänzend schwarz, mil einem schmal dreirckigen rüthlichen, zuweilen uur punktlörmigem Sclırägfleck jederseits am inneren Angenrande ïber der Augenlucht; auch Oberlippe und Mundtheile grelh]ich mit gebräunten Enden der Kinnbacken und Taster. Die Fülıler ungewölnnlich düun und kurz, kaun bis zum Hinterrande des IIalsschilds reichend, das Wurzelglied innerseits nur mässig aufgetrieben, retwa doppelt länger als breit, das zweite kurz unıl schmal hirnförmig, die drei folgenden sehır dümı verkehrtkegelförnig, und von ihnen das dritle dopıelt-, das vierte 
$2 \frac{1}{2} \mathrm{mal}$, das fünfte (längste) dreimal länger als das zweite, das sechste fast dem fünften gleich, oberwärts schon etwas dreieckig erweitert, auch die fünf letzten nur wenig zusammengedrückt und verbreitert, dabei sehr merlilich verkürzt und an Grösse wenig verschieden, das siebente und das Endglied je etwa dem dritten gleich. Die unteren bis zum fünften gelblich mit gebräunter Oberseite des Wurzelgliedes, die oberen schwarz mit gehräunter Wurzel des sechsten, zugleich dünn angedrückt hehaart, mit lang abstehend gewimperten Spitzen. Das Halsschild fast $2 \frac{1}{2}$ mal breiter als lang, mil fast grader in der Mitte nur sanft aufgebogener Mittelfirste, vorn etwas zusammengedrïckt und dadurch verengt, die Seiten fein gerandet, von den scharf stumpfwinkligen IIinterecken \%u den gleichfalls scharfen, spitzwinkligen Vorderecken hin in sanften Bogen abwärts geschwungen; der Hinterrand vor den Schultern bogig abgesclırägt, nach der Mitte zu etwas ausgebuchlet, mit wenirg vortretendem Mittelzipfel: vor letzterem jederseits ein tiefer und nach aussen verbreiterter, gegen die Yitte des Seitenrantes gerichteter, dieselbe aher nicht erreichender Schrägeindruck, und hinter diesem über den Ilinterecken die Halsschildfläche nochmals schräg niedergedrückt. Die Oberfläche nit einer sehr vereinzelten aber doch detitlichen Punktirung bestreut, dazwischen spiegelglatt, schmutzig ziegelgell, mit einem grossen, die grössere Vorderhälfte einuehmenden, linterwärts dırch die Schrägeindrüclie begränzten, zwischen ihıen aber fist den Hinterrand erreichenden, nach aussen verwaschenen schwärzlichen Querflecke hezeichnet, dessen breit zugerundeter Aussenrand die Seiten nicht erreicht, aber von hier aus mit aligeschwächter Intensität in die äusseren flacheren Enden der Eindrücke eindringt. Zuweilen dehnt sich dieser Fleck so weit aus, dass nur ein breiter Seiten- und ein schmaler verwaschener Vorder- und Hinterrand gell bleibt. Das Schildchen stark schräg ansteigend, so lang als vorn breit, hinterwir's stark rerschmälert und mit deutlicheon Ilinterzipfel stumpf abgerundet; die Oberfäche dicht und fein punktirt, fein behaart, schmutzig geschwärzt. Die Deckschilde kaum ${ }_{\text {i6 }}$ länger als breit, der abjeflachte Rüclien längs der Naht niedergedrückt, hinten mit kurzer Wölhung alıallend, am Schildchen höckerig aufgetrieben, vorn hinter der scharf erhöhten Wurzelhante quer eingedrückt; die Schultelbeulen kriftig, länglich eiförmig, die Seitenlappen tief herabgezogen und üher ihnen die Decliscliilde zusimmengedrïclit; daselbst zugleich die Punkte des 
achten und neunten Streifens merklich vergrössert. Die Punlitstreifen üherhaupt derb, im Ganzen regelmässig, mehrfach verdoppelt, dre Raum zwischen dem zweiten and der Nalıt mit vielen überzälhligen l'unkten hedeckit und dadurch der zweite, noch meh" aber der erste Streifen vielfach gestört und stellenweise verdunkelt, auch der sechste und siehente hinter der Schulterhenle etwas verwirrt, der achte und neunte ilırer ganzen Läıge nach vollständig und regelmässigg ausgebildet, und die gleichfalls regelmässig anslaufenden IHinterenden der übrigen bis über die Wölloung hinaus erkenubar. Die gläızendeu Zwischeuriume flach, der neunte und in geringerem Maasse das Vorderende des achten flach gewölht. Die Farlue ein schmutzig röthliches Lehmgelb, das Innere der Punlite gebräunt, anch der hintere Theil der Naht nehst der Spitze eben so gesäumt, mnd auf der Ifinterhälfte jecler Flügeldecke ein balıl schmalerer und mehr inteusiver, bald breiterer und melır verwaschen-wolkiger schwarzer Längswisch. Pygidium und Unterseite dūmn anliegend greishaarig, lehmgelb; das Unterende des ersteren, dic Mitte der Ilinterbrust mit den Paraplemren und der mittlere Theil des ersten Bauchıringes verwaschen geschıärzt. Die Beine röthlichıgelh, die unteren Enden der Schenkel und Schienen mit den Aussenkanten der Vorderschenliel und -schienen, sowie die Fussglieder gleichfalls schıär'zlich, seltuer Pygidium und Beine einfarbig lahmgelb. Das Prosternum grob zerstreut punktirt, flach, jederseits mit einer eingedrückten Längslinie. Das letzls Segment les $\delta$ tief quer eingedrückt, das \& unbeliannt.

Aus Brasilien, und zwar von Rio de Jan. (Mus. Holm., von Ferd. Sahlberg mitgebracht; auclı im Mus. Clark).

61. Sc. lacunosus in. Schwarz, Vorderhüften und Rand des IInterleibes wriss, ein Stirnfleck, die Hinterhälfte des zerstrent punktirten Halsscliilds, die Flügeldecken und die Beine bis auf die schwarzen Schenkel zirgelroth; die Punktstreifen fein, vorn elwas gestölt, mit flachen, leicht querrunzligen Zivischenräumen. L. 21/3"'; Br. $11 / 4 "$.

Auch eine ziemlich klciue, an der eigenthümlichen Farbenvertheilung leicht kenntliche Art. Der Kopif flach, fein punlitirt und gerunzelt, mit deullicher Stirnlinie, schwarz; ein loreiter, unten etwas ausgebuchteter längsfleck auf der Stirn ziegelroth, die grossen, (bei dem $q$ ) weit getremuten, breit und ziemlich tief ausgebuchteten Augen greis. Die düuneı Fübler ron haller liörperlänge, oben 
wenig erweitert, das vierte bis sechste Glied gleich lang, je fast doppelt lïnger als das dritte; die Farbe schwarz, die fünf unteren Glieder pechbräunlich mit geschwärzter Oberseite besonder's des ersten und zweiten. Das IIalsschild kuř und breit, längs dem Vorderrande breit und sanft eingeschnïrt, über den spitzwinkligen Vorderecken zusammengedrückit und dadurclı ver'schmälert; die Seiten fein gerandet, hinter der Mitte in schwachem Bogen erweitert, ror ihr leicht ausgeschweift; die Hinterecken stumpf, mit einer kurz aufgebomenen Schwiele besetzl, der Hinterrand jederseits des schmal aufyebogenen Mittelzipfels ziemlich stark ausgebuchtet. Ilas Mittelfeld nur schwach quer crhöht, hinten leicht schräg abfallend und flach gedrückt, auch jeder'seits des Mittelzi]fels ein nach aussen verbreiterter und verflachter Quereindruck; ein ziveiter, schwächerer zeigt sich ummittelbar in dem Hinterwinkel. Ile Oberfliche zerstreut- und nicht selı tief punktirt, mit mässig glänzendem Zwischengrunde, die Farhe der Vorderhälfte schwarz, hinten in der Hitte dreiecligg ausgeschnitten und scitlich in sanftem Bogen verschınilert, so dass die Mitte des Ilinterrandes dieser Färbung zwei hreite stumpfe Lappen bildet: die etwas grössere Hinterluälfte und die schwielige Spitze der Vordereckien ziegetroth. Das Schildchen schräg ansteigend, halb so lang wie vorn breit, hinterwärts starli verschmälert, mit abgerundeten Ecken und deutlichem Ilinterzipfel breit abgestutzt, dicht und fein punktirt, schwarz. Die Deckschilde um 1/. länger als breit, hinterwärts verschmälert, der alıgeflachte Rüclien die Naht entlang niedergedrüclit, auch vorn hinter der scharfen Wurzelkante schmal quer eingedrückt, hinten mit mässig abfallender Wölbung. Die Schulterlıeulen höclieriyg, die Seitenlappen von mässiger Ansbildung, und über ilmen die Declischilde etwas zusammengedrückt. Die Punktstreifen schwach, auf der Vorderhälfte durch übeřählig eingemengte Punkte etwas getrübt, aber doch als Begleiter von vieł dentlichen, ob auch flachen Lä̈ngsrip)pen lienntlich, von der Mitte ah regelmässig und bis zur Irölbung sichtbar. Die überhaupt flachen Zwischenräume leicht querrunzlig und deshalb wenig glänzend; dir Farbe ziegelroth mit verblichener Spitze, ein feiner Saum längs der Nalıt, Spitze und dem Anssen'ande bis an den Seitenlappren geschwärzl. Das Pygidium fein runzlig punktirt, schwarz, die oberen Enden des Seitenrandes schmal weisslich gesilumt. Auch die Unterseite schwarz mit breit weisslich gerandetem Ifinterleibe; die Vorderhüften gleichlalls weisslich, die Beine 
roth, die Schenkel schwarz mit breil geröthetюr Wurzel und Spitze, die Mitte der Schienen verwaschen gabräunt. Das Prostermun flach, in der Nitte der Länge mach scicht nierlergedrückt, hinten breit zugerunlet. Jas letze Segment des of mit einem kleinen Cirübchen; las of umbckaumut.

(Bleichfalls aus Brasilien (von S. Paolo: Sello in Mus. Berol.)

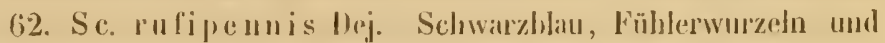
llechschilds bell zirgelloth; das Ialsschild fein und zerstreut punktirt, die Punktstreifin vorn mässig, riemfich regretmässig, hinten list ertoschen, der sechste und siclsente ahgekürzl, mit flachen, gfänzen-

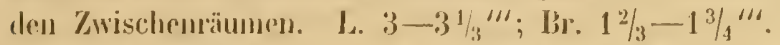

Eine zismlich breite, gedrungene, im Habitus den Arten der zweiten lotte nicht unähnliche Art. Der Kopf flach, dies Stirn äher den Fühlern leicht eingedrückt, mit feiner aher dentlicher Längstinne, nebst dem nichıt dentlich abyegränzten Kopl'schilde s»hr frein punktirt, schwil\%. Bie $\Lambda$ ugen nicht tiel'- aher ziemfich breit Jailbkreisförmig ausgerandet und ladurch sehr ungyleich getheilt, (hei dem q) getrenut und ebenfalls schwarz. Dies Fühler nicht von hallber Körperlänge, sehr schlauk, das zweite Glied breit eilörmig, die drei folgenden sehr dünn, fast gleichbreit, das dritte dopjelt-, das vierte und fïnlte je $2{ }^{1}{ }_{2}$ mal linger als das zweite, das secliste wieder den dritten gleich, die, folgenden his zum zelınten allmaihlich verlin̈r, und erst das Endglied mit seinem dreieckigen Fortsalze wieder so lang als dritte. Die sechs unteren bell durchscheinend honiggelb, das erste und zweite auf der Oberseite fast bis zur Spitze geschwärzt, auch das obere frittel des sechsten schwärzlich angelaufen; die fünf oberen schwarz, dabei alle vom sechsten ah etwas zusammengedrückt und nach oben erweitert. Tlas Halsschild loreit und zienlich flach gewölht, mit hinter der Hitte etwas aufwärts gekrümmter Mittelfirste; die spitzwinkligen Vorderecken tief eingezogen, die Seiten deutlich gerandet, linter der Jitte bogig erweitert, und dann his zu den Vorderecken fast grade verlaufend; die Hinterecken stumpfrinklig alggerundet, der Hinterrand jederseits geluclıtet, mit liurz bogenförmig heraustretendem Mittelzipfel, und zu jeder Seite des letzteren ein hräftiger bis zu den Hinterwiukeln zu verfolgender, schräg nach vorn und aussen gerichteter, längs dem Histerrande ein feines Querfältchen emporschiehender Quereindruck. Die Punktirung zerstreut, oben fein und er'st in den Hinterwinkeln etwas gröher, mit spiegelglänzendeın Zwischengrunde; 
die Farbe ein ins tief Stahllblane überspielendes Schwarz. Das Schildchen schrïg ansteigend, fast so lang wie vorn breit, hinten mit deutlichem Hinterzipfel algerundet, fein punlitirt und glänzend schwarz. Die Deckschilde kaum 1/4 lïnger als vorn breit, hinterwärts tentlich verschmülert, mit breit aligeflachın Rücken bis zur Wülbung allmählich und auch dann nicht viel stïlier abfallend, linter der breit aufgetriebenen Trurzellante schmal aber ziemlicls tief quer gefurcht, die Schulterloulen schınal, die Seitenlajpen lang heralgezogen. Die Punhtstreifen ron mässiger Stärlie, in Ganzen regelmïssig, die uberen auf der Vorderlülfte schwach wellig gekrümmt und ştellenweise verdoppelt, der Raum zwischen dem es'sten und der Nahı durch eine muortentliche iüberzällige Punktreihe ausgefüllt, der sechste und siehente auf der llitte siclı rerlierent, linterwärts alle Streifen schwächer und auf der Wölbung fast erloschen. Die flachen Zwischenräume spirgelglänzend, die Farbe ein lıelles Ziegelroth mit schumutzig gebräuntem Inneren der Punlite. Pygidium und Unterseite fein runzlig punktirt, mit den Beinen schwarz, Hüften und Selıenlielwurzelı lıräunlich durchscheinend. Das Prosternum breit, in der Vitte flach lïngswulstig, jederseits mit einem schwachen Längseindruclie, hinten liurz zugerundet. Das letzte Segment des $q$ mit dem gewöhnlichen, hier etwas quer gezogenen Grübchen; das ठ大 unbekannt.

Ehenfalls aus Brasilien (Mus. Deyrolle. Lacordaire. Clark. Hal. Berol. Vindub.)

63. Se.serricornis m. Metallschwarz mit strohgelhen Deckschilden; das Halsschild iusser'st fein punlitirt, spjegelylatt, die Punktstreifen sehr fein mit flachen, spiegeglänzenden Zwisehenrä̈men. L. 3-31/2"'; Br. 12/3-13/4"'.

Von der Grösse und Gestalt des vorhergehenden, aher hinten meln! gleichhreit, rein schwarz, und an den strohgelhen Decksehilden, wie den lreiten sägefömniöen Fühlern Jeicht kenntlich. Der liopf flach gewölht, zwischen den Augen mit einem kanm angedenteten Längseindrucke; das stark eingezogene liopfschild olyen durch einen leichten halbmondfömigen Querwulst algeselzt, und wir der untere Theil der Stiru mit rinigen dentlichen aber zerstrenten Punkten besetzt; die kleinen Augenbuchten elwas dichter nml friner punktirt, der Zwischengrund, sowie der obere nicht punktinte Theil des liopfes spiegelglatt. Die Farhe schwarz mit' leicht metallischem Anfluge. Die Fülıler des f) ron etwa ${ }^{2}{ }_{5}$ der Körperlänge, das Wrurzelglied 
stark aufgetrieben, um die Hälfte länger als hreit, das zweite kurz eiförmig, alle folgenden dreieckig, breit zusammengedrückt und dergestait verbunden, dass die Wurze] jedes Głiedes fast in der Mitte des quer ahgestutzten Oberrandes vom vorhergehenden befestigt ist, und der ganze Fühler sonach eine zweischneidige Säge darstellt, deren vom vierten Glietle ab fast gleichlange Glieler sich bis zum sechsten und siebenten allnällich verbreitern und sich von da ab oberwärts wietler eben so allınäblich verschmälern, aber noch weniger merklich verkürzen: das schmale Endglied mil seinem dreieckigen Fortsatze wieder dem fünften, das kurze dritte nur etwa $2 / 3$ des vierten gleich. Die Farhe schwarz mit dünner greiser Behaarung der oberen Glieder, die drei unteren am oberen Ende schmutzig gehräunt und die Wurzel des vierten eben so durchscheinend. Das Halsschild etwa $21 / 4$ mal so breit wie lang, ober flach und hinterwärts sauft quer niedergedrückt, durch die tiefe Einbiegung der scharf spitzwiukligen Vorderecken über letzteren sehr verschmälert; die Seiten fein gerandet, hinter der Mitte in einem stumpf abgerundeten Winkel verbreitert und von da ab nach vorı gradlinig verlaufend, die Hinterecken gleichfalls stumpfivinklig, scharf, aber nicht schwielig aufgebogen; der Hinterrand jederseits des breit abgerundeten Miltelzipfels tief ausgebuchtet, und ansserhalb dieser Ausbuchtung je ein lreiter, flacher, zum IIinterler'winkel hinziehender Quereindruck, hinter welchem sich ein schmales, den Hinterrand begleitendes Querfältchen emporschiebt. Die Farhe spiegelglänzend schwarz mit leichtem Metallschimmer und einer üheraus feinen, sehr zerstreuten P'unktiruny. Das Schildchen stark ansteigend, nichı ganz so lang wie vorn breit, hinter'wärts mit etwas ausgebuchteten Seiten stark verschmälert und mil abge rundeten Ecken abgestutzl, gleichfalls spiegelglänzend schwarz. Die Deckschilde um $1 / 6$ lïnger als breit, llach gewölbt und hinten mit sanfter Kirümmung al,fallend, hinter der Wurzel nur leicht quer eingedrïckt; die breiten, flachen Schulterbeulen innerseits durch das gekrünmte Aussenende jenes Qnereindrucks abgesetzt, die Sritenlappen mässig, und über ihnen die Deckschilde Jeicht zusammengedrücikt, welcher Eindruck sich in sehr schwacher Entwickelung quer üher den ganzen Rücken hin verfolgen lässt. Die P'unktstreifen selır regelmässig und lein, der liaum zu bejden Seiten des ahgekïrzten Streifens mit einzelıen ülocrzähligen Punkten bestreut; die Zwischenräume flach, überaus fein punktirt, spiegelglänzend 
strohgelb, die Schulterbeulen mit einem schmutzig hräunlichen Wische bezcichnet, und der Grund der Punkte eben so gefärbt. Das fein längskielige Pygidium mit der Unterseite und den Beinen einfarbig schwarz, dünn angedrïckt greishaarig; das Prosternum breit, jederseits der Länge nach niedergedrückt und dazwischen längsschwielig aufgetrieben. Das letzte Segment des \& mit dem gewöhnlichen Grübchen; das ơ umbekannt.

Aus Columbien (von Bogola: Mus. Kirsch; von Nova Valencia: Moritz im Mus. Berol.)

64. Sc. segmentarius m. Schwarz, Fühlerwurzeln, Deckschilde, Beine und der linterrand des ersten Bauchringes strohgelb; das Halsscliild äusserst fein punktirt, die Punktstreifen mässig, linten erlosclıen, mit flachen glänzenden Zwischenräumen. L. $2 \frac{1}{2} " \prime$; Br. $1 \frac{1}{4} "$ ".

Des beiden vorhergehenden ähnlich, aber etwas kleiner, den hinterwïts mehr verschmälerten Körper des Sc. rufipennis mit den strohgelhen Deckschilden des $S$ c. serricornis verbindend, von bejden aber durch die Fäbming der Unterseite und des beine leicht zu unterscheiden. Der Kíopf flach gewülbt mit dentlicher Stirnlinie und eingezogenem liopfschilde, gläuzend schwarz, auf der unteren IIälfte mit zerstrenten, der kuocliengelben Oberlijpe zu immer dichter gedrängten I'uukten besetzt. Ilie Taster bräunlich durchscheinend, die zjemlich breit ausgerandeten, (hej dem of) weit getrennten Augen greis. Die Fühler nicht ron balber liörperlänge und nach oben hin mur wenig zusammengedrüclit und erweitert, das dritte bis fünfte Glied allmählich verlängert, das sechıste wieder dem vierten gleich und die oheren eben so allü̈hlich abnehmend, so dass das zehnte nicht die Länge des dritten erreicht; das Endglied mit lang liegelförmigem, fast die Iälfte des Gliedes bildemien Fortsatze. Jie Farbe der füuf unteren gelthich mit geschwärter Oherseite, die oberen schwarz mit angedrückler, dünner, greises Behaarung. Das Halsschild etwa $2 \frac{1}{4}$ mal breiter als lang, linter der Mitte kaun merklich quer aufgewölht, und dimn leicht niedergedrückt, üher den spitzwinkligen Vorderecken zusanmengedrüclit und dadurch rerschmälest, die gerandeten seiten hinter der Mitte iu Bogen erweitert und ror ihr sanft ansgeschweift; die Ilinterecken stumpf, der Hinterrand jederseits des liurzen Mittelzipfels ausgeluchtel, unt seitlich von letzterem je ein breiter, nach aussen rerflachıter, läıgs dem Rande ein kielartiges Querfältchen empor- 
schiebender Quereindruck; ein zweiter, kürzerer und schwächerer zieht sich vor jenem gegen den Vorderwinkel lin. Die Oberfläche fein und zerstreut-, nach den Seiten und in den Hinterwinkeln etwas dichter punktirt, glänzend schwarz mit leicht metallischem Schimmer, die Hinterecken trüb bräunlich durchıscheinend. Das Schildchen mässig ansteigend, nicht so lang wie vorn breit, hinterwärts mit leicht ausgebuchteten Seiten verschmälert, und mit abgerundeten Ecken und undeutlichem Hinterzipfel breit abgestutzt, sehr dicht und fein punktirt, dünn greishaarig, schwarz. Die Deckschilde aus breiter Basis hinterwärts stark verschmälert, kaum 1/4 länger als vorn breit, hinter der Wurzel schwach quer eingedrüickt, auf dem Rücken alıgeflacht, nur zwischen der Schildchenspitze und den Schultern leicht anfgewulstet; die Schulterbeulen mässig, dagegen die Seitenlappen lang herabgezogen, mit breit umgeschlagenem Randle. Die Punktstreilen selır regelunissig, vorn kiriftig, von der Mitte ab allmählich feiner, der sechste bis achte daselbst schon verloschen, die übrigen bis zur Wülloung hin bemerkbar. Die Zwischenräume flach, stark glänzend, hell strohgelb. Pygidium und Unterseite fein und dicht runzlig punktirt, der Mittelzipfel des ersten Bauchringes mit dessen Hinterrande und den Seiten des zweiten, die in der Mitte tiefer gebräunten Schulterblätter und das Prosternum schmutzig verwaschen gellblich. Auch die Beine mit den Hüften schmutzig gell, die aulgetriebenen Schenkelenden und die Aussenseiten der Śchienen, hesonders der Vorderschienen stïker gehrüunt. Das Prosternum längs der Mitte zienlich breit unı flach aufgewulstet, grol) runzlig punktirt, lang und dümn greishaarig. Das letzte Segment des $q$ ınit der gewöhnlichen Girube; das ơ unbekannt.

Von Surinam (Mus. Berol.)

65. Sc. scabripennis m. Dunkel stahlblau mit schwarzen Fühlern, der Kopf und das schwarz gefleckte, zerstreut punktirte Halsschild strohgelb; die P'unktstreifeı grob, durch dicht eingemengte Punktirung bis über die Mitte linaus fast unkenntlich, hinten mit flachen, glänzenden Zwischenräımen. L. 12/3-21/2"'; Br. $1 \frac{1 / 6}{6}-11 / 2 "$.

Ltwas stïrker gewölbt als die vorhergehenden, von plumpem Aeusserm, und durch die grobe Sculptur der Dechschilde sehr ansgezeichnet. Der Kopf flach mit etwas eingezogenem Koplschilde, der Nacken der Läuge nach tief eingedrückt ınit deutlicher Mittel- 
linie, daher jederseits etwas beulig aufgetrieben; die Punktirung nicht tief, unterwärts etwas dichter gedräıgt, mit ziemlich glänzendem Zwischengrunde. Die Farbe hell strohgelb, die Vitte der Oberlippe gebräunt, die Taster, die breit und ziemlich tief ausgebuchteten, bei beiden Gesehlechtern weit getrennten Augen und die Fühler schwarz. Letztere bei dem o run halber liörperlïnge, den ठั etwas grösser, ziemlich dünn und schon rom dritten Gliede ab schwach zusammengedrückt, oben nur wenig verbreitert, das vierte his sechste Glied gleich lang und je un etwa $1 / 4$ länger als das dritte, auch die oberen nur wenig rerkürzı. Das Halsschild etwa $21 / 4$ mal breiter als lang, über die Mitte schwach quer aufgewülbt, über den scharf spitzwinkligen Vordereckrn quer eingeschnürt und dazu noch breit zusammengedrückt, laher stark verschmälert. Die Seiten gerandet, hinter der Mitte in schwachen Bogen erweitert und vor ihr leicht ausgesclıweift, die etwas niedergedrückten Hinterecken stumpfwinklig, der Hinterrand jederseits des leicht aufgehogenen Nittelzipfels breit aufgebuchtet, und seitlich von letzterem je ein zienlich schmaler, nach Aussen rerloreiterter und rerHachıter Quereindruck, durch welchen die Masse des Halsschilds als ein gestreckt-dreseckiger Querwulst bis gegen die Hinterwinliel hin aufwärts geschoben wird; ein zweiter kürzerer aher sehr kriftiger Quereindmuck liegt weiter nach vorn über der Mitte des Seitenrandes. Die Oberfläche deutlich zerstreut punktirt, mit gläızendem Zwischengrunde, hell strohgell, aul' der Mitte ein Länglich viereckiges, verwaschen schwärzliches Fleckchen. Das Schilelchen schräg ansteigemul, so lang wie vorn brejt, hinterwärts verschmälert und mit abgerumeten Echen unt dentlichen IInterzipfel alggestutzt; die Oherflache fein punktirt, schwarz mit blämichem Schimmer. Die Deckschilde um 1/4 lüıger als breil, stärker gewölbt als bei den vorhergehenden Arten, hinter der scharfen Vorterkante schmal quer eingedrückt und jederseits des Schilılchrus lıreit schräg niedergentrückt; die Schulterbenlen lneit und flach, innerseits durch einen leichten drejechigen Eindruck alogesetzt, amch dit: Seitenlappen nur schwach, und üher iluren die Dechschilde hreit zusammengedrïckt. Dis Punktirung and der vorderen llilfte grob und dicht, mit Spuren ahgerissener und gestörter l'mulstreifen, ron denen der achte und noch stärlier des neunte fast in ihrer ganzen luange liemutlich simel; limter der Mitte entwicheln sich die Streifen bei alogeschwächter Punlitirnng deutlicher, und lassen dadurch breite 
und glänzende Zwischenräume lervortreten, wälırend vorn der Zwischengrund durch mehr oder weniger deutliche Querrunzeln matt erscheint. Die Farbe stahlblau, stellenweise mit schwach grünlichem Anfluge. Pygidiun, Unterseite und Beine fein punktirt, dünı greishaarig, etwas dunliler schwarzblau, nur die umgeschlagenen Seiten des Halsschilds gelb. Das Prosternum grob punktirt, vorn leicht niedergedrückt. Das letzte Segment des ơ mil einem flaclıen, glïnzenden Quereindrucke, das $\&$ mit dem gewölmliclıen Grülscheı.

\section{Aus Brasilien (Sello im Mus. Berol.).}

Zehnt e Rotte. liörper klein und zierlich, länglichviereckiy, zienlich gleichbreit, uur flach gewölbt; die Färbung schwarz oder blau mit metallisclıem Anfluge, das Halsschild theilweise rötlılich, auch wohl, wie Unterseite, Beine und Deckschilde mit rothgelben oder weisslichen Zeichnungen. Die Aıgen des ơ zusammenstossend oder nur durch eine schmale Linie getrennt. Die Heimath dieser Rotte bilden überwiegend die Nordlantschaften von Südamerika, doch kommen auch in brasilien einige Arten ror. Von ınittelamerikanischen Arten gehören die im 7. Bande der Linn. Ent. von mir besclıriebeneı Sc. Montezuma und C'azicus lierlıer:

66. Sc. corruscaus m. Rothgelb, Fülılerenden, das Mlittelfeld des deutlich zerstreut punktirten Halsschilds, das Schildchen und die Seiten des Ifinterleibes schwar', die Deckschilde metallisch purpurblau; dic Pusktstreilen vorn durch üherzählige Punkte gestört, linten abgeschwächt, ıit flachen gläızenden Zwischenıäแmen. L. $12 / 3-21 / 3 " \prime$; Br. $3 / 4-1 "$.

ơ der Kiel des Seitenlapjuens weiss;

\& der'selbe den Flügeldecken gleichfarbig.

Im Mus. Berol. ist dieser Käfer mit dem folgenden und einer Form des $f$ von Sc. fallar. zu einer Art verbunden worden; er ist aber m. E. von beiden zureichend verschieden. Der Kopf ist flach mit feiner und liurzer Stirnlinie und wenig eingezogenem Kopfschilde, auf lctzterem und dem unteren Theile der Stirn vereinzelt punktirt, diese bei dem õ durch die grosson einander nahekommenden Augen sehr verengt. Die Augen selbst kurz dreieckig ausgebuchtet, greis; der líopf hell rothgelb mit knochengelber Oberlippe und leicht gebräunten Tasterenden. Die Fühler der beiden vorliegenden Stücke nur unvollständig, das dritte Glied ıopXVI. 
pelt-, das vierte fast dreimal länger als das zweite, das fünfte noch etwas vergrössert und diesem die oberen (bis zum neunten vorhandenen) etwa gleich, letztere dabei stark verbreitert und zusammengedrückt, schwarz; die fünf unteren rothgelb, das Wurzelglied auf der ganzen Oberseite gebräunt, die vier folgenden mit einem schmalen, dunkelı Längswische bezeichnet. Das Halsschild etwa doppelt breiter als lang, längs der Mitte fast abgeflacht, über den scharf spitzwinkligen Vorderecken etwas eingeschnürt und dadurch verschmälert; die Seiten frin gerandet, in der Mitte bogig erweitert und ror ilır merklich ausgeschweift, die Hinterecken scharf stumpfwinklig, der Hinterrand doppelt ausgebuchtet, mit liurzem Mittelzipfel, und vor diesem jederseits ein flacher, fast bis zur Mitte des Seitenrandes kenntlicher Schrägeindruck. Die Punlitirung grob, ziemlich zerstreut, die Einschnürung längs dem Vorderrande mit einer regelmässigen Querreihe von Punkten bezeichnet, die besonders hinter den Augen merlibar hervortritt. Die Farbe hell rostgelb, das Mittelfeld vom Vorder - his zum Hinterrande in scharfer Begränzung schwarz. Das Schildchen schräg ansteigend, nicht so lang wie vorn breit, mit abgerundeten Ecken und deutlichem Hinterzipfel quer abgestutzt, sehr feil punktirt und behaart, schwarz. Die Deckschilde länglich-viereckig, um 1/3 länger als breit, hinterwärts sehr wenig verschmälert, auf dem Rücken flach gewölbt und die Naht entlang niedergedrüclit, vorn leicht quer eingedrückt; die kräftigen rundlichen Schulterbeulen innerseits durch einen stärkeren dreieckigen Eindruck abgesetzt, die Seitenlappen schwach, und über ihnen die Deckschilde stark zusanmengedrückt. Die Punktstreifen von mässiger Stärke, vorn durch überzählige Punkte getrübt und stellenweise gestört, linter der Mitte regelmässiger, aber allmählich abgeschwächt, mit flachen, glänzenden Zwischenräumen. Die Farbe eiı schünes metallisches Purpurblaı, Wurzelkanten und Schulterbeulen, seltener die ganze Vorderhältte der Deckschilde ins Dunkelmessinggrünliche spielend, welcher Anflug, sowie ein dunkleres Blau, auch sonst noch stellenweise zum Vorschein kommt. Der Kiel und der umgeschlagene liand des Seitenlappens rein weiss (jedoch nur bei dem ठँ, vergl. die folgende Art), der letztere zart schwärzlich gesäumt. Unterseite und Beine rothgelb mit geschwärzten Fussgliedern, die Seiten des Hinterleibes bis auf einen schnalen Aussenrand breit rerwaschen geschwärzt, wogegen das Rothgelb dieses Aussenrandes und des Pygidiums in ein bleiches Ziegelroth 
übergeht. Das letzte Segment des $\delta$ einfach; das $q$ mit dem gewöhnlichen Grübchen.

Vom Puerto Cabello (Moritz im Mus. Berol.) und aus NeuGranada ohne näliere Angabe des Fundorts (Mus. Clark).

67. Sc. tripudians m. Rothgelb, die Fülılerenden und zwei Punkte des derb zer'streut punktirten IIalsschilds schwarz, die Deckschilde stahllhan mit purpurhläulichem Anfluge; die Punktstreifen deutlich mit flachen, gläızenden Zwischenräumen.

$\delta$ Der Kiel und der umgeschlagene Rand des Seitenlappens weiss, die Mitte des Hinterleibs breit geschwärzt;

q Seitenlappen und Hinterleib ohne abweichende Färbung.

L. $12 / 3-2 \frac{1}{3} " \prime ; \mathrm{Br}^{2}, 3 / 4-1^{\prime \prime \prime}$.

Dem vorlsergehenden sehr nahe verwandt, auch von gleicher Grösse, aber an der abweichenden Zeichnung und Sculptur des Halsschilds und dem rothen Schildchen von ihm leicht zu unterscheiden. Der Kopf flach mit sehr feiner Stirulinie, äusserst dicht und fein punlitirt, das etwas eingezogene Kopfschild mit zerstreuten gröheren Punkten besetzt. Die Farbe rothgello mit gebräunten Mundtheilen, die breit und tief ausgebuchteten, bei dem $\delta$ einander sehr genäherten, bei dem $q$ weit getremnten Augen schwarz. Die Fühler gebaut wie bei der vorhergehenden Art, die fünf unteren Glieder röthlich mit geschwärzter Oberseite, besonders des Wurzelgliedes, die folgenden ziemlich breit zusammengedrückt, schwarz. Das Halsschild reichlich doppelt breiter als lang, oben flach, die Nittelfirste hinter der Witte sehr leicht aufgebogen, der Vorderrand bis zu den scharf spitzwinkligen Vorderecken etwas eingeschmürt und dadurch das Halsschild verschmälernd, die Seiten fein gerandet, hinter der Mitte bogig erweitert und vor ihr leicht ausgeschweift, vor den scharf stumpfwinkligen Hinterecken deutlich nach unten eingezogen; der Hinterrand leicht doppelt ausgeschweift, das Mittelfeld vor dem kurzen Mittelzipfel sanft quer niedergedrückt und dann wieder jederseits längs dem Hinterrande durch einen flachen Schrägeindruck leicht wulstig emporgeschoben; ein zweiter, schwächerer Schrägeindruck ist noch jedlerseits vor der Mitte bemerkbar. Die Oberfläche grob zerstreut punktirt mit glänzendem Zwischengrunde, rein rothgelb; vor der Mitte jederseits ein rundlicher, etwas verwaschen begränzter, schwarzer Punkt. Das Schildchen stark schräg ansteigend, um die Hälfte breiter als lang, hinten mit ahgerundeten Ecken und grossem, flachem Hinterzipfel abgestutzt, aber wenig 
verschıälert, gleichfalls rothgelh mit dunklerem Saume. Die Deckschilde länglichviereckig, etwa um $1 / 3$ länger als breit, hinter der scharfen Wurzelkante loreit aber nur flach quer niedergedrïckt, auch hinter dem Schildchen flach rundlich eingedrückt; die grossen rundlichen Schulterbeulen inner'seits dur'ch einen tiefen Eindruck abgesetzl, die Seitenlappen breit zugerundet, und üher ihnen die Deckschilde eben so breit zusammengedrückt. Die Punktirung in deutliche Längstreifen geordnet, in die sich vorn zunächsı an Schildchen und Naht einzelne überzählige Punkte einmengen; hinter der Mitte werden die Streifen hesonders bei dem q plötzlich schwächer, und die mittleren sind anf der Wölbung fast ganz weggeschliffen. Die Zwischemränme flach, spiegelglänzend stahlblau, besonders auf der vorderen Uälfie ins Purpurblane oder Spangrüne spielend, auch wohl längs der Wurzel nit einem messinggrünlichen Schimmer. Pygidium, Unterseite und Beine rolhgell, Schienenenden und Fussglieder geschwärzl, der Sanm des llinterleibes etwas heller gell, der Hinlerleil) selbst bei dem ठ̋wischen diesem Saume lreit schwarz. Das letzte Segment des ơ einfach, des $\rho$ mit dem gewöhnlichen Grülschen.

Gleichfalls ans Columbien (Mus. Haag. Berol.; hei dem von Moritz mitgebrachten Stüclie des letzteren ist, wie bei der vorigen Art, Puerlo Cabello als Fundort angegehen), aus Neu-Granada (Mus. Clark).

69. Sc. Leucurus m. Oben bleich roth, Kopf, Schildchen, ein grosser Mittelfleck des zimulich dicht punktirten Halsschilds mit einem krenzflecke unıl dem Saume der Deckschilde schwarz. Das Pygidium weiss, unten wolkig gebräunt mit schwarz- und weissbunten Beinen; die Punktstreifen derb, wellig in einander gewirt, mit flachen glänzenden Zwischenrämmen. L. $13 / 4^{\prime \prime \prime}$; Br. $1^{\prime \prime}$.

Wie im Mlus. Berol. die beiden vorhergehenden Artrn, so ist in Mus. lirsch die vorliegende mit dem hekannteren, in manchen Stücken allerdings ähnlichen Sc. fallar vermengt worden, von dem sie sich aber, wie von jenen, anch algesehen von den Alweichungen in Färbung und Sculptur, sogleich durch die grossen, anl der stirn zusammenstossenden Augen des ơ unterscheidet. Her Kopf llach, bei dem allein vorliegenden of last ganz ron den durch eine schmale Aushuchtung sehr ungleich getheilten Augen eingenommen; der dreieckige Nackenzipfet mit dem unteren Theile der Stirn, den Angentuchten und dem wenig eingezogenen liopfschilde 
sehr dicht siebartig punktirt und der Unterkopf zugleich kurz angedrückt greishaarig; die Farbe schwarz. Die dünn fadenförmigen Fülıler von etwas über halber Irörperläuge, das zweite Glied kurz lugelig, das dritte drei - und das vierte viermal länger, das fünfte noch etwas verlängert und diesem das sechste gleich, die oberen sich allmählich verkürzend, so dass das zehnte wieder dem dritteı gleichkonmt; das Endglied mit seinem kurz kegelförmigen Fortsalze etwa dem achten gleich: dabei die oberen vom sechsten ab nach der Spitze zu schwach erweitert und zusammengedrückt. Die Farhe schwarz mil dümer greiser Behaarung der oberen Glieder, das erste und zweite auf der Unterseite breit geröthet, das dritte daselbst dunkler gebräunt. Das Halsschild breit abgeflacht, hinten leicht quer niedergedrückı, über den kurz und scharf zugespitzten Vorderecken zusammengedrückt und dadurch verschmälert; die Seiten breit gerandet, hinter der Mitte in einem stumpf abgerundeten Winkel rerbreitert und vor ihr sanft ausgeschweift; auch die Hinterecken scharf stumpfwinklig und mit einer kurz aufgebogenen Schwiele besetzt. Der Hinterrand jederseits des breit zugerundeten Mittelzipfels tief ausgebuchtet, und ron da ab nach Aussen ron einem breitrn, flachen Quereindrucke begleitet. Die Punktirung deutlich, auf der Mitte etwas feiner und sparsamer, seitlich gröber und dicht siebartig zusammengedrängt, mil besonders oben stark glänzendem Zwisehengrunde. Die Farbe eigentlich schwarz, das seitliche Viertel rechts und links hell rothgelb, nach den Seitenrïudern hin immer mehr ins verwaschen weisslichgelbe übergehend, und dieser breite Seitenrand zieht sich hinten mit einem schmalen schlecht begränzten Arme bis zum Mittelzipfel fort, so dass das schwarze Mittelfeld sich hier sehr merklich und bis zu seiner halben Breite verschıälert. Das Schildchen zienlich steil ansteigend, nicht röllig so lang wie vorn breit, hinterwärts stark verschmälert, kurz abgestutzt und vor dem Hinterrande sehr flach gekielt, äusserst fein punktirt und behaart, hinten etwas stärker glänzend, schwarz. Die Decksclilde um etwa $1 / 4$ länger als lreit, hinterwärts wenig verschmälert und dann kurz zugerundet; der Rücken flach, hinter der Mitte breit quer niedergedrückt und hinten mit schwacher Wölbung abfallend, der Nahtrand hinter dem Schildchen cin wenig aufgetrieben, die Wurzel hinter der scharfen Vorderkante ziemlich breit aber nicht tief quer eingedrückt. Die Schulterbeulen schmal, eckig heraustretend, die Seitenlappen hreit zugerundet, und äber ihnen 
die Deckschilde durch den sich hier herabsenkenden und flach ausbreitenden Quereindruck des Rückens etwas zusammengedrückt. Die Punktstreifen derb, längs der-Naht durch überzählige Punkte in einander gewirrt, auch die folgenden bis zu den Schulterbeulen hin etwas wellig gekrümmt, die äusseren hinter und unterhalb der Schulterbeulen regelmässiger, die Hinterenden überall schwächer, und die Spitze unter der Wölbung ganz glatt. Die Zwischenräume flach, bis über $2 / 3$ der Länge hinaus mehr oder weniger querrunzlig, und diese Runzeln vor der Mitte steltenweise zu deutlichen Querrücken verfliessend. Die Farbe ein bleiches Rothgelb, an den Rändern ins Weissliche abgeschwächt, ein feiner Aussen- und Spitzensaum der Deckschilde und eine gemeinsame, hinter der Nitte liegende Querbinde schwarz; eben so die Naht schwarz gesäumt, und dieser Saum zwischen der Binde und dem Schildchen zu einer breiteren, verwaschen begrïnzten Nahtbinde erweitert. Das oben schmal schwarz gesäumte Pygidium mit dem vorletzten Rückenringe und einem breiten Rande des Hinterleibes schmutzig weissgelb, die Mitte des letzteren trüb- und schmutzig geröthet, die Hinterbrust braun, die Mittelbrust und das leicht doppelt eingerlrückte Prosternum wieder röthlich gelb. Auch die Hüften röthlich gelb, die Vordersehenkel mit der Aussenseite der Vorderschienen und deren Fussgliedern schwarz mit bräunlich durchscheinender Wurzel der letzteren, die Innenseite der Schienen weisslich. Mittel - und Hinterbeine weiss, die Schienen auf der unteren Hälfte der Aussenseite geschwärzt, und die Schenkel auf der abgerundeten Aussenkante mit einem schwarzen Längsfleck, welcber in der Nitte auf die beiden breiten Schenkelnächen übergreift. Das letzte Segment des ơ einfach; das of unbekannt.

Von Bogota (Mus. lírsch).

69. Sc. diabolicus m. Schwarz, unten dicht greishaarig, Fülılerwurzeln, Seiten und Hinterrand des grob punktirten Halsschilds, Schulterblätter und Bauchseiten roth; die Punlistreifen fein, vorn gestört, von der Mitte ab fast erloschen. L. $2^{\prime \prime \prime}$; Br. $1^{\prime \prime \prime}$. Aus der nächsten Verwandtschaft des mittelamerikanischen Sc. Hontezuma und Cazicus m. (Linn. Ent. VII. S. 116 u. 119), aber voṇ beiden ausser andern Merkmalen sogleich an dem gänzlichen Mangel weisser Zeichnungen zu unterscheiden. Der Kopf flach mit etwas zurücktretender Stirn und sehr undeutlicher Stirnlinie, das Kopfschild oben durch eine feine Querlinie begränzt. Die 
Punktirung oben sehr wenig bemerkbar, weiter unten deutlicher, besonder's in den Augenbuchten gedrängt, auf dem Kopfschilde derb und dabci ziemlich diclıt. Die Farbe glänzend schwarz, die Mundtheile pechbraun, die dunklere Oberlippe gelblich gesäumt. Die Fühler wenig über den Hinterrand des Halsschilds hinausreichend, oben deutlich znsammengedrüclit und verbreitert, das zweite Glied knotig, das dritte doppelt länger und die beiden folgenden noch mehr zunehmend, die oberen etwa dem fünften gleich. Die unteren fünf durchscheinend rothgelb mit geschwärzter Oberseite des Wurzelgliedes, die oberen sclıwarz. Das Halsschild reichlich doppelt breiter als lang, flach gewölbt, üher den spitzen Vorderecken zusammengedrückt und dadurch verschmälert; die gerandeten Seiten in der Mitte bogig erweitert, vor ihr fast gerade, die Hinterecken stumpf abgerundet, der Mittelzipfel nur schwach, und auch die seitlich vor ihm liegendeu Schrägeindrücke nur seicht und daher wenig bemerkbar. Die Punktirung grob, oben mehr zerstreut, seitwärts besonders zwischen dem Schırigeindrucke und dem Hinterrande dichter zusammengedrängt, mit glänzendem Zivischengrunde. Die Farbe roth, der Vorderrand und ein an diesen angelehnter halbkreisförniger, hinten bis über die Mitte hinausreichender, den Zivischenraum der Augen an Breite etwas übertreffender Fleck schwarz. Das Schildchen schräg ansteigend, kurz und breit viereckig, hinterwärts etwas verschmälert, mit deutlichem Hinterzipfel, dicht und fein punktirt, schwarz. Die Deckschilke länglich viereckig, kaum $1 / 4$ länger als breit und hinterwäts wenig verschmälert, jeder'seits aın Schildchen und danı wieder iuner'seits der flach höckerigen Schulterbeulen eingedlrückt, die Wurzelkante scharf erhöht, die Seitenlappen kurz und breit, und üher ihnen die Deckschilde leicht zusammengedrüclit. Die Punktstreifen fein, yorı durch überzählige Punkte getrübt, von der Mitte ab fast erlosehen, nur die beiden äusseren regehmässig und fast bis zur Spitze dentlich. Die flachen Zwischenräume glatt und glänzend, nur die äusserste Spitze unterhalb der Wölbung durch feine Runzeln etwas matter. Die Farbe kohlschwarz. Das Pygidium fein punktirt, dicht greishaarig, matı schwarz, nur die obere Hälfte des erhöhten Seitenrandes und ein von diesem jederseits in die Fläche selbst hileintretendes Längsfleckchen leicht röthlich. Unterseite und Beine gleichfalls fein runzlig punktirt, schwarz, und licht angedrückt silberhaarig, nur die Schulterbätter und die Seiten der Bauclıringe 
vom zweiten ab hell .röthlich. Die Vorderschenkel stark aufgetrieheu uist entsprechend gekrümmten Schienen; das Prosternum flach, hinter den Vorderhüften quer nielergedrückt und dann liurz alogerundet. Das letzte Segment des $q$ mit einer tiefen halhkugeligen, an den Seiten etwas niedergednücliten Grube, das $\delta$ mulekamnt.

Aus. Südamerika, und angeblich aus Brasilien (Mus. Petrop.); jch möchte jedoch eher vermuthen, dass der Käfer in Columbien zuI Ilause ist.

70 Se. scutatus m. Schwarz mit knochengelber Oherlippe, das dicht siebartig punktirte mit einem schwarzen Schildfleck gezeichnete IIalsschild, eine abgekïrzte Qurrhinde und die Spitze der Flügeldecken, sowie die Säume des Pygidiums und des Hinterleibs ziegelroth; die Punktstreifen his über die Miite durch überzählige Punkte getrüht, mit flachen, glänzenden Zwischenräumen. L. ${ }^{3 / 4}{ }^{\prime \prime}$; Br. I"'.

Von dieser Art kann ich zwar nur ein einziges und nicht sonderlich erhaltenes Stück rergleichen; dasselbe ist jedoch durch seine Farbenvertheilung so ausgezeichnet, dass ilıre Sellostständigkeit keinem Bedenken unterliegen liann. Der liopf Hach, ohne Stirnlinie, mit stark eingezogenem Kopfsehilde, fein aber dicht punklirt, matt schwarz, die (bei denı o) ziemlich weit getrennten, dreieckig ausgehuchteten Augen grreis, Oberlippe und Mundtheile bis auf die schwarzen Kinnhacken lnochengell, mit gelıäunten Tasterenden; von den Fühleru nur das röthliche, auf der Oberseite mit einem schwärzlichen Längswische gezeichnete Wurzelglied vorhanden. Das Halsschild etwa $2 \frac{1}{4}$ mal loreiter als lang, mit sehr sauft anfgebogener Mittelfirste, üher den scharf spitzwiuliligen Vorderechen zusammengedrückt und dadurch verschmälert, die sehr fein gerandeten Seiten in der Mitte in stąrkem Bogen erweitert, vor ihr ausgeschweift, die sumpfwinliligen Hinterecken mit einer scharten, aufgebogenen Schwiele besetzt, der Hinterrand jederseits leicht gesehweift, mit lreitem, liräftig aufgebogenem Mittelzipfel. Dip Oberfläche fein aher sehr dicht siebartig punktirt, mit wenig glänzendem Zwischengrunde; die Farhe zirgelroth, der abgesetzte, in den Vouderecken erweiterte Vordersaum und ein auf dem Vorderrande ruhender, hinten mit geschweiften Seiten zugespitzter, die Gestalt rines Wappenschildes zeigender, den Hinterrand aher nicht herührender Fleck schwar\%. Das Schildchen sehräg ansteigend, nicht so lang als voru breit, mit deutlich dreieckigem, fach nie- 
derliegendem Hinterzipfel, gleichfalls dicht und fein punktirt, schwarz. Die Deckschilde um 1/4 lïnger als breit, hinterwärts etwas verschmälert, auf dem Rücken abgeflacht, mit seicht abfallender Wölhung, hinter der scharfen Vorderkante breit quer eingedrückt, mit rclig heraustretenden Schulterbeulen und kräftigen Seitenlappen, über letzteren die Deckschilde schräg zusammengedrückt. Die Punktirung deutlich und erst auf dem letzten Drittel ahgeschwächt, bis über die Mitte hinaus dicht gedrängt, so dass nur stellenweise Andentungen abgerissener, verdoppelter und durch üherzilllige Punkte getrübter Punlitstreifen lienntlich werden; der achte und neunte fast ilırer ganzen Länge ıach kenntlich, die übrigen erst von der Yitte ah allmählich sich cntwickelnd. Der Zwischengrund vorn schıächer-, hinterwärts bei deutlicher sich gestaltenden Zwischenräumen stärlier glänzend, der zweite und vierte den ganzen Rücken entlang als flach erhöhte feine Rippen sichthar, der neunte sehr leicht aufgewölbt. Die Farbe auch hier schwarz, ein ziemlich grosser rundlicher Spitzenfleck und eine abgekürzte schmale Querhinde vor der Mitte jeder Flügeldecke dunkel ziegelroth; die letztere reicht rom achten bis zum zwciten Punlitstreifen, und ihr Innenende ist durch den erhöhten zweiten Zwischenraum als ein vereinzeltes rothes Fleckchen ahgetrennt. Das Pygidium dicht und fein runzlig punktirt, schwarz, mit breit ziegelrothem Saume; Unterseite und Beine schwarz mit dünner greiser Behaarung, der Saum des Hinterleihes gleichfalls ziegelroth, die Hüften und Schienenenden, an den Ifittel - und Hinterbeinen auch die Unterseite der Schienen trüb geröthet. Das letzte Segment des $q$ mit einem grossen balbkugeligen Grübchen, das ơ unbekaunt.

Von Caraccas (Mus. Schaufuss).

71. S c. cazicus m. Schwarz, Unterseite und Beine weissbunt, ein viereckiger Vorderfleck der Deckschilde und der Schulterrand weiss, das dicht und grob punktirte Halsschild und ein runder Fleck des Unterkopfes roth; die Punktstreifen grob mit ziemlich flachen, glänzenden Zwischenräumen. L. $15 / 6{ }^{\prime \prime \prime}$; Br. $1{ }^{1} / 3^{\prime \prime \prime}$.

Scolochrus cazicus Suffr. Linn. Enı. VII. 119. n. 8!

Dieser mittelamerilianische Käfer findet sich auch in NeuGranada, von wo sich ein von dem beschriebenen $q$ nur durch den einfachen letzten llinterleibsring verschiedenes ơ im Mus. Clark befindet.

72. Sc. leucopygus m. Schwarz, die Hinterhälfte des dicht 
und groh punktirten Halsschilds ziegelroth, der unterbrochene Vorder- und Seitenrand nebst einem Spitzenflecke der Flügeldecken, den Seiten des Pygidiums und des Hinterleibes weiss; die Punktstreifen grob, vorn durch dicht eingemengte Punkte getrübt, hinten mit flachen, kaum querrunzligen Zwischenräumen.

$\delta$ mit einem rundlichen weissen Fleck an Unterkopfe, wo derselbe auch noch die obere grössere Hälfte des Kopfschildes einschliesst.

q Kopf schwarz.

L. $11 / 2-2^{\prime \prime \prime}$; Br. $1-11 / 6^{\prime \prime \prime}$.

Den vorhergehenden ähnlich, noch näher aber dem dort genannten mexicanischen Sc. Montezuma m. verwandt, und von letzterem hauptsächlich durch die ganz schwarzen Beine und den weissen Spitzenfleck der Flügeldecken abweichend. Der Kopf flach, grob und dicht punktirt, mit deutlicher Stirnrimne des o; die Farbe glänzend schwarz, hei dem ठे mit einem ziemlich grossen rundlichen weissen Flecke auf dem Unterkopfe und der oberen Hälfte des Kopfschilds; die Oberlippe schmutzig gebrïunt mit verwaschen geröthetem Rande. Die grossen, tief ausgebuchteten Augen bei dem $\delta$ fast zusammenstossend, bei dem o durch einen weiteren Zwischenraum getrennt. Die Fühler des ठ゚ von mehr als halber Körperlänge, das Wurzelglied schwarz und die nächstfolgenden pechbraun, bri dem $q$ das zweite heller röthlich mit gebräunter Oberseite, die folgenden dunkler; die oberen bei beiden Geschlechtern schwarz, dabei nur wenig zusammengedrückt und verbreitert. Das Halsschild doppelt breiter als lang, über den spitzen Vorderecken zusammengedrüclit und dadurch merklich rerschmälert, die gerandeten Seiten in der Mitte wenig erweitert und vor ihr nur leicht ausgeschweift. Die Hinterecken scharf, der Hinterrand doppelt gehuchtet, mit kurz aufgebogenem Mittelzipfel, vor diesem das Mittelfeld schräg abwärts gesenkt, und jederseits ein schräg nach vorn und aussen ziehender, anfangs schmaler und tiefer, nachher sich verbreiternder und verflachender Eindruck. Die Punktirung dicht und grob mit glänzenden Zwischengrunde, die Farbe schwarz, die hintere Iälfte ziegelroth, so dass die Begränzung dieser vom Schildchen fast bis zur Mitte reichenden Färlung von hier jederseits schräg nach vorn und aussen zieht, und dadurch rorn nur etwa der dritte Theil des Aussenraudes schwarz bleibt. Das Schildchen quer viereckig, halb so lang wie rorn breit und hinterwärts wenig ver- 
schmälert, sehr steil ansteigend, mit kurz und breit dreieckigem, auf der Mitte gekieltem, flach niederliegendem Hinterzipfel; gleichfalls sehwarz. Die Deckschilıle hreiı und flach gewölbt, länglich viereckig, um $1 / 3$ länger als breit, hinterwärts wenig verschmälert und zuletzt kurz zugerundet. Der Rücken hister der scharf erhöhten Vorderkante quer eingedrïckt, die Schulterbeulen sehr breit, flach abgerundet, die Seitenlappen tief herabgezogen und über ih-. nen die Deckschilde etwas zusammengedrückt; auch die Naht vom Schildchen ab der Länge nach seicht niedergedrückt. Die Punktirung grob, die Streifen auf den beiden ersten Dritteln durch überzälılig eingemengte Punkte von gleicher Stärlie fast ganz verdunlielt, so dass nur-die drei äussern überall kenntlich sind, wälırend die Rückenstreifen kaum anders, als sofern sie zwei über jede Flügeldeclie hinziehende flache Längsrippen begleiten, sichtbar werden. Auf dem letzten Drittel bleiben jene eingennengten Punkte allmählich zurück, und erst auf der Wölbung sind alle Streifen erkennbar, aber auch fast ganz abgeschliffen. Der Zwischengrund vorn glänzend, linterwärts nach der Bildung dentlicher, flacher Zwischenräume fein querrunzlig und dadurch etwas matter. Die Farbe schwarz, ein Querfleckchen auf der scharfen Vorderkante innerseits der Schulterbeule, der Kiel des Seitenlappens und Aussenrandes von der Schulter fast bis zur Wölbung, und eine mit jenem an der Schulter zusammentreffende Läıgslinie •auf dem neunten Zwischenraume lackweiss, eben so ein von einem zarten schwarzen Saume umzogener Spitzenfleck unter der Wölbung. Das Pygidium fein punktirt und dicht greishaarig, jederseits oben am Rande breit eingedrückt, schwarz, an den Seiten breit weiss gesäumt. Auch die Unterseite fein punktirt, kurz silberhaarig, schwarz; die Seiten des letzten Bauchringes bei dem $\delta$, aller Ringe vom Hinterrande des ersten Bauclıringes an bei dem $q$ breit weiss, die Mitte vom Hinterrande des letzten Ringes mit den Beinen schwarz. Letztere selır schmal und dünn, nur die Vorderschenkel ziemlich aufgescliwollen mit stark gekrümmten Vordersclienen. Das letzte Segment des $\delta$ einfach, des $q$ mit einer grossen, rundlichen Grube.

Aus Brasilien (Mus. Dohrn. Lacordaire. Deyrolle. Berol. Clark; in letzterem Minas als Fundort genannt).

73. Sc. perlatus 0liv. Schwarz, eine Mittellinie des diclut siebartig punktirten Halsschilds, der Kiel des Seitenlappens, drei Flecke der Flügeldecken $(1,1,1$.) mit einem hreiten Saume des 
Hinterleibs und Pygidiums weiss; die Punktstreifen mässig, vorn etwas gestört, mit flachen, ziemlich glänzendeı Zwischenräumen.

đo liopf und die schmalen Ränder des Halsschilds nebst der Aussenkante der Ilinterschenkel weiss;

q der Kopf und die breiten Seiten des Halsschilds roth, die Beine ganz schwarz.

L. $2-3^{\prime \prime \prime} ;$ Br. $1-1 \frac{1}{2}{ }^{\prime \prime \prime}$.

Cryptocephalus perlatus Oliv. Ent. V1. 825. n. 69. tab. 6. fig. 99. (das $q$ ).

Eine hïbsche bunte, anscheinend aber seltene und mit den beilen folgenden leicht zı verwechselnde Art. Der Kopf bei dem $\delta$ weiss, ins bleich röthliche fallend, die Stirn grösstentheils durch die einander oben berührenden Augen eingenommen, bei dem $f$ grob zerstient punktirt, mit deutlicher Stirnrinne, ziegelroth; nur der Nacken und der Unterrand des Kopfschilds mit Kimbacken, Oberlippe und Tasterenden schwärzlich. Die Fühler schlank und ziemlich kräftig, die Glieder vom vierten ab fast von gleicher Länge, die Farbe schwarz, die unteren unterseits und an der Wurzel und Spitze etwas ins Röthliclıe fallend. Das IIalsschild doppelt breiter als lang, mit algeflachtem Rücken, hinten etwas niedergedrückt, die Vorderechen scharf spitzwinklig, das Halsschild über ihnen sehr breit zusammengedrückt mol dadurch nach vorn stark-, fast kegelförmig verschmälert, die Seiten in breitem und flachem Bogen zugerundet, dic Hinterecken stumpfwinklig in den nur leicht gebuchteten Hinterrand ühergehend, und ror dem Mittelzipfel jederseits ein breiter, flacher Quereindruck, durch ten sich, der aufgeworfenen Vorderkante der Flügeldecken entsprechend, vor derselben ein leichter Querwulst emporschiebt. Die Punlitirung ron mässiger Stärke, dicht siebartig zusammengedrängt mit glatter Mittellinie und glänzenden Zwischengrunde. Die Farbe den breiten Rücken entlang schwarz, die Mittellinie auf der grösserı Vorderhälfte weiss, etwas ins Gelbliche fallend. Die Seiten bei llem of schnal weisslich, bei dem $q$ hreit ziegelroth, so dass hei letzterem die Breite dieses Randes der des schwarzen Mittelfeldes glcichliommt, zuweilen gar diese Seitenfärhung längs dem Hinterrande naclı der Nitte zu übergreift, und dadurch deren schwarze Fürhung auf die Länge der weisslichen Mlittellinie beschränlit. Dadurch entsteht eine Zeichnung, manchen Formen des Sc. fallax älılich, aber von letzterem immer noch an der dichten Punktirung des stälier verschmïlerten 
Halsschilds und der abweichenden Lage"der Flecke auf den Flügeldecken zu unterscheiden. Das Schildchen stark ansteigend, quer viereckig und hinterwärts verschmälert, mit ahgerundeten Ecken und deutlichem Hinterzijfel quer abgestutzt, fein punktirt und glänzend schwarz. Die Deckschilde breit und flach gewöllt, vor'ı hesonders hei dem of lreiter als das Halsschild, länglich viereckig und reichlich um $1 / 3$ länger als breit, hinter der scharfen Wurzelkante leicht quer eingedrückt, auch hinter den grossen rundlichen Schulterbeulen über den breiten Seitenlappen zusanmengedrückt; die Punktstreifen vorn kräftig und durch überzählig eingemengte Punkte von gleicher Stärlie verdunkelt, von der Mitte ab deutlicher aber auch feiner, hinten fast abgeschliffen, mit flachen glänzenden Zwischenräumen. Die Farbe reiı sclıwar', der Kiel des Scitenlappens weiss, und dieselbe Färbung, aher mehr ins Gelbliche und bei dem $q$ manchmal selbst ins Röthliche fallend zeigen drei aul jeder Flügeldecke in eine Längsreilie gestellte Flecke, der vordere im Nahıtwinkel am Schildchen, etwas schräg hinterwärts in die länge gestreckt, der zweite ein Querfleck auf der Mitte, von dem bei einzelnen Stücken mur das innere Ende vorhanden ist, und ein kleiner rundlicher Fleck im Nahtwinkel unter der Wöllung. Auch das l'ygidium weiss, ohen nit einem breiten schwarzen Querflecke. Unterseite und Beine schwarz mit einem breiten weisslichen Rande des Hinterleibes, die Hüften, und of anch der hintere Theil der Hinterbrust nelıst dem flachen, linten kurz zugerundeten Prosternum bräunlich, bei $\mathrm{d} \mathrm{cm}$ o die Ilinterschenkel mit einem gestreckten weissen Längsflecke aul der Aussenkante, auch wohl ins liöthliche fallenden Schienen. Das letzte Segment des ơ leicht quer eingedrückt, des $q$ mit einem ln'eiten rundlichen Grülschen.

In Französisch-Guyana (Olivier; auch im Mus. Clark) und Surinam (voll Paramaribo: Mus. Dohrn).

74. Sc. triguttatus Fab. Schwarz, Fühlerwurzeln, Vorderschienen und Füsse rothgell, Stirn, Mittellinie und Sciten des derl) zerstrent punktirten Halsschilds nebst drei Flecken auf jeder Flügeldecke $(1,1,1$.$) , dem Pygidium und dem Rande des Ilinter-$ leibes weiss; die Punktstreifen vorn deutlich, hinterwärts abgeschwächt, mit flachen, glänzenden Zwischenräumen. L. 11/3"'; $\mathrm{Br}, 3 / 4, "$.

Cryptocephalus trigultalus Fab. Syst. Eleuth. II. 55. n. 79.

Dem $\delta$ der vorhergehenden und einzelnen Formen von dem $ठ$ 
des unten folgenden $S c$. fallax (vergl, dessen var. $\beta$ ) zwar sehr ähnlich, aber doch nach meinem Bedenken ron beiden hinreichend verschieden. Das einzige mir vorliegende $q$ ist nicht nur bedeutend kleiner als selbst die (an sich schon lileinen) $\delta$ der beiden genannten Arten, sondern zeigt auch in der Zeichnung nur Aehnlichkeit mit liesem $\delta$, während es von den $q$ beider Arten sehr weit abweicht. Von letzterer unterscheidet er sich sogleich durch den Mangel jeglicher rother Färbung auf der Oberseite und den Mangel des weissen Kiels am Seitenlappen, durch die in der Mitte durch einen schmutzig geschwärzten Querwisch unterbrochene weisse Färbung der Stirn; daneben von dem $q$ des Sc. perlatus durch die zerstrentere aber etwas gröbere Punktirung des Halsschilds, die regelmässigeren P'unktstreifen der Flügeldecken, und die Stellung des mittleren weissen Flecks, welcher aus der graden Linie heraus nach aussen gerückt und an den neunten Streifen gelehnt ist, endlich durch die Gestalt dieses und des Vorderflecks, von denen jener ungeachtet seiner Grösse nicht in die Quere gezogen ist, währenl der letztere sich als Querfleck vom Schildchen fast bis zur Wurzel ausdehnt. Vou dem $q$ des Sc. fallax dagegen untersclieidet sich der Käfer hesonders durch den grossen Vorderfleck der Flügeldecken, die schwarze und nicht rothe Färlung von Unterseite und Schildchen, die regelnässigeren Punlitstreifen und das nach vorn viel stärker verschmälerte Halsschild, desselı grösste Breite, wie bei Sc. perlatus, nahe vor dem Hinterrande, und nicht wie bei Sc. fallax in der Mitte liegt. Mit den $\delta$ der genannten Art ist schon der weit getrenuten Augen wegen keiue Verwechslung möglich. Das letzte Segment des $q$ mit einem schwachen, rundlichen Grübchen.

Von Caraccas (von Hrn. Wagner mitgetheilt).

In Fabricius' eigner Sammlung fehlı die ron ihm ans del Lund'schen Sammlıng mil der allgemeinen Vaterlandsangabe Americ. merid. beschriebene Art. Die Beschreibung: "Parrus. Caput nigrum, punclo fronlali el verticali albis. Thorax laevis, aler, nitidus, margine exleriori, linea dorsali abbreviala albis. Elytra subpunclala atra, punclis 3 albis, uno pone alterum. Abdomen atrum, margine albo. Fenora basi albu" passljedoch sehr gul zu dem vorliegenden Kafer, namentlich lasss sich das von der Färbung der Stim Gesagle nur auf ihn allein von den Verwandten anweuden, und die Femorn basi alba mögen auch bei einzelnen Stücken vorhanden seiu: bei dem mir vorliegenden sind dieselben nil den Hüften schmutzig geröthet. Am wenig- 
sten dürfen F. Angaben über die Sculptur Bedenken erregen, da er in solchen Angaben namentlich bei kleineren Insecten sebr oft ungenau ist.

75. Sc. fallax Moritz. Rothgelb mit oft gebräunter Unterseite, der Saum des Hinterleibes und der Kiel des Seitenlappens weiss, die Flügeldecken und manchmal auch zwei Flecke des ziemlich derb zerstreut punktirten Halsschilds schwarz, meist nit weissen Flecken der ersteren; die Punktstreifen vorn gestört, hinterwärts erloschen, mit flachen glänzenden Zwischenräumen. L. 11/2 $-2 \frac{1}{2}{ }^{\prime \prime \prime}$; Br. $1-1 \frac{1}{3}{ }^{\prime \prime \prime}$.

Eine höchst veränderliche, in den Sammlungen nach ihren Formen auch unter den Namen Lebasii Dj., 4 guttalus Gory, quadrillum Chv. und nigripennis Moritz vorkommende Art, von welcher alle Abänderungen in eine einzige, die Art vollständig und kenntlich umgränzende Diagnose zusammenzufassen man gradezu als eine Sache der Unmöglichkeit bezeichnen möchte. Es bleibt deshalb nur übrig, zuerst das Allgemeine ohne Berïcksichtigung der Färbung und Farbenvertheilung zu geben, und nachher die Modificationen der letzteren besonders zusammenzustellen. Der Kopf flach, die Stirn bei dem $\delta$ durch die oben fast zusammenstossenden, nur durch einen schmalen Zwischenraum getrennten Augen sehr verengt, bei dem $q$ breit, bei beiden von einer feinen Längslinie durchzogen, das Kopfschild nur seitlich ziemlich deutlich begränzt und am unteren Rande eingezogen, mit wieder vortretender Oberlippe. Die Puuktirung grob und ziemlich dicht, mit lackglänzendem Zwischengrunde. Die schmal aber ziemlich tief dreieckig ausgebuchteten Augen greis. Die Fühler des $\delta$ etwa von halber Körperłänge, des + etwas kürzer, das Wurzelglied kurz eiförnnig aufgetrieben, um mehr wie die Hälfte länger als breit, das zweite noch kürzer eiförmig, halh so breit und fast dreimal kürzer als das erste, die drei folgenden gestreckt kegelförmig und merklich verlängert, so dass das dritte dem ersten, das vierte dem zweiten und dritten zusammen gleichkommt; das fünfte noch etwas länger, das sechste dem fünften gleich, nebst den folgenden zusammengedrückt und erweitert, die oberen allmählich wieder abnehmend, so dass das zehnte kaum noch die Länge des dritten erreicht, und das Endglied mit seinem kurz und stumpf dreieckigen Fortsatze nur wenig über das zehnte hinausreicht. Die Farbe der fünf unteren bei dem $\delta$ rothbraun mit mehr oder weniger geschwärzter Ober- 
seite der zwei oder drei unteren und tiefer gebräunter Spitze des fünften; bei den $q$ ist die Färbung gewöhnlich heller, und erst das sechste Glied zeigt sich bräunlich: die oberen bei beiden schwarz. Das Halsschild flach, doppelt breiter als lang, hinten breit quer niedergedrückt und davor mit der Mittelfirste liaum merklich aufwärts gekrümmt, über den tief eingezogenen, pfriemlich zugespitzten Vorderecken stark zusammengedrückt und dadurch verschmälert; die Seiten selı fein gerandet, in der Mitte in schwachem Bogen rerbreitert und vor ihr leicht ausgeschweift; dic Ilinterecken stumpf alggerundet und nur durch eine lileine Schwicle angedeutet, der Hinterrand schwach doppelt gebuchtet mit wenig vortretendem und schwach aufwärts gekrümmtem Mittelzıpfel. Hinter der Hitte jederseits ein leichter Schıägeindruck, dessen Hinterende sich in der niedergedrückten Fläche vor dem Mittelzipfel verliert. Ilie I’unktirung derh, ziemlich zerstreut, nit glänzendem Zwischengrunle, die Farbe ein verwaschenes, seillich besonders in den Vorderwinkehı ins Bleichgelbliche fallendes Ziegelıoth, bei dem $\delta$ gewöhulich mit schwarzer, zım Theil sehr überhand nehmender Zeichnung. Das Schildchen stark ansteigend, quer viereckig und hinterwärts verschmälert, mit abgerundeten Ecken unıl grossem Hinterzipfe] algestutzt, bei dem $\delta$ gewöhnlich weisslich, dem of ziegelroth, manchmal mit bleicherem IIinterrande, aber auch andrerseits durch Braun zum Schwarzen sich verdunliehıl. Die Deckschilde länglich vierechig, ziemlich gleichbreit, etwa ımı 1/4 länger als breit, hintẹ der scharfen an dic breiten und flachen Schulterbeulen angeschlossenen Vorderkante tief quer vingedrückı, übrer den kurzen Seitenlajpen zusanmengedrüclit; der Rucken flach, seitlich und hinten kurz abwărts gelirümmt. Die Punktirung deutlich, lıei dem ơ vorn zwischen Naht unt Schulterbeulen dicht gethïngt und daher nur Audeutungen von Streilen zrigend, nach aussen aber ausser dem Randstreifen noch deren drei deutlich ansgebildet; rom zweiten Drittel der Liinge ah treten die Streifen auch auf dem Rüclien immer deutlicher hervor, so dass auf der hinteren IIailfte die normalen Streifen kenutlich werden, aber auch almählich sich his zum Verschwinden abschwaichen. Bei tlen $q$ ist the P'unktirung ron der Wurzel ab schwächer, dir Streifenbildung aher auch weniger gestört, nur stellenweise durch Vertoppelung verwirrt, und auf der Wölbung fast ganz verschwunden. Der Zwischengrund vorn leicht gerunzelt, hinten wo er sich zu regehmissigeren Zwischenräumen 
streckt, glatt und glänzend. Die Farbe ein reines, schönes Schwarz, die Seitenlappen und bei dem $\delta$ eine über ihnen je auf dem neunten Zwischenraune liegende liüzere Längslinie weiss; auch meist die Deckschilde mit mehr oder weniger ausgedehnter weisser Zeichnung. Das Pygidium feiı runzlig punktirt, dünn behaart, bleich rötlılichoder weisslich gelb, am oberen Rande inanchmal mit einem dunkleren Querschatteu. Die Unterseite gleichfalls fein runzlig punktirt, dünn greishaarig, gelbroth, braunroth oder schwarzbraun, selbst bis zum fast Schwarzen verdunkelt, mit breit weisslichgelb gerandetem Hinterleibe. Die Beine in verschiedenen Alstufungen weisslich gelb-, rothbraun- und schwarzbunt, die Fussglieder fast immer sclıwarz mit lieller geringelten Wurzeln. Das Prosternum runzlig punktirt, laug greishaarig, in der Mitte der Länge nach seicht niedergedrückt, hiuten breit zugernudet. Das letzte Segment des $\delta$ leicht quer niedergedrückt, das + mit eiuer rundlichen, verhältnissmässig kleinen Grube.

Hinsichtlich seines Farbenzeichuung koummt der Käfer, wie schon bemerkt, in einer Reihe von Abänderungen vor, deren Extreme von einander sehr auffallend verschieden sind, aber durch kaum merkliche Uebergänge mit einander verbunden werden. Ich habe von denselben folgeude vor mir:

a. Der Kopf weiss, das Halsschild schwarz, seine Seiten (bei einem Stücke auf der rechten Seite unterbrochen) sowie der Vorderrand weiss, die Mitte mit einem abgerissenen Längsfleckchen; eben so der Kiel des Seitenlappens, ein quer gezogener Mittel- und ein Hinterfleck der Flügeldecken nebst dem Pygidium und dem Rande des Hinterleibes weiss. Das Schildchen schwärzlich, an den schwarzen Beinen die WVurzeln der Vorderschenkel gebräunt, und die Hinterschenkel weissbunt; die Unterseite selbst schwarz. ठ.

$\beta$. Eben so; aber der Mittelfleck des Halsschilds rerlängert sich zu einer vorn abgekürzten Läugsbinde, die sich zuweilen mit verwaschen röthlichem Scheine jederseits am Hinterrande etwas ausbreitet. Auch die Hinterecken des Halsschilds fallen leicht ins Röthliche, und diese Färbung dehnt sich auf dessen Unterseite von den Hinterecken bis gegen die Hüften hin aus. Auf den Flügeldecken zeigt die Wurzclkante manchmal ein weisses Querfleckchen. das Schildchen weiss. ठ.

$\gamma$. Eleen so ; der Seitenrand und die Mittelbinde des Halsschilds breiter, stärker geröthet; ersterer jelerseits am Hinterrande lıakenXVI. 
förmig nach Jnnen gebogen und sich verwaschen an das Hinterende der Mittelhinde anschliessend. Auf den Flügeldecken fehlt zwar das weisse Wurzelfleckchen, dagegén dehnt sich diese Färbung an den Hinterschenkeln aus, die Hinterschienen färben sich bleich rötlılich, und auch an den Wurzeln der Mittelschenkel kommt ein weisses oder röthliches Fleckchen zum Vorschein. $\delta$.

$\delta$. Kopf, Beine und Flügeldecken wie bei $\gamma$, nur mit allmählich sich vergrössernden Flecken der letzteren; auf dem Halsschilde aber schreitet die Ausdehnung der immer mehr ins Rotlsgelbe übergehenden lichten Färhung soweit fort, dass dasselbe ganz weissgelb oder rothgelb mit zwei grossen schwarzen, vom Vorderrande ausgehenden, auch wohl mit dem Hinterrande sich nach Aussen krümmenden Längsflecken erscheint. Das Schildchen auch hier weiss (ठ). Von hier aus geht nun die Varietätenbildung in zwei entgegengesetzten Richtungen weiter; auf der einen Seite schwinden die weissen Zeichnungen der Flügeldecken, besonders der Mittelfleck immer mehr, und auf dem Kopfe tritt ein schwarzer Nackenfleck hervor, wälırend auf der Unterseite sich die weisse Färbung immer mehr ausdelınt, immer mehr ins Röılliche übergehı, zuletzt auch Mittel-und selbst Vorderbeine ergreift (alles $\delta$ ), bis zuletzi

$\varepsilon$. der Mittelfleck der Flügeldecken ganz schwindet, und letztere bis auf den Spitzenfleck und den Kiel des Seitenlappens schwarz erscheinen. So lange das Schildchen weiss ist, bleibt auch die Färbung des Halsschilds bleich röthlich, am Rande.der schwarzen Flecken noch immer ius Weissliche fallend, so bald aber das Schildchen durch Roth allmählich ins Schwärzliche übergeht, dunkelt sich auch das Roth des Halsschilds, das Weiss an Kopf und Beinen geht ins Ziegelrothe über, und zuletzt hreitet sich der schwarze Nackensaum so weit aus, dass er fast den ganzen oberen Theil der Stirn einuimmt. ( $\delta$ ₹). Bei einem vereinzelteu hierher gehörigen $\delta$ ist der Mittelfleck nur noch auf der rechten Flügchdecke deutlich, auf der linken fast geschwunden, eben so ist der Kiel des Seitunlappens mit den Beinen schwarz, das Halsschild ziegelroth, das Schilılchen bräunlich. ILieran schliesst sich dam

$\zeta$. eine etwas seltsam aussehende Form: Kopf, Beine (zuweilen mit geschwärten Schienenenden und Fussgliedern), Schildchen und Halsschild einfarbig ziegelroth, letzteres zuweilen noch mit unregelmïssigen weisslichen Wolkentlecken, bei einem Stücke im Mus. 
Hal. 'mit zwei unscheinbaren schwarzen Pünktchen neben einander auf ler Mitte; Oberlippe, Seitenlappen, Pygidium und Saum des gleichfalls rothen Hinterleibes weiss ( $q$ ). Hierher gehört Pachybrachys humeralis Stål Till lïännedomen etc. in der öfversigt etc. S. 61. n. 1!, welchen Namen ich jedoch nicht habe beibehalten mögen, weil er bedeutungslos und überdem schon mehrfach in dieser Familie zur Verwendung gekommen ist. Dur'ch Stücke, bei denen sich das Weiss des Seitenlappens auf einen kleinen, von oben her gar nicht sichtbaren Fleck unter der Schulter beschränkt, geht diese Form endlich noch in eine andere

$\eta$. über, bei der auch der ganze Kiel und umgeschlagene Rand des Seitenlappens schwarz ist. $\$$. Zu dieser sehr seltenen Form gehört das früher erwähnte Stïck in Mus. Berol, welches von Moritz mit den oben beschriebenen Arten Sc. corruscans und tripudians verbunden worden war, und bei welchem seltsamer Weise auf der Mitte des rothgelben Halsschilds wiederum eine hreite verwaschen hellgelbe Längsbinde nit einem dunkleren Längsfleckchen vor ihrem Hinterende zum Vorschein kommt. An diese letztere Form und gleichzeitig wiederum an var. $\delta$. schliesst sich nun noch eine andere

ๆ. an: Kopf und Halsschild wie bei $\varepsilon$, meist mit der verwaschenen, zuweilen selbst ins Weissliche übergehenden Mittelbinde von $\zeta$; seltener anch die Seiten verwaschen weisslich, so dass jederseits der Mitte nur ein grosser, in die Länge gestreckter röthlicher Wolkenfleck übrig bleibt. Das Schildchen roth; die Beine schwärzlich, wie bei $\delta$., oder roth, wie bei $\varepsilon-\eta$., und dem entsprechend auch die Unterseite schwarz oder roth, mit breit weissem Rande. Der weisse Mittelfleck der Flügeldecken erweitert sich zu einer gemeinsamen, aussen mit dem Hinterrande des weisseu Seitenlappens zusammenstossenden Querbinde; die gleichfalls vergrösserten Hinterflecke nehmen je den ganzen Nahtwinkel ein, und stossen hier zu einem auf der Spitze der Deckschilde liegenden gemeinsamen weisslichen Halbkreise zusammen $q$. Am seltensten endlich ist dann noch eine Form

८. welche die Zeichnung von Kopf und Halsschild bei $\delta$. Init der noch weiter ausgebildeten Flügeldeckenzeichnung von $\vartheta$. verlindet; die Mittelbinde der letzteren erweitert sich nämlich jederseits der Naht zu einem grossen rundlichen Flecke, und fliesst mit drei röthlichen Längswischen, einem jederseits zwischen Schildchen 
und Schulterbeute, und einem mittleren lings der Nahı, bis zur Wurzel und dem (weisslichron) Schildchen älıer, während sie hini^rwäls ṇur durch einen schlecht begränzten und verwaschenen, schmalen Zwischenram ron dem Ilinterflecke getrennt ist. Hintorhrust und Hinterleib schwarz mit loreit weissem Rande des letzteren: die Beine bleich röhlich weiss; die Vorderkniee, die Ansseuseite der Vorder- und Vittelschienen, ein Fleckchen auf deu Hinterschenkehn, die Enden der IInterschienen und alle Fussglioder verwaschen geschwirzt. Ein einzelnes $\delta$ im Nus. firsch.

$\varkappa$. Ganz alweichend von allen diesen formen ist endlich noch eine vereinzelt distrhende, hei welcher nur der Unterkopf schunutzig geröthet ist. Mlas Halsschill bis anl' eine abgekünzte weissliche Mlttellinie schwal"\% 'r'scheint, mnd lie Flügeldecken ausser dem weissen liiele des Scitenlajpens nur noch den weisslichen Mittelfleck zeigen. Auch dis Schildchen isı gläuzend scluwarz, dis Pygidium weiss mit oberem schwarzon Quersaume, anch der loreite Rand des Initerleihes weiss, die Farbe der Beine dagregen wieder schwarz. Ein of in Mlus. Vindob.

Von diesen Varietaten, mit dronen die Reilar derselhen schwerlich erschöpft ist, lommen $\delta$. (als $\delta$ ) mul $\%$. (als f) am häufigsten in unseren Sammlungen vor, dic äbrigen nur melır odes weniger vereinzelt. Die Art lindet sich (und anscheinend nicht sel(en) in den Landschalten anı Caraihischen Meere vou ('arthagena bis Guyana, und ist in den meisten von mir verglichenen Sammlungen vorhanden. Dis Mus. Berol. Jesitzl auch ein aus Bolivia stammendes Exemplar. (Ilus. Dohrn. Haag. Holm. v. Bruck. Vindob. Schaum. Baly. (Yart. Deyrolle. Berol. Schaufuss. hirsch.)

76. Sc. yuadrillum m. Schwarz, ein Stirufleck, die Sciten des rothen, groh zorstreut punktirten Halsschilds und zwei lilecke auf jeder Fliggeldecke $(1,1)$ weiss; die Punktstreifen vorn gestiont, hinterwärts verschwindend, nit flachen glänzendrn Zwischenriumen. L. $12 / 3{ }^{\prime \prime \prime} ; \mathrm{Br}, 3 / 4{ }^{\prime \prime \prime}$.

Einzelnen Formen des vorhergehenden ăhnlich, alser an der ahweichenden Zeichumg von linpt, Halssehild und Beinen, sowie an den anch hei dem of weiter getremten dugen leicht kemtlich. Der liope thach mit tiefere Stirnlinie, anch das liopfschild unten eingezogen; die P'mlitirung groh und ziemlich dicht, anl' demı liopfschilde rumzlig verliessend. Die farlıe glänzend schwar\%; anf der unteren Stirn ein schunal ciförmiger weisser, lackglänzender und 
punkffreier Längsfleck; die Oherlippe gelhlich mil gelsräunter Mitte, die übrigen Mundtheile pechlırann. Die schmal abes tief dreieckig ausgeluchteten Augen obrin stark zusammengeneigt, aher auch hei dem $\delta$ um mehr als doppelt so weit von rinander getrennt wie bei den $\delta$ der vorhergehenden Arten. Dir Fühler (des ठठ) von etwas äher halber Körperlïnge; das Wurzclglied breit eiförmig aufgetrieben, halh so breit wir: lang, das zweite kur\% und knotig mit eingeschnürter Wurzel, die drei folgenden verkeh'l kngelförmig, und von ihnen das dritte doppelt-, das vierte dreimal lïnger als das zweite, die drei folgenden gleich lang und je fast um die Hälte länger als das vierte, das sechste oberwärts schon dreieckig erweitert, die oberen stärker zusammengadrürkt und verbreitert, vom achten ab wieder ziemlich gleich und ein wenig kürger als die vorhergehenden, das zehute chwa wierler so lang als das vierte, umb das Endglied mit seinem kurzen und lieitrn Fortsatze etwas über dieses hinausreichend. Die Farhe der sechs unteren honiggelh, das erste mit der Olserseite des zweiten und seclssten und einem Schatten auf dem füuften tiefer gebräunt, dir obesen schwarz, dünı angedrückt greeishaarig und an den Spitzen gewimpert. Mas Ilalsschild doppelt breiter als ling, mit flachem linten kaum niedergesenktem Rücken, ïber den kurz pfrienlich zugespitzten Vorderecken zusammengedrückt und daturch verschmälert; die Seiten fein gerandet, in der Mitte schwach hogig erweitert, vor ihr leicht ausgeschweift, die Hinterecken durch kurze, sclsarfe Schwielen gehililet; der Hinterrand fast grade, nur auf jeder Seite fles kurzen schwach aufgebogenen Mittelzipfels etwas ausgebuchtet. Auf dem Rücken hinter der Mitte jederseits ein breiter aber nur leichter, mit dem Hinterende nach einer eben so seicht quer niedergedrückteu Stelle vor dem Mittelzipfel sich herabsenkender Schrägeindruck. Ilie Punlitirung deutlich, alser sehr vereinzelt, mit spiegelglänzendem Zwischengrunde. Die Farbe blutroth, die breiten Vorderwinkel und im Anschlusse an diese ein sich hinterwärts immer mehr verschmälernder Seitenrand weiss. Das Schildchen quer vier'rckig, um die Hälfte breiter als lang, hinterwärts mit gerundeten Seiten verschmälert, stark ansteigend und stumpf gekielt, fein punktist, schwarz. Die Deckschilde längliclı viereckig, etwa $1 / 3$ länger als breit, oben abgeflacht, über deı mässig ausgebildeten Seitenlajpen zusammengedrückı und hinten mit abgerundeten Naht- und Aussenwinkelı fast quer abgestutzt, hinter den scharfen, seitlich an die breiten mässig erhōhten 
Schulterbeulen sich anschliessenden Vorderkanten tief quer eingedrückt: auch der Rücken hinter dem Schildchen schwach in die Quere und dann längs der Nahıt bis zu der sehr schräg abfallenden Wölbung hin niedergedrückt. Die Punktstreifen hinter den Schulterbeulen uud ausserhalb derselben deutlich ausgebildet, bei den inneren die Vorderenden stellenweise verdoppelt und der Raum zwischen dem zweiten und der Naht zugleich mit überzähligen Punkten bestreut. Die Punkte selbst von der Mitte ab merklich feiner, auf der Wölbung fast weggeschliffen. und schon vor der Spitze vollständig geschwunden : die Zwischenräume flach und glänzend, vorn leicht in die Quere gerunzelt. Die Farbe schwarz, ein grosser, rundlicher Fleck im linteren Nahtwinkel, und ein Querfleck auf der Mitte, rom vierten bis über den neunten Streifen hinausreichend, sonach viel weiter als bei den vorhergehenden Arten nach aussen gerückt, weiss. Das Pygidium äusserst fein punktirt, dünn greishaarig, schwarz; der Seitenrand oben jederseits durch das Uebergreilen des lichten Hinterleibsflecks schmal gelblich gesäumt. Auch die Unterseite schwarz, die Parapleuren und Ilüften nebst dem Mittelzipfel des ersten Bauchringes rothbraun, die Unterseite des Ialsschilds nit der Mittelbrust und den Schulterblättern heller blutroth; am Hinterrande des letzten Bauchringes jederseits ein schmaler, gelblicher Längsfleck. Die Beine glänzend schwarz, die Vorderschenkel stark aufgetrieben mit zahnartig vor-springenden Hüftenspitzen, die stark gekrümmten Vorderschieneı an den unteren Enden tief gebräunt. Die Vorderbrust breit und flach, in der Mitte seicht niedergedrückt, grob punktirt und dicht behaart, mit hall, kreisförmigem, heller geröthetem Hinterzipfel. Das letzte Segment des $\delta$ leicht quer niedergedrückt, das $f$ unhekannt.

Aus Brasilien (Nus. Schaum.)

Eilfte Rotte. Körper schmal und gestreckt, gleichbreit oder hinterwärts etwas verbreitert, oben flach gewölbt, mit kurzem, seitlich stark eingedrücktem Halsschilde. Die Punktstreifen deutlich, die Augen des $\delta$ zusammenstossend. Die Farbe schwarz, meist mit rothen oder gelben Zeichnungen auf ler Oberseite; seltener die Deckschilde gelb mit schwarzen Binden. Die Heimath diesel Thiere ist Brasilien und das Land südwärts bis zum La Plata-Flusse.

77. Sc. quadrita en i a lus m. Schwarz, Fühlerwurzeln, das 
zerstreut punktirte Halsschild, die doppelt schräg gefleckten Flïgeldecken, und die Beine bis auf die Vordersclsenkel und Füsse rothgell,; die Punktstreifen ziemlich derb, mit flachen, glänzenden Zwischenräumen. L. $23 / 4{ }^{\prime \prime \prime}$; Br. $11 / 4{ }^{\prime \prime \prime}$.

Eiı schlanker und gestreckter, übrigens an der selır eigenthümlichen Zeichnung der Flügeldecken leicht kenntlichıer Käfer. Der Kopf flach mit selı feiner Stimlinie, die Stiru zwischen den breiten und tiefen Augenbuchten seicht dreieckig niedergedrückt, das Kopfschild stärker eingezogen, oben durch einen schmalen flachen Querwulst begränzt. Die Punktirung fein, längs den Augenräıderı dicht gedrängt und zu Runzeln verfliessend, auf der Mitte von Nacken und Stirı sparsamer und deshalb hier der Zwischengrund glänzender. Die Farbe schwarz, die Taster pechbräunlich durchscheinend, die grossen breit vortretenden, einander zienlich stark genäherten Augen greis. Die Fülıler bei dem einzigen vorliegenden Stücke nicht vollständig, anscheinend etwa von halber Körperlänge, das dritte bis fünfte Glied langgestreckı, sehı düın verkehrt kegelförmig, das vierte lis sechste einander gleich und je uIn $1 / 4$ länger als das dritte, das siebente etwas verkürzl, das achte noch kaum dem dritten gleich und das neunte noch kürzer; die oberen von der Spitze des sechsten ab deutlich zusammengedrückt und erweitert. Die Farbe der lïmf mnteren durchscheinend rothgelb mit einer zarten schwarzen Längslinie auf der Oberseite, die oberen schwarz mit bräunlich durchscheinender Wurzel des sechsten, dabei dünu angedrückt greishaarig. Das Halsschild $2 \frac{1}{2} \mathrm{mal}$ breiter als lang, mit flacher hinten kaum etwas niedergedrückter Mittelfirste, über den scharf rechtwinkligen Vorderecken breit und tief schräg zusanmmengedrückt und dadurch verschmälert, die gerandeten Seiten hinter der Mitte sanft abgerundet, vor ihn fast gerade; die stumpfwinkligen Hinterecken nit einer kurzen scharfen Schwiele lesetzt, der Hinterrand jederseits leicht doppelt ausgeschweift, mit kurzem wenig aufgebogenem Mittelzipfel; beiderseits des letzteren eiı tiefer, längs lem Hinterrande einen kräftigen Querwulst emporschiebender Schrägeindruck. Die Punktirung weder grob noch tief, zerstreut, mit lackglänzendem Zwischengrunde. Die Farhe ziegelroth. Das Schildchen schräg ansteigend, etwas länger als vorn breit, dreieckig, hinten mit abgerundeten Ecken und kaum sichtbarem Hinterzipfel kurz abgestutzt, dicht und fein punktirt, dïnn greishaarig, schwarz. Ilic Deckschilde $1 \mathrm{~m}$ etwa $1 / 3$ länger als 
breit, ziemlich gleichbreit, auf dem Rïcken abgeflacht, hinter dem Schildchen breit und seicht quer niedergedrückt, auch längs der Wurzel nur schwach eingedrüclit; die langen Schulterbeulen mässig heraustretend, auch die Seitenlappen nur schwach entwickelt, und über ilınen die Deckschilde leicht zusammengedrückt. Die Punktstreifen aus theilweise verdopjelten Vorderenden ziemlich regelmässig verlaufend, hier und da etwas wellig gekrünmt, vorn kräftig, von der Mitte ab feiner und lintén fast abgeschliffen, die Zwischenräıme flach mit starkem Glanze. Die Farbe rothgelb, heller als das Halssclıild, auf jeder Flügeldecke mit zwei abgekürzten, von vorn und aussen nach hinten und innen zielıenden schwärzlichen Schrägwischen, die vorderen mehr' quer gestellt, auf der' niedergedrückten Stelle des Rückens liegend und an cler Nalıt zusammentreffend, die hinteren mehr schräg, die Naht nicht erreichend, alle mit lichtem ins Stahlblaue fallendem Glanze. Pygidium und Unterseite schwarz, lünn greishaarig; Hüften und Beine rothgelb, die Vitte der Vorderschenkel mit den Knien, Schienenenden umd Fussgliedern geschwärzt, was bei den Mittel- und Hinterbeinen nur an den drei unteren Fussglieder'n der Fall ist. Das Prosternum flach, mit zwei eingedrückten flachen Längshinien. Das letzte Segment des $q$ mit einer sphr grossen, rundlichen Grube, das đonbekannt.

dus Brasilien (Mus. Berol.)

78. Sc. scolopaceus m. Schwarzblau, die Fühler, das mässig und zerstreut punktirte Halsschild und die Wurzeln der Vorderschenkel geröthet, Deckschitde und Itinterbeine lehmgelb; die Punlitstreifen etwas wellig und unregelmässig verdoppelt, mit flachen glänzenden Zwischenräumen. L. $21 / 4{ }^{\prime \prime \prime} ; \mathrm{Br} .11 / 4 "$.

Ziemlich lang gestreckt und von sehr einfacher Farbenverthejlung. Der Kopf flach, die Stirn unten seicht eingedrïckt mit kurzer Stimlinie; die Punktirung deutlich, aber sehr zerstreut, nur unten in jenen Eindrucke, in den Augenbuchten und auf dem Kopfschilde etwas dichter gestellt, mit spiegelglänzendem Zwischengrunde. Vie Farbe stabllblau, die durch eine ziemlich tiefe Ausbuchtung sebr ungleiclı getheilteı, (bei den $\&$ ) weit getrennten Augen greis. Dip Fühler sehlank, von mehr als lıalber Körperłänge, bis auf die leicht gebräunten Enden rothgelb. Das Halsschild etwa 21/.2mal hreiter als lang, mit fast gerader Mittelfirste, linter den Augen etwas eingeschnürt und üher den kurz und scharf spitzwinkligen Vorderecken breit zusaminenged'ückt, dir Seiten stark gerandet, in der 
Mitte rundlich erweitert, die stunpfwinkligen Hinterecken mit einer kurzen und scharfen, aufgerichteten Schwieje besetzt, der Hinterrand jederseits des sehr kurzen Mittelzijfels ziemlich starli ausgebuchtet, Neben dem letzteren jederseits ein kurzer, tiefer Schrägeindruck, ein zweiter flacherer aber längerer weiter nach vorn zu den Vorderecken hin schräg absuärts zicheud. Die Punktirung ziemlich kräftig, auf der Mitte etwas schwächer und mehr zerstreut, seitlich stärker und auch dichter zusammengedrängt, mit glänzendem Zwischengrunde. Die Farbe ein etwas verblichenes Ziegetroth. Das Schildchen schräg ansteigend, nicht ganz so lang als vorn breit, dreieckig mit stunıf abgerundetem Hinterrande und undeutlichem Hinterzipfel, fein punktirt und nur gegen die Spitze hin glänzenḍ, sehr dümn greishaarig, schwarzblau. Die Deckschilde um die Hälfte länger als breit, hinterwărts etwas verbreitert, flach walzenförmig mit sehr sanft abfallender Wölhung, hinter der scharf erhöhten Vorderkante quer eingedrückt und dieser Eindruck innerseits der länglichen Schulterbeuleı hinterwärts erweitert; die Seitenlappen schwach, und über ihnen die Deckschilde mässig zusammengedrückt. Die Punktstreifen etwas wellig, auf der Mltte mehr oder weniger unregelmässig verdoppelt, auf der Wölbung erlöschend, diץ Punkte des siebenten in der Mitte sehr vereinzelt, der achte und neunte fast regelmässig, vorn etwas gröber, der zehute über dem Seiteılappen durch einige überzälllige grobe Punkte erweitert. Die Zwjschenräume flach und glänzend, dic Farhe hell lehmgelb mit etwas dunklerem Innern der Punkte. Pygidlium und Unterseite stahlblau, dicht angedrückt silberhaarig, auch die Vorderbeine stalılblau mit gerötheten Wurzeln der Vorderschenkel und gehräunten Vorderschieneı; Mittel- und Hinterheine holl lehmgell mit schwärzlichen Fussgliedern. Das Prosternum sehr hreit mit zwei lreiten, flachen Längsfurchen, runzlig punktirt und greishanrig. Das letzte Segment des \& mit einer grossen, rundlichen Grube, las ơ unbekaunt.

\section{Aus Brasilien (Mus. Vindob.)}

79. Sc. dors alis Sturm. Sclımutzig greisgelb, unten dicht weiss behaart, der Kopf, das fein zerstreut punktirte Halsschild, das Schildehen, ein hinten verbreiterter Nahtsaum und eine daselbst verengte Längsbinde der Flügeldecken mil den Vorderschenlipln schwarz; die Punktstreifen voru derh) und etwas gestört, hinten abgeschwächt, snit flachen glämzenden Zwischenräumen. L. $23 / 4-3{ }^{\prime \prime} ; \mathrm{Br}$. 11/4 $-1 \frac{1}{3}{ }^{\prime \prime \prime}$. 
Eine schmale und sehlanke, an der Längshiude der Flügeldecken selır leicht kenntliche Art. Der Kopf flach gewölbt, mit kurzer tief eingedrückter Stirulinie, das Kopfselild quer mondförmig eingedrüekt, oben nicht abgesetzt. Die Oberfläche sehr zerstreut punktirt, dünn greishaarig, mit glänzendem Zwischengrunde, lackschwarz, die grossen durch eine kurze Ausbuchtung sehr ungleich getheilten, oben (bei (lem $q$ ) etwas zusamnengeneigten Augen greis; der untere Rand der Oberlippe bei einem der vorliegenden Stücke verwasehen gelbliel. Die Füller etwa von halber Körperlänge, überaus dünı und schlank, die unteren Glieder gestreckt fadenförmig und auch die oberen nur wenig verbreitert, die Farbe schmutzig gelb mit geschwäızter oberer Hälfte. Das kurze Halssehild etwa $2 \frac{1}{2}$ mal breiter als lang, mit nur hinten selıwach abwärts gekrümmter Mittelfirste, die Vorderecken abgestumpft spitzwinklig, tief eingezogen, die Seiten gerandel, in der Mitte zugerundet, vor ihr etwas ausgeschweift, hinten durch die stumpf abgerumdeten, mit einer undeutlich'n Sehwiele besetzten Hinterecken mit breiten Bogen in den nur sehwach ausgebuchteten Hinterrand übergehend; der Nittelzipfel kurz, und nur schıvaeh aufwärts gekrümmt. Der hintere Theil des Mittelfeldes breit und flach niedergedrüekt, und hier jederseits des Mittelzipfels ein breiter Quereindruck, weleher die Masse des Halssehilds als ein deutliches, den Hinterrand bis zur Schulterbenle begleitendes Qnerfältchen in die Höhe sehieht. Dabei die Oberfläche deutlieh und ziemlich zerstreut punktirt, gläızend schwarz. Das Schildchen stark sehräg ansteigend, mit ausgebuchteten Seiten hinterwärts versehmälert, so lang wie vorn breit, hinten breit abgestutzt, dicht und fein punktirt, schwarz. Die Deekschilde um fast die Hälfte länger als breit, vorn etwas breiter als das Halsschild und damn mit ziemlich parallelen Sriten bis zu der kurz abgerundeten Spitze fortziehend; der Rüeken abgeflaeht, hinter dem Schildchen und dann wieder auf ter Mitte quer niedergedrückt, hinter der scharfen Vorderkante quer eingedrïekt; die länglichen Sehulterbeulen nur schwach, die Seitenlappen etwas stärlier entwickelt und über ilnnen die Deckschilde breit zusammengedrüelit. Die Punktstreifen auf der vorderen Hälfte derb und aus vereinzelten gröheren Punkten gebildet, zwischen dem Sehildchen und dem vierten Streifen durch überzählige Punkte und Streifenansätze getrübt, gegen die Mitte hin etwas wellig gehogen, und hinter den Schulterbeulen abermals durclı äberzählig eingemengte Punlite gestört; 
hinter der Mitte werden die Streifen regelmässiger, aber auch feiner, nach der Wölbung immer mehr abgeschwächt, und verschwinden auf letzterer soweit, dass nur noch von den Ranistreifen vereinzelte Punkte bemerkbar sind. Die Zwischenräume breil und flach, vorn sehr schwach gewölbı, der vierte vorm an der Wurzel durch das Divergiren des vierten und fünften Streifens dreieckig erweitert. Der Zwischengrund von mässigem Glanze, dlie Farbe greisgelb, ein breiter, vorn schon das Schildchen umziehender Nahtsaum schwarz; derselbe verschmälert sich allmählich bis zur Mitte hin, und erweitert sich dann wieder hinterwärts auf der Wölbung zu einem stumpfrhombischen Querflecke. Danehen tıägt jede Flügellecke noch eine schwarze stellenweise brandig begränzte Längshinde, welche mit schmalem Vorderende die Schulterbeule einnehmend sich hinter dieser beiderseits verbreitert, und dann zwischen dem vierten und neunten Streifen sich bis zur Wölbung hinzieht, aber nur vor der Nitte und auf der Wöllrung, dem hinteren Nahtllecke gegenüher ihre volle Breite zeigt, zwischen beiden aber durch eine breite Ausbuchtung auf der inmeren Seite sich his auf die Hälfte verschmälert. Nach Aussen ist dieser verschmälerte Theil der Binde genau an den neunten Streifen gelelıut, während sie vor und linter demselben auswärts auf den nemten Zwischenraum äherfliesst, und eins der vorliegenden Stücke hier auf demselben über dem hinteren Theile des Seitenlappens mit einigen gröberen Punkten besetzt ist. Pygidiun, Unterseite und Beine diclıt angedrückt greishaarig; das erstere schwarz, Hinterleib und Hinterbrust gelbgreis mit verwaschen geschwärzter Mitte, die Schulterblätter tief gebräunt, Mittel- und Vorderbrust schwarz, letzlere grob runzlig punktirt, mit hinterıärts anged’ückten greisen Borsteuhärchen besetzt, flach, mit breit dreieckigem, hinterwärts algerundetem Hinterzipfel. IDie Beine gleichfalls greisgelb, die untere IIilfte der Vorderschenkel, ein breiter Fleck auf der Aussenseite der Mittelschenkel, und ein schmalere ${ }^{r}$ auf den Hinterschenkeln schwarz. Das letzte Segment des $q$ mit einer kleinen rundlichen Grube; das $\delta$ unbekannt.

Aus Brasilien (Mus. Sturm. Clark. Deyrolle; in letzterem mit den Namen Pachybrachys lateralis Cheor. bezeichnet).

80. Sc. fastidiosus m. Schwarz, Fühlerwurzeln, Beine und Flügeldecken gelloroth mit einer hinteren schwarzen Querlinde der letzteren; las Halsschild selır fein und zerstreut punktirt, die Punkt- 
streifen vorn gestört, himten deutlicher, mit flachen, glänzenden Zwischenräumelı. L. $21^{1 / 1 "}$; Br. $1 \frac{1}{6}{ }^{\prime \prime \prime}$.

Von dieser Art hahe ich nur ein einziges, dazu unvollkommen ausgehärtetes Stück vor mir, und die Beschreibung desselben wird deshalb künftig noch mancherlei Ergänzungen zı erleiden habeı, wenn gleich die Beschaffenheit jenes Stückes immerhin zum Kenutlichmachen der Art ausreicht. Der Kopf flach, mit einer abgekïrzten, scharf eingeschnittenen Längslinic auf der unteren Stirn; das Kopfschild sehr tief eingezogen. Die Farbe glänzend schwar\%, die Punktirung fein, auf dem mteren 'Theil des Kopfes etwas dichter zusammengedrängt; die Nundtheile schmutzig gelhlich. Die Fühler kurz und sehr schlank, das erste Glied breit eiförmig, das zweite elliptisch, halb so lang und breit als das vorhergehende, die nächstfolgenden dünn verkehrtkegelförnig, das dritte $2{ }^{1 / 2}$ mal-, das vierte und fünfte je dreimal länger als das zweite, die folgenden ivieder dem dritten gleich, wenig erweitert und zusammengedrückt, mit lang dreieckigem Fortsatze des Endglieds. Die Farbe der vier unteren hellgelb mit einer schwärzlichen Längslinie auf der Oberseite des zweiten bis vierten, das fünfte bräunlich, die uberen schivarz. Das Halsschild fast doppelt breiter als lang, mit ziemlich grader Mittelfirste, über den scharf pfriemlich vorgezogen'n Vorderecken stark zusanmengedrückt und dadurch verschmälert, die Seiten deutlich gerandet, in der Mitte bogig erweitert, vor ibr leicht ausgerschweift, die Hinterecken abgerundet, der Hinterrand wellig gebuchtet, nit kurzem, breitem, anfgehogenem Mittelzipfel. Die Punktirung sehr fein und zerstreut, in den Vorder- und Hinterwinkeln etwas deutlicher; die Farbe glänzend schwarz. Das Schildchen wenig ansteigend, viereckig, hinterwärts merklich verschmälert und mit kurzem Hinterzipfel quer abgestutzl, dümn hehaart, schwarz. Die Deckschilde kaum 1/4 länger als breit, linter der leicht erhöhten Wurzelkante sanft quer niedergedrückt, die ziemlich flachen Schulterbeulen länglich, innerseits durch eineı seichten Längseindruck abgesetat, die Seitenlappen mässig, und ïber ihnen nochmals ein schwacher Längseindruck. Die I'unlitirung deutlich aber zerstreut; hinter den Schulterbeulen sind drei Punkistreifen, der sechste bis achte, ziemlich kenntlich, und ausserhalls des letzteren finden sich auf dem breiten Zwischenraume bis zum Rande mrhrere regellos zerstreute grobe Punkte, welche den rorn abgekürzten neuntei Streifen vertreten sollen. Weiter nach oben zeigen sich mehrere 
Ansätze von unordentlichen Doppelstreilen, die aber gegen die Wötbung hin versclıwinden. Die Zwischenräume glänzend, die Farbe hellgelbroth, mit einer verwaschenen nach Aussen verbreiterten Querbinde vor der Spitze. Pygidium und Hinterleil, (oh nur in Folge der unvollkommenen Ausfärbung?) schmutzig gelbbraun, die Hinterbrust schwarz mit gebräunten Schulterblättern, die Beine gleichfalls schmutrig gell, mit gebräunten Fussgliedern und Unterenden der Vorderschenkel und -Schienen. Das Prosternum breit umd flach, greisbehaart, schwarz. Das letzte Segment des $f$ mit einer flachen, rundlicheu Grube, das đo unbekannt.

Von Buenos Ayres (Mus. Haag).

81. Sc. imm a turus m. Schwarzgrün, Fülılerwurzeln, Beine, ein breiter Rand des Hinterleibes und die Flügeldecken strohgell, die Naht und ein breiter Randfleck der letzteren schwarzllau: das Halsschild fein und zerstreut punktirt, die Punktstreifen vorn grob und etwas gestört, binten erloschen, mit flachen, glänzenden Zwischenräumen. L. $13 / 4{ }^{\prime \prime \prime} ; \mathrm{Br}$. $5 / 6{ }^{\prime \prime \prime}$.

Dem unten folgenden Sc. supplex in der Färbung und Farbenvertheilung sehr ähnlich, aber merklich grösser, und nicht allein durch die Grundfarbe, sondern auch durch die Sculptur des Halsschilds von ihm abweichend. Der Kopf flach, mit kräftiger, unten in einen deutlicheı Quereindruck auslaufender Stirnlinie, deutlich zerstreut punktirt mit spiegelndem Zwischengrunde, metallisch schwarzgrün, die Oberlippe knochengelb, die tief ausgebuchteten, (bei dem \&) oben weit getrenuten Augen schwarz. Die Fülsler (nach den vorhandenen Resten) dünn und schlank, das 2te Glied kurz eiförmig, die drei folgenden verkehrt kegelförmig, allmählich an Länge zunehmend, das 5te (längste) reichlich so lang wie das 2te und 3te zusammengenommen, das 6te fast dem 5ten gleich, das 7te wieder ein wenig kürzer, die beiden letzleren zugleich ohen schwach zusammengedrückt und erweitert. Die Farbe der 5 unteren durchscheinend gelb mit gebräunter Oberseite des ersten bis dritten, das 6te unten gebräunt, die ohere Hälfte mit dem 7 ten (und ohne Zweifel auch allen folgenden) schwarz. Das Halsschild kurz und breit mit grader Mittelfirste, üher deı scharf rechtwinkligen Vorderecken stark zusammengedrückt und dadurclı verschmälert, die Seiten deutlich gerandet, in der Mitle leicht bogig erweitert, liuter ihr sauft ausgesclıweift, mit stunjpfwinkligen und dabei abgerundeten Hinterecken; der Hinterrand jederscits 
wellig ausgebuchtet, mit wenig liervortretendem Mittelzipfel. Vor diesem zu beiden Seiten ein tiefer, sich nach Aussen erweiternder und längs dem Hinterrande eine kräftige Quelfalte emporschiebender Schrägeindruck. Die Punktirung oben zerstreut und wie abgeschliffen, seitlich etwas dichter und grüber, der Zwischengrund glänzend metallisch schwarzgrün. Das Schildchen schı̈̈g ansteigend, breit viereckig, hinterwärts verschmälert, mit sehr liırzem Hinterzipfel und abgerundetem Ende; grob punktirt und gleichfalls schwärzlich grüı. Die Deckschilde breit und flach gewölbt, fast un die Hälfte länger als breit, und hinten mit flacher Wölbung abfallend, hinter der schwach erhöhten Vorderkante leicht quer eingedrückt, die Schulterbenlen kurz, aber eckig hervortretend, die Seitenlappen breit zugerundet, und über ihnen die Declischilde kräftig zusammengedıückt. Auch die Punktstreifen liräftig, die Vorderenden der äusseren hinter den Schulterbeulen und über den Seitenlappen durch üherzählige Punkte gestört, und von der Mitte ab, wo auch diese Streifen sich regelmässiger zu entwickeln beginnen, alle merklich an Stärke abnehmend, stellenweise verschwindend, und auf der Wölbung selbst nur noch rereinzelte Spuren von Streifen vorhanden. Die Farbe hell strohgelb, eine breite, etwas buchtige gemeinsame Nahtbinde, ein feiner Spitzensaum und an diesen sich anschliessend oder vielmehr denselben erweiternd ein breiter Randfleck, vorn bis zu dem Seitenlappen und einwärts bis zum 5teı Streifen auf jeder Flügeldecke reichend, dunkel schwarzblau. Das Pygidium schwarz; auf der Unterseite die Brust schwarz, der Hiıterleil schmutzig gelbbraun mit noch melı verdunkelter Mitte und lichterem Saume, welcher auch auf der Oberseite an Rande des Pygidiums sichtbar wird. Auch die Beine gelblichbraun, die Vorderschenkel und die Mitte der übrigen Schenkel metallisch schwarzgrrüı, auch die unteren Schienenenden mehr oder weniger getrübt. Das letzte Segment des $q$ mit einer grossen und tiefen rundlichen Grube; das $\delta$ unbekannt.

Aus Brasilien. (Mus. Lacordaire).

82. Sc. supplex m. Schwarz, Fühler, Beine, ein breiter Rand des Ilinterleibes und die Flügeldecken brann, die Naht und ein breiter Randfleck der letzteren schwwarz; das Halsschild dicht punktirt, die Punktstreifeu etwas wellig, längs der Naht und hinter den Schulterbeulen gestürt, mit flachen, glänzenden Zwischenräımell. L. $11 / 4{ }^{\prime \prime \prime}$; Br. $2 / 3{ }^{\prime \prime \prime}$. 
Eine kleine, zierliche, mir allerdings nur in cinem einzigen schlecht erhaltenen Stücke vorliegende, aber doch zum Wiedererkennen hinlänglich zu charakterisirende Art. Der Kopf' flach mit feiner Stirnlinie und etwas eingezogenem Kopfschilde, zerstreut punktirt mit mattem Zwischengrunde, schwarz; Oberlippe und Mundtheile bis auf die tiefer gebräunten Kinnbacken hellbraun, die mässig ausgebuchteten, (hei dem $q$ ) nur durch einen an Breite kaum der Oberlippe gleichkommenden Raum getrennten Augen greis. Die Fühler kaum von halber Körperlänge, das keulig verdickte Wurzelglied reichlich doppelt länger als breit, das 2 te kurz und knotig, fast so breit wie das erste, die folgenden verkelutkegelfürmig, das 3te kaum länger und nicht halb so lyreit wie das zweite, das the und 5te einander gleich, je etwa doppelt so lang wie das 3 te, die folgenden wiederum etwas kürzer, aber innerseits breit dreiechig erweitert, mit sehr kurzem Fortsatze des Endglieds. Die unteren bis zum 5ten durchscheinend honiggelb, die oheren elwas dunkler gebräunt und dicht angedrückt greishaarig. Das Halsschild fast doppelt breiter als lang, vor der Vitte quer aufgewulstet, und von dort ab stärker naclı vorn, mehr allmählich nach hinten abıärts gekrümmt, längs dem Vorderrande leicht eingeschnürt, über den spitzen Vorderecken zusammengedrückt und dadurclı verschmälert; die Seiten fein gerandet, vor der Mitte stark erweitert, hinter ihr bis zu den gleichfalls scliarfen und mit einer kurzen Schwiele besetzten Hinterecken breit ausgeschweift, der Hinterrand jederseits wellig ausgebuchtet, mit ziemlich breitem, etwas aufgebogenem Mittelzipfel. Vor letzterem die den Hinterrand begleitentle Querlinie sehr stark vertieft, und dann noch zu beiden Seiten vor dem Mittelzipfel ein breiter und tiefer, aber die Mitle des Seitenrandes nicht erreichender Schrägeindruck, durch welchen innerseits das erhöhte Mittelfeld begränzt, längs dem Hinterrande aber eine kräftige Querfalte emporgeschoben wirl. Die,Oberflïclıe dicht punktirt, die Punkte stellenweise in die Länge gezogen, besonders in den Hinterwinkeln etwas tiefer und gröber; der Zwischengrund nit seidigem Glanze, und die Farbe rein schwarz. Das Schildchen schräg ansteigend, viereckig und um die Hälfte länger als breit, linterwärts stark verschmälert, schıarz. Die Deckschilde läıglich viereckig, etwa um $1 / 3$ länger als breit, flach gewölbt und hinten kurz zugerundet, hinter der scharfen Vordcrkante schmal aber zienlich tief quer eingedrückt, die Schulterbeulen eckig heraustretend, 
und die Seitenlappen kurz, aber tief herabgezogen. Die Punktstreifen deutlich und nur die mittleren nach der Wölbung zu etwas feiner, schwach wellig und die Vorderenden der Rückenstreifen stellenweise verdoppelt, die Hinterenden der drei an der Schulterbeule entspringenden etwas gestört, und in gleicher Weise der Raum zwischeı dem zweiten und der Naht bis über deren Mitte hinaus mit überzähligen, den ersten Streifen fast ganz verdunkelnden Punkten unordentlich bestreut. Die Zwischenräume flach mil mässigem Glanze, der 9te völlig regelmässig ausgebildete leicht gewölbt. Die Farbe hellbraun, Naht, Spitze und Seitenrand bis zum Hinterende des Seitenlappens schwarz gesäumt, und dieser Saum auf der Naht vor der Wölbung zu einem verwaschenen Längswische erweitert; ausserdem auf jeder Flügeldecke ein breiter, innerseits bis zu dem dritten Punktstreifen reichender und ror'n das Hinter'ende des Eindrucks über dem Seitenlappen berülırender, daher reichlich die grössere Hinterhälfte des Seitenrandes bis ŭber die Wölbung hinaus einnehmender schwarzer Randfleck. Das Pygidium fein runzlig punktirt, dünn greishaarig, schwarz. Auch die Unterseite fein und dicht runzlig punktirt, schwarz, mit breitem, verwaschen rothbraunen Rande des Hinterleibes. Die Beine braun mit etwas dunkleren Schienen; an den Mittel- und Hinterbeinen die Schenkel auf der unteren Hälfte der Aussenseite pechbraun angelaufen und die Schienen noch stärker geschwärzt. Die flache Vorderlorust grob runzlig punktirt, hinten breit abgerundet. Das letzte Segment des $\uparrow$ nit einem tiefeı, länglichrunden, glanzlosen Grübchıen; das $\delta$ unbekannt.

Aus Brasilien. (Mus. Schaum.).

83. Sc. me mnonius m. Schwarz, Fühler, Beine und Mundtheile gelblich, die seiten des deutlich zerstreut punktirten IIalsschilds und des Hinterleibes mit dem Pygidium und zwei Stirnflecken weiss; die Punktstreifen derb, etwas wellig, mit vorn flachgewölbten, fein gerunzelten etwas glänzenden Zwischenräumen. L. $11 / 4{ }^{\prime \prime \prime} ; \mathrm{Br}$. $3 / 4$ "'.

Eine der kleinsten Arten dieser Gattung, zugleich durch die Einfachlıeit ihrer Färbung und Zeichnung sehr ausgezeichnet. Der Kopf flach gewölbt, nit stark eingezogenem Kiopfschilde; die Stiru (bei dem $\delta$ ) oben fast vollstandig durch die grossen, tief ausgebuchteten, fast zusammenstossenden, greisen Augen eingenommen. Die Oberfläche glänzend schwarz, olıne deutliche Punktirung; der 
dreiechige Stirnzipfel zwischeı den Angenränılern durch einen weissen Fleck eingenommen, welcher durelı die fein eingegrabene schwarze Stirnlinie in zwei Längsfleckchen getheilt wird, auclı die etwas vor'springende Oberlippr weiss; die Taster' gelblich. Die Fülıler nicht von halber Körperlïnge, das dünn verkehrt kegelförmige dritte Clied wenig länger als das stark aufgetriebene zweite, das vierte noch etwas grösser, das fünfte nach oben hin stärker verdickt und etwa doppelt länger als das dritte; lie oberen leicht verbreitert und zusammengedrückt, dis sechste und siebente je dem fünften gleich, las ichte etwas verkürzt, das neunte und zehnte wiederum einander gleich, wenig länger als das vierte, das etwas längere Endglied mit schmal kegelförmigem Fortsalze. Die fünf unteren Glieder durchscheinend hellgetb, die oberen schwarz mit gebräunter Wurzel des sechsten. Das Halsschild fast $2 \%$ mal breiter als lang, mit fast grader Mittelfirste, über den scharf reclıtwinkligen Vorderecken breit zusammengedrückt und dadurch verschmälert, seitlich sehr fein gerandet, dasellsst vor der Mitte in schwachen Bogen erweitert, und vor ihr, wie nach den scharf stumpfwinkligen Hinterecken $\mathrm{zu}$ fast gradliniy verlaufend; der Hinterrand kaum gebuchtet, mit eben so schwach vortretendem Vittelzipfel. Das Mittelfeld vor dem Hinterrande mit einem jederseits etwas schrïg nach vorn gerichteten, und daselbst tief und breit dreieckig erweiterten Eindruck, welcher längs dem Hiıterrande eine kräftige Querfalte aufwà'ts schiebt, und weiter nach Aussen in Hinterwinkel bei einem der vorliegenden Stücke noch ein tiefes, rundliches, gleichsam eine abgerissene Fortsetzung jenes Eindrucks bildendes Gröbchen. Die Punktirung deutlich, aber sehr unregehmässig vertheilt, in den Vertiefungen etwas dichter zusammengedrängt; die Farbe glänzend schwarz, ein breiter, schwielig aufgetragener Seitenrand eben so glänzend weiss; derselbe biegt sich in den lor'derwinkelı rechtwinklig nach vorn, und zieht sich her jedterseits soweit fort, dass nur die mittlere zwischen den Augen lipgende Hälfte des Vorderrandes schwar'z bleibt. Das Sehiddchen ziemlich stark ansteigend, reichlich so lang wie rorn breit, hinterwärts mit etwas ausgebuchteten Seiten verschmälert, und mit dentlichen Hinterziplel kurz abgestutzt, gleichfalls glänzend schwarz. Die Deckschilde länglichviereckig, um $1 / 4$ länger als breit, tlach gewölbt und hinten mit kurzer Krümmung ziemlich steil abfallend, hinter der mässig erhöhteı Vorderkante schınal quer gefurcht, hinter dem 
Schildchen und dann nochmals vor der Mitte sanft quer niedergedrückt; die Schulterbeulen kurz eiförmig, (lie Seitenlappen schwach, und übèr ihnen die Deckschilde breit zusammengedrückt. Die Punktstreifen derb, etwas wellig, und stelienweise, namentlich an der Wurzel, längs der Naht und hinter den Schulterbenlen durch überzählige Punkte und Streifenansätze gestört, hinter der Mitte merklich schwächer, regelmässiger, und auf der Wölbung fast gauz erloschen. Die Zwischenräume vorn flach gewölht, hinten tlach, fein querrunzlig und nur mässig glänzend; die Farbe schwarz. Pygidiun und Unterseite fein runzlig punktirt, dünn greishaarig; essteres weiss, die Unterseite schwarz mit breit weissem Rande des Hinterleibes. Die Beine gelblich, die breiten Vorderschenkel auf der Aussenseite mit einem verwaschenen weisslichen Längsflecke. Das Prosterıum breit und flach; das letzte Segment des ơ einfach, das \& unbekannt.

Aus Brasilien (vom Constancia und Pelropolis: Mus. Clark.)

84. Sc. quadrinus m. Schwar'z mit gebrämnten Fühlerwurzełı, eiı Stirnfleck, eiı Randfleck über den Seitenlappen, die Spitze der Flügeldecken und die seitlichen Vorderzipfel des ersten Bauchringes rothgelb; das Halsschild zerstrent punktirt, die Punktstreifen fast bis zur Wölbung durch dichte und grobe Zwischenpunkte unkenntlich, mit gerunzelten Zwischenräumen. L. $2 \frac{1}{3}{ }^{\prime \prime}$; Br. $1 \frac{1}{6}{ }^{\prime \prime}$.

Diese Art besitzt mit den beiden folgenden in Färbung und Zeichnung einige Aehnlichkeit mit manchen Arten der nemnten Rotte, kann aher mit jenen nach ilırem ganzen Hahitus nur hier eine geeignete Stelle erhalten. Der Kopf flach, Stim und Nacken der Länge nach tief eingedrückt, das Kopfschild kanm eingezogen, die Augenbuchten lıreit und tief, mit ahgernndetem lınenwinkel. Die Oberfläche grob und ziemlich dicht punktirt, nur die eingedrückte Mitte der Stirn ohne Punkte; die Farhe schwarz, mit einem verloschenen rohren Quertleck zwischen den Augenbuchten, der Unterrand der Oherlippe leicht gebrännt. Die Fühler kaum von halber liörperlänge, die Glieder vom vierten ab an Länge kaım verschieden, das dritte ein wenig kürzer, die oberen vom sechsten ab wenig zusanmmengedrückt und erweitert. Die fünf unteren pechbraun mil etwas luellerel Unterseite, die oberen schwarz. Das Halsschild hinter der Hitte quer aufgewölbt, und von da nach vorn sanfter, hinterwärts stärker abwäıts gekrümınt, längs dem Vorderrande üher den Augen rtwas eingeschnürt, über delı spitzen Vor- 
derecken breit zusammengedıückt und darlurch verschmälert; die Seiten gerandet, vor ller schwach erweiterten Mitte gerade, und hinter ihr mit sanften Bogen durch die stumpten Hinterecken in den Hinterrand ühergehend, letzterer jederseits breit ausgeschweift mit einem leichten, vor ilım liegenden Schı̈̈geindrucke. Die Punktirung auf dem Mittelfedde friner und mehr vereinzelt, mit gläızendem Zwischrugruude, seitlich gröher und dichter, wem auch nicht tief eingestochen, und der Zwischengrund hier fein gerunzelt. Die Farbe schwarz, auf dem linken Seitenrande des einzigen vorlipgenden Stückes ein kleines aber deutliches rothes Fleckchen. Das Schildehen dreieckig und hinten abgestutzt, runzlig punktirt, dünı greishaarig, schwarz. Die Deckschilde unı etwa $1 / 4$ länger als breit, längs der Naht seicht niedergedrückt, hinter der scharfen aber wenig erhöhten Vorderkante nur in einer !schmalen Querlinie eingedrückt, die schmalen Schnterheulen eckig heraustretend, die Seitenlappen tief herabgezogen. Die Punktirung auf der grösseren Vorderhäfte groh und dicht, mit Spuren gestörter Punktstreifen, welche theilweise durch das Hervortreten von zwei, dem zweiten und vierten Zwischenraum entsprechenden Längsrippen kenntlich werden; der achte und neunte Streifen ihrer ganzen Länge nach ausgebildet, die äbrigen erst vom letzten Drittel ab sich immer deutlicher entwickelıd, mit ziemlich gläızenden, flachen Zwischeuräumen: auf der vorderen Hälfte der Zwischengrund runzlig zusanmenfliessent, sehı l'ein genarbt, mit schwächerem Glanze. Die Farbe schwarz, ein länglicher, den Seitenlappen mit umfassender Schulterfleck unterhalb der Schulterbeule und die breite Spitze der Flügeldecken hell rotlıgelh. Pygidium und Unterseite sehr fein runzlig punktirt, dünn greishaarig, mit den Beinen schwarz; dip seillichen Vorderzipfel des ersten Bauchringes gleichfalls rothgell, die unteren Enten der Vorderschienen auf der Innenseite ziemlich hell gebräunt, unt auf der Aussenkante der Hinterschenkel vor den Knie ein weissliches Längstleckchen, von welchem bei den Yittelschenkehn nur eine kaum merkliche Andeutung vorhanden ist. Das Prosteruum groh runzlig punktirt, mit zwei flachen Längseindrücken, ziemlich lang greishaarig. Das letzle Segnent res $q$ mit dem gewöhnlichen, hier ziemlich kleinen Grübchen, das $\delta$ unbekannt.

Gleichfalls aus Brasilien (vom Collo del Sacramento: Sello in Mus. Berol.) 
85. Sc. scintillans m. Metallisch sclıwarz, Füllerwurzelı, Schenkel, Wurzel und Spitze der Flügeldecken roth; das Halssehild zerstreut punktirt, die Punktstreifeı vorı mmregelınässig verdoppelt und wellig, mit flachen, glänzenden Zwischenräumen. L. 11/3$2 \frac{1}{4}{ }^{\prime \prime \prime} ; \mathrm{Br} .2 / 3 \longrightarrow 1^{\prime \prime \prime}$.

Dem vorhergehenden nicht unälnlich, aber schnaler, zierlicher und in der Zeichung von ilm sehr verschiedeu. Der Kopf tlach mit kaum eingezogenem Kopfschilde, die ohere Stirn hei dem $\delta$ ganz von den grossen, durch eine schmale Ausbuchtung sehr ungleich getheilten, oben zusammenstusseuden Augen eingenonmen, letztere auclı bei dem $q$ ziemlich genähert. Die Oherfläche fast spiegelglatt, bei dem $q$ nit feiner, nur an den Enden mehr deutlicher Stirnlinie; der untere Theil der Stirn nebst dem Kopfschilde bei beiden ziemlich dicht und stark punktirt. Die Farbe, his auf die hellgreisen Augen, sclıwarz. Die Fühler des $\delta$ von $2 / 3$ der Körperlänge, des \& etwas kürzer, das zweite Glied kugelig, das dritte $3 \frac{1}{4}$ mal länger, das vierte mul tïnfte einander gleich und je um die Hälfte länger als das dritte, die oberen allıählich verküızt, sodass das zehnte wieder dem dritten gleichkommt, das Endglied mit seinem sehr kurz ausgezogenem Fortsatze wiederum dem fünften gleich. Die Farbe der fïnf unteren durchscheinend rothgelb mit gebräunter Oherseite; die olıeren wenig zusammengedrückt, dünn greishaarig, schwarz. Das Halsschild etwa $2 \frac{1}{4}$ mal hreiter als lang, ohen abgeflacht mit kaum aufgehogener Mitlelfirste, über den scharf rechtwinkligen Vorderecken lïngs dem unteren Theile des Vorderrandes stark zusammengeschuiurt und dadurch verengt, sodass das Mittelfeld jederseits mit einer bei denı ठ stärkeren, dem $q$ schwächeren Beule heranstritı; die Seiten selbst fein gerandet, unterhall, jener Beulen und ihmen entsprechend leicht erweitert, vor der Mitte kam merklich ansgeschweift; die Hinterecken stumpfwiuklig, der Hinterrand doppelt ausgebuchtet, mit schwachem Mittelzipleel, und jederseits des letzteren pin scharfer, tiefer Schrïgeindruck, welcher dten Rand entlang einen drejeckigen Querwulst emporschicht. Die zerstreute Punktirung bei den \& fein, dem ठ etwas stärker, mit spiegelglänzenden Zwischengrunde, die Farbe schwarz mit eiıem Jeichten, metallisch bläulichem Anflıge. Das Schildchen schı̈̈g ansteigend, hiıten stark virschmälert und mit deutlichem Ilinterzipfel kurz alggestutzt, äusserst fein und dicht punktirt, glänzend schıvarz. Die Deckschilde länglich 
viereckig mit abgeflachtem Rücken, etwa um die Hälfte länger als hreit und bei dem $\&$ hinterwärts etwas verhreitert, vorn schwach quer eingedrückt, Sclıulterbeulen und Seitenlappen wenig entwickelt, übes letzteren die Deckschilde breit alser uur flach zusanmengedrückt. I)ie Punktstreifen deutlich, die oberen zwischen Naht und Schulterbeule bis zur Mitte hin unordentlich verdoppelt und dadurch wellig gekrümmt, auch der sechste und siebente etıvas gestört; die Hinterendeı überall regelmässig, aber abgeschwächt, die vorn stellenweise erhöhten Zwischeuräume hinten breit und flach, spiegejglatt. Die Farbe ein in's Metallischviolette spielendes Schwarz, die Wurzel der Flügeldecken fast bis zur Mitte, jedoch hinter dem Schildchen einen schlecht begränzteı Nahtsaum freilassend, ziegelroth, und dieselbe Farbe zeigt auch noch ein grosser rundlicher Spitzenfleck. Pygillium und Unterseite fein punktirt, dicht angedrückt silherhaarig, schwarz, die Seiten des Hinterleibes und die Hinterränder der Bauchringe verloschen bräunlich durchscheinend. Die Beine gleichfalls schwarz, der Schenkel roth, die vorderen nach den Kinieu zu bei bei rlem $q$ gebräunt, bei deın $\delta$ verwaschen geschwärzt. Das Prosterıum breit und flach, gleichfalls dicht silherhaarig. Das letzte Segment des $\delta$ einfach, des $q$ mit einer grossen rundlichen Grube.

(Gleichfalls aus Brasilien (Sello iun Mus. Berol.).

S6. Sc. velutinus in. Schwarz, dicht greishaarig, die Fühler und Beine (bis auf die schwarzen Vorderschenkel), ein vorderer Hakenfleck und ein Spitzenfleck rler Flügeldecken rothgelb; das Halsschild kaum puuktirt, auch die Punktstreifen sehr fein, vorn getrüht, hinter der Mitte verlosehen, mit flachen Zwvischenräumen. L. $2^{3 / 4}{ }^{\prime \prime \prime} ;$ Br. $1 \frac{1 / 3}{\prime \prime \prime}$.

Eine durch ihre eigenthümliche Behaarung und Zeichnung leicht keuntlichı, im Habitus zunächıst der vorhergehenden verwandten Art. Der Kopf flach nit wenig eingezogenem, durch einen flachen gebogenen Querwulst zwischen den Fühlern oben abgegränztem Kopfschilde; dip Stirn (des ठ) durch die grossen, tief dreieckig ausgebuchteten, uben fast zusanmenstossenden greisen Angen sehı verengt, mit lem Nacken dicht und fein runzlig punktirt, zienlich lang angedrückt greishıarig, schwarz; die üleraus schmale Oberlippe mit de.ı an der Spitze leichıt gebräunten Tastern rothgelb. Die Fühler fadenförmiy, von $2 / 3$ der Körperlänge, das zweite Glied kurz und knotig, das dritte nebst den folgenden 
dünn verkehrt kegelförmig, dreimal so lang wie das zweite, das vierte um die Hälfte und das fünfte doppelt länger als das dritte, das sechste ein wenig länger als das fünfte, und auch die folgenden so langsam abnehmend, dass das zehnte noch die Länge des vierten erreicht; das Eulglied mit schımal kegelförmigem Fortsatze. Die oberen Glieder nach ihrer Spitze zu nur wenig erweitert, kaum zusammengedrückt, die Farbe rothgelh mit rauchgrauem Anfluge der letzten Glieder. Das Halsschild etwa $2 \%$ mal breiter als lang, mit kaum aufgekrümmter Mittelfirste, liuten abgeflacht, vor'n über den rechtwinkligen Vorderecken zusammengedrückt und dadurch verschmälert; die Seiten fein gerandet, in der Vitte iı einen fast winkligen Bogen erweitert, vor ihr fast grade verlaufend, die Hinterecken stumpfwinklig, der Ilinterrand nur jederseits des wenig bemerkbaren Mittelzipfels leicht ausgebuchtet, mid zu heiden Seiten des letzteren ein breiter, flacher Schrägeindruck. Die Oberfläche kaum sichtbar punktirt, einfarlig schwarz, überall mit eimer feinen und ziemlich dichten angedrïckten greisen Behaarung bedeckt, durch welche der Untergrund mit leicht metallisch-bäulichem Schimmer hindurch scheint. Das Schildchen stark ansteigend, kïrzer als vorn breil, hinterwärts nerklich verschınälert, und mit zugerundeten Ecken und leutlichem Hinterzipfel ahgestutzl; die Oberfläche gleichfalls schwarz und dicht greishaarig. Die leckschilde um $1 / 3$ länger als breit, fast gleichloreil, aul dem Rücken abgeflacht, hinter dem Schildchen und dam wieder auf der Mitte der Naht leicht quer niedergedrückı, hinter der Vorderkante schmal quer eingedrïckt und dahinter sanft yuer anfgewulstet; die Schulterbeulen wenig hervortretend, unr dir Seitenlappren ziemlich lang abwärts gezogen. Die Punktstreifen äusserst fein, durch die feinen Querrunzelı der flachen Zwischenräume und die dichle grane Behaarung noch mehr rerdunkelt, auf der hinteren Ifalfte kann noch bemerkbar; von den Zwischenräumen drei als übelaus schwache Längslinien unter selır schı̈̈ger Beleuchtumg 'twas stärlier emporgehoben. Die Farbe schwarz, ein Wurzellleck zwischen Schildchen und Seitenlappen, aber letzteren sowie die Sclunterbeule freilassend und dann hakenförmig mit den äusseren zwoi Dritteln lïngs dem zehnten Streifen bis zur Mitte der Flügeldeckenlänge fortlaufend, und ein rundlicher Fleck hinten in Nahtwintiel anf jeder Flügeldecke hell rothgelb; heirles, Grundfarbe und Zeiclmung, durch die dichte und kurze grause Behaarung matı. Das längskielige Pygi- 
dium mit der Unterseite gleichfalls dicht grauhaarig, schwarz; die Beine hell rothgelb nit schwärzlichen Vorderschenkeln, auch dip Inıenkanten der stark gekrümmten Vorderschienen, die Krallenhäkchıen und die lang gewimperten Lappeı des dritten Fussgliedes geschwärzt. Das Prosternum flach, läugs der Mitte seicht niedergedrückt, der Hinterlappen ziemlich star'h verschmälert. Das letzte Segment des o halbmondförnnig ifuer eingedrückt, des of unbekannt.

Ebenfalls aus Brasilien (b. Olfers in Mus. Berol.).

87. Sc. superbiens m. Scliwarz, ein Fleck aul der Stirn, vier des fein runzlig punktirten Halsschilds, drei der Flügeldecken und zwei des Pygilliums mit dem Rande des Hinterleibes und den Spitzen der Mittel- und Hinterschenkel röthlich weiss; die Punktstreifen vorn zu Runzehı verflossen, hiuten deutlicher, mit flachen Zwischenräumen. L. $1 \%{ }^{\prime \prime \prime} ; \mathrm{Br} . \mathrm{I}^{\prime \prime \prime}$.

Ein wegen seiner eigenthümlich hunten Zeichnung mit keinem ander'u zu rerwechselnder Käfer. Der Kopf breit und flach, mit etwas eingezogeuem unterem Rande des Kopfschilds, durch dichte und feine Punlitirung matt, die schmal aber ziemlich tief ausgebuchteten Augen (bei dem $\$$ ) olven durch einen breiten Zwischenraun getrennt. Die Farbe schwarz, ein verkelırt dreieckiger Fleck zwischen den Augenbuchten weiss mit schwach röthlichem Anfluge, auch die Oberlippe weisslich, und nur in der Mitte quer verwaschen geschwärzt. Die liühler nicht völlig rou lıalber Körperlänge, das Wurzelglied mässig aufgetriehen, über doppelt länger als breit, das zweite kugelig, clas dritte um die Hälfte und das vierte doppelt länger als das zweite, dem viertèn die oberen gleich, dabei von der Spitze des fünften ab mässig zusammengedrïckt unıl erweitert. Die Farbe schwarz, die unteren an den Spitzen und auf der Unterseite bleich geröthet. Has Halsschild breit und flach walzenförmig, mit sanft quer aufgewölhter Mitte, und von dieser aus mit der grösseren Hälfte nach vorn sehr allmählich, ınit der kleineren hinterwärts etwas stärker abfallend, über den scharf und breit spitzwinkligen Vordereckeı zusammengedrücht und dadurch verschmälert; die Seiten fein gerandet, in der Mitte schwach bogig erweitert, die Hinterecken stumpf alogerundet, und der Hinterrand jederseits des etwas anfgelogenen Mittelzipfels tiefer ausgebuchtet: vor letzterem zu beirlen Seiten ein breiter und stumpfer, sich nach Aussen bald verlierender Quereinlruck, und noch weiter uach Aussen 
am Hinterrande ein sehr unscheinbares Querfältchen. Die Oberfläche mit ziemlich dichten aber seichten Querrunzeln bedeckt und dadurch ziemlich matt, ausserdem sind seitlich auf denı dichten Rande noch vereinzelte Punkte bemerkbar. Die Farbe schwarz, ein abgekürzter Längsfleck auf der Mitte, eiı mit ihm nicht zusammenhängender hufeisenförmiger, ınit beiden Armeı nach vorn zeigender Hinterfleck vor dem Schildchen, und ein breiter mit dem hakenförmig umgehogenen Vorderende noch etwa je eiu Viertel des Vorderrandes begleitender Seitensaum weiss, mit schwach röıhlichem Anfluge. Das Schildchen kanm halb so lang wir voln hieit, stark ansteigend, der grosse dreieckige llinterzipfel fast halb so lang wie die vordere Schildchenfläche; letztere äusserst fein punktirt, mit Spuren abgeriebener greiser Behaarung, ziemlich glänzend schwarz. Die Deckschilde flach walzenförnig, etwa $1 / 3$ länger als breit, der Rücken längs der Naht niedergedriïckt, hintır der scharfen Vorderkante nur linienförmig quer gefurcht, mol diese Linie innerseits der ziemlich breit höckerigen Schulterhenlen zu einem breiteren und flacheren Eindrucke erweitert, anch die Seitenlappen breit zugerundet, und über ihnen die Deckschilde leicht zusammengedrückt. Die Punktirung vor'u nu' auf den hellgezeichueten Stellen deutlich, auf dem schwarzen Grumle zu nicht tiefen, meh» oder weniger welligen Querrumzeln verflossen, ans denen sich erst von der Mitte ab zunächst läng̨s Naht und Seitenrand regchmässige, aber ziemlich feine und meist schon vor der Wölbung erloschene Punktstreifen entwickeln. Die Zwischeuräume der'selloen loreit und flach, aber, wie auch der vorlere Zwischengrund, nur seidig schimmernd ohne eigentlichen Glanz. Die Farbe schwar\%, ein dreieckiger Schrägfleck vorı jederseits nehen dem Schilkchen, ein Kandfleck vorn ausserhall, der Schulterbeule his zum Ende des Seitenlappens, dem unseres Crypt. Yoraei ähnlich, und ein mondförmiger Fleck hinten in Nahtwinkel weiss, gleichfalls schwach in's Röthliche spielend. Das Pygilium zerstreut punktirt, sehr dümn greishaarig, schwarz, jeder'seits mit eincm dreieckigen, den Saum des Hinterleibes fortsetzenden Flecke. Die Unterseite schwarz, ein breiter, durch das Giühchen auf dem letzten Ringe unterbrochener, rorn die seitlichen Vorderzipfel des ersten Ringes mit umfassenden Rand des Hinterleibes weiss. Die Beine scluwarz mit gebräunten Fussgliederu, ein Fleck auf den Vorderhülten sammt den Spitzen der Mittel- und IInterschenkel weiss, auch an den Vorderschen- 
kelı Spuren eiuer erloschenen weissen Längslinie. Das Prosternum ziemlich breit, längsrunzlig, greishaarig, hiıten schmal zugerundet. Das letzte Segment des \& mit einer grossen, im Inmern geschwälzten Grube, das ơ unbekannt.

Gleichfalls aus Brasilien (von S. Arem: Mus. Baly).

$Z$ wölfte Rotte. Körper schnal, gestreckt walzenförmig, gleichlseit und ohen abgeflacht, mit kurzem, seitlich stark zusammengedrücktem und dadurch verschmälerten, aber nicht eingedrücktem Halsschilde. Dio Scnlptur derh, die Färbung unten schıvarz, oben gelh mit schwarzen Zeichnungen. Eine einzelne Art aus Brasilien und den La Plata-Lïndern.

88. Sc. cultus v. Heyd. Schwarz, Kopf, Pygidium und Beine gelbbunt, das grob zerstreut punktirte Halsschild und die Flügeldecken gelh, ein zweilappiger Vorderfleck des ersteren und eine abgeküızte Längshinde der letzteren schwarz; die Punktirung der Deckschilde derl, voln dicht gredrängt, liuten ınd seitlich unregelmässige Streifeı bildend, mit fein gerunzelten Zwischenräumen. L. $2 \frac{1 / 4}{4}-2 \frac{1}{2}{ }^{\prime \prime \prime} ;$ Br. $1 \frac{1 / 6}{6}-1 \frac{1 / 4}{\prime \prime \prime}$.

Ebenfalls eine bunte, durch Färbung und Farbenvertheilung autfallende, nicht leichı zu verkenuende Art. Der líopf flach, der Nacken und die breite Stirn der Länge nach sehr seicht eingedrückt, das Kopfschild unten etwas eingezogen, mit sehr stark wieder vorspringender Oberlippe. Die Punktirung grob, auf den lichten Stellen sehr zerstreut, anf den schıvarzen dichter gedrängt, mit glänzendem Zwvischengrunde. Dir Grundfirbe schwarz, ein grosser, halbrunder Stirnfleck, und zwei kleinere rautenförmige Querflecke auf dem Kopfschilde hell röthlichgell, dic letzteren fehlen bei zweien der vorliegenden Stücke. Die Mtundheile schwarz mit breit verwaschen gerötheten Rändern der Oberlippe, die grossen, breit gebuchteten und (bei dem $q$ ) weit getrennten Augen greis. Die Fühler nicht von halber Körperlänge, mässig stark, das Wurzelglied kurz eiförmig aufgetricben, um die Hälfte länger als breit, das zweite kugelig und halb so breit wie das erste, das dritte doppelt-, das vierte und füıfte je viermal länger als das zweite, und das fünfte oben anch schon ein wenig erweitert, das sechste und siebente je dem fünften gleich, die drei folgenden wieder allmählich abnehınend, sodass das zehnte nur dem dritten gleichkommt, das Endglied mit seinem kurz und breit dreieckigem Fortsatze wiederum den füuften gleich; dabei die oberen nur massig 
zusammengedrückt und verbreitert. Die Farbe schwarz, die unteren Glieder bis zur Mitte des sechsten an den Spitzen und Ränflern pechbräunlich durchscheinend, die oberen dünn angedrückt greishaarig. Das Halsschild nur etwa um die Hälfte breiter als lang, mit fast grader, nur in der Mitte sehr schwach aufwärts gekrïmmter Mittelfirste, über den scharfen, kurz pfriemlich abwärts gezogenen Vorderecken sehr breit zusammengedrückt und dadurch verschmälert, die Seiten fein gerandet, nach vorn in breiten bis zur Nitie stark abwärts geneigten Bogen zusammenlaufend, die Hinterecken nur als kurze scharfe Schwielen bemerkbar, der Hinterrand jederseits des Mıttelzipfels scharf ausgebuchtet, letzterer nur schwach aufgehogen; vor ihın und überhaupt den ganzen Hinterrand entlang die Oberlläche lreit und seicht niedergedrückt. Die Punktirung deutlich aber zerstreut, längs der Mitte schwächer und wie abgeschliffen, seitlich besonders in den Vorder- und Hinterwinkehn dichter gedrängt mit gläızendem Zwischengrunde. Die Farbe rothgelb, die Seiten ziemlich breit und verwaschen heller gell, und auf der vordren IIäffte ein grosser, an den Vorderrand gelehnter und hier die Breite des Nackens eimnehmender schwarzer Fleck, welcher hinterwärts bis zur Mitte reicht, und hier durch einen kırzen lichten Längseinschnitt in zwei quer abgestutzte Lappen getheilt ist: bei einem der vorliegenden Stücke, und zwar auffälliger Weise grade bei einem ler oben erwähnten mit fehlenden Flecken des Kopfschilds ist lerselbe vollständig in zwei rereinzelte Flecke zerrissen. Das Schildchen quer viereckig und hinterwärts etwas verschmälert, schräg ansteigend, mit grossem Hinterzipfel quer abgestutzt, glänzend schwarz. Ilie Leckschilde länglich-viereckig mud ziemlich gleichbreit, un die fläfte länger als breit und hinten kurz zugerumdel, vorn kanm breiter aber reichlich dopjelt länger als das Halsschild, hinter der scharten, an die breiten flachen Schulterbeulen angeschlossenen Vorderkante quer eingedrückt, üher den kurzen Seitenlappen leicht zusammenged'ückt; der Rïcken rom zweiten Drittel der Naht an abgrellacht und dann mit kur\%er, mässig gekrümmter Wölloung abfallend. 1)ie P'unktirung ron gleicher Stärke wie die des Halsschilds, auf der vorderen Häfte ziemlich dicht gedrängt, aher doch so, dass zwischen Schildchen und Schulterheule drei sehr schwache Längssippen sichtbar werden und sicli jederseits derselben Andeutumgen ron Punktstreifen erkemen lassen, deren ferncre Zwischenräume mit gleichstarken P'unkten be- 
deckt und dadu'ch verdunkelt sind; am Aussenrande ist jedoch ausser dem Randstreifen auch der neunte, und weniger deutlich der achte Streifen zu erkemuen. Von der Mitte ab treten dann zuförderst die der Naht zunäehst liegenden Streifen bis zum fünften, auf der Wölbung auch die Hinterenden der beiden auf der Schuiterbeule entspringenden (des sechsten und siebenten) hervor, deren auf der sehwarzen Binde liegender Zwischenraum fast bis zur Wölbung hin mit dichten Punkten besetzt ist: gleichzeitig mit dieser deutlicheren Streifenentwickelung nimmt aber die Stärke der Punkte ab, so dass dieselben auf der Wölbung nur noch schwach angedeutet sind, und unter ihr die Spitze ganz punktfrei daliegt. Der Zwischengrund äusserst fein gerunzelt, mit mässigem Glanze, nur der neunte Zwischenraun und die Wölbung etwas stärker glänzend; der ungeschlagene Rand des Seitenlappens glatt und ohne Punkte. Die Farbe bell rothgell, die Seitenlappen und die verwaschene Spitze heller gelb, das Innere der Punkte gebräunt; und ausserdem auf jeder Flügeldecke eine breite, vorn von der Schulterbeule bis zum Vorderende des zweiten Punktstreifens reichende, hinterwärts schırag der Nalıt zu gerichtete, aber auf der Wölbung abbrechende Längsbinde sclıwarz. I)as Hinterende derselben ist zuweilen soweit abgeschwäeht, dass der imnere Rand merklich über den äusseren hinitusreicht, und eben so funden sich Stücke, bei denen sich auch das Vorderende soweit versehmälert, dass es die Schulterbeule nicht einschliesst, sondern nur die innere Seite rlesselhen mit einem schmalen Wische die Wurzel erreicht. Das Pygidium äusserst fein rumzlig pmlitirt, dünn greishaarig, schwarz; jederseits an Rande ein zweilappiger weisslicher Fleck. Auch die Unterseite fein runzlig punktirt, angedrückt grpisharig, der Ilinterleib breit weissgell) gesiumt, und dieser Saum nur durch das Hinterleibsgrübchıeı des $\&$ unterlıvelıen, dafür aber hier mit seinen Enden an die Flecke des Pygidlums anschliessend. Die Beine schwarz mit rothlraunen Füssen; ausserdem an den Vorderbeinen ein Fleck an unteren Schenlielende nebst den Ilüften und den Schienen bis auf eine schwäraliche Linje an deren Anssenseite, an den Mittelbeinen ansser dem Kniefleck der Schenkel noch eine Längslinie auf deren lnnenkante, und der ganze ohere Theil der Schienen gelb; an den Hinterschenkehn ist nur die Unterseite und eine das Kuie nicht erreichende Längshinie auf der Oberseite schwarz, an den Schienen das untere Eude verwasclien 
gebräunt. Dahei sind die Vorderschenkel stark aufgetrieben und die Schienen entsprechend gekrümmt. Das Prosternum flach, der Länge nach jedlerseits leicht eingedlückt, lang weisshaarig, mit grossem, rundem, röthlich gesäumtenı Hinterzipfel. Das letzte Segment des $q$ mit einer breiten rundlichen gläızenden Grube, das ठt unbekanut.

Aus Südbrasilien und den La Plata-Landschaften (von Porto Allegre: Sello im Mus. Berol., und wahrscheinlich aus derselben Fregend das von Beslie stammende, nur als brasiliauisch bezeichnete Stïck des Mıs. Schnum, da Beske vorzugsweise in Südbrasilien gesammelt hat; fermer aus Paraguay: Vogt im Mus. v. Heyden; und von Buenos Ayres: Mus. IJaag).

Dreize hute Rotte. Körper kurz und gedrungen, hreit, mit stark kugelig gewölbtem, dicht siebartig punktirtem Halsschilde uıd derben stark kerbfurchigen Punktstreifen; die Angen selbst bei rlem \& sehr genälıert. Die Farbe unscheinhar braun nit schmutzig gelhlicher Zeichnung. Zwei Arten aus dem nördlichen Gebiete.

89. Sc. reticollis m. Braun gewölkt mit weissbuntem Kopfe, die Seiten und zwei Hinterllecke des dicht grubig punktirten Halsschilds, und Wurzel und Spitze der Heckschilde mit Lnterseite und Beinen heller gelblich; die Punlitstreifen regelnässig und derb, mit vorn kielig erhöhten, hinten flacheren, fein gerunzelten Zwischenräumelı. L. $2^{\prime \prime \prime} ; \mathrm{Br}$. $11 / 4{ }^{\prime \prime \prime}$.

Eine kurze und gedrungenc, ilırem ganzen Habitus nach keiner anderı südamerikanischen vergleichlare Art. Der Kopf unten flach, glänzend, grob junktiıt, mit schräg zurückgekrümmıtem Nackeu, die Stiru durch die (auch bei dem $f$ ) selır geuäherten Augen verengt, mit deutlicher Stiruriuue. Die Farbe schwarz mit gebräunter Oberlippe, ein olıerwärts verschmälerter Querlleck zwisclien und über den lugenbuchten, unıl jederseits der Stiruriune über de॥ Augen noch ein dreieckiges Nackenfleckichen weisslich. Die Fühler üheraus kurz und kaum dron Hinterrand des Halsschilds erreichend fast üherall gleich stark, das zweite Glied merklich anfgetrieben, fast kugelig, etwa $2 \frac{1}{2}$ mal kürzer aher wenig dünuer als das erste, das dritte dem zweiten gleich, aher schmal verkiblitkegrelförmig, das vierte fast doppelt länger, und diesem, his auf das noch etwas verlängerte fünfte ınd elfte, auch die übrigen gleich, Irtzlere rom sechsten ab wenigg zusimmengedrückt und erweitert, mit kurz dreieckigem Fortsatze des Endglieds. Die drei unteren 
rothgell, mit gebräunter Oherseite, die beiden folgenlen dunkler bramn, die oberen schwarz. Has Halsschild reichlich ım die Hälfte breiter als lang, hinter der Mitte stark quer aufgewulstet und dann nach vor'n kugelig abwärts gewölbt, vor dem Hinterrande tief quer eingedrückt, und lann seitwär's über der Mitte noch ein breiter Schrägeindruck. durch welchen der Seitenraud etwas bogig abwärts gerdrängt wird; vor und hinter ihr die Seiten leicht ausgeschweift, Vorter- und Hinterecken scharf, anch die letzteren rechtwinklig und dabei etwas aufgobogen, der Hinterrand fast grade, mit kurz heraustretendem Mittelzipfel. Die Oherfläche mil flachen, runden orler länglichen dicht an einanter stossenden Grühchen bedeckt, deren Zwischengrund als cin aus haardünnen Maschen gebildetes Nelz erscheint, und bei ungenaurer Betrachtung oder trüber Beleuchtung den Eindruck einer gekörıten Fläche hervorruft; nur der schmale abgesetzte Vordersaum und der Miltelzijfel deș Hinterrandes ohne solche Grübchen, zugleich zienlich glänzenıl schwarz. Die übrige Oberfläche nur seidig schimmernd, tiel schwarzbraun, die Seiten heller rothbraın, die Vorderwinkel und ein stärker ausgefärbter eirunder Schrägfleck jederseits vor dem Schildchen verwaschen gelb oder ziegelroth. Ilas Schildchen mässig ansteigent, merklich kürzer als vor'n breit, linten ahgestutzt mit algerundeten Hinterecken und lang ffriemlich ansgezogenem, hinter der Wurzel noch mit einem kleinen Querhöclier besetzten Hinterzipfel; die Oberfläche längsrissig punktirt, schwar'z. Die Deckschilde breit und flach gewölht, so breit wi̊ lang, seitlich und hinten starli abwärts gekrümmt, hinter der scharlen Vorderkante schmal quer eingedrückt, mit breiten Schulterbeulen und kriftig ansgehildeten Seitenlappen. Die Punktstreifen vorn kräftig, aus grossen tief ringedrrickten Punkten gebildet, welche von der Mitte ah plötzlich in schmale langgestreckte Pünktchen übergehen und his zur Wölbung noch mehr abnehmen; der sechste bis achte hinter der Schulterbeule laufen schon dem Hinterente des Seitenlappens gegenüber in einen einzigen Streifen zusammen, welchr' anf $\%$ der Flügehleckenlänge sich ganz verliert. Vorn, so lange die Punlitstreilen tief und derh, sind auch die Zwischenräume schmaler, mul als etwals gekerhte Rippen erhöht, hinterwärts werden diesellıen breiter und flach('r, sind aber überall durch dichte Querrunzeln matt. Die Farbe schwarz, nur der Kiel des Seitenlappens, dessen Färlınng sich bei einem Stücke zu einen länglichen Sclıulterfleck erweitert, ein grosser 
verwaschener Questleck histes Aer volderen Querfurche awischen

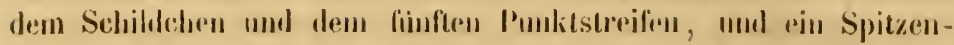
lleck unter der Wüllung gells mit röthlichem Antluge, oder aues,

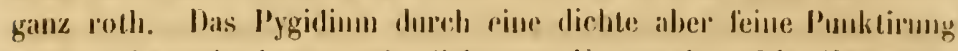
matt, schmutzig bram mit lichleren Unterende. Die Unterseite trüb gell, Unterseite son Sohenkehn und Schienen nebst Wurzel und Spitzo der ersteren ins Böbliche fallend; Mithel- mol Hinterdseine laleich-

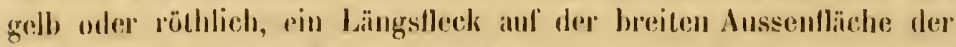
Schenkel, die untre Hillte der Schienen und die Füsse geschwär.t. Jas Prostcrumu breit, llach, groh runzlig, mit fast dreirekigem, durch vine leine Querlinie ahgeschnitturem Hinterypfel. Das letate Segunent des of mit riner kleinen rmudlichen Grube; das of unbekamul.

Aus Surinam (von Paramaribe: Mus. Moltrn. Clarh).

90. Sce. subluallatus m. Schwar\% mit weissem StirnHeck und gelblichen Beinen, zwei grosse Hinterflecke des dich grubig punktirten Ilalsschilds, dir Wurzel and rin Spitzenfleck der

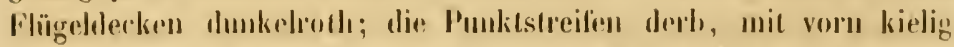
emŏhten, hinten thacheren, frin germonten Zwischenrämen. L. $2 \frac{1}{2}{ }^{\prime \prime \prime} ; 13 \mathrm{r}$. $1 \frac{1}{3}{ }^{\prime \prime \prime}$.

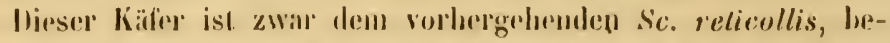

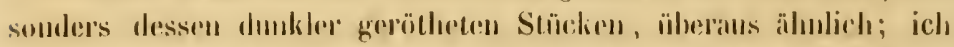

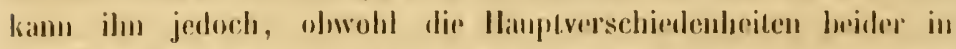

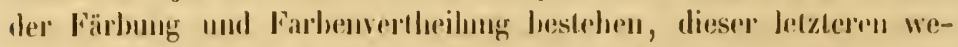

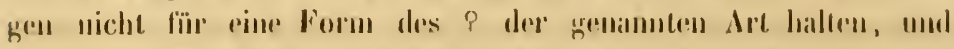

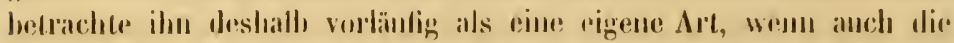

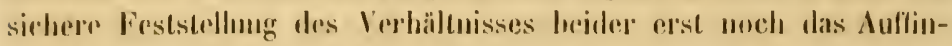
den viner grösseren Anzahl umbl leider lieschlechler voriusselzal.

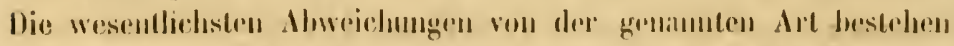

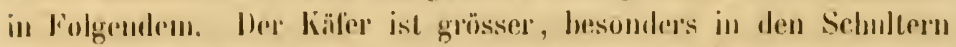

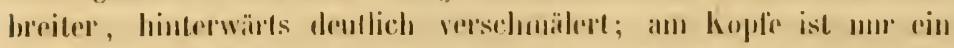

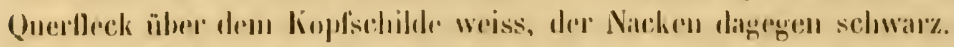

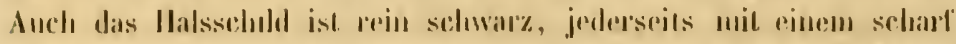

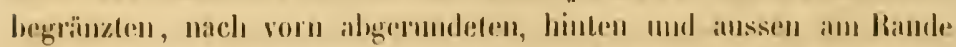

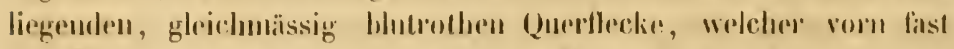

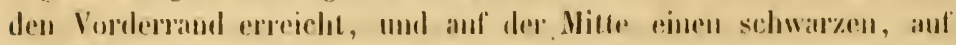
dem Mltheipfel des Ilinterramdes stehenden und diesem an Breite?

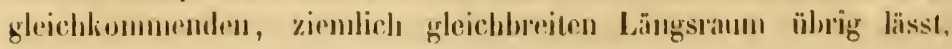




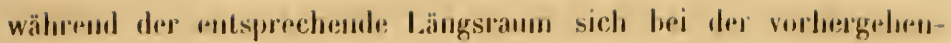
den Art hinterwirts stark versclmälent, und der danan gränzsude Theil der hrefleren Seitenzedchumug stark ius Gelloliche fallı, dadurch

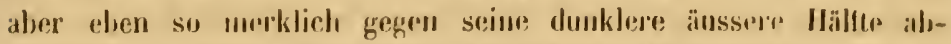

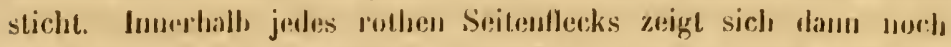
ein schwacher Schrägeindruck. Jas Schildchen eiufarbig schwar", mit sehn grossem, dreieckigen, mit seiner Spilze wiederum höckerig empor gerichletem Hintergiptel. Auch dir Flïgralderken schwark,

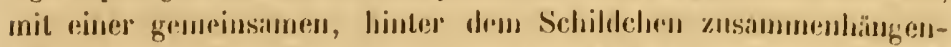

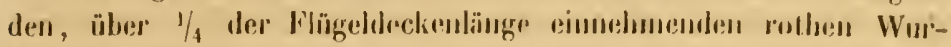

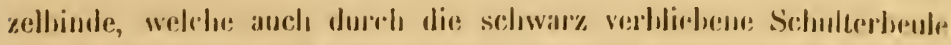
mal hinterwirts unterlurochen ist, aber vor dieser sich un den

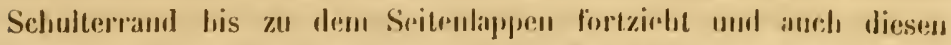
noch nit rinschliesst; ansserdenn die Spritzo durch einen schräg drejeckigen, am Aussemrande das hintere Drillel der Flögreldecken unfassenden rothen filock ringenommen. Das mit seinenn untren Theile stark einwïlts gekrïımmte Pygillium nelst der Unterseit:

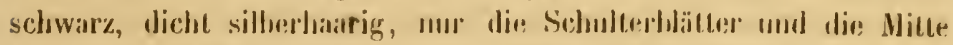

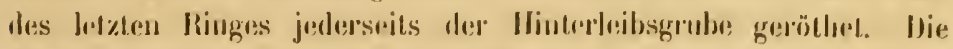

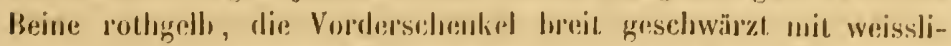
chen Vorderhiölen, die Viltelschenkel vor der helleren spritze vertwaschen dunkler geringelt. Alles Unlurige wie bri del vorhergehenden Art. Jas letote Segrnent des of mit rimer grossen halls kngeligen, gläızenden Girube, das of mulnekannt.

Aus Neu-Ciranada (Mus. Clark.).

Vierzehute Rotle. Körpar flach, gleichloreit oder hioler-

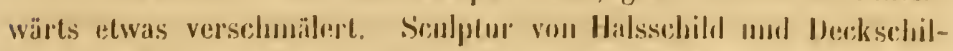

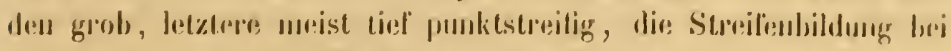

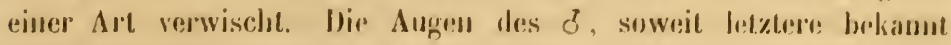

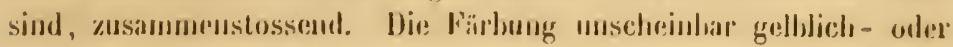

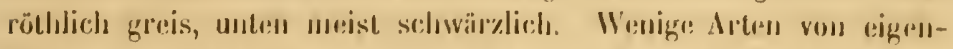

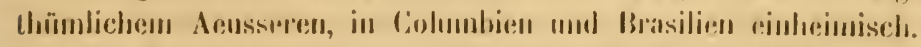

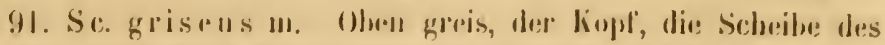

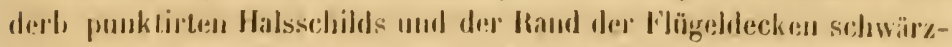

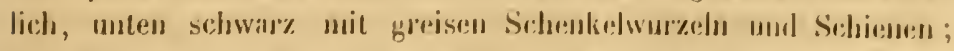

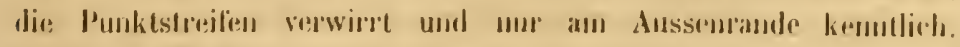
L. $2 \frac{1}{4}{ }^{\prime \prime \prime} ; \mathrm{Br}$. $1 \frac{1}{4}{ }^{\prime \prime \prime}$.

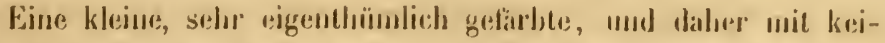

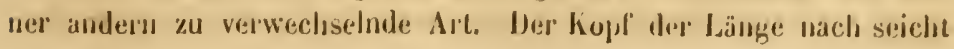


niedergedrückt, grob rumzlig punktirt, dicht greishaarig, schwarz mit greisgelber Oberlippe, die Stirı (des ठ) durch die einander ziemlich nalıe kommenden, sclunal und nicht sehr tief ausgerandeten Augen verengt. Die Fühler kaun von lıalber liörperlängr, das Wurzelylied stark aufgetrieben, das zweite eiförmig, die drei folgenden dïnn verliehrt legelförmig, die olesen nur schwach erweitert und zusammengedrückt, die Jarbe gleichfalls ein schmutziges Greisgelt. Das Inalsschilı um die IIälfte breitur als lang, von der quer aulgewölbten Mitte ah nach vor'n und hinten gleichmässigg ahwärts gekrümmn ; die Seitenränler bei dem einzigen vorliegenden Stïcke in seltsamer Weise verschieden gestaltet, rechts nämlich ror der Mitte stark bogig erweitert unt hinter ihr bis zu der scharlen Hinterecke tief ausgeschweifl, liuks dagegen einfach mässig zugerundet, erst dicht vor der nicht ganz so scharfen Ilinterecke kurz abgeschrägt: welche von diesen Bildungen nun die nornatı ist, wird erst der Vergleich einer grösseren Anzah! von Exemplaren entscheiden können. Der llinterrand jederseits leicht geschweili, mit kurzen etwas aulgebogenem Hittelziplol. Die Oherlläche über der Mitte der Suitunänder leicłıt zusammengedrückt, dicht siebartig punktirt mit schwach gläızenden Zwischengrundı; die Farbe schmutzig greisgell, ein leiner Saum schwarz, und ein grosser verwaschenbegräuzter yuer gerundeter Flech aul' der Scheibe selıwärzlich. Das Schildchen nicht völlig so lang wie vorn hreit, hinterwärts etwas verschmäler't und mit deutlichem Hinterziplel quer abgestutzt, gleichlalls schmutzig geschwälzt. Die Deckschille wenig länger als vorn lıreit, zientich flach, hinter der leicht aufgetrieheneı Wurzel breit ques nierlergedsrïckt, hinter der scharf erhöhteı Vorderkante schmal quergefincht; lis scludterbeulen breit und flach, die Seitenlappen schmal, aber tief alwil'ts gezogen. Dit? Punktirung eben so derh aber weniger dicht als die des Halsschilds; die ursprünglich rorhandenen P'unktstreilen meh" oder weniger in einander gewirnt, wellig gobogen und durch äberzählig eingemengte Punkte derartig getrübt, dass sie nur nocks stellenweise sich erkennen lassen: nur der achte und noch mehr der neunte sind vollständig vorhamlen, und auch ant der glatten Wölbung treten enige Streifenenden etwas deutlicher hervor. Die Farbe auch hier ein schmutziges Greisgell, ein die Schulterbeul. und den Seitenlappen einschliessender und sich an der Spitze zu einem schnalen Quertlecke erweiternder Saum der Flügeldecken 
schwarz. Pygidium und Unterseite gleichfalls schwarz, dicht greishaarig, mit gell,icher Vorderhälfte der hinten breit zugerundeten Vorderhrust. Die Beine gelb, die unteren Schenkelhälften bis auf ein helles Fleckchen über dem Knie, und eben so das obere Drittel der Schienen greisgell, die Fussglieder an der Wurzel heller durchischeinend. Das letzte Segment des $\delta$ einfach; das $f$ unbekannt.

Aus Columbien (Mus. Deyrolle).

92. Sc. sulcipennis m. Oben trüb ziegelıoth, Vorder- und Seitemrand des dicht siebartig punktirten, lappig schwarz gezeichneten Halsschilds nehst dem Kiel des Seitenlappens weisslich, die Ränder der Flägeldecken und ein Fleck vor deren Spitze schivarz, unten schwarz, dicht gellhaarig mil gelbbunten Beinen; die Punktstreifen derb, die oberen vorn verdoppelt, der sechste mnl siebente alogekürzt, mit rippentörmigen, fein gerunzelten Zwischen-

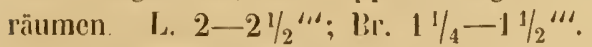

Dem vorhergehenden ähnlich, aber von ilım durch die deutlichen Punktstreifun der Deckschilde verschieden, in mancher Beziehung auch dem $S c$. relicollis verwand, gewissermassen die vorige unt diese Rotte mit einander verbindend. Der Kopf tlach, bei dem $\delta$ fast ganz durch die grossen, durch eine kleine dreieckige Ausluchtıng selı ungleich getheilten und iı einer langen Naht zusammenstossenden Augen eingenommen, solass von der Stirı nur Inten ein kurz dreieckiges, mit dem lioptschilde: zusammenfliessendes Feld, und oben ein eben so kurzes aber breit verkelurt dreieckiges von einer Längslinie durchzogenes Nackenfel] ührig bleilıt: bei dem $q$ ist diese Linie kriftiger und länger, auch die Stirn auf beiden Seiten derselhen derb zerstreut punktirt. Die Farhe bei dem $\delta$ ein ins matt Gelhliche fallendes Weiss, welches auch die Mundtheile nit unfisst; bei deon + der Kopf schwarz, mur eine ahgekürzte Querhinde zwischen den Augenbuchten Imd ein Bogenfleck ülıer dem ohern Augenraule jeder'seits, wie auch die Iränder der Oberlippe weisslich: dies Weiss wie anfgetragen, ohne Punkte. Die Fühler von halber Kïrpıerlänge, das Wurzelglied breit anfgetrieben, dlas zweite ku'z eiförmig, die elrei folgenten selı dünn verkehrt liegelförmig, das dritte um die Hälfte, und das vierte doppelt länger, als das zweite, das fïıftre und das diesenn gleiche sechste je noch etwas länger, das siebente bis zehute je wieder den vierten, und das Endglied mit seinem liurzen Fortsatze dem sechsten XVI. 
gleich: die sechs oheren nur schwach zusammengedrückt und an ihrer Spitze erweitert. Die Farbe der fünf unteren liellgelb, der oberen schmutzig rauchgrau mit dümner greiser Behaarung. Das Halsschild mit leicht aufgekrümmter Nittelfirste, üher deu spitzwinkligen Vorderceken und ehen so über den scharf stumpfwinkligen Hinterecken breit aher nicht stark zusammengedrückt; die Seiten fein gerandel, in der llitte rundlich erweitert und vor ilır ausgeschweift, der llinterrand jederseits leicht gebuchtet, mit ziemlich stark entwickeltem, schıäg aufgebogenem, muscheinbar längskieligem, und in die Quere noch von einer ansserst feinen, anf der Mitte elwas hinterwärts gekrïmmten Kreislinie durchzogenem Mittelzipfel; seitlich von diesem je ein Jeichter, sclırïg nach unten und vor's gekrümmter Eindruck. Ilie Oherlläche dicht und deutlich punktirt, die Punkte vorn etwas in die Länge gezngen und dadurch der Zwischengrund zu Längsrunzeln umgestaltet, übrigens zipmlich matt. I) Förbung eigentlich ein verwaschenes Sohwarzhraun, mit lıdl rothgelhem orler weissgellem scharf hegränzlem Vorder- und Seitentande; ansserdem vor dem Hinterrande jederseits ein grosser eifürmiger verwaschen hegränzter trïh röthlicher Selıräglleck, welcher nach vor'n und aussen allmählich und ımscheinhar in die schwarze Färbung des Nittelfeldes übergeht, während lotztere in der Vitle sich mit schïrferes liegränzung als ein dreipchiger, naclı und nach verschmälerter Zipfel bis zum Hinterrande fortzielıt. Der Saum des letzteren mit dem Mittelzipfel gleıchfalls schwarz. Das Schildchen stark ansteigend, halh so lang wie vorn breit, hinten breit aligestutzt, mit deutlichem Hinterzipfel, fein punktirt und matt schwarz. Die Deckschilde wenig länger als vorn breit, hiuterwärts dentlich rerschmälert, oben bueit abgellacht und linten mit ziemblich steiles Wülsung abfallend, hinter der scharfen Vordeskants quer eingedrückt, die Schulterlsenlen nur flich, aher die kurzen Scitenlappen tief herabgezogen. Dir Punktstreifen solur regelmässig, die obren his üher die Mitte himans ziorlich verdoppelt, der serhste und siebente ror der Mitte alogerissen, der dreickigan Raum zwisehen dem ersten und der Naht, sowie der an der Schulterlonle verbreiterte Ramm neben drom fünften Streifen mit ïhrezihligen Punkten ausgelïllt. Die P'unktstreifen sämmstich in dentliche Furchen ringedrüclit, von denen die achte sich himtor don Ende des sechsten und siehenten streilens reptieft mol erweitert, die Zwischemrüme als schmale fängsriplpen enjor- 
gehohen, von denen die zwischen dem fünften und achten Streifen liegende sich auf der hinteren Hälfte stark verbreitert, dabei alle fein querrunzlig und ziemlich matt. l)ie Farbe ein nur matt "schimmerndes truihes Ziegelroth, der an der Wurzel manchmal sehr verbreiterte Saum der Flügeldecken mit der Sehulterheule und ein manchmal nur verwaschener Querfleck ülıer der Wölbung schwarz; der hintere Rand der scharfen Vorderkante und bei einigen der vorliegenden Stücke auch einige vorloschene Längslinien auf den Ripren vor und in dem schwarzen IInterflecke fahl gelblich; des liiel des Seitenlajpens und ein auf den neunten Zwischenraum übergreifender Fleck weisslich. Pygidium und Unterseite fein runzlig punktirt, schwarz mit mehr oder weniger deutlicher, verwaschen gelblicher Unterlage und dicht angedrückter, gleichfalls gelblicher Behaarung; die Beine sclımutzig lehmgelh, die Aussenkante der Schınkel und ein Lüngswisch auf deren breiter Vorderfläche trüb geschwärzt, auch dic Schienenenden und das Krallenglied schwärzlich angelaufen. Das Prosternum flach, in der Mitte seicht niedergedrückt, dicht anliegend belıaart. Jas letzte Segment des o einlach, das $q$ nit dem gewölunlichen Grübchen.

Aus Columbien (vou Lebas: Nus. Deyrolle; speciell bei Bogota: Mus. Kirsch.) und Neu-Granada (Mus. Clark.).

93. Sc. planatus m. Lelımgell, der Oberkopf, ein Querfleck ales dicht runzlig punktirten Ilalsschilds. das Sehildchen und zwri Punkte der Flügrddecken $(1,1)$ mit der Brust und der Spitze von Pygidium und Hinterleib sclıwarz; die Punlitstreifen derh, furchenartig rertieft, mit tlach gewölbten, querrunzligen Zwischenräumen. L. $23 / 4 "$; Br' $1 \frac{1}{3}{ }^{\prime \prime \prime}$.

Von mehr schłankem Baı als die vorhergehenden Arten, mehr gleichlıreit, übrigens von denselben nicht zu treunen. Der Kopf flach gewölbt mit etwas zurückitretemlem Nacken und stark eingezogenem Kopf'schilde, von einer Stirnlinie nur auf' dem Nacken und dem oberen Theile der Stim eine schwache Spur. Die Punktirung groh und zu dichten liunzelı verflossen, der Oberkopf his zu den Angenbuchten hinah schwarz, der Unterkopt mit den Tastern lehıngelb, die Oherlippe knochengells und die Kinnlacken schwarz. Ilie grossen, pinander (auch bei den ?) ziemlich genäherten und die Stirn einengenden, breit und tief ansgelunchteten Augen greis. Die Fühler kaum von $1 / 3$ der Körperlänge, aus dïmner Wuzel vom sechsten Gliede ab deutlich rerbreitert und zusanmengedrückt, das fünfte und 
sechste Glied von gleicher Linnge, je etwas länger als das vierte, und fast doppelt so lang wie das dritte. Die Farhe hellgelb, die fünf unteren Glieder durchscheinend. Das Halsschild über der Mlitı stark quer aufgewöllst, üher den tief eingezogenen, scharfen Vorderecken zusammongedrückt, aber doch nur wenig verschmälert; die Seiten tirf herabgezogen, frin geramlet, vor der Mitte etwas erweitert, hinter ihr leicht ansgeschweift, mit scharf stumpfwinkligen Hinterecken. Der Hinterrand fast grade, mit kurz heraustretenden, durch einen davor liegenden sclumalen bogenförmigen Eindruck etwas aufwärts getrielnenen Nlittelzipfel; die Eurlen jenes Eindrucks jederseits noch ïber dem letzten Drittel des Seitenrandes Jemerkbar. Die Oberfläche dicht runzlig punktirt, der in schmale und theilweise durchıscheinende Brïcken zerrissene Zwischengrunl bei gewisser Beleuchtung seidig glänzend, auf der llitte mit einem trapezförunigen scharfbegränzteı schwarzen Querflecke, dessen Hiuterrand von dem parallelon Vorderrande un die Ifälfte ïbertroflen wird, Das Schildchen sehr steil ansteigend, etwas lïnger als vorn breit, hinterwänts wenig verschmälert, mit ahgermuleten Ecken mud sehr kurzen Hinterzipfe] grade abgestutzt, ïbrraus dicht und lein junktirt, schwarz. Die Deckschilde um 1/3 lïnger als lreit und fast ylcichbreit, der Rücken sehr flach, hinter dem Schildchen und dann wieder auf der Nitte der Nalıt eingedrückt, hinter der scharfeu Vorderkante seicht quer gefurcht; die Schulterheulen schmal höckerig, auch die Seitenlappen nur kurz, aber nit lappiger Rundung tief herabgezogen, und über ihnen die Deckschilde auch nur schwach zusammengedrückt. Die Punktstreifen sehr regelnässig, ans tief eingedrïckten, cinander selır nahe gerïckten Punkten gebildet und daher hesonders auf dem Rücken dentliche schmale Furchen einscukend, der sechste bis achte hinter der Schulterbenle etwas feiner, der siehente schon vor der Mitte, der sechste und achle gleicls hinter ilır abgerissen; die Zwischenräume llach gewölbt und durch dichte Querrunzeln matt. Die Farbe lehmgelb mit bräunlichem Spitzensaume, welcher, sich allmählichı abschwächeml, längs Naht mud Ausscuraul eine Strecke weit nach vorn reichı, und ausserdem auf jeder Flügeldeclie zwei schwarze Punlite, der vordere, grössere und etwas nach Aussen quer gezogene auf der' Schulterbeule und dem unter ihr liegenden Thrile des neunten Zwischenraums, der kieinere lintere mehr rund, etwas verwaschen, ror der Wölbung bei dom Zusammentreflen des vierten und 
fünften Punktstreifents. Das Pygidium unten elwas aufgetrieben, dicht runzlig punktirt und fein greishaarig, lehmgelb, nit einem schwarzen Längsflecke von der aufgetriebenen Stelle bis zum unteren Rande; auch der Ilinterleil) lehıgell, mil gebräunten Vorderzipfeln des ersten, und einem schwarzen Querfleck auf der Vitte des letzten Bauchringes. Die Brust schwarz, nur die durch zwei seichte Längscindrücke etwas anfgewulstete Mitte des Prosternums und der Hintersaum seines abgerumdeten Ilinterzipfols gleichfalls gelb. Die Beine gelb mit gebräunten Häften; das letzte Segnıent des of mit einer mässigen Grube, über welche der schwarze Querfleck jederseits noch um mehr als deren Breite hinausreicht. Das o unbekaunt.

Aus Brasilien (Virmond iu Mus. Berol.).

Fünfzehute Rotle. Körper flach und gestreckt, von $\mathrm{Pa}-$ chybrachysartigen Ansehen. Das Halsschild walzenförmig, vorn und hinten eingeschnürt, dünn greishaarig. Die Declischilde glcichbreit und breiter als das Halsschild, grob punktirt, kaum mil Spuren von Punktstreifen. Die Färbung trübe, die Augen des ơ zusammenstossend. Eine einzelne Art aus Brasilien.

94. Sc. pallidilabris Stål. Braun mit weisser Oberlippe, zwei Flecken des Kopfes mil den dunkler geringelten Hinterschenkehn 'und -schienen gelblich, die Deckschilde roströthlich und gelb gewölkt mit weisslicher Spitze; das fein und dicht punktirte Halsschild düın silberhaarig mit zwei liahılen buchtigen Mittelfeldern, die Punktirung der Deckschilde grob runzlig mit Resten verdunkelter Punktstreifen. L. $2 \frac{2}{3}{ }^{\prime \prime \prime}$; Br. $11 / 4{ }^{\prime \prime \prime}$.

Puchybrachys pallidilabris Slål Till Kännedomen etc. in der üfversigt etc. S. 63 . n. 8 !

Eine sehr eigenthümliche, von allen vorhergehenden namentlich durch die Gestalt und die Behaarung des Halsschildes abweichende Art, deren Eigenthümlichkeiten aus der von Hrn. Stål gegebenen, sich lediglich auf die Färbung des Käfers besclıränkenden Diagnose nicht zu entnehmen sind. Der Kopf gross und flach, (bei dem đ) fast ganz durch die grossen, tief ausgebuchteten, mit den oberen Inneuränderı fast zusammenstossenden Augen cingenommen, das schmale Kopfschild etwas eingezogen und halbmondförmig niedergedrückt, die 'wieder vorspringende Oberlippe weiss, die Taster gelblich. Die Oberfläche des Kopfes braun, mit einer groben, runzlig verfliesseuden Punktirung bedeckt, dünn und ziem- 
lieh kut'z greishaarig; ein schwieliger Längsfleck auf der unteren Stirn, bis zu dem Zwischenraume der Fühlerwurzeln hinabreichend, schmutzig gell, und dieselhe Färbung zeigt pin kleinerer Querllecki auf dem Nacken, an dessen unterem Rande die leine, die Augenränder trennende Länğslinie beginnt. Die Fühler les einzigen vorliegenden Stückes nur unvollständig, das Wurzelglied wenig aufgetrieben, das zweite kugelig, etwa $21 / 2$ mal küızer alıer kaum sehmaler als das vorhergehnule, das dritte doppelt-, das vierte dreimal und das füıfte (längste) riermal so lang wie das zweite, die oberen zusammengedrüclit und dreieckigg erweitert, an Länge allmählıch wieder abnehmend, das sechste den ften gleich, die beiden folgenden je noch etwas kürzer: die ülırigen felılen. Die Farbe hellgelb, die oberen Glieder etwas dunkler. Das Halsschild beiuah so lang wie breit, walzenförmigr, vor der Hitte feicht quer aufgewölbt und dasselbe auch seitlich in leichter líümmung erweitert, der Vorderrand zwischen den Augen in einem flachen Bogen vorgezogen; hinter ilınen eingeschnürt und dadurch das Halsschild über den stumpl' rechtwinkligen Vordereclien verengend, die fein gerandeten Seiten schräg hinterwärts zu den scharl' stumpfwinliligen, gleichfalls wieder eingezogenen Iluterecken ansteigend; der Hinterrand jederseits des kitrzen Mittelziplels ausgebuchtet, und vor letzterem das Nittelfeld seicht quer niedergedrüclit. Die Punktirung dicht und leiu, die Farbe ein mates, glanzloses Braun mit röthlich durchscheinenden Vordersaume; die breiten Seiten mit einer angedrückten, mässigg dichten, silberglänzenden Behaarung besetzt, und die kahle mittlere Hälfte durch eine schmale älıer ihre Mitte bis zum Vorderande hinziehende Inaarlinie in zwei längliche neben einander liegende Felder getheilt, deren jodes durch eine ähuliche, aber etwas lireitere und ror der Mitte unterhochene Querlinie nochmals in zwei milcinander zusammenlıängende kieinere Felder zerrissen wird. Diese eigenthümliche Haarzrichnung ist so deutlich, dass sie schon denu unbewallineten Ange murerlionnbar entgegentritt. Das Schildchen ziemlich steil austeigend, fist um ılie Hälfte länger als breit, hinterwïts wenig rerschmälert nnd mit ahgerundeten Ecken ahgestıtzt, schwarz, dümn grreishaarig, mit glinzendem Hinterranle. Die Deekschilde länglich viereckig, etwa um 1/4 länger als hreit unıl hinterwärts ein wenig rorschnälort, der flache Rïcken hinker der Vitte breit fure niedergedtrickl und hinten mit ziemlich steiler Wülbung abfallend, hinter der scharfen 
Vorderkimte ziemlich breit, aber ıur flach ouer eingedrückt, die Schulterbeulen lualb efförmig, die Scitenlappen tief lierabgezogen und ïber ihnen die Deckschilute starli sehı̈̈g zusammengedrúckt. Die Punktirung dicht und grob, die Streifenbildum fast bis zur Wüllıng hin durch Eimmischmng älserzälliger Punkte von ggleicher Starke so volständig unterdrückt, unt zugleich dureh riı theilweise runzliges Trrfliessen des Zwischengrundes so verwischt, dass nur hier und da Spuren davon sielıtbar werien, als regelrecht ausgehildet um der nemite vorhauden ist, und als Rest von Zwischenräumen nur statt des vierten und achten eine flache schmale Längslinic lervortsith. Auf drm letaten Viertel vereinzeln sich die Punkte mehr, und lassen auch einige weitere sich wellig krümmende Streifenenden erkenten; der Zwischengrund äherall noch l'ein genasbt, zirmlich matt, und mur auf der Wölnng mit schwachem, wie durch Abreilsen antstandenem Glanze, Ibir Farhe ein dunkler und heller gewölites Rothbraun, bei wolchem die helleres Stellen hirer umd da ins verwaschen Gelbliche verbleichen, namentlich längs der Wurzel, an den Seiten da wo das zweite und wiederum das letzte Drittel der Länge begimnen, hiuster denı Queréindrucke auf der Naht, mul von letzterer Stelle aus den ersten Zwischenraum entlang bis zu dru Jneiten gelb gefärlıten linteren Nalıtwinkel hin; meist sind diese helleren Stellen auch etwas stärker schwielig erhölıt, ein weng mehr glïnzend, und ron der dunkleren Färbung der sie durchstechenten grolen Punktirung zerrissen. Pygidium und Unterseite dichit angedrïcht-silberhaarig, mit einem rundlichen kahleu Fleck aul der Mitte des rsteren, schmutzig gelbbraun; ein breiter Raud des Pygidiums mit den hinteren Ende des letzten Batuchringes, der Vilic des vorhergehenden, den scitlichen Vorderzipfelı des ersten Ringes umı den Schultorhattern ins beller Gelbliche fallend. Auch die Beine bram; Höften, Schenkelwurzehn, Knie und die oberen Schienenbälften mit den Fussgliedlern gell, die schwarzen krallenhälichen an der Wurzel zu einem blattartigen Zïhnchen erweitert. Das P'rosternum breit und flach, längs der Mitte sehr seicht nicdergedrückt, nit breit abgerundetem gellslichen IIinturende. Das letzte Segment des o mit eineur leichten, etwas dümner behaarten, daher anscheinend dunkler gefïrbten Quereindrucke; das of unbekaunt.

Aus Brasilien (Mus. Holm.). 


\section{Metallactus in.}

A ॥ gen ausgerandet.

Rückentheile nach oben frei beweglich.

Vorderbrust länger als breit, vorn flach, hinterwärts dureh die aufgerichteten Seitenkanten schwach rinnenförmig, durch einen runden Zipfel geschlossen, ohne Halskragen.

Selildehen vorhanden.

Zur Aufstellung dieser zwischen Scolochrus und Pachybrachys mitten inne stehenden Gattung habe ich mich, was zu erklären ich mich in meinem entomologischen Gewissen verpflichtet halte, nur mil einem gewissen Widerstreben entschliesseı liönnen. Die in ihr vereinigten Formen nähern sich, wenigstens zum grössten Theile, der einen wie der andern Gattung habituell so selır, dass man sic hei einer geringeren Artenzahl immerlin unter beide hälte vertheilen kömnen: aber bei der schon jetzl, zumal beim Hinzuziehen der nordamerikanischen Arten, erdrïckenden Artenzahl in beiden Gattungen würle durch jene Vertheilung auch nichts Erhebliches gewonnen, vielmehr die Uebersichtlichkeit nur noch mehr gestört werden, und daneben lässt sich doch auch nicht verkemnen, dass die meisten hier zusammengefassten Arten in ilırer äusseren Erscheinung sogleich wenigstens den negativen Eindruck hervorrufen, man habe in ilunen weder einen echten Scolochrus noch einen echten Pachybrachys vor sich. Unter diesen Umständen wird auch ein an sich geringfügigeres Merkmal zur Abgränzung jener Arten nicht verschmäht werden dürfen.

Dass diese Gattung nun auch eine wirklich natürliche sei, wie wir sie z. B. in den eigentlichen Pachybrachen vor uns haben, wage ich nach dem vorstehend Bemerkten nicht zu behaupten. Es liegt hier vielmehr wiederum ein Fall vor, wo die Natur sich nun einmal nicht in unsern Gatlungsschematismus fïgen zu wollen scheint, und wenu man daher auch alle Arten, die sich nach ihırem HabiLus füglich an die heiden oben genannten Gattungen amreihen liessen, dorthin verweisen wollte, so bliebe doch immer noch ein Rest von solehen Arten übrig, den man keiner von bejden zingesellen kanı, und der den Anhä̈ngern der Gathungs-Vervielfältigungstheorie noch hiulänglichen Stoff zu neuen Schöpfungen bieten dürfte. Mir erscheint es jedoch verdienstlicher, zumäelıst die von mir begonnene Sichtung und Auseinandersetzung des überreichlichen Arten- 
Materials zu einigem Abschlusse zu bringen: eine Revision der Gattungen dieser anziehenden Clırysomelen-Familie mag denn einer späteren kundigeren und zugleich glücklicheren Hand vorbehalten bleiben.

In der Reilıenfolge der Arten habe ich thunlichst einen innem Zusammenhang zwischen deı einzelnen Gruppen zu befulgen gesucht. Auf die ersten Seoloclırus-artigen Gruppen folgen von ./T. guttula Fabr, ab diejenigen Formen, die sich immer mehr dem Pachybrachys-artigen IIabitus nähern, mit mehı walzenförmigem, gleichbreiten Körjer: und in der Mitte flach quer polsterförmig aufgewölbtem Halsschilde; zuletzt folgt dam noch eine Reihe gewissermassen isolirt stehender, grosser plumper Arten, die zum Theil sogar noels einer scharfen Artunterscheidung grosse Schwierigkeiten entgegen stellen, und deren typischer Character in dem brasilianischen M. Kollari Perty seine grôsste Ausbildung erreicht. Hier isı deshalb auch für die specifische Diagnostik noch ein weiter Spielraum übrig.

Erste Rotte. Körper gestreckt, hinterwärts etwas verbreitert, mit aljgeflachten Deckschilden. Halsschild nach vorn kegelförmig verschmälert, hinten jederseits leicht schräg eiıgedrückt. Die Farbe schwarz mit rothen Fleckenzeichnungen der Decksehilde, meist an deren Wurzel und Spitze, die zuweilen auch auf das Halsschild übergehen. Arten aus Brasilieu und den La Plata-Laudschaften.

1. H. minax m. Schwarz mit knochengelber Oberlippe, die Fühlerwurzeln, ein Schulter- und Spitzenfleck der Flügeldecken, anch wohl einige Flecke des zerstreut punktirten Halsschilds ziegelrotlı; die Punktstreifen fein, vorn dureh überzählige Punkte gestört, mit flachen, spiegelglatten Zivischenıäumen. L. $33_{3}^{2}-4 \frac{1}{2}{ }^{\prime \prime \prime}$; Br. 2-2 $2 / 3{ }^{\prime \prime \prime}$.

Ein stattlicher, durch seine feine Punktirung nicht weniger als durch seine Grösse und den hinten verbreiterten Körper ausgezeichneter Käfer. Der Kopf flach, die Stirn (bei dem $q$ ) der Länge nach eingedrückt, und dann noch von eiuer deutlichen Längslinie durchzogen, oben glatt, unterwärts an den inneren Augenräıdern grob und tief punktirt, welche Punktirung in den Augenbuchten und auf dem Kopfschilde zu dichten Runzehı verfliesst. Die Farbe schwarz, nur die in der Mitte verwaschen gebräunte Oberlippe hell knochengelb, die 'Taster pechbräunlich, umd die kurzen, 
tief und zirmlich hreit ausgebuchteten, weit getrennten Augen greis. Das Hilsschild hall, so lang als hiuten lreit, mit fast grader Hittellirste, ïher den scharfen fast rechtwiuliligen Vorderecken stark zusammengerlrüclit und dadurch verschmälert, die Seiten fein gerandet, in der Mitte rundlich erweitert, vor ilır leicht ausgeschweift, hinten in Machrn Bogen in den hreit gubuchtelen Ilinterrand übergrehend, die stumpfen Hinterecken nur durch eine leichte Aufbiegung des abgesetzten Randes kenntlich gemacht, mit wenig ausgebildetem Miltelzipfel. Das llache Millelfeld hinterwärts elwas niedergedrüclit, und dascrlbst jerterseits mit rinem breitrn, gegen die erweitute Nitte der Seiten sich lopalsenlienden Schrägendrucke versehen, vor wrolıen noch eine dndeutung pines zweiten kïrzeren und schwicheren zu bemerken ist. Dis Punktirung olıen fein und zerstrent, nach den Seiten zu dichter und gröber, in den Hiıterwinkeln stellenweise runzlig verlliessend, mit gläuzendem Zwischengrunde. Die Farbe meist schwarz olne weitere Zeichunng, die aber hei andern Stücken auch ohne Rürksicht auf die anderweite Austrhnung der rothen Färbung zum Vorscheiı kommt. So ist bei einem auch sonst stark ruthgefïrblen Stïcke ein schmaler sich am Vorderrande hakenfürmig lis zu den Augen umbiegender Seitenrand unıl ein grösserer Längsfleck auf der Mitte, hei einem anderı nur die gewöhnlichın heiden Flecke der Flügeldrcken zeigemden der ganze nur vorn ust hinten in der slitte unterbruchene Rand des Halsschilds, bei riuem drithen nur jederseits ein verloschener Querfleck an der Hinterecke rotls; wieder bei einem andern stark geschwärzten Stĭcle zeigt die Nitte eles IJalsschilds ein kleines lothes Fleckchen als Rest des uben gedachıen Längsflecks. Das Schildchen schräg ansteigend, nicht ganz so lang wie vorn breit, hinten mit algerundeten Erken und selı Ileutlichem Hinterzipfel algestutzl; die Farbe auch hire glämzend schwarz. Die Dechschilite tist un rin Drittel liuger als lreit, llach walzenförmig und hinten nit lüzer Wöllung ziemlich steil abfallenu, linterwärts merlilich verbreiler', sodass die grüsste Breite elwa zu Aıfang des letzten Viortels fällt: der Rüclien hinter der scharf aufgeworfenen Vorderkante in einer schmalen Querlinie eingedrückt. Die schulterhenlen klein und flach, dic Seitenlappen schmal und lief herabgezogen, und üher ihnen ein seichter Quereindruck. Die Punktstreifen frin und schwach, ans solir vereinzelten Punkten gebildet, auf ‘lev vorderen Ilälfte durch cingemengte Punkte und ülser- 
zählige Streifenansätze derartig gestört, dass nur stellenweise Andeutungen regelnässiges Streifen zu bemerken sind, als völlig regelrecht aber nur der neunte sich liemntlich macht. Erst auf der Limteren Itilfte entwickeln sich aus dem Gowirre mehr regelmässige, aber auch an stäke su sohr abnehmende Streifm, dass ihre Hinterenden schon vor der Wölbung fast ganz verloschen sind, und auf dem hellen Spizenllecke nur noch die dunklere Färlung der Punkte eiıe Spur von ihnen erblicken lässı. Dic Zwischenräune breit und flach, glänzend, der breilere neunte vorn mil einigen gröberen Punkten besetzl. Die Farbe schwarz, ein die schwarz bleibende Schulterbeule mmzichender, den Seitenlappen mit einschliessender, nach Inmen his an den dritten Zwischenranm reichender Schulterfleck mud die ziemlieh breite Spitze, letztere in noch bleicherer Färbung, ziegelroth. Von der Spitze zieht sichı diese Färhung längs dem Aussemrande schräg nach vorn last bis zur Mitte hin, der hinteren Aussenecke des Sclunterllecks an den neunten Zwischenraum entgegen, bis zum Entstehen einer Abart:

$\beta$. der Spitzenfleck am Seitmrande mit dem Sclublterflecke zusammeustossend, wobei sich zugleich der letztere bis zum Schildchen ausdehut, und hipr sich rine gemeiusame, nur durch das Schildchen unterhrochene Querlinde längs der Wurzel bilslet. In der Regel bleibt die Schulterbeule schwarz; bei einem einzehnen mir vorliegenden Stüclie ist sie jedoch roth, obwohl der Zusanmenhang des Sclutler- mod Spitzenflecks am Seitenrande nicht rollständigg erfolgt ist. Das Halsschild ist grade bei diesem Stücke einfarlsig schwarz, auch die Punktirung vorn ein wenigg deutlicher, sonst finde ich jeduch lieinen Unterschied. Anderseits aber bildet sich durch Zurückbleiben der rothen Zeichnung auch noch eine Form

$\gamma$. mit sclıwarzen, nur an der Spitze einen etwas kleineren rothgelhen Querfleck zeigenden Flügeldecken, welche allerdings anf den ersten Blick etwas fremdirtig erscheint, aher eben so wenig wie die vorhergehende wesentliche Verschiedenheiten von der Grundform darbietel.

Das Pygidium mit der dich anliegend greishaarigen Unterseite unı den Beinen siufarbig sehwarz mit gobräuılen Hüften. Das Prostemm ziemlich schual, rorn flach, hinter der llitle

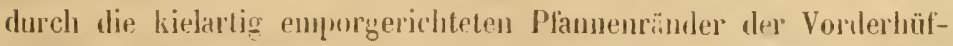
ten rimenförnig vertieft, mit ahgerundetem Ende. Das letzle Seg- 
ment des $q$ mit einer grossen und tiefen halbkugeligen Grube; das $\delta$ unbekannt.

Aus Brasilien (Mus. Deyrolle. Clark. Berol.).

2. M. inustus m. Schwarz, Fühler, Stirn, Sclieneu und die Flügeldecken bis auf einen grossen schwärzlichen Schrägwisch, manchnal auch noch die Seiten des daselhst fein aber dicht punktirten Halsschilds roth; die Punktstreifen fein, vorn getrübt, hinten nur an ten halberloschenen Enden kemntlich, mit flachen, fein quergerunzelten Zwischenräunen. L. $2^{3 / 4}-3^{\prime \prime \prime}$; Br. 11/6-1 1/3"'.

In Habitus den vorhergehenden nicht unähnlich, aber lileiner, und an der Zeichnung der Flügeldecken ron ihm leicht zu unterscheiden. Der Kopf Iach, mit seichtem breitem Stirneindruck und stark zurücktretendem Nackeı, die Oberfläche, soweit sie nicht abgerieben ist, durch eine dümue greise Behaarung matt, schwarz, ein grosser, auch wolıl den Nicken mit umfassender Querfleck zwischen dan oberen inneren Augenrändern heller oder dunkler J'oth, der Saum der Oberlippe rerwaschen röthlichgelb, die grossen, durch eine kurze mässig tiefe dreieckige Ausrandung selır ungleich getheilten, (hei dem $\&$ ) weit getrennten Augen schwarz. Die kurzen Fühler reichen wenig über den Hinterrand des Ilalsschilds hinaus; das Wurzelglied nach Aussen stark aufgetrieben, das zweite kurz und linotig, kaum länger als breit, das dritte düun verkehrtkegelförmig und $\mathrm{nm}$ die Hälfte, das vieste doppelt länger als das zweite, und demselhen alle folgenden gleich, die fünf oberen etwas verbreitert und zusanmengedrückt, mit deutlich sichtbarem Fortsatze des Endglieds. Die Farbe schmutzig rothgelb, die Oberseite der beiden unteren gläuzend scluwarz, auch bei den folgenden mil einem schwärzlichen Lïngswische gezeichnet, der je weiter nach oben desto deutlicher und ausgedehnter wird. Das Halsschild um die Hälfte breiter als lang, mit fast grader, von des Mitte aus nach vorn und hinten gleichmässig sanft abwärts gekrümmter Nittelfirste; die Seiten fein geraudel, nur leicht gerundet, vor der Mitte bis zu den scharf pfriemlich vorgezogenen Vorderecken etwas ausgeschweift, die Hinterecken sehr stumpf und fast alggerundet, um Ilurch eine scharf aufgebogene Schwiele bemerhlich; der Hinterland jerlerseits etwas ausgehuchtet, und durch einen schwachen, hart vor ibn liegrenden und nahe an den Hinterecken ein erböhtes glattes Pailtchen emporschiebenden Quereindruck etwas aufgebogen, mit sehr kurzem, etwas stãrker aufwärts gerichteten Hinterzipfel. 
Auch hinter dem Vorderrante jederseits die Spur einer schwachen Eiuschnïrung erkennhar. Die Punktirung sehr fein, auf dem Mittelfelde fast verschwindend, seitlich dentlicher und dichter, in den Hinterwinkeln fast zu Runzeln verfliessend, wodurch der Glanz der Oberfläche hier etwas geschwächt wird. Die Farbe schwarz, mit leicht bläılichem odler grünlichem Anfluge, bei Stïcken mit ausgedehnterem Stịnfleck ein schmalerer oder hreiterer, auch woh! eine Strecke am Hinterrande fortziehenter Seitenrand geröthet. Das Schildchen mässig ansteigend, etwa so lang wie vorn breit und hinterwärts wenig verschmälert, mit deutlichem flach niederliegendem llinterzipfel, gläızend schwarz nil feiner und zerstreuter Punktirung. Die Deckschilde breit und flach gewölht, hinterwärts ein wenig erweitert, hinter der leicht erJölıten Vorderkante schımal und schivach quergefurcht; die Schulterbeulen sehr breit und flach, imnerscits durch einen sehr seichten Eindruck abgesetzl: die Seitenlappen kurz und breit zugerundet, und über ihnen die Deckschilde leicht zusammengedrückt. Die Punktirung fein und ziemlich zerstreut, von Streifen nur der achte und nembte von der Schulterlseule ab nach ihrem ganzen Verlaufe sichtbar; weiter nach der Mitte zu zeigen sich in dem Punktgewire der vorleren Hälfte nur stellenweise Spuren abgerissener Streifen, zwischen denen einige feine Ripppenansätze als Andeutungen unausgebildeter Zwischenräume zu erkennen sind. Weiter hinterwärts sind die Rïclienstreifen in den dichten und feinen Querrunzeln des Zwischengrundes fast völlig verschwunden, während die seitlichen sich etwas deutlicher zum Theil his über die Wülbung hinaus fortzielıen, und dahei sind die Zwischenräume flach mit ziemlich starkem, wenn anch nicht spiegelndem Glanze. Die Farbe ziegelroth, ein breiter reswaschen begränzter, hiuter der Schulterbeule begimnender und mit dem Vorderende wieder hakig zur Mitte des Seitenrandes rückwärts gebrochencr schräger Läugswisch schwarz; sein Ilinterende erreicht die Naht schon ror der Wölbung und zieht dann mit dem des Gegenwisches rerbunden üher dieselle his fast zur Spitze hinab, welche, wie die hintere Hälfte des Seitentantles lis zu dem lıakigen Vorderende des Wisches gleichfalls fein schwarz gesäumt ist. Pygidimm und Unterseite fein punktirt, dünn greishaarig, mit den Beinen schwarz, die Schienen schmutzig ziegehroth, die obere Hälfte der Aussenseiten gebräunt: bei den heller gefär,ten Stücken mit rothen Halsschildsrändern sind die Seiten des Hinterleibes, 
oder auch der ganze Hinterleih mit den Parapleuren geröthet, mit ranchgran angeflogenen Banchringen, die rothe Färbung der Schienen wird intensiver, und dehnt sich anch noch über die Schenkelwurzeln ans. Das Prosternmm loreit und flach, hinten der Länge nach vertieft und dam breit alogerundet, lang greishaarig. Das letzte Segment des o mit einer breiten, aher nicht sehr tiefen, rundlichen Gruhe; das of mbekannt.

Von Buenos Ayres (Mus. Hang. Clart. Berol.).

3. M. succinctus m. Schwarz, oben mit kupfrigbläulichem Melallschimmer, die Fühlepwurzelı, eine schıäge Forderbinde und die Spitze der Flügeddecken rohggelh, Hinterleih und Beine rothbunt; das Halsschild zerstreut punktirt, die Punktstreifen derb und ziemlich regelmässig, mit flachen glänzenden Zwischenräumen. L. $234^{\prime \prime \prime} ; \mathrm{Br}, 1 \frac{1}{4}{ }^{\prime \prime \prime}$.

Dem vorhergehenden in Habitus und Farlsenvertheilung täuschend ahnlich, aher bei näherer Befrachtung doch an dem einfarbig schwarzen Kopfe und der ganz abwrichenden Sculptur der Deckschilde leicht von jenem zu unterscheiden. Der Kopf llach mit feiner, unten ctwas verbreiterter Stirnlinie, das ohen nur undentlich abgegränzte liopfschild etwas eingezogen, die Punktirung uben fern und zerstrent, unterwärts etwas dichter und gröher, mit glänzendem Zwischengrunde. Jie Farbe schwarz mit verwaschen helleren Ränderı der Oherlippe, die (bei dem of) ziomlich weit geireunten, kurz halhkireisförmig ausgebuchteten und dadurch schr ungleich getheilten Augen greis. Die Fühler von etwas mehr als 1/3 der liörperläıge, sehr dünn; das Wurzelgliesl stark aufgetrieloen, kanm doppelt länger als breit, das zwrite lurz eiförmig, das dritte um die Hälfte länger als das zweite, das vierte und fïnfte je dem zweiten und dritten zusammen gleich, das sechste nur etwas lïnger als das dritte, unrl die folgenden langsam verkïirzt, sodass das zehnte kamm noch dem dritten ghrichliommt; dabei dle oberen von der Spilze des sechsten al, schwach zusammengednüclit und prweitert. Jir Farbe der fünf unteren hell inrehscheinent rothgelb mit gedrämuter Oberseite der beiden muteren, das sechste rtwas dunkler mit geschwärzter oberer Hälfte, die fï̈nf olne'en schwarz.

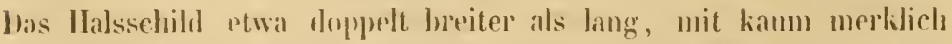
geklümmter, nur hinten efwas alwärts geneigler Viltelfirste, üloer den seltarf spitzwinkligen tirf eingezogenen Vorleresken zusammengedrückt und daturch sehr stark verschmälert, die Seilen fein ge- 
randet, von der Mitte pmullich erweilert, mit scharf stumpfwinkligen, leicht anfgehogenen Hinterecken, der Ilinterrand leicht ausgeschweift, mit hurzem, lreit zugerundetem Mittelzipfel; vor diesem jederseits ein tiefer, hreiter Quereindruck, und lart vor der äussern Hälfte des Hinterrantes ein frines, linienfürmiges Querfältchen: auch über der erweiterten Mitte des Seitentrandes ein seichter, rundlichel Eindruck. Die P'unktirmg oben fein und zerstrut, seitlich etwas dichıter umı grröber, der Zwischengrund spiegelgläuzenı, die Farhe ein metallisches, stellenweise ins lilpfrigstahlblaue spielendes Sclswarz. Das Schildchen zienlich stark ansteigenu, fast so lang wie vorn lneit, linterwärts stark verschmälert, daselbst mit algerundeten Ecken uni dentlichem Hinterziplel kurz ahgestutzt, fein punktirt, schwarz. Die Deckschille reichlich um $1 / 4$ länger als breit. hinterwärts stark verhreitert, den Rücken entlang abgeflacht, hinten mit kurzer und ziemlich steiler Wölbung ahfallend, hinter der scharfen Vorderkante schmal quer eingedrückt, und dann wieder leicht anfgewulstet: die Schulterbeulen ziemlich rund, die Seitenlappen tief lrerahgezogen. Die P'mlitstreifen derh und im Ganzen regelmässig, die Vorderenten der oleren etwas wellig und theilweise verdoppelt, der sechste mul sirhente grgen die Mitte sich verlierend; die Hintermulen der übrigen narh der Spitze zu alimählich alggeschwächt, mond lelztere unter der Wölbung fast ohne Punkte. Die Zwischeuräume flach und glänzend, dev neunte über dem Seitenlapıen mit einigen üherzähligen Punkten besetzt. Die Farbe schwarz mit srhwach bläılichem Schimmes, die Wurzel mit einer liellrothgellon Querbinle, die aber Schildchen und Naht nichut erreichi, soudern längs dem ersten I'unktstreifen einen schmal Areipckigen verwaschenen Längszipfe] his zur Mitte hinstreckt anch die spitze liell rotlgerlh. Das Pygidium frin punlitirt und dicht greishaarig, schwarz; der llinterleih trüh lrhmgell, mit schmutzig gesclıwärzter Milte, die Brust schwar\% mit sclmnutzig gebrämuten Inuruenden der Schulterb]ätter. Hlïfon und Boine rothgelh, die Schenkedenden aul der Aussenkante geschwärzl, ebru so die linie umol die Aussenseiten dej Schienen. Die Fussglieder schwarz. Das l'rosterumm groh punktirt, vor'u seicht nirderogedrückt, hinten stärlier rimurnförmig vertieft mul breit zugerundet. Das lefzte Segment des 9 mit dem gewöhnlichen Grübchen, das ơ mbekannt.

Glrichfails ans Brasilien (von S. Cathurina: Hus, Deyrolle. (lark.). 
4. MI. Palapmon $m$. Schwarz, der Kopf und das vereinzelt grob punktirte Halsschild mit Unterseite und Beinen rothgelbhunt, die Flügeldecken mit rothgelbem Schulter- und Spitzenfleck, die Punktstreifen derl, vorn und seitlich gestört, mit querrunzligen, glänzenden Zwischenräumen. L. 21/4"'; Br. 11/6".

Vou dem schmalen, gestreckten Bau der vorhergehenden Arten, aber noch etwas kleiner und besonders durch die eigenthümliche, bei dem $\delta$ wahrscheinlich noch ausgezeichnetere Farbenvertheilung auffallend. Der Kopf flach, die Stiru breit eingedrückt und noch von einer feinen Längsslinie durchzogen, das Kopfschild etwas eingezogen, die Oherlläche mit rereinzelten groben Punliten besetzt, mit glïnzendem Zwischengrunde. Die Farhe schwarz mit gebräunten Mundtheilen, die Oherlippe und eine aus fünf, manchmal theilweise zusammenlüngenden Flecken bestehende Querbinde zwischen den Augenluchten rothgelb. Die äussersten dieser Flecke sind klein, rund und punktförmig, in die Augenbuchten sellıst gestellt; zwischen ihnen stehen zwei grössere, dreieckige, einander hei einem der vorliegenten Stüclie berührende, beide gegen die äusseren etwas aufwärts gerückt, und unter dem Zwischenraume oder der Berührungsstelle dieser mittleren der fünfte wiederum kleinere, zuweilen ganz frlılende Fleck, der bei anderen Stïcken anch wohl mit jenen zusammenfliessen könnte. Die Augen selbst durch die tiefen Augenbuchten sehr ungleich getheilt, llie obere grössere Hälfte schräg zusammengeneigt, aber doch der (hei dem §) zwischen ihnen verbleibenle Raum an Breite reichlich $2 / 3$ des FülJerabstands erreichend. Die sehr schlanken Fülıler von etwas mehr als halber Körperlänge, das Wurzelglied keulig aufgetrieben, etwa doppelt so lang wie breil, das zweite kurz eiförmig, laum halb so lang und breit wif das vorhergehende, die drei folgenden dünn, sticlund, nach ohen leicht verdiclit, das dritle und vierte je so lang wie das erste, alıer dünner als das zweite, das fünfte so lang wic das zweite und dritte zusammengenommen, die folgenden allmählich wieder abnehmond, sodass das achte wieder dem dritten glrichkommt, das neunte und zrhnte noch etwas lïnger: das Endglied mit sehr kurz dreieckigen Fortsalze: llabei die oberen ron der Spitze des sechsten ab schwach zusammengedrüclit und rerbreitert. Die Farbe der unteren Gliesler his zur Mitte des fünften durchscheinend röthlichgelh mit gelırüunter Spitze des fünften, und einem schwärzlichen Schatten auf der Ober'seite des ersten und 


\section{7}

zweiten Gliedes; die übrigen schwarz, dümn belıart und kurz abstehend weisslich gewimpert. Das IIalsschild fast doppelt so breit wie lang, über die Mitte quer flach wulstig erhöht, daher die Mittelfirste nach vorn und hinten sanft abwärts gekrümmt, über den langen pfriemlich zugespitzten Vorderecken zusamnengedrückt und durch eine deu Vorderrand umziehende Einschnïrung verengt; die Seilen fein gerandet, in der flitte bogig erweitert, vor ihr seicht ausgebuelstet, die selir stumpf abgerundeten Hinterecken nur durch eine lileine Schwiele bezeichnet; der Hinterrand jederseits ausgeschweift, mit sehr kurzem, aufwärts gebogenem Mittelzipfel. Vor ihm das Mittelfeld leicht schräg abfallend, und hier jederseits ein tiefer Schrägeindruck angeschlossen, welcher sich gegen die Mitte des Seiteurandes hinstreckt und nach den Hinterecken zu die Masse des Halsschilds als einen glatten Querwulst empordrückt. Die Punktirung deutlich, oben vereinzelt, gegen die Ränder hin etwas mehr zusammengedrängt, aber nirgends sehr dicht, ınit glänzendem Zwischengrundle. Die Farbe schwarz, ein verloschener (zuweileı fehlender, aber aucl anderseits wohl zu einer hinterwärts verbreiterten und mit einem abgekürzten Längsfleckichen gezeichneten Längslinie erweiterter) Punkt auf der Nitte der Längsfirste, die schwieligen Spitzen der Vorder- und Hinterecken, und der aufgebogene Rand des Mittelzipfels zuveileu bis fast zu den Hintereckeu hin bis auf dessen geschwärzte Mitte hell rothgelb. Das Schildchen ziemlich stark ansteigend, breit quer viereckig und hinterwärts wenig 'verschmälert, mit deutlichem Hinterzipfel, dicht punktirt, vereinzelt greis behaart, schwarz. Die Deckschilde gestreckt, länglich viereckig und um die Hälfte länger als breit, vorn breiter als das Halsscliild und hinterwärts noch etwas erweitert, der Rüchen flach mit mässig abfallender Wölbung, hinter der scharfen aı die höckerig-rundlichen Schulterbeulen gelehnten Vorderkante quer eingedrückt und dann wieder leicht aufgewulstet; die Seitenlappen fäst halbkreisförmig zugerundet, und über ihnen die Deckschilde stark zusammengedrüclit. Die Punktstreifen derb, auf der Vorderhälfte durch eine Ueberzahıl eingemengter Punkte getrübt und der-artig gestört, dass nur die beiden äussersten am Rande einigermassen erkenubar bleiben: von der Mitte ab entwickeln sich aus dem Gewirre auch noch die oberen, während die drei an der Seluntterbeule entspringenden (der sechste bis achte) auch hinterwärts nur stellenweise mit einiger' Dentlichkeit hervortreten. Der' 
Zwischengrund vorn mehrfach durch feine Querrunzeln zerrissen und auch die Punkte selbst oft in die Quere ausgezogen, erst hinterwärts wirkliche, und zwar flache glänzendere Zwvischenräume bemerkbar; die Spitze unter der Wölbung spiegelglatt. Die Farbe schwarz, ein grosser unregelmässig viereckiger Schulterfleck, innerseits dem Schildchen bis auf dessen lalbe Breite nahekommend mud hinterwärts bis nahe an die Vitte der Flügeldecke reichend, hellrothgelb; eine gleiche lärhung zeigt die Spitze unterhalb der Wölbung, auch tritt aus dieser in der Gegend des fünften his siebenten Streifens ein stumpfer Zipfel hervor, welchem zuweilen eine ähnliche stumpfe Erweiterung aus dem Hinterrande des SchulterIlecks entgegen kommt, sodass es möglicher Weise auch Stücke geben könnte, bei denen beide Flecke untereinander zusammenhängelı. Das Pygidium fein punktirt und hehaart, schwarz, jederseits mit einem breiten, bleich röthlich-weissem Flecke hezeichnet. Die Unterseite gleichfalls fein runzlig punktirt, dümn silherhaarig, sclıwarz; ein schmaler, sich auf dem letzten Ringe zu einem grösseren Querflecke erweiternder und hier mit dem entsprechenden Flecke des Pygidiums zusammenhängender Seitenrand des Hinterleibes nebst dessen seitlichen Vorderzipfeln hellröthlich weiss, und gleiche Färbung zeigt das Innenende der Schulterblätter, und die untere Hälfte vom Innemrande der 'arapleuren. Die Beine schwarz, die Hüften und die nach den Kínien zu erweiterten Innenkanten der Nittel- und Hinterschenkel bleich röthlich, ins Weisse fallend, die Schenkelwurzeln mit den Vorderschienen und dem oberen Theile der Mittel- und Hinterschienen dunkler geröthet, die Füsse bräunlich. I)ie Vorderschenkel stark angeschwollen, die Schienen entsprechend gekrümmt und an den Spitzen imnerseits etwas hakig erweitert; Mittel- und Ilinterschienen grade, nach unten dreieckig sich verbreiternd. Das Prosternum ziemlich lreit, hinten tief rinnenförmig ausgelı̈hlt, die Ihinterzijfel dreieckig zugerundet, flach, l,eich rüthlich gesäumt. Das letzte Segment des $f$ mit einer tiefen laalkkugeligen Grube; das ठ unbekamnt.

Ebenfalls aus Brasilien (Mus. Hal. Lacordaire. Clark. in letzterem Minas als Ileimath genamnt).

5. M. insitivus m. Schwarz mit röthlichen Fühlerwurzelu; Unterkopf, Seiten und Mittellinie des grob punktirten Halsschilds, ein Fleck auf dem Schililchen, und cin grosser Schulter- und Spitzenfleck der Flügeldecken bleichroth, Unterseite und Beine 
weissbunt; die Punktstreifen grol,, uu linten und an den Seiten kenutlich, mit flachen, quprgerunzelten Zwischemräumen. I. 21/2"“; Br. $1 \frac{1}{6}{ }^{\prime \prime}$.

Eine Mittelart zwischen M. Palaemon und ruficeps, von letzterem sogleich an der groben Punktirung des nach vorn nicht verschmälerten Ilalsschilds zu unterscheiden, dem M. Palaemon aber so nahe ŝtehend, dass ich auf dessen Beschreibung Bezug nehmen, und mich anf die Angabe der Abweichungen beschränken kann. Die vorliegende Art ist wenig grösser, aber krältiger gebaut, noch mehr gleichbreit, und die Mitte des IJalsschilds stärker in die Quere aufgetrieben. Die Punktirung ist überall noch gröber, etwas dichter, auf dem oberen Theile der Stirn zu Längsrunzeln zusammengeflossen, auf dem Rücken der Deckschilde fast siebartig gleichmässig zusammengedrängt, sodass seitlich nur der achte und neunte Streifen einigermassen kenntlich werden, die oberen aber erst auf dem letzten Drittel hervortreten. Der Zwischengrund auf dem Rücken durch grobe, die ausgerissenen P'unkte treunende Querrunzeln zerrissen, die hinten erkennbaren Zwischenräume flach und feines' querrunzlig, der achte und neunte leichst gewölht, und auch auf dem dicht punktirten vorderen Theile der Flügeldecken einige Spuren erhöhter Längslinien sichtbar. Ile rothe Färbung der Zeichmungen fällt stark ins Bleiche, fast Weissliche; am Kopfe ist der ganze untere Theil der Stirn mit dem Kopfschilde bis zur Oberlippe weisslich, letztere sellost aber geschwärzt mit verwaschen röthlichem Saume; das hinten tief eingedrückte Halsschild zeigt eine vorn und hinten abgekürzte kräftige helle Mittellinie, eben so sind die Seiten breit weiss, welche Fürbung sich nach vorn noch mehr verbreitert, und damı hakenfürmig aın Vorderrande bis zu den oberen innern Augenräudern umbiegt. Eben so ist der mittlere Theil des Mittelzipfels breit hell gesäumt, und das Schildchen vor seinem Hinterıande mit einem eben solchen Flecken bezeichnet. Auf den Flügeldecken sind ein länglich viereckiger, die Schulterbeulen dunkel lassender Schulterfleck und ein grosser, im Nahtwinkel liegender Ilinterfleck ebenfalls bleich röthliclıweiss. Das Pygidium schwarz mit weissem Saume und zwei kurzen, diesen Saum unten berührenden weisslichen Längslinien. Die Unterseite ist schwarz mit einem breiten, weissen Samme des Ilinterleibes und einem verwaschenen lichten Querflecke vor der Mitte des ersten Ringes; die Vorderhüften sind mit einem weissen Flecke, die Hinterschenkel 
auf der alggerundeten Aussenkante mit einer breiten weissen Längslinie gezeichnet, und die Vorder- und Mittelschienen anf der Unterseite nach ler Spitze zu gebräunt. An den Fühlern ist das aufgetriebene Wurzelglied schwarz mit röthlichen oberen Ende, die fulgenden sind bis zur Mitte des sechsten rōthlich und die oberen wieder geschwärzt, mit angedrückter greiser Behaarung. Die Vorderbrust ziemlich schımal, vorn mehr flach, linterwärts deutlicher rimnenförmig. Das letzte Segment des $\&$ mit einer lıalbkugeligen Girube, das ơ unbekannt.

Aus Brasilien (Mus. Vindob.).

6. M. Inbricus m. Schwarz mit rother Wurzel und Spitze der Flügeldecken, ein Stirnfleck und die Ränder des fein, aber zienlich dicht punktirten Halsschilds weiss, Unterseite und Beine weissbunt; die P'unktstreifen ziemlich regelmässig, mit flachen, glänzenden Zwischenrä̈men. L. 2"“; Br. I"“.

Von dem Habitus des vorhergehenden, aber noch etwas kleiner, mit ausgedehnteren weissen Zeichumugen und regelmässigeren Punktstreifen. Der Kopf flach mit undentlicher Stirnlinie, dicht punktirt, schwarz, lie Oberlippe und ein mondförmiger Querłleck an oberen Rande des nur dadurch kenutlich gemachten Kopfschildes weisslich; die (bei dem f) weitgetrennten, durch eine kleine halblireisförmige, gleichfalls weiss gefärlte Ausbuchtung selır ungleich getheilten Augen greis. Die Fühler nur unvollständig vorhandeı, und nach diesen liesten in Gestalt und Färbung nicht von denen des Sc. Palacmon abweichend. Das Halsschild etwa $2 \frac{1}{2} \mathrm{mal}$ breiter als lang, mit abgeflachtem, hinterwärts leicht herabgeneigtem Mittelfelde, vorn über den scharf spitzwinkligen Vorderecken breit zusanmengedrïckit und dadurch verschmälert, die Seiten gerandet, in der Mitte bogig erweitert, vor ihr tief ausgeschweift; die Hinterechen scharl' stumpfwinklig, eler Hinterrand zweihuchtig mit wenig bemerkbarem Mittelzipfel; am Hinterıande nach den Seiten zu je ein breiter, sehr flacher Quereindruck. Die I'unktirmug ziemlich dicht, alser nicht tiel eingestochen, der Zwischengrund fein genarbt nit mässigem Glanze. Die Farhe schwarz, ein ziemlich lreiter Scitemrand bleich weissgelb, und der aufgeworlene Rand des Mittelziplels eben so bleich geröthet. Das Schildchen ziemlich steil ansteigend, breiter als lang, hinterwär's ver'schmälert und mit dentlichem flintergipfel abgeruntet, gleichlalls schwarz mit schwacher P'unktirumg. I)ie Deckischilde last um die Hãlfte länger als breit 
und hinterwärts deullich erweitert, dér Rücken flach unt himten mit kurzer Krüımung abfallend, hiuter der scharfen Vorderkante schmal, aber tief ruer eingedrückt, die kurzen Schulterbeulen fast halbkugelig, mil dem Hinterende etwas schräg nach Aussen ge-richtet, die Seitenlappen schwach. Die Punlitstreifen von mässiger Stärke, auf der vorderen Hälfte etwas wellig Innd daselbst sowulıl hinter den Schuitterbenlen als zunächst der Naht durch überzälılige, stelleuweise wieder verwischte Punkte getrübt, hinter der Nitte regelmässiger, aber immer mehr abgeschwächt und zuletzt fast erloschen, mit flachen, hinterwärts stärker glänzenden Zwvischenräumen. Die Farbe schwarz, ein lireiter viereckiger', Schulterbeulen und Seitenlappen einschliessender, mit der hinteren Gränzlinie verwaschen schrïg nach hinten und innen gerichteter Schulterlleck, dessen hinteres Innenende sich noch etwas zipfelförmig nach hinten verlängert, und die noch mehr verblichene Spitze der Flügeldecken hell ziegelrotlı. Das Pygidium gelblichweiss, Unterseite und Beine schwarz, auf ersterer der letzte Bauchring, die seitlichen Vorderzipfel des ersten Ringes, die innere Hälfte der Schulterblätter und der hintere Theil vom Imnenrande der Parapleuren weiss, eben so an den Beinen ein Längsfleck auf der Aussenseite der Schenkel. Die Hüften und Schienen trüb gebräunt mit hellerer Unterseite der letzteren, die Vorderschienen ziemlich stark gekrünmt. Das Prosternum vorn breit, hinterwärts merlilich verschmälert und linnenförmig vertieft, mit abgerundetem, hell rothgelbem Hintereude. Das letzte Segment des $f$ mit dem gewöhnlichen Grüluchen, das ơ unbekannt.

Aus Brasilien (Mus. Deyrolle).

7. M. Latiusculus in. Sclıvarz mit rother Wurzel und Spitze der Flügeldecken, ein Stirnfleck und die Ränder des seitlich zerstreut punktirten Halsschilds mit dem Saume des Ilinterleihes und den Vorderhüften weiss; die groben Punktstreifen vorn durch überzählige Punkte getrübt, mit flachen, etwas qnerrunzligen glânzenden Zwischenräumen. L. $1 \frac{5}{6}{ }^{\prime \prime \prime} ; \mathrm{Br}$. $1^{\prime \prime \prime}$.

Dem vorhergeheuden M. lubricus so ähnlich, dass man wohl versucht werden könnte, ihn für das andere Geschlecht desselhen zu halten, aber doch auch wieder von demselben, ausser der verschiedenen Heimath, in so manchen Merkmalen abweichend, dass mir jene Vereinigung einstweilen noch grossen Bedenken zn ınterliegen scheint. Jene Abweichungen zeigen sich theils in Grösse 
und Habitus, theils in der Sculptur, theils endlich in der Farbenvertheilung, und zwar in der letzteren so, dass wenn beide als $\delta$ und $q$ zusammengelı̈ren sollten, diese Farbenvertheilung durch die beschränktere weisse Zeichnung des ơ die entgegengesetzte sein würde, als sie sonst hei beiden Geschlechtern einer und derselben Art zu seiı pflegt. Die habituellen Abweichungen treten zunächst in der Gröse hervor, indem die vorliegende Art ein wenig kleiner, dafür aber mehı gleichbreit und dadurch gedıängter als die vorhergehende, auch auf dem Rücken etwas stärker gewölbt erscheint. Eben so ist das Halsschild nach vor'n weniger verschmälert und an den Seiten vor der Mitte kaum ausgeschweift. Die Punktirung der letzteren ist viel feiner, auf dem Mittelfelde unscheinbar, der Zwischengrund deshalb spiegelglänzend, und erst seitwärts finden sich an und auf dem breiten weissen Rande vereinzelte gröbere Punkte. Dagegen ist die Sculptur der Deckschilde merklich gröber, auf der Vorderhälfte scheiubar ohne Ordnung zusanmengedrängt, nur stellenweise Spuren abgerissener Punktstreifen zeigend, der neunte zwar in längerer Ausdehnung erlienubar, aber auch ausserhalb desselben über den Seitenlappen der erweiterte neunte Zwischenraum mit deutlichen Punkten besetzt. Erst von der Mitte ab entwickeln sich melır kenntliche, aber almmählich abgeschwächte Streifen, die sich dam auf der Wölbung vollends verlieren. Die Zwischenräume flach, vorn durch ansgerissene Punkte querrunzlig, aber doch ziemlich glänzend, hinten spiegelglatt. Die Vertheilung der rothen Färbung ist in Ganzen wie bei dem vorhergehenden, nur der Hintersaum des Halsschilds fehlend, der Spitzenfleck der Flügeldeckeı etwas breiter, der Schulterfleck dagegen kürzer, breiter als lang, nur durch einen schmal linealischen Zwischenraum an und hinter dem Schildchen von seinen Gegenflecke getrennt: die Schulterbeulen geschwärzt, der Kiel der Seitenlappen bleich röthlich, fast weiss, und an den Fühlerı nır die untere Seite der unteren Glieder tief pechbrann. Selır abweichend dagegen ist die Vertheilung der weissen Färluung. Am liopfe sind nur die Ränder der Oberlippe gelblich weiss, und ausserdem zeigt der untere Theil der oben durch die sehr genäherten Augen stark verengten Stim rinen dreieckigen, mit sein'm unteren Theile auch noch fast das ganze Kopfschild einnchmenden weissen Hittelfleck, welcher aber die tiefen Aıgenbuchıten unberührt låsst, und eben so sind die Seiten des Pygidiums durch das Uebergreifen des weissen Ilin- 
terleibsrantes weisslich gesäumt. Auf der Unterscite umzieht den Hinterleil) ein vorn jederseits an den weisslichen Kiel des Seitenlappens sich anschliessender weisser Rand, auch sind die Vorderhüften mit einem weissen Fleck bezeichnet, und ausserdem die Schenkelwurzelı, an Mittel- und Hinterbeinen auch die Schienenenden und Füsse fuchsig gebräunt; sonst aber ist die ganze Unterseite schwarz. Das runzlig punktirte und behaarte Prosternum vorn ziemlich flach, hinten riunenförmig vertieft. Das letzte Segment des $\delta$ einfach, das $q$ unlsekannt.

Aus Venezuela (Moritz im Mus. Vindob.).

8. M. ruficeps in. Schwarz, Fïlıler, Unterkopf, Schenkelwurzeln und Schienenenden nelsst der Wurzel und Spitze der Flügeldecken roth, der letzte Bauchring jederseits weissfleckig; das Halsschild zerstreut punktirt, die P'unktstreifen ;vorn unregelmässig verdoppelt und etwas wellig, mit flachen, glänzenden Zwischenräumen. L. 2" ${ }^{\prime \prime \prime}$ Br. .1"

Den vorhergehenden wiederum sehr ähnlich, aber vorn etwas breiter, der ganze Unterkopf roth, die Beine olne alles Weiss, und auch die Streifenbildung auf den Deckschilden etwas verschieden. Der Kopf flach gewöllht, mit deutlicher, unterwär's etwas erweiterter Nacken- und Stirnlinie, und stark eingezogenen Kopfschilde; oben fast glatt, unterwärts deutlich und ziemlich dicht punktirt, lackgläuzend; der Nacken schrvarz, Stiru und Kopfschild roth mit gebräunten Fühlerhöckern, die Oberlipje knochengell, die Kinnbacken trüb geschwärzt, die Taster wieder roth, die kurz halbkreisförmig ausgebuchteten, (bei dem $q$ ) weit getremnten Augen schwärzlich. Die dümmen Fühıler nicht von halher Körperlänge, das vierte und fünfte Glied gleich lang; die Farbe hell rotligelb, die einzelnen Glieder von der Mitte der Fühler ab am oberen Ende geschwärzt, so dass diese Färbung bei dem seclısten nur erst kaum den vierten Theil, bei den beiden letzten fast das ganze Glied einnimmt; diese oberen dabei schwach zusammengedrückt und erweitert. Das Halsschild etwa $2 \frac{1}{2}$ mal hreiter als lang, oben fast flach mit kaum aufwärts gekrümmter Mittelfirste, übes den scharf spitzwinkligen Vorderecken hreit zusammengedrückt und verschmälert; die Seiten fein gerandet, in ter Mitte bogig erweitert und vor ihr leicht ausgeschweift, die Hinterecken stumipfwinklig, mit einer unscheinbar aufgehogenen Schwiele besetzt, der Hinterraud doppelt gebuchtet, mit schmalem Hinterzipfel, und vor diesem jederseits 


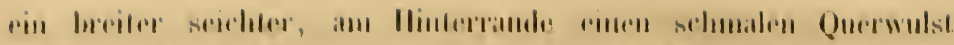

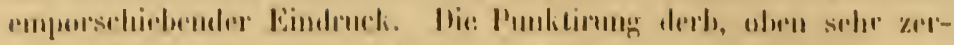

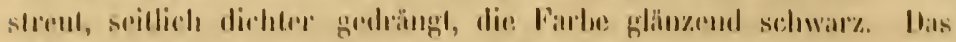

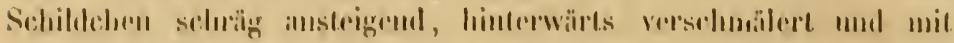

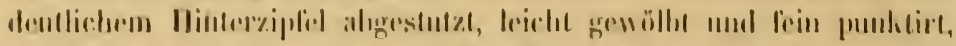

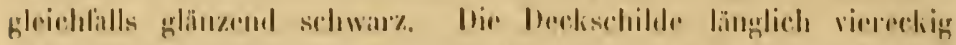

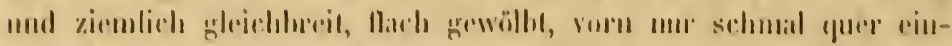

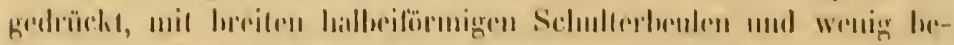

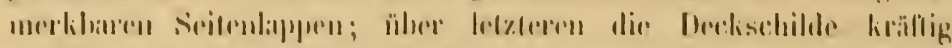

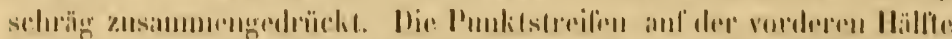

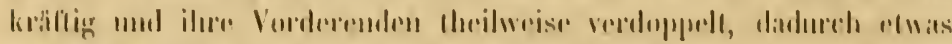

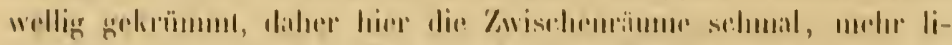

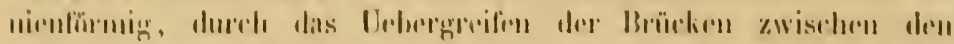

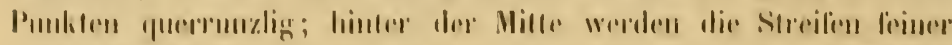

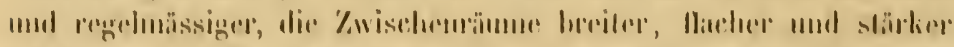

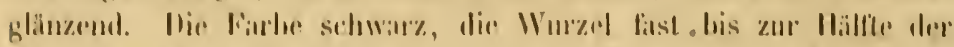

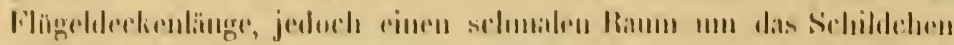

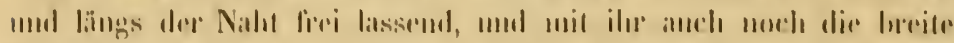

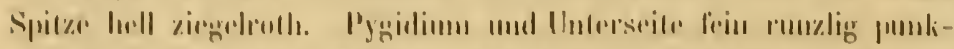

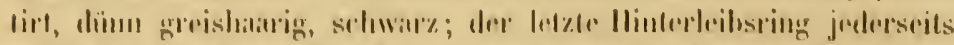

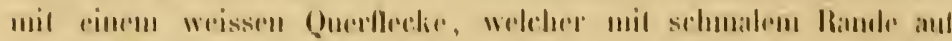

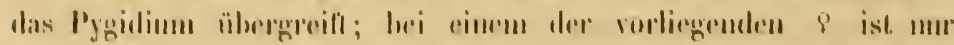

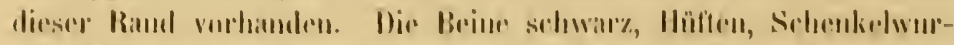

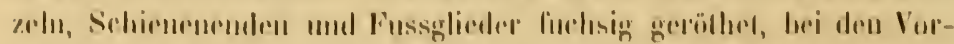

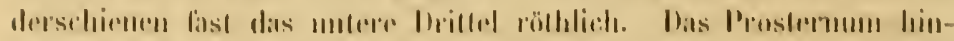

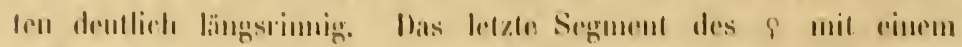

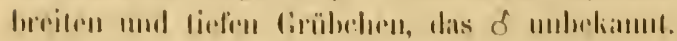

dus Rrasilien (run Cousupara: sollo iun Mus. lirerol.).

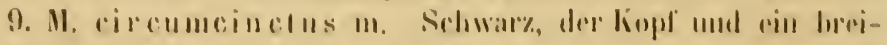

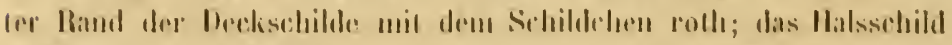

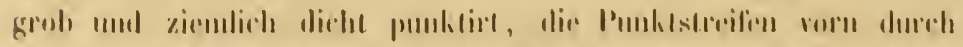

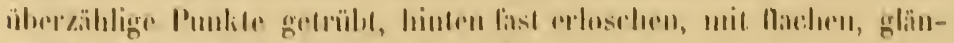

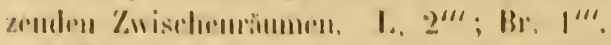

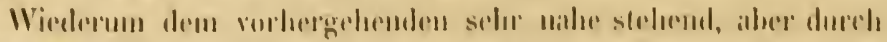

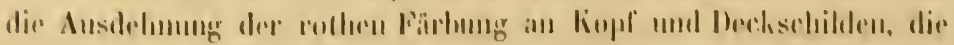

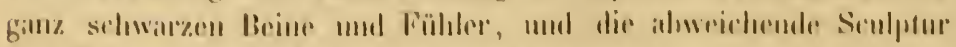

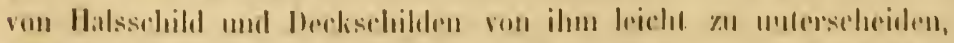

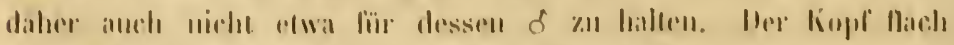

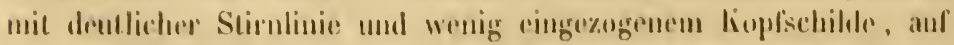




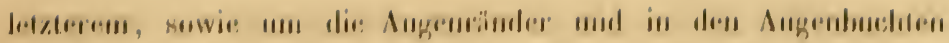

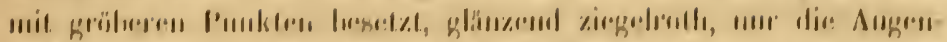

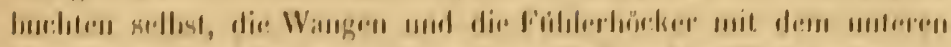

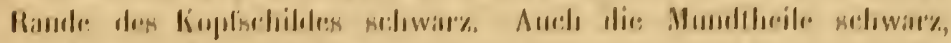

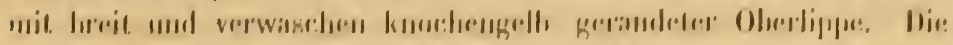

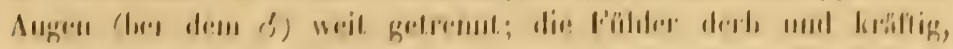

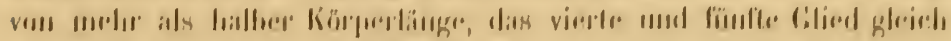

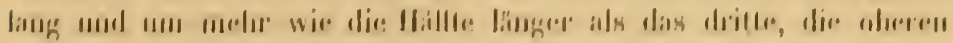

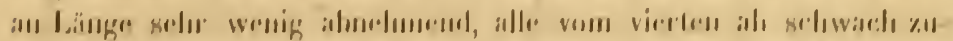

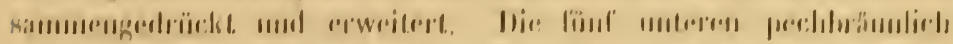

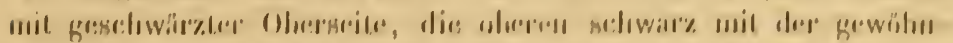

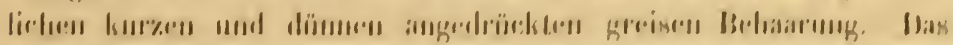

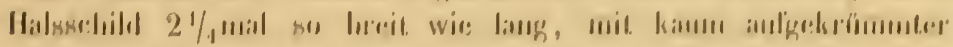

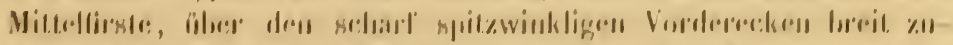

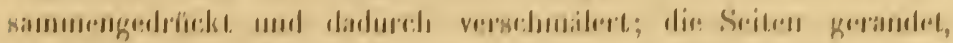

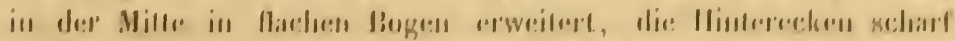

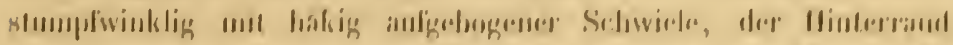

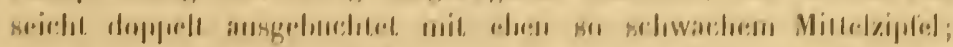

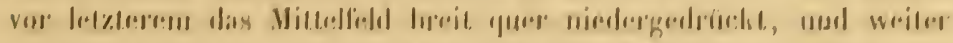

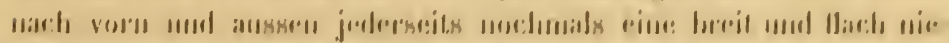

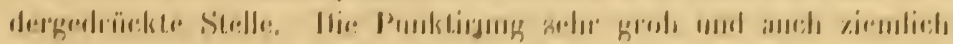

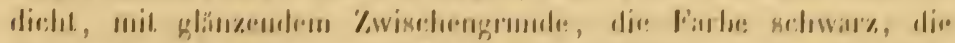

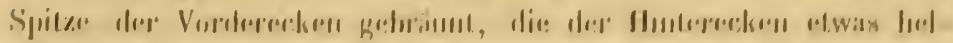

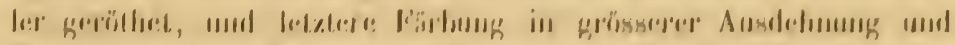

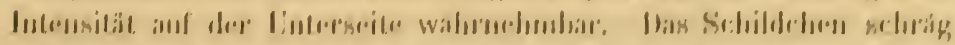

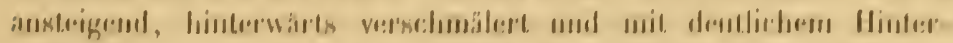

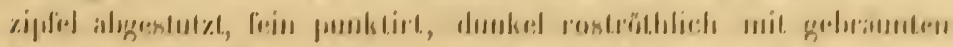

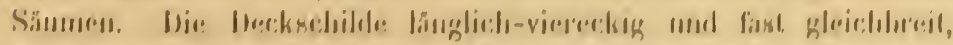

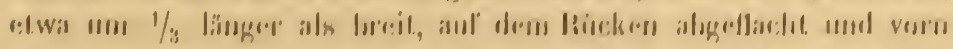

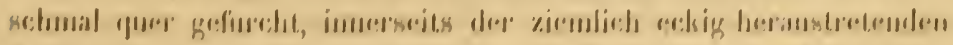

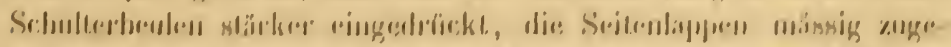

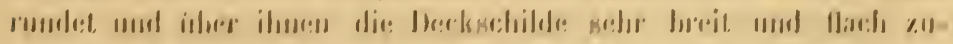

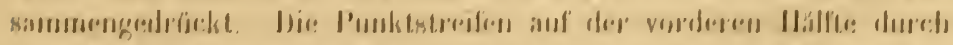

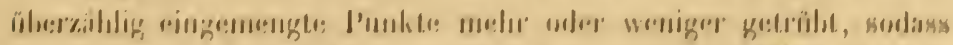

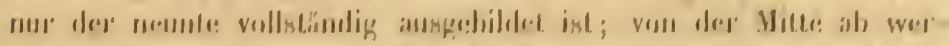

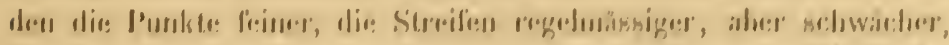

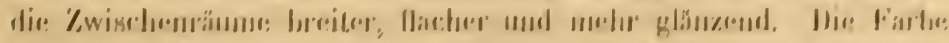

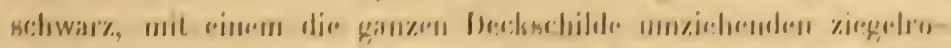

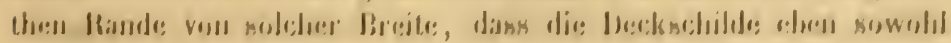


als roth mit einem grossen gemeinsamen elliptischen schwarzen Querflecke bezeichnet werden künnen. Pygidium und Unterseite fein runzlig punktirt, ziemlich dicht greishaarig, mit den Beinen schwarz; das hinten tief längsrinnige Prostemum aı den Seiten gebräunt. Das letzte Segnent des \& eiufach; das 우 unbekannt.

Aus Brasilien, und elenfalls von Caasapava (Sello im Mus. Berol.).

10. M. nobilis Laferté. Lehmgelb, ein dreieckiger Nackenfleck mit der Wurzel und einem Flecke vol der Spitze der Flügeldecken schwarz; das Halsschild fein und zerstreut punktirt, die Punktstreifen vorn derl) und längs der Naht durch ïberzählige Punkte gestört, hinten feiner, mit flachen, glänzenden Zwischenräımen. L. $2{ }^{2}{ }^{\prime \prime \prime \prime} ;$ Br. $11 / 6 "$.

Der Kopf flach mit etwas eingezogenem, oben durch einen seichten Quel'vulst alogegränztem Kopfschilde und wieder selır stark vorspringender Oherlippe, lehmgelb mit mässigem Glanze und sehr zerstreuter Punktirung; der Nacken schwarz, und diese Färbung nach vorn in einen dreieckigen Zipfel ausgezogen, sodass auch oben noch ein schmaler Augenrand gelb bleibt. Die grossen, durch eine dichter punktirte Ausbiegung sehr ungleich getheilten Augen einander (auch bei dem o) sehr genähert, greis. Die Fühler nach den vorhandenen Resten derl und kräftig, das Wurzelglied keulig aufgetrieben, um die Ilälfte länger als breit, das zweite kurz birnförmig und die folgenlen schon schwach zusammengedrücki und verbreitert, das dritte doppelt-, das vierte und fünfte je dreimal länger als das zweite; die oberen felılen dem einzigen vorliegenden Stïcke. Die Farbe pechbraun, Wurzel, Spitze uud Unterseite der einzelnen Glieder heller röthlichgelb. Das Halsschild etwa 21/4 mal breiter als lang, mit flachem, hinter der Mitte kaum etwas erhöhtem Rücken; über den scharf spitzwinkligen Vorderecken breit schräg zusammengedrückt unıl dadurch verschnı̈lert, die Seiten fein gerandet, hinter der Mitte in schwachem Bogen erweitert, vor ihr ausgeschweift; die breiten Hinterecken mil einer quer heraustretenden Spitze vorspringend, der Hinterrand jederseits des ülseraus kurzen Mittelzipfels wenig ausgebuchtet, das Vittelfell vor letzterem mit einem flachen, an den schräg nach voru und aussen gerichteten Enden etwas liräftigerem Quereindrucke. Die Punktirung fein und sehr zerstreut, die Farbe hell lehmgelb mit glänzendem Zwischengrunde, nur der Ilintersaum jederseits des Mittelzipfels leicht 
geschwärzt. Das Schildchen stark schräg ansteigend, fast gleichseitigdreieckig, mit kurz abgestutzter Spitze und kleinem Hinterzipfel, fein punktirt, gleichfalls lelımgelb, Seiten und Spitze verwaschen geschwärzt. Die Deckschilde ziemlich gestreckt walzenförmig, etwa $1 / 3$ länger als breit und vorn etwẩs breiter als das Halsschild, hinten mit sehr santter Krüunmung abfallend, hinter der scharfen Vorderkante breit quer eingedrückt, die Schulterbeulen als eiförmige Höcker heraustretend, die Seitenlappen sclıwach, und über ilhnen die Deckschilde breit und liräftig zusammengedrïckt; der neunte Zwischenraum vorn nochnals mit einer kleinen Beule besetzt. Die Punktstreifen im Ganzen regelmässig, der Raum zwischen den ersten und der Naht auf der Vorderhälfte mit überzälıligen Punkten bestreut fund dadurch jene Streifen selbst theilweise gestört; auch die hinter der Scluulterbeule liegenden Streifen etwas in einander gewirrt, hinterwärts in sehı vereinzelte Punkte aufgelöst. Die Streifen selbst bis über die Mitte hinaus derb und kräftig, dann plötzlich au Stärke abnehmend und die mittleren auf der Wölbung kaun noch kenntlich, wie weggeschliffen; die Zwischenräume flach und glänzend. Dic Farbe auclı lier lelımgelb, die Wurzel vom hinteren Ende des Seitenlappens ab bis zur vorderen Aussenecke des Schildchens schwarz, sodass diese Färbung sich mit lappiger hinterer Begränzung nach inneı verschmälert und das Schildchen nur an jener Vorderecke erreicht, hinterwärts aber von ilım und demnächst auch voı der Naht nochı durch eineı schmalen Zwvischenraum getrenut bleibt: eben so liegt noch ein grosser, quer eiförmiger schwarzer Fleck auf der Wölbung, wirl aber von der Spitze noch durch einen breiten, von Naht und Aussenrand durch einen schmäleren und mehr verwaschenen Zivischenraum getremit. Pygidium und Unterseite fein runzlig punktirt und dünn behaart, mit den Beinen lelımgelb, die breiten Hinterwinkel der Hinterbrust geschrvärzt. Das Prosternum grob gerunzelt, ziemlich breit, hinten mit aufgerichteten Rändern der Länge nach stark vertieft, mit stumpf dreieckigem Hinterzipfel. Das letzte Segment des $q$ mit einer tiefen, halbkugeligen Grube, das ơ unhekannt.

Von Cayenne (Mus. Clark).

$\mathrm{Z}$ weite Rotte. Körper gestreckt, flach walzenförmig, hïterwärts nicht verbreitert. Das Halsschild seitlich sehr breit zusammengedrückt und hinten vor dem Schildchen quer ahgeflacht. Die Färbung theilweise noch schwarz mit rothen und gelben Zeich- 
nungen, der vorigen Rotte entsprechend, theilweise rostroth and gelhbunt. Brasilien und die La-Plata-Länder.

11. M. planipennis m. Schwarz, unten dicht silberhaarig, ein unterer Stirnfleck, zwei Hinterflecke des fein und zerstreut punktirten Halsschilds, ein Schulterfleç und die Spitze der Flügeldecken roth; die Punktstreifen derb, vorn verdopjelt und durch überzählige Punkte getrübt, mit flachen, querrunzligen Zwischenräumen. L. $21 / 4-21 / 2 " ' ;$ Br. $1 \frac{1 / 6}{6}-1 \frac{1}{4}{ }^{\prime \prime \prime}$.

Dem unten folgenden, weniger seltenen M. generosus v. Heyd. täuschend ähnlich, sodass ich auf dessen Beschreibung Bezug nehınen, und mich auf die Angabe der Abweichungen beschränken kann. Er ist zunächst kleiner, indlem das grösste mir vorliegende $q$ das $\delta$ der genannten Art nur unbedeutend übertrifft, dabei anscheinend auch noch etwas flacher. Die Punktirung ist auf dem Halsschilde schwächer, namentlich weniger lief eingedrïckt, daher auch an den Seiten, wo sie fast die Stärke jener Art erreicht, nicht in gleicher Weise aulfallend, auch nicht so dicht zusammengedrängt. Auch auf dem Kopfe ist dieselbe gleichmässiger verhreitet, überall dichter gedrängt, daher die Fläche desselben ohne merklichen Glanz. Auf den Flügeldecken sind die Punkte dichter und zugleich merklich gröber; sie bilden auf der vorderen Hälfte ungeachtet der Verdoppelung deutlichere Punktstreifen, zwischen denen einzelne Zwvischenräıme, namentlich der zweite und vierte, als schmale Längslinien kenntlich werden. Ilinter der Mitte werden die Streifen ganz regelmässig, bleiben bis zur Wölbung deutlich, und lassen ihre Zwischenräume breit und in Ganzen flach hervor'treten. Letztere sind dabei durch dichte und feine Querrunzeln matt, leicht seidenschimmernd, und zeigen nur unterhalb der Wölbung einigen Glanz. Nancherlei Ahweichungen zeigt die rothe, im Allgemeinen mehr beschränkte Färbung. Dej Stirnfleck steht nicht oben zwischen den oberen inneren Augenrändern, sondern auf der unteren Stirn zwvischen den Augenbuchten, und streckt sich in Gestalt einer dicken, bei einem der vorliegenden $f$ allerdings sehr geschwundenen Linie in die Quere; die Fühlerwurzeln zeigen nur eine undeutliche Syur eines pechbräunlichen Anflugs, die Iralsschildsflecke sind mehr rhombisch, mit einem, dem Vorder- und Hintesrande des Halsschilds sellsst gleichlaufenden Vorderrande, auch die Schulterflocke kürzcr, nicht über das Ilinterende dess Seitenlappens hillausreichend, bei einem Stücke so schmal, dass selbst die Schul- 
terbeulen frei bleiben und nur auf ihrer Ilinterseite von jenen umzogen werden. Dagegen sind auf der Unterseite die seitlichen Vorderzipfel des ersten Bauchringes hell verblichen ziegelroth. Alles Uebrige wie bei der genannten Art. Das letzte Segment des $q$ mit der gewöhnlichen, rundlichen Grube, das ठ઼ mubekannı.

Aus Brasilien (von Caasapava: Sello im Mus. Berol.).

12. M. generosus v. Heyd. Schwarz, unten dicht silberhaarig, ein oberer Stirnfleck, der hintere Theil des zerstrent punktirten Halsschilds, ein länglicher Schulterfleck und die Spitze der Flügeldecken roth; die Punlitstreifen sehr fein, vorn durch übejzählige Punkte getrübt, mit flachen, wenig glänzenden Zwischenräumen. L. $21 / 4-31 / 2 " ' ;$ Br. $1 \frac{1 / 6}{6}-1^{3} / 4^{\prime \prime \prime}$.

Die grösste Art dieser Rotte, in mancher Beziehung an den früher beschriebenen M. minax erimernd. Ler Kopf flach mit wenig eingezogenem Kopfschilde, der Länge nach breit und tief eingedrückt und dann noch von einer scharfen Stirnlinie durchzogen, deutlich und ziemlich dicht-, auf dem rothen Stirnflecke sparsamer punktirt; letzterer zwisclıen den oberen inneren, auch bei dem ठठ weit getrennten Augenrändern gebogen, oben zugerundet und unten kurz zweilappig, stark gläızen̨d, der übrige Theil der Oberfläche schwarz, dünn angedrückt greisharig; die Oberlippe rüthlich gelb oder knochengelb mit manchmal gebräunter Mitte. Die Fühler des $\delta$ von $2 / 3$ der Körperlänge, des $q$ etwas kürzer, das vierte und fünfte Glied gleich lang, das sechste und die folgenden wiederum gleich lang, je etwas länger als das fünfte, dabei wenig zusammengedrüclit und verbreitert. Die Farbe der unteren hell röthlich gelh mit geschwärzter Oherseite, das stark anfgetriebene Wurzelglied fast ganz schwarz, und auch die oberen schwarz mit dünner greiser Behaarung. I)as Halsschild etwa doppelt breiter als lang, hinter der Mitte flach quer aufgewölbt mud von da nach vor'n in sanfter Krümmung alffallend, hinterwärts steiler niedergesenkt, üher den scharf spitzwinkligen Vorderecken den Vorderraud entlang cingeschnürt und daelurch verschmälert; dic Seiten fein gerandet, in der Mitte bogig erweitert und vor ihr etwas ansgeschweift, die Hinterecken scharf stumpfwinklig und etwas aufgelıogen, der Hinterrand doppelt ausgebuchtet mit kurzem Mittelzipfel; seillich von letzterem je ein schwacher, fast bis zu den Hinterwinkeh hinziehender Schrägeindruck. Dip Pnnktiıng dentlich, ohen zerstreut und auf der Mitte mtanchmal wie weggeschlif- 
fen, mit glänzendem Zwischengrunde. Die Farbe hei normaler Zeichnung schwarz, hinten jederseits mit einem grossen hellrothen Flecke, welcher vom Mittelzipfel ab den ganzen Hinterwinkel bis zur Mitte des Seitenrandes ausfüllt. Bei zunelımendem Roth tritt hierzu ein elliptischer Längsfleck vor dem Hinterzipfel, oder durch Vergrösserumg dieses Fleckes ein viereckiger Querfleck, welcher auf dem Mittelzipfel ruhend und diesen mit umfassend durch einen sclımalen verwaschenen röthliehen Saum jederseits am Hinterrande mit den Seitenflecken zusammenhängt. Weiter tritt dann aus dem Vorderrande dieses Hinterflecks eine schmal dreieckige Spitze hervor, welche bis zun ersten Drittel der Firstenlänge vordringt, wälırend sich die seitlichen Ilinterflecken zu einem breiten, die Vorderecken erreichendeu Seitenrande verlängern; und endlich fliessen alle diese Zeichnungen derartig zusammen, dass das ganze Ilalsschild roth ist, und nur am Vorderrande zwei, manchmal noch durch einen schmalen Vordersaum verhundene länglich viereckige schwarze Flecke ührig bleiben. Das Schildchen sclıräg ansteigend, quer viereckig und hinterwärts etwas verschmälert, mit deutlichem Hinterzipfel, ziemlich lang greishaarig, schwarz. Die Deckschilde lïnglich viereckig, fast um die IJälfte länger als breit, hinterwärts sehr wenig verbreitert, auf dem Rücken abgeflacht, vorn nur in einer feinen Querlinie eingedrückt; die grossen Schulterbeulen innerseits durch einen tieferen Eindruck abgesetzt, auch die Seitenlappen gross, mit sehr breiten umgeschlagenem Rande, und ïber ihnen die Deckschilde breit zusammengedrückt. Die Punktirung fein, die Streifenhildung auf der vorderen Hälfte besonders hinter den Schulterbeulen und längs der Naht durch üherzälılige Punkte gestört, hinter der Mitte etwas deutlicher, aber auch die Punkte sellıst feiner und auf der Wölbung fast abgeschliffen; die Zwischenr'üme flach, bei dem $\delta$ feiner-, dem $q$ etwas deutlicher quer gerunzelt, daher bei jenem mit stärkerem, hinten fast spiegelndem Glanze, dem $q$ matter und mehr seidig schimmernd. l)ie Farbe schwarz, ein sich an den entsprechenden Hinterfleck les Ilalsschilds anschliessender, langgestrecliter und fast bis zur Mitte der Flügeldecken reichender, den Seitenlappen mit umfassender Schulterfleck, und die breite bräunlich gesäumte Spitze der Flügeldecken hell rothgell; beim Umsichgreifen dieser Färbung entsteht eine Alart

$\beta$. bei welcher beide Flecke durch einen, an der schmalsten 
Stelle doch die Itälfte des neunten Zwischenraums eimnehmenden rothen Seitensaum zusammenlıängen, eine an die Zeichnung des M. circumcinchus erinnernde, mir in einem grossen of vorliegende For'm.

Pygidium und Unterseite fein runzlig punktirt, dicht angedrückt silherhaarig, mit den dünn behaarten Beinen schwarz. Das Prosternumi hinten breit rinnenförmig. Das letzte Segment des of flach quer niedergedrückt, des $\&$ mit einer tiefen rundlicheı Grube.

Aus Südbrasilien (von Porto Allegre: Sello im Mus. Berol.), Paraguay (Vogl im Mus. v. Heyden) und Montevideo (Mus. (lark).

13. H. angusticollis m. Sehwarz, die Füllerwurzeln, ein unterer Stirnfleck, die breiten Seitenränder und der Mittelzipfel des zerstrent punktirten Halsschilds, eine gelappte Vorderbinde und die Spitze der Flägeldecken rothgelb, I'ygidium, Hinterleib und Hinterbeine weissbunt; die Deckschilde vorn dicht siebartig punktirt, seitlich und hinten punktstreifig mit flachen, mässig glänzenden Zwischenräumen. L. $1 \frac{1 / 2}{}{ }^{\prime \prime \prime}$; $\mathrm{Br}$. $3 / 4{ }^{\prime \prime \prime}$.

Aeusserlich dem oben beschriebenen M. Palaemon nicht unähnlich, aber doch auch wieder durch den Bau des Halsschilds, wie durch Sculptur und Farbenvertheilung von ilım so abweichend, dass man beide Arten nur bei sehr oberflächlicher Betrachtung mit einander verweclıseln kömnte. Er ist, mit der genannten Art verglichen, um mehr als die Hälfte kleiner, auf dem Rücken der Deckschilde flacher, das IIalsschild seitlich sehı breit zusammengedrïckt, daher hier fast senkrecht abfallend und dadurch gegen seine Länge anscheinend selı verschmälert, sodass das Mittelfeld nur als ein schmaler, runder, seitlich stärker-, nach vorn und linten aber schwächer abfallenter Querwulst hervortritt; dagegen sind die Seiten kaum gerandet und nach vorn nur in flacher, vor der Mitte nicht weiter ausgeschweifter Krümmung zusammengeneigt. Die Oberflïhe des Kopfes ist fast glatt, die P'unktirung des IJalsschildes dentlich, aber nicht tief, oben sparsam, seitlich besonders in den Winkelı dichter gedrängt, mit lickglinzendem Zwischengrunde. Auf der vorderen llälfte der Flügeldecken zwischen Naht und Schulterbenle ist die P'unktirung dicht siebarlig zusammengedraingt mit schwachron Spuren alogerissener Punktstreifon, von denen nur der nennte und in geringerem Grade der achte zur Entwickelung ge- 
langt sind; linter der Mitte entwicheln sich die Streifen deutlicher, und bilden ziemlich breite und flache Zwischenräume, welche, wie der Zwischengrund rorn, durch Querrunzeln zerrissen und dadurch ziemlich matı sind, daher nur unter der Wölhung einigen Glanz zeigen. Nicht weniger wesentliche Verschiedenheiten von M. Palaemon bietet die Färbung und Zeichnung dar. Auf dem Ialsschilde ist nur die mittlere Hälfte der Länge nach glänzend schwarz mit ziegelrothem Mittelzipfel, die breiten Seiten sind hell ziegelroth, und zwar je weiter nach Aussen desto bleicher, längs dem Raude fast weisslich. Dieser Färbung der Halsschildsseiten entspricht ein auf den Fhügeldecken liegender länglichviereckiger Schulterfleck, welcher bis zum llinterende des Seitenlappens reicht, und immerseits desselben liegt noch ein grosser, länglich runder, die Naht erreichender Fleck, welcher mit dem Schulterfleck durch eine schmale Verbindung zusanmenhängt, sodass beide eine vorn und hinten tief ausgebuchtete, mit der immeren Hälfte die Wurzel nichı berüluende Querbinde bilden. Auch diese ist, wie der Spitzenfleck, bleicher ziegelroth als bei M. Palaemon, die Spitze selbst last weiss. Dagegen ist die weisse Zeichnung auf Pygidium und Unterseite mehr beschränkt als bei der genamnten Art; auf ersterem sind nur ein paar ganz schmale, durch das Uebergreifen der Färbung des letzten Bancluringes entstandene Randflecke weiss; die Unterseite ist bis auf den Rand des Hinterleibes schwarz, und an den Beinen sind nư die Vorderhüften, ein unscheinlsares Fleckchen vor der Spitze der Nittelschenkel, und die breite mit einer schwarzen Längshinde gezierte Aussenfläche der Hinterschınkel weiss. Das letzle Segment des $q$ mit der gewülnlichen Grube; das $ठ$ unbekannt.

\section{Aus Brasilien (Sello im Mus. Berol.).}

14. M. poricollis m. Schwarz, inten dicht silberharig, die Seiten und ein unterhrochener Hintersamm des grob und dicht rumzlig punktirten IIalsschilds, ein länglicher Schulterfleck und die Spitze der Flügeldecken ziegehroth; die Punklstreifen vorn verdoppelt und durch dicht eingenengte Punkte getrübt, mit flachen, gerunzelten Zwischenriumen. L. I $1 / 2{ }^{\prime \prime}$; Br. $3 / 4$ ".

Ein durclı seine grob punktirte und dadurch üherwirgend matte Oherlläche sehr aufallesder kiafer. Her kopf llach mit kaum eingezogenem Kopfschilde, dicht und ziemlich grob rmzlig punlitirt, wenig glinzend, schwarz, mit pechbräunliches, in der 
Nitte etwas starlier verdunkelter Oberlippe; die schmal drëieckig ausgebuchteten Augen greis. Die Fühler (des q) kaum von halber Kiörperlänge; das zweite Glied schmal eiförmig, die vier folgenden verkehrtkegelförmig und das sechste nach oben nur schwach erweitert, obschon deutlich zusammengedrückt; das vierte bis sechste ziemlich gleichlang ımıl je etwa um die Ilälfte länger als das dritte, die fünf oberen je etwas kürzer als das seclıste, stark verbreitert und zusammengedrückt; die Farbe schwarz, die unteren Glieder pechbrämnlich glänzend, die oberen dünn greishaarig. Das Halsschild kaum doppelt breiter als lang, hinier der Mitte stark quer buckelig aufgetrieben und von da nach vorn kugelig abwärts gekrümmt, auch hinterwärts stark schräg abfallend, über den scharf spitzwinkligen Vorderecken etwas eingedrückt und dadurch verschmälert, die Seiten breit zusammengedrückt und lang senkrecht herabgezogen, fein gerandet, in der Mitte nur schwach im Bogen erweitert, vor ihn sehr leicht ausgeschweift, nit kurzem Mittelzipfel. Die Punhtirung grob und dicht, vorn mit glatter Mittellinie. Die Farbe schwarz, auf dem Mittelfelde ein wenig glänzend; ein breiter Seitenrand, und ein schmaler, in der Einbiegung jederseits des Mittelzipfels unterbrochener Hintersamm hell ziegelroth. Das Schildchen sehr stark ansteigend, quer virreckig und fast doppelt breiter als lang, hinterwärts wenig verschnailert, mit ungewöhnlich grossem, flach niederliegendem Hinterzipfel, sehı fein runzlig punktirt, matt schwarz. Die Deckschilıle linglich-viereckig, gleichbreit und un $1 / 3$ lïnger als Jreit, iauf dem Riicken abgetlacht, hinter der scharfen Vorderkante schmal quer eingedrückı; die Schulterbeulen schmal und flach, die Seitenlappen breit zuger'undet und ülser ihnen die Deckschilde etwas zusammengedrückt. Die Punktirung auf der vorderen Hälfte aus ziemlich kenutlichen dichten Doppelstreifen gebildet, deren Zwischenräume nit überzähligen Punkten von gleicher Stärke so vollständig bedeckt sind, dass die Fläche dicht siebartig punktirt erscheint, und nur der zweite, und schwächer noch der vierte Zwischınraum als sclınale und schwache Längslinien hervortreten. Seitlich sind der achte und neunte Streifen ilırer ganzen Länge nach erkemubar und aus dicht gedrängten etwas quer ausgezogenen Punkten gehildet, und auch die des Randstreifens zielen sich quer iı den, besonders vorn noch weiter punktirten neunten Zwischenraum hinein. Hinter der Mitte werden durch das Zurückbleiben der überzähligen P'unkte die Streifen deutlicher, die XVI. 
Zwischenräume breiter und llacher, sind auch weniger als vorn durch Querrunzeln zerrissen, bleiben aber doch ziemlich matt, und zeigen nur auf der Wölbung einen schwachen Schimmer. Die Farbe ein besonder's vorn mattes Schwarz, der äussere Vorderwinkel der Flügeldecken durch einen grossen rothen Schulterfleck eingenommen, welcher die Schulterbeule lirei lässt, sich dafür aber mit der inneren Hälfte des Hinterrandes bis zur Mitte der Flügeldecke hinstreckt, während die äussere nur bis zum Ende des Seitenlappens freicht. Eben so ist ein grosser Spitzenfleck im hinteren Nahtwinkel hellroth. Pygidium und Unterseite dicht und fein runzlig punktirt, dicht angedrückt silberhaarig, nebst den etwas schwächer behaarten Beinen schwarz. Das Prosternum breit, der Länge nach seicht niedergedrückt, hinten kurz tiefer gefurcht. Das letzte Segment des $q$ mit der gewöhnlichen Grube; das ơ unbekannt.

Ebenfalls aus Brasilien (v. Olfers im Mus. Berol.).

15. M. ridibundus m. Schwarz, ein breiter Seiten - und Hinterrand des dicht siebartig punktirten Halsschilds, ein grosser Schulterfleck und die Spitze der Flügeldecken ziegelroth; von den Punktstreifen auf den dicht punktirten Deckschilden nur die Hinterenden nébst den äusseren Streifen kenntlich. L. 13/4" ; Br. $5 / 12{ }^{\prime \prime \prime}$.

Anscheinend ein seltsames Mittelding zwischen einem Metallactus, einem Monachus und einer Clythra; in Habilus und in der dichten Punktirung der Oberseite manchen Clythriden ähnlich, mit dem Fühlerbau eines Monachus, dem Halsschilde und der Vorderbrust eines Melallaclus, in welcher Gattung der Käfer nur unter der Voraussetzung eine Stelle findet, dass der seltsame Fühlerbau eine Eigenthümlichkeit des $q$ ist, und das $\delta$ darin von den nächstvorhergehenden, in Sculptur und Zeichnung so nahe verwandten Arten nicht abweichen wird. Der Kopf flach mit einem kaum merkbaren Nackeneindrucke, dicht und zientich grob punktirt, schwarz, die Oberlippe rötlllich gell, mit gebräunter Mitte, die Taster trüb gebräunt, die vorderen mit etwas verlängertem, übrigens wie überall kegelförmig verschmälertem und danı abgestutztem Endgliede. Die grossen Augen wenig ausgebuchtet, (bei dem \&) oben weit getrennt. Die kurzen Fühler erreichen nur etwa $2 / 3$ der Halsschildslänge; das Wurzelglied blasig aufgetrieben, um die Hälfte länger als breit, das zweite gleichfalls kurz und dick eiförmig, die bejden folgenden kurz, aber deutlich rerkehrt kegel- 
förmig, das dritte etwa dem zweiteı gleich, das vierte eiı wenig längè, das füıfte und seclıste an Läıge je dem vierten gleich, aber oberwärts viel stärker verdickt, und die fünf letzten bilden eine kurze gedrungene - Monachusartige - Keule, zusanmengesetzt aus breit dreiechig erweiterten Gliedern, deren obere Breite ziemlich ihrer Länge gleichlcommt, mit kaum bemerkbarem Fortsatze đles breit eiförmigen Endgliedes. Die Farbe schwarz, die sechs unteren mit einem nach oben almählich abnehmendem Lackglanze, dabei gegen das Licht bräunlich dırchscheinend, die Keule mit dicht angedrückter dünner greiser Behaarung. Das Halsschild etwa nur um die Hälfte breiter als lang, von dem rundlich gewölbten Mittelfelde ab nach vorn mit $2 / 3$ seiner Länge sanft abwärts gekrümımt, binten stärker loreit quer niedergedrückt, die ganzen fein gerandeten Seiten entlang breit zusammengedrückt, nach vorı etwas verschmälert, die Seiten selbst tief herabgezogen, nach den tief eingezogenen scharf spitzwinkligen Vorderecken zu mit kaum gekrümmten Rändern zusammenlaufend; die Hinterecken scharf stumpfwinklig, der Hinterrand zweiluchtig, der Mittelzipfel kurz, durch die ihn alsetzende, etwas veroreiterte Randfurche aufwärts geschoben. Vor ihm das Mittelfeld hreit dreieckig abgeflacht, und auf dessen vorderer Hälfte eine kurze, breite, aber kaum bis zum ersten Drittel der Längsfirste reichende glatte Stelle. Die Punktirung grob, siebartig zusammengedrängt, un die erwähnte glatte Längslinie noch etwas gröber, der stellenweise zu Rumzeln verfliessende Zwischengrund nur mit sclıwachem Glanze. Die Farbe schwarz, die breiten, nach Innen etwas buchtig hegränzten Seiten und ein eben so breiter Hinterrand ziegelroth, der letztere durch die seitlichen etwas hinterwärts elweiterten Zipfel des schwarzen Mittelfeldes da, wo er mit dem Seitenrande zusammenhängt, etwas verengt, so dass dieser Zusammenhang bei anderen Stücken auch unterbrochen sein könnte. Das Schildchen schräg ansteigend, kaum halb so lang wie vorn breit, hịterwärts stark verschmälert, mit abgerundeten Ecken und sehr deutlichem Hinterzipfel abgestutzt, dicht und fein narbig punktirt, schwarz. Die Deckschilde fast doppelt länger als breit, wodurch, verbunden mit dem verhältnissmåssig kurzem Halsschilde, der Körper eine gestreckt walzenfömige Gestalı erhält, ziemlich gleichbreit und binten kurz zugerundet, mit flach gewölbtem, auf der hinteren Wölbung sehr sanft abfallendem Rücken; letzterer hintes der scharfen Vorderkante schmal quer eingedrückt; die Schul- 
terbeulen länglich, ziemlichı stark lieraustretend, und die Seitenlappen lang herabgezogen. Die Punktirung noch etwas gröber, aher nicht ganz so dicht gedrängt wie die des Halsschilds, die ursprünglich vorhandenen Punktstreifen zwar stellenweise noch kenntlich, aber durch überzählige dichte und gleichfalls mehr oder weniger reihenweise gestellte Punkte soweit getrübt, dass in ilırer ganzen Ausdehıung nur die drei äusseren, ausserdẹnı von den der Naht zunächst liegenden die hinteren Enden zu sehen sind; der Zwischengrund fein genarbt unt deshalb nur matt schimmernd; die beiden äusseren Zwischenıäume flach erhöht, auch der zweite seiner ganzen Länge nach als schmale Längsrippe sichthar, und der breite Raum des neunten über dem Seitenlappen mit dicht gedrängten gröberen Punkten besetzt. Die Farbe schwarz, ein grosser viereckiger, nach Länge und Breite bis zur Hälfte der Flügeldecken reichender, alıer die Schulterheule freilassender Sclıulterfleck und die breite Spitze derselhen-hell ziegelroth. Pygidium, Unterseite und Beine fein runzlig punktirt, dicht angedrückt silberhaarig; die Vorderschenkel mässig verdickt mit schwach gekrïmmten Vorderschienen, die Hüften tief gebräunt, die Krallenhäkchen gelblich. Uas Prosternum, vorn flach, hinten leicht rimenförnigg und dann breit zugerundet, rumzlig punktirt und lang greishaarig. Das letzte. Segment des $q$ mit dem gewöhulichen Grübchen, das o unbekannt.

Aus Südamerika ohne genauere Angahe der Heimatlı, walırscheinlich aus Brasilien (Dlus. Deyrolle).

16. M. taeniatellus m. Oben gelh, die Fühlerenden, eine lappige Zeichnung des grob zerstreut punktirten Ilalsschilds, das Schildchen und eine algerissene Längsbinde der Flügeldecken schwarz; unten schwarz mit gelh) gerandetem Hinterleibe und gellbunten Beinen; die Punktstreifen bis über die Mitte durch dichte, grobe Punktirung unkenntlich, mit gerunzelten Zwischenräumen. l. $2 \frac{1}{3} " \prime$; Br. $1 \frac{1}{6}{ }^{\prime \prime \prime}$.

Ziemlich gestreckt walzenförnig und dadurch im Habitus mehr an die ächten Cryptocephalen der nördlichen Halhkugel erinnernd. Der Kopf flach mit deutlicher Stirnlinie, aher kaum eingezogenem Koplschilde, uur auf letzterem und in den Augenbuchten, seltener auch noch nach dem Nacken zu deutlich punktirt, sonst glatt, lackglänzend gelb, die Nitte der Oberlippe gebräunt, die Augenbuchten, die Wangen, die (hei dem $q$ ) oben wenig gen̈̈herten Augen sellst und der Grund der Stirnlinie, bei einem aul den Declischilden 
stark geschwärzten Stücke auch der Nacken schwärzlich. Die Fühler nicht von lıalber Körperlänge, das zweite Glied kugelig, die drei folgenden dünn verkehrtkegelförmig, das dritte dopjelt-, das vierte $2 \frac{1}{2}$ mal länger als das zweite, das fïmfte fast doppelt so lang als das dritte, das seclıste dem lïuften, die folgenden je dem vierten gleich, das Enrglied mit seinem breiten Fortsatze wieder so lang wie das fünfte. Die fünf unteren Glieder hell durchscheinend gelb mit stark gebräunter Oberseite der beiden unteren, die sechs oberen mässig znsammengedrückı unıl erweitert, schwar'z, mit dümner angedrückter greiser Behiarung. Das Halsschild walzenförmig, hinter der Mitte quer anfgewulstet und von da ab nach vorn und hinten merklich abwärts gekrümmt, nicht ganz doppelt so breit wie lang, über den lang heral,gezogenen, scharf spitzwinkligen Vorderecken hreit schräig zusanmengedrückt und dadurch etwas verschmälert, die Seiten fein gerandet, hinter der Mitte schwach bogig erweitert und vor ihr eben so schwach ausgeschweift; die Hinterecken scharf stumpfwinklig, der Hinterrand doppelt ausgebuchtet, und vor dem etwas aufgebogenen Mittelzipfel jederseits ein kräftiger Schrägeindruck. Die Oberfläche mit einer groben, oben mehr zerstreuten, seitlich dichteren Punktirung besetzt, mit lackglänzendem Zwischengrunde, gelb mit vier zusammenhängenden schıarzen Flecken, die mittleren besser ausgefärbten an die Mitte des Vorderrandes gelehnt und daselbst breit zusammenstossend, bei ausgebuchteten Innenräıdern mit den hinteren Ecken wieder zusammentreffend und dadurch einen elliptischen schımalen hellen Längsfleck einschliessend; die seitlichen nehr wischartig, besonders nach Aussen nur brandig begräızt, an den Eindrücken jederseits des hinteren Mittelzipfels schräg nach Aussen ziehend, und mit den inneren Vorderecken auf der Vitte die Aussenseite der Vorderflecken berührend. Bei dunkleren Stücken fliesst diese Zeichnung soweit zusammen und wird zugleich so intensiv, dass fast die ganze Oberfläche schwarz wird, und nur ein schmaler in den Vorderwinkeln hakig erweiterter Seitenrand, eiı schualer Läugsfleck auf der Mitte, und der aufgebogene Rand des Mittelzipfels gelb bleibt. Das Schildchen schräg ansteigend, nicht so lang als vorn breit, hinterwärts stark verschmälert und mit deutlichem Hinterzipfel breit abgestutzt, schwarz, bei helleren Stücken mit eineu gelblichen Querfleckchen vor dem Ilinterrande. Die Deckschilde walzenförmig, etwa doppelt länger als das Halsschild und nur um die Hälfte länger 
als breit, die Naht entlang abgeflacht, hinter der Wurzel nur leicht quer niedergedrückt, nit ziemlich breiten Schulterbeulen und lang abwärts gezogenen Seitenlajpen; üher letzteren die Deckschilde nur wenig zusammengedrückt. Die Punktirung auf der vorderen Hälfte grob, dicht gedrängt, nur mit Spuren von Punktstreifen, von denen der achte vorn und der neunte seiner ganzen Länge nach deutlich ausgebildet ist; die oberen entwickeln sich erst von der Mitte ab mit abgeschwächten Punkten und flachen Zwischenrăumen, während der fünfte bis achte hinten zu keiner deutlichen Ausbildung gelangen, und die Zwischenräume vorn melı oder weniger zu quergezogenen und gewuudenen Runzeln zusammenfliessen, daher der Glanz auch nur hinten mit einiger Bedeutung hervortritt. Die Farbe knochengelh, ein feiner Nahtsaum und eine breite, an den entsprechenden Halsschildsfleck sich anschliessende, bis zur Wölbung reichende Längsbinde der Flügeldecken schwarz; letztere hesonders nach Aussen schlecht und brandig begränzt, auf dem flachen Querwulste zwischen Schildchen und Schulterbeule verschmälert, abgeschwächt oder ganz unterbrochen, richtiger eigentlich in eine sich jederseits breit ausdelınende brandig bräunliche Färbung der Flügeldecke auseinander geflossen, deren stellenweise sich wieder vergrössernde Intensität sich bei einem der vorliegenden Stücke auch hinten zwischen dem Ende der Binde und dem Seitenrande wieder beınerklich macht, bei einem andern selbst eine fleckartige Erweiterung des abgerissenen Hinterendes der Binde bis zur Naht und dem neunten Streifen mit vorn und binten scharfer - dort dreieckig vortretender, hier aber dreieckig ausgeschnittener Begränzung hervorbringt. Das Pygidium fein punktirt, greishaarig, schwarz, am unteren Rande jederseits mit einem grossen gelben Flecke, von dem aus sich ein schmalerer gelber Rand aufwärts zieht; auch die Unterseite schwarz, dünı greishaarig, der Seitenrand des Hinterleibes mit dem Hinterrande des letzten Bauchringes gelb. An den Beinen die Hülten gelb, Schienen und Fussglieder rothgelb mit gebräunten Aussenkanten der ersteren; die Schenkel schwarz, die vorderen mit einem kleinen gelben Spitzenfleck, welcher sich bei den mittleren vergrössert und mit einer Verläıgerung an der inneren Schenkelkante hinaufzielıt; bei den Hinterschenkeln die breite Aussenseite hellgelb mit einer nach rlem Knie zu abgekürzten schwarzen Längslinie. Das Prosternum flach längsrinnig, hinten in schmaler Rundung auslaufend. Das letzte 
Segment des $\subsetneq$ mit einer halbkreisförmigeı, gläızenden Grube; das $\delta$ unbekannt.

Aus Brasilien (von Allegrelle: Sello im Mus. Berol.; die Var. in Mus. Clark).

17. M. dilutus m. Schmutzig lehmgelb mit dunkler geflecktem, grob zerstreut punktirtem IIalsschilde, Fühlerenden, Schildchen, Hinterbrust und sechs verwaschene Flecke der Flügeldecken $(2,2,2)$ schwarz; die Punktstreifen grob, vorn getrübt, hinten deutlich, mit flachen, glänzenden Zwischenräumen. L. $22_{3}^{\prime \prime \prime}$; Br. $1 \frac{1}{3}{ }^{\prime \prime \prime}$.

Dem vorhergehenden nahe verwandt, aber grösser und in Sculptur und Färbung genugsan verschieden. Der Kopf flach mit wenig eingezogenem Kopfschilde und deutlicher Stirnlinie, grob runzlig punktirt, schmutzig gelb; ein schmaler Nackensaum, der Innenrand der Augen, die Fühlerhöcker, der obere Theil der Oberlippe, sowie die Kinnbackenspitzen schmutzig rostroth, auch das Innere der Punkte schwach geröthet; die ziemlich grossen halhkreisförmig ausgebuchteten, (bei dem q) weit getrennten Augen greis. Die Fühler nicht von halber Körperlänge, das fünfte (längste) Glied kaum dem Wurzelgliede gleich, die folgenden etwas kleiner, die oberen stark zusanmengeschoben, zusammengedrückt und erweitert, sodass das kürzeste (zehnte) noch nicht wieder die Länge des dritten erreicht. Die fünf unteren durchscheinend honiggelb, mit gebräunter Oberseite des er'sten und zweiten, und einer schwarzen Längslinie auf den drei folgenden; die oberen schwarz mit dünner angedrückter greiser Behaarung. Das Halsschild etwa doppelt breiter als lang, über die Mitte hin sanft quer aufgewölbt und von da nach vorn und hinten gleichmässig abwärts gekrümmt, längs dem Vorderrande etwas eingesclınürt, über den spitzen Vorderecken flach zusammengedrückt und dadurch verschmälert; die Seiten gerandet, in der Mitte schwach erweitert und vor ihr fast grade, die Hinterecken scharf stumpfwinklig, der Hinterrand doppelt gebuchtet, mit wenig vortretendem Mittelzipfel, und vor letzterem jederseits ein flacher Schrägeindruck, dessen Enden fast bis zur Mitte des Seitenrandes verfolgt werden können. Die Punktirung grob zerstreut mit mässig glänzendem Zwischengrunde; die Farbe lelımgelb, zwei Vorderflecke und zwei an deren äussere Hinterenden anstossende, mehr nach Aussen stehende Hinterflecke nebst einem kleineren Querfleckchen vor der Mitte des Hinterran- 
des verwaschen rostroth. Das Schildchen schräg ansteigend, quer viereckig, linterwärts stark verschmälert ınd mit abgerundeten Ecken abgestutzt; der Hinterzipfel gross, flach niederliegend; die Oberfläche sehr dicht und fein punktirt, kurz und dünn behaart, schwarz. Die Deckschilde gestreckt, um die Hälfte länger als breit, ziemlich gleichbreit und hinten kurz zugerundet; der Rücken flach gewölbt, längs der Naht elwas niedergedrückt, auch vorn hinter der Wurzel nur leicht quer eingedrückt, mit schmalen wenig vortretenden Schulterbenlen und etwas kräftigeren Seitenlappen. Die Punktirung auf der vorderen Hälfte grob und ziemlich dicht, sodass die im Ganzen kenntlichen Punktstreifen durch überzählig eingenengte Punkte von gleicher Stärke vielfach gestört und verschoben werden; der achte und neunte ihrer ganzen Länge nach ausgebildet, die übrigen erst von der llitte ab deutlicher entwickelt, aber die mittleren schon vor der Wölbung erlöschend. Die Zwischenräume hinten breit, flach und glänzend, mit spiegelglatter Spitze, der Zwischengrund vor's mehr querrunzlig verfliessend mit schwächerem Glanze. Die Farbe lehmgelb, bei genauerer Betrachtung auf jeder Flügeldecke mit zwei verwaschenen roströthlichen Längsbinden, die innere, breitere von der Mitte der Wurzel bis zum Nahtwinkel reichend, die äussere an der Schulterbeule beginnend, und hinterwärts sich erweiterud an den Aussenrand gelehnt. Am Vorder - und Hinterende jeder Binde verdichtet sich deren Färbung zu einem verwaschen begränzten schwarzen Flecke, ausserdem zeigt die innere Binde noch einen solchen vor der Wölbung, und neben dem letzteren steht ein kleinerer nach Aussen auf dem Zwischenraume zwischen beiden Binden. Um die beiden Hinterflecke geht die Färbung der Spitze selbst fast ins Weisse über, gleich als ob ihr durch die Bildung dieser Flecke hier alles dunklere Pigment entzogen worden wäre. Pygidium und Unterseite dicht und fein runzlig punktirt, dümn greishaarig; jenes schmutzig gelb, der Hinterleib rostgelb mit rerwaschen hellerem Rande; Mittel- und Hinterbrust mit dem Prosterium schwarz, letzteres hinten tieflängsrinnig. Die Beine mit den Hüften rostroth, die Mittel- und noch mehr die Hinterschenkel an der Wurzel verwaschen geschwärzt. Das letzte Segment des $q$ mit einer nicht sehr grossen, im Innern glänzenden Grube; das ठ unl'ekannt.

Aus Brasilien (Sello im Mus. Berol.).

18. M. Larsalis m. Rostroth mit hellerem Hinterleibe, Füh- 


\section{1}

lerenden, Füsse und zwei hinten röthliche Längswische des grob punktirten Halsschilds schwarz, letzteres mit den Deckschilden strohgelb; die Punktstreifen vorn gestört, mit flachen, glänzenden Zwischenräumen. L. $21 / 2-3^{\prime \prime \prime} ; \mathrm{Br}$. $1 \frac{1 / 4}{4}-1^{2} / 3{ }^{\prime \prime \prime}$.

Gestreckt, im Habitus dem M. taenialellus ähnlich, an der sehr einfachen Färbung und Zeichnung leicht zu erkennen. Der Kopf flach gewölbt, mit kaum eingezogenem Halsschilde und tiefer Stirnlinie, grob und tief punktirt, mit runzligem Zwischengrunde, rostroth und bei dem $\delta$ ïber den Fühlerwurzeln leicht gebräunt; die Oberlippe knochengelb, die nicht grossen, aber tief halbkreisförmig ausgebuchteten, auch bei dem $\delta$ weit getrennten Augen schwarz. Die Fühler des $\delta$ von mehr als halber Körperlänge, des \& wenig kürzer, das zweite Glied kurz und knotig, das dritte $21 / 4$ mal länger, das vierte doppelt länger als das dritte, das fünfte bis achte je fast dem vierten gleich, das neunte und zehnte wieder ein wenig kürzer, das Endglied mit seinem kegelförmigen Fortsatze wieder so lang als das vierte. Die Farbe der fünf unteren durchscheinend rothgelb mit einem dunkleren, bei dem ठ schwärzlichen Längswische auf der Oberseite, die oberen schwarz mit angedrückter greiser Behaarung. Das Halsschild ivalzenförmig, hinter der Mitte leicht quer aufgewölbt und dann quer niedergedrückit, über den sclıarf spitzwinkligen Vorderecken am Vorderrande leicht eingeschnürt, dahinter breit zusammengedrückt und dadurch verschmälert, die Seiten gerandet, in der Mitte leicht bogig erweitert und dahinter eben so leicht ausgeschweift; die stumpfwinkligen Hinterecken mit einer scharf aufgebogenen Schwiele besetzt, der Hinterrand tief doppelt ausgebuchtet, mit kurz aufgebogenem Mittelzipfel, und vor diesem jederseits ein schwvacher, bei dem vorliegenden ठ kaum bemerkbarer Schrägeindruck. Die Punktirung grob und zerstreut mit hellglänzendem Zwischengrunde, die Farbe strolıgelb mit zwei wischartigen Längsljinden, welche am Vorderrande schwarz beginuen, in der Hitte sich zuerst am äusseren Rande röthen und zuletzt ganz ins Rothe übergehın, in welcher Färbung sie sich dann bis zum Hinterrande fortsetzen. Das Schildchen nicht ganz so lang als voru breit, hinterwärts wenig verschmälert, mit sehr grossem, flach niederliegendern Hinterzipfel breit abgestutzt, gleichfalls strohgelb. Die Deckschilde flach walzenförmig, ziemlich gleichbreit und etwa $1 / 3$ länger als breit, hinter der Vorderkante nur leicht quer eingedrückt, Schulterbeulen und Seitenlappen wenig 
ausgebildet, und über letzteren die Deckschilde breit und flach zusammengedrückt. Die Punktirung vorn von mässiger Stärke und nicht dicht, die ziemlich deutlichen Streifen durch eingemengte Punkte von glejcher Stärke gestört, der aclıte und neunte vollständig ausgebildet, die übrigen erst von der Mitte ab deutlicher, aber auch feiner; auf der Wölbung alle verloschen, die Zivischenräume flach uıd ziemlich glänzend, die Spitze spiegelglatt. Das Pygidium äusserst diclit und fein runzlig punlitirt, strohgelb, Unterseite und Beine rostroth, der Hinterleib verwaschen heller gelblich, der umgeschlagene Theil des Halsschilds mit der. Vorder- und Mittelbrust und den mittleren Theile der Hinterbrust, bei dem vorliegenden $\delta$ die letztere in weiterer Ausdehnung und auch die Parapleuren tiefer geschwärzt. Das Prosternum vorn seicht niedergedrückt, hinten tiefer längsrinnig mit stark erhöhten Pfannenrändern der Vorderhüften, und dabei lang greishaarig. Das letzte Segment des б mit einem elliptischen glänzenden Quereindrucke, das o mit einer rundlichen, besonder's vorı tiefer eingedrückten Grube.

Aus Südbrasilien (von Porto Allegre: Sello im Mus. Berol.).

19. II. trigrammus m. Schwarz, das dicht punktirte Halsschild und die Flügeldecken lehmgelb, zwei Punkte des ersteren und drei Längsflecken $(2,1)$ der letzteren schwarz; die Punktstreifen undeutlich, mit flachen dicht querrunzligen Zwischenräumen. L. $31^{1 / \prime \prime}$; Br. $2^{\prime \prime \prime}$.

Eine der grösseren Arten dieser Gattung, und von sehr eigenthümlicher Sculptur der Deckschilde, die aber mögliclierweise nur Geschlechtsmerkmal sein, und sich bei dem $\delta$ etwas abweichend gestalten könnte. Der Kiopf flach mit tiefer Längslinie, durch welche der Nacken in Gestalt von zwei flachen Längsbeulen aufgetrieben wird, das Kopf'schild etwas eingezogen, mit noch melır einwärts gebogenem Unterrande. Der obere Theil der Stirn glatt und glänzend, der untere punktirt, und diese Punktirung je weiter nach der Unterlippe zu desto dichter und gröber, daselbst auclı der Zwischengrund durch Runzeln zerrissen, mehr seidig schimmerud; die Farbe sclıwarz, nur die Oberlippe hellröthlich gelb mit pechbräunlichen Tastern. Die Augen gross, tief ausgeluuchtet, (auch bei dem \&) weit getrennt. Die Fühler schlank und etwa von halber Körperlänge, das Wurzelglied stark eiförmig aufgetrieben, nach aussen gekıümmt, doppelt läıger als breit, das zweite kurz und knotig, kaum länger als breit, die folgenden verkehrtkegelförmig, 
das dritte doppelt so lang wie das zweite, das vierte den zweiten und dritten zusammen gleich, und dem vierten alle folgenden gleichkommend, nur das Endglied mil dem lang kegelförmigen, innerseits durch eine deutliche Ausrandung abgesetzten Fortsatze noch über die Länge des vierten hinausreichend; die oberen vom fünften ab leicht zusammengedrückt, kaum erweitert. Die Farbe schwarz, das zweite bis vierte hell pechbraun mit einem schwärzlichen Längsschatten auf der oberen Seite. Das Halsschild um die Hälfte breiter als lang, init quer etwas aufgewulsteter Mitte, so dass von ihr aus die Längsfirste sich ziemlich gleichmässig aber doch nur schwach nach vorn und hinten zu abwärts neigt, vorn über den pfriemlich ausgezogenen Vorderecken etivas zusammengedrückt und dadurch verschmälert; die Seiten fein gerandet, in der Mitte bogig erweitert, vor ihr leicht ausgeschweift, die stumpfwinkligen Hinterecken mit einer kurzen Schwiele besetzt; der Hinterrand jederseits sanft gebuchtet, mit kurz aufgehogenem Mittelzipfel, vor letzterem der ganze hintere Theil des Mittelfeldes breit quer niedergedrückt, und jederseits noch ein flacher, eiförmiger Eindruck. I) Oberfläche punktirt, die Punkte auf der Mitte feiner und melır vereinzelt, je weiter wach den Rändern zu desto dichter und gröber, am gröbsten in den Hinterwinkeln, in denen sich zugleich noch ein flacher Schrägeindruck bemerkbar macht; der Zivischengrund glänzend und oben glatt, zwischen der dichteren Punktirung mehr oder weniger durch feine Runzeln zerrissen. Die Farbe lehmgelb, vor der Mitte jederseits ein unregelmässiges schwarzes Fleckchen, beide von einander etwa so weit wie jeder vom Seitenrande entfernt. Das Schildchen gross, etwas breiter als lang, mit deutlichem Hinterzipfel grade abgestutzt, fein punktirt und ziemlich dicht anliegend greishaarig, schwarz. Die Deckschilde länglich viereckig, um 1/4 länger als breit und vorn merklich breiter als das Halsschild, hinten kurz und breit zugerundet; die Wurzel hinter der scharf aufgeworfenen Vorderkante tief quer eingedrückt und dann etwas aufgewulstet, der Rücken die Naht entlang abgeflacht, seitlich und hinterwärts mit leichter Krümmung abfallend, Schulterbeulen und Seịenlappen nur schwach entwickelt, und über letzteren die Deckschilde ein wenig zusammengedrückt. Die Punktirung fein und ziemlich zerstreut, auf der vorderen Hälfte unordentliche, durch überzählige Punkte vielfach gestörte Streifen bildend, die sich erst von der Mitte ab kenntlicher entwickeln, 
hinterwärts aber sich bald abschwächen und zuletzt erlöschen; nur die seitlicheı bis zur Wölhung hin einigermassen zu erkennen. Dabei ist der ganze Zwischengrund mit fein eingerissenen, die Punkte verbindenden Querrunzeln bedeckt, dadurch nur seidig schimmernd, und nur die Schulterbeulen spiegelglatt. I) Farbe auch hier lehmgelb, ein feiner Nahtsaum und d’ei Lāngsflecke auf jeder Fügeldecke schwarz, ein kürzerer auf der Schulterbeule, und zwei etwas längere linter einander, der vordere an der Wurzel begimnende etwa in der Mitte zwischen Schulterbeule und Naht, der zweite hinter der Mitte, beide gewissermassen die Enden einer zerrissenen schwarzen Längsbinde bildend; den Anfang einer zweiten bildet dann der Sclıulterfleck, und deren Hinterende ein feiner schwäızlicher Längswisch zwischen dem sechsten und siebenten Punktstreifen neben der vorderen Hälfte des Hinterflecks. Das Pygidium ziemlich fein und dicht punktirt, schwarz, dünn greishaarig und an den abgeriebenen Stellen glänzend. Auch die Unterseite mit den Beinen fein runzlig punktirt, dicht greishaarig, schwarz; das Prosternum fast seiner ganzen Länge nach seicht eingedrückt, hinten durch die stärker aufgebogenen Rãuder tiefer rinnenförmig und dann kurz zugerundet. Das letzte Segment des $q$ mit einem rundlichen, glänzenden Grübchen, das $\delta$ unbekannt.

Aus Brasilien (Mus. Halens.).

Dritte Rotte. Körper gestreckt walzenförmig, das Halsschild seitlich in der llitte nur leicht erweitert, hinten sanft niedergedrückt; die Seiteneindrücke kaum bemerkbar. Die Färbung rostroth mit weissen Längshinden. Eine vereinzelte Art aus Brasilien.

20. M. albivittis m. Rostroth, die Fühler, Füsse, Halsschildsseiten und Schulterbeulen schwarz, Pygidium und Hinterleib gelb, das grob zerstreut punktirte Halsschild und die Deckschilde mil drei weissen Längshinden; die Punktstreifen derb und regelmässig," mit flachen, glänzenden Zwischenräumen. L. $2 \frac{1}{2}{ }^{\prime \prime \prime} ; \mathrm{Br}$. $11 / 5 "$.

Eine durch ihre Färbung und Zeichnung nicht weniger, wie durch die Regelmässigheit ihrer Punktstreifen ausgezeichnete Art. Der Kopf flach mit stark eingezogenem, oben durch einen flachen Längswulst abgegränztem Kopfschilde und kräftiger Stirnlinie, die Punktirung grob und tief mit runzligem Zwischengrunde. Die Farbe rostroth, die Oberlippe heller knochengelb, die Tasterenden ge- 
bräunt, die breit ausgebuchteten, auch bei dem ¿े weit getremnten Augen und die Fühler schwarz. Letzlese fadenförmig und hei dem allein vorliegenden $\delta$ von $3 / 4$ der Körperlänge, das Wurzelglied stark blasig aufgetrieben, kaum $1 / 4$ länger als breit, das zweite fast kugelig, das dritte kaum um die HäIfte länger, das vierte doppeltund das fünfte $2 \frac{1}{2}$ mal länger als das dritte, die folgenden bis zum zehnten ziemlich gleichlang, je reichlich dreinal länger als das dritte, das linienförmige Endğlied mit seinem lang kegelförmigen Fortsatze dem zweiten bis vierten zusammen gleich; dabei die sechs oheren zusammengedrückt, wenig verbreitert, und nach ihren Spitzen zu leicht dreieckig erweitert. Die fünf unteren auf der Unterseite in's Rothgelbe fallend, auch an Wurzel und Spitze in solcher Weise durchscheinend. Das Halsschild walzenfürmig, etıva $1 \frac{3 / 4}{4}$ mal breiter als lang, über die Mitte sanft quer aufgewölbt, von da nach rorn und hinten gleichmässig sanft abwärts gekrümmt, längs dem Vorderrande etwas eingesclıürt, über den spitzen Vorderecken zusammengedrückt und dadurch verschmälert; die Seiten feín gerandet, nach vor'n in flachen etwas ausgeschweiften Bogen zusammengeneigt, die wieder eingezogenen Hinterecken scharf stumpfwinklig, der Hinterrand jederseits tief ausgebuchtet, mit kurzen Mittelzipfel; die gewöhnlichen Schıägeindrücke kaum zu bemerken. Die Punktirung grob und zerstreut, mit lackglänzendem Zwischengrunde. Die Farbe rostroth, ein schmaler Seitenrand geschwärt, eine an letzteren gelehnte Seitenbinde jederseits und eine schınalere Mittelbinde in scharfer Begränzung weiss, leicht in's Gelbliche fallend. Das Schildchen wenig ansteigend, nicht ganz so lang wie voru breit, linten abgestutzt, fein punktirt, gleichfalls rostroth. Die Deckschilde fast um die Hälfte länger als lreit, gleichbreit, walzenförmig mit etwas abgeflachtem Rïcken und hinten ziemlich steil abfallender Wölbung, vor'ı nur schwach quer niedergedrückt, auch die schmalen Schulterbeulen und die Seiteulappen von geringer Entwicklung, mit breiten umgeschlagenem Rande der letzteren. Die Punktstreifen kräftig und sehr regelmässig, nur längs der Naht durch einige überzällige Punkte getrübt, der sechste auf der Mitte abreissend; die Zwischenräume flach, hinterwärts bei der Alıschwächung der Punktstreifen breiter und glänzender, der neunte leicht aufgewölbt. Die Farbe rostroth, und die Zeichnung genau an die des Halsschilds angeschlossen, daher zunächst eine schınalere gemeinsame, von der IVölbung ab sich erweiterıde Nahtbinde weiss; 
alsdanı auf jeder Flügeldecke eine breitere, zwischen dem vierten und siebenten Punktstreifen liegende, ebenfalls scharf begränzte Längsbinde von gleicher Färbung, die an der Spitze durch einen Bogen mit der Nahthinde zusammenläuft; endlich auf der Schulterbeule ein hinterwäı'ts verwaschıı auslanfender schwarzer Läıgsfleck, und ebenso unter der Wölbung zwischen den Binden und ausserhalb der seitlichen die rostrothe Gruindfarbe schwach gebräunt. Pygidium und Hinterleib sehr fein runzlig punktirt, heller gelb, mit gerötheter Mitte des ersten Bauchringes; der übrige Theil der Unterseite mit den Beinen rostroth, nur die unteren Enden der Schienen verwaschen geschwäızt und die Füsse schwarz. Das Prosternum hinten schmal längsrinnig. Das letzte Segment des $\delta$ mit einem kleinen, tlacheı Quereindrucke; das $\&$ unbekannt.

Gleichfalls aus Brasilien (von Allegrette: Sello im Mus. Berol.).

$\mathrm{Zweite} \mathrm{Rotte.} \mathrm{Körper} \mathrm{klein,} \mathrm{schmal,} \mathrm{oben} \mathrm{leicht} \mathrm{abge-}$ flacht, mit nach rorı rundlich rerschnälertem, seitlich kaum eingedrücktem Halsschilde. Fühler sehr lang, die Punktirnng der Deckschilde zerstreut mit hinten kaum angedeuteten Streifenenden. Farbe schwarz, mit gelber, auf den Deckschilden üherwiegender Zeichnung. Eine bis dahin einzelne Art aus Chile.

21. II. ochripennis m. Schwarz, Vorder- und Seitenrand des fein, aber ziemlich dicht punktirten Halsschilds gelb, die Flügeldecken gelb, deren Vorderrand, Schulterbeule, ein Randfleck und ein hinterer gemeinsamer Querfleck schwarz; die Deckschilde zerstreut punktirt, hinten mit Spuren verwischter Punktstreifen. L. 11/2 $-12 / 3{ }^{\prime \prime \prime} ;$ Br. $3 / 5-3 / 4 "$.

Klein, zierlich, im Habitus von den vorhergehenden, wie den nächstfolgenden Arten gar sehr abweichend, und deshalb an dieser Stelle selır vereinsamt, aber auch an kemer andern besser unterzubringen. Der Kopf tlach, grob runzlig punktirt, mit breiter und tiefer Stirnfurche; die Oberlippe schmutzig gelb, die grossen, tief ausgebuchteten, auch bei dem $\delta$ weit getrennten Augen, wie die übrige Fläche des Kopfes schwarz. Die Fühler dümn und schlank, fast von liörperlänge, das Wurzelglied dick blasig aufgetrieben, auch das zweite breit eiförmig, die drei folgenden dünn verkehrtkegelförmig und die oberen leicht zusammengedrückt; das dritte $2 \frac{1}{2} \mathrm{mal}$, das vierte dreimal, das fïnfte lis siebente je $3 \frac{1}{1} 2$ mal länger als das zweite, dıe folgenden allmählich wieder soweit verkinzt, dass das 
zehnte nicht ganz die Länge des vierten erreicht; das Lndglied mit schmal dreieekigem Fortsatze. Dic Farbe schwarz, das dritte bis fünfte gelblich orler bräunlieh durehseheinend. Das Halsschild kurz und breit, hinter der Mitte sehr leicht quer aufgewölbt und vor dem Hinterrande quer eingedrüekt, über den fast rechtwinkligen Vorderecken etwas zusanmengedrüekt; die Seiten fein gerandet, hinter der Mitte äusserst schwach erweitert und von da nach vorn in breiten Bogen zusammengeneigt; die-Jlinterecken stumpfwinklig, leicht schwielig anfgetriehen, der Hinterrand jederseits leicht gebuchtet, mit überaus schwach heraustretendem Nittelzipfel. Die Punlitirung ziemlieh dicht, deutlich, aher nicht tief eingestochen, auch nicht überall von gleicher Stärke, mit glänzendem Zwischengrunde, auf welehem vorn zuweilen unter schräger Beleuchtung eine schwach angedeutete Kiellinie bemerklich wird. Die Farbe schwarz, Vorder- und Seitemrand hoebgelb, sodass das schwarze Hinterfeld sich mehr oder weniger in Gestalt eines Halbkreises ahgränzt, und sich dadurch der gelbe Rand in den Vorderwinkeln zu grösserer Breite erweitert. Das Sehildchen stark schräg ansteigend, etwas länger als breit, hinterwärts ein wenig verschmälert und dann grade alggestutzt, mit wenig bemerkbarem Hinterzipfel, fein punktirt und glänzend schwarz. Die Deekscliilde breit und flach gewölbt, länglich viereckig und um $1 / 3$ länger als breit, auf der Naht linter dem Schildchen und dann wieder hinter der Mitte seicht quer niedergedrïckt, mit linten kurz abfallender Wölbung, hinter der scharf erhölıten Vorderkante schmal quer gefurcht und diese Furche bis zn den breiten, stumpfen Schulterbeulen reichend; die Seitenlappen kräftig, und ïber ilmen die Deckschilde stark zusammengedrückt, wodurch hart über ilırem Kiele eine kräftige Quergruhe gebildet wird. Die Punktirung scheinbar ungeordnet, nit Spuren abgerissener Punktstreifen, die auf der hinteren Hälfte dentlicher werden; der ülıer dem Seitenrande liegende, dem neunten entsprechende Streifen nach seiner ganzen Länge kenntlich, die Punkte übrigens auch hier nicht tief, daher stellenrveise, besonders nach der Wölbung zu, undentlich und mehr vereinzelt, der Zwischengrund lackgłänzend. Die Farbe ein sehönes Hochgelb, ein schmaler verwaschener, sich nach Aussen hin zu einem breiteren, auch die Schulterbeule mit unfassenden Flecke erweiternder Wurzelsaum schwarz, und dieselbe Färbung zeigen ein schmaler Ranılwisch lrinter dem Seitenlappen, und diesem gegenüber ein gemein- 
samer herzförmiger Querfleck auf der Naht hinter der Mitte, welcher seitlich bis auf $2 / 3$ der Flügeldeckenbreite hinausreicht.

Aendert ab

$\beta$. die Deckschilde bis auf den schwärzlichen Vordersaum einfarbig gelb. Ein ơ im Mus. v. Bruck mit einem dunkeln schmalen Längsschatten auf jeder Flügeldecke, gewissermassen dem abgerissenen Ende des Querflecks, bildet den Uebergang zu der Stammform.

Das Pygidium grob punktirt, mit Unterseite und Beinen schwarz, nur die Innenseite der Vorderschienen am unteren Ende gehräunt. Das Prosternum vorn der Länge nach niedergedrückt, hinten tiefer gefurcht, stumpf dreieckig zugerundet, Das letzte Segment des ठ breit abgeflacht, das $q$ unbekannt.

Aus Chile (Nus. Deyrolle, und nach eines dabei befindlichen Notiz hei Conception und im Araucaner-Gebiete gefunden; die var. $\beta$. im Mus. Vindob, auf der Reise der Novara gefunden).

Fünfte Rotte. Kïrper klein, gestreckt, hinterwärts etwas verbreitert; das Halsschild oben nur llach gewölbt, nach rorn kegelförmig versehmälert, hinten jederseits tief quer eingedrückt. Kleine, zierliche Arten aus Brasilien, in deren Fïrhung und Zeichnung sich lediglich das in andern Rotten typisch gewordene wiederholt.

22. M. semirufus m. Schwarz, der Kiopf und das derb punktirte Halsschild mit Fühlerwurzeln, Vorderbcinen, einer Mittelquerbinde und der Spitze der Flügeldecken roth; die Punktstreifen vorn unregelmässig verdoppelt, der sechste und siebente gestört, mit flachen, glänzenden Zwischenräumen. L. $1 \frac{1}{2}{ }^{\prime \prime}$; Br. 3/4"“.

Im Ilabitus manıchen Arten der ersten Rofte nicht unähnlich, aber klein, mit stark eingedrücktem Ilalsschilde, zugleich durch die abwechselnd schwarz- und rothgebänderten Deckschilde sehr ausgezeichnet. Der Kopf flach gewölbt, mit unten dreieckig erweiterter Stirnlinie, das oherwärts deutlich begränzte, etwas eingezogene Kopfschild ziemlich dicht punhtirt. Ilie Farbe des Kopfes bis auf die geschwärzten Kimubacken glänzend roth, die grossen, durch eine dreieclige Ausluchtung sehr ungleich getheilten Augen greis, und (bei dem + ) weit getremnt. Die Fühler ziemlich düm, von etwa halber Körperlänge, das Wurzelglied stark blasig aufgetrieben, etwa un die IIälfte länger als breit, der zweite fast kugelig, die drei folgenden selır dünn, das dritte doppelt-, das vierte 
dreimal länger als das zweite, und das fünfte noch etwas verlängert, das sechste oberwärts schwach dreieckig erweiterte wieder dem vierten gleich, und die folgenden allmälılich abnehmend, so dass das zehnte nur etwa dem dritten glcichkommt; das etwas längere Endglied mit kurz dreieckigem Fortsatze. Die Farbe der fïnf unteren durelischeinend rothgelb, das sechste an der Wurzel gebräunt, oben mit den folgenden gleichfalls nur schwach zusammengedrückten und verbreiterten Gliedern schwarz mit angedrückter greiser Behaarung. Das Halsschild etwa $2 \frac{1}{2}$ mal breiter als lang, in der Hitte leicht quer aufgewölbt, die Seiten lang herabgezogen, hinter den scharf rechtwinkligen Vorderecken breit zusammengedrückt und dadurch das Halsschild kegelförmig verschmälernd, fein gerandet, von der sanft gerundeten Mitte aus nach vorn fast geradlinig verlaufend; die Hinterecken nur durch eine stunpfe Randschwiele angedeutet, der Hinterrand leicht doppelt gebuchtet, mit kaum benerkbarem Mittelzipfel, und vor dem letzteren ein schmaler, ziemlich tiefer Quereindruck, der sich jederseits muldenfürmig verbreitert und über der Mitte des Seitenrandes allmählich verliert, während er nach den Hinterecken zu einen starken Querwulst emporschiebt. Die Punktirung derb und dielıt mit glänzendem Zwischengrunde, die Farbe ein einf̣aches, ziemlich dunkles Ziegelroth. Das Schildchen sehr steil ansteigend, etwa so lang wie voru breit, hinterwärts stark verschmälert, mit deutlichem Hinterzipfel und algerundeten Ecken abgestutzt, fein punktirt, braumroth mit heller durchscheinender Hinterhälfte. Die Deckschilde etwa $1 / 4$ länger als breit, hinterwärts merklich verbreitert, der Rücken flach gewölbt, hinten mit kurzer und ziemlich steiler Wölbung abfallend, hinter der ziemlich scharf erhöhten Vorderkante leicht quer eingedrückt, die länglichen Schulterbeulen stark heraustretend, die Seitenlappen mässig entwickelt, üher ilınen die Deckschilde kräftig zusammengedrückt, und vor diesem Quereindrucke noch eine rundliche, den neunten Zwischenraum und den neunten Streifen unterbrechende, oben an die Schulterbeule sich anlehnende Beule. Die Punktstreifen deutlich, die inneren und der achte auf der vorderen Hälfte durch viele überzählig eingemengte Punkte gestört und stellenweise verdoppelt, der sechste und siebente in der Mitte abgebrochen, und der dadurch entstandene breite Zwischenraum mit einer vereinzelten gröberen Punktreihe besetzt; auf der Hinterhälfte werden die Streifen merklich regelmässiger, aber kaum feiner. Die XVI. 
Zwischenräume glänzend, flach, der zweite und vierte vorn leicht erhöht. Die Farbe schwarz, die Wurzelkante am Schildchen rötlılich, ausserdem über lie Mitte eine breite, das grössere mittlere Drittel der Deckschilde einnehmende rothe Querbinde, und dazu noch die Spitze breit und hellziegelroth, schwach ins Weissliche verblichen. Pygidiun, Hinterleib und Hinterbrust, sowie die hintern Beine schwarz mit röthlichen Hüften; Vorder- und Miltelbrust mit den Vorderbeinen roth, erstere grob gerunzelt, in der Mitte breit niedergedrückt, und hinten zwischen den emporgerichteten Pfannenrändern tiefer rinnenförmig, mit kurz zugerundeten Hinterende. Das letzte Segment des \& mit einer halbkreisförmigen, tiefen Grube; das ơ unbeliannt.

\section{Aus Brasilien (Mus, Deyrolle).}

23. M. Clarkii m. Braungelh nit schwärzlichen Fühlerenden, die verwaschenen inueren Augensämme, der Rand des vereinzelt grob punktirten Halsschilds, die Vorderkante und vier Flecke der Flügeddecken mit Pygidium, Hinterleilssand und Beinen weissgelb; die Punktstreifen tlerb, der sechste und siebente abgerissen, mit flach gewölbten, glänzenılen Zwischenräumen. L. 1\%." "'; Br. $3 / 4 "$.'

Von der Grösse des vorhergehenden und elsen so zierlich, aber vorn nicht ganz so stark verschmälert, und in der Färbung einigermassen an den M. 15 gutlatus und guttula Fab. erinnernd. Der Kopf flach, die Stirn in der Mitte breit und seicht niedergedrückt, das Kopfschilıl stark eingezogen, die Punktirung deutlich, mässig dicht, mit lackartigem Zwischengrunde, die Farbe braungelb, zwischen den obren imneren, auch bei dem ơ weit getrennten Augenrändern zwei verwaschene, fast zusammenstossende weissliche Längsflecke, deren Unterenden sich mit gleichfalls verwaschener Begränzung den ganzen inneren Augenrand entlang ziphen; Wangen und Oberlippe elsenfalls weisslich gelb. Die Fühler von fast halbeł Körperlänge, schlank und von dem gewöhılichen Baı nur dadurch abweichend, dass das vierte und fïnfte Glied gleichlang, ınd doppelt so lang sind wie las dritte; die fünf unteren durchscheinend rothgell, mit gebräunter Spitze des fünften und einen schwärzlichen Fleckchen auf' der Ober'seite des zweiten und dritten, die oberen schwärzlich mit angedrückter düıner, greiser Behaarung. Das IIalsschild $2 \frac{1}{2}$ mal breiter als lang, mit list grader Mittelfirste flach walzenförmig, vorn über den scharf recht- 
winkligen Vorderceken breil zusammengedrückt und dadurch verschmälert, die Seiten fein gerandet, vor der Mitte leicht auswärts gebogen, und von da nach vorn, wie nach den scharf stumpfivinkligen Ilinterecken zu fast grade verlanfend; der Hinterrand jederseits sanft ausgelouchtet, mit wenig hemerkbarem Mittelzipfel, vor letzLesem lie Oberflache breit quer niedergedrückt, und dadurch die Masse des Halsschilds auf jeder Seite in Gestalt eines halbmondförmigen Wulstes aufwärts geschoben, welcher jenas niedergedrückte Querteld hinten ausserhalb des 'Hittelzipfels und seitwärts umzieht, sich daun vorn wieder uach der Mitte umbiegend sich in dem Mittelfelde verliert und hier weiter nach vorn von der vorderen Einschnürung dles Halsschilds begränzt wird. Die Punktirung derb, aber vereinzelt, und nur in der vertieften Stelle etwas dichter zusammengedrängt; die Farbe lackglïuzend braungelb, der Rand mit eirrer Unterlorechuug über dem Nacken und durch den hinteren Mitlelzipfel glänzend weissgelb ohne Punkte. Das Schildchen stark ansteigend, so lang wic vorn hreit, hinterwärts versclımälert und mit deutlichem Hinterzipfel grade alygestutzt, glänzend braungelh. Die Deckschilde fast um $1 / 3$ lïnger als breit, flach gewölbt und fast gleichbreit, hiuten kurz zugerundet und mit starker Krümmung abfallend, der Rücken hinter ler breit und stumpf aufgetriebenen Vorderkante unci dann nochmals über den Seitenlappen flach quer niedergedrückt und dazwischen eben so flach quer aufgewulstet; die breit eiförmigen Schulterheulen von mässiger Stärke, die Seitenlappen gleichfalls von mässiger Ausbildung, und über ihnen die Deckschilde sehr breit und stark zusammengedrückt. Die Punktstreifen deutlich ınıl in Ganzen regelmässig, der scchste unł siebente bald abgerissen, dic Zwischenräune flach gewölbt, die Farbe lackglänzend braungelb, der breite aufgeworfene Vorderrand und vier Flecken auf jeder Flügelłecke weiss; von dieseı der grösseste im hinteru Nahtwinkel, etwas schräg und nach vor'n leicht ausgebuchtet, die übrigen sind Längsflecke, und zwar eiuer, an den Wurzelrand stossend, auf dem vierten Zwischenraume, die beiden anderen hinter der Mitte, der äussere auf dem breiten Zwischenraume zwischen dem fünften und achten Punktstreifen, der innere zwischen dem ersten und zweiten Streifen, mit seinem stark versclımälertem und gewissermassen cinen kleinen (fünften) accessorischen Flecken bildendem Vorderende den ersten Streifen durchsetzend und anf den Zwischenraum zwischen dem ersten und den 
abgekürzten Streifen überspringend; alle Flecke zugleich etwas erhöht, wie aufgetragen, und nirgends von den Punkten selbst getroffen. Das Pygidium, ein breiter, verwaschen begränzter Rand des Hinterleibes und die inneren Ränder der Parapleuren weiss; die Beine bleichgelb, die unteren Schenkelenden verwaschen ins Weissliche fallend. Das Prosternum hinten ziemlich schmal rinnenförmig. Das letzte Segment des $\delta$ leicht quer eingedrückt, das q unbekannt.

Aus Brasilien (ron Conslancia und Petropolis: Mus. Clark).

Sechste Rotte. Körper von mässiger Grösse, gestreckt mit flachgewölbten und gleichlbreiten Deckschilden, das Halsschild nach vorn verschmälert und jederscits tief quer eingedrückt. Die Augen des $\delta$ einander fast berührend. Die Farbe gelb mit schwarzer Zeichnung. Eine einzelne Art aus Brasilien, die in mancher Hinsicht an die Arten der unten folgenden eilften Rotte erinnert.

24. M. a pocalypticus. Knochengelb, Kopf, Schildchen, Brust und Fühlerenden schwarz, die Flügeldecken mit drei stahlblauen Flecken $(2,1)$; das Halsschild grob zerstreut punktirt, die Punktstreifen derb, etwas wellig, die oberen gestört mit flach gewülbten, ziemlich glänzenden Zwischenräumen.

ठ Die Mitte des Halsschilds mit zwei bläulichen Flecken;

\& das Halsschild ungefleckt.

$$
\text { L. } 2 \frac{1}{2}-3 \frac{1}{4}{ }^{\prime \prime \prime} \text {; Br. } 11^{1 / 3}-13 / 4^{\prime \prime \prime} \text {. }
$$

Ein ziemlich grosser, durch die stahlblauen Flecken auf den Deckschilden sehı ausgezeichneter Käler, der durch das hinten selır breite, nach vorn im Bogen verschmälerte. Halsschild schon einen deutlichen Uebergang zu den näclıstfolgenden Rotten vermittelt. Der Kopf flach mit etwas eingezogenem Kopfschilde, die Stirn bei dem $\delta$ durch die fast zusammenstossenden Augen sehr verengt, nur durch eine feine, sich unterwärts gabelnde Kreislinie mit dem Nacken verbunden, bei dem $q$ breiter, leicht quer eingedrückt, und dieser Eindruck oberwärts in eine kurze Längslinie auslaufend. Der Nacken ziemlich glatt und glänzend, mitunter die Stirn mit deutlichen Punkten besetzt und dicht angedrückt greishaarig; bei dem $q$ ist diese Punktirung mehr zerstrent, mit matt glänzendem Zwischengrunde, bei dem ơ dichter, mehr runzlig verfliessend, fast ohne Glanz. Die Farbe̊ schwarz, die Mitte des Nackens und ehen so der untere Theil des liopfschilds verwaschen brïunlich gelb durchscheinend; die Oberlippe des $\delta$ hell knochengelb, des 웅 
in der Mitte leicht gebräunt. Die Fühler des $q$ von halber Körperlänge, dünn und schlank, das Wurzelglied keulig, fast $2 \frac{1}{2}$ mal länger als breit, unten stark eingeschuürt und etwas nach Aussen gebogen, das zweite kurz eiförmig, die folgeniden überaus dünn, sticlrund und nur an der Spitze etwas aufgetrieben, das dritte so lang wie das erśte, das vierte und fünfte je denı zweiten und dritten zusammen gleich, das sechste so lang wie das fünfte, aber oberwäts schon etwas verbreitert; die oberen schwach zusammengedrückt und erweitert, sich allmählich verkürzend, sodass das zehnte uur etwa dem dritten gleichkommt; das Endglied mit schmal dreieckigem, durch eine deutliche Ansrandung abgesetztem Fortsatze. Die Fühler des $\delta$ von $3 / 4$ der Körperlänge, in allen Gliedern etwas verlängert, und das Endglied unter seinem, dadurch stärker abgesetztem Fortsatze merklich mehr verbreitert. Die Farbe der fünf unteren Glieder hellgelb, der oberen schwarz mit kurzer und dünner angedrückler greiser Behaarung. Das Ilalsschild kurz und hinten sehr breit, flach, mit fast grader, nur hinterwärts sanft abwärts geneigter Mittelfirste, üher den tief eingezogenen pfriemlich zugespitzten Vorderecken breit zusammengedrückt, löngs dem Vorderrande zugleich etwas eingeschnnu't und dadurch sehr merklich verschmälert, die Seiten fein gerandet, in der Mitte in breiten Bogen erweitert und dann nach vorn fast in graden Linien zusammengeneigt, hinterwärts mit stumpfen in einer kurzen Schwiele vertretenden Hinterecken in den Hinterrand übergehend; vor den Hinterecken je ein breiter und flacher Quereindruck, durch welchen den Hinterrand entlang ein schmaler, glatter Querwulst emporgeschoben wird. Der Hinterrand selbst wellig ausgebuchtet, der Mittelzipfel kurz und breit aufwärts gebogen, vor ilım das Mittelfeld breit niedergedrückt, mit einem sich jederseits daran schliessenden stärkeren gegen die Mitte des Seitenrandes hin verlaufenden, anscheinend dessen Ausbiegung bewirkenden Schrägeindruck. Die Punktirung kräftig, aber sehr vereinzelt und nur vor den Hinterecken etwas dichter gedrängt, mit lackglänzendem Zwischengrunde, die Farhe hell knochengelb, bei dem vorliegenden $q$ einfarbig, stellenweise etwas dunkler gelb gewölkt, bei dem $\delta$ jederseits hinter der Mitte ein hinten an den Vorderrand des Schrägeindrucks gelehntes stahlblaues Fleckchen, bei einem vorliegenden Stücke diese Flecke etwas in die Länge gezogen, und zwischen ihnen vor dem Mittelzipfel noch ein ähnliches schwächeres Fleck- 
chen: die Wolkenflecke des $q$ sind dieser Zeichnung einigermassen analog gestellt, und könnten deslıalb wohl als eine Abschwächung derselben gelten. Das Schildchen gross, quer viereckig, hinterwärts stark ansteigend und eben so stark verschnälert, mit deutlichem Hinterzipfel, fein punktirt und dünn angedrückt greishaarig, schwarz mit bräunlich durchscheinendem Mittelfelde. Die Deckschilde länglich viereckig, etwa um $1 / 4$ länger als breit, vorn breiter als das Halsschild, ziemlich gleichbreit bis zur Spitze verlaufend und hier kurz zugerundet, hinter der scharf aufgeworfenen, seillich an die lang höckerig heraustretenden Sclıulterbeulen angeschlossenen Vorderkante tief quer eingedrückt und dahinter leicht aufgewulstet; der Rücken sehr flach gewölbt, erst hinten mit litrzer Krümmung stärker abfallend, hinter den Schulterbeulen etwas zusammengedrückt, und über den stark abwärts gezogenen Seitenlappen noch ein tieferer, in den neunten Punlitstreifen fallender Längseindruck. Die Punktirung derb, zu etwas welligen Streifen geordnel, welche von der Naht ab bis zum dritten Zwischenraume durch zalılreiche überzählige Punkte gestört und stellenweise verdoppelt sind; auch innerseits der Schulterbenle ist der Anfang des fünften, und hinter ihr das Vorderende des sechsten bis achten in älınlicher Weise getrübt. Nach der Wölbung zu werden die Punkte allmählich feiner, auf ihr fast abgeschliffen, und unter ihr ist die Spitze spiegelglatt. Die Zwischenräıme flach, vorn leicht querrunzlig, die mittleren durch die seitlich ausgerissenen Punkte etwas uneben; die Farbe lackglänzend knochengelb unit drei stahlblauen Flecken auf jeder Flügeldecke, von den beiden vorderı der äussere grössere im Schulterwinkel, viereckig und dic Schulterheule mil umfassend, aber nur bei dem $q$ bis zum Seitenlappen hinabreichend, der innere kleinere die Wurzel nicht erreichende zivischen lem ersten und dritten Punktstreifen, bei dem $q$ etwas in die Länge gezogen, hei einem der vorliegenden ơ zu einem schmalen Wische geschwunden: der vereinzelte Hinterlleck zwischen dem vierten und neunten Streifen, mil seinem Hinterende bis zur Wöllumg hinabreichend, ausserdem der vierte Punktstreifen mit einer bläulichen verwaschenen Längslinie angeflogen, welche den (grösseren) llinterfleck des $q$ berührt, während sie len des $\delta$ nicht erreicht.

Aendert ab

$\beta$. der Innenfleck fehlend, der lintere zu einem manchmal unscheinbaren Punkte geschwunden; zwei $\circ$, bei denen zugleich 
der Nacken nicht schwarz, sondern nur verwaschen gebräunt erscheint.

Pygidium und Unterseite fein runzlig punktirt und dünn greishaarig, jenes nebst dem Hinterleibe hell strohgelh, wie auch die Vorder- ind Mitlelbrust; die Hinterbrust schwarz mit leicht stahlbläulichem Anfluge. Die Beine gleichfalls gelb mit gelıäunten Krallenhäkchen, die Vorderschenkel stark angeschwollen und die Schienen entsprechend gekrümmt. Das Prosternum vorn mit zwei leicht eingedrücliten Längslinien, die sich hinterwärts zu einer Längsrinne vereinigen, mit breit zugerundetem Hinterzipfel. Das letzte Segment des $\delta$ mit einem flachen rundlichen, glänzenden Eindrucke, das \& nit einer tiefen, laalbkugeligen Grube.

Ebenfalls aus Brasilien (Nus. Halens. Lacordaire. Clark) in der letzteren Sammlung ist Minas Gerass als Heimath genamnt.

Siebente Rotte. Körper ron untermittlerer Grösse, breit und llach gewölbt, hinterwärts meist etwas erweitert; das Halsschild nach vorn verschmälert und hinten jederseits eingedrückt. Die larbe braungelb unil weissen Tropfen, oder schwarz mit mehr orler weniger, aber selır veränderlich gelleckter gelber oder weisslicher Oberseite. Arten aus Brasilien, eine einzelne und grade der veründerlichsten eine in Columbien einheimisch.

25. M. guttula Fab. Braungelb, Kopf, Pygidium, Hinterleilssand und Schenkelspitzen, sowie sieben Flecke des vereinzelt punktirten Halsschilds und sechs der Flügeldecken $(2,2,2)$ weiss; die P'unktstreifen vorn deutlich, hinten erloschen, mit flachen, glänzenden Zwischenräumen. L. 2-3"'; Br. 1-11/3"'.

Cryptocephalus guttula Fab. Syst. Eleuth. II. 52. n. 65.

Dem folgenden, viel weniger seltenen Käfer nah verwandt, aljer at der abweichenden Zeichnung des Halsschilds von ihm sogleich zu unterscheiden. Der Kopf flach mit etwas zurückgezogenem Nacken und seicht niedergedrücktem Kopfschilde, die Stirnlinie äusserst fein, und der Unterkopf nur mit einigen wenigen zerstreuten Punkten liesetzl, übrigens spiegelglatt. Die Farbe weiss, ein schmaler Nackenrand, ein Fleck jederseits um den Fühlerhöcker, und der verwaschene, unterseits etwas verbreiterte Grund der Stimlinie nebst dem oberen Rande der Oberlippe braungelb. Die grossen, durch eine liefe Ausbuchtung selır ungleich getheilten, auch bei dem $\delta$ weit getrennten Augen schwarz. Die Fühler des einzigen vorliegenden $\delta$ nur noch unvollstäudig erhalten, an- 
scheinend sehr dünn und schlank; das Wurzelglied keulig aufgetrieben, $21 / 2 \mathrm{mal}$ länger als breit und etwas nach Aussen gekrümmt, das zweite eiförmig, kaum halb so lang und breit wie das vorhergelıende, die vier folgenden dünn und stielrund, am oberen Ende kaum verdickt, und vom dritten, welches dem ersten gleichkommt, ab bis zu denı um die Hälfte längeren sechsten sich allmählich verlängernd : die Farbe hell bräunlich durchscheinend mit geschwärzter Spitze des seclısten. Die Fühler des $q$ von nicht völlig lıalber Körperlänge, gleichfalls überaus dünn, oben kaum erweitert, die unteren Glieder auf der Oberseite etwas dunkler gebräunt, die oberen vom sechsten ab bis zum zehnten noch weiter verkürzt, vou der Mitte des sechsten ab schwarz. Das Halsschild kurz und breit, mit fast grader, vorn laum niedergekrümmter Firste, über den scharf spitzwinklig vorgezogenen Vorderecken zusammengedrückt und dadurch verschmälert; die Seiten fein gerandet, hinter den Vorderecken leicht ausgeschweift, mit abgerundeten Hinterecken in den jederseits buchtig ausgeschnittenen Hinterrand übergehend, der Mittelzipfel schwach und nur leicht aufgebogen. Die Oberfläche spiegelglänzend, nur auf dem braungelben Grunde mit einigen zerstreuten gröberen Punkten besetzt, die fein aufgetragenen, lackweissen Zeichnungen nur vou einem oder dem anderen Punkte durchbrochen. Die letzteren bilden sieben, mitunter stellenweise zusammenfliessende Flecke; je ein grosser Hakenfleck im Vorderwinkel, dessen hinterer Arm die ganze Seite bis hart an den Ilinterwinkel einnimmt, während der vordere sich längs dem Vorderrande bis zum oberen inneren Augenende ausdelnt, so dass hier zwischen beiden Flecken nur etwa das mittlere Drittel des Vorderrandes frei bleibt. In diesem liegt ein länglich eiförmiger, deı Vorderrand selbst nicht erreichender Fleck, dann seitlich von diesem in dem Haken des Randflecks je ein kleiner, unregelmãssig rundlicker Fleck, welcher bei dem vorliegenden $\delta$ auf der linken Seite mit dem Hakenfleck zusammenhängt, während er bei einem \& ganz, bei einem anderen auf der rechten Seite geschwunden ist; endlich noch vor dem Hinterraude zwei rhombische Schrägflecke neben einander, zwischen welchen und dem hinteren Arme des Hakenflecks jederseits der dunkle Zwischengrund etwas eingedrückt erscheint. Das Schildchen gross, fast gleichseitig dreieckig, hinterwärts ansteigend, mit deutlichem Ilinterzipfel abgestutzt, glänzend braungelb. Die Deckschilde breit und flach walzenförmig, 
etwa um die Ilälfte länger als breit, und hinterwärts noch ein wenig erweitert, hinter der nach dem Schildchen zu scharf erhöhten Vorderkante leicht quer niedergedrüclit und dann wieder eben su leicht aufgeschwollen, die Schulterbeulen flach, imnerseits durch einen sehr undeutlichen Eindruck abgesetzt, die Seitenlappen je durch eineı darüber liegenden Quereindruck alıwäts geschoben, und dieser Quereindruck mit seinem abgeschwächten oberen Ende bis zur Naht hinter dem Schildchen walımehmbar; auch die Naht selbst der Länge nach seicht niedergedrückt. Die Punktstreifen bis zur Mitte hin deutlich, dann schwächer, die Hinterenden der mittleren auf der Wölbung erloschen, und nur die der Naht und dem Seitenrande zunächst liegenden bis zur Spitze zu verfolgen. Die Zwischenräume flach, glänzend und äusserst fein gerunzelt, die weisse Zeichnung stärker glänzend, lackartig aufgetragen und die Punktstreifen an den betreffeuden Stellen bedeckend, übrigens bei dem $\delta$, bei welchen die Grundfarbe dunkler ist als bei denı $q$, gegen letztere stärker abstechend. Jene Zeichnung bildet sechs getrennte, im Wesentlichen wie bei M. 15guttatus Fab. vertheilte Flecke in drei Paar'en, vorn der innere im Schildchenwinkel, der äussere auf und innerseits der Schulterbeule, von dem Mittelpaare der innere an der Naht, aber dieselbe nicht berührend, nach aussen zu von dem zweiten Punktstreifen durchschnitten, der äussere am Seitenrande, deutlich aus zwei Flecken zusammengeflossen, deren äusserer am Rande mehr nach vorn gerücki ist, sodass die vordere Ausrandung zwischen beiden den Quercindruck über den Seitenlappen umzieht: das tritte Paar unter der Wólbung, der innere gı’össere im Nahtwinkel, der äussere kleinere als Längsflẹckchen am Aussenrande, und dem grössern manchmal so nahe gerückt, dass beide bei einzelnen Stückeı auch wohl ganz zusammenfliessen kömnten. Das Pygidium kaum punktirt, glänzend lackweiss, ohen jederseits mit einer durch die hineindringende bräunliche Färbung des letzten Rückenringes gebildeten Ausbuchtung. Die Unterseite fein runzlig punktirt, kahl, mit schwachem Glanze; der Hinterleib schmutzig verwaschen gebräunt, ein breiter schlecht begränzter Seiten- und Ilinterrand mit den Vorderzipfeln des ersten Bauchringes weisslich. Die Parapleuren bei zweien der vorliegenden Stücke geschwärzt, bei den übrigen, wie die Vorderbrust, schmutzig hellgelb, die letztere hinter der Mitte init eiuer tiefen, hinten durch einen abgerundet dreieckigen Zipfel geschlossenen Längsfurche. Die Beine 
derb und kriftig, die Vorderschenkel stark aufgetrieben und die Vorderschienen entsprechend gekrümmt; die Farbe honiggelb mit weisslichen Schenkelspitzeı und schwarzen Krallenhäkchen. Das letzte Segment des ơ mit einem seichten, glänzenden, halbmondfồmigen Eindrucke, das $q$ mit einer nicht tiefen, rundlichen Grube.

Aus Brasilien (Mus. Halens. Lacordaire. Deyrolle).

Der von Fabricius aus der Schestedt'schen Sammlung beschriebene Käfer fehlt in F. eigener Sammlung: ich zweille indess an der Richtigkeil meiner Bestimmung nicht. F. selbst vergleicht seinen Käfer a. a. 0. mil seinem $C r$. 15 gutlatus, und bezeichnet die Färbung bei beiden mil ,rufus", gibl auch eben so auf dem Halsschilde (dessen Beschreibong durch Auslassung einiger Worte entstellt ist) das Vorhandenseiu von sieben weissen Flecken an. Die Flecke auf den Flïgeldecken bat er freilich nicht gezählt. Den Zusatz in der Beschreibung: "Variul rarius colore viridi-aeneo, loco rufi" weiss ich mir nichț zu erklaren, und es, kann demselben nur eine Verwechslung mit einer andern, mir eben so wenig bekannten Arl zum Grunde liegen, falls mas nicht annelımen will, dass F. dabei ein $\delta$ vor Angen gehabt, und dessen braunliche, bei einzelnen Stücken allerdings einen leiclit erzfarbigen Anflug zeigende Färbung ungenauer Weise als einen color viridi-aeneus bezeichnet habe.

26. M. 15 guttatus Fab. Braungelb, die Stirn, drei Flecke des seitlich grob und zerstreut punktirten Halsschilds und sechs der Flügeldecken (2, 2, 2), Pygidium und Hinterleilssrand weiss; die Punkistreifen deutlich, hinten erloschen, mit flachen, glänzen-

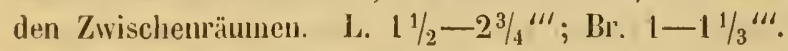

Cryptocephalus 15quttatus Fab. Ent. Syst. II, 66. n. 69. Syst. Eleuth.II. 52. ก. 64. Oliv. Ent. VI. 802. n. 30. -tab. 3. fig. 42.

Ein wenig kleiher als der vorhergehende, übrigens demselben überaus ähnlich, unı hauptsïchlich iı der Zeichnung des Halsschilds abweichend, ausserdem die beiden Geschlechter in der Grösse, und meist auch in der Grundfarbe noch mehr von einander verschieden. Der Kopf mit leichter Wölbung verflacht, die fast glatte Stirn mit deutlicher Stirnlinie, das etwas eingezogene Kopfschild mit vereinzelten groben Punkten besetzt. Die Augen tief ausgebuchtet, auch bei dem of weit getrennt, schwarz. Die Farke weiss, mit leicht gelblichem Anfluge, der untere Theil des Kopfes und der Nacken verwaschen bräunlich gelb. Die Fühler dünn, bei den $\delta$ fast von Körperlünge, dem $q$ hall, su lang; das zweite Glied lurz biruförmig, das dritte fast dreimal lānger, die 
beiden folgenden noch etwas verlängert, und die oberen je dem fünften gleich, llabei wenig zusammengedrückt und erweitert, das Endglied mit lang kegelförmigem Fortsatze. Die Farbe licht gell mit rauchgrauer Spitze, bei dem $\delta$ oben etwas tiefer geschwärzt. Das Halsschild fast doppelt breiter als lang, nach vorn allmählich verschmälert, vor der Mitle schwach aufgewölbt und liinter ihr sanft quer eingedrüclit. Das Ende dieses Eindruclis jederseits sclıräg nach vor'n gekrümut, aber nicht, wie bei anderen Arten, gegen die Seiten himab in die Fläche des Halsschilds einschneidend. Die Vorderecken scharf, die hinteren stumpf abgerundet; der Hinterrand jederseits leicht gebuchtet, mit kurzem, etwas aufgebogenem Mittelzipfel. Die Punktirung anf dem Mittelfelde sehr vereinzelt und schwach, seitlich und besonders lïngs dem Hinterrande, soweit die Grundfarbe reicht, gröber und auch stellenweise etwas dichter gedrängt. Die Grundfarbe lackglïnzend braungelb, bei dem ot hier; wie auf deu Deckschilden, mitunter ticfer gelıäunt, zuweilen fast schwarz; die weissen Zeichnungen gewöhnlich etwas ins Gelbe fallend. Dieselben bilden zunächst auf der Mitte einen eirunden, den Vorderrand nicht erreichenden Längsfleck, und eine gleiche Fär-bung zeigen damn auch die Seitenränder, sodiss sich dieselbe in den Vorderwinkelı erweiter, und lıakenförmig sich am Vorderrante umbiegend hier bis über die Angen fortzicht. Auch diese Zeichnungen liaben leblıaften Lackglanz. Das Schildchen schräg ansteigend, quer viereckig', hinterwïrts verschnıälert und mit unsclieiubarem Itinterzijfel abgestutzt, glänzend gelb mit dunkler'em Saume; die Färbung heller als die Grundfarbe, aber dunkler als dic Fleckenzeichnung. Die Deckschilde länglich viereckig, fast um die Hälfte länger als breit, hinterwär's kaum erweitert, oben fiach gewölbt ind hinten mit sanfter Kírümmung abfallend, hinter der nach dem Schildchen zu scharf erhöhten Vorderkante lief quer ringedrückl, die Schulterbeulen breit und flach, die Seitenlappen kurz, aber tief herabgezogen. Die Punktstreifen regelıässig, aus derben, etwas vereinzelten Punkten gebildet, nur der abgekürzte und der ersțe längs der Vorderhälite der Naht etwas gestört, der zweite und dritte einander vorn selır genähert, alle hinten fast erloschen, mit tlachen, glänzenden Zwischenräumen. Iabei die Streifeı durch die weissen, wie aulgetragenen Flecken unterhrochen, zuweilen einzelne Theile der letzteren unziehend. Dieser Flecken sind auf jeder Flügeldecke sechs in drei Paaren; zuerst zivei läng- 
lich viereckige an der Wurzel, der innere in Schildchenwinkel bis zum zweiten Streifen, der äussere vom fünften Streifen bis zur Schulterbeule reichend; die Flecke des zweiten Paares auf der Mitte, genau hinter denen des ersten, der innere kleinere diclıt an der Nahı, läıglich eirund, der äussere grössere unregelmässig viereckig, etwas nach vorn gerïckt, nach vorn und aussen zuweilen in eine lauge schmale Spitze ausgezogen, welche auf dem neunten Zwischenraume über das Hinterende des Seitenlappens hinaus, ja manchmal um die Schulterbeule herum bis zur Schulter reicht, noch seltener hier aber als ein abgerissenes überzähliges selbstständiges Fleckchen zu finden ist. Endlich wird an der Spitze der ganze Nahtwinkel durch einen grossen, rundlichen Fleck eingenommen, und auf dessen Aussenseite zwisclıen den beiden äussersten Streifen liegt der sechste schmale, kleine, mehr oder weniger länglich ausgezogene Fleck, welcher bei 'den Stücken mit sehr vergrössertem äusseren Mittelflecke am linteren Ende mit seinem grösseren Nebenflecke zusammenzuhängen pflegt. Die Zwischenräume flach und spiegelglänzend. Das Pygidium fein punktirt, weisslich mit schwach ins Roströthliche fallendem Rande. Die Unterseite braungelb, mehr oder weniger ins Roströthliche fallend, die Brust bei den dunkler gefärıten ठ Stïcken ebenfalls tiefer gebräunt, der Hinterleib breit weisslich gerandet. Dis Beine röthlich gelb mit helleren Schenkelspitzen und schwärzlichen Kralleu. Das Prosternum hinten ziemlich tief rinnenförmig. Das letzte Segment des $\delta$ breit und flach niedergedrückt, das $q$ mit einer mässigen, rundlichen Grube.

In Brasilien und daselbst anscheinend luäufig, daher fast in allen von mir verglichenen Sammlungen vorhanden. (Mus. Petrop. Hamburg. Holm. Berol. Vindob. Saunders. Drewsen. Schaum. Dohrn. Haag. Baly. Felix. Schaufuss. Clark.)

27. II. fumosus m. Schmutzig braun, der Kiopf, eine Seitenbinde der Flügeldecken, die Hinterbrust mit den Schenkel- und Schienenwurzeln verwaschen greisgelb; das Halsschild deutlich zerstreut punktirt, die Punktstreifen derb, vorn verwirrt, mit flachen glänzenden Zwischenräumen. L. 21/4"'; Br. $11 / 6 "$.

Dieser mir nur in einem einzigen Stücke vorliegende Käfer macht nach seiner ganzen Erscheinung deı Eindruck eines unausgrefärbten Thieres, zeigt aher überall so bestimmte Farben, und eine "solche Härte seiner einzelnen liörpertheile, dass ich nicht 
daran zweifle, ihn in seiner normalen Gestalt vor mir zu haben, und ilın deshalb auch als eine wohl unterschiedene Art betrachten muss. Der Kopf flach mit tief eingeschnittener Stirnlinie, der untere Theil der Stirn zwischen den Augenbuchten leicht quer niedergedrïckt, auch das Kopfschild unten etwas eingezogen. Die Oherfläche deutlich punktirt, mit lackglänzendem Zwischengrunde, die Farbe ein schmutziges, je weiter nach oben desto mehr in ein gleichfalls schmutziges Braun übergehendes, stellenweise noch dunkler gewässertes Greisgelb; auch die Fühlerlıöcker und die Kinnbacken gebräunt, die vorspringende Oberlippe hellknochengelb, die grossen, (bei dem $\&$ ) ziemlich weit getrennten, nicht breit aber tief ausgebuchteten Augen greis. Die Fühler sehr dünn und von mehr als halber Körperlänge, das zweite Glied kurz eiförmig, die drei folgenden sehr schlank verkelırtkegelförmig, und von ihnen der dritte $2 \frac{1}{4} \mathrm{mal}$, das vierte $2 \frac{1}{2} \mathrm{mal}$, und das fünfte (längste) fast dreimal länger als das zweite; die oberen schwach verbreitert und zusammengedrückt, allmählich bis zum zehnten soweil abnehmend, dass das sechste etwa dem vierten gleicht, das zehnte aber kaum die doppelte Länge des zweiten erreicht: das Endglied mit seinem dreieckigen Fortsatze wenig länger als das vorhergehende. Die Farbe der fünf unteren durchscheinend greisgelb mit einem leichten dunkleren Wische auf der Oberseite, die oberen schwarz, mit heller durchscheinender Wurzel des sechsten bis achten Gliedes. Das Halsschild etwa doppelt breiter als lang, über den scharf spitzwinkligen Vorderecken breit zusammengedrückt und dadurch verschmälert, die Seiten fein gerandet, in der Mitte in starken Bogen erweitert und vor ihr eben so stark ausgeschweift, die stumpfwinkligen Hinterecken als scharfe Schwielen etwas aufwärts gebogen, der Hinterrand jederseits breit ausgebuchtet, mit kurzem wenig vortretenden Mittelzipfel, und vor letzterem auf jerler Seite ein ziemlich breiter, aher nicht tiefer, bis nahe an die Mitte des Seitenrandes zu verfolgender Schrägeindruck. Das Mittelfeld abgeflacht, mit fast grader, vor und hinterwärts nur schwach abwärts geneigter Mittelfirste. Die Punktirung deutlich, aber unregelmässig vertheilt, oben mehr zerstreut, wach den Seiten hin und besonders in den hinteren Eindrücken etwas stärker, auch ein wenig dichter zusammengedrängt. Die Farbe ein schmutziges, an den Seiten verwaschenes und in den breiten Vorderwinkeln ins schmutzig Grelbgreise verblichenes Braun; ehen so gelbgreis sind die schwieligen 
Hinterecken und der mittlere Theil des aufgeworfenen Hinterrandes, sowie eine trübe abgekürzte Längslinie auf dem Mittelfelde; dabei isı der ganze Zwischengrund lackgläızend. Das Schildchen schräg ansteigend, nur halb so. lang als rorn breit, hinterwärts stirk versclımälert, mit abgerundeten Ecken und deutlichem Hinterzipfel grade abgestutzt, sehr dicht. und fein punlitirt, selhwarz. Die Deckschilde u๓n \% länger als lreit, hinterwärts etwas erweitert und dann kurz zugerundet; der abgeflachte, nur hinter dem Schildchen leicht quer viedergedrückte Rücken linten mit mässiger Krümmuıg abfallenul, hint:1 der scharf erhöhten, seitlich an die breiten und zienlich Ilachen Scluutterbenlen angesclılossenen Vorderkante schmal aber tief quer eingedrïckt, die Seitenlappen schwach, ınd über ilmen die Deckschilde breit aber nu seicht zusanmengedrückt. Die Punktiruug derb, die Streifenbildung obru bis über die: Mitte der Flügeldecken hinans durch üherzählige P'unlite und Streifenausätze derartig getribt, dass nur stellenweise Spuren der ursprünglichen J'unktstreifen sichtbar werden, und eigentlich nur der neunte vollstänlig entwickelt ist. Erst auf dem letzlen Drittel entwirren sich bei dem Zurückbleiben der accessorischen Punkte etwas regelmässiger', aber mehr oder weniger wellig gekrümmte und allmällich alggeschwächte Streifen, die aber gleich unter der Wölbung ganz verschwinden; der Zwischengrund und dic hinten sichı bildenden flachen Zwischenräıme lackgläızenı. Die Färbung lisst sich am hesten als schmutzig gelbgreis bezeichnen, eine breite gemeinsame, jeder'seits der Naht das grüssere obere Drittel der Flügeldeclien eimnelmmende, aber die Splitze nicht erreichende verwaschen begränzte längsbinde, und eiı noch mehr verwaschener, vom Hinterrante des Seitenlappens bis zur IVülbung reichender Randwisch schmutzig braun. Das Pygidium gleichfalls braun, dic obere Ecke jederseits durch einen dreieckigen gelhlichen Fleck eingenommen, und im Ansclılusse an dirsen auch dor hintere Theil des letzten Bauchringes breit gelblich. Der Ifinterleib selbst schwarzhıan, die Hitte der hinteren linge und die seitlichen Vorderzipfel des ersten Ringes verwaschen heller gebrüunt, die Hinterbrust schmotzig braungelb mit nach vorn allmählich sich verdunkelnden Parapleuren. Die Beine mil den IIüften schmutzig gellogreis, die Aussenkante der Schenkel mit auf' der Hreiten VorderIläche hesonder's nach den Knien hin übergreifender Färbung bräunlich angelaufen, mud dasselbe ist bei den unteren Schicnenenden 
und den Füssen der Fall. Die Vorderbrust hinten mit scharl erhöhten Kanten längsrinnig, dann breit zugermulet. Das letzte Segment des $q$ mit der gevöhnlichen, halhkngeligen Grube; ılas $\delta$ unbekannt.

Aus Brasilien, und zwar bei Rio de Jan. von Ferd. Sahlherg gefunden (Mus. IIolm.).

28. Mi. polymorphus m. Schwirz oder rosthraun mit rostrothem Kople, ein dreilappiger Vittelfleck und oft auch noch die Seiten des zerstreut punktirten Halsschilds mit dem Schildchen, dem Pygidium und den Flügeldecken bleich grïnlich gelb, letztere mit vier schwarzen Punkten (2, 2, das lintere Paar schräg); die Punktstreifen mässig, etwas wellig, vorn gestört, hinten last erloschen, mit flachen glänzenden Zwischenräumen. L. 21/2-23/4"'; Br. $1-1 \frac{1}{4} "$.

Ein überaus veränderlicher Käfer, dessen verschiedene Formen auch durch die oben von mir versuchte, schon mehr als zu lang gerathene Diagnose nicht vollständig zusammengefasst werden könneı, deren Zusammengehören aber durch eine Reilıe mir vorliegender, lediglich Farbenmodificationen zeigender Uebergänge unzwveifelhaft dargethan wird. Der kopf flach mit deutlicher Stirnlinie und etwas eingezogenem Kopfschilde, die Punktirung grob und zer'streut mit lackglänzendem Zwvischlengrunde. Die Farbe hell rost- oder ziegelroth, oft stark in's Gelbliche fallend, ander'erseits wird bei dunkleren Stücken auch der Nacken und ein lreiter Rand des Kopfschildes bis zu den Fühlerwurzelı nebsı einem schmalen Angensanme schwarz. Die Kinubacken und Tasterspitzen schwarz, die tief ausgebuchteten, (hei dem o) weit getrennten Atigen greis. Bei recht lichten Stücken zeigen sich nur diese letztgenannteı Theile rostroth, und die ursprüngliche rostrothe Grundfarbe schwächt sich zum hleich Grünlichgelben ab. Die Fühler vou hallıer Körperlänge, das Wurzelglied stark anfgetrieben, etwa doppelt lïnger als breit, das zweite eiförmig, mit seiner Länge kaum die Breite des ersten erreichend, die näclıstfolgenden düın verkelıttkegelförmig, das dritte melı wie doppelt länger als das zweite, das vierte dem zweiten und dritten zusammen gleich und das fünfte doppelt länger als das dritte; das sechste so lang wie das fünfte, und die oberen sich allmählich wieder verkürzend, so dass das zehnte dem dritten gleich kommt, und das Endglied mit seinem kurz dreieckigen Fortsatze das vorhergehende nur wenig übertrifft. 


\section{4}

Dabei das sechste nach oben hin schwach dreieckig erweitert, die folgenden stark verbreitert und zusammengedrückt; die Farbe der unteren pechbraun mit noch stärker verdunkelter Oberseite, die oberen vom sechsten ab schwarz. Das Ilalsschild etwa um die Hälfte breiter als lang, oben flach und nur vor der Mitte des Hinterrandes leicht quer niedergedrüclit, über den scharfen pfriemlich vorgezogenen Vorderecken zusammengedrückt und dadurch von der Mitte ab verschmälert; die Seiten fein gerandet, in der Mitte schwach bogig erweitert und vor ihr leicht ausgeschweift, die Hinterecken stumpf gerundet, nur mit einer leichten Schwiele besetzt, der Hinterrand doppelt ausgebuchtet, und vor ihm jederseits ein breiter, sich nach vorn allmählich verlierender, längs dem Hinterrande einen schmalen Querwulst emporschiebender Schrägeindruck. Die Punktirung deutlich aber zerstreut, oben längs der Mittelfirste fast ganz fehlend, seitlich etwas stärker zusammengedrängt, mit lackglänzendem Zwischengrunde. Die Färbung bei den normalen Stücken schwarz, mit einem dreilappigen, vorn zugespitzten und manchmal noch in der Mitte mit einem feinen Längspünktchen gezeichneten roströthlichen oder grünlich gelben, auf der Mitte des Hinterrands ruhenden Hinterflecke. Bei dunkleren Stïcken bedeckt die schwarze Färbung die Seitenlappen dieses Fleckes, welcher dadurch zu einer schmal dreieckigen nach vorn abgekürzten Längslinie zusammenschwindet, und es könnte daher auch wohl Stücke geben, bei denen auch diese Linie nicht mehr vorhanden ist. Bei anderen Stı̈cken dagegen bleiben die Seiten und je ein Schrăgfleck am Vorderrande, beide getreunt oder zusammenhängend, rostroth oder grüngelb, und es entsteht dachurch eine Zeichnung, wie sie bei dem unten beschriebenen M. flavopustulatus Stål als Regel gefunden wird. Von hier aus bildet sich die Zeichnung in zwei verschiedene Richtungen, durch Verbleichen oder durch Schwinden weiter aus; in ersterem Falle verbleicht das Schwarz zu einem dunkleren oder helleren, zuletzt in vereinzelte Wolkenflecke zerfallenden Rostroth oder Rostgelb bei stets bleich grünliclıem Zwischengrunde, auf welchem die Umrisse der ursprünglichen Zeichnung nur noch mit Mühe zu erkennen sind; im anderen Falle behalten der schwarze Grund und die rostrothe Zeichnung ihre ursprüngliche Intensität, der erstere schwindet aber so zusammen, dass von ihın nur zwei schwarze auf der Mitte neben einander stehende Punkte übrig bleiben, während die ganze ülsrige Oberfläche rost- 
roth gefärbt ist. Das Schildchen schräg ansteigend, um die Hälfte breiter als lang, stark verschmälert und mit dentlichem Hinterzi|fel abgestutzt, glänzend schwarz, r'ostrotlı oder bei den Stücken mit überwiegend lichtem IIalsschilde auch wohl grünlich gelb mit leicht vergilbten Säumen. Die Deckschilde länglich viereckig, um $1 / 4$ länger als hreit. mit flach gewölbtem, hinterwärts sehr sanft abfallendem Rücken; die Naht hinter dem Schildchen leicht quer eingedrückt, und dieser seitlich verhreiterte Eindruck sich bis zu den kurzen breiten Seitenlappen hinabziehend. Die scharfe Vorderkante ıur wenig emporgehoben, und deshalb auch die Querfurche linter ihr nur schwach eingedrückt, auch die breiten flachen Schulterbeulen nur wenig hervortretend. Die Punktirung deutlich aber vereinzelt, vom letzten Drittel ab schwächer und auf der Wölbung ganz verschwunden; die Streifen etwas wellig, die Vorderenden der oheren stellenweise verdoppelt, auch vorn der Raum vom zweiten Streifen bis zur Naht mit überzähligen, gleichfalls vereinzelten Punkten hestreut; die flachen Zwischenräume lackglänzend. Die Farbe ein bleiches in's Gelbliche fallendes Grün, Naht, Spitze und Aussenrand bis zum Hinterende des Seitenlappens schwarz oder rostbraun gesäumt, auch der untere Rand des letztern gewöhnlich ebenso eingefasst, und ausserdem auf jeder Flügeldecke vier schwarze linienförmige Flecke in zwei Paaren, das vordere aus etwas grösseren Flecken gebillete nahe hinter der Wurzel, der âussere auf der Schulterbeule stehend; das hintere Paar vor der Wölbung, seine beiden Flecke unscheinbar, der äussere mehr nach hinten gerückt; alle Flecke, hesonders aber die hinteren, mehr orler weniger brandig gesäumt. Von dieser normalen Zeichnung, von der ich sowohl Stücke mit überwiegend schwarzem als rostrotỉ gewölktem Halsschilde vor mir habe, gehen auch hier wieder die Abänderungen in doppelter Richtung auseinander, und bilden dadurch die Formen

$\beta$. mit einzelnen fehlenden Flecken, namentlich Hinterflecken; am auffallendsten bei einem Stücke, bci dem die Aussenflecke zu schmalen linienförmigen Wischen zusammengeschwunden sind, und welches zugleich an Halsschild, Unterseite und Beinen nur eine bleich röthliche Färhung zeigt; und

$\gamma$. die Flecke jedes Paars zu, einem schmaleren oder breiteren Querfleckie zusammengeflossen; der vordere an die Wurzel gelehnt und innerseits das Schildchen erreichend, der hintere nach Aussen prweitert, ımd mit den Aussenrande sich zipfelförmig nach hinten XVI. 


\section{6}

streckend. Bei einem Stücke dieser Abänderung ist das Halsschild schwarz mit schmal dreieckiger hellerer Mittellinie; den Uebergang zur Stammform macht ein Stück mit zusammenfliessenden Hinterflecken, während vun den Vorderflecken sich der innere fast bis zur Scliulterbeule ausdehnt, hier aber noch durch einen feinen linienförmigen Zwischenraum von dem Schulterflecke getrennt ist. Das Halsschild ist bé diesem Stïcke rostroth mit zwei schwarzen Punkten.

Das Pygidium fein runzlig punktirt und dünn behaart, grünlich gelb, oben mit einem schwärzlichen Querschatten; auch die Unterseite fein punlitirt und dichter greishaarig, Vorder- und Mittelbrust, wie der ungeschlagene Theil des Halsschilds ziegelroth, der Ifinterleib schwarz, bald ganz, balı nur auf dem letzten Ringe breit weisslich gesäumt. Die Beine weiss mit röthlichen Hüften und Schenkelwurzeln, seltener auch die Unterseite der Schenkel und die obere Hälfte der Schienen gelblich braun. Bei der var. $\beta$. ändert sich entsprechend auch die Farbe ler Unterseite, so dass sich Hinterleib und Beine rostroth färben. Die Vorderbrust flach, grob runzlig punktirt und lang belıart, vorn seicht niedergedrückt, hinten tiefer längsrinnig, mit halbkreisförmigem Hinterzipfel, in der Färbung gewöhnlichı der des Halsschilds gleich. Das letzte Segment des $q$ mit einer ziemlich kleinen rundlichen Grube; das $\delta$ unbekannt.

Von Caraccas (von Herrn Wagner mitgebracht und mir mitgetheilt; eben daher auch im Mus. Schaum. Felix. Berol. vorhanden; Mụs. Vindob., von Moritz mitgebracht).

29. M. a rgula m. Schwarz, zwei Stirnpunkte, drei Längsbinden des spiegelglatten, zerstreut punlitirten Halsschilds, das Schildchen, zwei Flecke und eine geschweifte Schrïghinde der Flügeldecken weiss; die Punktstreifen regelmässig, hinten erloschen mit flachen, glänzenden Zwischenräumen. L. $1 \frac{1}{2}-2 \frac{1}{4}{ }^{\prime \prime \prime} ; \mathrm{Br}$. $1-1 \frac{1}{6 \prime \prime}$.

Der Kopf flach mit etwas zurücktretendem Nacken unı mondförmig eingedrücktem liopfschilde, die Stirnlinie scharf eingeschnitten, die Punktirung deutlich, aher zerstreut, der Zwischengrund matt, schwarz, zwischen den oberen (auch hei dem ठ̋) weitgelrennten Augenrändern ein paar weissliche Querflecke, ınd auch die Oberlippe schmutzig weissgelb gerandet. Die Fülıler des vorliegenden $\delta$ sehr beschädigt; bei tem $q$ vou etwas mehr als lalber 
Körperlänge, dünn, das zweite Glied kurz und knotig, die beiden folgenden schmal verkehrtkegelförmig, das dritte fast dreimal, das vierte viermal länger als das zweite, das fünfte noch etwas länger und diesem die oberen gleich, wenig verbreitert, mit lang- aber stumpfkegelförmigem Fortsatze des Endglieds. Die Farbe schwarz, die vier anteren gelblich mit geschwärzter Oberseite. Das Halsschild kurz und breit, nach vorn stark verschmälert, mit wenig aufgebogener Mittelfirste; die Seiten fein gerandet, in der Mitte wenig erweitert und vor derselben nach den spitzen Vorderecken hin kaum ausgeschweift; die Hinterecken stumpf, mit einer kleinen Schwiele besetzt, der Hinterrand jederseits des kurz aufgebogenen Mittelziplels leicht ausgebuchtet. Vor dem Hinterrande auf jeller Seite noch ein seichter, sich seitlich abwärts ziehender Schrägeindruck. Die Punktirung zienlich grob aber sehr zerstreut, nur an den Seiten etwas dichter zusammengedrängt, die Mitle der Länge nach fast ganz frei, mit spiegelglattem Zwischengrunde. Die Farbe schwarz, ein breiter sich vorn hakig erweiternder Seitenrand und eine gleichfalls breite sich nach vorn etwas verschmälernde Mittelbinde weiss; im hinteren Theile der letzteren ein verwaschenes dunkles Längsfleckchen. Das Schildchen quer viereckig und binten etwas verschmälert, mit deutlichem, flach niederliegendem Hinterzipfel abgestutzt, weiss, mit schwärzlichem Saume. Die Deckschilde breit und flach gewölbt, vorn breiter als das Halsschild und hinterwärts noch ein wenig verbreitert, hinter der scharfen Vorderkante bis zu den flachen Schulterbeulen quer eingedrückt, der Rücken um das Schildchen leicht aufgetrieben und hinter demselben quer niedergedrückt, die Seitenlappen von mässiger Ausbildung. Die Punktstreifen regelnässig, vorn deutlich und nur zwischen der Nahıt und dem zweiten Streifen durch überzählige Punkte etwas getrübt, von der Mitte an merklich abgeschwächt und auf der Wölbung ganz erloschen. Die Zwischenräume flach und glänzend, die Farbe schwarz; auf jeder Flügeldecke zwei weisse Längsflecke, der vordere gleich hinter dem Schildchen und von der Naht nur durch einen schmalen schwarzen Saum getrennt, der zweite auf der Mitte, hart hinter dem Quereindrucke, beide etwas länger als breit, und unregelınässig begränzt. Ausserdem liegt auf jeder Flügeldecke noch eine weisse Schrägbinde, deren Vorderende die Schulterbeule aussen und hinten einschliesst, worauf sie, hinter dem Seitenlappen sich vom Aussenrande lösend, schı̈̈g sich nach 
Hinten und Innen biegt und im hinteren Nalitwinkel zu einem rundlichen Flecke erweitert. Das Pygidium dicht punktirt, greishaarig, schwar'z, mit einer' welligen, weissen Querbinde. Die Unterseite schwarz mit weissen Seiten der Bauchringe, auch die Beine schwarz mit schmutzig gelblıraunen Schienen und Füssen. Das Prosternum in der Mitte breit und hinten rinnenförmig nierlergedrückt, grob runzlig punktirt, hinten abgerundet. Ias letzte Segment des $\delta$ in der Mitte seicht quer niedergedrückt, des $q$ mit der gewöhnlichen runden Grube.

Aus Brasilien (Mus. Saunders. Lacordaire).

30. M. c onsularis m. Oben rothgelh, Kiopf, Schildchen, zwei Hakenflecke des zerstreui punktirten Halsschilds, der Saum und eine abgekürzte Längsbinde der Flügeldecken schwarz, unten schwarz mit rothgelben Schienen und Füssen; die Punktstreifen vorn runzlig verfliessend, seitlich und hinten deutlicher mit flachen glänzenden Zwischenräumen. L. 21/2 "'; Br. 11/6"'.

In der Färbung und Farbenvertheilung zeigl diese Art einc entfernte Aehnlichkeit mit dem Scolochrus cultus $t$. Heyd., ist aber nach ihrem ganzen Bau der zunächst folgenden am nächsten verwandt. Der Kopf flach mit friner Stirnlinie, grol, runzlig punktirt, das Kiopfschild oben durch einen flichen Querwulst zwischen den Fühlerwurzelı begränzt, unten wenig eingezogen. Die Farbe schwarz, die Mundtheile bräunlich, die durch eine kurze Ausrandung sehr ungleich getheilten, (bei dem $q$ ) weit getrennten Augen greis. Die Fühler nicht von halher Körperlänge, das Wurzelglied stark eiförmig aufgetrieben, kaum doppelt länger als breit, das żweite fast kugelig, das dritte um die Hälfte länger als das zweite, das vierte so lang wie das zweite und dritte zusammengenommen, das fünfte noch etwas verlüngert und diesem das sechste gleich, die folgendeı sich allnählich wieder verkürzend, so dass das zelnte wieder dem dritten gleichkommt, und diese oberen deutlich zusammengedrückt und erweitert, mit kiırzem, lıreiten Fortsatze des Endglieds. Die Farlse der vier unteren röthlich gelb mit geschwärzter Oberseite, das fünfte auf der Unterseite dunkler getbräunt, die oberen schwarz. Das Ialsschild ziemlich kurz, breit und tlach gewölbt, hinter der Mitte leicht fuer aufgewulstet, über den spitz ausgezogenen Vorderecken stark zusammengedrückit und dadurch verschmälert, seitlich fein gerandet, in der Mitte kanu erweitert; die scharfen Ilinterecken stumpliwinklig und etwas auf- 
gebogen, der Hinterrand jederseits des breit zugerundeten Mittelzipfels deutlich ausgebuchtet, und vor letzterem das Mittelfeld breit und flach quer niedergedrückt. Die Punktirung deutlich, oben melır zerstreut, seitlich diclıter gedrängt, mit fein genarbtem Zwischengrunde; die Farbe hell rothgelb, jederseits mit einem aus zwei rautenförmigen Flecken zusammengesetzten schwarzen Hakenflecke, deren Vorderenden sowohl den Vorderrand als einander berühren, während der jederseits nach Aussen im Zickzack angefügte Hinterfleck den Hinterrand nicht ganz erreicht. Das Schildchen stark ansteigend, etwas breiter als lang, linterwärts verschmälert, grob runzlig punktirt, schwarz. Die Deckschilde länglich viereckig, fast um die Hälfte länger als breit, hinter der schmal aufgeworfenen Vorderkante schmal aber ziemlich tief quer eingedrückt und durch das Aussenende dieses Eindrucks die auch nur schmalen Schulterbeulen imnerseits abgesetzt; die Seitenlappen lang abwärts gezogen, und über ihnen die Deckschilde breit zusammengedrückt. Die Punktstreifen grob, auf der grösseren Vorderhälfte zwischen Schildchen und Schulterbeule durch überzählige Punkte verdunlielt und zugleich quer ausgerissen, wodurch der Zwischengrund sich zu ebenfalls groben Runzeln gestaltet; der achte und ueunte nach seiner ganzen Länge, von den übrigen nur das letzte Drittel kenntlich entwichelt. Die Zwischenräume flach und glänzend, der brejtere neunte noch mit einigen zerstreuten Punliten besetzt. Die Farbe rothgelb, ein feiner den Seitenlappen freilassender Saum jeder Flügeldecke schwarz, und ausserdem noch auf jeder eine schwarze Längsbinde, welche vorn an den entsprechenden Halsschildsfleck sich auschliessend dic Wurzel berührt, und hier etwa zwei Zwischenräume füllend, hinter dem Seitenlappen aber sich nach Aussen hin um das Doppelte erweiternd auf der Wölbung abbricht. Pygidium und Unterseite schwarz, nur die Vorderzipfel des ersten Ringes und ein Randfleck jederseits auf dem letzten Ringe rötllich gelh; an den Beinen die Schenkel schwarz, Hüften, Schieneu und Fussglieder g!eichfalls bell rothgelh. Das Prosternum breit, grob gerunzelt, zwischen den Vorderhüften tief längsfurchig eingedrückt. Das letzte Segment des $q$ mit dem gewöhulichen Grübchenl, das o unbekannt.

Ebenfalls aus Brasilien (Mus. Lacordaire).

31. M. flavopustulatus Stål. Schwarz mit gelbbunten Kopfe, ein dreilappiger Mittelfleck und die Seiten des (zuweilen. 
ganz ungefleckten) zerstreut punktirten Halsschilds mit zwei grossen Querfleckeı der schwarzen oder braunrothen Deckschilde ( 1 , 1) und dem Pygidium weiss-gelb; die Punlitstreifen derb, etwas wellig, vorn und hinter den Schulterbeulen durch überzählige I'unkte getrübt. L. $2 \frac{1}{2}-2{ }^{3} / 4^{\prime \prime \prime} ;$ Br. $1-1 \frac{1}{4}{ }^{\prime \prime \prime}$.

P. Aavopustulatus Slål Till Kännedomen etc. in der Öfversigt etc. a. a. 0. S. 62 . ถ. 4 !

Eben so verïndeŕlich als der oben beschriebene $M$. polymorphus und der unten folgende M. nigro-ornatus Stål, auch mit dem letzteren in den Sammlungen vielfach rermengt, aber doch sicher eine gute, selbstständige Art, welche übrigens in Habitus und Sculptur der vorhergehenden so ähnlich ist, dass ich auf die dort gegebene Beschreiloung Bezug nehmen und mich auf die Angabe der Abweichungen beschränken kann. Die Punktirung des Kopfes ist etwas feiner und nicht zu Runzeln verfliessend, aber dichter gedrängt, eben so die des Halsschilds feiner und gleichmässiger; auf den Deckschilden ist sie weniger tief eingestochen, besonders längs der Naht feiner und dichter, schon von der Mitte ab merklich abgeschwächt und auf dem letzten Drittel oft schon fast geschwunden, nur längs Naht und Seitenrand noch erkennbar, der Zvischengrund vorn nicht zu Runzeln zerrissen, daher auch stärker glänzend. Höchst veränderlich ist, wie schon oben angegeben, die Färbung. Bei den dunkleren Stücken ist am Kopfe der Nacken mit dem Kopfschilde schwarz, und diese Färbung zieht sich unten jederseits am innern Augenrancle bis an die Augenbuchten hinauf, sodass in diesen zuweilen das Innere als ein kleines weisses Fleckchen von dem hellen Theile des Kopfes getrennt erscheint, sehr selten ist der Kopf ganz schwarz; bei Stücken mit hellerem Kopfschilde schwindet das Schwarz am Unterkopfe bis auf den unteren Saum des liopfschilds, verliert oben seine Intensität und geht mit verwaschener Begränzung in Schwarzbraum oder Rothbraun über, breitet sich aber in dieser Gestalt nicht über den ganzen Kopf bei etwas dunkler bleibendem Nacken aus. Das Halsschild ist bei normaler Färbung schwarz, mit einem weisslichgelben dreilappigen Mittelflecke, d. h. die beiden schwarzen Flecke der vorhergehenden Art haben sich soweit ausgedehnt, dass sie, wie bei M. polymorphus, den ganzen äusseren Theil des Halsschilds einnehmen, und dadurch in der Mitte jenen dreilappigen, in seinen Zipfeln aber stumpfer als bei M. consularis zugerundeten Fleck 
übrig lassen. Bei andern Stücken zeigen sich nur die Hakenflecke der genannten Art, verbleichen bei wieder anderen zu einem verwaschenen Roth, und sehwinden zuletzt ganz, wo dann das Halsschild rein und einfarbig weisslich gelb erseheint. Solche Stücke mit normaler Zeichnung der Deckschilde sind von Stål a. a. 0. als Pach. flavopustulatus heschrieben worden. Das Schildehen ist in der Regel schwarz, zuweilen in der Mitte weisslich, so bei einen mir vorliegenden Stück, bei welchem der ganze Kopf schwarz, die übrige Oberfläche aber ungefleckt weissgelb ist. Die Deckschilde sind bei den regelrecht gezeichneten und ausgefärbten Stücken schwarz mit weisser Spitze und einem grossen weissen Querflecke auf der Mitte, welcher aussen nur einen zarten schwarzen Saum übrig lässt, innen aber die breit schwarz verbleibende Naht nicht erreieht. Aendert jedoch ab

$\beta$. die Grundfärbung der Deckschilde (und zwar bei vollständiger Ausfärbung derselben) dunkler oder heller braunroth, selbst rothgelb, wo dann manchmal die hellen Mittelflecke bis zur Naht reichen und dadurch eine ungetrennte weissliche Mittelbinde bilden. Von Stål a. a. 0. wird auch dieser Form gedacht. Weiter entsteht durch Verbleichen der Grundfarbe und deren Ueberfliessen nach der Mitte zu eine Abänderung

$\gamma$. bei welcher die hellen Mittelflecke vôllig geschwunden sind, und bei rother, rothgelber und selbst fahl knochengelber Farbe der Deckschilde nur deren Spitze in nicht scharfer Begränzung weiss bleibt. Die Stücke mit schwarzen oder röthlichen Hakenflecken des Halssehilds gehören vorzugsweise diesen beiden Abänderungen an. Zuletzt verbleicht die Färbung der Deckschilde soweit, dass

$\delta$. jeder Farbenunterschied zwischen ihr und der Spitze verschwindet, und die Deckschilde einfarbig weissgelb erscheinen. Solche Stücke mit gleichzeitig weissem Halsschilde zeigen auf den ersten Blick ein etwas eigenthümliches Ansehen, und können leicht mit der entsprechenden Form des M. nigro-ornatus Stål verwechselt werden, sind aher von derselben leicht an dem abweichenden Bau des hinten viel weniger eingezogenen Halsschilds und dessen schärferen Hintereeken zu unterscheiden. Von Stål ist diese Form als Pachybrachys pallididorsis (a. a. 0. S. 62. n. 7!) beschrieben worden.

Das Pygidium ist in der Regel gelblich weiss, manchmal stark ins Röthliche fallend, zuweilen auch mit geschwärzter Mitte; die 
Schulterblätter schwarz, manchmal mit einem weissen Fleckchen am Innenrande. Auch die Unterseite selbst schwarz, bei den Stücken nit heltem Pygidium der Hinterleib breit weiss gerandet; bei den Stücken mit in der Mitte geschwärztem Pygidium pflegt auch nur ein Querfleck auf jeder Seite des letzten Bauchringes weiss zu sein. Die Beine schwar', die Schenkelwurzeln in sehr verschiedener Ausdehnung, auch die Unterseite oder die Unterenden besonders der Vorderschienen, bei lıellen Stücken auch die Füsse röthlich - oder gelblich weiss. Die Vorderbrust hinten tief längsrinnig. Das letzte Segment des $q$ mit einem rundlichen Grübchen, das đ̛ unbekannt.

Aus Brasilien, und in vielen Sammlungen vorhanden (Mus. Halens. Holm. Vindob. Riehl. Schaum. Deyrolle. v. Bruck. Clark). Im Mus. Holm. und v. Bruck ist Rio de Jan., in Mus. Clark Constancia, bei einem der Stücke in Mus. Deyrolle Bahia als Heimath genannt. Bei einem Stïcke der var. $\beta$. im Mus. Schaum ist Caraccas als Fundort angegeben.

32. M. I ucothyreus m. Oben ziegelroth, der Kopf, das groh zerstreut punktirte, doppelt hakenfleckig schwarz gezeichnete Halsschild und das Schildclıen weiss, unten schwarz mit gebräunten Beinen, der Rand des Hinterleibes und die Schulterblätter weiss; die Punktstreifen undeutliclı, vor'ı gestört, unit flachen glänzenden Zwischenräumen. L. $13 / 4 " \prime$; Br. $1^{\prime \prime \prime}$.

Ob dieser zierliche Käfer auch nur eine Form des vielgestaltigen M. flavopustulatus oder wirklich eine eigene Art bilde, wage ich nach dem einzigen vorliegeuden Stücke nicht zu entscheiden, glaube ihn aber einstweilen als solche festhalten zu mïssen, da ich keine Uebergänge gefunden habe, und auch neben den auffallenden Abweichungen der Färbung das hinten stärker eingezogene Halsschild und die flacheren, mehr gleichbreiten Deckschilde eine nicht zu verkennende Verschiedenlıeit darbieten. Der Kopf flach mit deutlicher Stirnlinie und etwas eingezogenem, oben kaum abgegränztem Kopfschilde, ziemlich fein und dicht punktirt mit mässig glänzendem Zwischengrunde, hellziegelroth, an den äussersten Enden dieser Färbung in ein fahles Gelblichweiss verblassend, der Nacken und die ziemlich stark ausgebuchteten, (hei dem o) weit getrennten Augen schwarz. Die Fühler nicht melır vollständig, anscheinenł dünı, das Wurzelglied eiförmig, etwa doppelt länger als breit, das zweite elliptisch, die drei folgenten gestreckt und nur an der Spitze elwas verdickt, und von ihnen das dritte doppelt-, 
das vierte $2 \frac{1}{2}$ mal länger als das zweite, das fünfte (längste) noch etwas länger, das sechste und siebente wieder je dem vierten gleich, und das achte etwas länger als das dritte; die drei oberen nicht melır vorhanden. Die fünf unteren durchseheinend braungelb, an den drei folgenden die obere Hälfte schmutzig geschwärzt. Das IIalsschild doppelt breiter als lang, mit fast grader Mittelfirste hinten breit niedergedrück, über den reclıtwinkligen, in einer spitzen etwas aufwärts gebogenen Schwiele vorspringenden Vorderecken zusammengedrückt und dadurch versclımälert; die Seiten fein gerandet, breit zugerundet, nach vorn etwas ausgeschweift und hinten wieder etwas eingezogen; die stumpfwinkligen IInterecken gleichfalls scharf schwielig, der Hinterrand doppelt gebuchtet mit wenig vortretendem Mittelzipfel, und vor diesem ein seichter Quereindruck. Die Punktirung grob und ziemlich dicht mit lackglänzendem Zwischengrunde, die Farbe weiss mit einer schwarzen gebroclıenen, aus füuf zusammenstossenden Flecken gebildeten Zeichnung, alle scharf eckig und einander nur mit den Ecken berührend. Von diesen Flecken ruhen drei auf dem Hinterrande, der mittlere kleinere fast quadratisch, die seitlichen dreieckig mit abgerundeter Aussenseite und nur mit der hinteren Spitze den Hinterrand berührend; zwei vordere, schräg viereckige, mit den Vorderrändern an die bogenförmige Nackienfärbung des Kopfes stossend, stossen mit den hinteren Aussenenden an die iuneren Vorderenden der seitlichen Hinterflecke, mit den etwas verlängerten hinteren Innenenden an die vorderen Aussenenden des quadratischen Mittelflecks an, sodass die beiden Aussenflecke jederseits einen der normaleı Zeichnung des M. polymorplius und mancher Formen des M. flavopustulatus analogen Hakenfleck bilden, und die in dem dreilappigen hellen Mittelfleck des M. polymorphus verbliebene dunkle Mittellinie hier sich zu einem fünften Flecke verbreitert hat. Das Mittelfeld des Halsschilds kanı sonach auch als schwarz, mit drei weissen, einen zusammengesetzten Dreiecksfleck bildenden Flecken bezeichnet werden. Das Schildchen schräg ansteigend, etwas breiter als lang und hinterwärts kaum verschmälert, glänzend weiss mit kurzem, rothgelbem Hinterzipfel. Die Deckschilde um 1/4 länger als breit, ziemlich gleichbreit, mit flach gewölbtem, hinten nur nit leichter Krümmung abfallendem Rücken, hinter der scharfen Vorderkaute schmal, aber tief quer eingedrückt, mit breiten, eckig hervortretenden Schulterheulen und nur schwach lierabgezogenen 
Seitenlappen; üher letzteren die Deckschilde breit und ziemlich tief zusammengedrückst, welcher Eindruck sich auch noch über den ganzen Rücken hin bemerkhar macht. Die Punktstreifen vorn von mässiger Stärke, zunächst der Naht durch viele überzählige Punkte getrübt, seitlich etwas gröber und auch regelmässiger, auch hinterwärts auf dem Rücken deutlicher und zugleich etwas abgeschwächt, auf der Wölbung fast ganz erloschen. Die flachen Zwischenräume überaus fein gerunzelt, die Farbe ein helles und reines lackglänzendes Ziegelroth, mit geschwärztem Innern der Punkte. Das Pygidium sehr fein punktirt und oben jederseits eingedrückt, glänzend weiss, von einer unten verbreiterten schwarzen Längsbinde durchzogen. Die Unterseite schwarz, die Schulterblätter weiss mit geschwärzten Aussenenden, die abgerissenen seitlichen Vorderzipfel des ersten Rauchringes nebst einem breiten Rande des Hinterleibes gleichfalls weiss, der letzte Ring nur auf der Mitte im Anschlusse an die Längsbinde des Pygidiums schwarz. Auch die Beine schwarz, das innere Drittel der Schenkel mit den Hüften rôtllich, Innenseite und Unterenden besonder's der Vorderschienen und. Füsse gebräunt. Das Prosternum auf der hinteren Hälfte tief längsrinnig mit breit zugerundetem, gleichfalls geröthetem Hinterrande. Das letzte Segment des $q$ mit einer rundlichen Grube, das $\delta$ unbekannt.

Ebenfalls aus Brasilien (Mus. Deyrolle).

33. II. decumanus m. Oben knochengelb, der Kopf bis auf die Stirn, zwei Sclırägflecke des vereinzelt punktirten Halsschilds und vier der Flügeldecken $(2,2)$ mit dem Schildchen schwarz, unten schwarz, der Hinterleibsrand, die Schienen und Füsse gelb; die Punktstreifen regelmässig und derb, vorn längs der Naht etwas verdunkelt, mit flachen glänzenden Zwischenräumen. L. $21 / 4-23 / 4 "$; Br. $1-1 \frac{1 / 3}{\prime \prime \prime}$.

In den Sammlungen häufig mit dem unteı folgenden und in ähnlicher Weise abändernden M. limbiventris Siål vermengt, aber von letzterem sogleich an dem Bau des nicht vor, sondern hinter der Mitte verbreiterten Halsschilds, sowie an der viel gröberen und regelmässigeren Punktirung der Flügeldecken zu unterscheiden. Der Kopf flach, die Stirn mit einem leichten, in der Mitte noch von einer feineren Linie durchzogenen Längseindrucke, deutlich und ziemlich dicht punktirt, lackglänzend; ein breiter Querfleck auf den Nacken und der ganze Unterkopf bis oberhalb der Fühler- 
wurzeln schwarz; die Stirn selbst verwaschen gelb, und nur die oberen Augenränder nebst der Oberlippe heller gelblich; die Augen tief ausgebuchtet und (bei dem \&) weit getrennt. Die Fühler dümn und fadenförmig, von mehr als halber Kïrperlänge, das zweite Glied eiförmig, das dritte Glied fast doppelt länger als das zweite, das vierte und fünfte je noch etwas verlängert und die oberen sich wieder allmählich rerkürzend; die oberen dabei wenig zusammengedrückı und erweitert, mit kurz kegelförmigem Fortsatze des Endglieds. Die Farbe schmutzig gelb mit rauchgrau überflogener Spitze. Das Halsschild doppelt breiter als lang, über den tief herabgezogenen und scharf spitzwinkligen Vorderecken zusammengedrückt und dadurch verschmälert, die Seiten fein gerandet, hinter der Mitte in Bogen erweitert und vor ihr stark ausgeschweift, die Hinterecken scharf stumpfwinklig und mit einer kurzen aufgehogenen Schwiele besetzt; der Hinterrand jederseits gebuchtet, mit schwachem, kurz aufwärts gekrümmtem Mittelzipfel. Das Mittelfeld breit und flach gewölbt, vor den Hinterrande quer seicht niedergedrückt, und weiter gegen die hintere Hälfte des Seitenrandes zu noch jederseits mit einem sehr flachen Quereindrucke. Die Punktirung kräftig, aber sehr vereinzelt, die Farbe knochengelb, mehr oder weniger ins Lelımgelbe fallend, lackglänzend; jederseits der Mitte mil einem grossen verwaschen begräızten schwarzen Schrägflecke, und zwischen den divergirenden Hinterenden dieser beiden (den Hakenflecken der vorhergehenden Arten entsprechenden) Flecke vor der Mitte des Hinterrandes noch ein unscheinbarer schwärzlicher Schatten; sehr selten alle Flecke zu bräunlichen Schattenwischen abgeschwächt. Das Schildchen schräg ansteigend, quer viereckig und hinterwärts verschmälert, mit kurz dreieckigem flachem Hinterzipfel, fein punktirt, schwarz. Die Deckschilde um 1/4 länger als breit, vorn etwas breiter als das Halsschild und hinterwärts noch etwas verbreitert, flach gewölbt, hinter dem jederseits an die kräftigen Schulterbeulen anschliessenden, scharf erhöhten Vorderrande tief quer gefurcht, die Seitenlappen kurz, und die Naht hinter dem Schildchen schmal aber kräftig quer eingedrückt. Die Punktstreifen derb, die oberen auf der vorderen Hälfte durch überzählige Punkte etwas gestört, hinter der Vitte allmählich feiner und auf der Wölbung, wo auch die äusseren abbrechen, ganz erloschen, daher die Spitze spiegelglatt; die Zwischenräume flach und glänzend. Die Farbe knochengelb, oft ins Lelingelbe fallend, 
mit zwei Paar schwarzen Längsflecken auf jeder Flügeldecke, der vordere Aussenfleck auf der Schulterbeule, der innere etwas rückwärts gestellt, meben dem Schildchen; das zweite Paar hinter der Nitte, der äussere länger als der innere und hinterwårts über letzteren merklich hinausreichend. Bei einem der vorliegenden Stücke sind alle Längsflecke nur schmal und linienförmig, der innere Vorderfleck fast gạnz geschwundeı, und es liönuten daher auch wohl Stücke vorkomnıen, denen einzelne Flecke ganz fehlen: anderseits aber entstehen durch Ueberhandnehmen der schwarzen Färbung mehrere Abänderungen, nämlich

$\boldsymbol{\beta}$. die beiden Hinterflecke in eine mach Aussen verbreiterte, abgekürzte Querhinde zusammengeflossen;

$\gamma$. die beiden äusseren Längsflecke zu einer Längsbinde zusammenfliessend, welche zuweilen mit ilırer Innenseite den innern Hinterfleck berührt, und sich dann auch hakenförmig bis zur Wölbung verlängert;

$\delta$. die beiden Imnenflecke eben so, wie die äuseren, zu einer Längshinde vereinigt, sodass sich auf jeder Flügeldecke zwei parallele schwarze Längshinden befinden.

Das Pygidium schwarz, jederseits mit einem breiten dreieckigen gelbeu Randflecke. Auch die Unterseite schwarz mit einem gelblichen Querflecke auf den Schulterblättern, der Hinterleib seitlich breiter-, hinten schmaler gelb gerandet; die Schenkel schwarz, an den Wurzelı gelblich, Knie, Schienen und Fussglieder schmutzig gelb. Das Prostermum llach, vorn mit zwei feimen eingegrabeuen Längslinien, hinten leicht rimenförmig, der abgerundete Hinterzipfel gleichfalls schmutzig gelb. Das letzte Seyment des $q$ mit einer tiefeu rumdlichen Grube, das ơ umbekannt.

Aus Brasilien (Mus. Petrop. Halens. Schaum. Deyrolle. Lacordaire. Clark). Im Mus. Clark sind Petropolis und Rio de Jan. als Fundorte genannt.

34. M. sugillatus m. Greisgelb mit schwärzlicher Brust, das zerstreut punktirte Halsschild nit füıf, die Flügeldecken mit vier verwaschen bräunlichen Flecken $(2,2)$; die Punktstreifen vorn unregeluässig verdoppelt, mit flacheı glänzenden Zwischenräumen. L. $1 \frac{1 / 2}{\prime \prime \prime}$; Br. $3 / 4 "$.

Von diesen Käfer habe ich nur zwei schlecht erhaltene und augenscheiulich unvollkommen ausgefärbte Stücke vor mir, kamn ihn aber doch nicht wohl mit der vorhergehenden Art verbinden, 
von der er mir in der mehr dem $M$. limbiventris gleichendeı Sculptur der Declischilde doch sehr wesentlich abzisweichen scheint. Ueberdem war er auch schon von Erichson im Mus. Berol. als eine eigene Art abgesondert worden. Der Kopf flach mit deutlicher, unterwärts etwas mehr verbreiterter Stirnlinie und etwas eingezogenem Kopfschilde, deutlich und ziemlich dicht punktirt, greisgelb; Nacken, Stirnlinie, das Innere der Punkte und der untere Rand des Kopfschildes bleich roströthlich. Die Fühler von mehr als halber Körperlänge, gestreckt fadenförmig, gleichfalls greisgelb mit röthlich angeflogener oberer Hälfte. Das Halsschild über zweimal breiter als lang, hinter der Mitte sclıwach quer anfgewölbt, über den scharf rechtwinkligen Vorderecken breit zusammengedrückt und dadurclı verschmälert; die Seiten fein gerandet, in der Nitte breit und flach abgerundet, mit scharf stumpfwinkligen, schwielig aufgebogenen Hinterecken; der Hinterrand doppelt ausgebuchtet mit kurzem, schmalem Mlittelzipfel; vor letzterem jederseits ein leichter Schrägeindrack. Die Punktirung deutlich, aber ziemlich zerstreut, mit glänzendem Zwischengrunde; die Farbe greisgelb mit fünf verwaschenen bräunlichen Flecken; ein grösserer jederseits am Hinterrande zwischen Mittelzipfel und Hinterecken, ein kurzer Längsfleck vor jenem, und vor diesem letzteren zwei divergirende Schrägflecke, jeder mit seiner Spitze nach dem oberen Ende des entsprechenden Seitenflecks gerichtet. Das Schildchen schräg ansteigend, fast quadratisch, hinten mit abgerundeten Ecken und deutlichem Ifinterzipfel grade abgestutzt, glänzend weiss mit zart gebräunten Säumeı. Die Deckschilde breit und flach walzenförmig, un etwa $1 / 4$ länger als breit, hinter der Vorderkante nur leicht quer eingedrückt, die Schulterbeulen vorn etwas zusammengerlrückt, dann aber verbreitert und gleichzeitig verflacht, die Seitenlappen flach, und üher ihnen der gewöhnliche, hier breite und ziemlich liräftige Quereindruck. Die Punktstreifen von mässiger Stärke, längs der Naht und dann wieder linter den Schulterheulen durch dicht eingemengte überzählige Punkte gestört, der vierte und fünfte, zwischen denen eine flache Längsrippe, und dann wieder der achte und neunte vollständig ausgebildet, die übrigen erst auf der hinteren Hälfte der Flügeldecken kenntlich entwickelt, mit breiten und flachen Zwischenräumen; der achte und neunte Zwischenraum schon von der Schulter ab flach gewölbt und ersterer dort gleichfalls cine schmale Rippe bildend. Die Oberfläche gläı- 
zend, hell greisgelb, 'mit vier schwärzlichen, braun gesäumten Flecken oder Wischen in zwei hinter einander stehenden Paaren: die beiden Aussenflecke grösser, an den neunten Streifen gelehnt, der vordere auf der Schulterbeule, der hintere auf der Wölbung; die beiden inneren etwas kleiner und schwächer, der vordere gegen den Schulterfleck etwas nach hinten, der hintere gegen seinen Nebenfleck etwas nach vorn gerückt. Bei einem der beiden vorliegenden Stücké fliessen die beiden hinteren zu einem unförmlichen Schrägflecke zusammen, und die beiden vorderen vergrössern sich so, dass sie auf der rechten Flügeldecke durch eine feine, die erwähnte Längsrippe durchsetzende Querlinie verbunden sind. Pygidium und Hinterleib greisgelh; die Ränder der Hinterleihsringe. und die Mitte des ersten Ringes gebräunt, die Brust schwärzlich oder bräunlich mit weisslichen Schulterblättern und eben so gefärbtem lnnenrande der Parapleuren. Die Beine röthliclı-greisgelb mit gebräunten Hüften, und bei einem Stücke auch die breite Aussenfläche der Hinterschenkel mit einem schmutzig bräunlichen Längswische. Das letzte Segment des $q$ mit dem gewöhnlichen Grübchen, das đo unbekannt.

Aus Brasilien (von Caasapava: Sello im Mus. Berol.).

35. M. umbrinus m. Greisgelb mit schwarzbuntem Kopfe, die Fühlerenden und sechs Flecke des sehr grob punktirten Halsschilds rostroth, ein Schulterfleck und eine hakenförmige Längsbinde der Flügeldecken nelsst der Brust und der Wurzel des Hinterleibs schwarz; die Punktstreifen derb, mit flach gewölbten, fein querrunzligen Zwischenräımen. L. 11/4"'; Br. 2/3"“.

Dem vorhergehenden nicht unähnlich, aber noch kleiner, und von ihm durch die viel gröbere Sculptur, besonders des Halsschilds, und die eigenthümliche Zeichnung der Flügeldecken genugsam verschieden. Der Kopf flach mit kaum eingezogenem liopfschilde, fein, aber ziemlich dicht punktirt, wenig glänzend, ein dreieckiger Stirnfleck und eine breite jederseits abgekürzte Querbinde zwischen den Augenbuchten schwarz, beide brandig begränzt. Die Augen ziemlich breit dreieckig ausgebuchtet, (bei dem + ) weit getrennt, zwischen ilınen die Stirn mit deutlicher Längslinie. Die Fühler von halber Körperlängre, schlank, oben mässig verbreitert und zusammengedrïckt, die fünf unteren Glieder durchscheinend hellgelb, an der Oberseite etwas dunkler gebräunt, die oberen schwarz. Das 
Halsschild vor der Mitte stark quer aufgewölbt, und von da al, hinterwärts mit breiter Fläche schräg abfallend, um den Vorderrand etwas eingeschuürt, über den scharfen, fast rechtwinkligen Vorderecken zusimmengedrückt und dadurch verschmälert, die Seiten fein gerandet, von den scharf stumpfivinkligen Vorderecken ab nach vorn in breiter Krümmung schräg abwärts verlaufend; der Hinterrand leicht doppelt ausgebuchtet mit litrzem Mittelzipfel, und vor diesem jederseits ein schnaler, längs dem Hinterrande ein Querfältchen emporschichender Quereindruck; weiter vorwärts je noch ein schärferer Schrägeindruck, dessen linienförmig eingegrabener Grund sich gegen die Vorderecken hin richtet, aber schon über der Mitte des Seitenrandes abbricht. Die Punktirung grob und dicht, mit mässig glänzendem Zwischengrunde, dic Farbe gellgreis mit sechs unförmlichen und verwaschenen roströthlichen Flecken; fünf in einem plumpen Halbkreise, welcher auf dem Hinterrande ruht, bei dem vorliegenden Stücke theilweise auf der linken Seite zusammenfliessend, der sechste kleinere vor dem Mittelzipfel. Das Schildchen quer viereckig, hinterwärts etwas verschmälert, mit abgerundeten Ecken und deutlichem Hinterzipfel abgestutzt, die vordere Hälfte schwarz mit hinten verwaschener Begränzung, die hintere weisslich mit gebräunten Säumen. Die Deckschilde flach walzenförmig, um $1 / 4$ länger als breit, hiuten mit sehr schwacher Wölhung abfallend, vorn nur leicht quer eingedrückt, die Schulterbeulen schmal, aber vorn eckig heraustretend, die Seitenlappen zugerundet, und über ihnen die Deckschilde breit und seicht zusammengedrückt. Die Punktstreifen deutlich und im Ganzen regelmässig, nur zwischen dem zweiten und der Naht viele überzählige, den ersten Streifen verdunkelnde Punkte, deren auch zwischen dem fünften und sechsten vorhanden sind; die Zwischenräume vorn schmal und linienförmig, leicht erhöht, linterwärts bei abgeschwächten Streifen breiter und flacher, fein querrunzlig mit mässigem Glanze. Die Farbe greisgelb, ein Längsfleck auf der Sclsulterbeule, eine auf der Mitte abgeschwächte und die Wölbung nicht crreichende Längsbinde, und ein mit letzterer schräg zusammenhängender Fleck auf der Wölbung in der verlängerten Richtung der Schulterbeule schwarz mit brandiger Begränzung. Pygidium, Hinterleib, Schulterblätter und Beine greisgelb, die ganze breite Basis des Hinterleibes schwarz, an Rande breit und verwaschen gebräunt, die Brust gleichfalls schwarz, das hinten rinnenfôrmige 
Prosternum greisgelb. Das letzte Segment des $q$ einfach, das $\delta$ unbekannt.

Aus Brasilien, und dort ebenfalls von Sello gefunden (Mus. Berol.).

36. M. distans m. Schmutzig strohgelb, der Nacken und ein Stirnfleck, sechs Längswische des ziemlich dicht punktirten Halsschilds, das Schildchen, einige verloschene Längslinien der Flügeldecken mit der Brust und der Wurzel des Iinterleibes schmutzig geschwärzt; die Deckschilde nur aussen und längs der Naht welligpunktstreifig, der dritte und neunte Zwischenraum stark verbreitert. L. $11 / 3 "$; Br. $2 / 3 "$.

Eine kleine und zierliche, an der Verbreiterung des dritten Zwischenraums sogleich kenntliche Art. Der Kopf flach mit kaum eingedrückter Stirn und tief eingezogenem Kopfschilde, ziemlich derb punktirt, mit glänzendem Zwischengrunde, strohgelb; der obere Nackenrand, ein runder Fleck auf der Mitte der Stirn, und die tief und ziemlich breit ausgerandeten Augen schwarz. Die dünnen Fühler schmutzig gelb, oben rauchgrau angeflogen. Das Halsschild hinten doppelt breiter als lang, über den tief eingezogenen, scharf rechtwinkligen Vorderecken sehr breit zusammengedrückt wnd da(lurch verschmälert, hinter der Mitte quer aufgewölbt und dann noch quer eingedrückt, die Enden dieses Eindrucks vor den Schulterbeulen stärker vertieft und in rlen Hinterwinkeln etwas nach vorn gebogen, die fein gerandeten Seiten fast gerade mit stumpfwinkligen, scharfen Hinterecken, auch der Hinterrand fast gerade mit wenig vortretendem Mittelzipfel. Die Oberfläclıe ziemlich dicht und derb punktirt mit glïnzentem Zwischengrunde, schmutzig strohgelb mit seclıs schlechıt begränzten dunkelı Längswischen neben einander, die beiden äussersten die schwäclısten und nur dunkel gebräunt, die näclıstfolgenden etwas deutlicher, anı Irinterrande etwas in die Quere erweitert, die beiden mittleren noch dunkler, mit den ahgeschwächten Hinterenden zusammengeneigt und vor dem Mittelzipfel zusammenstossend, Das Schildchen schräg ansteigend, abgestutzt dreieckig, mit deutlichem Hinterzipfel grade abgestutzt, glänzend schwarz, mit brïunlich durchscheinendem Mittelfelde. Die Deckschille um 1/3 lïnger als breit, der Rücken abgeflacht, linten mit leichter Wölbung abfallend, hinter der scharfen Vorderkante seicht quer eingedrückt, mit schmalen aber langen, eckig hervortretenden Schulterbeulen; dic Seitenlapjen schwach, und über ilınen 
die Deckschilde etwas zusammengedrückt. Die Punktirung zu unordentlichen Streifen an einander gereiht, der erste Streifen wellig und durch regellose Verdoppelung gestört, der Raum zwischen ihm und der Naht ziemlich diclit punktirt, der zweite und dritte Streifen regelmässig, sehr genähert, hinten-zusammentreffend und mit sanfter Krünmmung dem ersten Streifen und nach dessen Ende der Naht folgend, auch der vierte noch ziemlich regelmässig; die folgenden melır oder weniger gestört, nur stellenweise kenntlich, bis nach aussen der achte und noch mehr der neunte dann wieder ihre regelrechte Ausbildung erhalten. Der dritte und neunte Zwischenraum je doppelt breiter als die andern, was besonders bei. dem dritten durch den Vergleich mit dem daneben liegenden zweiten. in die Augen fällt; das Vorderende dieses dritten mit einigen überzähligen Punkten bestrent. Die Farbe der Flügeldecken strohgelb mit dunkler gesäumten Rändern; das Innere der Punkte, ein Wisch auf der Schulterbeule, der-an beiden Enden wischartig erweiterte neunte Punktstreifen, das gleichfalls wischartig gebräunte Vorder- und Hinterende des schmalen zweiten Zwischenraums, und die tiefer gebräunte Nitte des vierten Streifens schmutzig verdunkelt. Das Pygidium fein punktirt, angedrückt greisharig, schmutzig gelb mit gebräuntem oberen Rande; der Hinterleib gleichfalls gelblich mit gebräunter Wurzel, und breit lorandigem Saume und helleren Seiteuzijfeln des ersten Ringes; die Brust fast schwarz, mit bräunlichen Hinterecken der Parapleuren; die Schulterblätter heller gelb. Auch die Beine mit den Hüften gelb, die Hinterschenkel auf der breiten Aussenfläche mit einem feinen bräunlichen Fleckchen. Das letzte Segment des $q$ mit einem kleinen rundlichen Grübchen, das ơ unbekannt.

Aus Brasilien (bei Caasapava von Sello gefunden; Mus. Berol.).

37. M. cribrarius m. Scliwarz, der Rand und eine abgebrochene Mittellinie nebst zwei Hinterflecken des dicht und grob punktirten Halsschilds, zwei Längshinden und ein Schulterfleck der Flügeldecken mit Pygidium, IIinterleibsrande und Schenkelspitzen gelb; die Punktstreifen dicht und derb, die oberen vorn verdoppelt, mit flach gewölbten, dicht quergerunzelten Zwischenräumen. L. $1 \frac{1}{2}{ }^{\prime \prime \prime} ;$ Br. 1 "'.

In der Sculptur und der Zeichnung zeigt diese Art eine entfernte Aehnlichkeit mit dem nordamerikanischen Pachybr. othonus XVI. 
Say, ist aber kleiner, hinterwärts stark verschmälert und das Halsschild auch ungleich stärker gewölbt. Der Kopf flach mit kaum eingezogenem Kopfschilde und haarleiner Stirnlinie, grob und dicht runzlig punktirt, schwarz; eine unscheinbare Schräglinie jederseits am oberen imeren Augenrande, einige unregelmässige Fleckchen am unteren Rande des liopfschilds und die in der Mitte gebräunte Oberlippe gelb. Die Fühler von haber Körperläıge, zienılich gedrungen, schwarz, die fünf unteren Glieder auf der Unter'seite gelblich braun. Das Halsschild kaum doppelt breiter als lang, hinter der Mitte quer anfgewölbt und von da ab nach vorn in sanfter Krümmung, hinterwärts nit schräger Fläche abfallend, vorn über den scharf rechtwinkligen, tief eingezogenen Vorderecken zusammengedrückt und dadurchı verschmälert; die Seiten fein gerandet, in der Mitte in flachem Bogen erweitert, die Hinterecken scharf slumpfwinklig, mit einer kurz aufgelogenen Schwiele besetzt; der Hinterrand jederseits breit ausgebuchtet, mit wenig vortretendem Mittelzipfel. Die Punktirung grob und tief, dicht gedrängt, mit glänzendem Zwischengrunde; die Farbe schwarz, ein breiter, zwischen den Augen plötzlich verschmälerter, fast unscheinbar gewordener Vorder- und Seitenrand, ein schmaler Hinterrand und ein auf diesem liegender zweilappiger Querfleck weissgelb, und vor der Ausırandung des letzteren eine linterwärts abgekürzte, den Vorderrand berührende, punktfreie weissliche Längslinie; ebenso ist auch der weissliche Hinterrand zunächst nach den Hinterecken zu stäıker glänzend und sclıvielig erhölt. Das Schildchen schräg ansteigend, quer viereckig mit sehr dentlichem Hinterzipfel, dicht und fein punktirt, schivarz. Die Deckschilde aus breiter Wurzel hinterwärts stark verschıälert, um $1 / 4$ länger als vorn breit, flach walzenförmig, hinter der scharfen Vorderkante nur schmal quer eingedrückt, die Schulterbeulen halb eifürmig, die Scitenlappen zugerundet, und über ihnen die Deckschilde breit und seicht zusammengedrückt. Die Punktstreifen sehr deutlich, aus kräftigen dicht zusammengereihten Punkten gebildet, die oberen vorn verdoppelt, die hinter der Schulterbeule stehenden etwas verschoben und in einander gewirrt, die schmalen Zwischenräume leicht rippenförmig erhöht, dicht querrunzlig mit schwachem Glanze. Die Farbe schwarz, eine am Schildchen beginnende, längs dem schwarzen Nahtsaume hinziehende Längsbinde, eiıe zweite innerseits der Sclıulterbeulen beginnende, vor der Wölbung durchbrochene, in der Spitze nit der 
ersteren zusammenfliessende Binde, und ein sclınaler bis zum Hinterende des Seitenlappens reichender Schulterfleck weisslich gelb. Pygidium und Unterseite schr dicht und fein runzlig punktirt, jeıes weiss mit oben schwärzlichenı Rande, dieses schwarz, breit weisslich gesäumt. Auch die Beine schwarz, Schienen und Fussglieder bräunlich durchscheinend, die Schenkel vor der Spitze auf der breiten Vorderfläche mit einem kleinen gelblichen Flecke, ebenso die Vorderhüften gelb. Das Prosternum hinten breit rinnenförmig. Das letzte Segment des $f$ mit einer grossen lıalbkugeligeı, im Innern geschwärzten und darlurch den weissen Saum des Segments unterbrechenden Grube; das ơ unbekannt.

Gleichfalls aus Brasilien (v. Olfers im Mus. Berol.).

35. M. varipennis m. Rostroth mit schwarzen Fühlerenden, der Kopf und das grob punktirte glänzende Halsschild gelbbunt, die Deckscliilde mit gelben Längslinien; die Punktstreifen vorn stellenweise verdoppelt und etwas gestört, hinten schwächer, mit flachen, glänzenden Zwischenräumen. L. $2 \frac{1}{3}{ }^{\prime \prime \prime}$; Br. $1 \frac{1}{6}{ }^{\prime \prime \prime}$.

Eine sehr eigenthümliche, besonders durch ihre zierliche Färbung in die Augen fallende und deshalb mit keiner andern zu verwechselnde Art. Der líopf flach, mit ziemlich deutlicher, oberwärts bis über den Nacken hin sich fortsetzender Stirnlinie und quer mondförmig eingedrücktem Kopfschilde, grob runzlig punktirt mit lackglänzendem Zwischengrunde, rostroth; ein Hakenfleck jederseits über dem oberen Augenrande, die inneren Augenränder, die Wangen und der untere Rand des Kopfschildes nebst einem verwaschenen, schwieligen Querfleckchen auf der unteren Stirn über dem Kopfschilde hochgelb. Die Fühler von halber Körperlänge, schlank fadenförmig, das Wurzelglied aus schlank eingeschnürter Basis keulig aufgetrieben, doppelt so lang als breit, das zweite schmal elliptisch, die drei folgenden dünn verkehrtkegelförmig, das dritte um die Hälfte länger als das zweite, das vierte und fünfte je so lang wie das zweite und dritte zusammengenommen, das sechste (längste) doppelt so lang wie das dritte, an seiner Spitze wenig erweitert, die folgenden je dem fünften, und das linealische Endglied mit seinem spitzen Fortsatze wieder dem sechsten gleich; auch diese oberen dabei nur wenig verbreitert und zusammengedrückt. Die Farbe der fünf unteren rostbraun mit geschwärzter Oberseite des ersten und zweiten, der oberen schwarz. Das Halsschild hinten etwa $2 \frac{1}{4} \mathrm{mal}$ so breit als lang, mit flachem in der 
Mitte kaum aufgebogenem Rücken, vor dem Hinterrande leicht quer eingedrückt und dieser Eindruck jederseits flach erweitert, längs dem Vorderrande etwas eingeschnürt; die spitzen Vorderecken tief eingezogen und dadurch das seitlich nach vorn verschmälerte Halsschild hier noch stärker verengend; die vorn tief herabgezogenen Seiten fein gerandet, hinter der Mitte kaum erweitert, vor ilır sauft ausgeschweift. Die stumpfwinkligen Hinterecken mit einer kurz aufgebogenem Schwiele besetzt; der Hinterrand jederseits des schmalen, etwas aufgebogenen Nittelzipfels leicht ausgebuchtet. Die Oberfläche grob und ziemlich dicht pusktirt, mit lackglänzendem Zwischengrunde; die Farbe hell rostgelb, das Innere der Punkte und einige Wolkenflecke dunkler rostroth. Von den letzleren liegt ein grösserer vor dem Mittelzipfel, und lässt sich, ob auch abgeschwächt, his zum Vorderrande verfolgen, ein etwas kleinerer jerlerseits in der niedergedrückten Stelle vor den Hinterrande, vorn anscheinend mit dem zerfliessenden Vorderende des Mittelflecks zusammenbängend. Das Schildchen stark ansteigend, fast gleichseitig Ireieckig, mit undeutlichem Ilinterzipfel kurz abgestutzt, glänzend dunkelrostbraun. Die Deckschilde etwas breiter als das Halsschild, flach gewölbı, kaum $1 / 4$ länger als breit und hinten ziemlich flach abfallend, hinter der scharf aufgeworfenen Wurzelkante schmal aber tief quer gefurcht und auch hinter dem Schildchen auf der Naht sanft niedergedrückt, die kurzen Schulterbeulen innerseits durch jene Querfurche kräftig abgeselzt; auch die Seitenlappen nur schwach, mit breitem, vereinzelt punktirtem umgeschlagenem Rande, über ihnen die Deckschilde leiclıt zusammengedrückt. Die Punktstreifen ziemlich fein, auf der vorderen Hälfte zwischen Naht und Schulterbeulen unregelmässig verdoppelt, die hinter letzteren liegenden auf der Mitte mehr oder weniger gestört und in vereinzelte Punkte aufgelöst, der sechste laald abgerissen, der achte und noch mehr der neunte über dem Seitenlappen etwas stärker eingegraben. Die Zwischenräume flach, nur der achte und neunte auf der vorderen Hälfte flach gewölht; die Oherfläche lackglänzend. Die Färbung lässt sich an besten als hochgelb ansehen, die Punktstreifen in rostrothe Längslinien eingedrückt oder durch solche verbunden, auch das Innere der vereinzelten Punkte im seclssten und siebenten Streifen, sowie in dem theilweise in solche aufgelösten abgekürzten und ersten Streifen gleichfalls rostroth. Besonders deutlich sind diese rostrothen Längslinien auf dem zweiten, Iritten, 


\section{5}

vierten und achten, auch auf den Hinterenden des neunten Streifens, sodass die Flügeldecken dadurch als mit abwechselnd rostrothen und gelben Längslinien besetzt erscheinen; rostroth sind ausserdem die Schulterbeulen, der umgeschlagene Rand der Seitenlappen, ein zarter Saum um Naht, Spitze und Aussenrand, welcher von der Spitze bis zum Seitenlappen mit dem zehnten Streifen zu- . sammenhäıgt und von da ab dem umgeschlagenen Rande des Seitenlappens sich anschliesst; eben so fliesst auf der Mitte des neunten Zwischenraums die braune Färbung des neunten und zehnten Streifens zusammen, und füllt denselben dadurch fast vollstăndig aus. Das Pygidium schmutzig gelb, die Unterseite mit den Beinen hellgelblichbraun, Füsse und Brust dunkler gebräunt. Das Prosternum ziemlich breit, grob gerunzelt: das letzte Segment des $q$ mit einer tiefen, glänzenden Grube, das $\delta$ unbekannt.

Aus Brasilien (von S. João del Rey: Sello im Mus. Berol.).

Achte Rotte. Körper von mittlerer oder untermittlerer Grōsse, breit und flach gewölht, gleichbreit; das Halsschild in der Mitte breit quer aufgewölbt, und dem entsprechend seitlich in brejtem Bogen erweitert, hinten wierer eingezogen. Die Farbe schwarz mit röthlicher, gelblicher oder weisser, mehr oder weniger schwarz gezeichneter Oherseite, seltener oben schwarz mit weissen Zeichnungen. Arten aus Brasilien und den La-Plata-Läıdern.

39. M. 13 punctatus in. Oben lehmgelb, Kopf, Schildchen, sieben Flecke des ungleicbmässig punktirten Halsschilds und drei der Flügeldecken $(2,1)$ nebst der Unterseite schivarz; die Punktstreifen fein, vorn durch überzählige Punkte gestört und stellenweise verdoppelt, mit flachen, wenig glänzenden Zivischenräumen. L. $3-3 \frac{1}{4}{ }^{\prime \prime \prime} ;$ Br. $1 \frac{1}{2}-1 \frac{2}{3}{ }^{\prime \prime \prime}$.

Der Kopf schwarz, fein aber dicht punktirt, mit knochengelber glänzender Oberlippe, die grossen, breit und tief ausgebuchteten Augen auch bei dem $\delta$ weit getrennt, und zwischen ihnen eine feine, aber deutliche Stirnlinie. Die Fühler nicht von halber Körperlänge und oberwärts wenig erweitert, das Wurzelglied stark keulig aufgetrieben, das zweite kurz birnförmig, das dritte doppeltund das vierte dreimal länger als das zweite, und letzterem die folgenden bis auf das etwas kürzere zehnte gleich, der Fortsatz des Endgliedes schnıal dreieckig zugespitzt. Die vier unteren Glieder wachsgelb mit gebrïunter Oberseite, das fünfte tiefer braun, die oberen schwarz mit dünner angedrückter greiser Behaarung. Das 
Halsschild breit und ziemlich flach, hinten niedergedrückt, in der Mitte nur schwach, aber seitlich stärker quer aufgewölbt, die gerandeten Seiten fast grade, mit spitzen, scharfen Vorder- und etwas stumpferen schwach aufgebogenen Hinterecken; der Hinterrand jederseits des breiten, stumpfen Mittelzipfels etwas ausgebuchtet. Die gewöhnlichen seitlichen Eindrücke überaus schwach, über den Vorderecken das Halsschild etwas stärker schräg zusammengedrückt. Die Oberfläche ziemlich dicht, aber ungleichmässig und nicht tief punktirt, mit mässig glänzendem, stellenweise gerunzeltem Zwischengrunde, schmutzig lehmgelb, hinten fein schwarz gesäumt, mit sieben in zwei Querreihen gestellten schwarzen Flecken; in der ersten deren vier, die seitlichen rund, die mittleren grösseren etwas schräg nach Hinten und Innen ausgezogen; in der binteren Reihe drei, in der Mitte ein kleiner, länglicher Rautenfleck, und jederseits desselben ein grösserer vierecliger Querfleck, welcher von dem rundlichen Vorderflecke durch den seitlichen schwachen Querwulst getrennt wird. Das Schildchen schräg ansteigend, fast so lang wie vorn breit, hinten mit unscheinbarem Hinterzipfel scharf abgestutzt, fein punktirt, schwarz. Die Deckschilde breit und flach walzenförmig, ziemlich gleichbreit und kaum $1 / 4$ länger als breit, linter der aufgeworfenen Vorderkante quer eingedrückt, um den Hinterrand des Schildchens etwas aufgetrieben, und von hier aus seitlich 'stärker-, den Rücken entlang flacher abfallend, mit kurz abwärts gekrümmter Wölbung; Schulterbeulen und Seitenlappen wenig entwickelt, und über den letzteren ein breiter, seichter Quereindruck. Die Punktstreifen fein, bis über die Mitte hinaus durch überzählige, die Streifen theilweise verdoppelnde Punkte getrübt; die Zwischensäume flach mit mässigen Glanze. Die Farbe lehmgelb, manchmal ins hell Knochengelbe verblichen, Naht und Ausseurand zart bräunlich gesäumt, und auf jeder Flügeldecke drei schwarze Flecke, die beiden vorderen länglich, der äussere kleinere auf der Sclıulterbeule, der innere doppelt grössere zwischen ihr und dem Schililchen, rorn an den Quereindruck hinter der Wurzel gelehnt; der einzelıe hintere als schmales Läıgsfleckchen auf der Wölbung in der verlängerten Richtung des Schulterflecks. Zuweilen sind die Flecke zu grösseren, spitz dreieckigen Flecken ausgezogen, die vorderen mit der Spitze nach hinten, der hintere nach vorn gekehrt, selbst die vorderen mit den einander zugewandten Enden ihrer Grundlinien cinander berührend. Das Pygidium sehr 
fein punlitirt, weisshaarig, ziemlich hell knochengelb, jederseits mit einem bräunlichen Fleckchen. Unterseite und Beine sehr kurz und dümn greishaarig, die Hüften und ein breiter verwaschener Rand des Hinterleibes schmutzig gelb, seltner der ganze Hinterleib schnutzig. gebräunt; das Prosteruum hreit, hinten tief längsrinnig. Das letzte Segment des $\delta$ in der Mitte sehr leicht eiugedrïckt, das \& unbekannt.

Aus Brasilien (Mus. Dohrn. Deyrolle. Clark. Berol. Vindob.). In dem von Fry stammenden Stücke des Mus. Dohrn ist Rio de Jan. als Fundort angegeben; das Exemplar des Mus. Berol. ist von Sello bei S. Joâo del Rey gefunden worden.

40. M. luniger m. Schwarz, zwei Flecte des Kopfes, zwei Mondflecke und eine Mittelbinde des grob punktirten Halsschildes, drei abgekürzte Querbinden und die Spitze der Flügeldecken mit den Seiten des Pygidiums und des Hinterleibes weiss; die Punktstreifen ziemlich regelmässig, längs der Naht durch ïberzählige Punkte getrübt, mit flachen, glänzenden Zwischenräumen. L. $21 / 3$ $-3{ }^{2}{ }^{\prime \prime \prime} ; \mathrm{Br}$. $1 \frac{1 / 2}{2}-21 / 4 "$.

Die grösste Art dieser Rotte, übrigens in der Zeichnung und im Habitus den'nächstfolgenden überaus ähnlich. Der Kopf flach mit scharf und tief eingeschnitlener Läugslinie, das Kopfschild etwas eingezogen und oben nur undeutlich abgegränzt. Die Obelfläche grob und ziemlich dicht punktirt, mit sparsam weisslich behaartem, dazwischen glänzendem Zwischengrunde. Die Farbe schwarz, ein his auf das Kopfschild reichender Längsfleck zwischen den Fühlern und ein grosser, die beiden oberen inneren Augenränder berührender Querfleck auf der Stirn weiss. Die grossen Augen schmal aber tief ausgebuchtet, auch bei den ơ getrenut. Die Mundtheile bis auf die weissliche, in der Mitte verwaschen geschwärzte Oherlippe schwarz. Die Fühler vou mehr als halber Körperlänge, derb und kräftig, das zweite Glied kurz und knotig, das dritte $2{ }_{12}^{11}$ mal, das vierte viermal länger als das zweite, das fünfte noch etwas vergrössert, und den letzteren die oberen gleich, dabei mässig verbreitert und zusammengedrückt, mit kurz dreieckigem, inuerseits durch eine tiefe Ausrandung abgeselztem Fortsatze des Endglieds. Die Farbe schwarz, die drei oder vier unteren an der Spitze und Unterseite verwaschen gebräunt. Das Halsschild kurz und breit, die Längsfirste linter der Mitte leicht aufgebogen, nach vorn sehr schwach abwärts gekrümmt, das Mittelfeld hinten quer 
niedergedrückt; die Seiten fein gerandet, in der Mitte schwach bauchig erweitert, vor ihr gegen die spitzen stark eingezogenen Vorderecken hin leicht ausgeschweift, auch die wieder eingezogenen. stumpfwinkligen Hinterecken durch eine aufgebogene Schwiele zugeschärft. Der Hinterrand jederseits merklich ausgeschweift, mit aufwär'ts gekrümmtem Mittelzipfel, und zu jeder Seite der vor letzterem liegenden niedergedrücliten Fläche am Hinterrande ein schmaler Quereindruck. Die Punktirung grob, zumal nach den Seiten zu ziemlich dicht, mit glänzendem Zwischengrunde. Die Farbe schwaı'z, eine Vorder- und Hinterrand berührende Mittelbinde und die Seiten weiss; die Vorder- und Hinterenden dieser Seitenbinden krümmen sich längs Vorder- und Hinterrand einwärts, und bilden dadurch jederseits einen, einem plumpen ( ähnlichen Mondfleck. Das Schildchen stark ansteigend, quer viereckig und linterwärts etwas verschmälert, mit flachem Hinterzipfel grade abgestutzt, glänzend schwarz. Die Deckschilde breit und flach walzenförmig, vorn etwas breiter als das Halsschild, hinter der scharf erhöhten Vorderkante mässig quer eingedrückt, und dieser Eindruck innerseits der hreiten Schulterbeulen hinterwärts' eriveitert; der Rücken um das Sclildchen etẉas aufgetrieben, hinter demselben breit quer niedergedrückt und bis zu der schwach abfallenden Wölbung hin allmählich verflacht; die Seitenlappen tief herabgezogen. Die Punktstreifen im Ganzen regelmässig, vorn kräftig und hinterwärts allmählich abgeschwächt, jedoch nirgends ganz verwischt, längs der Naht besonders in und hinter dem Quereindrucke bis zur Wölbung hin durch eine überzählig eingestreute ziemlich dichte und derbe Punktirung verdunkelt. Die Zwischenräıme glatt und ziemlich glänzend, die Farbe schwarz, auf jeder Flügeldecke ein Vorderfleck im Schildchenwinkel und ein Hinterfleck vor der Spitze weiss; jener das abgerissene Innenende einer weissen Wurzelhinde, deren anderes Ende in dem Eindrucke innerseits der Schulterbeule beginnt, letztere längs der Schulter umzieht, und sich dann mit mondförmiger, den Seitenlappen mit einschliessender Krümmung linterwärts an die zweite Binde anschliesst. Diese liegt vor der Mitte, ist etwas wèllig gebogen und erreicht die Naht nicht ganz; diclıt vor der Wölbung liegt dann noch eine dritte, gleichfalls wellig gelogene und weder Naht noch Seitenrand erreichende Querbinde, und unter derselben der schon genannte rundliche Spitzenfleck; übrigens die Ränder dieser weissen Zeichnungen brandig umsäumt. In der 
Regel sind diese Zeichnumgen sehr dick und breit, zuweilen aber wird besonders die zweite und dritte Binde sehr schmal, und dann schwindet auch der Spitzenfleck zı einem schmalen Querfleckcheı zusammen. Das Pygidium fein punktirt und behaart, gläuzend schwarz, ohem jederseits am Rande ein dreieckiger, sich an die Zeichnung des letzten Bauchringes anschliessender weisser Fleck. Auch die Unterseite mit den Beinen schwarz, kaum behaart, die Hüften gebräunt, der Hinterleib breit weiss gerandet, welcher Rand sich auf dem letzten Ringe zu einem jederseits über $1 / 4$ des Ringes einnehmenden Querflecke erweitert. Das Prosternum breit, grob runzlig punktirt, hinten der Länge nach vertieft und in einen stumpf zugerundeten Lappen auslaufend. Das letzte Segment dés $\delta$ mit einem glänzeuden seichten Längseindrucke, das $f$ mit einer tiefen, seitlich breit niedergedrückten Grube.

Aus Brasilien (Mus. Hamburg. Thorey. Dohrn. Berol. Riehl. Baly. Clark) und Montevideo (Mus. Saunders).

41. M. crassicollis m. Schwarz, der Kopf, der vorn und hinten unterbrochene Rand nebst einer abgekürzten Mittelbinde des grob pünktirten Halsschilds, das Schildchen und sechs theilweise zusammenlıängende Flecke der Flügeldecken $(2,2,1,1)$ mit dem Pygidium und dem Hinterleibsrande weiss, die Beine rostroth; die Punktstreifen deutlich, mit flachen, gläuzenden Zwischenräumen. L. $2^{\prime \prime \prime} ;$ Br. $1 \frac{1}{2}{ }^{\prime \prime \prime}$.

Dem vorhergehenden ähnlich, aber bei bedeutend geringerer Grösse verhältnissmässiğ breiter und gedrungener, ausserdem an der Färbung des Schildchens und der Beine von ihm leicht $z u$ unterscheiden. Der Kopf flach mit feiner Stirnlinie und etwas eingezogenem Kopfschilde, mit vereinzelten, ziemlich deutlichen Punkten besetzt, weiss; ein schmaler Nackenstreif, die Augenbuchten und Fühlerhöcker schwarz, Oberlippe und Mundtheile roströthlich mit gebräunten Tasterspitzen, die gleichseitig-dreieckig ausgebuchteten, auch bei dem $\delta$ weit getrennten Augen schwarz. Die Fühler (des ठ) von $2 / 3$ der Körperlänge, derb und kräftig, das zweite Glied kugelig, das dritte doppelt- und das vierte $2 \frac{1}{2} \mathrm{mal}$ länger, das füıfte und die, folgenden einander gleich, je ein wenig länger als das vierte, dabei die oberen nur schwach erweitert und zusammengedrüekt. Die Farbe der fünf unteren rothbraun mit geschwärzter Oberseite, der oberen schwarz mit dünner, greiser Behaarung. Das Halsschild nicht ganz doppelt so breit wie lang, 
hinter der Mitte sehr breit quer aufgewölbt und von da ab hinterwärts abgeflachı, nach vorn sanft abwärts gekrümmt, über den scharf spitzwinkligen Vorderecken zusammengedrückt und dadurch verschmälert, die Seiten fein gerandet, nach unten etwas eingezogen, in der Mitte in flachen Bogen erweitert, vor ihr leicht ausgeschweift; die Hinterecken scharf stumpfwinklig, der Hinterrand doppelt ausgebuchtet mit wenig bemerkbarem Mittelzipfel. Die Oberfläche grob zerstreut punktirt mit lackglänzendem Zwischengrunde, schwarz; ein breiter, vorn und hinten im mittleren Drittel unterbrochener Rand und eine hinterwärts abgekürzte Mittellinie weiss; diése weisse Färbung überall nach Innen brandigbraun begränzt, und auch der Hinterrand, besonders am Mittelzipfel, eben so gesäumt, und bei einem der vorliegenden Stücke vor dem letzteren noch ein unscheinbares, weissliches Fleckichen. Das Schildchen sehr schräg ansteigend, nicht so lang wie vorn breit, hinterwärts verschmälert und mit deutlichem Hinterzipfel breit zugerundet, glänzend weiss mit gebräuntem Saume. Die Deckschilde kurz und gedrungen, kaum $1 / 4$ länger als breit, auf dem Rücken flach gewölbt und hinten init kurzer Wölhung alfallend, hinter der Wurzel kaum quer niedergedrückt, die eckigen Schulterbeulen innerseits durch einen drejeckigen Eindruck abgesetzt; die Seitenlappen schwach, und über ihnen die Deckschilde auch nur schwach, aber breit zusammengedıückt. Die Punktstreifen vorn kräftig, zunächst der Naht, und hinter den Schulterbeulen stellenweise verdoppelt und dadurch gestört, auf dem letzten Viertel "selır schwach und unter der Wölbung erloschen, mit flachen, besonders hinterwärts glänzenden Zwischenräumen: Die Zeichnung im Ganzen der vorhergehenden Art 'entsprechend. Am Vorderrande stelien zunächst auf jeder Flügeldecke zwei kleine weissliche Flecke, der äussere innerseits der Schulterbeule, der innere mehr linienartige am Schildchen und hinter diesem mit seinem Gegenflecke zusammenstossend; ein zweites Paar steht vor der Mitte, der innere, grössere rund und frei, der äussere, kleinere an den Seitenrand gelehnt und längs demselben durch einen den Seitenlappen mit einschliessenden Randbogen um die Schulterbeule herum mit dem äusseren Vorderflecke verbunden: dann folgt ein etwas welliger, bindenartiger Querfleck auf der Wölbung, zwischen dem zweiten und neunten Punktstreifen, und endlich noch ein vereinzelter rundlicher Fleck hinten im Nalıtwinkel; die weissen Flecken auch hier bran- 
digbraun gesäumt, und die Spitze mit dem hinteren Theile von Naht und Aussenrand eben so eingefasst. Aendert jedoch ab

$\beta$. der innere Fleck des zweiten Paares: mit dem äussern zu einer abgekürzten Querbinde zusammengeflossen, welche eine der vorhergehenden Art ganz gleiche Zeichnung herstellende Verbindung jedoch bei dem einzigen mir vorliegenden Stücke dieser Abänderung uur auf der rechten Flügeldecke vollständig zu Stande gekommen ist.

Das Pygidium weiss mit roströthlicher Spitze und oben breit geschwärztem Saume; die Unterseite schwarz, bei einem der vorliegenden Stücke fast ins Rostbräunliche fallend, der Hinterleib breitweiss gesätumt. Die Beine rostroth, die Schienenenden und Füsse schmutzig geschwårzt. Die Vorderschenkel stark aufgetrieben, das Prosternum hinten schmal und tief längsrinnig. Das letzte Segment des $\delta$ hinten mit einem leichten, glänzenden Eindrucke, das q mit einer mässig vertieften gleichfalls glänzenden und den weisslichen Rand des Hinterleibs unterbrechenden Grube.

Aus Brasilien (v. Olfers im Mus. Berol.).

42. M. albopictus Buq. Schwarz, zwei Flecke des Kopfes, zwei nebst dem hakenförmigen Seitenrande des grob zerstreut punktirten Halsschilds und vier der Flügeldecken nebst dem oberen Theile des Pygidiums und dem Hinterleibsrande weiss; die Punktstreifen mässig, vorn gestört und hinten abgeschwvächt, mit flachen, wenig glänzenden Zwischenräumen. L. $2-2 \frac{1}{2}{ }^{\prime \prime} ; \mathrm{Br}$. $1-1 \frac{1 / 4}{}{ }^{\prime \prime}$.

Gestreckter und schlanker als die vorhergehendeu Arten, die weisse Zeichnung aber eben so wie bei jenen an einzelnen Stücken (ob in Folge äusserer, z. B. der Witterungsverhältnisse?) ins Gelbliche verschossen. Der Kopf flach mit feiner Stirnlinie, nicht grob aber dicht runzlig punktirt, mattschwarz; zwei unten zusammenstossenden Schrägflecke zwischen den oberen inneren Augenrändern weiss; die nur schwach ausgebuchteten, sehr ungleich getheilten und (bei dem $₹$ ) weit getrennten Augen greis. Die Fühler sehr dünn und kaum von halber Körperlänge, das Wurzelglied stark aufgetrieben, kaum um die Hälfte länger als breit, das zweite elliptiseh, die folgenden schon ein wenig zusammengedrückt, aber erst vom sechsten ab oberwärts leicht verbreitert; das dritte reichlich doppelt-, das vierte dreimal länger als das ziveite, das fünfte bis siebente wieder gleich und je etwas länger als das vierte, die oberen sich wieder 
allmählich verkürzend. Das Wurzelglied schwarz mit gebräunter Spitze und Unterseite, die folgenden bis zur Wurzel des sechsten bräunlich gelh, die oberen schwarz mit dünner greiser Behaarung. Das Ilalsschild dopurelt hreiter als lang, hinter der Mitte sanft aufgewölbt, daher die Firste vorn leicht abwärts gekrümmt, der Vorderrand über den scharf zugespitzten Vorderecken etwas eingeschnürt und dadurch das Halsschild verschmälernd; die Seiten sehr fein gerandet, in der Nitte rundlich erweitert, vor ihr leicht ausgeschweift, die stumpfwinkligen Hinterecken zugeschärft, der Hinterrand jederseits gebuchtet nit unscheinbarem Mittelzipfel, und vor diesem zu jeder Seite das schräg abfallende Mittelfeld seicht quer niedergedrückt. Die Oberfläche auf der Mitte zerstreut - und etwas feiner-, seitwärts merklich dichter und dabei grob punktirt, der schwarze Zwischengrund mit schwächerem, die weisse Zeichnung mit stärkerem Glanze. Die letztere bildet jederseits einen breiten, sich in den Vorderecken erweiternden und längs dem Vorderrande fortziehenden Seitenrand, welcher vorn jederseits an dem entsprechenden Stirnflecke abbricht, und sich gewissermassen durch jene Stirnflecke auf den Kopf fortsetzt, und ausserdem noch zwei Hittelflecke, nämlich einen vorderen Längsfleck und einen Querfleck vor dem Hinterrande, welcher letztere eigentlich aus zwei, nur vorn durch eine dreieckige Ausrandung getrennten schrägen Rautenflecken zusammengesetzt ist. Das Schildchen stark ansteigend, viereckig und hinterwärts etwas verschmälert, mit deutliclıem Hinterzipfel grade abgestutzt, gleichfalls mattschwarz. Die Deckschilde um $1 / 3$ länger als breit, flach gewölbt, hinten ziemlich schräg abfallend, die Vorderkante nur auf der innern Hälfte der Flügeldecken erhöht und von einer eingedrückten Querlinie begleitet, Scbulterbeulen und Seitenlappen wenig bemerǩbar, aber der Kiel des letzteren durch das tief eingegrabene Vorderende des Randstreifens stark herausgehoben. Dic Punktstreifen aus vereinzelten Punkten gehildet, 'vorn ziemlich deutlich, aher mehrfach abgerissen, gestört und durch überzählige Punkte getrübt, hinter der Mitte regchnässiger, aber auch schwächer'; die Zwischenräume flach, die Oberfläche auch hier auf dem schwarzen Grunde matter, auf der weissen Zeichnung stärker glänzend. Die letztere hildet auf jeder Flügreldecke vier, theilweise recht unregelmässig gestaltete Fleclie; der erste derselben liegt vorn an der Wurzel, wo er den ganzen Winkel am Schildchen ausfüllt, dann auswärts ron ihm ein 
schmaler, die Schulterbeule hakenförmig umziehender, auch den Seitenlappen mit begreifender und mit dem Hinterende wieder ein wenig einwärts gehogener Randfleck; der dritte ein rundlicher oder quer gezogener Fleck auf der Mitte, jenem Hinterende des Randflecks gegenülser, wie bei der vorhergehendeu Art, und endlich noch ein Querfleck auf der Wölbung, von welchen nahe an seinem Aussenrande ein schmaler Zipfel sich hinterwärts über die Vitte hinaus erstreckt und an der Spitze zu einem breiten, den Nahtwinkel einnehmenden Saume erweitert. Das Pygidium runzlig punktirt, weisslich mit schwarzer Spitze; Unterseite und Beine sclivarz, der Rand des Hinterleibes vom Ende des Randflecks der Flügeldecken ab breit weiss, welche Färbung sich dann auf dem letzten Bauchringe an die des Pygidiums anschliesst, gewissermassen hier wieder auf die Oberseite überspringt. Das Prosternum grob gerunzelt, linten längsfurchig, mit kurz zugerındetem Hinterende. l)as letzte Segment des $q$ mit der gewöhnlichen rundlichen, auf dem nicht weiss gezeichneten Theile des Segments liegenden Grube; das $\delta$ unbekannt.

Gleichfalls aus Brasilien (Mus. Deyrolle. Berol., das Exemplar des letzteren von Sello bei Collo del Sagramento gefunden).

43. I. ha mifer m. Sclıwarz, ein Querfleck auf der Stirn, die hakenförmigen Seiten und eine Mittellinie des zerstreut punktirten Halsschilds, und vier Flecke der Flügeldecken mit dem Rande des Pygidiums und Hinterleibes weiss; die Punktstreifen fein, vorn leicht wellig, mit flachen glänzenden Zwischenräumen. L. 21/4$2 \frac{1}{2}{ }^{\prime \prime \prime} ;$ Br. $1 \frac{1 / 6}{6}-1 \frac{1}{4} "$.'

Diese Art verbindet den gestreckten Körper und die Flügeldeckenzeichnung des vorhergehenden mit der Halsschildszeichnung des M. crassicollis, ist aber von beiden leicht an der selır feinen Sculptur der Deckschilde zu unterscheiden. Der Kopf flach mit deutlicher Stirnlinie und stark eingezogenem, oben durch einen flachen Querwulst abgesetztem Kopfschilde; die Punktirung dicht und deutlich mit glänzendem Zwischengrunde, die Farbe schwarz, lie in der Nitte gebräunte Oberlippe und ein aus zwei verkehrt Jreieckigen Fleckien zusammengesetzter Querfleck zwischen den oberen, anch bei denı ठั weit getrennten Augenrändern, und bei einem Stücke atich noch ein rundlicher Fleck zwischen den Fülılerwurzeln weiss. Die Fühler etwa ron halber Körperlänge, das zweite Glied knotig, kaum länger als breit, das dritte dopjelt-, das 
vierte viermal und das fünfte fast fünfmal länger als das zweite, und dem fünften die oberen gleich, nur das Endglied mit seinem. lang kegelförmig ausgezogenen Fortsatze fast so lang als das dritte und vierte zusanmengenommen. Die Farbe schwarz, die vier unteren an den Spitzen und auf der Unterseite gebräunt. Das Halsschild etwa um die Hälfte breiter als lang, hinter der Mitte sanft quer aufgewölbt und nach vorn leichter, hinterwärts stärker abwärts gekrümmt, über den scharf spitzwinkligen Vorderecken breit zusammengedrückt und dadurch verschmälert, die Seiten fein gerandet, in der Mitte in sanften Bogen erweitert, vor ilır ein wenig ausgeschweift, die Hinterecken scharf stumpfiwinklig und etwas aufgebogen; der Hinterrand jellerseits des liurzen Mittelzipfels breit ausgebuchtet und die Fläche vor dieser Ausbuchtung leicht quer niedergedrückt. Die Punktirung deutlich, aber sehr zerstreut, mit spiegelglattem Zwischengrunde; die Farbe schwarz, die breiten, längs dem Vorder- und Hinterrande hakenförmig nach Innen ungebogenen Seitenränder und eine ebenso breite, über die Firste sich hinziehende Mittellinie weiss. Das Schildchen schräg ansteigend, nicht so lang als vorn breit, hinterwärts verschıälert und mit sehr langem Ilinterzipfel abgestutzt, fein punktirt und noch feiner behaart, schwarz. Die Deckschilde gestrecht viereckig, um etwa $1 / 3$ länger als breit, der Rücken hinter dem Schildchen leicht eingedrückt und hinten mit mässiger Krümmung abfallend, hinter der scharf erhöhten Vorderkante schmal abei tief quer gefurcht, die Schulterbeulen schmal zusammengedrückt und auch die Seitenlappen nur wenig ausgebildet. Die Punktstreifen fein und auf ler Wölbung fast erloschen, längs der Naht und an den Schulterbeulen durch überzälllige I'unkte verdunkelt, die flachen Zwischenräume mit ziemlichem Glanze : Die Farbe schwarz, die weisse Zeichnung ganz wie sie bei der vorigen Art beschrieben worden, nur der lintere (weisse) Fleck noch mehr in die Quere gezogen, scin hinterer Žipfel fast von der Nitte seines Ilinterrandes ausgehend, und dessen Hinterende im Nahtwinkel wieder angelhakenförmig die Naht entlang nach vorn gekrünmt. Der Randfleck zeigt hei dem einen der beiden vorliegenden Stücke heine nach Innen vorspringenden Enden, bei dem andern sind sie vorhanden, und das hintere tritt hier soweit var, dass es mit dem Mittelflecke zu einer der Bindenzeichnung des M. luniger entsprechenden Querbinde zusammenfliesst. Pygidium und Unterseite feiı runzlig punktirt und düun 
greisharig, jenes weiss mit schwärzlichem oberen Rande, diese schwarz, breit weiss gesäumt. Auch die Beine schwarz. Das Prosternum ziemlich breit, hinten tief rimıenförnig, mit etwas abwärts gebogenem Hinterende. Das letzte Segment des $\delta$ mit eimer leicht quer niedergedrückten, glänzenderen Stelle; das $q$ uıbekannt.

Aus Brasilien (Mus. Berol., von Sello gesammelt).

44. M. triplagiatus m. Schwarz, drei Stirnflecke, die Seiten und zwei Hinterflecke des grob und dicht punktirten Halsschilds, eine unregelmässige schräge Läıgsbinde der Flügeldecken und ein Spitzenfleck der Schenkel weiss; die Punktstreifen vorn derb und durch überzählige Punkte getrübt, hinten schwächer, mit flachen, glänzenden Zivischenräumen. L. $1 \frac{3 / 4}{}{ }^{\prime \prime \prime} ;$ Br. $1^{\prime \prime \prime}$.

Kürzer und flacher als die vorhergehenden und darlurch mehr zu dem Habitus des gemeinen M. limbiventris und seiner Verwandten hinüberleitend. Der Kopf flach mit etwas eingezogenem Kopfschilde und breitem, unten dreieckig erweitertem Stirneindrucke; die Punktirung auf der unteren Stirn und dem Kopfschilde grob und tief, in den breit dreieckigen Augenbuchten feiner, aber dichter gedrängt, oberwärts fein und zerstreut, mit glänzendem Zivischengrunde. Die Farbe schwarz mit schmutzig gebräunten Mundtheilen; Oberlippe uud Wangen, ein viereckiger Fleck zwischen den Fühlerı und zwei Längslinien, welche mit ihren unteren Innenenden die oberen Ecken jenes Fleckes berühren, weiss. Die Fühler bei den vorliegenden Stücken nicht mehr vollständig, die fünf unteren Glieder durchscheinend hell röthlich gelb mit einem sclıwarzen Längswische auf der Oberseite, welcher bei dem stark aufgetriebenen Wurzelgliede dieselbe ganz eimnimmt, die oberen Glieder mässig zusammengedrückt und erweitert, soweit sie vorhanden sind, schwarz mit dünner greiser Behaarųng. Das Halsschild breit und flach gewölbt, etwa $2 \frac{1}{4}$ mal breiter als lang, hinter der Mitte sanft quer aufgewulstet, vorn über den scharf spitzwinkligen Vorderecken zusammengedrückt und dadurch erweitert, die Seiten fein gerandet, nach unten und vorn schräg fast in graden Linien convergirend, die stumpfwinkligen Hinterecken mit einer kurzen, scharf aufgebogenen Schwiele besetzt, der Hinterrand jederseits sanft ausgebuchtet, und das Mittelfeld vor dem kurzen Mittelzipfel quer niedergedrückt. Vor jeder Seile des Hinterrandes ein schwacher Schrägeindruck; und ein noch schwächerer weiter vorn nach den Vorderwinkeln 
hinziehend. Die Punktirung nicht sehr dicht, aber grob, mit glänzendem Zwischengrunde; die Farbe schwarz, ein ziemlich breiter, in den Vorderwinkeln hakenförmig sich am Vorderrande fortsetzender Seitenrand und zwei Schrägflecke vor dem Mlittelzipfel des Hinterrandes weiss; auch zeigt der Vorderrand über dem Nacken hei beiden vorliegenden Stïcken ein paar weissliche Quernleckchen, so dass auch wohl Stücke mit zusammenhängend weissem Vorderrande gefunden werden könnten. Das Schildchen schräg ansteigend, merklich kürzer als vorn breit, hinterwärts mit leicht ausgebuchteten Seiten verschmälert, mit abgerundeten Ecken und kurzem Hinterzipfel breit abgestutzt, äusserst fein und dicht punktirt, schwarz. Die Deckschilde länglich viereckig, gleichbreit und hinten kurz abgerundet, etwa um 1/4 länger als breit, auf dem Rücken flach gewölbt, vorn nur leicht quer niedergedrückt; die länglichen Schulterbeulen wenig vortretend, auch die Seitenlappen nur schwach entwickelt und über ihnen die Deckschilde breit schräg zusammengedrückt. Die Punktirung auf der vorderen Iläfte grob, nicht sehr dicht, aber wenig geordnet, mit Ansätzen und Bruchstücken regelmässiger Punktstreifen, von denen nur der neunte etwas deutlicher zu erkennen ist; hinter der Mitte werden die Punkte feiner, sparsamer, und ordnen sich etwas melır zu welligen Streifen, die aber auch schon vor der spiegeiglatten Spitze fast ganz verschwinden. Die dadurch gebildeten Zwischenräume flach, stark glänzend, der vordere Zwischengrund zu unordentlichen Runzeln verfliessend, vou etwas schıwächerem Glanze. Die Farbe schwarz, ein grosser länglich viereckiger, die grössere äussere Hälfte der Wurzel und die kleinere Vorderhälfte des Aussenrandes einnehmender Schulterfleck und die Spitze weiss, beide bei den beiden vorliegenden Stücken durch einen schmaleren, unregelmässig begränzten, nach hinten gerichteten weissen Schrägwisch verbunden Grundfarbe in einen gemeinsamen viereckigen Nahtfleck und einen länglichen, jederseits die hintere Häfte des Aussenrandes einnehmenden Randlleck zerrissen wird. Pygidium, Unterseite und Beine fein punktirt, dümı greishaarig, schwarz; die Schenkel auf der Aussenkante vor dem Knnie mit einem kleinen weisslichen Fleckchen, welches bei einem der beiden vorliegenden Stücke auf den Vorderschenkeln fehlt; die letzteren ausserdem an der Wurzel auf der ausgehöblten Innenseite gebräunt und auch die Vorderhüften gelblich. Das Prosternum fast der ganzen Länge nach seicht 
rinnenförmig vertieft. Das letzte Segment des $\delta$ mit einer seicht quer niedergedrückten, etwas glïnzenden Stelle, das $q$ unbekaunt. Ebenfalls aus Brasilien (von S. João del Rey; Sello im Nus. Berol.).

45. M. gentilis m. Oben weisslich gelb, eine lappige Zeichnung des zerstreut punktirten Halsschilds, eine hinten fleckig erweiterte Nahıtbinde und eiı hinterer Randwisch der Flügeldecken schwarz, unten schwarz, ein breiter Saum des Hinterleibes, die Schulterblätter und die Beine gelb nit schwarzbunten Schenkelı; die Punktstreifen vorn unregelmässig verdoppelt, mit hinten flachen, glänzendeı Zwischenräumen. L. $1{ }^{2 / 3}{ }^{\prime \prime \prime} ; \mathrm{Br} .3 / 4{ }^{\prime \prime \prime}$.

Dem folgenden M. limbiventris allerdings sehr ähnlich, aber doch auch wieder von ihm namentlich in der Farbenvertheilung so sehr abweichend, dass ich beide nicht wohl mit einander verbinden kanı. Der Kopf flach mit etwas eingezogenem Kopfschilde und deutlicher Stimlinie, ziemlich dicht punktirt, weisslich gelb mit ınässigem Glanze; der Nacken, die Fühlerhöctier und der untere Rand des Kopfschildes schwarz, das Innere der Punkte und die Stirnlinie nelsst den Kinnbacken gebräunt, die tief ausgebuchteten, auch bei dem $\delta$ weit getrennten Augen greis. Die Fühler fadenförmig, von mehr als halber Körperlänge, oben sehr schwach verbreitert und zusammengedrückt, das fünfte Glied das längste, das vierte und sechste gleichlang und je etwas kürzer als das fünfte. Die Farbe greisgelb, die sechs oberen mit stark rauchgrauem Anfluge. Das Halsschild im letzten Drittel leicht quer aufgewölbt und von da ab naclı vorn in sanfter Krümmung, hinterwärts mit einer breiten Schrägfläche abfallend, über den spitzwinkligen Vorderecken breit zusammengedrückt und dadurch verschmälert, die Seiten fein gerandet, in der Mitte bogig erweiteri, vor ihr stark ausgeschweift, die Hinterecken fast rechtwinklig, scharf aufgebogen, der Hinterrand doppelt ausgebuchtet mit wenig vortretendem Mittelzipfel, und vor diesem jederseits ein leichter Schrägeindruck. Die Punktirung deutlich aber zerstreut, mit glänzenden Zwvischengrunde; die Färbung lässt sich am besten als schwarz bezeichnen, und dann ist ein breiter Seiten- und Vorderrand, letzterer im mittleren Drittel unterbrochen, ein zugleich den Mittelzipfel einnehmender und vorn bis auf zwei Drittel gespaltener viereckiger Fleck auf dem Hinterrande, und eine die vorderen $2 / 3$ der Mittelfirste einnehmende Längslinie weisslich gelb. Das XVI. 
Schildchen schräg ansteigend, quer viereckig. linten mit deutlichem Hinterzipfel grade abgestutzt, schıvarz, die Hinterhälfte bis auf den schwärzlicheı Saum gelb. Die Deckschilde un $1 / 3$ länger als breil, lïnglich viereckig, der abgeflachıte Rücken linten mit mässiger lirümmung abfallend, hinter der scharfen Vorderkante tief quer gefurcht, die schmalen Schulterheuleı kurz aher eckig hervortretend, die Seitenlappen auch nur kurz, aber über ilmen die Deckschilde krältig zusammengedrückt. Jie P’unktstreifen ziemlich r'egelmässig, deutlich, die der Naht zunächstliegenden vorn verdoppelt und dadurch deren Zwvischenräume als schmale, llache Rippen emporgeholsen: hinter der Mitte werden die Punkte feiner, die Streifen regelmässiger, die Zwischenriume hreiter und llacher, stirker glänzend, unıl die Spitze unter der Wölbung spiegelylatt. Die Farbe weisslichgellı; Schulterbenlen, Seitenlappen und der hintere Saum von Naht und Spitze dunkles ins Bräunliche fallend, eine bis zur Wülnung reichenle und hier jederseits zı einem vicreckigen Flecke erweiterte Nalıbinde, und ein breiter, die Mitte des Seitenrandes vom Seitenlappen bis zur Wöllung eimehmender, nach funen bis zum achteu Streilen reichnender Längswisch schwar\%. Pygidium und Unterseite fein und dicht punktirt, dünn weisslich behatart, ersteres gelblich, der obere Rand und die Spitze schwarz; der Hinterleil, schwar\% mit breitem gollon Rande und gleichfalls gelben Seitenzipfelu des ersten liuges; anch die Brost schwarz, die Hüften, lunenränder der Paraplenren und Schulterlbätter weisslich. Auch die Beine weisslich, die Schenkel aut der Aussenkante breit gesehwärzl, welche Pärbung an den aufgetriebenen Vorderschenkehn fast lie ganze iussere Hälfte der breiten Unterseite eimumint. Das Prosternum hinten schmal rimuenlörmig, lang greishtarigg, mit dem ungesehlagenen Rande des Ilalsschilds gell. Das letate Segment des $\delta$ seicht quer eingedrückt und dahinter in einen stumpfen IIöcker anfigetrieloen; das of unbekannt.

Libenfalls aus Brasilien (D. Olfers im Mus. Berol.).

46. M. Jimhiventris Stal. Ohen knochengelb mit schwarzbuutom liopfe, zwei Winkelflecke des zerstreut punktirteu Halsschilds, diss Schildchen, zwei Längsllecke, eine Längshinde und der Aussemrand der Deckschilde sclıwarz, Pygidimm, Unterseite und Beine schwarz- und gelbbunt; die Deckschilde vorn dicht unil ungeordnet funktirt, seillich und hinten regehnassiger punktstreilig 
mit flachen, gläızenden Zwischenrăumen. L. 12/3-21/2"'; Br. $3 / 4-11 / 4 "$.

Pachybrachys limbiventris Stål Till Känuedomen etc. in der öfversigı etc. S. $62.11,6 !$

Im Habitus dem vorhergehenden ähnlich, aber in deı Sammlungen viel weniger selten, in der Zeichnung melır dem oben beschriebenen 11 . decumanus verwandt, aber von demselben leicht an den genäherten Augen, rlem vorn viel breiteren Halsschilde und des viel feineren Sculptur der Deckschilde zu unterseheiden. Der Kopf flach mit etwas zurücktretendem Nacken, das Koptschild seicht quer muldenförnig eingedräckt, die Oberfläshe mit sehr feiner Stirnlinie, lein und dicht punktirt, mässig glänzend, schmuzig knochengell), ein dreieckiger l'leck je un die Fühlerwurzel, und der Nacken, ebenso auch die schmal aber tief ausgebuchteten, bei dem $\delta$ einander fast berülırenden, bei dem $?$ von einander doppelt weit entfernten Augen schwar\%, seltener greis. Die Oberlijpe hellgelb, die Kinnbacken schwar\%, die übrigen Mundtheiłe schmutzig durchscheinend knochengells; das Lndglied der Vordertaster ahgestutzt kegelförmig. Die Fühler lang und düm, das zweite filied ziemlich aufgeblasen birnförmig, das dritle kaum hall, so dick aher doppelt länger, das vierte und fünfle noch etwas verlinggert. IDas sechste wieder dem vierten gleich und die folgenden je noch ein wenig verkürzt, dabei auch nur wenig verbreitert und zusammengedrückt. Die Farbe durchscheinend honiggell, die oberen rauchgrau oder schwäızlich angetlogen. Das Halsschild un melı wie die Ilälfte loreiter als lang, in der Mitte polsterfürmig erhöht, nach dem Vorder- und Hinterrande zu sanft abwärts gekrüınnt und vor letzterem tief quer niedergesenkt, über den tief eingezogenen Vorderecken zusammengedrïckt und dadurch verschmälert, die Sejen fein gerandet, von den scharf' stumpfwinkligen wiedes stark eingezogenen Ilinterecken ab bis zu der Jeicht gerundeten Mitte schriig nach vorn und unten gerichtet, vor letzterer tief ausgebuchtet; de Ilinterrand leicht doppelt geschweift, mit sehwachem Mittelziplel. Die Oberfläche spiegelglatt, mit vereinzelten ziemlich kräftigen l’unkteı bestreut, knochengell); das Mittelfeld mit zwei unförmlichen, winklig gekrümmten, hinten fast den Ilinterrand berührenden, vor der Mitte sich nach vorn zusammenkrümmenden sclıwarzen filgcken, welche vorn mil linientörmiger Verlängerung ihres Inuenrandes bis an den Vorderrand des Halsschilds reicheı, vor der 
Mitte nur durch eine leichte Längslinie, hinten aber durch einen halbkreisförmigen, auf dem Hinterrande ruhenden Zwischenraum getrennt werden; in der Mitte des letzteren noch eine feine abgekürzte schwarze Längslinie. Seltener ist jeder Fleck in zwei lileinere aufgelöst, und alle vier bilden damn einen auf den Hinterrande stehenden, oben rechts und links etwas echig erweiterten Halbkreis: bei schlecht ausgefïrbten Stücken aher ist die ganze Zeichunng nicht schwarz, sondern schmutzig brauı. Das Schildchen schräg ansteigend, hinterwärts verschmälert und mit deutlichem, flach niederliegendem Hinterzipfel abgestutzt, schwarz, seltner vor dem Hinterrande gebräunt oder schmutzig gelblich durchscheinend. Die Deckschilde etwa un $1 / 4$ länger als hreit, sehr flach gewölbt und hinten kurz zugerunclet, hinter dem scharf erhöhten Vorderrande quer gefurcht und von den Innenenden dieser Furche das Schildchen leicht umzogen, der Rücken hinter der Mitte nochmals breit aber seicht quer eingedrückt. Schulterheulen und Seitenlappen nur schıvach entwickelt, üher letzteren die Deckschilde auch uır schwach zusammengedrückt. Die Oberfläche vorn bis zur Nitte hin derb aber ziemlich dicht und unordentlich punktirt, stellenweise mit Risten gestörter Punktstreifen oder Ansätzen von solchen, nur der achte und neunte zu regehrechter Ausbildung gelangt; hinter der Mitte enlwickeln sich aus der sich immer mehr vereinzelnden Punktirung des Rückens noch einige Streifen, sclıwächen sich aber auch inmer melı ab, und sind unter der Wölbung fast ganz verschwumden, indem zugleich der Glanz der flachen Zwischenräune immer mehr zunimmt. Jie Farbe knochen elb, ein feiner vorn und hinten abyelorochener Randsaum jeder Flägeldecke, eine auf der Sclsulterbeıle beginnend» his unter die Wölbung r'eichende und im Ganzen dem neunten Punktstreifen folgende Liingsbinde, und zwischen dieser unt der Naht noch zwei hinter einander stehende, eine zweite unterbrochene Binde bildende Länğrsllecke seluwarz.

Aendert jedoch ab

$\beta$. die Seitenbinde nach Aussen überfliessend und sich an den in der Mitte yeschwärzteı Seitenrand anschliessend, sodass hier vorn und aussen oft nur der die Schulter unziehende Kiel des Seitenlappens mit letzterem selbst weisslich bleibt. [Diese Form ist die gewölnnlichste, und wird auch von Sti̊l a. a. 0 , als var. b. aufyeführt. Bei einem hierher gehöremlen Stïcke ist der innere 
Hinterfleck soweit vergrössert, dass er an seinem Aussenraule mit dem hinteren Innenrande der Binde zusammenstösst.

$\gamma$. Die beiden lunenflecke zu einer zweiten Lăugsbinde zusanmengeflossen, die Seitenbiuden aber von dem, meist sich beiderseits weiter ausdehnenden Scitensaume getreunt. Stäl a. a. O. var. c. Alle Stücke dieser Form, die ichı bis jetzt geselıen, sind \&, ich halıe jedoch auch zwei $q$ von ıler var. $\beta$ vor mir.

$\delta$. Bei zwei vollstïndigen Längsbinden der Flügeldecken die äussere ınit dem Seitenrande und auf der vorderen. Hïfte auch mit der inneren zusanmenfliessend, so dass beide hier nur noch durch ein feines weisses Längsfleckchen getremt werden, sich vor und hinter diesem aber zusanmenschliessen. Bei unvollständig ansgefärbteı Stücken ist auclı auf den Flügeldecken die Zeiclınung mehr orler weniger schmutzig braun. Das Pygidium fein punktirt und behaart, kuochengelb, oder auch auf der Mitte mit einem breiten schwarzen Längsfleck. Die Unterseite dicht runzlig puuktirt, schwarz; die Schulterb]ätter und der glatte Innenrand der Parapleuren, die Vorderzipfel des ersten Bauchringes, die Seiten aller Ringe und die hintere Ilälfte des letzten Ringes gelb. Auch die Beine mit den Hüften gelb, die Aussenkante der Schenkel breiter oder schmaler geschwãrzt, die Schienen und die Spitzen der Fussglieder melır oder weniger gebräunt. Das Prosternum sclımal, vor'n seiclıt niedergedrückt, linten tiefer rimnenförmig, mit kurzem, zugerundetem hellgelloem Hinterende. Das letzte Segment des $\delta$ mil einer leiclıt niedergedrückten, stärker glänzenden Stelle, das q mit einer kleinen, rundlichen, mässig vertieften Grube.

Aus Brasilien, und dlort anscheinend nicht selten, weil in den meisten voll mir verglichenen Sammlungen vorhanden. (Mus. Pelrop. Mosqu. - von Eschscholz mitgebracht. - IIolm. Berol. IIalens. Riehl. Schaum. Vindob. Baly. Deyrolle. (lark). Im Mus. Deyrolle ist die Art unter der Benennung Pachybr. maculatus $D e j$. aufgefühırt.

47. M. fricator. Röthlich, der Kopf, ein Vorderfleck des derb zerstreut punktirten Halsschilds, eine Wurzelbinde und ein Hinterfleck der Flügeldecken mit den Beiıen schwarz, die Unterseite schwarzbunt; die Punktstreifen mässig, vorn gestört, mit flachen, etwas glänzenden Zwisclıcuräumen. L. $1 \frac{1}{2} "$ "; Br. 3/4".

Die vorliegende Art kommt eimzelnen Formen der folgenden sehr nahe, und könute deshalb leicht auch nur für eine Form der- 
selben gehalten werden, scheint mir aber doch durch den Bau des Halsschilds und die sehr gleichförmige Zeichnung der Deckschilde von derselben ausreichend verschieden. Der Kopf flach, der ganzen Länge nach eingedrückt, und im Grunde dieses Eindrucks noch von einer feinen Stirnlinie durchzogen, die Punktirung oben sehr deutlich, unterwärts dichter; die Farbe schwarz mit mässigem Glanze, die Oberlippe und ein äusserstes Pünktchen in den Augenbuchten röthlichgelb. Die Fühler kurz und dünn, das Wurzelglied länglich eiförmig, das zweite kugelig, das dritte doppelt länger als das zweite, das vierte noch etwas länger, und demselben je die drei folgenden gleich, die oberen wieder etwas verkŭrzt, vom siebenten ah stärker erweitert und zusammengedrückt, mit kurzem breitem Fortsatze des Endglieds. Die Farbe der sechs unteren gelblich mit gesclıwärzter Wurzel des ersten Gliedes und rauchbräunlich überlaufener Oberseite der folgenden, die oberen schwarz. Das Halsschild breit und flach gewölbt, doppelt breiter als lang, vorn seitlich stark zusammengedrückt und dadurch über den scharf spitzwinkligen Vorderecken verschmälert, die Seiten fein gerandet, in der Mitte schwach erweitert, vor ihr leicht ausgeschweift, die Hinterecken etwas eingezogen, stumpfwinklig und mit einer kurz vorspringenden Schwielenzpitze besetzt, der Hinterrand doppelt ausgebuchtet, etwas niedergesenkt, mit kurzem, breit zugerundetem Hinterzipfel. Der Rücken hinter dem Vorderrande etwas eingeschnürt, daher letzterer zwischen den Augen leicht schwielig erhöht; auf der Mitte jederseits ein kurzer Quereindruck, und ein zweiter, schwächerer vor dem Hinterwinkel. Die Punktirung derb, aber zerstreut mit glänzendem Zwischengrunde, die Farbe ein fahles Rothgelb, ein hinterwärts abgerundeter verkehrt dreieckiger Vorderfleck, zwischen den Augen an den Vorderrand gelehnt, schwarz. Das Schildchen stark ansteigend, kurz und breit dreieckig, hinten mit deutlichem Hinterzipfel grade abgestutzt, gleichfalls schwarz. Die Deckschilde flach gewölbt, hinterwärts ein wenig erweitert, hinter der scharf erhôhten Vorderkante quer eingedrückt, und dieser Eindruck auf jeder Flügeldecke innerseits der länglichen Schulterbeule nach hinten dreieckig erweitert, die Seitenlappen ziemlich lang herabgezogen und die hintere Wölhung sehr schräg abfallend. Hinter dem Schildchen auf der Naht ein flacher, breit herzförmiger Eindruck. Die Punktstreifen von mãssiger Stärke, vorn durch Verdoppelung gestört, die seitlichen auch 
noch über die Mitle hinaus etwas verwirrt und alle erst auf der Wölbung klar entwickelt, ;ort aber auch sehr fein und fast erlosrhen; die Zwischenräune §lach, mit mässigem Glanze. Die Farbe gleichfalls fahl rothgelb, eine jederseits abgekürzte, seitlich his zum Aussenrande der Schulterbeule, hinterwärts bis zum Anfange des zweiten Inittels oder Viertels der Flügeldeckenlänge reichende, zuweilen einen schmalen Nahtsaum freilassende Wurzelquerbinde schwarz, und dieselbe Färbung zeigt ein grosser rundlicher an den Aussenrand gelehnter, aber dessen aufgebogenen Saun frei lassender Hinterfleck, manchmal von solcher Grösse, dass er von Spitze, Naht und Vorderbinde nur noch durch einen schmalen bandförmigen rothgelhen Zwischenraum getrenıt wird. Das Pygidium fein purktirt, dünn greishaarig, schwarz, mit breit fahlröthlichem Saume. Auch die Unterseite fein runzlig punktirt, dünn behaart; ein hreiter Rand des Hinterleibs hellgelb, und dann noch ein ehen so breiter bogenförmiger Innensaum jenes Randes gebräunt, innerhalb dessen das grosse Mittelfeld des Hinterleibes roströthlich erscheint. Die Hinterbrust schwarzbraun, ihre verwaschene Mitte nebst den Parapleuren und Schulterblättern roströthlich; auch die hinten rinnenförmig vertiefte Vorderbrust schwarzbraun mit rostrothem breit abgerundetem Hinterzipfel. Die Beine schwarz, die Hüften und Schenkelwurzeln, bei einem der vorliegenden Stücke auch die Wurzeln der Schienen geröthet, die Vorderschienen stets wenigstens gebräunt. Das letate Segment des + mit einer mässig tiefen, rundlichen Grube; das ठ unbekannt.

Aus Brasilien (Mus. Hamburg. Lacordaire. Deyrolle).

48. M. nigro-ornatus Stål. Schwarz mit weissem Stirnfleck, das zerstreut punktirte Halsschild und die Flügeldecken weiss, jenes mit drei, diese mit zwei schwarzen Flecken, oder schwarz, ersteres mit vier, diese mit zwei weissen Flecken, Pygidium und Hinterleib weiss gerandet; die Punktstreifen vorn durch überzählige Punkte getrübt und gestört, hinten deutlicher, mit flachen, glänzenden Zwischenräumen. L. $11 / 3-13 / 4{ }^{\prime \prime \prime}$; Br. $5 / 6-11 / 6{ }^{\prime \prime}$.

Pachybrachys nigro-ornahus Stål Till Kännedomen etc. in der öfversigt etc. S. 62 . n. 5 !

Wiederum eine der veränderlichsten Arten, nicht blos dieser Gattung, sondern überhaupt der ganzen Familie, die sich in den Sammlungen unter sehr verschiedenen Benennungen findet, und deshalb auch schon zur Aufstellung einer ganzen Reihe von unech- 
ten Arten Anlass gegeben hat. Der Kopf flach mit etwas zurücktretendem Nacken, die Stirnrinne breit und seicht, das Kopfschild unten etwas eingezogen, oben nur undeutlich algegränzt. Die Punktirung oberwärts zerstreut, auf dem Kopfschilde runzlig zusammengedrängt. Die Augen schmal aber tief ausgerandet, bei dem $\delta$ einander merklich genähert, ohne jedoch zusanmenzustossen, bei dem $\subsetneq$ doppelt weiter entfernt. Die Farbe des Kopfes glänzend schwarz, die in der Mitte gebräunte Oberlippe, ein kleiner rundlicher Fleck zwischen den Augenbuchten, seltener noch eine unscheinbare Bogenlinie jederseits am oberen inneren Augenrande weiss. Dieselbe vergrössert sich zuweilen, und zwar ohne Rücksicht auf die übrige Körperfärbung zu einem verkehrt dreieckigem weisslichen Flecke, der bei einem der vorliegenden Stücke nur auf der rechten Seite vorhanden ist, und noch seltener fliessen alle diese Flecke zu einer weissen Gesammtfärbung des Kopfes zusammen, während andrerseits auch zuweilen der weisse Stirnfleck zu einer schwachen weisslichen Längslinie zusammenschwindet. Die Fühler des $\delta$ von etwas üher halber Körperlänge, das $q$ ein wenig kürzer, das zweite Glied kurz birnförmig, die folgenden allmählich vergrössert, aber auch das längste (fünfte) kaum dreimal länger als das zweite, das Endglied mit kurz dreieckigen Fortsatze; dabei die oberen Glieder etwas zusammengedrückt und erweitert. Die Farbe schwarz, Unterseite und Spitzen der unteren Glieder sclımutzig gelb oder hei dunkleren Stücken gebräunt. Das Ilalsschild kurz und breit, mehr wie zweimal breiter als lang, oben sehr flach mit kaum gebogener Mittelfirste, über den scharfen Vorderecken etwas zusammengedrückt und dadurch mit kurzer Rundung verschmälert, die fein gerandeten Seiten in der Mitte schwach zugerundet und vor ihr selır seicht ausgeschweift, mit stumpfen, wieder etwas eingezogenen Hinterecken; der Hinterrand schwach doppelt ausgebuchitet, der Mittelzipfel schmal und vor demselben jederseits ein seichter Quereindruck. Die Punktirung derb aber zerstreut, mit glänzendem Zwischengrunde, bei zunehmender schwarzer Färbung dichter gedrängt. Das Schildchen ku!̣ und breit Ireieckig, schräg ansteigend, mit flach niederliegendem Hinterzipfel grade abgestutzt, fein punktirt, schwarz. Die Deckschilde wenig breiter als das Halsschild, etwa um $1 / 3$ länger als breit, sehr flach gewöllht, hinter der scharfen Vorderkante seicht quer eingedrückt, mit länglichen, flach höckerigen Schulterbeulen; der Rücken um 
das Schildchen ein wenig aufgetrieben, hinter ihm quer niedergedrückt, mit wenig vortretenden Seitenlappen. Die Punktstreifen vorn sehr ungeordnet, durch überzählige Punkte verdoppelt und verdreifacht, unterbrochen und gestört, nur die äusseren etwas regelmässiger, die oberen von der Mitte ab etwas deutlicher, aber auch allmählich schwächer und zuletzt auf der Wölbung erloschen; der Raum zunächst der Naht dicht und grob punktirt. Die Streifen des $\delta$ ungleich dichter, mehr verwirrt, die Punktirung daher auf del vordern Hälfte fast siebartig zusammengedräıgt. Die Zwischenräume flach und glänzend. Die Färbung hietet vom einfarbigen Weiss bis zum fast ehenso einfarbigem Schwarz eine Reihe von Abäıderungen, und es scheint mir deshalb am zweckmässigsten, dieselben nach ihrem inneren Zusammenhange ohne Rïcksicht auf die Häufigkeit ihres Vorkommens zu ordnen, und dabei gleichzeitig der in der Färbung des Halsschilds vorliegenden Verschiedenheiten zı gedenken. Jene Abänderungen sind nun:

$\alpha$. Deckschilde rein weiss oder (bei anscheinend alten Stücken) ins Gelbliche fallend. Das Halsschild ist dann entweder gleichfalls rein weiss, zuweilen, besonders in der Mitte mit einem schwach angedeuteten gelblichen oder röthlichen'verwaschenen Wollienflecke; oder auf der Mitte des Halsschildes erscheint ein verkehrt dreieckiger, mit der Grundlinie am Vorderrande zwischen den Augen ruhender, mit alggerundeten Seiten hinterwärts schildförmig zugespitzter, den Hinterrand nicht erreichender schwarzer Fleck, neben welchem zuweilen jederseits am Hinterrande sich ein schwaches bräunliches Fleckchen bemerklich macht.

$\beta$. Deckschilde weiss, die Schulterbeulen mit einem feinen schwarzen Punkte bezeichnet, die Flügeldecken auf der Wölbung mit einem schräg nach hinten und aussen gerichteten schwarzen Flecke zwischen dem 4. und 9. Punktstreifen; das Halsschild wie bei den zuletzt erwähnten Stücken der var. $\alpha$, mit denen die vorliegende Form im Mus. Deyrolle unter dem Namen Pachybr. occipilalis Chv. verbunden war.

$\gamma$. Die Flügeldecken mit zwei grossen schwarzen Flecken, der vordere ein viereckiger Querfleck hinter der Wurzelkante zwischen dem zweiten und neunten Streifen, innerseits der Schulterbeulen ineist etwas ausgerandet und dadurch seine Entstehung aus zwei zusammengeflossenen Flecken andeutend, der hintere ein halbrunder Fleck von der Mitte bis über die Wölbung hinausreichend; alle 
Flecke zugleich brandig gesäumt, und von Naht, Wurzel und Aussenrand durch einen schmäleren, von einander und der schwarz gesäunten Spitze durch einen etwas hreiteren Zwischenraum getrenut. Auf dem Halsschilde erreicht der schildförmige Mittelfleck mit seiner Spitze den Hinterrand und jederseits von ilsm liegt auf dem letzteren ein kürzeres, gleichfalls schwarzes Längsfleckchen. Diese Form, deren Zeichnung bei schlecht ausgefärbten Stücken nicht. schwarz, sondern braun erscheint, ist der eigentliche von Stål a. a. 0. beschriebene Pach. nigro-ornatus, und sie gehört zu den weniger seltenen: sehr selten dagegen sind Stücke, bei denen unter vollstäıdiger Ausfärbung der Deckschildsflecke die Zeichnıngen des Halsschildes nicht schwarz, sondern rostroth ersclieinen.

$\delta$. Die Flecke der Flügeldecken sowveit vergrössert, dass der vordere Vorderrand und Naht erreicht und sich dadurch eine gemeinsame, von einer Schulterbeule zur andern reichende schwarze Wurzelbinde bildet; auch die hinteren Flecke erreichen Naht und Aussenrand, beschränken das Weiss der Spitze auf ein Fleckcheu im Nahtwinkel, und fangen an, längs der Naht durch einen bräunlichen Schatten mit der Vorderbinde zusammenzufliessen, bis endlich letzteres wirklich erfolgt und sich auch hier die breite Naht ehen so intensiv schwarz färbt. Weiss bleibt danı auf der Flügeldecke nur noch jener Spitzenfleck und eine innerseits abgekürzte Querbinde auf der Mitte, deren Aussenende sich an den hier weiss verbliebenen Seitenlappen nebst dem vordern Theile des neunte.ı Zwischenraums anschliesst und mit diesem einen schmalen vorn bis zur Schulter reichenden Hakenfleck bildet. Das Halsschild wie bei $\gamma$, oder die beiden hinteren Fleckchen mit ihren oberen Innenenden den Schildfleck erreichend, wodurch neben dem Hinterrande des letzteren vor dem Mittelzipfel zwei kleine weisse Fleckchen abgesondert werden. Diese Form ist P. marginiventris Chv. apurl Deyr.; bei Stücken mit bräunlicher verwaschener Verbindung zwischen der hinteren und vorderen Flügeldeckenzeiclınung ist auch die Halsschildszeichnung oder doch ihr hinterer Theil nicht selten mehr oder weniger gebräunt.

$\varepsilon$. Auf den Flügeldecken schwindel auch der vordere Arm des Hakenflecks und von der bei $\delta$. erwähnten weissen Querbinde bleibt nur der innere Theil als ein abgerissener Querfleck übrig. Die Flügeldecken sind sonach schwarz mit zwei vereinzelten weissen Punkten $(1,1$.$) . Stücke mit grössern Punkten zeigen, die Hals-$ 
schildszeiclınung der var. $\gamma$; werden die Punkte kleiner, so dehnt sich auch die schwarze Färbung des Halsschilds aus, der weisse Seitenrand wird selır schmal, vor dem Hinterrande erscheinen die beiden vereinzelten weissen Fleckchen, welche Form einzelnen $\delta$ des Scolochrus fallax m. täuschend ähnlich wird, und endlich verschwinden auch diese Punkte ganz, und das Halsschild wird schwarz mit einem sehr zarten, zuletzt sich auf die weissen Vorderecken beschränkenden Seitenrande. Diese, keinesweges seltene Form bildet den Pachybrachys pustuliger Stål a. a. 0. n. 3! und kommt ausserdem in den Sammlungen unter dem Namen Pachybr. funebris Dej. vor. $S l_{a ̊ l}^{0}$ erwähnt sowohl die Stücke mit den beiden weisseı Halsschildfleckchen, als olme dieselben. Weiter

$\zeta$. verschwindet auch der vordere Fleck der Flügeldecken, so dass nur zuweilen noch eine bei scharfer Vergrösserung erkennbare Spur übrig bleibt, und die Deckschilde erscheinen schwarz mit weissem Spitzenflecke. Bei einem mir vorliegenden Stücke dieser anscheinend selteneren Form ist das Halsschild schwarz mit schmalem, vorn etwas verbreitertem Seitenrande; bei einem zweiten zeigt es zwei vereinzelte weisse Fleckchen vor dem Hinterrande und jederseits über dem Auge den Rest eines schmalen weissen Vordersaums, bei zwei Stüclien ist es ganz schwarz. Endlich

$\eta$. schwindet bis auf den weissen Stirnfleck alles Weiss, und der Käfer ist ganz sclıwarz; ein einziges $\delta$ in Mus. Clark, wie denn überhaupt diese überwiegend schwarzen Stücke vorzugsiveise $\delta$ sind.

Das Pygidium weiss, oben schwarz gesäumt, oder durch das Eindringen dieses Saums in die Mitte die weisse Färbung lappig zerrissen, bei dunkleren Stïcken letztere auf einen oder zwei getrenute Flecke beschränkt, oder auch ganz verdrängt; die Unterseite gleichfalls dicht und fein runzlig punktirt, schwarz, der Hinterleib meist breiter oder schmäler weiss gerandet, oder auch nur der letzte Bauchring weiss gesäumt, selten ganz schwarz. Auch die Beine schwarz mit gebräunten Hüften, das Prosternum breit und flach, hinten längsrinnig. Das letzte Segment des $\delta$ quer niedergedrückt, des $q$ mit der gewöhnlichen Grube.

Aus Brasilien und dort, wie es scheint, nicht selten, daher in den meisten Sammlungen vorhanden. (Mus. Saunders. Halens. Berol. Holm. Baly. Clark. Vindob. v. Bruck. Deyrolle. Schaum. Dohrn.) 
Neunte Rotte. Körper von mittlerer Grösse, das Halsschild quer aufgewölbt, in der Milte etwas erweitert, mit kurzen Quereindrücken. Die Deckschilde schmal verkehrt eiförmig, hinterwărts ein wenig verschmälert; die Augen auch bei den $\delta$ weit getrennt. Die Färbung oben schwarz- und rothbunt mit weissen Längsbinden, unten schwarz oder weiss. Wenige, durch ihre auflallenden Farben ausgezeichnete Arten aus Brasilien.

49. M. pollinctor m. Schwarz, eine Querbinde im Nacken und das vierfach schwarzgefleckte, vereinzelt grob punlitirte Halsschild roth, die Naht, eine Längsbinde der Flügeldecken und der Kiel des Seitenlappens, eine Querbinde des Pygidiums und der Hinterleibsrand weiss; die Punktstreifen fein, linten erloschen, mit flachen, fein querrunzligen Zivischenräumess. L. $2-2^{3 / 4}{ }^{\prime \prime \prime}$; Br. $11 / 6-1 \frac{1}{2}{ }^{\prime \prime \prime}$ !

Der Kopf breit und flach, mit fein eingeschnittener Stirnlinie, die Oberfläche durch eine dichte Punlitirung matt, schwarz, mit bräunlicher, weiss gerandeter Oberlippe und pechbraunen Mundtheilen; die breit uud tief ausgebuchteten Augen auch bei dem $\delta$ weit getrennt, und über ilınen am oberen Stirnrande eine wellig gebogene, niit den schmaleren Ende jederseits den oberen Augenrand umziehende bleich röthliche Querbinde. Die Fühles von halber Körperlänge, ziemlich dünn, das Wurzelglied aus sehr schlanker Basis starli kenlig aufgetrieben, etwa doppelt länger als breit, das zweite kurz und fast kugelig, die drei folgenden schmal verkehrtkegelförmig, das dritte fast doppelt länger als das zweite, das vierte dem zweiten und dritien zusammen gleich, das fünfte noch etwas länger, das sechste so lang wie das fünfte, das siebente und achte wiederum einander gleich und je noch ein wenig länger als das fünfte, das neunte und zehnte wieder je dem fünften, und das Endglied mit seinem stumpfen Fortsalze dem siebenten gleich. Die oberen rom sechsten ab breit zusammengedrüclit und erweitert, was besonders bei dem Endgliede stark ins Auge fällt. Die Farbe der unteren bis zur Mitte der fünften schmutzig gellbbraun mit stark geschwärzter Oberseite des Wurzelyliedes, die oberen schwarz. Das Halsschild breit walzenförmig und etwa doppelt breiter als lang, hinter der Mitte sanft quer aufgewulstet und ron da ab nach vorn in leichter Krümmung, hinterwärts stärker abfallend, über den rechtwinkligen und dann noch in eine kurze, schwielige Spitze vorgezogenen Vorderecken zusammengedrückt und dadurch ver- 
schmälert, die Seiten fein geraudet, in der Mitte nur leicht auswärts gekrümmt, die wieder etwas eingezogenen Hinterecken stumpf abgerundet, -und der Hinterrand jederseits des kurzen, etwas aufgebogenen Mittelzipfels breit ausgebuchtet; vor ihm auf jeder Seite eiı kurzer seichter Quereindruck. Die Punktiruug grob, aber selır zerstreut mit mässig glänzendem Zwischengrunde, die Farbe ziegelroth, jederseits der Mitte ein grosser, länglich viereckiger, hinten und aussen leicht ausgebuchtetes schwarzer Fleck, und ein zweiter kleinerer, mehr runder Flıck jederseits zwischen dem ersteren und der Mitte des Seitenrandes. Das Schildchen schräg ansteigend, etwas breiter als lang, hinterwärts wenig verschmälert, mit deutlich dreieckigem 'Hinterzipfel fast grade abgestutzt, äusserst fein punktirt und belıaart, schwarz. Die Deckschilde flach walzenförniig, etwa $1 / 4$ länger als breit, hinterwärts nicht stark verschmälert, hinter der scharf erhöhteı Vorderkante seicht quer eingedrückt, und dieser Eindruck innerseits der flachen Schulterbeulen nur wenig hinterwärts erweitert, auch die Seitenlappen nur schwach entwickelt. Die Punktstreifen vorn ziemlich regelmässig, stellenweise durch üherzählig eingemengte Punkte verdunkelt oder doch gestört, bei dem o etwas schwächer, vom Anfange des letzten Drittels ab fast ganz regeluässig aber auclı immer melı ahgeschwächt, und auf der Wölbung von ilmen nur noch schwache Spuren vorhanden: die Zwischenräume flach, sehr dicht und fein quer gerunzelt, daher matt und kaum seidenartig schimmernd; ausser dem hellgefärbteı vierten Zwischenraume auch noch der zweite unter gewisser Beleuchtung leichıt erhöht. Die Farbe ein reines, tiefes Sclıwarz, die Naht und eine den vierten Zwischenraum einnehmende', mit jener im linteren Nahtwinkel zısammentreffende Lïngsbinde auf jeder Flügeldecke, endlich anch noch der Kiel des Seitenlappens mit diesem selbst weiss, zuweilen mit bleich röthlichım Anfluge. Pygidium und Unterseite sehr dicht und fein punktirt, kaum behaart, mit den Beinen sclıwarz, eine Querbinde des ersteren und an diese siclı anschliessend der Seitenrand des Hinterleibes bis zu dessen seitlichen Vurderzipfelı gleichfalls weiss. Das Prosternum groh runzlig punktirt, lang greishaarig, hinter der Mitte gefurcht. Das letzte Segment des $\delta$ in der Mitte mit einer seicht niedergedrückten glänzenden Stelle, des $\&$ mit der gewöhnlichen, verhältnissınässig kleineı Grube. 
Aus Brasilien (Mus. Baly. Berol., die Stücke des letzteren von Sello bei Caasapava gesammelt.)

50. M. moerens m. Schwarz, eine Querbinde im Nacken und das doppelt schwarz gefleckte, vereinzelt punktirte Halsschild bleich röthlich, die Nahıt, eine breite Lāngsbinde der Flügeldecken und ein breiter Rand des Hinterleibes weiss; die Punktstreifen fein, hinten erloschen, mit flachen, fein querrunzligen, seidig schimmernden Zwischenräumen. L. 2"'; Br. 11/12"'.

Dem vorheschriebenen M. pollinctor täuschend ähnlich und voll ihm eigentlich fast nur durch Unterschiede in der Farbenvertheilung abweichend, aber doch nach meinem Dafürhalten eine von jener wolıl unterschiedenen Art. An Grösse gleicht er, $\delta$ mit $\delta$ verglichen, den kleineren Stücken des M. pollinctor, und ist dabei wohl noch etwas schmaler; die Punktstreifen sind etwas feiner, schon fast von der Mitte ab erloschen, die Zwischenräume daher auch etwas glänzender; dagegen ist die breite weisse Nahtbinde bis über die Häfte mit einer ziemlich dichten Punktirung bedeckı, während sie bei der vorhergehenden Art fast glatt erscheint. Eben so ist auch die Punktirung des Halsschildes ungleichmässiger vertheilt und vor dem Hinterrande merklich dichter gedrängt als auf der Mitte, und der Kopf bei nur leicht eingedrückter Stirn dicht siebartig punktirt. Den Hauptunterschied bildet allerdings die Farbenvertheilung, und diese gestaltet sich so, dass die lichte Färbung auf dem Kopfe weniger, an den ührigen Theilen der Oberseite mehr ausgedehnt ist, als bei der vorhergehenden Art. Die Oberlippe ist viel trüber greis, die weisse Querbinde auf dem Oberkopfe bricht jederseits am oberen Augenrande ab, ohne sich, wie bei II. pollinctor, längs demselben fortzuziehen und dadurch einen halbkreisförmigen schwarzen Nackenfleck abzuschneiden. Auf dem Halsschilde finden sich nur die beiden mittleren schwarzen Längsflecken vor, erweitern sich aber nach vorn und hinten - so sehr, dass vorn nur ein sehr schmaler, linten ein kaum merklicher, nur verwaschen lichterer Saum übrig bleibt; auch am Aussenrande ist jeder dieser Flecke dadurch verbreitert, dass die bei dem volhergehenden hier vorhandene, dem Aussenflecke gegenüber liegende Ausrandung vollständig ausgefüllt erscheint. Auf den Flügeldecken ist die weissliche Naht- und Mittelbinde merklich breiter, der umgeschlagene Rand des Seitenlappens ganz weiss, nicht wie bei dem vorigen fein schwarz gesäumt, und die helle Färbung des Kiels 
greift auch ein wenig auf den neunten Zwischenram über. Dabei fällt auch diese weisse Zeichnung der Deckschilde, wie die des Halsschilds, etwas ins bleichröthliche und ist dadurch viel weniger von der des Halsschilds verschieden, als dies bei jener Art der Fall ist. Endlich ist das ganze Pygidium weiss, der helle Saum des Hinterleibes ungleich breiter als bei M. pollinctor, und auch diese Färbıng mit deutlich röthlichem Anflıge. Alles übrige wie bei der genannten Art. Das letzte Segment des ơ einfach, auf der Mitte geschwärzt, wenn auch nicht so breit wie bei der vorhergehenden Art, und auch nicht eingedrückt; das of unbekannt.

Im Mus. Clark ist Brasilien fraglich als die Heimath des Käfers angegeben; ich zweifle jedoch an der Richtigkeit dieser Angabe nicht.

51. M. ag ouista m. Rostroth mit gelbem Pygidium und Hiıterleibe, Fühler, Füsse, die Seiten und sechs Längsflecke des grob zerstreutpunktirten Halsscliildes mit den Flügeldecken schwarz, drei Läugsbinden des ersteren, der Rand und eine Längsbinde der letzteren weiss; die Punktstreifen derb und ziemlich regelmässig, stellenweise verdoppelt, mit flachen gläızenden Zwischenräımen. L. $3^{\prime \prime \prime} ;$ Br. $12 / 5 "$.

Noch etwas bunter, als die vorluergehenden, bei etwas grösserer Länge schmaler, mit gröheren Punktstreifen, übrigens ihuen sehr nahe verwandt. Des Kopf flach, die Stirn der Länge nach seicht niedergedrückt, mit deutlicher Stirulinie, das Kopfschild etwas eingezogen, die Punktirung ziemlich fein aber dicht, daher der Glanz nur matt. Die Farbe rostroth, die Rander der Oberlippe verwaschen knochengelb, die Tasterenden gebräunt, die breit und tief ausgebuchteten Augen schwarz; die Augenbuchten selbst und die Wangen etwas bleicher geröthet. Auch die, etwa $3 / 4$ der Körperlänge erreichenden Fühler schwarz, das zweite und dritte Glied auf der Unterseite geröthet und nebst dem vierten zugleich an der Spitze röthlich durchscheinend, von ihnen das dritte $1 \frac{1}{2}$ mal, das vierte doppelt läıger als das zweite, das fünfte und die folgenden bis zum zehnten je dem $2 \frac{1}{2}$ fachen zweiten gleich, das linealische Eudglied mit seinem langgestreckten Fortsatze fast so lang als das dritte und vierte zusammengenommen: dabei die oberen vom sechsten ab etwas zusammengedrückt, aber doch nur wenig verbreitert. Das Halsschild etwa um $1 \frac{3}{4} \mathrm{mal}$ länger als breit, hinter der Mitte quer aufgewölbt, und von da ab nach vorn stärker-, linterwårts 
sanfter abfallend, über den spitzwinkligen Vorderecken breit zusammengedrückt und verschmälert; die Seiten gerandet, in der Mitte flach bogig erweitert und vor ihr, wie hinter ihr nach den scharf stumpfwinkligen wieder etwas eingezogenen Hinterecken zu sehr leicht ausgeschweift; der Hinterrand doppelt ausgebuchtet mit liurz aufgebogenem Mittelzipfel. Vor dem letzteren jederseits ein sehr flacher, nach aussen oberhalb der Hinterwinkel etwas verstärkter Quereindruck, und ein zweiter etwas derberer vor jenem über der Mitte des Seitenrandes gegen den Vorderwinkel hinabziehent. Die Punktirung grob und zerstreut, in den Eindrücken etwas dichter zusammengerïckt, mit lackglänzendem Zwvischengruıde; die Grundfarbe rostroth, eine Mittel- und jederseits noch eine breite Scitenbinde weiss, der Zeichnung des oben beschriebenen il. albivittis ähnlich. Ausserhalb der letzteren ist der schmale abgesetzte Seitenrand nebst der über ihr liegenden in die Randlinie eingedrückten Punktreihe bis auf die rötllich verbliebene Spitze der Vorder- uud Hinterecken schwarz; dann aber liegt noch aı der Innenseite jeder Seitenbinde cin von vorn bis über die Hitte hinausreichender, hinterwärts abgeschıächter schıvarzer Läıgsfleck, gewissermassen eine unausgebildete Immenbinde, und an der Mittelbinde jederseits ein schwarzer Fleck an Vorderrande und ein zweiter hinter der Mitte, auch hier je eine Art unterbrochener Längsbinde bildend. Das Schildchen ınit schwacher Krümmung sehr schräg ansteigend, quer viereckig, hinterwärts mit ausgebuchteten Seiten verschmälert und mit deutlichem Hinterzipfel grade abgestutzt, glänzend rostroth. Die Deckschilde walzenförmig und hinterwärts etwas verschmälert, mit flach gewölhtem Rücken und hinten sanft abfallender Wölbung, hinter der Vorderkante nur in einer schwachen Querlinie eingedrückt, auch Sclıulterbeulen und Seitenlappen nur wenig entwickeht. Die Punktstreilen vorn kräftig, etwas wellig und längs der Naht durch üherzählige Punkte gestört, der sechste und siebente schon auf ter Mitte abgebrochen, unt auch die übrigen von da ab ınerklich abgeschwächt; die Zwischenräıme flach uncl glänzend, die Spitze unter der Wölbung spiegelglatt. Die Farbe schwar", eine gemeinsame breite aber die erhöhte Nahtkante schwarz lassende Nahtbinde, der unten fein schwarz gesäumte Seitenlappen und eine an letzteren sich anlehnende, aber den zehnten P'unktstreifen und die hintere Hälfte der Aussenkante freilassende Randbinde, endlich noch eine zwischen dem vierteu 
und sechsten (hinterwärts dem achten) Punktstreifen liegende, in der Spitze mit den beiden anderen zusammenstossende Mittelbinde weiss. Pygidium und Hinterleib hellgelb mit stïlker gerötheter Mitte des letzteren, die Brust rostroth, die vorderen Nähte der Ilinterbrust und die Parapleuren zunächst an den Seitenlappen geschwärzt. Auch die Beine rostroth, die Füsse, die untere IIälfte der Schienen, und die erhühten, die Vorderbrustrimıe hegränzenden Pfannemränder der Vorderfüsse schwärzlich. Itas letzte Segment des \& mit einer tiefen, hinter fast grade abgestutzten Grolse.

Aus Brasilien (Virmont in Mus. Berol.)

Zehnte Rolte. Körper gross und etwas plump, gestreckt walzenförmig nit ziemlich stark abgeflachtem, nach vor'n liegelförmig verschmälertem Ilalsschilde; die Färbung oben lehmgelb mit schwarzen Fleckenzeichnungen, unten meist schwarz. Arten aus Brasilien und Patagonien.

52. M. patagonicus Guér. Bleichröthlich gelb, Nacken, Schildchen, sechs manchmal zusammenfliessente Flecke des zerstreut punktirten IIalsschilds und sechs der Flügeldecken (2, 2, 2, schwarz; die Punktstreifen inässig, vorn durch überzählige Punkte gestört, hinten verschwindend, mit llachen, etwas narbigen und glänzenden Zwischenräumen. L. $3 \frac{1 / 2}{2}-4 \frac{1}{4}{ }^{\prime \prime \prime} ; \mathrm{Br}$. 1 1/2-2"'.

Eine grosse, durch den selır gestreckten, vorı verschmälerteı und ahgeflachten lïrpuer etwas auffallende Art, die mir zwar in mehreren, aber durchgängig schlecht erhaltenen Stücken vorliegt, und derer Beschreiluung deshalb wohıl später noch mancher Ergäızung bedürfen wir't. Der Kopf flach, mit ungleichmässig vertheilter, zerstreuter Punktirumg und stark glänzendem Zwischengrunde, die breite Stirn von einer gleichfalls Jreiten, aber flachen Stirulinie durchzogen, die Augen breit und tief dreieckig ausgebuchtet. Die Farbe bleichrötlılich-lehıngelh, der Nacken und zuweilen noch eine von ilhm ausgehende auf der Stirnsime liegende Längslinie, nebst einem Flecke auf der Oberlippe und je über den Fühlerlı̈ckern, auch die Tasterenden sclıwälzlich. Die Fühler von $\% / 3$ der Körperlänge und ziemlich kräftig, unten dünn, nach oben mässig verbreitert und zusimmuengedrüclit, diłs Wurzelglied liur'\% eiförmig aufgetrieben, das zweite kugelig, das dritte melır als doppelt-, das vierte dreimal länger als das zweite, das fümfte noch elwas vergrössert, und diesem die oberen Glieler gleich, letatere zugleich ïber der Mitte mit gerundeter Aussenseite etwas erwriXVI. 
tert, das Endglied mit breit dreieckigem Fortsatze. Die Farhe der unteren Glieder bräunlich mit heller geringelter Wurzel und Spitze, die oberen vom vierten ab schwarz. Das Ialsschild um die Hälfte breiter als lang, liuter der Mitte äusserst schwach quer aufgewulstet und leicht nach vorn abwärts gekrüımm, lıiıten jederseits mit einem sehr breiten und flachen, das Halsschild etwas zusanmendrückenden Schrïgeindruck, in dessen seitlich nach vor'ı und aussen verlängerter Richtung sich die nach vor'n stark zusammengeneigten Seiten in schwachem Bogen erweitern; die fast rechtwinkligen Vorderecken, wie lie stumpfwinkligen Hinterecken scharf, der Hinterrand leicht doppelt gehuchtet, mit kurzem, etwas aufgebogenem Mittelzipfel. Die Punktirung deutlich aber sehr zerstreut, längs der Mitte fast fehlend, seitlich etwas dichter gedrängt und zugleich noch kräftiger, mit einem überaus fein punktirten, stark glïnzenden Zwvischengrunde; die Farbe cin fahles, wie verschossenes, ins Lehmgelle fallendes Rothgell, der aufyeworfene Hinterrand fein schwäızlich gesäumt, und auf de!r Mitte jederseits ein atwas wellig gelirümmter, eigentlich ins drei, zuweilen stellenweise getrennteı Flecken zusammengesetzter Querfleck, heile auch wohl zı einer jederseits abgekïrzten, in der Mitte hiıterwärts zijfelig ansgezogenen Querbinde zusammengellossen. Das Schildchen stark ansteigend, breiter als lang, hinten stumpf abgerundet, mil dentlichem Hinterzipfel; die Olnerfläche mit vereinzelten feinen Pünktchen losstreut, glïnzend schwarz. Die Deckschilde lreit und flach gewölbt, ziemlich gleichlneit und etwa $1 / 4$ länger als loreit, hinter der scharf und besonders gegen das Schildchen zu breit erhöhten Vorderkante tief yuer eingedrücht; dic Schulterbeulen nur flach, die Seitenlappen tief' herabgezogen und über ihmen die Deckschilde stark zusammengedrückt. Hie Punktstreifen aus sehr vereinzelten Punkten gebildet, vorn zwischen Schulterbeulen und Naht durch ühorzihlig eingenengte, dem Schildchen zu etwas dichter gedrängle Punkte gestört ; die äusseren Streilon auch vorn deutlich; von der Mlitte ab werden die auch vorn nicht sehr kräftigen Punkte schwächer, die Streifen sellost dadurch r'egehnässiger, aber auch friner, his sıe aul' der Wöllonng last ganz erloschen sind. Die Zwischenl'̈̈m, flach, vorn leicht narbig gerunzelt, himterwäits glatter und dadurch anch elwas glänzenter. Die Farhe auch hier jenes verschossene rölhliche Lolumgelh, ein feiner Samm lïngs Naht, Spitzen und dem hinteren Theile des Aussemandes schwärzlich, und ausser'- 
dem zeigt jede Flügeldecke noch sechs schwarze Punkte in Irei Paaren von hinterwärts abrehmender Stårke; vonı ersteu Pare der äusser's 'iu Längsfleckchen auf der Schulterheule, der innere rundlich, zwisclıen jenem und der Naht, das zweite Paar hiıter der Mitte und das dritte unter ler Wölbung, und von diesen letzteren Paaren zuweilen ein oder der audere l'unkt zu einem unscheinbaren Wische algeschwächt oder auch ganz fehlend. Pygidium, Unterseite und Beine schmotzig lehngelb, die lıreite Mitte des Hinterleihes mit verwaschener Begräinzung schwarz, Hinterbrust und Paraplenren gleichfalls schwarz mit langer greiser Behaarung; an ıleı Beinen die Schienenenden und Fussglieder geschwärzt. Die Vorlerbrust linten lief ausgefurcht. Das letzte Segment des $\$$ mit einer grossen, rundlichen Grube, das o unbekanut.

Alle mir vorliegende Stücke (Mus. Dohrn. Clark. Berol.) haben nur die ganz allgemeine. Heimathsangabe: Palagonien, und stammen ihrer Beschaffenheit nach anscheinend aus einer und derselben Quelle. Das Exemplar des Mus. Berol. ist von Guérin selbst mitgetheilt worden. Ob die Art ron Guérin irgendwo beschrieben worden ist, lıabe iclı nicht erınitteln können, glaube es aber nicht, da sie in einem alten Goudot'schen Handelscataloge als (Tr. pat. Guérin Manuscr. aufgeführt ist. Nach demselben Cataloge stammt sie von der Halbinsel St. Joseph. (L. v. Heyden in litl.)

53. M. dodecastictus m. Oben gelb, die Fühler, ein zweilapuiger Nackenfleck, zwei Querflecke des zerstreut punktirten Halsschilds nebst dem Schildchen und fünf Flecke der Flügeldecken $(2,2,1)$ schwarz, unten schwarz, Hinterleibssand und Beine gelb; die Punktstreifen durch eine gleichstarke Zwischenpunktirung fast unkentlich, mit fein runzligpunktirtem Zwischengrunde. L. $3 \frac{11}{2}{ }^{\prime \prime}$; Br. $11 \frac{2}{\prime \prime \prime}$.

Dem vorhergehenden überaus ähnlich, llaher es nur einer genatueren Angabe der Abwreichungen hedürfen wird. An Grösse gleicht die Art den kleinsten mir vorliegenden Stïcken der vorhergehenden, ist dahei etwas melır walzenförmig, stärker gewöllht, und im Habitus an manche Clythriden aus der Gruppe der $\mathrm{Cl}$. macropus und 4punctala erınnernd. Die Punktirung des Halsschilds ist ein wenig feiner, noch melır vereinzelt, die fler Flïgellecken überaus feiı, diclıt zusammengedrängt, mit quer- unıl schrägrunzligen, fein nadelrissigen Zwischengrunde, welcher nur von den seitlichen Punktstreifen und den Ilinterenden der übrigen schwache 
Spuren wahrnehmen lässt. Ebenso bedeutend sind die Verschiedesheiten in der Färbung und Zeichnung der Oberseite. Jene ist ein reines, schönes Lehmgelb ohne den röthlichen Schein der vorigen Art; in der Zeichnung ist der schwarze Nackenfleck dreieckig ausgeschnitten und tritt deshalb mit zwei gerundeten Lappen auf die Stirn hinal, und das Halsscliild zeigt jederseits einen nierenförmigen, aber nicht gebrochenen, vorn teicht aısgebuchteten Schı̈ig月eck. Die schwarzen Junkte der Flügeldecken sind rleutlicher, sclıärfer begränzt, hei einem dler vorliegenden Stücke überaus gross und liriftig, aber auch bei diesem fehlt der Innenpunkt des dritten Paars, so dass füuf Punkte wohl als die normale Zeichnung der Hlügeldecken anzuschen sein werden; bei mehreren andern sind die Punkte kleiner, der innere des zweiten Paares fehlt, und von dem einzelnen Hinterpunkte ist nur eine schwache Spur vorhanden. Die Unterseite ist schwarz mit einem rein und breit gelhem Saume, dicht angedrückt silberhaarig; die Beine gell, mit etwas ins Röthliche fallenden Vorderschenkehn, das untere Drittel der Schienen mit den Füssen schwarz. Das Prosternum lang greisharig und hinten tief "rinnenförmig. Das letzte Segment des $q$ mit einer grossen halbkugeligen Grube, das $\delta$ unbekimnt.

\section{Aus Brasilien (Hus. Baly. Vindob. Berol.)}

54. M. p oll ens m. Lehmgelb, Fühler, Nacken, eine wellenfürmige Querbinde des zerstreut punlitirten Halsschildes und scclıs Punkte der Flügeldecken $(2,2,2)$ mit der Hinterbrust und der Mitte des Hinterleilss schwarz; die Punktstreifen fein, rorn durch, ïberzählige Punkte getrübt, mit flachen, querruzligen Zwischenräumen. L. $3 \frac{1}{1}{ }^{\prime \prime \prime}$; Br. 12/3" ".

Wiederum den beiden vorlsergehenden schr nahe verwandt, aher bei gleicher Länge doch merklich breiter, mul anch ausserdem an der Zeichnung von Kopf und Halsschild, dem liau des letzieren umıl der Scufptur der stärker abgeflachten Deckschilde leicht kemutlich. Der Kopf flach mit etwas eingezogenem Kopfischilde mul tiefer, lıreiter Stimlinic, ziemlich fein und zerstrent punktirt mit mässigem Glanze, lehmgelh; der Nacken und die damit zusammenhängende, bei cinem der vorliegenden Stücke miten Ireieckig repbreilerte Stirnlinie, ein sich je über den Fühlerhöckern zı einem Flecke erweiteruder Saum der Angen mud die Fülılerhücker sellıst sclıwarz, die kurz uncl hreit nierenfürmigen, tief ansgebuchtetru und auch bei dem of weit getrennten Angen greis. Die Fühler des 
$\delta$ fasi von liörperläıge, des $q$ kürzer, schwarz, das zweite bis vierte Glied auf ter Unterseite schmutzig greisgell. Das Wurzelglied kurz und stark aufgetrieben, nur etwa um die Ilälfte läıger als breit, das zweite schr kurz und lnotig, das dritte verkehrtkegelförmig und doppelt läıger als das zweite, das vierte $2 \frac{1}{4} \mathrm{mal}$ länger als das dritte, und ihm alle folgenden his zum zehnten gleich, letztere vom sechsten ab deullich zusammengedrückt, aber wenig erweitert, daher fast gleichbreit; das linienförmige Endglied mit scinem schmalen deutlich abgesetztem Fortsatze noch etwas verlängert. Das Halsschild kurz und breit walzenförmig, die Firste luinter deın zweiten Drittel der Länge sauft aufwärts gekirümınt, und dahinter das Mittelfeld leicht quer niedergerlrückt, der Rücken über den scharfen breit spitzwinkligen Vorderecken stark zusammengedrückt und dadurch verschmälert, die Seiten fein gerandet, nach vorn fast in graden Linien zusammenlaufend, mit stumpfwinkligen Ilinterecken, der Hinterrand doppelt ausgebuchtet, nit kurz aufgehogenem Hinterzipfel. Die Punktirung derb, aber sehr zerstreut und nu' seitlich etwas dichter zusammengerückt, mit ziemlich stark glänzendem Zwischengrunde. Die Farbe ein etwas ins verblichen Röthliche fallendes Lelımgelb, mit einer, ein plumpes flaches $(D$ darstellenden etwas winklig gebrochenen, zuweilen in der Mitte tuterbrochenen orler auch jederseits noch von einem vereinzelten Punkte begleiteten schwarzen Querbinde. Das Schildchen schräg ansteigend, ehen so lang als vorn breit, hinterwärts verschmäler' und grade abgestutzt mit deutlichem Hinterzipfel; sehr dicht und fein punktirt, fein greishaarig, schwarz. Die Deckschilde breil und flach walzenförmig, etwa um $1 / 3$ läıger als breit, hinter der scharf erhöhten Vorderkante schmal aber tief quer gefurclıt, dann bis zum Hinterende des、Schildchens leicht aufgetriebeı; die vorn kräftigen Schulterheulen hinterwärts bald verbreitert und verflacht, und hinter ihnen über den mässig entwickelten Sejtenlappen cin gleichfalls breiter und flacher, die Dechschilde etwas einengender Quereindruck. Die Punktirung fein, die Streifenbildung vorn durch überzählig eingemischte Punkte verdunkelt, erst gegen die Mitte hin deutlicher, die Streifen selbst aber von da ab soweit sich abschwächend, dass auf der Wöllıng kaum nach Spuren von ilmen vorhanden sind. Die Zwisclıenräume breil, flach, mil schwachem, besonders in der Mitte durch feine Querrunzeln noch melır gedämpftem Glanze. Die Farbe lehmgelb, nicht so stark 
ins Röthliche fallend wie die des Halsschilds, der Saum längs Naht, Spitze und Aussenrand bis zum Hinterende des Seitenlappens schwarz, und ausserdem auf jeder Fin̈gcldecke drei Paar schwarzer Punkte, wie bei M. patagonicus; vor'u ein grosser Längsfleck auf der Schulterbeule, und ein eben so grosser etwas quer gezogener zwischen jenem und dem Schildchen, auch die Flecke der zweiten Reihe gross und etwas in die Quere gezogen, grade hinter jenen stehend und der äussere an den schwarzen Randsaum gelehnt; die des letzten Paares nur kleiı und mehr punktförmig unter der Wölbung; bei dem einzigen vorliegenden $q$ nur der Schulterpunkt und das letzte Paar vorhanden. Das Pygidium deutlich punktirt, dünn behaart, mit Hinterleib und Beinen heller knochengelb, der mittlere Theil der vorderen Bauchringe breit und verwasclıen geschwärzt. Die Brust schwarz mit dümner, greiser Behaarung, die Schienenspitzen schmutzig gebräunt und dic Füsse schwärzlich. Das Prosternum grob rumzlig punktirt, lang greishaarig, der Länge nach hinten deutlich riunenförmig. Das letzte Segment des $\delta$ mit einer leicht eingedrückten, rundlichen, glänzenden Stelle, das $f$ mit einer tiefen, gleichfalls runden Grube.

Aus Brasilien (Mus. Baly. Berol.) und Corrientes (Mus. Clark.

55. M. incultus m. Schwarz, unten dicht silberhaarig, das zerstreutpunktirte Halsschild und die Flügeldecken lehmgelb, eine unterbrochene Querbinde des ersteren und ein Schulterpunkt nebst einem hinteren Schrägflecke der letzteren schwarz; die Punktstreifen durch eine gleichstarke Zwischenpunktirung vorn fast unkenntlich, hinten schwach angedeutet, mit fein runzlig punktirtem Zwischengrunde. L. $3 \frac{1}{4}{ }^{\prime \prime \prime}$; Br. $1 \frac{1}{2}{ }^{\prime \prime \prime}$.

Bei gleicher Breite mit dem vorhergehenden ein wenig kürzer, in der Sculptur der Deckschilde fast ganz mit lem M. dodecastictus übereinkommend, aber an dem einfarbig schwarzeu Kopfe und dem Schrägflecke der Flügeldecken von den vorbergehenden leicht zu unterscheiden. Der Kopf tlach mit deutlicher Stirnhinie und am untern Rande tief eingezogenem Kiopfschilde, der Nacken und die Mitte der Stirn nach unten verschmälert spiegelglatt, die Innenseiten der Augen in nach unten verbreiterter Ausdelınumg dicht punktirt und angedrückt greishaarig, welche punktirten Flächen zwischen den Augenluchten zusammenstossen und dann unterwärts den ganzen liopf einnehmen. Die Farbe schwarz, nur die Oberlippe gelb, die breit und tief ausgebuchteten Aıgen greis. Die 
Fühler von haller Kiörperlänge, das zwrite Glied fast kugelig mit eingeschnürter Wurzel; das dritte dreinal, das vierte viermal, das fïnfte fast fünfmal länger als das zweite, die oberen vom sechsten al) wieder dem vierten gleich, dahei schwach verbreitert und zusammengedrückt, mit stark abgesetztem Fortsatze dles Endglietles. Dir Farbe der fïnf unteren schmutzig gelb mit geschwïzter Oherseite, der oberen schiwarz. Das IIalsschill etwa $2 \frac{1}{2}$ mal so breil wic lang, mit fast grader, nur vor dem letzten Drittel leicht aufgekrümmter Mittelfirste, und dahinter schräg ahwïrts flach gedrückt, über den spitzen Vorderecken breit aber niclıt stark zusammengedrückt, und dadurch weniger als die vorhergehenden Arten verschmälert; die Seiten fein gerandet, linter der Mitte schwach erweitert und vor ilır sanft ausgebuchtet, die Hinterecken stumpf; der Hinterrand leicht doppelt ausgeschweift, mit wenig vortretendem Mittelzipfel. Vor diesem jederseits ein hreiter, sich nach aussen verflachender Schrägeindruck, und vor dessen äusserer IJäfte ein zweiter schwächerer, welcher sich in den flachen Vol'derwinkeln verliert. llie Punktirung oben zerstreut und ziemlich lein, seitlich und besonders nach den Hinterwinkelı zu gröber und dichter, mit lackglänzendem Zwischengrunde; der alıgesetzte zarte Samn und ein rechteckiger Querfleck jeder'seits der Mitte schwarz, die vorderen Innenecken der letztern in schräge Zipfel ausgezogen und Jetztere bei einem Stücke durch einen verwaschenen dunkeln Bogenwisch mit einander verbunden; weiter hinterwärts zwischen beiden noch ein vereinzeltes, auf das Schildchen hinweisendes Längsfleckchen. Das Schildchen sehr sanft ansteigend, nicht ganz so lang wie vorn breit; hinterwärts verschmälert und mit abgerundeten Ecken und deullichem Hinterzipfel abgestutzt, dünı und fein hehaart, kaum sichıtbar punktirt, schwarz und an den abgeriebenen Stellen glänzend. Die Deckschilde breit und flach walzenförmig, fast un die Hälfte länger als breit, die Naht entlang abgellacht und hinten mit mässiger Krüummung abfallend, hinter der Vorderkante mur leicht quer eingedrückt, auch die Schulterbeulen nur schmal und flach, die Seitenlappen lang herabgezogen und über ihnen die Deckschilde hreit zusammengedlrückt. Die Punktirung sehr fein, mässig dicht, auf der vorderen IIälfte lurch Quer- und Schrägrunzehn verbunden, mil schwachen Andeutungen zerrissener und gestörter Punktstreifen, hinter der Nitte fast ganz in nadelrissigen Lüngsrunzeln verschwimmend, zwischen denen die Strei- 
fenendeı unter schräger Beleuchtung mehr durch ihre dunklere Färlung als durch ihre Stärke sichtbar werden; daher der Glanz des Zwischengrundes auch nur matt. Die Farbe schmutzig lehmgelb, ein feiner Saum läugs Naht, Spitze und der hinteren Hälfte des Aussenrandes schwarz, und eben so auf jeder Flügeldecke zwei Flecke, ein kleinerer auf der Schulterbeule, und cin grösserer hinter jenem vor der Mitte, plump dreieckig, schlecht begränzt, und mit der abgerundeten Spitze schräg nach vorn und imnen gegen das Schildchen hin gerichtet; bei einem der vorliegenden Stüclie ist dieser Hinterfleck gar nicht vorhanden; bei einem dritten fehlt auch noch der Schultertleck, und die Flügeldecken erscheinen dadurch einfarbig lehmgelb. Pygidium und Unterseite dicht und fein runzlig punktirt, mit den Beinen dicht angedrückt silberhaarig, schwarz. Das Prosternum fast seiner ganzen Länge nach rinnenförmig vertieft. Das letzte Segment des $q$ mit einer grossen, runden Grube; das ơ unbekannt.

Ebenfalls aus Brasilien. (Mus. Berol. Vindob. Clark).

Eilfte Rotte. Körper gross und plump, breit walzenförmig, flach gewölbt, mit hinten meist stark niedergedrücktem, nach vorn stark verschı̈lertem Halsschilde. Die Punktirung meist zerstrent, besonders bei den hellgefärbten Arten fein; die Färbung hesonders der Oberseite hell mit selı veränderlicher, meist querbindenförmiger Zeichnung der Deckschilde. Brasilianische Arten von etwas fremdartigem Ansehen, und nicht immer leicht zu unterscheiden.

56 M. Kollari Perty. Oben röthlich gelb, zwei Hinterflecke des grob punktirten Halsschilds, und drei an der Naht zusammenfliessende, aussen abgeh ürzte Querbinden der Fhügeldecken schwarz, unten schwarz, dicht silberhaarig; die Punktstreifen vorn undeutlich und durch ïberzälılige Punlite getrüht, linten abgeschwächt, mit flachen, querrunzligen Zwischenräumen. L. $3 \frac{3 / 4}{-5} 5^{\prime \prime \prime}$; Br. $2-23 / 4 "$.

Cryptocephalus Kiollari Perty delect. animal. etc. S. 104. Tab. 21, fig. 2.

Der Riese nicht bloss unter den Arten diesser Gattung, sondern unter den amerikanischen Cryptocephaliden überhaupt, und auch nach der Zeichnung eine sehr eigenthümliche, nicht zu verkennende Art. Der Kopf breit und flach mit etwas zurücktretendem Nacken und stark eingezogenem unterem Rande des Kopfschilds; die Stirnlinie tief eingeschnitten, die Oberfläche durch eine dicht siebartige grobe Punktirung matt, stellenweise mit feinen, 
sonst wohl nur abgeriebenen feinen Silberhäärclıen hesetzt. Die Augen breit und tief ausgehuchtet, weit getrennt. Die Faphe schwarz, ein grosser, oberseits doppelt ausgerandeter, die oberen inneren Augeuränder berührender, unten mit verwaschener Begränzung bis in die Fühlergegend hinabreichender Stirnfleck lehıngelb. Die Oberlippe glänzend schwarz mit gelblichem Saume. Die Fühler von etwa $\% \frac{1}{3}$ der Körperlänge, des ठ noch etwas länger; das zweite Glied kurz birnförmig, das dritte dreimal-, das vierte viernal länger, die oberen bis zum achten allmählich noch etwas zumehmenı, das Endglied mit kurzem abgestutzt kegelförmigem Fortsatze. Das Wurzelglied bräunlich mit hellerer Spitze, die vier folgenden durchscheinend honiggell, die oberen, kräftigen und wenig zusammensammengedrückten Glieder schwarz. Ilas Halsschild reichlich doppelt hreiter als lang, über den spitzen tief herabgezogenen Vorderecken breit zusammengedrückt und dadurch sehr merklich verschmälert, vor dem Scliildchen elsen so breit quer niedergerlrückt, die Mittelfirste nach vorn wenig abwärts gekrümmt, hinter der Mitte jederseits ein breiter aber ziemlich schwacher Quereindruck, vorn von einem noch schwächeren begleitet. Die Seiten fein gerandet, in der Mitte in einen breiten flach gekrümmteu Bogen erweitert, vor ihr seicht ausgeschweift, die Hinterecken stumpf, der IIinterrand jederseits des schwachen Mittelzipfels leicht ausgebuchtet und eingedrückt. Die Oherfläche grob punktirt, die Punkte mebr zerstreut, nach den Rändern zu dichter gedrängt, mit glattem Zwischengrunde; die Farbe lehmgell, mit breit schwarz gesäumtem Hinterrande. Auf dem letzteren ruht jederseits ein unförmlicher, breiter, nach vorn meist bis zur Mitte, seltener bis an den Vorderrand reichender, oft nach vorn und innen noch cinen Schrägzipfel aussendender schwarzer Fleck, und in dem hinterwirts erweiterten Raume zwischen beiden noch eine kurze, gleichfalls deu Ilintersaum berührende schwarze Längslinie. Das Schildchen kurz unl breit viereckig, hinterwärts weuig verschmälert und stark ansteigend, mit deutlichem Hinterzipfel grade abgestutzt, längs der Mitte etwas aufgewulstet, runzlig punktirt und dünn greis behaart, inatt schwarz. Die Deckschilde breit und flach gewölbt, hinter del' scharf aufgeworfenen Vorlerkante sclımal aber tief quergefurcht, und diese Querfurche im Nahtwinkel schwächer, innerseits der schmal höckrigen Schulterbeulen stärker erweitert; die Seitenlappen tief heralıgezogen, und über ibmen je auf dem neunten Zwischen- 
raune eine Benle, welche von einem unterseits am Randstreifen liegenden Läıgsgrülıcheı, unı yon dem die Deckschilde hinter den Sclulterbeulen einengenden, oberseits bis über die Mitte der Flügeldecke hinaus bemerkibaren Quereindrucke gebildet wird. Der Rücken um dis Schildchen schwach aufgetriehen, und hinter dem letzteren die Naht der Länge nach seicht niedergedrückt. Die l'unktirung deutlich, vorn ziemlich ungeordnet, lïngs der Naht dicht und regellos zusannmengedrängt und je weiter nach aussen desto mehr in eine regelmässige Streifenbildung übergehend; hinter der Mitte werden auch auf dem Rücken die Streifen deutlicher aber auch schwächer, und sind auf der Wölbung nur noch wenig kenntlich. Dabei sind die flachen Zwischenräume von zahlreichen Runzelı und Rissen durchschnitten, kaum seidig schimmernd, llie Farbe röthlich gelb, manchmal ins Lehmgelbe verblichen, der umgeschlagene Rand des Seitenlappens lackglänzend weisslich gelb. Ausserden trägt jede Flügeldecke drei nach Aussen abgekïrzle schwarze Querbinden; die vordere, auf der Schulterbenle beginnend, erstreckt sich wellig bis zur Naht, von der sie aber durch die das Schildchen umziehende röthlich verblcibende Wurzelkante getrennt wird; die zweite hinter der Mitte reicht nach Aussen bis auf den neunten Zwischenraum, nach Innen bis zur Nahı, und längt hier mit der ersten durch einen schmalen Nalıtsaum zusammen; die dritte endlich unter der Wölbung schliesst sich mit einem Nahtsaume unmittelbar an die zweite, reicht aber auswärts nicht bis zur halben Breite der Flügeldecken, und verläuft sich dann nach hinten in einen zarten, auch die Spitze umzichenden Randsaum. Zuweilen fliesst der Zwischenraum der zweiten und dritten Binde derartig über, dass die zweite hinterwärts nur durch einen quer viereckigen Anhang aul ihrem mittleren Theile erweitert crscheint. Aendert jedoch ab

$\beta$. Alle Binden verloreitert und durch einen gleichmässig breiten Nahtsaum verbunden, die mittlere mit ihren Aussenende nach vorn bis zum Zusammentrellen mit ler vorderen erweitert, sodass hier jederseits der Naht ein breiter rothgellser Querfleck abgeschnitten wird, und umgeliehrt

$\gamma$. Alle Binden sclmaler, und die dritte jederseits zu einem vereiuzelten, die Naht nicht berührenden schwarzen Punkte geschwumden.

Von beiden Varietäten habe ich nur o ror mir, und von var. 
$\beta$. fällt die Grundfärbung eben so stark ins Röthliche, als sie bei var. $\gamma$. ins Fahlweisslichgelhe verblichen ist, was wahrscheinlich mit der Ausdelınung bez. Beschränkung der schwarzen Zeichnung zusanmenlıängt.

Pygidium und Unterseite fein punktirt, mit den Beinen schwarz, mit dicht angedrïckten Silberhäärchen besetzt, die Vorderschenke! mässig aufgetrieben mit leicht gehräunten Schienen. Das Prosternum grob gerunzelt, bei besonders hinterwärts stark erhöhten Seitenkanten daselbst doch nur flach längsrinnig. Das letzte Segment des $\delta$ mit einer rundlichıen kahlen und glänzenden Stelle, das $q$ mit einer tiefen hallkugeligen Grube.

Aus Brasilien (Mus. Saunders. Baly. Clark. Lacordaire. Holn. Berol. Vindob.). Einen speciellen Fundort nennt nur Perly a. a. 0., nämlich Sebastianopolis; ausserdem ist im Mus. Clark die Provinz Minas Geraes als Heimath angegeben. Bei einem (von Hrı. Endrulat mitgetheilten) Stücke in Mus. Dohrn ist Paramaribo im holländischen Guyana als Heimath genannt, welche Angabe aber wahrscheinlich auf einem Irrthume beruht.

57. M. nigrofasciatus $\mathrm{m}$. Oben knochengelb, eine abgekürzte Querbinde des grob zerstreut punktirten Halsschilds, zwei der Flügeldecken und zwei Punkte vor deren Spitze schwarz, unten schwarz, ein breiter Hinterleibsrand und die Beine gelblich; die Punktstreifen vorı durch überzählige Punkte gestört, hinten fast erloscheı, mit flacłıen, äusser'sı fein gerunzelten, glänzenden Zwischenräumen. L. $3-33^{3 / \prime \prime}$; Br. $11 / 2-2^{\prime \prime \prime}$.

Dem vorhergehenden nicht unähnlich, aber merklich kleiner, lıełler gefärbu, und an der Zeichnung von Halsschild, Flügeldecken und Unterseite leicht kenntlich. Dor kopf flach, der Länge nach eingedrïckt mit feiner Stirnlinie, grob zer'streut punktirt mit glänzendem Zwischengruude, oben bis zu den Augenbuchten hinab schwarz, unten knochengelb mit geschwärzten Fühlerhöckern; die breit abcr nicht tief ausgebuchteten, weit getrennten Augen greis. Die Fühler von lıalber Körperlänge, schwarz mit gebräunter Unterseite der unteren Glieder, das zweite Glied kugelig, die nächstfolgenden an Länge soweit zunehmend, dass das fünfte und das ihm gleichkommende sechste gegen $3 \frac{1}{2} \mathrm{mal}$ länger ist als das zweite; das siebente wieder dem vierten gleich, die folgenden bis zum zehnten wenig kürzer, das lincalische Endghied mit seinem schmal kegelförmigen Fortsatze noch etıvas länger als das fünfte; dabei die 
oberes von der Mitte des sechsten ab stark zusammengedrückt und verbreitert. Das Halsschild etwa $2 \frac{1}{2}$ mal hreiter als lang, mit kaum aufyebogener Mittelfirste, am Vorderraude hinter den Augen etwas eingeschnürt, ïber deu sclarf spitzwinklig ausgezogenen Vorderecken breit zusammengedrückt und dadurch verschmälert, die lein gerandeten Seiten in der Mitte nur in flachem Bogen unterwirts erweitert und vor ihr sehr leicht ausgeschweift, mit fast abgerundeten, stumpfivinkligen Hinterecken ; der Hinterrand jederseits nur leicht ausgebuchtet, mit schwach aufgebogenem Mittelzipfel, und vor diesem das Mittelfeld breit quer niedergedrïckt, die Seitenenden dieser niedergedrückten Stelle nach den Hinterwinkeln zu etwas tiefer eingedrückt. Die l'nuktirung grob, zerstreut und nur in den Hinterwinkeln etwas dichter zusammengedrängt, mit lackglänzendem Zwischengrunde; die Farbe lıell knochengelb, mit einer alıgekürzten ziemlich scharf aber etwas wellig begränzten Querbinde, welche manchmal so breit wird, dass das Halsschild als sclıwarz mit gelbem Rande bezeichnet werden kömute, während sie andrerseits auch bei einem mir vorliegenden Stücke durch eine leinc gelbe Längslinie in der Mitte durchschnitten ist. Das Schildchen schräg ansteigend, nicht so lang als vorn breit, mit deutlichem Hinterzipfel und abwärts gebogenen Ecken abgestutzt, der Länge ıach ctwas aufgewulstet, fein punktirt, schwarz, dünn greishaarig und an den abgeriebenen Stellen glänzend. Die Declischilde breit und flach walzenförmig, um $1 / 3$ länger als breit, vorn kaum tuer niedergedrückt, die rundlichen Schulterbeulen innerseits durch einen breiten, aber ziemlich seichten Eindruck alıgesetzt, die Seiteulappen mässig mit breitem umgeschlagenem Rande; über ilıen die Deckschilde kräftig zusammengedrückt und vor diesen Eindrucke auf den neunten Zwischenraume cine kleine, rundliche Benle. Die: Punktirung auch rorn nur fein und nicht dicht, längs der Naht ziemlich ungeordnet, seitlich deutlichere Punktstreifén entwickelnd, die von der Mitte ab auch oben kenntlich werden, aber seitwärts sich immer mehr alsschwächen und auf der Wölbung fast erloschen sind. Jie Zwischenrïume flach, fein gerunzelt, mit ziemlichom Glanze. Die Farhe lıell knochengelb, Nalıt, Spitze und der hintere Theil des Aussenrandes bis an die Scitenlappen scliwarz gesäumt, und ausserdem zeigt jede Flügeldecke zwei den heiden ersten Binden der rorheryehenden Art entsprechende Querbinden, von denselben nur dadurch unterschieden, dass sie nicht durch 
eine diekere Verhindung an der Naht zusammenhliungen, und dass die hintere von beiden den bis zu ihr reichenden schwarzen Saum des Aussenrandes erreicht. Die Stelle der dritten Binde aber vertreten zwei vereinzelte, hald kleinere hald grössere Punkte auf jeder Flügeldecke, welche, wenn sie klein sind, geirennt stehen, während bei grösserer Ausdehnung der'selben der äussere den Anssenrand erreicht, und der innere jenem manchmal so nahe kommt, dass hier auch noch wohl ein Zusammenstossen bei einzelıen Stücken erfolgen könnte. bas Pygidium und ein sehr breiter Rand des Hinterleibes gelb, die Nitte mit breit verwaschener Begränzung geschwärzt, die Brust selıwarz, meist mit einem grösseren oder kleineren gelben Flecke innerseits der Parapleuren. Die Beine gelb, ein breiter, auf die flachgewölbte breite Vordernïehe bueltig übergreeifender Rand auf der Anssenkante der Vorderschenkel und der grössere Theil der Vorderschienen sowie die Füsse, an den Mittelund Hinterheinen nur die Sehienenenden und Füsse sehwarz. Seltener sind alle Sehienen schwarz, in welehem Falle sieh dann auch die Vorderhinde der Flügeldecken verbreitert, Innd unmittelbar an deren Wurzel und das Sehildchen anlegt. Das Prosternum hisiten deutlich rinnenförmig. Das letzte Segment des $q$ mit einer ziemlich grossen, halbkugeligen, im Innern mattgeschwärzten Grubı; das ơ unbekannt.

Aus Brasilien. (Mus. Saunders. Dohrn. Baly. Clark. Deyrolle, in letzterem mit dem Namen Pachybr. jocosus Chv. hezeiehnet).

58. II. alhifrons m. Sehwarz mit gelbem Nackenfleck, das dicht und grobpunktirte Halssehild, die Flägeldeeken und das $\mathrm{Py}$ gidium weisslieh gelb, zwei Hakenflecke des ersteren und zwei Querbinden nebst zwei linteren P'unkten der letzteren schwarz; die P'muktstreifen vorn durch üherzällige Punkte verdunkelt, linten last erlosehen, mit flaehen, fein quer gerunzelten Zwischenräımen. L. $2 \frac{2 / 3}{\prime \prime \prime}$; Br. 1 1/3"'.

Von der Gestalt, Färbung und Farbenvertheilung des vorhergehenden, aher die Zeichnung von Kopf und Ifalsschild sehr ahweichend, unul die Beine ganz sclıwarz, ausserdem der Köfer kloiner als die kleinsten mir lis jetzt rorgekommenen Stücke der vorhergehenden Art. Der Kopf flach mit einen undentlichen Stirueindruck, grob runzlig punktirt, mit den Mundtheilen und Viüller'n sehwarz, InIr im Nacken ein unterwärts bis unter die olep'en An- 
genränder hinausreichender rundlicher, weissgelber Fleck, auclı die Ränder der Oherlippe verwaschen heller gefärbt. Die Fühler (des q) von halber Körperlänge, das zweite und dritte Glied pechbräınlich durchscheinend, das sechste linger als eins der übrigen, nur das Endglied mit seinem langgestreckten Fortsatze ihm gleichkuımend; die oberen rum sechsten als mässig verbreitert und zusammengedrückt. Das Halsschild etwa $2^{1}{ }_{4}$ mal breiter als lany, gebant wie hei der vorhergehenden Art, nur die Seiten etwas stär'lier im Bogen erweitert, die flinterecken mit einer etwas schärfer'n Schwiele hesetzt, und der Hinterrand jederseits des Mittelzijpfels rtwas tiefer ausgeluchtet und stärker eingedrückt. Die Punktirung elıen so grub, aber viel dichter zusammengedrängt, daher die Oherfliche weniger glänzend: dic Farbe ein helles, weissliches tielh, jederseits der Mitte mit einem breiten, hinten ahgerundeten sclıwarzen Querflecke, dessen inneres Ende sich lıakenförmig nach rom Jiegl, und zwischen den Angen und dem zugespitzten oberen Limle des weisslichen Nackenflecks den Vorderrand erreicht, sordass dieser Fleck sellsst nur die (erweiterte) fortsetzung des zwischen jenen lıeiden Halsschilılslecken liegenden weissen Zwischenraums zu bilden scheint. Schildchın und Deckschilde wie bei der vorigen Art, die P’unktirunı vor'n grüles, mässig dichı, mit Spuren von Punktstreifen, deren namentlich von einen Theile des vierten und fïnften zu finden sind; hinter der Mille wird die Punktirung feiner, sich zı regelnässigeren Streifen cutwirrend, aber auch schwïcher, und ist anf der Wülbung kaum noch zı erliennen. Die Grundfarlse (ob individuell?) etwas melı' weisslich als bei der vorhergehenden Art; die vordere Binde kräftiger und loreiter, an die Wurzel gelehnt und das Schildchen auch hinten mit umziehend, der zweite dagegen schmaler, an Rante stärlier wellig gebuchtet, nach aussen stark verschmïlert, die beiden einzelnen Hinterpunkte gross, der äussere an den, wie auch bei dem vorigen, schwach gebrämnten Aussenrand gelehnt. Das l'ygidium weisslich gell), die Unterseite schwarz, seitlich schmaler, hinten breiter verwaschen gelhlich gerandet. Die Beine einfarlhig schwarz. Das letzte Segment des $f$ mit einer tiefen, im Imnern glänzenden Grube, das $\delta$ unbekannt.

Gloiclifalls aus Brasilien (Mus. Berol.).

59. M. albifes m. OJıen linoclıengell, mit geschwärztem Nacken, eine alugeliürte mnd oft unterbrochene Querbinde des fein 
zerstreut punktirten Halsschildes mud sechs Flecke der-Flïgeldecken $(2,2,2$.) schwarz, Unterseite und Vorderbeine schwarzund gelbbunt, die hinteren Beine weisslich gelb; die Punktstreifen f'ein, vorn durch überzählige Punkte gestört, hintev vełloschen, mit flachen, glänzenden Zwischenräumen. L. $2^{1 / 2}-4^{3 / 4}{ }^{\prime \prime \prime}$; Br. 1 1/3-3"“" So sicher ich auch bei der Unterscheidung der nächstvorhergelienden, wie der folgendeu Arten zn sein glaube, so wrnig ist dies bei den unter der vorliegenden zusammengefassten Furmen der Fall. Ich lrabe jedoch viel Zeit und Mühe veryeblich aufgewandt, um unter den äusserlich ausserordentlich abweichenden und doch wieder durch mannigfache Uebergänge verlundenen Stücken schneidende Unterschiede zu entdecken, und fasse dieselben daher einstweilen in eine einzige Art zusimmen, gestehe aber gern, dass ich dieselbe nur als eine Collectiv-As't betrachte, unter der immerhin noch eigene Arten, möglicher Weise auch die bis dahin unbekamnten $\delta$ der bejden vorhergehenden verborgen sein können. Vielleicht sind Andere im Entwirren dieses Formen-Conglomerats glücklicher, wiewohl ich glaube, dass nur Beobachtung an Ort ınd Stelle und namentlich das Auffinden der verschiedenen Geschlechter in Paarung uns lier zu einer unbedingten Gewisslseit verhelfen kann.

Die liser unter dem Namen M. albipes zusammengefassten Thiere haben sämmtlich einen plumpen, walzlich abgeflachten, einzelnen Clythridenformen ähnlichen Körper, welcher, je grösser die Stücke werden und jemehr die schwarzen Zeichnungen sich verlieren, desto mehr aus dem Walzlichen ins Breitverflachte übergeht, und in gleichem Maasse das Halsschild sich nach vorn verschmälern lässt. Meist wird mit der zunehmenden Körpergrösse, in welcher die grössten Stücke fast das Doppelte der kleinsten elreichen, auch die Punktirung feiner und melır zerstrent, bis sie zuletzt bei einzelnen Stücken ganz versclıwindet. Bei allen Stïcken aher ist der liopf breit und flach, die Stirn der Länge nach eingedrückt und imnerlsalb dieses Eindrucks noch mit einer feineren Linie bezeichnet, das Kopfschild unten etwas eingezogen. Der Oberkopf ist unr lein und sparsamer, der untere von den Augenbuchten ab dichter und gröher punktirt, der Zwischengrund glänzend, die Farbe entweder (hei den helleren Stücken, fast nur o weissgell, die Fühlerhücker und ein Saum um dieselben, der untere Rand des Kopfschildes und die verwaschene Mitle der Ober- 
lippe schwarz, oder auch noch ein lileiner zweilappiger Nackenlleck, gewöhulich aber der schmaldreieckige Nacken und ein von diesem ausgehender, auf der Stirnlinie sich herabziehender Längszipfel schwarz, wo damı duch die imneren Augenräuder bis zu den FühIrrhöcker'n eben so gesäumt erscheinen und meist auch die Augenbuchten ganz oder doch grösstentheils in solcher Weise gefürbt sind. Die Fühler von mehr als halber Körperlünge, llerh und kräftig, das zweite Gilied liurz hirufürmig, das dritte doppelt-, das vierte viermal länger als das zweite, und dem vierten die folgenden gleich, mit breit zugespitztem Fortsatze des Endglieds, die oberen Glieler vom sechsten ab zusimmengedrücki und erweitert. Die Farh: schwarz, Spitze und Unterseite des zweiten, bei helleren Stüchen anch noch wohl der beiden folgenden ins Bräunliche oder Roüluliche fallezid. Das Halsschild von dem Bau der beidein vorhergehemlen Arten, wohei je kleiner die Stücke sind, desto mehr meist die Schrägeindrücke jederseits des Mittelfelds hervortreten, wälırend bei den grösseren eine etwas stäliere seilliche Erweiterung des Halsschildes stattzufinden scheint. Die Farloe meist etwas mehr ins Lehmgelbe fallend, als dies bei den Deckschilden der Fall ist; die Zeichmung höchst verschieden. Entweder ist gar keine vorhanden, oder es erselıeinen jederseits eitı, ulcr zwei, oder drei schwarze Punkte in einer in der Mitte etwas nach vorn gerückten Querreilıe, in welcher balıl die ausseren bala die mittleren P'unlite die grösseren siml; die Punkte vergrössern sich zu eckigen Plecken, liommen dadureh einander nïher, his die drei P'mlkte jeter Seite sich zu einem winkligen, durch allmähliche Ans:ï̈llung der Winkel immer derberen, mit den Aussenenden chwas mehr nach hinten gehogenen schwarzen Quer- oder Schüigflecke veremigen. Bald verengert sich dam auch der Zwischenraum zwischen heiden Qucrflecken bis zu eincr feinen gelben Linie, bis beide mit den Hinterenden zusammentrelfen und ron hipr aus pinen linienfürmigen Längszipfel nach himten ausstrecken, wclcher lıei eiıem Stücke mit noch getremuten Flecken als zartr selbstständige schwarze Längslinie hinter ıem Zwischenranne auftritt. Eudlich arlolgt eine rollständige Vereinigung beider Flecke zn einer wellenfürnigen, in Jer Mitle immer noch etwas nach vorn gerïckten Querbinde, deren Lutstehung ans riuzehen Flecken sich aber stets noch an den Aushuchlumgen des Vorder- und Hinterrandes benterklich macht. Bei einem der vorlingenden Stücke ist 
diese zusammenhăıgende Binde nur aus den vier mittleren Punkten gebilulet worden, und der äusserste jederseits frei geblieben. Das Schildchen bei den Stücken mit weissem Kopfe gleichfalls weiss, bei denen mit schwarzem Nacken selten weiss, oder auch auf der Vorderhälfte schwarz, der hinteren weiss, bei der grossen Melırzalıl aber schwarz. Die Deckschilde bei den kileineren Stücken mehr walzenförmig, den grösseren mehr verbreitert und verflacht, im Bau in Algemeinen den beiden vorhergehenden Arten entspreclıend ; die P'unktstreifen zirmlich fein, aus ziemlich vereinzelten, nicht tief eingestochenen, vielfach aus grösseren Punkten gebildet, vorn stellenweise verdoppelt und verdreifacht, zumal längs der Naht durch überzählige Punkte getrübt, nach aussen und hinten etwas deutlicher, aber von der Mitte ab auch feiner, und auf der Wölbung kaum noclı sichtbar. Die Zwischenräume breit, flach, durch Schräg- und Querrunzeln zerrissen, aber doch ziemlich glänzend. Die Farbe ein ins Weissliche oder bleich Strohgelbe fallendes Knochengelb, ein feiner Saum längs Naht und Spitze, bei dunkleren Stücken stärker und auch den hinteren Theil des Aussenrandes mit umfassend, schwarz; und gleiche Färbung zeigen sechs schlecht begränzte, meist etwas wischarlig in die Länge gezogene Flecke in drei Paaren, welche wie bei M. patagonicus und seinen Verwandten gestellt sinıl. Die Ausbildung dieser Flecke steht mit der Zeichnung von Kopf und Halsschild in keinem Zusammenhange; es finden sich vielmehr, und nicht selten, Stücke mit schwarzem Nacken und dicker schwvarzer Querbinde des Halsschilds, bei denen nur der niemals fehlende Fleck auf der Schulterbeule, oder auch noch ein und der andere unscheinbare, eine der übrigen vertretende Wisch vorhanden ist, neben Stücken mit eben so gezeichueten Deckschilden und weissem Kopfe und Schildchen, und andere dieser letzteren Beschaffenheit, welche alle sechs Flecke der Flügeldecken zeigen; bei den meisten Stücken aher fehlen einzelne Flecke oder Paare; desto seltener sind Stücke, bei denen sich die Flecke der beiden vorderen Paare in die Quere strecken und dadurch die Entsteliung von Querbinden, wie bei den beiden vorhergehenden Arten, vorbereiten. Bei einem Stücke im Mus. Berol., welches ich nicht von dieser Art zu trennen vermag, sinl die Flecke des Mittelpaares wirklich zu einer solchen, die Naht jedoch nicht erreichenden Binde zusammengeflossen, und die beiden vorderen einander fast bis zum Berühren nahe gerückt. Das Pygidium XVI. 
immer gelb, die Unterseite meist schwarz, der Uinterleib seitlich schmaler, hinten breiter und mit schlechter Begränzung gelhlich, seltener auf der Hinterbrust an den Paraplemren jederseits ein kleinerer oder grösserer gelber Fleck, dessen Färbung sich bei einzelnen Stücken bis auf den unteren Theil iler Parapleuren ausdehnt; bei einem derselben (mit schwarzem Nacken und in der Mitte zerrissener dicker schwarzer Querbinde des Halsschilds, aber weissem Schildchen und kleineren Flecken der Flügeldecken, von (lenen der äussere Hinterfleck fehlt) erhält zugleich der gelbe Seitenrand des Hinterleibes eine solche Ausdehnung, dass die sclıwarze Färbung des Mittelfeldes durch ein über den ersten Bauchring hinwegziehendes gelbes Querband zerrissen wird. Hinter- und Mittelbeinen gelb mit schwarzen oder doch gebräunten Ilüften, Knien, Schienenenden und Füssen, die Schenkel manchmal auf der Unterseite bräunlich oder sclıwärzlich, und manclımal auch die Aussenkante der Nittelschenkel von dieser Färbung. An den Vorderheineı die Aussenkante der Schenkel breit geschwärzt, umd diese Färbung auf der Unterseite bis auf deren Mitte, olsen an der Wurzel und Spitze mehr oder weniger breit übergreifeud, die Innenseite der Schienen mit den Füssen melır oder weniger hraun oder schwarz. Seltener, und besonders bei $\delta$, die Mittel- und Hinterbeine einfach gelb, und dann auch an den Vorderbeinen ilie schwarze Zeichnung merklich eingeschrïnkt. Das letzte Segment des $\delta$ seicht quer niedergedrückt, das $q$ mit einer grossen hallkugeligen Grube.

Aus Brasilien (Mus. Saunders. Dohrn. Deyrolle. Holm. Berol. Clark). - Die Exemplare des Mus. Berol. sind meist voll Sello lei Porto Allegre und Caasapava gesammelt worden. - unl Corrientes (Mus. Clark).

60. II. corruptus m. Oben knochengelb, eine Fleckenbinde des zerstreut punktirten IIalsschilds, das Schildchen mul siehen Punkte der Flügeldecken $(2,3,2)$ mit den Fühlern schwarz, unten schwarz mit breit gelbem llinterleibssaume und gelbbunten Beinen; die Punktstreifen vorn lurch üherzählige Punkte getrübt, hinten erloschen, mit flachen fein querrunzligen Zwischenrïnmen. l. $2 \frac{1 / 3-2}{3} / 3^{\prime \prime \prime} ;$ Br. $11 / 2-13 / 4{ }^{\prime \prime \prime}$.

Gleichlalls den vorhergehenden Arten ähnlich, aher kleiner und an dem dritten Punkte der mittleren Reihe auf ilen Deckschilden, sowie den dentlicheren Punktstreifen derselhen kenntlich. Her 


\section{1}

Kiopf flach mit etwas eingezogenem Kopfschilde, der Nacken mit dem oberen Theile der Stirn tief eingedrückt, und dieser Eindruck noch von einer tief eingeschnittenen Längslinie durchzogen; die Oberlläche zer'streut und mässig stark punktirt, ziemlich gläızend, knochengelb, ein kurz und breit dreieckiger Nackenfleck, die schmalen Augensăume, die Fühlerhöcker und Mundtheile schwarz, nur die Oberlippe gelb mit breit geschwärzter Mitte. Die Fülıler von halber Körperlänge, derb und kräflig, das Wurzelglied mässig aufyetrieben, unten stark eingeschnïrt, fast doppelt länger als breit, das zweite kugelig, das dritte um die Hälfte, das vierte doppelt länger als das zweite, das fünfte noch etwas verlängert und diesem auch je die fünf folgenden gleich, dabei breit zusammengedrückt und erweitert, das linealische Endglied mit seinem stumpf dreieckigem Fortsatze noch etwas länger als das fünfte. Die Farbe schwarz. Das Halsschild knrz und lıreit walzenförmig, reichlich doppelt breiter als lang, mit hinter der Nitte leicht abwärts gekrünmter Firste, über den scharf spitzwinlkligen, tief eingezogenen Vorderecken zusammengedrückt und dadurch verschmälert; die Seiten fein gerandet, in der Mitte stärker als bei der vorhergehenden Art erweitert, vor ihr ausgeschweift, die wieder etwas eingezogenen Hinterecken scharf stumpfwiuklig; der Hinterrand jederseits des kurzen Vittelzipfels ausgebuchtet und eingedrückt, und vor letzterem ein breiter siclı zu beiden Seiten gegen die Nitte des Seitenrandes hin krümmender Eindruck. Die Punltirung ziemlich grob aber zerstreut, mit glänzendem Zwischengrunde, die Farlıe kinochengell, auf der Mitte eine in der Regel unterbrochene, aus zweimal drei schwarzen Punkten oder Fleckchen gebildete, bei einem der vorliegenden Stücke aber zusammenhängende und dadurch wellig gebruchen erscheinende Querbinde. Das Schildchen schräg ansteigend, quer viereckig und hinterwärts verschmälert, mit lang dreieckigem Hinterzipfel breit abgestutzt, schıvarz. Die Deckschilde walzenförmig, etwa $1 / 3$ länger als breit, der Rücken lïngs der Naht flach niedergedrückt, hinter der scharfen wenig erhöhten Vorderkante schmal linienförmig quer gefurcht, auch die flachen Schulterbeulen immerseits nur durch einen seichten Findruck abgesetzt; die Seitenlappen wenig ansgebildet und über ihuen je ein breiter und starker Quereindruck. Die Punktstreifen äusserst fein, vorn zu Querrunzeln verfliessend und dazwischen noch durch äherzilhlige Punkte verdunkelt, zwischen denen nur bei günstiger Belench- 
tung die eigentlichen Streifen sichtbar werden; hinterwärts, wo die Runzeln abnehmeı, schwächen sich auch die allmählich regelmässigeren Streifen bald so ab, dass von ilnen nur noch schwache Spuren sichtbar bleiben. Die Zwischenräume flach und in Folge jener Runzelbildung nur seidig schimmernd; auf der Wöllung und der unter ihr liegenden Spitze stärker glïnzend. Die Farbe auch hier luell knochengelb, ein feiner Saum längs Naht, Spitze und Aussenrand bis zum hinteren Ende des Seitenlappens schwarz, und ausserdem noch auf jeder Flügeldecke sieben schwarze Flecke in drei Reihen, in der Stellung wie hei der vorhergehenden Art, nur die Vorderflecke verhältnissmässig grösser und dann immer elwas in die Quere gezogen, wie aus zwei dicht aneinander stossenden Flecken zusammengeflossen, in der zweiten Reihe dieser dritte Fleck auf der Innenseite des inneren wirklich rorhanden, die der dritten zu feinen Punkten abgeschwächt, auch wohl ganz fehlend. Bei dem uben schon erwähnten ठ大 mit zusammenhängender Querbinde des Halsschilds fliessen die Flecke der beirlen ersten Reilıen zu älınlichen schmalen welligen Querhinden zusammen, von denen die vordere nach Aussen, die zweite innerseits abgeküuzt ist; bei anderen schwächen sich einzelne Punkte zu Wischen ab oder fehlen ganz, so bei einem der Innenpunkt der Mittelreihe; bei einem andern ist nur ller Schultę- und der äussere Hinterpunkt, bei noch einem anderen allein der erstere vorhanden, aber auch bei solchen Stücken sint, wo nicht eine unzweifellıft mangelhafte Ausfärbung des ganzen Thieres vorliegt, Schildchen und Nackenfleck immer schwarz. Das Pygidium nebst dem Hinterleibe äusserst fein punktirt, dünn greishaarig, knochengelb mit hreit geschwärzter Nitte der vorderen Bauchringe, die Brust schwarz, mit einem verwaschen gelblichen Fleck auf jeder Seite der Hinterbrust, welcher nur bei dem erwähnten stark schwarz gezeichnetem Stïcke geschwunden ist. Hinter- und Mittelbeine gelh, Knie, Schienenden und Füsse schwarz; an den Vorderbeinen ausser den Füssen auch die stark gekrümmten und verlängerten Schienen schwarz mit bräunlich durchscheinender Wurzel der letzteren; an den stark aufgetriehenen Vorderschenkeln werden dip algerundeten Aussenkanten mit dem daran. stossenden Drittel der breiten Vorder- und Hinterfläche schwarz, und ebenso dié beiden scharfen Hinterkanten. Bei dem genannten stärker geschwärzten Stücke delınt sich entsprechend die schwarze Färbung an den Beinten noch weiler ans, während sie bei Stücken 
mit fehlenden Flecken der Deckschilde bis zum fast völligen Weisøwerden der Mittel- und Hinterschienen und -Schenkel schwindet. Die Vorderbrust ziemlich schnnal, lang greishaarig, linten seicht rimnenförmig. Das letzte Segment des đ mit einer leicht rundlich eingedrückten Stelle, das $\&$ mit einer runden, ziemlich tiefen Grube.

Aus Brasilien (Mus. Baly. Deyrolle. Vindob. Berol.).

61. M. languidus m. Schwarz, ein unterer Stirnfleck, der Rand des Hinterleibes, das grob zerstreut punktirte Halsschild und die Flügeldecken knochengelb, jenes nit zwei, diese mit sechs schwarzen Punkten (2, 2, 2); die Punktstreifen derb, vorı etwas gestört, mit flachen, gläızenden Zwischenrä̈umen. L. $2 \frac{1}{2}-31 / 2 "$; Br. $11 / 3-13 / 4 "$.

Abermals den vorhergehenden ähnlich, aber Kopf und Beine schwarz, und dlie Punktirung der Deckschilde selır grob mit ungleich regelmässigeren Punktstreifen. Der Kopf Alach, der obrre Theil der Stirn tief und breit rinnenförnigg eingedrückt, auch der obere Theil des deutlich begränzten Kopfschildes quer eingedrückt, und dieser Eindruck mit spitzen Zipfel auf den unteren Theil der Stirn übergreifend; die untere Hälfte des Kopfschilds eingezogen. Die Punktirung grob und zerstreut, der Zwischengrund und die oben durch die Stirnfurche gebildeten Beulen spiegelglatt. Die Farhe kohlschwarz, ein kleiner dreieckiger oder querrundlicher Fleck in der Vertiefung über dem Kopfschilde und die Oberlippe gelblich mit gehräunter Mitte der letzteren. Die Augenbuchten breit und tief, leutlich punktirt. Ile Fühler kräftig, das zweite Glied kurz birnförnnig, das dritte doppelt länger und die beiden folgenden noclı etwas verlängert, die oberen mässig zusanmmengedrückt und erweitert; die Farbe schwarz, die Spitzen der unteren Glieder mit bräunlichem Anfluge. Das Halsschild kurz, seitlich durch einige kurze aber mehr oder weniger tiefe Schrägeindrücke merklich zusammengedłückt und durch eine Einschnürung an Vorderrande hier noch mehr verschmälert; das Mittelfeld hinten quer niedergedrückt, ınit leicht erhöhter und nach voru sehr sanft abfallender Mittelfirste; die Seiten fein gerandet, in der Mitte schwach erweitert, vor ihl' etwas ausgeschweift, die Vorderecken kurz und pfriemlich zugespitzt, die hinteren scharf stunpfwinklig, der Hinterrand wellig ansgebuchtet, mit kräftigen Mittelzipfel. Die Oberfläche spiegelglatt, auf der Mitte nur mit wenigen zerstrenten, in 
den Hinterwinkeln dagegen mit dichteren und gröberen Punkten besetzt. Die Farbe knochengelb mit einem Stich ins Lehmgelbe; auf der Mitte neben einander zwei kleine aber scharf begränzte schwarze Punkte, die sich zuweilen in Schrägflecke strecken und damn nach vorn auseinander gehen: bei einem der vorliegenden Stücke ausserhalb jedes Punktes ein tiefer, eiförmiger Quereindruck. Das Schildchen breit dreieckig, mit alggerundeten Ecken und flach uiederliegendem Ilinterzipfel abgestutzt, glänzend schwarz. Die Deckschilde hreil und flach gewölbı, etwa $1 / 3$ länger als breit, hinter der schwach erhöhten Vorderkante Jeicht und unterbrochen quer gefurcht, daher nur die Enden dieser Furche in Nahtwinkẹl Ind innerseits der breiten, flachen Schulterheulen als breitere Eindrücke bemerkbar; der Rücken um das Schildchen schwach erhölıt, dalıinter quer niedergedrückt, und ïlıer den lang herabgezogenen Seitenlappen ein tiefer Schrägeindruck. Die Punklirung zwar nicht dicht, aber derb, zwischen Naht und Schulterbeulen auf der vorderen Hälfte ziemlich ungeorinet und die vorhandenen Streilenansätze durch rïberzählige Punkte gestört, auch wohl verdoppelt, die drei äusseren Streifen ziemlich regelmässig; von der Mitte ab entwickehı sich dureh Zurückhleiben der äherzähligen Punkte die Streifen regelmässiger, werden aber auch allmählich feiner und dic mittleren sind aul' der Wöllhung l'ast erloschen. Die Zwischenrämme flach und stark glänzend. Die Varbe linochengelb, ins bleich Strolıgelbe fillend, mit drei Paar schwarzen, manchmal nur punktartigen Flecken, gestellt wie bei den vorhergehenden Arten, die Jnnenflecke des Vorder - und Mittelpaars zuweilen in die Quere vergrössert, vorn und hinten leicht ausgebuchtet, wie aus je zwei Flecken zusammengellosseı; andererseits aber fehlen manchmal einzelne oder mehrere Punkte oder sind doch zu wischartigen Schatten alıgeschwächt: nur die drei ïusseren sind bei allen mir vorliegenden Stücken, obwohl nicht in gleicher lntensität, vorhanden. I)as feinpunktirte, stump£ längskielige Pygidiun bleich gelb; Unterseite und Beine schwarz, der llinterleib breit gelb gerandet. Die Vorderbrust grob punktirt, hinten der Länge nach breit und tief gefurclıt. Das letzle Segment des $\delta$ mit einem kleinen, glänzenden Quereindruck, das $f$ mit einer tiefen halhliugeligen Grube, deren Seitenand jederseits durch eine, in die Fläche des Ringes eingedrückte Querfurche durchschnitten wird.

Ebenfalls aus Brasilien (Mus, Saunders. Baly. Berol.). 
62. M. veriuus m. Hellgelb mit gebrïunter Brust, ein Nackenfleck, die Fühler, vier verlosche Punkte des grob und dicht punktirten Halsschilds und fümf der Flügeldecken $(2,2,1)$ mit den Füssen schwarz; die Punktstreifen l'ein, vorn theilweise verdunkelt, hinten fist erloschen, mit flachen stark glänzenden ZwischenrïuInen. L. $2 \frac{1}{3}-23 /$ " $"$; Br. $1 \frac{1}{4}-12 / 5 "$.

- Wiederum den vorhergelienden Arten nilie verwandt, und wahrscheinlich auch in der ursprünglichen Zeichnung der Flügeldecken mit ilnnen ïlsereinstimnend, aber kleiner. Die Deckschilde mehr gleichbreit, auf dem Rücken flacher, das Halsschild vorn stärker verbreitert, dichter punktirt, und die ganze Oberfläche spiegelglatt. Der Kopf flach mit tiel' eingedrückter Stimrinne und etwas eingezogencm Kopl'schilde, grob und vercinzelt punktirt, gläızend gelb mit gebräunten Kinnbacken und Tastern; die tief dreieckig ausgebuchteten Augen schwïzlich, ein unten ausgerandeter jederseits abgeküızter Querlleck im Nacken mit den Füłler'ıöckern und Fühlern schwarz. Letztere von meh’ als halher Körperläıge; das zweite Glied kurz eiförnig, das dritte doppelt-, das vierte viermal länger', dem letzteren lie oberen gleich, und nur das linealische Endglied mit seinem dreieckigen Fortsatze noch etwas verlängert: dabei die oberen von der Syilze des fünften ab ziemlich breit erweitert und zusammengedrückt. Was Wurzelglick auf der Unterseite, das zweite überall, die drei folgenden an der Spitze uud bei einem Stücke auch auf der Unterseite hell gebriunt. Das IIalsschild dopjelt breiter als lang, olven fast ganz flach, über den tief eingezogenen, spjitzwinkligen Vorderecken breit zusammengedrückt und dalurclı stark verschmälert, die Seiten feiı gerandet, hinter der Nitte in flachen Bogen erweitert und vor ihr leicht ausgeschweift, die stunpfivinkligen Vorderecken scharf und etwas aufgebogen, der Hinterrand doppelt ausgelsuchtet, unit kurzem Mittelzipfel, und vor letzteren joderseits ein breiter und llacher, gegen die Mitte des Sejtenrandes Linıabziehender Schrägeindruck. Jie Oberfläche grob und tief-, zienlich dicht punktirt, mit lackglinzendem Zwischengrunde, strohgelh, bei einem anch auf der Unterseite stärker geschwärzten Stücke aul der Mitte mit zwei feinen schwarzen Punkten, deren jeder die Spur einer zweiten fast verloschenen auswärts neben sich trägt. Das Schildchen sehıäg ansteigend, quer viersckigr, hinterwärts verschmälert und nit deutlichem Hinterziplel alggestut», glänzend gell’ ınit dunkleren Säumen. 
Die Deckschilde gleichbreit und etwa nur $1 / 3$ länger als breit, oben flach gewölbt und hinterwärts mit starker Krümmung abfallend, vorn nur schwach quer eingedrüclit, anch die Schulterbenlen wenig hemerkbar. Die Seitenlappen stärker abwärts gezogen, und ülser ihnen die Deckschilde sehr breit zusammengedrückt. Die Punktstreifen aus sehr vereinzelten Punkten gebildet, fein und mehr an der Färbung der Punkte als an deren Stärke erkennbar, die oberen hesonders gegen die Naht hin durch eingemengte Punkte von gleicher Grösse mehr oder weniger gestört, mit deren Ausbleiben hinter der Mitte auch einzelne Streifen selbst, namentlich die hinter den Schulterbeulen liegenden, allmählich verschwinden. Die Zwischenräume flach, mit vorn etwas schwächerem, hinterwärts starkem Glanze. Die Farbe gelb, etwas hleicher als die des Halsschilds; die schwarze Zeichnung wahrscheinlich dieselbe wie bei den vorhergehenden Arten, wenn gleich bei dem, von den vorliegenden Stücken am vollständigsten gezeichneten vor der Spitze der Flügeldecke statt des dritten Paars nur dessen äusserer Punkt vorhanden ist, während bei anderen auch der vordere und mittlere Innempunkt fehlen. Stets aher sind die schwarzen Punkte fein, nicht fleckartig, und gewöhnlich am Rande fein gebräunt. Pygidium und Hinterleib gelb mit verwaschen gebräunter oder geschwärzter, aber den mittleren Vorderzipfel licht lassender Mitte des letzteren: die Brust rostroth, die Mitte der Hinterbrust, die Nähte derselben und die Vorderhälften der Parapleuren geschwärzt. Die Beine gelh mit schwarzen Schienenenden und Füssen, die Knie und die Vorderschienen roströthlich; die Aussenkante der Vorderschenkel bei einem Stücke gleichfalls rotsroth, bei den übrigen aber geschwärzt. Das Prosternum linten leicht rinnenförmig vertieft; das letzte Segment des $\delta$ mit einem leichten Quereindrucke, das $q$ mit einer runzligen, glänzenden Grube.

Aus Brasilien (Mus. Deyrolle. Berol., das Exemplar des letzteren von Sello bei Allegrette gefunden.)

63. M. spilotus m. Schwarz, die Seiten des zerstreutpunktirten Halsschilds, der Saum des Hinterleibes und die Deckschilde gelb mit einer abgekürzten schwarzen Spitzenhinde der letzteren; die Punktstreifen etwas wellig, längs der Naht und hinter den Schulterbeulen gestört, mit flachen, glänzenden Zwischenräumen. L. $3 \frac{1}{3}{ }^{\prime \prime \prime} ;$ Br. $1{ }^{3 / 4}{ }^{\prime \prime \prime}$.

Eine durch ihren grossen kräftigen Körper nicht weniger, wie 
durch ihre einfache Färbung ausgezeichnete, anscheinend sehr seltene, mir nur in einem einzigen Stücke vorliegende Art. Der Kopf flach gewölbt mit tiefer Stirnrinne und der Länge nach seicht eingedıückten Kopfschilde; die Punktirung grob und zerstreut, mit lackglänzendem Zwischengrunde, die Farhe schwarz, die Oberlippe breit verwaschen gelblich gesäumt, die grossen (bei dem $q$ ) weit getrennten Augen tief ausgebuchtet. Die Fühler kräftig und von mehr als halber Körperlänge, das Wurzelglied aus sehr dünner Basis breit birnförmig aufgetrieben, um die Hälfte länger als breit, das zweite eiförmig, die drei folgenden verkehrtkegelförmig mit schwach erweitertem oberem Ende des fünften, und von ihnen das dritte doppelt länger als das zweite, das vierte den beiden vorhergehenden zusammen gleich, das fünfte so lang wie das vierte, die drei folgenden wieder einander gleich und je etwas länger als das fünfte, das neuntq und zehnte etwas verkürzt, und das Endglied mit seinem dreieckig zugespitztem Fortsatze wieder die Länge des sechsten erreichend; dabei die sechs oberen breit zusammengedrückt und erweitert. Die fünf unteren Glieder pechschwarz, an den Rändern stellenweise trüb bräunlich durchscheinend, die oberen schwarz Init angedrückter dünner greiser Behaarung. Das Halsschild nicht ganz doppelt so breit wie lang, mit fast flachem, nur vor dem Hinterrande leicht quer niedergedrücktem Rücken, über den scharf spitzwinkligen Vorderecken zusammengedrückt und dadurch verschmälert, die Seiten fein gerandet, in der Mitte nur schwach erweitert, die Hinterecken stumpf abgerundet, und der Hinterrand zu beiden Seiten des kurz aufgebogenen Mittelzipfels ausgebuchtet; vor letzterem nach den Hinterwinkeln zu jederseits ein breiter, flacher Quereindruck. Die Punktirung grob, aber sehr vereinzelt, mit fast lackglänzendein Zwischengrunde, der in der Mitte etwas verschmälerte, vou den Vorderecken ab aber das ganze seitliche Drittel des Vorderrandes einnehmende Seitenrand breit knochengelb. Das Schildchen quer viereckig, fast unı die Hälfte breiter als lang, stark ansteigend, mit deutlichem Hinterzipfel, glänzend schwarz. Die Deckschilde länglich viereckig, vorn breiter als das Halsschild und hinterwärts noch mehr erweitert, kaum $1 / 4$ länger als breit, mit breit gewölbtem Rücken linterwärts sanft abfallend und erst von der Wölbung ab etwas stärker abwärtsgekrümmt, hinter der scharfen Vorderkante quer eingedrückt, mit sehr breiten und flachen, hinterwärts durch einen gleichfalls 
breitelI, seichten, zu den ehenfalls nur schwach entwickelten Seitenlappen hinabziehenden Quereindruck abgesetzten Schulterheulen. Hinten am Schildchen nochmals eine seicht niedergedrückte Stelle. Die Punktstreifen deutlich, aus sehr vereinzelten Punkten gebildet und etwas wellig gekrünmt, hinter den Schulterbeulen und dann wieder auf dem Raunie zwischen dem zweiten Streifen und der Naht etwas verwirrt und durch ïberzählige Punkte gestört, hinterwärts feiner und die mittleren aul' der Wölbung erloschen, mit flachen, glänzenden Zwischenräumen. Die Farhe hell knoclıengelb; ein gemeinsamer breiter quer viereckiger Spitzenfleck, welcher fast das ganze hintere Drittel der Flügeldeckenlänge einnimmt und vorn an der Naht in seichtem Bogen ausgerandet erscheint, schwarz. An den Seiten reicht derselbe vorn bis zum siebenten Punlitstreifen, von wo aus sein äusserer Rand die äusseren Zwischenräume schräg Jis zum hintern Aussenwinkel durchschneidet. Bei dem einzigen vorliegenden Stücke findet sich nun noch durch ein Spiel des Zufalls im Nahıwinkel der rechten Flügeldecke ein schmal dreieckiger, scharf begränzter gelber Längsfleck. Pygidium und Hinterleih, fein querrunzlig punktirt und sparsam kurz hehaart, schwarz, mit schmal gelhlichem Seitenrande des letzteren; die Brust schwarz, gröber und auf den Parapleuren dicht runzlig punktirt; die Beine schwarz mit bräınlichen Hüften; die Vorderschenkel stark verdickt mit weit gekrümmten Schienen. Das Prosterıum grob rumzlig punktirt, lang greishaarig, der Länge nach niedergedrückt und hinten breit rinnenförmig, mit breit abgerundeten Hinterzipfel. Das letzte Segment des $q$ mit einer nicht sehr tiefen, halbkugeligen Grube, das ơ unbekannt.

Aus Brasilien (Mus. Schaum.)

\section{v. Sternoglosus m.}

A ugen ausgerandet.

Rïckentheile nach oben frei beweglich.

Vorderbrust länger als breit, vor der Mitte beulig aufgetrieben und diese Auftreibung in einen holen, scharf zusammengedrückten, mil seiner hinteren Spitze auf die schnale Vittelbrust übergreifenden Kiel auslaufend, ohne Halskragen.

Schildclıen vorlanden.

Diese kleine Gattung stimmt habituell mit Scolochrus so vollständig überein, das ich in Allem auf die früher bei letzterer 
gegebenen Beschrcibung Bezug nehmen darf. Die einzige, aber sehr wesentliche Verschiedenheit zeigt sich in dem Bau der Vorderbrust, und diese gestattet nicht, die hierher gehörenden Thiere, die zugleich zu den grösseren Arten der Familie überhaupt gehören, mit einer der vorhergehenden Gattungen zu verbinden.

Die Vorderbrust ist zwar auch länger wie breit, aber doch in geringerem Grade als bei den verwandten Gattungen, indem die Breite reichlich drei Viertel der Länge erreicht. Ihre Fläche ist vorn zu beiden Seiten längs den Vorderhüften breit niedergedrückt; die Mitte erhebt sich fast schon vom Vorderrande an zu einer länglich eiförmigen, hoch aufgetriebenen Beule, dercn hächste Stelle grade zwischen die Vorderhüften fällt; hinterwärts verläuft sich dieselbe in einen, eben so hoch aufgetriebenen, seitlich stark zusammengedrückten scharfen Längskiel, welcher anf der hinten in stumpfen Bogen abgeschrägten Vorderbrust bis $\mathrm{zu}$ deren hinterem Ende rulıt und anit seiner etwas vorspringenden Spitze auf die überaus schmale, nur seitlich ein wenig verhreiterte Mittelbrust übergreift und deren Mitte fast ganz bedeckt: eine Bildung, welche schon mit dem unbewaffneten Auge ohne Mühe zu erkennen ist.

Von dieser eigenthümlichen Cryptocephaliden-Form sind his jetzt nur die $q$ von zwei Arten bekannt geworden, von denen die eine in Brasilien, die Andre in Cayenne zu Hause ist. Durch die Beschaffenheit der Vorderbrust bilden dieselben einen Uebergang zu Mastacanthus, bei welcher Gattung aber der Hinterzipfel der Vorderbrust selbst in eine pfriemliche, seitlich bogenförmig ausgeschweifte Spitze ausgezogen ist.

1. St. cruciger m. Schmutzig gelb, die Stirn, zwei Querflecke des grob zerstreut punktirten Halsschilds, der Rand und eine hintere Querbinde der Flügeldecken schwarz, die Beine schwarzbunt; die Deckschilde vorn grob siebartig punktirt, hinten und atssen punktstreifig mit flachen Zwischenräumen. L. $3 \frac{1}{1}{ }^{\prime \prime \prime}$; Br. $2^{\prime \prime \prime}$.

Der Kopf flach mit etwas zurücktretender Stirn, der Länge nach breit eingedrïckt uud dann nochmals von einer feinen Längslinie durchzogen, das kurze Kopfschild mondförmig quer niedergedrückt. Die Punktirung unten grob runzlig zusammengedrängt, auf der Stirn mehr zerstreut mit glänzendem Zwischengrunde; die Farbe schwarz, der untere Theil der Stirn mit dem Kopfschilde schmutzig lehmgelb, die schmale Oberlippe weisslich. Die Fühler 
(des ₹) nicht von halbel Körperlänge, zienılich dünı; das zweite Glied kurz verkehrtkegelförmig, das Iritte Glied doppelt länger und die beiden folgenden noch je etwas verlängert, die oberen dem tünften gleich, stark zusammengedrückt und elweitert, mit kurz dreieckigem Fortsatze des Endgliedes. Die unteren Glieder gelb, das dritte und vierte auf der Oberseite etwas dunkler angeflogen, Ilas fünfte an der Spitze gebräunt, die oberen schwarz. Das Halsschild hurz, fast alogestutzt dreieckig und hinten doppelt breiter als vorn, vor dem Schildclıen hallskreisförmig eingedrückt, mit fast grader Mittelfirste nach vor'ı wenig abfallend und hier leicht quer eingeschnürt, auch hinter der Mitte leicht zusammengedrückı; diœ Seiten fein gerandet, in der Mitte kaum erweiter', vor ilır sanft ausgeschweift, mit spitzen tief lerabgezogenen Vorder- und in einer pfriemlichen Spitze quer vorspringenden Hinterecken; der Hinterrand jederseits breit und seicht ausgesclıveift. Die Oberfläche sehr zerstreut- und ungleichmässig punktir, die Farbe lehmgelb, jederseits der Mitte ein grosser, schwarzer Querflech, beide nur durch einen schmal linienförnigen Zwischenraum getrennt. Das Schildchen stark ansteigend, quer viereckig mit abgerundeten Hinterecken und kurzem Hinterzipfel, vorn quer niedergedrückt, glänzend schwarz. Die Deckschilde breit und flach gewölbt, länglich viereckig, hinterwärts kaum erweiter', aber hinter den Schultern leicht zusammengedrückt, mit hinten zienılich flach abfallender Krüımung; hinter der scharfen Vorderkante ein aus vereinzelten Grübchen gehildeter Quereindruck, der sich am Schildchen und innerseits der höckerigen Schulterbeulen zu einer grösseren rundlichen Grube erwejtert; unter den Schulterbeulen über den kurzen aber tief herabgezogeneı Seitenlappeı noch je eine schwächere Beule und hinter letzterer ein schmaler aber tiefer Eindluck. Die Punktirung auf der vorderen Hälfte grob und siebartig zusammengedrängt, vou zwei unscheinbaren, dem zweiten und vierten Zwischenraume entsprechendeı Längslinieıı durchzogen, nur die heiden äussersten Punktstreifen kemullich; hinter der Mitte treles aus jenem Punktgewirre regelmåssigere Punktstreifen herror, die sich aber bald absclıwächen und auf der Wölbung fast ganz ellöschen. Die Zwisclıenräume daselbst lreit, flach und glänzend. Die Farbe lehmgell); ein breiter Saum längs der Wurzel und der vorderen Hälfte vou Naht und dussenrand schwarz, und die IInterenden dieses Naht- und Seitensaums durch eine hinter der Mitte liegende etwas 
wellige Querbinde verlunden, hinter welcher der hintere Theil von Naht und Aussenrand nur zart schwar'z eingefasst sind; der Kielrand des Seitenlappens weiss. Pygidium, Unterseite und Beine lehmgelb, fein punktirt und düm greishaarig; erster'es der laange nach seicht eingedrückt. Die Brust schmutzig gebräınt; die Vorderschenkel stark aufgetrichen mit entsprechend gekrümmten Schieuen, die Spitzen der Miltelschenkel und -schienen, die Innenkante und Spitze der Vorderschenkel, und die Vorderschienen schwarz, auch die Fussglieder schwärzlich. Das Prosternum grob runzlig punktirt, vorn niedergedrïckt. Das letzte Segment des $q$ mit einer kurzen, tiefen, rundlichen Grube; das of unbekannt.

Aus Brasilien (Mus. Saunders).

2. St. scalaris m. Rothbraun nit bläulichem Anfluge, ein zackiger Nalıtsaum mit der Spitze und einem Seitenflecke der Flüguddecken gelb, die Vorderfüsse schwarz; das Halsschild kaum punktirt, die P'unktstreifen fein, mit flachen, glänzenden Zwische»1räumen. L. $4^{\prime \prime \prime} ; \mathrm{Br} .21 \%$ "

Noch grösser als der vorhergehende, und zugleich durch seine eigenthümliche Farbenvertheilung noch mehr ins Auge fallend Der Kopf flach mit deutlicher, unterwärts breit dreieckig erweiterter Stirnrinne und stark eingezugenem, oben durch einen bogenförmigen, flachen Querwulst begränztem Kopfschilde, auf und über letzterem init wenigen Punkten bestreut, fast glatt, glänzend rothhraun mit hellerer Oberlipję die Kinnbacken schwarz. I)ie durch eine schmale, aher ziemlich tiefe rundlich dreieckige Ausbuchtung sehr ungleich getheilten, weit getremuten Augen greis. Die Fühler hıi dem einzigen vorliegenden Stücke nur unvollständig vorhanden, nach den erlıaltenen Ueberresten sehr dünn und schlank; das zweite Glied kurz und knotig, breiter als lang, die drei folgenden fast stielrund und nur nach der Spitze zu etwas aufgetrieben, das dritte dreimal-, das vierte viermal länger als das zweite, das fünfte noch etwas vergrössert, das seclıste wieder dem vierten gleich und oberwärts etwas erweitert. Die Farbe der fünf unteren durchscheinend honiggelb mit geschwärzter Oberseite der beiden ersten, die Spitze des fünften trüber gebräunt, das sechste mit gelbbräunlicher Wurzel, und das obere Ende mit dem Ueberreste des siebentrol Gliedes schwarz. Das Halsschild etwa $2 \frac{1}{2}$ mal breiter als lang, mit ziemlich grader Mittelfirste und fast llachem Rücken, seitlich lang lıerabgezogen, und über den tief einwärts gekrümmten sclıarf spitz- 
winkligen Vorderecken sehr verschmälert; die Seiten breit gerandet, in der Mitte in einem scharf herausspringendem Bogen verbreitert, vor ihr tief ausgeschweift; die stumpfwinkligen Hinterecken durch eine scharf aufgebogene Randschiviele bezeichnet: der Hinterrand breit und tief zweibuchtig mit kurzem, breit zugerundetem Mittelzijfel; vor letzterem jederseits ein breiter und tiefer Quereindruck, welcher längs dem Hinterrande eine kräftige Querfalte emporschiebl, und ausserdem noch die Seiten ülser ihrer Mitte stark zusammengedrückt. Die Oberfläche mit sehr vereinzelten und feinen Punkten bestreut, dazwischen spiegelglatt, dunkel rothbraun mit schwach metallisch bläulichem Anfluge. Das Schildchen stark ansteigend, etwa so lang wie vorn breit, vorn quer eingedrückt, hinten mit abgerundeten Ecken und deutlichem Hinterzipfel quer abgestutzt, glänzend rothbraun mit dunklerem Samme. Die Deckschilde breit und flach walzenförmig nit hinterwärts stäı'ker abgeflachten Rücken und kurzer, sehr schräg abfallender Wölbung, hinter der scharfen Vorderkante leicht quer eingedrückt; die Schulterbeulen sehr flach, die Seitenlappen lang herabgezogen nit breiten, ungeschlagenem Rande, und ïber ihnen auf dem neunten Zwischenraune die Deckschilde breit zusammengedrūckt. Die Punktstreifen fein und im Ganzen regelmässig, nur der abgekürzte und der erste etwas in einander gewirrt und durch äberzählige Punkte gestört, auch der sechste und siebente etwas wellig gekrümmt: überall aher die Punkte sehr vereinzelt, nur die des Randstreifens dichter zusammengedrückt und besonder's auf dessen Vorderhälfte tiefer eingegraben, wodurch der Kiel des Seitenlappens als scharfer Rand emporgetrieben wird. Die Farbe ein schönes, ins Purpurfarbige überspielendes, hinterwärts etwas helleres Rothbraun; ein breiter, vor'n auch das Schildchen begleitender, in oler Mitte kur\% zackig erweiterter, vor der Wülbung verwaschen unterbrochener, und zuletzt noch die Spitze mmziehender Nahtsaum, sowie ein eiförmiger Schrägfleck auf der Mitte zwischen dem fünften Streifen und dem Rande hellgelb: der letztere liegt der zackigen Erweiterung des Nahtsaums grade gegrenüher, sodass hier bei anderen Stücken wohl ein Zusammenfliessen beider statufinden könnte. Das Pygidium fein runzlig punktirt, schmutzig lehmgelb. Unterseite nnd Beine tief rothbraun, die Vorderfïsse schwarz; die Vorderschenkel loreit aufgetriehen, mit stark gekrümmten Schienen. Der Ilinterleib des vorliegenden Stückes slark beschïdigt: nach der 
Sculptur der Declischilde glaube ich jedoch darin ein $\&$ zu erkennen.

Von Cayenne. (Mus. Deyrolle).

\section{V1. Pachybrachys Chv.}

(Linn. Ent. III.)

Erste Rotte. Fühler meist lang und dünn; Körper breiter und llacher, oder schmaler und mehr gestreckt walzenförmig. Kopf und Halsschild feiner, die Deckschilde vor'ı gröber punktirt, von der Mitte ab und aussenseits manchnal längs ihrer ganzen Ausdehnung unordentlich längsrippig, mil mehr oder weniger deutlich liervortretenden Punktstreifen oder Furchen. Farbe schivarz, meist mit weissen oder gelben Zeichnungen; seltener das Schwarz vertrethn durch Braun oder Gelb. Linn. VII. 157. Vierte Rotte. IVie in Norlamerika, so bildet auch lier diese Rotle mit his jetzt mehr als dreissig Arten den Kern der Gattung, und ist in allen bis jetzt durchforschten Theilen des südamerikanischen Festlandes vertreten.

1. P. cariosus Erichs. Greisgelb mit dunkleren Wolkenflecken, Kopf und Halsschild dicht siebartig punktirt, die Deckschilde vorn sehr grob punktirt, hinten punktstreifig mit flachen, gläızenden Längsrippen. L. $2 \frac{1}{6}{ }^{\prime \prime \prime} ; \mathrm{Br}$. 1“”.

Pachybrachys cariosus Erichs. Conspect. Ins. Col. Peruan. in Wiegmanns Archiv 1847. I. S. 164. n. 1 !

Eine durclı ihre Färbung und Sculptur unter den südamerikanischen Arten diesser Rotte ganz allein stehende Art, die aber unter den nordamerikanischen wenigstens vereinzelte Verwandte findet. Der Kopf flach, mit breiter, in der Mitte seicht aber lang niedergedrückter Stirn, fein eingeschnittener Nackenlinie und wenig eingezogenem Kopfschilde; die Oherfläche dicht siebartig junktirt mit lackglänzendem Zwischengrunde; die Farbe schwärzlich, der hreite Nacken oberhalb der Augen, die innereu Augenränder von der Mitte der Augenbuchten ab und der untere Theil des Kopfschildes schmulzig und verwaschen greisgelb; die Mundtheile etwas dunkler, die lang aber nicht sehr tief ausgebuchteten Augen greis. Die Fühler etwa von halber Körperlänge, ziemlich derb; das Wurzelglied blasig aufgetrieben, ım die Hälfte länger als breit, das zweite breit eiförınig, die drei folgenden dünn verkehrthegelförmig, das dritte um die Hälfte, das vierte um $2 / 3$, das fünfte doplvelt länger als das zweite, das sechste, siebente und das Endglied init 
seinem schnal dreieckigem Fortsatze den fünften, das achte bis zehnte je dem vierten Gliede gleich, und dabei die oberen selır sclıwach erweitert und zusammengedrückt; die Farbe schmutzig bräunlichgreis, die uberen noch etwas dunkler, die Oberseite des ersten und zweiten geschwärzt. Das Halsschild etwa $2 \frac{1}{2}$ mal breiter als lang, hinter der Mitte sehr sanft quer aufgewölbt uud vor dem Hinterrande eben so leicht quer niedergedrüclit, über den scharf spitzwinkligen ziemlich tief eingezogenen Vorderecken zusammengedrückt und dadurch verschmälert; die Seiten fein gerandet, hinter der Mitte schwach bogig erweitert, die Hinterecken stumpfwinklig, der Hinterand jederseits des schwachen Mittelzipfels selır seicht ausgebuchtet. Die Oberfläche seitwärts dieser Ausbiegung noclmals der Läıge nach flach eingedrückt. Die Punktirung ziemlich derb, dicht zusammengedrängt, besonders in den drei vertieften Stellen vor dem Hinterrande, die durch das geschwärzte Innere der Punkte deshalb auch etwas dunkler erscheinen; der Zwischengrund glänzend, sich zwischen und vor jenen dunkleren Stellen sowie läıgs den Seiten in vereinzelten kleinen Schwielenfleckichen erhebend. Die Farlue schmutzig greis, jene Schwielenfleckchen ins heller Gelbliche fallend, die vertieften Stellen als verwaschene dunklere Wolkenflecke bemerkbar. Das Schildchen stark ansteigend, lualb so lang als vorn lreit, hinten mit abgerundeten Ecken und deutlichen Mittelzipfel abgestutzt, schmutzig geschwärzt, mit einen helleren gelblichen Flecke vor dem Hinterrande. Die Deckschilde loreit und flach walzenförmig, etwa $1 / 3$ länger als breit, hinten mit mässiger Wölbung abfallend, hinter der scharfen aber wenig erhölten Vorderkante in einer schmalen Querlinie eingedrücht; die Schulterheulen lang ausgezogen, die Seitenlappen kräftig mit einer groben Punktreilıe auf dem unıeschlagenem Rande; üher ihnen die Deckschilde breit und starli quer zusammengedrückt. Die Punktirung sehr grob und dabei ziemlich dicht, die ursprünglich vorInandenen Punktstreifen auf der vorderen Hälfte durch überzählige Punkte derartig gestört, dass nur stellenweise abgerissene, auch wohl cine unregelnässige Verdoppelung verrathende Ueberreste solcher Streifen erkembar werden, und von Zwischenräumen nur der an der Schulterbeule entspringende achte seiner ganzen Länge nach hervortritt. Der zwischen dem fast regelmässigen, aber wellig gekrümmten neunten und dem Raudstreifen liegende neunte Zwischenraum ungewöhnlich breit, aher überall mit groben Punkten 
besetzt. Von der Mitte ab entwickeln sich die Streifen regelmässiger, und auf dem letzten Drittel erheben sich die Zwischenräume zu deutlichen, ziemlich breiten Längsrippen, welche aber die wieder ahgeflachte, uи mit einzelnen groben Punkten besetzte Spitze nicht erreichen. Der Zwischengrund lackglänzend, die FarJe ein ziemlich helles Greisgelb, durch das geschwärzte Innere der Punkte und drei grosse verwaschene schwärzliche Wische auf der hinteren Hälfte wolkig ersclseinend. Von den letzteren liegen zwei auf der Wölbung neben einander, der äussere, grössere etwas mehr naclı vorn gerückt und mehr oder weniger von abgerissenen, den höchsteı Theil der Rippen einnehmenden gelblichen Längslinien durchschnitten; der dritte liegt linter der Mitte, vor dem Zwischenraume der beiden hinteren, und einzelne ähnliche kleine Wische finden sich weiter nach vor', eben so ist die Schulterbeule mit einem schmalen schwärzlichen Längswische bezeichnet. Das Pygidium gellgreis, der obere Rand und drei mit ihm zusammenhängende Flecke geschwärzt, von deuen der mittlere, grössere sich mit dreieckiger Zuspitzung bis zu dem unteren Rande fortsetzt. Die Unterseite schwärzlich, der letzte Ring, die schmalen Hinterränder und Seiten des vorhergehenden, die breite Mitte des ersten und dessen seitliche Vorderzipfel gelblich, Auch die Beine schwärzlich, an den Vorderbeinen die Schenkelwurzeln und die Unterseite der Schenkelspitzen, die Wurzeln und Unterseite der Schienen gell,lich braun, an den Mittel- und Hinterbeinen die Wurzeln und Spitzen an Schenkeln und Schienen heller gelb. Das letzte Segment des \& mit einer kleinen, länglichen Grube, das $\delta$ unbekannt.

Aus Peru. (von Lima: Tschudi im Mus. Berol.)

2. P. paganus Oliv. Rothbraun- und gelbbunt; das schwielig gelbgelleckte Halsschild ziemlich fein aber dicht punlitirt, die Deckschilde vorn groh runzlig punktirt, hinten wellig längsrippig. L. $11 / 2 " ' ; \mathrm{Br} .2 / 3{ }^{\prime \prime \prime}$.

Cryptocephalus payanus Oliv. Ent. VI. 811. n. 46. tab. 5. fig. 80 (nicht fig. 89., wie im Text steht).

Von dieser Art kann ich nur ein einziges und dabei selı schlecht erhaltenes Stück vergleichen, und die Beschreibung wird deshalb künftig noch mancher Ergänzungen bedürfeu, doch alser wohl zum Wiedererkennen des Thieres ausreichen, sobald erst eine grössere Zahl von Exemplaren desselben aufgefunden sein wird. Der Kopf flach mit leichı eingedrückter Stirn und eben so schwach XVI. 
eingezogenem, oben durch eine kaum merkbare Querkante abgesetztem Kopfschilde, dicht und fein punktirt und dadurch matt; die Farbe tief schwarzbraun, der obere und innere Augenrand eben so trüb gelblich gesäumt, welcher Saum sich, aber etivas algeschwächt, unterwärts bis zu den etwas helleren Wangen hinabstreckt. Das Kopfschild, besonders dessen olere Kante, fält gleichfalls mehr oder weniger ins trübgelbliche; an den Fühlerhöckeru innerseits je ein hellerer Punki, und auch die Nunltheile, bis auf die schwarzen Kinnbacken, Init der Oberlippe hell knochengelb. Die Fühller des einzigen vorliegenden Stückes sehr beschärligt; das zweite Glied kurz eiförmig, das dritte um die Hälfte länger und verkehrtkegelförmig, das vierte (längste) doppelt länger ats das zweite, die drei folgenden einander gleich, je fast so lang als das vierte, das sechste und siebente oberwär's sehr schwach verbreitert und zusammengetrückt. Die Farbe bleich gelb, die beiden unteren Glieder etwas mehr ins Röthliche fallend, und mit einem dunkteren Wische auf ihrer Oberseite. Das Halsschild etwa $2 \frac{1}{2}$ mal breiter als lang, hinter der Mitte stark quer aufgewölht und von da ab nach vorn mit sanfterer, hinterwärts mit etwas stärlierer Krümmung abfallend, seitlich tief herabgezogen, über den scharfen fast rechtwinkligen Vorderecken breit zusammengedrückt und dadurch verschmälert; die Seiten selbst fein gerandet, vor der Nitte fast eckig erweitert und von da nach rorn und hinten beinahe gratlinig verlaufend; die Hiuterecken stumpfininklig, der Hinterrand jetlerseits leicht gebuchtet, mit schwachen Mittelzipfel, und vor diesem ein tiefer, sich nach vorn allmällich abschwächender Quereindruck. Die Oberfläche dicht und fein punktirt, matt rothlıraun, die unterbrochenen Känder unt einzehne unregelmässig vertheilte Stellen heller gebräunt, und auf diese dann wieder eine Anzahı kleinerer, bald getremnter bald regellos zusammenhängender golänzend geller Schwielenfleckchen aufgetragen, die sich hesonders gegen die Mitte hin zusammendrängen und hier ein grosses unregelmässiges, in der Mitte der Lănge nach getheiltes, vorn und linten die Ränder des Halsschilds erreichendes Feld zu bilden scheinen. Das Sctiildchen um die Hälfte breiter als lang, hinterwärts nur mässig verschmälert, mit deutlichem Hinterzipfel stumpf algyerundet, fein punlitirt und matt, trübgells mit bräunlichem Saume. Die Deckschille flach walzenförmig, kaum $1 / 4$ länger als breit, hinter der scharfen aber wenig erhöhten Vorderkante schmal quer ein- 
gedrückt und dahinter etwas aufgewulstet, hinter dem Schildchen und dann nochmals in weiterer Ausdehnung anf der Nitte quer niedergedrückt, wodurch vor der letzteren ein flacher nach deu Schulterı sich hinziehender Schrägwulst gehildet wird; die Schulterbeulen breit und flach, die Seitenlappen nur als cine schivache Erweiterung der Flügeldecken bemerkbar. I)ie Punktirung grol, auf der vorderen Häfte zwischen Naht und Schulterbeulen ein Gewirre von dicht gedrängten, theilweise runzlig verfliessenden Punkten clarstellend, in dem sich stellenweise abgerissene Punktstreifen, durchgreifend dagegen zwei erhölıte Längslinien (der zweite und vierte Zwvischenraum) lienntlich machen. Nach Aussen hin wird die Punktirung noch gröber, lockerer, aber olne deutliche Streifenentwickelung; eine solche zeigt sich erst auf der hinteren Hälfte dadurch, dass aus jenem Gewirre wellige und vertiefte, aber nur zum Theil noch in ihrem Innern Punlite zeigende Längslinien hervortreten, und durch eben so wellige, mehrfach unterl,rochene und einander durchkreuzende flache Längsrippen von einander geschieden werden. Die Farbe auch hier, wie die des Halsschilds, matt röthlich brauı, hesonders auf den vertieften Stellen, sowie im Inneru der Punkte und Längslinien; darunter mischen sich hellere, wip durclischeinende Stellen, und, theilweise auf diesen, meist aher auf den Längsrippen vertheilt, hellgelbe schwielige Punkte und Fleckchen, meist unterbrochene oder abgerissene Längsflecke bildend, aber nicht einmal auf beiden Flügeldecken gleichmässig vertheilt, nur die Spitze vollständig mit einer solchen bogenförmigen Schwirle ausgefüllt, und an diese strahlenförmig auf den Längsrippen siclı ıach vorn erstreckende gelhe Längslinien angeschlossen, die zwar bald abreissen, in ihren Fortsetzungen aber auf der Wöllung eine Art unterbrochener Querbinde zu bilden scheinen, Das fein runzlig punktirte, stumpf gekielte Pygidium trüb gelbbraun mit dunkleren Säumen; die Unterseite schwarzlıraun, der letzte Ring, die Vorderzipfel des ersten, und die Seiten der übrigen Ringe trül gelhbrauu, auch die Schulterblätter heller gebräunt. I)ie Schenkel schwärzlich, die Ḱnie und ein vor diesen liegender, bei den Vorderschenkelı von ihnen getrennter Fleck gellılich, dic in der Mitte bräunliclı verwaschen geringelten Schienen und die Füsse sclımutzig gell. Das Prosternum tief rinnenförnig ausgehöhtt; das letzte Segment des of mit einer tiefen, rundlichen Grube, das ơ unbekannt. Aus Guyana (Mus. Deyrolle). 
Im Museum Deyrolle ist der vorbeschriebene Käfer als Cr. paganus Oliv. bezeichnel, und ich habe diese Bestimmung angenommen, da Oliviers Beschreibung sich ganz wohl anf denselben deuten lässt. Die Abbildung passt dazu freilich nicht, stimmt aber eben so wenig zu den genanntea Beschreibung, und ist daher als wenig gelungen zu betrachten.

3. P. spurcans m. Schwarzbraun, Kopf, Beine, Pygidium und letzter Bauchring gelbbunt, der unterbrochene Rand und rine Anzahl Punktflecke nebst einer abgekürzten Mittellinie des dicht und fein punktirten Halsschildes, sowie die Spitze und eine unterbrochene hintere Querbinde der Deckschilde hellgelb; letztere deutlich punktirt, hinten wellig längsrippig. L. $1 \frac{1}{2}{ }^{\prime \prime \prime} ;$ Br. 3/4"'.

Bei gleicher Länge breiter und flacher als der vorige und deshalb mehr den beiden folgenden verwandt, aber von $P$. musivus hauptsächlich an der feineren Sculptur und den zahlreicheren Punktflecken des Halsschilds, von $P$. adspersus durch die doppelte Grösse und die deutlicheren Längsrippen der Deckschilde abweichend, übrigens mir auch nur in einem einzigen sehr beschädigten Stücke vorliegend, und deshalb die Beschreihung für die Zukunft noch der Ergänzung bedürftig. Der Kopf flach, längs der Mitte leicht vertieft, sehr dicht und fein runzlig punktirt, durch eine dünne und kurze greise Behaarung matt, schwarzhraun; die inneren Aıgensäume, die Wangen mit der Oberlippe und ein trüber Querfleck zwischen den Fühlerwurzeln verwaschen gelblich, die lıreit und tief ausgebuchteten Augen greis. Die Fühler nicht mehr vollständig vorhanden, und diese bis zum neunten Gliede reichenden Ueberreste schmutzig gelb. Das Halsschild doppett breiter als lang, über die Mitte sanft quer aufgewölbt, und von da ab die Firste naclı vorn und hinten gleichmässig ahwärts gekrümmt, über den scharf rechtwinkligen Vorderecken breit zusammengedrückt und dadurch verengt, die Seiten sanft gerundet und mit stumpfen Hinterecken in den scharf erhöhten, jederseits leicht wellig gekrünmıten Hinterrand ïbergehend; der Mittelzipfel kurz und breit zugerundet, und vor ihm das Mittelfeld durch cine seichte Querfurche etwas niedergedrückt. Die Punktirung überaus fein und dicht, der Zwischengrund matt, mit iusserst feiner und kurzer, wie geschorener sillsergrauer Behaarung bedeckt und dadurch bei gewvisser Beleuchtung seidig schimmernd; die Farbe brann, ein den alogesetzten Rand begleitender, vielfach unterbrochener, schwielig erlölıter und schwach glänzender Saım gelb, und gleichı Färbung zeigt eine abgekürztr, 
erhöhte Mittellinie sammt einer Anzahl sehr vereinzelter kleiner schwielig erhöhter Punkte oder Wärzchen, die grösseren auf der Hinterhälfte und meist mit einem verwaschenen bräunlich gelben Hofe umgeben, welcher theilweise auf die bei anderen Arten hier vorhandenen abgekürzten, jederseits der Mitte auf dem Hinterrande stehenden gelblichen Längsbinden hindeutet. Das Schildchen bei dem vorliegenden Stücke kaum noch erkennbar. Die Deckschilde kaum 1/5 länger als breit, ziemlich gleichbreit mit sehr flach gewölbtem Rücken und eben so flach abfallender Wölbung; hinter der scharfen Vorderkante kaum quer eingedrückt, mit länglich eckigen Schulterbeulen, aber sehr schwach ausgebildeten Seitenlappen; die dichte Punktirung gröber als die des Halsschilds, zwischen Naht und Schulterbeulen schon auf der Vorderhälfte jeder Flügeldecke mit zwei deutlichen Längsrippen (der zweiten und vierten), an die sich auswärts hinter der Schulterbeule zwischen der vierten und der wieder stärker hervortretenden achten noch einige undeutlichere Rippenansätze anschliessen. Auf der hinteren Hälfte bilden sich dann auch diese nebst der ersten und neunten zu deutlichen etwas wellig gekrümmten Rippen aus. Farbe und Behaarung wie die des Halsschilds; auf der Vorderhälfte nach aussen einige unregelmässig zerstrente gelbliche Längsflecke auf den Rippenansätzen, und hinter der Mitte eine aus solchen gebildete, aussen etwas naclı hinten zichende Querbinde; ausserdem die Spitze gelb und von dieser aus Ansätze solcher Längslinien auf der ersten und neunten Rippe mit unregelmässigen gelben Fleckchen auf deı Enden der Zwvischenrippen. Pygidium und Unterseite schwarz mit dünner angedrückter silbergrauer Behaarung; die Seiten des ersteren verwaschen gelblich gesäumt und dieser Saum unten fleckartig erweiter't, der letzte Bauchring mit einer wellig unterbrochenen gelben Querbinde bezeichnet. Die Beine schwarz, Hinter- und Mittelschenkel, sowie Vorder- und Mittelschienen in der Mitte verwaschen bräunlich gerunzelt, die Hinterschienen nur an den Knien trüb gelblich, die stark aufgetriebenen Vorderschenkel nur auf der Innenkante gelh mit einem ähnlichen Längsfleckchen auf der breiten Vorderfläche. Die Mittelrinne der Vorderbrust ziemlich tief, ihr Ilinterzipfel stumpf dreieckig init gelhlichem Ende. Das letzte Segment des $\&$ mit einem breiten, runden, tiefen Grübchen, das $\delta$ unbekannt.

Aus Chile (ron Si. Jago: Mus. Deyrolle). 
4. P. adspersus m. Zimmtbraun, oben mit weissen Warzenfleckchen bestreut, die Beine bleichgelb mit dunkler geringelten Schenkeln und Schienen, das weiss gerandete Halsschild und die Deckschilde dicht punktirt, letztere nur auf der Wölbung mit Andeutungen abgekürzter Längsrippen. L. $1^{\prime \prime \prime} ; \mathrm{Br}$. 1/2"'

Eine kleine, zierliche, durch die schwache Ausbildung ihrer Längsrippen und die eigenthümliche Fleckenbildung sehr ausgezeichnete Art. Der flache Kopf dicht und fein punktirt, dünn und kurz behaart, ınatt, die Stirn der Länge nach seicht eingedrückt, zimmtbraun, die oberen Augenränder, die Innenecken der breiten und tiefen Augenbuchten, die Wangen und die Unterecken des Kopfschilds verwaschen gelblich; auch die Oberlippe knochengelb mit quer verdunkelter Mitte, und die Kinnbacken schwärzlich. Die Fühler von halber Körperlänge, dünn, das zweite Glied breit eiförmig, so dick wie das erste, die folgenden ziemlich von gleicher Länge und je doppelt länger als das zweite, von der Spitze des sechsten ab leicht zusammengedrückt und nur schwach erwejtert, die sechs unteren gelb, die folgenden an der Spitze geschwärzt, und diese Färbung immer mehr zunelımend, sodass die beiden letzten fast ganz schwarz erscheinen. Das Halsschild fast $2 \frac{1}{2} \mathrm{mal}$ breiter als lang, hinter der Mitte schwach quer aufgewölbt und vor dem Hinterrande stärker niedergedrückt, über den scharf rechtwinkligen Vorderecken zusammengedrückt und ladurch verschmälert, die Seiten fein gerandet, sanft gerundet; die Hinterecken stumpf, der Hinterrand fast gerade, nur jederseits des kurzen Mittelzipfels leicht ausgebuchtet. Die Olserseite durch eine sehr dichte und feine Punktirung matt, dunkelzimmtbraun, Vorder- und Seitellrand breit weisslich gelh gesäumt; ein älınlicher Saum längs dem Ilinterrande ist den ganzen Mittelzipfel entlang unterbrochen und auch weiter seitlich mehrfach in vereinzelte Punkte zerrissen. Die Mitte zeigt auf der vorderen IIälfte eine mit dem Vordersaume zusammenhängende, an beiden Enden verbreiterte Längslinie, und ausserlem findet sich noch eine Anzahl ziemlich regelmässig vertheilter rundlicher, wie aufgetragener weisser Flecke, deren jederseits fünf von Vorderwinkel nach der hinteren IIälfte des Seitenrandes zu, zwei schräg gestellt zwischen der Mittellinie und dem oberen Augenrande, und noch zwei schräg vom Hinterende dieser Linie ab, der hintere derselben grade über der Stelle stehend, wo am Mittelzipfel der hintere Saum abbricht, so dass dadurch über 
jenem ein breites dachförmiges Fünfeck gebildet wird. Das Schildchen kurz und breit dreieckig, stark ansteigend, hinten mit abgeI'tundeten Ecken abgestutzt, fein punktirt, schwarzbraun. Die Deckschilde langlichviereckig und hinten kurz ahgerundet, kaum 1/4 länger als breit, vor der Mitte quer abgeflacht, die Schulterbenlen nur als schwache Längshöcker hemerklich und auch die Seitenlappen nur wenig absvärts gezogen. Die Punktirung doppelt stärker als die des Halsschilds, eben so dicht gedrängt, und der schmale Zwischengrund mehrfach runzlig verfliessend; erst hinten auf der Wölbung finden sich Spuren abgekürzter und theilweise gekrümmter Längslinieı, zwischen denen sich auf jeder Flügeldecke 5-6 rippenförmige Läıgsfelder bilden. Die Farbe auch lier ein mattes dunkles Zimmtbraun, ein unterbrochener, hinter der schwärzlichen Wurzelkante liegender Vordersaum und eine Anzahl grösserer melır eckiger, und kleinerer mehr linienförmiger Flecke weisslich gelb. Dieselben sind nicht so symmetrisch, wie die des Halsschilds, gestellt, aber doch auf der äusseren und hinteren Hälfte zahlreicher und grösser als vorn und längs der Naht; auf der Wölbung nehmen sie die Rippenfelder vollständig ein, und bilden unter ihr zugleich einen mondförmigen Fleck in jedem Nahtwinkel. Das Pygidium fein runzlig punktirt, mit angedrückter gelblicher seidenglänzender Behaarıng, dunkelbraun, jederseits am Rande mit einem rundlichen weissen Flecke, und zwischen beiden ein grösserer Hufeisenfleck am Unterrande. Auch die Unterseite dunkelbraun, die hinteren Bauchringe jederseits mit einem verwaschenen gelblichen Querflecke. Mittel- und Hinterbeine bleich gelb mit bräunlich geringeiten Schenkeln und Schienen, die Vorderschenkel braun, die Knie und ein rundlicher Fleck auf der breiten Vorderfläche nebst den Schienen gelblich. Das letzte Segment des $\delta$ einfach, des $q$ mit einem ziemlich flachen Grübchen.

Aus Brasilien (von Santarem: Mus. Baly.) und von Cayenne (Nus. Clark.)

5. P. musivus Grin. Zimmetbraun mit gelbbunter Oberseite, Pygidium und letzter Bauchring mit den Beinen gelbfleckig; das seitlich fast gerade Halsschild dicht und ziemlich fein punktirt, die Deckschilde gröber punktirt, fein wellig längsrippig. L. 1$1 \frac{1}{2}{ }^{\prime \prime \prime} ;$ Br. $1 / 2-2 / 3^{\prime \prime \prime}$.

Dem vorhergehenden und noch mehr dem nordamerikanischen P. spumarius $m$. älunlich, von beiden aber durch die kaum ge- 
rundeten Seiten des Halsschilds, und mehr noch durch die obwohl feine, doch fast über die ganze Fläche der Deckschilde sich ausdehnende Rippenbildung abweichend. Der Kopf flach mit breiter, sehr seicht niedergedrückter Stirn; die Punktirung dicht und feiı, nach der dunkleren Mitte zu dichter zusammengedrängt und hier der Zwischengrund matt und glanzlos. Die Farbe tiefbraun, der Unterrand des Kopfschildes, ein undeutlicher Querfleck an dessen Spitze, und der gewöhnliche jederseits den oberen inneren Augenrand umziehende, mit dem unteren Ende auch in die tiefen spitzdreieckigen Augenbuchten eindringende Hakenfleck gelb, etwas stärker glänzend und nur mit einzelnen Punkten besetzt. Meist sind auch noch die Wangen gelb; bei lichter gefärbten Stücken fliessen die schlecht begränzten Innenıänder dieser gelblich gefärbten Stellen besonders am unteren Ende des Kopfes ineinander und der ganze Kopf erscheint dann mehr oder weniger gelb, der Nacken, die nach unten erweiterte Mitte der Stirn, und ein grosser Querfleck auf der Mitte des Kopfschildes dunkler gebräunt. Die Fülıler kaum von halber Körperlänge, dünn und schlank, das Wurzelglied aus sehr dünner Basis breit keulig aufgetrieben, etwa doppelt länger als breit, das zweite eiförmig, halb so lang und breit wie das vorhergehende, das dritte dem zweiten au Länge gleich aber merklich dünner, die beiden folgenden noch ein wenig zunehmend, das sechste bis achte je dem fünften gleich, und die drei letzten etwa wieder wie das dritte, mit selır kurz dreieckigem Fortsatze des Endgliedes; diese oberen von der Spitze des sechsten ab schwach zusammengedrückt und erweitert. Die Farbe der fünf unteren gelb, manchmal mit gebräunter Oberseite, die oberen schwarz, dünn angedrückt greishaarig und an den Spitzen weisslich gewimpert. Das Halsschild breit und flach walzenförmig, etwa halb so lang wie - breit, über den rechtwinkligen und dann noch kurz pfriemlich vorgezogenen Vorderecken etwas zusammengedrückit, in der Mitte leicht quer aufgewölbt und hinter ihr alogeflacht, daher die Hittelfirste lier etwas stärker niedergesenkt; die Seiten grade, nur der ausserhalb der stark ausgeprägten Randlinie liegende schmale Saum in der Mitte ein wenig verbreitert; die Hinterecken stumpfwinklig abgemundet, der Ilinterrand nur jederseits des kurz und schmal aufycbogenen Mittelzipfels etwas ausgebuchtet. Die Farhe heller oder dunkler zimmetbraun, ein breiter Vorder- und Seitenrand, und ein unterbrochener Hinterrand lackartig aufgetragen gelb: das 
dicht und deutlich punktirte Mittelfeld mit einer Anzahl regellos vertheilter, gegen die Mitte hin zu einem zerrissenen Längsflecke zusammengedrängter gleichfalls gelber, bald punktfreier bald durch vereinzelte Punkte unterbrochener Schwielen bestreut, und zwischen ihnen der braune Grund matt und glanzlos. Das Schildchen kurz und sehr breit dreieckig, schräg ansteigend, hinten mit deutlichem Hinterzipfel grade abgestutzt, glänzend schwarz, bei helleren Stücken in der Nitte gebräunt. Die Deckschilde länglich viereckig, reichlich doppelt länger aber vorn nur wenig breiter als das Halsschild, etwa um $1 / 4$ länger als breit, hinter der schwach erhöhten Vorderkante leicht quer niedergedrückt, auf der Naht hinter dem Schildchen nochmals verflacht; die Schulterbeulen schmal höckerig, die Seitenlappen breit zugerundet, und über ihnen je ein gleichfalls breiter, aber nur schwacher Quereindruck. Die Punktirung grob, vorn anscheinend regellos, aber doch mit deutlichen Spuren dicht gedrängter und etwas welliger, durch überzählige Punkte getrübter Doppelstreifen, deren Zwischenräunie stellenweise als erhöhte schmale gelbe schwielenartige Längslinien hervortreten. Auf der hinteren Hälfte werden der eingemengten Punkte inmer weniger, die Streifenbildungen daher immer klarer, so dass auf der Wölbung vier deutliche, durch stärkere rippenförnige Zwischenräume getrennte Doppelstreifen kenntlich werden, zwischen denen auch noch die abwechselnden Zwischenräume als schmalere, minder deutliche Längsleisten wahrzunehmen sind. Auch die ungeschlagenen Ränder der Seitenlappen je mit einer kräftigen Punktreilıe besetzt. Die Farbe heller oder llunkler zimmtbraun, der aufgeworfene Vorderrand nebst dem Kiele des Seitenlappens gelb, und ausserdem noch die Zwischenräume in grösserer oder geringerer Ausdehnung und bei den verschiedenen Stücken verschiedener Gestalt mit abgerissenen gelben Längslinien besetzt, deren gewöhnlich zwei aus der Wurzel zwischen Schildchen und Schulterbeule entspringen, während die übrigen sich regellos vertheilen, sich manchmal auf dem Raume hinter den Schulterbeulen mehr zusammendrängen, bei heller gebräunten Stücken zahlreicher vorhanden sind und dann besonders die breiteren Zwischenräıme bis über die Wölbung hinaus einnehmen, hier auch wohl mit ihren Hinterenden im Nahtwinkel zu einem lappigen Spitzenflecke zusammenfliessen. Auf den breiteren gelben Schwielen zeigen sich hier und da wohl einzelne gröbere Punkte. Das Pygidium fein aber dicht runzlig 
punktirt, braun, mit einem grossen nach oben offenen gelben Hufeisenflecke, dessen Aussenenden sich obeı an den gelben Saum des letzten Bauchringes anschliessen. Auch die Unterseite dicht runzlig punktirt, bei dunkleren Stücken braın mit breit gelbem Hintersaume des letzten Ringes, auch wohl einem ähulichen Randflecke auf jeder Seite des vorhergehenden; bei helleren färbt sich der ganze Seitenrand des Hinterleibes mit dem ganzen ersten Ringe oder doch dessen drei Vorderzipfeln verwaschen gelb. Auch die Beine gelb, Schenkel und Schienen in der Mitte breit heller oder dunkler braun geringelt, die Füsse oder auch nur deren Krallen schwärzlich. Die Längsrinne der Vorderbrust ziemlich breit und seicht, mit sehr kurz dreieckigem Hinterzipfel. Das letzte Segment des $\delta$ kaum benerkbar quer niedergedrückt, des $q$ mil einem mässig vertieften Grübchen.

Aus Brasilien und daselbst von Beske gesammelt (Mus. Schaum. Halens,; auch in Mus. Vindob. Clarl. vorlıanden). Bei einem von Sello herstammenden Stücke im Mus. Berol. ist S. Paolo als Fundort genannt.

Ein etwas tiefer gebräuntes $ð$ von Rio de Jan. mit mehr beschränkter gelber Zeichnung der Deckschilde, bei welchem zugleich die Zeichnungen des Halsschilds in lauter vereinzelte Alomenflecke aufgelöst sind, aber doch noch durch deren Stellung die Umrisse der normalen Form erkennen lassen, findet sich im Mus, Deyrolle als $I$. contcmptus Dej. Ich finde aber elsen so wenig bei ihm einen weiteren wesentlichen Untersehied von dem Beske'schen Käfer, als bei einem hellzimmtrōthlichen Stücke, welches in derselhen Sammlung als $P$. eburatus Chr, vorbanden ist.

6. P. eburifer Chr. Lederbrauı, das dicht runzlig punktirte gelbgesäumte Halsschild mit vereinzelten gelben Schwielenflecken, die Deckschilde mit welligen gelben Längslinien, um das Schildchon dicht regellos punktirt, daneben wellig kerbstreifig mit flach gewölbten Längsrippen. 'L. $5 / 6{ }^{\prime \prime} ; \mathrm{Br}$. $1 / 2{ }^{\prime \prime \prime}$.

Eine selır kleine und zicrliche, an der reinen Sculptur und der hell lederbraunen Färbung leicht bemerkliche Art. Der Kiopf flach mit seichter aber deutlicher Stirnlinie, durch eine feine, mässig dichte Punktirung matt, hell lederbraun, mit einzelnen greisen Iäärchen besetzt; die Wangen rothbraun, die Enden der Kimnbacken und Taster geschwärzt, die grossen dreieckig ausgel)uchteten, '(bei dem १) weit getrennten Augen greis. Die Fühler von einem Drittel der Körperlängą, das Wurzelglied stark aufgetriehen, um die 
Hälfte länger als breit, das zweite kugelig, die folgenden dünn verkelırtkegelförmig, das dritte und vierte je um die Hälíte länger als das zweite, das fünfte noch ein wenig länger, die folgenden je etwa wieder dem dritten gleich, nach der Spitze zu wenig verbreitert und zusammengedrückt. Die Farbe hell greisgelh, die Enden der oberen auf der Innenseite geschwärzt, deutlich abstehend gewimpert. Das Halsschild etwa $2 \frac{1}{2}$ mal breiter ais lang, hinter der Mitte stark quer aufgewölbt und von da ab nach vorn in sanfter Krümmung, nach dem tiefer niedergesenkten Hinterrande zu steiler abwärts geneigt, vorn über den scharf rechtwinkligen, tief eingezogenen Vorderecken breit zusammengedrückt und dadurch verschmälert; die Seiten fein gerandet, vor der Mitte rundlich erweitert, und von da ab nach den scharf stumpfwinkligen Hinterecken fast in graden Linien schräg ansteigend; der Hinterrand jederseits leicht gebuchtet, mit schmalem wenig aufgebogenem Mittelzipfel, und vor diesem ein gleichfalls schmaler aber deutlicher', fast his zu den Hinterecken reichender und das Halsschild etwas einschnürender Quereindruck. Die Oberfläche dicht längsrunzlig punktirt, mit schwachem Seidenschimmer; der schwielig erhölıte Rand und eine Anzahl regellos zerstreuter, jederseits der Mitte zu einer lockeren und zerrissenen breiten Längsbinde etwas mehr zusammengedrängter Schwielenfleckichen gelb; die Grundfärbung hell lederbraun. Das Schildchen schräg ansteigend, merklich kürzer als vorn breiı, hinterwärts stark verschımälert und mit dentlichem Hinterzịfel ahgerundet, kaum sichıbar punktiıt, mässig glänzend, dınkelhraun mit noch tiefer gebräunten Säumen. Die Deckschilde nur etwa $1 / 6$ länger als breit, gleichbreit und mit abgerundeten Ecken länglich viereckig, der Rücken breit und llach gewölbt, zwischen Schildchen und Schulterbeulen leicht aufgewulstet, die Vorderkanten schwach erhöht, die Schulterbeulen selbst słmal höckerig, die Seitenlappen mässig herabgezogen; über ihnen die Deckschilde hreit zusammengedrückt und dieser Eindruck bis zum Rücken linauf hemerkbar, wo die Naht von ihn vor der Mitte flach durchsetzt wird. Die Punktiruug auf' der Vorderhälfte von der Naht etwa bis zı dem stark nach Aussen geschobenen zweiten Punktstreiten hin dicht zusammengedrängt, wodurch hinter dem Schildchen ein gemeinsames herzförmiges, dicht punktirtes, nach Aussen von dem schräg nach der Naht zu gekrïmmten zweiten Streifen hegränztes Feld gebildet wird: auch die weiter nach Aussen liegenden Strei- 
fen wellig gekrümmt, stellenweise unterbrochen, bis sich auf der hinteren Hälfte deutlichere aus dicht gedrängten Punkten bestehende Kerhstreifen entwickeln. Die Zwischenräume vorı schmaler und volı ungleiclıer Breite, hinten breiter und mehr rippenförmig; die Farbe der Oberfläche lederbraun, die Längsrippen mehr oder weniger intensiv gelb, wodurch sich breitere und schmalere, zuweilen unterbrochene gelbe Längslinien bilden. Pygidium, Unterseite und Beine einfarbig lederhraun, der Unterrand des ersteren, der letzte Bauchring und die Schenkelenden rerwaschen ins schmutzig Gelbliche fallend. Das letzte Segment des $q$ mit einer rundlichen, nicht sehr tiefen Grube, das ठ̃ unbekannt.

Von Cayenne (Ilus. Deyrolle. Clark).

7. P. syrites $m$. Oben gelb und zimmtbraun gewölbt, lie Mitte der Stirn und drei Flecke des dicht punktirten, vorn stark schwieligen IIalsschilds dunkler, die Deckschilde mit zahlreichen gelben Längslinien und Fleckchen, unten braun mit hellerem Unterleibe und gelblich geringelten Beinen; die Punktstreifen vorn unregelmässig verdoppelt und durch überzählige P'unkte gestört, hin ten deutlicher, mit aussen schwach rippenfürmigen Zwischenräumen. L. $2 \frac{3}{4}{ }^{\prime \prime \prime} ; \mathrm{Br}, 1 \frac{1}{2}{ }^{\prime \prime \prime}$.

Den vorhergehenden Arten, ebenso dem folgendeu $P$. idiota nahe verwandt, aher grösser als das grösste Stück dieses letzteren, und von ihmen auch ausser dieser Grösse durch die überaus schwach und nur vor der Spitze der Declischilde einigermassen kenntlich ausgebildeten Rippen abweichend. Der Kopf flach, die Stiru in der Nitte der Länge nach niedergedrückı, mit schwach eingezogenem Kopfschilde, bleiclıgelb, sparsam aber deutlich und regellos punktirt, das Innese der Punkte dunkelhram und daher diejenigen Stellen, an denen die Punkte sich dicht zusammendräugen - so namentlich cin halhrunder Nackenlleck, die damil zusammenhäıgende der Länge nach niedergedrückte Mitte der Stirn, ein Fleck jederseits über den Fülılerwurzeln, und eine schmale, diese mit der Mitte der Stirn verbindende Schräglinie schmutzig gebräunt. Auch der Unterrand des Kopfsehildes mit den Kinubacken bräunlich, die tief dreieckig ausgebuchteten Augen greis. Die Fülıler dünı, liaum his zum Ilinterrande des Halsschilds reichend, das zweite Glied elliptisch, das dritte $u$ m die Hälfte und das vierte doppelt länger, das fünfte rloppelt länger als das dritte, die oberen wieder allmälslich verkürzt, ıur schwach zusammengedrückt und erweitert, das 
Endglied mit seinem stumpfwinkligen Fortsatze etwa dem vierten gleich. Die Farbe trüb bräunlichgelb mit geschwärzter Oberseite ler beiden unteren Glieder, die oberen noch dunkler angelaufen und dahei dünn greishaarig. Das Halsschild ülıer $21 / 2$ mal breiter als lang, über die Nitte quer aufgewölbt, vor ihr sanft abwärts gekrümmt, hinten breit und tief quer eingedrückt, über den spitzwinkligen Vorderecken breit zusammengedrückt und dadurch stark ver'schmälert; die Seiten lang lıerabgezogen, lein gerandet, in der Nitte bogig erweitert und vor ilı sehr seicht ausgeschweift; die stumpfen Hinterecken fast abgerundet, der Hinterrand jederseits des kurzen Vittelzipfels flach ausgebuchtet. Die Oberflache mit einer ziemlich kräftigen, ungleich vertheilten Punktirung bedeckt, die sich besonders an drei ziemlich ausgedehnten Stellen, nämlich vor dem Mittelzipfel und je mitten zwischen diesem und der Hinterhälfte des Seitenrandes stïrker verdichtet, während die Ränder fast ganz punktfrei sind, und auch auf der vorderen Hälfte sich der nichtpunktirte Zwischengrund in einer Anzahl grösserer oder kleinerer Schwielenflecke emporhebt. Dieser Zwischengrund ist sammt den Rändern durchscheinend wachsgelb, das Innere der Punkte dagegen zimmtbraun, und die ganze Oberfläche erscheint ıladurch gewölkı, indem namentlich jene drei dichter punktirten Stellen als grosse verwaschen gebräunte Wolkenflecke hervortreten, bei denen die braunc Färlung siclı über den nur ein zartes Netz bildenden Zwisclıengrund mit ausgedelınt hat. Das Schildchen stark ansteigend, halb so lang wie vorn breit, hinterwärts stark verschmälert, mit deutlichem Ilinterzipfel grade abgestutzt, punktirt, tief braun, mit einem verwasclien gelblichen Flecke vor dem hinteren Rande. Die Deckschilde breit und flach gewölbt, vorn etwas breiter als das Halsschild, gleichbreit und nur etwa $1 / 4$ länger als breil, hinter der schwach erlıöhten Vorderkante nur leicht quer niedergedrückt, hinter dem Schildchen und dann nochmals vor der Vitte stärker quer eingedrïckt, und dadurch das vordere Drittel der Flügeldecken leicht emporgewulstet. Die Schulterbeulen als kräftige Längshöcker heraustretend, auch die Seitenlappen stark entwickelt, und über ihnen ein breiter, die Deckschilde einengender, sich oberwärts an die niedergedrïckte Stelle des Rückens anschliessender Schrägeindruck. Die Punlitirung derb, vorn Ansätze zu unorlendlichen Doppelstreifen billend, die sicli aber schon vor iler Mitte durch überzählige Punkte trüben, und besonders auf dem Querein- 
druck immer mehr in ein regelloses Gewirr von Punkten übergehen, während auf der Aussenhälfte zahlreiche abgekürzte, zum Theil wurmförmig gewundene Punktreileen gleichfalls regellos und nicht einmal auf beiden Flügeldecken übereinstimmend hervortreten. Er'st auf dem letzten Viertel beginnen sich wieder etwas deutlichere streifen zu entwickeln, doch bilden sich nur die drei oder vier äussern auf der Wölbung zu solcher Regelınässigkeit aus, dass zwischen ihnen die Enden von 2-3 gegen die Nahtwinkel lin gekrümmten kurzen Längsrippen sichtbar werden. Das Innere aller Punkte rostbraun, daher die Fïrbung der Flügeldecken überall da rostbraun, wo die Punktirung dichı zusammengedrängt ist, am dunkelsten auf.der tiefsten Stelle des Quereintrucks vor der Mitte, auclı noch ziemlich dunkel hinter dem Schildchen und auf der Wülbung: da wo dip Punkte sich mehr vereinzeln, erhebt sirh der gellue Zwischengrund zu zahlreichen Schwielenfleckichen, die sich seitlich zwischen den abgekürzten Streifen und diesen entsprechend bald in die Läuge strecken, bald auch unregelmässig krümmen. Ausserdem ist die schwach erhöhte Vorderkante vom Hinterrande des Schildchens ab und der sich an diese anschliessende Kiel des Seitenlappens gelb, der umgeschlagene Rand des letzteren dagegen wieder braun, auch liegt vor fler Spitze ein schmaler, saumartiger Querfleck. Das Pygidium ror seinem unteren Rande mit einem mondfürmigen Quereindruclie, wodurch dessen unterer Theil als nacher Höcker emporgehoben wird, übrigens ınit der Unterseite dünn greishaarig, gelblich, der Quereindruck dunkler gelsräunt, und die Nitte entlang noch ein dunkler Schatten. Der Hinterleib rolblsaun, der letzte Ring, je rin dreieckiger Querflect an den Seiten der drei vorhergehenden und die breiten Seiten des ersten mil Einschluss der seitlichen Vorderzipfel heller gelb, auch die Nlitte des ersten Ringes ins verwasehen Gelbliche fallend. Die Brust tief braun, die Beine hellgelh mit bräunlichen Füssen, auch die Schenkel und Schienen unter der Hitte hräunlich geringelı. und dieser King an den Vorderschenkeln soweit ausgedehnt, dass er fast die ganze Unterseite eimnimmt und auch auf der Oherseite nır Wurzel und Spitze nehst einem vor letzterer liegenden Schrïglleck licht lïst. Das letzte Segment des $f$ mit einer klpinen und ziemlich flachen Grube, das o unbekannt.

Aus Bolivia (Warscewicz in Mus. Berol.).

8. P. idiota m. Tief braun mit weiss- oder gelbbunter Ober- 
seite, Pygidium, letzter Banchring und Beine hell gefleckt; las seitlich sanft gerundete Halsschild dicht und ziemlich fein punktirt, die Deckschilde grob punktirt und wellig längsrippig. L. 1-2"'; br. $2 / 3-11 / 4 "$.

Abermals den vorhergehenden, besonder's dem P. musivus Grm. ähnlich, aber meist noch etwas grösser', das Halsschild nur vorn gell gerandet, und die Streifenbildung, wenn auch mit einzełnen Störungen, schon gleich an der Wurzel der Deckschilde beginnend. Der Kopf flach mil feilier Stirnlinie, die Oberfläclıe durch eine gleichmaassig verbreitete feine Punktirung matt, die Farhe dunkelzimmıbraun; die Oberlippe, die unteren Ecken des Kopfschildes und die inneren Säume der breit und spitz ausgebuchteten Augen nebst einem Fleckchen zwischen den Fühlerwurzeln gelb. Die Fühler schlank, von melır als $2 / 3$ der Körperlänge, das zweite Glied kurz und knotig, das dritte fast doppelt-, das vierte dreimal länger und die folgenden noch etwas vergrössert, die oberen schwach erweitert und zusammengedrückt. Die Farbe der unteren gelblich mit braun überflogener Oberseite, die oberen dunkelrauchgrau. Das Halsschild kurz und breit, in der Mitte schwach quer aufgewölbt und von dem Hinterrande tief niedergesenkt, seitlich fein gerandet und daselbst in der Mitte in flachem Bogen erweitert, nach den spitzen Vorderecken zu ein wenig ausgeschweift; die Hinterecken stumpf, der Hinterrand jederseits des kurzen Mittelzipfels leicht ausgeluuchtet. Die Oberseite durch eine dichte und feine Punktirung matt, braun; ein schmaler Vorderrand und eine Anzahl kleiner lackartig aufgetragener Fleckchen gelb; letztere besonders zu zwei gelockerten und unterbrochenen Mittelbinden zusammengedrängt, und ausserdem vorzugsiveise im Innern der Vorderwinkel verbreitert. Das Schildchen sehr stark ansteigend, breit dreieckig, mit deutlichem Hinterzipfel kurz abgestutzt, dicht punktirt und matt schwarzbraun. Die Deckschilde etwas breiter als das Halsschild, und etwa $1 / 5$ länger als breit, ziemlich gleichbreit, flach gewölbt, um das Schildchen leicht aufgetrieben und dahinter breii quer niedergedrückt, mit wenig hervortretender Vorderkante; die Schulterbeulen schwach, und die Seitenlappen breit zugerundet. Dir Punktirung etwas gröber als die iles IIalsschilds, zu vorn unordentlichen, von der Mitte ab sich immer regelmässiger gestaltenden Längsstreifen an einander gereilıt; die Streifen wellig gebogen, durch vorn liürzere, linten mehı zusammenlıängende und mehr 
gerade verlaufende Längsrippen getrennt. Die Farbe braun, die Längsrippen vorn mit einzelnen unregelmässig vertheilten, hinter der Mitte mit grösseren und fast alle Rippen einnehmenden gelleu Längsilecken bedeckt, auch die Spitze und die unmittelbar vor ihr zusamnenstossenden Längsrippen durch solche, wenn gleich schwächeren Flecke eingenommen. Pygidium und Unter'seite dunkelbraun, fein aber licht punktirt und seidenartig schinmernd; ersteres anı unteren Ende mil zwei verloschenen gelben Längstlecken; eben so an jeder Seite des letzten Bauchringes ein verloschener, auf den Rand des Pygidiums übergreifender gelllicher Querfleck. Die Beine braun, Wurzel und Spitze der Schenkel und Schienen ins Trübgelbliche faliend, ausserdem die flache Aussenseite der stark verdickten Vorderschenkel mit einem kleinen gelblichen Längsflecke. Das letzle Segment des ơ seicht nietergedrückt, des \& mit (iner mässigeu, etwas gestreckten Grube. Bei einem der vorliegenden Slüche ist die Zeichnung fast weiss, und das Pygidium nebst dem ganzen Hinterleibe gelblich braun mit fast weisslichen Flecken; - walıscheinlich Folge unvollständiger Ausfärbung.

Aus Brasilien (Nus. Saunders. Halens.; in letzterem Rio de Jan. als Fundort genannt.

Bei einem grossen $q$ aus Suntarem in Nus. Baly nimmt die gellıiche Färlung auf den Deekschilden die ganzen Rippen ein, sodass nur das Innere der P'unkte und die Schulterbeulen bräunlich bleiben, und die beiden Flecken des Pygidiuns häıgen unter einander zu einem grossen, nur durch eine dunkle Längslinie getheilten Hakienllecke zusammen. Das Stück erhält dadurch ein etwas fremdartiges Aenssere, doch wage ich nach einem einzigen Stücke niclst, es als eine eigene Art aufzufülıren.

9. P. aegrotans $\mathrm{m}$. Strohgell mit gebräunter Brust und ruströthlicher Punktirung; das seitlich vor der Mitte erweiterte Halsschild auf dem Mittelfede diclt und fein punktirt, die Punktstreifen etwas wellig, hinter der Schulterbeule unterbrochen, mit flachen Zwischenräumen. L. ${ }^{\prime \prime \prime}$; Br. 2/5"“.

Eine kleine zierliche, bein ersten Anblicke einem Stylosomus mocht mülunliche, zugleichı durch die Regelmässigkeit ilırer hinten wurmufürmig gewundenen Punktstreifen auffallende Art. Der Kopf flach, die Stirn mit einem unterwärts verbreitertem, zugleich etwas dunkler gefïbıem leichtem Längseindrucke; die P'unktirung von mässiger Stärlic, ziemlich dicht, aber nicht überall gleichmässig 
verbreitet, die Färbung hellstrohgetb, die Mitte der Stirn und mit dieser zusammenhängend der Nacken und die Augenbuchten dunkler braunroth, die Unterecken des Kopfschilds nebst Wangen und Oberlippe noch heller, fast weiss, alıer auch auf diesem helleren Grunde das Imsere der Punlite gebräunt. Der Zwischengrund mässig glänzend, die breit und tief ausgebuchteten Augen greis. Die Fühler (des ठ̋) von etwas über halber Körperlänge und mässiger Stärke, das längliche Wurzelylied hirnförmig aufgetrieben, fast doppelt so lang wie breit, das zıveite kurz und sclımal esförmig, die folgendeı dünn verkehrikegelfürmig, das dritte un die Hälfte, das vierte und fünfte je fast doppelt länger als das zweite, und die folgenden bis auf das etwas kürzere zelnnte sämmitlich etwa dem vierten gleich, dabei die oberen nur schwach zusammengedrückt und erweitert, mit sehr kurzem Fortsalze des Endglieds. Die Farbe gelb, die oberen Glieder rauchgrau überflogen, das zweite Glied auf der oberen Seite mit einem dunkleren Längswisch. Das Halsschild flach valzenförmig mit in der Mitte leicht anfgebogener Längsfirste, fast doppelt breiter als lang, über den scharfen fast rechtwinkligen und dann in eine liurze Spitze ausgezogenen Vorderecken schwach zusanimengedrückt und dadurch etwas verschmälert, seitlich fein gerandet, vor der Mitte bogig erweitert, und dann nach den scharf stumpfwinkligen etwas aufgebogenen Hinterecken hin nit den Rändern schı̈̈g aufwärts gerichtet; der Hinterrand fast gerade, mit wenig bemerkbarem, kurz aufgebogenem Mittelzipfel. Die Punktirung deutlich, ziemlich dicht gedrängt, ein breiter Seiten- und ein schmalerer Hinterrand fast punktfrej, leicht schwielig erlıölıt, und eben so die Punkte auf einer schlecht begränzten Stelle jederseits der Mittelfirste etwas spar'samer gestelt. Die Farbe hell strohgelb, das Innere der Punkte dunkler rostgelb, daher die dichter punktirten Stellen zugleich stärlier geröthet erscheinen. Das Schildchen schräg ansteigend, unı die Hälfte kürzer als vorn breit, hinterwärts stark verschnälert, mit unscheinbarem Hinterzipfel, strohgelb mit rostgelben Säumen. Die Deckschilde gestreckt walzenförmig, doppelt länger und vorn etwas breiter als das Halsschild, vorn kaum quer niedergedrückt, die Schulterbeulen sclımal höckerig, und auf ihrer Aussenseite die Flügeldecken sehr schräg abfallend; die Seitenlappen ziemlich kräftig und über ihmen die Deckschilde leicht buchtig verengt, der Rücken längs der Nahıt etwas abgeflacht mit wenig gelirümmter Wöllung. Die Punktirung XVI. 
zu deutlichen Längsstreifen geordnet, der zweite nahe vor der Mitte mit starker lírümmung nach der Naht zu ausweichend und dadurch ler zweite Zwischenıaum hier zu einem breiten Felde erweitert, der Raum zwischen diesem Felde, der Naht und dem zweiten Streifen selbst mit überzähligen Punkten bestreut, durch welche der erste und der abgekïrzte Streifen melır oder weniger verdunkelt werden: die drei auf der Schulterbeule entspringenden Streifen (der sechste bis achte) schon vor der Mitte gestört und stellenweise, aber nicht einmal auf beilen Flügelıecken gleichmässig, unterbrochen, linterwärts aber wieder deutlich ausgebildet, sodass aul dem letzten Drittel sämmtliche Punlitstreifen klar hervortreten. Die Zwischenräume selır flach gewölbt, die Farbe hell strolıgell, das Innere der Punkte auch hier rostbräunlich, worlurch die Deckschilde den Anschein erhalten als ob sie von röthlichen Längslinien durchzogen seien. Auf der Wölbung tritt dliese Färlung manchmal in schunalen, schlecht begränzten Wischen über die Streifen hinaus, und elıen so sind auch die Schulterbeulen rostfarben gebräunt oder geröthet. Pygidlium und Unterseite dicht und fein runzlig punktirt mit gröber punktirten Parapleuren, dabei sehr dünn greishaarig, lıellstrohgelb, ein Mittelfleck und je ein schmaler Seitenfleck des Pygidiums, die Ründer der Bauchringe und die Nähte der Ilinterbrust mit den Paraplemren braun, der Farle des geronuenen Blutes ähnlich. Die Beine gelb mit schwarzen Krallenhälichen, die Hinterschenkel in der Mitte leicht geJräınt. Die Prosternalrinne schmal aber deutlich: das letzte Segment des $\delta$ in der Mitte leicht niedergedrückt, des of mit dem gewöhnlichen Grübchen.

Aus Columbien (Mus. Schaum. Haag. Berol. Vindob.).

10. P. pallens B la $11 \mathrm{ch}$. Schmutzig röthlich gelb mit schwarzund gelbbunter Unterseite; Halsschild und Deckschilde dicht und ziemlich fein punktirt, letztere aussen und hinten mit undeutlichen Punktstreifen und daselbst flachen Zwischenräumen. L. 11/4 $11 / 2 " \prime$; Br. $2 / 3-3 / 4 "$.

Pachybrachys pallens Blanchard in Gay Hist. fisica etc. de Chile. V. 541. n. 4.

Aus der nächsten Verwandtschaft des nordamerikanischen $P$. melanostictus und occator, durch die einfarbige Oberseite aber mehr dem vorhergehenden ähılich, nur grösser, etwas mehr ins Röthliche fallend und in der Sculptur der Deckschilde wesentlich 
abweichend. Der Kopf flach, fein und zerstreut punktirt, die Punkte auf der Stim und an den oberen inneren Augenrändern etwas dichter gedrängt, fast zusammenlliessend, auch im Innern dunkler geröthet, wodurch auf der Stirn einige regelmässig vertheilte dunklere Schatten entstehen. Die Grundfarbe der Stirn etwas heller knochengelb, die Oberlippe noch etwas lielıter, die tief ausgebuchteten Augen schwarz. Die Fühler kurz und schlank, die oberen Glieder kaum merklich zusammengedrückt, die Farbe hell röthlichgelb mit rauchgrau angellogener Spitze. Das IIalsschild fast doppelt lïnger als breit, flach gewölbt und über die Mitte leicht quer erhöht, jederseits längs dem Hinterrande breit und seicht niedergedrückt, über den seharf rechtwiukligen Vorderecken etwas zusammengedrüclit und dadurch ver'schmälert; die Seiten fein geranlet, in der Mitte leicht erweitert, die Hinterecken stumpfwinklig, der Hinterrand jederseits leicht ausgebuchtet mit kurzem etwas aulgebogenem Mittelzipfel. Die, Oberfliche dicht und ziemlich fein punktirt, die Punkte nach den Seiten und noch mehr dem Hinterrande zu stärker zusanmengedrängt, auch im Innern etwas dunkler, wodurch der Raum vor den Hinterecken und dem Schildchen unter gewisser Beleuchtung etwas trüber erscheint, während anderseits linter der Mitte eine etwas lichtere, schwächer punktirte Stelle zum Vorschein kommt. Die Farbe bis auf jene schwachgetrübten Stellen röthlich gelb. Das Schildchen viereckig, mit ausgeschweiften Seiten und kaum merklichem Hinterzipfel abgestutzt, wenig ansteigend, glat, röthlich gelb mit zartem bräunlichem Saume. Die Deckschilde flach walzenförmig, etwa un $1 / 3$ länger als breit, hinter der schwach aufgeworfenen Vorderkante seicht quer eingedrückt, mit einem gemeinsamen Quereindrucke auf der Naht hinter dem Schildchen, und einem noch breiteren aber weniger deutlichen auf der Nitte der Naht, vor welcher sich zwischen beiden ein flacher Querwulst emporlıelst. Die Schulterbeulen länglich höckerig, die Seitenlappen wenig hervortretend. Die Punktirung dicht, auf der vorderen Hälfte zwischen Nahıt und Schulterbeulen bis über den hinteren Quereindruck hinaus unordentlich zusammengedrängt mit stellenweise angedeuteten Längsreihen; ausserhalb der Schulterbeulen finden sich vou solchen deutlichere Ansätze, aus denen sich hinterwärts regelınässiger'e Punktstreifen entwickeln, ebenso von der Nitte ab längs der Naht jederseits zwei solche Streifen, und zwischen diesen danı noch einige weniger deutliche bis zur 
Wölbung hinab. Der äusserste (neunte) Zwischenraum ist breit, stellenweise mit unordentlich vertheilten Punkten besetzt, und eben so zeigt sich hinter der Vitte ausserhall, des zweiten Streifens ein breiter, Ansätze abgerissener Streifen tragender Zwischenraum. Die Zwischenränme selbst hinterwärts llach und wenig glänzend; die Farbe ein ziemlich helles aber nicht reines Rothgelb, das Immere der Punkte gebräunt, und eben so auf den Schulcerbeulen ein schmutzig bräunlicher Lüngswisch, zuweilen auch noch ein solcher mehr ins Schwärzliche fallender hinten auf der Wölbung, bald an der Naht, bald mehr nach Aussen hin. Das Pygidium fein punktirt, dünn greishaarig, jederseits und in der Nitte etwas eingedrückt und auf Jetzterer mit einem brïunlichen Schatten, sonst schmutzig gelb. Die Brust grob-, Hinterleib und Parapleuren feiner punktirt, fein silberhaarig. Die Farbe der Brust schwarz, die Schulterblätter, die Mitte der hinteren Bruststücke und eine nicht punktirte Längslinie am Inuenrande der Parapleuren verwaschen gelblich; der Hinterteib bald einfarbig gelb, bald die einzelnen Ringe breit verwaschen schwarzbraun gesäumt. Die Beine einfarbig gelb mit mässig verdickten Vorderschenkeln und kaum gekrümmten Schienen. Das letzte Segment des $\delta$ mit einer flach niedergedrückten, nicht junktirten und daher glïnzenden Stelle, des $q$ init einer elliptischen, gläızenden Grube.

Aus Chile (Nus, Petrop. Dohrn. Clark. Haag. Holm. Deyrolle, in letzterem unter dem obigen Namen enthalten, an dessen Richtigkeit zu zweifeln Blanchards Beschreibung lieinen Anlass lietet. Als Fundort wird ron diesem Autor Santiago angegeben).

11. P. foetidus m. Schmutzig gelhbraun, fünf Flecke des Kopfes, die Schulterbeulen und zwei Hinterflecke der Fligeldecken mit Brust und Nitle des Ilinterleilses tiefer gesclıwärzt; das hinten tief quer eingedrïchte Ilalschild grob punktirt, anch die Punktstreifen grob, vorn gestürt, mit hinten breiten, flach rippenförmigen Zwischeuräumen. L. 1 $1 / 3{ }^{\prime \prime \prime}$; Br. 3/4"'.

Durch die schmutzigen Wische auf der Wülbung der Flügeldecken einigermassen dem $P$. conformis Dej., wie auch den unten gleichfalls beschriebenen $P$. callifer ähnlich, aber nach seiner gauzen Beschaffenheit doch zunächst der vorhergehenden und der folgenden Art verwand, der letzteren besonders durch die grobe Punktirung der Deckschilde nahe konmend. Der líopf flach, vereinzelt und grob punlitirt, gelb, ein Querfleck jederseits im Nacken, 
ein Mittelfleck auf der unteren Stirn, ein Fleck jederseits über dem Fühlerhöcker und der breite Untersaum des Kopfschildes schwarz; alle jene Flecke unregelmïssig hegräızt, aher durch die Schärle ihrer Ränder ausgezeichnet. Die Tasterenden geschıärzl, die grossen, dreieckig aber nicht tief ausgebuchteten Augen greis. Die Fühler bei den vorliegenden Stücken nur zum Theil erhatten, gelb mit rauchgrau angeflogenem oberem Theile, das dritte und vierte Glied lang gestreckt, fast gleich und je merklich länger als das elliptische zweite, die oberen nur wenig erweitert. Das Halsschild um die Häfte breiter als lang, von der stark (uer aufgewölbten Mitte ab nach vorn und hinten ziemlich gleichförmig niedergekrümmt, die Seiten fein gerandet und sanft zugermndet, die scharf rechtwinkligen Vorderecken noch etwas ausgezogen, die hinteren stumpf, nur mit einer kurzen Schwicle besetzt, der Hinterrand jederseits des kurzen, dentlich aufgehogenen und fast quer abgestutzten Hinterzipfels etwas ausgebuchtet; vor ihm ein tlach muldenförmiger, seitlich sich allmählich verlierender Quereindruck. Die l'unktirung grob und ziemlich vereinzelt, mit schwach glänzendem, besonders in der Mitte in grösseren Schwielen hervortretendem Zwischengrunde; die Farbe ein schmutziges, durch das gelıräunte Immere der Punkte stellenweise noch mehr getrübtes röthliches Greisgelh. Das Schildchen schräg ansteigend, dreieckig nit breit abgestutzter Spitze, glatt und gelb mit geschwärztem Saunse. Die Deckschilde um etwa ein Drittel läıger als breit, flach gewölbt, mit scharf emporgehobener Vorderkante; die Schulterbeulen länglich höckerig, innerseits durch einen breiten Eindruck abgesetzt, und über den ziemlich stark herabgezogenen Seitenlappen gleichfalls ein breiter seichter Quereindruck, welcher sich schräg nach dem Rücken heraufzieht, die Naht bald hinter dem Schildchen durchsetzt, und mit dem flachen Eindruck innerseits der Schulterbeulen sich vereinigend, jederseits hinter jenem ein breites flach erhöhtes Feld emporhebt. Die Punktirung grob und mässig dicht, auf der vordern Hälfte durch überzählige Punkte derartig gestört, lass voı Punktstreifen nur einzelne Rudimente hervortreten, und von Zwischenräumen nur das Vorderende des ersten an seiner Breite und der zweite zugleich als eine von der Vorderkante ausgehende Längsrippe bemerkbar wird. Nur der Randstreifen und eine auf dem umgeschlagenen Rande des Seitenlappens stehende Punktreihe sind auch vorn deutlich; jener zweite Zwischenraum aber erweitert sich 
erst neben der Mitte der Naht zu einer breiteren Schwiele, von welcher ab der zweite und dritte Streifen sich hinterwärts entwickeln; noch etwas später entwirren sich auch die nächstfolgenden und zwar paarweise, so dass der vierte und fünfle, sechste und sicbente, achte und neunte linten zusammenlaufen, der Vereinigungspunkt des vierten und fünften, sowie des sechsten und siebenten aber schon auf der Wölbung zurückbleibt, während der des zweiten und dritten, sowie des achten und neunten erst unter ihr, und zwar nahe bei einander liegen. Die Zwischenräume treten hier als breite, flache Rippen hervor, der sehr breite neunte aber ist fast bis zur Wölbung hin mit unregelmässig vertheilten ziemlich groben Punkten besetzt. Die Farbe ist ein schmutziges, mässig glänzendes Knochengelb, durch das schwärzliche Innere der Punkte getrübt, ausserdem die Schulterbeulen mit einem schmalen, schwärzlichen Längswische gezeiehnet; zwei ähuliche aber im Innern sehr verwaschene finden sich jederseits auf der Wölbung, der innere auf dem zweiten bis fünften Streifen, da wo der vierte und fünfte sich vereinigen, der äussere grössere aber schwächere vom sechsten Streifen ab schräg hinterwärts bis zum Seitenrande zielıend. Das Pygidium fein punktirt, düın behaart, greisgelb mit einem schmalen schwärzlichen Längsschatten auf der Mitte, die Hinterbrust schwarz; Hinterleib und Beine gelb, die Mitte des ersteren wolkig unterbrochen gebräunt, Mittel- und Hinterschenkel und -schienen in der Mitte leicht bräunlich angelaufen; auch die Schulterblätter, die Hüften und eine Längslinie am Innenrande der Parapleuren gelblich. Das letzte Segment des $q$ mit einer rundlichen, glänzenden Grube, das đ̛ unbekannt.

Aus Buenos Ayres (Mus. Haag) und Brasilien (Mus. Deyrolle), das letztere Stück etwas dunkler, melır ins Röthliche fallend mit entsprechend tiefer geschwärzten Wischen, sonst aber nicht verschieden.

12. P. ferrugatus m. Rostroth mit gebräunter Unter'seite und einem schwärzlicheı Wische vor der Spitze der Flügeldecken; das Halsschild ungleichmässig dicht punktirt, die Punlitstreifen grob, vor'n unordentlich wellig und längs der Naht durch üherzählige Punkte gestört, mit hinten abgeschliffenen, schwach prhölıten Zivischenräumen. L. $11 / 4-11 / 2 "$; Br. $2 / 3-3 / 4$ "'.

An der rostruthen Färbung und der groben Sculptur der Deckschilde leicht kenntlich, ausserdem von dem vorhergehenten durch 
den einfachen linteren Wisch der Flügeldecken sogleich zu unterscheiden. Der Kopf flach, grob und ziemlich dicht punktirt, mit glänzendem, stellenweise schwielig hervortretendem Zwischengrunde, ohne Stirulinie; der untere Saum des flachen Kopfschildes schwärzlich, die grossen, tief ausgebuchteten Augen greis. Die Fühler von etwas mehr als halber Körperlänge, oben nur schwach zusaınmengedrückt und verbreitert, rostgelb mit leicht geschwärztem Anflıge der oberen Hälfte. Das Halsschild breit und llach walzenfürmig, in der Mitte quer anfgewulstel und von da ab nach rorn sanft abwärts gekrümmt, hinter der Mitte breit aber nicht tief quer eingedrückt und dieser Eindruck seillich nach vorn gewandt, noch über den Vorderecken bemerkbar, aber durch den grade über der Mitte des Scitenrandes deutlicher hervortretenden Querwulst des Rückens unterbrochen; die Seiten fein gerandet, hinter der Mitte leicht ansgeschweift, mit scharfen fast rechtwinkligen Vorder- und stumpfen Hinterecken; der Hinterrand jederseits nur leicht ausgebuchtet, mit wenig vortretendem, etwas aufgebogenem Hinterzipfel. Die Punktirung von mässiger Stärke, ungleich vertheilt aber meist ziemlich dicht gedrängt, sich besonder's in dem hinteren Eindrucke und in den Vorderwinkeln anhäufend; der erhöhte Zwischengrund von mässigem Glanze. Die Farbe hellrostroth, durch das schmutzig gebräunte Innere der Punkte mehr oder weniger getrübt. Das Schildchen schräg ansteigend, fast gleichseitig-dreieckig mit kurz abgestutzter Spitze und undeutlichem Hinterzipfel, glänzend rostgelb mit dunklerem Saume. Die Deckschilde walzenförnig und hinten etwas erweitert, etwa um 1/3 länger als breit, hinter der schwach erhöhten Vorderkante leicht quer niedergedrückt, die Schulterbeulen flach höckerig, der Rücken von ıler Mitte ab die Naht entlang abgeflacht, mit liurz abfallender Wölbung. Die Punktirung grob, wenigstens um das Doppelte stärker als die des Halsschilds, die Punktstreifen auf der vorderen Hällte sehr undentlich, durch Unterbreclıungen, Krümmungen und ülıerzählige Punkte getrübt, stellenweise durch ihr Anlehnen an die als flache Längsıip)pen hervortretenden Zwischenräume kenntlicher gemachı, von welchen letzteren sich besonders jederseits der Schulterbeulen einer emporhebt. Bei dem $q$ sind lie überzähligen Punkte jederseits auf dem dreieckigen Ramme zwischen der Schulterbenle, dem Schildchen und der Hitte der Naht in grösserer Anzahl vorhanden, daher dichter gedrängt und dadurch die Streifenbildung un- 
gleich undeutlicher als bei dem ð. Auf dem letzten Drittel werden die Streifen kenntlicher, und die, flache Längsrippen bildenden Zwvischenräume regelmässiger, wobei jene vom dritten ab sich in selır characterischer Weise schräg dem Nalıtwinkel zuwenden. Die Zwischenräume selbst bei beiden Geschlechtern glatt und glänzend, die Farbe hellrostrotlı, die Schulterbeulen und das Innere der Punkte gescbwärzt, wodurch besonders bei dem $\delta$ (vielleicht bei dem vorliegenden Stücke nur indiviluell) auf jeder Flügeldecke unter der Wölbung ein unklarer schwärzlicher Wisch gebildet wird. Das Pygidium fein punktirt und dümn greishaarig, rostgelb; die Unterseite geschwärzt, ein breiter verwaschener Rand des Hinterleibes mit dessen Vorderzipfeln, die verwaschene Mitte der grob punktirten Hinterbrust, und die Parapleuren nebst Schulterblättern und Hüften röthlich gells. Auch die Beine hellrothgelb, die Lappen des dritten Fussgliedes und das Krallenglied nehst einem Fleckchen auf der Aussenseite der IInterschenke] bräunlich. Das Jetzte Segment des ơ mit einer flach gedrückten glänzenden Stelle, des + mit einer gleichfalls glänzenden, grossen rundlichen Grube.

Aus Chile (Mus. Dohrn. Clark. Holm., das Exemplar des letzteren von F. Sahlberg mitgebracht.) und Peru (Mus. Deyrolle).

13. P. callifer m. Oben schmutzig knochengelb, unten schwarz mit gelben Beinen, die Mitte des grob pimlitirten Halsschilds, einige Vorderwische und ein Querfleck vor der Spitze der Deckschilele gebräunt; die Punktstreifen ziemlich regelmässig, mit flach gewöllten, hinteı schwach rippenförmigen Zwischenrăumen. L. $12 / 3^{\prime \prime \prime} ;$ Br. $1^{\prime \prime \prime}$.

Dem mittelamerikanischen $P$. labyrinthicus nicht unähnlich, aber deutlicher gezeichnet und auch durch die regelmässigeren Punktstreifen von ihm verschieden. Des Kopf flach mit feiner Stirnlinie und etwas eingezogenem liopfschilde, ziembich dicht punktirt und die Punktirung auf den dunkleren Stellen dicliter gedrängt; die Farbe schmutzig gelb, ein Quersaun im Nacken und an diesen sich anschliessend eine schmale Stirnlinie, sowie die Fühlerhöcker und der untere Rand des Kopfschildes bräunlich, auch auf dem lichten Grunde das Innere der Punkte etwas verdunkelt. Die Oberlippe etwas heller knochengelb, die grossen tief ansgebuchteten Augen schwärzlich. Die Fühler ron $2 / 3$ der liörperlänge, schlank fadenförmig, das Wurzelglied läıglich eiförmig aufgetrieben, das zweite kurz eiförmig, die folgenden sehr dünn, 
bis zum fünften allmählich an Länge znnehmend, die oheren je etwa dem fïnften gleich, kaum verbreitert, mit deutlich abgesetztem Fortsatze des Endgliedes. Die Farbe gelb mit rauchgrau überflogener Spitze. Das Halsschild doppelt breiter als lang, über den scharf rechtwinkligen Vorderecken wenig zusammengedrïckt, die Seiten fein gerandel, binter der Nitte kaum erweitert. Die Hinterecken abgerundet, der Hinterrand jederseits nur schwach ausgeschweift, mit kurzem wenig aufgebogenem Mittelzipfel. Der Rücken hinter der Mitte leicht quer aufgewölbt, vor dem Hinterrande leicht niedergedrückt, die Mittelfirste nach vorn our mit schwacher Krümmung abfallend. Die Oberfläche auf der Mitte und vorn auch jederseits derselben umregelmässig aber ziemlich dicht punktirt, und die punktirten Stellen dadurch etwas niedergedrückt; an den Seiten, dem schmalen Vorderrande und hinten jederseits der Mitte sind die Punlite sparsamer und fehlen stellenweise ganz, daher solche Stellen danu schwielig erhöht und hell kuochengelb erscheinen, während der dichter punktirte Theil der Oberfläche, besonders längs der vorderen Mitte, mehr ins schmutzig Rothbraume fällt. Diese braunen Stellen bilden dadurch drei unförmliche, mehrfach durch hellere Atome gelockerte Längsflecke, einen vorn verbreiterten auf der Mitte und jederseits daneben einen hinten breiteren, von denen aber keiner den Rand des Ilalsschilds erreicht. Das Schildchen dreieckig, mit ausgehuchteten Seiten hinterwärts stark verschmälert und daselbst kurz abgestutzt, nit kaum bemerkbarem Hinterzipfel; die Farbe schwarz mit einem verwaschen gelbbräunlichen Mittelflecke. Die Deckschilde um 1/4 länger als breit, mit scharfer aber wenig emporgehohener Vorderkante, die Schulterbeulen kurz aber eckig hervortretend, iunerseits durch einen schwachen Längseindruck abgesetzt, die Seitenlappen sclıwach, und über ihnen je ein deutlicher Quereindruck. Die Punktstreifen im Ganzen regelmässig, nur der abgekürzte längs der Naht durch überzählige Punkte verbreitert, fler erste und ziveite genähert, neben der Mitte der Naht zusammenfallend und ihr zugekrümmt, der zweite sich hinterwärts wieder nach Aussen biegend und wellig gegen die Spitze lin verlaufend, sodass die erste grössere Krümmung an der Naht hier ein dreieckiges nicht punktirtes Sclıwielenfeld entstehen lässt; der Zwischenraum zwischen beiden Streifen mit einigen Punkten bestrent. Der dritte und vierte Streifen verlaufen regelmässig bis zur Wölbung hinah, der fünfte biegt sich 
gleich an der Wurzel hakenförmig gegen die Schulterbeule hin, wodurch sich hier der anstossende Zwischenraum gleichfalls schwielig erweitert, und verläuft damı regelmässig bis zur Wölbung, wo er mit den beiden vorhergehenden zusammenfällt. Der sechste ist auf der vorderen Hälfte mehrfach unterbrochen, der siebente und achte mit wenigen Krümmungen regelmässig, während der neunte über dem Seitenlappen eine winklige Biegung nach Aussen macht, dadurch den achten Zwischenraum breit dreieckig erweitert und auf dem neunten vorn einen halbkreisförmigen Schwielenfleck abgränzt; das Vorderende des neunten Streifens unter der Schulterbeule erscheint durch einige unregelmässige Punkte verdoppelt. Die Zwischenräume treten besonders linten als flach gewölbte Rippen hervor. Die Farbe schmutzig knochengelb, das Innere der Punkte schwarzbraun, und dieselbe Färbung zeigen die Schulterbeulen, einige undeutliche Wische vorn längs der Naht, und ein paar verwaschene, ursprünghch wolıl zusammenhängende Querflecke auf der Wölbung, da wo die Hinterenden des zweiten bis fünften, und wieder des sechsten bis neunten Streifens zusammentreffen. Auch Naht und Spitze sind fein schwärzlich gesäumt. Das Pygidium fein punktirt, dünn greishaarig, schmutzig greisgelb, oben und in der Mitte verwaschen geschwärzt; die Unterseite schwarz mit gelblicher Hinterhälfte des letzten Bauchringes; Schulterblätter, Hüften und Beine gelb; die Schenkelflächen auf der Vorderseite über dem Knie mit einem weisslichen Flecke gezeichnet, die Schienen auf der Mitte der Aussenkante leicht gebräunt. Das letzte Segment des $\delta$ auf der Mitte leicht quer niedergedrückt, das $q$ unbekannt.

Aus Columbien (Mus. Haag.)

14. P. congener Dej. Dunkelrostroth, Kopf, Pygidium und Beine gelbbunt, die Ränder, drei theilweise unterbrochene Längsbinden und einige Flecke des grob punktirten Halsschilds hellgelb, die Deckschilde gelb mit gebräunten Punktstreifen; letztere ziemlich regelmässig, auf der Nitte gestört, mit flachen hinten etwas wellig gekrümmten Zwischenräumen. L. $15 / 12{ }^{\prime \prime \prime}$; Br. $3 / 4{ }^{\prime \prime \prime}$.

Der Kopf flach, die Stirn der Länge nach seicht niedergedrückt, mit stark eingezogenem Kopfschilde, grob- und nur auf den dunkleren Stellen dichter punktirt, die Farbe gell, die Mitte ller Stirn ziemlich breit dunkelrostroth, welche Färbung sich den Augenbuchten gegenüber gabelt und mit den beiden Unterenden bis zu 
den Fühlerhöckern reicht; auch das Kopfschild unten bräunlich gesäumt. Der Zwischengrund besonders auf den dunkleren Stellen matt; die Augen tief dreieckig ausgebuchtet. Die Fühler bei dem einzigen mir vorliegrenden Stïcke nus unvollständig erlıalten, nach den vorhandenen Resten gelb mit gebräunten Enden, die beiden unteren stark aufgetriebenen Glieder mit einem schwarzen Wische auf der Oberseite. Das Halsschild vor der Mitte leicht quer aufgewulstet und von da ab nach vor'n etwas stärker, hinterwärts sanfter abwärts gekrümmt, über den scharf rechtwinkligen Vorderecken etwas zusamnengedrückt und dadurch verschmälert, die Seiten fein gerandet, vor der Mitte unter einem sehr stumpfen Winkel schwach erweitert und von da bis zu den Vosderecken gerade verlaufend, hinter der Mitte sehr leicht ausgeschweift, mit gleichfalls scharfen und fast rechtwinkligen Hinterecken; der Hinterrand jederseits leicht gebuchtet, mit kurzem und ziemlich schmalem Mittelzipfel, und vor dem letzteren das Mittelfeld flach quer niedergedrüclit. Die Punktirung ziemlich grob und dicht, nur auf den helleren Stellen sclıvächer und theilweise ganz fehlend; die Farbe dunkelrostroth, der abgesetzte Rand schwäızlich, und hinter diesem ein ziemlich hreiter, mehrfach unterbrochener Saum hellgelh. Losgelöset von diesem zeigen sich in den Vorderecken und auf der Mitte seiner Innenseite grōssere, theilweise von der Grundfarbe zerrissene, gleichfalls schıvielig erhöhte gelbe Flecke, und ausserdem auf der Mitte drei gelbe Längsbinden, die mittlere schmaler, schärfer begränzt, mehr längslielartig und am letzten Drittel abreissend, die seitlichen breiter, in ihrer Mitte etwas nach Aussen gekrümmt, und, wie die Seitenflecke, durch eindringende Punkte der Grundlarbe mehrfach zerrissen und missgestaltet. Das Schildchen schräg ansteigend, so lang wie vorn breit, hinterwärts stark verschmälert und mit undeutlichem Hinterzipfel abgestutzt, schwarz. Die Deckschilde kaum $1 / 4$ länger als breit, ziemlich gleichbreit, der Rücken sehr flaclı gewölbt mit hinten leicht abfallender Krümmung, hinter der schwach erhölıten Vorderkante nur seicht quer eingedrückt; die länglichıen Schulterbeulen eckig heraustretend. Die Seitenlappen stark herabgezogen, und über diesen je ein breit muldenförmiger, mit einigen üherzähligen Punkten besetzter Eindruck. Die Punktstreifen derb und ziemlich regelmässig, die oberen ror’n durch Ansätze überzähliger Streifen stellenweise verdoppelt, auf der Mitte etwas wellig gekrümmt und der 
Naht zugewandt, hinten auch wohl uuterbrochen; die Zwischenräune vorn linienförmig, der zweite und neunte auf der Mitte stärker erweitert, auf der Wölhung alle melır oder weniger verbreitert und verflacht, und zugleich schräg dem Nahıtwinkel zugerichtet. Die Farbe hell knochengelb, das Innere der Punkte roth, ınd dadurch entstehen rostrotlıe Längslinien, welche da, wo die Streifon einander sehr nahe kommen - so namentlich der zweite his vierte hinter der Nitte, der achte und neunte auf der Wölbung -, ühergreifen und wischartig auch den Zwischenraum hedecken; die Schulterbeulen tiefer gebräunt. Das Pygidium bleichgelb mit bräunlichem Saume, die Unterseite trüb rothlbraun, der letzte Ring und die Ränder des Hinterleibes verwaschen gelblich; auch die Beine gell, Schienen und Schenkel auf der Mitte verwaschen- und an den Vorderschenkeln unterbrochen gebräunt, die Füsse und der grössere Theil der Hinterschienen braun. Das letzte Segment des $\delta$ leicht flach gedrückt, das $q$ unbekannt.

Von Cayenne (Mus. Deyrolle) und aus Brasilien (von Para, Mus. Clark und hier unter den Namen P. acupunctus Melly vorhanden).

15. P. anxius m. Rostroth, die Seiten und zwei verloschene Längsbinden des dicht und fein punktirten Halsschilds gelblich, die Spitze, ein lappiger Seitenfleck und einige Längslinien der Flügeldecken mit Pygidium, Beinen und dem letzten Bauchringe heller gelb; die Deckschilde vorn unordentlich punktstreifig, hinten längsrippig. L. $13 / 4 "$; Br. $1^{\prime \prime \prime}$.

Mehr walzenförmig als die vorhergehenden Arten, im Habitus am nächsten dem folgenden verwandt. Der Kiopf flach mit kaum sichtbarer Stirnlinie, dicht und ziemlich fein punktirt, rostroth und nit vereinzelten gelhen Schwielenpünlitchen bestreut, die Oberlippe knochengelb, die Tasterenden gebräunt, die tief ausgebuchteten Augen greis. Die Fühler von gewöhnlichem Bau, oben nur schwach zusammengedrïckt und erweitert, röthlich gelb mit rauchgranen Enden, das Wurzelglied auf der Oberseite mit einem dunkleren Wische bezeichnet. Das Halsschild reichlich doppelt breiter als lang, in der Mitte sanft quer aufgewölbt, vorn durch die tief eingezogenen scharf rechtwinkligen Vorderecken walzlich verengt, die Seiten fein gerandet, in der Mitte in flachem Bogen erweitert, vor ilı leicht ausgeschweift, die scharfen Hinterecken stumpfwinklig, der Hinterrand jederseits schwach gebuchtet, mit wenjg 
aufgebogenem Mittelziplel. Vor letzterem das Mittelfeld sanft nach hinten abwärts gesenlit. Die Punktirung von der Färbung abhängig: ein ziemlich breiter Seiten-, ein schmalerer Vorder- und Hinterrand, letzterer durch den Mlittelzipfel unterbrochen, schwielig erhöht, gelb und ohne I'unlite; die eigentliche Scheibe dagegen ist rothbraun, dicht und fein punktirt, glanzlos, jedoch schliesst sich jederseits an den Seitenrand ein nach rorn verbreitertes Längsfeld, welches ïberwiegent durch grössere oder kleinere, unregelmässig zusammenhängende und gestaltete gelbe Sclıwielenflecke gebildet und auf diesen Flecken mehr oder weniger punktfrei ist. Durch älnnliche Flecke bildet sich jederseits der Mitte eine unregelmässig nach vor'n verbreiterte und sich hier dem Mittelfelde zuneigende Läıgshinde, und auf der Mitte selbst eine Andeutung eines algekürzten gelblichen Längskiels: alle diese Bildumgen sind aber nur undeutlich, und an besten mit dem blossen Auge von einer gewissen Entfernung aus walnmehmbar. Das Schildchen kurz und breit dreieckig, merklich länger als vorn breit, mit abgerundeten Ecken und deutlichem Hinterzipfel abgestutzt, fein und dicht punktirt, inatt rostroth. Die Deckschilde walzenförmig, etwas breiter als das Halsschild und bis zu der kurz abgerundeten Spitze gleichbreil verlaufend, mit wenig abgeflachtem Rücken und zienlich kurz abfallender Wölbung, hinfer der scharf aufgeworfenen Vorderkante schmal quer gefurcht; die glänzenden Schulterbeulen nur schmal, die Seitenlappen wenig ausgebildet, aber mit breitem mit einer Punlitreihe besetztem umgeschlagenem Rande; über ihnen ein breiter und seichter, aber doch bis oben hin zu verfolgender, die Nahı vor der Mitte durchsetzender Quereindruck. Lie Punktirung auf der Vorderlälfte zu unordentlichen, durch Verdoppelung und überzählig eirigenıengte Punkte getrübteı Längsstreifen zusanmengereiht, zwischen denen nur ein paar deutliche Längslinien als Vertreter des zweiten und vierten Zwischemraums hervortreten, während seillich der achte und neunte Zwischenraum schon rom Seitenlappen ab kenntlich sind; auf der hinteren Ilälfte aber entwickeln sich, und zwar von Aussen der Naht zu fortschreitend, regelmässige Punktstreifen, deren Zwischenrïume deutliche flach gewöllste, sich etwas dem hinteren Nahtwinkel zu krümmende Längsrippen bilden, und zuletzl in einer grossen gelben, die ganze Spitze einnehmenden Querschwiele zusammenlaufen. Iuf dem breitern neunten Zwischenraune finden sich noch einige zerstreute 
Punkte, und die ganze Scbulterecke unter der Schulterbeule ist beim Zusanmentreffen des neunten und zebnten (des Rand-) Streifeıs mit überzähligen Punkten und Ansätzen überzähliger Streifen ziemlich dicht besetzt. Das Innere aller Punkte nebst den grössten Theile des Grundes zwischen Sclıulterbeulen, Nalıt und Mitte der Deckschilde rostroth mit einzelnen verwaschenen gelblichen Längslinien; der übrige Theil der Oberfläche wird am besten als getb bezeichmet, durch die hinterwärts breiter werdenden rostrothen Furchen zerrissen, und über der hellgelben Endschwiele mit einer über die Wölbung hinzielıenden und nur den neunten Zwischenraum fast ganz freilassenden, schlecht begränzten roströthlichen Querbinde besetzt. Das Pygidium kaum punktirt, hellgelblich mit einem röthlichen verwaschenen Flecke auf der Mitte; die Unterseite etwas dunkler rostroth, der letzte Bauchring und die Seiten des vorhergehenden mit den Vorderbeinen, den Schenkel- und Schienenwurzeln gelblich, auch die Vorderzipfel des ersten Bauchringes verwaschen gebriunt. Das letzte Segment des $\delta$ mit einem länglichen Quereindrucke, das $q$ unbekanut.

Aus Brasilien (Mus. Clark).

16. P. nigronotalus Boh. Rostroth mit sechs verwaschemen dunkteren Längslinieı des dicht runzlig punktirten Halsschilds, die Fühlerenden, sechs Lüngsflecke der Flügeldecken (2, 2, 2), die Hinterbrust und die Mitte des Hinterleibes schwarz; die derben Punktstreifen der Deckschilde nur seitlich und linterwärts kenntlich, mit flach gewölbten, mässig glänzenden Zwischen-

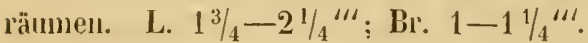

Pachybrachys nigronotatus Roheman Freg. Eug. Resa Ins. S. 159. n. 332!

Auch diese Art zeigt, wic die vorhergehende, melır den walzenfürmig gestreckten Bau eines echten Cryptocephalen, ist aber ron jener und allen andern Arten dieser Gattung leicht an den groben Runzeln des Halsschilds und der Fleckenzeichnung der Deckschilde zu erkennen. Der liopf flach, längs der Stirn seicht cingedrückt und dieser Eindruck noch von einer feineren Längslinie durclızogen, unten in eine breite flache Mulde auslaufend, das etwas eingezogene Kopfschild oben nicht abgesetzt. Die Farbe rerwaschen rostroth, der Nacken und das Innere jener nicdergedrückten Stelle dunkler gerölhet. Die Punktirung dicht und ziemlich stark, zu Runzehn rerfliesscnd, mit glanzlosem Zwischengrunde; die weitgetremnten, breit und zicmlich ticf ausgebuchteten Augen schwarz. 
Die Fülıler kurz und gedrungeı, den Hinterrand des Halsschilds nicht erreichend; das wenig gekrümmte Wurzelglied aus dünner Basis stark blasig anfgetrieben, etwa $1 \frac{1}{2}$ mal länger als breit, das zweite kurz eiförmig, die drei folgenden verkehrlkegelförmig, das dritte und vierte je um die Hälfte länger als das zweite, das fünfte noch etwas verlängert, das sechste etwa dem zweiten und dritten zusamınen gleich, oberwärts stark dreieckig erweitert und mit den oberen in ähnlicher Weise verbreiterten eine Art ziemlich gedrungener Keule bildend, mit abgerumdeten oberen Ecken des achten bis zelnten Gliedes, das Endylied nit einem kurzen und stumpfen Fortsatze. Die fünf unteren durchsclieinend rostgelb, das sechste und siebente oben breit geschwärzt, die vier oberen Glieder schwarz. Das Halsschild etwa doppelt breiter als lang, mit der vorderen Hälfte stark kugelig übergewöllst und auch hinterwärts wieder tief quer niedergedrückt, hinter den Augen über den scharf rechtwinkligen Vorderecken eingeschnürt und dadurch verengt, die Seiten deutlich gerandet, in der Nitte flach nach Aussen gekrümmt und vou da ab nach vorn in leiclıten Bogen zusammengeneigt; die Hinterecken scharf stumpfwinklig, der Hinter'rand jederseits leicht gebuchtet, der Mittelzipfel kurz, aber mit seiner Vitte nicht nochmals vorgezogen, und vor ihm ein breiter flacher, mit den Ausseneuden etwas nach vorn gerichteter Quereindruck. Die Oberfläche dicht uud ziemlich grob runzlig punktirt, mit stellenweise schrvielig glänzendem Zwischengrunde, die Farbe hell roströthlich mit breiten, verwaschen dunkler gerötheten Lüngslinien oder Längswischen, deren zunäclıst zwei zu einem plumpen $\mathbf{V}$ hinten zusammenfliessende auf der Hitte, und jederseits der letzteren nochmals zwei, deren äussere die kürzere und schwächere; die ganze Zeichnung aber zuweilen nur bei gewisser Entfermung von dem unbewaffineten Auge zı erkennen. Das Schildchen mässig ansteigend, quer viereckig und fast doppelt breiter als lang, hinterwärts nur wenig verschmälert, mit alogerundeten Ecken abgestutzt, der Hinterzipfel deutlich und gleichfalls Jreit abgestutzt. Die Oberfläche fein und ziemlich dicht punktirt, die Farbe braun mit breit röthlich verwaschener Mitte. Die Deckschilde wakzenförmig mit hinterwärts etwas abgeflachtem Rücken und sanft abwärts gekrümmter Spitze, binter der Vorderkante mur sclımal mud nicht tief quer eingedrückt, die länglichen Schulterbeulen nur flach, wenig herrortretend, auch die Seitenlappen wenig bemerkbar, und üher ilmen die Deckschilde 
auch nur leicht quer zusanmengedrückt. Die Punktirung derb, auf der Vorderhälfte ron der Nahı bis gegen die Mitte hin etwas feiner und mehr zusammengedrängt, nach Aussen mehr getrennt mit deutlicheren Resten gestörter Punktstreifen, die auf dem letzten Irittel auch gegen die Naht hin merkbar hervortreten; der '̌wischeugrund vorn fein gerunzelt und besonders auf den schwärzlichen Flecken ziemlich matt, hinterwärts bei dem deutlichen Auftreten flach gewölbter 'Zwischenräume etwas mehr glänzend. Die Farbe rostroth mit schmutzig gebräuntem Nahtsaume und sechs schwärzlichen Längsllecken auf jeder Flügeldecke, welche in drei Paaren georduet eigentlich zwei unterbrochene sclıwarze Längsbinden bilden, deren äussere, auf der Schulterbeule beginnend, bis zum Zusammentreffen des achten und neunten Streifens reicht, während die innere zwischen jener und der Naht etwa in der Mitte liegt, und in der Querfurchı hinter der Vorderkante anfanyend, beim Zusanmenstossen des zweiten und dritten Streifens abbricht. Die Entstehung dieser Flecke, ron denen die des Ilinterpaar's die kleinsten sind und sich nach der Spitze hin schräg zusammenneigen, aus solchen unterbrochenen Längsbinden zeigt namentlich noch ein wischartiger Schatten, welcher bei einem der mir vorliegenden Stücke auf beiden Flügeldecken den ersten und zweiten Innenfleck mit einander verbindet. Das Pygidium deutfich punktirt, dün greisharig, mit den Beinen und den letzten Ilinterleibsringe gelblich, der übrige Theil des llinterleibes schwärzlich, bei dem o mit breit und rerwaschen iıs schmutzig Gelbliche fallenden Seiten, der Mittelzipfel des ersten Ringes heller gell, die Brust schwarz mit gelblichem Hinterende des fast flachen Prosteruums. Bei dem vorliegenden $\delta$ ist anch der ganze Hinterleil) bis auf den letzten Ring schwarz, der gelbe Seitenrand nur aul dem vorletzten Ringe und in den Hinterwinkeln des ersten Ringes kenntlich. Das letzte Segment des $q$ mit einer nichıt selır tiefen, rundlichen und im Inneru geschwärzten Grube, des $\delta$ leicht quer niedergedrüclit.

Aus Montevideo (Mus. Holm., vou limberg mitgebracht: auch ini Mus. Clark).

17. I'. lavandus m. Greisgelb mil schwarzem Schildchen, drei Doppellinden des grob punktirten Halssclilds und sechs Wische der Flügeldecken $(2,2,2)$ sclınutzig geschwärzt, die Schenkel und Schienen in der Nitte bräunlich geringelt: die P'unht- 
streifen grob, durch überzälılige Punkte getrïbt, uur vor der Spitze längs Naht und Seitenrand deutlicher ausgebildet. L. L1/3"'; Br. $3 / 4 "$.

Durch Sculptur, Färbung und Zeichnung von den Verwandten leicht zı unterscheilen, in sler letzteren nur dem vorhergehenden einigernassen ähnlich. Der Kopf flach gewölbt, mit undeutlicher Stirnlinie mol wenig eingezogenem lioptschilde, mil ziemlich derher, etwas ungleich vertheilter Punktirung, durch welche zwischen der Mittellinie und den inneren Augenrändern noch jederseits eine etwas gebrämnte längslinie niedergedrückt wird. Die Farhe greis mit schwachem Glanze, seine beiden niedergedrïckten Stellen etwas feiner abev dichter punktirt, leicht gehrïunt, die breit dreieckig ausgebuclıteten, weit getrennten Augen schwarz. Die schlanken Fühlẹ fast von halber Körperlänge, das Wurzelglied stark aufgetlielsen, ctwa $1 \frac{1}{2}$ mal länger als breit, das zweite birnförmig mit tief eingeschnïrter Wurzel, die drei folgenden verkehrtkegelförmig, das dritle $1 \frac{1}{4}$ mal länger als das zweite, das vierte (lïngste) fast doppelt länger als das dritte, und die folgentlen allmählich wiedler alınelıment, so dass das zehnte nur noch wenig öher das dritte hinausreicht, die oberen vom sechsten ab etwas zusammengedrückt, nach ihren Enden zu verbreitert, mil kurz dreieckigem Fortsatze des Endgliedes. Die Farbe durchscheinend gell mit schwïzlichen Anfluge dcr oberen; anch das Wurzelglied mit einem ähnlichen Liingswische aul' seiner oberen Seite. Das IIalsschild etwa doppelt breiter als lang, hinter der Nitte leichı quer aufgewöllı, seitlich besonders vorn tief heralggezogen, über den scharf spitzwinkligen Vorderecken breit zusimmengedrückt und darhurch verschmälert, die fein gerandeten Sciten fast gerale, die Hinterecken scharl stumpfwinklig, der Ilinterrand tief zweibuchtig mit schıvatı aufgelongenem Nittelzipfel, und vor letzterem cin breiter, sich nach den Hinterwinkelı zn allmählich verllachender Quereindruck. IDe Punktirnng grob und ziemlich dicht, die Farbe greis mit sechs verwaschen geschwärzten Längshinden, von denen die heiden seitlichın je an beiden Enden, die beiden mittleren nur an Ilinterende zusammenstossen; die letzteren werden durch eine glatte unt glänzende Kiellinie getrenn, sind übrigens die dunkelsten, und von iluren ans sclıwächt sich die färloung ler seitlichen immer mehr ab; die Ränder aber werden nirgents von diesen zugleich durch ilure dichtere P'mbtirung etwas niedergedrückten Binden erreicht. Das 
Schildchen schräg ansteigend, wenig breiter als lang, hinterwärts verschmälert, mit deutlichem Hinterzipfel abgestutzt, matt schwarz mit schmutzig gellolich durchscheinender Spitze. Die Deckschilde um etwa $1 / 4$ länger als breit, ziemlich flach walzenförmig mit hinten nur sanft abfallender Wölbung, hinter der scharfen Vorderkante quer eingedrückt und dann wieder leicht aufgewulstet, mit flachen länglichen Schulterbeulen und wenig bemerkbaren Seitenlappen; über letzteren ein muldenförmiger Längseindruck, und von diesem aus die Deckschilde ziemlich stark quer zısammengedrückt. Die Punktirung elwas ungleichmässig, vorn zwischen Naht und Schulterhenlen dichter gedringt aber etwas feiner, seitlich und hinterwärts lockerer und gröber; die ursprünglich vorlandenen Punktstreifen durch überzählig eingemengte Punkte derartig verschoben und getrült, dass vorn nur zerrissene Ansätze sulcher Streifen und Doppelstreifen sichtbar sind, weiter hinterwärts zwar die überzähligen Punkte sich verlieren, aher die gröbere Punktirung bis über die Wölbung hinaus fortzieht, und nur zunächst der Naht der erste und zweite, aussen der mil eingen hiömmungen bis zu dem Seitenlappen zu verfolgende neunte Streifen kenntlich hervortritt. Zwischen diesen finden sich dann noch einige unvollkommnere, nicht einmal auf heiden Flïgeldecken gleichmässig entwickelte Streifenenden vor. Der Zwischengrund ziemlich gläuzend; vorn die Vorderenden des zweiten und vierten, hinter den Schulterbeılen auch des achteı Zwischemaums als schmale erhöhte Läıgslinien kenntlich, auch der neunte und dic Ilinterenden der übrigen flach gewülbt, und die Grube üher den Seitenlappen mit einer feineren Punktirung ausgefüllt. Die Farbe greisgelb, sechs rerwaschene, paarweise gestellte und nach hinten an Intensität abnehmende schmutzige Längswische auf jeder Flügeldecke schwärzlich: von den vorderen der äussere auf der Schulterbenle, der innere (läıgste) zwischen dem rrhöhten zweiten und vierten Zwischenraume, das zweite Paar auf der Mitte und der innere daron etwas mehr nach hinten gerïckt, das dritte sehr unscheinhare Paar auf der Wöllung, fast zu einem leichten Querschatten rerfliessend. Pygidimn, Unterseite und heine gleichfalls greis, die Nitte des Hinterleibes tiefer gebräunt, die Hinterbrust fast schwarzbraun; Schenkel und Schienen in der Mitte bräunlich geringelt, an den etwas verdickten Vorderschenkeln auch die Aussenkante brauı; dic Fussglieder schınutzig geschwärıt. Das letzte Segment des of einfach, das of unbekamnt. 
Aus Brasilien (Mus. Deyrolle.)

15. P. phthisiacus m. Weisslichgelb- und schwarzbunt mit schwarzen Fühlern; das Halsschild fein und zerstreut punktirt, die Deckschilde vorn unordentlich welligdoppelstreifig, hinten mit einfachen Schrägstreifen und breiten flachen Zivischenräumen. L. $12 / 3{ }^{\prime \prime \prime} ; \mathrm{Br} .{ }^{5}{ }^{\prime \prime \prime}$.

Von dem Hahitus des vorhergehenden, aber etwas grösser, heller gefärbt und von abweichender Bildung der Punktstreifen auf den Deckschilden. Der Kopf flach, ungleichmässig fein punktirt, die Punkte auf den geschwärzten Stellen dichter gedrängt, die lichteren schwielig erhöht und glänzend. Die Grundfärbung ein bleiches Weissgelb; ein Querfleck im Nacken, ein verkehrtherzförmiger Fleck auf der Mitte der Stirn, der obere Theil des Kopfschildes, und in Anschlusse an diesen eine von den Fühlerwurzeln je bis zu den oberen Innenrändern der Augen sich hinaufziehende Längslinie schwarz. Auch die Oherlippe schwarz, die übrigen Mundtheile gelblich mit geschwïrzten Tasterenden. Die Fühler von etwas mehr als halber Körperlänge, schwarz, die unteren Glieder an Wurzel, Spitze und Unterseite gebräunt. Das Halsschild breit und flach gewölht, mit kaum aufgewulsteter Nitte und daher fast gerader Mittelfirste, der hintere Theil leicht quer niedergedrückt, die Seiten fein gerandet, in der Mitte sehr schwach erweitert, die scharfen, tief eingezogenen Vorlerecken fast rechtwinklig, die hinteren stumpf; der Itinterrand fast gerade, nur jederseits des schwach heraustretenden Mittelzipfels leicht ausgebuchtet. Die Punktirung sehr fein, stellenweise dicht gedrängt, andrerseits längs den Räıderı und an der vorn kielig erhöhteı glänzenden Mittelfirste sehr vereinzelt; da wo sie sich verdichtet, die Fläche niedergedrückt und bei der trüben Färbung des Inneren der Punkte verdunkelt, was namentlich auf einen grösseren Felde jederseits der Vitte und in einer plump ringformigen Stelle zwischen jener und dem Seitemrande der Fall ist. Lliese dichter punktirten Stellen e'scheinen deshalb schmutzig gebräunt, der übrige Zwischengrund bleich weissgelb. Das Schildchen stark ansteigend, dreieckig und mit deutlichem Hinterzipfel abgestutzt, gleichfalls weisslich mit geschwärzten Säumen. Die Deckschilde breit und flach walzenförmigg, fast $1 / 3$ länger als breit, hinter der erhöhten Vorderkante leicht quer eingedrückt, über den lang herabgezogenen Seitenlappen stärker zusammengedrückt, mit breiten, wenig hervortretenden 
Schulterbeulen und ziemlich schräg abfallender Wölsung; der Raum von der Schulterbenle bis zun vorderen Drittel der Naht in Gestalt eines fhach erhöhten Schrägfeldes emporgehoben. Die P'unktstreifen auf der grösseren Vorderlıälfte durch Verdoppelung, wellige hrümmungen und liesonders gegen die Naht hiı ïberzïllig eingemengtr Punkte gestürt und getrübt, sodass die Zwischenr:̈ume nur als schmale unregelmissige längslinien sichthar werden; auf dem letzteren Drittel verbreitern sich dieselben, werden klarer und einfach, die äusseren wenden sich iı schräger lichtung dem Nahtwinkel zu und fliessen zusammen, hevor sie densellen erreichen. Die Färbung bleich weisstich gelb, die Schulterbeulen, das Innerc der Punkte, und einige trühe Längswische vor und auf der IVölbung der Deckschilde schmutzig schwarzbrann. Das Pygilimu gleichfalls hleich weisslichgell, äusserst fein junlitirt und behaart, jeterseits leicht eingedrückt, auf der Nitte mit einem brännliclıen Lüngsflecke. Die Unterseite dicht und fein punktirt, dünn und kurz silberlaarig, mit schwarzem Untergrunde, die Schulterbiattrer und ein breiter, rerwaschener Rand des Ilinterleibes gelblich, anch die Beine gelblich mit gebrämten Füssen. Schenkel und Schienen in der Mitte bräunlich geringrelt, an den Vorderschenkeln auch die Anssenkanten gebräunt, unı der breite dunkle Nittelring nochmals durch einen lichteren Fleck gethrilt. Das letzte Srgment des ơ mit einem flachen Längseindruck, des $f$ unbeliannt.

Aus Brasilien (von Minas Geraes: Mus. Dohrn, von Drewsen mitgetheilt).

19. P'. strictus m. Ohen greisgelb, die Punktirung und die vordere Häfle des Schildchens schwarzhraun, unten schwarz, Sclulterduatter, Beine und der Rand des llinterleibes greisgell,; las Halsschild dicht sichantig punktirt; die l'unlistreifen rowas wellig,

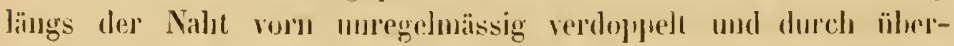
zählige Punhle geslört, mit hinten verbreiterten \%vischenrämen. l. $11 / 2 "$; I3r. $3 / . "$.

Den vorlergehenden iiludich, aher besonder's in IJalsschilde schmaler und auf dessen Seriten wemiger dentlich geschwärat, die

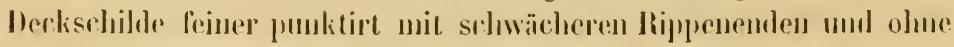

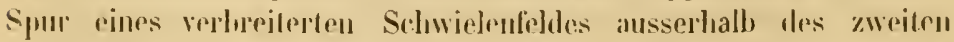

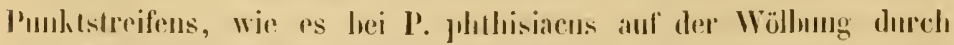
eine Erwritrumg des zwriten Zwischenramms zu fimden ist. Dep

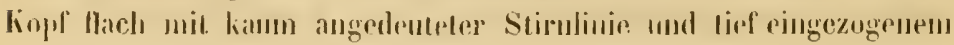


Kopfschilde, derb und ziemlich dicht punktirt mit mattem Zwischengrunde; die Farhe schuntzig greisgelb, der Nacken, ein ciförmiger Fleck aul der Stirn, ein rundlicher Fleck joderseits über dem Fülılerhöcker, der untere Theil des Kopfschildes und die Mitte der hurz vorspringenden Oberlippe schwar\%; auch auf dem greisen Grumde das Inuere der P'unlite geschwärzt: die grossen, tiel' schräg ausgebuchteten Augen schmutzig greis. Die Fühler (des ơ) ron melır als halber Kï̈rperlünge, das Wurzelglied aus sclımaler IBasis keulig aufgetrieben, doppelt länger als breit, das zweite kurz und kugelig, hall, so breit als das erste, das dritte um dic fiälfte unıl das vierte doppeht länger als das zweite, das fünfte noch etwals linger und diesem die oberen grleich, letztere zugleich etwas zusanmmengedrückit und erweitert, nit kurzen breitem fortsatze des Endglieds. Das Wurzelglied gelb mit einer schwarzen Lüngslinie auf der Oberseite, die folgenden bis zur Mitte tles vierten durchscheinend pechbraun, die oberen schwar'z, angedrückt greisharig und an den Spitzen vereinzelt weisslich gewimpert. Das Halsschild kurz und breit, mit flachem nur vor dem Hinterrande seicht yuer niedergedrückten Rücken, der Vorderraud leicht vorgezogen; die spitz vortretenden Vorderecken tief eingezogen, über ihuen das Halsschild zusammengedrückt und dadurch verschmälert; die Seiten fein gerandet, vor und hinter der schwach herausgebogenen Hitte leicht ausgeschweift, mit stumpf zugerundeten Hinterecken; der Hinterrand jederseits schwach ausgebuchtet, mit leicht aufwärts gebogenen Mittelzipfel. Vor den Ilinterecken jederseits ein ln'eiter nacher, längs dem Ilinterrande einen deutlichen Querwulst empordrängender Schı̈̈geindruck. Die P'unktirung grob, seitlich mehr zerstreut, jederseits der Mittelfirste dichter zusammengedrängt; das Innere der Punkte geschwärzt, und dadurch auf deın gr'eisgelben schwach glïnzenden Grunde jederseits der Mittellinie ein lıreiter, verwaschencr Längsschatten gebildet, dessen etwas deutlicheres Vorderende sich an den schwärzlichen Nackenlleck inschliesst. Das Schildchen fast gleichseitig-dreieckig, hinterwärts schräig ansteigend, mit scharf abgestutzter Spitze und undeuthichen Hinterzipfel; die Farbe vorn schıvarz, hiuten kuochengelb mit dunklerem Samuc. Die Deckschilde etwa um 1/3 länger als lıreit, vorı etwas breiter als das Halsschild und hinterwärts noch ein wenigr verbreiter't, der Rïcken Ilach, vol der Mitte leicht quer eingerlückt, und die Vorderenden dieses Eindrucks jederseits bogentörnigg bis zur Innen- 
seite der Schulterbeule nach vorn reichend, so dass dadurch die innere Vorderhälfte der Flïgeldecken je als ein flach gewölbtes Feld emporgehoben wird. Die Vorderkante scharf erhöht, aussen an die schmal höckerigen Schulterbeulen angeschlossen, und hinter ihr ein leichter Quereindruck; ein zweiter grösserer aber noch flacherer liegt über dem rundlich herabgezogenen Seitenlappen. Die Wölbung sehr flach abfallend, und die Spitze schräg nach Aussen zugerundet. Die Punktirung deutlich, in ziemlich regelmässige Streifen geordnet, die oberen etwas wellig und dabei die Vorderhälfte des ersten bis vierten verdoppelt, der Raum zwischen dem ersten und der Naht mit vielen überzähligen Punkten bedeckt, die auch theilweise noch auf die nächstfolgenden Zwischenräume ühersetzen. Die äusseren Streifen regelmässiger, doch auch das Vorderende des neunten eine Strecke hin verdoppelt, unò besonders der sechste und siebente Zwischenraum hinterwärts, der ueunte über dem Seitenlappen mit überzählig eingemengten Punkten bestreut. Die Zwischenräıme vorn schmal linienförmig, gewölbt, hinterwärts breiter und flacher, die äusseren auf und unter der Wölbung zu breiten Längsschwielen erweitert, deren Enden hinten im Nahtwinkel zusammenfliessen. Die Farbe gelbgreis, hinten ins Knochengelbe fallend, das Innere der Punkte auch hier geschwärzt. Pygidium und Beine einfarbig gelb, die Unterseite schwärzlich, fein punktirt und dlünn greishaarig; ein breiter verwaschener Saum des Hinterleibes nebst den Vorderzipfeln des ersten Bauchringes, den Schulterblättern und der Vorderbrust gelbgreis, die Längsrinne der letzteren schmal, und dabei scharf gerandet. Das letzte Segment des $\delta$ mit einem leichten rundlichen Quereindruck, das $q$ unbekanut.

Aus Brasilien (Mus. Halens.).

20. P. conformis Dej. Oben schmutzig gelb mit braunen Längshinden des sehr dicht und fein gleichmässig punktirten Halsschilds und zusammenfliesseuden schwarzen Längswischen der Deckschilde, unten schwarz; die Declischilde mit welligen durch unterbrochene Kerbstreifen hegränzten Läugsrippen: L. 1-1 1/4 "“; Br. $1 / 2-2 / 3 "$.

Pachybrachys conformis Suffr. Linn. Ent. VII. 205, n. 39!

Eine der wenigen Arten, wolche der Norden von Südamerika mit Mittelamerika gemeinsam besitzt. Es liegen mir von derselben füuf südamerikanische $q$ Exemplare vor, ein grösseres mit dem 
a. a. 0. von mir beschriebenen Stücke übereinstimmend, dann noch ein eben so grosses und einige etwas kleinere, welche von jenem nur durch eine etwas hellere Färbung sowohl des Grundes als der nur dunkel gebräunten Wische auf den Deckschilden abweichen. An den Fülılern sind das vierte, fünfte und sechste Glied die längsten, und je um die Hälfte länger als das dritte, die oberen nehmen wieder allmählich ab, sodass das zehnte nur etıa dem dritten gleichliommt. Das dritte bis fünfte sind nach ihrer Spitze hin stark kegelförmig verdickt, die oberen zusammengedrückt, das sechste und siebente oberwärts stärker dreieckig erweitert, die folgenden ziemlich gleichbreit und vom oberen Ende des sechten ab geschwä̀zt. Die Schulterblätter sind eben so hell gefärbt, wie der Rand des Hinterleibes.

Aus Columbien (Mus. Berol. Clark. Haag. Deyrolle; in dem letzteren ist speciell Carthagena als Fundort genamnt.) Von den Stücken des Mus. Berol. ist eins von Häberlin bei La Guayra gefunden.

21. P. sordidulus m. Schwarz, Kopf und Beine gelbbunt, die Ränder, zwei zerrissene Längshinden und eine vordere Mittellinie des dicht punktirten Halsschildes mit einer Anzahı Längsflecken und der Spitze der Flügeldecken, zwei Flecken des Pygidiums und den Ecken der beiden letzten Bauchringe weisslich gelb; die Punktstreifen vorn durch eingemengte Punkte gestört, hinten durch wellige Länḡsrippen getrennt. L. $1^{\prime \prime \prime}$; $\mathrm{Br}$. $1 / 2{ }^{\prime \prime \prime}$.

Den kleineren Stücken des vorhergehenden in Grösse und Habitus ähnlich, eben so zierlich, und an dem reinen Schwarz der gegen die weisslichgelbe Zeichnung sehr abstechenden Grundfarbe leicht kenutlich. Der Kopf flach, mit der Länge nach sanft niedergedrückter', dleutlich punktirter, matter Stirn, schwarz, jederseits ein die oberen und inneren Augenräıder umziehender, in den dreieckigen Augenbuchten unterbrochener Hakenfleck mit den Wangen, den unter'en Ecken des Kiopfschildes und einem kleinen Querflecke an Ilessen oberem Rande weisslich gelb; alle diese hellen Stellen zugleich etwas glänzend und schwach erhöht. Die Oberlippe fahl lehmgell, mit etwas verdunkelter Mitte. Die Fühler von hallıer Körperlänge, verlıältnissmässig kräftig, das Wurzelglied stark blasenförmig aufgetrieben, kaum $1 \frac{1}{2}{ }_{2}$ mal so lang wie breit, das zweite ziemlich gross, breit eiförmig, das dritte sehr dünı und an Länge dem zweiten gleichkommend, die folgenılen in ilırer Länge 
nicht erheblich versehieden, je etwa $1 / 2$ mal länges als das dritte, von der Spitze des sechsten ab stink zusammengedrückt und erweitert, mit sehr kurz dreieckigem Fortsatze des Endglieds. Die Farbe schmutzig lehmgelb, die Oberseite des Wurzelgliedes und die oberen vom sechsten ab mit leicht bräunlichem Anfluge. Das IIalsschild etwa doppelt länger als breit, über die Mitte sanft quer aufgewulstet und die Mittelfirste von da ab nach vorn und hinten grleichmässig abwärts gekrümmt, ler Rücken vorn über deı scharf rechtwinkligen Vorderecken zusanmengedrückt und dadurch verschmälert, die feiı gerandeten Seiten in der Nitte utr in flachem Bugen erweitert und von da nach den scharf stump,fwinkligen Vorderecken lin aufsteigend, der Hiuterrand fast gerade mit wenig hervortretendem Mittelzijfel. Die Oberfläche dicht und deutlich punktirt, matt schwarz, der alogesetzte schwarze Rand von einem luinten in der Mitte und vor den Schulterbeulen unterhrochenen gelblichen Saune hegleitet; ausserdem anf dem Mittelfelde zwei breite, etwas zerrissene, aber nicht unterbrochene und den Vorderrand nicht erreichende weisslich gelbe Längsbinden, zwischen ilıen noch eine abgekürzte vordre gelbliche Längslinie, und zwischen der Mitte jeder Bunde und dem hier etwas erweiterten Seitenrande noch einge unregelmässige gleichfalls grelbliche Atomentlecke. Das Schildchen schräg ansteigend, fast gleichseitig dreirekig nit kurz alyestutzter Spitze und deutlichem Hinterzipfel, glänzenıl schwarz. Die Deckschilde um 1/3 länger als breit, flach walzenförmig, vorı nach der Basis mil selır sanfter Krünmmng, nach der Spitze zu stärker abfallend, hinter den lïnglichen Schulterbeulen über den mässig verbreiterten Seitenlappen etwas yuer zusammengedrückt; die Punlitirung grob, die Streifenbildung auf der vorderen IIalfte durch überzählige Punkte gestört, so dass lijer eigentlich nur der nach der Naht zu gelirümmte erste mus zweite Streifen, sowie die Vorderenden des fïnften bis achten kenutlich werden; hinter der Mitte werden die Streifen deutlicher, wenn auch vielfach wellig, die Zwvischenräune breiter und mehı rippenartig, den Streifen entsprechend gekrümut. Die Farbe ein mattes umd glanzloses Schwarz mit vielen weisslich gelben Längsflecken, welche auf der Vorderhälfte überall zum Vorschein kommen, wo sich grössere Zwischenräume gebildet haben, laher nansentlich innerseits des ersten Streifens, auf den ersten und zweiten, weiter hinterwärts auch dem dritlen Zwischenraume; eben so ist auch 
der lange Kiel des Seitenlappens sellost weisslich. Weiter hinterwärts zeigt sichı eine Querreihe solcher Flecke vor der Wöllıung, und in dem Nalıtwinliel sellsst ein gleichgelïrbter Bogenlleck, an den sich das ebenfalls weissliche Hinterende der fünften: Riple ansehliesst. Das Pygidium nebst der Uuterseite schwarz, anf jenem vier Flecke neben einander gell, von denen die seitlichen kleineren auf den letzten Bauchring ühergreifen und dessen Enden färben; vor diesen auch noch die schmalen Ecken des nüchst vor'hergehenden Ringes gelhlieh. Die Briue lehmgell, mit weisslichen Schenkelenden; Schenkel und Schienen in der Mitte breit und verwaschen schwarzhraun geriugelt. l)as letzte Segment des ơ loreit puer niedergedrückt, das $q$ umhekanut.

Aus Brasilien (bei Rio de Jan. von F. Sahlberg gefundeu: Mus. Holm.).

22. P. dissolutus in. Zimmubaun, zwei Hakenllecke des Kopfes, die Räuder, drei abygekürzte Lüugslinien und zwei Seitenwische des überaus frin und dicht punktirten Ilalssehilds, die Vorderkante und eine Anzahl Läıgslinieu der Deckschilde mit einem breiten Rande des Ifinterleibes und den Beinen hochgell) mit dunkler geringelten Schınkeln; die Punktstreifen lein, etwas wellig, mit schmalen, hinten zart rip’ęıförmigen Zwischınräumen. L. I $1 / 6{ }^{\prime \prime}$; Br. $1 / 2 "$.

Der Kopf flach mit stark eingezogenem Kopfschilde, die Stiru der Länge nach seicht niedergedrückt, die Farbe zimmtbraun, die gewölnulichen die Augen oben und innen unziehenden Iakenfleckis hellgelb, auch das Kopfschild ziemlich hell gelb mit braunen, oben schleelıt begränzten Ränlerı. Die Punktirımg auf dem brauneı Grunde dicht gedrïngt und dadurch dieser Grund selıst matt, die Hakenflecke flach schwielig erhöht und last ohue Punkte, das Kopfschild mit vereinzelten in Innern gebräunten P'unkteı wie durchstuchen, die ziemlich tief dreieckig ausgebuchteten Augen schwarz. Die Fühıl selı düıı, kaum von 1/3 der Körperläıge, gelblich, die oleren Glieder an ihrer oberen Hälte leicht ins Rauchgraue falleud. Das Halssehild doppelt breiter als langr, mit voru sanft ahwärts gelirümmter, linterwärts stärker schräg abfallender Mittelfirste, hinten breit quer niedergedrückt, üher den scharf rechtwinkligen und dann noch kurz vorgezogenen Vorderecken zusim!mengedrüclit und dindurch verschmälert: die Seiten fein gerandet, in der Nitte flach bogig erweitert, die stumpfivinkligen Hinterecken 
mit einer kurz aufgebogenen, scharfen Schwiele besetzt, der Hioterrand jederseits des schwach heraustretenden Mittelzipfels wenig ausgeschweift. Die Oberfläche auf dem dunkleren Grunde dicht siebartig und etwas stärker als der Kopf punktirt, der helle etwas schwielig erhöhte Rand ohne Punkte und auch die übrigen lichten Zeichnungen nur sparsam damit besetzt. Uie Farbe gleichfalls zimmtbraun, ein hinten nur durch den Mittelzipfel unterbrochener ziemlich hreiter Rand lıellgelb, ebenso eine hinterwärts abgekürzte, den Vorderrand berührende Mitteilinie, und jederseits der'selben eine auf dem Ende des Mittelzipfels stehende nach vor'm abgekürzte hintere Linie nebst einem zerrissenen Winkelflecke innerhalb der Vorderecken gelblich. Das Schildchen schräg ansteigend und vorn quer niederyedrückt, nicht so lang als vorn breit, hinterwärts stark verschmälert, mit deutlichem Hinterzipfel, zerstreut punktirt und zienılich glänzend braun. Die Deckschilde um $1 / 3$ länger als breit, flach walzenförınig, hinter der scharf erhölsten Wurzelkante quer eingedrückt, die flachen Schulterbeulen länglich, die Seitenlappen von Inässiger Stärke aber mit breit umgeschlagenem Rande, die lintere Wölbung sehr schräg abfallend. Die Punktirung auf der vorderen Hälfte läıgs der Naht dicht gedrängt und in einander gewirrt, je weiter nach aussen desto deutlicher in Reilıen geordnet, vom vierten Streifen ab etwas wellig und die äusseren regelmässig ansgebildet, aber stellenweise bald genähert, bald regellos die Zwischenräume schräg durchschneidend, die äusseren hinten vollständig entwickelt, ähılich aıch die der Naht zunäclıst liegenden, die mittleren dagegen abgekürzl, und die Zwischenräume hinten zu ziemlich regelmïssigen, leicht gegen den Nahtwinkel zugekrümmte Längsrippen ausgebildet. Die Farbe auch hier zimmtbraun, die Vorderkanten der Flügeldecken von den Hinterecken des Schildchens ab um die Schulterı bis zum Hinterrande des Seitenlappens hellgelb, und dieselhe Färbung zeigt eine Aızahl unregelmässig auf den Zwischenräumen vertheilter Längsflecke und Längslinien, die sich besonders auf den äusseren Zwischenräumen in die Länge strecken, und unter denen namentlich eine nit Unterbrechungen fast den ganzen neunten Zwischenraum eimmelınsende. lsinten längs der Naht sich wieder etwas vorwärts krümmende Linie in die Augen fältt; das Vorderende derselben ist durch einige dicht gedrängte Punkte üher dem Seitenlappen als rereinzelter Fleck unter der Schulterbeule ahgeschnitten. Das Pygidiun weisslichgelb, der 
Saum und eine Mittellinie braun. Die Unterseite braun, der letzte Ring, die breiten Seiten der vorhergehenden, besonders des ersten, ind der verwaschene Mittelzipfel dieses ersten Ringes weisslichgelb. Auch die Beine weisslich, die Mittel- ınd Hinterschenkel und -schienen bräunlich geringelt, an den Vorderheinen die Schenkel bleich gebräunt. Das letzte Segment des ? mit einer länglichen, glänzenden Grube, das $\delta$ unbekannt.

Aus Columbien (Moritz im Mus. Berol.).

23. P. flavo-varius Boh. Schwarzhraun mil gelbbunter Oberseite und gelbem Schildchen, auch die Seiten der Bauchringe, das Pygidium und die Beine gelbfleckig; das seitlich gerade Halsschild dicht und ziemlich fein punktirt, die Punktstreifen wellig und unterbrochen, mit längsrippenförmigen, hinten breiteren Zwischenräumen. L. $11 / 2{ }^{\prime \prime \prime} ; \mathrm{Br}$. $3 / 4{ }^{\prime \prime \prime}$.

P. Ravo-varius Boh. Freg. Eug. Resa Ins. S. 159. n. 333 !

In mancher Beziehıng rem oben beschriebenen $P$. musivus ähnlich, und von ihm hauptsächlich nur in der Sculptur der Deckschilde abweichend, daher es ausreiclien wird, wenn ich mich auf die Angabe der Verschiedenheit beider Arten beschränke. Der mir in drei o Stücken vorliegende Käfer gleicht an Grösse dem $q$ der genannten Art, an Färbung deren dunkleren Stücken, ist jedoch in der Zeichnung des Halsschilds dadurch verschieden, dass die aufgetragenen gelben Schwielen sich zu zwei hreiten zerrissenen, über die ganze Länge des Halsschildes hinziehenden Binden zusammenschliessen, sich zwischen ihnen eine deutliche, gleichfalls gelbe Kiellinie emporhebt, und in gleich zerrissener Weise auch die ganzen Vorderwinkel gefïllt sind. Ebenso ist das schmalere, aber länger und steiler ansteigende Schildchen ganz hellgelb mit scharf begränztem schwärzlichem Saume, und auf der Unterseite sind ausser dem breiten Rande des Hinterleibes auch die Intrenränder der Parapleuren, die Innenenden der Schulterblätter und die Mitte der Prosternalrinne trüb gelb. Auf den Deckschilden tritt die Streifenbildung deutlich hervor; die Streifen, obwohl mehrfach unterbrochen und mit welligen Krümmungen in einander laufend, doch nach ihrem ganzen Verlaufe kenutlich. Die zwischen Naht und Schulterbeule liegenden krümmen sich dabei in breiten gegen die Naht concaven Bogen der letzteren zu, und zwar so dass der erste und zweite, der dritte und vierte einander genähert sind, der fünfte ziemlich gerade verläuft, der sechste sich in eine Reihe 
vereinzelter Punkte auflüset, der siebente und achte wieder ziemlich regelmässig verlaufen, und der neunte bei mehrfacher Verwerling besonders über dem Seitenlappen sich zu einem flachen, dicht und gröber punktirten Längseindrucke erweitert. Diesen Stürungen entsprechend sind auch die Zwischenräunie nur unregehässig und in verschiedener Breite zu flachen Längsrippen ausgelsildet, und es entstehen bei ihrem Zusammentreffen mehrfach grössere gelbliche Schwielenflecke, so namentlich eine grosse Querschwiele vor der Wülloung durch Zusammenstossen des vierten bis achten Zwischenraums, hinter welcher sich dam die Rippen in sehr regelmässiger und gleichlaufender Schrägrichtung dem Nahtwinkel zuwenden: andere deutliche Schwielen zeigen sich in dem Winkel, wo der dritle und vierte Punktstreifen zusammentrelfen, und im Nahtwinkel sellost, in welchem letzterem anch der verbreiterte erste Zwischenraun ausliuft. Alle diese Zwischenräume sind gelb, geschwärzt ist nur das Innere aller Punkte, ein Wisch aul der Schulterbeule, das zugleich mit äberzähligen Punkten besetzte und darlurch niedergedrïckte vordere Drittel des drilten Zwischenraums, das den neunten Streifen elweiternde Grübchen äber dem Suitenlappen nebst einigen, die Quersehwiele vor der Wölbung imnen und hinten begränzenden Wischen und einem Fleckchen auf dem neunten Zwischenraume unter ler Wölsung. Alles Uebrige, bis anf die oben schon angegebenen geringen Abweichungen in ter Firloung ter Unterseite, wie bei P. nusivus, mit dem auch das allein vorliegrende $\delta$ im Bau des letzten Iluterleibsringes übereinstimmt.

Aus Brasilien (von Rio de Jan.: Nus. Holm.). Von den beiden daher vorliegenden of stamm eins ron der Roise der Fregatte Eugenic und bildet den Typus von Bohemans Beschreibung, las zweite ist von $F$. Sahlberg mitgehracht worden. Eben daher auch in Ilus. Clark.

24. I'. mysticus Reich. Schmutzig braungelb-bunt, das dicht und fein punktirte Italsschild mit vier, die Flügeldechen mit sechs dunkler gebräunten Wischen; die Deckschilde grob punktirt, hinten undeutlich läıgsipplig. L. 2-2 2/3"'; Br. 5/6-11/4"'.

Cirösser und besonter's thacher als die vorhergehenden, durch dis drei Pare dunkellmaner Wische aul den Flügeldecken einigermassen dem P. Iavandus verwantu. Her liopf flach, die Stirn der Länge nach seicht nichlergedrüchl, das liepplschild wenig einge- 
zogen, die Punklirung sehr dicht, die Färbung dunkelgell- oder rohlıbraun; ein loreiter, etwas erhöhter und die Augeu umziehender Wulst nebst dem oberen und dem unteren Theile des Koptsehildes heller gelblich, weniger punktirt, mit etwas schwielig glänzendem 'Lwischengrunde; die grossen, ziemlich breit aber nicht tief ausgebuchteten Augen greis. Die Fühler (des f) sehr kurz und nicht die lıalbe Körperlänge erreichend, das Wurzelglied rilürmig, etwa um die Hälite länger als breit, das zweite sehmal elliptisch, die drei folgenden verkehrtkegelförmig, das dritte dem zweiten gleich, das vierte und fünfte wiederum einander gleich, je um die Iälfte läıger als das dritte, die folgenden bis zun zehnten allmählich an Läıge abnehmend, sodass das zehnte etwa wieder dem dritten gleichkunmt und das Endglied mit seinem kurzen Fortsatze kaum die Länge ıles vierten erreicht. Dabei die oberen vonı sechsten al) ıur schwaeh zusammengedrückt und erweitert; die Farbe schmutzig' gellogreis nit gebräunter Ober'seite des Wurzelgliedes, die oberen Glieder dicht angedrückt behaart und vereinzelt abstehend gewimpert. Das Halsschild abgeflaeht mit fast gerader Mittelfirste, last doppelt breiter als lang, über den seharfen schwielig vorgezogenen Vorderecken breit schräg zusammengedrückt und dadurch ver'selmälert; die Sıilen fein gerandet, in der Mitte stark bogig erweitert, vor ilı leicht ausgeschweift und hinterwärts nach deu stumpfwinklig abgerundeten Hinterecken zu sehıäg aufivirts gerichtet; der Hinterrand fast gerade, jederseits des unseheiubaren Mittelzipfels leicht ausgebuchtet, und vor demselben beiderseits ein breiter, flacher Schrägeindruck. Die Punktirung ziemlich dicht alser nichı tief, an den Seiten melır oder weniger runzlig verfliessenıl, mit lackiglünenden Zwisehengrunde; die Farbe ein schmulziges Cielbbraun nit vier unförmlichen verwaschenen dunkler gelıriunten Flecken, leren je ein grösserer Schrägiviseh jederseits, und dazwisehen ein paar likeinere hinterwärts zusammengeneigle, dasellss die Mithellinie einschliesseml. Das Schildehen seln'äg anstrigend, linterwärts wenig verschmälert, etwas breiter als lang, mit deutlichem Ilinterzipfel gerade alogestutzt, fein punktirt und behart, braun und bei abgerichener Behaarung glinzent. Die Veclischilde llash gewöllo, etwa $2 \frac{1}{2}$ mal länger und vorn anch etwals breiter als das Ilalssehild, hinterwärts noch mtwas verbreitert, linter der scharfen Wurralkante nur schwach yner eingedrüclit; die flachen schuldrphenlen hinterwärts ein wenigr erweitert, der 
Rücken über den schwachen Seitenlappen ebenso schwach quer zusammengedrückı, auch die Wölbıng hinterwärts nur sehr sanft abfallend. Die Punktirung derb, vorn leiderseits der Schulterbeulen zu regelmässigen Streifen geordnet, sodass diese vom zweiten ab kenntlich hervortreten; der Raum zwischen diesem und der Naht bis über die Nitte hinaus mit dicht gedrängten, etwas feineren Punkten hedeckt, wodurch der er'ste und der abgekürzte Streifen fast unkenntlich werden; auch auf' den übrigen Zwischenräumen, besonders dem neunten, hier und da überzällige Punkte. Hinter der Mitte werden die hinter der Schulterbeule liegenden Streifen unordentlich und in einander gewirnt, die Zwischenräume fliessen dureh runzlige Querbrücken in einander, und er'st auf der Wölbung kommen jederseits der Naht die Hinterenden einiger Längsrippen zum Vorschein, während die regellose gröbere Punktirung seitlich mehr oder weniger auch auf den nemten Zwischenraum übergreift. Die Farbe hell gellogreis mit mässigem Glanze der nicht punktirten schwielenarlig erhöhten Stellen, durch das gebräunte Innere der Punkte braunbunt, und ausserdem auf jeder Flügeldecke drei Paar tiefer gebräunte Längswische; vor'n der äussere auf der Schulterbeule, der innere zwischen ihr und dem Schildchen, das zweite Paar linter der Nitte, der äussere (Schräglleck) am Aussenrande und hier von dem neunten streifen durchsetzt, der innere etwas mehr rückwärts und von der Naht nur durch einen geringen Zwischenraum getrennt; das letzte Paar auf der Wölbung auf dem schwielig erhöhten Hinterende des zweiten und achten Zwischenraums, beide, weil seitlich und hinten durch Punktreihen eingeschlossen, scharf begränzt, und vor ihrem Mittelıaume gewöhnlich nuch ein kleinerer, eine Art von Verbindung mit dem Mittelpaare darstellender Schräglleck. Das Pygidium fein runzlig punktirt, sclıwach längskielig, und mit dem gewölntich gleich,alls unbedeckten vorletzten Rückenringe dichı angedrüclit greishaarig, schwarzbraun, unten rerwaschen hellbraun gerandet; anch die Unterseite braun, nit breit verwaschen heller gesäımtem Hinterleibe, dicht kurz greisharig; die Beine gelbgreis, die Schenkel in der Mitte, die Schienen unten breit bräunlich geringelt, die Mitte iler Vorderschenkel mit einem lichteren F'leckehen bezeichnet. [)as Prosternum schmal rinnenförnig, lang behaart; das letzte Segment des 9 mit einer kleinen rundlichen Grube, las ơ unbekannt.

Aus buenos Ayres (ron Dr. Waltl mitgetheilt, auch in Mus. 
Dohrn. Berol. Ilaag. Baly. Sturm. Schaum. Clark, in dem letzteren mit dem Namen P. erosus Buq. bezeichnet.

25. P. judaicus Grm. Braungelh-bunt, oben grob runzlig punktirt, die Deckschilde mit abgerissenen schwach erhöhten Längslinien und regellos fvertheilten grösseren gelblichen Schwielen. L. $12^{\prime \prime \prime} ;$ Br. $3 / 4-1^{\prime \prime \prime}$.

Etwas kleiner als der vorhergehende, übrigens ihm im Habitus sehr älunlich, und hauptsächlich durch die grobe Punktirung des Halsschilds, wie durch die vorn weit weniger deutlichen Punktstreifen der Deckschilde abweichend. Der Kopf flach mit etwas eingezogenem Kopfschilde, grob und ungleich dicht punktirt, schmutzig gelbhraun, auch das Innere der Punkte bräunlich und dadurch die Farbenvertheilung ungleichmässig; der Zwischengrund mässig glänzend, und da, wo die Punkte sich mehr vereinzeln, schwielig erhöht. Die breit aber nicht tief ansgebuchteten Augen greis mit schwärzlichen Flecken. Die dünnen Fühler kaum von halber Körperlänge, das Wurzelglied eiförmig aufgetrieben, um die Hälfte länger als breit, das zweite aus stark eingeschnürter Basis auf der Innenseite birnförmig er'veitert, kaum hall so lang und breit wie das erste, die folgenden schınal verkehrtkegelförmig, das dritte um die Hälfte und das vierte doppelt länger als das zweite, das fünfte und sechste einander gleich, je fast so lang als das zweite und dritte zusammengenommen, die folgenden wiederum einander und je etwa dem vierten gleich; das Endglied mit seinem sclımalen durch eine tiefe Ausrandung abgesetzten Fortsatze so lang wie das fünfte. Die olseren vom sechsten ab sehr schwach erweitert und zusanınengedrückı; die Farbe gelb mit einem schwärzlichen Längswische auf der Oberseite der unteren Glieder, die oberen schmuizig rauchgrau angeflogen, dünı weisslich behaart und gewimpert. Das Halsschild beinalue doppelt breiter als lang, mit flachem nur längs der Mitte leicht quer aufgewölbtem Rücken, über den rechtwinkligen und daun noch in eine pfriemliche Schwiele vorgezogenen Vorderecken etwas zusammengedrückt und dadurch verschmälert; die Seiten fein gerandet, vor der Mitte leicht ausgeschweift, hinter ihr in breitem Bogen zu den gleichfalls mit einer feinen Schwiele besetzten Ilinterecken aufsteigend; der Hinterrand wellig gebuchtet, und jederseits des kurzen, breiten Mittelzipfels ein flacher, längs den Hinterrande ein wulstiges Querfälıchen emporschiebender Quereindruck. Die Oberfläche dicht grob punktirt mit glänzendem Zwi- 
schengrunde; einzehe nicht punktirte Stellen am Vorder- und Seitenrande schwielig erhöht und zugleich gewöhnlich heller gefärbt. Die Farbe hell gelblichbraun mit drei dunkler gebräunten verwaschenen Längsbinden, deren mittlere längs ihrer grösseren Vorderhällte gabclig getheilt ist. Das Schildchen un die Hälfte breiter als lang, schräg ansteigend und hinterwärts stark verschmälcrt, mit deutlichem Hinterzipfel algerundet, glïnzend braun. Die Deckschilde etwa $2 \frac{1}{4}$ mal länger und vorn auch breiter als das Halsschild, der Rücken Jreit und llach gewölht, hinter dem Schildchen leicht quer niculergedrückt und hinten mit sehr schräger Wölbung abfallend, auch hinter der scharlen Vorderliante nur leicht quer gefurcht, zwischen Schulterbenten und Naht sanft erhöht; die Schulterheulen lïnglich-lı̈ckerig und hinter ihnen über den wenig entwickelten Seitenlappen die Deckschilde buchtig zusanmengedrücht. Die Oberflïche auf dem vorderen Drittel ınit drei schwachen Längslinien, deren zwei innere (der zweite und vierte žwischenraum) zwischen der Schulterbeule und Naht von der Vorderkante ausgehen, wällremd die dritte (der achte Zwischenraum) an der Aussenseite der Schulterbeule entspringt; dabei jener erhöhte Ranm zwischen Schulterbeule und Naht mit derlon, bei dem ơ etwas weitläufiger gestellten, dem of dichter runzlig verstrickten Punkten hesetzt, welche linter jenem Raume noch grüber werden, aher breite Zwischenschwiclen lassen, und aus denen sich dann auf dem hinteren 1)rittel einge abgerissene Enden llacher Längsrippen entwickeln, von denen alıer nur eine oder zwei jederseits der Naht deutlicher hervortreten. Die Farbe braun, die Wurzelliante mit den vorderen längslinien und den breiteren Schwiclen zwischen den Punkten grellı; die letztere Fäılrung zeigt sich loesonders intensiver in zwei unregehuässigen und vielfach zerrissenen, und daher nur schwach erkembaren Qucrbinden, deren vordere vom Ilinterrande des Seitenlappens sclıräg linterwirts gegen die Naht zieht, während dip hintere die ganze Wülbung der Flügeldechen einnimmt. Bei dem vorliegenden, ährhatupt ctwas hellerem ơ nehnien diese Schwielen soweit äberhand, dass die lleclischilde üherwiegend grłb mit lıäunlicher Schulferbenle und zerstreuten brämlichen Schatlenflecken rrscheinen. Uehrigens ist die Zeichnung der Flügeldecken weder lwi dem of nach dem $f$ stes symmetrisch gleish. Das Pygidium

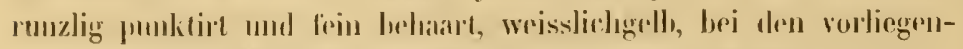

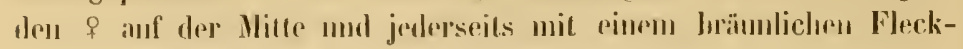


chen. Auch die Unterseite fein runzlig punktirt und dünn behaart, braun, die Schulterblätter und der letzte Bauchring gelthich, bei dem $\delta$ auch noch die Vorderzipfel des ersten Bauchringes und ein verwaschener Seitenrand des Hinterleibes schunutzig gelb. Die Vorderschenkel stark aufgetrieben, braun mit einem breiten, fast die ganze Vorderseite einnehmenden gellen Längsflecke, die Vorderschienen sammt Schenkeln und Schienen der Mittel- und Hinterbeine trüb gelb, in der Hitte bräunlich geringelt, die Hüften gelblich, die Füsse tief braum. Das letzte Segment des $\delta$ breit quer niedergedrüclit, des $\&$ mit einem grossen aber nur flachen, rundlichen Grübchen.

Aus Brasilien (Mus. Schaum. Riehl. Clark, in dem letzteren ist Petropolis als Fundort angegeben).

26. P. xanthogrammu s m. Lederbraun, zwei Hakenflecke des Kopfes, die Ränder und drei abgekürzte Längslinien des dicht punktirten Halsschililes, nebst zahlreichen Linienflecken und einer Hinterschwiele der Flügeldecken, auch den Beinen gelb mit dunkler geringelten Schenkelı; die Punktstreifen ziemlich derb, etwas wellig, mit hinten und aussen rippenförmigen Zwischenräumen. L. $11 / 6{ }^{\prime \prime \prime} ; \mathrm{Br} .1 / 2 " \prime$.

Eine sehr zierliche, auch abgesehen von Färbung und Zeichnung durch den schlank walzenförmigen, hinten etwas erweiterten Kïrper ausgezeichnete Art. Der Kopf flach, die Stirn der Länge nach seicht eingellrückt, zwischen den Augenbuchten schwach yuer aufgetrichen, mit etwas wieder eingezogenem Kopfschilde; die Punktirung auf dem dunkeln Grunde etwas dichter, auf den lichten Stellen melır vereinzelt, ubrigens deutlich, mit lackglänzendem Zwischengrunde. Die Farbe lässt sich am besten als knochengelb bezeichnen, ein schmaler Nackensaum und an diesen sich anschliessend eine unterwärts etwas verbreiterte Stirnlinie lederbraun, letztere unten gabelig getheilt, und ihre abgeschwächten Enden bis zu den Fühlerwurzelı zu verfolgen. Auch der Unterrand des Kopfschilds und das Innere der Punkte gebräunt, die breit und ziemlich tief ausgebuchteten Augen schwarz. Die Fühler bei dem einzigen vorliegenden Stücke nicht mehr vollständig, die vorhandenen Glieiler von der Spitze des sechisten ab schwach zusammengedrŭckt und erweitert. Die Farbe schmutzig gelb, die Oberseite der beiden unteren und die Spitze der erweiterten oberen überaus schwach gebräunt. Das Halsschild doppelt breiter als lang, mit XVI. 
fast grader Mittelfirste, seitlich breit zusammengedrückt und dadurch nach den scharfen, kurz pfriemlich zugespitzten Vorderecken hin sehr merklich verschmälert, die Seiten selbst fein gerandet, in der Mitte schwach gebogen, die Hinterecken scharf stumpfwinklig, der Hinterrand sehr schwach doppelt gebuchtet mit kaum bemerkbarem Mittelzipfel, und vor letzterem jederseits ein deutlicher Quereindruck. Die Punktirung derb und ziemlich dicht, bei lackglänzendem Zwischengrunde stellenweise zu Runzeln verfliessend; die Farbe lederbraun, ein breiter in den Vorderecken noch mehr erweiterter Seitenrand, der schmalere Vorder- und der noch schwächere, durch den Mittelzipfel unterbrochene Hinterrand bleichgelb. Dieselbe Färbung zeigen auch noch drei alggekürzte Längslinien, zwei seitliche hinten auf den Enden des Mittelzipfels ruhende, welche mit ilıren verwaschenen Vorderenden fast den Vorderrand erreichen, und eine mittlere vordere, welche von dem Vorderrande ausgeht und mit kielartiger Erhöhung die grössere Vorderhälfte der Mittelfirste einnimmt. Das Schildchen schräg ansteigend, nicht so lang als vorn breit, linterwärts stark verschmälert und mit deutlichem Ilinterzipfel abgestutzt, glänzend hellbraun mit etwas dunkleren Säumen. Die Deckschilde walzentörmig und hinterwärts etwas erweitert, etwa $1 / 3$ länger als breit, oben wenig abgeflacht und hinten mit sehr sanfter Wölbung abfallend, der Rücken hinter der scharf erböhten Vorderkante nur leicht quer eingedrückt, die läıglichen Schulterbeulen hinten abgeflacht, die Seitenlappen schwach mit ziemlich breit umgeschlagenem Rande, der untere Saum des letzteren mit einer regelmässigen Punktreihe besetzt; die Punktstreifen derb, der erste bis dritte und danu wieder die drei hinter der Schulterbeule liegenden etwas in einander gewirrt, der vierte, fünfte, neunte und der hintere Theil les achten fast ganz regelmässig, die beiden letzteren furchenartig eingedrückt. Die Zwischenräume vorn flach gewölbt, der achte und neunte ihrer ganzen Länge nach rippenförmig aufgetrieben, und ein Gleiches ist auch bei den Hinterenden der, der Naht zunächst liegenden Streifen der Fall. Die Farbe glänzend lederhraun, ein dreistrahliger Sclıwielenfleck im hintern Nahtwinkel jerler Flügeldecke, bei dem jedoch der an der Naht liegende Arm selır kurz ist, der Kiel des Seitenlappens und eine Anzahl mehr oder weniger unterbrochener gelber Längslinien auf den Zwischenräumen gelb, von diesen eine besonders lange auf dem aclıten, eine mehrfach zerrissene auf dem neun- 
ten Zivischenraume. Weiter nach der Naht zu werden diese Linien theilweise durch Schwielenflecke ersetzt, die von den Punktstreifen durchschnitten und unterbroclien werden. Das Pygidium fein runzlig punktirt, auf der Mitte der Länge nach seicht niedergedrückt, braun und jederseits mit einem grossen verwaschenen gelben Flecke bezeichnet. Auch die Unterseite braun, der Hinterleib breil verwaschen gelblich gerandet und der Mittelzipfel des ersten Bauchringes ebenso gefärbt. Die Beine etwas trüber gelb, die Schenkel besonders an den Hinterbeinen bräunlich geringelt, die Aussenkanten der Schienen und die Füsse heller gebräunt. Das letzte Segment des $\subsetneq$ mit einer mässigen, rundlichen Grube, das ơ unbekannt.

Von Buenos Ayres (Mus. Berol. und daselbst als $P$. intricatus Reich vorhanden, welcher übrigens ganz passende Name wegen des viel älteren nordamerikanischen $P$. intricatus Knoch nicht beibehalten werden kounte).

27. P. stomachosus m. Schwarz, der Rand des dicht punktirten Halsschilds und zahlreiche Längslinien auf den Deckschilden mit zwei Flecken des Pygidiums und jedes Bauchringes, wie auch die Beine gelb, die Schenkel bräunlich geringelt; die Deckschilde vorn grob und ziemlich regellos punktirt, hinten längsrinnig. L. $2 \frac{3}{4}{ }^{\prime \prime \prime} ;$ Br. $1 \frac{1}{3}{ }^{\prime \prime \prime}$.

Ein grosser Käfer, dem folgenden $P$. signifer nicht unähnlich, aber plumper, in den Deckschilden verhältnissmässig breiter und durch die groben Längsrippen auf dem letzten Drittel derselben melır an manche nordamerikanische Arten der Gattung erinnernd. Der Kopf flach, der Länge naclı seicht niedergedrückt, mit wenig eingezogenem, oben durch einen flachen Querwulst abgesetztem Kopfschilde, dicht runzlig punktirt, lackglänzend schwarz, die iıneren Augenränder vom Nacken bis zu den Wangen von einer ziemlich breiten gelben, wie aufgetragenen Linie umzogen; auch das Kopfschild gelb, unten und an den Seiten schwärzlich gesăumt, die Mitle mit einem bräunlichen Querwische. Oberlippe und Mundtheile gleichfalls gell, die breit und tief ausgebuchteten, (bei dem $q$ ) weit getrennten Augen greis. Die Fühler bei dem einzigen vorliegenden Stücke nur unvollständig vorhanden, anscheinend sehr schlank, das Wurzelglied keulig, etwas nach Aussen gekrümmt und $21 / 2$ mal länger als breil, das zweite elliptisch, die folgenden verkehrtkegelförmig, vom sechsten ab oberwärts schwach zusammen- 
gedrückt und erweitert, das dritte um die Hälfte länger als das zweite, das vierte und die kaum längeren folgenden je etwa $2 \frac{1}{2} \mathrm{mal}$ so lang wie jenes; die beiden oberen fehlen. Die Farbe der unteren hell durchscheinend honiggelb, das sechste und siebente dunkler mit schmutzig gebräunter Spitze, die folgenden schwarz mit dünner greiser Behaarung. Das Halsschild etwa $2 \frac{1}{2}$ mal breiter als lang, in der Mitte sanft quer aufgewölbt, und von hier aus die Mittelfirste nach vorn und hinten leicht und gleichmässig abwärts gekrümmt, die Seiten über den scharf rechtwinkligen Vorderecken breit zusammengedrückt, fein gerandet, von ihrer Mitte ab in flachem Bogen und zuletzt fast abgeschrägt zu den scharf stumpfwinkligen Hinterecken aufwärts ziehend; der Hinterrand kaum gebuchtet, mit ebenso schwachem Mittelzipfel, und vor letzterem ein über das ganze flalsschild hinziehender breiter und seichter Quereindruck. Die Oberfläche dicht und ziemlich grob runzlig punktirt, seidig schimmernd, schwarz; ein seitlich nach vorn verbreiterter und die Vorderecken ganz ausfüllender, hinten vor dem Mittelzipfel sehr abgeschwächter, den alggesetzten Rand begleiteuder Saum lackgelb; eine hinten abgekürzte Mittellinie, und zwischen dieser und dem Seitenrandel einige unregelmässige theilweise zerrissene grössere Flecke, die sich jederseits einigermassen zu einer unvollkonmenen Längsreihe zusammenordneı, ausserdem nahe an Seitenrande linter der Mitte noch ein grösserer schwielenartiger Punkt gleichfalls gelb. Das Schildchen mässig ansteigend, etwas breiter als lang und hinterwärts verschmälert, daselbst mit deutlichem Hinterzipfel abgestutzt, fein punktirt und glänzend schwarz. Die Deckschilde ziemlich breit und flach 'walzenförmig, etwa 1/4 länger als breit, mit hiuten ziemlich leicht abfallender Wölbung, vorn hinter der schwach erhöhten Wurzelkante auch nur leicht und schmal quer eingerlrückt und dahinter wieder etwas aufgewulstet; die breiten Schulterbeulen ziemlich stark hervorgehoben, die Seitenlappen breit, und über ihnen die Deckschilde kräftig zusammengedrückt. Die Punktirung derb, die Streifenbildung oben zwischen Naht und Schulterbeulen durch überzählige Punkte mehr oder weniger gestört oder in die Bildung von Doppelstreifen hinübergedrängt, hinter den Schulterbeulen etwas klarer, unter ihmen der breite Raum über den Seitenlappen mit etwas feineren aber dicht gedrängten Punkten und Streifenansätzen ausgefüllt. Gegen die Mitte bin schwinden allmälılich die überzähligen Punkte und 
Punktreiheı, und es entwickeln sich, anfangs unter allerlei Windıngen und mit manchen durch die gelben Schwielenflecke veranlassten Unterbrechungen, bald aber mit grösserer Regelmässigkeit die gewöhnlichen Punktstreifen, die durch ihre dicht an einander geschobenen Punkte als Kerbstreifen so tief einschneiden, dass die Zwischenräume als kräftige Längsrippen emporgelıoben werden, wie der neunte schon vom Hinterrande des Seitenlappens ab eine solche bildet. Auch vorn treten schon einzelne Zwischenräume, namentlich der zweite und vierte, als schmale, erhöhte Längslinien, weın yleich minder stark als jene Rippen, hervor. Die Farbe ein seidig schimmerndes Schwarz, Wurzel und Aussenrand bis zum Nahtwinkel weisslichgelb und danı noch der erste Zwischenraum von der Nitte, und der neunte vom Seitenlappen ab gelb, mit dem Hinterende gleichfalls in den Nahtwinkel auslaufend. Auf dem Mittelfelde eine grosse Zahl abgerissener gelber Längslinien, welche auf und unter der Wölbung in mehr oder weniger ausgedehutem Maasse die Längsrippen einnehmen, theilweise sich auch bis zur Mitte auslehnen und auch weiter vorn überwiegend den Zwischenräumen zu folgen scheinen, deren jeder mehr oder veniger, aber nicht einmal immer auł beiden Flügeldecken gleichmässig, mit einer solchen Linie besetzt ist. Das Pygidium schwarz mit zwei gelben Längsflecken, von denen jeder mit dem oberen Ende sich nach Aussen umbiegt, beide wie aufgetragen und dadurch merklich gegen den schwarzen Grund erhöht. Auch die Unterseite schwarz mit einem gelben Fleck am Aussenrande jedes Ringes, welcher besonders bei dem ersten, vierten und fünften Ringe hervortritt. Die Beine schmutzig röthlichgelb, die Aussenkante der Schenkel geschwärzt, und diese Färbung in der Mitte verschmälert als ein verwaschener Ring die Schenkelfläche umziehend; die Vorderschenkel ziemlich stark aufgetrieben mit entsprechend gekrümmten Schienen; der Hinterzipfel des Prosternums gelblich. Das letzte Segment des $q$ mit einer flach vertieften, rundlichen Grube; das $\delta$ unbekannt.

\section{Aus Brasilien (Mus. Deyrolle).}

29. P. signifer Stål. Schwarz mit rothgelben Fühlern und Beinen, Kopf und Pygidium gelbbunt, die Ränder und fünf Flecke des derb punktirten Halsschilds, sowie die Ränder und viele Längsflecke der Deckschilde gelb; letztere vorn grob zerstreut punktirt, 
hinten undeutlich wellig-längsstreifig mit flach gewölbten Zwischenräumen. L. $1 \frac{3 / 4}{4}-2^{3} / 4 "$; Br. $1-1 \frac{1}{3}{ }^{\prime \prime \prime}$.

Pachybrachys signifer Stål Till Kännedomen etc. in der öfversigt etc. S. 62. n. 2 !

Dem vorhergehenden, wenn man $q$ mit $q$ vergleicht, an Grösse gleich, in der analogen Anlage der Zeichnung noch näher dem folgenden $P$. guttipennis $m$. verwandt, aber doch aucls von ihm wieder in der Färbung und Farbenvertheilung so abweichend, dass ich ungeachtet der Uebereinstimmung beider im Habitus doch bei den Fehlen aller, die Sculpturverschiedenheiten vermittelnden Zwischenformen sie nicht mit einander vereinigen kann. Ich werde mich jedoch in Bezugnahme auf die unten folgende Beschreibung des P. guttipennis hier auf die Angabe jener Abweichungen beschränken können. Dieselben zeigen sich zunächst in der Sculptur, welche auf dem Halsschilde gröber aber weniger gedrängt ist, und daher auch einen grösseren ob auch immer nur mässigen Glanz des Zwischengrundes hervortreten lässt. Die Punktirung des vorderen Theils der Deckschilde ist durchaus der des Halsschilds an Stärke und Dichtigkeit gleich, nur in den seitlichen Eindrücken zu eigentlichen Runzeln verfliessend, bei gleichfalls etwas glänzendem Zwischengrunde; sie ordnet sich schon vor der Mitte zu Längsstreifen, die aber mit welligen Verlaufe die dazwischen liegenden gelben Längsflecke wie Inseln umziehen und dadurch ihre Zwischenräume sehr unregelmässig gestalten, ja sie zuweilen gänzlich verschwinden lassen. Die Färbung fällt entschicden stärker ins Gelbliche, an Hüften und Beinen ins Rothgelbe; an den ersteren sind nur die oberen Enden rauchgrau überflogen, und an den Beinen fallen nur die Schenkelspitzen ins Weissliche. Ausserdem sind die gelben Zeichnungen viel weiter ausgedelınt. Am Kopfe nehmen sie ausser den Augenbuchten und Wangen auch die Oberlippe, und bei dem $\delta$ das ganze Kopfschild (bis auf dessen Untersaum und zwei Pünktchen am oberen Rande) ein, und diese Färbung dehnt sich oberwärts auch über den unteren Theil der Stirn aus, und der den oberen Augenrand einschliessende gelbe Hakenfleck ist jederseits vollständig ausgebildet. Bei den $q$ zeigt das Kopfschild wenigstens zwei deutliche gelbe Flecke und zwischen den Augenbuchten eine abgekürzte gelbe Querlinie. Auf dem Halsschilde ist der ganze Rand, auch vor dem Mittelzipfel des Hinterrandes, gelb und zugleich in den Vorderwinkeln fleckenartig er- 
weitert; auf dem Mittelfelde sind die drei Längsflecke des P. guttipennis zu deutlichen Längsbinden, die seitlichen hinten fleckenartig erweitert und nach voru, die mittlere hinterwärts abgekürzt, und zwischen den ersteren und der Mitte des Seitenrandes ist noch ein deutlich ausgebildeter Fleck vorhanden. Auf dem Schildchen des $\delta$ vor dessen Hinterrande ein gelbliches Fleckchen. Auf den Flügeldecken ist der ganze Saum längs der Wurzel, der Kiel des Seitenlappens und der den Aussenrand begleitende neunte Zwischenraum, auch mit diesem zusammenhängend die Spitze nebst dem ersten Zwischenraume von der Mitte ab wieder bis zur Spitze hin ununterbrochen gelb, nur über dem Seitenlappen mit einigen schwarzen Pünktchen bezeichnet: auf dem Mittelfelde finden sicb die Einzelflecke des P. guttipennis mehr oder weniger zu Längsflecken gestreckt oder zu solchen zusammenfliessend, daher auch die beiden grösseren Flecke neben der vorderen Naht länger ausgezogen, aber schmaler als bei der genannten Art. Auf der Unterseite sind bei dem $q$ alle Bauchringe seitlich gelb gefleckt, besonders stark der erste, vierte und fünfte, letzterer hinten nur durch die Hinterleibsgrube unterbrochen gelb gesäumt. Das letzte Segment des $\delta$ mit einem leichten Eindrucke, des $q$ mit einer kleinen, aber deutlichen Grube.

Aus Brasilien (Mus. Hal. Dohrn. Deyrolle. Clark. vom Bruck. Holm.; in den drei letztgenannten Sammlungen ist Minas Geraes als specielle Heimath angegeben).

29. P. fervidus m. Schwarz, die Fühlerwurzeln und die weissfleckigen Beine rothgelb, Kopf und Pygidium gelbbunt, die Ränder und fünf Flecke des dicht punktirten Halsschilds, sowie die von schwarzen Punktreihen durchzogenen Deckschilde lochgelb; letztere ziemlich dicht wellig punktstreifig mit flach gewölbten Zwischenräumen. L. $1 \frac{1}{3}{ }^{\prime \prime \prime} ; \mathrm{Br}$. $2 / 3{ }^{\prime \prime \prime}$.'

Dem Habitus nach dem vorhergehenden $P$. signifer überaus nahe verwandt, und von demselben eigentlich nur durch die geringere Grösse, die hochgelbe Farbe der Zeichnung, welche die Deckschilde gelb mit schwarzen Punktlinien erscheinen lässt, und die grössere Regelmässigkeit dieser Linien verschieden, durch welche die Art einen Uebergang zu den Arten mit ganz regelıässigen Punktstreifen vermittelt. Es bedari deshalb hier auch nur einer Angabe der Abweichungen von der genannten, in den Sammlungen weniger seltenen Art. Kopf und Halsschild sind nach 
Sculptur, Färbung und Zeichnung ganz wie bei jenem, nur ist die Punktirung etwas dichter zusammengedrängt bei matterem Zwischengrunde; die obere Hälfte der Fühler ist schwarz, die helle Zeichnung hochgelb, etwas breiter und kräftiger, was besonders bei den beiden Hinterflecken des IIalsschilds ins Auge fällt. Die Farbe der Deckschilde lässt sich am besten als hochgelb bezcichnen, da nur das Innere der Punkte schwarz erscheint, und deshalb bei ihnen Färbung und Sculptur auf das Genaueste zusammenhängt. Auf einem gemeinsamen, lıerzförmigen Flecke hinter dem Schildclien, dessen Aussenrand durch den hinten nach der Naht zu gekrünmmten und unregelmässig verdoppelten zweiten Punktstreifen gebildet wird, ist doch sowohl von dem hinten mit jenem zusammenfallenden ersten, als von dem abgekürzten Streifen eine Andeutung zu erkennen, aber so zerrissen und sich so durchkreuzend, dass dadurch der Zwischengrund in unregelmăssige, nicht einmal auf beiden Flügeldecken gleiche gelbe Flecke zerrissen wirl; dann folgen nach aussen der dritte und vierte Streifen mit zienılich regelmässigem Verlaufe, beide vorn durch ülserzählige, den Zwischenraum niederdrückende Punkte verbunden, letzterer auch noch weiter hinterwärts mit solchen besetzt. Der fünfte, stärker wellig gekrümmte und vorn bogig nach der Scluulterbeule zugewandte Streifen trifft hinten mit dem vierten zusammen, die drei hinter der Schulterbeule liegenden aber sind mehrfach unterbrochen, ihre Theile gehogen und einander durchkreuzend, der neunte bis auf das etwas gestörte Vorderende regelmässig ausgelsildet. Von der Mitte ab sind der zweite und dritte, der achte und lieunte Streifen ganz regelmässig, und zwar so, dass linten der zweite und neunte, und innerhalb dieser der dritte und achte Streifen zusammenlaufen; in dem Raume zwischen den letzteren vereinigen sich der vierte und fünfte, wälırend der sechste und der eine Strecke weit mit dem achten verbuudene, dann wieder von ihm getrennte siebente einzeln und für sich auslaufen. Durch diese Streifenbildung wird die Oberfläche vor'n in melıfach unregelmässige, zum Theil linealische Felder, auf der hinteren Hälfte in flach gewölhte, ziemlich breite Längsrippen getheilt. Die Farbe aller dieser Felder hochgelh, das Innere der ziemlich derben, dicht an einander gerückten Punkte schwarz, sodass die Oberflăche gelb und mit melı oder weniger regelmässigen schwarzen Punktliniens durclızogen erscheint. An der Krünmung des zweiten Punktstreifens hildet sich 
durch diese zwischen ihm und dem grade laufenden dritten Streifen ein grösseres, nach der Nalıt zu dreieckig erweitertes Längsfeld. Pygidium und Unterseite dünn silberhaarig, ersteres gelb, der breitere obere Rand, die Vlitte des unteren Saumes und eine fein eingedrückte, unten alggekürzte Längslinie geschwärzt; neben letzterer jederseits noch ein eingedrückter, leicht gebräunter Punkt. Die Unterseite schwarz, der letzte Ring, die Seiten der drei vorhergehenden und die breiten Ilinterecken des ersten hochgelb. Die Beine röthlichgelb, die Schenkelspitzen breit weisslich, und diese Färbung bei den Mittel- und noch stärker bei den Hinterschenkeln von der Grundfarbe durch einen verwaschenen Bing geschieden. Das letzte Segment des $q$ mit einer schwachen, im Innern geschwärzten Grube, das $\delta$ uubekannt.

Aus Brasilien (von S. Joañel Rey: Sello in Mus. Berol.)

30. P. curvatulus m. Oben gelb, der Nacken und ein Stirnfleck, vier Längshinden und zwei Hackenflecke des dicht punktirten Halsschilds, das Schildchen und ein paar zerrissene Längsbinden der Deckschilde schwarz, unten schwarz mit gelb gerandetem Hinterleibe und gelben Beinen; die Deckschilde unordentlich punktstreifig mit flachen, hinten rippenförmigen Zwischenräumen, L. $13 / 4 " \prime$; Br. $5 / 6 "$.

Abermals dem P. signifer sehr ähnlich, an Habitus und Grösse ihm gleich, aber an der gröberen Sculptur und der eigenthümlichen Zeichnung des Halsschilds leicht von ihm zu unterscheiden. Der Kopf flach mit kurzer, scharfer Stirnlinie und wenig eingezogenem Kopfschilde, fein aber dicht punktirt, matt hochgelb, der Nacken, ein damit zusammenhängender Stirnfleck, die inneren Augensäume, ein Fleck jederseits zwischen den Fühlerwurzeln, dazwischen noch ein Querschatten, und der untere Rand des Kopfschildes nebst den Kinnbackenspitzen schwarz, die Oberlippe heller knochengelb. Die Fühler kurz, auch ihı'e obere Hälfte wenig zusammengedrückt und erweitert, gelb mit ranchgrauen Enden, das Wurzelglied auf der Oberseite mit einem schmalen, schmutzig gebräunten Schatten. Das Halsschild etwa $2 \frac{1}{4}$ mal länger. als breit, flach walzenförmig mit kaum gebräunter Mittelfirste, üher den scharf rechtwinkligen Vordereckien etwas zusammengedrückt und dadnrch verschmälert; die Seiten fein gerandet, in der Mitte bogig erweitert, vor und hinter ihr kaum merklich ausgeschweift; die Hinterecken scharf stumıpfwinklig, der Hinterrand jederseits nur schwach ausgebuchtet, 
mit wenig vortretendem, durch einen bogenförmigen Quereindruck etwas aufwärts gedrücktem Mittelzipfel. Die Oberfläche gleichmässig und auf den schwarzen Zeichnungen dichter- auf dem gelben Grunde etwas weniger dicht punktirt, hochgelb, ein zarter Hintersaum und vier kräftige, scharf begränzte, an beiden Enden ahgekürzte Längsbinden schwarz, die beiden mittleren hinten in Gestalt eines plumpen $\mathrm{V}$ zusammenlaufend, jede auf ihrer Aussenseite wie angenagt und daselbst auf dem hinteren Drittel stark verschmälert, die äusseren hinten verbreitert und von der Mitte einer jeden nach Aussen ein Seitenarm in Gestalt eines wach hinten gekrümmten Hackenflecks ausgehend, dessen wieder einwärts gebogenes Hinterende der äusseren Hinterecke der Binde sehr nahe kommt, und auch wohl bei einzelnen Stücken mit ihr zusammenstossen und dadurch einen gelben Augenfleck bilden könnte. Der Zwischengrund von mässigem Glanze. Das Schildchen schräg ansteigend, nicht so lang als vorn breit, mit deutlichem Hinterzipfel kurz abgestutzt, schwarz, hinter der Mitte mit einem gelblichen Querflecke. Die flachwalzenförmigen Deckschilde etwa 1/4 längel als breit, hinter der aufgeworfenen Vorderkante quer eingedrückt, Schulterbeulen und Seitenlappen von mässiger Ausbildung, über letzteren die Deckschilde breit zusammengedrüclit. Die Punktstreifen melırfacb gestört und sich in ihrer Ausbildung den gelben Zeichnungen anschliessend, die oberen bis zum vierten an den Vorderenden theilweise verdoppelt und von ihnen der vierte und fünfte, seitlich der neunte am meisten regelrecht ausgebildet, dieser letztere in eine schwache Längsfurche eingedrückt. Dagegen der sechste bis achte, sowie überhaupt Alles, was auf dem gelben Grunde liegt, am meisten gestört, und die Bildung von breiten, flachen Zwischenräumen überhaupt erst auf dem letzten Drittel merklich. Das Innere der Punkte überall schwarz, die gelbe Färbung schwielenartig aufgetragen und daher das Schwarz als die ejgentliche Grundfarbe zu betrachten. Hiernach zeigt jede Flügeldecke einen breiten, längs der Naht schwärzlich-, um die Spitze und den hinteren Theil der Seiten bräunlich gesäumten gelben Rand und eine Anzahł längerer oder kürzerer gelber Schwielenflecke, vorn vorzugsweise auf dem zweiten und vierten Zwischenraume, auf dem an den letzteren gränzenden breiten Raume hinter der Schulterbeule zwischen dem fünften und neunten Punktstreifen und auf den breiten flachen, schräg gegen den hinteren Nahtwinkel 
gerichteten Zwischenrăumen des letzten Drittels, deren gelbe Schwielenflecke theilweise von Punkten durchstochen sind, auch nicht auf beiden Flügeldecken sich entsprechend gestalten. Das Pygidium in der Mitte seicht eingedrückt, fein runzlig punktirt und greishaarig, gelb mit einem schwärzlichen Schatten in der Mitte, auch der untere Theil des Randes fein schwärzlich gesäumt. Die Unterseite schwarz, der letzte Ring und je ein Querfleck an den Seiten der vorhergehenden Ringe hochgelb; die Beine dunkler lehmgelb, mit einem helleren Flecke auf der Aussenseite der Vorderschenkel. Das letzte Segment des $q$ mit dem gewöhnlichen Grübchen, das $\delta$ unbekannt.

\section{Aus Brasilien (Mus. Clark.)}

31. P. guttipennis m. Schwarz, Kopf, Beine und Pygidium gelbbunt, die Ränoler und drei Längsflecke des dicht punktirten Halsschilds nebst vielen Einzelflecken der Deckschilde gelb; letztere vorn grob runzlig punktirt, hinten undeutlich punktstreifig mit flach gewölbten Zivisclıenräumen. L. $17 / 1{ }^{\prime \prime \prime}$; Br. ${ }^{5} / 6{ }^{\prime \prime \prime}$.

Eine an den zahlreichen scharf begränzten weissgelben Flecken auf dem schwarzen Grunde der Deckschilde leicht kenntliche, übrigens, wie die vorhergehende, in Habitus und Zeichnung an die Europäischen Arten aus der Gruppe des P. histrio Oliv. erinnernde Art. Der Kopf gross, flach, das Kopfschild leicht eingezogen, unten schwach ausgebuchtet; die Stirnfläche dicht und deutlich punktirt, mit mattem und glanzlosem Zwischengrunde; Oberlippe, Wangen, die damit zusammenhängenden Augenbuchten und eine Anzahl unregelmässig gestalteter und vertheilter Fleckclien gelb, deren je einer über den unteren Ecken des Kopfschildes, ein Paar zwischen den Augenbuchten, je ein Schrägfleck neben dem oberen inneren Angenrande, und ein von diesem getrennter, etwas geschweifter Querfleck über dem oberen Augenrande, mit jenem den Rest des - bei anderen Arten vorhandenen Hakenflecks vorstellend. Die Fühler nach den bei dem einzigen vorliegenden Stücke vorhandenen Unterresten gelb, dünn und schlank, von dem Bau der verwandten Arten, die beiden unteren Glieder auf ihrer Oberseite mit einem schwärzlichen Längsfleck. Das grosse Halsschild breit quer walzenförmig, fast doppelt breiter als lang, vor dem Hinterrande quer niedergedrückt, hinter der Mitte leicht erhöht, und von da ab die Mittelfirste nach vorn in einem schwachen Bogen abwärts geneigt: die Seiten fein gerandet, in der Mitte in leichtem Bogen erweitert, 
vor ihr hinter den pfriemlich zugespitzten tief eingezogenen Vorderecken sanft ausgeschweift, hinter ihr zu den stumpfwinklig abgerundeten Hintereckeı schräg aufwärts gerichtet; der Hinterrand jederseits ausgebuchtet, mit schmal aufgebogenem Mittelzipfel. Die Oberfläche jederseits über der Mitte des Seitenrandes schräg zulsammengedrückt, welcher Eindruck leicht mit der Quervertiefung vor dem Mittelzipfel zusammenhängt, dabei dicht und deutlich punktirt, mit matt schwarzem Zwischengrunde; ein breiter dell abgesetzten Rand innerseits der eingegrabenen Randlinie begleitender, nur vor dem Mittelzipfel unterbrochencr Saum, dann im Anschluss an die Enden des Mittelzipfels je eine vorn abgekürzte, etwas einwärts gekrümmte Längsbinde und zwischen beiden eine abgekürzte Mitlellinie gelb. Ausserdem noch cinige unregelmässige gelbe Atomenflecke je zwischen den Längsbinden und dem Seitenrande. Alle diese gelhen Zeichnungen schwach glänzend, wie aufgetragen und in der Regel punktlos, nur die breiteren Stellen der Längsbinden mit einzelnen kleinen Punkten besetzt. Das Schildchen stark ansteigend, breiter als lang, quer viereckig und hinterwärts merklich versclımälert, mit deutlichem Hinterzipfel; matt schwarz mit feiner Punktirung. Die Deckschilde kurz und gedrungen walzenförmig, um die Hälfte länger aber wenig breiter als das Halsschild, etwa $1 / 4$ länger als breit, mit flachem, hinterwärts schr sanft abfallendem Rücken und kurz zugerundeter Spitze, hinter der scharfen aber kaum aufgeworfenen Vorderkante nur seicht quer eingedrüclit; auch die schmalen Schulterbenlen wenig hervortretend, und die Seitenlappen schwach abwärts gezogen. Die Punktirung auf der vorderen Hälfte noch gröber als die des Halsschilds, elen so dicht gedrängt, und stellenweise, besonders in der Mitte zwischen Schulterbeule und Naht, zu Runzeln verfliessend. Auf der hinteren Hälfte werden die Punkte allmählich feiner, sparsamer, und ordnen sich $\mathrm{zu}$ den gewöhnlichen etwas welligen Längsstreifen, . zwischen denen deutliche und auf der Wölbung ein wenig aufgetriebene Zwischenräume hervortreten. Der Zwischengrund matt seidig schimmernd, die Farbe schwarz, als Zeichnung darauf eine grosse Anzahl anscheinend regellos vertheilter und wie aufgetragener, daher auch nicht punktirter gelber Fleckchen und Linien die wahrscheinlich nicht bei allen Stücken in gleicher Zahl und Gestalt vorhanden sind. Als charakteristisch erscheinen davon auf jeder Flügeldecke ein gelber Vordersaum von der Spitze des Schild- 
chens bis zum dritten Theile des Raumes zwischen Schildchen und Schulterheule, dessen Aussenende sich hakig naclı hinten wendet, ein zwischen diesem und der Schulterbeule liegender, die Wurzel berührender Längsfleck, der Kiel des Seitenlappens, und ein den hinteren Nahtwinkel eimnehmender Hakenfleck. Von den übrigen Flecken liegen zunächst drei neben der Naht, und zwar vorn ein elliptischer, hinterwärts zugespitzter Schrägfleck, dann ein rundlicher Querfleck (der grösste vou allen) auf der Mitte, und dahinter noch hart an der Naht ein kleiner Längsfleck, anscheinend das algerissene Ende von dem vorderen Arme des Lakigen Spitzenflecks. Mit diesem kleinen Fleck begiunt eine nach Aussen und hinten über die Wölbung ziehende Schräglinie von Flecken, in welcher zunächst ein etwas grösserer Längsfleck auf der Wölbung selbst, dann ein winkliger Hoppelfleck auf derselben, und dann noch ein kleiner Randfleck auf dem neunten Zwischenraume folgt. Vor diesen nach Aussen hin ein aus drei Fleckchen (auf dem achten, siebenten und sechsten Zwischenraume) und einigen Atomen bestehender Querfleck, und noch weiter nach vorn über dem Seitenlappen ein aus 4-5 Einzelfleckchen gebildeter unregelmässiger Winkelfleck, unter dessen Bestandtheilen besonders eine Längslinie auf dem neunten Zwischenraume, ein Schrägfleck hinter der Scluulterbeule, und auf dessen Innenseite noch ein grösserer rundlicher Fleck zu bemerken sind. Das Pygidium fein punktirt, schwarz, mit einer welligen, sowohl mit den Enden als der nach unten gerichteten Mittelkrümmung den Rand berührenden gelben Querbinde. Auch die Unterseite schwarz, die Ränder der drei letzten Ringe seitlich mit einem, je weiter nach linten desto grösseren gelben Flecke bezeichnet. Die Hüften schıvarz niit einem gelben Flecke auf den vorderen, die Sclienkel gelb, in der Mitte breit schwarzbraun geringelt, der ohere Theil etwas ins Röthliche fallend, die Schienen und Füsse röthlichgelb, die ersteren in der Mitte etwas dunkler angelaufen. Das letzte Segment des $\delta$ mit einem leichten länglichen Eindrucke, das $q$ unbekannt.

\section{Aus Brasilien (Mus. Halens.)}

32. P. nigricollis m. Sclıwarz, die Seiten des diclıt punkttirten Halsschildes, die Schenkel- und Schienenspitzen und eine Anzahl Flecke der Deckschilde weisslich gelb; die Deckschilde vorn grob runzlig punktirt, hinten unordentlich längsrippig. L. $13 / 4^{\prime \prime \prime} ; \mathrm{Br}$. 1"'.

Ahermals den vorhergehenden ähnlich, von überwiegend Euro- 
päischem Aeussern und besonders an den P. maculatus Parr. erinnernd, durch Habitus und Farbenvertheilung auch den Nordamerikanischen .Arten aus der Gruppe des $P$. luridus $F$. verwandt. Der Kopf flach, dicht und feiı punktirt, matt schwarz, ein Fleckchen zwischen den Augenbuchten und die verwaschenen Ränder der Oberlippe gelblich, die breit ausgebuchteten Augen greis. Das Wurzelglied der Fühler breit eiförmig aufgequollen, um die Hälfte länger als breit, das zweite birnförmig und nur wenig länger als breit, das dritte um die Hälfte länger als das zweite, das vierte so lang wie das zweite und dritte zusammen, und dem vierten je die folgenden gleich, letztere vom sechsten ab deutlich zusammengedrückt und verbreitert. Die beiden ersten pechschwarz, glänzend mit bräunlich durchscheinenden Rändern, die drei folgenden pechbraun mit helleren Spitzen, die oberen schwarz mit feiner angedrückter Behaarung. Das Halsschild in der durch bogiges Vortreten des mittleren Vorderrandes merklich verlängerten, in der Nitte aufwärts gekrümmten Nittelfirste kaum $2 / 3$ so lang als breit. über den scharf spitzwinkligen Vorderecken breit zusammengedrückt und dadurch verschmälert; die Seiten fein gerandet, gerade, durch die stumpf zugerundeten Ifinterecken in den jederseits kaum ausgebuchteten Hinterrand übergehend; der Mittelzipfel kurz aufgebogen, und vor lemselben die Oberfläche in einem tiefen Bogen eingedriickt, welcher Eindruck sich verbreiternd und gleichzeitig verflachend bis über die hintere IIälfte des Seitenrandes verfolgt werden kann. Vor ihm die Mitte des Halsschilds breit quer aufgewulstet. Dic Punlitirung ziemlich dicht, von mässiger Stärke, mit schwarzem seidig glänzendem Zwischengrunde; der abgesetzte Seitenrand von einem ziemlich breiten, die Hinterecken nicht erreichenden, auf eine kurze Strecke noch am Vorderrande sich hinziehenden gelben Saume begleitet, auch auf der vorderen IIälfte der Mittelfirste eine ähnliche, aber schwächere abgerisscne Lăngslinie. Das Schildchen schräg ansteigend, hinterwärts stark verschmälert, mit scharfen Ecken und grossem, flach niederliegenden Hinterzipfel grade abgestutzt, dicht und sehr fein punktirt, matt schwarz. Die Deckschilde vorn etwas breiter als das ILalsschild, etwa $1 / 4$ linger als breit, der abgeflachte Rücken vor der Nitte seicht aber breit quer eingedrückt, und dadurch vorn zwischen Schildchen und Schulterbeulen ein flach erhöhtes Feld abgegränzt, die Vorderkante kaum erhöht; die Schulterbeulen sellsst eckig heraustretend, die 
Seitenlappen lang herabgezogen, und über ihnen ein deutlicher Schrägeindruck, welcher gegen den Rücken hin mit dem das Vorderfeld abgränzenden Quereindrucke zusammenfliesst. Die Punktirung deutlich und kräftig, auf jenem Vorderfelde dicht gedrängt, sodass nur stellenweise Ansätze von Punktstreifen und Spuren erhöhter Längslinien hervortreten; seitlich werden die Punkte noch gröber, aber mehr vereinzelt, sich in deutliche Längsreihen ordnend, die beiden äussersten Streifen ziemlich regelmässig ausgebildet, und zwischen ihnen der neunte Zwischenraum als flache Rippe emporgehoben. Auf der hinteren Hälfte sind die Punkte feiner und sparsamer, aber regelmässiger zu Streifen an einander gerichtet, sodass zuletzt die gewölnlichen Streifen sich herausbilden, und deren Zwischenräume als breite, flache Längsrippen bemerklich werden. Der Ziwischengrund fast matt, nur auf der Wölbung wie leicht abgeschliffen, mit schwachem Seidenschimmer. Die Farbe rein Schwarz, mit sparsamen lackartig aufgetragenen gelben Zeichnungen. Von solchen liegt eine unregelmässige, stellenweise unterbrochene und hinterwärts lappig erweiterte Querbinde hinter der Vorderkante zwischen der Schulterbeule und Schildchenspitze, gewissermassen die bei anderen Arten hier befindliche Querfurche bedeckend, und setzt sich dann ausserhalb der Schulterbeule auf dem Kiele des Seitenlappens fort, über welchem man noch einen Längsfleck auf dem neunten Zwischenraume und einige Atomenflecke hinter der Schulterbeule wahrnimmt. Hinter der Mitte liegt dann eine gemeinsame, jederseits aus zwei den Feldern anderer Arten entsprechenden Flecken bestehende Querbinde, der innere schräg dreieckige zwischen der Naht und dem dritten Streifen, der äussere schräg rautenförmige vom fünften bis zum neunten Streifen reichend und durch den achten in zwei Theile zerrissen; endlich ist die breite Spitze gleichfalls gelb. Pygidium und Unterseite dicht und fein runzlig, schwarz, die Bauchringe an äusseren Ende fein gelb gefleckt, und diese Flecke am deutlichsten auf den beiden letzten Ringen. Auch die Beine schwarz; ein Fleck auf den Vorderhüften, ein gleicher vor den Schenkelspitzen, welcher bei den Vorderschenkeln in zwei ungleiche Theile zerrissen ist, und die Schienenenden gelb; die Wurzeln der Schienen melır oder weniger dentlich verwaschen gebräunt, auch die Füsse brüunlich. Das letzte Segment des ơ mit einer flach quer niedergedrückten, etwas glänzenden Stelle, das $q$ unhekannt. 


\section{Aus Brasilien (Mus. Halens.)}

33. P. annexus m. Schwarz, zwei Längsflecke des Kiopfes, der Rand und drei Längsflecke des derb punktirten Halsschilds, die Seiten und eine damit theilweise zusammenhängende Hittelbinde der Flügelılecken nebst einem Schenkelflecke weisslich gelb; die Deckschilde derb punktirt mit nur hinten deutlichen Punktstreifen und daselbst flach gewölbten, glänzenden Zwischenrïumen. L. $1 \frac{1}{2}-1 \frac{2 / 3}{\prime \prime \prime}$; Br. $11 / 12-1^{\prime \prime \prime}$.

Der Kopf flach, unteı kaum eingezogen, dicht punktirt, glänzend schwarz, die inneren Augenrander bis in die Augenluchlen, und das Kopfschild unten hellgelb gesäumı; auch die Oberlippe gelblich mit gebräunter Mitte. Die Fühler von $2 / 3$ der Körperlänge, oben mässig, erweitert und zusammengedrückı; die fünf unteren Glieder durchscheinend bräunlich gelb, die oberen schwarz unit dünner greiser Behaarung. Das Halsschild 21/2mal so lıreit wie lang, hinter der Mitle stark quer aufyewölbt und linterwärts stark schräg abfatlend, über den spitzen Vordereclien etwas zusammengedrückt und dadurch versclımälert; die Seiten fein gerandet, nach vorn in geraden Linien convergirend, die scharfen Hinterecken fast rechtwinklig und etwas aufgebogen, der Hinterrand doppelt ansgebuchtet mit weuig vortretendem Mittelzipfel, und vor letzterem jederseits ein ziemlich breiter Schrägeindruck, durch den sich an Hinterrande nach den IInterecken zn ein wulstiges Querfältchen in die Hölıe schiebt. Die Oberfläche derl und ziemlich dicht punktirt mit gläızendem Zwischengrunde, schwasz; ein breiter Vorder- und Seitenrand, welcher sich hinten unscheinbar bis zum Mittelzipfel hinzieht, aber nur auf letzterem ganz unterbrochen ist, gelblich weiss, und ploen so drei Längsfleclie, ein vorderer von der Hitte des Vorderrandes ausgehend, und zwei bintere, letztere auf dem Hinterrande scitlich vom Schildchen aufgesetzt, und ehen so nach vorn, wie der vordere nach hinten zugespitzl, beide beim Auseinanderfahren das Hinterende des Vorderflecks zwischen sich aufnehmend. Das Schildchen schräg ansteigend, ıicht ganz so lang als vorn breit, hinterwärts verschmälert, mit algerundeten Ecken und deutlichem Hinterzipfel abgestutzt, äusserst fein punktirt und behaart, glänzend schwarz. Die Deckschilde fast um $1 / 3$ länger als breit, ziemlich gleichbreit und llach walzenförmig, vorı leicht quer eingedrüclit und dahinter eben so leicht aufgewulstet, die halb eiförmigen Schulterbeulen alggeflacht und die Seitenlappen kaum be- 
merkbar. Die Punktirung kräftig, auf der Vorderhälfte die Streifenbildung durch üherzählig eingemengte P'unkte vielfach gestört, sodass ıur der vierte, fünfte und neunte Streifeu ihrer ganzen Länge nach vollständig ausgrebildet sind, und zwischen den beiden ersteren vorn ein dentlich längsschwielig erlıöhter Zwischenraum hervortritt. Von der Mitte ab werden die Streifen durch das Zurückbleiben der üherzähligen Punkte deutlicher, aher auch feiner, die Zıvischenräıme breiter und mehr glänzeud, hleihen aber im Ganzen flach, sodass nur der neunte in seiner ganzen Länge aufgewölbt erscheint. Die Oberfläche ziemlich glänzend, die lichteren Stellen wie aufgetragen, mit stärlierem Lackglanze. Die Farbe schwarz, ein ziemlich breiter, den aufgeworfenen Saum der Flügeldecken begleitender, auch die Seitenlajpen mit einschliessender, nur längs der IVurzel und auf der Wülbung an der Naht abgeschwächter, vor der Mitte fleckig erweiterter Saum weisslichgetb, Ind eine gleiche Färbung zeigt eine aus drei grossen Längsflecken zusanmengesetzte, daher ziveimal gebrochene Längsbinde, deren mittlerer Thei] etwas nach Aussen gerückt ist und an beiden Enden (vorn hinter der Schulterbeule und hinten vor der Wölbung) quer mit dem Aussenrande zusammenhängt, während der dritte, wieder etwas mehr einwärts gerückte Fleck von dem zweiten durch einen kurzen Zwischenraum getrennt ist und linten in die lichte Spitze der Flügeldecke ausläuft. Pygidium und Unterseite fein runzlig punktirt, mit den Beinen schwarz, die Schenkelwurzeln gebräunt, die Vorderhüften und ein Fleck vor dem Knie auf der breiten Schenkelfläche hellgelb. Das letzte Segment des $q$ mit einer seichten, halbkugeligen Grube; das $ð$ unbekannt.

Aus Brasilien. (Von S. João del Rey: Sello im Mus. Berol.)

34. P. striatulus m. Scliwarz init gelbluntem Kopfe, der Rand mit drei Längsflecken und zwei Punkten des derb und dicht punktirten Halsschilds, die Seiten und eine Längshinde der Flügeldecken, Pygidiun und Beine gelh mit bräunlich geringelten Schenkeln; die Deckschilde derb punktirt mit nur hinten deutlichen Punktstreifen und daselbst flach gewölbten, glänzenden Zwvischenräumen!. L. $1 \frac{1}{2}-13 / 4{ }^{\prime \prime \prime}$; Br. $11 / 12-11 / 12{ }^{\prime \prime \prime}$.

Dem vorhergehenden überaus ähulich, sodass man ihn bei olserfliichlicher Betrachtung leicht fïr eine blosse Form desselben halten köınte, aber doch von ihm genugsam verschiedeı. während XVI. 
es übrigens nur einer Angabe der Abweichungen beider Arten bedarl. Die Punktirung ist bei dem vorliegenden auf dem Kopfe, mehır noch auf dem Halsschilde dichter gedrängt, auf dem letzteren stellenweise zu Runzeln verflossen, auf den Flügeldecken bis zu deren Mitte lin viel dichter, auch feiner, stellenweise Ansätze zu Doppelstreifen zeigend; der vierte und fünfte Streifen weniger ausgebildet, dagegen auf der ganzen Hiuterlıälfte alle Streifen regelmässiger, daher die flachgewölbten Zwischenräume zu deutlichen Rippen entwickelt, der nemnte auch hier nach seiner ganzen Länge flach gewölht, und über dem Seitenlappen, wie hei dem vorigen, mit einigen tieferen Punkten besetzt. Die Färbung zeigt im Ganzen melı vorherrschend ein auch hier ins Weissliche fallendes Gelb; am Kople sind die Stiruflecken bei dem $q$ breiter und deutlicher, ausserdem Wangen, Taster, je ein Fleck auf ler unteren Ecke des Kopfschilds und ein Querfleck auf der unteren Stirn gellı: bei dem $\delta$ hängen alle diese Zeichuungen zusammen und erweitern sich so, dass nur der Nacken, ein daran stossender längstleck auf der Stirn, jeder'scits ein Fleck an dem Fühlerlı̈cker und der untere Rand des Kopfschilds schwarz bleiben. Auf dem Halsschilde ist die gellıe Färbung des Randes deutlichıer, längs dem Vorderrande nicht abgesclıwächt, aber schärfer begränzt, an demsellen jederseits über dem oberen Augenrande fleckig erweitert, auch die Hinterflecken breites, melı nach Aussen divergirend und gegen jene fleckige Erweiterung des Vorterrandes gerichtet; ausserdem zwischen letzterer und dem Hinterwinkel jederseits noch ein einzehner freistehender gelber Punkt nehen der Mitte des Seitenrandes. Die Flügehlecken zeigen deuselben gelben Rand wie die vorhergehende Art; derselbe ist jęloch auf der Vorderkante deutlicher, läugs der hiuteren Hälfte der' Nalıt, um die Spitze und an Seitenrande schärfer begränzt, weil an einen deutlicheren Punktstreifen angelehnt, auf der Mitte der Naht bei dem Begrime jener schälfren Begränzung von einer schriigen Punktreilse Jurchsetzt und zugleich zipfelig nach Aussen und hinten erweitert. Das Pygidiun mit zwei grossen runden, gelblichen Flecken, die hei einen der rorliegenden Stücke zu einem grossen, oben ausgerandeten, nierenlörnigen Quedflecke zusinmentliessen. Der letate Ilinterleibsting jederseits mit inem gellen Querflecke; die Beine gleichfills gell, leicht ins Röthliche falleud, die Schenkel verwaschen hräunlich geringelt, und auch die Hinterschienen unter der Mitte nit eimpm noch schwächeren bräun- 
lichen Anfluge. Das letzte Segment des $\delta$ einfach, des $q$ mit einem kleinen rundlichen Grübchen.

Aus Brasilien (Mus. Berol., von v. Oljers gesammelt).

35. P. tenebrosus m. Schwarz, ein par Stirntlecke, die Seiten des grob punktirten IIalsschilds mit Vorderrand und Mittellinie, der unterbrochene Rand und einige Fleckic der Flïgeldecken gelb, die Beine röthlielogelbbunt; die Deckschilde grob punktirt, hinten undeutlich längsstreifiơ, mit flachen theilweise längsrippigen Zwischenrïumen.

L. $2 \frac{1}{2}{ }^{\prime \prime \prime} ;$ Br. $11 / 4 "$.

Dem oben beschriehenen $P$. nigricollis in mancher Beziehung ähnlich, aber von ihın durch die ganz sclıwarze Färbung des Hinterleibes und die abweichende Vertheilung der gelhen Zeichnung auf der Oberseite genugsam verschieden. Der Kiopf flach gewölbt, die Stirn der Länge nach und danı nochnnals zwischen den Augen oben in die Quere seicht niedergedrückt, mit etwas eingezogenem flachem Kopfschilde, dicht punktirt, mit glänzendem Zvvischengrunde. Das Kopfschild bis auf den Unterrand und das Innere der P'unktè gelb, eben so die Oberlijpe und die Mundtheile, die Enden der Vordertaster schınutzig geloräunt und auf der Stirn längs jedem Auge eine ziemlich breite, alser nicht recht klare gelbe Längslinie. Die tief dreieckig ausgebuchteten, (bei dem o) weit getrennten Augen greis. Die Fühler des vorliegeutlen Stückes unvollständig, anscheinend sehr dünn; das Wurzelglied gestreckt keulenförmig, etwa $2 \frac{1}{2}$ mal länger als breit, das zweite sclımal plliptisch, die drei folgenden dünn verliphrtkegelförmigg, das dritte $1 \frac{1}{2}$ mal, das vierte doppelt länger als das zwcite, das fünfte, sechste und siehente je noch rtwas verlängert, das achte (und wahrscheinlich auch die fehlenden letzten) wieder etwas kürzer, dic oberen vom Eude des sechsten ab sclıwach zusammengedrückı und verbreitert. Die fünf unteren durchscheinend gelb mit gebräunter Oberseite der heiden ersten, die Wurzel des sechsten bräunlich durchscheinend, die Reste des oberen Theils der Fühler schwarz. Das flalsschilı flach walzenförmig, etwa $2 \%$ mal breiter als lang, anf der Mitte leicht quer aufgewölbt, und rous da ab die Mittelfirste nach ror'u hin sinft-, hinterwärts rtwas stärker ab)wärts gelirünnt; die scharf spitzwinkligen Vorderecken tiel pingezogen umd dadurch das IIalsschild rerengend; die Seiten frin gerandel, ron der kaum erweiterten Nitle nach den scharf stumpfwinkligen Hinterecken in leichter Krömmung ansteigend; der Hın- 
terrand jederseits sanft gebuchtet; mit wenig hemerklarem Ylittelzipfel. Vor letzterem das Mittelfeld quer niedergedrüclit und damn jederseits nach dem Hinterwinkel zu noch ein breiter, flacher Quereindruck. Die Oherfläche derb und ziemlich dicht punktirt, mit ziemlich glänzendem, zu Runzeln verfliessendem Zwischengrunde; die Farbe schwarz, cin innerseits les abgesetzten Randes liegender, ziemlich breiter Vorder- und Seitenrand gelb, und dieselbe Färbung zeigt eine den Vorderrand berührende aber hinterwärts abgekürzte schmale Mittellinie. Das Schildchen mit leichter Querwölbung schräg ansteigend, liaum so lang wie vorn breit, auch hinterwärts nur wenig verschınä]ırt, grade abgestutzt mit deutlichem Hinterzipfel, glänzend schwarz. Die Deckschilde um 1/4 länger als breit, ziemlich flach walzenförmig, hinter der erhöhten Vorderkante nur in eines schmalen Quprlinie eingedrïckt, die scluulterbenlen klein, halbkugrlig, und auch die Seitenlappen nur wenig abwärts gezogen; ülser ihnen die Deckschilde yuer zusammengedrückt, und dieser Eindruck auf dem neunten Zwischenranme zu einer flachen Längsmulde erweitert. Die Punktirung vou mässiger Stäke, auf der vurderen Hälfte dicht zusammengedrängi und theilweise runzlig verfliessend, so dass Andeutungen von Punktstreifen nnr hier und da zum Vorschein kommen, sellst der fast hei allen Arten liemntliche neuntr erst von Seitenlappen an gehörig ausgehildet. Eine etwas deutlichere Streifenentwickelung zeigt sich erst auf dem letzten Drittel, wo namentlich der zweite und dritte klarer hervortueten. Der Zwischengrund lackglänzend, vorn mehr oder weniger uneben, sodass zugleich ein paar schmale erhöhte, dem zweiten und vierten Zwischenraume entsprechende Lïngslinien hervortreten; ausserdem der neunte Zwischenıam kräftig aufgewölbs, dir übrigen hinten ahgeflacht. Die Farlıe schwarz, die erhöhte Wurzelkante mit dem Kicle des Scitenlappens und im Anschlusse an diesen ein den ahgesetzten schwarzen Rand hegleitender Saum gelb; letztorer fehıt jedoch aussen an Seitenlappen und innen rom Schildchen his zum letzten Drittel der Flïgeldechenlänge, und erlangt da, wo er die Spitze umzieht, seine grösseste Brute, während er sich nach vor'ı lïngs Naht und Aussenrand allmälhlich versehmälert unt zuletzt ganz verliert. Danehen zrigen die Vorderenden der erhöhten Längslinien Spuren gellor linienartiger Fäbung, und das Mittelfeld ausserdem bei einer geringeren Zahl gellore hier und da zerstrenter Atomenfleclichen je vier grös- 
sere Flecke, nämlich zwei grosse Längsflecke auf dem ziemlich breiten, unregelmässig erhöhten und etwas wellig verlaufenden achten Zwischenraume, wovon einer vor, der andre hinter der Mitte, einen dritten kürzeren aber breiteren innerseits des zweiten, und einen vierten ziemlich unregelmissig begränzten in der Mitte nahe der Naht auf dem zweiten Zwischenraume. Ein fünfter merklich kleinerer ist noch weiter vorwär'ts auf dem ersten Zwischenraume walırzunehmen: dabei sind alle diese Flecke, wie gewölnnlich schwielig erhöht und wic aufgetragen. Das Pygidium dicht und fein runzlig punktirt, mit der dünn aber ziemlich lang greishaarigen Unterseite schwarz; die Ilüften und Vorderbeine röthlich gell mit gebräunter Unterseite der stark verdickten Vorderschenkel, Mittelund Hinterbeine schwarz mit einem gelblichen Flecke vor den Schenkelspitzen und gebräunten Unterenden der Mittelschienen. Das letzte Segment des $q$ mit einer tiefen halbkugeligen Grube, das ơ unbekannt.

Aus Brasilien (Mus. Deyrolle.)

36. P. reticulatus Fab. Rostgelb- und weissbunt, das Halsschild grob zerstreutpunktirt, die Punktstreifen auf den Deckschilden verdoppelt und die aufgetragenen weissen Fleckenzeichnungen umziehend. L. $1 \frac{1 / 3}{3}-21 / 2 " '$; Br. $2 / 3-1 \frac{1}{4}{ }^{\prime \prime \prime}$.

Cryplocephalus reticulalus Fabr. Ent. Syst. II. 69. n. 85. Syst. Eleuth. II. 56. n. 84 .

Eine zierliche, durch ihre eigenthümliche Farbenvertheilung ausgezeichnete und durch die Leziehung der Punktstreifen zu der aufgetragenen Zeichnung an manche Chrysomelen aus der gleichfalls amerikanischen Calligrapha-Gruppe erinnernde Art. Der Kopf flach mit deutlich abgesetztem, wenig eingezogenem Kopfschilde und fein eingeschnittener Stirnlinie, die Punktirung grob aber zerstreut, die grossen Augen tief ausgebuchtet, einander oben stark genähert und bei dem đ fast zusammenstossend, schwärzlich oder greis. Die Farbe des Kopfes hell rostgelb mit gebräuntem Inneren der Punkte. Die Fühler von melır als halber Körperlänge, sebr dünn und schlank, das zweite Glied knotig aulgetrieben, das dritte kaum halb so dick aber doppelt länger als das zweite, und die folgenden bis zum sechsten noch allmählich verlängert, die oberen vom sechsten ab schwach zusammengedrückt und wenig erweitert, mit kurz dreieckigem Fortsatze des Endglieds. Die Farbe der unteren bis zur Mitte des fünften leicht gelb, vom zweiten 
ab mıt immer mehr gebräunter Oberseite, die oberen schwärzlich und dünn greishaarig. Ilas Halsschild kurz und breit, linter der Mitte quer eingedrïckt und dadurch die Mittelfirste in leichtem Bogen enporgehoben, die Seiten f'ein gerandet, von den stumpfwinkligen Hinterecken ab bis über die Mitte hinaus gerade verlaufend und er'st vor letzterer mit schwacher lirümmung den spitzen tief eingezogenen Vorlerecken zugewandt: der Hinterrand jederseits des kurzen und breiten Mittelzipfels sanft ausgebuchtet. Die Punktirung grob aber sehr zerstreut, die lichten Stellen kaum berührend, der Zwischengrund spiegelglatt. Die Farbe lsellrostgelb, die Seiten und ein jederseits zu einem sclmalen Querflecke erweiterter Vorder- und Hintersaum weiss, und diesellse Färhung zeigt ein breiter linienfürmiger Mittelfleck, und jederseits ein gleichfalls linienförniger, weniger gut hegränzter und auf dem Hinterrande stehender Schrägfleck. Das Schildchen schräg ansteigend, dreieckig. mit deutlichem Hinterzijfel kurz abgestutzı, glänzend weiss. Die Deckschilde etwas mehr wie doppelt so lang als das Halsschild, breit walzenfürmig und nur hinter den Schulterłseulen etwas zusanmmengedrückt, die Vorderliante nur zunächst am Schildchen etwas stärker aufgeworfen, die Schulterbeulen kurz eckig hervortretend und die Seitenlapjen lang abwärts gezogen. Die Streifenbildung von der Farhenvertheilung ablängig; die Grundfarbe hell rostgelb und nur die Seitenlappen gebräunt, mit einer Anzahl aufgetragener weisser lackglänzender Flecke von verschiedener Lage und Grösse: drei grosse Längsflcclie zunächst der Nahıt, deren vorderer zuuächst am Schildclıen, der hintere den hintereı Nahtwinkel ausfüllend; weiter ein die Schulterhenle umzichender an der Wurzel, welcher über den Seitenlappen mit eincm zweiten Querflecke hinter der Schulterbeule zusammenhängt, und an Aussenrande vor der Spitze noclı ein schmaler Längsfleck; endlich noch sieben vereinzelte Flecke in den Bimnenraume der Flïgeldecken, und zwar drei vercinzelte Längsfleckchen ror der Mitte, ein gr'osser unregelnässig viereckiger Fleckie dem mittleren Nahıflecke gegenüber, und drei mehr gebogene, etwas längliche Fleckchen in dem freien IJinterraume. Die Punkitstreifen nur auf dem rostgellsen Grmule bemerkbar, auf dem sie sich in geschlängelten Doppelreihen zwischen den Flecken hinziehen und dieselben einschliessen, auch hei etwaigem Zusammenfliessen einzelner Flecke ih eigene Lagre entsplrechend ändern, sodass die Flecke dadurch als Zeich- 
nungen auf den stellenweise bauchig erweiterten Zwischenräumen erscheinen. Grössere freie Stellen auf der vorderen Hälfte der Flügeldecken sind damn noch mit regellos zerstreuten Punkten besetzt. Das Pygidium fein punktirt, sclıwach gekielt, weiss und dünn greishaarig; der Ilinterleib schmutzig weissgelh mit dunkleren Nälıten, Vorlerbrust, Parapleuren und Mitte der Hinterbrust tief verwaschen rothıraun, auch wohl schwäızlich lıaun; die Schulterblätter und die übrigen Theile der Hinterhrust etwas lichter. Die Beine schmutzig weissgelb mit stark aufgetriebenen Vorderschenkeln und entsprechend gelirümmten Schienen. Das letzte Segment des $\delta$ leicht quer eingedrückt, des $q$ mit einer kleinen, aber tiefen elliptischen Grube.

In den Landschaften an Caraibischen Meere und dort anscheinend weit verbreitet. Aus Cayenne (Fabricius); am Orinoko Moritz im Mus. Berol.), von Aragua in Venezuela (derselbe ebd. und im Mus. Vindob.), am Magdalenenstrome (Mus. v. Bruck), und selbst noch in Bolivia (Warscewicz im Mus. Ber.); in Columbien ohne specielle Bezcichnung der Heimath (Mus. Saunders. Deyrolle. Dohrn. Felix. Clark. Schaum; auch von Herm Murdfield mitgetheilt.)

Zuweilen finden sich Stücke, namentlich $\delta$, bei denen der rostgelbe Grund auf Halsschild und Deckschilden ganz orler theilweise, melı oder weniger intensiv geschrvärzt ist, wie etwas Aehnliches auch schon oben bei M. 15gullatus Fab. von mir bemerkt worden ist. Eine Varietät vermag ich in solchen Stücken nicht zu erkennen: es wird dahei vielmehr ein ähnliches Verhältniss stattfinden, wie es die Europäische Fauna hei unsrer Coccinella 20 gutlata L. und ihrer Farben-Form C. tigrina aufzuweisen hat, und wie es von mir in der Ent. Zeit. XXI (1S60) S. 409 besprochen worden ist.

Den von Fabricius a. a. 0. beschriebenen, übrigens in seiner Sammlung noch vorhandenen Käfer habe ich zwar nicht vergleichen können, zweifle jedoch an der Richtigkeit meiner Deutung nicht. Die Beschreibung in der Ent. Syst. a. a, 0. passt auf die vorliegende Art so gut, als es nach Fabricius Beschreibungsweise nur irgend erwarlel werden darf; man muss dahei nur nicht inbersehen, dass $\mathbf{F}$. die weisse Färbnug als die Grundfarbe, und das, was ich als rostgelben Grund angenommen, als Zeichnung betrachtet; sowie dass seine das Halsscsild betreffende Angabe: "Thorax albus, lineolis quatuor testaceis, quarum laterales antice, intermediac postice cocunt," 
durch übermässige Kürze undeutlich geworden ist. Denn wenn man, wie er, das Halsschild als weiss bezeichnet, sind wirklich vier rostgelbe Längswische rorhanden, von denen die beiden mittleren, linienartigen hinten zusammenstossen; die seitlichen treffen aber vorn nicht mit einander, sondern jede mit der zunächst liegenden mittleren zusammen, nnd das hat $\mathrm{F}$. auch ohne $\mathrm{Z}$ weifel ausdrucken wollen, da zu einem vorderen Zusammenstossen der beiden seitlichen Linien oder Wische schwerlich bei irgend einer bierher gehörigen Art Raum vorhanden ist. Ausserdem aber ist aus dem ganzen weiten Bezirke längs dem Caraibischen Meere keine andere Art bekannt, auf welche sich die von Fabricius gegebene Beschreibung auch nur annähernd deuten liese, als die einzige vorliegende, welche übrigens in den Sammlungen sich unter den Benennungen P. hilaris Klug und jucundus Dej. zu finden pflegt.

37. P. clathratus $m$. Rostgelb- und weissbunt, das Halsschild grob zerstreut punktirt, hinten tief zweigrubig, die Punktstreifen derb, durch vier grössere Schwielenflecke unterbrochen, mit flachgewölbten mit weissen abgerissenen Längslinien gezeichneten glänzenden Zwischenräumen. L. $1 \frac{3 / 4}{4}-2{ }^{3} /{ }^{\prime \prime \prime} ; \mathrm{Br}$. $1-1{ }^{1}{ }_{3}{ }^{\prime \prime}$.

Dem vorhergehenden nahe verwandt, aber etwas grösser, in der Mitte stärker erweitert, und an den beiden Quergruben des Halsschilds, wie an den weissen Längslinien der Declischilde von ihm leicht zu unterscheiden. Der Kopf flach nit tiefer Stirnlinie und zerstreuter grober Punktirung, das Halsschild etwas eingezogen, die Farbe weiss mit Lackglanz, das Innere der Punkte ulid die Stirnlinie, die Fühlerhöcker und ein Fleck über jedenı, die Wangen und der Unterrand des Kopfschilds samml den Mundtheilen rostgelh, die bei dem ot nur durch einen schmalen Zwischenraum geschiedenen, dem $q$ weiter getrennten, tief dreieckig ausgebuchteten Augen schwarz. Die Fühler des $\delta$ von mãssiger Länge, bei dem $q$ kaum den IInterrand des Halsschilds prreichend; das Wurzelglied keulenförmig, etwa doppelt länger als breit, das zweite kurz und kugelig, die drei folgenden gestreckt- verkehrtkegelförmig, fast gleichbreit, das dritte $11 / 2 \mathrm{mal}$, das vierte $21 / 2$ mal, das fïnfte fast dreimal länger als das zweite, das sechiste dem fünften und die oberen je wieder den vierteı gleiclı. Die unteren bis zur Nitte des sechsten durchscheinend gelb, die übrigen geschwärzt und zugleich vom sechsten ab schwach zusammengedrückt und erweitert. Das Halsschild etwa $2 \frac{1}{4}$ mal breiter als lang, oben breit abgeflacht, mit kaum aufgebogener, durch ein schwaches 
Vortreten des Vorderrandes noch etwas verlängerter Mittelfirste, üher den scharf spitzwinklig ansgezogenen Vorderecken breit zusammengedrückt und dadurch nach vorn kegellörmig verjüngt; die Seiten fein gerandet, schwach gerundet, mit scharfen fast rechtwinkligen Hinterecken; der Hinterrand sanft doppelt gebuchtet, mit schwach hervortretendem Mittelzijfel; jederseits vor dem letzteren eine tiefe rundliche, etwas in die Quere gezogene Grube, und answärts derselben noch ein flacherer, in dem Hinterwinkel liegender Schrägeindruck; ein zweiter noch schwächerer fiudet sich vor lem letzteren über der vorderen Häfte des Seitenrandes. Vie Ober-fläche auf dem dunkleren Grunde groh zerstreut punktirt, die Punkte in den Hintergrübchen dichtes zusammengedrängt, auf der weissen Zeichnung nur hier und da ein vereinzelter Punkt. Die Farbe lackglänzend rostgelb, je weiter nach vorn desto dunkler, ein breiter, mit schlecht begränzter Intenseite nach vorn noch mehr erweiterter und dadurch nur ein schmales Stück in der Vitte des Vorderrandes freilassender Seitensaum, eine sich hinter der Mitte zu einem breiten unregelmässig viereckigen Flecke erweiternde Längsljinde, und jederseits ein Fleckchen zwvischen ihır und dem Seitenrande weiss, wie aufgetragen. . Auf der hinturen Erweiterung der Mittelbinde tritt manchmal, wie durchscheinend ein elliptisches Fleckchen von der Grundfarbe hervor, und eben so bleibt der durch eine Punktreilse abgesetzte Aussenrand vorn und längs der vorderen Hälfte der Seiten roströthlich. Das Schildchen schräg ansteigend, um $1 / 4$ länger als breit, hinterwärts etwas verschıälert und mit deutlichem Hinterzipfel breit abgestutzt, gylänzend weiss mit dunklerem Saume. Die Deckschilde um etwa $1 / 3$ länger als vor der Mitte breit, hinter der Wurzel am breitesten und hinterwärts wieder etwas verschmälert, wenn auch nicht in demselben Grade als der Körper sich nach vorn verjüngt; die durch eine deutliche Querfurche abgesetzte Vorderkante scharf aufgeworfen und das emporgerichtete Schildchenende derartig umziclıend, dass um dasselbe sich ein breiter, durch die flach niedergedrückte Nalıt auch hinterwärts abgesetzter Querhöcker bildet. Die Schulterbeulen schmal und ziemlich flach, auch die Seilenlappen nur wenig abwärts gezogen und über ihnen die Deckschilde breit quer zusammengedrückt, welcher Eindruck, wenn auch abgeschwächt, doch bis gegen die Naht hin verfolgt werden kans, und dadurch nach der Querfurche hinter der Wurzel zu ein breites, lịach er- 
höhtes Querfeld abgränzt. Die Punktstreifen, bis auf den bald abreissenden siebenten, auf der vorderen Hälfte deutlich, aber durch die aufgetragenen weissen Zeichnungen theilweise derartig aus ihrer Richtung gedrängt, dass sie sich jenen Zeichnuugen entsprechend wellig krümmen und zu Doppelstreifeı zusammengeschoben werden, die da, wo sie durch Schwielen eingeengt sind, dann noch manchmal zu einem eimzigen Streifen zusanmen fallen. Solche Doppelstreifen bilden der erste und zweite, dritte und vierte, der fünfte und der etwas gestörte sechste, wälırend der achte und neunte ganz getrennt bleiben, dafür aber stellenweise von der weissen Zeichnung unterbrochen werden. Die letztere umfasst zunächst des Wurzelrand und den voll ihm durch die sclımale Schulterbeule getrennten Kiel des Seitenlappens, denn weiter vier grössere Schwielen, deren erste jederseits des Schildchens den entsprechenden Theil des Schildchenhöckers bildet, und durch einen Vorderzipfel längs dem Schildchen mit dem Wurzelrande, und durch eine fast anunterbrochene die Naht begleitende Längslinie mit der die ganze Spitze einnehmenden vierten Schwiele zusammenhängt. Die beiden andern liegen auf der Mitte und sind sehr unregelmässig viereckig, die innere auf dem erweiterten zweiten Zwischenraume und dadurch das erste Streifenjaar zu einem einzigen Streifen zusammenschielıend, die äussere auf dem achten Zwischeuraume, denselben aber beiderseits überschreitend, den achten Streifen etwas nach Innen drängend, und an jede dieser Schwielen schliesst sich uach vorn und hinten eine theilweise mit ihr zusammenhängende bleichgelhe Läugslinie au. Aehuliche abgerissene, meist verwaschene Längslinien finden sich auch noch auf den übrigen Zwischenräumen, so auf dem vierten und neunten in der Mitte und linten, auch auf dem dritten, dessen Jängslinie sich auf der Wölbung zu einer kleinen viereckigen Schwiele erweitert, und eine schwächere, daher die Streifen nicht unterbrechende weissliclıe, mehr wischartige Stelle hinter der Schulterheule: übrigens sind diese verschiedenen Linienzeichnungen nicht bei allen Stücken, nicht eimmal immer auf beirlen Flügeldecken desselben Stückes cinduler gleich. Pjgrilium, Ilinterleib und Beine rostgelb oder weisslich mit manchmal gehrämnteu Kinien; die Brust dunkler rostgell, auch wohl rostbraun, die Schulterblätter, die Innenseiten der Parapleuren mnd manclınal ein Längswisch jederseits auf der Hinterbrust mit dem dreieckigen Ilinterzipfel des Prosternums 
bleicher gelblich. Das letzte Segment des $\delta$ einfach, des $q$ mil einer breiten, rundlichen, aber nicht tiefen Grube.

Aus Brasilien (Mus. Hamburg. Halens. Clark. Deyrolle. Berol.).

38. P. glyphicus Klug. Lehmgelb- und rostgelb bunt, das Halsschild grob und dicht punktirt; die Punktstreifen gleichfalls grob, hinter den Schulterbeulen etwas verwirrt, mit flachen glänzenden Zwischenräumen. L. 2-21/2"'; Br. 1-1 1/3"'.

In Sculptur und Färbung steht dieser Käfer bis dahin in dieser Gattung ziemlich vereinsamt, schliesst sich aber doch am besten an die nächst vorhergehenden Arten an; anderntheils zeigt el aber auch mancherlei Aulogien mit der mittelamerikanischen Gruppe der echten Cryptocephalen, welche durch den mexicanischen $\mathrm{Cr}$. flavo-notatus St. und dessen Verwandten gebildet wird. Der Kopf flach, zwischen den Augen breit und seicht eingedrückt, und die Stirn noch von einer feinen Längslinie durchzogen, das Kopfschild unten fast gerade abgestutzt und die Oberlippe nur wenig vertretend. Die Punktirung deutlich, im Nacken und auf dem Stirneindrucke dicht gedrängt, unterwärts sparsamer und regellos vertheilt; die Punkte im Innern geröthet, daher die dichter punktirten Stellen, namentlich ein Querfleck im Nacken und der Stirneindruck rostroth, der übrige Zwischengrund lehmgelb, und da wo die Punkte auf einer grösseren Strecke fehlen, schwielig glänzend, was namentlich in den Augenbuchten und auf dem an diese anstossenden Theile der Augenränder der Fall ist. Oberlippe und Wangen noch heller-, fast weisslich gelb, die grossen weit getrenoten Augen greis. Die Fühler dünı, auch bei dem $q$ kaum von halber Körperlänge, das Wurzelglied stark hlasig aufgetrieben, kaum um die Hälfte länger als breit, unten flach muldenförmig ausgehöhlt, das zweite kurz und schmal eiförmig, die drei folgenden düın verkehr'kegelförmig, das dritte um die Hälfte länger als das zweite, die folgenden bis zum zehnten einander gleich und je etwa um die Hälfte länger als das dritte, dabei vom sechsten ab schwach zusammengedrückt und erweitert; das Eudglied mit seinem schmal dreieckigen Fortsatze wieder etwas länger. Die Farbe hellgell, die unteren Glieder gläızend und durchscheiuend, die oberen dünn helıart nit leicht rauchgrauem Anfluge. Die Fühler des $f$ noch etwas kürzer, aber sonst nicht abweichend. Das IIalsschild breit und flach walzenförmig, um mehr als die Hälfte breiter als lang 
mit vorn leicht übergekrümmter, hinterwärts leicht abfallender Mittelfirste, über den spitzen Vorderecken etwas zusammengedrückt und rer'schmälert: die Seiten fein gerandet und mit fast geraden Rändern rach vorn und unten zusammengeneigt, die Hinterecken stumpfwinklig abgerundet; der Hinterrand jellerseits des kurz und breit dreieckig aufgebogenem Mittelzipfels ausgeschweift, und vor diesem die Oberfläche schräg niedergedrückt, ausserden aher zu beiden Seiten längs dem Hinterrande ein breiter, flacher, ein schmales IInterfältchen emporschiebender Quereindruck. Die Punktirung grob, auf den dunkleren Stellen dichter gedrängt, während auf den lichteren der Zwischengr'und schwielig glatt hervortritt. Die Farbe hell rostgelb, die Ränder, eine schmale Mlittellinie und jederseits zwei den Hinterrand, nicht aber auch den Vorderrand erreichende verwaschene Längshinden heller lehmgelh; manchmal aber nehmen diese gelben Zeichnungen soweit überhand, dass das Halsschild lelımgelb mit fünf roströthlichen Längsbinden erscheint, deren mittlere sich hinter der Mitte gabelt und dann zweitheilig nach vorn ausläuft. Der Zwischengrund überall lackglänzendl. Das Schildchen um die Hälfte breiter als lang, schräg ansteigend und hinterwärts stark verschmälert, mit dentlichem Hinterzipfel, glänzend gelb mit breit röthlichem Saume. Die Deckschilde breit und flach walzenförmig, reichlich doppelt länger und vorn etwas breiter als das Halsschild, seitlich hinter den Schulter'm etwas buchtig zusammengedrückt, hinter dem Schildchen quer eingedrückt und dann hiuter einem kurzen Benlchen die Naht der Länge nach abgeflachı, mit kurzer, schrăg abfallender Wölbung. Hinter der scharfen aber nur schwach erhöhten Vorderkante die IVurze] schmal quergefurcht, die Schulterbeulen flach, und auch die Seitenlappen wenig entwickelt. Die Punktstreifen derb, besonders bei den $\delta$ zu etwas welligen, zwischen Naht und Schulterbeulen stellenweise gepaarten Streifen zusammengeorlnet, was dann namentlich bei dem ersten und zweiten, auch dem dritten und vierten, weniger deutlich bei dem siebenten und achten Streifen hervortritt, und dadurch den zweiten Zwischenraum in der Mitte merklich erweitert erscheinen lässt. Bei dem $q$ tritı diese Bildung weniger leutlich, dloch unmerhin noch kemutlich hervor; wälırend dagegen bei den $\delta$ die Streifen zunächst der Schulterbeule verwirt und unterbrochen sind, stellenweise auch ganz aussetzen, sind bei den $q$ die imneren Zwischenräume voru bis zur Nitte hin mit überzähligen Punkten 
bestrent, und dadurch die Streifen selbst etwas getrübt. Hinterwärts laufen nur der erste und zweite, der vierte und neunte Streifen bis zur Wölbung aus, und trefien auf letzterer paarweise zusammen, während der fünfte bis achte schon früher abreissen und nur ein maschig verschlungenes Ende derselben hiuten in dem Verbindungswinkel des vierten und neunten nochınals zum Vorschein kommt. Dạs Innere aller Punkte ist gerötlıet, und dadurch werden bei dem ơ seiner derberen P'unktirung weyen einige unregelmässige röthliche Längslinien auf dem heller lehmgelben Grunde erzengt, die sich namentlich zwisehen der Naht und dem dritten Zwisehenraume hinziehen; bei dem $q$ sind dieselben schwächer und nur in gewisser Entfernung voin Auge zu bemerken. Die Zwischenräume selbst sind flach, bei dem ơ mit starkem Lackglaıze, dem $q$ sehwach quergerunzelt und dadurch matter. Das Pygidium äusserst fein punktirt, dünı weissbehaart, hellstrolıgelb, die Unterseite gleichfalls fein querrunzlig punktirt, kuız und dünn behaart, dunkler gelb, Brust und Wurzel des Hinterleibes mehr oder weniger verwaschen gebräunt. Die Beine einfarbig gelb, bei dem ơ die Vorderschenkel stark verbreitert, mil entsprechend gekirümuteı Schienen. Das Prosternum lang weissbehaart, mit schmaler Längsrinne. Das letzte Segment des ơ nur leicht quer niedergedrückt, des $q$ mit einer flachen rundlichen, etwas glänzenden Grube.

Aus Brasilien (Mus. Berol. Schaum. Sturm. Haag. Clark. Holm.). Die Stücke aller dieser Sammlungen stammen aus dem Mus. Berol., und sind bei Porto Allegre von Sello gesammelt worden.

Zweite Rotle. Fühler, hesonders des $\delta$ lang und dünn; der körper breit und flach mit grob runzlig punktirter, auf den Deckschilden des $q$ matter Oberfläche und undeutlichen Läıgsstreifen der letzteren. Die Farbe schwarz, mit gelber auf den Decksehilden des $\delta$ weiter ausgedehnter Fleckenzeichnung. Eine vereinzelte Art aus Chile.

39. P. Gayi Blanch. Schwarz, der Kiopf, das grob runzlig punktirte Halsschild mit Deckschilden und Beinen gellobunt; die Deckschilde vorn regellos punktirt, aussen und hinten punktstreifig mit breiten flach gewölbten Zwischenräumen und einer Reihe erhühter Schwielenflecke.

o Kopf gelb mit schmutzig sehwärzlicher Zeichnung, Decli- 
schilde glänzend gelb, der Aussenraud und eine manchmal zerrissene Längsbinde schwarz;

q Kopf schwarz mit zwei gelblichen Längslinien, Deckschilde mattschwarz, zuweilen noch nit gelblichen Linien und Wischen neben den Schwielenflecken.

L. $13 / 4-21 / 4{ }^{\prime \prime \prime} ;$ Br. $3 / 4-11 / 12{ }^{\prime \prime \prime}$.

Pachybrachys Gayi Blanchard in Gay Hist. fisica etc, de Chile. V. 541. n. 6.

Eine durch den flachen Körper und die matten, glanzlosen Deckschilde des $q$ sehr ausgezeichnete Art. Bei diesem letzteren, in den Sammlungen weniger seltenen Geschlecht ist der Kopf flach mit breit und seicht niedergedrückter Stirn, grob runzlig punktirt, schwarz, der Unterrand der nur undeutlich abgesetzten Oberlippe und zwei trübe Längslinien auf der Stirn gelh. Die Fühler von halber Körperlänge, sehr dünn, das Wurzelglied stark aufgetrieben, liaum um die Hälfte länger als breit, das zweite eiförmig, halb so lang und breit wie das vorhergehende, die folgenden schmal verkelırtkegelfürmig, fast gleich dick und sich allmählich verlängernd, die oberen schwach erweitert und zusammengedıückt, das sechste und siebente je dem fünften gleich, die folgenden allmälilich ein wenig verkürzt, sodass das Endglied mit seinem schmal kegelfö̀migem Fortsatze etwa wieler dem vierten gleichliommt. Das Wurzelglied schwarz mit gelblicher Spitze, die folgenden gelb mit gebräunter Oberseite des zweiten, das fünfte fast braun, und die oheren schwarz mit fein angedrückter, greiser Behiarung. Die grossen, durch eine tiefe Ausbuchtung selı ungleich gethrilten Augen greis und dabei weit getremnt. Das Halsschill fast dopjelt hreiter als lang, sehr flach gewöllst, daher die Mitteltirste nur wenig aufwirts gekrümmt, die tief' eingezogenen Vorderecken spitzwiuklig, die fein gerandeten Seiten schwach nach aussen gekrümmt, die Hinterecken sehr stumpt, und auch der durch eine tief eingedrückte Querlinie abgesetzte Hinterrand nur leicht wellig gebuchtet, mit wenig benerkbarem IJinterzipfel; jederseits des letzteren ein lreiler, vor den Hinterande ein wulstiges Querfïltchen enuporschiebender Quereindruck. Die Oberflïche grob rmulig punktirt, mit glänzendem Zwischengrunde, ein schmalerer Vorder- und ein breiterer Seitenrand, meisı anch drei linienartige Längsfleckclıcn, das vordere grössere und glattere eine vom Vorderramle ansgehende hinten alogekin̈zte Nittellinie darstellend, während die hinteren melı seitlich stehenden meist muscheinhar werden, gelblich. Das Schild- 


\section{3}

chen stark ansteigend, quer viereckig mit scharfen Hinterecken, fein aber dichı punktirt mit glatter Mittellinie, glänzend schwarz. Die Deckschilde breit und sehr flach gewölbt, etwa $1 / 3$ länger als breit, die feine aber scharfe Vorderkante durch eine schmale, aber tief eingedrückte Querlinic gehoben, und seitlich an die schmalen, aber kräftigen Sclıulterbenlen angeschlossen, die Seitenlappen derb, durch einen tiefen muldenförnigen Längseindruck abwärts gedrückt; auch der Rücken hinter dem Schildchen und nochmals hinter der Mitte breit und seicht quer niedergedrückt, mit linten schwach abfallender Wölbung. Die Punktirung deutlich, auf der Vorderhälfte zwischen Naht und Schulterbeulen nur mit Spuren getrübter Punktstreifen, welche nach aussen und hinter der Mitte sehr hemerklich hervortreten und die Zwischenräume als hreite tlach gewölbte Längsrippen emporheben. Die Schulterbeulen und die umgeschlagenen Ränder der Seitenlappen glänzend, die übrige Oberfläche matt und glanzlos, schwarz, ein paar Querflectichen auf der erhölıten Vorderkante und eine Längsreihe von drei erhölıten Sclıwielenfleckchen hinter der Scluulterbeule weisslich gelb, die beiden vorderen derselben mit dem Aussenrande an den neunten Punktstreifen gelehnt, der erste dem Seitenlappen gegenüber, der dritte quer gezogen an der spitze, der zweite zwischen beiden in der Mitte stehend. Bei einzelnen helleren Stücken zeigen sich auf dem schwarzen Grunde noch einige schmale gelbe Längslinien, auch wohl ein grösserer Wisch jederseits der Naht hinter dem Schildchen, die sich dann aber von jenen Schwielenflecken durch eine merklich dunklere Färbung unterscheiden. Pygidium, Unterseite und Beine schwarz; ersteres fein punktirt, am unteren Rande zuweilen mit einzelnen gelblichen Atomenfleckclıen, ausserdem ein Querfleck auf den Schulterblättern, die Spitze des Mittelzipfels vom ersten Bauchringe und auch wohl einzelıe Pünktchen auf dem Hinterrande der Hinterbrust gell. Die Iüften mit den Schenkelwurzelı gelblich, die Vorderschienen unten und innen ebenso angetlogen, zuweilen auch ein Fleckchen auf der breiten Seite der Vorderschenkel oder an der Spitze der Mittelschenkel gelb, und die Füsse bräunlich. Das Prosternum grob punktirt, längsrinnig; der letzte Ring mit einer tiefen kreisrunden Grube.

Das von Blauchard a. a. 0. anscheinend verkanute und als Varietät betrachtete $\delta$ unterscheidet sich ausser der geringeren Grösse hauptsächlich durch ein stärkeres Hervortreten der' gelben 
Färbung an Kopf, Deckschilden und Beinen. Auf ersterem sind die Zeichnungen grösser und deutlicher, das Kopfschild ist ganz gelb, und die gelbe Färbung der Stiru oft soweit ausgedehnt, dass dieselbe als schmutzig gelb mit schwärzlicher Atomenfleckung beschrieben werden kann. Die Augen sind grösser und einander merklich genähert. Die Zwischenräume der Deckschilde sind nicht matı, sondern lackglänzend. Die Schwielenflecke rergrösser't, sodass der Hinterlieck sich manchmal in der gewöhnlichen Pachybrachen-Zeichnung dreistrahlig nach vorn erweitert; die gelben Linien und Wische werden bei gleich dunkler Färbung grösser, intensiver, und fliessen zuletzt soweit zusammen, dass von dem schwarzen Grunde fast nur ein breiter Aussenranı und eine Längsbinde imnerseits der Schwielentlecke übrig bleiben, und anch letztere sich zuweilen noch in kleinere schwarze Längswische und Linien autlöst. An den Beinen ist ausser Wurzel und Spitze der Schenkel auch die Spitze der Hittel- und Hinterschienen gelb, und auf der breiten Vorderfläche der Vorderschenkel erweitert sich der gelbe Fleck zu einer langgestrecktell gelbeı Lüngsbinde, welche fast die ganze miltlere Hälfte der Schenkelfläche einnimmt. Das letzte Hinterleibssegment einfach.

Aus Chile (Mus. Riehl. Haag. Clark. Felix. Schaufuss. Berol.).

Dritte Rotte. Fühler kurz und dünn; Körper schmal und gedrungen walzenförmig. Die ganze Oberfläche dicht siebartig punktirt. Die Farbe schmutzig braun, hinten mit helleren Wischen. Linn. VII. 221. Sechste Rotte.

40. P. mixtus Blanch. Oben rostroth und gelbbraun gewölkt, mil zwei helleren Wischen vor der Spitze der Flügeldecken, unten braun; Halsschild und Deckschilde siebartig punktirt, je mit einer scharfen Längshante hinter den Schulterbeulen. L. 11/2"'; Br. $3 / 4 "$.

Pachybrachys mixlus Blanchard in Gay Hisl. fisica etc. de Chile. V. 541. n. 5 .

Durch die Färbung sehr ausgezeichnel, noch mehr aber durch den Mangel aller Punktstreifen von allen vorhergehenden Arten abweichend, und lis jetzl mit der folgenden einer der wenigen südamerikanischen Vertreter dieser in allen Erdtheilen nur spärlich auftretenden Pachybrachenform. Der liopf flach, dicht punktirt, mit mïssig glänzendem Zwischengrunde, das Kopfschild etwas eingezogen, die Stirn der Länge nach breit eingedrückt und dieser 


\section{5}

Eindruck noch von einer feinern Längslinie durchzogen, daher der Nacken mit zwei schmalen Längsbeulen vortretend. Die Färbung dunkelrostroth, die Nackenbeulen und in deren unterer Verlängerung ein Paar Längswische nebst einzelnen zer'streuten Atomenflecken heller gelb, die Mundtheile etwas dunkler gebräunt. Die Fülıler dünı und von etwas mehr als halber liörperlänge, rostroth; das stark aufgetriebene Wurzelglied auf der Oberseite gebräunt, die oberen Glieder schwarz mit angedrückter greiser Behaartung. Das Halsschild kurz und breit, hinter der Nitte nur sehr schwach quer aufgewölbı und daher die Mittelfirste fast grade, der Rücken über den spitzen Vorderecken stark zusammengedrückt und dadurch verschmälert, und auch hinten jederseits ein sehr breiter, mässig tiefer Schrägeindruck. Die Seiten deutlich gerandet, iı der Mitte leicht erweitert und vor ihr sant ausgeschweift; lie Hinterecken stumpf abgerundet, der Hinterrand leicht wellig ausgebuchtet, mit kurzem aber merklich aufgebogenem Mittelzipfel. Die Oberfläche dicht siebartig punktirt, der ans schmalen etwas in die Länge gezogenen Runzeln bestehende Zwischengrund lackartig glänzend, dunkelrostrotlı, mit sparsam vertheilten gelblichen Atomenflecken, die sich jederseits an der Hinterhälfte des Seitenrandes zu einer grösseren Längsschwiele vereinigen, ausserdem aber nur in der Mitte und jeder'seits derselhen in Gestalt dentlicherer, mehrfach zerrissener Längsflecke hervortreten. Das Schildcheı stark ansteigend, fast quer viereckig, mit deutlichem Hinterzipfel scharf abgestutzt, die mit einzelnen deutlichen Punkten bestreute Oberfläche glänzend schıvarzbrauı. Die Deckschilıle walzenförmig, hinterwärts kaum erweitert, um $1 / 3$ länger als breit; der Rücken hinten sanft abgeflacht und dann init steiler Wölbung abfallend, unter welcher die Spitze leicht eingedrückt; hinter der scharf aber nicht hoch emporgerichteten Vorderkante ein sehmaler Quereindruck, von weichem aus sieh die Deckschilde sanft aher merklich aufwärıs wölben, sodass dadureh 1 m das Schildchen her eine erlröhte hinterwärts stärker abfallende, und auch nach vorn wieder leieht eingedrückte Flïche gebildet wird. Auf ihr findet sich hinten am Schildchen jeder'seits noch ein durch einen kräftigen Quereindruck stärker abgesetztes Beulchen, nach Aussen wird sie von einem flachen, innerseits der Schulterbeule mit der vorderen Querfurehe zusammenhängenden Längseindruck begränzt, welcher hinterwärts wieder nit einem von dem Seitenlappen aus sich erhebenden, durch XVI. 
eine von der Schulterbeule ausgehende Längskante in ein paar längliche Mulden getheilten Quereindrucke zusammenfliesst. Von diesen Mulden ist besonders die zunächst über dem Seitenlappen liegende merklich eingedrückt, und der äussere Theil der Flügeldecken dadurch etwas einwärts gedrängt. Die Punktirung grob siebartig, dicht gedrängt, mil lackglänzendem Zwischengrunde, ohne Spur von Punktstreifen, und als Reste geschwundener Zwischenräume nur ein paar feine Längslinien bemerklich, deren eine stärkere, fast kantenartige, wie schon erwähnt, von der Schulterbeule ausgeht, den Quereindruck über dem Seitenlappen durchsetzt und sich hinter der Nitte verliert, während eine zweite schwächere sich weiter hinterwärts auf dem letzten Drittel, doch der Naht näher als dem Aussenrande, bemerkbar macht. Die Farbe rostroth, verwaschen bräunlich gervölkt, die vordere Kante unterbrochen gelblich, und älmliche gelbe leicht schıvielig erhöhte Atomenflechichen sind auch anderwärts hesonders um das Schildchen und auf der hinteren Hälfte zerstreut, wo sie sich an der Wölbung zu zwei deutlichen Wischen, einem grösseren mehr unförmlichen nahe am Aussenrande und einem kleineren mehr zerfaserten zwischen der Mitte der Wölbung und der Naht vereinigen: zwischen beiden und vor dem Innern verdunkelt sich der rostrothe Grund derartig, dass es scheint, als ob ihm zur intensiveren Ausfärbung der beiden helleren Wische jegliches lichte Pigment entzogen worden sei. Das Pygidium schr fein punktirt, verloschen gekielt, rostroth mit rerwaschen helleren Rändern; die Unterseite schwarzbraun mit breit heller gerandetem Hinterleibe; anch die Beine braun, die Wurzeln und Spitzen der Schenkel nebst den Schienenwurzeln verwaschen gelblich. Das letzte Segment des $q$ mil einer tiefen rundlichen Grube, das $\delta$ unbekannt.

Aus Chile (Mus. Dohrn. Clark. Deyrolle, aus dem letzteren als P. mixtus Blanch. erhalten, womit auch Blanchards a. а. 0. gegebene Beschreibung gut übereinstimmt. Als specieller Fundort ist daselbst Santa Rosa genannt).

41. P. quadricollis m. Schwärzlieh greis, das dicht punktirte Halsschild mit den Deckschilden undeutlich heller gewölkt, zwei hintere Schwielenfleckchen des ersteren, der schwielige Nahtrand am Schildchen und der Seitenrand der letzteren weisslich gelb; die Flügeldecken dicht siebartig punktirt, mit einem breiten Zivischemraume am Anssemrande. L. 11/4"'; Br. $2 / 3{ }^{\prime \prime \prime}$. 
Nach Habitus, Sculptur und Färbung einzelnen mittelamerikanischen Arten, namentlich dem P. hepaticus Knoch. und P. pinguis $m$. nahe verwandt, und ein neuer Beweis für die vielfache Uebereinstimmung, welche zwischen den Formen von Mittelamerika und dem nördlichen Theile von Südamerika stattfindet. Der Kopf flach mit undeutlicher Spur einer Stirnlinie und etwas eingezogenem, durch eine sehr feine Querlinie abgesetztem Kopfschilde, dicht siebartig punktirt, schwach glänzend, schwärzlich greis mit trülb knochengelber Oberlippe, der Nacken etwas heller, die langgestreckten, (bei dem o) sehr weit getrennten, breit ausgebuchteten Augen schıärzlich, am oberen Rande je von einer kurzen gekrümmten glänzend gelblichen Schwiele umzogen. Die Fühler sehr kurz und den Hinterrand des Halsschilds nicht erreichend, das erste Glied aus stark eingeschnürter Wurzel eiförmig aufgetrieben, um die Hälfte länger als breit, das zweite bei fast gleicher Breite sehır kurz, breiter als lang, die folgenden einander ziemlich gleich, je fast doppelt länger als das zweite, das dritte bis sechste sehr dünn, die fünf oberen dreieckig erweitert und zusammengedrückt, mit kurzem und breitem Fortsatze des Endgliedes. Die Farbe schmutzig gelblichgreis, vom siebenten ab die Glieder an ilırer oberen Hälfte geschwärzt und an der Spitze deutlich gewimpert, die beiden letzten schwärzlich mit heller durchscheinender Wurzel; auch die beiden unteren auf der Oberseite leicht gebraunt. Das Halsschild mehr wie doppelt breiter als lang, in der Mitte hoch quer aufgewölbt und nach vorn und hiuten ziemlich gleichmässig abwärts gekrümmt, über den tief eingezogenen, scharf spitzwinkligen Vorderecken breit zusammengedrückt und dadurch rerschmälert, die Seiten fein gerandet, von den scharf stumpfwinkligen Vorderecken ab fast in graden Linien nach vorn und unten zusammengeneigt; der Hinterrand mässig ausgebuchtet, mit kurzem, durch einen bogenförmigen Quereintruck aufwärts gedrücktem Nittelzipfel: die Aussenenden jenes Eindrucks schräg nach vorn gerichtet und daselbst verbreitert aber kaum verflacht. Die Punktirung auch hier dicht siebartig zusammengedrängt, mit schwach glänzendem Zwischengrunde; die Farbe schmutzig schwärzlichgreis, längs den Seiten und jederseits der Mitte etwas lichter gewölbt und dadurch hier zwei undeutliche sehr verwaschene Längsbinden andeutend, deren jede am Hinterrande mit einer deutlichen weissgelben und glänzenden Schwiele endigt; die Mlite vorn schwach längskielig 
erhöht und gleichfalls etwas heller, und ebenso finden sich auch über der Mitte des Seitenrandes Spuren feiner, durch die Trennung der Punkte gebildeter schwieliger Stellen. Das Schildchen schräg ansteigend, hinterwärts verschmälert und mit undeutlichem Hintel'zipfel kurz abgestutzt, schwärzlich greis mit mässigem Glanze. Die Deckschilde kurz und breit, kaum $1 / 4$ länger als breit, ziemlich gleichbreit und hinten mit sehr flacher Wölbung abfallend, hinter der scharfen Vorderkante schmal quer eingedrückt, auch die Schulterbeulen nur als kurze, schmale Höcker bemerkbar, die Seitenlappen unbedeutend, mit breit umgeschlagenem, grob punktirtem Rande. Die Punktirung bildet nur längs dem Rande den gewöhnlichen zehnten (Rand-) Streifen vollständig aus, auch der neunte ist seiner ganzen Länge nach vorhanden, aber besonders hinterwärts etwas wellig gekrümint, und vom achten zeigen sich abgerissene Stücke; die übrigen Punkte sind dicht und siebartig zusammengedrängt, wenn sich gleich auch hier einige Spuren lïngerer oder kürzerer Längsreihen verfolgen lassen. Der Zwischengrund ziemlich glänzend; von Zwischenräumen nur der neunte vorhanden, und zwar ziemlich breit und mit einer weitläufigen und ungeordneten Reilıe gröberer P'unkte besetzt; auch zeigen sich auf dem Rücken Andeutungen von zwei feinen, fadenförnigen Längslinien als Reste geschwundener Zwischenräume. Die Farbe auch hier schwärzlichgreis, scitlielı mehr ins Gelblich-Greise über'gehend, und auch auf der Mitte mit lichteren, theils wolkigen, theils schı̈rfer begränzten Flecken; ausserdem der Kiel des Seitenlaplens mit dem nemnten Zwischenraume und den darüber liegenden Spuren des achten fast weisslich gelb, ebenso des schwielig anfgetriebene Nahtrand jederseits am Schildchen glänzend weissgelb. Auch das Pygidium dicht siebartig pumktirt, auf' der oberen Iälfte geschwärzl, der unteren weissgelb; die Unterseite dünn greishaarigg, schwärzlich, der Hinterleib an den Seiten verwaschen gelbgreis gerandet. Die Beine schmutzig bräunlich gelb, Spitzen und Wurzeln der Schenkel mit den Vorderhüften ins Weisslichgelbe fallend. Das letzte Segment des $q$ mit dem gewöhulichen, hier ziemlich unscheinbaren Grübchen; das $\delta$ unlıekannt.

Von Cayenne (Mus. Clark). 


\section{Ambrotodes m.}

A ug en ausgerandet.

Rüclientheile nach oben frei beweglich.

Vorderbrust länger als breit, die Mitte entlang aufgewulstet und jederseits deutlich längsfurchig, hinten in einen stumpfdreieckigen Zipfel auslaufend, ohne Halskragen.

Schildchen vorhanderl.

Der Kopf ist bei den wenigen hierher gehörenden Arten flach; die kleinen Augen bei beiden Geschlechtern weit getrennt, nicht ausgebuchtet, sondern nur leicht ausgerandet, die fadenförmigen Fühler vou melır als halber Körperlänge.

Das $\mathrm{H}$ alsschild ungewöhnlich kurz, breit und flach, nach vorn verschmälert und sanft abwaärts gekrümmt, vor dem Hinterrande tief quer eingedrückt, mit stark vortretendem Mittelzipfel. Die Oberfläche grob punktirt mit glänzendem Zwischengrunde, schwarz mit mehr oder weniger ausgedehnter lichter Zeichnung.

Das Schildchen schräg ansteigend, so breit oder noch etwas breiter als lang, mit deutlichem Hinterzipfel, glänzend schwarz.

Die Deckschilde gestreckt, mehr wie dreimal länger als das Halsschild, hinterwärts etwas verbreitert und den Rücken entlang abgeflacht, Schulterbeulen und Seitenlappen von geringer Entwicklung. Die Punktirung grob, dicht gedrängt, nur an und unter der Wölbung längse Naht und Seitenrand mit Spuren von Streifenbildung, mit glänzendem Zwischengrunde. Die Färbung r'oth oder gelb mit schwarzen mehr oder weniger veränderlichen Zeichnungen.

Unterseite und Beine von selır verschiedener Färbung. Die Vorderbrust grob runzlig punktirt, breit und verhältnissmässig kurz, ohne Halskragen. Die Mitte derselben längswulstig aufgetrieben und jederseits dieser Auftreibung von einer mehr oder weniger furchenartig eingegrabenen Längslinie durchzogen, mit breit dreieckigem Hinterzipfel.

Diese kleine Gattung beschränkt sich auf Chile, und zerfällt in zwei durch den Habitus deutlich geschiedene Rotten, denen voraussichtlich die Ehre, zu besonderen Gattungen erhoben zu werden, über kurz oder lang zu Theil werden wird. Ich will jedoch diese leichte Mühe gern Anderen überlassen, da ich eine solche Trennung bei der geringen Zahl der Arten für sehr überflüssig halte, und sie auch ausserdem höchstens durch habituelle Abweichungen 
begründen könnte, zu denen man nach meinem Dafürhalten nur da greifen darf, wo eine Gattung durch die Ueberzahl ihrer Arten zu einer nicht mehr zu übersehenden Ausdehnung anzuschwellen droht.

Erste Rotte. Das Halsschild vorn stärker übergekrümmt, seitlich breit gerandet, oben zerstreut punktirt, mit stumpf dreieckigem Hinterzipfel. Die Punktirung der Deckschilde måssig dicht: das Halsschild des đ̊ überwiegend geschwärzt.

1. A. chilensis Blanch. Schwarz, der Kopf, das zerstreutpunktirte Halsschild und die Unterseite weiss- oder bleichrüthlichbunt, die Deckschilde roth (oder strohgelb) mit zwei unterbrochenen schwarzen Querbinden, grob punktirt mit glänzendem Zwischengrunde.

ð. Ein Fleck am Kopfe, Vorder- und Seitenrand des Halsschilds, und zuweilen ein paar Fleckchen vor dessen Hinterrande wejss oder röthlich.

․ Drei Flecken am Kopfe, das Pygidiun, ein oft unterbrochener Seitenrand des Hinterleibes, der Mittelzipfel des ersten Ringes und ein Fleck vor den Schenkelspitzen weiss: das Halsschild bleichröthlich mit vier hinten zusammenfliessenden schwarzen Löngsflecken.

L. $21 / 4-2{ }^{2} / 3 " \prime ; B r .1-11 / 2 "$.

o Cryplocephalus chilensis Blanchard in Gay Hist. fisica etc. de Chile. V. 538. n, 2. cf. Philippi Ent. Zeit. 1864. S. 388.

\& Cryptocephalus elegans Blanch. ibid. 537. n. 1. tab. 31. fig. 8.

Ein sehr eigenthümlicher Käfer, welcher nach seiner Färbung und Farbenvertheilung gar sehr an die europäische Gruppe des Cryplocephalus variabilis erimnert und darlurch auch den ersten Beschreiber verleitet zu haben scheint, ilhm unter den echten Cryptocephalen seine Stelle anzuweisen, zu denen er nach dem Bau seines Halsschilds in keiner Weise gehören kanu. Der Kopf flach gewölbt, die Stirn des Länge nach stärker oder schwächer eingedrückt, bei tieferem Eindrucke oben jederseits desselhen buckelig aufgetrieben und unterwärts zwischen den Fühlern in die Quere stärker emporgehoben; die Oberfläche fein punktirt, mit glänzendem Zwischengrunde. Die Punkte längs den kleinen nur sebr flach ausgerandeten Augen gröber und dichter zusanmengedrängt, auch das etwas eingezogene, oben nicht abgesetzte liopfschild dicht und fein punktirt, dadurch matt, und mit feinen, zer- 
streuten Härchen besetzt. Die Farbe schwarz, bei dem $\delta$ ein manchmal zu einem Punkte geschwundener Querfleck zwischen den Fühlerhöckern weiss oder blejch geröthet, auch der Unterrand der Oberlippe verwaschen gebräunt; hei dem $q$ ist jener Fleck grösser, mit den Enden bogig nach unten gekrümmt, dazu sind noch die Wangen und ein grösserer Schrägfleck oben zwischen der Stirnrinne, und den Augen gleichfalls bleichroth oder weisslich. Das Endglied der Taster nur bei dem $q$ nach vorn verschmälert, bei dem ơ gleichbreit, vorn schräg abgestutzt und daselbst leicht gebräunt. Die Fühler von mehr als halber Körperlänge, schlank fadenförmig, das Wurzelglied aus sehr dünner Basis plötzlich stark keulenförmig aufgetrieben, wenig gekrümmt, das zwveite eiförnig, um die Hälfte länger als breit, die nächstfolgenden schlank verkehrtkegelförmig, das dritte doppelt läıger als das zweite, das vierte wiederum doppelt länger als das dritte, das fünfte und sechste je unı die Hälfte länger als das vierte, die oberen wieder je den! dritten gleich, schwach zusaminengedrückt und erweitert, das Endglied fast gleichbreit, mit deutlichem, durch eine Ausrandung abgeselztem Fortsatze. Die Farbe der fünf unteren röthlich, die Spitze des fünften und die IVurzel des sechsten gebräunt, die Oberseite des Wurzelgliedes geschwärzt; die oberen Glieder schwarz, dïnn behaart und mit vereinzelten weisslichen Wimpern besetzt. Das Halsschild mehr wie doppelt breiter als lang, vorn mit halber Länge kugelig übergebogen, die kurzen breiten Vorderecken etwas vorgezogen; die Seiten sehr breit gerandet und in der Mitte bogig erweitert; auch die Hinterenden kurz und breit, hinterwärts ein wenig heraustretend: der Hinterrand jeder'seits in einem breiten und flachen Bogen ausgeschnitten, mit stumpf dreieckigem, etwas aufgebogenem Mittelzipfel. Vor dem letzteren ein den Rand etwas auftreibender, seitlich abgeschwächt sich bis zu den Hinterecken hinziehender Quereindruck, auch jederseits über der Erweiterung des Seitenrandes das Mittelfeld mehr oder weniger tief aber breit quer zusammengedrüclit. Der abgesetzte Seitenrand mit gröberen Punkten besetzt, die übrige Oberfläche zerstreut-, bei dem $\delta$ gröber als dem \& punktirt, mit spiegelglänzendem Zwischengrunde. Die Farbe schwarz, die Zeichnumg auch hier bei beiden Geschlechtern sehr abweichend. Bei dem $\delta$ manchmal nur ein verwaschener, vor den Hinterecken unterbrochener, vorn etwas fleckartig erweiterter Seitenrand und ein dreieckiges Fleckchen auf der Mitte 
des Vorderrandes gelb, oder letzteres ist noch mit der gleichzeitig etwas ausgedehnteren Färbung der Vorderecken durch einen schmalen Randsaum verbunden, oder die lichte Zeichnung dehnt sich soweit aus, dass der Vorderfleck sich zu einer hinterwärts gerichteten abgekürzten Hittellinie ausbildet, auch hinten der aufgeworfene Rand des Mittelzipfels sich hell färbt, und vor demselben jederseits ein röthlicher Querfleck zum Vorschein kommt. Diese letzteren Stücke bilden den Uebergang zu der normalen Zeichnung des $q$, bei welcher die lichte, in der Mitte röthliche und nach den Rändern zu ins Gelbliche verbleichenden Färbung soweit die Oberhand bekommt, dass sie füglich als die Grundfarbe angesehen verden kann. Dann bleiben auf dem hellen Grunde ausser einem manchmal fast unscheinbaren Fleckchen hinter der Mitte des Seitenrandes nur vier schwarze bald hinten zusammenhängende, bald ganz getrennte Längsflecke übrig, die beiden mittleren nach vorn schwach divergirend und bis auf den abwärts gekrïmmten Theil des Halsschilds reichend, die beiden seitlichen stets mit breiler Basis auf dem Hinterrande ruhend, aber kürzer, noch mehr verschmälert und stärker nach Aussen gekrümmt. Solche $\&$ mit hinten zusammenhängenden Flecken stellt die angeführte Abbilduug in dem Atlas zoológico. - Entomologia, Coleopleros, Läm. 31. fig. 8 treffend dar. Bei einzelnen, übrigens auch vollstäıdig ausgehärteten $q$ Stïcken ist die Grundfarbe des Halsschilds, wie auch die der Deckschilde rein strohgelb; derartig gefärbte $\delta$ sind inir aber unter den mir in ziemlicher Anzahl vorliegenden Exemplaren des Käfers noch nicht vorgekominen. Das Schildchen stark ansteigend, quadratisch, vorn im Bogen leicht quer eingedrückt, hinterwärts fast ein wenig erweitert, grade abgestutzt und mit den Hinterenden etwas abwärts gekrümmt, spiegelglänzend schwarz, mit vereinzelten Pünktchen bestreut, zuweilen auch mit unı'egelmässigen Längseindrücken besetzt; der kurze breit dreieckige Hinterzipfel deutlich. Die Deckischilde gestreckt, um die Hälfte länger als breit und ziemlich gleichbreit, hinten mit kurzer flacher Wölbung abfallend, auch der Rücken längs der Naht abgeflacht. Die Schulterbeulen haum bemerkbar, auch die Seitenlappen schwach, und über ihnen je ein muldenförmiger Längseindruck, ron dem sich eine schwächere Spur längs der vorderen schwarzen Querbinde den Rüchen hinaufzicht. Die kaum aufgeworfene Wurzel punktfrei und stark glänzend, der ührige Theil der Oberfläche grob aber nicht sehr dicht siebartig 
punktirt, mit fein runzlig zerrissenem, aber doch glänzendem Zwischengrunde; auf dem letzten Viertel werden die Punkte feiner, mehr vereinzelt und zeigen auf der Wölbung Andeutungen von Streifenbilduog, nanientlich längs der Naht; die unter der Wölbung ein wenig eingedrückte Spitze dicht und fein runzlig punktirt. Bei einzelnen kleineren $\delta$ ist die Punktirung zwar nicht gröber, aber doch dichter, und bis zur Spitze von gleichmässiger Stärke. Die Farbe ziegelroth und dann besonders bei grösseren Stïcken längs der Ränder, zumal hinterwärts, mehr oder weniger ins verwaschen Gelbliche fallend, oder, wie bemerkt, bei einzelnen $f$ auch ganz strohgelb; ein längliches Fleckchen auf den Schulterbeulen, und zwei zackige, augensclieinlich auch aus Flecken izusammengesetzte und deshalb öfters unterbrochene oder nach Aussen algekürzte, seltener ganz in Fleckchen aufgelösete Querbinden schwarz. Die erste vor, die andere linter der Mitte, letztere bei vollständiger Ausbildung je aus einem Querflecke an der Naht, einem nach vorn und Aussen gerichteten Sclurägflecke und einem Querflecke am Rande bestehend, daher mit dem inneren Ende hinterwärts zurücktretend; erstere ans einem Längsfleckchen an der Naht, einem unregelmässig vièreckigen, mil einer Spitze nach vor'n gerichteten Hittelfleck und einem meist vereinzelten Randflecke gebildet, daher mit ihrer Mitte zipfelförmig nach vorn erweitert, die Naht zwischen beiden B̄inden gewöhulich schwarz gesäumt. Im Allgemeinen ist diese Zeichnung bei dem $\delta$ weniger ausgebildet, häufiger unterbrochen oder nach Aussen abgerissen, auch das Schulterfleckchen nicht selten fehlend; es finden sich aber auch $q$, bei denen die Binden zerrissen, ja theilweise geschwunden sind, und in solchen Fällen sind dann die übriggebliebenen Fleckchen häufig brandiggelb gesäumst: überhaupt aber pllegl, wenn derartige Abschwächungen vorhanden sind, die zweite Binde davon stärker betroffen zu werden als die erste. Das Pygidium grob punktirt, bei dem $\delta$ schivarz, dem $\&$ weissgelb. Auch die Unterseite mit den Beinen schwarz, ein Querfleck auf den Schulterblättern, der Mittelzipfel des ersten Bauchringes und die Schenkelspitzen mit den Hüften weissgelh. Bei dunkleren zunal kleineren $\delta$ sind Unterseite und Beine bis auf die stets weisslich bleibenden Hüften ganz schwarz; andrerseits sind bei den ? die weissen Zeichnungen an Unterseite und Beinen ausgedelınter und klarer, auch greift die weisse Firrbung des Pygidiums jerlerseits auf den letzten Bauchring hinüher, und letzterer 
zeigt jederseits des Mittelgrübchens noch einen weisslichen Punkt, seltener sind auch noch die Hinterenden der Parapleuren und die Seitenzipfel des ersten Bauchringes weiss, und die Vorderschienen unten auf der Innenseite bräunlich oder röthlich angelaufen. Das Prosternum breit und flach, vereinzelt grob punktirt, mit längerer greiser Behaarung sparsam besetzt, mit seinem dreieckigen Hinterzipfel auf der quer viereckigen Mittelbrust aufliegend; die Farbe von beiden schwarz, die Mitte der Vorderbrust bei dem $q$ mit einem weissliclıen Längsflecke. Das letzte Segment des $\delta$ einfach, des $\&$ mit der gewöhnlichen rundlichen, hier sehr tiefen Grube.

Aus Chile, und daselbst nach Gay bei Coquimbo, Santa Rosa, Santiago und an anderen Orten einheimisch (Mus. Dohrn. Schaum. Deyrolle. Clark. Schaufuss. Vindob. Berol.).

$\mathrm{Z}$ weite Rotte. Das Halsschild vorn nur kurz und schivach übergekrümmt, seitlich fein gerandet, oben dicht und grob runzlig puuktirt, mit liurzem, breit abgerundetem Hinterzipfel. Auch die Deckschilde dicht und grob runzlig punktirt, rötlılich oder gelblich, mit mehr oder weniger ausgedehnten dunkleren Zeichnungen.

2. A. ignobilis m. Schwarzgrün, Fühlerwurzelı, Oberlippe und Hüften, sowve das derb und diclıt punktirte Halsschild und die Deckschilde roth mit theilweise zusammenfliessenden buchtigen schwarzgrünen Flecken der leızteren; auch die Deckschilde grob punktirt mit seidig glänzendem Zwischengrunde. L. $2-2 \frac{1}{2}{ }^{\prime \prime \prime}$; Br. $1-1 \frac{1}{\prime \prime \prime}$.

Wie die vorhergehende Art eine gewisse äussere Aehnlichkeit mit einer Gruppe der echten Cryptocephalen, so zeigen die Arten der gegenwärtigen eine solche mit einzelnen Pachybrachen-Formen, weshalb auch $\mathrm{Hr}$. Blanchard die einzige ihm bekannt gewordene zu der Gattung Pachybrachys gebracht. Allein bei genauerer Betrachtung heschränkt sich jene Aehnlichkeit auf eine Uebereinstinmung im Baı von Seiten und Hinterzipfel des Halsschilds, während die ganz abweichende Beschaffenheit der Vorderbust diese Arteı vielmehr zu der vorhergehenden in die nächste Beziehung stellt. Bei der vorliegenden ist der Kopf flach, längs der Stirn seicht niedergedrückt, und diese zuweilen eine Spur einer feineren Längslinie zeigende Stelie in Nacken zu einer breiteren Mulde erweitert. Die Punktirung dentlich und ziemlich dicht mit etwas glănzendem Zwischengrunde, die Farbe dunkel schwarzgrüı mit rother Oberlippe, das Kopfschild bei einem (dem dunkelsten) der 
drei vorliegenden Stücke gleichfalls roth, dem zweiten nur unten breit gerötliet, dem dritten, wie der übrige Theil des Kopfes, schwarzgrün. Die breit aber sehr seicht ausgehuchteten, weit getrennten Augen greis. Die Fühler von $2 / 3$ der Körperlänge, düun und schlank, ılas Wurzelglied breit eiförniig aufgetrieben, das zweite kurz elliptisch, die drei folgenden dünn verkehrtkegelförmig, etwa gleich lang und je treimal länger als das zweite, die folgenden sehr schwach dreieckig erweitert und zusammengedrückt, das sechste und siebente je kaum kürzer als das fünfte, die drei folgenden allmählich sich verkürzend, und das Endglied mit seinem spitzdreieckigen Fortsatze wieder dem fünften gleich. Die Farbe der fünf unteren röthlich mit einer schwarzen Längslinie auf ihrer Oberseite, der oberen schwarz mit sehr dünner angedrückter greiser Behaarung. Das Halsschild $2 \frac{1}{2}$ mal breiter als lang, über die Mitte leicht quer aufgewölbt, mit nach vorn sanft abwärts gekrümmter, hinterwärts stärker abfallender Mittelfirste, über den scharf spitzwinkligen Vorderecken breit zusammengedrückt und dadurch verschmälert; die Seiten sehr fein gerandet, in der Mitte sanft zugerundet, mit stumpfwinkligen Hintereckes, der Hinterrand jederseits leicht geluchtet, mit einem kurzen, breiten, ziemlich stark emporgerichteten Mittelzipfel: vor dem letzteren jederseits ein tiefer mit den Enden schräg nach vorn ziehender Quereindruck, welcher sich über der Mitte des Seitemrandes noch zu einer flacher oder tiefer eingedrückten Mulde erweitert. In den Hinterwinkeln zeigt sich noch ein zweiter, flacherer Eindruck, und zwischen diesem und dem Mittelzipfel längs dem Hinterrande eine mehr oder weniger deutlich emporgeschobene Querfalte. Die Punktirung kräftig und ziemlich diclst, besonder's in den Hinterwinkeln runzlig verfliessend, mit glänzendem Zwischengrunde; die Farbe hellroth, der aligesetzle Hinterrand mit dem Mittelzipfel und einem vor letzterem liegenden zugespitzten Längsflecke schwarzgrïn, und dieselbe Färbung zeigen auch zwei hakenförmige dicke rechtwiuklige Flecke, deren Hinterarme auf dem Hinterrande stehen, während die rechtwinklig angelïgten Seitenarme sich nach innen richten und mit dem Mittelflecke ein zerrissenes plumpes [I] darstellen. Bei dunkleren Stücken fliessen diese drei Flecke wirklich zu einer derartigen plumpen Zeichnung zusammelı, und zeigen dabei überall verwaschene Ränder, welche auf ein weiteres Ueberfliessen hiıdeuten, und es mögen sich deshalh auch wohl noch Stücke finden lassen, 
bei denen das ganze Halsschild bis etwa auf einen schmalen Vorder- und Seitenrand sich schwarzgrün färbt. Das Schildchen stark ansteigend, fast so lang wie vorn breit, mit leicht gebuchteten Seiten hinterwärts verschmälert, mit deutlichem Hinterzipfel grade abgestutzt, schwarz. Die Deckschilde gestreckt- und flach walzenförmig, fast um die Hälfte länger als breit, hinterwärts deutlich verbieitert, hinter der scharfen Vorderkante schmal quer gefurcht, dicht hinter dem Schildchen und dann nochmals vor der Mitte leicht quer eingedrückt; die länglichrunden Schulterbeulen eckig heraustretend, die Seitenlappen schwach, und über ihnen die Deckschilde breit zusammengedrückt. Die Punktirung dicht und ziemlich derb, stellenweise zu Runzeln verfliessend, von vorhanden gewesenen Punktstreifen nur hier und da schwache Spuren, indem auf dem Rücken der zweite und vierte, weiter auswärts der achte Zwischenraum als feine Längsrippen einigermassen keuntlich werden: auf dem letzten Drittel vereinzeln sich die Punkte nehr, werden feiner, und lassen die Reste der Punktstreifen klarer hervortreten, deren Zwischenräume dann auch als leichte Längsrippen wahrnehmbar sind. Der Zwischengrund ziemlich glänzend, die Farbe roth, eine die Schulterbeule miteinschliessende, aber weder Naht noch Schulter erreichende, auch den inneren grösseren Theil der Vorderkante frcilassende Querbinde auf jeder Flügeldecke und ein mit beiden Armen nach vorn gerichteter dicker lıfeisenförmiger Querfleck hinter deren Mlitte schwarzgrüı. Aendert jedoch ab

$\beta$. der Hinterfleck seitlich mit verwaschener Begränzung zur Naht und dem Seitenrande überfliessend, längs der ersteren nach vorn fast bis zum Schildchen verlïngert, und auch die Vorderbinde in gleicher Weise nach Innen ausgedehnt; und

$\gamma$. die dunkle Zeichnung intensiver geworden und beide Arme des Hinterflecks nach vorn soweit rerlängert, dass sie mit der Vorderbinde zusammentreffen. Die Flügellecken sind dann schwarzgrün, nur die breite Spitze, eine abgekin̈zle Längshinde auf der Mitte, der aufgeworfene Schulterkielrand, das Innenende der erhöhten Vorderkante und deren kurze Fortsetzung längs der Naht hinter dem Schildchen roth. Möglicherweise gibt es auch Stücke, bei denen diese rothe Färbung noch weiter verschwindet.

Pygidium, Unterseite mol Beine schwarz, die Schenkelwurzeln, Vorderhüften, und die unteren Schienenenden in melı oder weniger grosser Ausdehnuug geröthet. Die Vorderschenkel stark ver- 
dickt mit entsprechend verlängerten und gekrümmten Vorderschienen. Das Prosternum groh punktirt. Das letzte Segment des ठ quer niedergedrückt und in der Nitte noch mit einem flachereı Längseindrucke, des 9 mit einer ziemlich tiefen, rundlichen Grube.

Aus Chile, ohue nähere Angahe des Fundorts (von Hrn. Burchard mitgetheilt).

3. A. signatipennis Blancls. Schmutzig rostgell, der Kopf und das groh punktirte Halsschild schwarzbunt, das Schildchen, die Brust und zwei hinten zusammenstossende Längsflecke der Flügeldecken nebst den Schulterbeulen schwarz; die Deckschilde dicht und grob punktirt nit glänzendem Zwischengrunde. L. 2$2 \frac{1}{2}{ }^{\prime \prime \prime} ; \mathrm{Br} .1-1 \frac{1}{4}{ }^{\prime \prime \prime}$.

Pachybrachys signatipennis Blanchard in Guy Hist. fisica etc, de Chile. V. 540. ก. 3 .

Von gleicher Länge mit dem vorigen, alıer etwas breiter, hinterwärts deutlicher verbreitert, ïbrigens denselben nahe verwandt. Der Kopf flach und der Länge nach seicht niedergedrückt, mit einem flachen, rundlichen Grühchen üher dem wieder etwas eingezogenen Kopfschiłde, dicht und derh punktirt, mit lackgliinzendem Zwischengrunde. Die Farbe schwarz, die Mitte des Kopfschilds mit Oberlippe, Wangen und Kinnbacken, wie auch zwei grosse von Oben und Innen nach Unten und Aussen sich herabstreckende rhombische Schrägflecke auf der Stirn hochgell; diese Zeichuung bald mehr oder weniger ausgebildet und klar, bald nur verwascheı begränzt, zuweilen so ausgedehnt, dass auch der untere innere Augenrand bis in clie Augenhuchten hinein sich mit unregelmässiger Begränzung gell fïrbt. Die Augen Jang aber nicht tief ausgebuchtet greis. Die Fühler (des $\dot{q}$ ) von mehr als halber Körperlänge, sehr düun unıl schlauk fallenförmig; das Wurzelglied breit eiförnig aufgetrieben, etwa um die Hälfte länger als breit, das zweite kurz eiförmig, kaun halb so lang und breit wie das erste und gleichfalls etwa um die Hälfte länger als breit, die drei folgenden gleich lang, fast linienförmig, je etwa dreimal länger als das zweite, die sechs oberen leicht zusammengedrückt und erweitert, an Lïnge allıälılich aber nur schwach abnehmend, das Endglied mit dreieckigem kurz abgesetztem Fortsatze. Die Farbe der fünf unteren gelblich, die Olıerseite der beiden unteren manchnal schwïrlich angeflogen, das füıfte an der Spitze gebräunt, die oberen schwarz, fein angedrüclit greishaarig und an den Spitzen vereinzelt gewimpert. Uas Hals- 
schild etwa $2 \frac{1}{2}$ mal breiter als lang, vor der Mitte leicht quer aufgewölbt, die Vorderecken scharf und spitz vorgezogen, die hinteren gleichfalls seharf aber stumpfwinklig, etwas aufgebogen; die fein gerandeten Seiten in der Mitte bogig erweitert, vor ihr kaum merklich ausgeschweift, der Ilinterrand leicht wellig gebuchtet, mit breitem aber sehr kurz aufgehogenem Nittelzipfel. Vor dem letzteren ein breiter, aussen nach vorn gekrümmter Quereindruck, dessen Enden bis über die Mitte des Seitenrandes hin bemerkhar sind und anscheinend die Masse des IIalsschilds soweit hinabdrängen, dass sie hier als eine bogenförmige Erweiterung der Seiten hervortritt. Die Punktirung grob und ziemlich dicht, stellenweise zu Runzeln verfliessend, mil lackglänzentem Zwischengrunde. Die Farbe, welehe Blanchard mpassend als schwarz bezeichnet, ist bei den am klarsten gezeichneten Stücken hochgelb mit schwarz gesäumter Mitte des Hinterrandes und einer plumpen und dicken schwarzen Zeichnung in Giestalt eines (D, sodass die trei Hinterenden auf dem schwarzen Saume des Hinterrandes ruhen, wăhrend die beiden vorderen Bogen den Vorderrand nicht berühren. Bei einzelnen Stücken ist der Zusammenhang dieser Bogen mit ler dicken Mittellinie unterbrochen, wähı'end bei anderen die schwarze Färbung mit verwasehen geworlener Begränzung soweit um sich greif, dass der Innenraum beider Bogen sich theilweise füllt; das Halsschild wirl dann überwiegend schwarz, und nur ein breiter Seitenrand, ein sehmaler Vordersaum und zwei vereinzelte Hinterflecke verbleiben gell)lich. Was Schildchen stark ansteigend, mit etwas ausgebuchteten Seiten von der Mitte ab wenig verschmälert, mit kurzem aber deutlichem Hinterzipfel abgestutzt, glänzend schwarz. Die Deckschilde breit und flach gewölbt, $\mathbf{m}$ fast die Ilälfte länger als breit, mit hinten stark ablallender Wölbung; die fein aber scharf aufgeworfene Vorderkante durch eine schwache Querfurehe abgesetzı, seitlichı an die länglichen, stark hervortretenden Schulterbenlen angeschlossen; die Seitenlapjen von mässiger Stärke, und über ihnen je ein tiefer, rundlicher Eindruck. Die Punktirung vor'n grob und dicht, liaum mit Andeutungen begimender Streifenbillung; in der Verhängerung der Scluulterbeule als Analogon des achten Zwisehen'aums eine zienlich deutliche Längsrippe. Von der Mitte al wird die Punktirung feiner und sparsamer, die Streifenbildung etwas deutlicher, tritt aber erst auf der Wölbung mit mehr erkennbarer Entwickelung einiger breiter und 
flacher Zwischenräume hervor. Die Farbe gleichfalls hochgelh, manchmal leicht ins Rostgethe fallend, der Kiel des Seitenlappens zuweilen starh ins Weissliche verbleichend, die Naht mit der Spitze und dem linteren Theile des Aussenrandes schwarz gesäumt. Ausserdem ist das Innere der Punkte schwarz, und dieselbe Färbung zeigt ein verwaschener Fleck an der Wurzel zwischen Schildchen und Schulterbeule, ein Längsfleck auf der letzteren, und eine ahgekürzte doppelte Längsbinde hinter der Mitte der Flïgeldecken, deren äusserer meist stärkerer Arm in der verlängerten Richtung des Schulterflecks liegt, während von dem inneren zuweilen sich eine wischartige Verlängerung nach der inneren Seite des letzteren hin bildet. Gewölınlich erweitern sich beide Arme hinterwärts dreieckig, und treffen dann auch wohl ınit dem Hinterenden in einem schmalen Bogen zusammen; die gelbe Färbung pflegt sich zunächst un sie zu trüben, zwischen ihnen dagegen und besonders in der Winkelspitze ins Weissliche abzubleichen, als ob durch die Bildung der Binden der dazwischen liegenden Fläche alles dunkle Pigment entzogen worden wäre. Pygidium, Hinterleib und Beine schmutzig gelb mit gebräunten Füssen; die Aussenkante der Vorder- und Mittelschenkel, sowie der Hinter-, auch wolıl der vorderen Schienen manchmal leicht gebräunt. Die Vorderschenkel stark eiförmig verdickt, mit entsprechend gekrümmten Schienen. Die Brust schwarz mit einem helleren Längsfleck auf der Mitte des Prosternums: letzteres grob punktirt und ziennlich breit, die Ausbildung des Hinterzipfels bei den verschiedenen Stücken sehr verschieden, und vom stumpfureieckigem bis zum langpfriemlichen abändernd; der flache Längswulst auf der Mitte des Prosternums davon jedoch nicht berührt. Das letzte Segment des $q$ mit einer ziemlich tiefen, rundlichen, stark glänzenden Grube, das ơ unbekannt.

Gleichfalls aus Chile (Hus. Riehl. Iohrn., auch von Hrn. Burchard mitgetheilt. Als specielle Fundorte werden von Hr. Blanchard Santa Rosa und Conception genannt.

Unbekannt gehlieben sind mir die nachstehend verzeichneten, von den Schriftstellern erwälınten Arten.

I. Cr. lineatus Fab. „Rufescens, thorace maculis, elytris lineis duabus nigris. 
Habitat in Brasilia. Uus. Dom. Banks.

Caput nigrum, fronte rufescente. Antennae thorace longiores, filiformes, nigrae, basi rufescentes. Thorax maculis duabus magnis, dorsalibus, nigris. Scutellum uigrum. Pedes nigri femoribus basi rufis."

Fal. Ent. Syst. II. 55. n. 13. Syst. Eleuth. II. 42. n. 6.

Dieselbe Art beschreibt auch Olivier Ent. VI. 787. n. 5 aus derselben Sammlung und mit denselben Worten, nur zwischen den beiden letzten Sätzen der Descr. mit dem Einschiebsel: „Elytra rufescentia, villis duabus longiludinalibus nigris, allera ad marginem, altera ad suluram. Corpus sublus rufescens." Ich wage jedoch die Art hiernach nicht zu deuten, und auch Oliviers Ablildung Tab. III. fig. 39 . gibt darüber keine Auskunft, obwohl sie eine rohe Aehnliclukeit mit Eumolpus bigalus Germ. zu verrathen scheint. Uehrigens ist der Käfer im Mus. Fabr, noch vorhanden.

II. Cr. modestus Fab. "Thorace rufo, elytris flavis rufolineatis.

Habitat in America meridionali. D. Smidt. Mus. D. Lund.

Medius. Antennae elongatae, ferrugineae, apice fuscae. Caput et thorax glabra, rufa, nitida. Elytra flava nitida, lineis numer'osis, punctatis, rufis, intermediis duabus ante apicem coeuntibus. Corpus flavescens."

Fab. Syst. Elentl. II. 42 . 1. 10.

In Fubricius Sammlung fehll der Käfer, welcher nach der Angahe üher die Sculptur der Flingeldecken ein Pachybrachys sein könnte.

III. Cr. impressus Fab. „Ater, thorace punctato, elytris sulcatis; sulcis rugosis.

Ilabitat in America meridionali. I). Smidt. Mus. 1), de sehestedt.

Thorax punctis numerosissimis impressus. Elytra striis elevatis, hinc inde interruptis, sulcata, sulcis rugosis."

Fab. Syst. Eleuth. II. 45, n. 25.

Vielleicht ein dunkles Stück meines Sc. sulcipcnnis oder einer verwandten

Art. Im Mus. Fab. fehlt derselle ebenfalls.

IV. Cr. obliquus m. „Rufus, elytris oblique striatis, pedibus flavescentiluss.

Habilat in America meridionali. D. Smidt. Mus. D. Lund.

Statura ommino Cr. congesti. Thorax laevis, rufus, nitidus, immaculatus. Elytra uti in Cr. congesto ohlique striata, rufa. Pedes flivescentes."

Fab. Syst, Eleuth. I1. 47, n. 35. 
Die Beschreibung ist so allgemein, dass daraus Nichts für das Erkennen des in Fabricius Sammlung gleichfalls nicht vorhandenen Käfers zu entnehmen ist.

V, Cr. cinctus Fab. „Capite thoraceque rufis, elytris nigris margine jufo.

\section{Habitat in America meridionali. D. Hunter.}

Antennae fuscae basi rufae. Elytra striato-punctata, nigra, margine anteriori late rufo. Pedes rufi, geniculis nigris."

Fab. Ent. Syst. Il. 63. n. 53. Syst, Elenth. II. 48, n. 40.

Denselben Käler beschreibt auch Olivier Ent. VI. 824. n. 67. aus derselben Sammlung und mil denselben Worten, nur mil dem Zusazze: „Magniludo $C r$. villati." Die französische Beschreibung enthält uoch einige weitere Angaben: „L' ecusson est rougeâtre cl arrondi postérieurement. Les élytres ont des stries formées par des points enfoncés; elles sont noires, avec les bords lateraux d' un rouge fonce. Le dessous du corcelet est rougeâtre. La poitrine est noire, avec les côtés rougeâtres. L' abdomen est noir, avec un peu des bords rougeâtre. Les pattes sont d' un roux brun, avec les articulations des cuisses el les tarses noirs." Ich vermag die Art weder nach dipser Beschreibung noch nach der beigegebenen Abbildinng Tab. VI. fig. 97. zu bestimmen; in Fabricius Sammlnng fehlt sie, wie fast alle von ihm hescluriebenen Hunter'schen Käfer.

VI. Cr. li mbatus Fab. „Ferrugineus thorace rufo, elytrorum suturis cyaneo-nitidis.

Habitat Cayennae. D. Schulz.

Elytrorum margines omnes cyanei, nitidi."

Fab. Ent. Syst. II. 64. n. 60. Syst. Elenth. II. 50. n. 53.

Auch diese Art ist im Mus. Fab. niclıt mehr vorhanden.

VII. Clytlua bipustulata Fab. Atra, capite, thorace elytrorumque macula disci rufis.

IIabitat in America meridionali. D. Smidt. Mus. D. Lund.

Statura et summa aflinitas praecedentis [1. 55. clytra bicolor Fab. Monachus bicolor m.], et forte mera ejus varietas. Differt imprimis puncto elytrorum ferruginco. Femora antica rufa."

Fab. Syst. Elenth. II. 40. n. 56.

Ohne Zweifel ein Monachus, und zwar cine muthıaasslich schon beschriebene Art aus des Reilie des H. rubropustulatus Stal und seiner Verwandten, aber bei der Allgemeinheit obiger:Angaben ohne Vergleich von F. Sammlung, in welcher der Käfer noch vorhanden ist, nicht $\mathrm{zu}$ bestimmen.

XVI. 
VIII. Cr. glabratus Fab. „Violaceus, thorace elytrisque viridi-aeneis, antemis fuscis.

llabitat in Brasilia. Mus. Dom. Banks.

Caput aeneum froute canaliculata. Antenuae fuscae basi ferrugineae. Elytra levissima. Subus totus violaceus."

Fab. Ent. Syst. II. 64. n. 5S. Syst. Elenth. II. 49. n. 48., wo jedoch die mnrichtige Vaterlaudsangabe: „Ilubital in turopae anstralioris graminosis" nach der Augabe in der Ent. Syst. zu berichtigen ist, auch die drei beigefügten Citale gestrichen werden müssen, da diese unrichtigen Angaben hier augenscheinlich von $C r$. vittalus $n$. 52. nochmals wiederholt sind.

Auch Olivier Ent. VI. S18. n. 57 heschreilı den Käfer ans derselben Samminng und fast mit denselten Worten, setzt aber als weitere Bestimmungen nach hinzz: „Crypt. sericeo paulo minor. - - Caput viridi-aeneum, fronle canaliculala. - Elytra vix punctalo-striata (elles ont des stries pen murquees, formees par des points enfoncés, à peine distincts)." Die rohe Ablildumg Talb. III. fig 41. gibt keinen Aufschluss über die Arl, welche auch im Mus. Fub, nicht vorhanden ist.

IX. Cr. I o ugimanus 0liv. "Thorace rubro nitido, elytris punctato-striatis cyaneis, pedibus auticis elongatis.

Parvus, cylindricus. Antemnae nigrae, bạsi testaceae, fere longituline corporis. Caput antice flavotestaceum. Oculi magni reniformes nigri. Thorax laevis ruber. Scutellum rulnum. Elytra cyanea, punctis magnis impressis seriatis. Pectus. abdomen et pedes quatuor postici flavi, geniculis nigris. Pedes antici longiores nigri, basi, femorum tilbiarumyue inferiori parte pallidis.

Il se trouve à la Guyane française. Du cabinet de M. Richard."

Olivier Eut. VI. 826. 1. 71. Tab. VI. fig. 101.

Anscheinem ein Scolochrus.

X. Cr. juvencus Oliv. "Sujura fusco-sanguineus, elytris punctato-striatis hasi fitsciaume pustica nigris.

Miuntus. Antenuar nigrae lasi rufar. Caput nigrum. Thorax subtilissime punctulatus, obscure sanguineus, macula dor'sali nigra. Scutellum oblongun nigrum. Ejytra punctato-striata fusco-sanguinea, fasciis dualus, altera baseos, altera ver'sus apicem, marginem non attingentibus, nigris. Corpus nigrmm. Pedes fusci, tibiis basipue femormm ohscure sanguimeis.

ll se trouve a la Gmyane française. Du calinet de M. Richard." 
Oliv. Ent. VI. 826. n, 72. Tab, VI, fig. 102.

Nach der Beschreibung und dem Unrisse der in der Färbung augenscheinlich zu grell gehaltenen Abbildung ohne Zweifel ein Monachus aus der Gruppe des M. rubromustulatus, vielleicht eine Form von M. punctum Chv., wemn diese Art soweit nördlich vorkommen sollte.

Die von Fabricius noch weiter angegebenen $\Lambda$ rten $C r$. dubius (Syst. Eleuth. II. 53. 1. 69), saliens (il. 57. 11. 92) und saltator (il. 57. u. 93) habe ich hier, weil nicht zu den Cryptocephalen gehörend, nicht mil aufgefühırt. Der erstere ist, wie schon Illiger (Mag. III. 165. n. 69) richtig erkannt hat, ein Eumolpide, und die beiden andern werden schon durch die ilnnen beigelegten Femora saltatoria den Haltikenartigen Chrysomelinen zugewiesen. 


\section{Systematisches Artenverzeichniss.}

1a. Heptarthrius $m$.

1. longimanus Moritz.

1. Monachus Chv.

\section{Rotte.}

1. sulfuripes $\mathrm{m}$.

1b. (63). flavicaudis $\mathrm{m}$.

2. phalacroides $\mathrm{m}$.

3. anachoreta $\mathrm{m}$.

4. nigritulus Boh.

5. umbrinus $m$.

6. picipes Boh.

7. scrobiculatus $\mathrm{m}$.

8. rotundatus Mor.

9. obscurellus m.

10. orbicularis $\mathrm{m}$.

\section{Rotte.}

11. melanospilıs $\mathbf{m}$.

12. peltasta $\mathrm{m}$.

13. furcifer $m$.

14. variabilis Blanch.

15. gemellus $\mathrm{m}$.

16. semicyaneus $m$.

17. bicolor. Fab.

17b. (64) globator m.

18. haematopygus $\mathrm{m}$.

19. cribricollis $\mathrm{m}$.

20. rebellis $\mathrm{m}$.

21. fasciolatus $m$.

22. biplagiatus Boh.

3. Rotte.

23. anthreniformis

24. plagiellus $\mathbf{m}$.

4. Rotte.

25. rubidulus $m$.

26. giganteus $\mathrm{m}$.

27. tumidulus $\mathrm{m}$.

28. pallipes Stål

29. jnvenilis $\mathrm{m}$.

30. coenobita $\mathrm{m}$.
31. seriepunctatus $\mathrm{m}$.

32. brunneus Fab.

33. modestus Bob.

34. consimilis Dej.

35. contractus Bols.

36 . pygidialis $m$.

XV. 82

37 . contrusus $m$.

38. decolorans $m$.

39. rubropustulatus Stål

40. diacreticus $m$.

41. argutulus Dej.

42. rejectus $m$.

42b. (65) curtulus $\mathrm{m}$.

43. punctum Chv.

44. peccator $\mathrm{m}$.

45. quietus $\mathrm{m}$.

46. metallescens $\mathrm{m}$.

47. psammites $\mathrm{m}$.

48. sordidulus $\mathrm{m}$.

- 95

- 97

- 98

- 99

- 101

- 102

- 104

XVI. 7

XV. 106

$-108$

- 109

- 110

- 112

48b. (66) pusellimus $\mathrm{m}$.

48c. (67) microscopicus

\section{Rotte.}

49. Iucidulus m.

IV. 153

$49 \mathrm{~b} .(68)$ splendidulus m. XVI. 12

49c. (69) oblongulus m. - 13

49d. (70) convexicollis $\mathrm{m}$.

50. granarius $m$.

51. binarius $\mathrm{m}$.

- 14

XV. 153

$-155$

6. Rotte.

52. melanippus $\mathrm{m}$.

53. hemichlorus $\mathrm{m}$.

54. acaroides $\mathrm{m}$.

- 113 55. stricticollis Klıg

- 115 56. deplanatus m.

$-157$

$-158$

- 160

- 161

- 163

7. Rotte.

- 117 57. unctus m.

- 166

- 119 58. tenebricosus m.

$-167$

- 121

- 122

- 124

- 126

\section{Rotte.}

59. basilaris $\mathrm{m}$.

60. pustulipennis Sıål 
61. ulcerosus m.

62. babioides $\mathrm{m}$.
XV. 171

$-172$

\section{Cryptocephalus Geoffr.}

1. Rotte.

1. obliquatus $\mathrm{m}$.

1b. (96) pectinicornis m

2. Jubronotatus Blanch.

3. socius Stål

4. crassicollis Blanch.

2. Rotte.

5. abhorrens $\mathrm{m}$.

3. Rotte.

6. costulatus $\mathrm{m}$.

7. bombarda $m$.

8. luteicollis Stål

9. cyanopterus Stål

10. monachodes $\mathrm{m}$.

11. perplexus $m$.

12. cuprascens $\mathrm{m}$.

13. xanthopygus $\mathrm{m}$.

14. chloropterus $\mathrm{m}$.

15. chalcites $\mathrm{m}$.

16. hemixanthus $m$.

17. absconditus $m$.

18. ochropus Stål

19. semicircularis m.

20. indecoratus Stål

21. xanthocephalus $m$.

22. hebetitus $\mathrm{m}$.

23. pasticus $\mathrm{m}$.

23b. (97) compressicollis m. XVI. 20 23c. (98) limitatus $m$.

\section{Rotte.}

24. moribundus $\mathrm{m}$.

25. hippocraticus $\mathrm{m}$.

26. apocryphus $\mathrm{m}$.

27. laesus $m$.

28. leucospilus $m$.

28b. (99) cachecta mi.

29. turgidus $\mathrm{m}$.

5. Rotte.

30. multiguttatus Mns. Fab.? - 228

6. Rotte.

31. aduncus $m$.

32. profugus $\mathrm{m}$.

33 . brunneus $\mathrm{m}$.

\section{Rotte}

34. bisseptemguttatus m.
$-175$

XVI. 16

XV. 177

- 179

$-181$

XVI. 18

XV. 186

- 188

- 190

- 191

- 193

- 194

- 196

- 197

- 199

- 201

- 203

- 205

- 207

- 208

- 210

- 212

- 213

- 214

- 22

XV. 216

$-218$

- 220

- 222

- 224

XVI. 24

XV. 226

- 229

- 231

- 232
8. Rotte.

35. anceps Dej.

XV. $236^{\circ}$

- 236

36 . turbatus $\mathrm{m}$.

XVI. 26

XV. 239

37. silaceus $\mathrm{m}$.

9. Rotte.

38. cordatus $\mathbf{m}$.

- 241

39. consentaneus Dej.

39b. (101) bullatus $\mathrm{m}$.

40. topiarius m.

$-243$

XVI. 28

XV. 246

$40 \mathrm{~b}$. (102) simplicipennis m. XVI, 29

10. Rotte.

41. praeposterns $\mathrm{m}$.

XV. 249

42. incredulus $\mathrm{m}$.

$-251$

11. Rotte.

43. quadrivulnerus $\mathrm{m}$.

$-253$

12. Rotte.

44. cinctellus Mus. Ber.

45. fulvescens $\mathrm{m}$.

- 256

- 258

13. Rotte.

46. miserabilis $\mathrm{m}$.

$-260$

47. formosellus Moritz $\quad-261$

48. atomarioides $\mathrm{m}$. $\quad-263$

49. fusculus $\mathrm{m}$. $\quad-264$

50. fumigatus $\mathrm{m}$. $\quad-266$

51. abbreviatellus $\mathrm{m}$. $\quad-268$

52. nigro-plagiatus Guér. (-flagitiosus $\mathrm{m}$.)

53. consputus m.

- 269

53b. (103) bigatus $m$. XVI. 32

53c. (104) circumfusus $m$. - - 33

54. plicatus $\mathrm{m}$. $\mathrm{XV}, 273$

54h. (105) patulus $m$. XVI. 35

54c. (106) uniformis $m$. $\quad-37$

54d. (107) piceolus m. $\quad$ - 38

54e. (108) liquidus $\mathrm{m}$. $\quad-\quad 39$

54f. (109) obfuscatus m. - 41

54g. (110) melanogastrius m. - 42

54h. (111) urbanus $\mathrm{m}$. - 44

54i. (112) laetificus m. - 45

54k. (113) lividipennis $\mathrm{m}$. $\quad-47$

541: (114) haematopterus $\mathrm{m}$. $\quad 49$

55. impressus $m$. XV. 275

55b. (115) parvicollis m. XVI. 50

56. coeruleolus Moritz XV. 277

57. climactericus $\mathrm{m}$. $\quad 278$

57b. (116) decorus $m$. XVI. 52

14. Rotte.

58. viridi-aeneus Boh.

59. globulosus $\mathrm{m}$.

XV. 281

$-282$

XVI. 54 
60. auratus Fab.

60b. (118) pauxillus $m$.

61. aenescens $\mathrm{m}$.

61b. (119) humilis $m$.

62. misellus $m$.

63. striola $\mathrm{m}$.

15. Rotte.

64. bisignatus Grm.

65 favoplagiatus $m$.

66. consobrinus $\mathrm{m}$.

66b. (120) paleaceus $\mathrm{m}$

67. miniatus $\mathrm{m}$.

68. ventricosus $m$.

68b. (121) rufocinctus m.

69. laqueatıs $\mathrm{m}$.

70. pentagrammus $m$.

70b. (122) sphacelatus in.

71. incommodus $\mathrm{m}$.

72. ellipticus m.

73. nigriventris $\mathrm{m}$.

74. bisulcatus $\mathrm{m}$.

74b. (123) ochrosomus m.

75. melampus $\mathrm{m}$.

76. laticornis $\mathrm{m}$.

77. siccus $\mathrm{m}$.

78. esuriens $\mathrm{m}$.

78b. (124) bicostatus $m$.

79. mancus $m$.

80. figulinus $m$.

$80 \mathrm{~b}$. (125) strangulatus $\mathrm{m}$.

81. philothermus $m$.

82. varipes $m$.

83. succulentus $m$.

84. geniculatus Stål

85 . Iutarius $\mathrm{m}$.

86 . velatus $\mathrm{m}$.

87. ruficens $\mathrm{m}$

88. ambitiosus $\mathrm{m}$.

88 b. (126) virgineus $m$.

16. Rotte.

89. Salılbergii Stål

90. chromaticus $\mathrm{m}$.

91. hispaeformis $m$.

17. Rotte.

92. clathratus m.

93. Lar Fab.

94. carneolus Perty

95. dictyopterus $\mathrm{m}$.

\section{Scolochrus m.}

\section{Rolle.}

1. fragrans $m$

2. auricapillus $\mathrm{m}$.
XV. 283

X VI. 54

XV. 283

XVI 55

XV. 284

- 286

- 288

- 290

- 292

XVI. 57

XV. 293

- 295

XVI. . 55

XV, 297

XV
$-\quad 299$

XVI, 60)

XV. 301

- 303

- 304

- 306

XVI. 62

XV. 308

- 309

- 310

- 312

XVI. 63

XV. 314

- 315

XVI. 65

XV. 317

- 318

- 319

- 320

- 321

- 323

- 325

- 326

XV1. 67

XV. 328

- 330

- 332

- 334

$-\quad 337$
$-\quad 340$

- 340

- 342
3. halcyoneus $m$

4. viridi-cinctus $m$.

XV1. 75

$-76$

2. Rotte.

5. curtus $m$.

75

6. cernuus $\mathrm{m}$.

7. platynotus $\mathrm{m}$.

8. rotundatus $m$.

3. Rotte.

9. bicallosus m.

4. Rotte.

10. corpulentus in.

86

11. luxurians $\mathrm{m}$.

12. octo-maculatus $\mathrm{m}$.

5. Rotte.

13. abbreviatulus $\mathrm{m}$.

14. incomparabilis $\mathrm{m}$.

6. Rotte.

15. parabolicus $\mathrm{m}$.

\section{Rotte.}

16. 17 guttatus $m$

17. posticatus $\mathrm{m}$.

18. distigma $m$.

19. sciurellus in.

20. parcus $m$.

21. expeditus $m$.

22 . luxatus $m$.

23. paradoxus $m$.

24. sèmiluteus $m$.

25. Hyacinthinus Erichs.

26. boops $\mathrm{m}$.

27. causticus $\mathrm{m}$.

28. gibbipennis $m$.

29. bipes $\mathrm{m}$.

30. luctuosus m.

31. erythrospilus m.

32. tetrax

33. pygidiellus $m$.

8. Rotte.

34. Iurideolus $\mathrm{m}$.

35 . ahstersus $\mathrm{m}$.

36 . bilineolatus $m$.

$-92$

- 95

- 85

$-\quad 90$

37. conspurcatus $\mathrm{m}$.

9. Rotte.

38. metallescens $\mathrm{m}$.

39. crux nigra m.

40. parmulatus $\mathrm{m}$.

41. flavofasciatus $\mathrm{m}$.

42. praetextalus m.

43. ephippiatus m.
$-138$

- 140

- 142

- 144

$-99$

$-101$

$-104$

$-105$

$-106$

$-108$

- 109

- 111

- 114

$-116$

- 118

- 120

- 121

- 123

- 125

- 126

- 128

- 129

$-131$

- 133

- 135

- 136

- 146

- 148 
44. rufomarginatus $\mathrm{m}$.

45. commulatus $m$.

46. cupripennis $\mathrm{m}$.

47. superciliosus $\mathrm{m}$.

48. argentatus Erichs.

49. triangularis m.

50. scrofa $\mathrm{m}$.

51. pilicollis $\mathrm{m}$.

52. callens $\mathrm{m}$.

53. rufopallens $m$.

54. rubicundus $\mathrm{m}$.

55. spectabilis $m$.

56. arcuatus $\mathrm{m}$.

57. melancholicns $\mathrm{m}$.

55. caesus $\mathrm{m}$.

59. foetens $m$.

60 . illotus $\mathrm{m}$.

61. lacunosus m.

62. rufipennis Dej.

63. serricornis $m$.

64. segmentarius m.

65. scabripemnis $\mathrm{m}$.

10. Rotte.

66. corruscans m.

67. tripudians $\mathrm{m}$.

65. lencurus m.

69. diabolicus $\mathrm{m}$.

70. scutatus $\mathrm{m}$.

71. cazicus $\mathrm{m}$.

52. leucopygus m.

73 perlatus 0liv.

74. triguttatus Fal.

75. fallax Noritz

76. quadrillum $\mathrm{m}$.

11. Rolte.

77. quadritaeniatus $\mathrm{m}$.

is. scolopaceus m.

79. dorsalis St.

S0. fastidiosus $\mathrm{m}$.

S1. immaturus $m$.

82. supplex m.

S3. memnonius m.

84. quadrinus

85. scintillans $\mathrm{m}$.

S6. velutinus $m$.

87. superbiens m.

12. Rolte.

85. cultus v. Heyil.

13. Rotti.

\$9. reticollis $\mathrm{m}$.

90. subquadratus $\mathrm{m}$.

14. Rotle

91. griselıs in.
XVI. 150

- 154

- 155

- 157

- 160

- 162

- 164

- 166

- 167

- 170

- 172

- 174

- 175

- 177

- 179

- 181

- 183

- 185

- 187

- 155

- 190

- 191

- 193

- 195

- 196

- 198

- 200

- 201

- 201

- 203

- 205

-207
$-\quad 212$

- 212

- 214

- 216

- 217

- 219

- 221

- 222

- 224

- 226

- 228

- 229

- 231

- 233

- 236

- 238

$-\quad 239$
92. sulcipennis $\mathrm{m}$.

XVI. 241

93. planatus $\mathrm{m}$.

- 243

94. pallidilabris Stål

15. Rotte.

IV. Metullactus $m$.

1. Rotte.

1. miuax $\mathrm{m}$.

- 249

2. inustus $m$.

3. succinctus $\mathrm{m}$.

4. Palaemon m.

5. insitivus $m$.

6. lubricus $\mathrm{m}$.

7. latiusculus $\mathrm{m}$.

8. rnficeps m.

9 circunucinctus $m$.

10. nobilis Laf.

2. Rolte.

11. planipeunis $\mathrm{m}$.

12. generosus v. Heyd.

13. angusticollis $\mathrm{m}$.

14. poricullis $\mathrm{m}$.

15. ridibundus $m$.

16. taeniatellus m.

17. dilutus $m$.

18. tarsalis $m$.

19. trigrammus m.

3. Rotte.

20. albivittis $m$.

$-245$

- 252

- 254

- 256

- 258

- 260

- 261

- 263

- 264

- 266

- 268

- 269

- 271

- 272

- 274

- 276

- 279

- 280

- 282

- 284

4. Rotte.

21. ochripennis $m$.

$-286$

5. Rotte.

22. semirufius m.

23. Clarkii m.

- 288

- 290

6. Rotte.

24. apocalypticus $\mathrm{m}$.

- 292

7. Rotte.

25. gutula Fab.

26. 15 guttatus Fab.

27. fumosus $n$.

28. polymorphis m.

29. argula $\mathrm{m}$.

30. consularis $m$.

31. flavo-pustulatus Stål

32. leucothyreus $m$.

33. decumanus $\mathrm{m}$.

34. sugillatus $\mathbf{m}$.

35. nmbrinus in.

36. distans $\mathrm{m}$.
- 295

- 295

- 310

- 303

- 306

- 305

- 309

- 312

- 314

- 316

- 318

- 320 
37. cribrarius $\mathrm{m}$.

38. varipennis $m$.

\section{Rotle.}

39. 13punctatus $m$.

40. luniger $\mathrm{m}$.

41. crassicollis m.

42. albopictus Bug.

43. hamifer $m$.

44. triplagiatus $\mathrm{m}$.

45. gentilis $m$.

46. limbiventris Stål

47. fricator $m$.

48. nigro-ornatus Stål

9. Rotte.

49. pollinctor $\mathrm{m}$.

50. moerens $m$.

51. agonista $\mathrm{m}$.

\section{Rotte.}

52. patagonicus Guér.

53. dodecastictus $\mathrm{m}$.

54. pollens $\mathrm{m}$.

55. incultus $\mathrm{m}$.

\section{Rotte}

56. Kollari Periy.

57. nigro-fasciatus $m$.

58. albifrons ni.

59. albipes $m$.

o0. corruptus $m$.

61. languidus $\mathrm{m}$.

62. verrinus $m$.

63. spilotus $\mathrm{m}$.

\section{Sternoglossus m.}

1. cruciger $\mathrm{m}$.

2. scalaris $m$.

V1. Pachybrachys Chv.

\section{Rotte}

1. cariosus Erichs.

2. paganus 0liv.

3. spurcans $\mathrm{m}$.

4. adspersus $m$.

5. musivus Grm.
XVI. 321

- 323

- 325

- 327

- 329

- 331

- 333

- 335

- 337

- 338

- 341

- 343

- 348

- 350

- 351

- 353

- 355

- 356

- 358

- 360

- 363

- 365

- 366

- 370

- 373

- 375

$-\quad 376$

39. Gayi Blanch.

6. eburifer Chv.

7. syrites $\mathrm{m}$.

8. idiota $\mathrm{m}$.

9. aegrotans $\mathrm{m}$.

10. pallens Blanch.

11. foetidus $m$.

12. ferrugatus $m$.

13. callifer $m$

14. congener Dej.

15. anxills $\mathrm{m}$.

16. nigro-notatus Boh.

17. lavandus $\mathrm{m}$.

18. phthisiacus $m$.

19. strictus m.

20. conformis Dej.

21. sordidulus m.

22. dissolutus $\mathrm{m}$.

23. flavo-varius Boh.

24. mysticns Reich.

25. judaicus Grm.

26. xanthogramuis m.

27. stomachosus $\mathrm{m}$.

28. signifer Stål

29. fervidus m.

30 . curvatulus $m$.

31. gultipennis $\mathrm{m}$.

32. nigricollis $\mathrm{m}$.

33. annexus $m$.

34. striatulus $\mathrm{m}$.

35 . tenebrosus $m$.

36. reticulatus Fab.

37. clathratus $m$.

38. glyphicus Klng.

2. Rotle.

3. Rotte.

- 379 40. mixtus Blanch.

- 381 41. quadricollis m.

VII. Ambrotodes $m$.

\section{Rotte.}

- 383

- 385

- 388

- 390

- 391

1. chilensis Blanch.

2. Rotte.

2. ignobilis $\mathrm{m}$

3. signatipennis Blancl.
XVI. 394

- 396

- 398

- 400

- 402

- 404

- 406

- 408

- 410

- 412

- 414

- 416

- 419

- 420

- 422

- 423

- 425

- 427

- 428

- 431

- 433

- 435

-437
$-\quad 439$

- 439

$-441$

- 443

- 445

- 448

- 449

- 451

- 453

- 456

- 459

- 461

- 464

- 466

- $47 t$

\begin{tabular}{l}
-477 \\
\hline
\end{tabular} 


a 

QL Suffrian, E.

596 Zur kenntniss der suda-

C77S9 merikanischen CryptocephaEnt. len. 
SMITHSONIAN INSTITUTION LIBRARIES

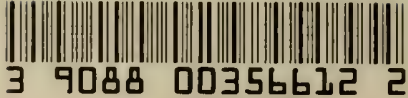

nhent QL596.C77S9

Zur kenntniss der sudamerikanischen Cryp 